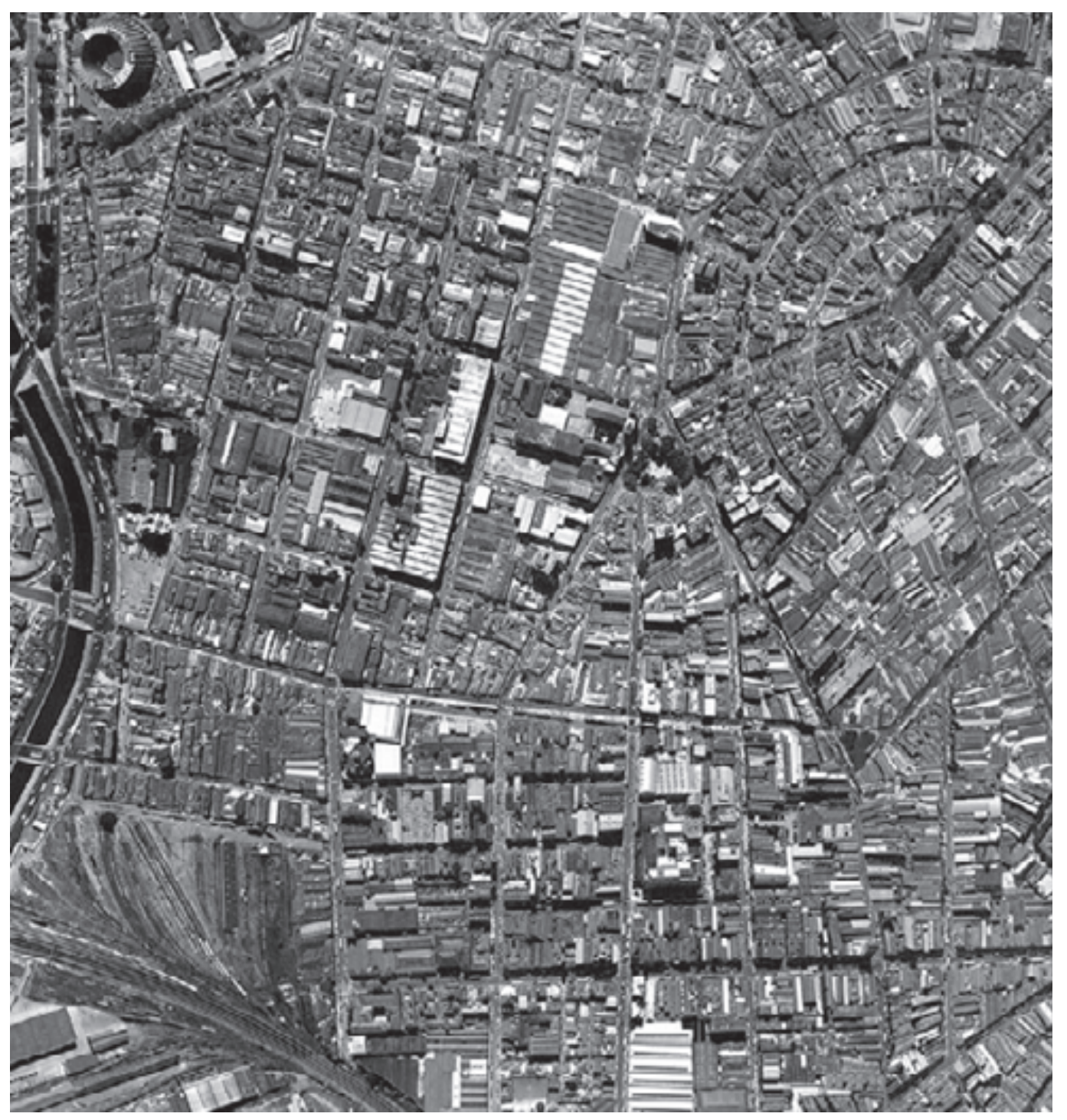

Desenho Urbano e Bairros Centrais de São Paulo Um estudo sobre a formação e transformação do Brás, Bom Retiro e Pari

Decio Amadio FAU-USP 


\section{Desenho urbano e bairros centrais de São Paulo Um estudo sobre a formação e tansformação do Brás, Bom Retiro e Pari.}

Orientador:

Prof. Dr. Adilson C. Macedo

\section{Decio Amadio}

Tese de Doutorado

Área de Estruturas Ambientais Urbanas

Curso de Pós-Graduação

Faculdade de Arquitetura e Urbanismo da

Universidade de São Paulo

São Paulo, 2004. 


Agradecimentos

Este trabalho não seria realizado sem a colaboração generosa de tantas pessoas envolvidas, às quais retribuo com imensa gratidão:

Primeiramente ao meu orientador, Prof. Dr. Adilson Costa Macedo, que pacientemente esteve presente na elaboração e nas fases decisivas do trabalho de tese, compreendendo os momentos de "silêncio", que foram muitos. Aprendi com o amigo e professor a insistência em delimitar os campos do arquiteto e urbanista na análise que um trabalho de pós-graduação deve apresentar.

Igualmente grato sou à banca de qualificação, formada pelos Prof. Dr. Lúcio Gomes Machado e Prof. Dr. Vladimir Bartalini, pelos comentários ao que havia sido realizado até então e por relevar as possibilidades de complementação da pesquisa, o que sem dúvida, se constituiu em valiosa contribuição à tese.

À Prof ${ }^{a}$. Dr ${ }^{a}$ Cristina Leme e ao Prof. Dr. Paulo Bruna, pelos conteúdos abrangentes dos seus cursos, que auxiliaram o desenvolvimento dos trabalhos programados, e por conseqüência, a estruturação da pesquisa e dos enfoques desenvolvidos.

Ao apoio solidário e amigo do arquiteto Alfredo Francelino Faljana, em todo o árduo processo de montagem dos levantamentos cartográficos, observações sobre a estruturação do trabalho, conversas voltadas ao tema e à competente editoração.

Aos colegas professores da Faculdade de Arquitetura e Urbanismo Braz Cubas, particularmente a Paulo José Amaral, pelo auxílio permanente na área da habitação social, Carlos Costa e Marcelo Novaes, pelas importantes imagens.

A todos os alunos pelas lições que juntos aprendemos e particularmente à Márcia Maria Fonseca e Tatiana Tâmbara Francisco, pelo trabalho de compilação da hemeroteca. À France Iwashita pela ajuda nas pesquisas iniciais e Wanderléa Steidle, pela amizade e apoio.

À equipe da Secretaria Municipal de Planejamento do Plano Diretor Estratégico de São Paulo, coordenado por Ivan Maglio, pelas valiosas contribuições a este trabalho.

À Helena Mena Barreto, pela cessão do material e de todos os colegas arquitetos que elaboraram as pesquisas e propostas dos $\mathrm{PRIHs}$, que constaram das pesquisas.

A todos colegas de trabalho na Sub-prefeitura Sé e do Procentro.

Aos amigos da Regional da Sé, da gestão 1989-1992, pela vivência das duras questões ligadas à gestão pública desta cidade, particularmente ao prof. Vicente y Plá Trevas e ao prof. Rubens Possati. 

Aos funcionários das bibliotecas da FAUUSP e SEMPLA, que viabilizaram a coleta do material cartográfico e de pesquisa.

Aos funcionários do Departamento do Patrimônio Histórico, da Prefeitura de São Paulo, que igualmente o fizeram.

Aos urbanistas Clementina De Ambrosis e Domingos Theodoro de Azevedo Neto, que além da sua dedicada colaboração profissional à cidade, traduziram o resumo do trabalho para o italiano e também ao amigo Stephen McGee, na versão para o inglês.

A todos os amigos e colegas da Faculdade de Arquitetura e Urbanismo de São José dos Campos, experiência inesquecível de ensino, de luta e de trabalho para rumos diferentes ao exercício profissional e ao país.

Dedico este trabalho à Tereza Cristina Vespoli, minha companheira de vida e de mundos, que divide comigo a crença e a luta dos dias. Agradeço igualmente o seu auxílio em todos os momentos, à sua competente contribuição urbanística e à editoração dos mapas temáticos que constam neste trabalho.

Dedico in memorian este trabalho àquelas pessoas que instigaram a permanente inquietação social, política e profissional, sem esquecer a dimensão humana que deve acompanhar o fazer:

À Daisy Amadio Fujiwara, minha irmã amada

À Mayumi Watanabe e Sérgio de Souza Lima, meus mestres queridos. 



\section{Prefácio}

Este trabalho analisa alguns dos resultados da construção da cidade de São Paulo no tempo e pautou-se por investigar o desenho urbano de uma região determinada, os bairros centrais, encontrando no seu caminho os desafios que são colocados pelo método e pela objetividade de enfocar o tema e a área.

Desculpando-me pelo resultado final, que sempre exige outros prováveis aprofundamentos, o trajeto de realização de um trabalho de pós-graduação, todos que o fizeram ou o estão elaborando, sabem que não é tão linear como se supunha inicialmente ser. Em parte, deve-se a isso a contingência de realizá-lo juntamente com outras atividades profissionais, o que coloca difíceis momentos para a sua continuidade.

A pesquisa realizada sofreu, portanto, em primeiro lugar, as limitações do próprio autor, mas foi enriquecedor o aprendizado que o trabalho proporcionou em seu curso. Sua proposta inicial se baseou nas indagações a respeito da produção da forma urbana de determinados bairros centrais de São Paulo, em comparação aos demais que circundam o centro da cidade. Os bairros delimitados, Bom Retiro, Brás e Parí, foram fruto de um processo de ocupação histórico heterogêneo e popular, confrontados com os outros que, de maneira diferenciada foram estruturados.

Um dado significativo que os diversos estudos e trabalhos técnicos pesquisados permitiram observar, foi o da morfologia urbana existente nos bairros da cidade ter se mostrado um campo quase que exclusivo dos geográfos. Certamente, não era desconhecida pelos arquitetos e urbanistas, que se viram na contingência de formular propostas de Planejamento Urbano para São Paulo, mas ao se generalizar diretrizes e instrumentos, foram privilegiadas as concepções tecnofuncionalistas em várias propostas, que não deram atenção aos importantes aspectos do mosaico estabelecido em cada fração da vida citadina. Com isso a relação entre espaço e ambiente foi dissociada, apesar de dever nortear o pensamento urbanístico.

As pesquisas no campo do desenho urbano buscam superar as incompatibilidades da relação entre cidade, paisagem urbana e edifício, criadas pela divisão das escalas edifício-cidade e este trabalho se volta a compreender os componentes de uma estruturação urbana específica, que se traduziv em um ambiente com diferentes formas de apropriação do território, diferentes tipologias e diferentes soluções para os objetivos de moradia, trabalho e outras atividades ligadas à vida de sua população, resultando em um urbano síntese das arquiteturas ou no seu inverso, uma arquitetura plural e coletivamente estruturada. 
Nesse sentido, nos passos iniciais deste trabalho, optou-se por uma reflexão sobre bairros como o Bom Retiro, Ponte Pequena, Pari, Canindé e Brás, situados junto à centralidade de São Paulo, mas com grande parte das vantagens dessa localização sub-aproveitadas, fruto de um processo de esvaziamento populacional e de deterioração física e ambiental que não encontrou na legislação do zoneamento que vigorou de 1972 a 2002, ou de outras estratégias urbanísticas, possibilidades de transformação para melhores padrões de qualidade urbana.

Esse quadro indicou a necessidade de se recorrer ao campo do Desenho Urbano como forma de compreensão dos processos envolvidos na estruturação desses bairros e das suas características atuais, destacando as suas formas de ocupação, seus elementos tipológicos e paisagísticos, isto é, seus elementos de configuração. Para tanto, a metodologia de abordagem do trabalho, que foi apresentada preliminarmente no plano de pesquisa, mereceu ser revista e ampliada, para abarcar as questões urbanas envolvidas.

A investigação propôs hipóteses iniciais que foram confirmadas no seu transcorrer: necessidade de adensamento dos bairros com infra-estrutura, valorização de seu patrimônio construído, melhoria da sua qualidade arquitetônica e ambiental, etc. Foram muitas as propostas urbanísticas concretizadas que coincidiram com o tempo de elaboração desta tese e que deram sustentação à necessidade de transformação dos espaços colocados em foco.

Merece destaque o fato de ter ocorrido nos últimos quatro anos um debate diferenciado sobre a cidade, que levou não apenas à formulação e aprovação do novo Plano Diretor Estratégico, mas também, e pela primeira vez, à elaboração de Planos Regionais. Essa nova escala de atuação urbanística no território proporciona, pelo menos potencialmente, a mudança das abordagens e temas relacionados aos espaços da cidade e com isso, maiores oportunidades para ações direcionadas à realidade e problemática local.

Contribuiu também para a estruturação deste trabalho, a prática com ensino de Desenho Urbano, enfocando as questões do espaço da área central de São Paulo e de seus bairros vizinhos. Dentro disso, a pesquisa de características morfológicas, a problematização sobre a ociosidade da ocupação habitacional e o processo de deterioração do espaço construído, versus as potencialidades existentes nos bairros centrais, tornaram-se temas presentes cotidianamente e provocaram um sem número de indagações sobre as perspectivas de transformação e superação dos problemas existentes desses lugares, vinculandoos a novos padrões de qualidade urbana e a uma outra imagem de São Paulo, sempre relacionada aos símbolos arquitetônicos e urbanísticos das áreas de maior padrão econômico, apagando da memória urbana, espaços altamente significativos e importantes para a vida do conjunto de sua população. 
Outro fator se colocou em auxílio para a escolha do tema e para o desenvolvimento da pesquisa, que foi o de ter vivenciado pessoalmente essa região e aprendido com sua organização espacial e social a dinâmica de um bairro heterogêneo, repleto de contrastes, interrelacionado a outros com as mesmas características. Este trabalho procura também entender determinados eventos ou acontecimentos espaciais, que não estavam ao alcance de uma pessoa que, há décadas atrás, andava por ruas semeadas de casas e fábricas e viajava de bonde para fazer alguma rara compra "na cidade", como era chamado o Centro. A memória pode até se afastar das pessoas, mas permanece gravada no traçado das ruas, nos limites entre os bairros, sempre subjetivamente fixados, nas construções modestas e aquelas com maior pretensão, nas sensações dos espaços diferenciados no mesmo bairro, enfim, percepções que se são pessoais, foram e continuarão a ser estruturadas coletivamente na cidade e em suas partes.

Buscou-se desenvolver o trabalho a partir de um entendimento sobre a estruturação do anel de bairros que circunda o Centro de São Paulo, uma vez que nele ocorreu a diferenciação entre os setores urbanos da cidade. Foram examinados os processos decorrentes da implantação da infra-estrutura de transporte, da fixação diferenciada das tipologias habitacionais e do papel desempenhado pelas políticas do setor público. Essa abordagem destacou os principais elementos que intervieram na configuração dos bairros centrais, do fim do século XIX até a atualidade.

A seguir, numa segunda parte, foi examinada em maiores detalhes a estruturação dos distritos Bom Retiro, Brás e Parí, a fim de se identificar as especificidades morfológicas de cada bairro, dentro do período 1930-2000. Esse desenvolvimento reuniu a evolução do traçado, parcelamento e edificação, relacionando também as ações que provocaram alterações na configuração.

A terceira parte incluiu uma definição de possíveis cenários para alguns dos espaços desses bairros, não com o objetivo da simulação de projetos ou planos, mas com o intuito de interrelacionar alternativas hoje já existentes, e que poderão ser debatidas e aperfeiçoadas em proveito dos moradores e usuários dessas áreas. Além disso, essa parte reúne o fechamento do trabalho através de suas conclusões. 



\section{RESUMO}

Este trabalho analisa um setor urbano de São Paulo que é formado pelo anel de bairros que envolve o núcleo central da cidade. Seu objetivo é identificar como a espacialidade dos bairros centrais foi definida e para isso foram investigados os agentes e fenômenos que regeram a formação desse setor urbano e como se assemelharam ou diferenciaram dentro do processo de urbanização da cidade.

Foram focalizados três distritos em particular, o Brás, o Bom Retiro e o Parí, que reúnem uma série de bairros cuja estruturação reporta a própria estruturação da cidade. Buscou-se compreender as condicionantes que definiram as características da morfologia urbana dos bairros mencionados e as mudanças ocorridas nessas áreas, que se constituíram no primeiro locus da industrialização da cidade, e que também abrigaram funções habitacionais e comerciais diversificadas.

A análise aborda a implantação da infra-estrutura de transportes na cidade, considerando-a junto com a normatização do uso do solo, as principais componentes da estruturação espacial dos bairros centrais até a década de 1940. A partir desse período, outros processos interferiram no arranjo desse setor urbano, provocando ao mesmo tempo, a permanência das suas características morfológicas e funcionais e uma crescente sub-utilização para fins habitacionais.

trabalho foi organizado em três escalas de abrangência para o estudo das questões relativas ao tema:

- Escala da cidade - envolvendo a macro-configuração, a estruturação dos bairros centrais e as interfaces existentes no arranjo intra-urbano entre os bairros e entre o núcleo central. Relação das políticas públicas com os aspectos ligados à infra-estrutura, ao parcelamento e à edificação. Análise das características funcionais e morfológicas gerais e tendências recentes de transformação.

. Escala dos bairros - caracterização dos bairros centrais presentes nos distritos Brás, Bom Retiro e Parí. Delimitação dos setores e sub-setores, estudo das características funcionais e morfológicas. Planos e projetos incidentes e articulação com as propostas de requalificação física-ambiental.

. Escala local - estudo de alternativas e cenários para o desenho urbano local, relacionando as propostas urbanísticas formuladas para essas áreas e hipóteses de desenho urbano para espaços nesses bairros. 



\section{RIASSUNTO}

Questo lavoro focalizza un settore urbano di S. Paulo che è formato dall'anello di quartieri che avvolge il nucleo centrale della città. II suo obijettivo è quello di individuare in che modo si è andata formando la caratteristica spaziale dei quartieri centrali e per fare ciò si é indadgato su quegli agenti e quei fenomini che contribuirono alla formazione di questo settore urbano e in che modo si sono somigliati o differenziati nel processo di urbanizazione della città.

Sono stati analizzati tre "distritos" ${ }^{\text {, }}$ in particolare: il "Brás", il "Bom Retiro" e il "Pari" che raggrupano una serie di quartieri la cui strutura si ricolega alla strutura stessa della città. Si è cercato di capire i fattori piú marcanti che hanno definito lê caracteristiche della morfologia urbana dei quartieri citati e i cambiamenti che sono avvenuti in queste zone, "primo locus" dell'índustrializazzione della città e che accolsero anche funzioni abitative e commerciali, le più diverse.

L'analisi focalizza la constituzione della strutura dei transporti, insieme alle norme dell'uso del suolo, e i principali componenti della tipologia degli spazi in questi quartieri centrali fino alla decade del 1940. Da questo periodo in poi vi furono altri processi che hanno interferito nella sistemazione di questo settore urbano provocando allo stesso tempo la conservazione delle sue caratteristiche morfologiche e funzionali e nel tempo una scarza utilizzazione a scopi abitazionali.

Il lavoro è stato organizzato in tre gradi secondo l'ampiezza dell'argomento:

- Scala della città - comprendendo la macro-configurazione, la strutura dei quartieri centrali e le relazioni esistenti nello spazio urbano trai i quartieri e il nucleo centrale. Relazioni delle politiche pubbliche com gli aspetti legati all'infrastrutura, alle lottizazione e alla edificazione. Analisi delle caratteristiche funzionali e morfologiche generali nonchè recenti tendenze di transformazione.

. Scala dei quartieri - caratteristiche dei quartieri centrali presenti nei "distritos" Brás, Bom Retiro e Pari.Delimitazioni dei settori e sotto settori, studio delle caratteristiche funzionali e morfologiche. Piani e progetti esistenti e la loro sintonia com le proposte di rivalorizzazione física e ambientale.

. Scala locale - studio delle alternative future per modelare i progetti urbanistichi dei quartieri e il paesaggio locale.

${ }^{1}$ La strutura amministrativa del território nazionale è composta da: stati, municipi e distriti. 

This work analyses an urban sector of São Paulo that is formed by a ring of boroughs that surround the city centre. Its aim is to identify how the area of the inner city boroughs was defined and in order to that we investigated the agents and phenomena that governed the formation of this inner city sector and how it differeciated itself within the city urbanization process.

Three boroughs in particular were focused on, "Brás", "Bom Retiro" and "Parí", that gather together a series of neighbourhoods whose structures relate to the structure of the city. We sought to understand the conditions that define the characteristics of the urban morphology of the above mentioned boroughs and the changes taken place in these areas, that constitute the first locus of the industrialization of the city and housing and commercial diversities as well.

The analysis deals with the introduction of the infrastructure of the city transport system, considering it together with the restoration of land use, the principle components of the structure space of central neighbourhoods up until de 1940's. From this period on, other processes interfered with the arrangement of this urban sector, causing at the same time, the unchanging morphological characteristics and functions and a growing under-use for housing means.

The work was organized into three scales of understanding for the study of the questions relative to the theme:

. City scale - involving the macro-configuration, the structure of the central neighbourhoods and the existing interfaces on the infrastructure arrangement between the boroughs and the city centre. The relation of public policies with aspects linked to de infrastructure, the partitioning and the buildings. Analyses of the functional characteristics and general morphologicals and recent transformation tendencies.

. Neighbourhoods scale - characterization of the central neighbourhoods present in the Brás, Bom Retiro and Parí. Outlining boundries of the sectors and subsectors, study the functional and morphological traits. Planning and design incidents and connetions with the environment requalification proposals.

. Local scale - study of alternatives and settings for local urban desing, relating to the urban proposals put forward for these areas and possibilities of urban design for spaces in these neighbourhoods. 



\section{Sumário}

Agradecimentos

pág. III

Prefácio

Resumo

1. Introdução

pág. VII

pág. XI

pág. 01

pág. 03

pág. 04

1.2. Justificativas e caracterização do problema

pág. 07

1.3. Pressupostos e Hipóteses

pág. 08

\section{Parte I}

1. Estruturação do anel de bairros centrais

1.1 A industrialização emergente: o apito das fábricas no cotidiano paulista

pág. 15

pág. 29

1.2 A cidade e os novos requisitos de sua expansão

pág. 38

1.3 A implantação da infra estrutura urbana

pág. 50

1.4 Imbricação: transporte, energia e água

pág. 52

1.5 Imbricação: sanitarismo, parcelamento do solo e legislação urbanística até a década de 1930

pág. 68

1.6 Imbricação: sanitarismo e habitação popular nos bairros centrais - cortiços e as vilas operárias

pág. 81

1.7 Imbricação: infra-estrutura e novos bairros de alto padrão - os bairros-jardim

pág. 97

2. $\bigcirc$ quadro urbano a partir de 1930: área consolidada e formação metropolitana

pág. 107

2.1 A expansão da área urbanizada e novos elementos viários _ pág. 120

2.2 As propostas urbanísticas para a cidade: 1930-1960) _. . pág. 127

2.2.1 Melhoramentos de São Paulo

pág. 130

2.2.2 Relatório Moses

2.2.3 Estudos para a Segunda Perimetral, Metrô

pág. 139

e proposta de Plano Diretor

pág. 143

2.2.4 Estrutura Urbana da Aglomeração e

Relatório Planejamento

pág. 146

2.3 Habitação popular: bairros centrais e periferia 1930-1960_ pág. 151

2.4 Legislação: as setorizações consagradas pelas normas urbanísticas

3. As transformações do período 1960-1980

pág. 161

3.1 As propostas de Infra-estrutura e zoneamento do PUB e PDDI

pág. 170

3.2 Cidade Real: Transformações ao longo das radiais do Plano de Avenidas

3.3 Habitação: os espaços diferenciados para os ricos e pobres pág. 242 

4. Período 1980 - década de 2000: novas relações presentes na cidade

pág. 249

4.1 Habitação e o mercado imobiliário

4.2 A cidade e as novas ocupações industriais e de serviços

pág. 253

4.3. Operações Urbanas: Remodelações dirigidas e espacialidade corporativa

4.3.1. Operação Urbana Água Branca

4.3.2. Operação Urbana Faria Lima

pág. 261

pág. 267

pág. 268

pág. 275

5. Considerações I

pág. 291

Parte II

6. Observações sobre a análise dos bairros centrais

pág. 301

6.1. Distrito do Bom Retiro

pág. 313

6.1.1. Luz

6.1.2. Ponte Pequena

pág. 313

pág. 320

6.1.3. Bom Retiro

6.1.4. Análise dos sub-setores

pág. 322

pág. 328

pág. 338

pág. 347

6.2.1. Análise dos Sub-setores

pág. 358

pág. 362

6.3.1. Análise dos sub-setores

pág. 403

7. Considerações sobre a estruturação do Bom Retiro, Brás e Pari

\section{Parte III}

8. As remodelações da década de 1980 e 1990

pág. 407

8.1. Parque do Tietê

8.2. Maharishi Tower

pág. 410

pág. 418

8.3. Breves comentários sobre o Parque do Tietê e Maharishi Tower

pág. 423

9. Requalificação dos bairros centrais

pág. 425

pág. 427

9.1. Programa reconstruir o centro

pág. 429

9.2. Projetos nos bairros Brás e Parí

9.3. Propostas do Programa de Habitação no Centro

pág. 431

9.3.1. Programa de Reabilitação Integrada do Habitat - PRIH

9.3.2. Conjunto Hab. para o Bom Retiro - Parque do Gato

pág. 433

pág. 438

pág. 440

9.4. Propostas do Progrma Habitacional CDHU

pág. 443

9.5. Plano Diretor Estratégico

pág. 448

9.7. Planos Regionais Estratégicos dos

Distritos Bom Retiro, Brás e Pari

pág. 451

pág. 461

Bibliografia

pág. 469 



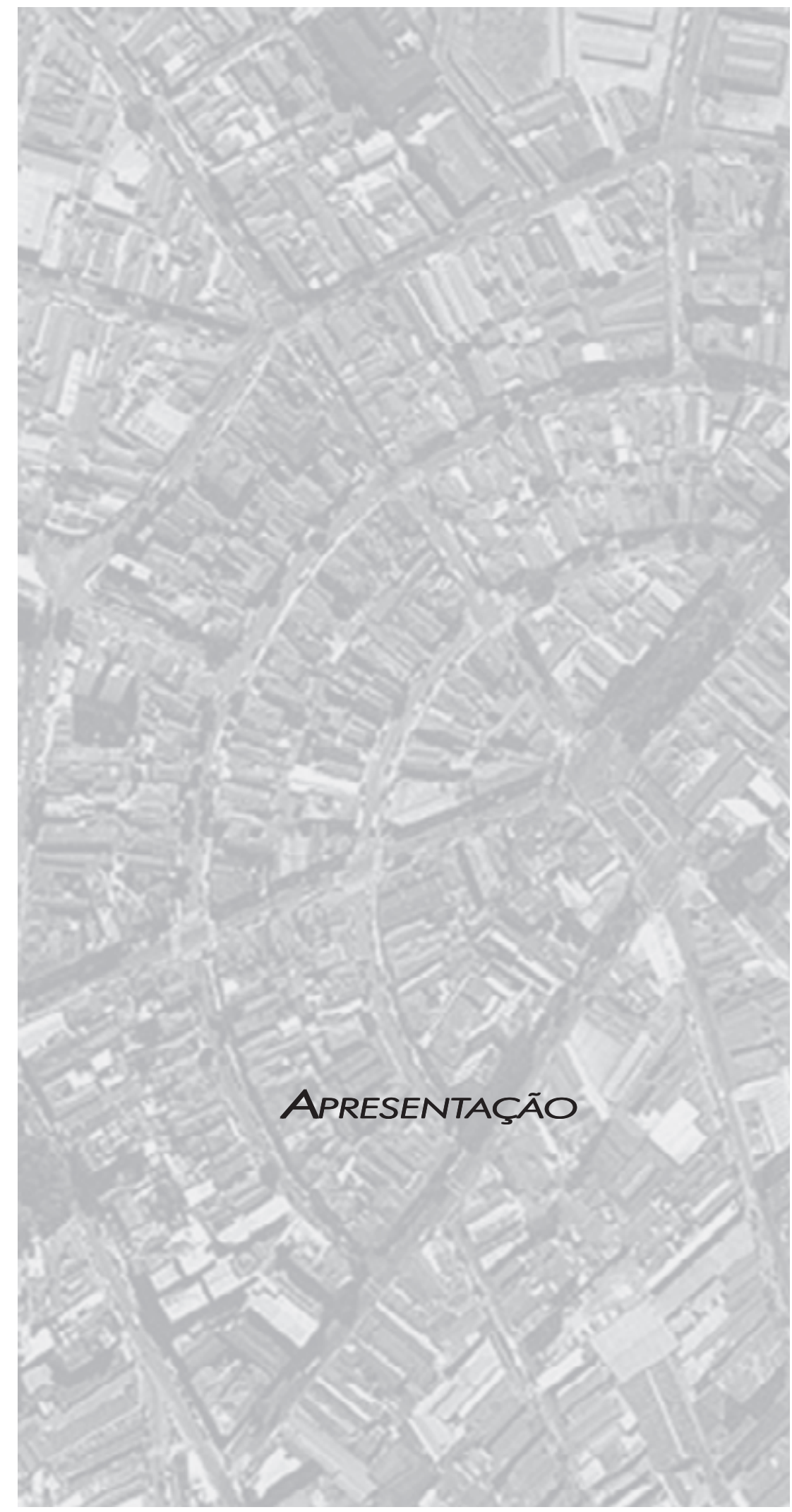




\section{Apresentação}

\section{1 - Objetivos}

Este trabalho propõe um estudo para os bairros situados a norte, nordeste e leste do núcleo central, contidos respectivamente no interior dos distritos Bom Retiro, Pari e Brás, que objetiva:

- Compreender as condicionantes relativas ao uso e ocupação do solo, que definiram a morfologia urbana dos bairros abordados. Para tanto será desenvolvida uma análise da estruturação urbana e das mudanças ocorridas nessas áreas, que se constituíram no primeiro locus da industrialização da cidade.

- Compreender as características urbanas que eles apresentam atualmente, sob o ponto de vista funcional e morfológico, já que gradativamente deixaram de abrigar a localização industrial desde as décadas de 1960 e 1970, transformandose em espaços de atividades comerciais especializadas e apresentando também contínuo esvaziamento populacional a partir da década de 1970.

- O estudo das alternativas e cenários existentes para o desenho urbano local e regional, relacionando as propostas urbanísticas formuladas para essas áreas e analisando os possíveis desdobramentos das mesmas

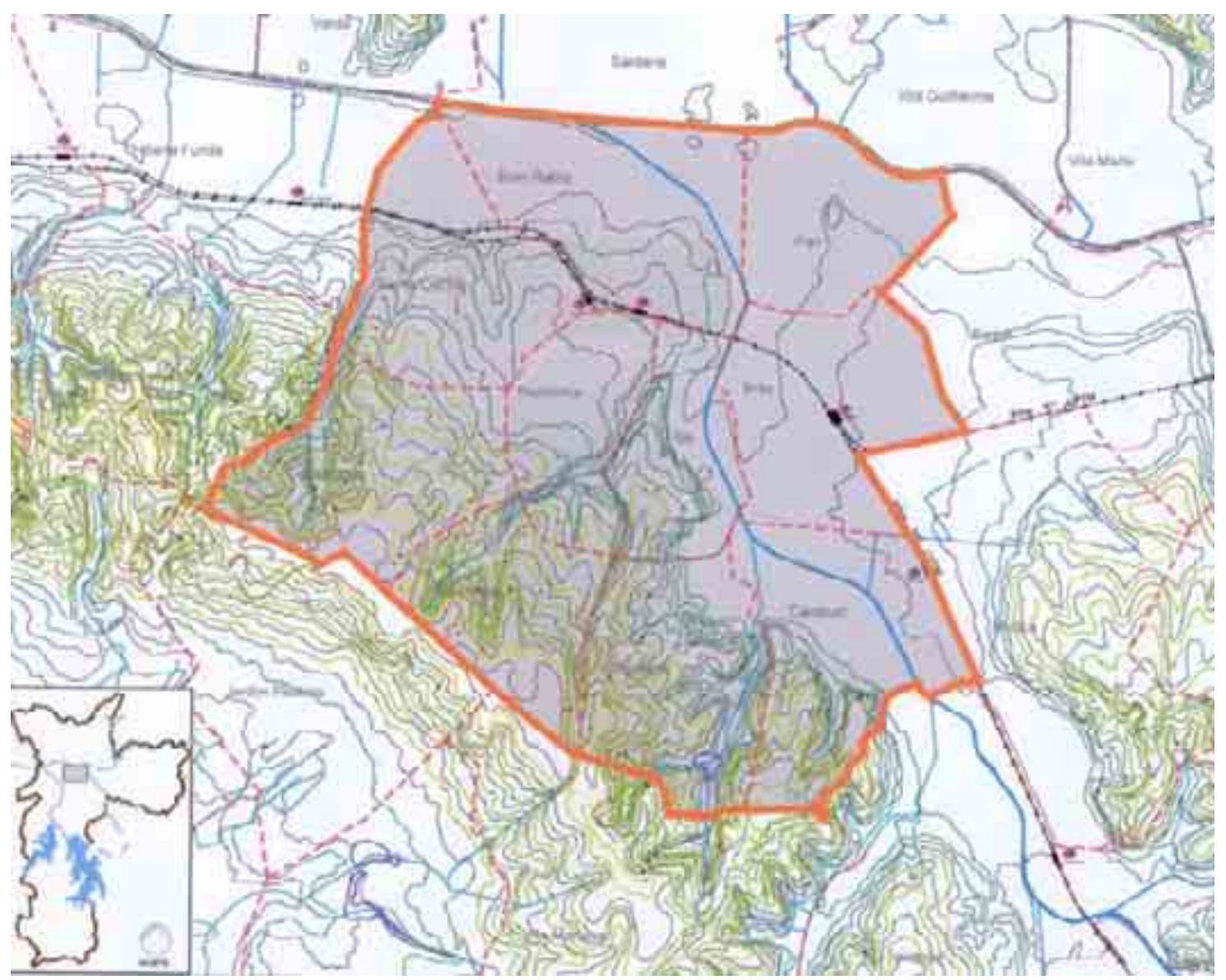

Distritos centrais de São Paulo 


\subsection{Justificativas e caracterização do problema}

Interessou-nos pesquisar, dentro do anel de bairros que circunda o Centro, aqueles situados ao norte, nordeste e leste do núcleo central devido:

- A origem histórica dos setores escolhidos, ligados às ferrovias, à industrialização e a formação social que os mesmos apresentaram.

. A inadequação urbanística de serem mantidas áreas sub-aproveitadas próximas ao Centro, tanto pelos custos impostos à cidade, como também pelas conseqüências físicas, ambientais e paisagísticas que um vasto setor urbano em condições de visível precariedade impõe a ela.

- A existência nesses espaços de uma base territorial com disponibilidade de áreas livres e baixa densidade populacional, que pode suportar um aumento do número de moradores, aliado a ações revitalizadoras do ambiente urbano, quer no sentido das suas funções, quer na sua paisagem.

Levando em conta esses aspectos, considerou-se que o processo de ocupação e adensamento do território que envolve o núcleo central de São Paulo diferenciou em profundidade os setores urbanos da cidade no que diz respeito ao caráter funcional e morfológico. A partir da década de 1950 e mais intensamente ao longo da década de 1960, ocorreu o fenômeno da expansão das atividades centrais para fora do perímetro do centro tradicional, nas áreas que passaram a abrigar novos pólos de negócios e serviços. Essa expansão esteve condicionada ao setor sudoeste, já que por ali, tanto a base fundiária como a proximidade com bairros de alta renda viabilizaram os investimentos imobiliários.

Os bairros situados ao norte, nordeste e leste da área central, por sua vez, se constituíram historicamente em um território com a ocorrência de atividades industriais, serviços voltados às camadas sociais mais populares e alta incidência de habitação horizontalizada, com fraca presença de verticalização.

Relacionou-se a eles a existência de uma infra-estrutura voltada ao transporte da população trabalhadora e de cargas, tais como ferrovias, estações e grandes terminais de linhas de ônibus, além de zonas de comércio atacadista, vias de tráfego pesado inter-regional, aliados a uma base fundiária fragmentada em pequenas propriedades e com presença significativa de habitação de baixa renda, representada pelos inúmeros cortiços. Com esse caráter urbano, mesmo se localizando junto à centralidade, essas áreas localizadas em terras baixas das várzeas dos rios Tietê e Tamanduateí, tiveram reforçada a tendência de desvalorização ambiental e imobiliária.

A situação desses bairros revela simultaneamente um quadro de grande complexidade e de igual potencialidade urbana. Grande parte da infra-estrutura industrial encontra-se atualmente esvaziada e mesmo sucateada, por conta das 
transformações estruturais no seio da economia brasileira, que acarretaram, no âmbito regional, a mudança de uma parcela expressiva de indústrias para fora do Município e até da Região Metropolitana de São Paulo. Junto a esse processo, também foi intensificada a especialização terciária de regiões do Bom Retiro, Brás e Pari, acarretando não apenas a substituição de uma atividade econômica por outra, mas também repercussões para a população moradora daquelas localidades. Observa-se nessas áreas um contínuo esvaziamento dos habitantes nas últimas três décadas e baixo índice de novas construções com finalidade de moradia.

A histórica característica de existência de uma mescla de habitação de classe média com a popular, nos distritos do Bom Retiro, Pari e Brás, vem sendo transformada por essa dinâmica de esvaziamento. Os dados do censo 2000, divulgados pelo IBGE, demonstram que entre 1991 e 2000, o Bom Retiro perdeu $26,47 \%$ dos moradores, o Brás $26,93 \%$ e o Pari $31,82 \%$.

\begin{tabular}{|c|c|c|c|c|c|c|c|}
\hline \multirow[t]{2}{*}{ Distritos } & \multirow{2}{*}{$\begin{array}{c}\text { Censo de } \\
1980\end{array}$} & \multirow{2}{*}{$\begin{array}{c}\text { Censo de } \\
1991\end{array}$} & \multirow{2}{*}{$\begin{array}{c}\text { Censo de } \\
2000\end{array}$} & \multirow{2}{*}{$\begin{array}{c}\text { TCA } \\
80 / 81\end{array}$} & \multirow{2}{*}{$\begin{array}{c}\text { TCA } \\
91 / 2000\end{array}$} & \multirow{2}{*}{$\begin{array}{c}\text { ÁREA } \\
\mathbf{k m}^{2}\end{array}$} & \multirow{2}{*}{\begin{tabular}{|c|} 
Densidade \\
hab/ha
\end{tabular}} \\
\hline & & & & & & & \\
\hline B. Vista & 85.333 & 71.825 & 63.143 & $-1,55$ & $-1,42$ & 2,6 & 242.9 \\
\hline B. Retiro & 47.542 & 36.136 & 26.569 & $-2,46$ & $-3,36$ & 4 & 66,4 \\
\hline Brás & 38.592 & 33.536 & 24.505 & $-1,27$ & $-3,43$ & 3,5 & 70 \\
\hline Cambuci & 44.807 & 37.069 & 28.620 & $-1,71$ & $-2,83$ & 3,9 & 73,4 \\
\hline Consolação & 77.264 & 66.590 & 54.301 & $-1,34$ & $-2,24$ & 3,7 & 146,8 \\
\hline Liberdade & 82.392 & 76.245 & 61.850 & $-0,7$ & $-2,3$ & 3,7 & 167,2 \\
\hline Pari & 26.942 & 21.299 & 14.521 & $-2,11$ & $-4,17$ & 2,9 & 50,1 \\
\hline República & 60.940 & 57.797 & 47.459 & $-0,48$ & $-2,17$ & 2,3 & 206,3 \\
\hline Sta. Cecília & 94.451 & 85.829 & 71.111 & $-0,87$ & $-2,07$ & 3,9 & 182,3 \\
\hline B. Funda & 17.877 & 15.977 & 12.936 & $-1,02$ & $-2,32$ & 5,6 & 23,1 \\
\hline Sé & 32.933 & 27.186 & 20.106 & $-1,73$ & $-3,3$ & 2,1 & 95,7 \\
\hline Belém & 58.300 & 49.697 & 38.268 & -1.44 & $-2,86$ & 6 & 63,8 \\
\hline Mooca & 84.501 & 71.999 & 63.211 & $-1,45$ & $-1,44$ & 7,7 & 82,1 \\
\hline T. distritos & 751.874 & 651.185 & 526.600 & $-1,3$ & $-2,23$ & 51,9 & 101,5 \\
\hline MSP & 8.493 .226 & 9.646 .185 & 10.405 .867 & 1,16 & 0,85 & 1509 & 69 \\
\hline
\end{tabular}

Comparativamente com distritos Bela Vista e Santa Cecília, que embora perdendo população mantiveram alta densidade, com 242,9 e 182,3 hab/ha. respectivamente, aqueles focalizados por este trabalho, além da baixa densidade populacional que possuem atualmente, demonstram que o processo de esvaziamento se aprofundou com maior intensidade no período 1991/2000.

Aliada à deteriorarão de parte considerável dos edifícios e do ambiente urbano, atualmente a reciclagem das antigas fábricas pode ser notada com certa intensidade, visto se tratar de instalações adequadas para grandes depósitos, mas dificilmente essas transformações por si só sejam indicadoras de melhorias 
nos padrões físicos- ambientais das áreas abordadas, uma vez que se prendem aos interesses do capital comercial e imobiliário

Outros aspectos sobre a caracterização dessas áreas merecem ser mencionados:

1 A heterogeneidade existente no interior dos bairros, com áreas dominadas pela incidência de numerosos cortiços, espaços com morfologia urbana do início do século passado, setores ocupados com residências de classe média e áreas que sofreram renovação urbana radical, como a que ocorreu no Brás, em que o Metrô demoliu as quadras existentes que deram lugar, posteriormente, a numerosos edifícios para a classe média, construídos pela $\mathrm{COHAB}$.

2. A exigüidade de espaços livres no tecido urbano desses bairros, principalmente no Brás, dado o intenso parcelamento do solo e a máxima utilização dos lotes, características históricas do processo de urbanização. Em contrapartida, há grande disponibilidade de áreas públicas sub-utilizadas e mesmo não utilizadas, remanescentes da drenagem da várzea do rio Tietê e do posterior traçado da avenida Marginal.

3. $O$ predomínio de comércio especializado que ocorre em setores que se tornaram referência para a cidade e mesmo para outras regiões do Estado e do país: confecções no Brás e Bom Retiro, zona cerealista, madeireira e de couros no Brás e comércio de utilidades domésticas e doces no Pari, etc. Nesses locais a oferta de habitação é condicionada a edificações quase sempre deterioradas, com alta incidência de cortiços horizontais ou verticais.

4. A diversificação social existente nesses bairros, com pequeno número de antigos moradores italianos e portugueses, mesclados com imigrantes árabes e judeus radicados há muitas décadas, migrantes nordestinos, e mais recentemente, coreanos e os imigrantes da miséria existente nos países latino-americanos vizinhos, os bolivianos e peruanos, que se constituem na mão-de-obra ultrabarata para o setor de confecções, que domina o Brás e o Bom Retiro. Essa população passou a ocupar significativamente os cortiços desses dois bairros mencionados, além do Pari, Belenzinho e Vila Guilherme, devido à proximidade das áreas de trabalho e oferta de equipamentos sociais de saúde e educação. 


\section{3 - Pressupostos e Hipóteses}

processo de estruturação de São Paulo no período da sua industrialização implicou na organização de um conjunto de bairros no entorno do núcleo central da cidade e definiu uma especificidade funcional e morfológica da área da pesquisa em relação aos demais bairros centrais. Essa dinâmica estabeleceu uma hierarquia entre os mencionados bairros e considerando esse quadro, o trabalho associou as seguintes hipóteses:

- As especificidades físico-ambientais do Bom Retiro, Brás e Parí, devem-se, além das estabelecidas pela sua estruturação inicial, ao fato de após as décadas de 1940 e 1950, esses bairros serem contíguos ao Centro Velho, diferentemente dos espaços ligados ao Centro Novo. Os lugares próximos ao Centro Velho tiveram mantidas as condições "antigas" devido a ausência de intervenções públicas dinamizadoras dos investimentos privados, como ocorreu com o mercado imobiliário nos bairros centrais a sudoeste.

- As áreas abordadas garantiram ao longo de décadas uma reserva de solo urbano com valores inferiores a outras localizações junto ao Centro, definidor da posição hierárquica desses bairros na cidade. Isso não se deveu apenas à heterogeneidade física e social do Bom Retiro, Pari e Brás, pois os bairros da Lapa e Pompéia apresentaram nas primeiras décadas do século XX características tipológicas semelhantes. Para estes últimos, foram decisivos nas décadas seguintes dois fatores: localização junto à alta renda e junto ao setor terciário de elite. Junto ao núcleo central, bairros como Bom Retiro, Pari e Brás, se constituíram em ilhas do terciário inferior, ligados aos setores alimentício, de madeira, vestuário, máquinas e peças, etc.

- Dadas as características atuais dos bairros pesquisados, os mesmos apresentam condições para estruturar uma intensa transformação física-ambiental do setor central da cidade de São Paulo, permitindo o adensamento populacional, fundamentado na disponibilidade de áreas livres públicas em grande parte ociosas, tais como a orla ferroviária e as áreas remanescentes do traçado da avenida Marginal Tietê. A elas, somar-se-iam parcelas desse território que se encontram atualmente estagnadas, mas que apresentam base fundiária para aquele adensamento, aliada à oferta de transporte público já instalado. 


\subsection{Metodologia}

O trabalho considerou o Desenho Urbano como campo do conhecimento, que reúne os elementos interdisciplinares necessários para a identificação, análise e proposição para o território enfocado. Para tanto, foram associadas três escalas de abrangência e uma abordagem metodológica que permitiu a utilização de diferentes instrumentos de análise, em função dos problemas que cada escala envolveu:

- A escala da cidade: relacionada à configuração macro, estruturação das áreas enfocadas e as interfaces existentes no arranjo intra-urbano entre bairros e entre eles e o núcleo central. Análise das características morfológicas gerais e tendências recentes de transformação.

. A escala dos bairros: relacionada à caracterização de setores e sub-setores, suas características morfológicas, aspectos do uso e ocupação do solo.

. A escala local: projetos urbanos propostos, alternativas de desenho urbano contemplando a valorização de espaços públicos, o adensamento habitacional, equipamentos, etc.

Para a análise da estruturação dos bairros centrais, o trabalho seguiv a elaboração metodológica de Solà-Morales, constituída das componentes "urbanização, parcelamento e edificação", que caracterizam as diferentes maneiras de organização de ruas, terrenos e casas - infra-estruturas, parcelas e tipos. Esse autor relacionou a urbanização às formas infra-estruturais dos traçados viários, as redes de serviço, as margens de água, os nós de comunicação, os grandes acessos, etc. O parcelamento foi relacionado ao desenho do solo com toda sua variedade de formas, sistemáticas ou casuais, compostas geometricamente ou por repetição, dependentes das situações topográficas, agrícolas e cadastrais precedentes (Solà-Morales, 1997, 15).

Essas categorias permitem uma abordagem do processo histórico do crescimento da cidade através de instrumentos pertencentes ao campo do arquiteto e urbanista, segundo o autor mencionado. Isso ocorre porque, ao afirmar que para se entender a forma urbana em toda sua variedade, significa entendê-la como o resultado de idéias e projetos sobre "a forma da urbanização + a forma do parcelamento + a forma da edificação" e reconhecer a independência que possa existir em cada uma dessas formas em relação às demais. Solà-Morales defende que dessa forma ampliam-se os elementos para a pesquisa urbana, se comparado às abordagens sobre os determinismos dos grandes processos sociais, que se constituíram em um modismo teórico décadas atrás e que "priva o processo de urbanização de toda a sua autonomia", isto é, "adota a cadeia conceitual industrialização-migrações-urbanização como paradigma causal de uma seqüência quase indestrutível", como afirma o autor (Solà-Morales, 1997, 14). 
Relacionada à proposição de Solà-Morales, uma formulação da profa ${ }^{\text {. Maria }}$ Adélia de Souza sintetiza de forma exemplar o desafio colocado aos trabalhos que desenvolvem estudos a respeito da urbanização: "a direção tomada por essa expansão, num primeiro momento, pode ser determinada pelo espaço natural ou pelo espaço produzido (ou pela combinação dos dois); e num segundo momento, é quase exclusivamente determinada em função do espaço produzido ou adaptado. Trata-se da sobreposição de um sítio social (fruto do trabalho do homem) a um sítio natural, onde diferenciação de renda se assemelha a diversificação morfológica" (Souza, 1994, 181).

Para a abordagem do trabalho, adotou-se portanto:

- A compreensão de como as formas infra-estruturais e de parcelamento transformaram o território enfocado, caracterizando-o em relação aos demais espaços da cidade. Trata-se de estabelecer uma ligação entre os fatores determinantes da estrutura espacial, os "poderes homogeneizantes" derivados da abordagem a partir das relações de produção e os aspectos de heterogeneidade, também relevantes para o conhecimento do espaço. Com relação a estes, considera o estudo "Anotações sobre Espaço e Vida Cotidiana" que mesmo "um conceito-chave da análise das cidades, como o de tecido urbano, busca uma continuidade que não verificamos no espaço cotidiano", corroborando a análise da prof ${ }^{a}$. Maria Adélia, onde a heterogeneidade é um elemento intrínseco no arranjo urbano. (Albano, Werneck, in Espaços \& Debates 17, 1986, 37).

. A distinção da abordagem, daquilo que poderia se constituir em um registro historiográfico. Para a pesquisa da estruturação dos bairros centrais recorreu-se além das fontes bibliográficas, aos trabalhos sobre planos urbanísticos, legislação e projetos que intervieram na configuração de São Paulo que, como no caso dos transportes, "..sempre foram, em qualquer modo de produção, os maiores modeladores do espaço, tanto intra-urbano, quanto regional", como afirmou Villaça $(1998,136)$.

Para fundamentar a abordagem do trabalho, a abrangência das escalas propostas e conceitos por ele utilizados, consideramos também as formulações do professor Milton Santos sobre a relação região e lugar, presente no tema proposto e na realidade fragmentada da cidade:

"A região e o lugar não tem existência própria. A região e o lugar, aliás, definemse como funcionalização do mundo e é por eles que o mundo é percebido empiricamente... A cada momento histórico, tais recursos (o capital, a população, a força de trabalho, o excedente) são distribuídos de diferentes maneiras e localmente combinados, o que acarreta uma diferenciação no interior do espaço total e confere a cada região ou lugar a sua especificidade e definição particular. Sua significação é dada pela totalidade de recursos e muda conforme o movimento histórico "(Santos, 1995, 131, grifo nosso). 
Segundo Santos, para o estudo da sociedade e do espaço, o estudo da totalidade da realidade social se mostra impossível de ser empreendido, sendo necessário "fragmentá-la para em seguida reconstruí-la". Para tanto o geógrafo propôs as seguintes categorias que representariam o movimento da totalidade: Estrutura, Processo, Função e Forma, definidoras do espaço em relação à sociedade (1997 57). Segundo o autor:

"Forma é o aspecto visível de uma coisa. Refere-se, ademais, ao arranjo ordenado de objetos, a um padrão. Tomada isoladamente, temos uma mera descrição de fenômenos ou de um de seus aspectos num dado instante do tempo. Função, de acordo com o Dicionário Webster, sugere uma tarefa ou atividade esperada de uma forma, pessoa, instituição ou coisa. Estrutura implica a inter-relação de todas as partes de um todo; o modo de organização ou construção. Processo pode ser definido como uma ação contínua, desenvolvendo-se em direção a um resultado qualquer, implicando conceitos de tempo (continuidade) e mudança" (idem, 50, grifo nosso).

Milton Santos também observou a inter-relação das instâncias urbanas, caracterizando o espaço como a soma da paisagem (configuração geográfica) e da sociedade. Quanto ao lugar e localização, afirma que não se pode confundilos, pois "o lugar pode ser o mesmo, as localizações mudam" Esses conceitos foram assim explicados:

"A localização é resultante do movimento do mundo, apreendido em um ponto geográfico, que vem a ser o lugar. $O$ lugar apresenta sempre mudanças de significação devido ao movimento social, isto porque as frações da sociedade se transformaram". Conclui Santos que "lugar é o objeto ou conjunto de objetos. A localização é um feixe de forças sociais se exercendo em um lugar" (idem, 2, grifos nossos). 
PARTe 1 


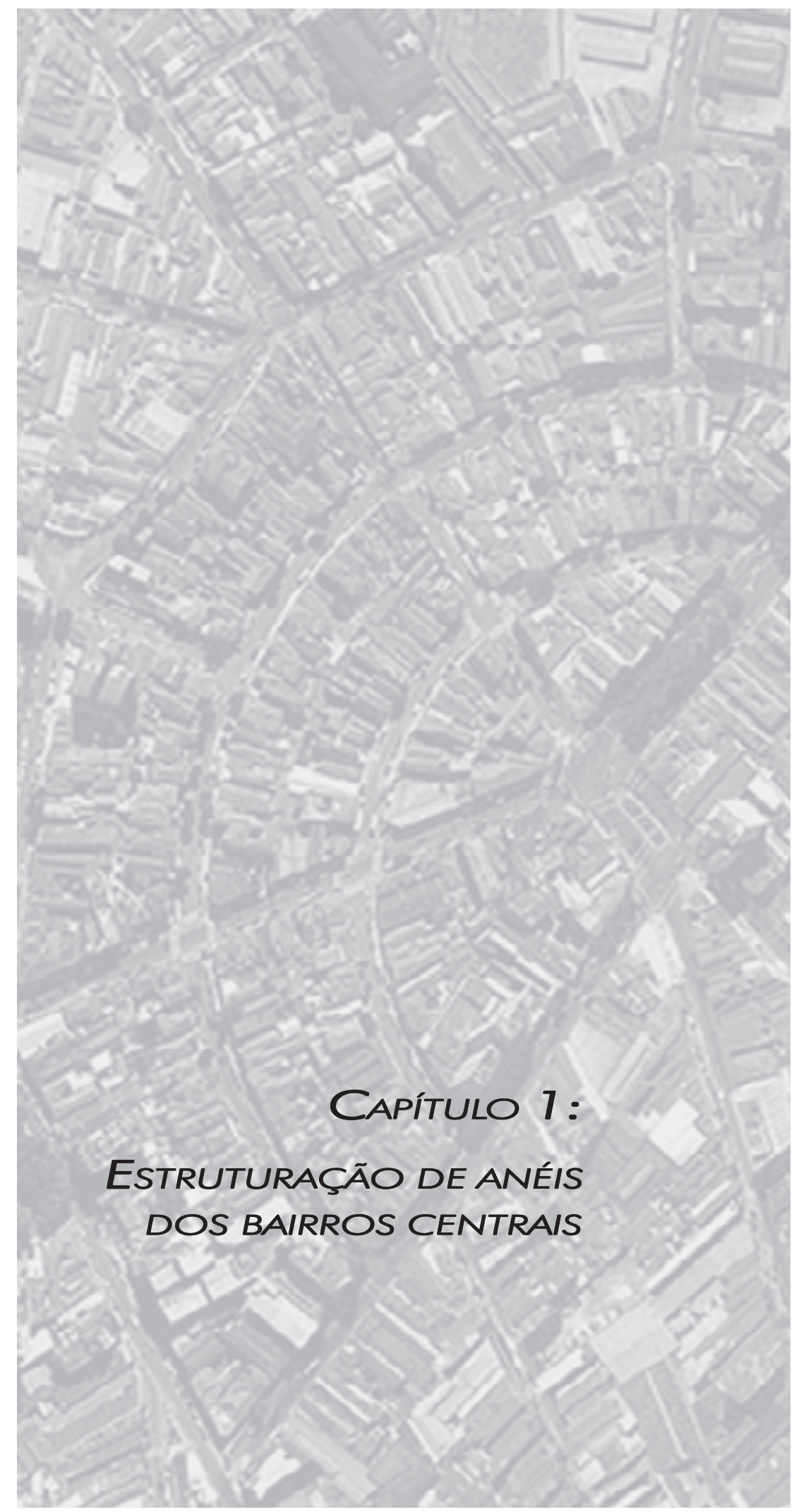




\section{Estruturação do anel de bairros centrais}

A ferrovia foi o elemento de infra-estrutura implantado pela economia cafeeira para ligação das áreas de produção do interior com o porto de Santos, que se tornou importante organizador do espaço urbano, definindo novos usos e ocupações e indutor da ampliação da malha viária da cidade. A profunda mudança que a cidade sofreu da década de 1870 até os anos 30 do século XX, esteve alicerçada em dois fortes ciclos econômicos, sendo que da metrópole do café à fase da industrialização que precedeu a crise de 1929, a cidade saltou de um pouco mais de vinte mil para quase um milhão de habitantes.

Nesse mesmo período, a ocupação física de São Paulo passou aproximadamente, de modestos $3 \mathrm{Km}^{2}$ para 104 km² (Emplasa, DIF, CIG), atestando a relevância do processo de expansão, que resultou na organização de uma cidade estruturalmente hierarquizada, a qual manteve as suas características físicas e funcionais até a metade do século $X X$, quando então surgiram novas áreas industriais, novos eixos de transportes rodoviários e novos setores de serviços.

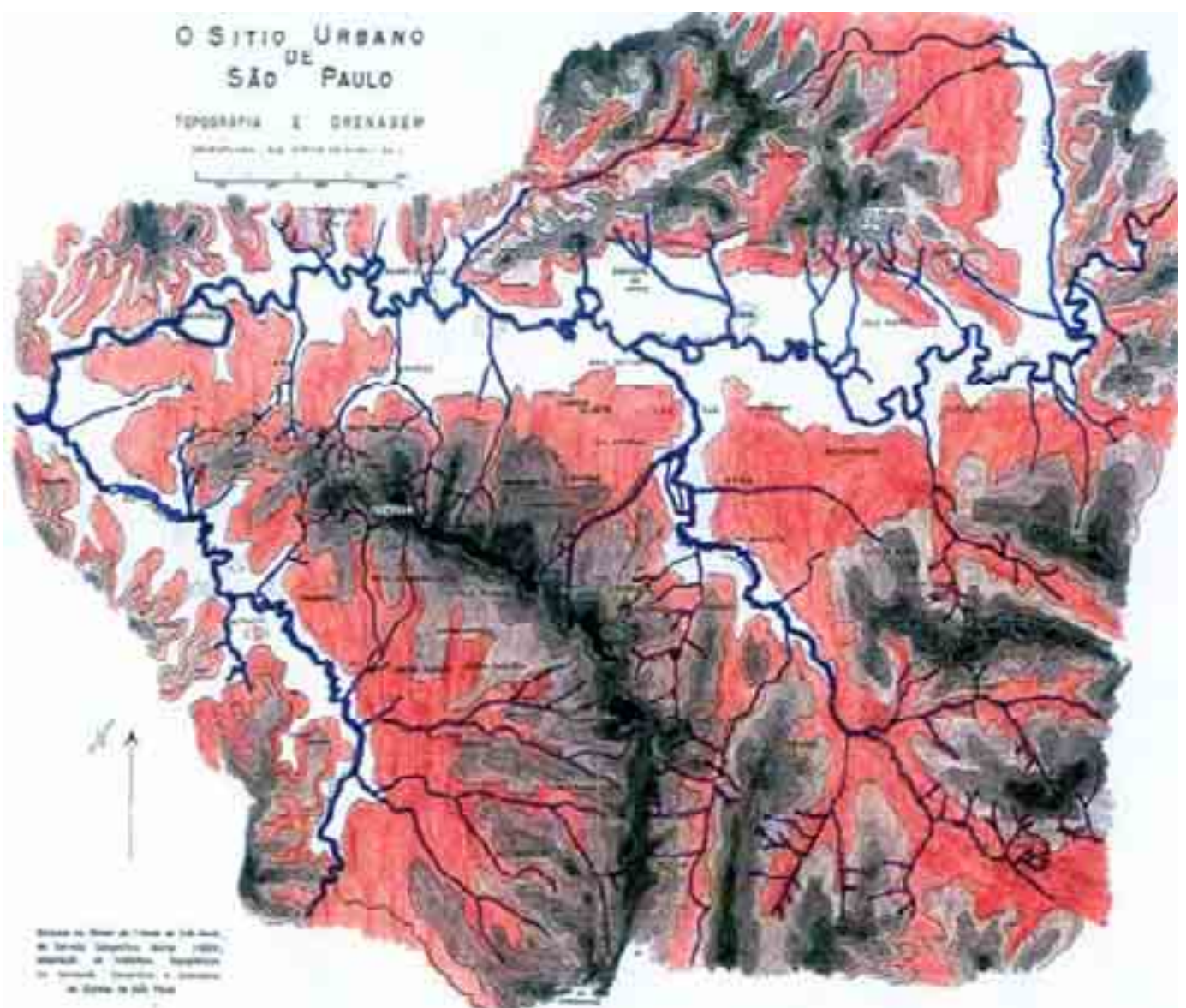

Mapa 01: Comissão Geográfica e Geológica do Estado de São Paulo, adaptadando os levantamentos na Planta da Cidade de São Paulo, de 1924, do Serviço Geográfico Militar. As cores mais escuras correspondem às áreas mais altas, o branco às várzeas. 
Inúmeros estudos no campo da geografia e da história do urbanismo indicam a década de 1870 como marco das transformações que a cidade experimentou nos tempos seguintes, sendo o café o principal agente deflagrador desse processo, modificando o que era antes o "burgo de estudantes" (1828-72) para "metrópole do café" ou "capital dos fazendeiros" (1872 a 1918) (Azevedo, 1958, 70).

Quais foram os principais fatores geradores das transformações que São Paulo experimentou? Considerando a análise de Morse, três aspectos foram fundamentais para a nova espacialidade da cidade a partir de 1870:

- a função de São Paulo se constituir em ponto mediador para o contato comercial e ideológico com países estrangeiros

- a transformação técnica ocorrida nos transportes e o aparecimento do mercado de trabalho nos moldes capitalistas

- a vinda massiva dos imigrantes estrangeiros que crescentemente se fixaram na cidade. (Morse, 1970, 20)

Até o advento das ferrovias, a cidade de São Paulo apresentava o seu núcleo mais denso e consolidado - o chamado "Triângulo" histórico - circundado por duas faixas concêntricas, onde ocorriam atividades diversas de caráter semiurbano ou rural. $\bigcirc$ primeiro cinturão, denominado "cinturão das chácaras", esteve organizado para a cidade, com função de residência de fazendeiros do interior e secundariamente com função de produção.

Além disso, nesse cinturão das chácaras havia também instalações que requeriam isolamento ou grandes áreas, tais como pouso de tropas, cemitérios, hospitais, depósitos de pólvora, etc. Esses setores, mais próximos aos arredores do núcleo da cidade, tornaram-se o suporte da expansão urbana de São Paulo.

O segundo, o "cinturão caipira", que mais tarde foi afetado pela expansão suburbana dirigida em parte pela ferrovia, se caracterizou por não estar organizado inteiramente em função da cidade, dada a presença da cultura de subsistência, áreas incultas e ainda modestos núcleos populacionais que desempenhavam também algum papel de convergência (Langenbuch, 1971, 76).

A circulação pelo território se deu por modestas rotas principais e caminhos de ligação entre elas, mais precários ainda. A importância dessa rede de estradas convergente a São Paulo, foi de torná-la um pólo mediador comercial urbano, como apontou Morse, e também de estruturar os seus arredores, segundo Langenbuch.

A significativa circulação de âmbito local e regional para o foco representado por São Paulo, era ocasionada pela função abastecedora do núcleo central da 
cidade que algumas áreas dos arredores desempenhavam, além de centro de peregrinação para finalidades diversas (Langenbuch, 1971, 74)

É preciso destacar, entretanto, importância do "sistema São Paulo-Santos" para o setor da economia paulista, estabelecido pelos antigos caminhos, que colocou a cidade em contato com o exterior e exerceu atratividade

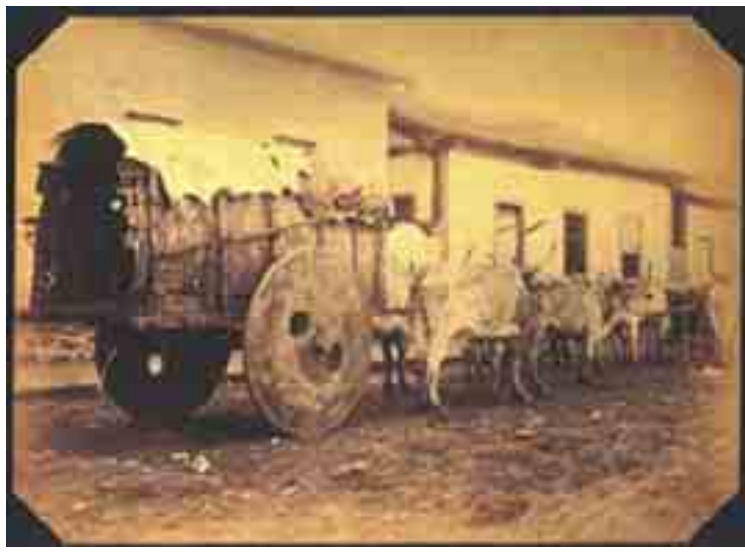

Fig 01: Primórdios dos tranportes de carga: tropas e carros-de-boi para senhores de engenho da cana de açúcar, que antes dos fazendeiros do café, fixaram residência na cidade (Singer, 1968, 26).

Com a implantação da ferrovia pioneira, a "San Paulo Railway Co", o sistema São Paulo-Santos se consolidou, sendo que já na última década do século XIX, as exportações de café pelo porto de Santos superaram do Rio de Janeiro a sua posição hegemônica.

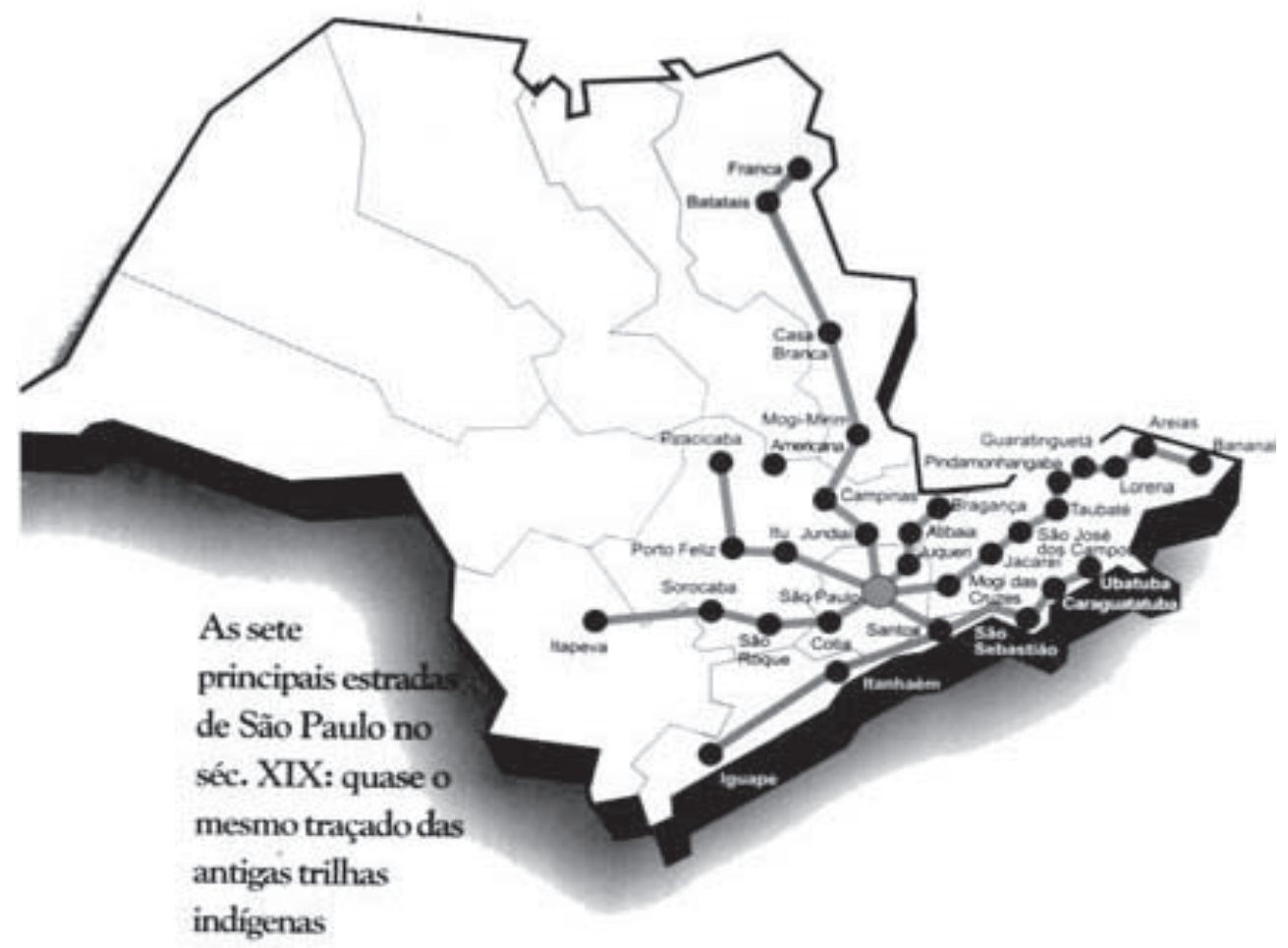

Fig. 02: Estradas de ferro no estado de São Paulo em fins do século XIX 
As rotas principais que confluíam à cidade ligando-a a outras regiões apresentavam as seguintes orientações:

-A nordeste para o Rio de Janeiro, ao longo do rio Paraíba, ligando São Paulo à capital do império e posteriormente da república, além das áreas onde havia nascido a agricultura cafeeira

-Ao norte, para Minas Gerais, através de Atibaia e Bragança

-A noroeste, em direção a Jundiaí e Campinas, sendo a direção que a ferrovia inglesa seguiria, penetrando nas novas áreas cafeeiras

-A oeste-noroeste, seguindo a direção de ltu, onde partiram as Monções do século XVIII em direção a Mato Grosso

-A oeste, para Sorocaba, centro de comércio de animais e desse núcleo em direção ao sudoeste, para as províncias criadoras de gado (Morse, 1970, 42)

Geograficamente, as ferrovias expandiram a lavoura do café para o oeste, com a cidade de Campinas desempenhando importante função nessa rede. Com efeito, a precariedade dos transportes para o planalto e posteriormente para o porto de Santos limitava a distância da área de plantio para o centro de comercialização, a cidade de São Paulo, o que na economia da cultura extensiva do café representava prejuízo comercial dada a inviabilidade de expansão da produção em terras mais distantes.

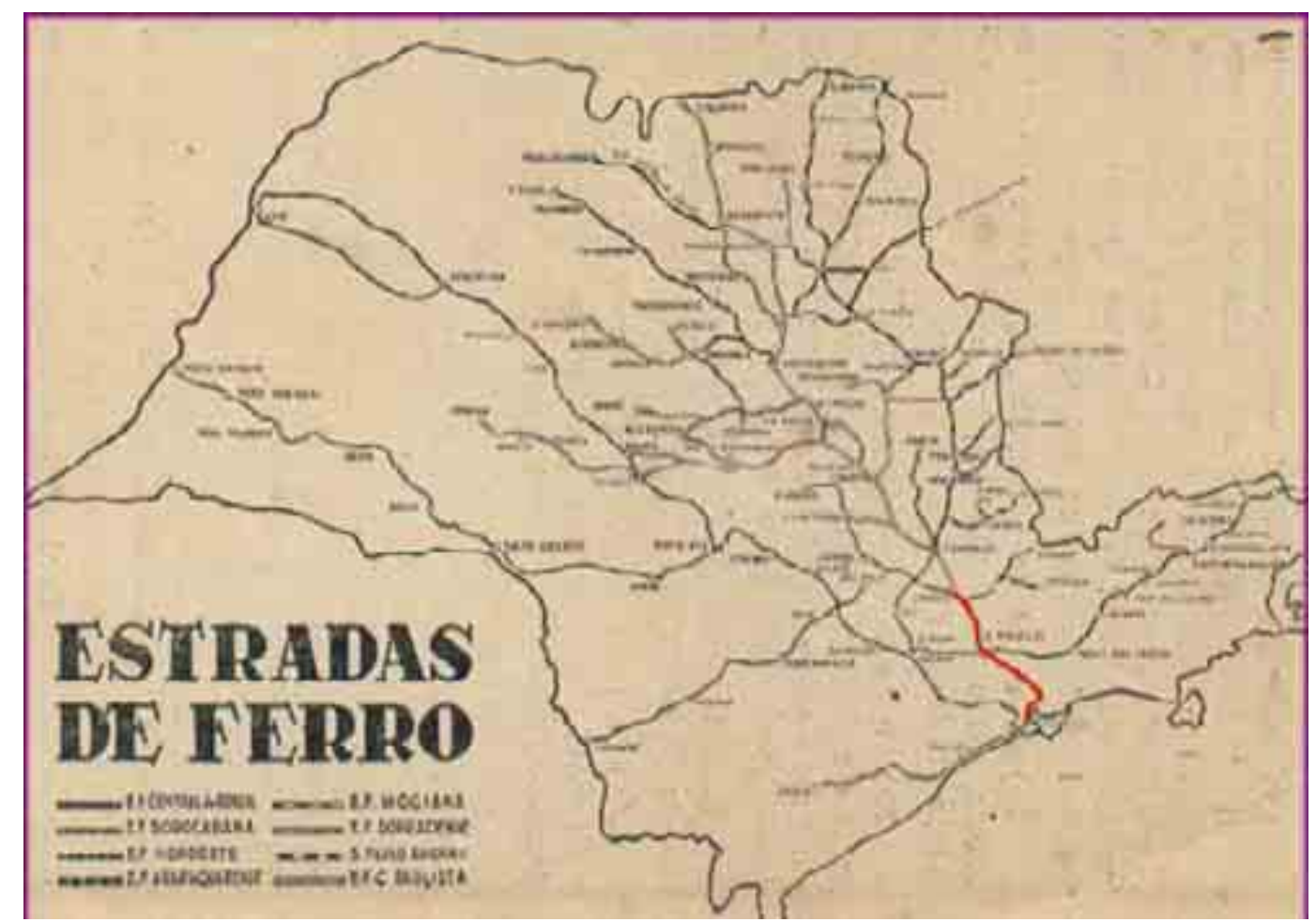

Fig.03: Estradas de ferro no Estado de São Paulo em 1929 
Embora não coincidentes em traçado, a correspondência geográfica entre os antigos caminhos e os eixos ferroviários atendeu aos interesses de escoamento da produção cafeeira que penetrava os sertões das terras paulistas. Reforçando a importância da circulação do interior no sentido da capital, apenas oito anos após a ferrovia Santos-Jundiaí ser concluída, já funcionavam também as quatro principais ferrovias da Província:

A Cia. Paulista, extensão do eixo Santos- Jundiaí, concluída após as seguintes etapas:

de Jundiaí a Campinas em 1872; a Limeira e Rio Claro, em 1876 e a Descalvado em 1881 .

Cia. Ituana, construída entre 1873 e 1879, ligando Piracicaba a ltu, a partir de Jundiaí

Cia. Sorocabana, aberta em direção a oeste, concluída a ligação com Sorocaba em 1875 e a Tietê em 1883

Cia. Mogiana, aberta em direção ao norte, de Campinas a Moji Mirim e Amparo em 1875, a Ribeirão Preto em 1878 e Poços de Caldas em 1886, ligando São Paulo também a uma região do sul de Minas Gerais, trazendo-a à esfera econômica de São Paulo, como observa o autor.

Cia. São Paulo e Rio de Janeiro, que seguia em direção leste-nordeste, ligando a cidade à Capital do país através do Vale do Paraíba, com sua cultura cafeeira já considerada decadente (idem, 228)

Deve ser considerada, como relatou Nestor Goulart Reis Filho, a grande dificuldade técnica da execução da ligação ferroviária planalto-litoral, iniciada por Irineu Evangelista de Souza em 1856, o Barão de Mauá, fator que impediu a realização dos planos elaborados nas décadas de 1830 e 1840 para essa finalidade, dada a escala dos investimentos e dos riscos que então desestimularam os investidores (Reis Filho, 1994, 27).

A precariedade dos caminhos utilizados pelas tropas impediu o crescimento do núcleo urbano de São Paulo, diferentemente das metrópoles coloniais litorâneas brasileiras, que utilizavam com vantagens o transporte marítimo. Essa precariedade do sistema arcaico de transporte se apresentava muito mais acentuada no Brasil do que nos países onde as ferrovias já haviam substituído outras formas de transporte animal, que utilizavam estradas melhores do que aquelas aqui existentes e trilhadas pelas rotas tropeiras. Quando esse processo ocorreu em São Paulo, desencadeou importantes mudanças nos espaços semi-rurais que antes abrigavam as atividades de apoio às tropas, como indicou Langenbuch: "as ferrovias, antes de funcionarem como agentes orientadores da reorganização dos arredores 
paulistanos, provocaram a derrocada do sistema de transportes até então vigente, isto é, o transporte por tropas de burros" (Langenbuch, 1971, 98).

Como corolário do desmantelamento do antigo sistema de transporte, foram profundamente atingidas as atividades destinadas a lhe servir de suporte, como criação, venda, aluguel e tratamento de animais, pousos, abastecimento, etc. Essa prestação de serviços era a principal função de estabelecimentos ou aglomerados existentes nos arredores paulistanos (idem, 98). As ferrovias como inovação técnica dos transportes, como afirma também Reis Filho, "redefiniram as relações no espaço e permitiram o aparecimento de graus significativos de concentração em alguns pontos" (Reis Filho, 1994, 27).

Concorreu também para a nova organização espacial da cidade, o fato da ferrovia utilizar caminhos diferentes das antigas estradas, desvalorizando as áreas que as rotas atravessavam, e conseqüentemente, as atividades ali presentes. Em contrapartida, ao valorizar as áreas por onde passavam, as ferrovias provocaram um desvio nas ruas e caminhos, com o objetivo de se criar acesso elas. $\bigcirc$ trem desencadeou uma vocação suburbana nas faixas por onde passava e suas estações tornar-se-iam pólos de atração de estabelecimentos fabris e de novos assentamentos, os "povoados-estações", que se transformaram em núcleos suburbanos no século XX (Langenbuch, 1971, 129).

Como se observa no mapa 02 (São Paulo, 1810), o plano de ruas de São Paulo foi polarizado pelo caminho que deixava a cidade para o porto marítimo, fazendo com que os edifícios existentes se agrupassem ao longo de um eixo norte-sul. $\bigcirc$ advento das ferrovias fez com que essa orientação fosse gradualmente modificada. Já em 1890, o que era considerada periferia urbana havia adquirido forma circular, alongada a leste em razão da ferrovia para o Rio de Janeiro, e a oeste em direção ao interior, ao encontro das novas áreas de cultivo do café. Esse eixo leste-oeste se constituiu no eixo dominante no século seguinte, o século XX (Morse, 1970, 41 1). As antigas estradas, muitas vezes intransitáveis nos períodos das chuvas, tornaram-se vias de ligação das áreas que gradativamente se tornaram povoadas, como por exemplo o Brás, Mooca e a Penha, através da rota que partia de São Paulo para o Rio de Janeiro.

O crescimento de São Paulo nas décadas seguintes a 1870, foi denominado de "extensão urbana por aglutinação", na análise de Langenbuch relativa à expansão do espaço urbano sobre o "cinturão das chácaras", que passou a integrar a cidade através de parcelamento do solo. Esse processo se mostrou continuamente ativo ao longo do século XX (Langenbuch, 1971, 79). Como fator que contribuiu para a dinâmica de ocupação espacial, diferentemente do que ocorria antes das ferrovias, o crescimento urbano ocorreu também nas áreas até então evitadas pela cidade ou pelos velhos caminhos sinuosos das tropas de burros, isto é, as várzeas e os terraços fluviais de baixadas relativamente enxutas. Como analisou $\mathrm{Ab}$ 'Saber "grandes trechos das principais ferrovias que cruzam a cidade 


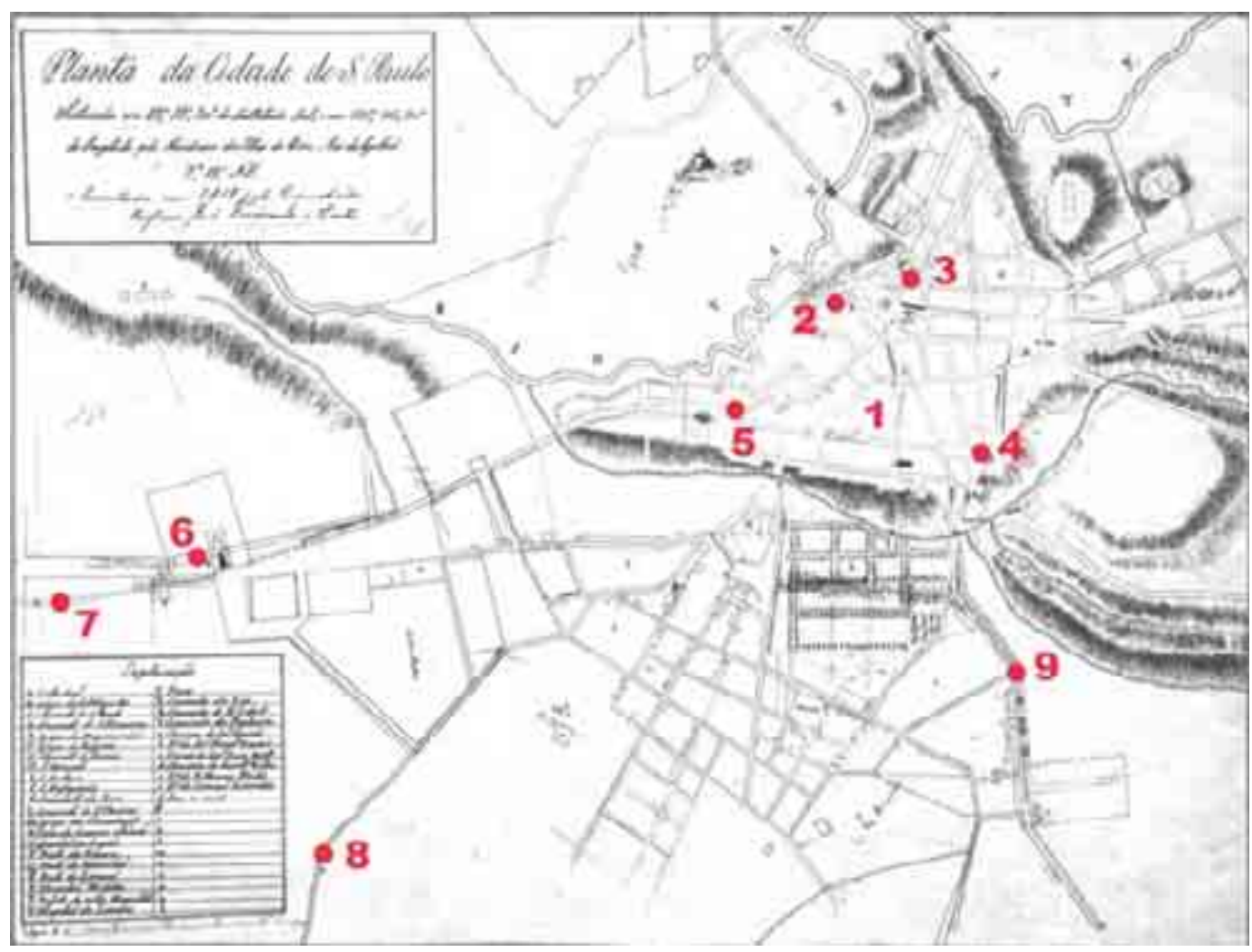

Mapa 02: A cidade em 1810. Foram assinaladas as referências:

1. Triangulo Central; 2. Colégio dos Jesuítas; 3. Catedral; 4. Convento de São Francisco; 5. Convento São Bento, 6. Convento da Luz; 7. Caminho da Luz; 8. Caminho N. S. do Ó;

9. Consolação (caminhos dos Pinheiros)

justapuseram-se aos aludidos terraços" (Ab'Saber apud Langenbuch, idem, 99), espaços que se configuraram posteriormente como áreas industriais ou de moradia operária.

Dessa forma, a estruturação da cidade de São Paulo submeteu-se às características relativas ao sítio físico associada ao transporte de mercadorias da economia paulista. Segundo Villaça, as barreiras representadas pelo eixo da Estrada de Ferro São Paulo Railway definiram uma divisão espacial onde um lado do espaço urbano seria mais vantajoso ao acesso ao núcleo central que o outro. Em virtude desse fato, as camadas de alta renda tenderam a se localizar no lado mais vantajoso, mesmo considerando que essa ocupação apresentava também heterogeneidade social (Villaça, 1998, 193).

A análise de Morse também considerou os obstáculos naturais como condicionantes à ocupação das áreas urbanas ao analisar o crescimento da cidade como um contraponto entre as várzeas do Tietê e do Tamanduateí ao norte e ao oeste (Morse, 1970, 356). Ainda segundo o mesmo autor "ao contrário de muitas estradas históricas que convergiam para São Paulo, as estradas de 


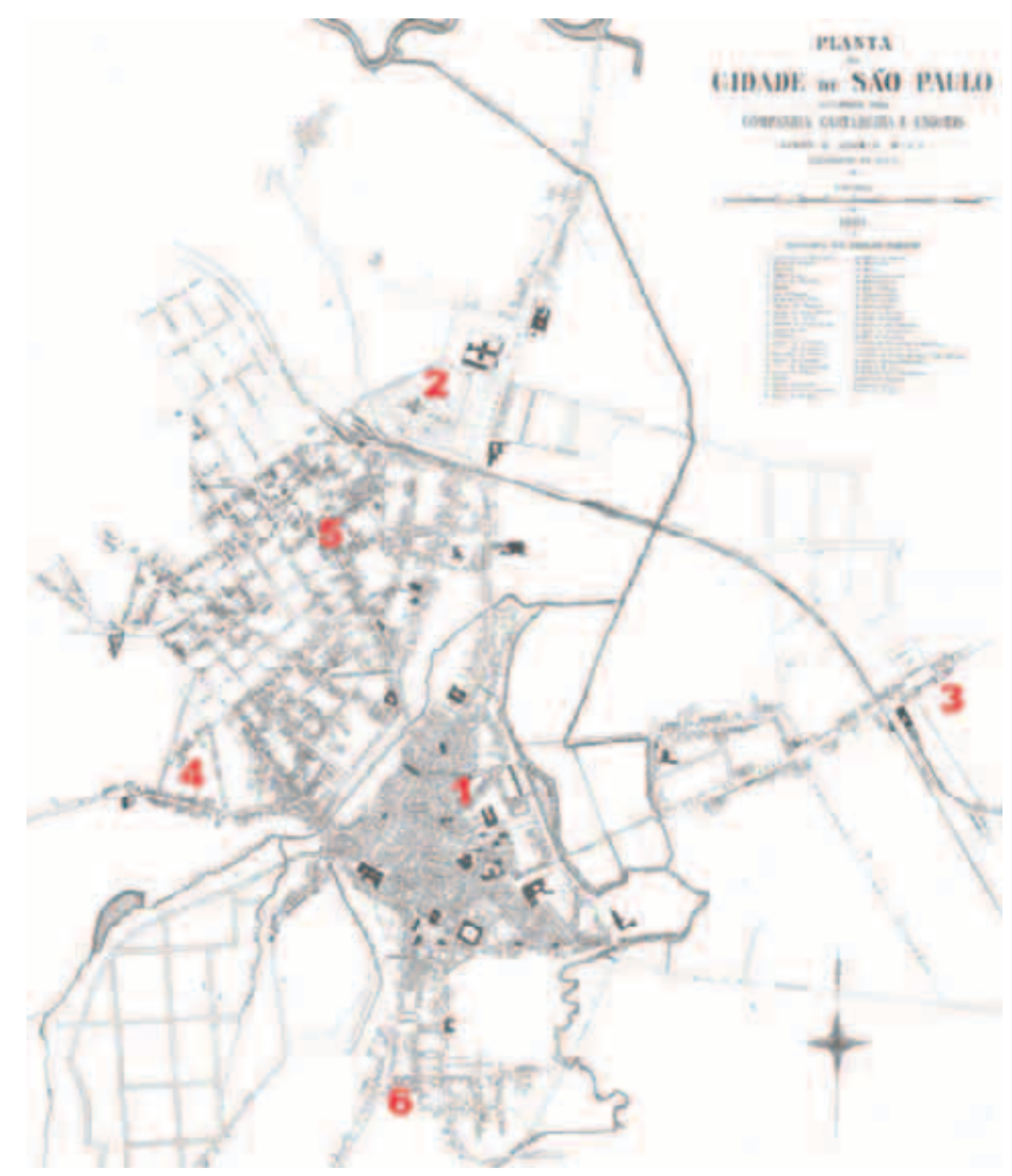

Mapa 03: São Paulo, 1881

Re ferências: 1. Triângulo; 2. Jd. Botânico, 3. Lgo da Concórdia, 4. Rua da Consolação.

5. Sta. Ifigênia; 6. Liberdade.

ferro ficaram ao nível dos rios. A São Paulo Railway chegava de Santos margeando o Tamanduateí, contornava a colina central e então seguia o Tietê antes de dobrar para o norte. A bacia do Tietê era também seguida pela Sorocabana que vinha do oeste; e pela Central do Brasil, vinda do Rio, a este. A São Paulo Railway, em parte pela sua vasta quantidade de desvios, veio determinar a formação de uma faixa industrial que se estendeu por um amplo arco a este ao norte do centro, e do qual muitos terrenos já eram indesejáveis por serem baixos e úmidos. Neste 
arco, principalmente no Brás e na Mooca, foi morar a maioria dos trabalhadores" (idem, 250)

O geógrafo Pasquale Petrone também atribuiu a constituição das áreas industriais ao Leste, Oeste e Sul da cidade aos trilhos das ferrovias: "Não resta dúvidas que as principais áreas industriais acompanham as vias férreas - Brás, Belenzinho, Tatuapé, Comendador Ermelino e São Miguel Paulista ao longo dos trilhos da Central do Brasil; ainda o Brás, Pari, Mooca, Ipiranga, São Caetano do Sul e Santo André, acompanhando a Santos-Jundiaí; Barra Funda, Água Branca, Lapa e Osasco, servidas tanto por esta via férrea como pela Sorocabana". (Petrone apud Azevedo, 1958, 104).

Villaça observou uma questão ligada à ocupação das áreas cortadas pelas ferrovias e principalmente pela vizinhança das estações, explicando o caráter da urbanização da cidade: "note-se que, nesse tempo, as estações ferroviárias eram equipamentos urbanos de prestígio; praticamente não havia indústrias na cidade, tanto que, quando Campos Elísios foi loteado, a proximidade com a Estação da Luz não o prejudicou. Dez anos depois da ferrovia para Santos, a ferrovia para o Rio e a Estação do Norte (depois Roosevelt) não atraíram alta renda da mesma forma que a ferrovia na Barra Funda (a oeste), atraiu menos indústrias que o Brás e a Mooca, a leste. Definia-se, assim, a divisão da cidade em "lado de cá" e "lado de lá" dos trilhos" (Villaça, 1998, 193, aspas do autor).

Outro trabalho a apontar as diferenças já existentes na estruturação e apropriação da cidade afirma que, a partir da década de 1880, passou a haver uma diversificação de funções com o aparecimento ao lado do centro de bairros operários e de bairros residenciais para a classe abastada. Segundo essa análise, "enquanto manteve-se enclausurada na colina histórica, a cidade não conhecia diferenças funcionais relevantes, além das chácaras em sua periferia. Os primeiros bairros operários se localizaram nas terras baixas vizinhas ao Tamanduateí, próximas à colina e nas proximidades das estações ferroviárias e ao longo das vias férreas (a SPR e posteriormente a São Paulo-Rio de Janeiro), estruturando os bairros do Brás, Luz e Bom Retiro. Por outro lado, os primeiros bairros residenciais da elite se instalaram nas terras mais altas situadas além Anhangabau, a oeste, onde foram abertas ruas largas, como foi o caso de Campos Elísios" (Petrone apud Azevedo, 1958, 90).

No já mencionado cinturão das chácaras, Villaça afirma ter ocorrido um processo de urbanização generalizado em todas as áreas circunvizinhas da cidade: "com a proclamação da República, quase todos os donos de chácaras antigas dos bairros de Santa Efigênia, Bom Retiro, Brás, Consolação, Liberdade, Cambucí, Higienópolis, avenida Paulista, Mooca, Pari, Ipiranga, Barra Funda e Água Branca mandaram abrir ruas e avenidas". Segundo o autor, esse fato mostra que a aristocracia paulistana era proprietária de chácaras nos quatro quadrantes da 
cidade, e não apenas no sudoeste, sendo esse, entretanto, o escolhido para sua moradia. Sobre a escolha ter recaído nessa área da cidade, Villaça afirma ainda que esse setor era privilegiado em termos de autenticidade dos papéis legais de propriedade, o que seria de conhecimento do próprio criador dos planos urbanísticos para a "cidade nova" na década de 1870, João Teodoro, para definir localizações em Campos Elísios, Vila Buarque, Consolação e Higienópolis. (Villaça, 1998, 196)

Em contraponto a essa ocupação da camada de alto poder aquisitivo, bairros proletários e zonas de comércio e indústria situaram-se no arco Tietê-Tamanduateí. Do bairro industrial de Água Branca a noroeste, o arco se prolongou pela faixa industrial e proletária do Pari, Brás, Belenzinho e Mooca, atingindo o lpiranga e Vila Prudente a sudeste (Morse, 1970, 357). As áreas do Brás, Mooca, Belém, Belenzinho, Pari e Catumbi se encontravam divididos apenas pela avenida da Intendência (atual Celso Garcia-Rangel Pestana), ligando-se à Luz, Bom Retiro, Canindé e lpiranga, constituindo uma vasta região fabril e de moradia operária. (SEMPLA, 1985, 15).

Associado ao crescimento da cidade, o incremento demográfico foi marcado pela imigração estrangeira, que se constituiu na força de trabalho rural e posteriormente urbana da economia cafeeira e industrial. Os dados relativos à entrada de trabalhadores estrangeiros no Estado de São Paulo atestam a intensidade do movimento migratório: 13 mil entre 1870 e 1880; 184 mil na década seguinte e 606 mil entre 1890 e 1900 (Furtado, 1971, 128).

destino urbano dos imigrantes europeus foi analisado por Morse, que estabeleceu importantes eixos para a compreensão do fenômeno, como se segue em sua análise: "é fácil compreender que europeus ricos ou da classe média podiam vir para a capital por conta própria (como haviam feito em menor escala nas décadas anteriores), atraídos pela sua crescente fama de cidade em rápida expansão ou por relatos de companheiros. Mas, admitindo-se que até mais ou menos 1895, a maior parte da imigração da classe inferior era subvencionada e assim destinada às fazendas, de onde vinham então aqueles estrangeiros que de 1870 a 1890 apareciam como operários têxteis e engraxates, vendedores ambulantes e trabalhadores manuais? Como explicar que, entre 1872 e 1886, a população estrangeira da cidade se tivesse elevado de $8 \%$ para $25 \%$ do total?" (Morse, 1970, 240).

Segundo esse historiador, esse fenômeno se deveu:

- em primeiro lugar ao fato do sistema de colonização estabelecido pelos fazendeiros ter ocorrido dentro de moldes capitalistas, assegurando ao imigrante transporte e satisfação das necessidades vitais, porém mantendo intacta a propriedade da terra. $O$ trabalhador, denominado então colono, mesmo sem recursos, estava livre para se transferir, quando cumpridas suas obrigações com 
o proprietário das terras. As disparidades entre as oportunidades urbanas e as rurais, cada vez mais pronunciadas, deram forças à tendência de fixação na cidade por parte dos imigrantes.

- em segundo lugar, muitos imigrantes subvencionados se fixaram diretamente nas cidades. A Sociedade Promotora de Imigração em São Paulo, organizada pelos cafeicultores e subsidiada pelo Estado, informou que, entre 1886 e 1888, embora a maioria dos primeiros imigrantes fosse para a agricultura, muitos encontraram trabalho na capital ou em outras cidades mais populosas do interior, desenvolvendo consideravelmente todos os ramos de indústria. Segundo essa pesquisa, de 1889 a 1891 a tendência se inverteu e apenas dois quintos iam para a agricultura (idem, 240).

Outra análise, que associa a incorporação urbana da força de trabalho dos imigrantes, aborda o relevante impulso que a economia de mercado nos moldes capitalistas representou para as transformações subseqüentes em São Paulo. Enfocando esse tema, Singer afirma que o escravo não dispunha de nenhuma autonomia como consumidor, iá que sua liberdade pessoal era usurpada. Assim, era sustentado apenas para a subsistência, situação muito diferente dos imigrantes estrangeiros. Estes últimos obtinham parte da remuneração em dinheiro, passando a integrar como consumidores a economia de mercado, e não como no caso dos escravos, a economia de subsistência (Singer, 1968, 43).

Conforme analisou Morse, a dinâmica da ocupação do território nas cercanias do núcleo urbano de São Paulo foi crescente, denominando-a de lutas pelo "espaço vital". O colapso da casa bancária de Mauá, em 1875, ocasionou, segundo o autor, novo impulso à especulação dos terrenos urbanos. Nesse sentido, - bairro da Liberdade, que conduzia à zona sul da cidade se transformaria num bairro "respeitável". Em contrapartida, segundo o mesmo autor, "para os terrenos perto da estação (da Luz) só se podia haver pretensões mais humildes". Um anúncio da época, reproduzido na íntegra, demonstra essa situação:

"Grande attenção: terreno para os pobres

È a primeira vez que em São Paulo vendem-se lots de terrenos por $200 \$ 00$.

Quem pensaria que nesta cidade, no pittoresco bairro da Luz, se havia de vender lotes de terrenos tão baratos, ao alcançe de todos.

Quem quizer verificar esta verdade, recorra á casa de Eugênio Seide, em frente á estação de carga da estrada de ferro Ingleza, e alli encontrará quem vos mostre riquíssimos terrenos entre as ruas do Dr. João Teodoro e o Seminário, perto do jardim botânico, e com bondes a algumas braças de distância, pelo diminutíssimo preço de $200 \$ 000$ o lote, terrenos perfeitamente promptos para receber edificações" (Diário de São Paulo, 20/9/1877 apud Morse, 1970, 249) 
Em contraste aos bairros fabris que se formaram nas terras baixas, ocorreu 0 surgimento do primeiro bairro de alto padrão na cidade em 1879, quando Frederico Glette, adquiriv extensa chácara a oeste do centro, no bairro de Campos Elísios. "Depois de traçar mais de uma dúzia de ruas, ao custo de 100 contos, vendeu os lotes com um lucro igual a oito vezes essa soma. M. Burchard, outro alemão e sócio de Victor Nothmann, também se dedicou à propriedade imobiliária nessa zona e abriu a avenida que atravessa o aristocrático bairro de Higienópolis" (idem, 249)

A partir do parcelamento da área dos Campos Elísios, a ocupação das classes de alta renda seguiu a direção oeste para posteriormente dirigir-se ao sul, em direção ao espigão. Villaça considerou frágil a hipótese da busca de terras altas como a única determinante para explicar a ocupação pelas camadas abastadas da sociedade paulista na transição para o século XX, salientando ser a acessibilidade ao centro fundamental para entender o controle sobre os tempos de deslocamento que as camadas de alta renda detiveram no processo de ocupação territorial. (Villaça, 1998, 197). Na realidade, como veremos adiante, o parcelamento de terras baixas foi empreendido pela Cia City na várzea do rio Pinheiros, nas primeiras décadas do século e com lotes destinados à população de alta renda.

Em continuidade a essa ocupação, o avanço dos bairros de alto padrão, considerados por Morse como "um dos mais expressivos aspectos do desenvolvimento", começou em 1890 através de Higienópolis até a avenida Paulista, no espigão, para prosseguir depois pelas vertentes até os Jardins (Morse, 1970, 249). A avenida Paulista, foi inaugurada em dezembro de 1891, a partir da compra e fracionamento da chácara do Capão e fruto de um projeto do engenheiro-investidor Joaquim Eugênio de Lima. Os melhoramentos introduzidos nessa artéria emblemática da burguesia do café duraram mais de uma década, porém no início do século XX, inúmeras mansões se misturavam ao paisagismo do grande boulevard criado pelo engenheiro uruguaio.

Considerando os aspectos que a estruturação da cidade apresentou no período enfocado, mencionamos novamente Villaça que afirmou ser os dois elementos mais importantes de estruturação do espaço metropolitano, as zonas industriais e a região de concentração dos bairros das camadas de renda mais altas, pelo grau de independência que desfrutam na escolha e produção de suas localizações. Em relação às zonas industriais, estas são determinadas por parte de forças externas à cidade, como no caso de São Paulo, onde as ferrovias foram indutoras das principais áreas de ocupação fabril. No caso das áreas de concentração das camadas de renda mais alta, um fator determinante para essa escolha se constitui no controle dos tempos de deslocamento espacial, como já mencionado anteriormente (Villaça, 1998, 140/197). 


\subsection{A industrialização emergente: o apito das fábricas no cotidiano paulista}

A atividade industrial iniciada ainda nas décadas finais do século XIX, de forma esparsa e ligada a setores tradicionais, tornou São Paulo o principal pólo econômico e financeiro do país ao longo do século seguinte, possibilitando o desenvolvimento de uma crescente complexidade urbana, espaços especializados e novos e importantes atores sociais: a classe média e o proletariado, cujo crescimento esteve ligado aos novos postos de trabalho tanto na indústria, como na expansão do comércio e serviços.

A industrialização criou na cidade uma dinâmica diferenciada do período em que a economia girava em torno do café. Inicialmente porque este se constituía em produção rural, transladada ao porto de Santos, assim como também ocorria em relação ao porto do Rio de Janeiro para o escoamento da produção fluminense. De forma diversa, a exigência fundamental para os estabelecimentos fabris funcionarem, era a de mão de obra permanente. Isso implicava na existência de trabalhadores estabelecidos na cidade e em número suficiente para esse setor empregador. Ligada a esse contingente de trabalhadores, impôs-se a necessidade da manutenção de suas condições de vida - alimentação, saúde, habitação, transporte - isto é, a reprodução da força de trabalho, que ocorreu sob severas condições. Na cidade, novas ocupações e novas funções urbanas surgiram para tanto, espontâneas ou estruturalmente criadas.

Tomando a entrada do século XX como marco cronológico indicativo das mudanças urbanas, Saes analisa que até 1900 "a cidade teve sua dinâmica determinada pelos vínculos com a produção e com o comércio cafeeiro. A partir de 1900, a cidade adquire crescentemente as feições de uma cidade industrial na qual a indústria determina o caráter e a dinâmica da capital do Estado" (Saes apud Eletropaulo, 1990, 33). Reis Filho também abordou esse quadro analisando que, no período, São Paulo já aparentava possuir a paisagem de um centro industrial de tipo europeu "com grandes pavilhões das fábricas e ao redor, as vilas operárias"(1993, 109).

Como mostrava o levantamento de Bandeira Jr e Heitor Ferreira Lima para o Estado de São Paulo, em 1900, excetuando-se o têxtil, a maioria dos ramos industriais se encontravam na cidade:

- 20 tecelagens existentes, sendo 8 na capital, com o primeiro, o segundo e o quinto lugar em tamanho

- 7 fábricas de chapéu, sendo quatro na capital e entre elas as três maiores

- 5 fábricas de calçados, todas na capital

- 10 fábricas de bebidas, sendo nove na capital e uma em Campinas

- 8 fábricas de roupas, todas na capital 


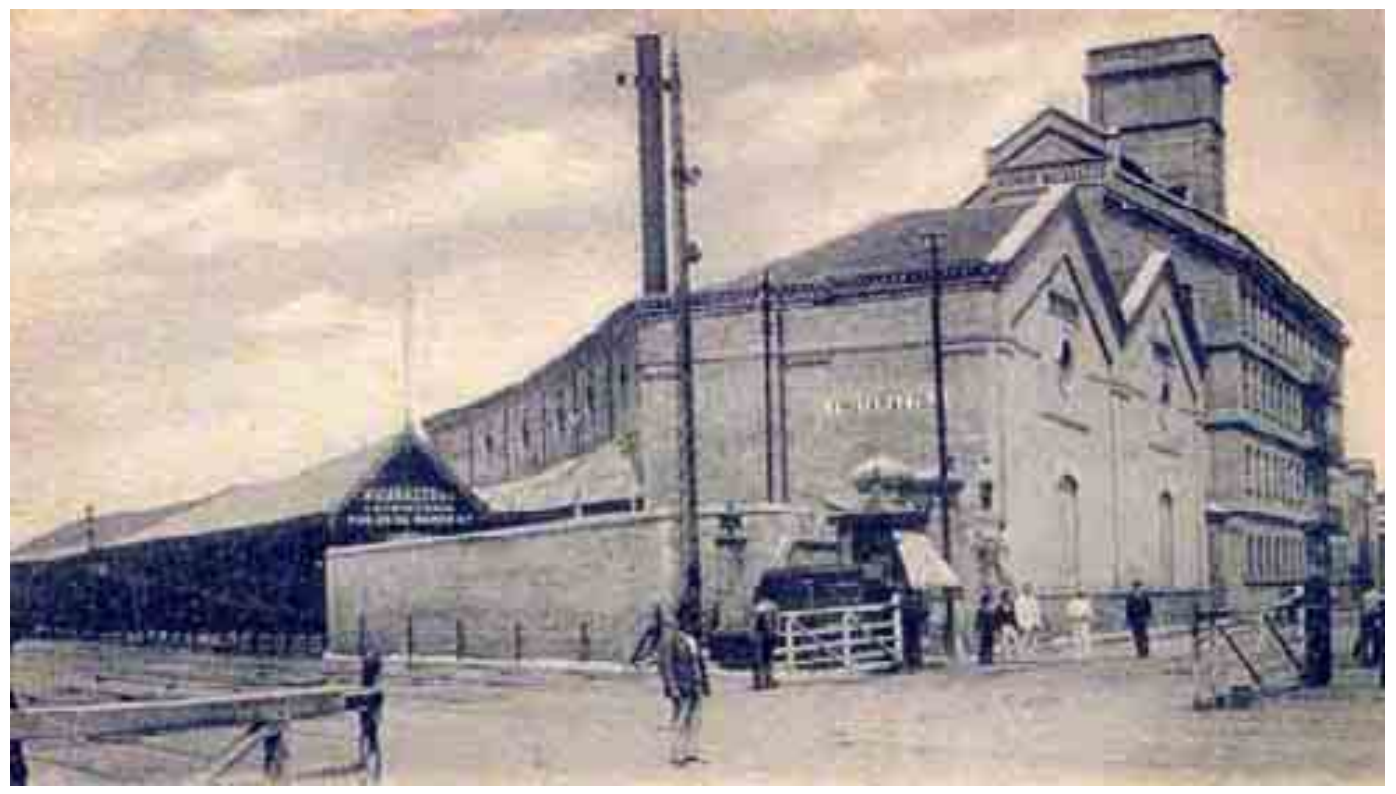

Fig. 04: Moinho Matarazzo, rua Monsenhor andrade, Brás, 1900.

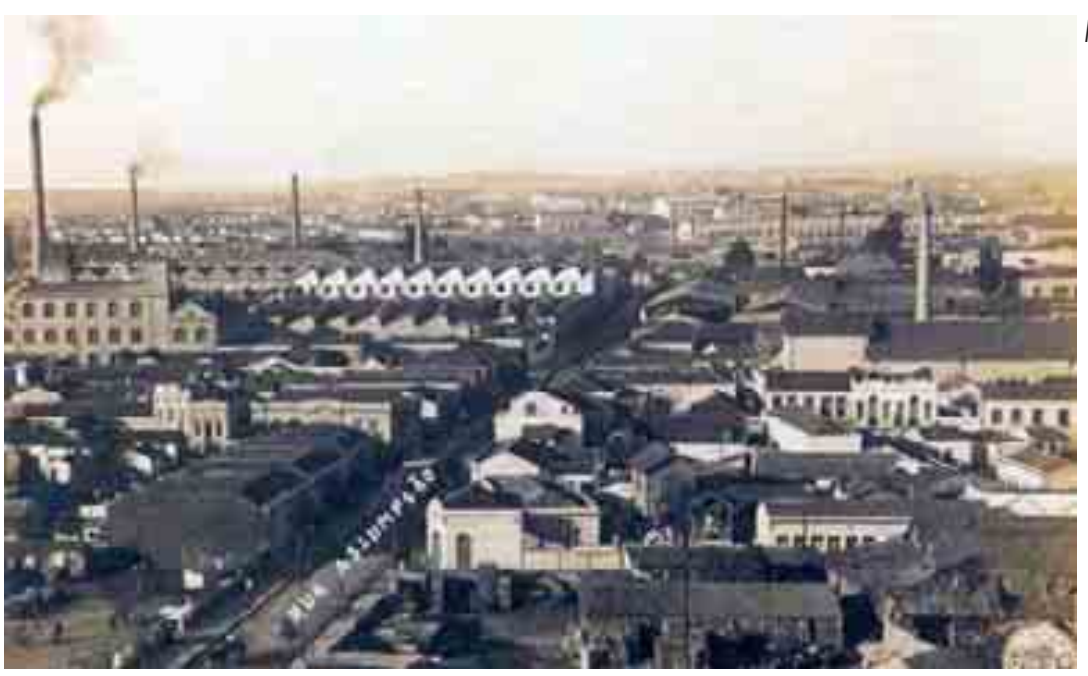

Fig. 05: Brás, 1925

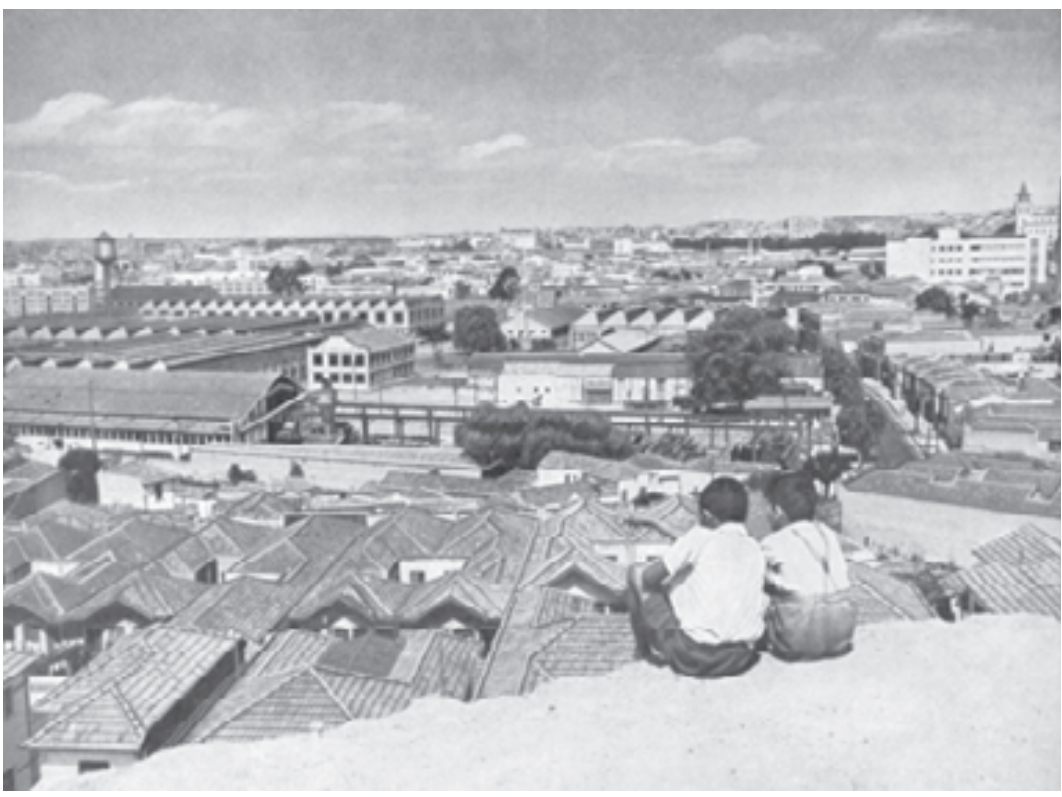

Fig. 06: Brás, 1953 
- 1 fábrica de cimento, no interior

- 1 fábrica de vidro, na capital (Singer,1968, 48)

De acordo com Wilson Cano, a superioridade da indústria paulista começou a se estabelecer já entre 1905 e 1907, ganhando impulso entre 1907 e 1913 e se consolidando durante a I Guerra Mundial. As raízes desse crescimento se deveram ao maior dinamismo da economia cafeeira, ao desenvolvimento da agricultura mercantil de alimentos e de um mercado de trabalho amplo, isto é, a um maior desenvolvimento das relações sociais de produção capitalista (Cano apud Aureliano, 1981, 35)

Quais fatores contribuíram para a industrialização ocorrer nos moldes como ocorreu em São Paulo? Uma pré-condição importante foi dada pela economia cafeeira, transformando a cidade ao longo das três últimas décadas do século XIX. Segundo Dean: "o comércio do café não gerou apenas a procura da produção industrial: custeou também grande parte das despesas gerais, econômicas e sociais, necessárias a tornar proveitosa a manufatura nacional. A construção de estradas de ferro proveio, toda ela da expansão do café. As linhas foram construídas pelos próprios plantadores com os seus lucros ou por estrangeiros seduzidos pela perspectiva do frete do café. Importantíssimo para os primórdios da indústria, mercê da necessidade de matérias primas importadas, como a juta e o trigo, o porto de Santos foi igualmente um empreendimento do café" (Dean, $1990,14)$.

Outro fato significativo do surgimento e desenvolvimento da industrialização em São Paulo foi o de ela não ter acontecido dentro dos moldes sociais e econômicos ocorridos no início do século XIX, no continente europeu. Muitas décadas depois da industrialização dos países centrais, a que surgiu em São Paulo impôs que o industrial, no início de suas atividades, se apoiasse no comércio e não na pequena empresa industrial. Isso porque, numa economia que dependia basicamente de tudo do exterior, os comerciantes importadores e exportadores passaram a realizar operações industriais (ou como querem alguns autores, manufatureiras), dando origem a vários grupos familiares associados à essas atividades, que se tornaram representantes da burguesia industrial (Silva, 1995, 90).

conhecido exemplo de Francisco Matarazzo, que implantou muitas indústrias nos bairros paulistanos desde o início do século XX, foi seguido também pelo arquiteto Ramos de Azevedo, que associado a outros italianos ilustres da colônia, Emílio Menotti Falchi, Nicola e Giuseppe Puglise Carbone e Rodolfo Crespi, fundou em 1910, a Companhia Cerâmica Vila Prudente (Lemos, 1993,77).

crescente mercado consumidor urbano era a verdadeira garantia de rentabilidade aos investidores, com a indústria manufatureira surgindo dentro do quadro da relação entre importadores e consumidores, ou por perturbações 


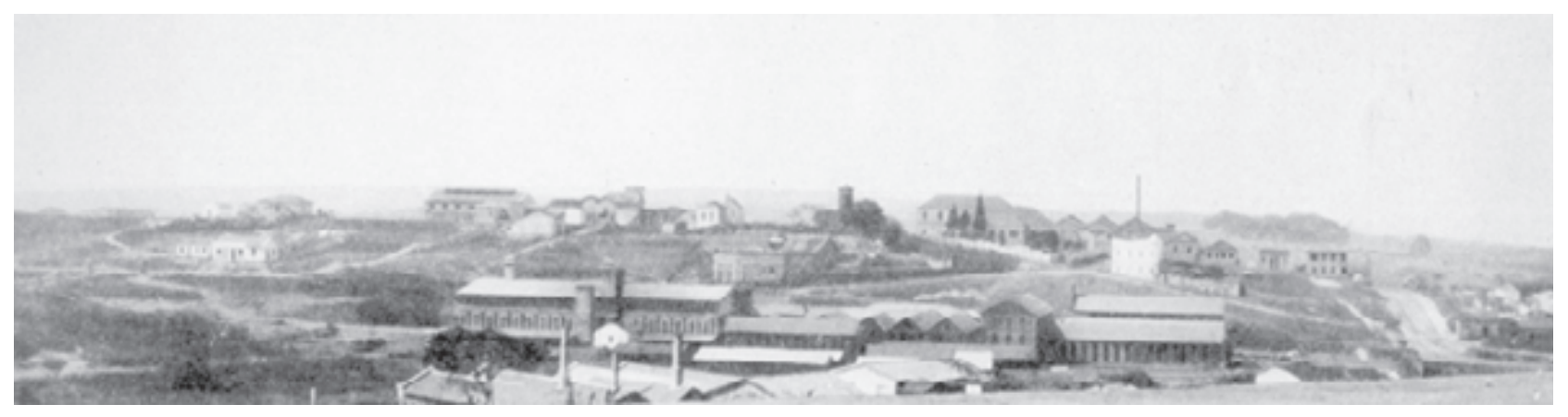

Fig.07: Cerâmica Vila Prudente, 1914.

da mesma. (Martins, 1973, 5), ou seja, a eventual falta de um tipo de mercadoria, poderia ser suprida por similar local.

Em relação a essas condições para o surgimento e desenvolvimento da industrialização, Singer esclarece que "a constituição do mercado interno para produtos industriais....toma principalmente a forma de urbanização. As cidades crescem em função do movimento exportador, pois elas são a sede de uma série de serviços: transporte, armazenamento, comercialização, embalagem, embarque e desembarque, complementares do comércio externo" $O$ autor assinala que essa série de serviços constituiu um setor de mercado interno, dependente do setor de exportações, mas que evidentemente teve sua produção consumida no próprio país (Singer, 1968, 44).

A estrutura financeira do grande comércio importador e exportador, com ramificações em todo o Estado, alargou as possibilidades de substituição de bens de consumo e além disso, investidores ligados ao comércio ou à economia cafeeira expandiram os negócios, atuando dentro de conglomerados em integração vertical para diminuir as incertezas do suprimento de matéria-prima, do transporte e da energia (Dean, 1990, 72). A conseqüência dessa integração vertical foi o predomínio dos grandes estabelecimentos, que internalizaram numerosas etapas da produção e distribuição dos bens de consumo, devido ao pequeno número de indústrias com condições técnicas e financeiras para participar nas diversas etapas de produção das mercadorias.

A formação do parque industrial de São Paulo esteve ligada os seguintes fatores, segundo Petrone:

1. A facilidade inicial de obtenção de energia elétrica

2. A existência e ampliação de um mercado consumidor em razão do aumento populacional da cidade e do Estado

3. $\bigcirc$ afluxo de capitais, nacionais e estrangeiros, que possibilitou o surgimento de grandes estabelecimentos 
4. Abundância de mão-de-obra operária, inicialmente sendo constituída de imigrantes e posteriormente resultante do êxodo rural

5. A existência de mercado fornecedor de matérias primas dentro ou nas proximidades do próprio Estado, como no caso do algodão

6. A existência de uma importante rede de transportes, tendo a cidade como o seu centro (Petrone apud Azevedo, 1958, 102)

A análise do relatório da pesquisa SAGMACS indicou a onda imigratória como um dos fatores responsáveis pelo crescimento da indústria em São Paulo, inicialmente porque encontrou já um setor fabril em gestação no período 1880 1900, que empregou os imigrantes como força de trabalho. Segundo o mencionado relatório: "(o imigrante) não é apenas 'braço para trabalho'; traz consigo a exigência de um nível de vida mais alto; seu papel como consumidor vai alargar consideravelmente o campo de procura. A procura diversificada de produtos determinará maiores compras no exterior, e a insuficiência de nossa capacidade de importar cria a necessidade da produção local. A formação de um mercado consumidor interno facilitado pelos rendimentos da produção agrícola, especialmente o café, foi um dos fatores de maior importância no desenvolvimento industrial de São Paulo" (SAGMACS, PMSP, 1958, I-18).

Para ilustrar as mudanças que o novo período econômico introduziu, dentro do quadro da produção brasileira, o valor da produção industrial das duas unidades da federação representadas pelo então Distrito Federal (a cidade do Rio de Janeiro e sua periferia) e o estado de São Paulo cresceu de 49\% em 1907 para $52 \%$ em 1920. Nesse mesmo período, o estado de São Paulo cresceu em participação de 17\% em 1907 para 32\% em 1920, contra o decréscimo de 33 para $21 \%$ do Rio de Janeiro nesse mesmo período (Silva, 1995, 74).

Embora estes sejam dados genéricos sobre o crescimento da industrialização no estado, estudos mostram que já, entre 1920 e 1938, a cidade de São Paulo havia superado o Rio de Janeiro enquanto centro industrial. A predominância de São Paulo e sua capital no processo de industrialização da economia brasileira pôde ser explicado levando em conta diversos fatores, segundo os estudos de Singer. Perguntando-se como o centro industrial de São Paulo, de menores proporções, pôde superar já nas primeiras décadas do século XX, as vantagens relativas do Distrito Federal, o autor considerou que quando uma área adquire vantagem decisiva na corrida industrial, ela tende a acumular cada vez mais essas vantagens em relação às áreas vizinhas (Singer, 1968, 50). Para justificar essa afirmação, o autor identificou os seguintes fatores:

- A situação geográfica, que assegurou a São Paulo o acesso a uma ampla área do país, onde se localizava o seu mercado consumidor. $\bigcirc$ transporte ferroviário, 
que ligou a cidade ao "hinterland" de São Paulo e do Rio de Janeiro para atender ao escoamento do café, foi preponderante para essa vantagem.

- A garantia de abastecimento de matérias-primas que o "hinterland" agrícola representou para um tipo de industrialização baseada na substituição de bens de consumo importados. Os ramos que mais se desenvolveram nesse período foram o têxtil e de alimentação. Em São Paulo, apesar do predomínio da lavoura cafeeira, a produção de algodão foi crescente nas décadas de 1900 a 1930, proporcionando uma ampla diversificação baseada no aproveitamento da matéria-prima. Ao contrário, o Rio de Janeiro não gozava das mesmas possibilidades, devido ao fato de seu "hinterland" permanecer em economia de subsistência.

- A crescente autonomia que os estados adquiriram com a proclamação da República, o que representou para São Paulo a participação do governo do estado no financiamento da imigração estrangeira e de parte da malha ferroviária paulista.

- A conseqüente expansão do fornecimento de energia elétrica por concessionária estrangeira, fruto da solicitação de uma industrialização em forte crescimento. As primeiras instalações geradoras foram construídas num período posterior ao de 1890 e 1900, quando São Paulo iniciou a sua trajetória de metrópole industrial do país (idem, 57).

Como vimos anteriormente, o fornecimento de matéria-prima para geração de energia dependeu inicialmente da ferrovia, o que definiu a proximidade das indústrias junto à estação ferroviária da San Paulo Railway no Brás. Posteriormente, a localização junto à ferrovia permaneceu vantajosa, não mais pelo fornecimento de combustível para as fornalhas das indústrias, mas pelo fornecimento de matériaprima para transformação.

Um aspecto relevante foi ainda apontado por Singer, que afirmou ter a industrialização permitido à cidade de São Paulo crescer mesmo depois da crise cafeeira de 1930, que entre outras conseqüências, desviou a lavoura para terras paranaenses e a corrente comercial para o porto de Paranaguá. Esse fator, segundo o autor, poderia ter tornado São Paulo uma cidade estagnada, usufruindo apenas do que restou do anterior período de crescimento econômico e urbano (Singer, 40, 1968), como foi o caso de outras cidades brasileiras, como Belém, Manaus, Recife e Salvador, que também atravessaram períodos de acumulação devido a ciclos de exploração de produtos primários.

Em síntese, nas três primeiras décadas do século XX, a industrialização se voltou principalmente para a substituição por produção nacional dos bens de consumo importados, sendo a indústria têxtil e de produtos alimentares, os ramos predominantes (idem, 53). O ramo industrial com maior número de 
estabelecimentos, os cotonifícios, eram 17 em 1900, saltando para 41 em 1915, com o número de empregados quadruplicado (Dean, 1990, 91). Até 1925, a cidade contava com 2.000 indústrias e 70.000 operários que ocupavam principalmente as áreas de várzea próximas aos trilhos ferroviários, sendo os bairros mais característicos, Brás, Mooca e Belenzinho. Em 1932, o número de estabelecimentos industriais já havia crescido para 2.100 (Petrone apud Azevedo, 1958, 103 - 137).

As características principais do parque paulista se deveram ao tamanho do mercado e a tecnologia. Essas duas condicionantes exigiram de alguns ramos industriais, grandes plantas industriais, que incluíram a produção de energia,como foi o caso das indústrias têxteis, de vidro, papel, moinhos de trigo, etc, todas apresentando pouca flexibilidade tecnológica em face das exigências que a mecanização lhes impunha.

Por outro lado, nos ramos em que não era exigida a mecanização integral, dois segmentos se fizeram presentes: um com maior flexibilidade tecnológica, constituído de pequenas empresas, como serrarias, indústrias de móveis, olarias, artefatos de couro, produtos alimentícios, etc. Outro segmento se constituíu de estabelecimentos tecnologicamente mais rígidos, preponderando a média empresa, constituída dos ramos de calçados, curtumes, chapéus, etc.

Com essas características do parque industrial paulista, a paisagem dos setores urbanos onde a industrialização ocorreu com intensidade, não se configurou como a de como zonas industriais homogêneas, ocupadas exclusivamente por estabelecimentos fabris. Segundo Petrone, a existência desses estabelecimentos intercalados em meio a residências proletárias, deu origem aos bairros mistos e a razão desse fenômeno ocorreu exatamente por predominarem as fábricas de tamanho pequeno e médio, destinadas principalmente à transformação. (Petrone apud Azevedo, 1958, 105)

A heterogeneidade da paisagem e a pouca segregação dos usos estavam presentes em todas as áreas da cidade, com exceção dos bairros da aristocracia. A característica de usos mistos esteve presente mesmo nos espaços centrais, como ocorreu no início do ramo industrial que se tornou o setor de ponta da industrialização brasileira no período posterior à década de 1950: a indústria automobilística.

Funcionando basicamente como manufatura, pois apenas a montagem de automóveis era feita na sede paulista, a Ford que então era a maior indústria automobilística do mundo, inicialmente se instalou na rua Florêncio de Abreu no ano de 1919, em um galpão de dois andares, empregando 12 operários. Em 1920, a montadora se transferiu para um galpão maior na Praça da República e em 1921 passou a ocupar instalações próprias no Bom Retiro, onde permaneceu até 1951. Esse edifício (ainda existente), situado na rua Sólon e construído 
especialmente para essa finalidade, teve B.R. Brown como engenheiro responsável pela obra, que foi supervisor da construção da fábrica norte-americana de Higland Park, a principal instalação industrial da Ford na época. A montadora iniciou as operações com um capital de 25.000 dólares, transferidos da filial argentina, e alcançou já em 1924, a marca de 24.250 veículos, entre automóveis e caminhões (disponível em <http://www.ford.com.br> em 2004)

Já a General Motors, principal concorrente da Ford nos Estados Unidos, iniciou as atividades em São Paulo no ano de 1925 no bairro do Ipiranga (para onde a Ford se deslocou também em 1958), transferindo-se para o município de São Caetano do Sul em 1929, mas segundo dados da própria empresa, esta havia alcançado, em 1927, a cifra de 25.000 veículos montados em suas instalações (disponível em <http://www.gmb.com.br> em 2004)

Depreende-se desses exemplos que, embora em seu estágio inicial, a internacionalização da economia para a produção de mercadorias consideradas bens de consumo duráveis, já se iniciara nesse período. Entretanto a atuação de empresas estrangeiras, como será abordado adiante, se deu fundamentalmente
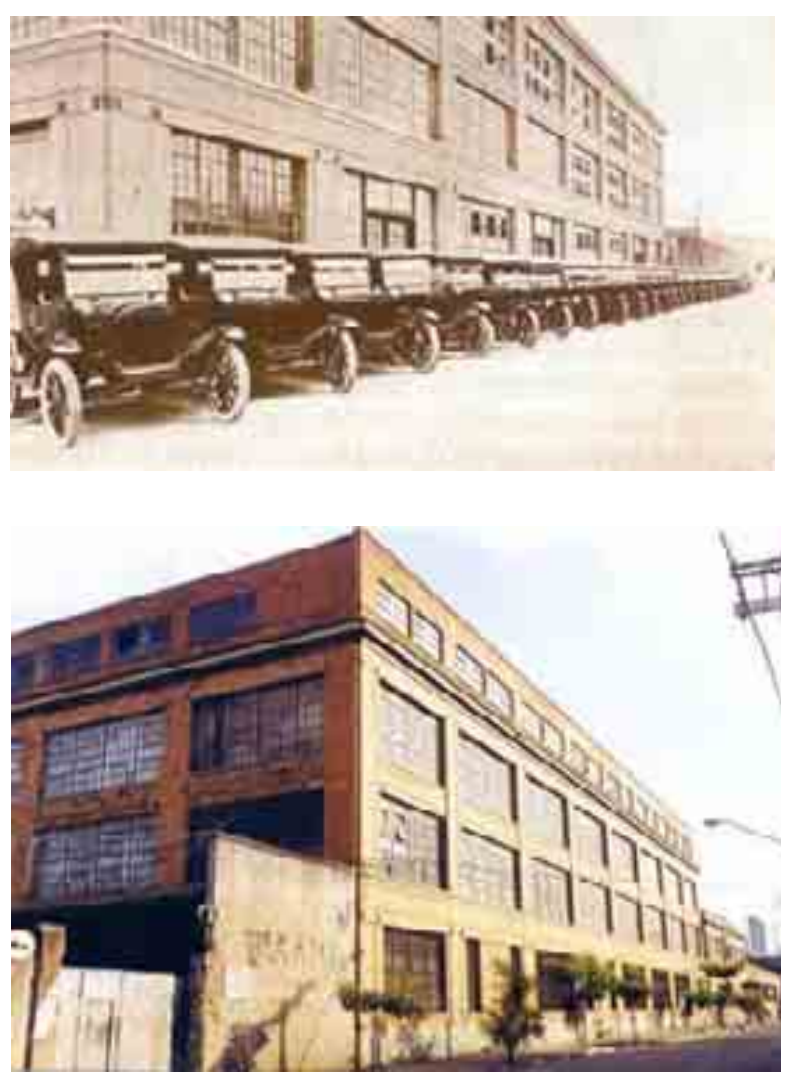

Fig 08 e 09: Acima: antigas instalações da Ford do Brasil, no Bom Retiro, em 1921.

Abaixo: Aspecto atual do edifício na provisão de infra-estrutura e não na cadeia da transformação, o que só se concretizou a partir da década de 1950. Porém, mesmo que apenas de forma manufatureira, os princípios da assembly line, a linha de montagem implantada por Henry Ford e que estruturou a produção em massa, foram incorporadas nos primórdios da industrialização paulistana. Em comum, aos dois períodos, uma constante: a localização junto aos eixos de transporte estruturais, primeiro ferroviários e depois rodoviários, devido à dependência ao porto de Santos em relação à importação e à distribuição na escala nacional dos produtos.

As relações espaciais que a industrialização produziu na cidade, como foi abordado no início deste desenvolvimento, 
foram ditadas primordialmente pelos fatores necessários para a sua viabilização. Segundo a análise de Francisco de Oliveira, "espacialmente a dinâmica de acumulação desse capital (industrial) tinha por base a contigüidade física das unidades de produção, em função sobretudo da ocupação dos poucos territórios da cidade com infra-estrutura para o desenvolvimento da produção (onde a estrada de ferro e o abastecimento de água parecem ser os elementos mais importantes), mas territórios que também oferecessem a possibilidade de acesso à força de trabalho capaz de colocar em movimento todo esse processo. Essa contigüidade espacial era ainda pouco relacionada à complementaridade entre essas unidades, fruto de uma divisão social do trabalho pouco desenvolvida" (Oliveira, F. apud Fernandes, E\&D, $\left.n^{\circ} 17,1986,71\right)$.

Considerada toda a heterogeneidade do território urbano transformado pela industrialização, a descrição de Petrone, mencionada em diversos trabalhos sobre o cenário fabril paulistano de então, se constitui em um registro precioso sobre a paisagem dos bairros industriais: "dentro do perímetro urbano, em zonas como - Brás, a Mooca e o Belenzinho, observa-se um ininterrupto suceder de pequenas habitações, quase sempre térreas e sem nenhum jardim à frente, geralmente geminadas (duas a duas, quatro a quatro), todas mais ou menos iguais, de estilo pobre ou indefinível. Estendem-se assim, em sua monotonia e em sua humildade, intermináveis, que chegam a ocupar quarteirões inteiros. No meio delas, porém, surge de quando em vez, a pesada e característica fachada de uma fábrica, ou então, pequenas oficinas ou fabriquetas. Estas são muito numerosas, aparecendo instaladas numa casa igual às demais, em antigas garagens, em barracões ou simples telheiros, no fundo dos quintais. Já as fábricas maiores se destacam, quando não por suas chaminés, pelo menos pela grande extensão de suas fachadas e seu amplo portão de entrada " (Petrone apud Azevedo, 1958, 105).

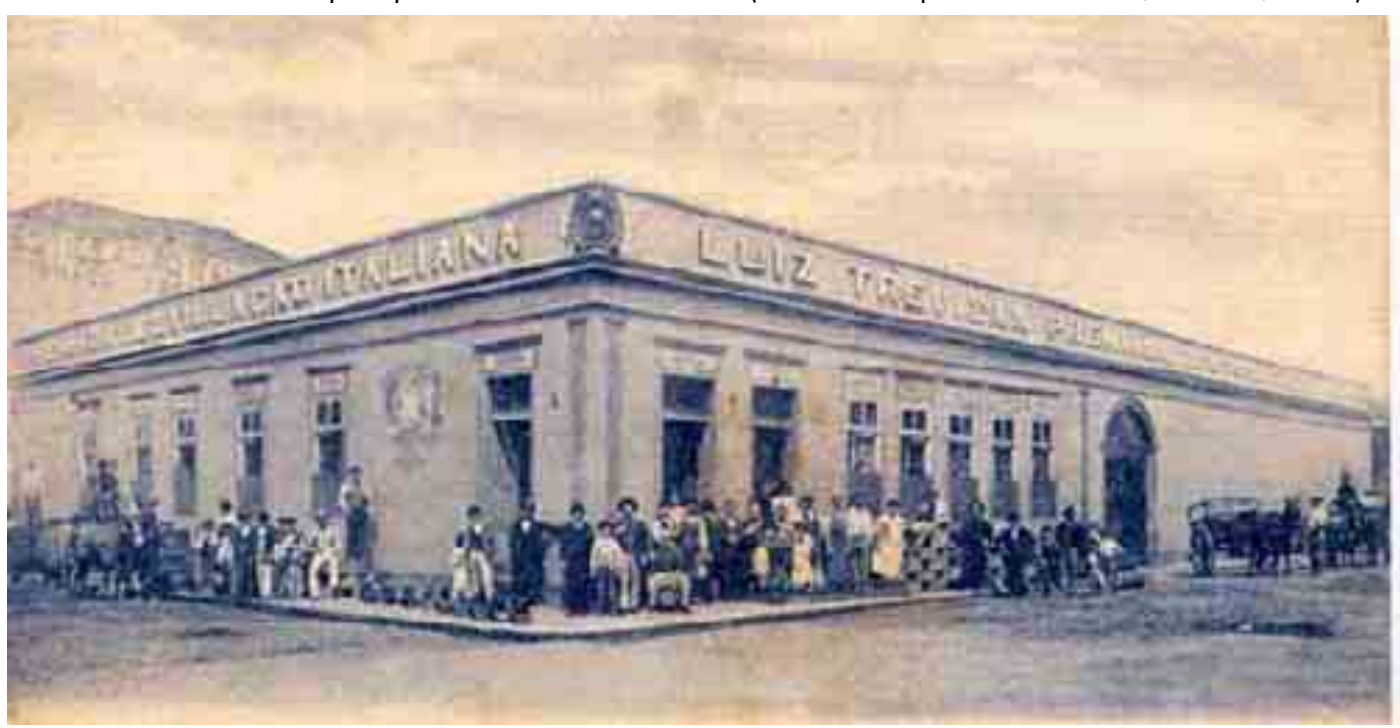

Fig. 10: Destilação Italiana, 1900 


\section{2- A cidade e os novos requisitos de sua expansão}

Confrontando a planta de 1881 - Planta da Cidade de São Paulo, de Henry B. Joyner - com as de épocas anteriores, Langenbuch indicou a expansão da cidade nas direções oeste e noroeste, assinalando a urbanização da área entre o Campo dos Curros (atual Praça da República) e o Vale do Anhangabaú, com os Campos Elísios em parte arruado, mas sem construções. No Brás, nesse período, a ocupação já havia ultrapassado as estações do Brás (da SPR) e do Norte (atual estação Roosevelt). A urbanização seguiu à rua do Brás (atual avenida Rangel Pestana), que se ligou em direção ao norte a rua do Gasômetro, que também se constituía em eixo linear de articulação do bairro. A rua Piratininga se apresentava traçada, juntamente com a rua da Moóca, mas não se encontrava ocupada. Pela planta de Jules Martin, de 1890, a área entre a Luz, o Brás e o Bom Retiro já se apresentava arruada (Langenbuch, op. cit, 79).

No período 1872-1893, o Brás teve sua população aumentada quatorze vezes. A ocupação desse território pelo binômio vila operária-indústria empregadora,

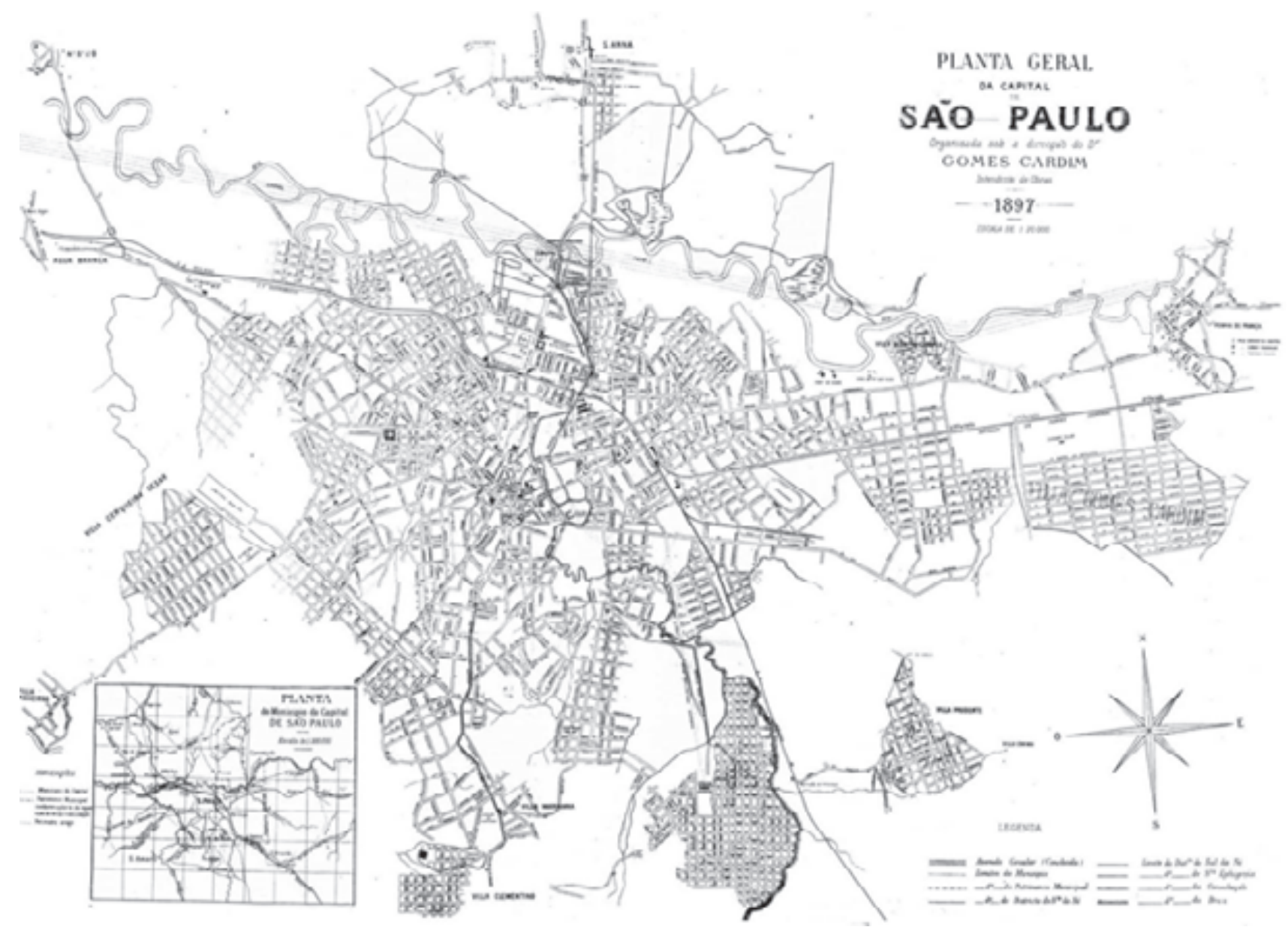

Mapa 04: Gomes Cardin, 1897 
tornou-se uma característica dos bairros fabris atravessados pelos eixos ferroviários: "iniciado o fracionamento de suas chácaras, foi criada uma nova mancha urbana, que se caracterizou pelos grandes lotes destinados às indústrias, entremeados de áreas grandemente parceladas, destinadas à residência e ao pequeno comércio. Neste processo, está o cerne da diversidade de funções, observável ainda hoje nos bairros antigos da Zona Leste" (COGEP, 1978, 03)

Os números sobre o crescimento habitacional no Centro e suas cercanias mostram que uma parcela considerável dos imigrantes estrangeiros fixou-se na Capital, formando um contingente de trabalhadores autônomos, de estabelecimentos comerciais e industriais. É possível perceber, que os dois distritos, Brás e Santa Efigênia, foram aqueles que tiveram sua população aumentada de forma mais expressiva.

Uma descrição da intensidade da ocupação do território da cidade na última década do século XIX, quando a população passou de 65 mil para 240 mil habitantes, mostra que: "no norte da cidade, a epidemia de urbanização propagouse a partir da Estação da Luz. Santa Ifigênia, Campos Elísios, Barra Funda e Bom Retiro desenvolviam-se tão depressa como o Brás. Os bondes Notmann e Glete facilitaram-Ihe o acesso, melhor ainda, ofereceram aos fazendeiros terrenos afastados do centro para o estabelecimento de um bairro novo, de artérias bem traçadas, com verdadeiras avenidas e bastante espaço para construir luxuosamente, conforme o gosto do dia; era o bairro dos Campos Elísios, colonizado pelas melhores famílias paulistanas. Ao longo e de ambos os lados das vias férreas abriram-se ruas populares na Barra Funda e no Bom Retiro (18841886) pela reforma e prolongamento das ruas Helvetia e José Paulino. A conquista da Várzea encetou-se com as primeiras casas do Pari e do Canindé" (Mendes Torres, 1985, 11 1). A ligação entre o núcleo central e os bairros a leste se dava por duas artérias, seccionadas pelos trilhos da Estrada de Ferro do Norte. A principal, que era a antiga estrada da Penha ou rua do Brás - um velho caminho que ligava o núcleo central aos pousos no percurso para o Rio de Janeiro - e a rua do Gasômetro, paralela à primeira, e aberta após a instalação do gasômetro em 1872, que abastecia o sistema de iluminação urbana. A localização do gasômetro na Várzea do Carmo se deveu à necessidade desse equipamento se situar nas proximidades da estação ferroviária da "San Paulo Railway Co", que o abastecia com carvão importado que chegava do porto de Santos.

\begin{tabular}{|l|c|c|c|c|}
\hline \multicolumn{5}{|c|}{ Quadro 1: Evoluçâo da populaçâo 1872-1893 } \\
\hline Distrito & 1872 & 1886 & 1890 & 1893 \\
\hline Sé & 9.213 & 12.821 & 16.395 & 29.518 hab \\
\hline Sta. Efigênia & 4.459 & 11.909 & 14.025 & 42.715 hab \\
\hline Consolaçäo & 3.357 & 8.269 & 13.337 & 21.311 hab \\
\hline Brós & 2.308 & 5.998 & 16.807 & 32.387 hab \\
\hline \multicolumn{5}{|c|}{ (Fonte: MendesTorres, 1985, 112) } \\
\hline
\end{tabular}


Como já afirmado, na última década do século XIX a população da cidade quase quadruplicou. Esse incremento tão significativo acarretou também uma expressiva ocupação do antigo "cinturão das chácaras", sendo que a planta de 1897 foi mencionada por Langenbuch como registro desse impressionante aumento demográfico. O subúrbio de Penha de França, que fora considerado um aldeamento, apresentava arruamento maior que o de Pinheiros, por exemplo, e a razão do ocorrido se deveu ao ramal ferroviário que servia a primeira localidade em detrimento do segundo bairro.

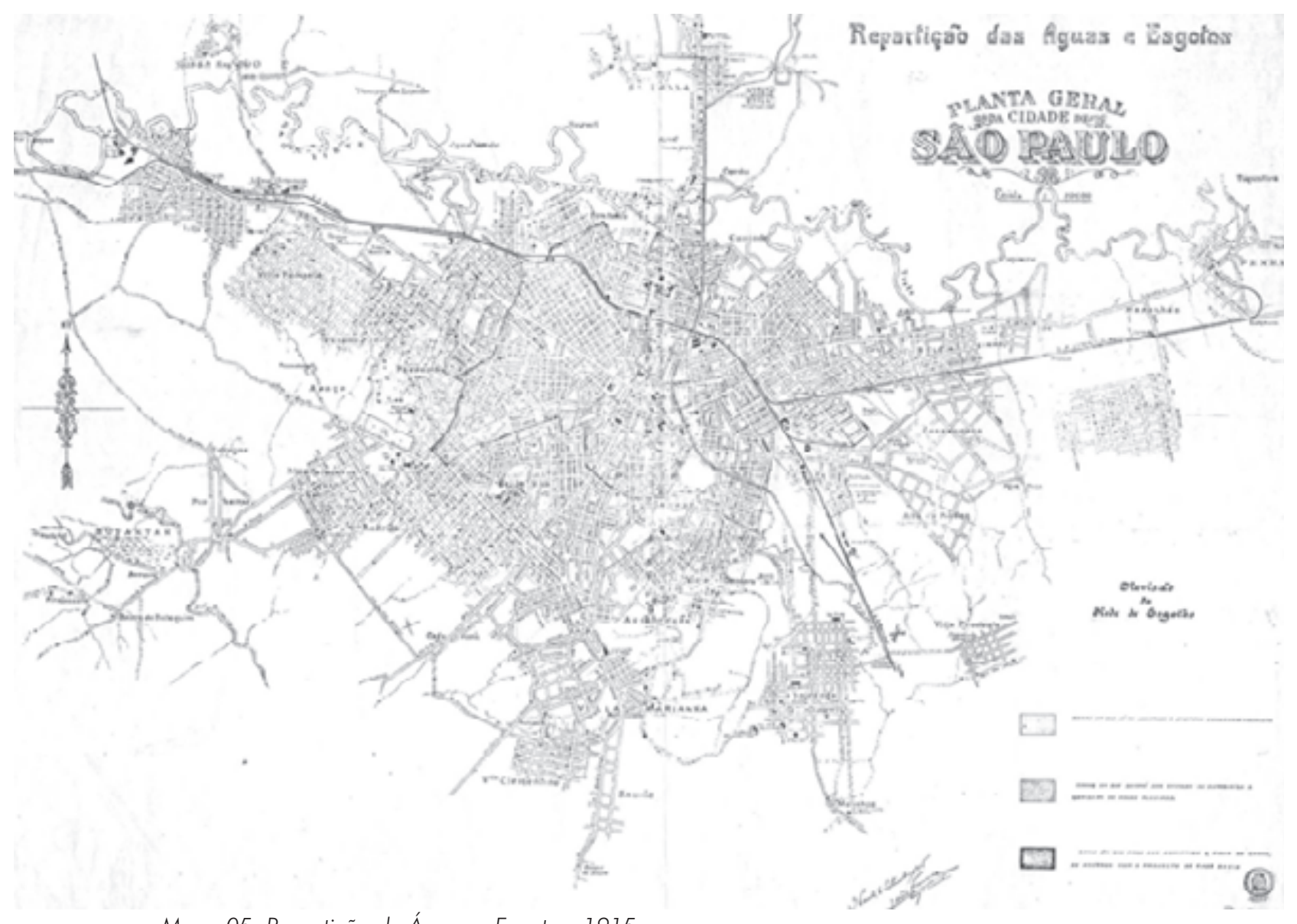

Mapa 05: Repartição de Águas e Esgotos, 1915

Na planta de 1915, a mencionada tendência de desdobramento se aprofundou enquanto que a área consolidada da cidade pouco havia se expandido. Entre 1900 e 1920, o acréscimo de população foi de 339.213 habitantes e entre 1920 e 1940, de 715.190 habitantes (Langenbuch, 1971, 82, 131). Levando em conta 0 crescimento que a cidade apresentou nas primeiras décadas do século XX, o quadro 02 e os mapas 04 (pag.38), 05 e 06 nos permitem avaliar a relação entre o aumento demográfico e a ocupação do território: 


\begin{tabular}{|c|c|c|c|}
\hline \multicolumn{4}{|c|}{ Quodro 2 } \\
\hline Ano & Area Ocupada (ho) & Populaçōo Urbana & Densidade por ho \\
\hline 1881 & 375 & 31.000 & 83 \\
\hline 1905 & 2.739 & 279.000 & 102 \\
\hline 1914 & 3.760 & 415.000 & 110 \\
\hline 1930 & 17.653 & 822.400 & 47 \\
\hline \multicolumn{4}{|c|}{ Fonte: Villaça apud Rolnick, 1997, 165 } \\
\hline
\end{tabular}

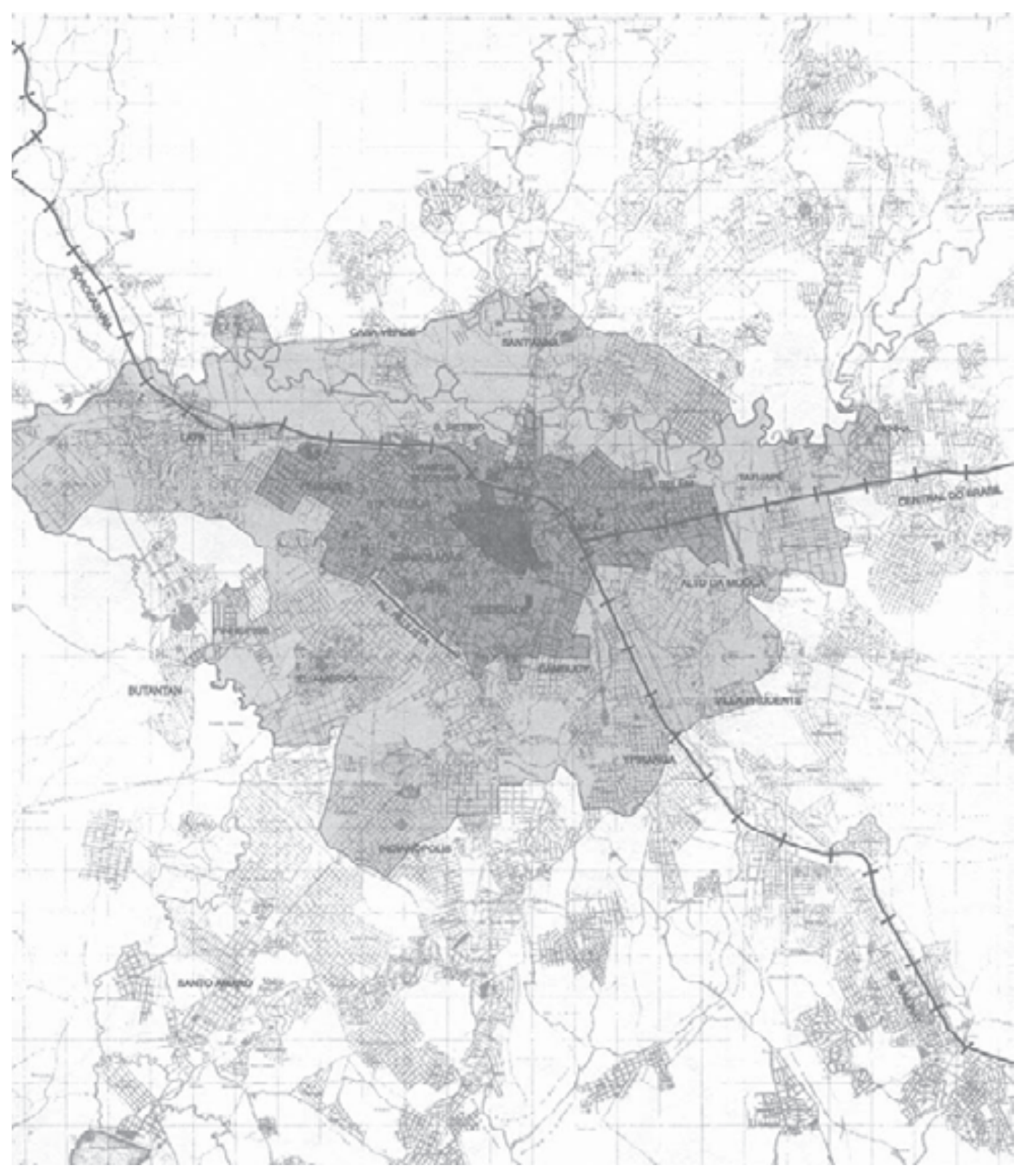

Mapa 06: Elaborado em 1929 com a demarcação dos perímetros central, urbano, suburbano e rural. 
Pode-se depreender, a partir dos dados do quadro 02, que a área ocupada do território quase quintuplicou no período 1914-1930, enquanto a sua população praticamente dobrava, no mesmo período. Segundo os números indicadores da densidade, verifica-se que a cidade mais concentrada espacialmente de 1914 espraiou-se horizontalmente, uma vez que esse índice anteriormente ascendente, caiu para menos da metade. Os fatores para essa expansão urbana, segundo Langenbuch, podem ser compreendidos levando em conta:

- A estruturação do setor industrial, ocupando áreas até então desprezadas pela urbanização, correspondendo a uma localização geográfica em que a malha ferroviária do estado de São Paulo se tornou em um fator estratégico, determinando a localização das indústrias ao longo das linhas "San Paulo Railway" e São Paulo -Rio de Janeiro. O transporte ferroviário se constituiu na forma mais rápida e segura de distribuição, tanto das mercadorias importadas necessárias às indústrias, quanto do abastecimento dos mercados do interior paulista e do Triângulo Mineiro.

- O transporte urbano: a nova oferta representada pelo bonde elétrico e a atratividade das estações ferroviárias. No primeiro caso, já em 1914, todos os quadrantes de São Paulo haviam recebidos os trilhos dos bondes elétricos da "Light \& Power Co. Ltd" , que atravessavam grandes extensões não urbanizadas para atender os bairros mais afastados como Santana, Penha de França, Ipiranga, Vila Prudente, Bosque da Saúde, Pinheiros e Lapa.

Já as estações ferroviárias se constituíram em fator locacional importante, tendência que se acentuaria nas décadas seguintes com os "subúrbios-estações". Os casos de Água Branca e Lapa, bairros que se encontravam centralizados em relação à estação e o de Penha de França, já mencionado anteriormente, servem como exemplo dessa atratividade.

- A topografia: com exceção da várzea do Tamanduateí, parcialmente ocupada após a retificação do rio, a urbanização evitou as várzeas e as áreas baixas. Isso ocasionou a existência de grandes espaços não ocupados e a correspondente expansão horizontal para áreas mais propícias.

- Os serviços: polarização em torno de povoados ou antigos núcleos que apresentavam equipamentos minimamente estruturados, tornando-os mais convenientes do que as áreas das proximidades que nada ofereciam aos moradores iniciais. Antigos núcleos como Penha de França, Nossa Senhora do Ó e Pinheiros se incluíam nesse caso (Langenbuch, op.cit., 85).

Assim como vinha ocorrendo desde as últimas décadas do século XIX, após o irrompimento da Primeira Guerra Mundial (1914-1918), o processo de especulação do solo se aprofundou em São Paulo: "pelas várzeas, acompanhando as linhas de trens, se instalavam indústrias e se formavam os bairros operários Brás, Pari, Mooca, Ipiranga, Bom Retiro, Barra Funda, Água Branca. Pelas colinas adjacentes ao centro se expandiram os bairros de classe média, entremeados de 
bolsões mais antigos de casebres e gente humilde, enquanto, em torno da avenida São João, avenida Angélica e avenida Paulista, se localizavam os loteamentos mais abastados, formando bairros ponteados de grandes sobrados e mansões, como Campos Elísios, Higienópolis e Cerqueira César". (Sevcenko, 1992, 123)

Na segunda metade da década de 1920 (mapa 06), a área urbana da cidade apresentava o seguinte arranjo espacial:

1. Um núcleo central, compactamente edificado, limitado ao Norte pelas vias férreas, a Leste pelo Vale do Anhangabaú, a Oeste pelo Vale do Pacaembú e ao Sul pelo espigão da avenida Paulista

2. Uma área compactamente edificada, a Leste do Tamanduateí, compreendendo o Brás, a Mooca, e o Belenzinho, cortada em três pontos por estradas de ferro 3. Uma área pequena, porém populosa, situada na várzea, ao Norte das Linhas férreas, compreendendo o Bom Retiro, a Luz e a Baixa Casa Verde

4. Uma área a Oeste do Vale do Pacaembu, compreendendo Perdizes, Vila Olímpia, Água Branca, Lapa e o início do Alto da Lapa

5. Uma zona de bairros novos, situados nas vizinhanças do Tietê (margem esquerda) e colina da Penha

6. O Ipiranga, então bairro-subúrbio, instalado parte na várzea e parte nas vertentes do Tamanduateí

7. Uma zona irregular, nucleada pelo centro da cidade, entre o vale do Anhangabaú e a Aclimação

8. A zona localizada a Sudeste do espigão da avenida Paulista, compreendendo Vila Cerqueira César, Pinheiros, Vila América e Jardim América

9. Uma zona situada ao sul da avenida Paulista, constituída principalmente pela Vila Mariana

10. Uma pequena área ao Norte do Tietê, com o antigo núcleo de Santana (Petrone apud Azevedo, op. cit, 123.)

Ainda segundo o autor, a cidade tinha a seguinte definição de áreas funcionais:

- Zona comercial: que compreendia principalmente o centro tradicional. Dentro dessa zona, iá se estabelecia alguma setorização entre as áreas de comércio varejista e a do comércio atacadista, instalada junto ao rio Tamanduateí e da colina histórica. Dentro do Triângulo histórico, ocorria a distinção entre o "mundo elegante" da rua Direita, das confeitarias, casas de bebida e casas comerciais e - "mundo dos negócios" da rua 15 de Novembro, dos bancos, redações de jornais, etc..

- Zona industrial: que se encontrava localizada principalmente nos bairros de várzea, não longe das vias férreas. Brás, Mooca e Belenzinho eram os mais característicos

- Área residencial: caracterizada por três modalidades 
- A dos bairros de classe média, na periferia do centro

. Bairros operários, na vizinhança da zona industrial

. Bairros aristocráticos, incluídos os Campos Elísios, a avenida Paulista, o Jardim América, Liberdade, Higienópolis e Brigadeiro Luís Antônio (idem, 140).

Associados ao crescimento da cidade, foram necessários diferentes fatores para a viabilização da atividade econômica e de suporte à população, provocando dessa forma, transformações na organização espacial, antes apenas articulada pelo e para o fluxo comercial exportador-importador. Com o crescimento do parque fabril paulistano, a cidade passou a abrigar uma estruturação de maior complexidade, fruto da cadeia "produção-circulação-distribuição-consumo", como define Milton Santos (Santos, 1997,3).

As redes de infra-estrutura para as novas ocupações urbanas, abastecimento de água, energia, circulação, transportes e regulação do uso e ocupação do solo, tornaram-se requisitos da expansão da cidade e da sua gestão. Nesta parte do trabalho serão analisadas essas formas de distribuição das redes e serviços, interconectadas com o parcelamento do solo e as suas diferentes formas de regulamentação, seguindo:

- O papel desses elementos na estruturação da cidade, em particular dos bairros centrais e qual as diretrizes direcionadas para o atendimento diferenciado às áreas urbanas, uma vez reconhecido o compromisso das concessionárias que atuaram em São Paulo com os lucros operacionais.

-A atuação do poder público (estadual e municipal) em relação ao sanitarismo, que correspondeu à primeira forma de tratamento científico das questões urbanas ligadas à salubridade e qualidade dos padrões construtivos da cidade, interconectando as diretrizes higienistas com as leis de uso e ocupação do solo, habitação social, etc..

No período de três décadas, a começar pelo início do século XX, a cidade de São Paulo contou com cinco prefeitos, sendo o primeiro eleito para o cargo que foi criado pela constituição republicana, o Conselheiro Antônio Prado, que administrou o município de 1899 a 1911 . Foi seguido por Raimundo Duprat, de 1911 a 1914, Washington Luís, de 1914 a 1919, Firmiano de Moraes Pinto, de 1920 a 1925 e finalmente José Pires do Rio, de 1926 a 1930.

Os registros urbanísticos atribuem aos antigos prefeitos um elenco de realizações transformadoras da cidade, e nesse período, principalmente a Área Central, mereceu atenção especial desses administradores, sendo promovido o alargamento e embelezamento de várias ruas e logradouros e construção de elementos notáveis, como o Viaduto Santa Ifigênia, o Teatro Municipal, a nova 
Praça da Sé, etc. Entretanto, a complexidade do processo de crescimento urbano que São Paulo experimentou, exigiu novas formas de atuação do poder público, ainda que restritas a alguns setores da cidade, impondo uma racionalidade nas ações provindas das experiências de urbanistas estrangeiros ou da influência que suas teorias exerceram nos quadros técnicos paulistanos.

As propostas para remodelação de áreas do Triângulo e do Vale do Anhangabaú e seu entorno, datam da primeira década do século XX, visando um paisagismo condizente com a visão da oligarquia cafeeira que dirigia a cidade na República Velha. Esses projetos procuraram estabelecer um paisagismo monumental, ligações intra-urbanas mais eficientes no núcleo central e a valorização dos espaços para o lado sudoeste do Centro. Simões Jr. relacionou a construção do primeiro Viaduto do Chá (1892) e do Teatro Municipal (1911) como fatos indicadores dessa intenção (Simões Jr. apud Leme, 1999, 205).

No núcleo central, dentro das propostas de desconcentração da área do Triângulo, foi construído entre 1910 e 1913 o viaduto Santa Efigênia, cuja estrutura foi fabricada na Bélgica. Esse Viaduto estabeleceu uma ligação importante do velho Triângulo com a área da Luz, onde, em 1900, foi inaugurada a nova estação da "San Paulo Railway". Além disso, o Viaduto Santa Efigênia também foi fundamental para a conexão do núcleo central com o loteamento planejado dos Campos Elísios, ocupado pela oligarquia paulista.

Referindo-se à reformulação do Centro que passou a ocorrer a partir do período de Antônio Prado como prefeito, Rolnick afirma que: "conferir um novo desenho ao centro significa não só poder ocupá-lo com atividades mais rentáveis, mas também marcá-lo com uma estética peculiar. O desenho do centro funciona como uma espécie de sinal do 'caráter' da cidade, cartão de visita, imagem que a cidade exibe para fora, mas sobretudo que o poder urbano exibe para a totalidade da cidade" (Rolnick in E\&D, 17, 1986, 51, aspas da autora).

Até 1920, o ano da proposição do "Perímetro de Irradiação" por Ulhoa Cintra, posteriormente reestudado por Prestes Maia em 1924 e incorporado ao Plano de Avenidas em 1930, a Área Central de São Paulo conheceu os seguintes projetos urbanísticos:

- Remodelação do Vale do Anhangabaú - Augusto Carlos da Silva Telles, 1906

- Melhoramentos do Centro - Diretoria de Obras Municipais - Victor da Silva Freire e Eugênio Guilhem, 1910

- Grandes Avenidas - Alexandre Albuquerque, 1910

- Melhoramentos no Vale do Anhangabaú e Triângulo - Samuel das Neves, 1911

- Melhoramentos do Centro - Joseph Antoine Bouvard, 1911. 
No debate surgido das propostas para a área central, contrapuseram-se as posturas baseadas nas reformas urbanas ao estilo de Haussman (Samuel das Neves) e daquelas referenciadas em Camillo Sitte, Eugènne Henard e Joseph Stubem (Prestes Maia e Ulhoa Cintra). Mas coube a Victor Freire, diretor de obras municipais, a introdução de fundamentos teóricos, preconizando três preceitos básicos para um plano conjunto capaz de nortear os novos projetos para a cidade:

1. $O$ princípio técnico, no sentido de se garantir a circulação fácil e rápida de homens e coisas.

2.O princípio higiênico, ao assegurar uma natalidade elevada e uma mortalidade reduzida.

3.O princípio estético, no sentido de se fazer artisticamente tudo o que diz respeito à higiene e técnica, incluindo as construções de utilidade pública, os monumentos e as obras decorativas em geral (Simões Jr. 1990, 106).

Coube ainda a Victor Freire a sugestão da contratação de um especialista em urbanismo para um parecer sobre os diversos projetos de melhoramentos propostos no âmbito do governo municipal e estadual, com aspectos conflitantes entre si. Tal sugestão baseou-se na experiência de reformulação do centro de Buenos Aires, executada por Bouvard entre 1907 e 1910 (idem 116).

Efetivamente, apenas o último plano foi implantado, já que "a passagem de Bouvard por São Paulo revestiu-se de um duplo significado: por um lado seus estudos sobre a cidade avançaram de forma mais abrangente, propondo não só soluções para áreas mais distantes do Centro, mas principalmente para as lacunas semi-rurais do Vale do Tamanduateí e do Vale do Anhangabaú. Por outro lado, Bouvard conseguiu contemporizar os projetos antagônicos para o arranjo da cidade vindos de Samuel das Neves e Victor Freire, conferindo ainda uma legitimidade européia às ações do Poder Público" (ibidem, 120).

No Vale do Tamanduateí, o Parque do Carmo, concluído em 1920 e que em 1921 passou a ser denominado de Parque D. Pedro II, foi projetado por Bouvard em 1911, mas tornou-se realidade a partir de 1914, com a retificação do rio Tamanduateí e o aterro da várzea. Inaugurado no início da segunda década do século XX, esse parque foi o principal vínculo entre os bairros do Brás e da Mooca. (Urbs, n॰8, 1998)

Desde a última década do século XIX, novos aspectos institucionais contribuíram para a coordenação das ações do poder público, então revestido de novas atribuições devido:

1.Emancipação política dos municípios a partir da constituição republicana para os estados (1891), definidora de novas atribuições que seriam canalizadas para 


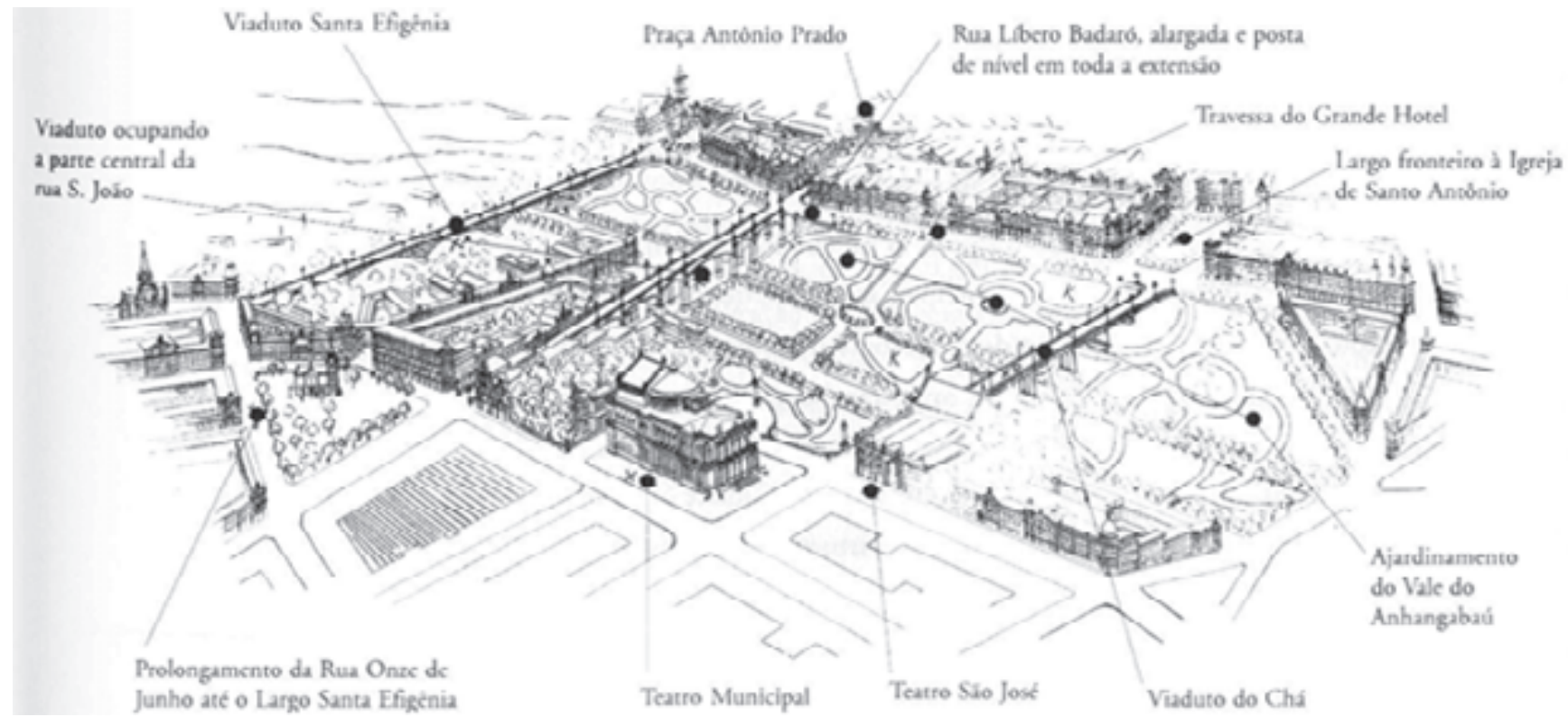

Fig. 17: Projet de Freire-Guilhem

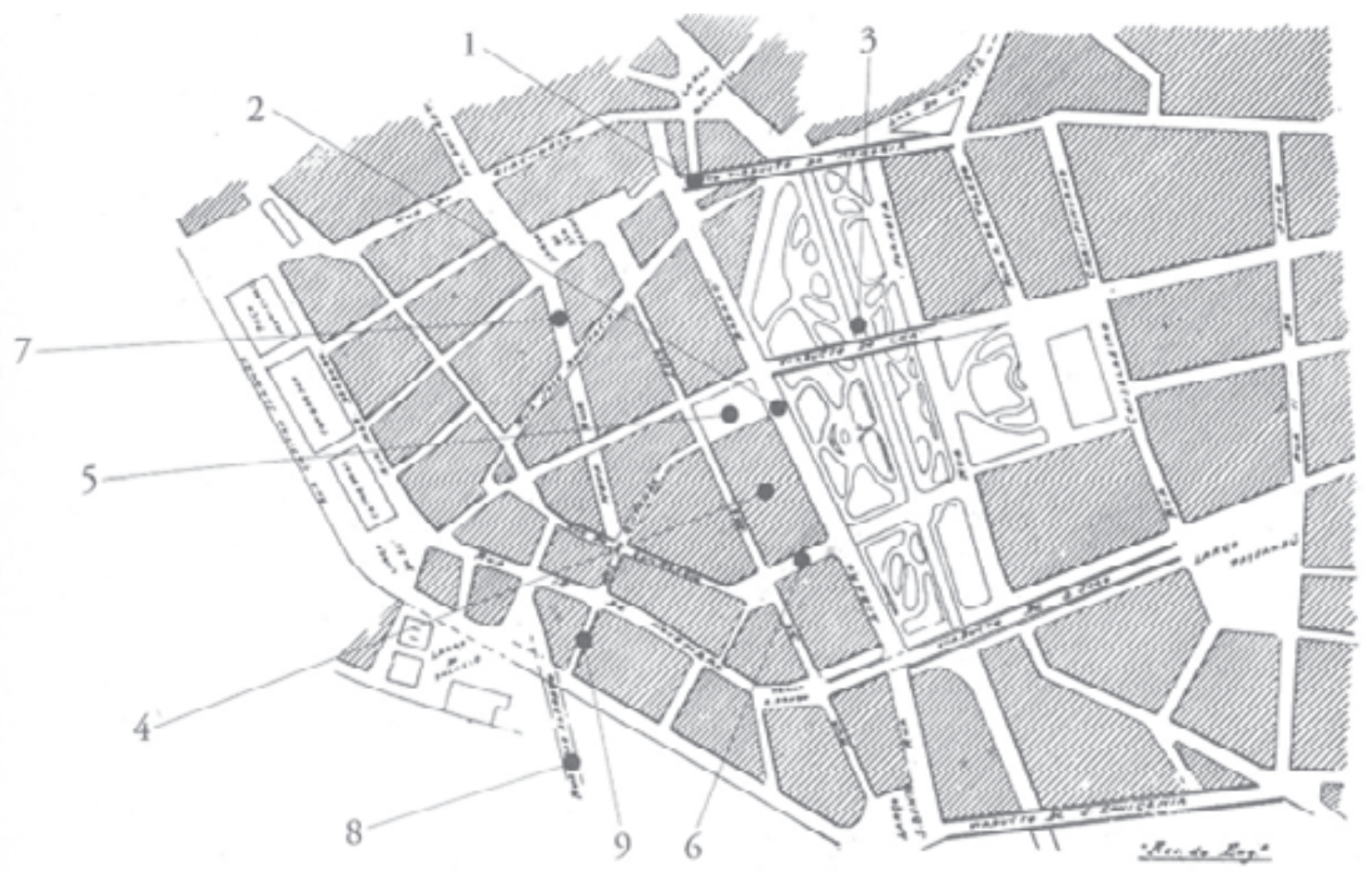

Fig. 12: Projeto Samuel das Neves:

1-Continuação da ponte lgo. do Ouvidor-Xavier de Toledo. 2-Alargamento da rua Líbero Badaró. 3-Rua lateral ao vale.

4-Construção de edifícios na Líbero Badaró com duas fachadas decoradas. 5-Abertura de praça defronte a lgreja Sto. Antônio (lgo. do Patriarca). 6-Alargamento da rua Miguel Couto. 7-Rua ligando o Lgo. São Francisco à rua da Quitanda. 8-Construção do viaduto Bela Vista. 9-Prolongamento da rua da Quitanda até viaduto da Boa Vista. 
a Intendência de Obras Municipais (1892), posteriormente denominada Diretoria de Obras Municipais (1899).

2.Maior legitimação dessa estrutura operacional em relação à administração estadual devido à especificidade de atuação no urbano

3.Formação específica dos profissionais para essa atividade (engenheiros e engenheiros-arquitetos) diferentemente dos órgãos estaduais onde os cargos de direção eram exercidos por juristas, sendo destinada aos técnicos apenas a função fiscalizadora.

4.Estreita relação dos técnicos com o principal órgão de difusão dos conhecimentos urbanos, a Escola Politécnica (Simões Jr, apud E\&D n 34, 1991, 73).

Juntamente com o embelezamento do Centro da cidade, a falta de salubridade fez com que a questão sanitarista assumisse um caráter primordial na atuação do poder público. Além disso, o crescimento da área urbana, os transportes e a necessidade de circulação no núcleo central e nos espaços vizinhos, também se constituíram em temas presentes na cidade, resultando em atuações nos seguintes campos:

1.No campo das disposições sanitárias, que se constituíram nas preocupações iniciais do poder público municipal e estadual, para o combate da falta de salubridade das habitações (dos mais pobres) e de parcelas do núcleo urbano que ainda não dispunham de serviços básicos de saneamento.

2. No campo da regulamentação urbanística das construções, dos loteamentos e larguras de ruas, orientada inicialmente pelo enfoque sanitarista e de controle da expansão desordenada da cidade.

3. No campo do provimento de infra-estrutura urbana, tanto para a população demandatária, como para sustentar o crescimento da industrialização. Implicou em pavimentação, drenagem de várzeas, transposições de rios e córregos e através de concessões a companhias privadas, na implantação das redes de água e saneamento, eletricidade e transportes.

4. Na ampliação do núcleo central da cidade, numa primeira etapa com objetivos de embelezamento urbano e posteriormente subordinada a uma nova rede urbana de circulação, consolidada a partir de 1938 pelo Plano de Avenidas.

Visto que esses campos possuíram aspectos e problemas inter-relacionados, no desenvolvimento a seguir, além da caracterização de cada um, procurou-se estabelecer a conexão entre os mesmos, que utilizou o conceito de imbricação, o qual, segundo o dicionário de Aurélio Buarque de Holanda, significa "disposição que apresentam certos objetos quando se sobrepõe parcialmente uns aos outros, 
como as telhas de um telhado ou as escamas de peixe" (Holanda Ferreira, 1975, 743).

Essa conexão foi utilizada como um recurso de análise, uma vez que:

- no processo real de ocupação e transformação urbana, os aspectos institucionais, da infra-estrutura e do espaço construído, embora constituindo fatos de natureza técnica diferente, ocorrem, se não simultaneamente, pois apresentam tempos diferentes, pelo menos de forma complementar, uma vez que são parte integrante de um processo geral que se implanta na cidade.

- seria extremamente complexo o desenvolvimento de uma análise que contemplasse, passo a passo, todas as relações existentes entre legislação urbanística, produção imobiliária, implantação de nova rede viária, redes de infra-estrutura, configuração espacial, etc.

Dessa forma, os capítulos seguintes do trabalho abordam:

- as redes básicas de transportes, energia, água e saneamento

- as normas urbanísticas relativas ao controle do uso e ocupação do solo, que também incorporaram a legislação sanitarista

- a habitação popular consentida em grande parte da cidade e que constituiu uma tipologia importante nos bairros centrais pesquisados

- os espaços diferenciados produzidos pela incorporação de extensas áreas direcionadas a ocupação segregada da alta renda, os bairros-jardim da "Cia. City of São Paulo Improvement Ltd." 


\subsection{A implantação da infra-estrutura urbana}

No início do século XIX, no período que antecedeu a industrialização, as necessidades de água, energia, saneamento e transporte, foram solucionadas por meios particulares, sem a existência de sistemas unificados de oferta desses serviços. Criadas a partir da intensificação do processo de urbanização, as redes de infra-estrutura apresentaram nos países desenvolvidos, duplo caráter de serviço público, isto é, foram dirigidas à população e se constituíram em suporte às atividades econômicas (Toledo apud Deák, Schiffer, orgs, 1999, 264).

Seguindo essa análise de Toledo, a constituição dos serviços de infra-estrutura ao exigir uma oferta específica, devido a extensão geográfica das redes e a complexidade de sua operação técnica, reúne condições para o caráter de monopólio dos sistemas. No plano local, o controle necessário para garantir a eficiência dos serviços e para não haver desvios das atuações das concessionárias, se tornou um dos pontos críticos do poder público, que até 1930 não dispunha de uma legislação integrada para os governos federal, estadual e municipal, atuando sempre de forma desconexa (idem, 1999, 297).

Assim como também ocorreu no Rio de Janeiro, no caso de São Paulo, desde 1870 as companhias estrangeiras participaram majoritariamente da implantação e operação de redes, iniciadas com os transportes ferroviários, para se estender ao gás, eletricidade, transportes e telefonia, como se verifica:

-em 1869, a "São Paulo Railway Co. Ltd", inicia a operação, construída e explorada por capitais ingleses.

-em 1872, a usina de gás situada na Várzea do Carmo, a Casa das Retortas, que produzia e fornecia o gás para iluminação urbana, foi construída e operada por uma companhia inglesa, a "San Paulo Gas Company Ltda".

-em 1899 a "São Paulo Light and Tramway Co. Ltd", com capitais anglocanadenses estabelece o monopólio de geração e distribuição de energia e transportes urbanos. Posteriormente adquiriu a "San Paulo Gás Co Ltda".

-Em 1914 a Companhia Telefônica do Estado de São Paulo, também se tornaria subsidiária da Light.

Uma análise sobre a atuação das empresas estrangeiras aborda quais implicações tiveram os objetivos dessas concessionárias para a cidade: "a carência de recursos aliada à vinculações externas, teria levado o Estado a apelar para as concessionárias privadas no fornecimento de serviços público, notadamente os ingleses e americanos. Essas concessionárias não orientavam suas redes de serviços para áreas carentes ou para a população em geral, mas para novas ocupações urbanizadoras, com vista à especulação na forma de demanda antecipatória, provocando uma marcante elitização dos serviços. Por outro lado, a escassez e irregularidade dos recursos disponíveis (usualmente empréstimos 
estrangeiros) para atender a maiores compromissos com a provisão de serviços de utilidades urbanas...impedia que os mesmos fossem despendidos de forma extensiva sobre a área urbana. Isso provocava, obviamente, grandes desequilíbrios intra-urbanos na provisão e acesso a essas facilidades"(Smolka apud E \& D, n $21,42)$.

Os estudos sobre as empresas concessionárias que atuaram em São Paulo (como de resto na maioria das cidades brasileiras), mostram que, em se tratando de investimentos privados que visavam a lucratividade empresarial, a funcionalidade da cidade como um todo foi preterida ao serem introduzidos novos componentes na ordenação do espaço urbano. Os verdadeiros monopólios que se formaram tiveram extensas repercussões, acarretando uma compartimentação social e funcional da cidade, que assim ficou profundamente marcada e a priorização de algumas áreas em detrimento de outras definiu, inclusive, os locais em que se instalaram os bairros-jardim (Eletropaulo, 1993, 51).

Esses aspectos também foram analisados por Saia, que viu na concessão de serviços públicos da cidade, atrelada à esfera estadual, uma forma negativa de dependência a grupos estrangeiros, voltados a obter alta lucratividade com baixo padrão de prestação de serviços, impondo também compromissos negativos no aproveitamento das disponibilidades espaciais e técnicas $(1978,53)$.

Outra abordagem que sintetiza a relação entre o poder público e as empresas concessionárias dos serviços urbanos mostra que a construção dos sistemas de abastecimento de transporte, água, luz e energia e telefonia consolidou a distinção entre espaço urbano e espaço rural. Os lucros das empresas foram realizados principalmente em função da valorização diferenciada das áreas e terrenos da cidade, ocorrendo mais em função da valorização fundiária gerada pelos investimentos localizados em infra-estrutura, do que pela distribuição desses mesmos investimentos pela cidade como um todo. Seguindo essa análise, "essas companhias, apesar de detentoras da maior racionalidade técnica da época, esgotaram seus objetivos na realização de lucros financeiros, fugindo a quaisquer compromissos mais amplos relacionados com a organização do sistema urbano" (Sempla, 1990, 74). 


\subsection{Imbricação: transportes e energia, água e recursos hídricos}

A imbricação entre o fornecimento de energia elétrica para os diferentes usos urbanos e a operação de transportes públicos, aliada à utilização dos recursos hídricos sob a forma de monopólio, fruto da presença da mesma concessionária em todos esses serviços, provocou ao longo das décadas de 1910 e 1920, inúmeros conflitos entre o poder público e a população, de um lado, e de outro, a empresa detentora dos direitos de exploração e operação, a "Light and Power Co".

Quase sempre os interesses da população foram prejudicados devido à grande capacidade de manobra da empresa e aos seus laços políticos, resultando na vinculação da implantação das redes de infra-estrutura e de serviços com o mercado imobiliário. Essa relação ocorreu através do transporte operado por bondes, da anexação de grandes áreas nas margens dos rios da cidade e direcionamento das redes para essas localidades, que transformaram em terras economicamente lucrativas áreas anteriormente imprestáveis. Como se depreende dos aspectos mencionados na análise a seguir, foi grande a influência dessa concessionária de serviços públicos na configuração urbana da cidade, particularmente na área entres os rios Pinheiros e Tietê.

Em relação aos transportes na cidade de São Paulo, dois períodos podem ser observados: o primeiro compreendido entre 1900-1930, com a predominância dos serviços de bonde e a entrada dos primeiros ônibus em 1924; um segundo período de 1930 a 1965, com uma inflexão em 1945, onde de 1930 a 45 surgiram t $r$ a n s form a çõ e $s$ institucionais na regulação do serviço, que levaram à criação de uma empresa pública de transportes coletivos e de 1945 em diante, a vinculação aos processos ligados ao desenvolvimentismo e da implantação da indústria

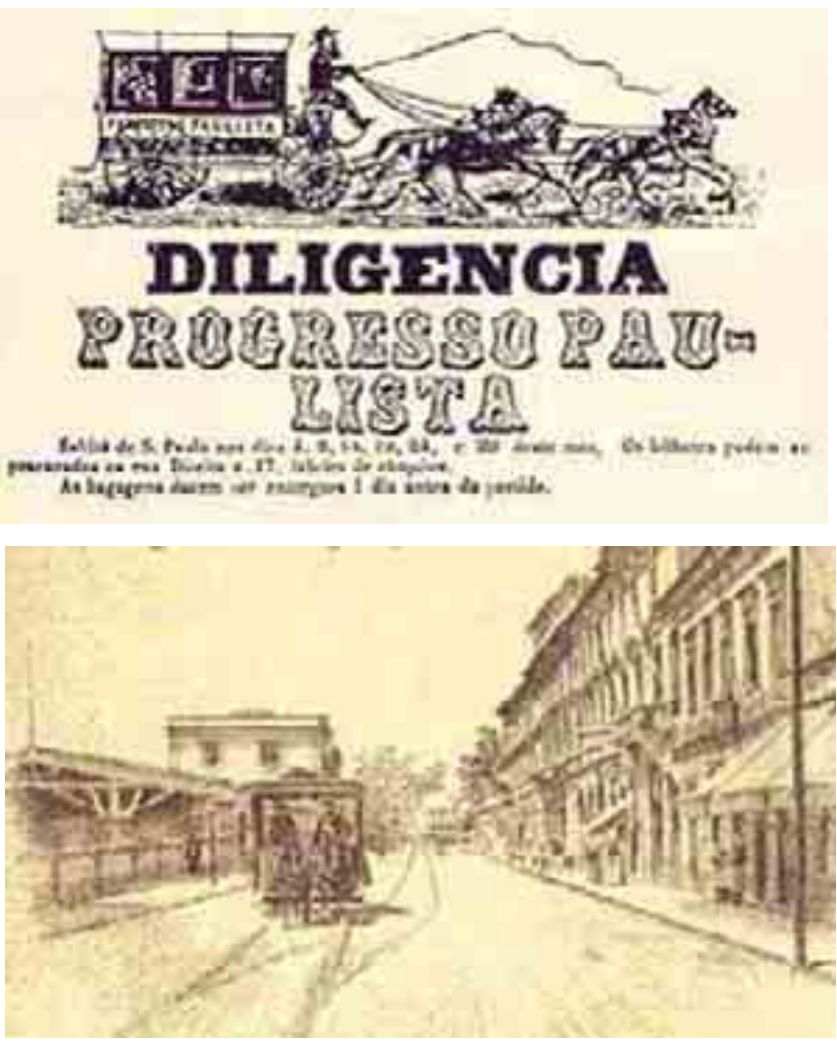

Fig. 13 e 14: Primórdios dos transportes urbanos na ciadde: acima, anúncio de diligências, provavelmente ligando a cidade às redondezas. Abaixo, bonde de tração animal defronte a antiga estação da Luz 
automobilística (Zioni, 1999, 41-69).

Os diversos estudos existentes sobre o papel desempenhado pelos transportes em São Paulo, mostram a sua estreita ligação com a valorização das terras. As ferrovias, inicialmente, seguidas dos bondes elétricos e pelo traçado das linhas de ônibus, "atuaram diretamente no desenho da expansão da cidade, segundo uma lógica que não era dada pela ocupação racional e progressiva do território" (Wolff, 1998, 50).

O exemplo mais claro da atuação das empresas estrangeiras se deu com a "São Paulo Tramway Light and Power Co. Ltd", ligada à busca de mercados tanto para a distribuição de energia para as indústrias e a cidade, como também ao transporte urbano. A Light tornou-se um instrumento decisivo na expansão da cidade, já que as linhas de bondes elétricos promoveram mudanças na acessibilidade intra-urbana, o que significou também a alteração no valor do solo, que foi apropriado pelo mercado imobiliário. Como passou a ser a única detentora da distribuição de energia, gás e telefonia, além dos transportes, a troca de favores e os vínculos com os negócios imobiliários na cidade se mostraram presentes desde o início da atuação daquela empresa, confirmando a análise de Smolka citada anteriormente.

Um procedimento permanente da Light foi a contínua incorporação de outras companhias, com quem disputava litígios a respeito das concessões públicas: em 1900 foi comprada a Cia. de Água e Luz do Estado de São Paulo, que contava apenas com dois geradores a vapor na rua Araújo; em 1901 foi comprada a Viação Paulista e a Cia. Carris de Ferro, em 1914 a Cia. Telefônica e depois de vários anos de disputas, foi adquirida a San Paulo Gaz Co. Ltd, como será visto adiante (Eletropaulo, 1990, 170).

Se outras cidades brasileiras já dispunham de hidrelétricas, algumas ruas iluminadas à eletricidade e no caso do Rio de Janeiro, desde 1892 uma rede de bondes elétricos, em São Paulo isso ocorreu um ano após a autorização de operação (1899), quando a Light inaugurou cinco linhas desse transporte. Os itinerários alcançaram o Largo São Bento, Rua dos Italianos, Vila Buarque, Avenida Paulista e Brás (idem, 114).

O processo seguido pela concessionária foi de localizar as paradas finais em lugares de população rarefeita, tais como Penha, Lapa, Santana, Ipiranga, Vila Mariana, Pinheiros, gerando valorização imobiliária que seguia a direção dos trilhos. As lacunas entre o centro e bairros já dotados de infra-estrutura, ao receberem também da Light os serviços de luz e gás, além do transporte, sofreram altas especulativas no preço dos terrenos e aluguéis, o que se tornou um ponto crítico da carestia verificada no período que antecedeu a I Guerra Mundial e seguiu durante a década de 1920. Além disso, essa prática resultou em bairros desconectados, "uma heterogeneidade de arruamentos desencontrados, além 

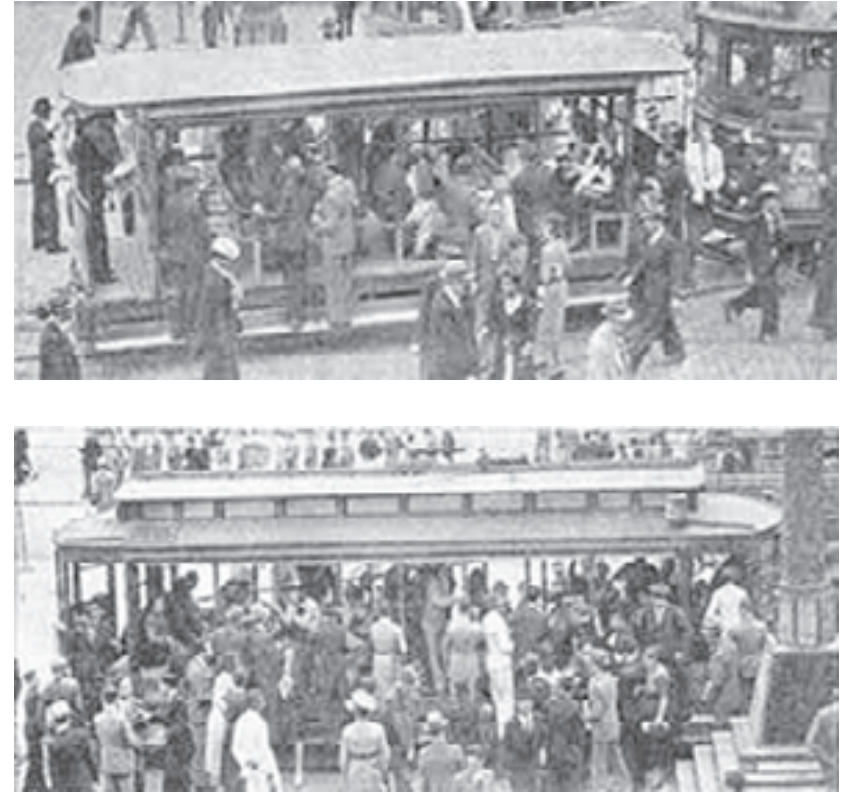

Fig. 15 e 16: O único meio de transporte organizado na cidade: os bondes e a frequente superlotação, década de 1920. da escassez drástica de praças, espaços públicos e amenidades. Essa anarquia especulativa era o oposto mesmo de qualquer idéia de planejamento ou princípio de urbanismo" (Cevcenko, 1992, 124).

Reportando-nos a uma análise sobre a atuação dessa empresa anglocanadense, que dispunha de representantes junto ao poder público para a obtenção das concessões, temos que: "nestas condições e cheia de poderes, a light passou a interferir de forma marcante

no desenho e no redesenho de São Paulo. Se os limites espaciais e econômicos foram delimitados até 1900 pelas ferrovias e pelos bondes de tração animal, a partir de então os bondes elétricos da Light se constituíram em fator decisivo não só para uma nova reordenação do espaço urbano, como ainda para a incorporação de capital ao valor da terra". Segundo registros, entre 1901 e 1912, a média anual de linhas implantadas foi de 15,7 quilômetros, totalizando 188,7 quilômetros (idem, 1990,14).

Outro estudo corrobora a mesma visão desse processo, já que os bondes elétricos alteraram em profundidade a escala de correspondência espaço-tempo, pelo fato de incorporar uma extensão territorial urbana muito maior à vida cotidiana dos cidadãos (Eletropaulo, 1993, 53).

Buscando economia na operação dos transportes e dos serviços de distribuição de energia elétrica e telefonia, a Light desencadeou a saturação das áreas já urbanizadas, pois até a década de 1920 a acessibilidade oferecida pelo bonde era uma importante condição para a abertura de novas áreas, visto ser o único modo organizado de transporte urbano. Uma análise sobre essa empresa nesse período mostra que "a política de restrição da expansão das linhas de bonde tendia a produzir um crescente adensamento urbano, conforme aumentava a população da cidade. A estrutura radial das linhas de bonde, que concentrava vantagens de acessibilidade no Triângulo Central, agravava essa tendência, chegando ao congestionamento da área central na década de 1920. A relação entre a estrutura dos transportes coletivos e congestionamento do Triângulo Central 
é registrada na argumentação de Prestes Maia contra o Metrô da Light e a favor do Plano de Avenidas" (Filardo Jr, 1998, 19-20).

\begin{tabular}{|c|c|}
\hline \multicolumn{2}{|c|}{ Quadro 3 } \\
\hline \multicolumn{2}{|c|}{ Possogeiros Transportados pela Light 1917.1927 } \\
\hline Anos & Possogeiros \\
\hline 1917 & 58.619 .758 \\
\hline 1918 & 58.455 .792 \\
\hline 1919 & 70.697 .355 \\
\hline 1920 & 86.414 .566 \\
\hline 1921 & 97.292 .923 \\
\hline 1922 & 111.955 .073 \\
\hline 1923 & 124.815 .804 \\
\hline 1924 & 128.950 .062 \\
\hline 1925 & 141.190 .025 \\
\hline 1926 & 158.920 .915 \\
\hline 1927 & 169.516 .025 \\
\hline \multicolumn{2}{|c|}{ (Fonte: Sfiel in Emplaso, 2001, 102) } \\
\hline
\end{tabular}

A alternativa de negócios coordenados se apresentou com a expansão das linhas de bonde e da rede de distribuição de energia serem custeadas por loteadores, como no caso da Cia. City, o que provocou distorções na distribuição desses serviços na cidade, com o benefício das áreas de incidência da população de alta renda (idem, 21). De acordo com o estudo sobre essas atividades, as extensões de linhas e redes para os loteamentos da City, foram estabelecidos em contratos com a Light, como o de 1915, onde essa empresa recebeu terrenos em troca da extensão da rede elétrica e de gás (ibidem, 82).

A expansão do sistema de transportes baseado nos ônibus, que passou a ocorrer em meados da década de 1920, ameaçou o monopólio do serviço de bondes da Light. Esse crescimento se verificou a partir da crise do fornecimento de energia elétrica causada pela seca de 1924, havendo a necessidade de suspensão dos serviços de várias linhas dos bondes. Nos anos seguintes, ocorreram manifestações da municipalidade em favor dos "auto-ônibus" contra os serviços que eram oferecidos pela Light. Esses fatos apontaram não apenas a vantagem de um modo de transporte sobre o outro, mas também a necessidade da atuação direta do poder público na gestão e operação dos transportes com veículos sobre pneus (Zioni, 1999, 62-75, aspas da autora).

crescimento do número de ônibus se constituiu em um dos fatores que foram utilizados pela Light para incluir em 1927 um plano de monopólio dos serviços de transporte sobre pneus em São Paulo. As restrições impostas aos bondes para a livre penetração no perímetro central, não ocorria com os ônibus e automóveis, que transformaram desde cedo, espaços públicos do Centro em terminais e 


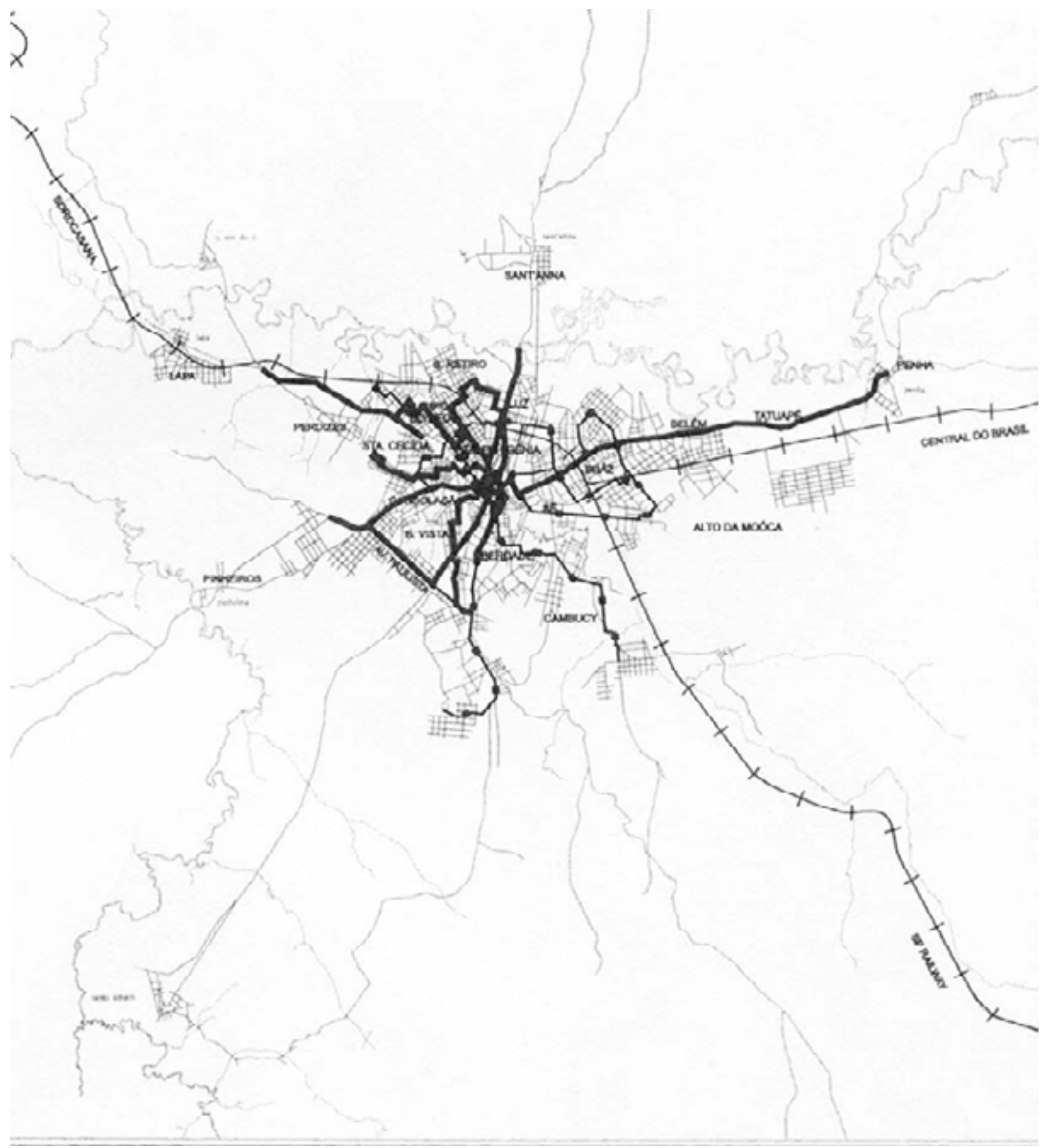

Mapa 07 e 08: Mapas comparativos da expansão das linhas de bonde entre 1905 (acima) e 1930 (próxima página). 


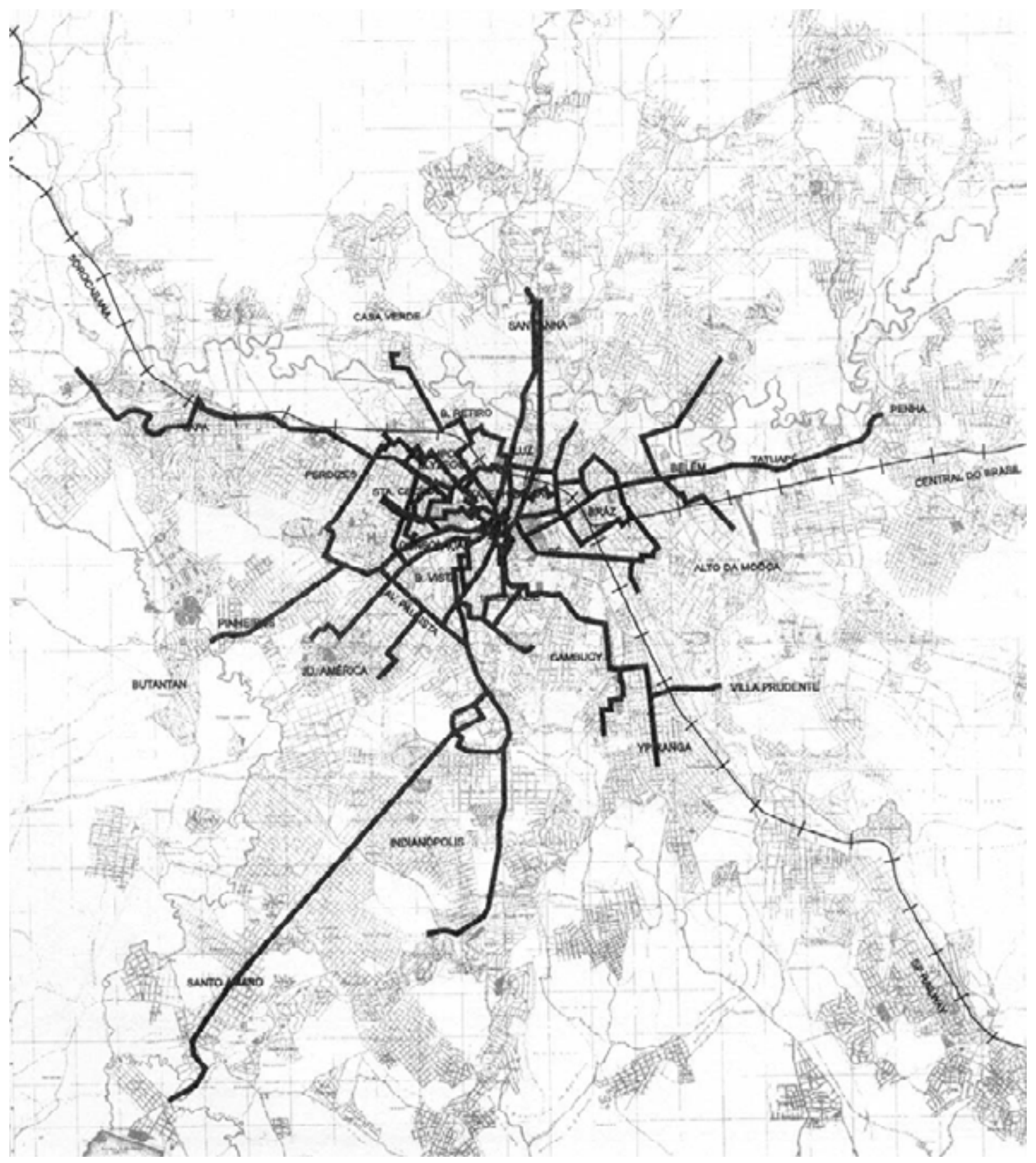




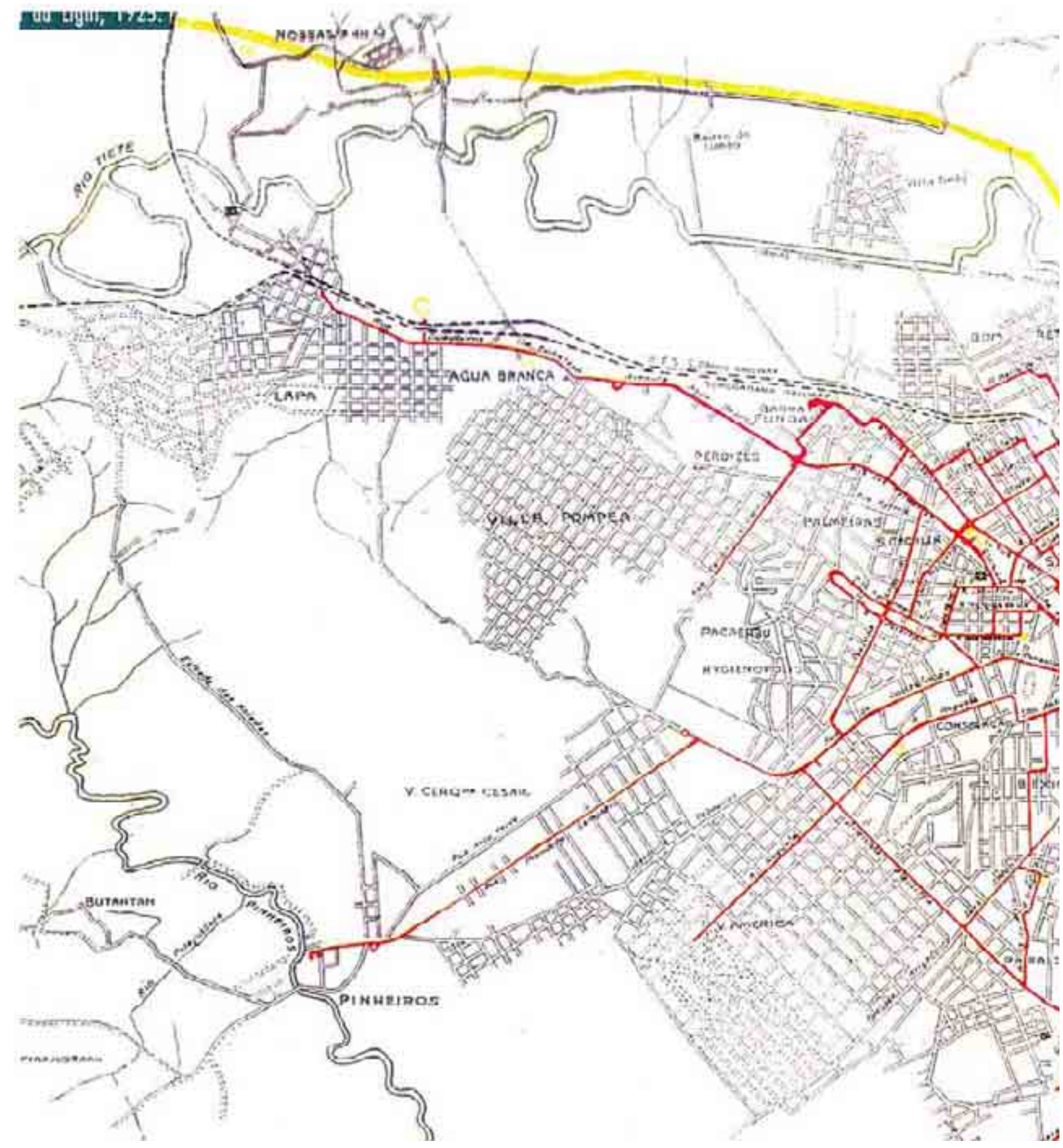

Mapa 9: Mapa da Light de 1925, com traçado das linhas de bondes. Notar a extensão das mesmas em todos os quadrantes da cidade, além da área urbanizada, corroborando a tese de Smolka sobre a demanda antecipatória. Em amarelo, direção Centro-NO, a linha de transmissão de energia. 
estacionamentos. $\bigcirc$ modo de transporte mais elástico, representado pelos ônibus, resultou também na expansão maior da periferia, alterando as relações de acessibilidade estabelecidas anteriormente pelos bondes (Lefèvre apud Amadio, 1998, 55)

Como se verifica no quadro, na década de 1930 o número de ônibus mais que dobrou em apenas seis anos:

\begin{tabular}{|l|c|}
\hline \multicolumn{2}{|c|}{ Quodro 4 } \\
\hline \multicolumn{2}{|c|}{ Número de Onibus em circulaçóo } \\
\hline Anos & Onibus \\
\hline 1933 & 323 \\
\hline 1934 & 363 \\
\hline 1935 & 389 \\
\hline 1936 & 427 \\
\hline 1937 & 451 \\
\hline 1938 & 513 \\
\hline 1939 & 704 \\
\hline \multicolumn{2}{|c|}{ [Fonte: Stiel in Emplata, 2001, 103] } \\
\hline
\end{tabular}

Com relação aos serviços de iluminação da cidade e de distribuição de energia elétrica, estes se constituíram em uma longa disputa entre a Light e a "San Paulo Gas Company", que perdurou até o final da primeira década do século XX. A absorção da companhia de gás se deu em 1913, através da compra no mercado londrino de suas ações, uma operação realizada por terceiros e repassada a outra empresa do ramo controlador da Light. Inaugurado o serviço em 1872, a concessão à "San Paulo Gaz" foi prorrogada por trinta anos em 1897, havendo, entretanto, cláusulas que permitiam ao Poder Público a contratação de iluminação elétrica das vias públicas. Por meio de uma estratégia que foi a de instalar iluminação festiva para as comemorações da Proclamação da República, em 1907, a Light logrou iniciar a conquista do mercado lucrativo do Centro, condição que impunha para iluminar as áreas suburbanas, não atendidas pela iluminação a gás (Filardo Jr., 1998, 36).

A sobreposição de competências entre os governos estadual e municipal também favoreceu o surgimento de espaços para que os contratos com a Light pudessem ser firmados, sem conflito direto com a concessão à empresa "San Paulo Gaz". Visto que o poder de concessão era de competência do governo estadual, a partir de 1911 , sob o impacto da iluminação de vias como as avenidas Brigadeiro Luís Antônio, Higienópolis e Paulista, foram firmados contratos que se estenderam para ruas da Penha, Lapa e Ipiranga. Em 1912, sobrepondo-se à iluminação a gás, as ruas de Santa Ifigênia, Liberdade e Campos Elísios foram também equipadas com iluminação elétrica (idem, 37).

Um relato da época mostra que "se quiser avaliar a cidade, verá no mapa uma imensa aranha cujas pernas peludas são as linhas de bonde da Light ('o polvo canadense') rodeadas de casas... De permeio entre as pernas do Canadian 
Octopus, zonas verdes e vazias. São Paulo tinha em 1922 a extensão de Paris, com três milhões de habitantes nesse tempo, para uma população de $600 \mathrm{mil}$ em São Paulo" (Americano apud Sevcenko, 1992, 124).

Como analisou também Filardo Jr, as empresas concessionárias de gás, eletricidade e transportes urbanos, dispunham de

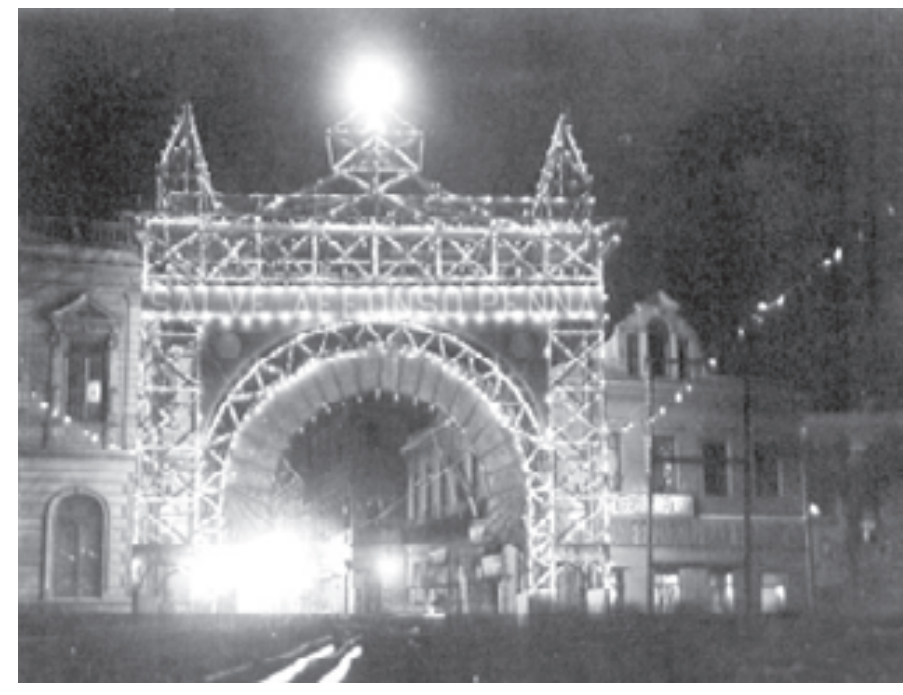

Fig. 17: Iluminação festiva da Light. maneiras legais para adquirir, por meios amigáveis ou não, terras para construção de instalações, depósitos, garagens de bondes, etc, e em relação à Light os negócios imobiliários eram inerentes à sua atividade.

Essa articulação entre transporte urbano e o setor imobiliário, existente também em diferentes cidades do mundo, se fez para garantir o sucesso de loteamentos, só viabilizados se houvesse a ligação por meio dos bondes com o Centro. Também na aquisição pura e simples de glebas para valorização, a presença da Light em negócios imobiliários se fez presente, com atuação coordenada entre figuras da política paulista ou empresas, como no caso da Cia. City (Filardo Jr., 1998, 7980).

Análises sobre a Light mostram que, na segunda metade da década de 1920, gradativamente o interesse pelos transportes coletivos diminuiu, fruto das divergências e disputas com o Poder Público que lhe impediram de implantar um plano que incluía a construção de um sistema de Metrô, absorver o serviço de transportes coletivo realizado pelos ônibus e aumentar as tarifas para custear obras na área central. $\bigcirc$ número de bondes, que em 1910 era de 201, chegou à metade da década de 1930 perfazendo 567 veículos.

Em face do interesse dispensado aos ônibus e automóveis que o Poder Público manifestou no Plano de Avenidas, encomendado pelo Prefeito Pires do Rio, em 1928, a Light voltou-se à obras de retificação e inversão do curso do rio Pinheiros, como forma de ampliar a capacidade de geração de energia elétrica, terminando a operação do serviço dos bondes em 1947 (Eletropaulo, 1993, 14). Deve-se acrescentar que, essa inversão autorizada em 1946 pelo presidente Eurico Dutra, se foi proveitosa para os interesses da concessionária, foi altamente prejudicial 
ao meio ambiente e aos mananciais de São Paulo, como demonstram os trabalhos de Branco, Silva e Alves, mencionados a seguir.

Analisando a baixa capacidade de abastecimento que São Paulo dispunha, aliada a crescente polvição do Rio Tietê, Murgel Branco comentou que para a então detentora do monopólio energético, a Companhia Light, "não interessava a questão do abastecimento e, muito menos, a despolvição do Tietê e Billings, uma vez que esgotos, ao passar por turbinas, geram eletricidade do mesmo jeito" (Branco in Polis, $n^{\circ}$ 3, 1991, 55)

O trabalho de Filardo Jr. é incisivo em apontar a estratégia da empresa: "os termos leoninos do projeto de modernização dos transportes coletivos (o metrô da Light) de 1927 e a ampliação no mesmo ano, das concessões do Projeto da Serra, de forma a incluir as operações imobiliárias no vale do rio Pinheiros, com perspectivas de ganhos fabulosos, constituíam a única perspectiva de convencimento dos investidores estrangeiros a assumir o risco Brasil (sic), percebido então como alto, tanto do ponto de vista do câmbio, quanto da estabilidade política". O autor analisou a inviabilidade de aumentos de 50 a 100\% no valor das defasadas tarifas dos bondes ser suportada pelo público, depois das greves de 1917 e da Revolução Tenentista de 1924. Quanto ao rio Pinheiros, a situação se apresentou de forma diferente, pois a proposta de retorno das operações imobiliárias seria feita em mercado futuro, sendo ainda diluído pela expansão urbana e por isso mesmo aceito pelas autoridades governamentais (Filardo Jr. 1998, 162).

Uma visão abrangente sobre o alcance da atuação dessa concessionária é obtida através da análise da sua receita nas duas primeiras décadas do século XX: em 1905 o transporte representava principal fonte de receita, $71,3 \%$, contra $28,7 \%$ do fornecimento de energia elétrica para a habitação, comércio e indústria, perfazendo 4.213 consumidores. Já em 1920, esses números mudaram para $58,2 \%$ para o transporte e $41,8 \%$ para o fornecimento de energia, significando 54.116 consumidores. Praticamente no mesmo período, o uso da eletricidade como força motriz da indústria subiu de 4,29\% em 1907, para 47, 3\% em 1920 (Eletropaulo, 1990, 116).

As usinas que proporcionavam a maior cota de energia, as de São Paulo e Sorocaba, foram construídas por empresas estrangeiras (européias e norteamericanas), buscando inicialmente lucros relacionados ao crescimento urbano funcionalmente dependente do comércio do café (Dean, 1990, 14). Posteriormente, a geração de energia elétrica tornou-se um importante suporte para o crescimento industrial, como se depreende da análise de Singer: "As primeiras fábricas eram acionadas por motores a vapor, alimentados por carvão de lenha ou carvão importado, mas a produção subseqüente das máquinas dependia da instalação de sistemas urbanos de energia hidroelétrica" (1968, 39). A confirmação desse fato é dada pela construção da primeira usina da 
"Light and Power Co. Ltd": a usina Parnaíba, construída no município de Santana do Parnaíba no ano de 1901, e que foi a primeira hidrelétrica no rio Tietê. Como explicou Singer, a capacidade inicial dessa usina era de 2.000 kw, não havendo demanda significativa de energia elétrica por parte das indústrias. Já em 1912, quando a demanda se elevou, a usina passou a produzir oito vezes mais, uma vez que a capacidade para o atendimento às indústrias já existia. (idem 39).

custo ambiental da geração de energia, aspecto que pouca importância recebeu na época e, ainda mais manipulado politicamente pelos interesses da concessionária, foi alto para a cidade. Conforme estudo da Secretaria Municipal de Planejamento "em 1901, com o início do funcionamento da usina de Parnaíba, a Light define a primeira etapa de um longo plano, visando apropriar-se de todo o potencial hidráulico da região de São Paulo para a produção de energia elétrica. Em 1907, represam-se as águas do rio Guarapiranga, um dos formadores do rio Pinheiros, com finalidade de regularizar o funcionamento da usina. Em 1926, após represamento do rio Grande - represa Billings - inaugura-se a usina de Cubatão, alimentada pelo lançamento das águas da Billings serra abaixo. Em 1927, a Light obtém concessão para captar águas diretamente no Tietê e lançálas para Cubatão" (Sempla, 1990, 75).

Concomitantemente ao crescimento de fornecimento de energia elétrica, através da utilização dos recursos hídricos da cidade para esse fim, a ampliação das redes de distribuição de água e de esgotos se mostrava imperiosa e se constituiu em um problema crônico, pois, ainda em 1893, uma epidemia de febre amarela teve como causa a contaminação por esgotos dos poços utilizados para abastecimento familiar. Essa medida culminou com a formação pelo governo da Província, nesse mesmo ano, da Repartição de Água e Esgotos - RAE, incumbida de expandir os serviços que a Companhia Cantareira havia se mostrado incapaz de fazê-lo.

A RAE logrou completar, de 1895 a 1898, as obras de adução dos recursos hídricos existentes na Serra da Cantareira, incluindo a construção de novo reservatório na rua da Consolação, e para isso foi construída até uma ferrovia, - "Tramway da Cantareira". Segundo registros dessa atuação, o abastecimento alcançava apenas algumas áreas urbanas e eliminava as possibilidades de uso até então gratuito da água: "o primeiro esforço da Repartição de Águas e Esgoto foi fazer canalizações para regularizar o abastecimento de água em alguns bairros da cidade. Mas, para forçar os moradores de certos locais a ter água encanada, a Repartição mandou demolir alguns principais chafarizes que a Cantareira entregara ao público anos antes, além daqueles que havia nos largos do Carmo e Rosário. Quando derrubavam esse último, moradores e populares se opuseram com violência, resistindo até que a força policial entrasse em ação" (Sabesp, 2000, 17). 
A racionalidade que passou a fazer parte das empresas concessionárias para o fornecimento dos serviços e sua relação com a ocupação do solo foi assim assinalada: "A construção de sistemas de abastecimento de água, esgotos, etc. torna inviáveis construções fora das exigências estipuladas por lei. Ou seja, para se obterem os benefícios oferecidos, por exemplo, pela Companhia Cantareira era preciso construir-se dentro de determinado perímetro considerado urbano, bem como obedecer às disposições estabelecidas pela companhia em contrato" (Silva apud Grostein, 1987, 63).

Reside aqui uma importante mudança, que não se limita apenas à diferença entre a forma antiga de abastecimento e o fornecimento por rede. $\bigcirc$ estudo de Gronstein afirma que o que contribuiu fundamentalmente para a definição das áreas consideradas urbanas, suburbana e rural, mais do que o Código de Posturas de 1886, foi o padrão de assentamento das edificações para receberem os serviços urbanos, estabelecendo-se assim uma nova ordem modeladora de localização e alinhamentos (Grostein, 1987, 63). Esse estudo corrobora a relação estabelecida por Solà-Morales (1997) entre urbanização (infra-estrutura), parcelamento e edificação, para o caso da estruturação das áreas mencionadas.

Abordando as condições gerais de saneamento da cidade, que incluíam a drenagem, um estudo da Secretaria Municipal de Planejamento analisa a não aprovação do plano de Saturnino de Brito para a retificação do rio Tietê em 1925, sob a alegação dos altos custos que as desapropriações envolveriam (Sempla, 1990, 75). Isso impediu a existência de um sistema de áreas verdes e lagoas de contenção das águas pluviais, que evitariam as freqüentes enchentes que passaram a ocorrer nas áreas da várzeas e mostra a influência da Light nas decisões urbanas da cidade e conseqüentemente, no desenho urbano resultante, pois o plano de Saturnino contrariava os interesses daquela concessionária, uma

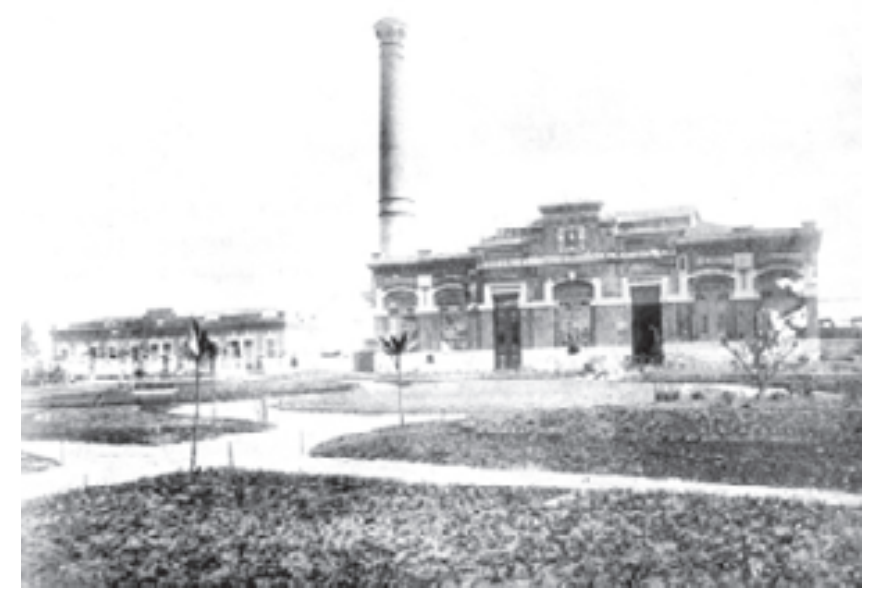

Fig. 18: Usina de Esgotos da cidade, construída em 1876 às margens do rio Tietê, no bairro da Ponte Pequena. vez que o mesmo propunha o represamento das águas do rio antes da cidade.

Os estudos sobre o abastecimento de água em São Paulo mostraram que os recursos hídricos tiveram ao longo do século XX seu uso definido para a utilização em um sistema hidrelétrico, que ofereceu energia abundante e barata para o crescimento do parque industrial 
paulistano. $O$ estímulo ao crescimento econômico, ao provocar o crescimento da aglomeração urbana, desencadeou uma competição entre o crescimento demográfico e o desenvolvimento industrial no uso da água, fato esse que gerou problemas de abastecimento em 1929, obrigando a utilização do reservatório Guarapiranga para o abastecimento público (Amaral e Silva, Polis n³ 3, 1991, 58).

Em outra análise, a competição entre os usos dos recursos hídricos também foi apontada como estratégia da Light em obter a utilização das águas disponíveis ao abastecimento público para a geração de energia. Conseguindo autorização governamental do presidente Arthur Bernardes para a construção das represas Guarapiranga e Billings, em 1925, a concessionária passou a não cumprir os estatutos da concessão em que constava a ressalva de que o uso energético daquelas águas não poderia prejudicar o abastecimento da população, tornandose, segundo essa análise, proprietária das águas de São Paulo (Alves, idem, 65). Assim é que, o sistema hidrelétrico estruturado para garantir a produção de energia passou a comprometer as condições de abastecimento de água, passando também a se constituir em um fator de agravamento das enchentes (Sempla, 1991, 75).

Diferentemente dos espaços de moradia da alta renda, onde os serviços urbanos foram implantados já no nascimento dos bairros, a continuidade do processo de transformação do território implicou na precariedade crescente desses mesmos serviços para a população mais pobre. No início do século XX, com o crescimento demográfico, agravaram-se os problemas sanitários e em 1914, ocorreu grave surto de febre tifóide nos "bairros baixos", provocado pelo uso das águas já poluídas do rio Tietê no reservatório do Belenzinho, construído em 1909 (Sabesp, 2000, 26). O reservatório da Mooca, iniciado em 1926, só entrou em funcionamento onze anos depois, mas, contratos com as concessionárias de gás, água e esgoto foram estabelecidos pela Cia. City, sendo que entre $1918 \mathrm{e}$ 1928 os únicos bairros novos incorporados às redes de água e esgotos foram os recém parcelados Jardim América e Jardim Europa (Morse, 1970, 135). 


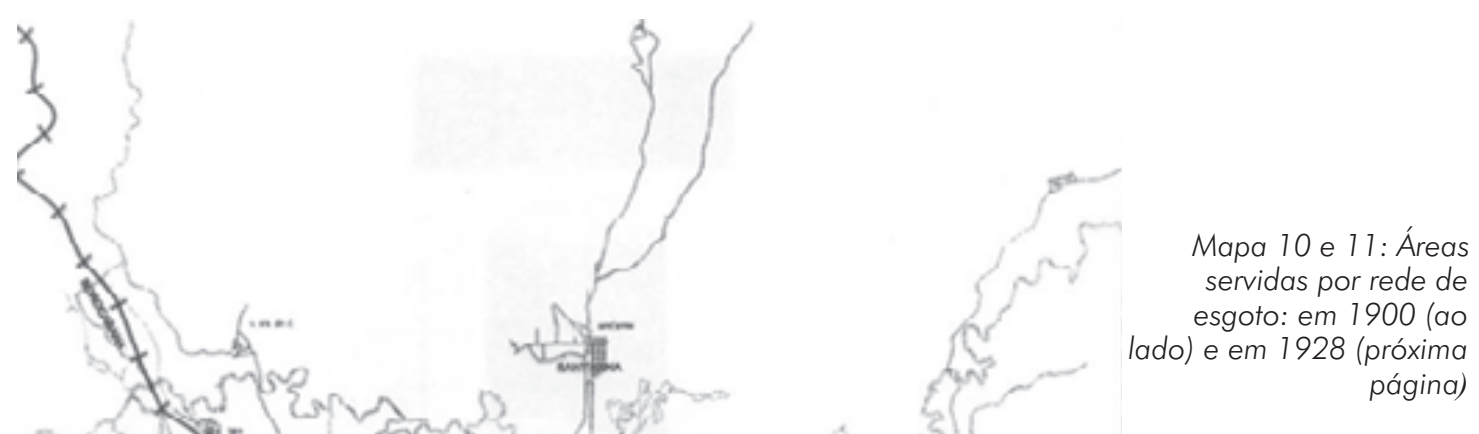

Mapa 12 e 13: Áreas servidas por rede de água em 1900 (ao lado) e em 1928 (próxima página). 

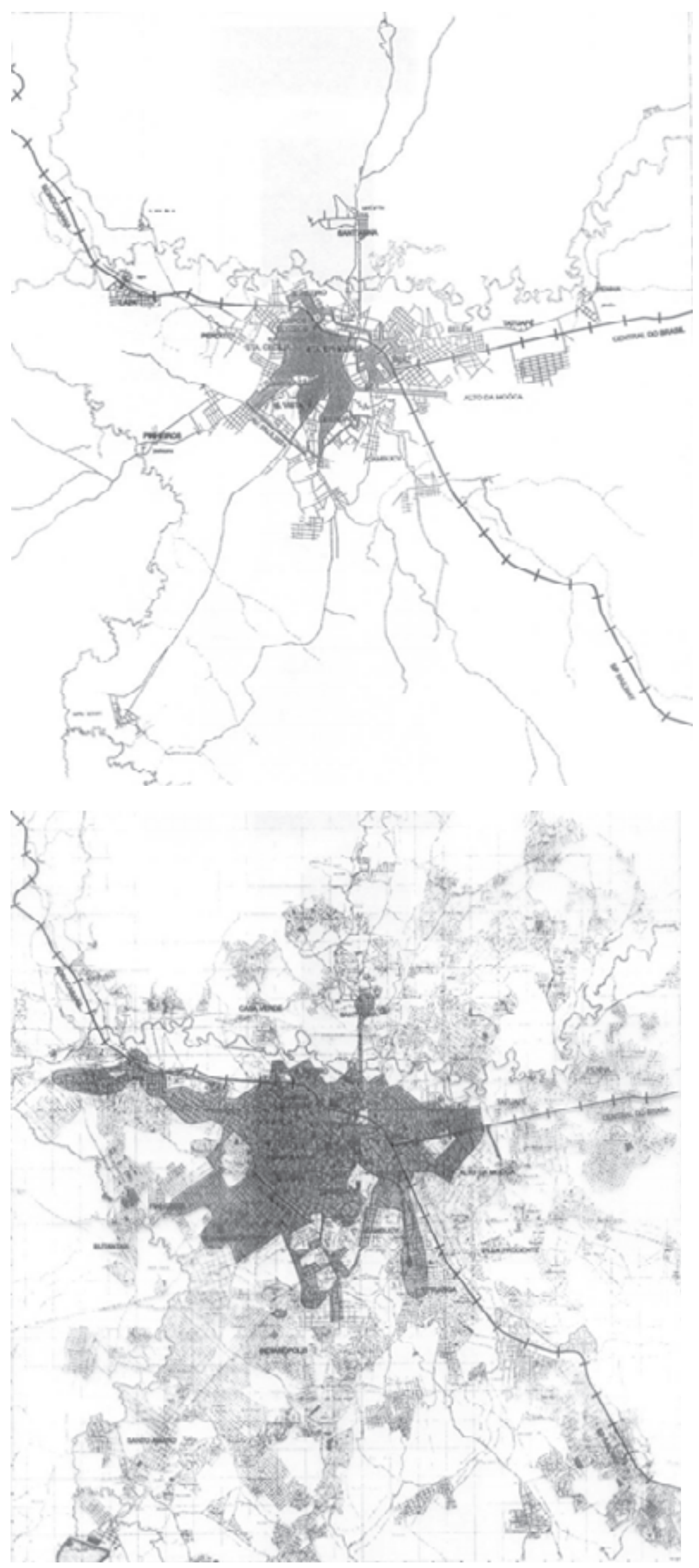


\subsection{Imbricação: sanitarismo, parcelamento do solo e legislação urbanística até a década de 1930}

Frente ao quadro de expansão urbana descontrolada, da abertura de loteamentos e dos problemas de ordem sanitária, a regulamentação urbanística surgiu como forma de se condicionar esse processo de expansão a padrões aceitáveis e estabelecer normas sanitárias para as construções e a cidade, a fim de se debelar as epidemias cíclicas que assolavam a mesma.

Osello, em seu trabalho sobre o Planejamento Urbano em São Paulo, mostra que desde as origens a interferência do Poder Público no processo de produção e reprodução do espaço urbano foram limitadas pelas normas liberais vigentes, muito embora se reconhecesse a necessidade de controle público sobre as construções (Osello, 1983, 26).

Segundo o autor, as leis urbanísticas modernas que foram implantadas, se destinaram a fazer frente aos problemas decorrentes do desenvolvimento industrial na cidade, formando, segundo suas palavras, "dois grupos distintos e complementares: um de leis sobre os loteamentos e outro de leis sanitárias que estabeleceu dimensões e características mínimas para as construções urbanas", já que as que as precederam, ainda no século XIX, não foram capazes de fazer frente ao crescimento que a cidade experimentou (idem, 31). No desenvolvimento a seguir, esses grupos de normas legais serão detalhados, a começar pela legislação de cunho sanitarista, para posteriormente ser enfocada a relação entre as normas urbanísticas e o parcelamento do solo dirigido pelo mercado imobiliário.

O controle urbanístico da cidade, até a década de 1930, através atuação da municipalidade caracterizada pelo "Planejamento Normativo", se deu através dos seguintes instrumentos:

- De 1890 a 1913, vigorou o Código de Posturas sobre a abertura e largura das vias e execução de obras de 1886 (Lei n ${ }^{\circ}$ 1.666/13).

- Em 1915 (Lei n 1874), foi regulamentada a legislação sanitária existente, relacionando-a também com as construções, e além disso, estabelecida por ato complementar do ano seguinte (ato $n^{\circ}$ 849), a subdivisão do município em zonas central, urbana e suburbana.

- A Lei estadual de 1917 ( $\left.n^{\circ} 1956\right)$ regulamentou padrões sobre construções, reformas e licenciamento de edificações.

-1923: Lei de arruamento juntamente com a Lei no $2.611 / 23$

-1929: Código Arthur Saboya (Lei n 3.427). 
Os problemas que atingiam os bairros populares vizinhos ao centro, acumularamse durante as últimas décadas do século XIX e nas primeiras do século XX. As condições sanitárias da cidade, nesse período, foram descritas pelo médico Bruno Rangel Pestana, do Instituto Bacterológico, que demonstrou que $80 \%$ dos casos de febre tifóide ocorridos entre 1913 e 1916, deram-se nos bairros situados em áreas vizinhas aos rios Tietê e Tamanduateí. Outros casos de doenças demonstram a freqüência com que epidemias ocorriam na capital: em 1893 e 1908, varíola; em 1899, 1904, 1913 e 1916, febre tifóide; focos de rubéola em 1906, encefalite em 1920, febre amarela em 1893 (Bertolli F, 2003, 56). Duas situações se distinguiram, com relação ao enfrentamento desses problemas:

-A determinância geográfica dos acontecimentos, onde as doenças que assolavam a cidade tiveram como cenário os distritos suburbanos e os bairros operários, especialmente as áreas onde se encontravam os cortiços.

-A diferença entre os bairros proletários, onde pouco se fez para melhorar as condições sanitárias e aquelas das áreas nobres da cidade. Segundo relatório de Emílio Ribas, quando ocorreram casos de febre tifóide em 1895 na Vila Buarque, "em poucos meses foi feita a total recuperação dos sistemas de água e esgoto daquela área, vindo a doença a desaparecer completamente da região" (Ribas apud Bertolli F, 2003,57).

Mesmo as intervenções paisagísticas na área central, como o alargamento da rua Líbero Badaró foram relacionadas ao urbanismo sanitarista, como afirmou Someck, pois nessa área ocorria a incidência de cortiços e de prostíbulos. Nas palavras da autora "nessa época, o discurso sanitarista domina o pensamento urbanístico. A eliminação da pobreza coincidia com a eliminação da doença e se justificava por isso. Não se cogitava qualquer programa de cunho social" (Someck, 1997, 76).

Considerando a escassez de infra-estrutura de saneamento e de abastecimento de água, um estudo sobre as condições sanitárias das áreas da cidade nas primeiras décadas do século XX corrobora a distinção existente entre as áreas urbanas: "a explosão demográfica não foi acompanhada de ampliação equivalente da rede de serviços básicos... Na virada do século, era quase absoluta a falta de infra-estrutura urbana na zona leste. Os operários - em sua maioria italianos - viviam em condições precárias nos casebres e cortiços que proliferavam no Brás e na Moóca. Transportes, rede de água e esgotos, iluminação pública, escola e outros serviços eram praticamente inexistentes. A construção de vilas operárias junto às fábricas representou uma tentativa de algumas grandes indústrias para remediar essa situação calamitosa.... Somente na época da Primeira Guerra Mundial, tais equipamentos urbanos passaram a ser instalados. As melhorias urbanas introduzidas no Brás e na Moóca provocaram uma valorização dos terrenos e, com isso, o deslocamento da população de menor poder aquisitivo 
para a região mais a leste, onde se formaram novos bairros" (Sempla, 1985, 15).

Para fazer frente aos surtos, as ações do poder público no controle sanitário e no combate às epidemias (do cólera e posteriormente febre amarela) foram desencadeadas uma série de medidas que se estenderam do meio urbano ao controle dos domicílios, resultando nas seguintes ações:

- Criação da Diretoria de Higiene, visando o controle sanitário através de poder de polícia e a promulgação do Código Sanitário de 1894 (nos moldes do código francês de 1850);

- A encampação da concessionária Companhia Cantareira de Águas e Esgotos, em 1892, devido a morosidade na implantação das redes de distribuição de água e coleta de esgoto;

- A criação da legislação do uso do solo, inicialmente com o Código de Posturas, de 1886, o já mencionado Código Sanitário e da Lei 38 de 1893 que estabelecia como obrigatória a aprovação de plantas para as novas edificações de São Paulo (Bonduki, 1998, 30-38).

Detendo-nos inicialmente na atuação da Diretoria de Higiene, esta se voltou prioritariamente à tarefa de debelar o surto epidêmico de febre amarela e do cólera, este último descoberto na Hospedaria dos Imigrantes em 1893. Após a identificação do foco inicial, as inspeções domiciliares foram adotadas como estratégia para a descoberta de outras possíveis ocorrências em São Paulo e essa atuação incluiu além do ataque a focos e remoção dos doentes, a invasão de casas, desinfecção de imóveis, demolição e queima de casebres, prisão de suspeitos, etc. (idem, 31).

As medidas sanitaristas tiveram como paradigma a atuação do médico Oswaldo Cruz, no Rio de Janeiro. Atingida por epidemias de febre amarela e varíola, Oswaldo Cruz fez derrubar cerca de 600 cortiços do centro daquela cidade, eclodindo em novembro de 1904, sob o governo de Rodrigues Alves, a "Revolta da Vacina", com incontáveis mortos e feridos que se opuseram às medidas impostas pelo governo central. A incidência das epidemias reduziu-se drasticamente (469 casos de febre amarela em 1903 e 3500 de varíola em 1904 para números insignificantes, nos anos seguintes). As medidas sanitárias reduziram as doenças, mas contribuíram para o aumento das favelas na então Capital Federal (disponível em <http://www.fiocruz.br> em 2004).

Em São Paulo a questão sanitária foi tratada inicialmente pelo Código Sanitário Estadual, de 1894, referenciado na Lei de Higiene Residencial, decretada na França em 1850. As teorias presentes nesses instrumentos influenciaram os médicos higienistas que desenvolveram a teoria do contágio na qual a propagação das doenças ocorria em função de um meio inadequado. $\bigcirc$ combate à presença 
de lixo, águas estagnadas, pântanos e várzeas, aglomerações humanas concentradas e ar viciado era fundamentado pela "Teoria dos Miasmas", onde o ar era o principal vetor de transmissão das doenças (Simões Jr in IPPUR/UFRJ, 1994, s/pág).

Posteriormente, as teorias de Pasteur corresponderam a um avanço científico de grande importância na identificação dos microorganismos, dando origem a novas medidas higienizadoras que dirigiram uma atuação ao combate aos insetos e animais transmissores e propugnaram a vacinação em massa e cuidados com a insolação, além da ventilação das residências, como forma das populações evitarem as tão recorrentes doenças e epidemias.

Dessa forma, a teoria do contágio foi deslocada do meio físico (tipos de solo, rios, pântanos, topografia, ventos) para o meio social, do espaço público para o espaço privado, apontando para os perigos do modo de moradia e vida da população miserável das cidades. Como explicou Simões Jr. "a repercussão desses novos princípios vem trazer alterações significativas na organização dos ambientes de permanência humana prolongada, e portanto, em muitos dos parâmetros utilizados pela arquitetura" (idem, 1994, s/pág.).

Retomando as teorias sanitaristas anteriores a 1900, focadas na "viciação do $a r^{\prime \prime}$, as mesmas contribuíram para incorporar ao Código de Obras medidas preventivas como pé-direito e cubagem mínimas por cômodos, que foram criticados pelo engenheiro Victor da Silva Freire, que chefiou a Diretoria de Obras Municipais e esteve presente nos congressos internacionais sobre construções de cidades realizados na Europa entre 1890 e 1920 (Simões Jr, in E\&D n 34, $1991,73)$

Já em 1907, Freire abordou o aspecto higiênico dos Melhoramentos de São Paulo, mais especificamente em relação à importância da luz e do ar na salubridade das aglomerações humanas. Comparando com o que se realizava na Europa, para ele a questão do arejamento urbano se iniciava na arquitetura da habitação. Apontou o fato dos técnicos e legisladores esquecerem de levar em conta os fatores "casa e rua, rua e casa" para a formação da cidade salubre e criticou a cópia das disposições estrangeiras que não atendiam as condições próprias do meio e do clima.

Além disso, o excessivo parcelamento interno das habitações seria o responsável pelas más condições de insolação e ventilação nas casas de São Paulo, onde 75\% das habitações da cidade corresponderiam à repetição de "meia dúzia de tipos" nos quais os cômodos de permanência habitual e noturna enfileiravam-se em relação ao corredor, sacrificando o ar e o sol, fazendo com isso, menção ao mesmo problema encontrado pelo engenheiro inglês John Frick nas casas do Rio de Janeiro (Freire in Revista Politécnica, 1914, $\left.n^{\circ} 48,324\right)$. 
Considerando o que foi observado, as alterações na legislação em relação a casa provocaram:

1. A eliminação das exigências relativas à cubagem, presentes ainda no Código Sanitário Estadual de 1917 (a lei estadual de 1911 estabeleceu o volume mínimo de $30 \mathrm{~m}^{3}$ por aposento)

2. A diminuição dos pés-direitos, tanto por serem inúteis do ponto de vista da ventilação, como por encarecer os custos de construção e exigir mais esforço de um pavimento a outro.

3. A revisão do Código Sanitário, definindo novas disposições em função da climatologia do estado de São Paulo, prescrevendo a necessidade da orientação das edificações garantir uma insolação mínima de três a quatro horas por dia.

4. A lei específica sobre insolação, que foi incorporada ao Código de Edificações de 1916 (ato $n^{\circ}$ 900/1916) e definiu aberturas para a frente das edificações, áreas internas ou corredores de iluminação com largura mínima de 2 metros, podendo ainda crescer em função da orientação da construção em relação à linha N-S. (Simões Jr in IPPUR/UFRJ, 1994, s/pág.)

Em relação à legislação urbanística voltada às ruas, essa lei incidiu também na:

1. Orientação das ruas, quadras e lotes em relação à linha norte-sul, visando melhor insolação e buscando dificultar a abertura de ruas com traçados perpendiculares a ela.

2. $\bigcirc$ Código de Posturas de 1866 definia a ortogonalidade da malha urbana, através da obrigação de ruas retilíneas e praças quadradas. As ruas deveriam ter uma largura invariável de $16 \mathrm{~m}$. Victor Freire propôs a diminuição desse padrão importado da França, alegando ser 8 metros uma largura suficiente e incorporando para as áreas de expansão da cidade os princípios de hierarquia viária estabelecidos por Stübben vinculando às dimensões de tráfego local, de passagem e avenidas e a altura dos edifícios.

3. Pelos instrumentos normativos de 1920 e 1923 (Padrão Municipal e Lei dos Arruamentos), os edifícios passaram a ter suas alturas fixadas de acordo com a largura das vias, como será visto adiante.

4. Outra alteração significativa, decorrente da diminuição das dimensões do arruamento e das quadras, enfatizada por Freire, se deu em relação à economia proporcionada pela menor necessidade de terraplenagens e de menores distâncias para a instalação de infra-estrutura urbana (idem, s/pág).

A decorrência dessas medidas em São Paulo foi a de terem transformado a volumetria, considerada "antiga", das tipologias existentes. 
Simultaneamente à questão sanitarista, outro problema crescente em São Paulo, desde as duas últimas décadas do século XIX, foi o da autorização ou proibição de usos e padrões construtivos em sua área urbana. $\bigcirc$ rápido crescimento populacional foi acompanhado do intenso parcelamento das antigas chácaras, que passaram a servir de base fundiária aos loteamentos. Associado ao crescimento das atividades econômicas e a conseqüente diversificação da cidade, o incentivo ao mercado imobiliário também contou com os seguintes fatores:

- o período do Encilhamento, que em 1890 favoreceu a constituição acionária de empresas que dispunham de emissões de bancos para o financiamento na compra de terras e para a construção civil (Yazigi, 2000, 100).

- o lançamento de hipotecas sobre os imóveis urbanos, em 1900, como condição para a concessão de créditos aos fazendeiros, fator que estimulou o processo de expansão urbana com o lançamento de novos loteamentos (Souza, 1994, 57).

Castillo abordou esses fatores como marcos da intensificação da mercantilização do solo da cidade. A valorização da terra urbana, a ponto de torná-la um investimento lucrativo, ocorreu segundo o autor, como um reflexo material decorrente dos melhoramentos na cidade (Castillo, 1993, 92). Em relação ao Encilhamento, mencionou que: "é assim, sob esse contexto que São Paulo conheceu a instalação da Bolsa Livre, de efêmera vigência, de várias companhias industriais, de casas comerciais e bancos. Muitas dessas companhias e bancos tinham a atividade imobiliária - venda e compra de terrenos urbanos - sua base de sustentação" (Barbosa apud Castillo, 1993, 92). É estreita, portanto, a relação entre os investimentos públicos em infra-estrutura do período, e a conseqüente internalização desses investimentos pela atividade imobiliária.

O outro fator para a mercantilização do solo, as hipotecas de imóveis urbanos para subsidiar a expansão cafeeira, teve desdobramentos igualmente importantes para o mercado imobiliário: "no governo de Bernardino de Campos (19021904), se tomam todas as providências no sentido de habilitar o imóvel urbano como bem hipotecável para fins de crédito agrícola. Ou seja, a cidade estava se aprontando, se embelezando para que seus imóveis tivessem mais que um valor de uso, mas um valor substancial de troca" (idem, 95, grifo nosso).

Um exemplo expressivo da relação entre bancos e investimentos imobiliários foi dado pelo arquiteto Ramos de Azevedo, que participou de ambos. Segundo Lemos, em 1911 Ramos de Azevedo fundou o Banco Ítalo Belga, juntamente com outros ilustres membros da aristocracia local'. Já em 1913, fundou a Companhia Suburbana Paulista, voltada a parcelar as terras entre o Butantã e Osasco para chácaras, lotes residenciais e industriais (Lemos, 1993, 77).

Em São Paulo, além do núcleo central da cidade, que abrigava o Triângulo histórico, já haviam sido definidas algumas localizações de bairros da elite, áreas 
industriais e de moradia popular, estas situadas junto aos bairros onde se situavam as fábricas. A atividade imobiliária superava a demanda e criava ao longo das vias de transporte, uma sucessão de loteamentos desconectados e muitas vezes sem obediência às tímidas recomendações da municipalidade, expressas ainda pelo Código de Posturas de 1886.

Apenas para as áreas consideradas nobres, as exigências fixadas pelos loteadores foram rigorosas, preservando-as contratualmente de usos incômodos, fracionamento e edificações julgadas incompatíveis nesses empreendimentos. Assim como ocorreu nos Campos Elísios, Higienópolis e avenida Paulista, ainda no século XIX, esse fato se repetiu também com a Cia. City a partir de 1913 e com os bairros-jardim de outras empresas loteadoras, como será mostrado adiante.

A diferenciação dos espaços que a cidade passou a apresentar foi fruto das diferentes formas de apropriação e comercialização do solo urbano de São Paulo. Segundo Rolnick, os loteamentos populares prescindiam de proibições aos usos que foram feitos em outras partes da cidade, como o Triângulo Central ou na zona urbana, constituindo esse aspecto "um importante fator de atratividade para oportunidades imobiliárias de pequenos e grandes investidores "(grifo nosso). Nas palavras da autora, "ao contrário dos loteamentos residenciais exclusivos, que procuravam predefinir o tipo de uso ao estabelecer um tamanho de lote e, posteriormente garantir uma forma de implantação através de lei, o loteamento no subúrbio popular era o que Victor da Silva Freire denominava de 'lote para o que der e vier"2 (Rolnick, 1997, 116).

O estudo de Grostein mostra que até 1913 o Poder Público contou com precários meios de controle e registro dos arruamentos e parcelamentos, atuando com o Código de Posturas do Município. Apenas em 1913, surgiu a primeira lei de arruamentos, seguida da lei de oficialização das vias clandestinas em 1916. Até a promulgação do Código Arthur Saboya, apesar de ser solicitado que os arruamentos se submetessem a diretrizes viárias ditadas pela municipalidade, quando da abertura de novas vias, conviviam na cidade dois tipos de vias, as particulares e as públicas, gerando problemas em relação à clandestinidade das primeiras (Grostein, 1987, 41).

Em 1923, através da Lei Municipal n²611, o poder público buscou interferir na abertura de loteamentos e arruamentos, visando a continuidade da malha urbana. Como será visto adiante, essa lei definiu a hierarquização das vias, padrões para o tamanho dos lotes, taxas de ocupação e recuos, sem contudo estabelecer os usos que seriam permitidos na área urbana. Embora tenha avançado em relação às anteriores, essa legislação não logrou resultados na regulação da expansão da área urbana do município, por conta da prática 
comum do loteamento clandestino e pela falta de fiscalização nas áreas mais afastadas do núcleo central. (Wakisaka, 1991, 52)

Com exceção do núcleo central e dos bairros de elite, no restante da cidade os interesses dos loteadores prevaleceram sobre as poucas diretrizes da municipalidade sobre o parcelamento e arruamento. Até 1923, o loteador era obrigado a apresentar apenas o traçado do arruamento, sem a delimitação dos lotes. Além disso, o arruamento poderia ainda não estar de acordo com os preceitos do antigo Código de Posturas, ou seja, largura de 16 metros e malha viária ortogonal. A delimitação do perímetro urbano em 1913 foi definido simplesmente como um círculo com 3.300 metros no entorno da Praça da Sé, sendo o perímetro suburbano o restante da área do município (idem, 90).

A verdadeira anarquia que se constituiu o processo de parcelamento da cidade, antes da lei de 1923, permitiu que a ocupação dos lotes dos arruamentos aprovados ou oficializados fosse feita sem qualquer restrição, dando origem a bairros como Casa Verde, Vila Cerqueira César, Vila Maria baixa, Jardim Japão, Vila Pompéia, Vila Jaguara, Vila Mangalot, Vila Anastácio, Aclimação, Bosque da Saúde, Mirandópolis, etc. (Trapé apud Grostein, 1987, 90)

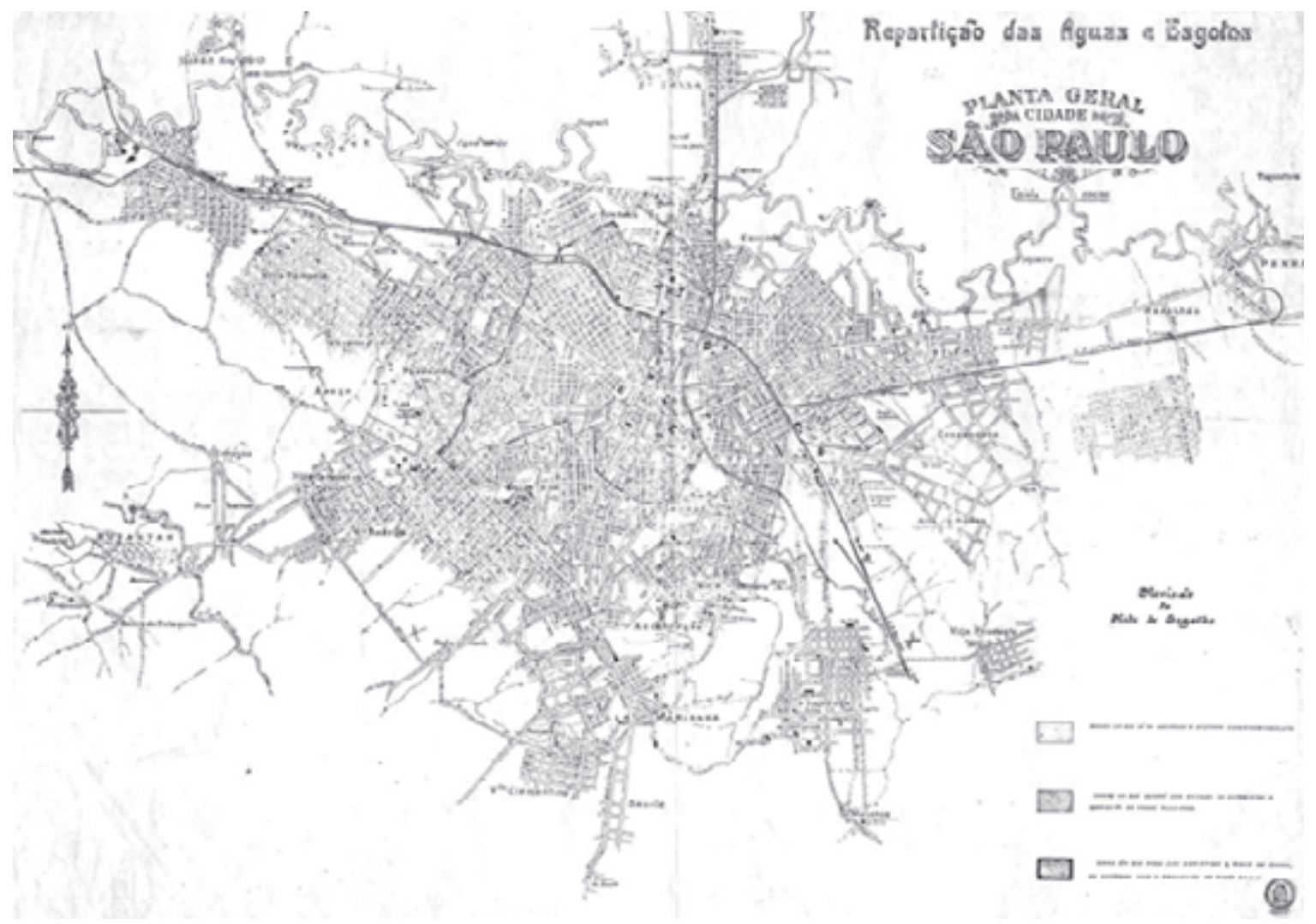

Mapa 14: A cidade em 1915, Repartição de Águas e Esgotos. 
A Lei de 1923 instituiu:

- Necessidade de diretrizes viárias para a abertura de ruas ou arruar e lotear com um plano de referência ou conectado à estrutura já existente da cidade

-Alvarás de licença

-Plano de loteamento das quadras resultantes do arruamento, constando a situação com curvas de nível, arruamento, espaços livres, plano de nivelamento das ruas, sistema de escoamento de águas superficiais.

- Obrigatoriedade de saneamento dos terrenos alagadiços para execução de arruamentos

Além desses dispositivos, instituiu-se a doação de áreas à municipalidade quando o empreendimento ocorresse em terrenos com mais de $40.000 \mathrm{~m}^{2}$, sendo $20 \%$ para as vias de comunicação e uma gradação para áreas livres: $5 \%$ da área total na zona urbana, $7 \%$ na suburbana e $10 \%$ na rural. Foi instituída também a área de $300 \mathrm{~m}^{2}$ como área mínima permitida para os lotes, e o agrupamento de até seis casas.

Observando o que foi disposto, é necessário mencionar que continuaram a coexistir as vias públicas e particulares, estas últimas abertas e sob a responsabilidade de proprietários. A duplicidade de competências transformou as vias particulares em uma alternativa para os loteadores escaparem dos controles da municipalidade, fazendo com que fosse adotada uma política de oficialização recorrente por parte do poder público (idem, 143).

Langenbuch aponta na planta da cidade de 1922, organizada pela comissão Geográfica de São Paulo, os seguintes arruamentos isolados em maior ou menor grau da malha contínua da cidade: Vila Maria Baixa e Jardim Japão (então já interligados), Vila Guilherme, Tucuruvi, Chácara Itaim, Vila Anastácio e Indianópolis, que aparecia ainda no início de arruamento.

Como núcleos isolados, separados da cidade apareciam Nossa Senhora do Ó, Casa Verde, Santana, Penha, Vila Gomes Cardim, Vila Prudente, Ipiranga e Vila da Saúde.

Foi também verificado um início de arruamento entre o bairro da Consolação e Pinheiros. Entre Perdizes e Lapa, a Vila Pompéia e Vila Romana preencheram os vazios existentes. Entre a Lapa e Vila Leopoldina, apareceram os loteamentos do Alto da Lapa e Bela Aliança. Além deles já eram vistos os novos loteamentos situados em áreas vizinhas ao bloco central da cidade, que já apresentavam ruas arruadas, como o Pacaembu, Jardim América, Jardim Europa, Jardim Paulista e Alto da Mooca. Langenbuch concluiu que a maioria dos loteamentos se encontrava sem ocupação e que o espaço dessa expansão urbana superava 
muito as necessidades da cidade, "permanecendo a especulação imobiliária que já caracterizara o período anterior", segundo suas palavras $(1971,132)$.

O Código de Obras Arthur Saboya, de 1929, consolidou as disposições sobre arruamentos, loteamentos e construções de 1923, contendo ainda normas relativas à salubridade e estabelecendo gabaritos das construções em função da largura das vias. Observou-se ainda que, o Código buscou estimular a verticalização na zona central e tornou-a possível sob condições, na zona urbana. Com relação a esses novos padrões, esse Código tornou mínimos os padrões que a legislação de 1920 (lei n² 2 322) considerava máximos. A conseqüência dessa legislação foi a de possibilitar um potencial construtivo maior para a área do Centro (que incluía o Triângulo e grande parte da área além-Anhangabaú), ocasionando com isso a contínua elevação dos preços dos terrenos e imóveis naquela área (Rolnick, 1997, 129). Na análise sobre a Av. São João, desenvolvida adiante, será possível verificar a aplicação dessas normas que definiram novas volumetrias à cidade de São Paulo.

Retomando, o artigo 142 do Código Arthur Saboya instituiu que, para os edifícios construídos no alinhamento das vias públicas na zona central, a altura mínima era de cinco metros; duas vezes quando a largura da via fosse de nove metros; duas vezes e meia quando a largura da via fosse de nove a doze metros e de treze vezes quando a largura da via fosse mais de doze metros. A lei considerou a largura da rua São Bento, no Triângulo Central, de nove metros e o Art. 180 proibia a construção com menos de quatro pavimentos (sem contar o embasamento, isto é, descontado o porão) em todo o Triângulo comercial, avenida São João, avenida Anhangabaú, ruas do Centro Novo e rua das Palmeiras, entre a praça Mal. Deodoro e Largo Padre Péricles. Fora dessa zona, as construções edificadas no alinhamento das vias teriam no mínimo, três metros "sob condição de não servirem para habitação" (Netto, 1947, 46). Essa restrição se dirigia claramente às condições precárias dos casebres, combatidas pelos órgãos públicos.

No tocante aos seus dispositivos voltados aos novos loteamentos, como na Lei de 1923, o Código recomendou o máximo de 20\% da área destes para o sistema viário e $5 \%$ para praças. Estipulou ainda uma utilização de $3 / 5$ das ruas para a parte carroçável e 1/5 para cada calçada (Yázigi, 2000, 107). Também presente nesse Código, a divisão da cidade por zonas central, urbana, suburbana e rural, uma vez que a divisão dos perímetros urbano, suburbano e rural datava de 1914.

Essa divisão incluía como primeira zona, ou Central, toda a área hoje compreendida atualmente pelo Centro Velho e Centro Novo ${ }^{3}$. Como segunda zona, ou urbana, um anel compreendendo grande parte dos atuais distritos que hoje circundam o Centro, incluindo também Lapa, Pompéia, Perdizes, Vila Mariana e Mooca ${ }^{4}$. Já a zona suburbana incluía as áreas de bairros como Pinheiros, 
Ipiranga, Santo Amaro, Jabaquara, Tatuapé, V. Guilherme, Santana e Casa Verde (Netto, 1947, 13)

O sistema viário da cidade foi hierarquizado segundo as seguintes categorias constantes no Art. 734:

$1^{a}$ categoria - estradas, só permitidas na zona rural e com largura mínima de treze metros

$2^{a}$ categoria - caminhos, igualmente só permitidos na zona rural e com largura mínima de oito metros.

$3^{a}$ categoria - passagens, só permitidas para construção de "casas populares" (sic) com largura mínima de quatro metros.

$4^{a}$ categoria - ruas de interesse local ou de caráter exclusivamente residencial, com largura variando de oito a doze metros.

$5^{a}$ categoria - ruas secundárias, com largura de doze a dezoito metros.

$6^{a}$ categoria - ruas principais, com largura de dezoito a vinte e cinco metros.

$7^{a}$ categoria - que abarcava as vias de grande comunicação e as artérias de luxo com mais de vinte e cinco metros. (Netto, 1947, 162).

Conforme foi observado anteriormente, a cidade apresentou uma expansão horizontal notável no período 1914-1930, mesma época em que os estudos do Plano de Avenidas foram desenvolvidos e apresentados, objetivando a desconcentração da Área Central. Essa expansão, responsável pela ocupação quase que total dos bairros centrais e pela criação dos subúrbios, trouxe a marca da cidade irregular. Incapaz de fazer frente aos loteadores, mesmo com a promulgação do Código Artur Saboya, a municipalidade não dispunha de uma visão urbanística integrada, muito menos condições de fiscalizar o conjunto de arruamentos e loteamentos abertos de forma irregular. Já em 1931, o então prefeito Anhaia Mello comprovava que a cidade clandestina era maior que a cidade oficial (Rolnick, 1997, 149).

Muito embora os bairros centrais já estivessem grandemente consolidados enquanto traçado e parcelamento, a liberalidade para com a expansão da cidade nos subúrbios persistiu até 1950. Como conseqüência desse processo, denominado de "descontrole consentido" por Grostein, (1987, 172), as concessionárias de serviços públicos não instalavam redes nas ruas particulares, já que todas as despesas das instalações correriam por conta do proprietário das vias e lotes não oficiais, o que obviamente não era feito.

Desse modo, à medida que o processo de abertura de loteamentos teve continuidade, o poder público se viu na contingência de sucessivas oficializações, como a de 1936 (Ato 1.123), considerada a primeira grande lei de anistia para 
os assentamentos populares (Rolnick, 1997, 172). A morfologia urbana dos bairros centrais traz a marca desses eventos.

De forma diversa, nas áreas ocupadas pela população de alto poder aquisitivo, a legislação se constituiu em uma incorporação de normatizações mais rígidas, vindas dos loteadores particulares, o que definiu, já nas primeiras décadas do
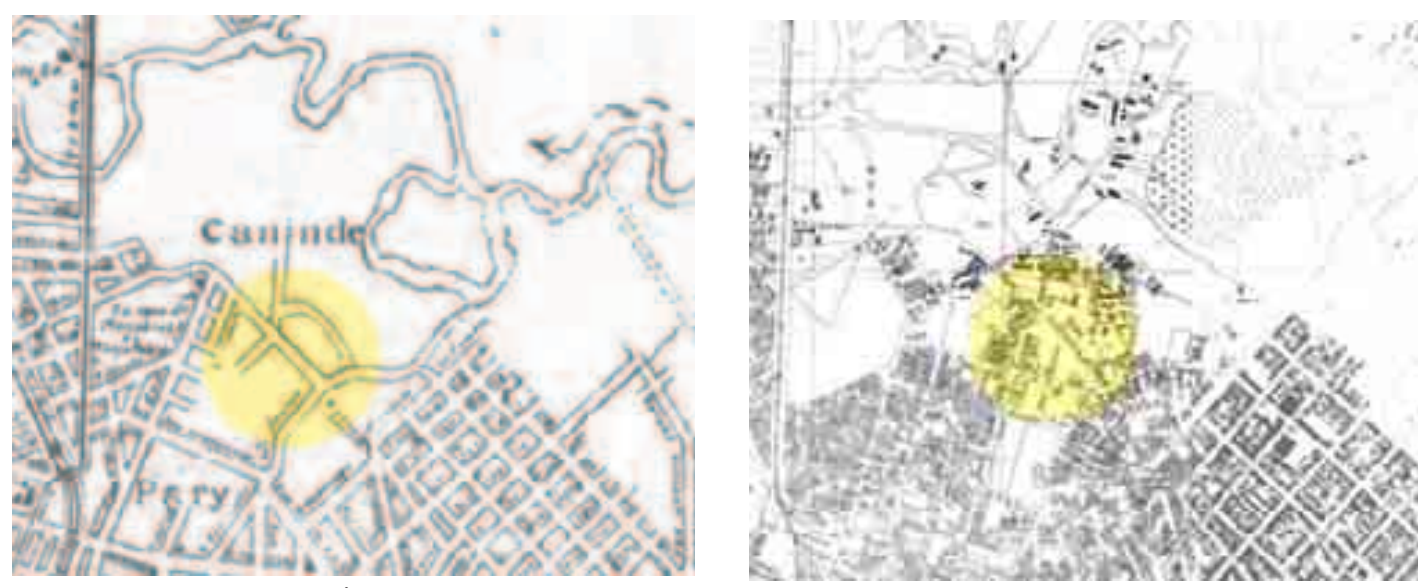

Mapa 15 e 16: À esquerda: detalhes do mapa de 1915, onde a várzea do rio Tietê foi mapeada sem os arruamentos e construções do morro do Pari. À direita, detalhe do mapa Sara Brasil, onde foram registrados lotes, e não arruamentos, que, no caso, ainda eram irregulares.

Fig. 19 e 20: Acima, as travessas e becos do Morro do Pari. Abaixo, habitação remanescente do iníco do

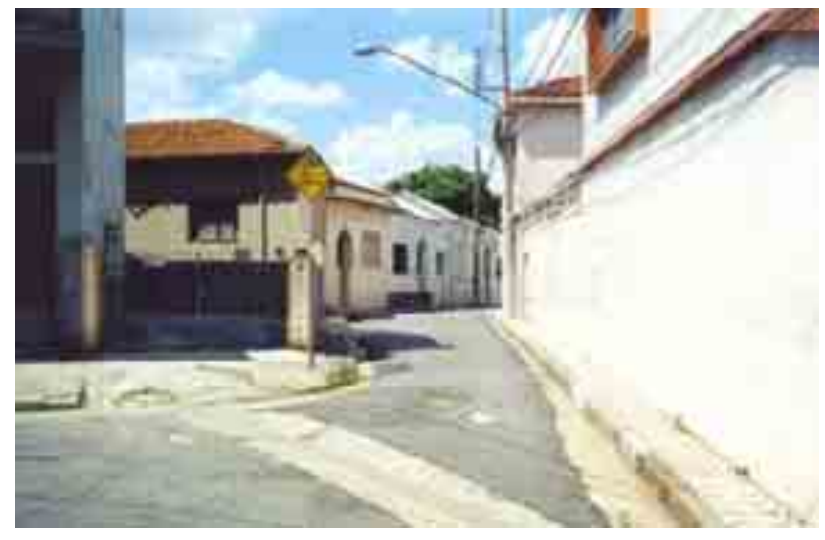
século XX.

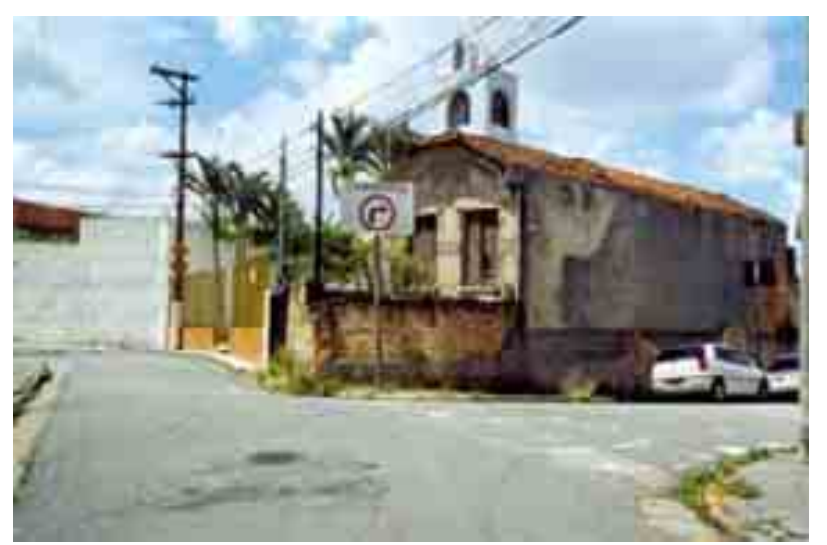


século passado, um pré-zoneamento para esses espaços específicos: os bairros nobres e o Centro histórico.

Além da obrigatoriedade de recuos que a legislação instituiu para os diferentes bairros da cidade, nos bairros de alta renda o Código Arthur Saboya incluiu também a proibição de construção de fábricas, como no caso do artigo 35, referente à avenida Paulista e autorizou somente construções para fins residenciais nas áreas ocupadas pelos bairros-jardim. Nos artigos 39 e 40, que trataram dessa matéria, cuidou-se inclusive de incluir uma série de medidas necessárias para que, com a anuência dos proprietários de imóveis distantes até 400 metros fosse autorizada a criação de núcleos comerciais nas proximidades desses bairros (Netto, op.cit, 21). 


\subsection{Imbricação: sanitarismo e habitação popular nos bairros centrais - cortiços e as vilas operárias}

Considerando a questão da habitação social no quadro urbano que São Paulo apresentava no período 1897-1930, foi essencial o contingente de mão-deobra ter se mantido próximo aos locais de trabalho, nas etapas iniciais do processo de industrialização, sendo dois fatores determinantes para tal:

1. O processo de industrialização ter ocorrido impondo condições extremamente desvantajosas ao operariado, sujeitando-o a moradias de aluguel disponíveis nas zonas fabris ou em suas proximidades, áreas então desvalorizadas pelo mercado imobiliário.

2. A abertura de novos espaços urbanos distantes do Centro ocorrer em função do transporte ferroviário, que não oferecia flexibilidade para os deslocamentos. Mesmo o bonde, que desempenhava o papel de distribuidor na malha da cidade, representava um grande dispêndio aos trabalhadores. A comprovação disso é demonstrada pela necessidade da empresa "Light and Power Co. Ltd." ter que destinar algumas de suas composições ao transporte de operários, em que eram cobradas tarifas mais baratas nas linhas que corriam os bairros centrais com destino às áreas industriais.

Dessa forma, para a população trabalhadora (incluindo partes da baixa classe média representada por funcionários públicos e empregados no comércio), as relações urbanas se pautavam pela proximidade entre os locais de trabalho e de moradia. Com a ferrovia servindo de principal elemento estruturador da localização das indústrias, outro fator relacionado ao processo de ocupação

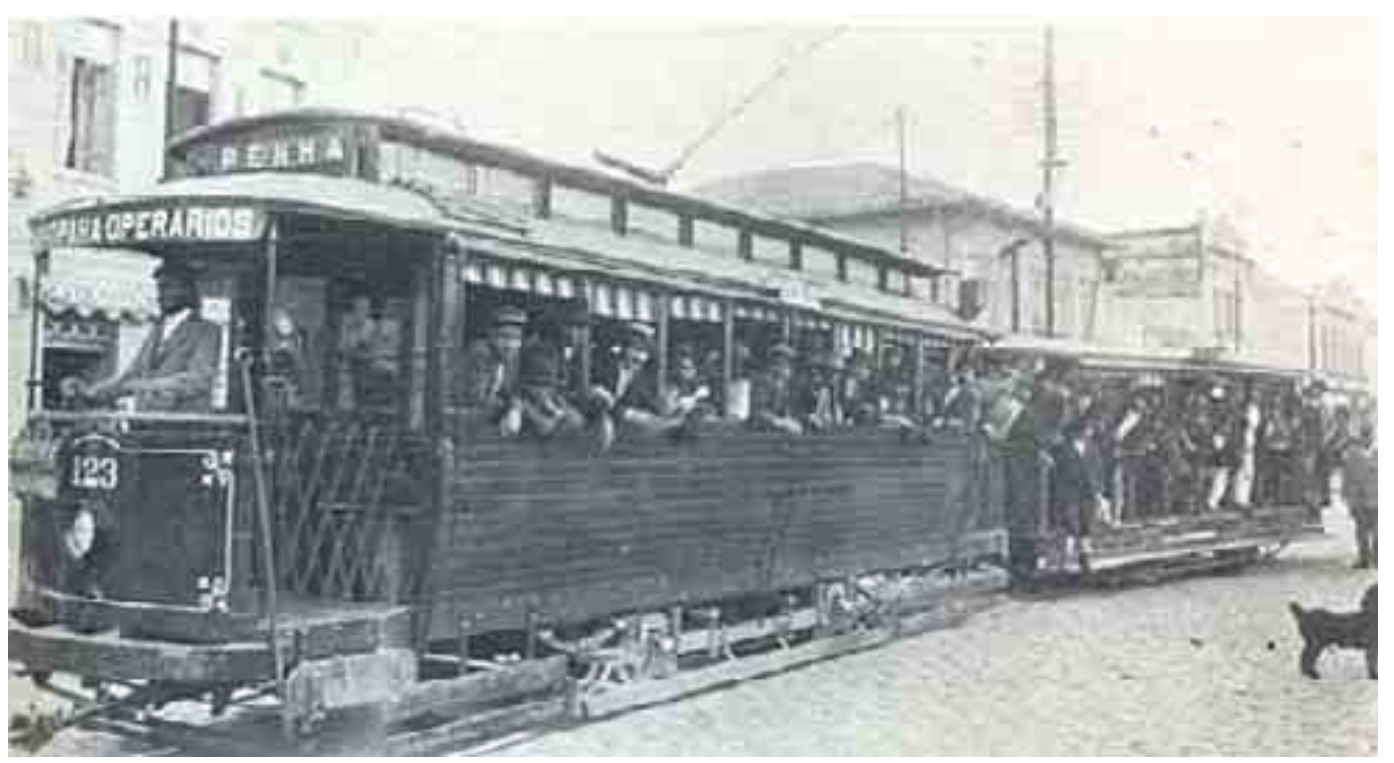

Fig. 21: Bonde operário. 
das atividades foi o bonde, que necessitava de regiões adensadas para sua operação e foi responsável por um modelo de cidade concentrado, se comparado com os períodos seguintes da expansão urbana. Ao mesmo tempo que esse modelo não estimulou a formação de bairros mais populosos distantes do Centro, cumpriu um papel essencial dentro da estratégia de "manter o trabalhador próximo ao emprego, uma vez que suas jornadas de trabalho eram extensas e ele não dispunha de tempo para o transporte" (Sempla, 1985, 14).

O surgimento dos cortiços, como alternativa para a moradia da classe trabalhadora, remonta o início do ciclo da industrialização em São Paulo, ainda no final do século XIX, com a vinda massiva do imigrante europeu que se constituiu na mão-de-obra das fábricas implantadas nos bairros próximos às ferrovias. Diferentemente do Rio de Janeiro, onde desde meados da década de 1880 a suburbanização havia se iniciado e já se constituindo em uma das alternativas de moradia popular, em São Paulo este tipo de habitação se localizou nas áreas próximas ao Centro, através de edificações com precárias condições físicas e sanitárias e alta densidade de moradores.

Segundo o estudo de Lílian F. Vaz sobre a habitação popular no Rio de Janeiro, no começo do século passado, posturas municipais procuraram restringir a presença das habitações coletivas no núcleo central, ampliando a área de proibição dos cortiços. Estes se multiplicaram nessa área por se constituir em uma forma possível de aproveitamento do restrito espaço existente e responder à necessidade de moradias baratas para os trabalhadores, proporcionando a obtenção de rendimentos aos proprietários e arrendatários dos prédios e terrenos, dado o alto valor dos aluguéis (Vaz apud Sampaio (org), 1998, 40/43).

As preocupações com o sanitarismo e o controle social presentes na reestruturação da parte central da cidade do Rio de Janeiro, então Capital Federal, convergiram para a ação conjunta dos governos municipal e federal em torno de três focos: o controle sanitário, urbanístico e de circulação. Esses aspectos se constituíram no eixo dos melhoramentos propostos no Programa de Renovação Urbana da administração de Pereira Passos (1902-1906), cuja atuação contra as condições da habitação popular na zona central, através das obras de saneamento e embelezamento da cidade, foram conhecidas também pelo nome de "botaabaixo". Como resultado dessas medidas, ocorreu uma dispersão dos moradores pelas casas de cômodos situadas em áreas mais próximas, pelos subúrbios por onde circulava a ferrovia e pelas favelas, que "passaram a fazer parte da imagem urbana carioca num contraponto à modernização" (idem, 44).

Na cidade de São Paulo, nas últimas décadas do século XIX, a tentativa de estabelecer a proibição de casas de cômodos ou cortiços esteve presente no Código Sanitário de 1886. A existência dessas habitações, em grande número na área central e em bairros onde a população negra ocupara, como Bexiga, 
Barra Funda e Santa Efigênia, fez com que esse Código incorporasse uma série de restrições à sua construção e de exigências para as novas edificações. Assim como ocorreu no Rio de Janeiro, essa intervenção visou adequar a cidade à sua nova imagem pública e responder às precárias condições sanitárias que grande parte dos distritos paulistanos apresentava. Como exemplo, mencionamos o distrito de Santa Efigênia, onde a população passou de 14.025 moradores em 1890 para 43.715 em 1893, e que em 1892 foi atingido por uma epidemia de febre amarela, sendo responsabilizados o intenso adensamento e as condições de higiene nas habitações (Rolnick, 1997, 37).

Os problemas que a cidade apresentou no início do século XX se originaram devido ao rápido crescimento demográfico provocado pelo afluxo de trabalhadores a São Paulo, iniciado no século anterior. As péssimas condições dos bairros operários e das suas habitações suscitaram medidas por parte dos órgãos públicos com o objetivo de debelar os focos de doenças, que tinham como causa, segundo as teorias higienistas daquele período, o meio promíscuo em que se encontrava a maioria da população. Nesse sentido, a casa e a cidade se tornaram objeto de estudos do urbanismo sanitarista, concebido para o controle das situações críticas originadas pela revolução industrial nos países centrais, particularmente os europeus.

As condições extremamente precárias para os trabalhadores da cidade de São Paulo reclamavam por soluções, como atestou Bandeira Junior em 1901: "Nem um conforto tem o proletário nesta opulenta e formosa capital. Os bairros em que mais se concentram por serem os que contém o maior número de fábricas, são os do Brás e do Bom Retiro. As casas são infectas, as ruas, na quasi (sic) totalidade não são calçadas, há falta de água para os mais necessários misteres, escassez de luz e esgotos. O mesmo se dá em Água Branca, Lapa, Ipiranga, São Caetano e outros pontos um pouco afastados. Entretanto sobra espaço para a fundação de uma grande ou mesmo mais de uma vila operária, com secções balneárias, lavanderia, escolas noturnas, secções de recreio, posto médicofarmacia e outros confortos que constituem esses núcleos quando bem organizados (Bandeira Júnior apud Blay, op. cit., 52).

Embora os cortiços fossem coibidos pela legislação urbanística, inclusive pela consolidação do Código de Obras Arthur Saboya, na década de 1930 a cidade dispunha de poucas alternativas para a população trabalhadora que não fossem as habitações coletivas e estas se constituíram por décadas uma fonte de renda segura para proprietários e construtores, a despeito de suas precárias condições e da irregularidade perante as normas urbanísticas.

De acordo com os princípios higienistas, defendidos por urbanistas como Victor de Assis Freire, as habitações coletivas ocupadas pela população pobre eram contrárias à saúde física e moral dos trabalhadores. Para debelar as epidemias 
e estabelecer um controle da "contaminação moral", o Código Sanitário Estadual, de 1894, entre outras disposições, proibia as habitações coletivas, as casas subdivididas e as vilas operárias, estas permitidas apenas se possuíssem até seis unidades e localizadas fora da aglomeração urbana.

No mesmo ano, a "Comissão de Exame e Inspeção das Habitações Operárias e Cortiços no Distrito de Santa Ifigênia", ao constatar a presença nesse distrito de 65 cortiços em 14 quadras, sugeriu o incentivo a empresários para construir casas operárias distantes 15 quilômetros da cidade. A construção dessas residências obedeceria aos seguintes critérios:

-Localização reunindo facilidade de comunicação e terrenos baratos.

-Estabelecimento de padrão distinto, implicando em maior aproveitamento horizontal do lote.

-Transporte através de trens de subúrbio às áreas de emprego.

- Isenção dos impostos municipais e estaduais incidentes sobre as construções. (Rolnick,1997, 123; Lemos apud Sampaio, 1998, 13; Blay, 1985, 64).

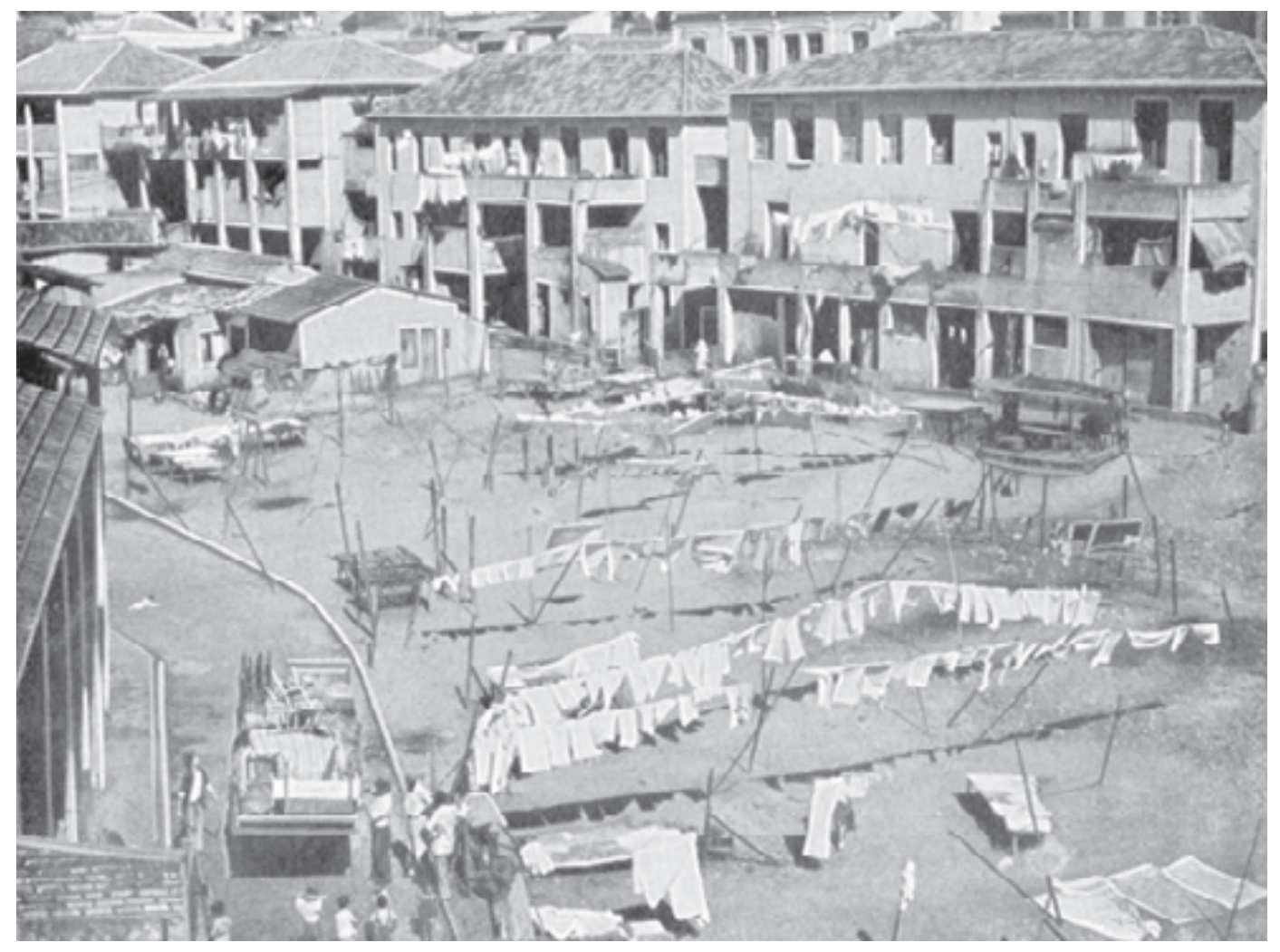

Fig. 22: Cortiço no Bexiga. 
Configurou-se um quadro contraditório em que o Poder Público por um lado restringia a possibilidade de uma tipologia no Centro e por outro preconizava a sua construção em áreas mais afastadas (Rolnick, 1997, 59). A mesma Comissão encarregou-se de definir duas tipologias: uma de casas mais baratas, que poderiam ser construídas em qualquer área e outra mais cara para substituir os cortiços centrais ou nos bairros mais próximos. Ficou patente também a relação que a municipalidade estabeleceu com o transporte ferroviário, no sentido de dispersar a aglomeração dos núcleos de casas populares para fora do Centro e da Zona Urbana (Blay, 1985, 73), fato este que se tornaria o modelo de expansão da cidade nas décadas seguintes, direcionada pela habitação popular.

Crescimento da cidade nas primeiras décadas do século XX trouxe como conseqüência direta a expansão territorial diferenciada para os diversos segmentos sociais de São Paulo. Abordando esse processo, Grostein analisa que os loteadores asseguraram o uso por uma só classe das áreas nobres e ao mesmo tempo, o poder público legislou de forma a direcionar e incentivar o investimento imobiliário na produção de novas tipologias residenciais populares, que se constituíram nas vilas operárias (Grostein in Sampaio, 1998, 103).

Como foi visto no quadro 2, a população de São Paulo saltou de 279.000 habitantes em 1905, para 415.000 em 1914, chegando a 822.400 em 1930. Em conseqüência desse incremento, a crise da moradia nesse período teve duas componentes: a inexistência de uma política definidora de regras para o inquilinato e uma produção oscilante da construção civil a partir da metade da segunda década.

A alta dos aluguéis tornou-se um fator de pressão sobre o custo de vida e como a maioria das moradias da cidade eram alugadas, o impacto recaiu sobre a população de menor renda, com conseqüências

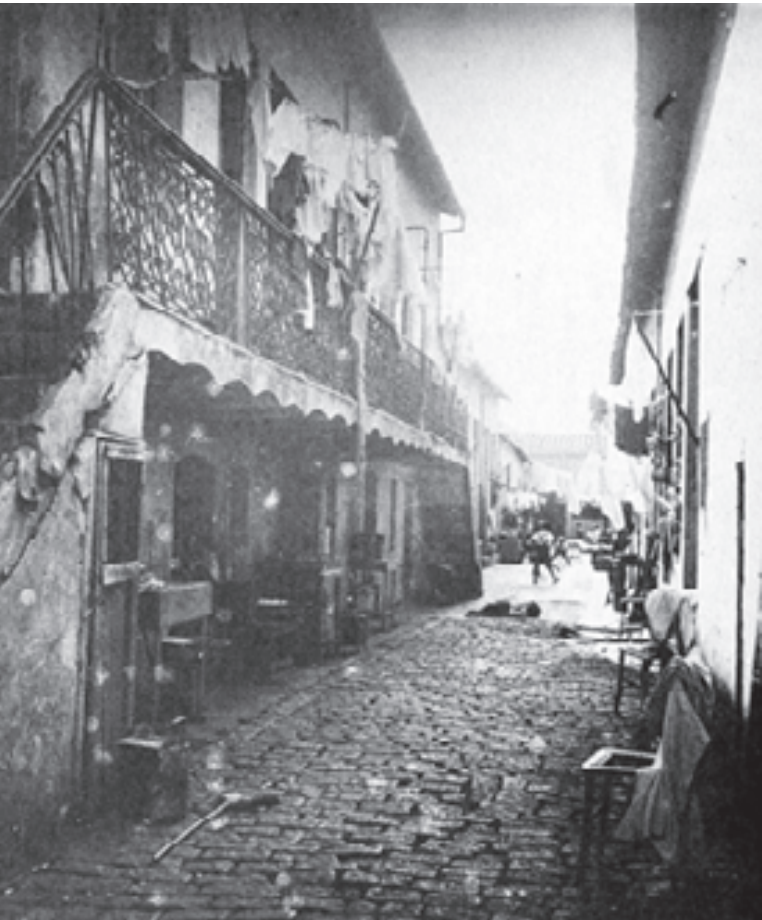

Fig. 23: Cortiço do Brás, do início do século XX, na rua Carneiro Leão, foto da década de 1940 diretas em relação a qualidade da habitação possível de ser alugada. Além da imprensa 
ligada aos anarquistas e movimentos populares, que denunciaram continuamente a espoliação que os aluguéis representavam para a classe operária, a crise foi registrada também pela grande imprensa: "Em São Paulo de há muito tempo que não há casas para alugar. Não se constrói mais. Os proprietários, que alguns anos antes estavam numa verdadeira febre de construção, empregando principalmente em casas para aluguel os seus capitais, com o encarecimento dos materiais e por outras razões, que nos escusamos de numerar aqui, guardam agora cuidadosamente o seu dinheiro e, quando abrem suas bolsas, é para empregá-lo em coisas mais rendosas. Como a população aumenta, o resultado é que vai se tornando mais difícil alugar-se uma casa e os proprietários vão se tornando cada vez mais exigentes" (O Estado de São Paulo 25/1 1/1919, apud Segawa, 2000, 128)

A queda da produção de construção de casas, que ocorreu durante e após a I Guerra Mundial foi significativa. Segundo estatísticas da municipalidade, no ano de 1907 foram registradas 1.237 licenças para construção; no ano de 1913, esse número cresceu para 5.791 , quase $400 \%$ a mais que o número anterior, mas em 1916, foram expedidas apenas 1094 licenças (idem, 131). Outra pesquisa mostra que entre 1914 e 1918 foram construídos, na cidade inteira, menos de 6.000 prédios (Bonduki, 1998, 46).

Sob influência das idéias higienistas, as tipologias das habitações - casas unifamiliares e vilas operárias - seguiram as leis que criaram restrições à possibilidade de outro tipo de residência popular nas áreas central e urbana, pelo menos dentro do quadro da legislação instituída. $O$ alcance da legislação, entretanto, mostrou-se limitado, na medida que a produção dessas habitações para obtenção de renda de aluguel se constituiu em um empreendimento rentável para particulares, criando-se um fosso entre os padrões legais e a atividade de construção de moradias populares desde fins do século XIX.

Os níveis de remuneração da mão de obra trabalhadora não permitiam acesso a um mercado formal de moradias unifamiliares, propugnado pelo enfoque higienista e disseminado pelo poder público como o ideal da moradia operária. A construção barata, com alta densidade de moradores, precárias condições de higiene e uso comum de sanitários foi a alternativa possível, dadas as condições de pobreza existentes (Bonduki, idem, 39).

Como a maior área de incidência dessas habitações era o Centro ou os bairros centrais operários, grande parte dos cortiços e habitações coletivas foi tolerada. Bonduki menciona a existência de inúmeras referências à demolição das habitações tidas como insalubres, mas também o fato do poder público nunca ter podido aplicar ao pé da letra a legislação, pois acarretaria desabrigar uma grande parte dos trabalhadores que viviam naquelas condições (ibidem, 39). 
Em 1927 uma comissão de notáveis entregou ao prefeito Pires do Rio um relatório intitulado "A quanto monta a deficiência de alojamentos em São Paulo", onde para uma população calculada em 800 mil habitantes, 518 mil residências apresentavam condições toleráveis de higiene. Os restantes 282 mil habitantes, relegados aos cortiços e porões, demandariam o equivalente a 45.500 prédios "para seu conveniente alojamento", segundo o referido relatório concluiu (R.A.M.,82, 1942, 328).

Nos bairros centrais o aproveitamento máximo do lote urbano para a ocupação horizontal de casas geminadas tornou-se o modelo para a habitação popular. Foram previstas tipologias urbanísticas para a construção de conjuntos residenciais populares pelo Código de 1929 e sua consolidação em 1934. Artigos específicos da legislação instituíram diretrizes para a "abertura de passagens para a construção de casas populares", dispondo sobre a construção de casas com vias de acesso - as passagens - com 4 metros de largura, que não poderiam fazer parte do sistema viário da cidade. Os artigos 532 a 542 do Código de 1929, reproduzidos em 1934 sob os números 749 a 761 foram revogados apenas em 1968 pela lei $n^{\circ} 7.164$ (Grostein apud Sampaio, 1998, 106).

Essas disposições apenas oficializaram a prática existente, já que inúmeras vilas foram construídas por indústrias ou por particulares. Como afirma Bonduki, a solução do problema da habitação pela tipologia das vilas, revestiu-se de duplo objetivo: por um lado a municipalidade, através do discurso higienista, preconizava a sua construção e a incentivava com isenções; por outro lado, o máximo aproveitamento dos terrenos e a racionalização das construções tornavam esses empreendimentos extremamente rentáveis em relação ao capital investido, acrescido o fato de serem isentos de impostos municipais (Bonduki, 1998, 50).

As vilas obedeceram a diferentes padrões construtivos, o que as colocava em uma situação mais próxima ou distante daquelas encontradas nos cortiços, conforme áreas e equipamentos que as caracterizavam. Os cortiços também possuíam diferenciações quanto às dependências e instalações, comuns ou individuais. $O$ ponto de ligação entre essas tipologias era a rentabilidade do investimento imobiliário aferido pelo aluguel, o que ocasionou a sua disseminação pela cidade (idem, 53). Já nas primeiras décadas do século XX, a paisagem de bairros como o Brás, Mooca, Ipiranga, Cambuci, Bexiga e Lapa, revelava a presença das vilas, casas enfileiradas e cortiços em vielas.

Código de Obras de 1934 revogou a legislação anterior, referente às vilas operárias, substituindo-as pelo conjunto de normas aplicáveis às casas populares e condições dos cortiços, estes últimos proibidos. Esse Código instituiu também a necessidade de aprovação da planta da unidade, juntamente com o parcelamento da quadra ou área de implantação. 
Além disso, normas rígidas fizeram parte das "Condições Especialmente Aplicáveis às Casas Populares e das Condições de Cortiços", como por exemplo, a proibição de ocupação superior a $2 / 3$ da área do lote pela construção, a exigência de recuo lateral de 1.60 metros para unidade isolada ou conjunto de casas. Em relação ao parcelamento do solo, o artigo 775 do Código Arthur Saboya instituiu a largura mínima de oito metros para lotes nos bairros considerados populares, permitidos, aliás, apenas na zona suburbana. Nas demais zonas, urbana e central, a legislação definiu uma frente mínima de dez metros! (Netto, 1947, 76).

Nesse sentido, a construção de vilas operárias por parte de algumas indústrias, conquanto atendesse às normas sanitárias, alojava menor número de trabalhadores em proporção aos cortiços e geralmente eram acessíveis aos funcionários especializados (Sempla, 1985, 13). Num período em que o Estado brasileiro não interferia nas relações de trabalho e muito menos nas questões ligadas à habitação social, Blay caracterizou as vilas, durante a primeira etapa da industrialização, como uma alternativa de recuperação do investimento econômico por parte dos capitalistas através do aluguel, da mesma forma como ocorria com os cortiços (Blay, 1985, 144).

Em se tratando de vilas operárias construídas pelas próprias indústrias, as mesmas proporcionavam ainda outras vantagens ao empregador-investidor, como por exemplo, a redução de aluguéis em troca de salários mais baixos, a absorção de outros membros da família como empregados na fábrica e uma vinculação casa-emprego que desencorajava a procura de melhores salários por parte dos empregados, uma vez que isso implicava na obrigatória saída da habitação (Bonduki, 1998, 49). Da mesma forma, Blay analisou que nas vilas operárias a casa representou uma forma de reduzir o preço da força de trabalho, ampliar a capacidade de acumulação (via aluguéis) e induzir o trabalhador a permanecer no emprego (Blay, op.cit, 53).

Muito embora as vilas não oferecessem um número expressivo de moradias em relação à demanda existente, suprida pelos cortiços, eram vistas como tipo ideal de habitação proletária, ainda que eventualmente esse modelo fosse concebido para áreas bem mais distantes do Centro, como propunha o "Relatório de Comissão de Exame e Inspeção das Habitações Operárias e Cortiços no Distrito de Santa Ephigênia" de 1893: "A situação mais conveniente para as vilas operárias deve ser, sem dúvida, aquelas que reúnam facilidade de comunicação, a barateza dos terrenos, que devem ser amplos, bem como a vantagem de um abastecimento regular". Em seguida, o relatório propunha a sua localização em torno da cidade de São Paulo, num raio de 10 a $15 \mathrm{~km}$, mediante certos requisitos como duplicação de ferrovias, que favoreceriam o surgimento espontâneo dessas construções "talvez sem maior auxílio dos cofres públicos" (Lemos apud Sampaio, 1998, 35). 
No mesmo Relatório, entretanto, se revelavam as contradições sobre o problema habitacional, mostrando os limites da atuação liberal do poder público na Velha República. Recomendações sobre a construção de vilas com a participação dos poderes municipal e estadual foram feitas, a título de não onerá-los com futuros combates a epidemias e além disso, foi preconizada a necessidade de construção das vilas "com auxílios mais diretos, visto não ser tolerável que se condene os cortiços urbanos e que se desalojem as populações operárias sem thes proporcionar facilidades de obter agasalho em qualquer outro posto" (idem, 35).

Apesar dos cortiços serem combatidos pelo poder público e pelos membros que os constituíam, a maioria da aristocracia paulista, Lemos apontou a existência de proprietários de cortiços dentro da sociedade tradicional tais como o professor Brasílio Machado, o Dr. Carmo Cintra, - fazendeiro de café José do Amaral Campos, Antonio Cãndido da Costa Aguiar e outros que assim agiam para suplementação de suas rendas (ibidem, 17).

As recomendações do "Relatório de Comissão de Exame e Inspeção das Habitações Operárias e Cortiços no Distrito de Santa Ephigênia" convergiram para os aspectos definidos pela legislação específica para habitação social, que surgiu em 1900 através da Lei 498, estabelecendo as "Prescrições para a Construção de Casas de Habitação Operária" fora do chamado perímetro urbano, ou seja, da área que abrangia pouco mais que o Triângulo Histórico. Assim, nos bairros do Brás, Belenzinho,
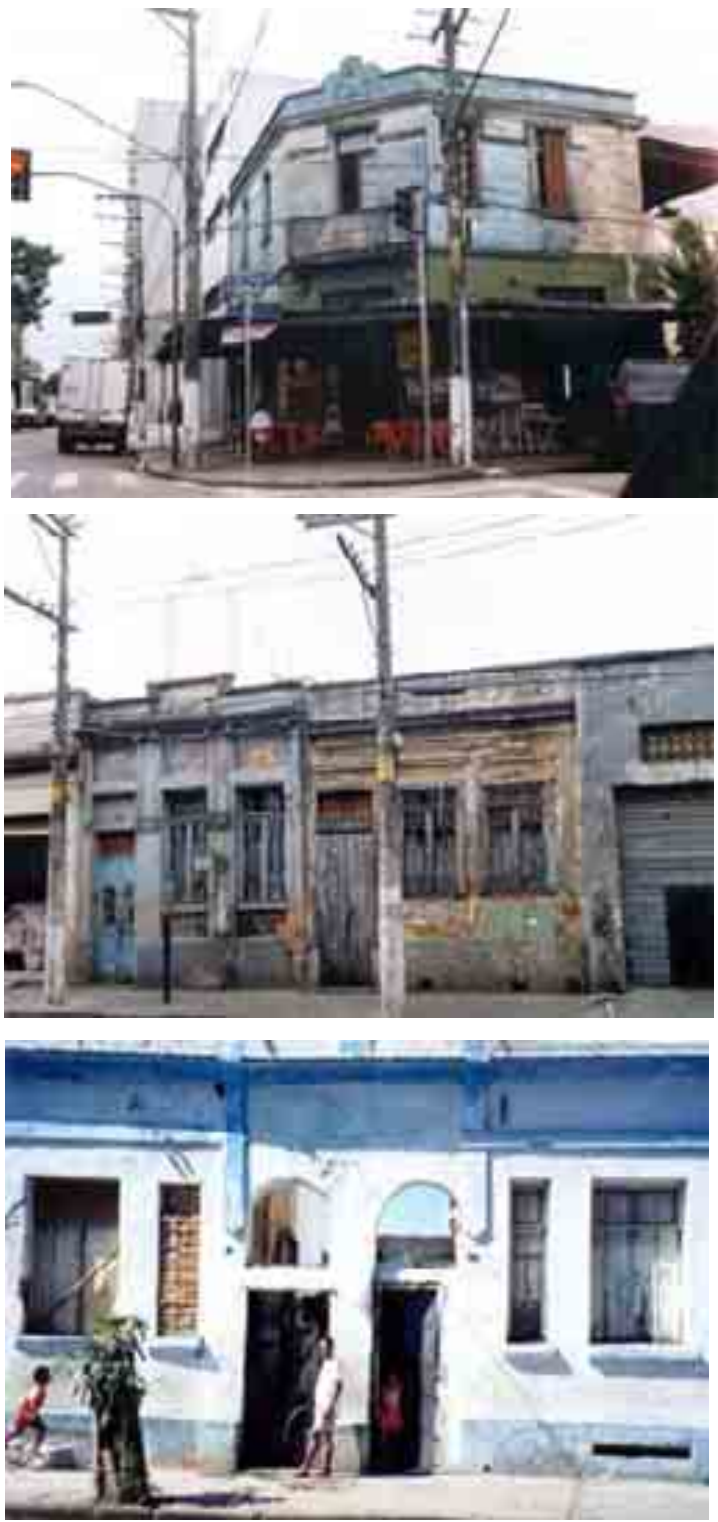

Fig. 24, 25 e 26: Cortiços remanescentes nos bairros centrais.

De cima para baixo: Bom Retiro, Brás e Canindé, 2003 
Moóca, Pari, Luz, Barra Funda, Água Branca, Ipiranga e Vila Prudente, a construção das vilas operárias foi permitida com o incentivo de isenção de impostos municipais, benefício estendido ainda aos agentes construtores (Rolnick, 1997, 125).

Comprovando o déficit que a cidade então apresentava em relação à habitação social, em 1916 a administração do prefeito Washington Luís procedeu a abertura de uma "Concorrência Pública para a Apresentação de Projetos de Casas Proletárias Econômicas destinadas à Habitação de uma só Família". Esse concurso foi registrado como tendo alcançado sucesso no relatório entregue ao prefeito Pires do Rio, em 1927, havendo a premiação de 20 projetos que estariam à disposição de interessados na sua construção. Entretanto, o próprio relatório ressalvava ter sido construída apenas uma e assim mesmo pela própria Prefeitura (RAM, n82, 1942, 331), não havendo registro qual tenha sido realizado e sua localização.

Esses projetos foram submetidos a uma comissão julgadora formada por Ramos de Azevedo, Victor da Silva Freire e Adolfo Augusto Pinto, e as tipologias selecionadas em quatro grupos revelavam com nitidez os aspectos que eram pretendidos em relação ao aproveitamento dos lotes e acomodação do programa exíguo, satisfazendo as condições de higiene, comodidade, estética e economia:

- Grupo 1: projetos de edificações formando blocos de quatro casas geminadas

- Grupo 2: projetos de edificações formando renques geminados

-Grupo 3: projetos de edificações geminadas com apenas uma parede em comum entre elas

- Grupo 4: projeto de edificações isoladas (Segawa, 2000, 135).

É necessário considerar a vinculação da legislação de 1900 com essas propostas de "casas proletárias", ao adotar no programa das habitações áreas mínimas para os diversos tipos. Além disso, a segregação social mostrou-se presente pelo fato das diretrizes daquele concurso não terem considerado a área de implantação, definida apenas como sendo fora do perímetro urbano, assim também como o custo do terreno, evidentemente abaixo dos valores das áreas central e urbana (idem, 135).

Além das vilas que as indústrias construíram para parte de seus próprios empregados, grande parte da produção desses conjuntos foi promovida por uma gama de agentes que reuniu, desde pequenos investidores a empresas construtoras e sociedades mutuárias, para a construção de vilas particulares destinadas ao aluguel. Estas se configuraram com tipologias e dimensões muito distintas entre si, que ora abrangiam várias quadras, ora constituíam pequenos conjuntos de casas dispostas no alinhamento das quadras ou em renques 


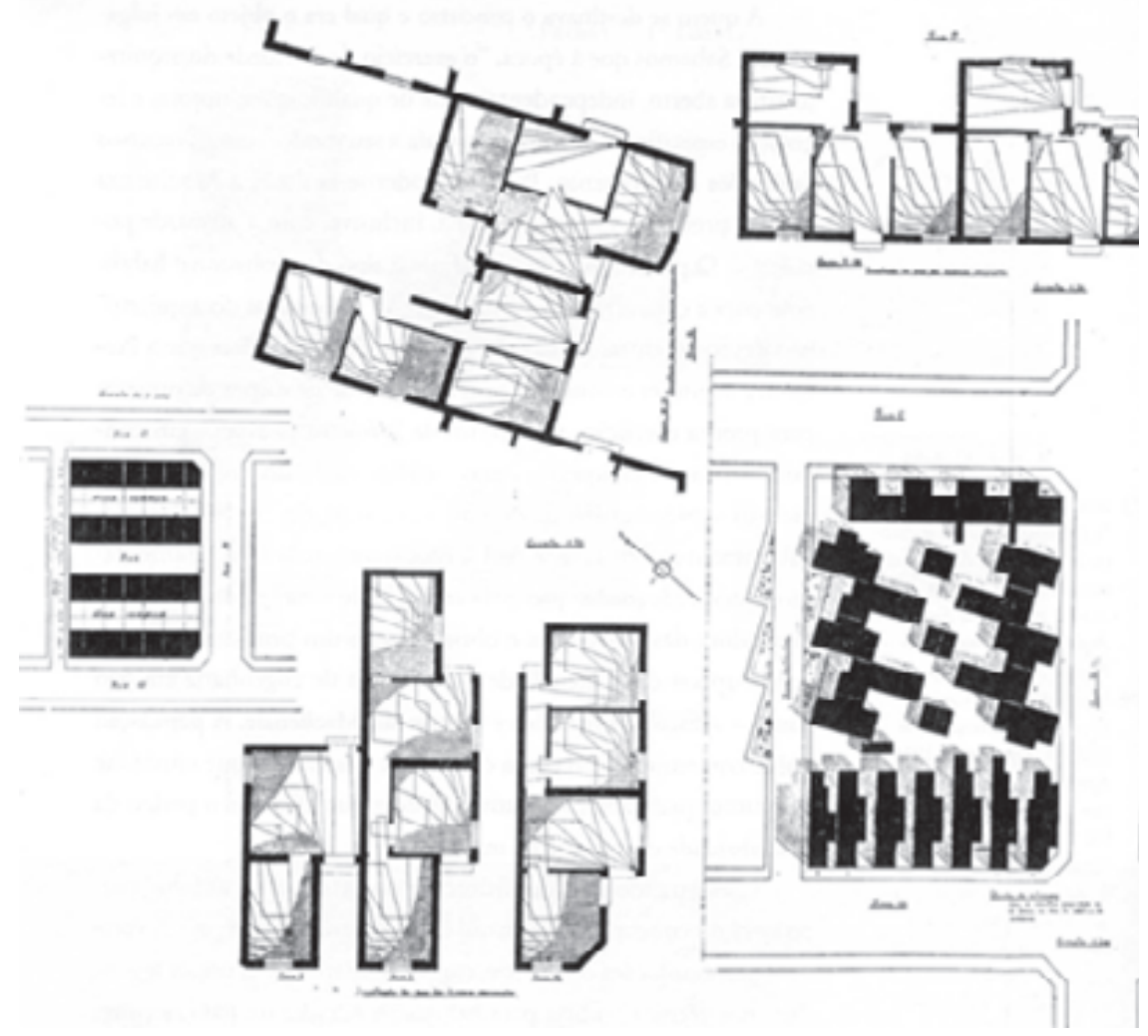

Fig. 27: Acima: Heliópolis, pseudônimo do engenheiro-urbanista Alexandre de Albuquerque. Implantação Urbanae orientação derivada de estudos de insolação.
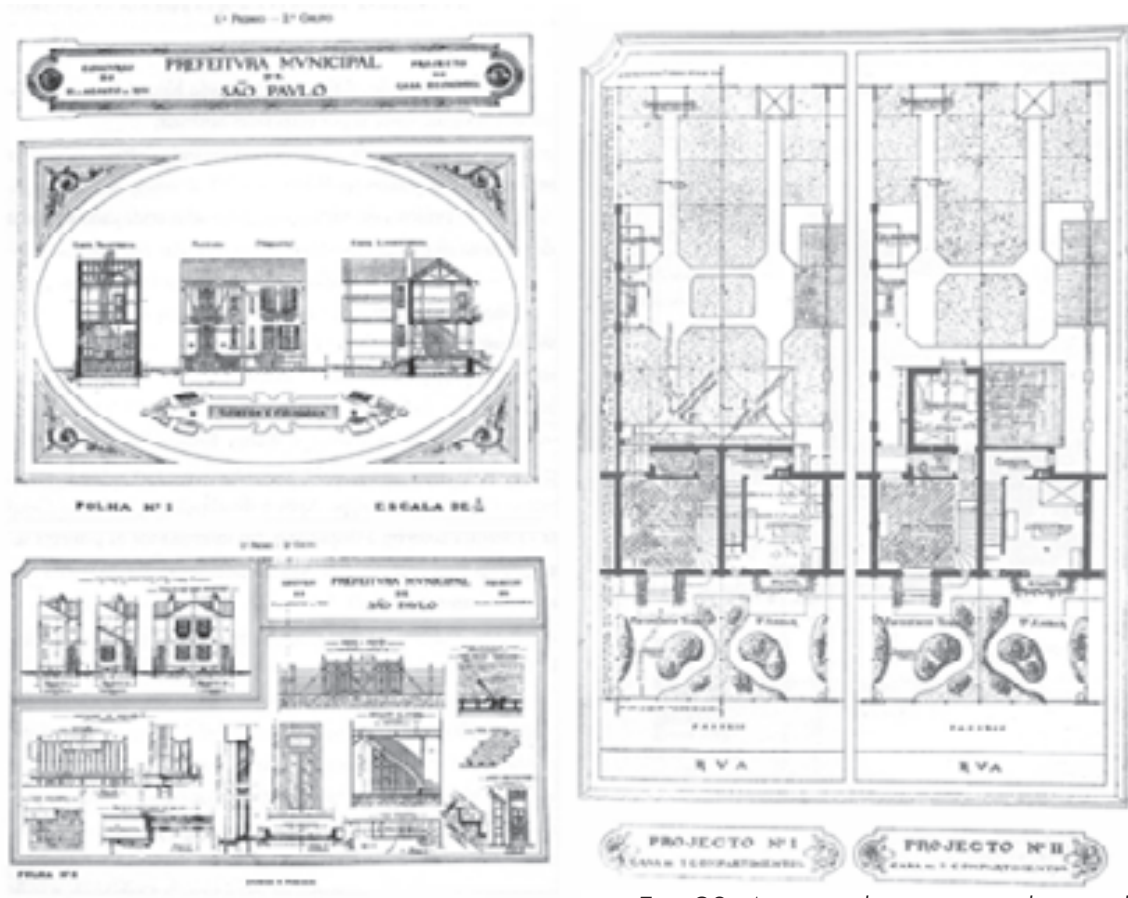

Fig. 28: Acima: elevações e plantas de Joourdan \&Pochon, vencedores do $2^{\circ}$ grupo 
transversais às ruas principais, ou mesmo mescladas as duas formas de implantação para se obter a máxima ocupação dos terrenos. Tinham em comum algumas características que garantiram a rentabilidade do empreendimento: elevada taxa de ocupação, áreas livres exíguas, economia de materiais mediante a construção de casas geminadas, ausência de recuos, etc. (Bonduki, 1998, 50).

Levando em conta a variedade construtiva que apresentavam, Bonduki afirma serem imprecisos os limites que diferenciavam algumas vilas dos cortiços-corredor, pois em muitos casos, a implantação em relação à quadra dessas duas tipologias era equivalente, uma vez que utilizavam terrenos com grande profundidade e perpendiculares à rua de acesso. Também, a dimensão entre a menor casa de vila, constituída de sala, cozinha e cômodo, se equivalia aproximadamente à maior unidade de cortiço. A diferença existia na oferta de equipamentos como banheiro e tanque, individuais para as vilas e coletivos para os cortiços, ressalvado se nos fundos dos cortiços houvesse disponibilidade desses equipamentos para uma unidade, que assim ganhava novo "status", podendo ser auferida maior renda em relação ao seu aluguel (idem, 53/54).

Exemplos de vilas operárias de indústrias, vilas particulares e antigos cortiços existem em quantidade nos antigos bairros centrais fabris e também em suas imediações, constituindo uma das principais características morfológicas desses espaços. Em uma pesquisa realizada sobre as vilas operárias no fim dos anos 1970, foram utilizados dados sobre uma área de 737 hectares englobando parte dos bairros do Brás, Luz e Mooca, dentro do perímetro de interesse do

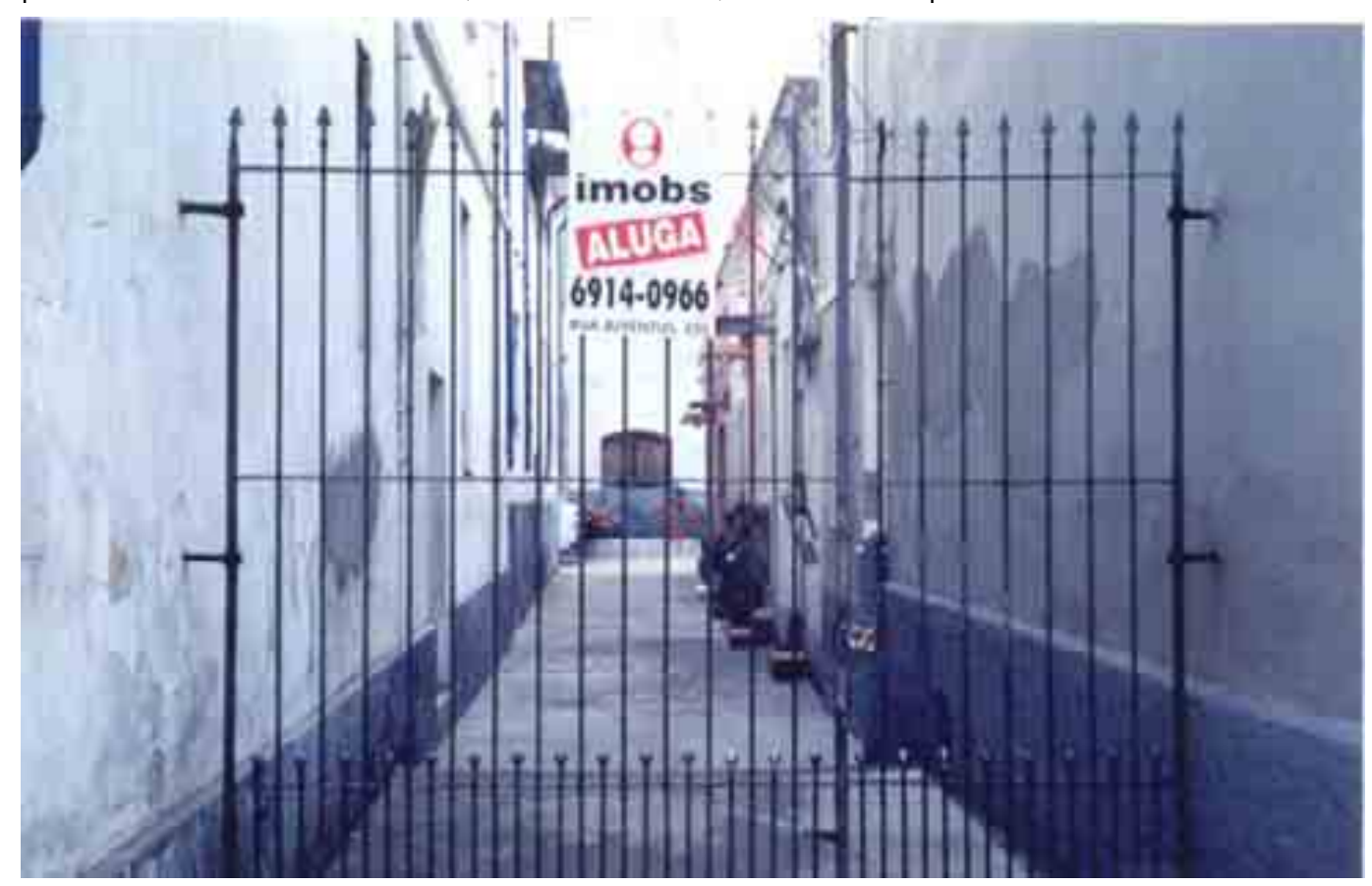

Fig. 29: Vila laia, rua Visconde de Parnaíba, Brás, 2003. 
"Projeto Cura Brás-Bresser" da linha do Metrô Leste-Oeste 5 . Nessa área foram relacionadas 162 vilas, com um total de 2.990 lotes, sendo 2.951 ocupados por residências, perfazendo um total de 11.000 moradores. A maioria desses conjuntos (71\%) foi construída antes de 1930, com 56,5\% de casas térreas e os restantes 43,5\% de sobrados (Blay, 1985, 153).

Dentre os inúmeros conjuntos remanescentes do período do início do século XX, foram relacionadas as vilas a seguir como exemplos relevantes das tipologias existentes nos bairros centrais:

\section{-Vila Economizadora}

Construída em 1907 no bairro da Luz por um mestre de obras italiano (Antonio Bocchini) para a sociedade financeira de ajuda mútua "A Economizadora Paulista", como investimento para habitações de aluguel. (Sempla/Emplasa , 1984, 254; Bonduki, op.cit, 66). Atualmente a Vila se encontra ocupada predominantemente pela função residencial, tendo frentes comerciais para as ruas São Caetano e Cantareira. A maioria das residências ainda mantém as características tipológicas originais.

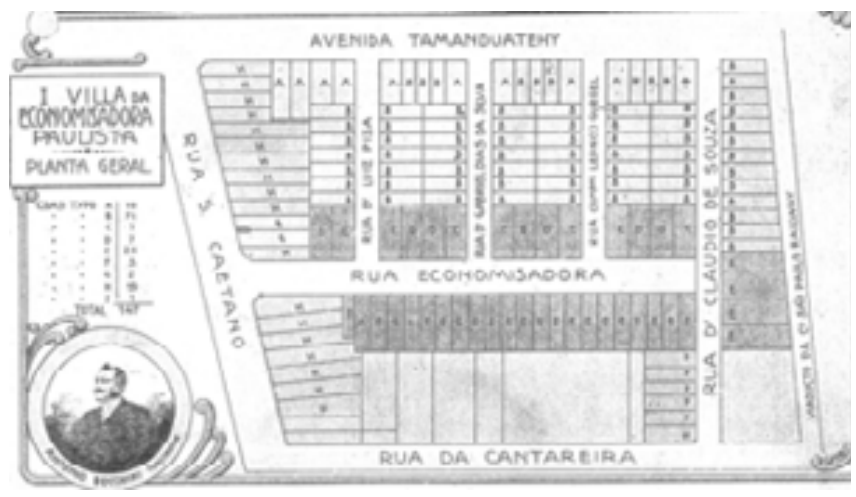

Fig. 30: Planta com homenagem ao construtor.

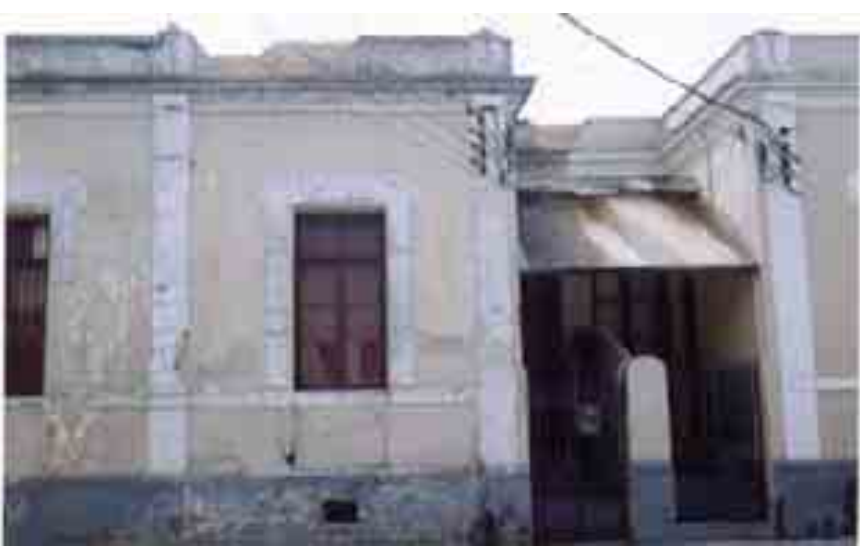

Fig. 32: Edifiação remanescente, 2003.

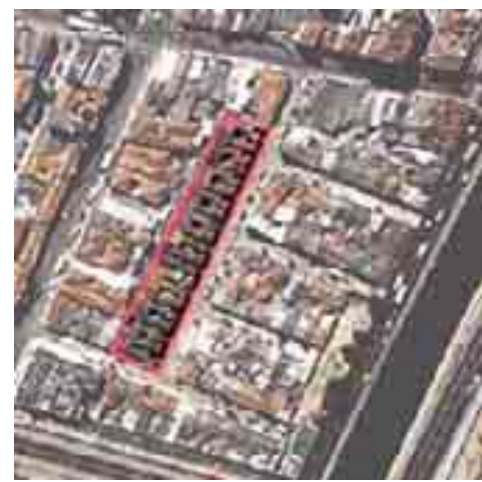

Fig. 31: Vista aérea, 2000.

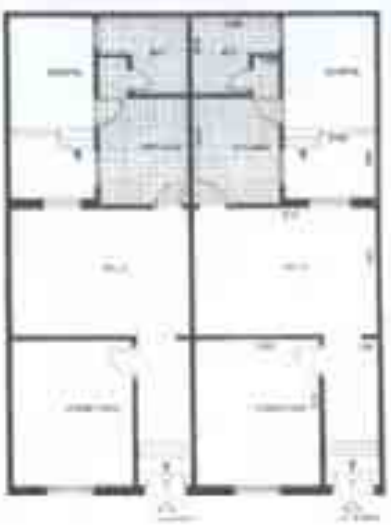

Fig. 33: Planta da residência de 1 dormitório 


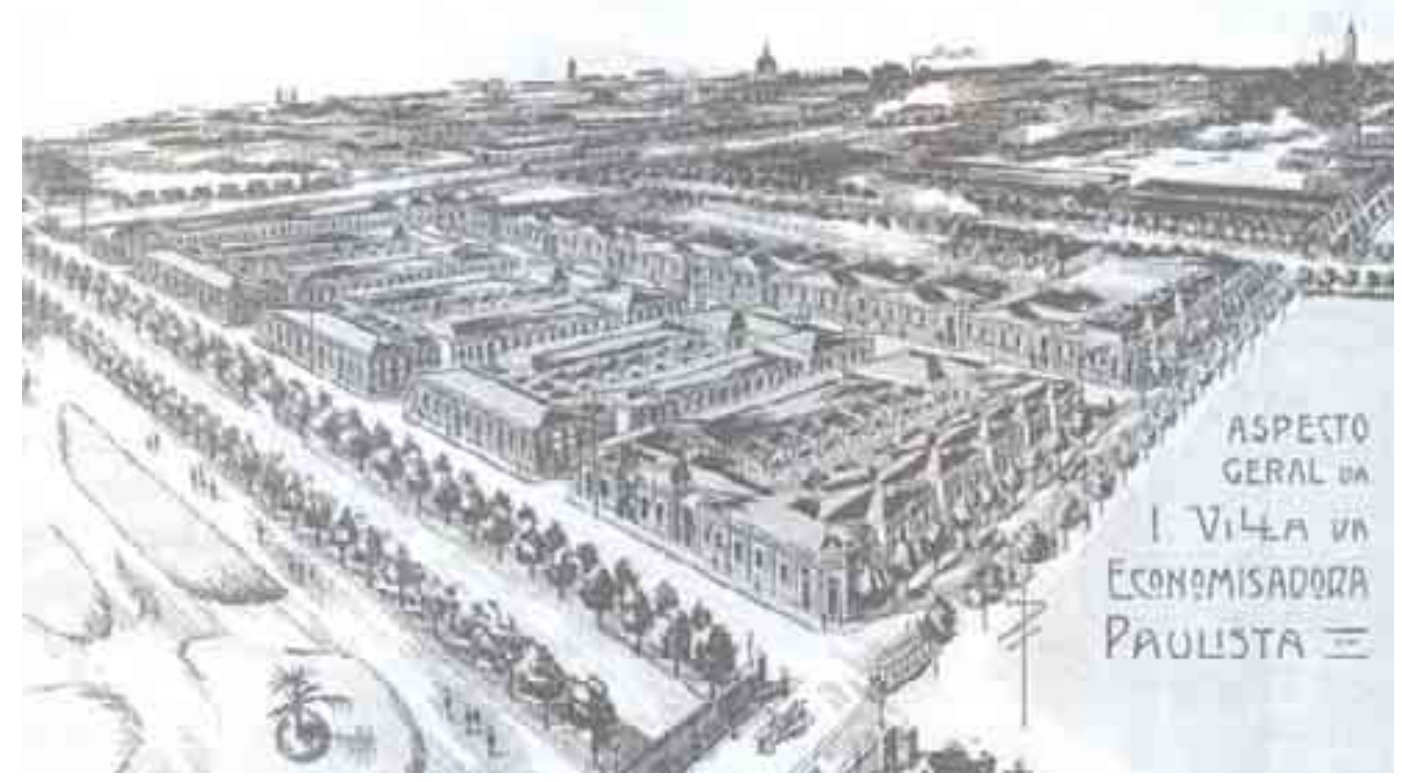

Fig. 34: Perspectiva Artística da Vila.

\section{-Vila Queiroga}

Construída no Brás, próximo ao atual Parque D. Pedro II, na antiga Chácara da Figueira, por José Bernardino de Queiroga, a partir de 1905, para finalidade de aluguel (Sempla/Emplasa, 1984, 252). Poucas casas não sofreram adaptações ou acréscimos transformadores da sua tipologia original.
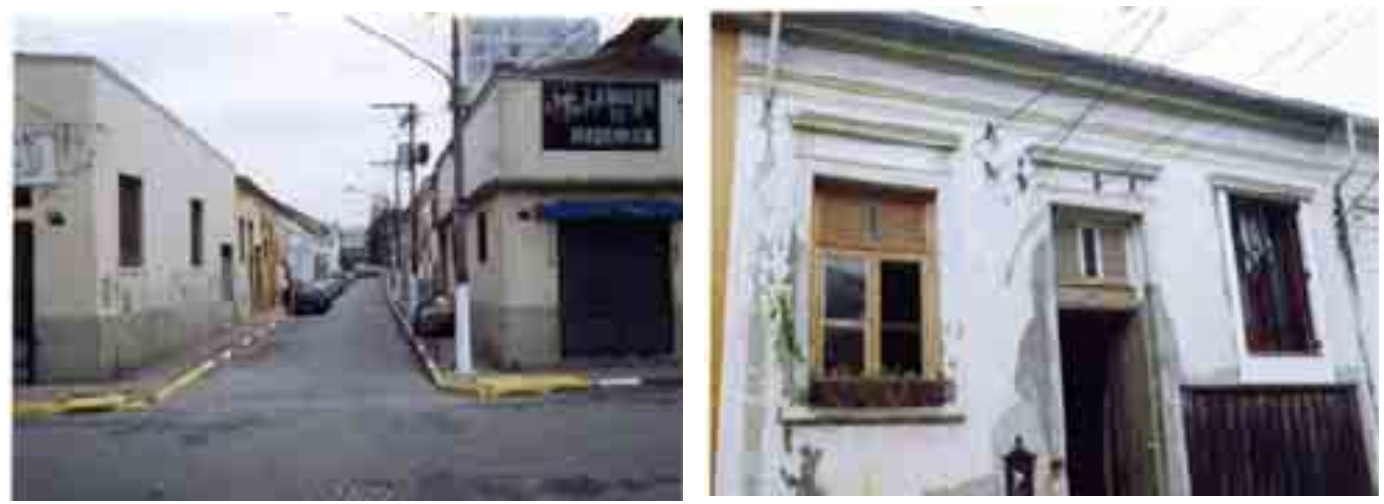

Fig. 35 e 36: Vila Queiroga, Brás, 2003.

\section{-Conjunto de residências da rua Dr. Rodrigo de Barros}

Conjunto da década de 1910, construído no bairro da Luz, pertencentes ao conjunto urbanístico do Museu de Arte Sacra (idem, 258). As casas apresentam uma ocupação variada, com funções residenciais, comerciais e de serviços e definem ainda uma volumetria que predomina na rua onde se situam.
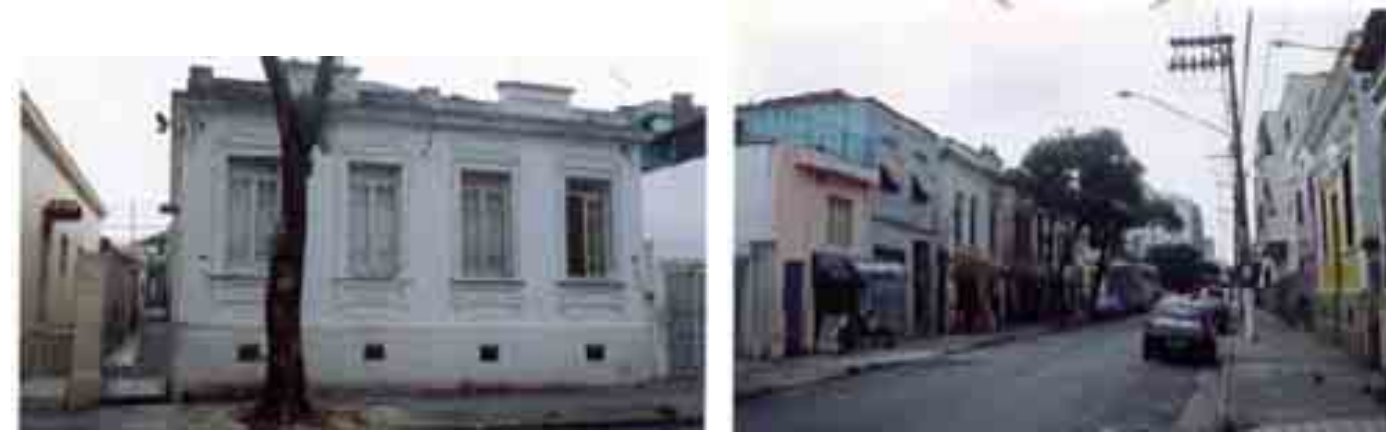

Fig. 37 e 38: Conjunto de residências da rua Rodrigo de Barros. Pertencem ao conjunto urbanístico do Museu de Arte Sacra, 2003. 


\section{- Vila Maria Zélia}

Situada no bairro do Belenzinho, próxima ao Pari, sua fundação ocorrev em 1916, sendo construída pelo empresário Jorge Street para os operários da fábrica de tecidos de sua propriedade. Obedeceu ao projeto do arquiteto francês Pedariex, que incluiu igreja católica, grupo escolar, armazéns e depósitos (Blay, 1985, 225). $\mathrm{Na}$ década de 1940, a Vila foi adquirida para servir de modelo ao Instituto de Aposentadoria e Pensões dos Industriários - IAPI, criado no Estado Novo (Bonduki, $1998,65)$. Atualmente a Vila tem suas unidades habitacionais totalmente ocupadas, mas apenas uma minoria não sofreu transformações. Os equipamentos, por sua vez, encontram-se totalmente abandonados e em estado de grande deterioração.
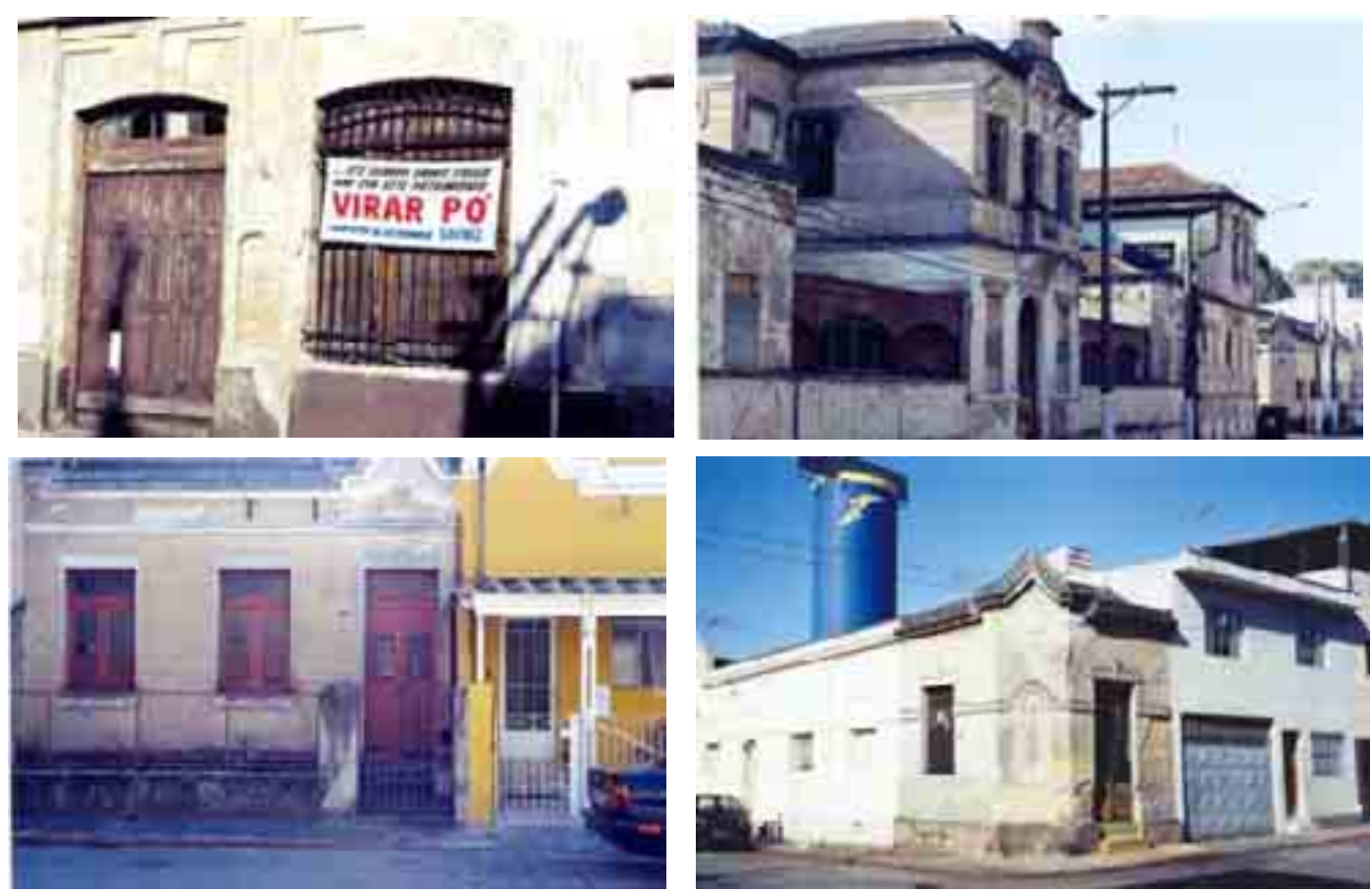

Fig. 39 e 40 (ao alto): Edifícios remanescentes em precário estado de conservação, 2003. Fig. 41 e 42 (acima): Remanescentes das tipologias residenciais, 2003.

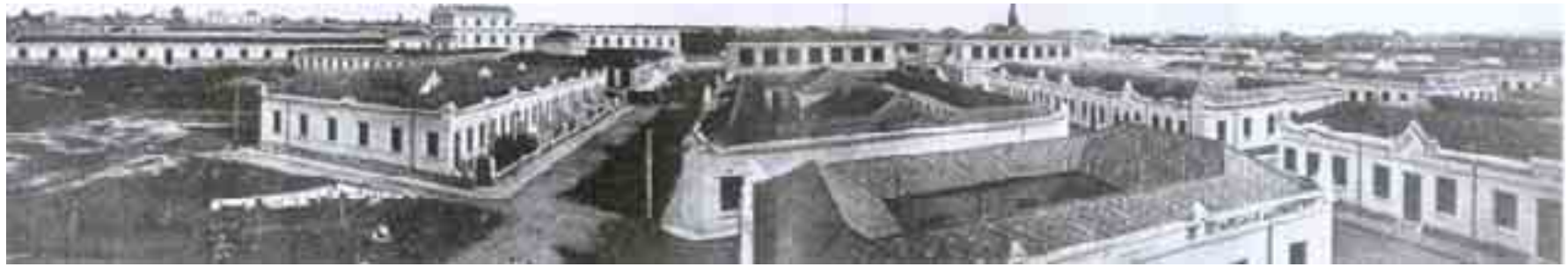

Fig. 43: Situação da Vila no início do século XX. 


\section{- Conjunto de casas na Baixada do Glicério}

Casas em renque construídas na Baixada do Glicério em torno de 1910, voltadas ao programa de casas de aluguel, mostrando uma solução que deixou de ser posta em prática após a crise de 1929 e da Lei do Inquilinato (SEMPLA/Emplasa, 1984, 256)

\section{- Vila Suíça}

Conjunto de residências também situado na Baixada do Glicério, na rua dos Estudantes, rua Conde de Sarzedas e Praça Dr. Mário Margarido, datando da mesma época e igualmente com as mesmas finalidades originais de habitação para aluguel (idem, 256).
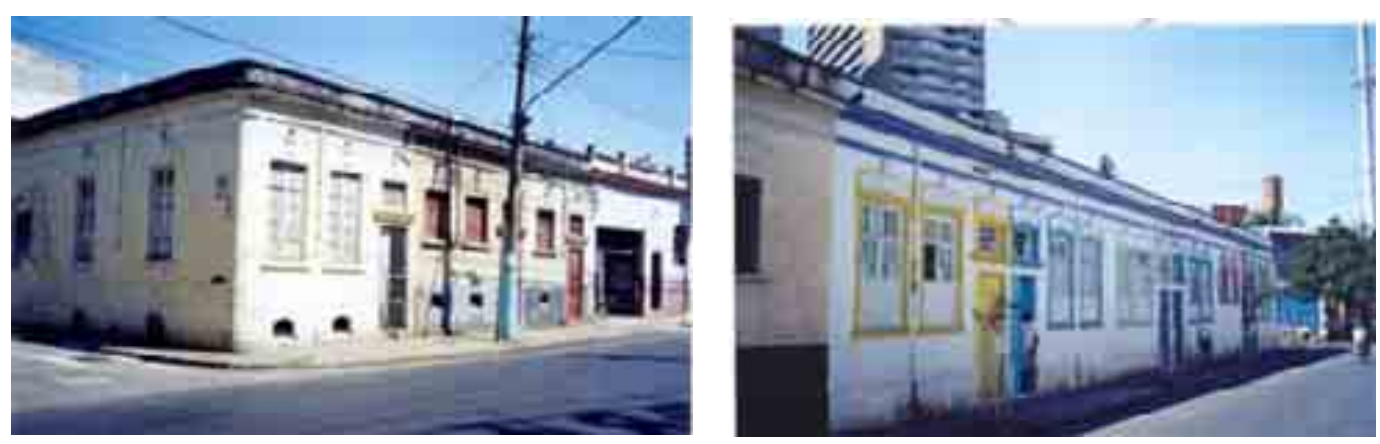

Fig. 44 e 45: Vila Suiça, 2003. 


\subsection{Imbricação: infra-estrutura e novos bairros de alto padrão - os bairros-jardim}

Diametralmente opostos ao problema da habitação popular, e mesmo à maioria da cidade, sem normas urbanísticas a definir as atividades e as construções permitidas ou não permitidas, os bairros-jardim se constituíram em uma exceção, tanto em relação ao assentamento propriamente dito, quanto ao seu caráter segregado no tecido urbano. Esses setores consolidaram, já nas primeiras décadas do século passado, a localização preferencial da população de maior poder aquisitivo e dos serviços, equipamentos e infra-estrutura a ela ligados.

A partir de 1912, a participação da "Cia. City of São Paulo Improvements Ltd" teve início na cidade, atuando de forma bastante diferenciada da expansão desregulamentada que ocorria na maior parte da cidade, exceção feita aos espaços destinados à população de alta renda já existentes, como Higienópolis, avenida Paulista e Campos Elísios. Utilizando a concepção das cidades-jardim inglesas, como haviam proposto seus criadores, Raymond Unwin e Barry Parker, a City contou também com a participação de Antoine Bouvard e chegou a deter em 1912, 37\% de toda a área urbana da cidade (Rolnick, op.cit, 134).

A participação inglesa na Cia. City não chegou a se constituir uma novidade na cidade. Desde a implantação da ferrovia "San Paulo Railway", em 1867, empreendimentos ligados a infra-estrutura e ao setor têxtil contaram com a participação de grupos ingleses. A diversificação de investimentos provenientes da Grã Bretanha se fez presente em diferentes países, atuando nas ferrovias, portos, telégrafos, carris urbanos, mineração, plantações, bancos, seguros e comércio. As idéias urbanísticas também se difundiram, sendo a das cidadesjardim, concebidas por Ebenezer Howard em 1898, uma das que tiveram grande penetração não só em São Paulo, mas também no Rio de Janeiro, Belo Horizonte e Goiânia, todas posteriores à experiência paulista (Ottoni apud Howard, 1996, 47).

Os investimentos da Cia. City tiveram grandes proporções, comparadas as áreas das experiências inglesas das cidades-jardim e as de São Paulo: a área de Lechtworth era de 1.138 hectares e de outra cidade-jardim, Welwin, de 525 hectares, não computados os cinturões agrícolas. As terras compradas pela empresa em São Paulo, somavam 1.200 hectares, sendo 109 hectares o correspondente ao Jardim América. (idem,70)

Iniciando seus negócios numa área ligada ao Centro, ocupada atualmente pela rua Avanhandava, onde Bouvard interferiu no desenho das ruas em curva, os bairros-jardim da Cia. City - Jardim América, Lapa e Pacaembu -além de outros loteamentos como o Jardim Europa e Cidade Jardim, de propriedade de outras empresas, já apareceram configurados no mapa de 1924, cinco anos após o lançamento do Jardim América (Wolff, 1998,68) 


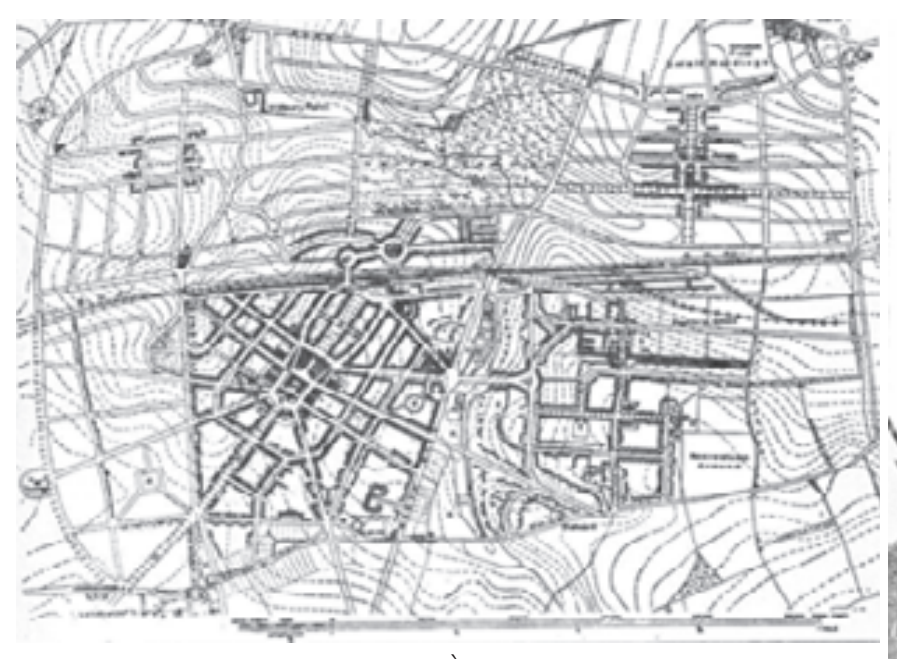

Fig. 46 e 47: À esquerda: Plano de Letchworth publicado em 1904. À direita: inserção na região.
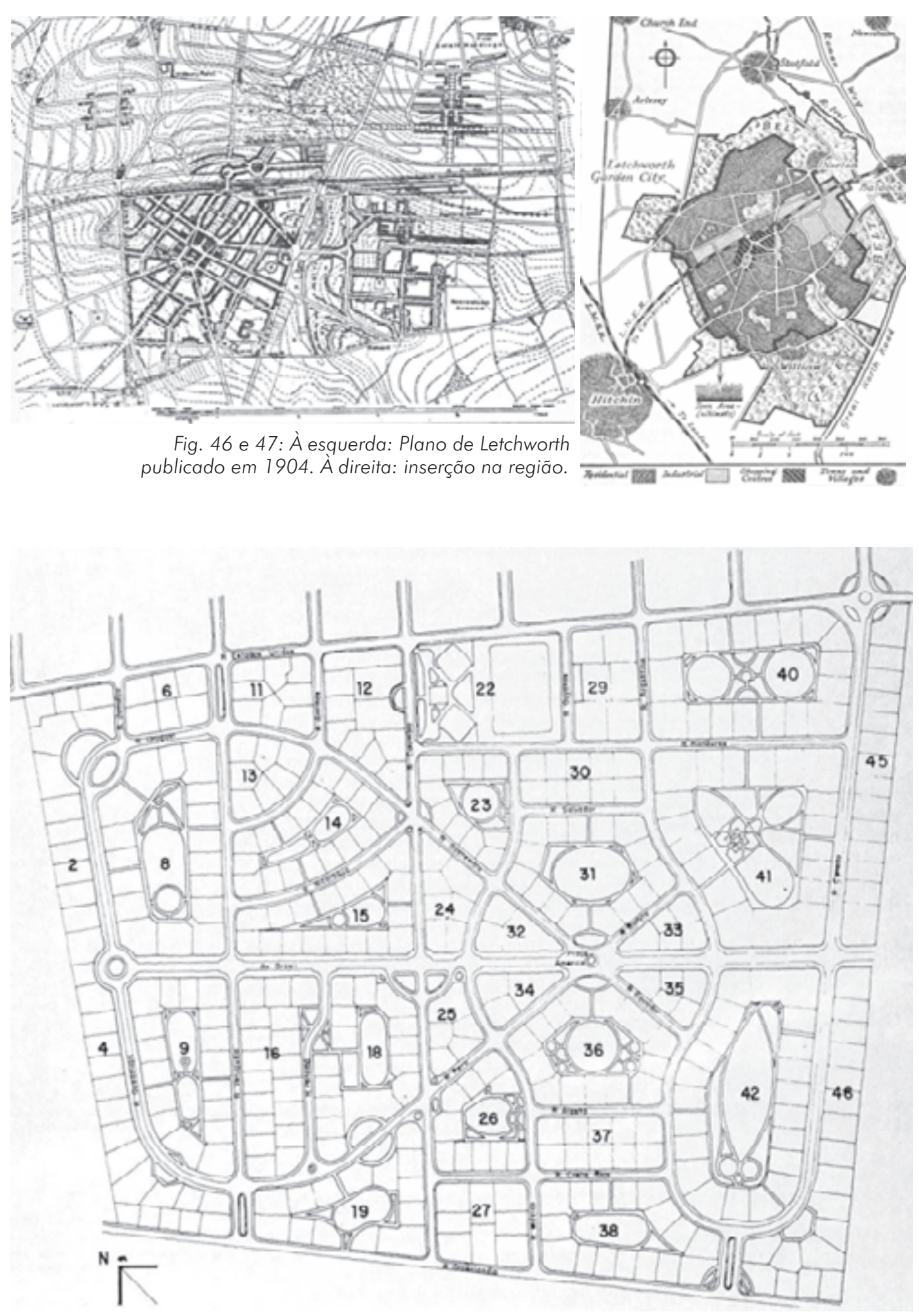

Fig. 48: Plano de Parker e Unwin, de 1919, para o Jardim América. 


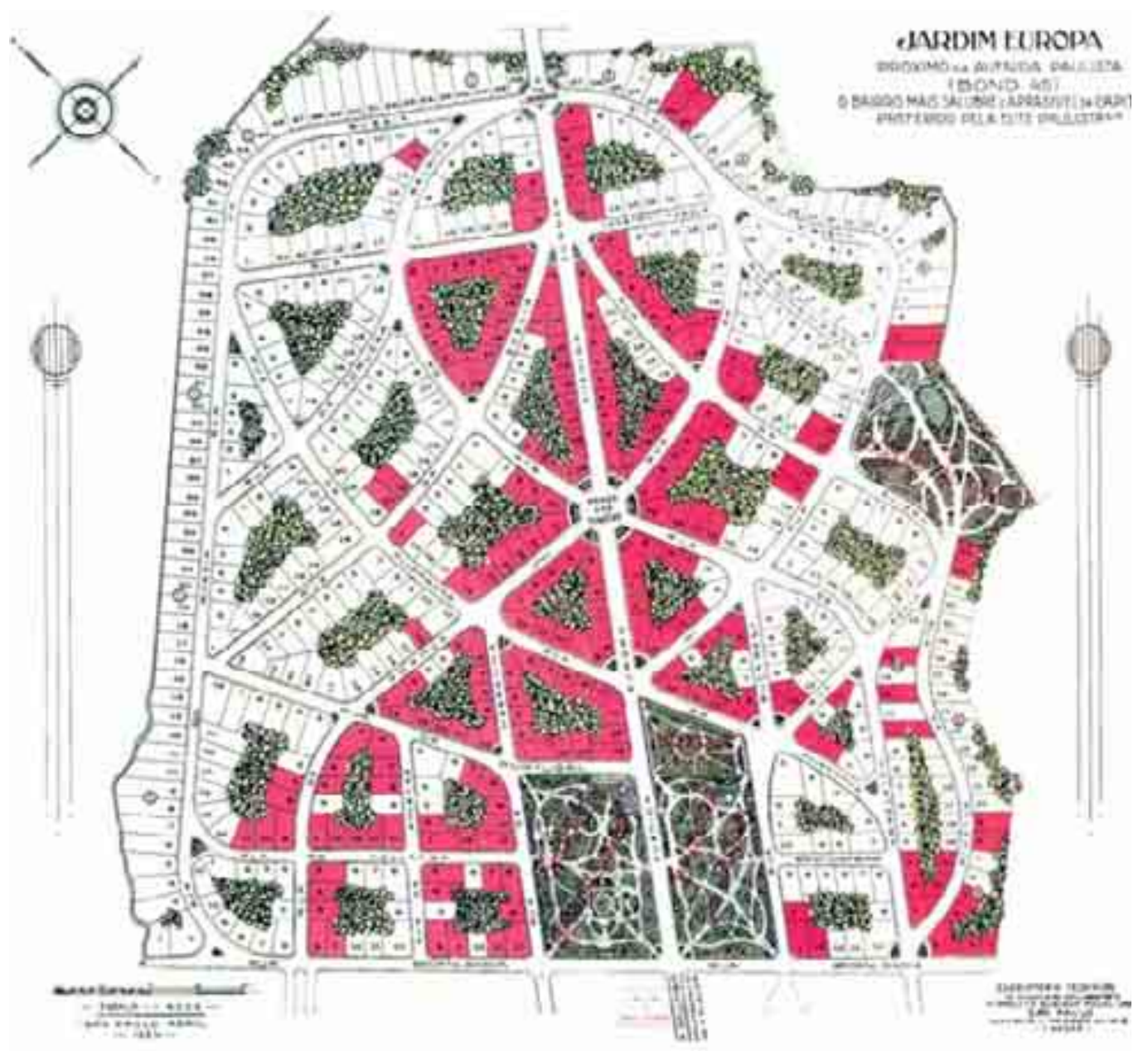

Fig. 49: Planta de 1924, de Gustavo Pujol Jr. A cor vermelha, no centro, indica os lotes já vendidos naquela data.
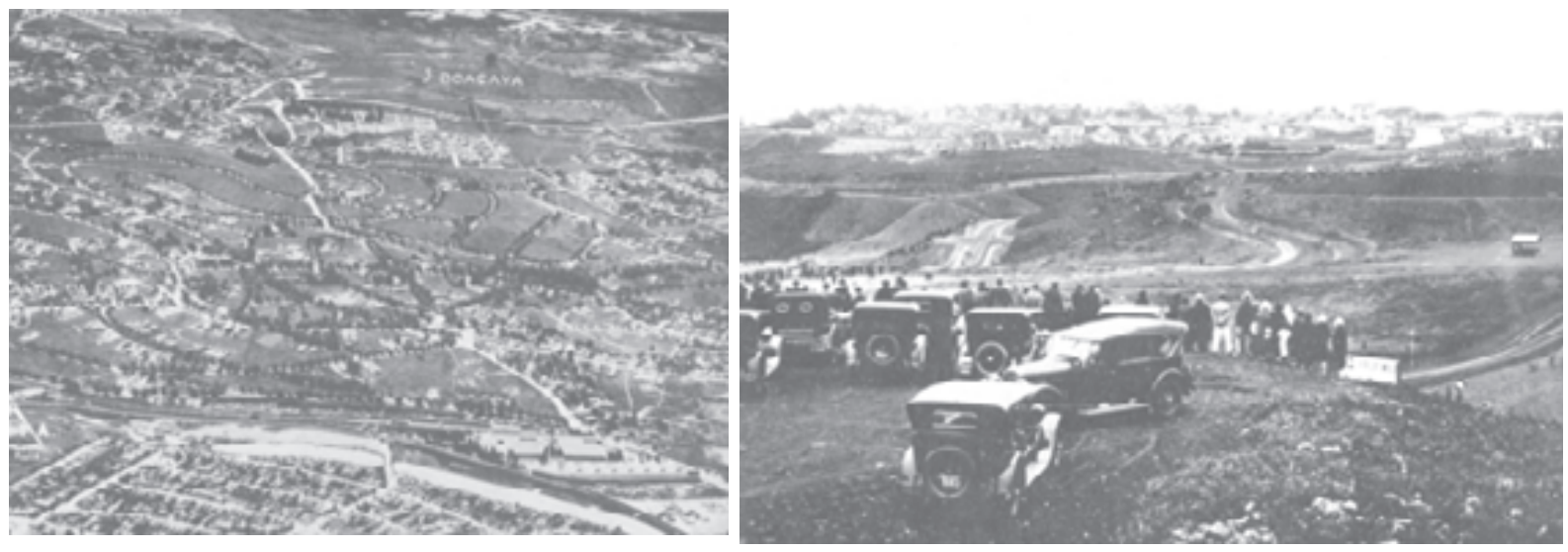

Fig. 50 e 51: À esquerda: loteamento da City do Alto da Lapa.

À direita: loteamento do Pacaembu, década de 1930. 
Essa incorporação imobiliária, até então inédita em São Paulo, se diferenciou muito do que se observava na cidade, como afirmou Morse, na citação reproduzida a seguir:

"Uma exceção ao regime dos loteamentos mal planejados, destituídos de zoneamento e altamente especulativos foi a Companhia City. Os vaticínios sobre o futuro brilhante de São Paulo, feitos em 1911 pelo arquiteto francês J. Bouvard levaram o belga $E$. Fontaine de Laveleye a adquirir mais de doze milhões de metros quadrados de terrenos na zona oeste da cidade, os quais por sua vez vendeu em 1912 por novecentos e cinqüenta mil libras à 'City of San Paulo Improvements and Freehold Land Co Ltd', organizada em Londres com um corpo de quatorze diretores, onde se incluíam ele próprio, Bouvard, Cincinato Braga, Campos Sales e Lord Baltour. Contratando os serviços do urbanista inglês Barry Parker - conhecido por seu planejamento da cidade de Letchworth, da aldeiajardim de Earswich e do centro cívico do Porto - a City começou a executar planos de longo alcance para bairros residenciais...exigia do comprador acatamento às suas estipulações quanto ao tamanho das residências e conservação dos espaços livres, proporcionando em troca ruas cujo traçado obedecia à topografia dos terrenos, arborização, todos os melhoramentos, estritas regulamentações de zoneamento, títulos válidos de propriedade e algumas casasmodelo..." (Morse, 1970, 367).

Contraste entre os padrões urbanísticos praticados fica evidenciado pela análise comparativa com outros bairros da cidade:

"A City, entretanto, só conseguiu proporcionar uma ou outra ilha estável e planejada no revolto mar urbano. Dentro da ampla configuração estabelecida pelas várzeas e pelo maciço, tem sido regra a mistura sem plano de zonas residenciais (da classe alta e da classe baixa), comerciais e industriais, o que tem levado à rápida e devastadora 'contaminação' (por exemplo Ipiranga, Barra Funda, Campos Elísios, Glória) bem como à ganância nas valorizações repentinas. Além disso, os espaços reservados para jardins ou parques infantis são insuficientes, muitas vezes negligente e inconvenientemente situados e, com algumas exceções, destinados mais a enfeite do que a uso." (idem, ,368).

O texto que se segue, de uma publicação da própria Cia. City, expõe também a formação e atuação da empresa na cidade:

"Apesar de seu nome inglês, e de ter sido na origem dirigida e controlada por ingleses, a Companhia City surgiu por iniciativa de franceses.

Em 1911, contratado pela Prefeitura de São Paulo, chegou a esta Capital o arquiteto J. Bouvard, encarregado de planejar e construir a Av. São João, no centro da cidade. Entusiasmado pela capital paulista, o arquiteto entrou em contato com capitalistas interessados em empreendimentos imobiliários. Conquistando a 
simpatia de alguns deles, retornou à França, onde se dispôs a abrir uma sociedade que explorasse comercialmente amplas extensões de terra na região da cidade de São Paulo, situadas fora da zona urbana na época.

Conseguindo inicialmente $12.000 .000 \mathrm{~m}^{2}$ dos 20.000.000 que haviam sido solicitados pelo arquiteto, um grupo francês decidiu iniciar os negócios. Como houvesse, entretanto, dentro dessa sociedade participação de capital inglês, iniciouse disputa pelo controle, logo no início de sua incorporação. Com o apoio de alguns brasileiros, a sociedade passou definitivamente para o controle dos ingleses. Dessa forma, em novembro de 1911, foi fundada em Londres a 'City of São Paulo Improvements and Freehold Land Company Limited', com a finalidade de realizar operações imobiliárias e de urbanização em São Paulo.

Em janeiro de 1912 foram adquiridos os terrenos para loteamento, num total de mais de 12 milhões de metros quadrados correspondentes a áreas retiradas do centro urbano, praticamente desertas. Essas áreas foram sendo progressivamente transformadas em aprazíveis bairros residenciais: Jardim América, Pacaembu, Alto da Lapa, Alto de Pinheiros, Butantã e outros.

A concepção urbanística utilizada para o desenvolvimento desses bairros demonstra a categoria de um dos maiores arquitetos e urbanistas da época, Sr. Barry Parker, trazido pela City Improvements para planejá-los" (Cia. City de Desenvolvimento, 1980, 1).

O estudo de Wolff mostra que no mapa de 1924, além dos traçados dos bairrosjardim, já estavam presentes as áreas do Alto de Pinheiros e Butantã que posteriormente fizeram parte da expansão da empresa loteadora. Nesse sentido, segundo a autora, as áreas que a Cia. City tinha como disponíveis definiram um eixo de concentração dos bairros residenciais de elite da cidade. Essa localização, decorrente da implantação dos bairros aristocráticos desde as últimas décadas do século XIX, prosseguiu através do rumo indicado pela rua Augusta, pela Vila América, Jardim América, Jardim Europa, Cidade Jardim e Morumbi (Wolff, 1998, 68).

A abertura dos loteamentos da empresa seguiu critérios de proximidade com os espaços já valorizados e segundo Reale, a Cia. City comprou em 1912, 80 terrenos da Cia. Edificadora de Vila América, porém devido ao alto índice de construções existentes, a City não pôde implantar nenhum plano urbanístico, atuando em conseqüência, como agente de vendas. $\mathrm{Na}$ época, a parte valorizada do bairro era a compreendida entre as ruas Augusta e Pamplona, que recebeu melhoramentos inexistentes em trechos próximos, constituídos de padrões mais modestos (Reale, 1982, 128).

Essa proximidade também foi observada por Wolff na escolha dos loteamentos da Cia. City, que se orientou pelos padrões que estruturavam as regiões próximas e os bairros pré-existentes: "foi o caso das primeiras áreas que comercializou nos 
loteamentos já implantados, Vila América e Vila Nova Tupi, em torno da rua Augusta e na Vila Romana. Teve também glebas na Vila Mariana e no Ipiranga. Estas terras da zona sul foram uma das poucas áreas das quais a City se desfez em bloco" (Wolff, 1998, 68).

O motivo para não ter desenvolvido os loteamentos em outros quadrantes de São Paulo pode estar na explicação do próprio Barry Parker: "o fracasso ou sucesso dependiam em um grau excepcional de projeto, planejamento e gerenciamento, e ainda, do tipo de casa e morador assegurado" (Parker apud Wolff, 69). Essa estratégia certamente definiu uma hierarquia entre as áreas adquiridas pela empresa, como mostrou o relato que associou diretamente a relação de vizinhança entre as glebas daquela empresa: "quanto ao Alto da Lapa, que, segundo os técnicos daquela Companhia Imobiliária, era o local que oferecia melhores condições para um bairro aristocrático, foi sempre prejudicado pela vizinhança de um bairro operário, o que impediu que o caráter aristocrático, que the era originalmente destinado, pudesse encontrar todos os requisitos para firmar-se" (IBGE, 1962, 63)

Através dos dados da Cia. City, torna-se possível avaliar dentro das áreas que foram adquiridas na cidade até 1931, o predomínio das glebas no setor sudoeste:

\begin{tabular}{|c|c|c|}
\hline \multicolumn{3}{|c|}{ Quadio 5} \\
\hline $\begin{array}{l}\text { Urbonizaçōo } \\
\text { inicioda em }\end{array}$ & Bairros & Área em m? \\
\hline 1915 & Jondim América & 1.091 .118 \\
\hline 1917 & Anhangabou & 170.849 \\
\hline 1918 & Butanse & 2.341 .379 \\
\hline 1921 & Alio do Lapo e Belo Alianca & 2.126 .643 \\
\hline 1925 & Pocoembu & 998.130 \\
\hline 1931 & Vilu Americu & 186.200 \\
\hline 1931 & Vila Nevo Tupi: & 180.000 \\
\hline 1931 & Vila Mariana & 210.000 \\
\hline 1931 & Vila Leopoldina & 10.000 \\
\hline 1931 & Mooco & 366.667 \\
\hline TOTAL & & $7680986 \mathrm{~m}^{2}$ \\
\hline \multicolumn{3}{|c|}{ Fonte: Co Citr de Desenvolvimento, 1980} \\
\hline
\end{tabular}

Levando em conta as terras que foram adquiridas após a década de 1930, a atuação da empresa em relação às áreas loteadas destacou o partido urbanístico e paisagístico, além de associá-los aos critérios contratuais, como mostra a explicação:

"Em 1954, ano do quarto centenário da cidade de São Paulo, a Companhia City possuía cerca de 17 milhões de metros quadrados de áreas loteadas. Mantendo sempre a tradição e os princípios de urbanização com que iniciou suas atividades nos idos de 1912, a Companhia procurou, reservando amplas áreas verdes, presenvar o conforto de seus bairros jardins, tornando famosos o Jardim América, 
- Pacaembu e tantos outros. O traçado sinuoso de suas ruas, criticado a princípio, mostrou-se bastante eficaz, sendo precursor da moderna concepção que evita grande volume de tráfego pelas ruas sossegadas de bairros nitidamente residenciais....

O padrão de seus loteamentos foi preservado por rígidas disposições contratuais, capazes de garantir uma série de limitações no aproveitamento racional dos imóveis, tais como a percentagem máxima de área construída, recuo e altura das edificações."(Cia. City de Desenvolvimento, 1980, 13).

Essas características urbanas iniciadas com o Jardim América em 1915, tiveram dois aspectos pioneiros, como enfatizou Reale: o primeiro se referiu à infraestrutura urbana, pois foram colocados à venda lotes providos de todos os melhoramentos, como rede de água e esgoto, luz elétrica, gás e iluminação pública. $\bigcirc$ segundo se relaciona ao plano viário, que abandonou o traçado em tabuleiro de xadrez e adotou as ruas em curva, "como alamedas de um vasto jardim", com exceção da avenida Brasil, ampla radial com 20 metros de largura, que percorria o loteamento de um extremo a outro. As vias internas eram arborizadas, apresentavam cruzamentos com cantos arredondados, com curvas de 8 metros, proporcionando ampla visão aos condutores de veículos (Reale, 1982, 147-149).

Como vimos anteriormente, no Jardim América, assim como nos outros bairros da elite paulistana, a regulamentação do uso do solo foi, desde o início, muito mais rigorosa do que o instituído nos códigos municipais, sendo incorporada na totalidade pela municipalidade. As normas foram estabelecidas nos contratos de compra dos terrenos: a obrigatoriedade do uso residencial, a área máxima possível ser construída, os recuos obrigatórios do alinhamento das ruas, das laterais e fundos dos terrenos. A área mínima dos lotes era de $450 \mathrm{~m}^{2}$, com testada de 15 metros, mas a grande maioria dos terrenos possuía area superior a mil metros quadrados (idem, 150).

As análises em relação à Cia. City mostram a associação dos interesses imobiliários com as concessionárias de serviços e o próprio poder público, como um fator determinante para o sucesso dos empreendimentos: "graças aos seus laços com a Light e figuras-chave da política local, a City pôde usufruir do acesso, em condições privilegiadas, a serviços básicos de infra-estrutura e valorização estética dos seus loteamentos, podendo contar com serviços subsidiados, financiados e priorizados da prefeitura, além de isenções de impostos por períodos prolongados, às expensas dos cofres públicos e de áreas mais populosas e carentes da cidade, urgentemente necessitadas de serviços básicos. Como resultado, ela pôde oferecer loteamentos de alto gabarito urbanístico e arquitetônico em condições excepcionais de venda facilitada, tirando o máximo proveito do surto de enriquecimento do pós-guerra". (Souza apud Cevcenko, 1991, 126). 
Como exemplo dessa associação entre a concessionária de serviços públicos e os interesses imobiliários, Morse registrou que em 1928 foi iniciada a pavimentação do bairro Jardim América e em 1934 a City conseguiu o asfaltamento do mesmo sem qualquer ônus, em contrapartida à cessão de 7 mil metros quadrados de terrenos de sua prorpiedade, necessários para a abertura da avenida Nove de Julho, uma artéria do Plano de Avenidas que garantiu a ligação daquele bairro com o Centro, garantindo um grande fator de valorização dos terrenos (Morse, 1970, 135).

Além da cessão de áreas para a municipalidade, com finalidade de dotar os loteamentos com melhores acessos ou equipamentos, os vínculos com as concessionárias dos serviços públicos, mais especificamente a Light e suas subsidiárias, também se constituiu uma forma de garantir a valorização dos terrenos e o sucesso dos empreendimentos imobiliários. Um exemplo foi a implantação da linha de bonde para servir o Jardim América: a empresa logrou firmar acordo com a Light \& Power para que o bonde que ligava a rua Augusta ao Centro tivesse seu percurso estendido pela rua Colômbia. A partir de 1918, a linha chamada "Garden City" passou a funcionar com horários limitados, mas para a implantação e funcionamento da linha de bonde, era necessário que a rua fosse pavimentada, serviço solicitado e executado pela Prefeitura. (Wolff, 1988, 50).

A estratégia da cessão de áreas para a incorporação de valor aos empreendimentos já havia ocorrido antes, dirigida à instalação de equipamentos de prestígio em meio aos loteamentos de propriedade da empresa, como por exemplo em 1917, quando amplas facilidades foram dadas para a instalação do Clube Atlético Paulistano, no Jardim América e em 1929, para a Sociedade Harmonia de Tênis, no mesmo bairro. No Pacaembu, a empresa cedeu para o Governo do Estado, em 1921, uma área equivalente a cinco hectares para a construção de outro equipamento de prestígio para o bairro: o Estádio Municipal. Ivimento, 1980, 12). Em 1935, complementou com mais 2,5 hectares à municipalidade, que recebeu do governo estadual a área anterior (Cia. City de Desenvolvimento

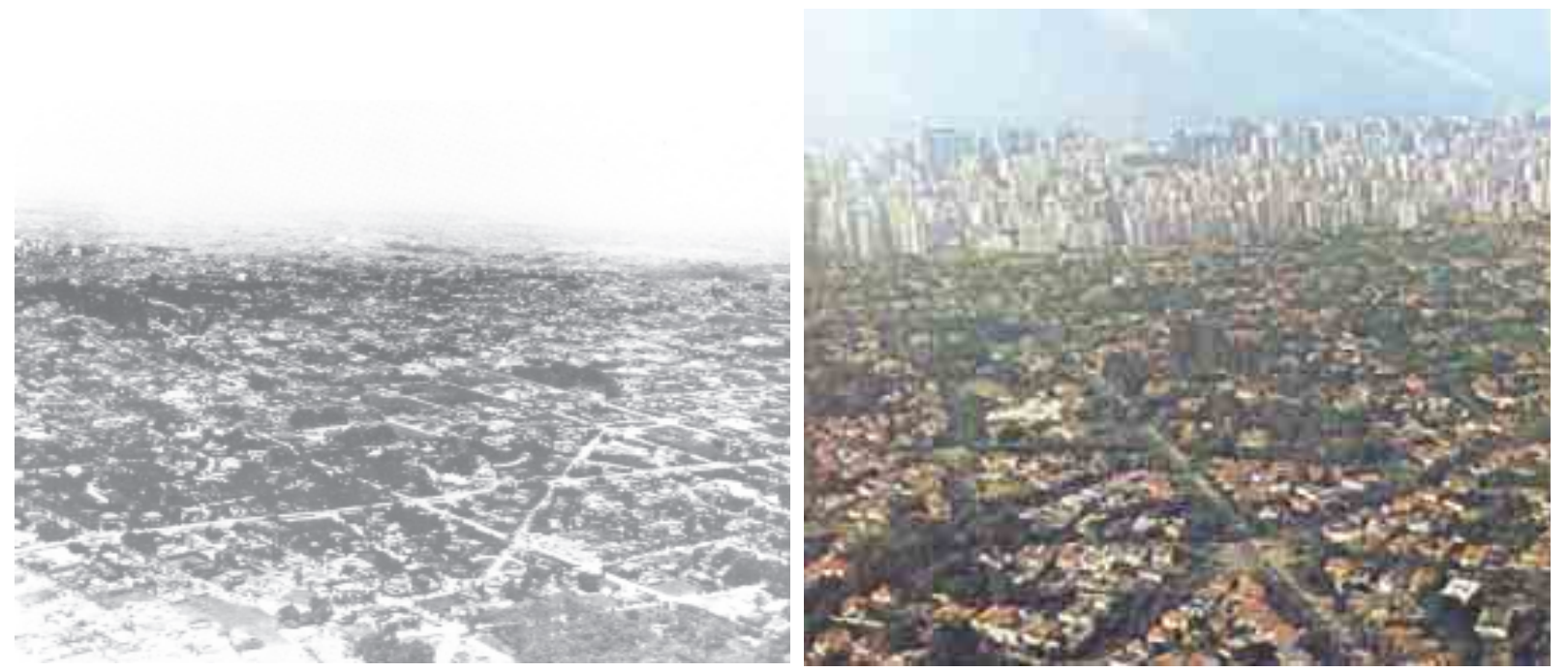

Fig. 52 e 53: À esquerda: Jardim América, década de 1930. À direita, em 1970. 


\section{Notas:}

${ }^{1}$ Francisco Ferreira Ramos, Hermelindo Matarazzo, Antonio Carlos da Silva Telles, Eugênio Terroir e Felix Delaborde.

2 "quando não existe em uma cidade a divisão em bairros com destino certo e imutável, como se pratica na Allemanha e começa agora a realizar-se na América do Norte, é necessário constituir o lote para o que der e vier" (Freire apud Rolnick, 1997, 45)

${ }^{3}$ Zona Central: começa no entroncamento da rua Tabatinguera com a avenida Exterior do Parque D. Pedro II; segue por esta avenida até seu encontro com a Avenida do Estado; por esta e pelas ruas Mercúrio, Anhangabaú, Florêncio de Abreu, Mauá, Duque de Caxias, Maria Tereza, Largo e Rua do Arouche, Praça da República, 7 de Abril, ladeira e Largo da Memória, largo, ladeira e rua do Riachuelo, rua Rodrigo Silva, rua Livre, Largo7 de Setembro, rua Conde do Pinhal e rua Tabatinguera.

${ }^{4}$ Zona urbana: começa na Ponte Grande, sobre o rio Tietê, segue pela avenida Tiradentes, praça José Roberto, ruas Jorge Velho, Afonso Pena, Bandeirantes, Joaquim Murtinho, Tocantins, Mamoré, Capitão Matarazzo, Jaraguá, avenida Rudge, ruas do Bosque, da Casa Verde, Alameda Olga, segue pela divisa da estrada de ferro Sorocabana até a rua 12 de Outubro, subindo por esta até a rua Afonso Sardinha, descendo por esta até a rua Anastácio e por esta até a rua Guaicurus e por esta até a avenida Pompéia, segue pela avenida Pompéia até a rua Desembargador Vale e por esta, Caiubi, Cardoso de Almeida, avenidas Dr. Arnaldo e Dr. Rebouças, rua Jaú, avenida Brigadeiro Luís Antônio, ruas Tutóia, Dr. Amâncio de Carvalho, avenida Conselheiro Rodrigues Alves, ruas Tangará, França Pinto até a rua Rio Grande, por esta e pelas ruas Dr. Álvaro Alvim, Major Maragliano, França Pinto até a Domingos de Morais, por esta até a rua Pinto Ferraz, seguindo pelas ruas Vergueiro, Correa Dias, Apeninos, Pires da Mota, Castro Alves, Safira, avenida Jardim da Aclimação, ruas Muniz de Souza, Lavapés, Largo do Cambucí, ruas da Independência, Major José Bento, Vicente de Carvalho, Da. Ana Néri, av. do Estado, ruas Conselheiro João Alfredo, Mooca, Taquari, rua dos Trilhos, Tobias Barreto, Padre Adelino, Córrego Tatuapé, avenida Celso Garcia, ruas Catumbi, Cachoeira, Carlos de Campos, Rio Bonito, Hahnemann, Afonso Arinos, avenida Cruzeiro do Sul até o rio Tietê e por este abaixo, até a Ponte Grande (Netto, 1947, 13).

${ }^{5}$ Projeto Cura: "Comunidades Urbanas de Reurbanização Acelerada" - Programa que visava intervir urbanisticamente nas áreas onde ocorreram desapropriações ligadas à implantação do Metrô, buscando ordenação de usos e ocupação do solo (Metrô, 48, 1978) 


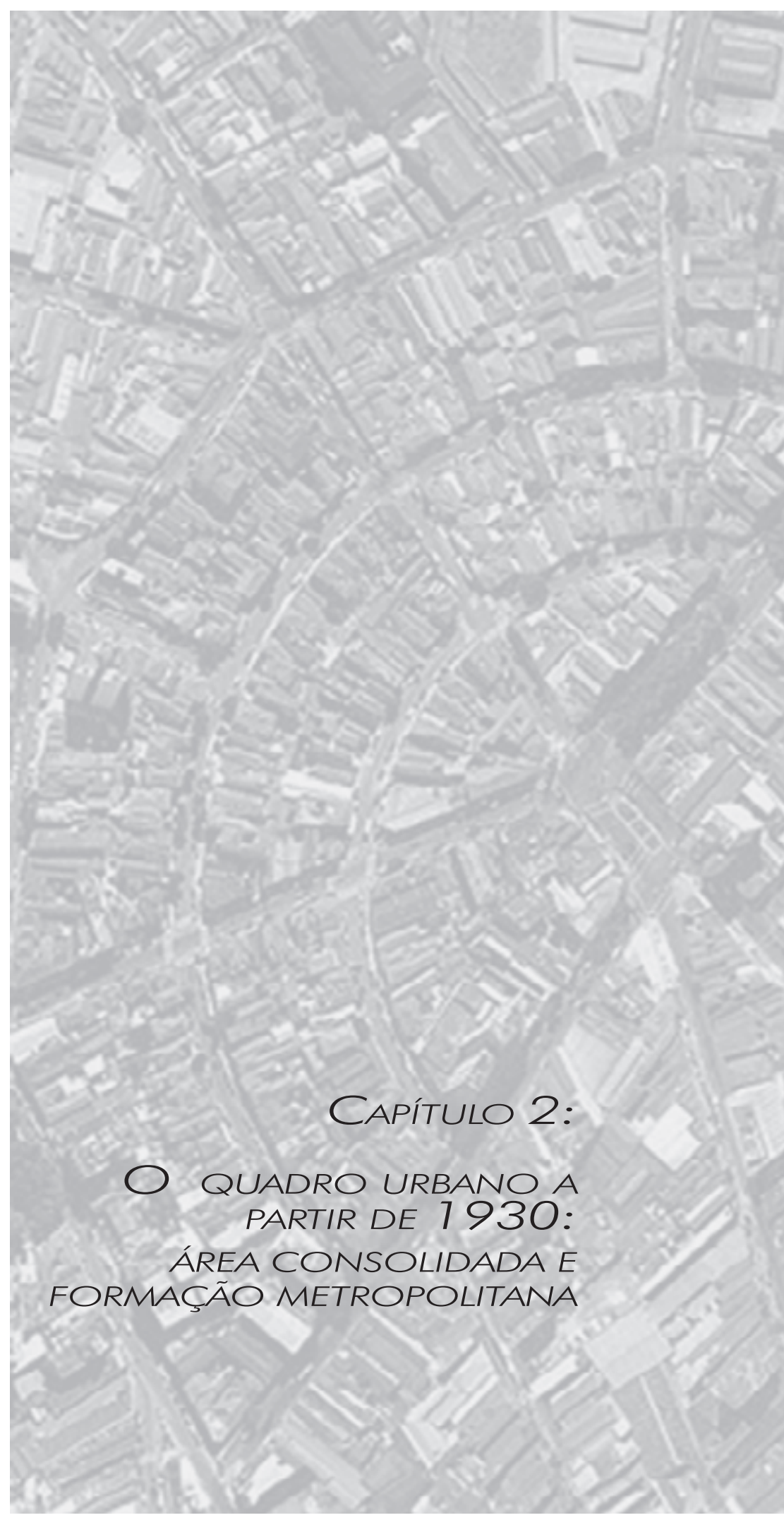




\section{O quadro urbano a partir de 1930: área consolidada e formação metropolitana}

Os elementos de infra-estrutura implantados na cidade, analisados até então, aliados aos diferentes padrões de parcelamento do solo, foram decisivos para que as diversas ocupações e vocações urbanas fossem estruturadas. A partir de 1930 deu-se início ao processo de metropolização de São Paulo, com o conseqüente desdobramento do espaço urbano muito além dos limites anteriores, como se verá a seguir.

A inserção do país na nova esfera econômica mundial, iniciada após o crack de da bolsa americana em 1929, até o período do pós-guerra, em 1945, foi preponderante para o novo patamar de relações que se estabeleceu nas grandes cidades brasileiras. Juntamente com o tumultuado cenário internacional, durante a década de 1930, o Brasil assistiu a implantação do regime autoritário do Estado Novo, que presidiu uma reformulação estrutural da economia, beneficiando novos setores de acumulação, que passaram de rurais a urbanos.

Nessa etapa, devido à predominância da industrialização paulista perante aos demais estados do país e a intensificação das migrações internas (sobrepujando em uma década a imigração estrangeira do período 1900-1930), aprofundaramse os fatores já em curso das décadas de 1910 e 1920, fenômenos esses que de forma associada contribuíram para um crescimento demográfico exponencial.

A ocupação dos setores da cidade no período agora abordado, pode ser compreendido levando-se em conta:

1. O momento da concentração populacional, até os anos de 1930, particularmente da força de trabalho operária, que dependia diretamente do transporte por bondes e trens para o acesso às áreas industriais, concentradas ainda no Brás, Bom Retiro, Mooca, Belenzinho, Cambuci, Ipiranga e Água Branca. Com as restrições de mobilidade ocasionada pelos modos de transportes disponíveis, mesmo a classe média necessitava residir nas proximidades do centro.

2. O momento em que a necessidade de concentração foi rompida, com a conseqüente dispersão da cidade, fruto, entre outros fatores, da crescente leva de migrantes como oferta de mão de obra e a expansão do transporte baseado nos ônibus, e não apenas nos bondes. (Sempla, 1986,14).

Em relação ao processo urbano que se verificou nesse período, Langenbuch identificou três características principais:

1. A compactação da área edificada, que ocorreu através do acentuado crescimento vertical no Centro e de bairros próximos: Santa Ifigênia, Campos Elísios, Santa Cecília, Vila Buarque, Higienópolis, Consolação, Vila América, Paraíso, Liberdade e Aclimação. Esse aspecto ocorreu com menor intensidade na Vila Mariana, Cambuci e Brás, mas incidiu também nos bairros onde se 
estruturaram subcentros, como foi o caso de Santana, Penha, Pinheiros, Lapa. Foi notado também o crescimento da densidade nas áreas que não possuíam uma ocupação efetiva, como foi o caso dos bairros-jardim, Vila Clementino e Mirandópolis.

2. Expansão da área edificada sobre espaços suburbanos anteriormente não adensados: tratava-se de áreas mais afastadas da malha viária contínua, raras, pois o parcelamento precedia o avanço dessa malha. Nesse caso se incluíram as áreas do Morumbi-Cidade Jardim.

3. Ocupação pela área edificada dos espaços suburbanos anteriormente ocupados: processo em que as ferrovias ainda desempenharam papel de indução da ocupação de suas faixas lindeiras, complementadas pela circulação rodoviária e pela polarização dos "subúrbios-estação", que se constituiriam em focos de estruturação e expansão urbana (Langenbuch, 1971, 179, aspas nossas).

Enfocando a cidade no período pós-1930, pode-se observar que o crescimento populacional esteve profundamente relacionado ao papel de principal centro dinâmico da economia brasileira, representado por São Paulo. Os registros mostram que em 1930 a cidade possuía 822.400 habitantes, passando para 1.350.000 habitantes em 1940. Na década seguinte, saltou para 2, 2 milhões de habitantes (fonte: FIBGE).

Aspectos contraditórios marcaram o cenário urbano no período posterior à década de 1940: a mesma cidade que passava por uma reestruturação viária na sua área central, através do Plano de Avenidas, apresentava, em alguns setores, um alto déficit de construção de moradias novas. A intervenção do Governo Federal nos contratos de locação dos imóveis, através da promulgação da Lei do Inquilinato em 1942, provocou repercussões na produção da construção civil, pois devido o congelamento dos aluguéis, estes deixaram de ser uma atividade rentável, desestimulando o investidor que aplicava em imóveis para auferir renda com a locação do mesmo. Por outro lado, apesar da queda verificada na construção civil comparativamente ao período anterior à Lei do Inquilinato, essa medida implicou em um fomento à produção para venda e à auto-construção (Souza, 1994, 98).

Concomitantemente ao crescimento horizontal de São Paulo, através da anexação de espaços periféricos, o aproveitamento vertical do solo caracterizou-se como aspecto relevante presente nos espaços centrais, resultando em um fenômeno que acentuou as diferenças entre os setores consolidados da cidade. Até fins da década de 1930, a verticalização se mostrou restrita ao Centro histórico e contou com incentivos para sua intensificação por parte da legislação urbanística, como no Código de Obras Arthur Saboya, que estabeleceu padrões de aproveitamento não alcançados durante muitos anos. 
Em relação à produção de edifícios para a classe média, a criação do condomínio proporcionou alternativas de viabilização econômica para a compra de apartamentos. Através dessa forma, inédita até então, de viabilizar financeira e juridicamente os empreendimentos, tornou-se possível para os interessados dividir os custos do terreno, da construção e remunerar o responsável pelo processo através de uma taxa de administração (idem, 109).

O aproveitamento vertical do solo urbano em São Paulo, surgiu como produto de uma relação entre o capital imobiliário, o capital financeiro, o capital fundiário e o capital produtivo, articulados numa estratégia de interesse mútuo (ibidem, 27). A convergência dos interesses das empresas voltadas à comercialização do solo urbano, juntamente com os agentes financiadores, os proprietários de lotes e glebas e a indústria de construção civil, resultou em operações em que a verticalização se constituiu em um elemento realizador de lucros para toda essa cadeia.

A condição necessária para a cadeia de agentes descrita se concretizar foi a da existência de demanda, que no caso de alguns bairros centrais paulistanos, foi constituída pela procura das classes médias e altas às localizações próximas ao Centro e não em sítios mais afastados. Nesse sentido, é procedente retomar a tese de Villaça sobre o controle que as camadas de alta renda exercem sobre o tempo dos deslocamentos, para a definição de seu local de moradia (Villaça, 1998, 198).

Iniciada na segunda década do século XX, até 1939 a verticalização ocorreu em São Paulo em sua área central majoritariamente, e com uso comercial predominante. Dos 813 edifícios então existentes na cidade, 70\% localizavamse no Centro e $65 \%$ atendiam ao comércio e serviços. Duas décadas depois, a situação se inverteu pois, dos 3.533 edifícios existentes em 1957, 2.720 foram construídos a partir de 1940. Do total, apenas 29\% se situavam no Centro, enquanto os $71 \%$ restantes, nos bairros (Someck, 1987, 54/152).

O estudo de Someck sobre a verticalização em São Paulo mostra que esse processo apresentou algumas fases, começando com aquela que esteve ligada à reprodução de padrões europeus, no período que se iniciou em 1920, chegando a 1939. Além das características tipológicas, com profusão de ornamentação eclética, ela também ocorreu sem controle de coeficiente de aproveitamento, sendo o Edifício Martinelli um exemplo desse padrão. Uma segunda fase foi a que abrangeu de 1940 a 1956, com características tipológicas norte-americanas e ainda sem limitação de coeficiente de aproveitamento, o que ocorreu a partir de 1957, ano que segundo a autora, inaugurou a terceira fase da verticalização até meados da década de 1960, onde o uso do automóvel definiu novas ocupações e acentuou o crescimento vertical em alguns setores da cidade (idem, 23/25). 


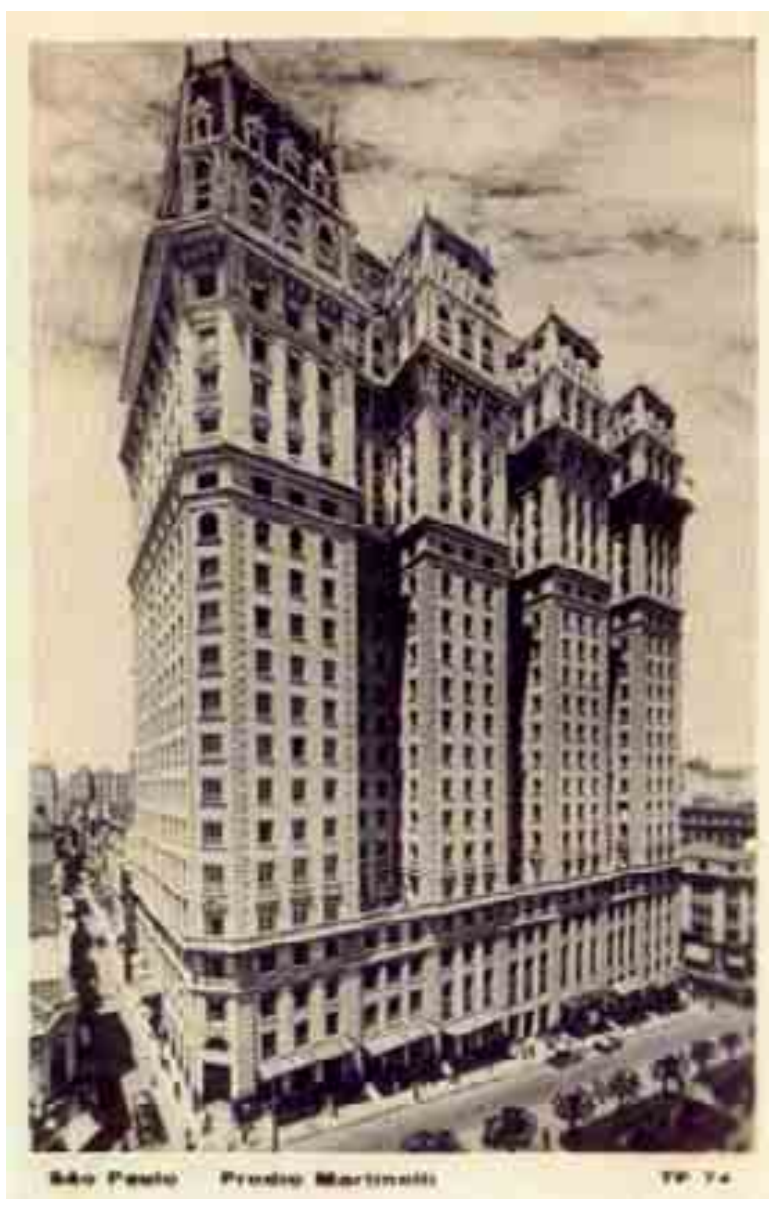

Fig 54: Cartão postal do Edifíco Martinelli.
Para a intensificação da verticalização do Centro e sua ocorrência nos bairros vizinhos, a reestruturação do sistema viário provocada pelo Plano de Avenidas foi um fator da maior importância, como atestam os estudos de Bonduki (1998), Meyer (1991), Rolnick (1997), Someck (1987), Souza (1984) e Leme (1999). A transformação da área central teve como aspecto principal as mudanças ocorridas no Centro Novo, isto é, a substituição de residências, lojas, oficinas e manufaturas, por edifícios comerciais. O crescimento vertical e o adensamento central dos anos posteriores a 1940, ocorreram como colorário da acessibilidade traçada à régua e compasso para a utilização intensiva dos veículos produzidos pelo símbolo mundial do progresso, a indústria automotiva.

Em alusão a esse processo, Petrone analisou toda a transformação ocorrida na área central, que teve início com o prefeito Fábio Prado (1934-38) e concluída por Prestes Maia (1938-45), como a "quarta fundação de São Paulo". Em sua análise, essas realizações superaram as de João Teodoro e Antônio Prado e o conjunto de obras obteve o mérito de transformar a cidade. Segundo suas palavras: "largas e extensas avenidas, diversos viadutos, quarteirões inteiros transformados, arranha-céus substituindo velhos pardieiros mal arejados e inestéticos deram a área central uma fisionomia inteiramente nova" (Petrone in Azevedo, 1958, 152).

Como decorrência da nova acessibilidade proporcionada pelas avenidas do Plano de Prestes Maia, um fator significativo foi a transformação das tipologias então existentes nas áreas próximas daquelas vias: mansões que marcaram a paisagem até as décadas de 1930 e 1940 e que anteriormente dominaram locais como a avenida Paulista e Higienópolis, gradativamente passaram a dar lugar a edifícios, prenunciando a verticalização das décadas de 1950 e 1960. 
Esse processo, segundo o estudo de Azevedo, pode ser compreendido levando em conta os seguintes fatores:

1. A grande valorização dos terrenos;

2. A necessidade de se obter lucros mais compensadores;

3. A deterioração de muitas dessas residências construídas no início do século;

4. A impossibilidade ou dificuldade de alugá-las;

5. Os problemas relativos a propriedades de muitos herdeiros;

6. $\bigcirc$ crescimento do sistema de construção de apartamentos em condomínio financiados a longo prazo;

7. A desvalorização da moeda devido à inflação no período (Azevedo apud Macedo, 1987, 75).

Considerando que outras áreas próximas ao centro, como os Campos Elísios, possuíam características semelhantes às de Higienópolis, possibilitando também o aproveitamento vertical dos terrenos, e que entretanto o mesmo fenômeno não se verificou, no período pós-1940 a diferenciação dos setores urbanos vizinhos à área central se deu com o aumento do aproveitamento vertical dos bairros próximos ao Centro Novo, escolhidos para local de moradia de uma parcela da classe média e média alta, que substituiu gradativamente os habitantes das áreas aristocráticas do período anterior.

Um fato determinante para essa localização residiu na oferta da acessibilidade provocado pelo Plano de Prestes Maia, que não foi igual para todas as regiões dos bairros centrais. Como será visto adiante, os setores sul e sudoeste tiveram o maior número de vias implantadas e nessas áreas o preço dos terrenos já se apresentava alto em comparação às demais áreas da cidade, devido ao fato da infra-estrutura instalada nesses bairros ter se constituído no principal indexador do valor do solo urbano (Villaça, 1998, 138).

Seguindo essa análise, a chave que permite explicar a tendência à concentração, em maior ou menor grau, da burguesia em uma única região da cidade, segundo Villaça, é o estudo das localizações dos elementos da estrutura e das suas correlações com os outros elementos urbanos. A localização dos melhoramentos em uma região, e não em outra, se torna vital para o estudo do arranjo territorial decorrente. Nesse sentido, o fator fundamental no caso de São Paulo, foi a população de mais alta renda usufruir o melhor sistema de vias radiais da cidade - as avenidas Angélica, Consolação, Rebouças, Nove de Julho e Brigadeiro Luiz Antônio - localizadas no vetor sudoeste a partir do Centro (idem, 138).

$\mathrm{Na}$ área central se concentrou até fins da década de 1960, a maior parte dos empregos dessa faixa de renda, os seus locais de compra, serviços, órgãos 
públicos, lazer, cultura, etc...Villaça concluiu que desse modo foi produzida a melhor localização para as burguesias morarem, tendo como ponto de contato entre esses bairros, alguns espaços do Centro Novo, representado pelas avenidas Ipiranga, São Luís, Vieira de Carvalho, Praça da República (ibidem, 154).

Cabe observar que a partir da década de 1940 até a década de 1960, o Centro Histórico da cidade viveu o seu período de apogeu, embora em seu interior a divisão entre o Centro Velho e o Centro Novo já apresentasse uma distinção de contornos sociais, funcionais e espaciais nítidos, o que influenciou a localização dos bairros de alto poder aquisitivo junto aos espaços do Centro Novo.

Um estudo do IBGE sobre a cidade de São Paulo, datado de 1962, relaciona as diferenças entre as áreas ocidentais e orientais do Anhangabaú (Centro Velho e Centro Novo, respectivamente), considerando que, a partir da década de 1940, gradualmente o Centro Velho passou a abrigar também a função de centro financeiro, pois antes se apresentava como exclusivamente varejista. $\bigcirc$ Centro Novo, após ver a sua função residencial das primeiras décadas do século XX ser paulatinamente substituída pela comercial, apresentou em fins da década de 1950 uma dinâmica ocasionada principalmente pelas reformulações espaciais, sendo assim explicada: "a abertura da Avenida Ipiranga e da Rua Marconi, a construção do Viaduto do Chá, muito mais amplo que o anterior, o deslocamento do ponto final de bondes e ônibus para a rua Xavier de Toledo e Praça Ramos de Azevedo, foram todos fatores favoráveis ao desenvolvimento comercial dessa área, surgindo em poucos anos, numerosos edifícios de muitos pavimentos no local dos antigos sobrados e residências térreas" (IBGE, 1962, 73).

mesmo trabalho também apontou:

-Predomínio de comércio de luxo nas ruas Barão de Itapetininga, Marconi, com a função comercial se estendendo às ruas 24 de Maio, D. José de Barros, Sete de Abril, Conselheiro Crispiniano, Xavier de Toledo e avenidas São João, Ipiranga e São Luís. Concentração de consultórios médicos e dentários principalmente nas ruas Marconi e Xavier de Toledo. Agências bancárias, escritórios comerciais e de corretagem (idem, 73).

A importância dessa nova centralidade para parcelas da população de maior renda, não se limitou aos novos postos de trabalho de profissionais liberais ou comércio especializado, como o trabalho dos geógrafos do IBGE registrou. Foi também associada ao papel aglutinador de atividades de lazer e cultura representado pela "Cinelândia", que distinguia claramente as duas áreas do Centro, como se percebe na análise: "a localização de modernos cinemas na Avenida São João, Largo do Paissandu, Avenida Ipiranga e outras vias, bem como o funcionamento de numerosos restaurantes, casas de lanche, bares, cafés, trazem ao Centro Novo uma extraordinária movimentação, não só durante o dia, como até altas horas da noite, particularmente aos sábados, domingos e feriados, 


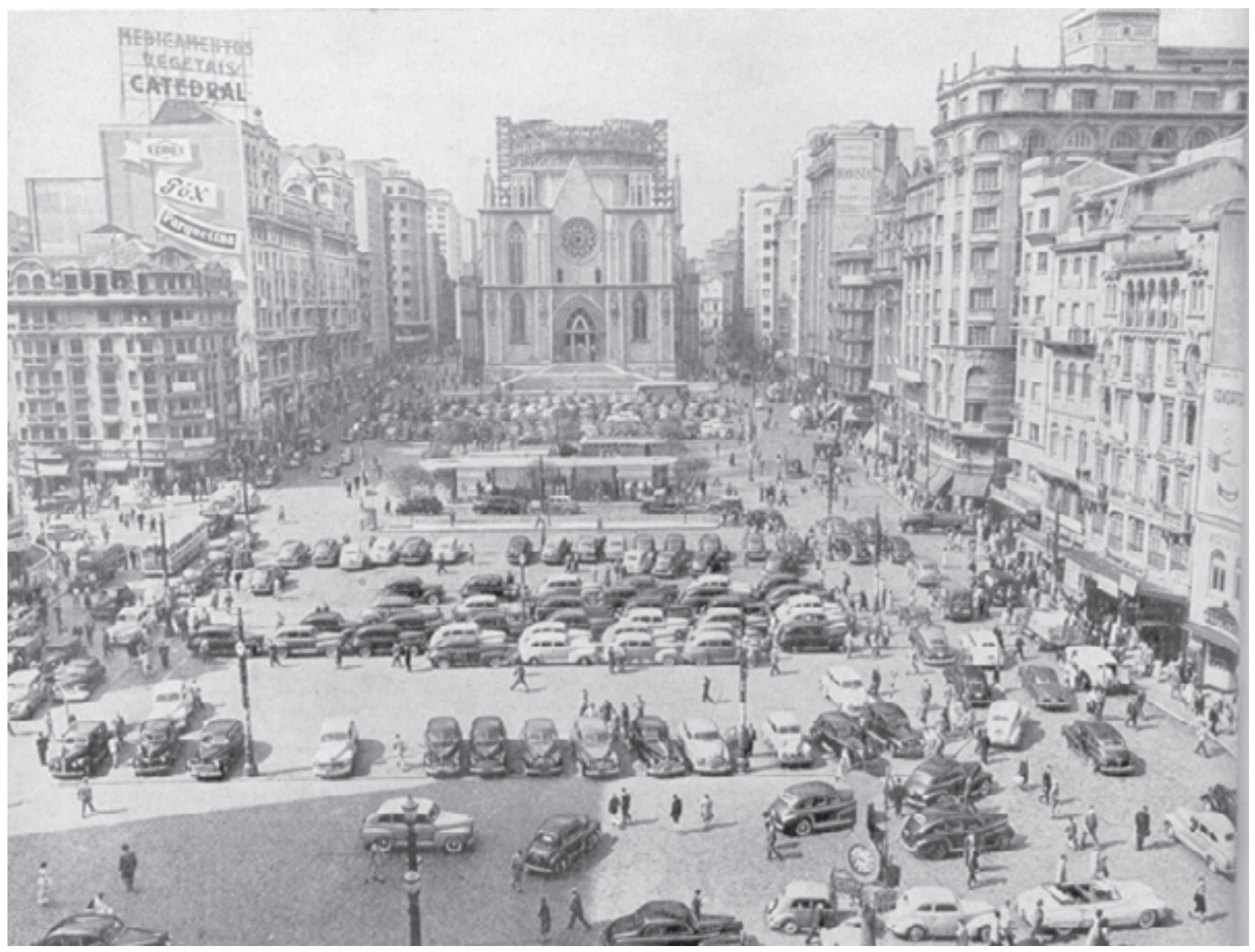

Fig 55: Praça da Sé, década de 1940.

contrastando com a escassa circulação que se verifica à noite no centro antigo, após o fechamento de escritórios e lojas" (ibidem, 73)

Retomando a análise de Villaça sobre a autonomia das classes de renda mais altas na escolha e produção de suas localizações residenciais, esta se deu como resultado do seu comando do setor imobiliário urbano e da ligação aos seus interesses de consumo. Em conseqüência, torna-se importante a rede de interrelações espaciais entre os bairros e os outros elementos vitais definidores dos deslocamentos espaciais, isto é, todos os locais de empregos, comércio e serviços. Dessa forma, abandonar a área de maior segregação de uma faixa de renda significa ficar "longe de tudo", ficar "fora de mão", piorando a acessibilidade ao se afastar da direção radial (Villaça, 1998, 203, aspas do autor).

No período 1940-1960 os subcentros de comércio e serviços foram desenvolvidos pela população constituída pelas classes média e média baixa, que conseguiu se fixar junto aos locais de trabalho, mas à certa distância do Centro. Todos esses subcentros não possuíam as mesmas qualidades urbanísticas do Centro principal, por não contarem com a presença de órgãos do Estado e se constituírem 
em uma concentração de comércio e serviços com caráter mais popular. Nesse caso incluíam-se os subcentros de Pinheiros, Santana, Lapa, Penha, Santo Amaro, etc (idem, 139). Mencionamos também o Brás, que historicamente desempenhou o papel de maior subcentro da cidade, superado unicamente pelo Centro tradicional de São Paulo.

Parte desses subcentros remontavam ainda ao período anterior à industrialização e foram os polarizadores dessas localizações, por apresentarem, como foi mencionado anteriormente, equipamentos minimamente estruturados, tornandoos mais convenientes do que as áreas das proximidades que nada ofereciam aos moradores iniciais. Antigos núcleos como os já citados bairros de Penha de França, Nossa Senhora do Ó e Pinheiros se incluíam nesse caso. (Langenbuch, 1971, 85).

Os dados populacionais apresentados a seguir mostram a transformação ocorrida nos setores urbanos de São Paulo, no período que se iniciou em 1934 chegando a 1960. É possível distinguir os grandes traços desse período, representados pela expansão da mancha urbana e a diminuição relativa do crescimento populacional dos bairros centrais, aspectos que serão analisados mais à frente.

No Quadro 6, é possível observar o crescimento da cidade em suas diferentes regiões, que no período 1934-1960, teve um acréscimo de 2.765.231 habitantes. É necessário ressalvar a diferença que a divisão político-administrativa dos subdistritos tem com os atuais distritos, mas a utilidade dos dados não é prejudicada devido a abrangência geográfica dos mesmos, que mostra a dinâmica demográfica vivida pela cidade ao longo de três décadas.

Os números mostram que entre 1934 e 1940, além dos subdistritos centrais Sé e Santa Efigênia apresentarem diminuição de população, com novo decréscimo na década seguinte, aqueles da industrialização pioneira também sofreram o mesmo processo, como ocorreu no Bom Retiro, Brás e Mooca. Mesmo o Belenzinho teve modesto crescimento entre 1940 e 1950, fenômeno que também ocorreu no Pari. Em contrapartida, percebe-se nesse período 1934-50, uma inequívoca expansão da cidade em todas as direções, com expressivos aumentos populacionais nos distritos da zona sul (Jd. Paulista, Indianópolis, Saúde, Ipiranga, Ibirapuera e Socorro), zona norte (N. S do Ó, Casa Verde, Tucuruvi e Vila Maria) e da zona leste (Penha, Vila Matilde, Vila Prudente) (Araújo Filho apud Azevedo, 1958, 233).

O principal aumento populacional nesse período se dev em áreas que receberam de 150 a quase $500 \%$ de incremento:

Entre 150 e 200\% - subdistritos Tucuruvi, Casa Verde, Pirituba, Osasco, Santo Amaro, Indianópolis, Saúde e Tatuapé.

Entre 200 e 300\% - subdistritos Ibirapuera, Vila Prudente, Vila Maria, Vila Matilde, Guaianases. 


\begin{tabular}{|c|c|c|c|c|}
\hline \multicolumn{5}{|c|}{ Quadro 6 - Crescimento da Populaçāo segundo os Subdistritos e Distritos } \\
\hline Sub-distritos & 1934 & 1940 & 1950 & 1960 \\
\hline 1. Aclimaçăo & 12.932 & 18.809 & 29.432 & \\
\hline 2. Alto da Mooca & 33.021 & 46.835 & 69.107 & 125.475 \\
\hline 3. Barro fundo & 23.734 & 28.254 & 29.696 & 32.500 \\
\hline 4. Bela Visto & 43.861 & 47.440 & 45.657 & 57.906 \\
\hline 5. Belenzinho & 48.165 & 61.749 & 63.435 & 6.3 .242 \\
\hline 6. Bom Retiro & 28.449 & 27.617 & 23.043 & 26.494 \\
\hline 7. Brós & 82.955 & 80,914 & 68.138 & 64.061 \\
\hline 8. Butanto & 16.272 & 29.809 & 33.263 & 79.964 \\
\hline 9. Cambucí & 29.183 & 37.841 & 46.034 & 49.970 \\
\hline 10 Copela do Socorro & & 9.494 & 77.742 & 28.503 \\
\hline 11 Cosa Verde & 13.452 & 22.120 & 58.571 & 104.359 \\
\hline 12 Cerqueira Cósar & 18.734 & 23.324 & 26.365 & 32.085 \\
\hline 13 Consoloçâo & 30.229 & 32.858 & 35.718 & 51.771 \\
\hline 14 lbirapuera & & 7.571 & 27.390 & 99.784 \\
\hline 15 Indianópolis & 7.492 & 10.790 & 28.710 & 54.800 \\
\hline 16 Ipiranga & 40.825 & 60.563 & 114.744 & 156.986 \\
\hline 17 Jardim Américo & 17.531 & 25.855 & 38.192 & 50.133 \\
\hline 18 Jardim Paulista & 15.877 & 32.757 & 55.245 & 80.286 \\
\hline 19 Lapo & 45.378 & 60.959 & 87.516 & 107.703 \\
\hline 20 Liberdode & 39.726 & 43.795 & 43.473 & 55.951 \\
\hline 21 Mobco & 45.986 & 50.953 & 48.180 & 42.852 \\
\hline 22 N. Senhora do 0 & 7.866 & 13.436 & 51.012 & 133.712 \\
\hline 23 Osasco & 12.091 & 15.258 & 43.427 & \\
\hline 24 Pari & 36.675 & 37.738 & 41.079 & 46.227 \\
\hline 25 Penho de França & 30.716 & 44.369 & 82.814 & 149.179 \\
\hline 26 Perdizes & 31.573 & 44.225 & 68.823 & 91.438 \\
\hline 27 Pirituba & 5.467 & 9.340 & 27.281 & 75.137 \\
\hline 28 Santona & 45.588 & 55.081 & 90.198 & 166.597 \\
\hline 29 Santa Cecilia & 31.096 & 36.542 & 39.264 & 60.586 \\
\hline 30 Santo lfigênio & 43.623 & 41.555 & 39.367 & 47.318 \\
\hline 31 Sonto Amaro & 26.918 & 15.248 & 40.115 & 109.263 \\
\hline 32 Soúde & 27.676 & 41.614 & 107.827 & 213.994 \\
\hline $33 \$ 6$ & 11.469 & 10.331 & 9482 & 8.802 \\
\hline 34 Tatuape & 63.253 & 54.002 & 135.195 & 219.612 \\
\hline 35 Tucuruvi & 24.632 & 33.761 & 88.729 & 223.412 \\
\hline 36 Vila Madalena & & & 30.983 & 46.241 \\
\hline 37 Vila Mario & 5.722 & 15.288 & 54.373 & 99.018 \\
\hline 38 Vilo Mariono & 32.700 & 43.100 & 58.442 & 77.007 \\
\hline 39 Vila Matilde & 6.119 & 12.141 & 38.253 & 81.339 \\
\hline 40 Vilo Prudente & 11.675 & 29.764 & 90.408 & 197.945 \\
\hline \multicolumn{5}{|l|}{ Distritos } \\
\hline Guaianuses & 1.642 & 2.967 & 10.413 & 24.689 \\
\hline Itoquero & 6.220 & 7.892 & 15.515 & 33.570 \\
\hline Jaroguá & & & 2.625 & 9.817 \\
\hline Parelheiros & & & 7.701 & \\
\hline Perus & 3.504 & 5.985 & 5.745 & 9.266 \\
\hline S. Miguel Paulista & 2.224 & 7.700 & 39.375 & 65.992 \\
\hline TOTAL MSP & 1.060 .027 & 1.320 .450 & 2.228 .722 & 3.288 .921 \\
\hline
\end{tabular}


Entre 370 e 450\% - subdistritos de Nossa Senhora do Ó e o distrito de São Miguel Paulista.

Comparada à ocupação do início da década de 1930, onde a cidade apresentava vetores de expansão com vazios entre eles, a ocupação de 1950, que ocorreu em todos os quadrantes, deu lugar ao que foi denominado de "cidade em nebulosa", visto o espraiamento se dar sem espaços vazios consideráveis (idem, 241, grifo nosso). O processo de ocupação da periferia urbana pode ser comprovado pela ocupação predominantemente popular nas áreas que apresentaram aumento populacional superior a 150\%, constituída de "operários de fábricas e trabalhadores em geral, funcionários públicos de categoria inferior - que se beneficiam das facilidades oferecidas pelas empresas loteadoras de terreno ou habitam em casas construídas, aos pouquinhos, nas horas de folga..."(ibidem, 239).

Já no período 1950-1960, ao norte da cidade, se destacaram os subdistritos Casa Verde, Santana, Vila Maria, Nossa Senhora do Ó e Tucuruvi, este com mais de $150 \%$ de crescimento, em relação aos demais, na faixa dos 100\%. Ao leste, se destacaram o Alto da Mooca, Penha, Tatuapé e Vila Prudente, este último com mais de $200 \%$ de crescimento. Na região vizinha, ao sudeste, o Ipiranga também teve crescimento expressivo, na casa de 50\%, mas considerado o crescimento no período anterior, muito acentuado, se constituiu em um vetor de forte ocupação, juntamente com Saúde, que teve mais de 100\%.

Ao sul, destacou-se Santo Amaro, com mais de 150\% de crescimento, mas Ibirapuera e Indianópolis também apresentaram índices expressivos, em torno de $100 \%$

A oeste, a Lapa se caracterizou por um acréscimo de 20.000 habitantes, que manteve o mesmo crescimento das décadas anteriores.

A ocupação do sudoeste manteve-se crescente, sem taxas excepcionais, apenas demonstrando uma ocupação de baixa densidade.

Durante a década 1950-60, todos os bairros tradicionais formados nas primeiras décadas do século, no entorno do Centro, tiveram crescimento mais reduzido:

A Barra Funda teve um acréscimo de 2.804 habitantes, passando de 29.696 para 32.500 .

A Bela Vista, com o maior crescimento de todos os subdistritos envoltórios da Área Central, teve acréscimo de 12.253 habitantes, passando de 45.657 para 57.906. Deve ser considerada, nesse caso, a verticalização incidente na região próxima à avenida Paulista, como causadora desse aumento. 
O Belenzinho praticamente estagnou o seu crescimento populacional, apresentando mesmo um decréscimo de 193 habitantes, passado de 63.435, em 1950, para 63.242, em 1960.

Bom Retiro teve um acréscimo de 3.451 habitantes, passando de 23.043 para 26.494 habitantes.

Brás teve o decréscimo mais acentuado entre todos os subdistritos da região e da cidade, passando de 68.138 habitantes para 64.061, o que significou uma diminuição de 4.077 habitantes. Nesse caso, foi confirmada uma tendência que já havia se manifestado desde 1934, onde houve decréscimo de 2.041 habitantes de 1934 a 1940 e de 12.776 habitantes entre 1940 e 1950.

O Pari teve um acréscimo de 5.148 habitantes, passando de 41.079 para 46.227 habitantes, o que pode ser explicado não só pelo adensamento de seu núcleo, mas também pela ocupação das áreas drenadas da várzea do rio Tietê, cujo processo de retificação estava em curso. 


\section{1- A habitação popular: bairros centrais e periferia -1930 - 1960}

Na etapa em que a industrialização se estruturou na cidade, como já abordado anteriormente, o encortiçamento foi resultado de três aspectos principais: a necessidade elementar de moradia dos trabalhadores, a ausência de políticas públicas voltadas a habitação social e a crescente especulação do solo somado a altos aluguéis, como forma de reposição do capital empregado na construção das unidades. As formas de habitação popular, os cortiços e as vilas operárias, coexistiram com a ocupação residencial de baixa renda, cada vez mais freqüente, das áreas suburbanas da expansão da cidade no período pós 1940.

Nessa etapa, o arranjo urbano de localização da habitação popular foi decorrente da nova relação moradia-emprego, que alterou aquela estruturada anteriormente, em virtude da expansão que a cidade apresentou em todos os seus quadrantes. Analisando esse quadro, um estudo da Secretaria de Planejamento indicou que "a reprodução operária, no tocante à moradia, apoiou-se no tripé loteamento de periferia, muitas vezes clandestino, casas próprias e autoconstrução. Assim, embora a grandes sacrifícios para os trabalhadores, tornou-se possível a expansão para o espaço urbano disperso. É nessa década, 1930-40, por sua vez, que vêm para São Paulo grandes levas de migrantes, prosseguindo o aumento demográfico rapidamente e constituindo vasto exército industrial de reserva" (Sempla, 1985, 14).

A habitação social seguiu um roteiro diferente da etapa anterior, provocado desta feita, por fatores de ordem institucional, associados às mudanças das regras da locação, afetando a produção e ocupação imobiliária. Dois desses fatores, essenciais para o entendimento do quadro urbano que se seguiu, foram a promulgação da Lei do Inquilinato e a nova lei federal para os loteamentos urbanos.

A produção de moradias para aluguel havia sido um investimento seguro até a promulgação da Lei do Inquilinato, em 1942, quando o congelamento dos valores de locação provocou o desinteresse em relação a esse tipo de produção, responsável pela grande maioria das habitações em São Paulo. Para o mercado de baixa renda não houve a migração de capitais que ocorreu em relação aos de renda mais alta, que transformaram a propriedade imobiliária e a construção civil em uma alternativa de investimento com grande liquidez e rentabilidade (Rolnick, 1997, 192).

Para a habitação popular, a Lei do Inquilinato foi mantida até a década de 1960 com modificações, mas uma das conseqüências diretas foi a desaceleração da construção de moradias de aluguel. A crise dos anos 1940, segundo a visão de Bonduki, apresentou o problema de forma mais aguda, pelo desestimulo à produção habitacional privada e insuficiência de iniciativas estatais. $\bigcirc$ recurso à construção de casas nos subúrbios e favelas começou a se tornar prática corrente, 
justificando assim a expansão horizontal da cidade no período agora abordado (Bonduki, 1998, 248).

Aliada a essas mudanças, a partir de 1937 procedeu-se à regulamentação do loteamento de terrenos por parte da legislação getulista (Decreto-lei $n^{\circ} 58$ ), transformada em um incentivo ao auto-empreendimento na periferia, uma vez que foram privilegiados aspectos jurídicos em detrimento ao controle urbanístico e da punição ao loteamento clandestino. Com isso, de forma conjugada ao congelamento de aluguéis, foi proporcionada uma alternativa para a construção da habitação com recursos dos próprios trabalhadores, sem qualquer medida que pudesse evitar a precariedade dos loteamentos, uma vez que isso poderia encarecer o custo do terreno, ocasionando demandas por salários mais altos por parte desses trabalhadores (idem, 289).

Apesar das diversas propostas e recomendações vindas dos meios técnicos, em sua maioria referenciadas pelo sanitarismo, a ausência de um plano habitacional extensivo para o atendimento da crescente demanda por habitação, levando em conta a análise de Villaça, pode significar o início da atuação que caracterizou o poder público desde então, no sentido de privilegiar as condições gerais de produção, em que "as obras de infra-estrutura são priorizadas enquanto as de habitação são relegadas ao esquecimento" (Villaça apud Deák, org, 1999, 199).

Entretanto, a presença de grandes massas urbanas nas principais cidades brasileiras, não permitia mais o ocultamento da problemática habitacional. De acordo com Rossetto, a pressão para que a questão passasse da esfera dos problemas privados para se constituir em uma questão abordada pelo poder público aumentava, na medida em que a escassez e as condições de precariedade de grande parte da população cresciam (Rossetto apud Sampaio, org, 2002, 39).

Como exemplo de propostas de ordem investigativa e técnica, são mencionados a seguir trabalhos apresentados na Jornada da Habitação Econômica, realizada em $1941^{6}$, em que esse assunto recebeu um tratamento diverso daquele que o caracterizara no início do século. Na conferência inaugural, Roberto Simonsen considerou que o problema da habitação passava a ser principalmente um problema do urbanismo, levando em conta as necessidades de ordem individual, social, técnica, demográfica e econômica, salientando ainda que para a sua solução, a participação do Estado era considerada indispensável (R.A.M., n 82, 1942, 25).

Além da participação pública ser ressaltada, a necessidade de produção de um grande número de unidades, dado o tamanho da demanda, ficou evidenciada pelo surgimento de propostas de verticalização da habitação popular e a adoção do sistema de condomínio, como formas de racionalizar a obra, a ocupação do solo e viabilizar sua construção.

Um exemplo expressivo foi a proposta do engenheiro Siciliano (idem, 98), que preconizava como solução, a verticalização da habitação econômica. 
Argumentando que a mesma deveria se localizar o mais próximo possível do local de trabalho, mas impossibilitada devido ao alto custo dos terrenos, deveriam as indústrias se encarregar de construir edifícios para seus empregados, para viabilizar unidades adequadas aos mesmos. À racionalização da obra, sem elementos supérfluos para a vida de seus ocupantes, aliava-se a menor ocupação do terreno e as condições de salubridade, sendo possível prever-se ampliações futuras para equipamentos, reproduzindo em parte o que havia sido construído na Vila Maria Zélia. $\bigcirc$ industrial seria, desse modo, beneficiado triplamente:

- pela permanência dos empregados no local da produção, afastando-os dos perniciosos cortiços

- pelo aumento da produtividade e manutenção da qualidade dos equipamentos e das mercadorias produzidas

-pelo retorno "a um juro razoável" do capital invertido na construção (ibidem, 98)

Deve-se registrar que a Jornada de Habitação Econômica ocorreu um ano antes da promulgação da Lei do Inquilinato, mas pelo menos por essa recomendação, a idéia da exploração rentista da habitação social ainda persistia.

Um trabalho que analisou mais profundamente as diferenças entre os setores urbanos da cidade, no tocante à habitação, foi o estudo sobre as condições de 200 moradias em São Paulo, realizado pelo sociólogo Donald Pierson, em 1941. Nele, os bairros do Bexiga, Moóca e Canindé foram considerados como representativos do "nível inferior" de moradia, atribuído ao "nível superior", aquelas encontradas no Jardim América, Pacaembú e Higienópolis. A área que foi denominada Moóca pertencia, na realidade, ao bairro do Brás, correspondendo às ruas Carneiro Leão e Caetano Pinto, onde a incidência de cortiços era alta. No Canindé a pesquisa foi realizada na Avenida dos Estados, próxima da ferrovia da Cantareira e no Bexiga, na rua Manoel Dutra (R.A.M., ${ }^{\circ}$ 81, 1942, 201). Foram selecionadas dessa extensa pesquisa, algumas características das habitações dos chamados nível inferior e superior, a saber:

- Sub-parcelamento das edificações

No Brás, 18 edificações comportavam 50 moradias

No Bexiga, 13 edificações comportavam 25 moradias

No Canindé, 13 edificações comportavam também 25 moradias.

Apenas cinco edificações foram consideradas em boas condições, sendo que três delas se encontravam no Bexiga. Além disso, cerca de um terço delas, no Brás e no Bexiga, apresentava uso misto, com exceção do Canindé. Neste caso foram encontrados porões habitados, juntamente com o Bexiga.

Em compensação, todas as edificações do nível superior eram unifamiliares 
- Área do terreno

No Canindé, máximo de $200 \mathrm{~m}^{2}$ e mínimo $60 \mathrm{~m}^{2}$

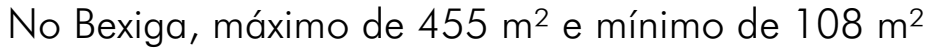

No Brás, máximo de $280 \mathrm{~m}^{2}$ e mínimo de $15 \mathrm{~m}^{2}$ (tratava-se provavelmente de apenas um aposento)

No Jardim América, máximo de $12.000 \mathrm{~m}^{2}$ e mínimo de 300 m²

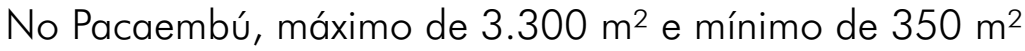

Em Higienópolis, máximo de 4.000 m² e mínimo de 126 m²

- Equipamentos

Moóca: 22 tanques para 50 moradias, 20 banheiros

Canindé: 16 tanques para 25 moradias, 16 banheiros

Bexiga: 13 tanques para 25 famílias. 12 banheiros

- Densidade

Brás: 225 habitantes para 67 cômodos usados para dormitório - 3,4 pessoa por cômodo

Canindé: 3,1 habitantes por cômodo de dormir

Bexiga: 2.5 habitantes por cômodo de dormir

- Rede de água

Bexiga: das 25 habitações, 9 não dispunham de fornecimento de água

Canindé: das 25 habitações, 8 não dispunham de fornecimento de água

Brás: das 50 habitações, apenas 1 não dispunha de fornecimento de água

Em contrapartida, todas as habitações do Pacaembú, Higienópolis e Jardim América, dispunham de fornecimento de água (idem, 207/223)

Pierson ressalvava que essa pesquisa se constituíra em uma amostra de um universo pesquisado pelo censo. A sua abrangência não deixa dúvidas que o espaço pesquisado foi de bairros próximos ao Centro, sendo colocado também, que o mesmo deveria ser realizado para uma amostra da área periférica, o que entretanto não ocorreu (ibidem, 201).

Juntamente com a dispersão da moradia dos trabalhadores pelo território, a produção da habitação social nos bairros centrais se restringiu a um número reduzido de novas unidades construídas pelos Institutos de Aposentadorias e Pensões - IAPs, com a permanência e crescimento do número de cortiços como 
alternativa para diminuir os custos do transporte incidentes na renda desses trabalhadores.

Criados durante o Estado Novo, a partir de 1937, efetivamente as condições para a atuação dos Institutos de Aposentadorias e Pensões passaram a existir, se constituindo na tentativa de se estabelecer uma nova cultura da habitação no país, mediante novas formas de abordá-la "em termos formais, produtivos, sociais e culturais" (Bonduki, 1998, 142). Apesar de terem sido produzidas inúmeras referências de conjuntos habitacionais por importantes arquitetos brasileiros, nos bairros centrais de São Paulo foram construídos apenas três desses exemplares, na década de 1940 e um na década de 1950.

Segundo as análises sobre a produção de habitação pelos IAPs, esse modelo chegou à década de 1960 exaurido por problemas de ordem financeira e administrativa, pois parte dos recursos destinou-se para o financiamento de edifícios para a classe média e classes de renda mais alta, originando um problema crônico que se manifestou nas décadas seguintes, quando o $\mathrm{BNH}$ passou a atuar nessa questão. Entretanto, a produção dos IAPs, significou um avanço na concepção da habitação social, coerente com as soluções da Arquitetura Moderna adotadas nos países centrais após a I Guerra, tais como os Hôfes, Siedlungen e ainda as Unités d'Habitacion de Le Corbusier, contando com arquitetos brasileiros de renome (Monteiro, Bonduki, orgs, 1993, 10).

A seguir, são relacionados dois exemplos desses conjuntos, que foram implantados em bairros centrais: o Glicério e o Bexiga.

- Conjunto Residencial da Baixada do Carmo

Bairro: Glicério

Órgão financiador: Instituto de Aposentadoria e Pensões dos Industriários - IAPI

Número de unidades: 480

Construção: década de 1940 Projeto: arq. Atílio Corrêa Lima

Edifício Japurá

Bairro: Bexiga

Órgão financiador: IAPI

Número de Unidades: 288

Construção: década de 1950

Projeto: arq. Eduardo Kneese de Mello

(Bonduki, idem, 171, 184, 187) 
Com exceção dos conjuntos mencionados, nenhuma outra solução foi encaminhada pelo Poder Público para tratar da habitação social nos bairros centrais de São Paulo, que devido ao processo urbano em curso durante as décadas seguintes de 1960, assistiu ao crescimento da população favelada e encortiçada, concomitantemente ao crescimento periférico e da degradação ambiental de significativas áreas da cidade.

Fora do âmbito oficial, no período 1930-1960 intensificou-se a produção de novos elementos tipológicos para a habitação de baixa renda e também a de classe média baixa: nas periferias assistiu-se a presença de conjuntos de casas térreas, modestamente construídas. Nas áreas mais centrais, conjuntos de residências assobradadas e geminadas, com o surgimento de edifícios de três ou quatro pavimentos, não equipados de elevador (Osello, 1983, 165).
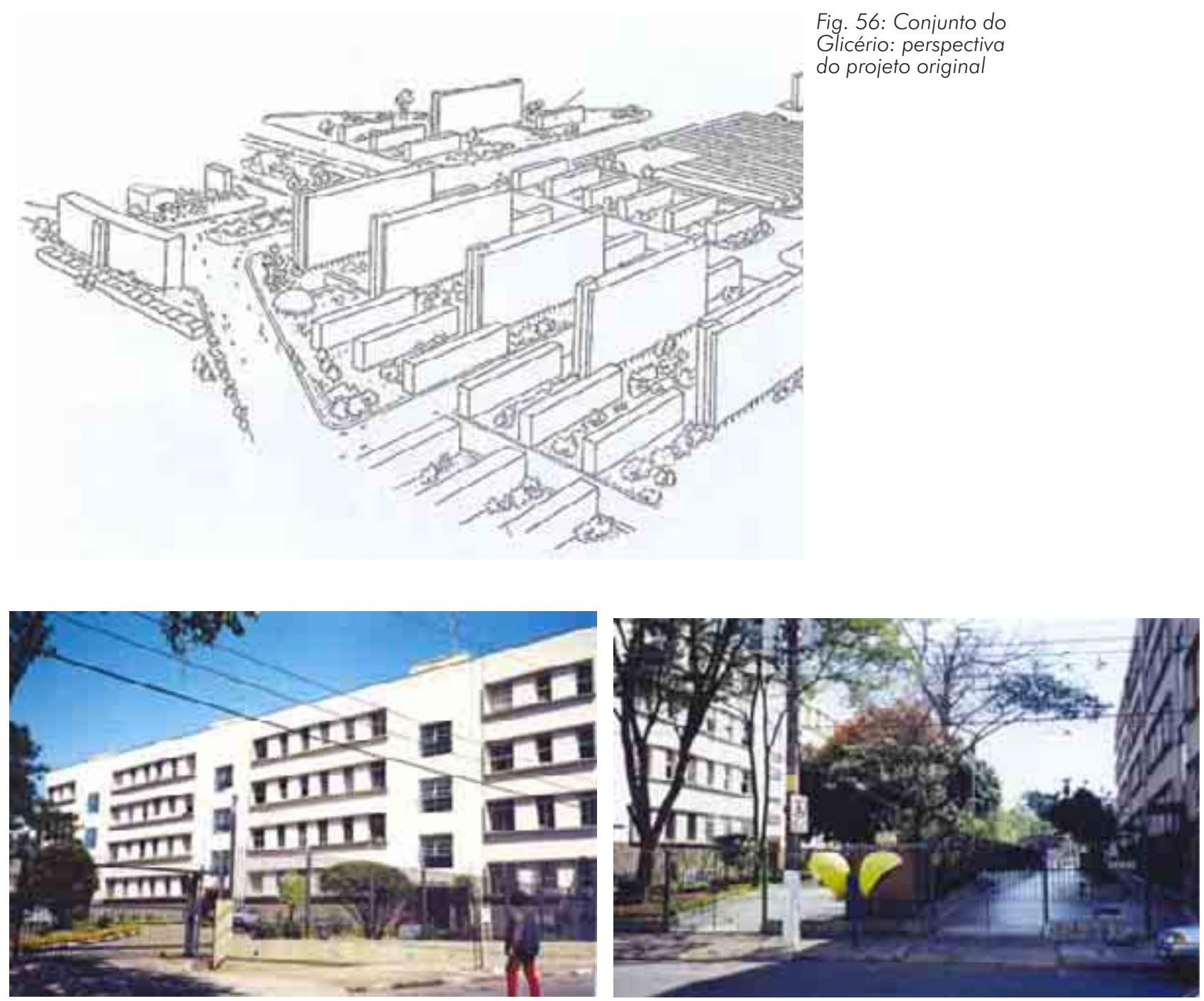

Fig. 57 e 58: Conjunto do Glicério, 2003. 

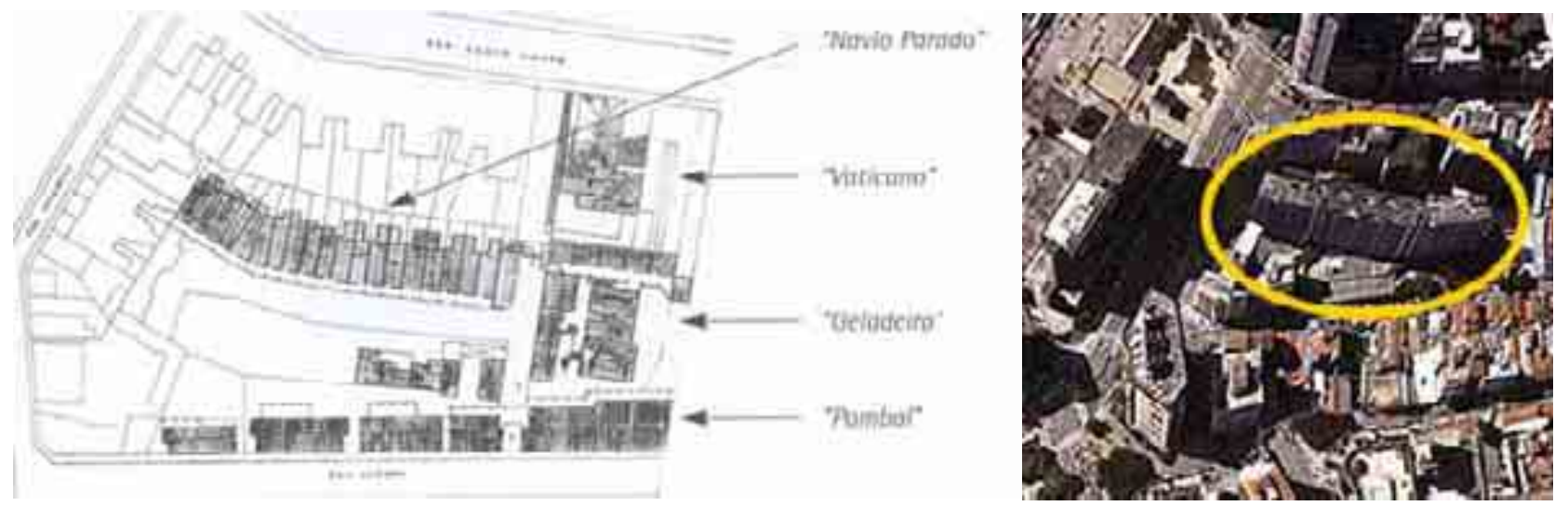

Fig. 59 e 60: Implantação do cortiço Navio Parado (esquerda) e Ed. Japurá (direita)

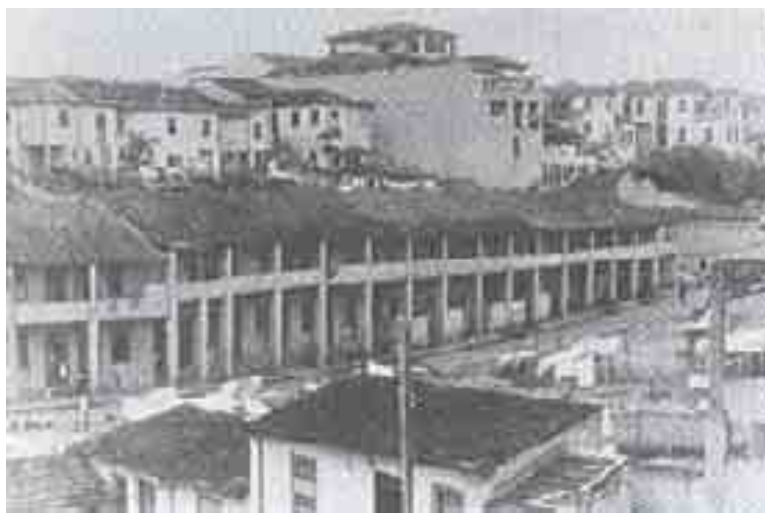

Fig. 61 e 62: Cortiço Navio Parado (acima) e Ed. Japurá (ao lado ), 2003.

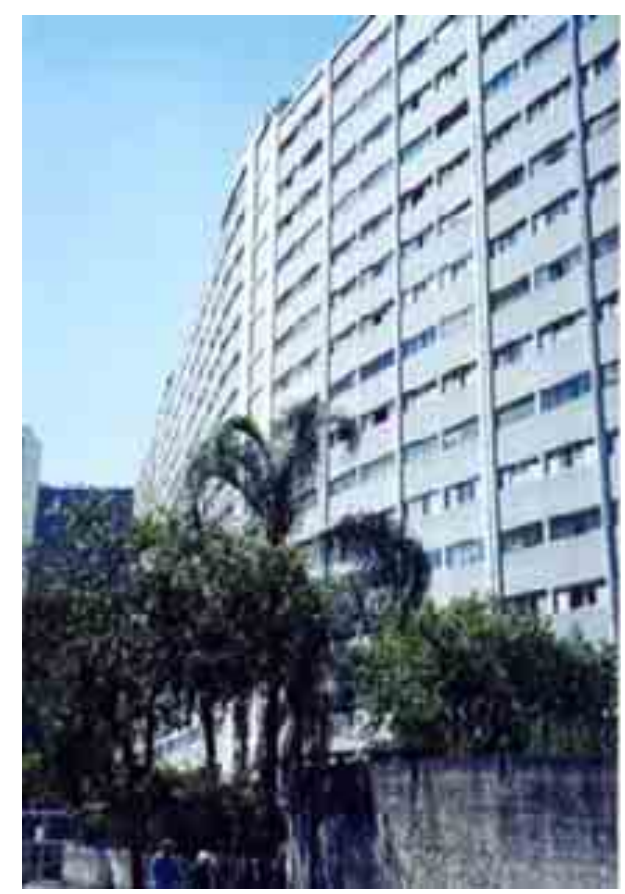

Fig. 63: Ed. Japurá,
2003.

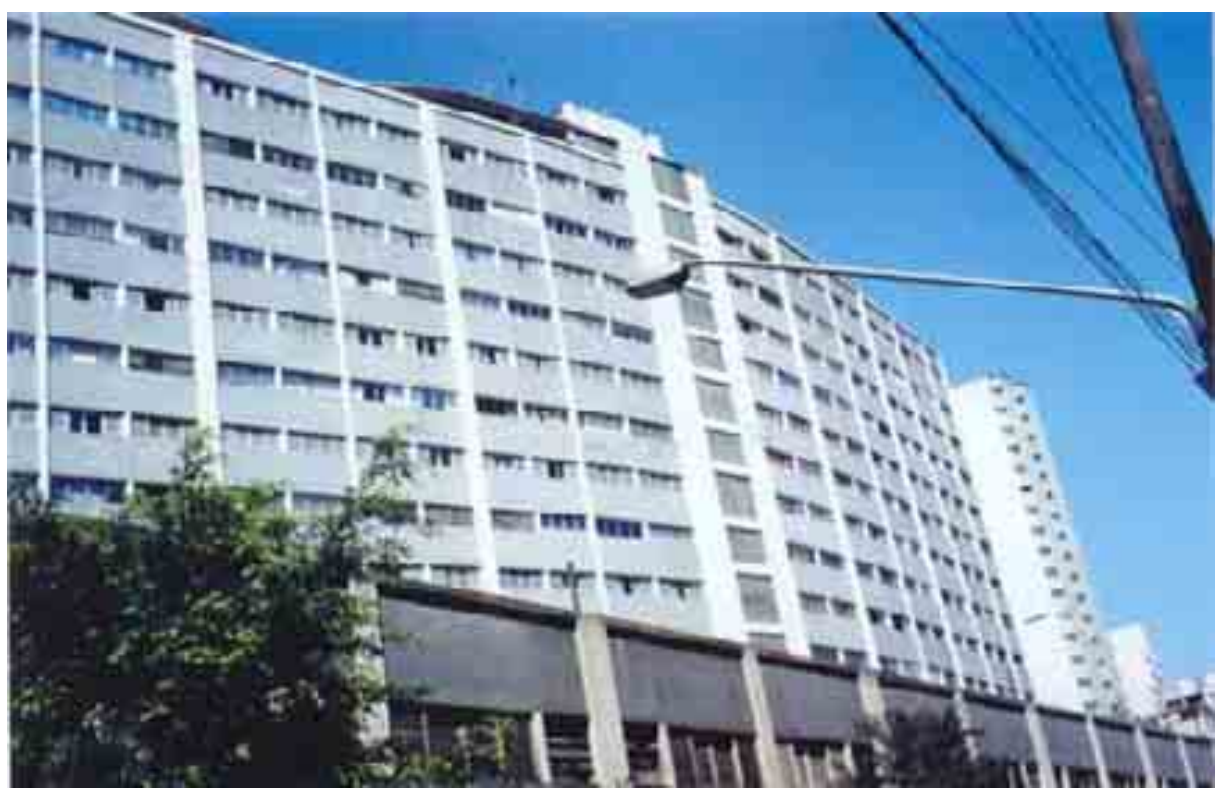




\subsection{As propostas urbanísticas para a cidade: $1930-1960$}

Dando seqüência à análise das transformações que configuraram a estrutura urbana da cidade e dentro disso, o processo ocorrido com os bairros centrais, buscou-se investigar nas propostas urbanísticas para São Paulo, aquelas direcionadas à infra-estrutura e ao uso e ocupação do solo. Nesse sentido, assinala-se a predominância dos planos viários na década de 1930 e as propostas para o zoneamento que ganharam importância nas décadas de 1940, 50 e 60.

Ressalvando se tratar de uma investigação de inegável importância, não cabe aos objetivos deste trabalho um aprofundamento sobre os problemas e contradições da parte do poder público para a não implantação das diversas propostas de planos urbanísticos, mas buscar entender as suas principais formulações, caracterizando a cidade no período 1930-1960. Outro campo de análise que também não será desenvolvido é o da relação Estado-Urbano, mas admitido que após 1930 essa interconexão obrigou a uma abordagem diferenciada daquela em que as concessionárias de infra-estrutura ditaram os rumos da expansão urbana.

Face aos problemas de toda ordem que a expansão da cidade apresentava, a formulação de um plano diretor vinha sendo reivindicado pelos urbanistas paulistas já em meados da década de 1930, como forma de equacionar o parcelamento desmesurado, a contínua abertura de ruas sem observância dos padrões municipais, as construções de todo tipo, conflitantes entre si e o congestionamento da parte central de São Paulo. As propostas lançadas ainda em fins da década de 1920, por exemplo nas palestras de Anhaia Melo, foram retomadas na metade do século, com um quadro urbano muito diferenciado do seu início, mas com problemas que apresentavam as mesmas raízes: especulação imobiliária, concentração na área central, carência de infra-estrutura na periferia urbana, precariedade do transporte público, etc.

Ao longo do período mencionado, uma importante transformação ocorreu na concepção dos planos, que passaram a não mais se submeter às intervenções viárias como elementos de organização-estruturação da cidade, mas a uma visão mais complexa e abrangente dos problemas urbanos, que requereu instrumentos e atuação diferenciada dos planos viários. Em seu trabalho sobre o Planejamento Urbano em São Paulo entre 1899 e 1961, Osello distinguiu as seguintes etapas de formulações urbanísticas:

- Planejamento Normativo - correspondente a normas, leis e códigos que estipulavam os controles sanitários e urbanísticos referentes a arruamentos, alinhamentos, edificações e sua altura, situação no lote, insolação, etc...

- Planos de Embelezamento: visando a reformulação da parte central da cidade 
- As Grandes Realizações: 1926 - 1945. Referente ao período de formulação e implantação do Plano de Avenidas

- Emergência do Plano Diretor: 1945 - 1961. Nesta categorização foram incluídos as tentativas de formulação de planos abrangentes, correspondentes ao Plano Moses em 1950, à proposta de Plano Diretor de 1954 e à pesquisa SAGMACS (Osello, 1983, 174)

Referindo-se a esse último período, Osello mencionou a importância que as mudanças de ordem institucional tiveram para com o planejamento da cidade. Superada a hegemonia do pensamento aristocrático, da etapa do planejamento normativo e as intervenções viárias, que foram realizadas sob o Estado Novo getulista, em conseqüência da redemocratização do país, a necessidade de apoio político para os governantes passou a ser um dado de real e crescente importância ${ }^{2}$. Osello considerou que, nessa circunstância, o leque de aspectos que eram considerados problemas urbanos se ampliou, passando daqueles relativos apenas à área central e proximidades, para os existentes nos bairros periféricos, que cresciam desprovidos de infra-estrutura e à margem do conjunto de leis urbanísticas (idem, 174).

Considerados esses novos problemas, fruto da expansão que a cidade experimentou a partir da década de 1940, dentro do quadro de técnicos envolvidos com o planejamento da cidade, posturas diferentes foram defendidas para o encaminhamento de soluções urbanísticas, com vários defensores da limitação do crescimento urbano, onde se alinharam os engenheiros Gomes Cardim, Carlos Lodi e Anhaia Melo (ibidem, 174, 176).

De outro lado figurou Prestes Maia, que negava a idéia de controle do crescimento da cidade, vinda da proibição da instalação de indústrias, aspecto preconizado por Anhaia Melo ou, do combate à especulação imobiliária, segundo Lodi. De acordo com Prestes Maia, a cidade não poderia estancar o crescimento simplesmente, sendo então necessária a adequação periódica das condições urbanas, ou seja, a distribuição de sua infra-estrutura, necessitando-se para isso, de um planejamento dinâmico (op.cit, 197).

No campo dos instrumentos urbanísticos, a análise de Feldman indica que o zoneamento passou a representar, em fins da década de 1940, uma formulação que deslocou o foco dos planos do início do século, com predominância dos aspectos viários e estéticos, para o de organização funcional, atribuindo assim ao sistema viário o papel de interconectar as funções. $\bigcirc$ zoneamento passou a ser caracterizado por três aspectos estruturadores de sua atuação: o de ordenar o solo do conjunto da cidade, o da aplicação sistêmica das normas e o da proteção dos valores imobiliários, através da vinculação entre uso do solo e seu controle e os processos econômicos atuantes na cidade (Feldman, 1994, 68,75). 
A tese da autora considera que o conjunto de normas urbanísticas voltou-se a uma regulamentação diferenciada, em que predominaram os interesses imobiliários das áreas mais valorizadas da cidade. Em suas palavras: "o zoneamento passa a atuar como instrumento que responde às novas necessidades de controle dos setores mais valorizados da cidade, com a intensificação e diversificação da atividade imobiliária a partir dos anos 40, em São Paulo. A demarcação de zonas, com articulação de diferentes índices urbanísticos, amplia as possibilidades de controle à escala assumida pela ocupação do setor sudoeste pelas classes da alta renda, e à escala das transformações que ocorrem na cidade" (idem, 175).

No desenvolvimento a seguir, serão caracterizadas as principais formulações urbanísticas até a década de 1960, para que os seus aspectos sejam relacionados ao quadro urbano da cidade, particularmente à infra-estrutura, parcelamento e edificação. 


\subsection{1. "Melhoramentos de São Paulo"}

No estudo "Melhoramentos de São Paulo", Prestes Maia considerava o zoneamento como o instrumento de estruturação e organização da cidade. Segundo sua análise, além do zoneamento espontâneo, fruto dos elementos étnicos, de classe social e de atividades, e do zoneamento que dividia a cidade nas zonas central, urbana, suburbana e rural, o zoneamento deveria se constituir:

1. Como construtivo e organizador, e não meramente proibitivo

2. Na construção do plano geral da cidade, a repartição desta em zonas se configuraria como elemento integrante e eficiente (Cogep, 1980, 28)

Nas "Normas de Urbanismo Geral", Prestes Maia expôs três aspectos visando ajustar o enfoque para:

1. Início do zoneamento sistemático

2. Escalonamento dos recuos dos edifícios nas artérias principais, procurandose também evitar as empenas cegas.

3. Através de diversas leis, fossem estabelecidas as normas urbanísticas para os bairros-jardim, avenida Paulista e Higienópolis, com a fixação das taxas de ocupação, dos usos, alturas e recuos das edificações. Prestes Maia denominou essas de "zoneamento contratual" (idem, 28, 59)

4. Restrições de altura dos edifícios, mais rígidas no Centro que nas bordas do Perímetro de Irradiação

5. Restrições a indústrias nos bairros centrais, onde o Brás foi destacado

6. Áreas industriais na margem direita do rio Tietê e na margem esquerda do rio Pinheiros e ao longo das ferrovias (que segundo o estudo do Perímetro de Irradiação, seriam transferidas para as margens desses rios)

7. Transferência de indústrias "nocivas" para núcleos afastados

8. Faixas e núcleos comerciais ao longo das avenidas radiais e nos seus pontos de convergência, nelas se localizando também zonas de habitação coletiva

9. Zonas de habitação individual entre esses setores, garantindo faixas de arejamento.

Esse conjunto de diretrizes propunha também que, próximo aos distritos industriais, deveriam se localizar as faixas de "residência de segunda classe", separadas das indústrias por um cinturão verde (ibidem, 28).

Muitas dessas normas foram incorporadas na consolidação do Código de Obras em 1934, mas como já observado, a Prefeitura não contava com meios eficientes para o cumprimento das mesmas, principalmente nas áreas mais afastadas do 


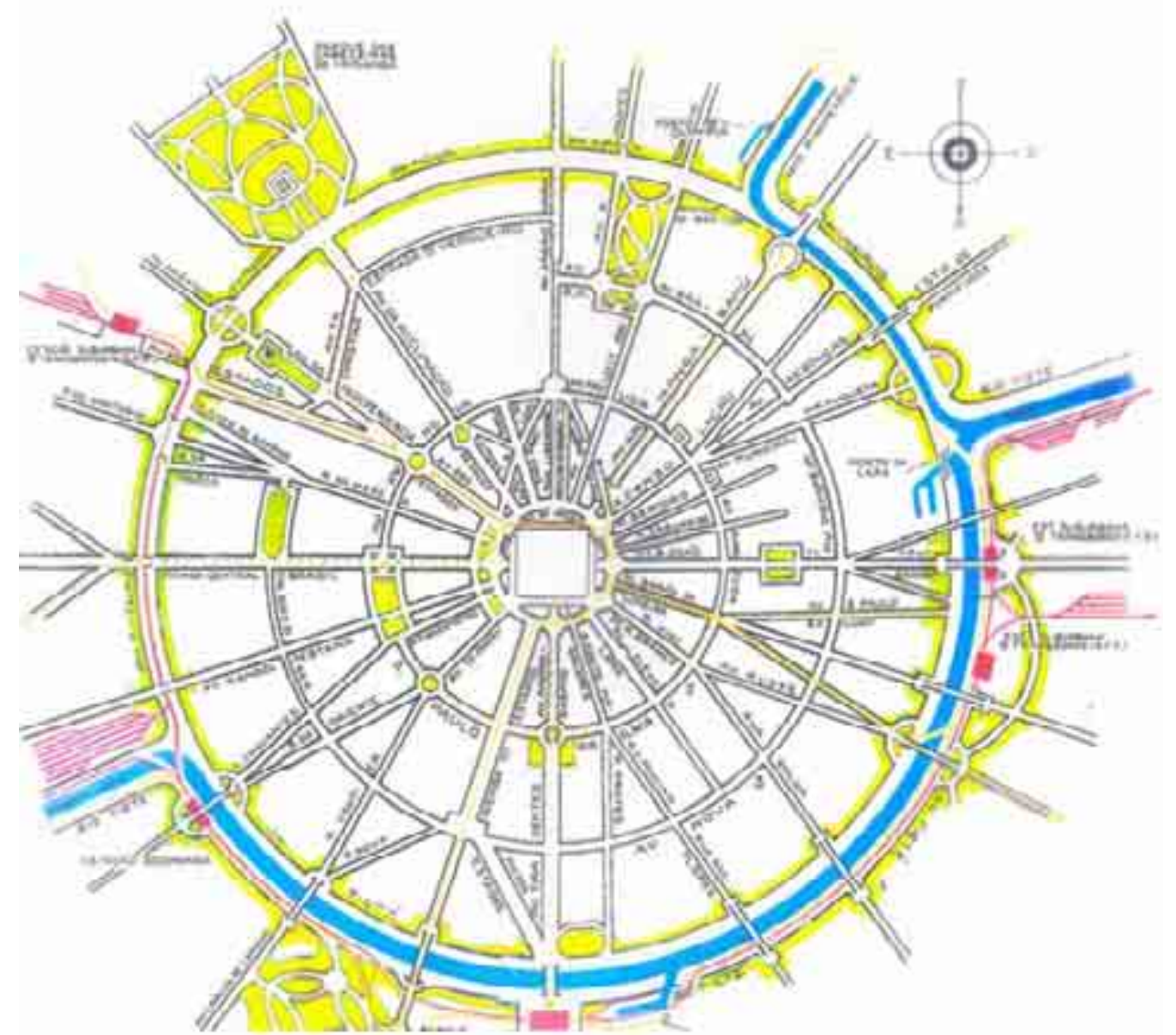

Fig 64 e 65 .

Acima: Esquema do Perímetro de Irradiação. Ao lado, Plano Geral dos Melhoramentos Centrais.

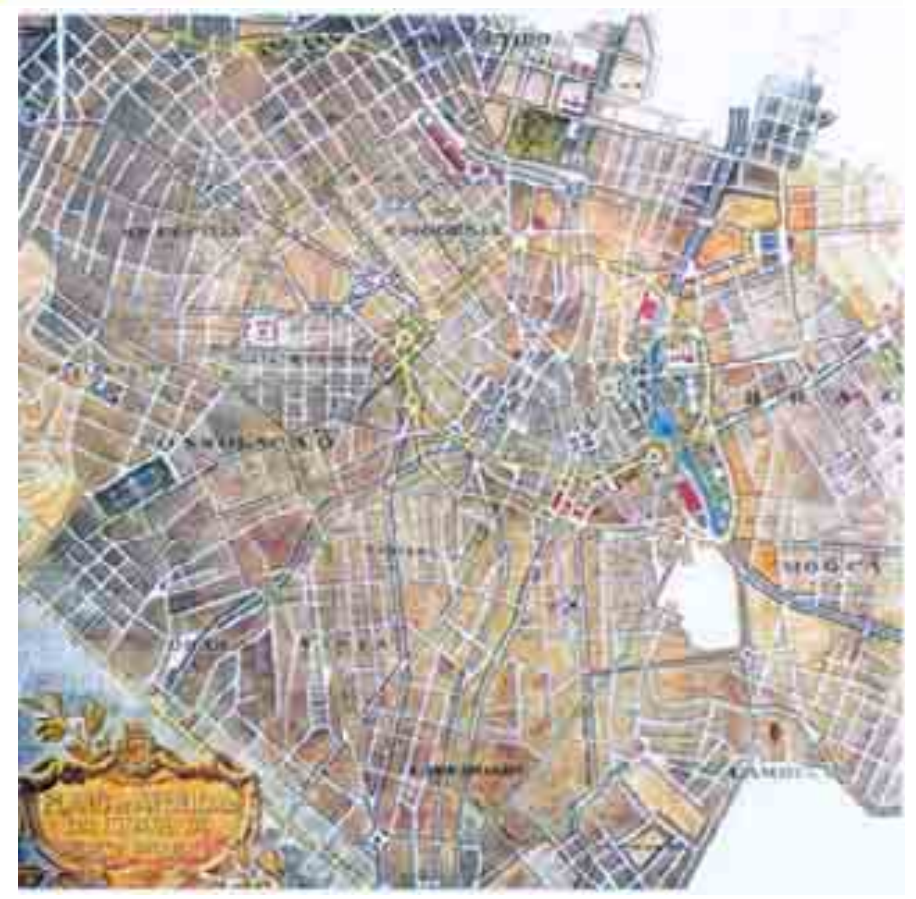


centro. Neste, por sua vez, os congestionamentos e conflitos entre o transporte público e o particular eram permanentes, propondo-se para tanto o Plano de Avenidas.

Esse Plano, lançado em 1930, foi implantado efetivamente em 1938 com Prestes Maia como prefeito, tendo sido concluída a sua primeira componente, a avenida Ipiranga, em 1941. Os problemas do congestionamento do núcleo central tiveram um peso relevante nas justificativas do Plano que, entretanto, tratou de viabilizar também as ligações intra-regionais através de vias radiais que interseccionavam o anel central de avenidas baseadas no "Perímetro de Irradiação" do urbanista Eugènne Henard ${ }^{3}$.

O "Perímetro de Irradiação" se constituiu na primeira proposta de âmbito mais abrangente para a expansão da área central da cidade e definiu a concepção do Plano de Avenidas. Esse plano influiu decisivamente na definição de limites dos bairros centrais, que passaram a se constituir um anel no entorno do núcleo central.

Centro, então limitado ao Triângulo, apresentava três grandes problemas, segundo a análise de Prestes Maia:

-Exiguidade de área

-Dificuldade de acesso

- Cruzamento de correntes externas

Prestes Maia destacava que um dos fatores mais preponderantes no congestionamento do núcleo central era o tráfego diametral, que o comunicava inutilmente a bairros e setores vizinhos, visto a dificuldade das ligações pelos vales e encostas que os separavam: "este tráfego de travessia, inútil ao centro, embora até certo ponto criador de ruas comerciais, é um dos fatores mais notáveis do congestionamento". Os alargamentos que então se faziam no Centro (1929), foram avaliados por Prestes Maia como paliativas e "meias-medidas" e nas suas palavras em relação aos mesmos: "alargamento das ruas 15, João Brícola, 3 de Dezembro, Anchieta, Álvares Penteado e das praças Antônio Prado, Tesouro, etc. Nestes empreendimentos, tem-se insistido demasiado e em pura perda. Podem por vezes apresentar interesse local, mas o seu alcance para a cidade é sempre insignificante ou nulo" (Maia, 1930, 34).

Entre várias citações dos planos para cidades da Europa e Estados Unidos, Prestes Maia utilizou dois exemplos que alicerçaram a argumentação do Plano, ambas utilizando o enfoque urbano-sanitarista. A primeira, a do Rio de Janeiro, em que a abertura da avenida Rio Branco foi assim comentada: "É o processo brutal do sventramento ${ }^{4}$ que requerem os centros extensos, compactos e insalubres. Viramno os napolitanos, após o cólera de 84, aplicado à parte baixa da sua cidade. 
Dela participou a avenida Rio Branco na capital do país, quando o conselheiro Rodrigues Aves resolveu transformar um conjunto de vielas e foco de epidemias numa cidade moderna e sã". Na segunda citação de planos para as cidades, Prestes Maia não se negou a comentar a proposta de Paris: "Outros, em São Paulo, desejariam arrasar tudo para reconstruir de novo, como Le Corbusier em Paris, onde prega avenidas de 200 metros com arranha-céus de 60 andares. Mas a solução de Le Corbusier, conquanto sugestiva e impressionante, é ainda livresca, ao menos para a época" (idem, 35).

Em função das características que o Centro apresentava então, o "Perímetro de Irradiação" foi tomado como a concepção urbanística adequada por definir um circuito fechado ou coletor em que "todas as vias de expansão e penetração convergem bem para o núcleo central, mas não todas para o mesmo ponto, nem para o mesmo monumento", como no caso dos planos de Berlin, Londres e Moscou. Utilizando-se dos "Études sur les transformations de Paris" de Eugènne Hénard, referendado também por estudos norte-americanos, explicitou o que se tornaria a idéia norteadora do Plano para São Paulo, definindo um núcleo central e anel de bairros no seu entorno:

"todas essas vias, ao contrário, ligam-se a uma espécie de circuito fechado ou coletor, que nos propomos chamar de Perímetro de Irradiação, e que é traçado a uma certa distância do centro matemático da cidade. Este perímetro representa um grande papel no plano das três capitais; é, por assim dizer, o regulador da circulação convergente, que atingiria a inextricável chãos se todas as vias concorressem à mesma praça. É ele que recebe as correntes afluentes e que as distribui em seguida, com auxílio das pequenas ruas secundárias, até o edifício ou a casa que é o escopo do movimento individual de cada elemento da circulação. Para que o perímetro de irradiação seja eficaz, é mister, que ele não contenha em um núcleo muito grande, todos os edifícios principiais, todos os pontos de atração da cidade, mas antes, que passe através do semeado irregular desses edifícios, deixando-os ora de um lado, ora de outro do seu percurso fechado" (ibidem, 35).

Mencionando o que seria a palavra de ordem do urbanismo moderno, "espalhar o movimento e a atividade, multiplicar os centros", Prestes Maia criticou o papel preponderante do velho Triângulo: "em São Paulo ainda persiste o prestígio provinciano do Triângulo. É tempo, de uma vez por todas de fazer-se-lhe justiça. A vida comercial, administrativa e mundana de um milhão de habitantes, onde se constroem aduções para uma população de dois milhões, evidentemente transbordará de uma área de 300 x 600 metros". Propugnando a forma anelar do Perímetro de Irradiação como capaz de produzir uma dilatação do centro, atraindo a circulação e o comércio, assim foram descritas as funções do Perímetro de Irradiação por Prestes Maia: 
1.Descentralizar a vida comercial e, assim, ampliar o centro

2.Desviar as correntes de passagem

3.Distribuir a circulação pelas ruas secundárias

4.Integrar no centro os setores segregados

5.Conservar-lhe o aspecto local, na medida do possível (Maia, op.cit, 46).

Abordando as áreas no entorno do núcleo tradicional, Prestes Maia avaliou que apenas uma reunia condições para a expansão do centro: "Realmente, das regiões cardeais, três são menos satisfatórias (pelas condições do relevo e outras) a esse desenvolvimento: Norte (Florêncio de Abreu), Este (Várzea do Carmo) e Sul (lombada da Liberdade e vale superior do Anhangabaú). O quarto, entretanto, apresenta as melhores condições. É o tabuleiro de Sta. Efigênia ou, melhor, toda a zona que se estende além do Anhangabaú, da Luz ao Arouche e mesmo á Consolação. Vasto, plano, com facilidades de comunicação em todas as direções (condição indispensável a um centro) e com facilidades de contato com o centro atual (condição para a transfusão da vida comercial), apresenta os requisitos necessários para constituir a principal zona de expansão do centro"(Maia, op cit, 53, grifo do autor).

Na seqüência, Prestes Maia descreve que os requisitos dessa área eram o seu sistema de ruas, que mesmo consideradas estreitas $(13,00$ e 16,00 m) e em xadrez um tanto rígido, era o mais satisfatório dentro de um raio limitado. Possuía ainda artérias de primeira classe, entre elas algumas diagonais: São João, Barão de Limeira, Arouche, Conceição, Timbiras, etc, além de diversas praças: Paissandú, República, Arouche, etc. Eram vizinhas à área as duas maiores estações da cidade: Luz e Sorocabana. $O$ vetor aludido ficou claramente escolhido como preferencial à expansão do Centro, conforme suas palavras: "detivemo-nos a seu respeito para tirar esta conclusão: cabe ao poder público preparar convenientemente a área e incrementar esse movimento, porque ele vai realizar em grande parte o fenômeno de descentralização de cuja necessidade nos capacitamos" (Maia, op. cit, 53, grifo do autor).

Discorrendo sobre o sistema viário complementar ao anel de avenidas em torno do Centro, que o Plano preconizava, Prestes Maia almejou uma hierarquia onde um conjunto de avenidas radiais principais se subdividiria em outras tantas secundárias, cumprindo o papel de atender o movimento centrífugo e centrípeto da população, do centro à periferia e vice-versa. Assim se referiu ao mencionálas: "que em regra é o sistema radial o mais conveniente e é justamente o que possui São Paulo. Cabe-nos torná-lo melhor e completá-lo, aproveitando quando possível as linhas mestras existentes". (Maia, op cit, 82, grifo do autor). 
Em relação ao conjunto da cidade, considerando a legislação vigente no período da proposição do "Perímetro de Irradiação", a Lei de Arruamentos de 1923, Prestes Maia analisou que faltava à cidade um plano de artérias principais, de modo a possibilitar à Prefeitura definir diretrizes de hierarquização viária conectada ao parcelamento e arruamento. A estruturação dessa rede viária principal articularia o necessário zoneamento das funções urbanas e critérios para a implantação das ruas, quadras e lotes segundo as diretrizes sanitaristas de melhor insolação, ventilação, adequação topográfica, etc. (Cogep, 1980, 28-29).

No Estudo para o Plano de Avenidas, foram assinaladas como não excedendo uma dezena, as radiais consideradas básicas, para as quais primeiro deveria ser dirigido o "cuidado do administrador": São João, Rio Branco, Tiradentes, Rangel Pestana, Central do Brasil, Estados, Liberdade, Itororó, Major Diogo, Anhangabaú, Consolação (Maia, 1930, 97). Tecendo considerações quanto às transformações que cada uma deveria sofrer, a fim de adequarem-se às exigências da nova estrutura, temos esse sistema nas seguintes vias principais e radiais secundárias, que efetivamente possibilitaram a expansão pretendida pelo plano:

\section{-Avenida São João}

Estabelecendo a ligação da Praça Antônio Prado à Lapa, uma avenida de 10 quilômetros prolongável até Osasco e Pirituba. O prolongamento da São João com a avenida Água Branca mereceria o mesmo tratamento de recuos a serem definidos por posturas municipais. Essa radial, que inclusive passaria a ser denominada avenida Colombo, também se constituiria uma alternativa para a interligação do sistema viário proposto com as linhas férreas (Centro-Lapa).

As alamedas Barão de Limeira e Nothmann foram consideradas radiais secundárias à São João - Água Branca, servindo o bairro dos Campos Elísios e articulando-se com a Timbiras, então em projeto para ser ampliada de rua a componente da rótula central do "Perímetro de Irradiação". Para a circulação no distrito de Santa Ifigênia e ampliação do centro, propunha-se entre outras ampliações, a da rua Visconde de Rio Branco, posteriormente avenida Rio Branco, que estabelecia a ligação do Centro com a avenida Rudge, no bairro da Barra Funda e também com o da Casa Verde.

\section{-Anhangabaú-Tiradentes}

Integrada à proposta para o Vale do Anhangabaú e para a "cidade nova às margens do Tietê", que fazia parte dos Melhoramentos de São Paulo. Assim, era prevista como via rápida até a Ponte Pequena e via semi-rápida até Santana. Era considerada a via mais espaçosa e portanto merecedora de "tratamento condigno". 
A radial secundária era a rua Anhangabaú, para a qual se preconizava um túnel sob a rua São Bento e uma ligação com a rua Oriente, ao leste, em função de uma eventual mudança do Pátio do Pari.

\section{-Rangel Pestana}

Considerada a principal radial do vetor leste, para a qual se preconizava o seu alargamento no sentido Belenzinho e a solução ao problema representado pela travessia em nível das ferrovias, juntamente ao Largo da Concórdia, que se constituía no centro comercial do Brás. Em igual situação se encontrava também a avenida do Gasômetro.

Como radiais secundárias, a rua Florêncio de Abreu e a Cantareira, esta servindo a região do então novo Mercado, dos armazéns do Pari e da zona atacadista da rua 25 de Março. $\bigcirc$ Estudo do Plano de Avenidas não considerou necessário o alargamento dessa via "confiando seu desafogo à avenida dos Estados (op.cit 102)".

\section{Avenida Central do Brasil}

Projeto de via semi-rápida que foi substituída pela atual avenida Alcântara Machado, ou Radial Leste, contando com as sub-radiais Bresser, Siqueira Bueno, Álvaro Ramos, Salles Leme e Tatuapé. A função dessa radial seria a de desafogar as avenidas Rangel Pestana-Celso Garcia, Visconde de Parnaíba e Moóca, cortando os bairros do Brás, Moóca, Tatuapé e Penha. No projeto original estava prevista uma largura de 60 metros, que receberia uma linha central de alta velocidade.

\section{Rua da Mooca}

Considerada principal pelas ligações e circulação, encontrava obstáculos para o alargamento devido a densidade das suas construções e o preço dos terrenos. No estudo inicial seria o início da avenida Central do Brasil e interligava-se com vias secundárias como a Oratório, duplicada até o Alto da Mooca pela avenida Paes de Barros, início da ligação com São Caetano e São Bernardo, já considerados subúrbios industriais.

\section{-Avenida da Independência}

Considerada sub-radial pela função viária, mas de grande importância pelo aspecto paisagístico e cenográfico, ligando-se ainda à avenida Nazareth.

\section{-Rua Conselheiro Furtado e Rua Glória}

Definidas como radiais por se ligarem ao Perímetro de Irradiação, servindo ao Cambucí e Aclimação. 


\section{-Liberdade}

O Estudo para o Plano de Avenidas considerava as ruas da Liberdade e Domingos de Moraes, prolongadas ao norte pela rua Florêncio de Abreu e avenida Tiradentes, a espinha dorsal da cidade, o que demonstrava ser feita até então a ligação norte-sul, pelo interior do Triângulo, buscando-se com isso, desviar esse fluxo através do Perímetro. Prestes Maia considerou ainda algumas componentes do sistema viário já existentes, que seriam classificadas com algumas diferenças em relação às artérias cuja execução constava do Plano. Dessa forma, essas vias poderiam fazer parte da categoria definitiva, de acordo com as necessidades de circulação, como por exemplo a avenida Angélica, as ruas Netto de Araújo e Lins de Vasconcelos, que de circuitos secundários passariam a circuitos de primeira classe (Maia, op. Cit, 117).

Para o setor oeste-sul-sudoeste da cidade foram dirigidas as obras da nova avenida Itororó, atual 23 de Maio, prolongamento da avenida Nove de Julho até a avenida cidade Jardim, dobrando sua largura ao atingir o Jardim América; alargamento da rua da Consolação e conexão com avenida Rebouças e Dr. Arnaldo e ainda o alargamento da rua Pedroso de Morais.

Para o setor norte-nordeste-leste da cidade foram dirigidas as obras da avenida Anhangabaú-Inferior, atual Prestes Maia, sendo o tronco do "sistema Y" e ligando a avenida Tiradentes ao Parque Anhangabaú (o plano original previa cruzamentos inferiores com a avenida Senador Queiroz e com a avenida São João); a avenida dos Estados, com um trecho inferior ligando o Parque D. Pedro II com o setor norte da cidade e o trecho superior ligando a região do $A B C$; alargamento da avenida Cruzeiro do Sul; transposição sob viadutos, ou passagem inferior para as linhas férreas que cruzavam em nível a avenida Rangel Pestana e finalmente, a avenida Leste, partindo do Parque D. Pedro II para a Vila Matilde. (Porto, 1992, 151).

As avenidas marginais do rio Tietê e Pinheiros também constavam do Plano, e sua execução só foi concluída na década de 1960, com muitas modificações de seu projeto original, que previa inclusive uma linha ferroviária na margem direita do Tietê, para ali se transferirem os trilhos que cortavam a cidade.

Em 1944 foi definido o alargamento da avenida Pedroso de Morais, que obedecia diretrizes da Cia. City e teria a função de interligar, através da avenida Rebouças, a marginal Tietê e a via Anhanguera. Também foi definida a avenida Sumaré, que interligava a Lapa ao espigão da Paulista e ao Araçá. Outras artérias propostas, cujas obras também se iniciaram nesse período foram a avenida Jaguaré, interligando a Lapa e Osasco, a ligação avenida Brasil e Sena Madureira. O alargamento da Avenida São João também foi concluído até o Largo de Perdizes (Padre Péricles), assim como o túnel da avenida Nove de Julho (Cogep, 1980, 55). 
Ao alterar a acessibilidade intra-urbana, diminuindo os tempos de deslocamento para o automóvel e os ônibus, o Plano consagrou o arranjo das localizações na cidade: os setores residenciais de alto padrão e seus serviços, os setores atacadistas, a moradia da classe média, o centro de negócios ampliado, os acessos às áreas industriais, os bairros populares próximos e os subúrbios, etc. Foram relacionadas a seguir duas observações que sintetizaram a importância que esse Plano teve para a cidade:

"A concepção de cidade, implícita nas propostas do Plano de Avenidas, de ocupação extensiva do solo estruturada por um sistema viário radial-perimetral, corresponde ao nível de estrutura urbana, por um lado, ao novo padrão de ocupação periférico da cidade e, por outro lado, garante uma integração mais eficiente entre os diferentes bairros e o centro da cidade. Prepara-se dessa forma uma estrutura urbana mais integrada e homogênea, condições necessárias à expansão do processo de industrialização que ocorrerá na próxima década" (Leme, 1999, 397)

"O novo sistema viário, projetado pelo engenheiro Francisco Prestes Maia, iria permitir a extensão da cidade em direção à periferia, ao mesmo tempo em que se priorizava o transporte através de automóveis e ônibus. A área sudoeste da cidade, privilegiada por maciços investimentos, foi particularmente beneficiada pelo Plano. A importância desse modelo na configuração da metrópole paulistana foi decisiva, dela resultando um centro verticalizado, adensado e a continuação de um padrão periférico que as linhas férreas já haviam definido e que a flexibilidade trazida pelo ônibus multiplicou" (Sampaio, (org), 1999, 22). 


\subsubsection{Relatório Moses}

Mesmo com a abertura das avenidas do Plano de Prestes Maia, os problemas que a cidade apresentava não se restringiam apenas ao sistema viário, como indicavam os vários trabalhos e participações técnicas dentro e fora de órgãos oficiais. Em 1950 a Prefeitura de São Paulo contratou o "IBEC-International Basic Economy Corporation", instituto de Nelson Rockfeller, para elaboração de um estudo para São Paulo, que abrangia: relatório sobre o planejamento de obras públicas e novos estudos daquelas necessárias, sistema de vias arteriais, transporte coletivo, sistemas de parques e praças, engenharia sanitária relativa à coleta de lixo e aterros, retificação do rio Tietê e zoneamento de suas várzeas a serem urbanizadas, plano de zoneamento para a cidade e métodos de financiamento de obras públicas (Leme, org, 1999, 398).

Esse Relatório, elaborado por uma equipe de especialistas norte-americanos foi dirigido por Robert Moses, urbanista responsável pela renovação urbana de Nova lorque no pós-guerra, que entre outras recomendações, descartou o sistema de transportes de massa sobre trilhos e prescreveu a revisão do Código Arthur Saboya para normatizar e redirecionar a concentração existente no Centro (Amadio, 1998, 60). Seus estudos resultaram em um conjunto de propostas onde três problemas iniciais foram considerados:

1. Falta de uma planta oficial atualizada, com todas as ruas e melhoramentos, já que a existente, o levantamento aerofotogramétrico SARA-Brasil, datava de 1929. Em decorrência disso, foi contratado o levantamento que resultou na planta do consórcio VASP- Cruzeiro do Sul, em 1954.

2. Ausência de um zoneamento que fixasse normas para utilização do solo e para a altura dos edifícios.

3. A ausência de um código de obras atualizado (Cogep, 1980, 93).

Fruto de uma legislação que datava ainda da década de 1930, a cidade era dividida em quatro zonas - central, urbana, suburbana e rural - e as prescrições existentes nesses perímetros eram apenas de diferenciação de usos (reservando as áreas exclusivamente residenciais), limitações de altura e ocupação das edificações dentro de cada zona. Segundo Moses, as normas necessárias para a cidade, constantes de um novo zoneamento urbano, deveriam ser dirigidas para:

- O estabelecimento de restrições à concentração de construções na área central, limitando-se também alturas e usos.

- Revisão e reunião dos dispositivos legais existentes que estabeleciam normas ao uso e ocupação do solo em áreas determinadas. 
- Definição do uso das construções, uma vez que na cidade se mesclavam indústrias ao lado de residências, edifícios ao lado de habitações unifamiliares e nas áreas mais distantes do centro, construções para qualquer finalidade.

O corpo normativo que o Relatório propôs para o zoneamento da cidade incluiu a subdivisão do uso do solo nas seguintes categorias:

- Indústria: tipos 11 e 12

- Comércio: tipos $\mathrm{C} 1$ e $\mathrm{C} 2$

- Residência: Ri, R2, R3, R4 (idem, 96)

Nessa subdivisão, a área central corresponderia à categoria de distrito $\mathrm{Cl}$, possibilitando residência, comércio e até indústrias leves. A altura das edificações e a área construída sofreriam reduções para a diminuição dos congestionamentos. No distrito $\mathrm{C} 2$, envolvendo $\circ \mathrm{Cl}$, seriam permitidos os mesmos usos além da presença de armazéns e depósitos.

Para a indústria, além do Relatório considerar a maior parte da cidade reservada aos distritos 11 e 12 , seguindo as áreas existentes e em expansão, propunha a limitação do crescimento industrial ao leste e para a descentralização dessas

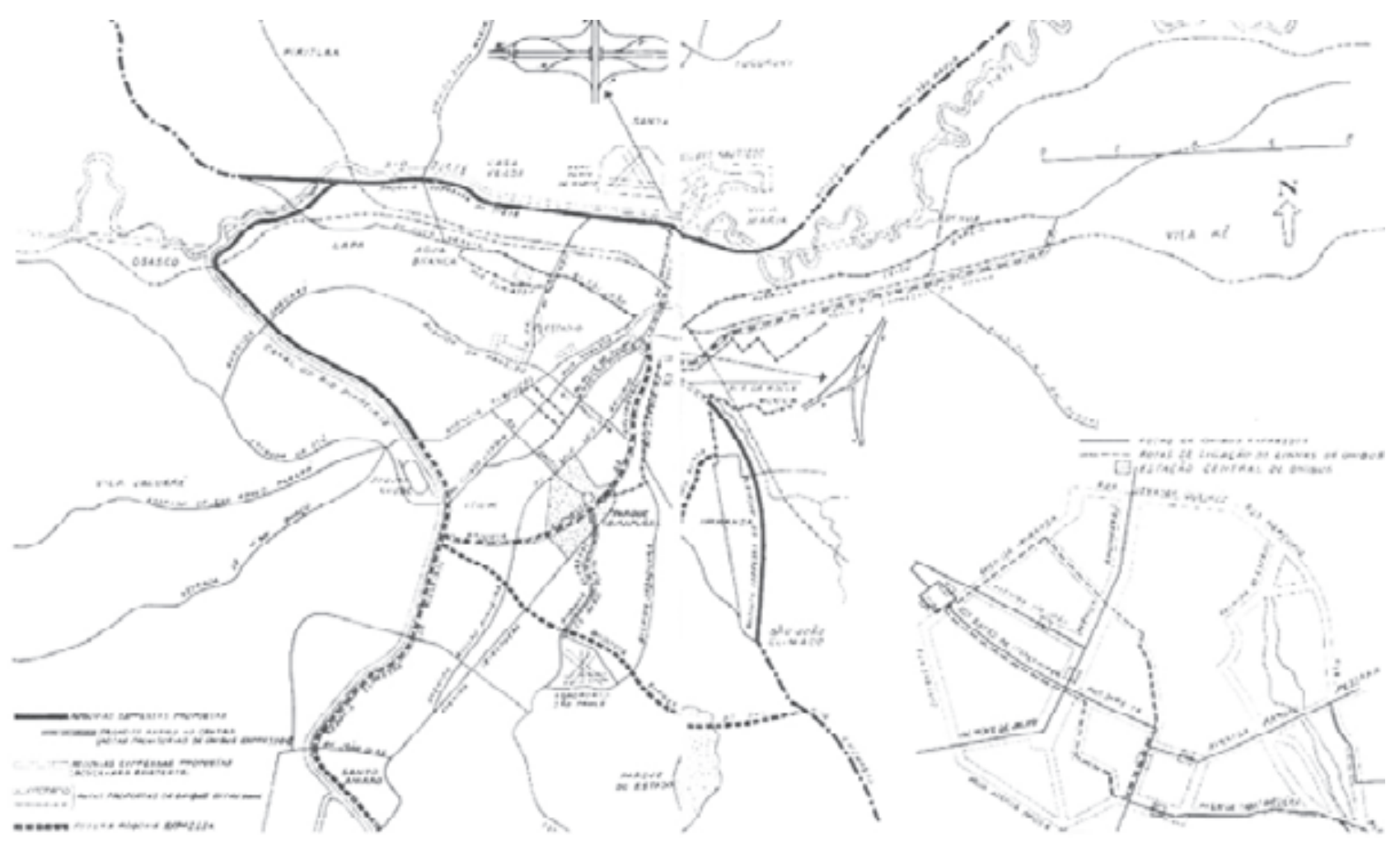

Fig. 66: Sistema viário proposta pelo Relatório Moses 
atividades e maior facilidade para o transporte de operários, a recomendação de uso industrial para as vizinhanças do canal do rio Pinheiros. Sobre as zonas industriais, o Relatório não considerava possível a transferência de parte das vias férreas para a margem direita do rio Tietê, argumentando, além dos custos dessa transferência, as conseqüências que a a mesma poderia acarretar nas áreas industriais existentes.

As zonas de habitação foram propostas como R2 e R3, exclusivamente residenciais, com R1 permitindo uso misto juntamente com comércio e indústrias leves, mas seguindo uma restrição à expansão desses usos caso uma zona se mostrasse mais residencial, isto é, propondo uma transformação de R1 para R2 ou R3. Na R4, a gama de usos era maior, apenas não se admitindo indústrias pesadas ou nocivas, mas transferindo para uma futura revisão, a adoção de parâmetros mais detalhados (Cogep, 1980, 96, 97).

$\mathrm{Na}$ prática, assim como as categorias $\mathrm{C} 1$ e C2 abrangiam quase todas as atividades já existentes no centro e bairros centrais, o mesmo acontecia com as demais, tanto para indústria, como para o uso residencial. À parte a ausência de um levantamento cadastral atualizado para a elaboração desse trabalho, as recomendações para o zoneamento constantes no relatório Moses foram consideradas genéricas e superficiais, tais como a reserva de áreas para parques e sistema viário precedendo a definição de zonas (Cogep, 1980, 97). Segundo ainda a sua equipe de consultores, essa proposta de zoneamento deveria tomar como base e ajuda para a redação do seu decreto de regulamentação, o zoneamento de Nova lorque (Leme, 1999, 398).

A influência das concepções norte-americanas foram visiveis também nas recomendações e propostas visando preparar a cidade para o aumento do número de automóveis, através da ampliação dos espaços para estacionamentos privados nas construções, ainda que unifamiliares e o estabelecimento da tarifação de estacionamento na área central.

outro aspecto, relativo aos transportes, foi que mesmo considerando as vantagens de um sistema radial sobre trilhos na solução dos problemas dos transportes coletivos, essa solução foi preterida, dando lugar a recomendações de melhoria do sistema de ônibus (que incluía a compra de 500 veículos) e construção de vias expressas, sob alegação dos altos custos envolvendo o transporte baseado no metrô. Algumas das radiais propostas incluíram a reserva de faixas para um sistema rápido de transporte, que no início seria baseada nos ônibus que posteriormente poderiam ser substituídos por trilhos (idem, 1980, 99).

As vias arteriais consideradas prioritárias pelo Relatório Moses foram:

- Ligação, através de via expressa na marginal do rio Tietê, das rodovias Anhanguera e Dutra 
- Ligação da zona sul com a via Anhanguera através da marginal do rio Pinheiros

- Ligação norte-sul através do prolongamento da avenida Tiradentes na direção da Itororó (23 de Maio), com faixa para transporte rápido.

- Ligação do anel central com a via Anchieta através da avenida dos Estados

- Via expressa para a Penha, correndo paralela aos trilhos da ferrovia, dispondo também de faixa reservada para transporte rápido.

Como se percebe, várias dessas vias já faziam parte daquelas propostas no Plano de Avenidas, o que juntamente com recomendações relativas ao Código de Obras, zoneamento industrial, exigências para estacionamentos e limitações para construções, se encontravam também em estudos nos órgãos de planejamento da Prefeitura (idem, 99,100).

Apesar das observações que numerosos autores fazem em relação a esse Relatório, considera-se que esse estudo teve um papel estratégico na época de sua elaboração, dado o impasse existente causado pelo fato do planejamento urbano em São Paulo ser disputado pelas correntes lideradas por Anhaia Melo e Prestes Maia, uma disputa entre o controle da expansão da cidade de um lado, que incluía até a proibição de instalação de novas indústrias e de outro lado, a expansão contínua da cidade (Leme, 1999, 399). As críticas se direcionaram à superficialidade das propostas que o Relatório incluiv, ao fato de muitas se basearem na experiência norte-americana e principalmente ao fato de suas recomendações negarem o transporte estrutural sobre trilhos, o que já era reivindicado e postergado desde o Plano Light, de 1927. 


\subsubsection{Estudos para Segunda Perimetral, Metrô e proposta de Plano Diretor}

Outro estudo que estava sendo desenvolvido desde 1953 era o da conclusão do projeto da Segunda Perimetral, confiado a Prestes Maia. Nesse trabalho, a ênfase viária era novamente justificada pela necessidade de ampliação das avenidas do "Perímetro de Irradiação", construídas entre 1938 e 1948 quando o próprio Prestes Maia era prefeito. Visava a ampliação do anel central de avenidas através de um outro circuito exterior, que se integraria às vias marginais aos rios Tietê e Pinheiros, também em projeto (Cogep, 1980, 117 ).

Parte dessa nova componente viária já havia sido iniciada ainda sob a gestão de Prestes Maia, que foi o alargamento da avenida Duque de Caxias, com a aprovação do projeto da avenida Amaral Gurgel, ambas se configurando como ruas locais, antes dessa intervenção. Constavam ainda o alargamento das ruas Pedroso e Tamandaré, para acesso à várzea do Glicério e das ruas Piratininga, Monsenhor de Andrade ou Bresser, interligando-as com a rua João Teodoro, na área Brás - Pari (idem, 115).

Outro aspecto levado em conta pelo plano era o da eliminação dos obstáculos causados pelas linhas férreas, que ao contrário do que o Relatório Moses propunha, eram deslocadas para a margem do rio Tietê, segundo a proposta original de Prestes Maia, desaparecendo dessa forma as barreiras dos trilhos nos bairros do Brás, Belém, Moóca, Penha, etc. (ibidem, 117).

Diferentemente da ligação diametral Norte-Sul proporcionada pelo sistema "Y", implantado no Plano de Avenidas, a diametral Leste-Oeste se revestia de especial importância nesse plano, uma vez que a travessia entre as avenidas São João e Rangel Pestana era dificultada pela passagem através das vias do Centro Velho (op. cit, 117).

Em 1955, o mesmo Prestes Maia foi nomeado presidente da comissão para elaboração de um projeto de Metrô. Esse grupo propôs que, antes mesmo da construção desse modo de transporte, fossem concluídas as avenidas definidas pelo Plano de 1930 e presentes também no projeto da Segunda Perimetral. As direções do Metrô seriam coincidentes com as das novas vias, que incluiriam faixas exclusivas para a posterior implantação de trilhos (como o Relatório Moses também propôs), e seriam voltadas inicialmente para o sul, norte e leste, para posteriormente, outras três linhas alcançarem o oeste, o sudeste e o sudoeste. Essa implantação implicaria na maior parte das linhas ser em superfície ou aérea, havendo pouca extensão em nível subterrâneo (Osello, 1983, 201).

Tanto a proposta da Segunda Perimetral quanto a do Metrô não se concretizaram, sendo que a perimetral leste-oeste foi concluída apenas em fins da década de 1960, parte através de via elevada e passagem sob a Praça Roosevelt, com 
grandes perdas para o ambiente urbano e funcionando fundamentalmente como corredor de tráfego para automóveis, como será visto adiante.

Em relação ao estudo para implantação do Metrô, este teve seu projeto abandonado pelo poder público e também sofreu críticas por parte de técnicos com afinidades às idéias de Anhaia Melo. Em sua análise desse projeto, Gomes Cardin enumerou os pontos negativos de sua concepção, considerando ser um projeto concentrador, já que se apoiava numa rede rádio-concêntrica, induzindo a um maior adensamento de atividades na área central. Para esse técnico do Departamento de Urbanismo, o controle do uso do solo deveria preceder as obras, sendo anuladas as futuras vantagens do Metrô devido ao adensamento que poderia induzir (idem, 201)

As diferenças profundas entre a concepção urbanística de Anhaia Melo e a de Prestes Maia ficam explícitas nesse período: o primeiro buscava no planejamento um controle sobre a iniciativa privada e o crescimento caótico da cidade e o segundo, uma afirmação da obra pública como solução para os problemas urbanos, sendo necessário para tanto um planejamento técnico e pragmático (ibidem, 190,193).

Em contraposição aos planos viários preconizados por Prestes Maia, a concepção defendida pelos técnicos do Departamento de Urbanismo, como o engenheiroarquiteto Carlos Lodi, pautava-se por um planejamento estruturado em três eixos de atuação:

- Ser abrangente, envolvendo todos os aspectos urbanos, integrando aqueles de ordem jurídica, financeiras, administrativas, técnicas e sociais.

- Se constituir em rumo, uma formulação diretiva que subordine as atuações técnicas específicas.

- Ser flexível, adaptável às transformações urbanas, constituindo-se em um processo contínuo associado às políticas administrativas (Feldman, 1996, 48).

Deve ser considerado que as propostas para o Plano Diretor de 1954 constituíram um rol de análises e propostas com continuidade dentro do Departamento de Planejamento da prefeitura, que após incorporar as pesquisas realizadas no final da década de 1950, foram apresentadas na década seguinte novamente como proposta de Plano Diretor. Com relação ao projeto de Segunda Perimetral, que posteriormente foi denominada Contra-Rótula, não foi concluída na sua totalidade e também mostra a significativa distância entre um planejamento urbano voltado ao controle do crescimento urbano, como Anhaia Melo preconizava e a ênfase viária presente nos planos de Prestes Maia, que inclusive vinculou o trajeto do Metrô ao traçado das avenidas. Este modo de transporte, cujo projeto e execução por diversas vezes foram adiados sob a alegação dos altos custos envolvidos em sua implantação, foi preterido em relação à expansão 
viária, e só foi inaugurado vinte anos depois, em 1974, com o funcionamento da linha Norte-Sul.

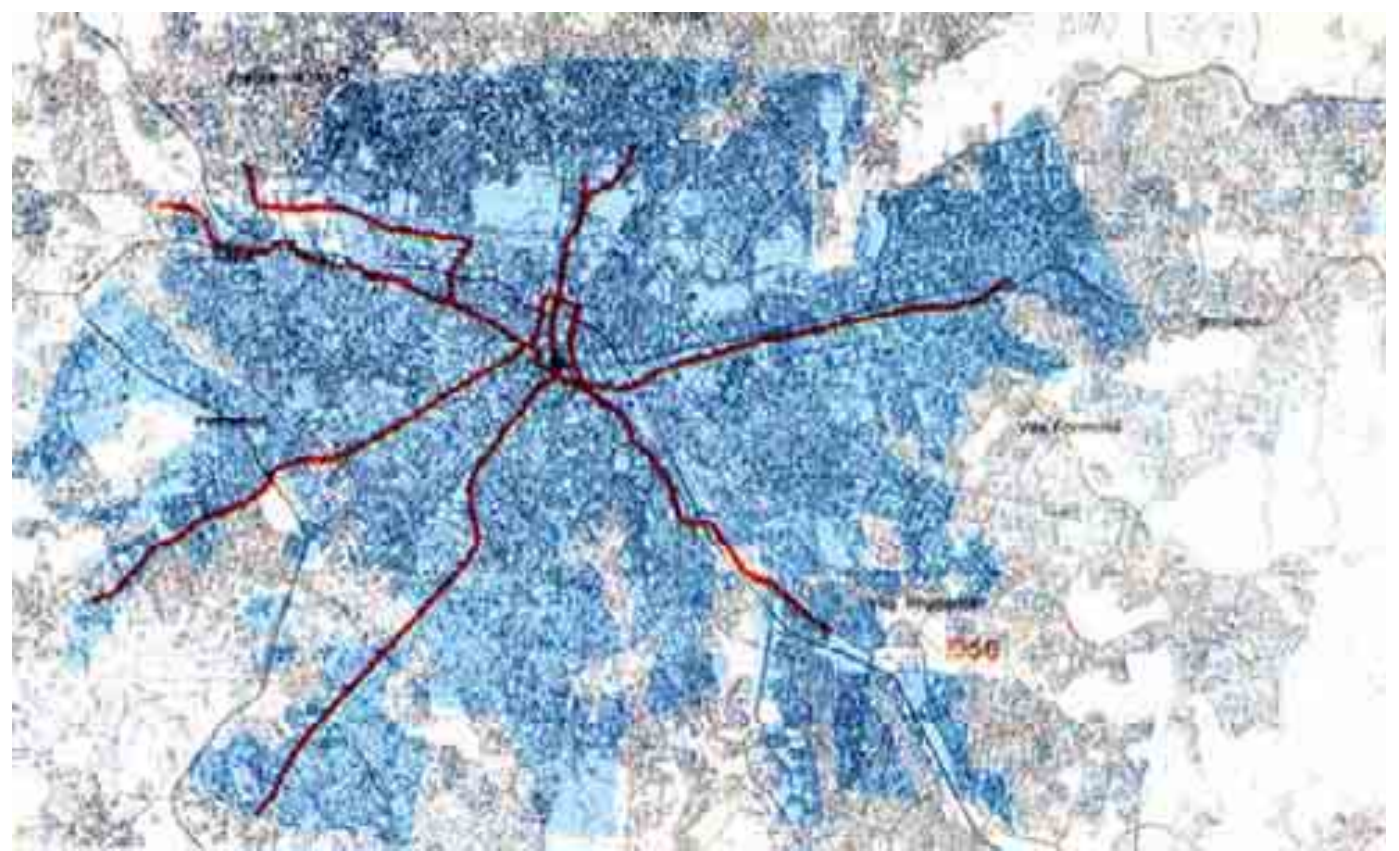

Fig. 67 : Proposta de Prestes Maia para o metrô de São Paulo, 1955.

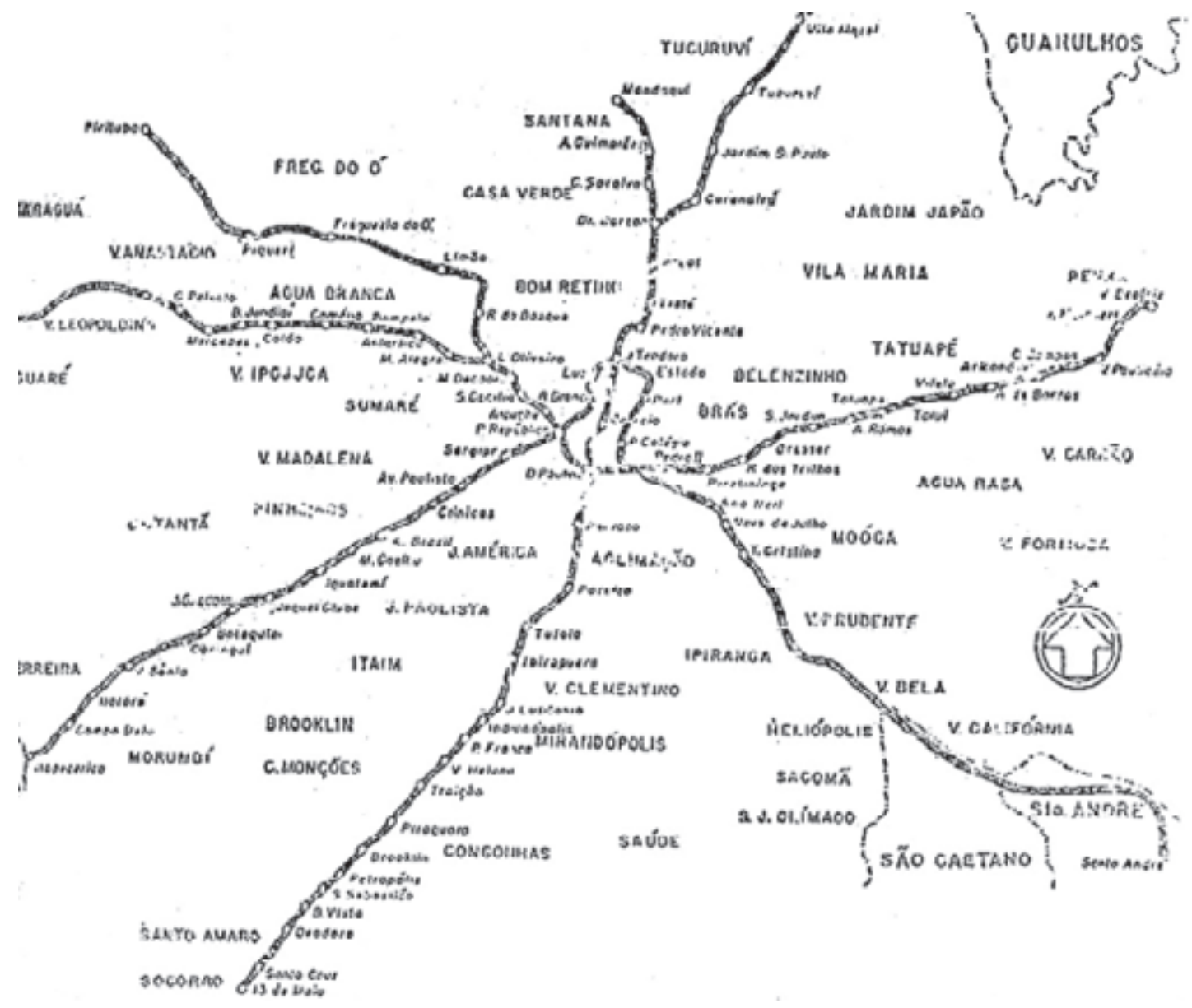

Fig. 68 : Esquema das linhas da propostade metrô de Prestes Maia. 


\subsubsection{Estrutura Urbana da Aglomeração Paulistana - SAGMACS e Relatório Planejamento}

Foram reunidos nesta última abordagem sobre o urbanismo na década de 1950, dois trabalhos, consubstanciados em relatórios, que seguiram a linha da descentralização urbana de São Paulo, como encaminhamento de soluções aos problemas existentes. As pesquisas da SAGMACS, iniciadas em 1956 se mostraram qualitativamente diferenciadas dos trabalhos anteriores, e além de serem aproveitadas para as análises e diagnósticos do projeto de plano diretor apresentado em 1961, serviram para referenciar os planos posteriores e estabeleceram uma nova compreensão dos problemas urbanos de São Paulo, malgrado não terem se convertido concretamente em planos aplicados.

Em 1956 a Prefeitura de São Paulo contratou a Sociedade para Análise Gráfica e Mecanográfica Aplicadas aos Complexos Sociais - SAGMACS ${ }^{5}$ para realização de pesquisa em conjunto com a Comissão de Pesquisa Urbana, vinculada ao Departamento de Urbanismo. Este incorporou a pesquisa da SAGMACS na publicação de seus trabalhos realizados entre 1957 e 1961, que se consubstanciaria no relatório denominado Planejamento, apresentado ao governo do estado nesse último ano (Feldman, 1996; Leme, 1999).

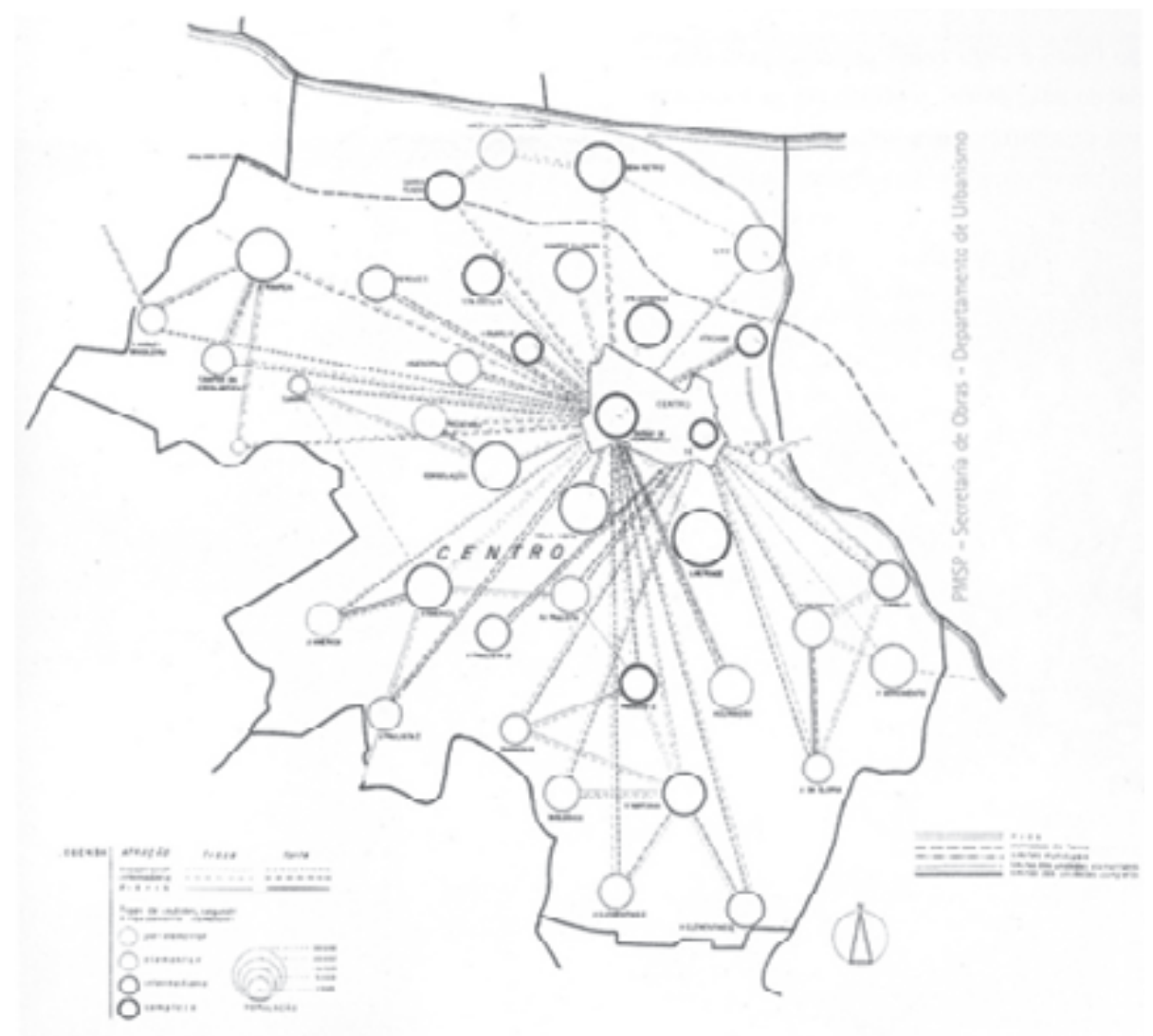

Fig. 69: Estudo SAGMACS: Polos regionais 
Apesar das diferenças entre as propostas do Departamento de Urbanismo de 1961 e as que constaram do relatório da SAGMACS, o estudo aprofundado da estrutura sócio-econômica da cidade serviu de base às recomendações de multipolarização da cidade, fundamentada na reorganização do uso do solo para descentralizar suas atividades, a distribuição de zonas industriais, subcentros e zonas residenciais, como forma de reduzir o excessivo fluxo para a área central e seus bairros mais próximos (Cogep, 1980, 153).

A análise da estrutura urbana levou em conta uma setorização do território para obtenção de conjuntos relativamente homogêneos da população, formulando a hipótese de que a vida coletiva da população se organizava em três unidades:

- a Elementar, baseada em uma setorização que considerava os limites naturais e construídos num raio máximo de $2 \mathrm{Km}$ e população de 1000 habitantes. Essa seria a escala onde as necessidades cotidianas da população deveriam ser satisfeitas.

- a Complexa, que agregava várias unidades elementares e corresponderia a um diâmetro de $3 \mathrm{Km}$.

- a Completa, que agregava um conjunto de unidades elementares e complexas, constituindo um território com certa auto-suficiência e contendo também uma unidade Polar, representada por um sub-centro secundário. Essa escala foi delimitada a partir dos equipamentos comerciais, de serviços e sociais.

A análise da estrutura urbana da cidade definiu também três regiões:

- a região central, que formava o núcleo mais concentrado de comércio e serviços

- a região externa ou periférica, com maior atração do sub-centro regional que o centro principal

- a região de transição, no entorno da região central, com certa autonomia, mas dependente da central para finalidades específicas (idem, 153).

Através dos levantamentos dos equipamentos e serviços, o trabalho da SAGMACS consolidou, dentro do planejamento, a idéia de que as condições de moradia e falta de equipamentos e infra-estrutura da já extensa periferia da cidade, se constituíam em um problema urbano prioritário. Identificou a especulação imobiliária como responsável pelo crescimento desprovido de infra-estrutura, com grande sub-aproveitamento do solo, problemas que evidenciavam a ausência de urbanismo metropolitano e de descentralização administrativa (Osello, 1983, $211,212)$.

No que se refere à recomendações incluídas na parte conclusiva do relatório, a centralização da cidade foi analisada como tendo atingido o seu limite máximo 
de saturação econômica e física, e as artérias projetadas da Segunda Perimetral junto com a proposta de Metrô poderiam congestioná-lo mais ainda. Segundo a SAGMACS, a característica monopolar da cidade necessitava ser alterada mediante:

- a transformação da sua aglomeração em multipolar, através do desenvolvimento de subcentros em cada unidade completa, da mesma forma que uma cidade média.

- uma necessária organicidade entre unidades de várias escalas, sem o que a multipolaridade não seria suficiente para a alteração da estrutura presente. Essa organicidade, que moldaria uma nova concepção de zoneamento diferenciada daquela com finalidades funcionalistas, estaria baseada numa escala que partia do loteamento, a sua agregação em uma unidade elementar, a agregação delas em uma unidade complexa, o conjunto dessas que constituiriam uma unidade completa e estas as unidades municipal e supra-municipal.

- o estabelecimento de uma rede viária fundamentada na estrutura multipolar, que partiria de um anel externo, constituído pelas avenidas marginais, com estações rodoviárias ao longo das mesmas que interconectariam subcentros regionais também dispostos nas proximidades das mesmas. Além de defender a proposta do Departamento de Urbanismo para essas vias, o Relatório procurou inverter o fluxo irradiador da centralidade, através da idéia de uma nova acessibilidade à extremidade da área central consolidada. Esse Relatório previa ainda a necessidade de ligações entre esses subcentros e a adoção de um sistema metropolitano interligado aos outros modos de transporte, rodoviário e ferroviário, necessário para uma aglomeração suportar mais de 10 milhões de habitantes (Cogep, 1980,157).

- Como proposta para descentralizar a excessiva concentração representada pela monopolaridade, o relatório propôs também a criação de um novo centro que seria desenvolvido em São Mateus, onde havia área disponível para tanto. Esse novo núcleo suportaria uma população de 200 a 300 mil habitantes e foi concebido para desempenhar estrategicamente as funções de capital política e econômica, superando a escala da aglomeração (idem, 158).

\section{Relatório do Departamento de Planejamento}

Elaborado após o Relatório da SAGMACS, o relatório do Departamento de Planejamento, de 1961, sintetizou as propostas que esse órgão desenvolvia e defendia para o Plano Diretor, incorporando a linha defendida por Anhaia Melo e pela SAGMACS, de descentralização da cidade. Fundamentava-se nas pesquisas desenvolvidas pelo próprio Departamento e pela SAGMACS, que resultaram 
em um complexo conjunto de coleta, análise e interpretação de dados sobre os variados aspectos da vida urbana. Estava estruturado em:

- Planejamento da circulação e transporte através de planos viário, rodoviário e ferroviário.

- Legislação para o uso e ocupação do solo visando a estruturação dos aspectos relacionados à vida e trabalho da população.

- Descentralização da administração pública, com nova estrutura dos órgãos de planejamento (ibidem, 166).

Com relação à estrutura de circulação e transportes, o plano viário desse relatório partiu de uma crítica ao sistema rádio-concêntrico da cidade através da transformação do sistema radial-perimetral, implantado pelo Plano de Avenidas, em uma nova estrutura diagonal-perimetral, baseado em diametrais expressas, vias principais e locais, criando uma divisão urbana baseada em bolsões de grande ou pequena extensão. Das quatro principais componentes, apenas duas diferiam das propostas por Prestes Maia: a diagonal norte-sudeste, através da ligação entre as avenidas Cruzeiro do Sul e dos Estados e a diagonal sul-leste, composta pelas avenidas Radial Leste e Itororó, ambas projetadas e a serem construídas. $\bigcirc$ anel rodoviário proposto pelo relatório Planejamento equivalia à terceira perimetral, do plano de Prestes Maia e a diagonal norte-sul era formada pelas avenidas Anhangabaú (Prestes Maia)-Tiradentes e Nove de Julho, ambas existentes no período (Cogep, 1983, 165; Osello, 1983, 218).

A ligação sul-leste se constituiu na principal obra desse plano para o centro da cidade, uma vez que transformaria o sistema " $Y$ " existente, em um " $\mathrm{H}$ ", através da ligação por um túnel sob a Liberdade, das duas avenidas projetadas. Essa obra se encarregaria também de descongestionar a perimetral do Plano de Avenidas (atual Rótula), ao absorver parte do fluxo que se dirigia ao Brás através das Praças João Mendes e Clóvis Bevilácqua, para atingir a avenida Rangel Pestana. A ligação entre as avenidas Cruzeiro do Sul e Estados seria uma via paralela a Tiradentes-Anhangabaú, passando ao leste da área central e interligando a zona norte ao Brás, Ipiranga e as cidades industriais do $A B C$ (Cogep, op. cit, 167)

Apesar de ter proposto um conceito diverso do existente, o plano viário do Relatório "Planejamento" absorveu os projetos existentes de administrações anteriores, constituindo, segundo Feldman, uma "continuidade à adequação da cidade ao sistema sobre rodas iniciado por Prestes Maia". Segundo a autora, as vias propostas se restringiam ao sistema viário principal, não alcançando as áreas mais distantes desprovidas de acessibilidade e suas melhorias viárias e as ligações intra-bairros não se concretizaram (Feldman, 1996, 61). 
Na mesma direção, Osello analisou que a nova estrutura viária poucos resultados acarretaria para a pretendida descentralização, pois não se diferenciava da estrutura radial que a cidade possuía. Um exemplo é a diagonal sul-leste proposta, em que o traçado da Segunda Perimetral defendido por Prestes Maia também possibilitava a mesma ligação, desafogando a perimetral existente e evitando uma obra de alto custo representada pelo túnel projetado (Osello, 1983, 218).

A nova estruturação urbana, compatibilizada com a dos bairros, e onde a vida local se desenvolveria, seria resultante da malha viária composta de vias expressas e as principais locais, consideradas "precintos viários", ou seja, ligação entre uma hierarquia e outra (Cogep, op. cit, 171).

No interior dos 27 distritos que seriam formados por essa malha, os instrumentos normativos presentes no novo zoneamento, estariam voltados à compactação da cidade através de parâmetros de densidade, à formação e desenvolvimento de núcleos distritais compostos por comércio, serviços e equipamentos e à adequação das localizações industriais. Mesmo com a tendência já existente de expansão das atividades centrais para o vetor sudoeste, o relatório "Planejamento" propunha também a criação de um novo centro, que diferentemente do relatório da SAGMACS, se localizaria ao norte do núcleo central (Osello, op. cit, 220; Cogep, op.cit, 173), idéia que teria continuidade no Plano Urbanístico Básico PUB, de 1968.

Em relação à legislação de uso do solo propriamente dita, foram incluídas nesse relatório leis já existentes, que incidiam sobre:

- a classificação das atividades urbanas, dividindo a cidade em cinco tipos de zonas: industriais, predominantemente residenciais, exclusivamente residenciais, mistas e central (lei 4805/1955).

- os coeficientes de aproveitamento para edifícios residenciais e comerciais (lei $5261 / 1957)$

- a regulamentação dos bairros da Cia. City, Pacaembú e Pacaembuzinho (Lei 4792/1955) (Feldman, 1996, 64, 105).

No que se refere às propostas mais gerais contidas no Relatório, voltadas à descentralização da cidade, no período seguinte as mesmas sofreriam críticas sobre sua eficácia, uma vez que a ênfase viária e nas obras urbanas se tornariam novamente predominantes com a volta de Prestes Maia à prefeitura após 1961. À proposição das unidades de vizinhança, ele contrapôs o raciocínio de serem divisões fictícias, uma vez que a mobilidade da população ocorreria devido às condições sociais, profissionais e culturais presentes. Ainda segundo Prestes Maia, a rede viária principal subordinaria outras medidas urbanísticas necessárias para a cidade e o verdadeiro problema urbano não se configurava na falta de planejamento, mas no grande atraso das obras necessárias para São Paulo, isto é, na atualização de sua infra-estrutura (Osello, 1983, 222). 


\subsection{A expansão da área urbanizada e novos elementos viários}

Os trabalhos de Meyer, Saia e Petrone sobre a expansão urbana que ocorreu na cidade mostram que o processo de metropolização em curso implicou na mudança de escala da aglomeração, que como já visto, rompeu uma estruturação que se apresentava até fins da década de 1930 muito mais concentrada. Meyer analisou essa dinâmica relacionando o crescimento em extensão das faixas residenciais e industrias na periferia, a compactação acompanhada pela verticalização da área central e mais tarde nas áreas do entorno do centro e a construção da rede rodoviária complementando o sistema ferroviário, como os principais elementos presentes nesse processo (Meyer, 1991, 17).

Por sua vez, Saia abordou a expansão que a cidade sofreu, referindo-se ao que denominou ter se constituído um crime urbanístico o crescimento ocorrido, dos $130 \mathrm{~km}^{2}$, que a cidade ocupava em 1930, para $420 \mathrm{~km}^{2}$ em 1954, expansão essa que foi dirigida pelo setor imobiliário sem qualquer diretriz ou disciplina urbanística (Saia, 1978, 237).

Em sua análise sobre o crescimento da área urbanizada no período 1925-1950, Petrone indicou a importância dos elementos de infra-estrutura como indutores da ocupação de setores da cidade:

1. Ao Norte, as obras de drenagem e retificação parcial do rio Tietê, aliadas à ferrovia da Cantareira, com seus ramais na direção do Tremembé e do município de Guarulhos.

2. A Oeste, através da ocupação da faixa entre a ferrovia e a radial Água Branca, favorecendo a ligação com a Lapa e da ocupação dos espaços atualmente ocupados pelos bairros ao sul da rua Guaicurus.

3. A Leste, seguindo os trilhos da antiga Central do Brasil e ao longo da radial Celso Garcia, espaços onde se multiplicaram os bairros populares. Segundo o autor, essa ocupação se deveu ao crescimento do Brás, que expandiu a cidade à distância de 10 quilômetros do centro.

4. Igualmente para o Sudeste, a ferrovia foi a responsável pela expansão, interligando a área central da cidade ao bairro do lpiranga , com desdobramentos na direção do $A B C$. Petrone analisou que a característica principal dessa expansão não foi a distância alcançada, mas sua rapidez, uma vez que o perfil da ocupação foi de bairros proletários.

5. Ao Sul, a interligação da cidade com o núcleo de Santo Amaro representou a maior distância da expansão, devendo-se ao transporte por bondes, às rodovias e à construção das represas da Light. Nessa região, apesar do surgimento de bairros residenciais de classe média, estabelecimentos industriais também se 
instalaram, "estendendo a influência da cidade até um raio de mais de 15 quilômetros", segundo o autor.

6. Finalmente ao Sudoeste, que teve sua expansão diferenciada dos outros vetores, onde não foram determinantes as indústrias ou sistema viário. Imputou-se ao ocorrido nessa área, os melhoramentos desenvolvidos na várzea do rio Pinheiros, que transformaram os terrenos imprestáveis, como no caso dos bairros-jardim América e Europa, ou muito acidentados, como no caso do Pacaembu, locais onde foram se instalar bairros residenciais de alta renda. Segundo a análise "e assim tinha de acontecer, pois as despesas realizadas com aqueles melhoramentos só poderiam elevar os custo dos terrenos, ocasionando uma natural seleção no que se refere aos seus habitantes". Prosseguindo na abordagem, essa ocupação de alta renda ligou-se àquela em direção ao Sul, preenchendo os vazios entre as mesmas, apesar de um ritmo mais lento em direção ao velho núcleo de Pinheiros (Petrone apud Azevedo, 1958, 148-149).

Foram consideradas ainda nessa análise, três elementos que possibilitaram a intensificação da ocupação urbana, em todos os quadrantes da cidade: a retificação dos rios Tietê e Pinheiros, com a conseqüente drenagem de suas várzeas, a abertura das avenidas do Plano de Prestes Maia e a construção de rodovias. Estas, no período já próximo à década de 1960, cresceram de importância e equipararam-se às ferrovias, no tocante à indução da ocupação urbana (idem, 149).

Assim é que, com exceção do crescimento para o Norte, onde a Serra da Cantareira se constituía em obstáculo naquele período, todos os outros quadrantes associaram um dos modos de transporte, ferrovia ou rodovia, ou mesmo, os dois. Ainda seguindo a análise do geógrafo, a relação das rodovias com o crescimento urbano ocorreu:

-Para o Leste, além da antiga Central do Brasil, a via Dutra passou a estabelecer ligações com os bairros operários de São Miguel Paulista e Ermelino Matarazzo, que também abrigavam funções industriais.

-Ao sudeste, a ferrovia Santos- Jundiaí e a via Anchieta estabeleceram o binário de ligação com as cidades do $A B C$, então pólos industriais consolidados, interligando-as à São Paulo.

-Ao Oeste, a mesma Santos-Jundiaí e Sorocabana, aliadas à via Anhanguera, desempenharam o papel de indutores de expansão e elementos de interconexão com Pirituba e Osasco, que além da Lapa e Vila Industrial Jaguaré, abrigavam moradia operária e indústrias.

-Ao Sul, as avenidas Nove de Julho e Cidade Jardim se constituíram vias urbanas de expansão da ocupação próxima ao Centro, mas Petrone salientou a importância da avenida Santo Amaro, que estabeleceu a ligação daquele núcleo 
à área de consolidada de São Paulo, ressaltando a mescla existente entre bairros residenciais e de área em que algumas indústrias já se encontravam em funcionamento (idem, 157-158).

Ainda que não mencionadas nesse trabalho, outras duas importantes rodovias se encontravam no quadrante sudoeste, a via Raposo Tavares e a estrada de ligação São Paulo-Curitiba, ambas juntas ao Butantã e próximas a Pinheiros.

A relevância das estradas de rodagem como principal elemento de infra-estrutura relacionado à acessibilidade, manifestou-se também na estruturação ou crescimento dos seguintes elementos, segundo Langenbuch.

- Os "subúrbios-estação", surgidos nas décadas anteriores devido às ferrovias, que passaram a ser conectados à cidade consolidada através de ônibus, favorecidos pela nova circulação rodoviária.

- Intensificação da ocupação suburbana através dessa circulação, dando origem aos "subúrbios-ônibus" e aos "subúrbios-entroncamento", estes últimos pontos de concentração e cruzamento de correntes de circulação.

- Impulso à industrialização ao longo das principais rodovias, onde os estabelecimentos puderam se situar em localizações aptas à expansão e sob novos padrões construtivos. (Langenbuch, 1971, 258).

Espacialmente, o resultado da expansão da área urbanizada pode ser verificado através dos números a seguir:

\begin{tabular}{|c|c|c|c|}
\hline \multicolumn{4}{|c|}{ Quadro 7 } \\
\hline Ano & $\mathrm{Km}^{2}$ & $\begin{array}{c}\text { Cresc, absoluto } \\
\left(\mathrm{Km}^{2}\right)\end{array}$ & Cresc. relativo (\%) \\
\hline 1929 & 103,51 & & 158 \\
\hline 1949 & 267.51 & 164.00 & 133 \\
\hline 1962 & 624,5 & 356.99 & \\
\hline \multicolumn{4}{|c|}{ (Fonte: Emplasa, DIF, CIG) } \\
\hline
\end{tabular}

crescimento da cidade foi analisado por um estudo da Secretaria Municipal de Planejamento, que apontou as características presentes nesse modelo expansão: "A partir de 1940...o tripé loteamento periférico /autoconstrução/ moradia própria, altera profundamente a estrutura urbana paulistana, alargandoa para a periferia e deixando-a apta à industrialização acelerada. Para tanto, expandiu-se a rede viária, facilitando a circulação de mercadorias e da força de trabalho, num contexto em que o transporte coletivo passa a ser o ônibus, e não mais o bonde. O reflexo dessa expansão é percebido pela acentuada queda da densidade demográfica bruta, que cai de cerca de 110 habitantes por hectare, em 1914, para 47 hab/ha em 1930. Em 1960 era ainda menor, 24,6 hab/ha..." (Sempla, 1990, 35). 
Se a industrialização pioneira se pautou por uma concentração espacial específica em relação ao tecido urbano da cidade, no período 1930-1960 agora analisado, com uma inflexão na década de 1950, as transformações ocorridas na base industrial fizeram com que o setor não se baseasse mais em bens de consumo não duráveis, como alimentação, vestuário, mobiliário, etc, pois a partir da década de 1950 passou-se a produzir bens de capital e de consumo durável, o que produziu novas localizações fabris.

Analisando esse novo quadro, Fernandes considerou que "essas indústrias, estruturadas já num momento de integração do mercado consumidor em nível nacional e de novos desenvolvimentos dos transportes e comunicações, além de novas necessidades da própria produção... apresentam também novas características de localização, articulando outros espaços a essa lógica produtiva, espaços que vão muito além da simples continuidade física. Aliás, é nesse processo que a região metropolitana de São Paulo se constitui de fato" (Fernandes in E\&D, $\left.\mathrm{n}^{\circ} 17,1986,71\right)$.

Um fator fundamental para a nova espacialização metropolitana foi a instalação da indústria automobilística no quadrante sudeste da cidade e em municípios vizinhos dessa região, São Caetano do Sul, Santo André e São Bernardo. Em 31 de janeiro de 1956, o presidente Juscelino Kubstchek instituiu o Grupo Executivo da Indústria Automobilística-GEIA, órgão que precedeu o funcionamento das montadoras e autorizou a entrada no mercado brasileiro das mesmas. Durante mais de uma década e meia a totalidade dessas indústrias esteve sediada em São Paulo (com exceção da Fábrica Nacional de Motores, no Rio de Janeiro), expandindo suas unidades do $\mathrm{ABC}$ para o Vale do Paraíba. Com isso, todo o parque industrial de setores co-ligados às montadoras localizaram-se nas proximidades dessas concentrações ou num raio próximo da metrópole.

Nesse período, a importância da infra-estrutura rodoviária, que veio se somar às ferrovias, manifestou-se como determinante para as novas localizações industriais. Langenbuch mencionou esse fator de atratividade relacionando-o à posição que os municípios do $\mathrm{ABC}$ tinham em relação à ferrovia e a situação intermediária que essas cidades tinham entre a metrópole e o porto de Santos (Langenbuch, 1971, 215).

Mais uma vez, o terminal marítimo desempenhou um papel estratégico, pois as indústrias automobilísticas receberam maquinaria pesada do exterior e mesmo a montagem dos veículos dependia da importação, dado o baixo índice de nacionalização das peças no início de funcionamento do setor. Completando esse quadro, algumas indústrias puderam aproveitar instalações de grande porte já existentes, enquanto outras construíram novas plantas industriais que arquitetonicamente procuraram traduzir a pujança da empresa (idem, 1971, 215). 
O mesmo estudo mostra que, nesse período, a importância da ferrovia já não se equiparava à rodovia, uma vez que o transporte pesado passou a se dar pelas estradas, fator que reforçou ainda mais a sua atratividade. Também com relação ao transporte de passageiros, o transporte ferroviário passou a apresentar uma crescente incapacidade de atender a demanda, o que também provocou a expansão do modo de transporte baseado nos ônibus (ibidem, 190,215).

Sobre as transformações que as rodovias provocaram na cidade e seus limites com municípios vizinhos, foi observado que:

A Via Dutra intensificou a ocupação residencial e industrial ao leste, incluindo a porção sul de Guarulhos e de parte da zona leste paulistana próxima ao Tietê. Isso foi importante porque, anteriormente, o acesso a essa região se dava exclusivamente pela avenida Celso Garcia, que segundo Langenbuch, era há duas décadas a avenida mais congestionada da cidade (op. cit, 206).

Por sua vez, a via Anchieta intensificou fortemente o crescimento urbano de São Bernardo do Campo, em diferentes setores onde predominaram as ocupações habitacionais e em outros, as industriais. Apesar da importância da indústria automobilística, outros ramos também se localizaram nessa área, somando-se àquele do setor moveleiro, que caracterizou o período da industrialização baseada nos setores tradicionais (op. cit, 209).

As condições topográficas e o fato da via férrea não ter induzido uma ocupação mais intensa, nem habitacional nem industrial, fez com que no setor noroeste a Via Anhanguera não ocupasse o mesmo papel desempenhado pelas duas rodovias anteriores, permanecendo aquele território, no período que antecede a década de 1960, caracterizado por uma ocupação agroindustrial ligada às indústrias de Perus e Caieras (op. cit, 212).

As demais rodovias mencionadas, Raposo Tavares, Régis Bittencourt e Fernão Dias aproveitaram parcialmente o traçado de caminhos pré-existentes e desempenharam pouca influência na área mais próxima à cidade, constituindo uma ligação com setores industriais mais distantes ou com áreas de lazer e habitacionais fora de São Paulo (op. cit, 214).

Diversamente do período em que a cidade se estruturou compactamente, 0 espraiamento urbano ficou evidenciado como uma das características principais das décadas de 1940 e 1950, como os estudos de Petrone (1958) e Langenbuch (1971) mostraram, direcionado pelas transformações na estrutura de circulação e estabelecendo o padrão de expansão horizontal e autoconstrução periféricas que persistiu nas décadas seguintes.

O item "Aspectos Históricos do Desenvolvimento" que inclui a análise "Fatores Governamentais no Desenvolvimento", constante no Plano Urbanístico Básico- 
PUB, de 1968, abordou com precisão esses fatores presentes no período analisado:

"Com a II Guerra Mundial, face às dificuldades de obtenção de produtos importados e à demanda insatisfeita, o desenvolvimento industrial passou a ser uma necessidade. São Paulo, embora com um mercado e um parque industrial incipientes, reunia as melhores condições de localização para se beneficiar dos estímulos industriais criados. Na década de 50, com a política desenvolvimentista e a implantação da indústria automobilística, o processo de industrialização ganhou novo impulso. Nesse período, as dimensões do parque industrial já eram de tal ordem que os grandes incentivos federais criados para estimular a industrialização de outras regiões do País não alteraram o processo de desenvolvimento da Metrópole" (PUB, 1968, 42).

Na seqüência, esse documento relacionou também a importância das ações do governo federal no tocante à construção de rodovias, a partir de 1950, ressalvando que embora tenha havido a responsabilidade do governo estadual na construção da maioria delas, as rodovias federais Presidente Dutra, Fernão Dias e Regis Bittencourt, ampliaram a rede viária do Estado de São Paulo, particularmente suas ligações com os estados vizinhos (idem, 42).

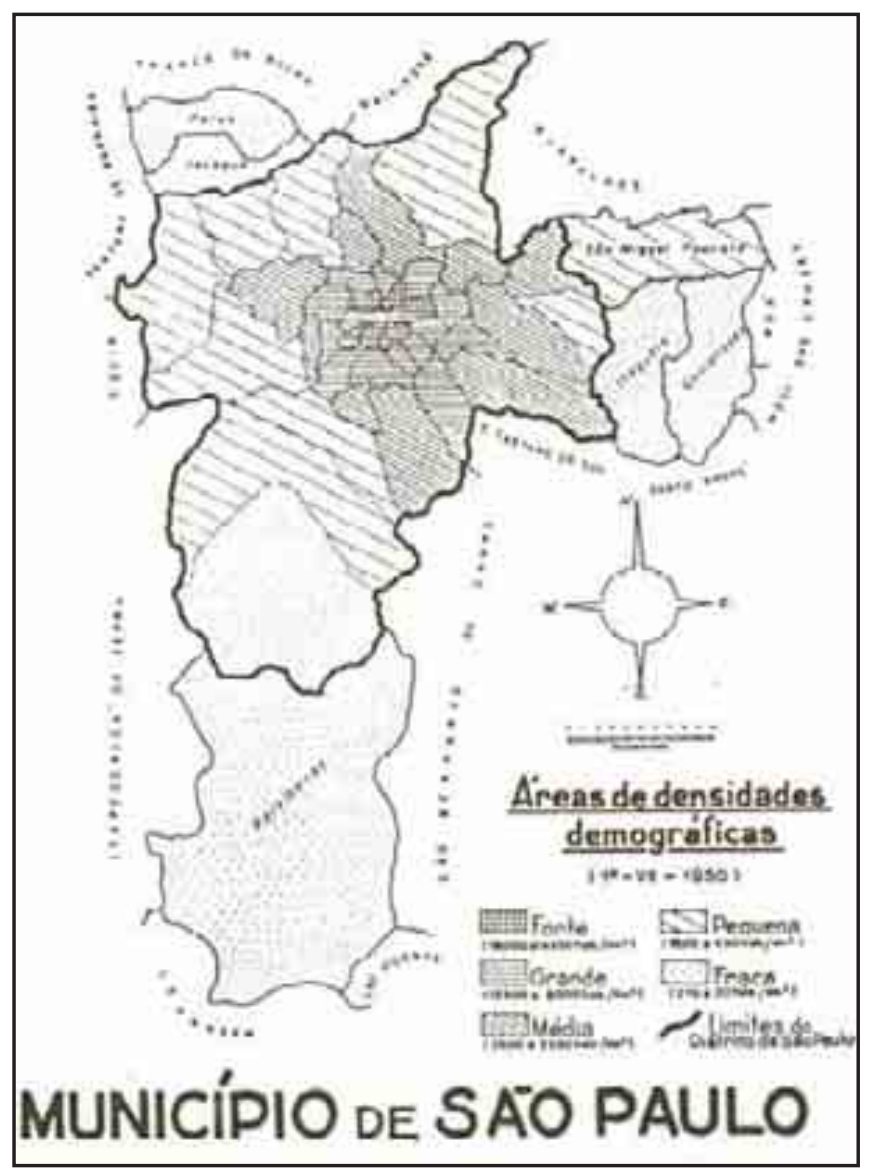

Fig. 70: Densidade demográfica, 1950. 


\subsection{Legislação: as setorizações consagradas através da normatização urbanística}

A evolução da legislação corresponde ao período em que o Código Arthur Saboya foi promulgado e permaneceu em vigor, incorporando alterações referentes à demarcação dos bairros de alta renda, ao estabelecimento de coeficientes de aproveitamento na área central e aos critérios para classificação de atividades incômodas:

Em 1934 houve a incorporação do artigo 40 ao Ato 127 do Código Arthur Saboya. Esse artigo demarcou a área do Jardim América, perdurando até 1954, representando a preservação do uso residencial ao bairro em formação. A lei 3571, promulgada em 1937, ampliou a aplicação do Ato 40, que da sua incidência em áreas, como os Jardins, passou a ser aplicável também a vias públicas consideradas estritamente residenciais. A questão envolvendo essa lei foi a de preservação dos valores imobiliários, em função das modificações que já estavam ocorrendo nos bairros de alta renda, sendo necessária a definição de locais para a construção de edifícios ou outros usos. Na década de 1950, essa lei sofreu modificações para permitir a construção de edifícios de serviços na avenida Paulista e nas outras vias onde a lei também incidia, permissão para comércios locais, como floriculturas e salão de beleza, além de museus e agências bancárias, segundo Feldman. De acordo com essa autora, esse conjunto de alterações introduzidas na legislação demonstra a presença de interesses existentes em cada parte da cidade, integrando o processo de construção do zoneamento, que se tornou sistemático a partir de 1947 (Feldman, 1994, 97,99).

A demarcação dos bairros da Cia City ocorreu entre 1954 e 1957, seguindo os moldes do zoneamento de parcelas da cidade ocupadas pela elite. Dessa forma, em 1954 aos bairros Jardim Paulistano, Jardim Europa, Vila Nova Conceição, Vila Paulista e Vila Primavera, foi aplicado o artigo 40 e, em 1957 ao Alto da Lapa e à avenida Morumbi. Em 1955, ocorreu a demarcação dos bairros do Pacaembú e Pacaembuzinho, através da Lei 4.792 (idem, 102,103, 105). Alterações no zoneamento dos bairros-jardim foram propostas pela própria Cia. City, ainda em 1948, para dotar o Pacaembú de área de serviços. Para tal finalidade, a partir de prescrições da própria empresa, foi definido o coeficiente igual a 2 para abrigar o centro comercial, que após divergências de ordem legal com a Prefeitura, foi previsto em lei de 1951 (ibidem, 107).

Souza abordou esse assunto considerando ser uma característica desse período, a adoção de normas para áreas e ruas com padrão dos bairros-jardim, incorporando-se medidas na legislação urbanística para preservação do valor dos imóveis e da presença de usos incômodos na vizinhança (Souza, 1994, 222). Além dessas leis, outras se destacaram por tratar dos usos incômodos e dos coeficientes de aproveitamento: 
Lei 4805/55 - Lei dos Ruídos:

Definição de zonas estritamente residenciais, predominantemente residenciais, mistas e fabris. Os seus perímetros foram delimitados em 1958, consolidando a situação existente no Bom Retiro e Jaguaré, no tocante às indústrias, e os bairros de alta renda, no tocante à habitação. $\bigcirc$ restante da cidade foi considerada zona mista (idem, 223).

A espacialização resultante da demarcação das zonas industriais, que evitou sua implantação nas áreas estritamente residenciais no vetor sudoeste, obedeceu ao que já existia na cidade, ou seja, as áreas industriais dispostas ao longo dos eixos ferroviários e rodoviários e seus espaços vizinhos, tais como várzeas e áreas sub-ocupadas. Da análise dessa norma, se depreende que não houve intenção de alterar a estrutura existente, a não ser em dois casos, representados pelas áreas ao norte e nordeste da áreas central - Bom Retiro, Pari e Brás, que apesar de sua vocação fabril tradicional, foram consideradas mistas visando a expansão das atividades centrais de comércio e serviços para as mesmas (Osello, 1983, 224).

Essa delimitação consagrou as áreas industriais existentes, como foi visto, mas proporcionou também uma importante caracterização funcional do conjunto de bairros analisados neste trabalho - Bom Retiro, Luz, Pari, Canindé e Brás - já que nas décadas seguintes, a proporção entre estabelecimentos industriais e comerciais tornou-se favorável a estes últimos, configurando assim a nova vocação desses espaços: bairros residenciais pouco verticalizados, com presença de atividades comerciais, setores de indústrias leves (não incômodas, como prescrevia essa lei para as zonas mistas) e serviços locais.

Lei 5261/57 - Lei dos Coeficientes de Aproveitamento

Essa lei foi decorrente da proposta de Anhaia Melo visando o controle da verticalização e da densidade. Estabeleceu um coeficiente de aproveitamento 4 para construções com finalidades habitacionais e 6 para comerciais. Foi fixada ainda densidade líquida máxima de 600 habitantes por edifício residencial através de cota de 35 m² $^{2}$ de área mínima para cada habitação (Feldman, 1996, 110).

Segundo estudo da Secretaria Municipal de Planejamento, a verticalização no período de 1940 a 1957 apresentava as seguintes características:

- A média dos coeficientes de aproveitamento no Centro variava de 8 a 10, sendo ultrapassado em alguns casos, como por exemplo no Edifício Martinelli, construído em fins da década de 1920 .

- Nesse período, $71 \%$ ainda estavam localizados próximos ao Centro, mas apenas $25 \%$ destinados ao uso comercial e passando a ter metade de seu número 
pertencentes a unidades de aluguel, contra $79 \%$ do período anterior da verticalização, que apresentava predominância central e para aluguel.

- Apesar da definição dos coeficientes para a área central, a partir da lei de 1957, fora dela a legislação permitia até 25 andares, através da fixação de um gabarito de 80 metros, não representando restrição à construção vertical, visto as limitações construtivas da época (Sempla, 1990, 110).

Posteriormente à promulgação dessa lei, o mercado imobiliário adotou uma estratégia para burlar as limitações impostas, através da construção de edifícios comerciais com coeficiente 6, para transformá-los em residenciais, após o "habitese". As prescrições sobre densidade e cota mínima de terreno por unidade, elevaram a área mínima de apartamento para $210 \mathrm{~m}^{2}$, fator que colaborou para a expansão da verticalização para o vetor sudoeste, uma vez que ali se encontravam as condições necessárias de base fundiária e renda (idem, 110).

Esse processo de crescimento vertical no quadrante sudoeste, já estudado nos trabalhos, de Souza (1994), Someck (1987 e 1997), Villaça, (1998), Rolnick (1997), caracterizou com maior intensidade a expansão imobiliária diferenciada da cidade a partir de então, e com ela, os requisitos para sua continuidade, podendo ser identificadas as seguintes decorrências:

- aos elementos da infra-estrutura, já delineados desde o Plano de Avenidas, juntaram-se novas remodelações viárias nas décadas subseqüentes à de 1950, objetivando atender o crescimento dos deslocamentos por automóveis.

- juntamente com a consolidação dos bairros da alta renda, através da legislação urbanística promulgada especificamente para os mesmos, o setor de serviços também se transformou, adequando a demanda antes existente apenas na área central, para novas espacializações do terciário. Como para a sua relocação necessitou ocupar áreas que anteriormente não eram destinadas a essas atividades, a remodelação espacial do setor sudoeste passou a se constituir um ciclo contínuo que reforçou a necessidade de mais ampliações do viário em conseqüência do processo de verticalização como será visto adiante. A rua da Consolação, na década de 1960 e a avenida Paulista, no início da década de 1970, são exemplos dessas transformações, irradiando também a ocupação para espaços próximos.

- esse conjunto de fatores que passou a influir decisivamente na expansão das atividades centrais para fora do perímetro central, contribuiu ao processo de mudanças que o centro passou a apresentar a partir da década de 1960, onde os espaços que associavam prestígio para as mais amplas atividades do setor de serviços (consultórios, escritórios, bancos, comércio de luxo, etc), deixaram aquela região para se instalar junto à nova centralidade terciária, a avenida Paulista. 


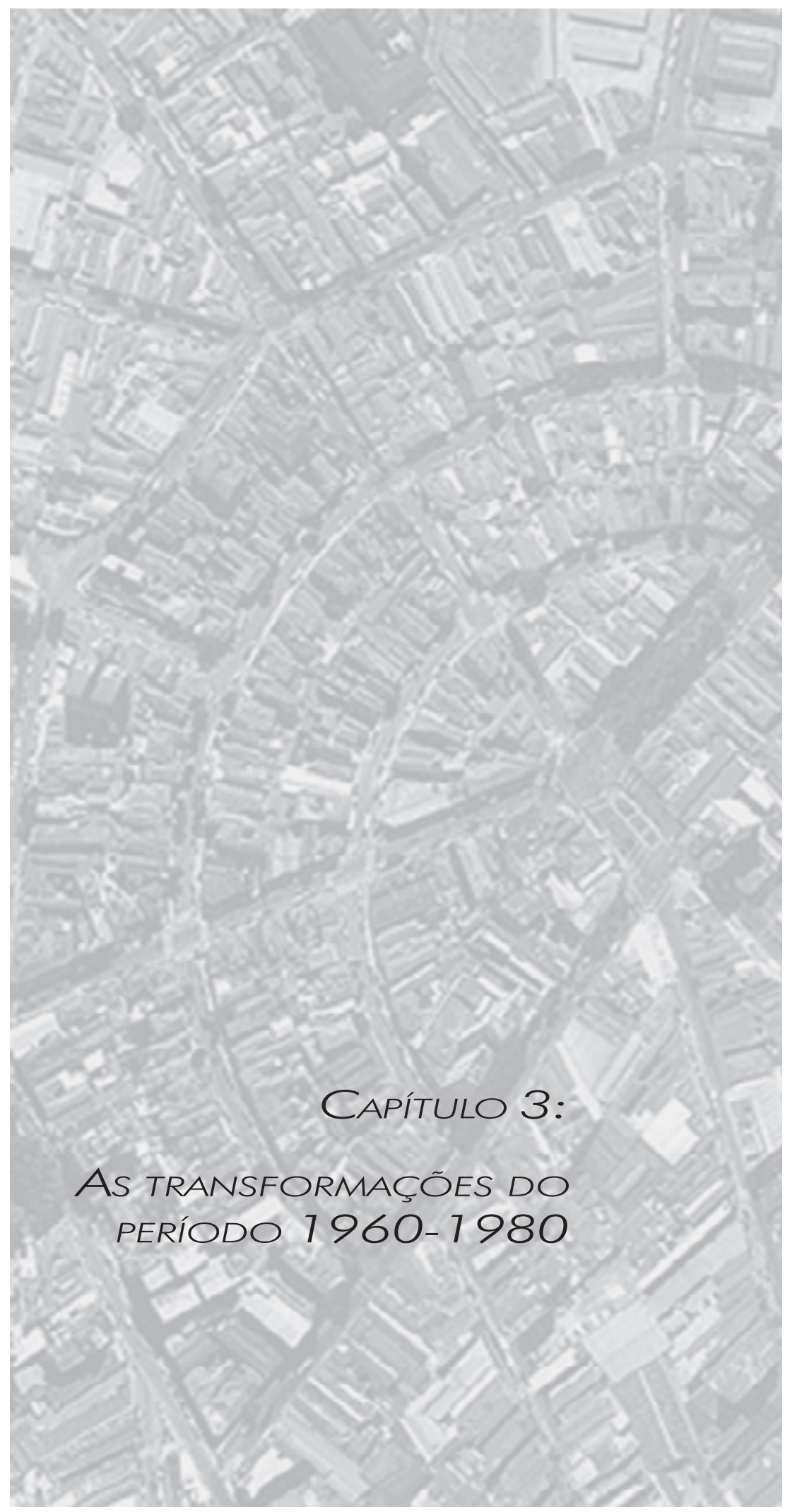




\section{As transformações do período 1960-1980}

A cidade, nesse período, seguiu as tendências delineadas a partir da segunda metade da década de 1940, mas com intensidade bastante superior em relação ao processo de metropolização e adensamento central. Essa dinâmica correspondeu ao processo de acelerada urbanização que o país apresentou no pós-guerra e em relação ao mesmo, Souza mostrou que a população urbana brasileira quase triplicou entre 1940 e 1950, tendo esse processo apresentado duas características principais:

- o aprofundamento das diferenças inter e intra-regionais

- a polarização de mão-de-obra exercido pelos centros mais dinâmicos (Souza, apud Déak, Schiffer, orgs., 199, 126).

Um conjunto de fatores econômicos, de âmbito nacional e regional, concorreu para que a industrialização em curso desde o pós-guerra confluísse majoritariamente para a região metropolitana de São Paulo, tornando-a o pólo mais dinâmico da economia brasileira e em conseqüência, um forte indutor das migrações para a cidade de São Paulo e municípios vizinhos, como é possível observar pelos dados a seguir?.

\begin{tabular}{|c|c|c|c|c|c|}
\hline \multicolumn{7}{|c|}{ Quadro 8 } \\
\hline Ano & Populaçãóio de São Paulo - Evolução da População & $\begin{array}{c}\text { Crescimento } \\
\text { decenal }\end{array}$ & $\begin{array}{c}\text { Saldo Vegetaivo } \\
\text { decenal }\end{array}$ & Saldo migratório & $\begin{array}{c}\text { Taxa de } \\
\text { cresc.anual (\%) }\end{array}$ \\
\hline 1950 & 2.198 .096 & 871.835 & 242.810 & 629.025 & 5,18 \\
\hline 1960 & 3.666 .701 & 1.468 .605 & 667.459 & 801.146 & 5,25 \\
\hline 1970 & 5.924 .615 & 2.257 .914 & 972.571 & 1.285 .343 & 3,92 \\
\hline 1980 & 8.493 .226 & 2.568 .611 & 1.424 .665 & 1.143 .946 & 3,67 \\
\hline \multicolumn{7}{|c|}{ (Fonte: FIBGE/Sempla) } \\
\hline
\end{tabular}

A partir das informações do quadro 8, pode-se relacionar o acentuado crescimento populacional com pressões, ainda maiores que as ocorridas nas décadas passadas, à capacidade das redes de infra-estrutura, transformando o saneamento, transportes e habitação em problemas que assumiram uma escala tal que, a partir da metade da década de 1960, a participação dos agentes financeiros para a construção da casa popular e de programas de saneamento para as periferias urbanas, extremamente precárias, foi estruturada a partir do nível federal, como alternativa à demanda expandida pelo intenso processo de urbanização que o país apresentou nesses anos. 
Essa nova etapa da urbanização se associou a duas características da industrialização nesse período: a grande diversificação do parque fabril, e o início de sua descentralização.

Esse modelo de industrialização teve como marco inicial o Plano de Metas de 1956, que priorizou a indústria pesada de produção de bens, continuando na década de 1960 a expansão industrial até o seu auge, caracterizado pelos anos do "milagre econômico", a partir de 1968 até os primeiros anos da década seguinte. Com a crise que marcou esse modelo econômico a partir de 1974, tanto o município de São Paulo, quanto a Região Metropolitana apresentaram uma desaceleração do ritmo industrial, desenhando-se a partir daí a desconcentração espacial do setor, que ganhou impulso na década de 1980 (Emplasa, 1994, 35).

Deve-se acrescentar ainda à essa dinâmica a incidência da legislação estadual, a partir de 1978 e também federal ${ }^{2}$, que em conjunto redefiniram a localização industrial, impondo limites à sua expansão na cidade e transferência para espaços regionais próximos a ela.

Esse processo, que se fez notar com maior nitidez na década de 1980, não impediu nem diminuiu a expansão periférica que por fim estabeleceu a conurbação da cidade com os municípios vizinhos da Região Metropolitana (criada institucionalmente em 1973). A área urbanizada do Município de São Paulo em 1962 era de 624,5 Km², saltou para $700 \mathrm{Km}^{2}$ na década de 1970 e $848 \mathrm{Km}^{2}$ em 1985, representando mais de três vezes a área ocupada do início da década de 1950, que era de 267,5 Km² (Emplasa/Sempla).

Conjuntamente ao processo de expansão da área urbanizada através do parcelamento dos espaços periféricos, sem os requisitos mínimos de infra-estrutura, equipamentos e serviços, o crescimento do setor terciário estruturou-se com bases na nova etapa da economia brasileira, principalmente nas cidades região SulSudeste. A explicação estrutural para tanto recai sobre a perda que o setor secundário já apresentava na década de 1970, sendo considerado o setor de serviços, construção civil incluída, "um regulador de absorção de mão-de-obra urbana" (Souza, 1999, 128 apud Deák, Schiffer, orgs)

Nessa dinâmica estiveram presentes a ampliação do mercado de consumo para a classe média e sua inclusão em programas de financiamento de bens, antes inacessíveis para um grande número de famílias dessa classe social, como por exemplo automóveis, eletrodomésticos, televisores e principalmente a casa própria. Dessa forma, diversos agentes, inclusive governamentais, fizeram parte da mediação entre a produção e consumo, ampliando e diversificando a cadeia de atividades urbanas. Sinteticamente, nesse novo quadro, os seguintes aspectos pode ser identificados: 
- a diversificação industrial, que gerou serviços especializados voltados à produção em massa.

- a expansão dos serviços vinculados às ocupações de alta qualificação (ampliando o mercado "white collar").

- a crescente condição de metrópole nacional, que centralizou serviços especializados.

- os ajustes produtivos, tecnológicos e de gestão, promovidos a partir de 1980 na indústria, que incorporou novas atividades decorrentes da terceirização (Emplasa, 1994, 41).

Esses elementos mostram um processo qualitativamente diferente das etapas anteriores, devido às alterações na cadeia produção-circulação-distribuiçãoconsumo, causadas pela maior presença do trabalho intelectual nesse circuito (Santos, 1997, 3). À crescente gama de bens e mercadorias produzidas, verificouse uma intensificação da reformulação espacial do setor de comércio e serviços, em curso desde a década de 1950, mas acelerada no período agora abordado.

Em São Paulo, esse processo induziu a transformações espaciais, como a que ocorreu na avenida Paulista, que passou a concentrar as sedes administrativas das grandes indústrias, empresas multinacionais e bancos, estando a verticalização agora vinculada a utilização do automóvel, como indicam as análises de Someck, 1997; Villaça, 1998 e Souza, 1994. Um exemplo paradigmático da transformação funcional e espacial da nova centralidade de São Paulo ocorreu na avenida Paulista com a construção em 1955 do Conjunto Nacional, na totalidade de uma quadra ocupada por uma mansão demolida, cujo projeto havia sido de Victor Dubugras (Amadio, 1998, 40).

Segundo análise sobre as atividades urbanas ligadas ao setor terciário e residencial, três fatores são decisivos para a viabilização da localização: o mercado imobiliário, as empresas de incorporação e a ação das instituições financeiras (Vargas, 2001, 86-283). Com relação ao mercado imobiliário, a necessidade de estacionamentos para uma frota de automóveis em crescimento foi, por exemplo, um ponto que influiu no deslocamento das atividades de serviços para fora do Centro tradicional, na direção da avenida Paulista. No caso dos demais agentes, a participação das políticas oficiais de estímulo à construção civil, caracterizada a partir da década de 1960 e mais fortemente através dos planos e programas pós-1964, tiveram papel decisivo para as novas configurações espaciais ocorrerem (Souza, 1994, 83) .

A identificação desses fatores estaria incompleta se não fosse também considerado o papel que a legislação urbanística desempenhou, juntamente aos interesses do mercado imobiliário, no aumento dos coeficientes de aproveitamento que possibilitou a verticalização desses novos espaços de serviços da cidade. Nesse 

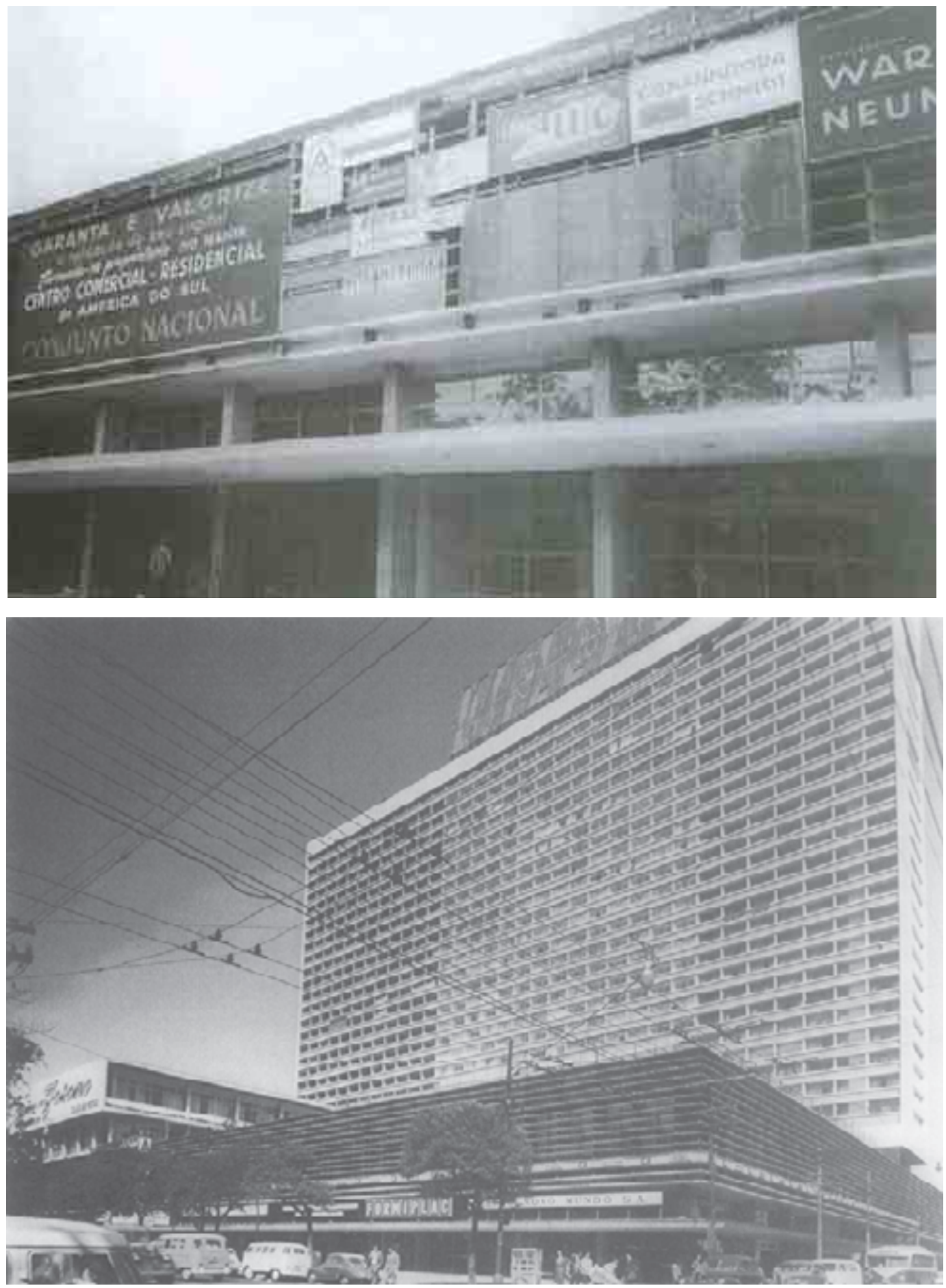

Fig. 71 (ao alto): Conjunto Nacional em obras.

Fig.72 (acima): Condomínio Conjunto Nacional, década de 1960. 
sentido, a Lei dos Coeficientes de Aproveitamento (Lei n 5261), instituída em 1954, sofreu modificações em 1961 e 1964, quando foi adotado o coeficiente 6 para todo tipo de construção (Rolnick, 1997, 199), fator preponderante para a viabilização da verticalização da avenida Paulista.

Um estudo do IBGE sobre a "Região da Capital Paulista" contido no "Guia do Estado de São Paulo" de 1962, aborda esse processo ressaltando as novas construções do Centro e regiões vizinhas, registradas como forma de enfatizar o contraste morfológico entre o núcleo central, intensamente verticalizado e as áreas periféricas e bairros residenciais, com predominância de casas térreas e sobrados: "É bem verdade que, numa análise mais pormenorizada da paisagem urbana, verificaremos a crescente construção de edifícios de apartamentos residenciais ao longo das radiais e em algumas áreas periféricas (Vila Buarque, Santa Ifigênia, Bela Vista, ou bairros como Santa Cecilia, Higienópolis ou avenida Paulista) tende a tornar menos acentuado o contraste, no que se refere ao tipo de construções" (IBGE, 1962, 65).

Nessa etapa a utilização do automóvel como meio de deslocamento da classe média foi consagrada, já que a frota de veículos cresceu permanentemente ao longo da década de 1960 e das seguintes, resultando na necessidade de contínuos investimentos em obras viárias. Apesar da crise dos transportes públicos, as ampliações de avenidas, construção de viadutos e ênfase nas obras de grande vulto, marcaram a fase mais aguda do "milagre econômico", onde a abertura de espaços na malha viária para a indústria automobilística se tornou uma necessidade urbanística que exigiu investimentos públicos para a expansão econômica do setor privado, estratégia financiada por vultuosos empréstimos do exterior ${ }^{3}$.

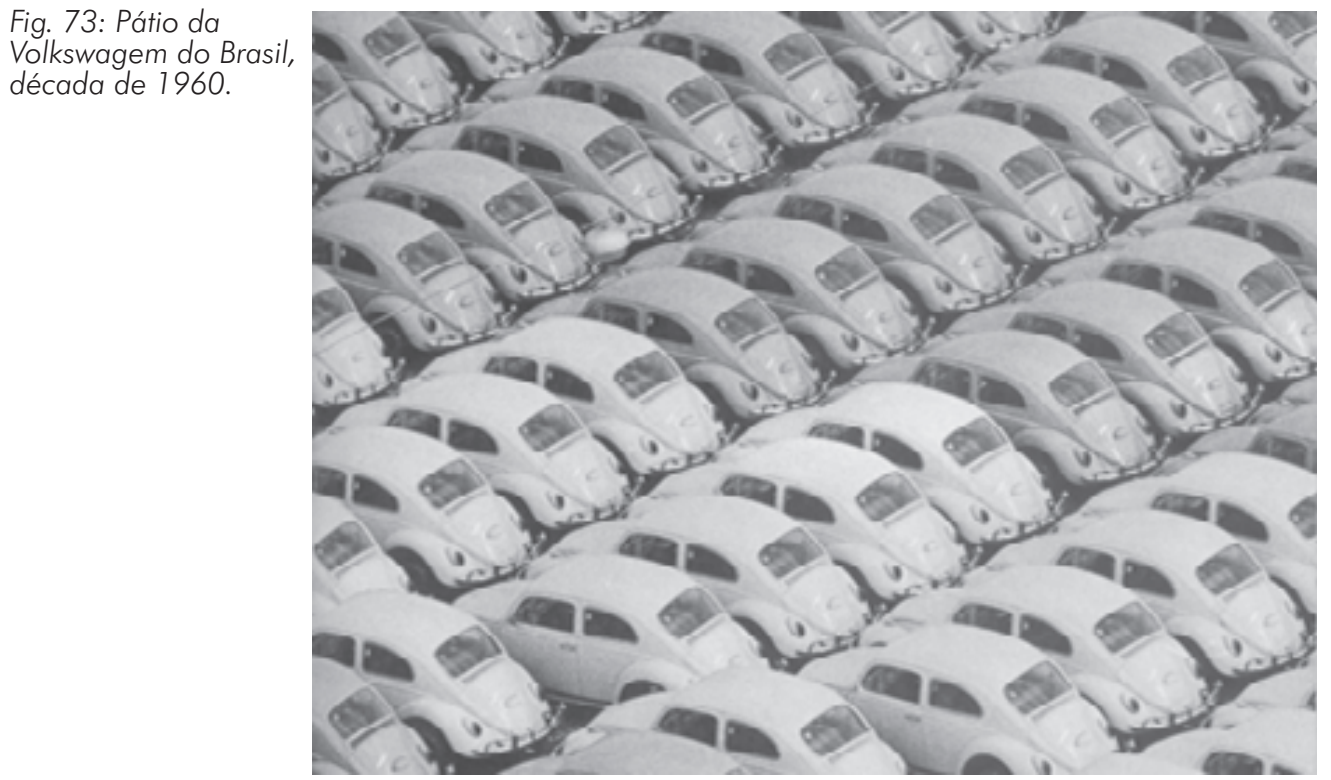


De toda forma, a distinção entre as áreas da cidade foi fortalecida pela caracterização de dois setores que corresponderam:

- Àqueles vinculados ao terciário avançado, onde a tecnologia de ponta se caracterizou como componente principal (os edifícios sofisticados, os senviços vinculados ao mercado financeiro, imobiliário e corporativo, o crescimento das comunicações e processamento computacional), que ampliou o seu desdobramento funcional e tipológico para o quadrante sudoeste.

- Àqueles vinculados ao comércio e senviços tradicionais, cuja característica continuou sendo a do emprego de mão-de-obra sem maior especialização técnica e a adaptação física de instalações dos bairros tradicionais, processo verificado no Brás, no Pari e no Bom Retiro.

O quadro mostrado a seguir, que demonstra a dinâmica populacional da cidade nas duas décadas a partir de 1960, revela a tendência de esvaziamento dos distritos do centro histórico, todos com taxas negativas de crescimento de 1960 a 1970, e apenas o Cambucí, Santa Ifigênia, Mooca, Barra Funda e Sé apresentando pequeno crescimento entre 1970 e 1980. É necessário ressaltar que nessa última década a linha Norte-Sul do Metrô já havia sido concluída, não representando incentivo ao adensamento no entorno das estações situadas nos bairros da Luz e Ponte Pequena, ambos pertencentes ao distrito Bom Retiro.

Por outro lado, todos os outros distritos da cidade apresentaram crescimento, alguns com valores muito elevados, comprovando a direção à localizações mais periféricas, como é possível inferir para o caso de Santo Amaro, Socorro, Vila Prudente, São Miguel Paulista, Tucuruvi e Pirituba.

No chamado centro expandido, os maiores crescimentos se registraram entre 1970-1980 nos distritos de Santa Cecília, Cerqueira Cézar ${ }^{5}$, Vila Mariana, Liberdade, Indianópolis e Perdizes. Nesses locais, o crescimento moderado, mas constante, certamente se relacionou com a verticalização dos bairros, que ocorreu e se disseminou em todos os distritos, mas com pontos de concentração em Higienópolis e Vila Buarque (distrito Santa Cecília), Paraíso (distrito Vila Mariana), Liberdade, Moema (distrito Indianópolis), região próxima à avenida Paulista e Pinheiros (distrito Cerqueira César) e Perdizes.

Nesse sentido, considerando o trabalho de Someck sobre o processo de verticalização da cidade, o crescimento populacional esteve relacionado aos períodos que a autora classificou como verticalização induzida pelo uso do automóvel (1957-1967), da verticalização resultante do período do "milagre econômico", que contou com a participação do BNH na promoção do desenvolvimento imobiliário (1967-1972) e da verticalização pószoneamento, que atravessou um período de desaceleração com o fim do "milagre", mas definiu os setores de maior incidência de construção de edifícios (Someck, 1997,24). 


\begin{tabular}{|c|c|c|c|c|c|}
\hline \multicolumn{6}{|c|}{ Qude 9} \\
\hline \multicolumn{6}{|c|}{ 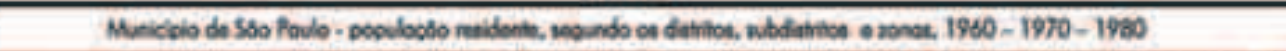 } \\
\hline 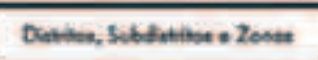 & 1960 & 1980 & 1960 & \multicolumn{2}{|c|}{ 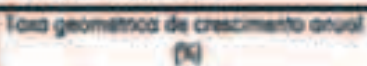 } \\
\hline & & & & lomive & $10 \cos m$ \\
\hline Then & क्ज़ा & ड़्रण्गा & 2860 & 2.72 & 2,31 \\
\hline nitin. & (2) is) & $2921 n$ & 49050 & 2,4 & Au \\
\hline Condvis & 49.900 & 60600 & 50590 & -2.26 & Q.97 \\
\hline Dowe thones & 52.306 & 38.960 & 6.439 & $-2,7$ & Q.Ae \\
\hline Mooce & 2.192 & so $29 y$ & 40113 & $+1,+1$ & $0.23:$ \\
\hline $\ln$ & 3450 & 30 eqs & $27 \geqslant 6$ & 2.17 & if \\
\hline Benve fundo: & 32.45 & 20702 & 30691 & 0,86 & 0.31 \\
\hline besketse & 26.45 & 25606 & 25.109 & 0.53 & 0.2 \\
\hline & istas & sous & +181 & Ast & Q.12. \\
\hline Tond Combor Haberice & 372446 & 223617 & 321.730 & 1,91 & Q.,06: \\
\hline fave & $3005 \%$ & mडsm & 5 क्येत & 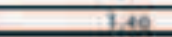 & 10 \\
\hline $7 \mathrm{ren}$ & णाग & किाइा & Pros? & 605 & $2 x$ \\
\hline 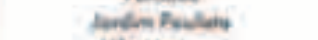 & 00173 & $91,92 \%$ & 114510 & 1,20 & 2,4 \\
\hline Whatolese & 76 ane & \%919 & 166031 & Q.51 & 2.90 \\
\hline intonepulis & 50000 & $70 \mathrm{ma}$ & 02706 & 207 & 1,50 \\
\hline Soenciecia & 60501. & 6809 & Sesis & 1.10 & 220 \\
\hline Cersoleçses & S1 QVe & 02226 & $n 232$ & 1.80 & is \\
\hline Ibendode & $55 \mathrm{~km}$ & 30700 & 73246 & 0.68 & 2.05 \\
\hline Nelinorbs & 44230 & 49058 & 55376 & $\mathrm{Cot}$ & $12 n$ \\
\hline indondentive & 42643 & 210 & 55301 & roi & is: \\
\hline nives & 36201 & 44000 & 17.180 & $i n$ & $\alpha=0$. \\
\hline Contem Ctan & $32 \mathrm{Me}$ & alsis & MA15 & xis & 4.14 \\
\hline Solo Vats & 57.025 & $\rightarrow 10$ & To $>0$ & Q.5T & 2.62 \\
\hline Vhe Moliden & $20) 112$ & 39025 & 41202 & 1,12 & 245) \\
\hline Cento fapondide & 818843 & 735123 & 1.151 .968 & 1,34 & 2,11 \\
\hline Anote & 10.659 & 175.00 & 212602 & F.s. & 6.12 \\
\hline Telal Oente & $\Delta A B C 2$ & 125800 & He.402 & 9.8B & 8.12 \\
\hline $\cos 2$ & एकाण & $m$ mas & 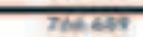 & $\overline{5021}$ & 7,75 \\
\hline nowions & avin & 195 क20 & 204520 & 0.17 & 2,14 \\
\hline Secome & 28.40 .5 & 165.437 & Asi ese & 19,24 & 10.50 \\
\hline theswers & 67.416 & 110761 & ISE 667 & 5,00 & 3.60 \\
\hline Palleing & 809 & 1237 & 27.08 & 434 & 2.24 \\
\hline Toted IS & 390.254 & 86134 & 1.871 .994 & 11,04 & 6.35 \\
\hline Wafudele & Ty/66e & T5916 & 96.856 & 8.15 & JW \\
\hline Seide & 15981 & 234528 & 269969 & 100 & 2.31 \\
\hline $\ln _{n \rightarrow 0}$ & 156760 & inise & isom & ont & a.s. \\
\hline 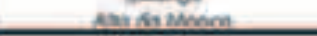 & 125208 & 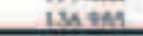 & $13 \times 100$ & as & sent \\
\hline Toed Sudener & 397.004 & pol.*e? & 1.701219 & 2.53 & 2.02 \\
\hline Tateed & T7DESO & 254.201 & 27.658 & 2.7 & 0.06 \\
\hline INatertse & 71016 & is2 187 & 241521 & 7.38 & in \\
\hline verevilts & at ns & 151,162 & $2 m+0$ & 6.41 & $* 2$ \\
\hline 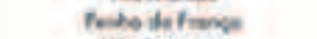 & 100 20s & ispare & 102520 & 230 & 0,34 \\
\hline Who formowe & $n \in e$ & $96 \times 2$ & 1200203 & $2 . n$ & 2.25 \\
\hline Sonmbe & to bus & 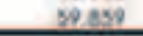 & $32 \times 2$ & 402 & 202 \\
\hline Towlin late I & 851172 & $\operatorname{ssish}$ & tosones & 444 & 7.98: \\
\hline Soo Mipow Foulian & $\overline{s 5 m}$ & 235306 & $46 .{ }^{2} 9$ & 7336 & $\overline{s, 57}$ \\
\hline newen & $309 / 0$ & 160103 & $41<011$ & 18,81 & s.15 \\
\hline Coniosoin & 24690 & 74.994 & $150 \mathrm{xs}$ & 1174 & 722 \\
\hline Teat leots 2 & 124281 & 000383 & 1000 . & 16,92 & 72 \\
\hline Then & स्राफ & 80261 & $7 / 895$ & 7.95 & 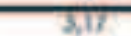 \\
\hline We haved & 34013 & 52034 & 71930 & 407 & 3.20 \\
\hline knand & gat7 & 20932 & siose & 7.31 & 0.32 \\
\hline fros & 9260 & 27767 & Af.ru & 114 & $5 \sqrt{2}$ \\
\hline Tubal Neter I & 74.115 & 106989 & 2000.307 & 7,31 & 4,46 \\
\hline Thonem & 228124 & 35034 & 463363 & 4,06 & 237 \\
\hline Sinten & 13024 & ton-100 & micse & 3112 & 200 \\
\hline 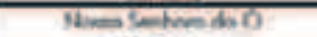 & 8200 & किकि & Triog & 25 & 2.11 \\
\hline Ylomplas & Quile. & 116.300 & 131.852 & 3,14 & 1.26 \\
\hline hastedus & Al.me & posat & Majas & 9.1 & s.2. \\
\hline Com Vent & no220 & คลตงเ & Horta & 2.35 & 1.13 \\
\hline Vo ovawn & \$1.202 & 76.025 & $n 136$ & 6.09 & 0,1 \\
\hline $\tan$ & S1 set & av way & nin & 2.14 & 21 \\
\hline Wha Plope Cochoerinha & $24.1 \pi$ & s24) & 3738 & $2.4 \%$ & Wh \\
\hline Telal Norts 2 & $m m$ & $1.183 \mathrm{~m}$ & 1590841 & 4.80 & 2,48 \\
\hline Feld Maridelo de SSo Pavio & 2700274 & 5.24615 & tavs & $4 N$ & 367 \\
\hline \multicolumn{6}{|c|}{ 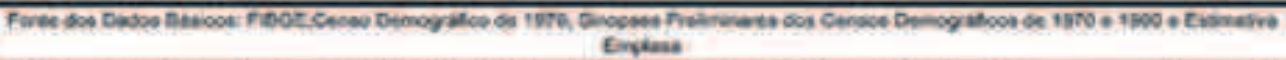 } \\
\hline
\end{tabular}




\section{1 As propostas de infra-estrutura e zoneamento do PUB e PDDI}

A exemplo do ocorrido nos períodos anteriores, a participação do planejamento na cidade foi caracterizada pela produção de trabalhos técnicos que, embora tenham realizado análises aprofundadas sobre a complexidade e contradições da estruturação urbana, tiveram pouca influência para transformar o quadro apontado. Em face disso, duas direções podem ser consideradas:

- As semelhanças entre o afirmado e os dois planos, Urbanístico Básico - PUB (1968) e Diretor de Desenvolvimento Integrado - PDDI (1971), são observadas no que se referiu às diretrizes que esses trabalhos propuseram e que não foram concretizadas: extensas malhas viária e metroviária, resultando em nova estruturação urbana; novas áreas de expansão das atividades terciárias e institucionais ao norte da centralidade, sub-centros regionais estimulando a desconcentração existente, etc..

- As diferenças que ocorreram por causa da consolidação da Lei de Zoneamento, decorrente do PDDI e da implantação do Metrô, em 1974, cujos estudos foram iniciados no período do PUB e constavam em suas propostas. Pelo fato desses aspectos terem se consolidado, pode-se considerar que, desde o Código Arthur Saboya e o Plano de Avenidas, cujas obras foram efetivamente concluídas na década de 1960, o mesmo não havia ocorrido com outras propostas de planejamento urbano voltadas a dotar a cidade de infra-estrutura e normas de parcelamento e edificação, descontada a legislação promulgada na década de 1950, como foi visto anteriormente.

Embora o PUB tenha sido um extenso trabalho de planejamento, muito mais aprofundado do que as propostas anteriores datadas da década de 1950, alguns elementos o ligam aos conceitos anteriormente propugnados. Nesse sentido, segundo Feldman, a característica de se constituir em um plano abrangente de todos os aspectos da vida urbana e de compreender a Região Metropolitana, fez com que o PUB 4 se constituísse no modelo de plano defendido há quase quatro décadas por Anhaia Melo (Feldman, 1996, 146).

No diagnóstico-síntese, o Plano relacionou os problemas decorrentes da falta de controle do uso do solo, além do atendimento precário dos serviços urbanos e transportes. Em relação a esses últimos temas, foi descrito que em 1968, 45\% da população não dispunha de abastecimento de água, 63 \% não era servida por rede de esgoto e $10 \%$ não dispunha de coleta de lixo, sendo ainda muito deficiente o sistema de pavimentação e de iluminação pública (apenas $40 \%$ das ruas oficiais eram pavimentadas e só $24 \%$ das mesmas dispunham de iluminação). Um dos motivos da excessiva concentração da cidade, segundo essas análises, se encontrava na grande deficiência dos serviços urbanos, que no caso do transporte público incluía as extensas jornadas diárias para o deslocamento da população (PUB, 1968, 13). 
Em relação ao uso do solo, o Plano descreveu a cidade apresentando uso comercial tanto na área central, como nos subcentros regionais de Santana, Lapa, Pinheiros, Santo Amaro, Brás e Penha, alem dos eixos seguindo as vias de transporte. A área central se prolongava nas avenidas São João, Rangel Pestana, Consolação, Brigadeiro Luís Antônio e Liberdade. O uso industrial, por sua vez, desenvolvia-se ao longo das ferrovias e das rodovias Dutra e Anchieta, destacando-se as concentrações da região Brás-Moóca, Vila Leopoldina, Jaguaré e Jurubatuba.

No tocante ao uso residencial, que atingia $75 \%$ da área de ocupação urbana, o Plano descreveu a sua distribuição como sendo a de uma área de grande densidade em torno do eixo centro principal e dos eixos comerciais, zonas de residências de padrão elevado na região oeste, no Vale do rio Pinheiros e as zonas residenciais populares, que embora se distribuíssem no restante da área da cidade, predominavam na periferia aquelas de mais baixo padrão. $\bigcirc$ PUB considerou que essa distribuição evidenciava certa segregação, "embora não muito nítida" (idem, 12).

A falta de controle do uso do solo foi considerada como causadora de uma grande mistura na sua distribuição, provocando inconvenientes devido aos usos incompatíveis. Nesse caso, diferentemente das propostas anteriores de zoneamento, que fixavam coeficientes de aproveitamento para cada zona de uso definida, o PUB estabeleceu uma variação mais complexa dentro de cada zona, vinculada ao tamanho da parcela do solo, sendo admitida, além da mistura de usos e tipologias, o uso residencial em todas as zonas. Para a proposta de zoneamento foram definidas 13 categorias de uso e 10 zonas (Feldman, 1994, 146).

A maior flexibilização construtiva e funcional, até na mesma construção, implicava em controles mais rígidos de parâmetros urbanísticos na ocupação dos lotes, para os seus recuos, gabaritos, áreas livres e áreas arborizadas. Por outro lado, foram propostos índices de aproveitamento superiores aos praticados até então: 7 para usos residenciais e serviços e 10 para garagens verticais, se estas últimas fossem construídas praticamente isoladas no lote, dado os recuos exigidos (idem, $147,148)$

As propostas de construção de um novo sistema viário e de transportes direcionaram-se a:

- Expansão do sistema de transportes de passageiros por trilhos (Metrô), de $66 \mathrm{~km}$ para $450 \mathrm{~km}$, utilizando $185 \mathrm{Km}$ das faixas de domínio das ferrovias de modo a atender $40 \%$ dos passageiros que utilizavam transportes coletivos. Esse sistema deveria estabelecer ligações entre sub-centros regionais propostos e deles com o Centro. 
- Construção de sistema de vias expressas com 388 Km no interior do Município de São Paulo (815 Km contando com a Região Metropolitana). Esse sistema previa ainda a adoção de controle de fluxo e deveria atender $55 \%$ do tráfego total, ocupando 5\% da área urbana (ibidem, 29).

Para o Centro metropolitano, considerado do rio Tietê à avenida Paulista, o Plano destacou a necessidade da regulamentação pormenorizada do uso do solo, além do detalhamento das linhas e estações do Metrô e da circulação dos ônibus e pedestres, incluindo a localização de estacionamentos e de terminais. Ao norte da área central estava prevista a localização do Centro Administrativo Municipal, nas proximidades do rio Tietê, no bairro da Ponte Pequena.

Para as áreas de alta e média densidades, entre os rios Tietê e Pinheiros, o Plano previa transformações decorrentes da construção do Metrô e do sistema viário, sendo necessário também, um planejamento em conjunto com aquele da área central. Essa área incluía os principais corredores de atividades múltiplas, sendo aquele julgado mais importante, o do espigão divisor de águas entre os rios e onde estava situada a avenida Paulista. Para ele, o Plano propunha uma regulamentação especial a ser desenvolvida, com ênfase em seus aspectos paisagísticos.

No vale do rio Tietê, a também necessária proteção paisagística e do prosseguimento das obras de retificação da sua calha, associaram um plano de uso do solo voltado à sub-utilização das áreas, à relevância de sua posição central e aos equipamentos propostos.

Um aspecto já proposto pela SAGMACS era o do planejamento distrital como complementar às escalas metropolitana e municipal, que seguindo o proposto pelo Plano, se estenderia também "ao nível das unidades de vida em que a cidade pode ser decomposta". A subdivisão regional já existente serviria de limites ao planejamento detalhado de cada área (fora da delimitação daquelas de alta e média densidades já mencionadas), para as quais foi recomendada também a criação de conselhos de representantes sob a presidência do administrador regional $^{5}$. O planejamento distrital deveria desenvolver a regulamentação do solo, a localização de equipamentos sociais e do traçado do sistema viário arterial e local e o conselho de representantes teria a finalidade de assessoramento dos planos distritais, que seriam realizados por um proposto Escritório Municipal de Planejamento (op. cit, pag 128, 129).

Como se depreende pelo exposto, o PUB considerou como essencial a existência do planejamento urbano a longo prazo e propôs uma minuta de projeto de lei do Plano Diretor de Desenvolvimento Integrado. Assim como a proposta de Plano Diretor de 1961 associou os estudos da SAGMACS (incorporadas também pelo PUB no que se referiu às unidades territoriais), o Plano Diretor de 
Desenvolvimento Integrado se constituiu na formalização do PUB em lei (Sócrates, 1993, 261).

Assim sendo, em 1971 o PDDI foi instituído e incorporou as diretrizes do PUB, dando continuidade à proposta do sistema de vias expressas, uso do solo, controle da polvição ambiental, circulação, transportes e incentivos ao desenvolvimento urbano, assumindo uma associação de plano viário com zoneamento,como modelo de plano, segundo as análises de Feldman e Yoshioka (Felman, 1994, 153; Yoshioka apud Sócrates, 1993, 18).

Entretanto, o PDDI não foi uma simples continuação do Plano anterior, pois em seu desenvolvimento constaram aspectos diferenciados do ponto de vista conceitual e concretos, afastando-se do PUB em relação ao seu elemento mais importante, a estruturação urbana a partir dos elementos de infra-estrutura viária e de transportes, apesar de a princípio admiti-los.

Essencialmente o PDDI utilizou uma hierarquização do sistema viário, articulando uma complementaridade entre as zonas, equipamentos e serviços, áreas verdes, etc. Partiu, portanto, da proposta de divisão da cidade em módulos com cerca de $9 \mathrm{Km}^{2}$ que se constituiriam em unidades com certa auto-suficiência no tocante à moradia, trabalho, cultura, lazer e atividades administrativas. Segundo os seus defensores, esses bolsões ou zonas não se caracterizariam apenas por uma consolidação das situações urbanas existentes, no interior de cada uma, mas nas mesmas seria aplicada uma normatização e uma disciplina de uso do solo de modo a tornar a cidade mais organizada, eficiente e humana (Feldman, 1994, 163; Sócrates, 1993, 276).

Entretanto, como mostram as análises sobre o PDDI, este se fundamentou na malha viária proposta para romper a estrutura radio-concêntrica da cidade, com a diferença de que a mesma poderia ser implantada ao longo do tempo, pois as áreas de seu percurso encontrar-se-iam preservadas pelas normas do zoneamento. Por não serem imprescindíveis, as vias expressas poderiam ser substituídas por arteriais, com a mesma disposição ortogonal e com funções relativas à ligação metropolitana, estruturação urbana e expansão periférica. (Sócrates, 1993, 277).

Considerando a delimitação deste trabalho de tese à análise dos aspectos propositivos dos planos, relacionados à infra-estrutura e do uso do solo (normatização do parcelamento e tipos de edificação), inúmeros autores e trabalhos da Secretaria de Planejamento apontam os motivos do PDDI não ter logrado concretizar os padrões de circulação e transportes propostos. À semelhança do PUB, a elaboração e aprovação do Plano se deu em meio ao clima de ufanismo do "milagre econômico", desconsiderando os custos de implantação da rede viária e descolado da prática imposta à cidade pelo mercado imobiliário formal e informal ${ }^{6}$. Outro motivo, a crise de petróleo de 1974, se 
constituiu em argumento para forte contestação (técnica, bem entendido) à proposta da malha de vias expressas, gerando uma expectativa em relação ao transporte público, que também não se efetivou (Osello, 1983; Sócrates, 1993; Feldman, 1994).

Ainda em 1973, um documento da Secretaria Municipal de Transportes analisou a baixa mobilidade da população, comparada à de outras cidades do mundo, causada pela precariedade dos modos existentes, pela concentração de atividades originadas da estrutura urbana e pelo subdimensionamento do sistema viário, propondo para um horizonte de vinte anos, a reestruturação da circulação baseada na integração de modos, desestímulo ao transporte individual e reserva de faixas ao longo da malha viária, a fim de garantir as necessárias ampliações, como é explicado pela citação a seguir:

"Através dos conhecimentos que se dispõe e das experiências em outros países, este sistema viário deve ser dimensionado de modo a exigir uma reserva de área compatível com as características da cidade.

Outro elemento do novo sistema deverá ser o desestímulo ao transporte individual, favorecendo o aparecimento de novos tipos de transporte rápido em massa, como melhor alternativa para as viagens urbanas.

A importante atividade-meio, que é o transporte, deve ser desenvolvida sobre a infra-estrutura de um sistema adequado de vias expressas e arteriais, de vias de distribuição e locais, complementadas com um sistema de transporte coletivo integrado. Por fim, harmonizando o transporte individual e o de carga com esses sistemas, obteremos o equilíbrio que assegurará o perfeito desempenho desta função urbana (SMT, 1973, s/paginação).

Para a obtenção dos objetivos expressos, a estrutura viária proposta seguiu aquela desenvolvida pelo PUB, articulada com o plano do Pequeno Anel Rodoviário e considerada complementar ao Metrô e ferrovias (idem, s/pag.)

Analisando os resultados concretos das propostas do PDDI para circulação e transportes, um estudo da Secretaria Municipal de Planejamento considerou a enorme redução de suas componentes, conforme expresso na citação a seguir, reproduzida por se tratar de uma análise conclusiva sobre a questão:

"As propostas técnicas de transporte urbano sobre trilhos e sobre pneus já haviam se confrontado na década de 1930, tendo vencido o pneu com o Plano de Avenidas de Prestes Maia. Na intensa atividade de planejamento, do final da década de 60 , início da de 1970, as grandes alternativas se confrontavam novamente. $O$ PUB (1968) propunha uma extensa rede de Metrô de 650 Km como novo elemento estruturador do transporte metropolitano; o Projeto DERMU, por sua vez, preconizava uma rede composta de malha quadrada, de $4 \mathrm{Km}$ de lado, de vias expressas, totalizando cerca de $400 \mathrm{Km}$ de extensão. Desta vez, porém, não houve vencedor nem vencido. Nenhuma das alternativas chegou a eliminar a 
outra, senão que ambas foram reduzidas a tal ponto que, em conjunto, reproduziram e mesmo aumentaram o nível de carência em infra-estrutura viária e de transportes, após um período inicial de algum alívio e uma tímida reestruturação da aglomeração metropolitana.

Essencialmente, o que foi implantado em 20 anos, desde 1970, é um embrião de ambos os projetos. Do Metrô, uma "rede" mínima, com $45 \mathrm{Km}$, composta de duas linhas em cruz; do sistema de vias expressas, apenas as Marginais do Tietê e do Pinheiros e a Avenida 23 de Maio, se não considerarmos a Radial Leste e avenida dos Bandeirantes" (Sempla, 1990, 154)

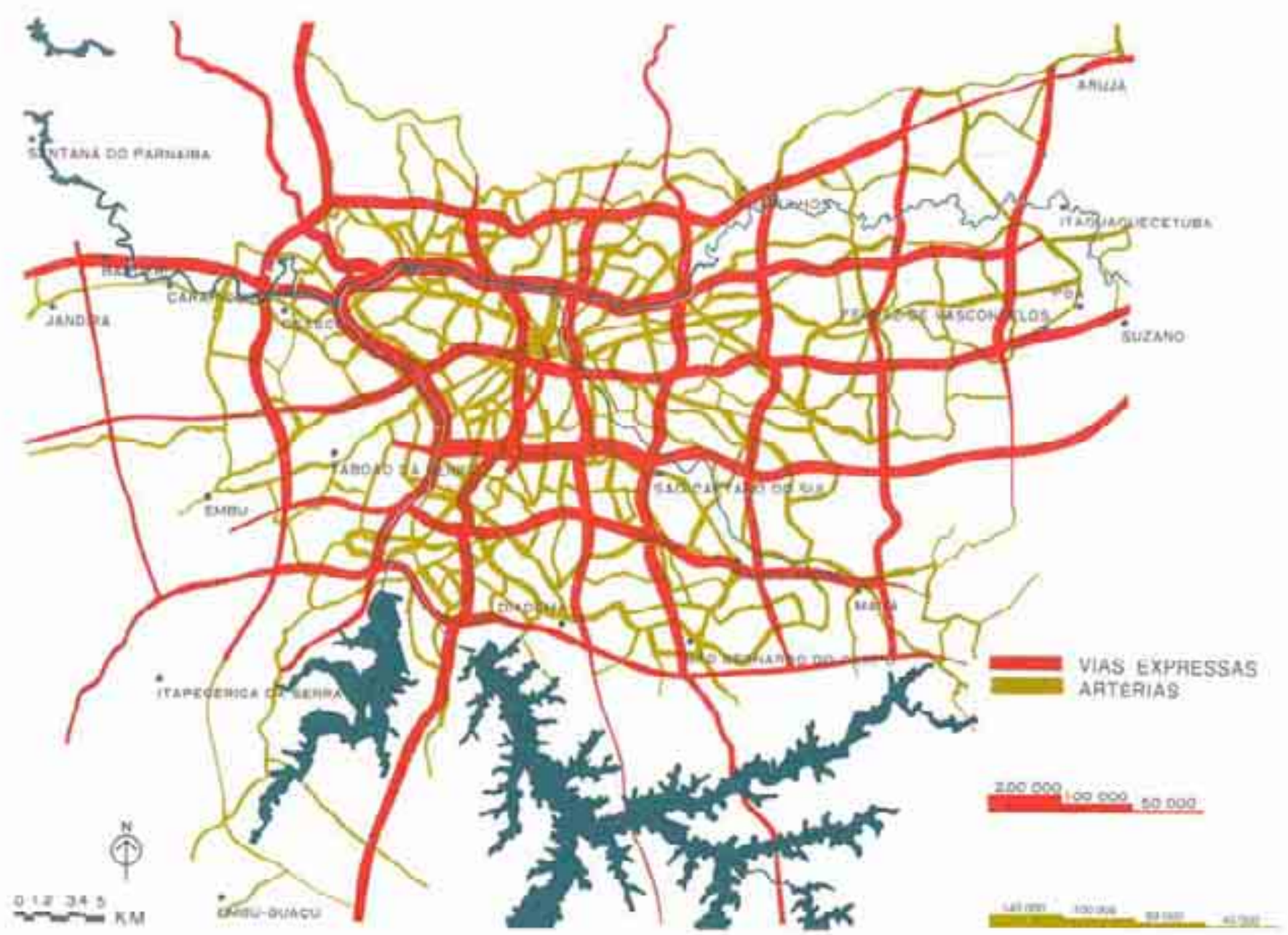

VOLUMES DAS RODOVIAS NA CAPACIDADE DO SISTEMA - 1900

Fig. 74: Vias expressas e artérias - PUB 


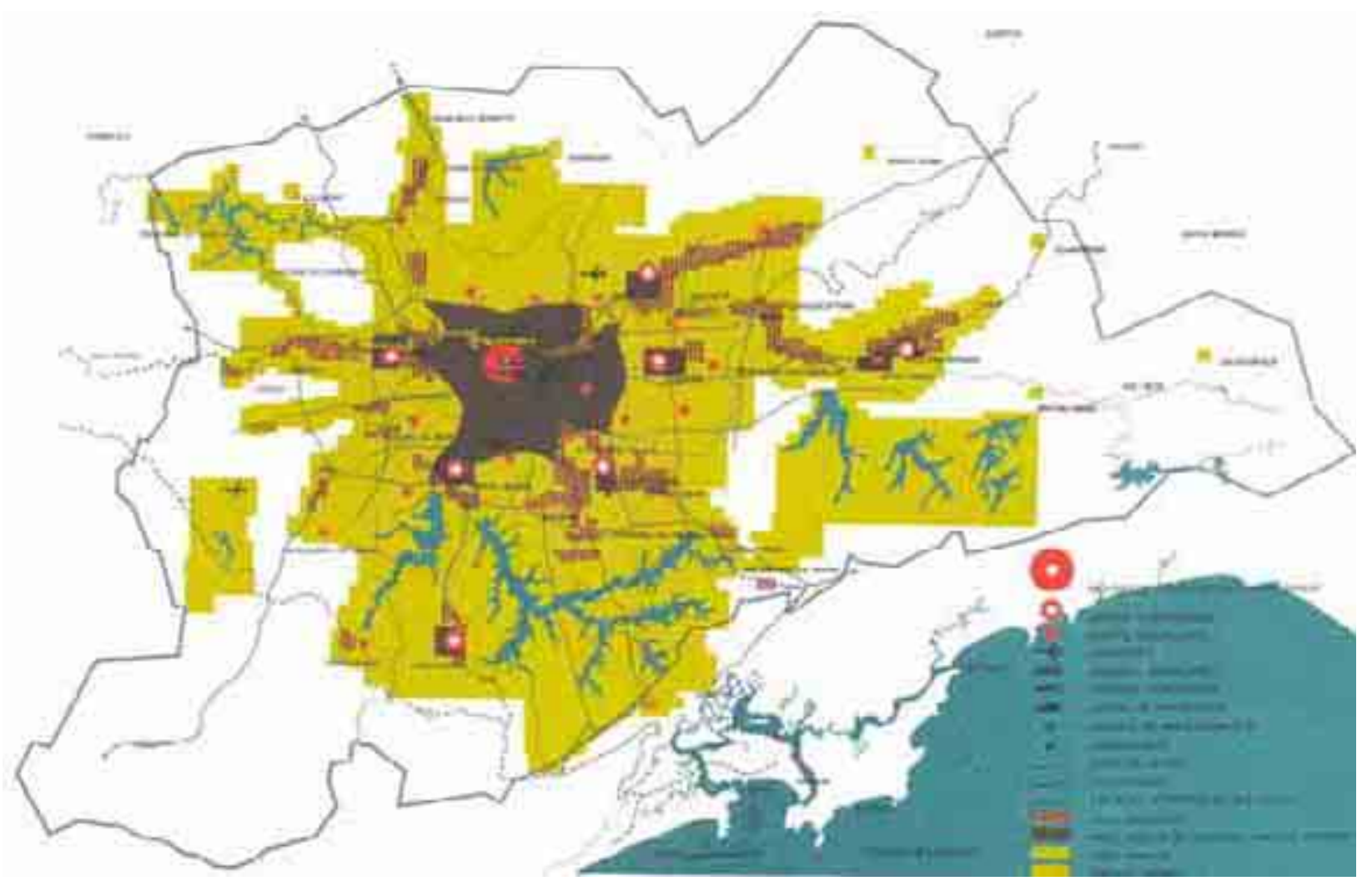

Fig. 75: Hipótese de estrutura metropolitana, 1990

Se as propostas do PUB E PDDI relacionadas à estrutura urbana não foram efetivadas da forma proposta pelos mesmos, o resultado do longo processo de propostas urbanísticas foi a normatização de uso e ocupação do solo representada pela Lei de Zoneamento da Cidade de São Paulo 7 . Segundo a análise de Feldman em relação ao papel desempenhado pelo zoneamento, este passou a substituir o plano urbanístico através da inclusão de um modelo de organização da cidade e do atendimento de demandas dos espaços mais valorizados da cidade (idem, 8).

Convergindo também à tese da autonomia que zoneamento ganhou em relação ao PDDI, outra análise mostra que apesar da predominância dos aspectos normativos sobre todos os outros propostos pelo Plano Diretor, o zoneamento se consolidou como o mais importante instrumento urbanístico já estabelecido para a cidade, absorvendo os seguintes objetivos:

1. Assegurar a reserva e destinação dos espaços necessários ao desenvolvimento das atividades urbanas em localizações adequadas.

2. Assegurar, através do controle do uso e ocupação do solo, a concentração equilibrada de atividades e da população no território do município.

3. Orientar e estimular o desenvolvimento urbano (Sócrates, 1993, 105; Zoneamento, 1978, 1). 
O zoneamento utilizou para a definição dos tipos de zonas em que a cidade foi dividida, uma relação das categorias de uso com o sistema viário existente e a malha viária proposta pelo PDDI, a hierarquização dessas vias, os vários tipos de usos existentes, bem como sua ocupação, a infra-estrutura e equipamentos sociais, taxas de ocupação, recuos, densidades, etc.. Processados por computadores, os dados serviram para constituir um mapeamento de uso por quadras, associado ao cadastro de rendas imobiliárias, onde o valor venal de cada lote se encontrava fixado. Através desse cruzamento de informações sobre a situação existente, o perímetro de cada zona foi fixado, obedecendo aos parâmetros de predominância de uso, da densidade populacional e dos coeficientes de aproveitamento também predominantes (Sócrates, op. cit, 112/ 116).

É importante frisar a profundidade das pesquisas que embasaram a proposta de zoneamento, pois as mesmas foram desenvolvidas utilizando informações vinculadas à escala dos lotes, agregados em quadras ${ }^{8}$. Para cada quadra, pesquisou-se a área bruta, área e porcentagem de ocupação, quantidade de casas e prédios, alem das áreas vazias. Os usos da área construída foram especificados em porcentagens para residências, edifícios, comércio, serviços, indústria, equipamentos, etc. No tocante ao uso residencial, até mesmo a quantidade e área de residências coletivas e cortiços foram detalhados (idem, 116).

Chegou-se assim a uma divisão da cidade em zonas com perímetros delimitados, abrangendo todo o município, com o objetivo de estabelecer o equilíbrio entre as funções urbanas de habitação, trabalho, circulação e lazer. A caracterização dessas zonas obedeceu os seguintes critérios:

1. Manutenção das situações existentes de uso e ocupação do solo, estruturadas ao longo do tempo.

2. Demarcação de faixas de alta e baixa densidades em função de diretrizes do PDDI para as vias expressas, transportes coletivos, pólos e corredores de atividades.

3. Vinculação da localização de futuros pólos regionais ou expansão dos existentes com a oferta de circulação e transportes, observando a disponibilidade de espaços para as funções urbanas e tendências para o setor de comércio e serviços.

4. Delimitação das áreas industriais a partir das diretrizes e estudos setoriais do PDDI.

5. Delimitação dos perímetros obedecendo a elementos físicos existentes, tais como vias de circulação, espaços livres, cursos d'água, etc, como forma de evitar a divisão de uma mesma quadra em zonas diferentes.

A primeira lei do zoneamento da cidade caracterizou oito tipos de zonas: 
Z1 - uso estritamente residencial, com densidade demográfica baixa

Z2 - uso predominantemente residencial, com densidade demográfica baixa

Z3 - uso predominantemente residencial, com densidade demográfica média

Z4 - uso misto, com densidade demográfica média e alta

Z5 - uso misto, com densidade demográfica alta

Z6 - uso predominantemente industrial

Z7 - uso estritamente industrial

Z8 - usos especiais (Zoneamento, 1978, 4)

Para cada zona, as categorias de uso foram enquadradas em padrões de conformidade e não conformidade, existindo ainda padrões de tolerância e de adequação para os mesmos. Essas categorias encontravam-se concebidas em linhas gerais já nos planos da década de 1950 e 1960. Até 1980 várias alterações foram incorporadas ao zoneamento, criando zonas para corredores de uso especial, zonas de proteção dos mananciais e zonas de transição entre as áreas mistas e as estritamente residenciais. Nesta última alteração, foram criadas as zonas 17 e 18, nas áreas junto às Z1, a fim de definir uma gradação de uso e intensidade de ocupação do solo, mas que na realidade proporcionou uma nova oportunidade para a verticalização do entorno das áreas residenciais de alto padrão.

Além das normas voltadas à ocupação das áreas consolidadas, o zoneamento dispôs também sobre o parcelamento de zonas consideradas de expansão urbana, definindo uma série de exigências à abertura e aprovação de loteamentos.

A vinculação do parcelamento do solo com a Lei de Zoneamento foi um dos aspectos de diferenciação do PDDI com os planos. Entretanto, o maior rigor da legislação e sua vinculação a uma proposta de estrutura urbana polinucleada e com menor intensidade de crescimento centrífugo, concepções já presentes na SAGMACS e no PUB, não impediu a continuidade do parcelamento indiscriminado das áreas periféricas da cidade.

Outro ponto do PDDI em relação à aglomeração urbana que merece destaque, foi a redução do coeficiente de aproveitamento 6 para 4, e a não inclusão como área construída dos espaços sob pilotis e garagens de edifícios desde que não excedessem duas vezes a área do lote . O rebaixamento do coeficiente não impedia, entretanto, a construção dos edifícios cuja licença se encontrava em andamento, sujeitando-os aos critérios anteriores dessa legislação (Feldman, 1994, 154; Souza, 1994, 234; Sócrates, 1993, 129). Ao não incluir as garagens como área construída, na prática, a Lei liberou a construção desses espaços 
vinculados ao programa dos edifícios de classe média, que já contava com altos índices de motorização na década de 1970.

Como foi abordado no início deste capítulo, os dois planos, PUB e PDDI, não alteraram a dinâmica que a cidade apresentava, dirigida pelo mercado imobiliário. O parcelamento extensivo da periferia urbana, para finalidade de habitação de baixa renda e a concentração de atividades no centro expandido tiveram continuidade, apesar da existência da legislação promulgada e de diretrizes que, em pouco tempo, foram abandonadas. Como exemplo podem ser mencionadas as ambiciosas propostas para a rede de circulação e transportes, a nucleação modulada da cidade, a proteção aos ambientes frágeis, como os mananciais e a Serra da Cantareira, as diretrizes voltadas às margens dos rios Tietê e Pinheiros e a proposta do Centro Administrativo ao norte da área central, existente desde o Relatório de Planejamento de 1961 e também incorporado pelo PUB.

Por sua vez, as conseqüências da Lei de Zoneamento sobre a estruturação da cidade, e em particular dos bairros centrais abordados neste trabalho, foram relevantes no que se referiu à consagração dos usos e ocupações já existentes, uma vez que admitiu para a extensa zona mista que caracterizou as zonas Z2, a nucleação das indústrias, galpões e armazéns dos bairros do Bom Retiro, Pari e Brás, que como veremos adiante, se tornou em um dos fatores que fortaleceu 0 afastamento da população moradora, conforme o Quadro 9 mostrou. 


\subsection{Cidade real: Transformações ao longo das radiais do Plano de Avenidas.}

Após terem sido examinados os planos urbanísticos nas suas propostas que visaram alterar a infra-estrutura e o uso e ocupação do solo da cidade, o capítulo presente analisa as transformações reais que ocorreram entre as décadas de 1930 e 1970 em algumas das radiais componentes do Plano de Avenidas, relacionadas com o conjunto de bairros abrangidos por este trabalho.

Vale lembrar que o Plano de Avenidas definiu um vetor para o crescimento do centro, como foi explicado pelo próprio Prestes Maia na exposição do Plano: "É o tabuleiro de Sta. Efigênia ou, melhor, toda a zona que se estende além do Anhangabaú, da Luz ao Arouche e mesmo á Consolação. Vasto, plano, com facilidades de comunicação em todas as direções (condição indispensável a um centro) e com facilidades de contato com o centro atual (condição para a transfusão da vida comercial), apresenta os requisitos necessários para constituir a principal zona de expansão do centro"(grifo do autor) (Maia, op cit, 53).

As avenidas foram divididas em sub-setores correspondentes a áreas com características diferenciadas e foram considerados como limites nos mapas SARABrasil, de 1930, VASP, de 1954 e Gegran, de 1972, aqueles definidos pela atual divisão distrital da cidade.

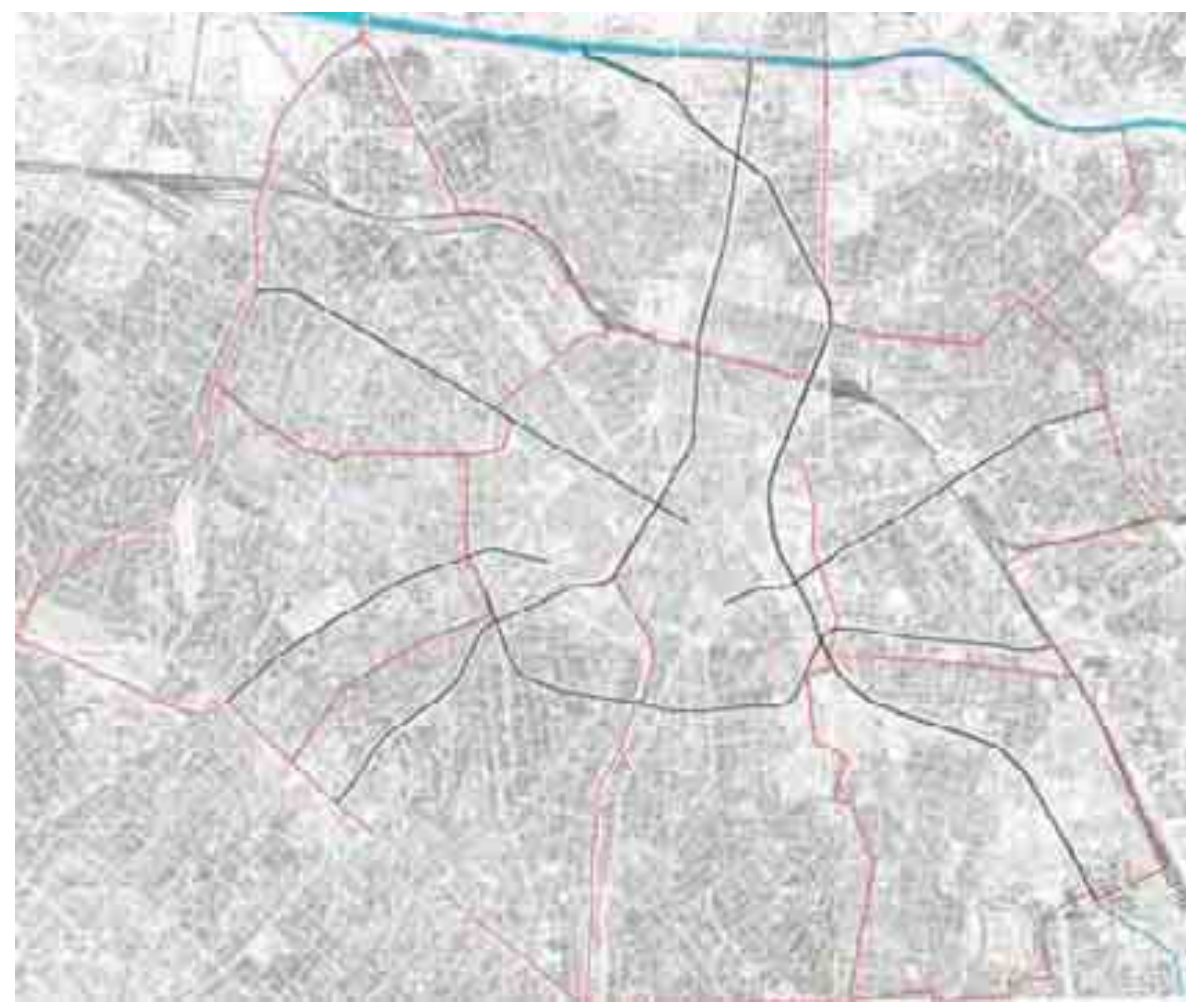

Fig. 76: Os traçados em preto correspondem aos elementos viários estudados no mapa GEGRAM 


\subsection{1 - Componentes do Sistema Norte-Sul: Avenidas Nove de Julho, Prestes Maia e Tiradentes}

O viário analisado inclui o sistema " $y$ " constante no Plano de Avenidas, as avenidas Anhangabaú (superior e inferior), futuras Nove de Julho e Prestes Maia e as avenidas Tiradentes-Santos Dumont:

Sub-setor 1 - Corresponde à extensão da avenida Nove de Julho, do túnel sob a avenida Paulista até o Viaduto do Chá, entendido este como um limite da área do centro com os bairros ao sul.

Na década de 1930 verificou-se o adensamento do bairro do Bexiga e a ligação do centro com os bairros-jardim através da avenida que ainda recebia o nome de Anhangabaú. As primeiras desapropriações e as obras dessa avenida tiveram início em 1920, na gestão de Pires do Rio, configurando-se nos planos iniciais como uma avenida-parque até a Paulista, superando inicialmente esta última através de rampas. Apenas em 1933 as obras foram retomadas, na gestão de Fábio Prado e concluídas por Prestes Maia em 1941, iá com o nome de Nove de Julho (Porto, 1996, 124).

O túnel sob o espigão da avenida Paulista foi inaugurado em 1938. Segundo Bosetti, no final dos anos 1940 surgiram os primeiros edifícios na avenida Nove de Julho e durante as décadas de 1950 e 60, cerca de 69\% dos prédios foram construídos, com grande contraste entre a verticalização nessa via e o interior do bairro do Bexiga. Definiu-se a vocação residencial ao longo da Nove de Julho, com a oferta de prédios de moradias baratas, destinadas ao aluguel ou venda. Nas décadas de 1970 e 80 passou a ocorrer estagnação devido à diminuição de lotes desocupados (Bosetti apud Sampaio, org, 2002, 85).

Sub-setor 2 - do Viaduto do Chá até os trilhos da ferrovia, na Estação da Luz.

Sub-setor 3 - Da ferrovia até o rio Tietê.

1 - O mapa de 1930 mostra a avenida Nove de Julho, ainda com sua denominação anterior, sem ocupação em todo o trecho correspondente à atual Praça 14 Bis, que se chamava Praça São Manuel, até o espigão da avenida Paulista. Apenas na altura da confluência com a rua Rocha (ref.1), percebe-se uma concentração de edificações. Da Praça até o Largo da Memória, percebese os fundos de lotes da ocupação da rua Santo Antônio (ref. 2) e do outro lado, a rua Avanhandava mostrando o traçado sinuoso que Bouvard definiu para $\circ$ viário do primeiro loteamento da Cia. City (ref. 3).

No mapa de 1954, elaborado a partir de vôo de 1954, com o atual traçado já definido e o túnel executado (ref. 4), percebe-se que os taludes provenientes do corte da avenida Nove de Julho ainda se encontravam sem ocupação até a Praça 14 Bis (ref. 1), para daí em diante se verificar um parcelamento de grandes lotes e a ocupação por edifícios lindeiros à Avenida. A área da rua Avanhandava 


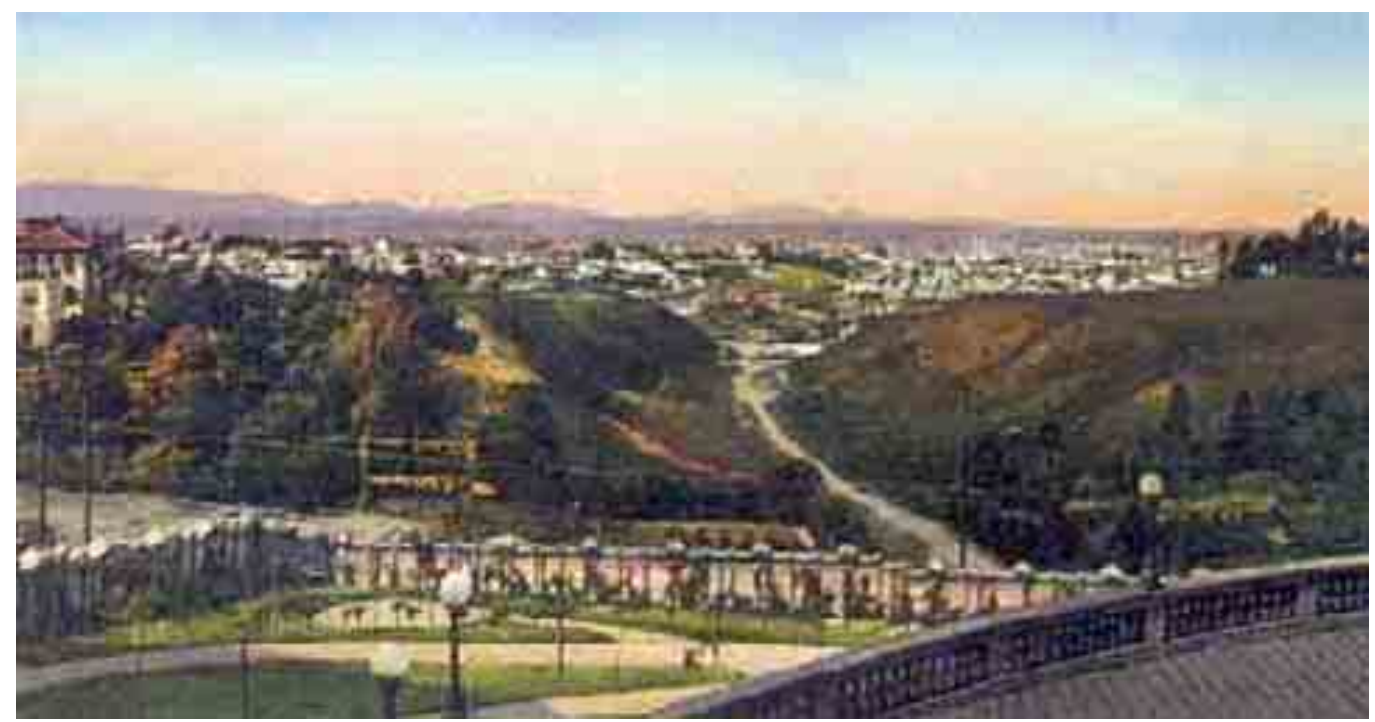

Fig. 77: Vista da Av. Anhangabaú, futura Nove de Julho, à partir do Parque Trianon, 1920.

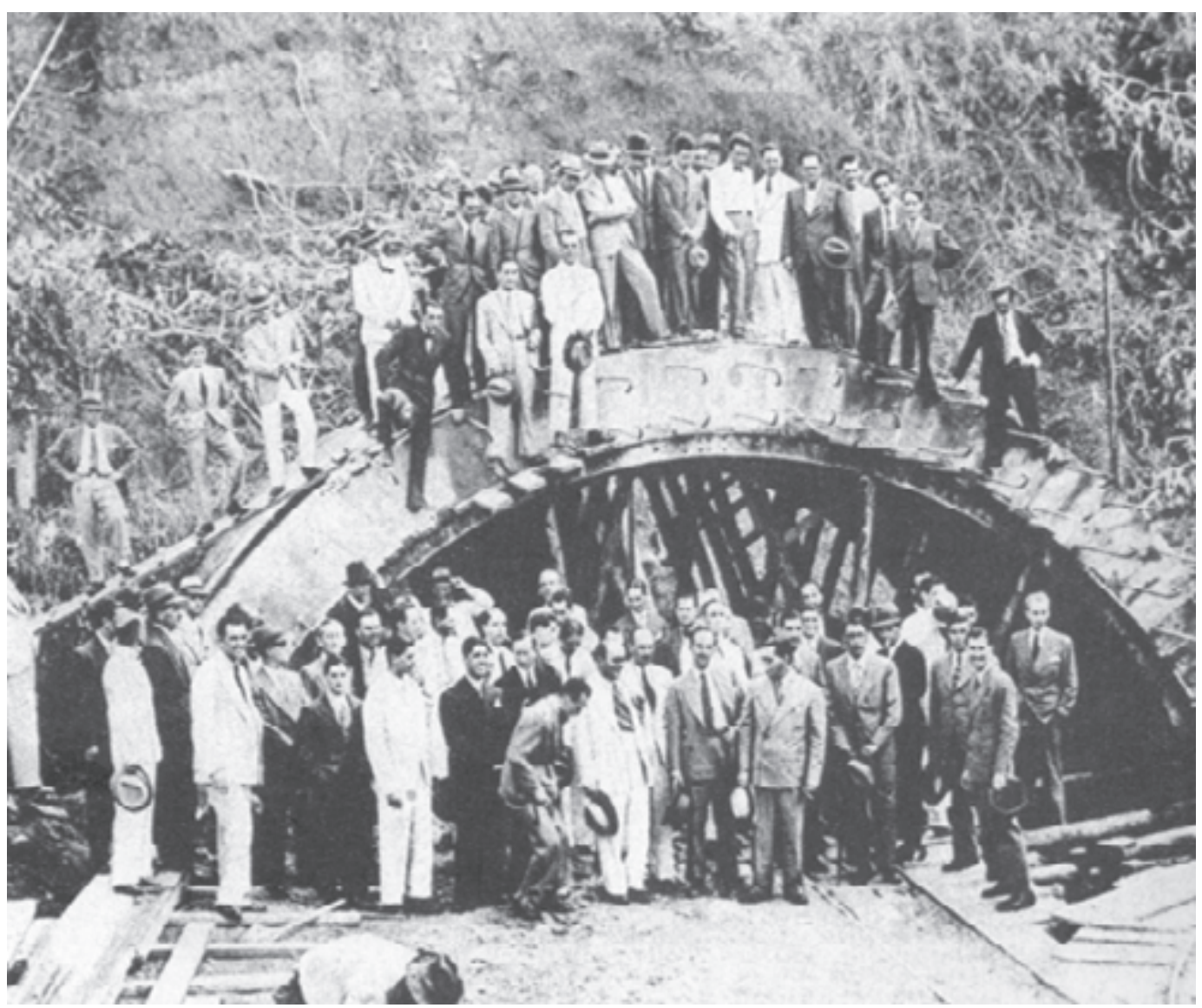

Fig. 78: Construção do Tunel 9 de Julho, década de 1930. 
Fig. 79: Praça 14 Bis, década de 1950 .

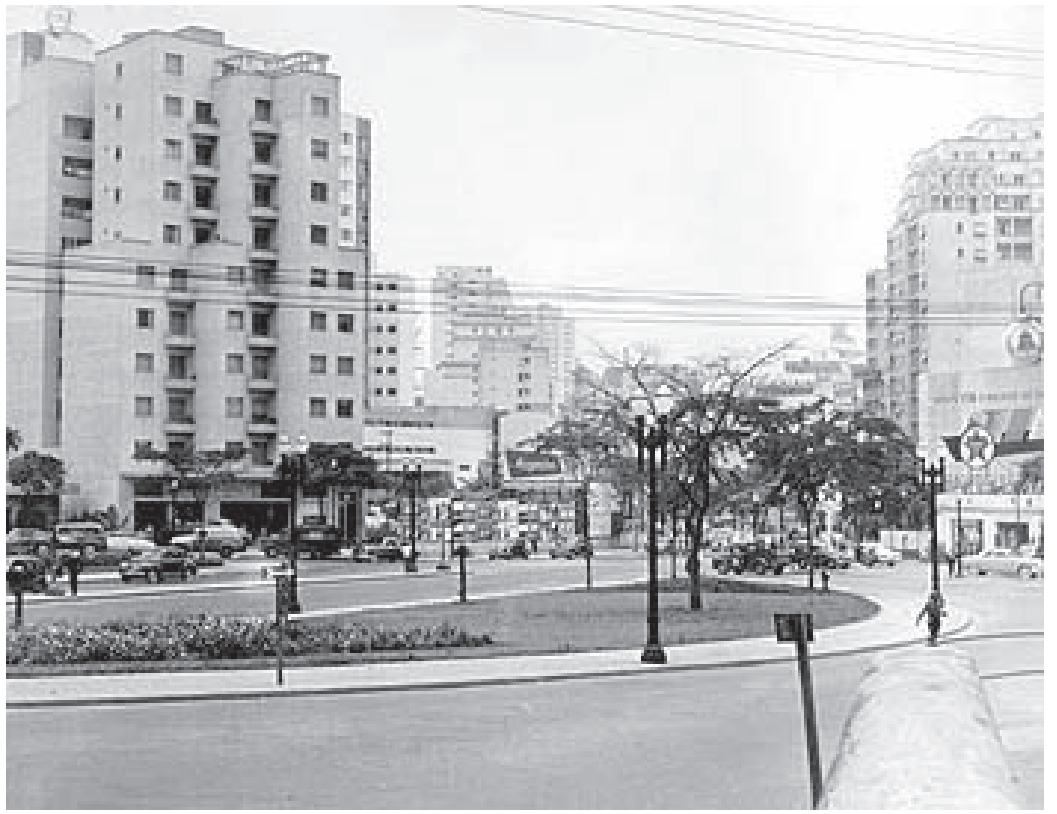

já se mostrava edificada e é possível notar também a mudança do parcelamento e da ocupação no entorno da Praça das Bandeiras e Largo da Memória, indicativas da verticalização da área central.

No mapa de 1972, toda a extensão da avenida Nove de Julho já havia sido ocupada por edifícios, no Vale do Anhangabaú e implantado também o elevado sobre a Praça 14 Bis (ref. 5) e junto ao centro, o viaduto sobre a avenida 23 de Maio (ref. 6).

2. Esse sub-setor mostra uma das principais transformações viárias do Plano de Avenidas, que foi a abertura da ligação do Parque do Anhangabaú com a avenida Tiradentes. Pelo mapa de 1930 verifica-se ainda existir o paisagismo definido pelo projeto de Bouvard para o Vale e a ligação deste com a região da Estação da Luz se fazendo pelas ruas da Conceição, futura Cásper Líbero (ref. 7), Brigadeiro Tobias (ref. 8) e Florêncio de Abreu (ref. 9), com esta última estabelecendo a ligação Norte-Sul pelo interior do Triângulo. A rua Anhangabaú (ref. 10), que foi incorporada em parte pela futura avenida de ligação com o Norte, dirigia-se à região do Parque Dom Pedro II. As edificações ainda existentes naquela quadra são remanescentes desse período, como indica a foto da ampliação da via.

O mapa de 1954 mostra o Vale do Anhangabaú já alterado pela retificação de traçado e implantação de passagem subterrânea sob a avenida São João (ref. 11), implantados respectivamente por Prestes Maia e Ademar de Barros. A avenida Anhangabaú, também implantada, apresentava considerável mudança no parcelamento, que indica a verticalização de algumas faces de quadra ao longo do eixo viário. Outra componente do Plano de Avenidas, a Senador Queirós (ref. 12), também já havia sido ampliada, percebendo-se a ocupação vertical denunciada pelos grandes lotes ao longo de seu percurso. A passagem 


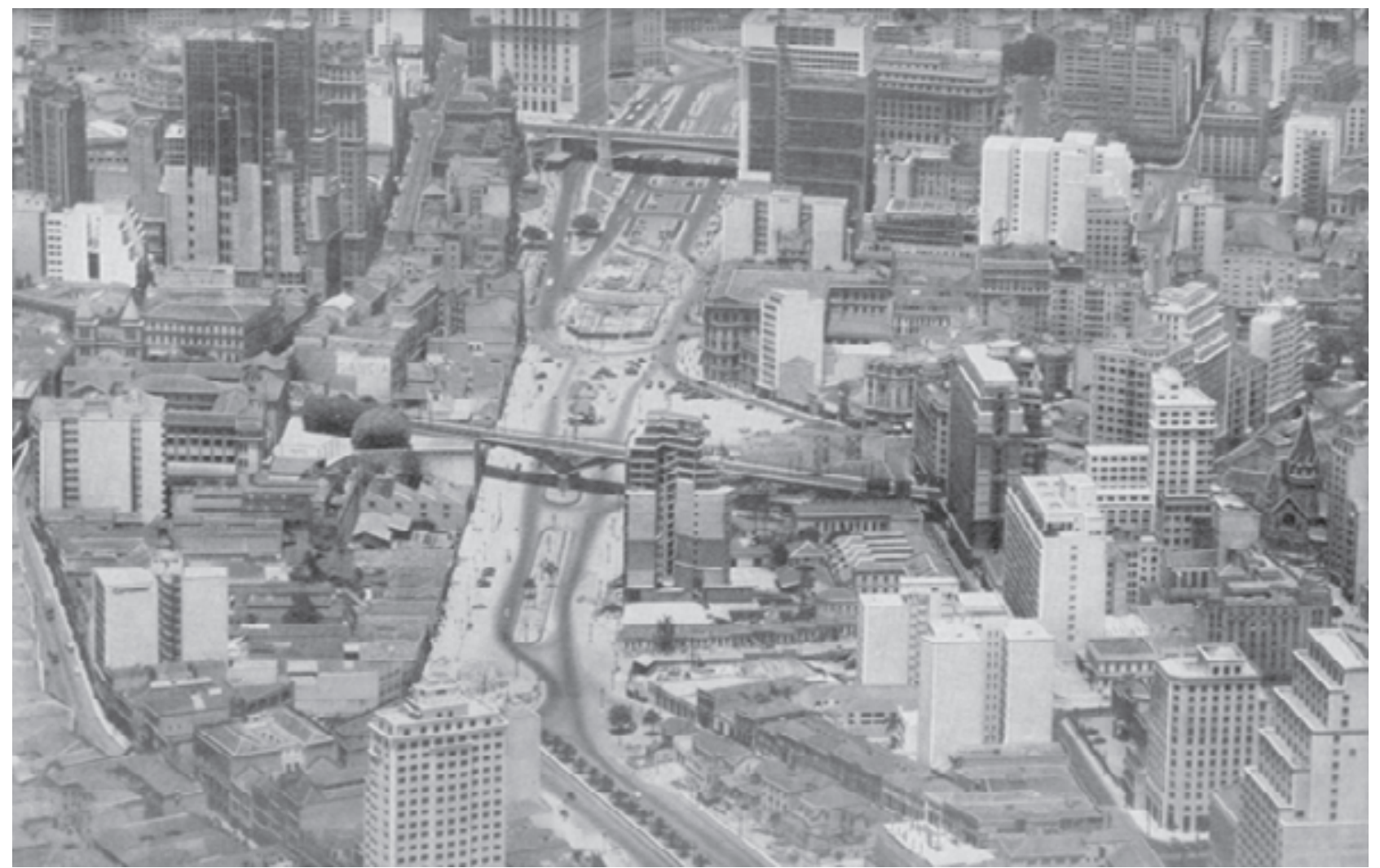

Fig. 80: Transformaçãoes viárias: Alargamento da Avenida Anhangabaú, futura Prestes Maia.

subterrânea da avenida Anhangabaú sob a Senador Queirós, que havia sido prevista naquele Plano, não foi executada.

O mapa de 1972 mostra a existência das obras do Metrô ao longo da avenida Prestes Maia (ref. 13), denominação definitiva da avenida Anhangabaú. A ocupação revela mudanças ao longo do seu percurso, com a alteração das faces de quadra, indicando a verticalização que ocorreu também na avenida Senador Queirós.

3 - Pelo mapa de 1930, o trecho da avenida Tiradentes mostra essa via com seu traçado antigo, anterior a sua conexão com a Santos Dumont. Ocorria um estreitamento a partir das ruas Bandeirantes e Rodrigo de Barros (ref. 14) e nas proximidades da avenida Tamanduateí, existia a Praça José Roberto ladeada pela rua Itaporanga (ref. 15). Após vencer o rio Tamanduateí, a avenida se estreitava novamente, chegando até a Ponte Grande (ref. 16), que conectava a Tiradentes à avenida Voluntários da Pátria, em Santana. Junto da Ponte Grande, verificava-se a existência da Praça dos Esportes, ladeada também pela continuidade da rua ltaporanga (ref. 17).

O mapa de 1954 mostra o traçado da via já alterado, conectada à avenida Santos Dumont (ref. 18), aberta por ocasião da inauguração da Ponte das 


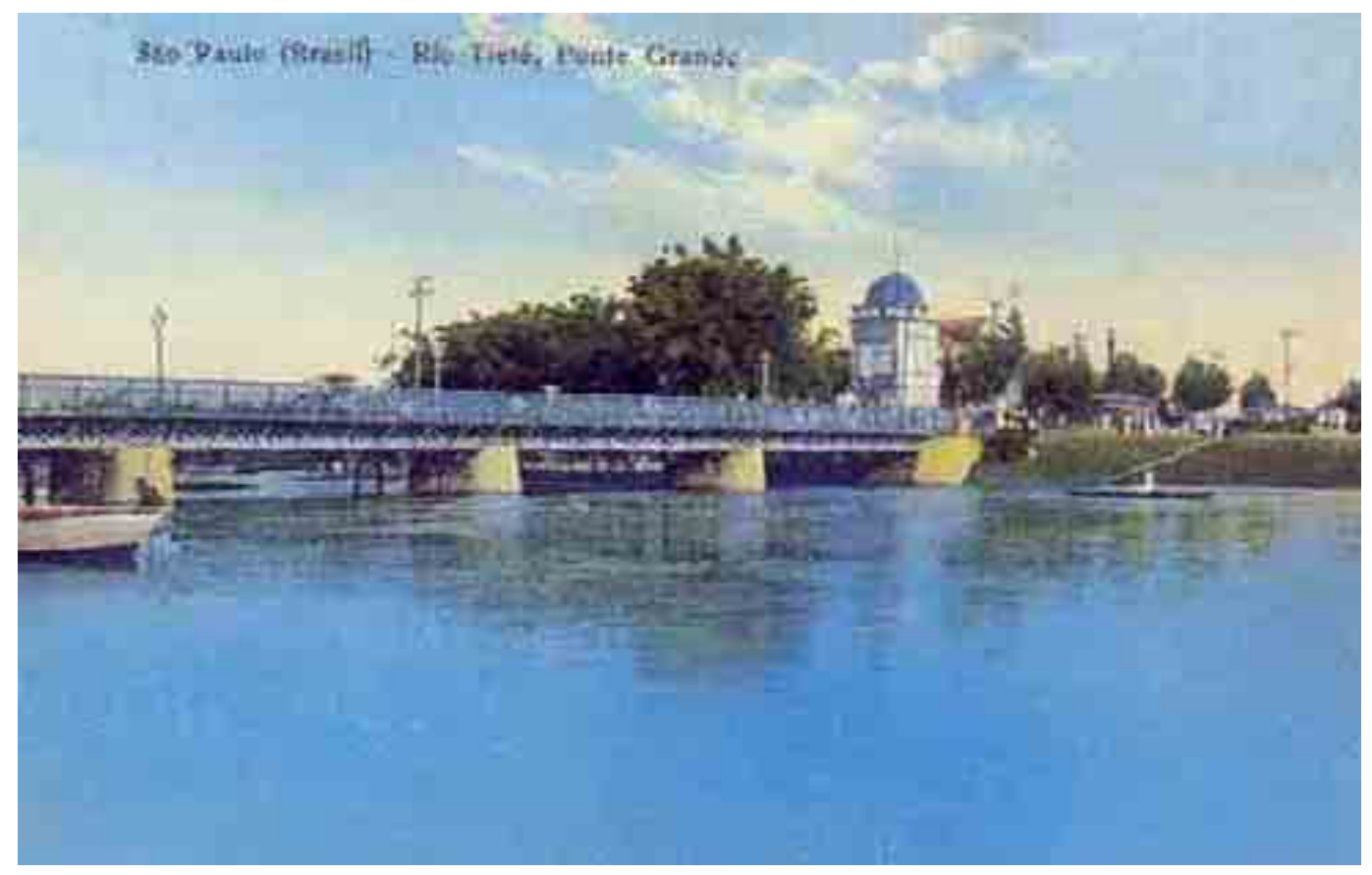

Fig. 81: Ponte Grande em um Cartão Postal

Bandeiras em 1942. O novo traçado incorporou a rua ltaporanga antes e depois de vencer a avenida dos Estados e o rio Tamanduateí, sobre nova ponte. Dessa forma, a Praça José Roberto ficou situada entre as avenidas Santos Dumont e Tiradentes ref. 19). $\bigcirc$ trecho entre o rios Tamaduateí e o Tietê mostra o novo traçado, com a ponte das Bandeiras situada a jusante da antiga Ponte Grande (ref. 20). Mesmo com essa ampliação, não se verifica a transformação do parcelamento ao longo das vias, em relação à década de 1930.

O mapa de 1972 revela um reordenamento do parcelamento em determinadas quadras, principalmente entre a rua Bandeirantes e a avenida dos Estados. Nessa altura, a passagem do Metrô mostra a vala aberta defronte ao trecho da Pinacoteca do Estado (ref. 21) e a transformação da Praça José Roberto em canteiro de obras. A estação do Metrô em elevado sobre o rio Tamanduateí e sua extensão na Ponte Pequena, em direção a avenida Cruzeiro do Sul, são outras transformações já concluídas (ref. 22). A estação denominada Ponte Pequena, passou a ser conhecida como Armênia, assim como a antiga Praça José Roberto, novamente reconfigurada pelo Metrô. No trecho entre os rios Tamanduateí e Tietê, a Ponte das Bandeiras passou a superar também a avenida marginal, com as alças incorporando uma parte da antiga Praça dos Esportes, denominada Bento de Camargo Barros (ref. 23 ). 
AS TRANSFORMAÇÕES DO PERÍODO $1960-1980$

Sistema Norte-Sul: Av. Tiradentes, Prestes Maia e Nove de Julho.

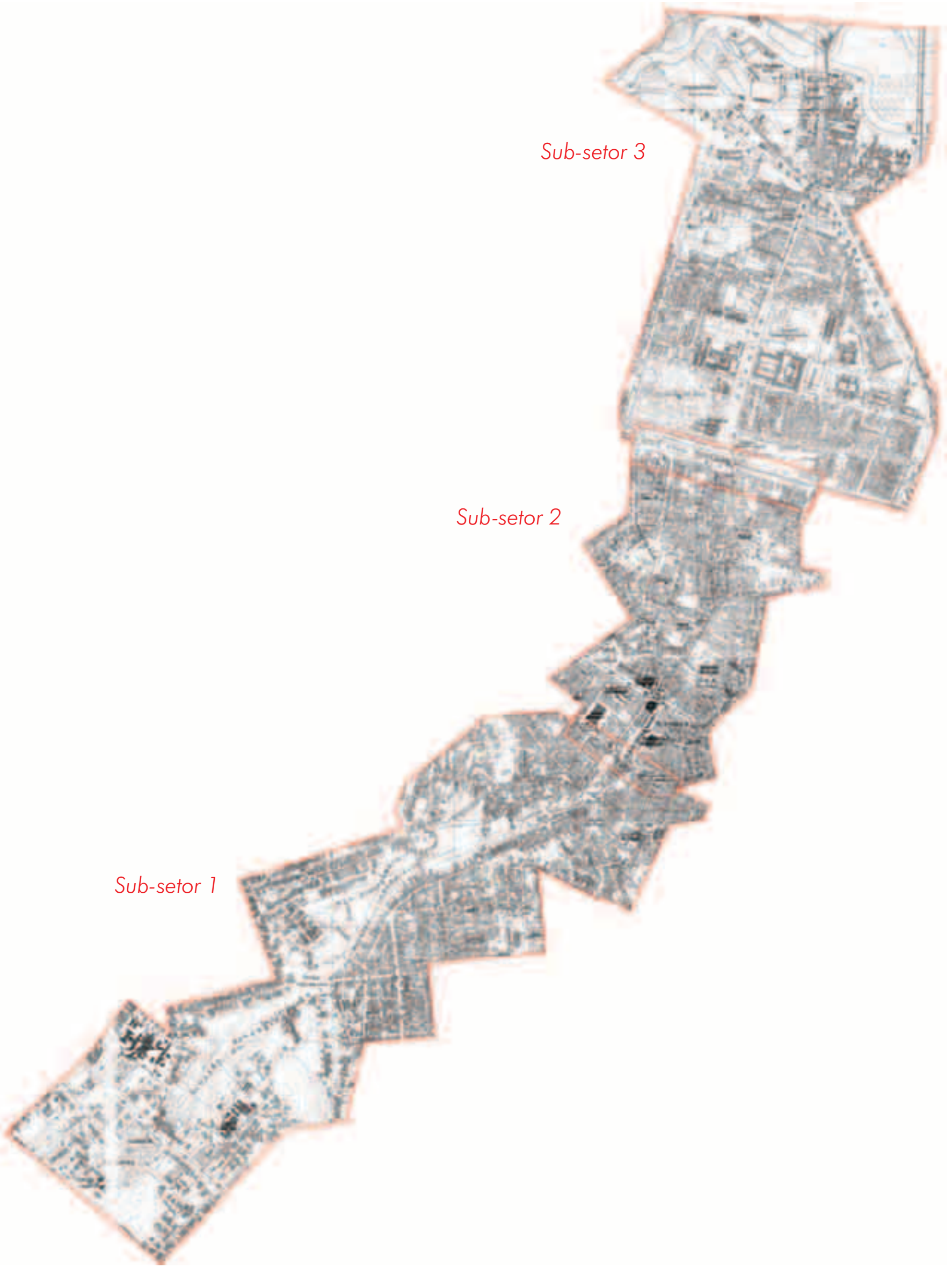

Mapa índice 1930: avenidas atuais. 


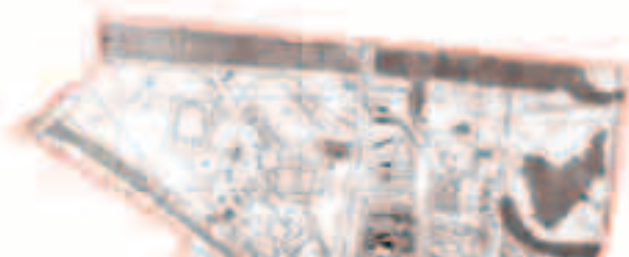

Sub-setor 3

Sub-setor 2

Sub-setor 1 
AS TRANSFORMAÇÕES DO PERÍODO $1960-1980$

Sistema Norte-Sul: Av. Tiradentes, Prestes Maia e Nove de Julho.
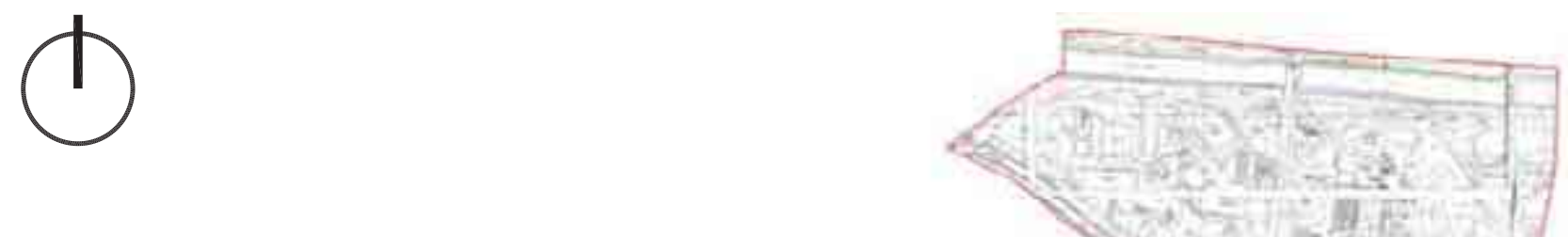

Sub-setor 3

Sub-setor 2

Sub-setor 1

Mapa índice 1972:

Componente Norte-Sul: (Avenida Tiradentes, Av. Prestes Maia e Av. Nove de Julho). 

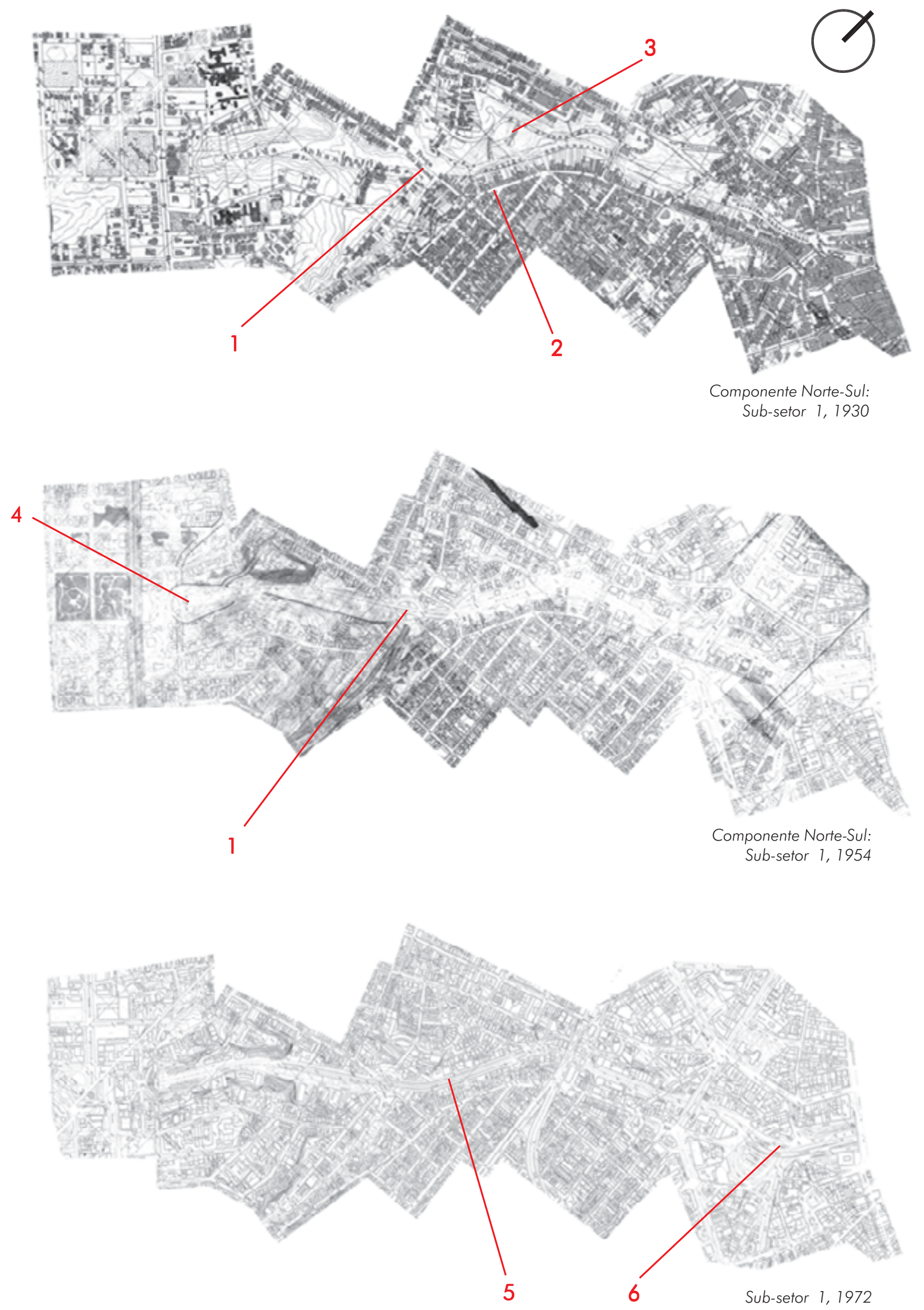
AS TRANSFORMAÇÕES DO PERÍODO 1960-1980

Sistema Norte-Sul: Av. Tiradentes, Prestes Maia e Nove de Julho.

Componente Norte-Sul: Sub-setor 2, 1930

Componente Norte-Sul: Sub-setor 2, 1954

Componente Norte-Sul: Sub-setor 2, 1972
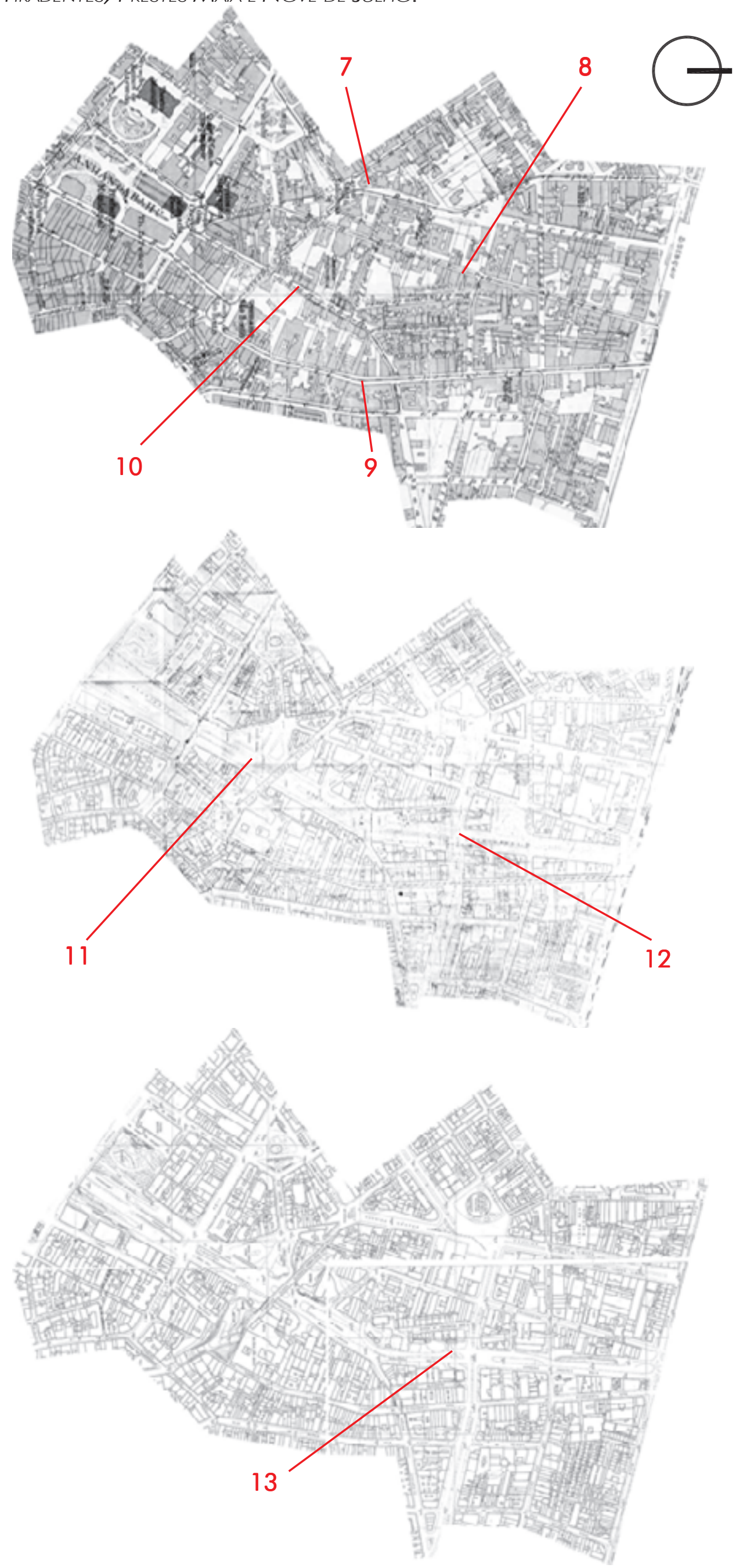
AS TRANSFORMAÇÕES DO PERÍODO 1960- 1980
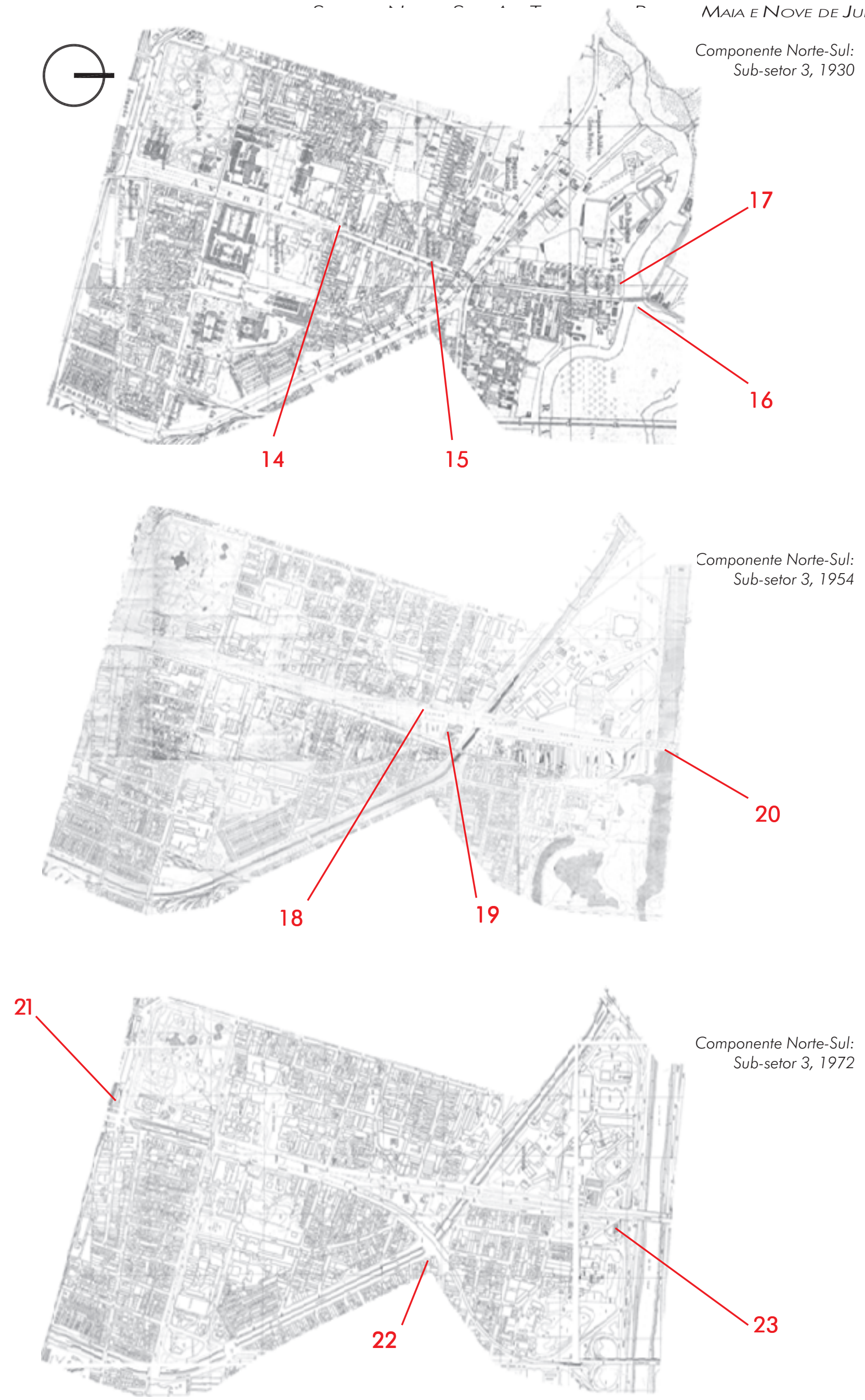


\subsection{2 - Componente Leste 1: Avenida Rangel Pestana}

Dentro do limite do atual distrito do Brás, a avenida Rangel Pestana foi dividida em três sub-setores:

Sub-setor 1 - correspondente ao trecho que se inicia na Praça Clóvis Bevilacqua até o final do Parque Dom Pedro II

Sub-setor 2 - dos limites do Parque D. Pedro II até os trilhos da ferrovia

Sub-setor 3 -dos trilhos da ferrovia até a rua Júlio César da Silva, superando as ruas Bresser e João Boemer.

1. Através do mapa de 1930, a Rangel Pestana ainda não havia recebido essa denominação no trecho que abrangia o seu início, na rua Santa Tereza até o Parque D. Pedro II. Denominada Ladeira do Carmo (ref. 1), apresentava como marco o convento ali existente, demolido em 1928 para dar lugar ao futuro edifício da Secretaria da Fazenda (Porto, 1996, 153). Essa via superava o rio Tamanduateí através da ponte construída em 1895 (ref. 2), cruzando o Parque em nível (idem, 152). Este ainda exibia o paisagismo do projeto de Bouvard, realizado em 1911, com o rio Tamanduateí retificado e ainda a presença da Ilha dos Amores ao lado da ponte. Na Ladeira do Carmo, a ocupação mostra apenas o parcelamento das quadras entre a rua 25 de Março e a Santa Tereza (ref. 3).

Confrontando o mapa de 1930 com o de 1954, já são percebidas inúmeras transformações no viário e no parcelamento. De 1926 a 1930 a gestão de José

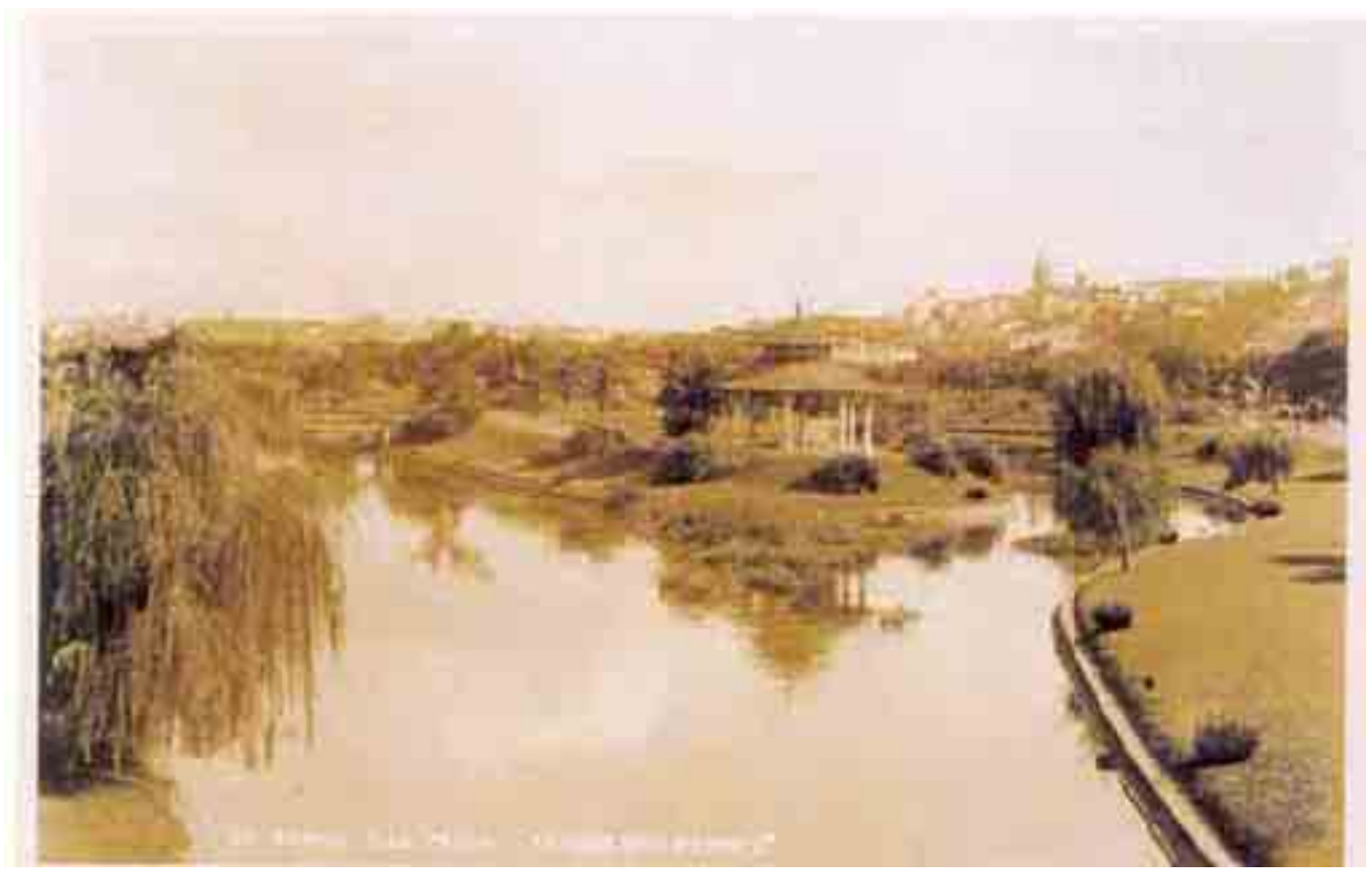

Fig. 82: Parque D. Pedro II - "Ilha dos amores" - 1910. 
Pires do Rio promoveu o alargamento da antiga Ladeira do Carmo (ibidem, 152) e em 1942, no governo de Prestes Maia, foi aberta a Praça Clóvis Bevilacqua defronte ao Palácio da Justiça (ref. 3) e ampliada a Rangel Pestana que incorporou a Ladeira do Carmo. Nessa Praça, o Plano Melhoramentos de São Paulo previa a instalação do Paço Municipal da cidade (Amadio, 1998, 58). O Parque D. Pedro II já havia perdido parte de suas características originais, com nova canalização do rio Tamanduateí e a avenida Rangel Pestana seccionando sua área interna, superando-o através de nova ponte (ref. 2). A ocupação revela a transformação do parcelamento das quadras entre a rua 25 de Março e a Praça Clóvis (ref. 3) e a sua manutenção na rua do Carmo. O edifício da Secretaria Estadual da Fazenda, projeto da década de 1940 de Júlio Ferrúcio Pinoti, encontrava-se ainda em obras em 1954, quando do vôo VASP (informação prestada pelo arq. Márcio Serra, da Secretaria Estadual da Fazenda, 2004)

mapa de 1972 mostra as profundas mudanças introduzidas pelo complexo de viadutos construídos em 1968 durante a gestão de Faria Lima (ref. 4), e a destruição da Praça Clóvis Bevilacqua e quadras vizinhas, para a construção da Estação Sé do Metrô (ref. 5). A ocupação das quadras lindeiras à avenida (ref. le 3) se mostra completa, só não ocorrendo verticalização ao longo da rua do Carmo.

2 - No mapa de 1930, o sub-setor compreendido entre o Parque D. Pedro II e os trilhos ferroviários mostrava a Rangel Pestana com todas as referências implantadas, visto datarem da transição do século XIX para o século XX: Grupo Escolar Romão Puiggari, de 1898 (ref. 1), Igreja Matriz do Brás, de 1903 (ref. 2)

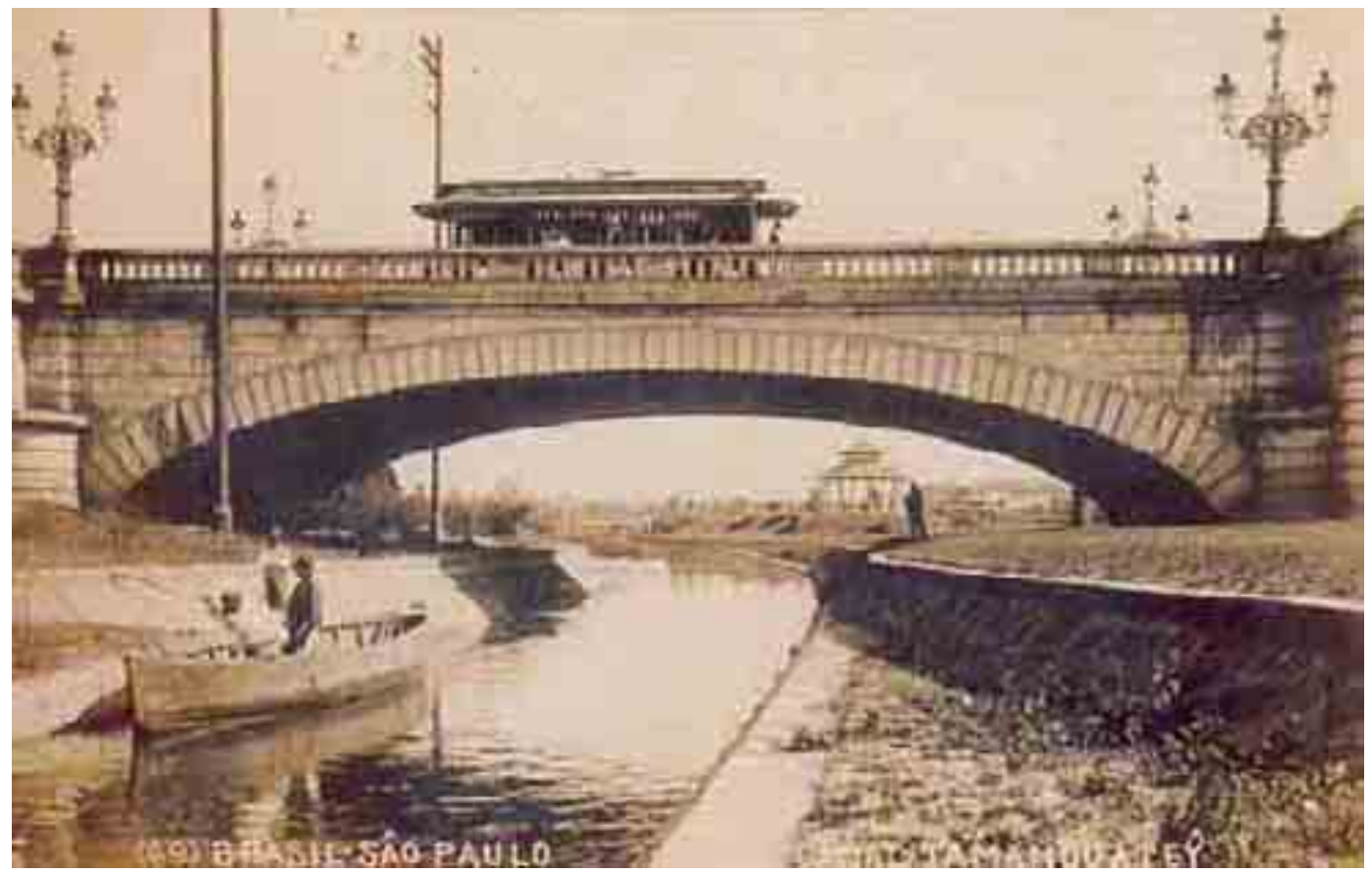

Fig. 83: Ponte sobre o rio Tamanduateí, cartão postal, aproximadamanete 1930. 
e Estação do Brás, de 1897 (ref. 3) (Sempla/Emplasa, 1984, 388-420; Porto, $1996,152)$. O parcelamento e a ocupação revelam a implantação dos maiores edifícios ao longo da avenida, que já apresentava caráter misto. Além disso, entradas e passagens para o miolo das quadras do Brás podem ser percebidas, que apresentavam uma das maiores incidências de habitações coletivas e cortiços da cidade (ref. 4). As quadras próximas à ferrovia, por sua vez, configuravam-se como densamente construídas, verificando-se a presença de galpões da zona fabril. A avenida Rangel Pestana possuía uma passagem em nível sobre a ferrovia, servida por porteiras, o mesmo acontecendo com rua do Gasômetro.

Comparado com o mapa de 1930, o de 1954 indica poucas alterações no parcelamento, o que demonstra ter havido a manutenção das funções anteriormente existentes. No caso da quadra entre as ruas Caetano Pinto e Piratininga, verifica-se inclusive o aumento da área construída em seu interior, com a entrada se dando pela Rangel Pestana. Esta ainda contava com passagem em nível sobre a ferrovia (ref. 5), enquanto na rua do Gasômetro já havia sido construído o viaduto, que exigiu a divisão da quadra defronte ao mesmo (ref. 6). A principal alteração no mapa de 1972 é a da construção do viaduto da avenida Rangel Pestana sobre os eixos ferroviários (ref. 7), caracterizando-a como um corredor ligando a Zona Leste ao centro da cidade pelo complexo viário implantado sobre o Parque D. Pedro II.

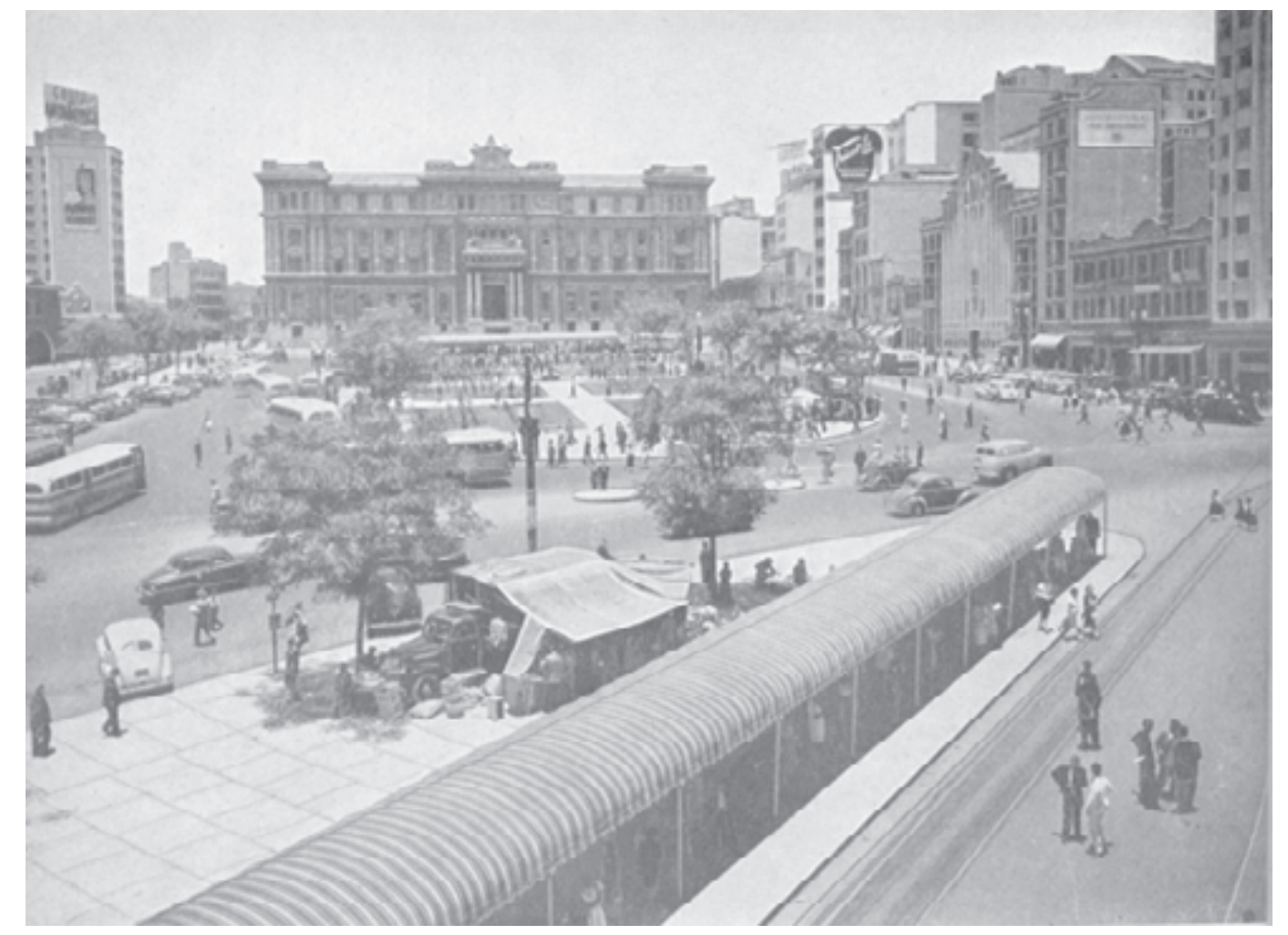

Fig. 84: Pça Clóvis, década de 1950. 


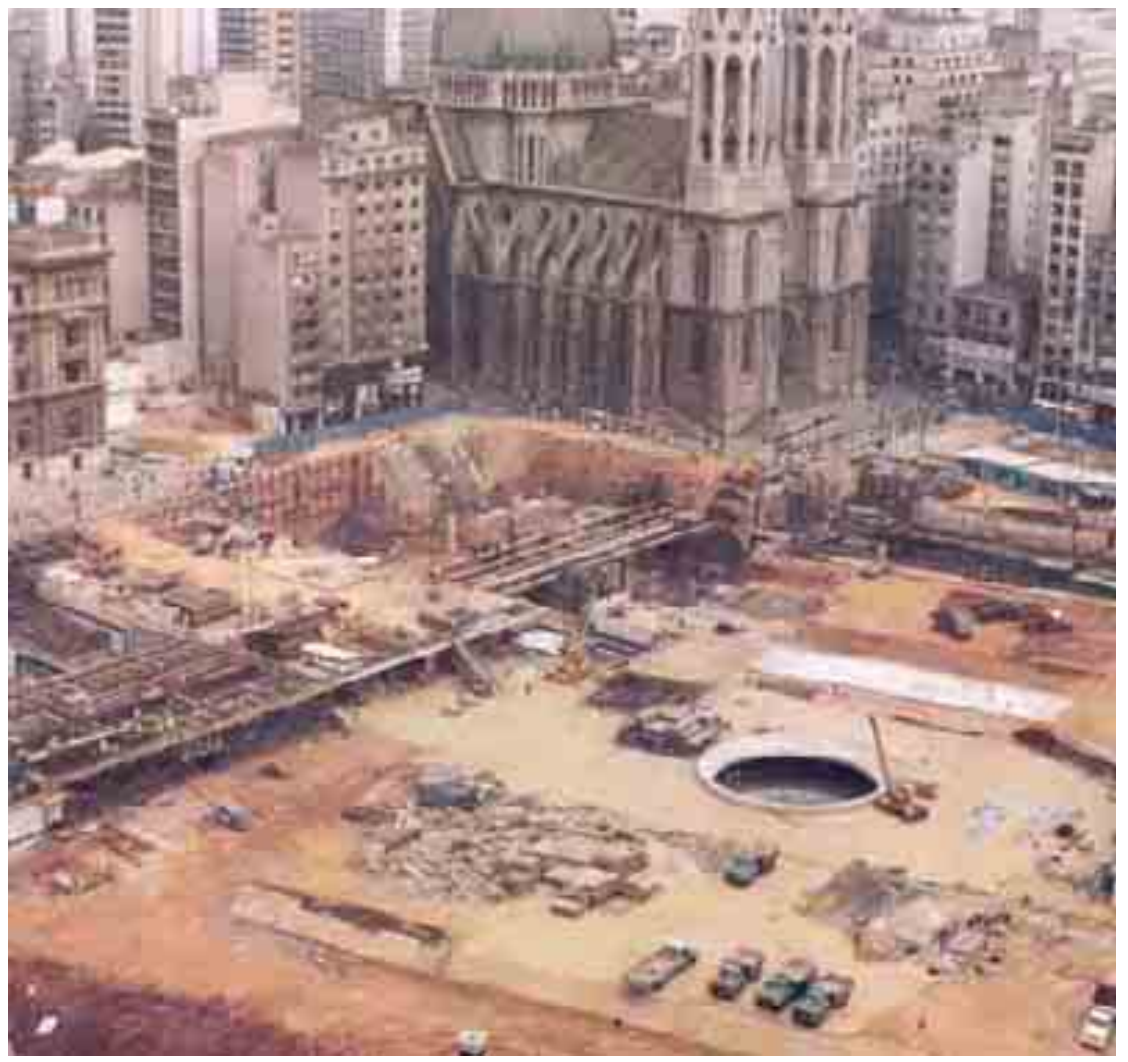

Fig. 85: Construção da Estação Sé do Metrô, com a praça Clóvis Bevilacqua iá desconfigurada.

3. No sub-setor que se inicia nos trilhos da ferrovia e se estende até a rua Júlio César da Silva, nas proximidades do Largo Senador Moreira Barros, pelo mapa de 1930 é possível identificar o Largo da Concórdia e a Praça Agente Cícero, defronte da Estação do Norte, ambos com sua configuração original (ref. 8). Percebe-se também, através dos mapas índices, o estreitamento de pista que ocorre na avenida algumas quadras após o Largo, o que se manteve nas décadas seguintes (ref. 9). Outra referência importante, nas proximidades da Escola Normal do Brás (ref. 10), era a garagem de bondes (ref. 11), que ocupava uma grande área na quadra onde se situava.

O mapa de 1954, confrontado com o de 1930, mostra o Largo da Concórdia seccionado para a passagem da pista de acesso ao viaduto da rua do Gasômetro e também dos trilhos de bonde que por ele circulavam, acessando os bairros ao leste (ref. 12). Verifica-se ter ocorrido a manutenção das características gerais da ocupação, com a ocorrência de lotes maiores nas proximidades do Largo da Concórdia (ref. 13). Essa era a zona comercial que se formara desde a década de 1940, quando ali se instalaram grandes lojas de departamentos e de móveis (Porto, 1996, 153).

Através do mapa de 1972, a principal transformação ocorrida foi aquela provocada pela construção do viaduto sobre a ferrovia, que alterou o entorno 
do Largo da Concórdia, contribuindo para torná-lo um terminal de ônibus (ref. 14). Sua construção anexa, o Teatro Colombo, já fora demolida e foi transformada a garagem de bondes que, com a extinção destes, passou a ser ocupada por ônibus (idem, ref. 14). Percebe-se através da comparação com os mapas anteriores, a manutenção das características da ocupação também nesse subsetor, assim como ocorreu nos anteriores.

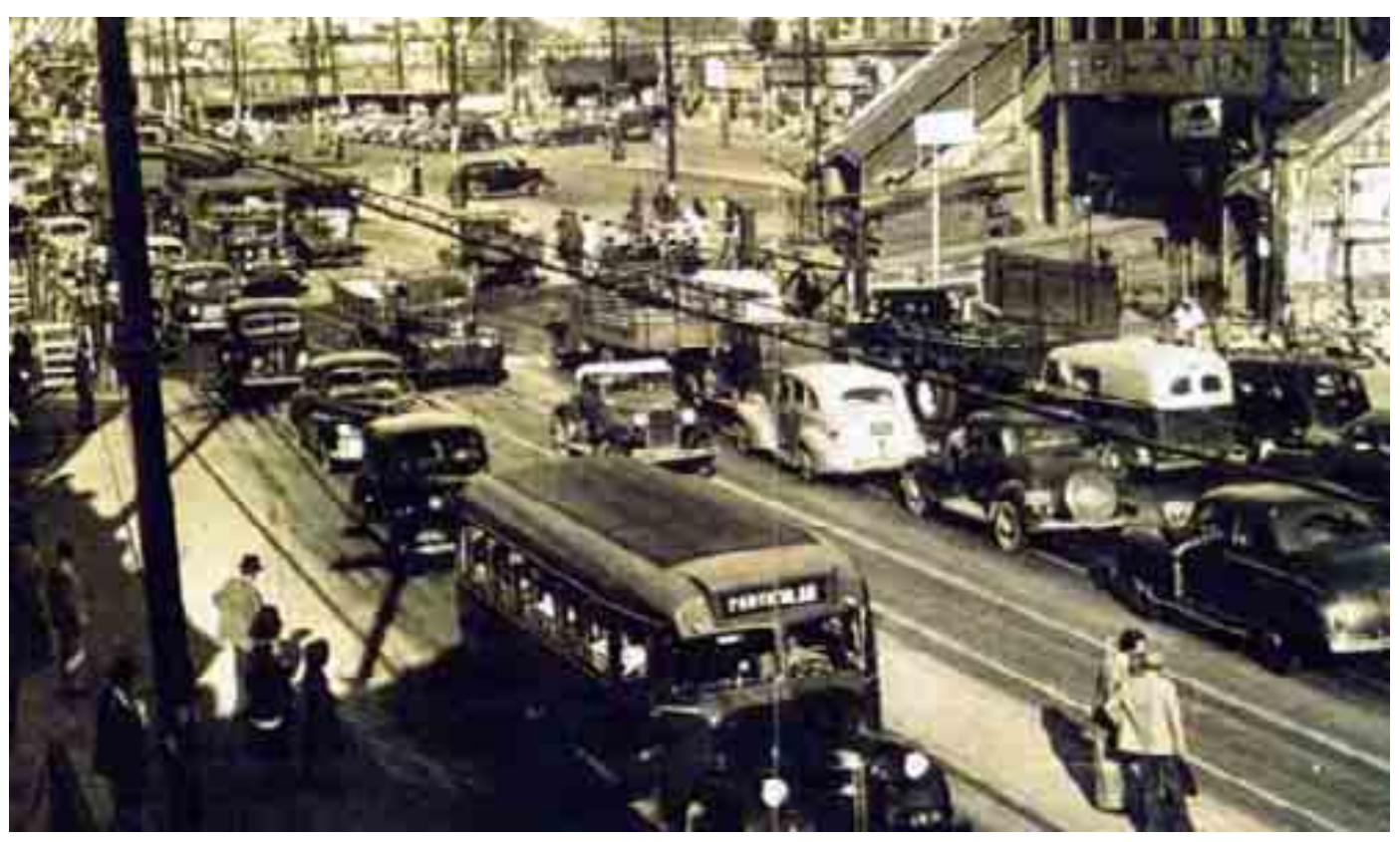

Fig. 86 e 87: Acima: Largo da Concórdia em 1950 com as velhas porteiras do Brás, substituídas por viaduto em 1968.

Ao lado: Largo da Concórdia em 1958.

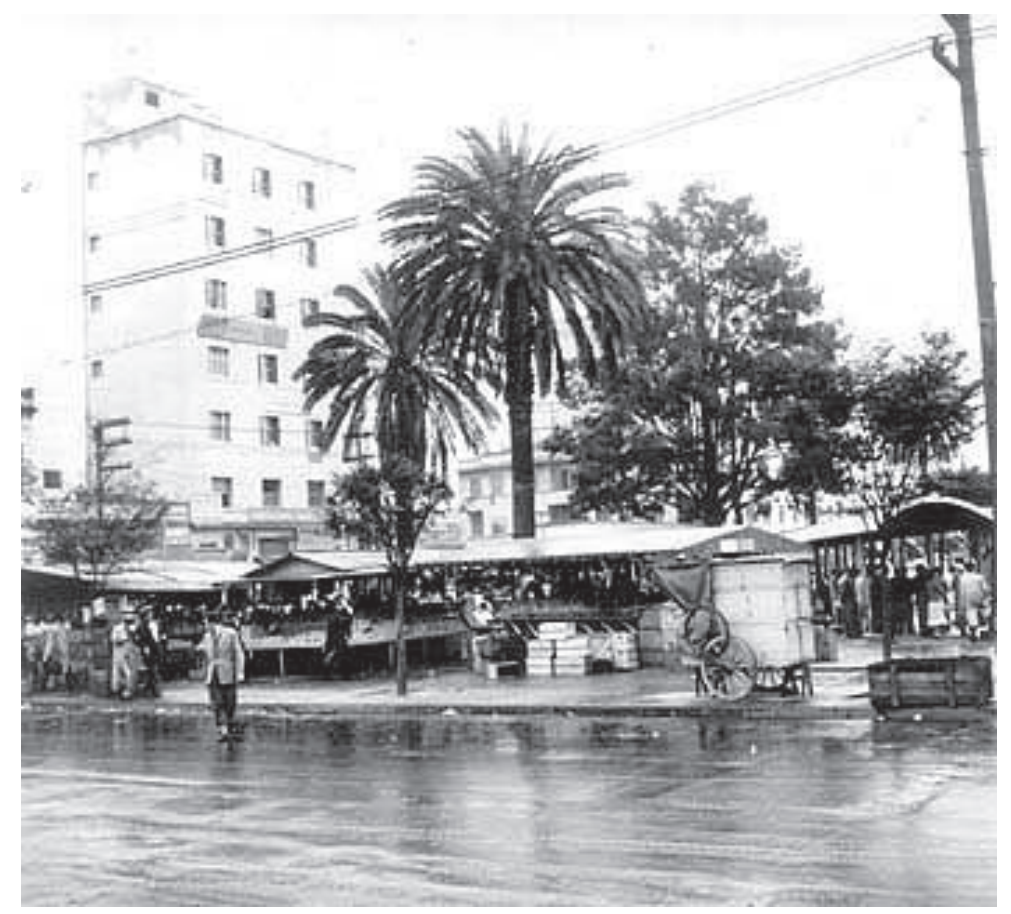



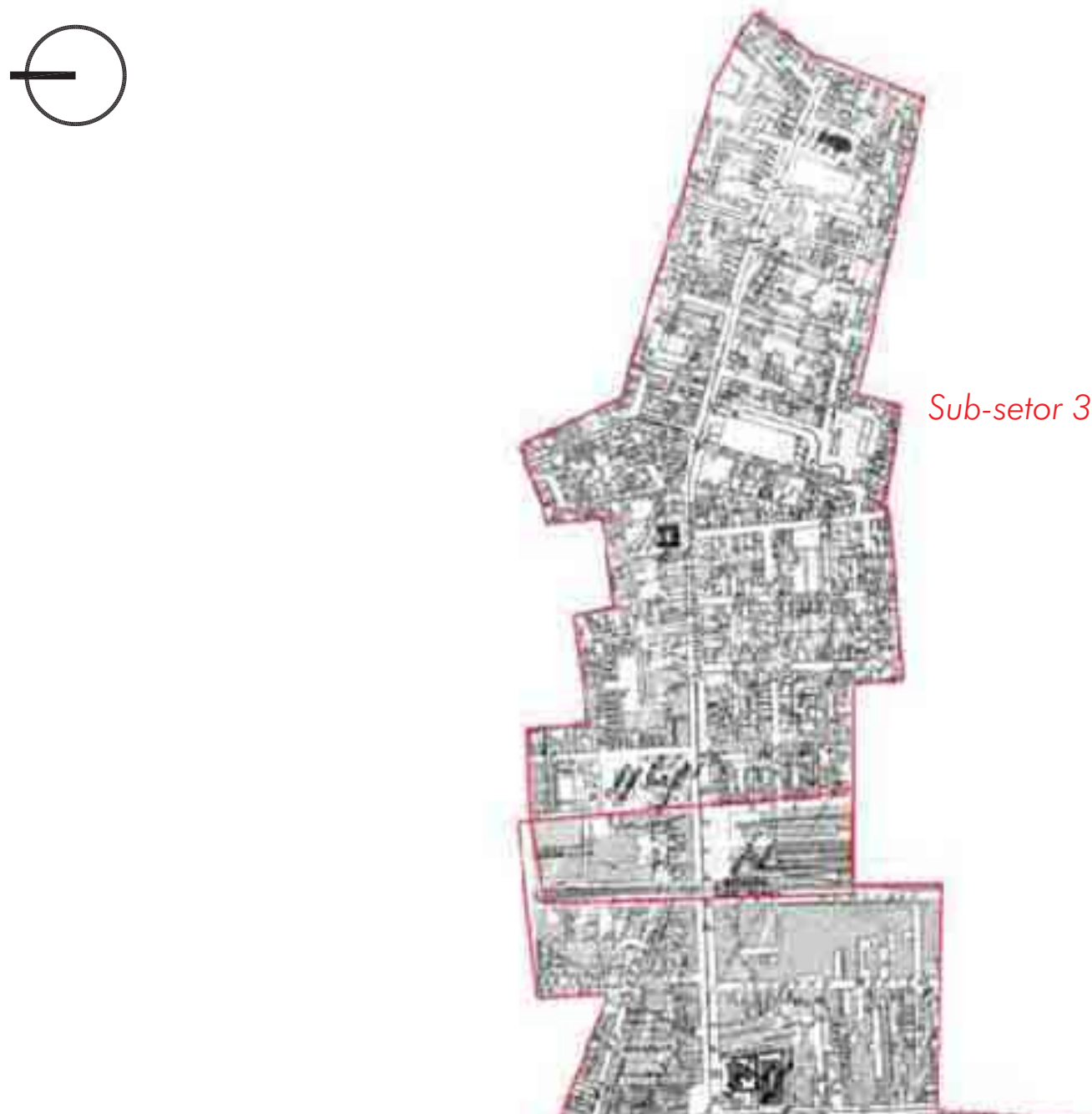

Sub-setor 2

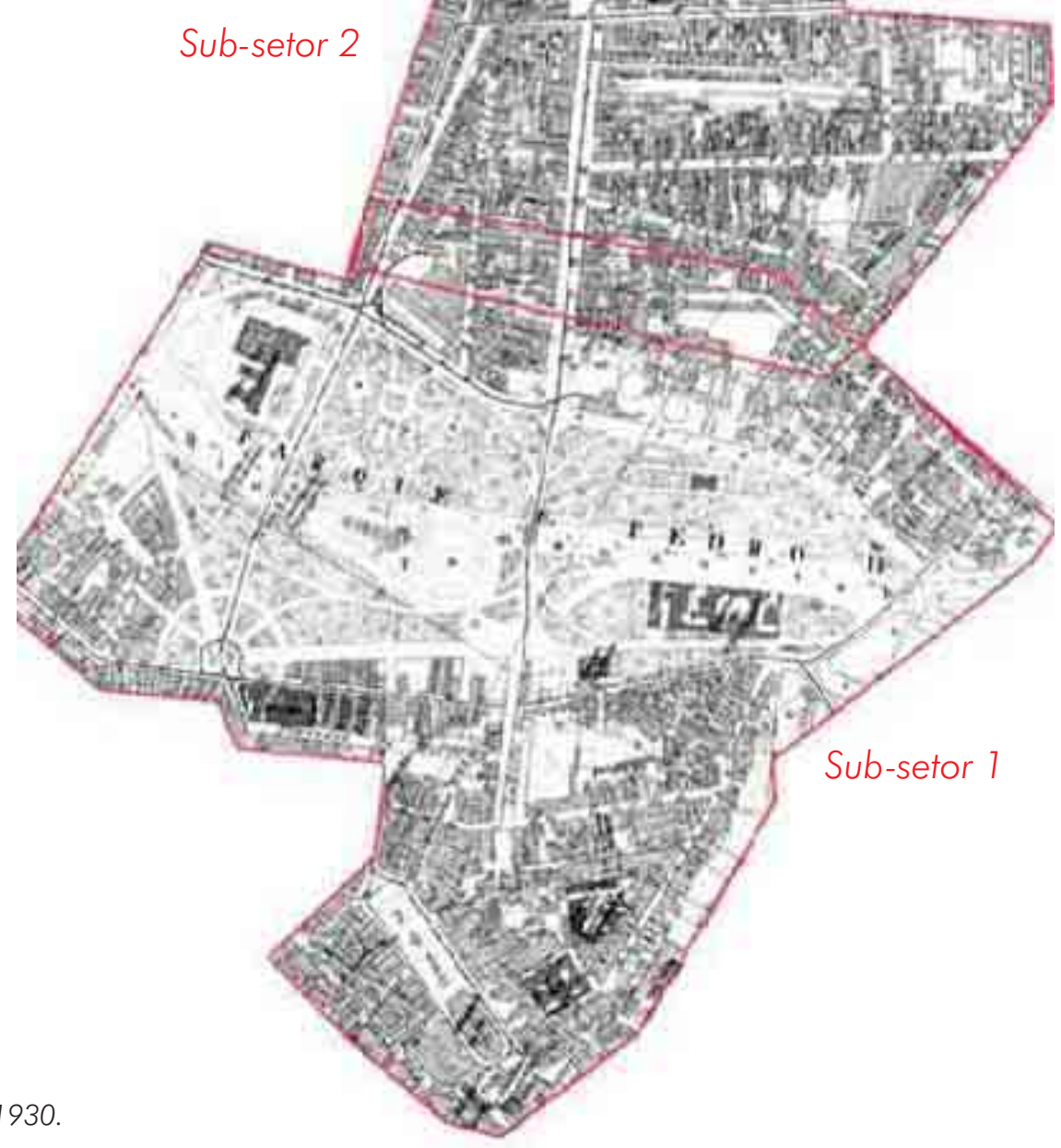


AS TRANSFORMAÇÕES DO PERÍODO $1960-1980$

Avenida Rangel PESTANA

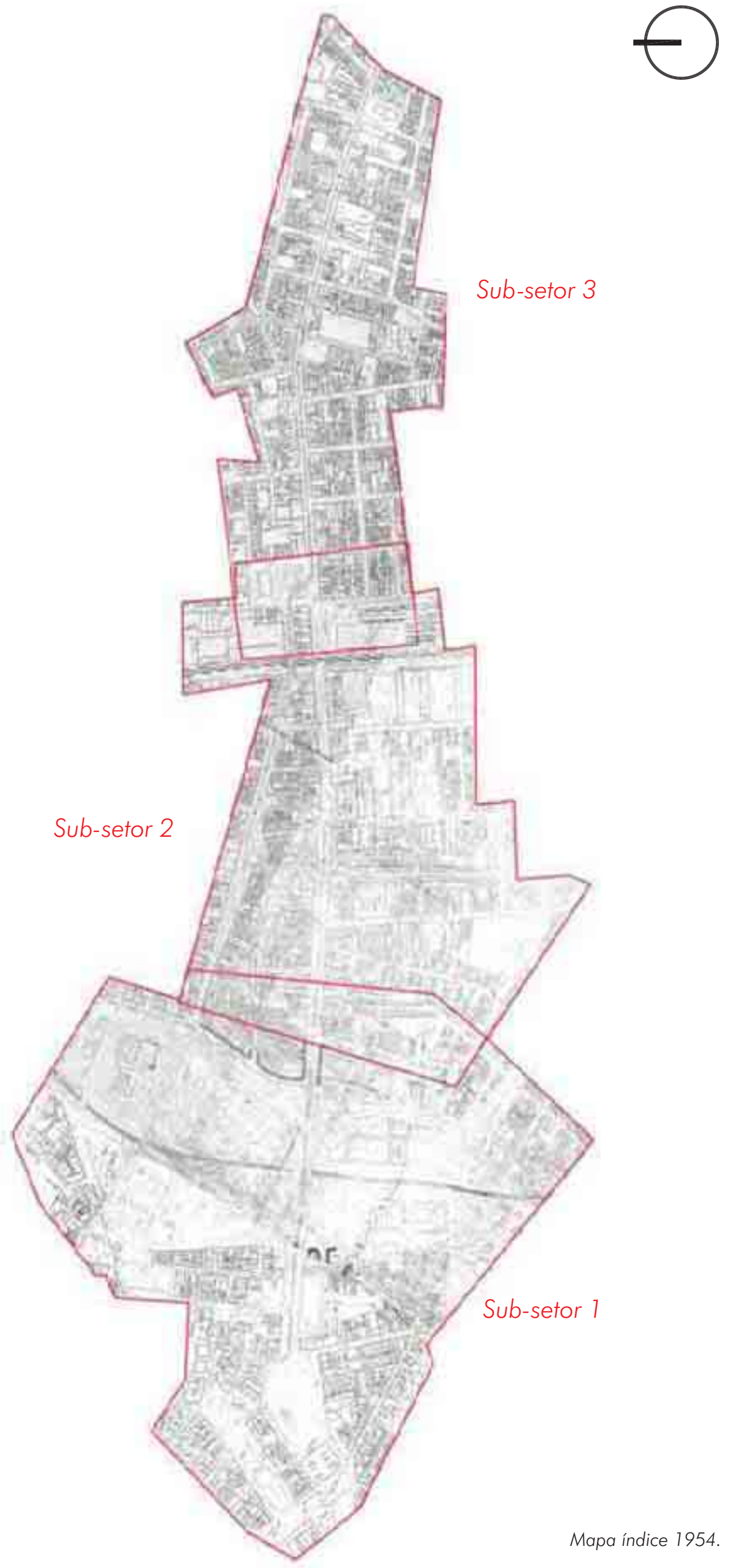



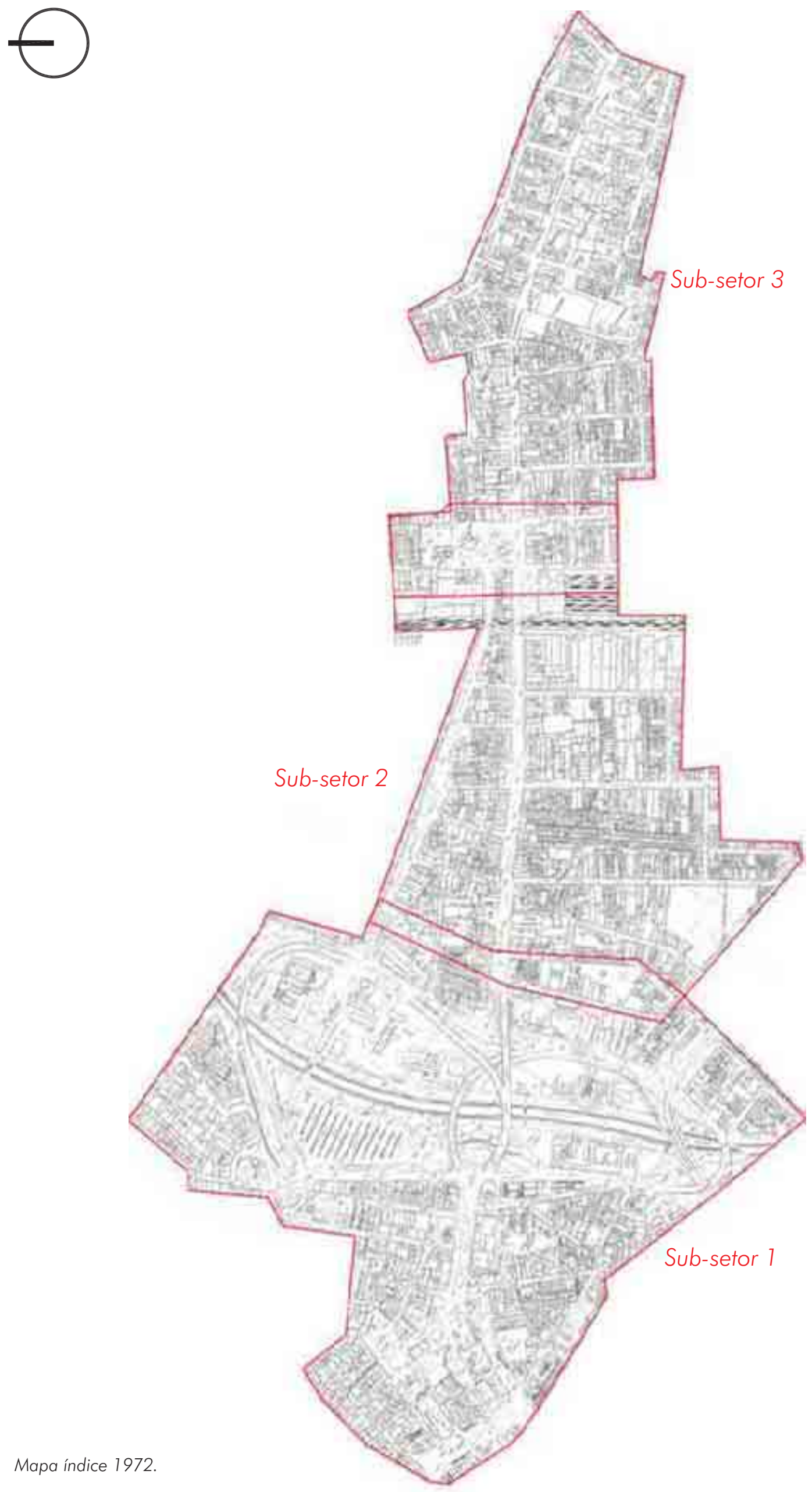
AS TRANSFORMAÇÕES DO PERÍODO 1960 - 1980

Avenida Rangel Pestana

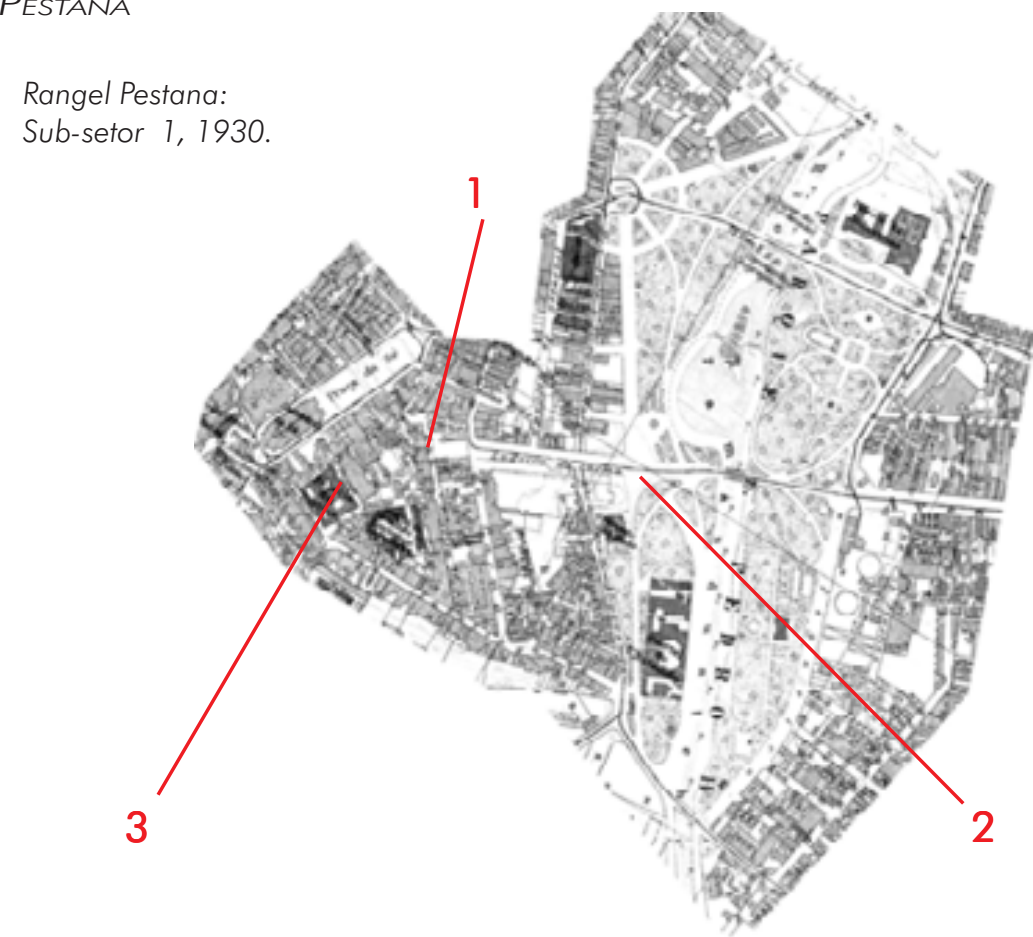

†
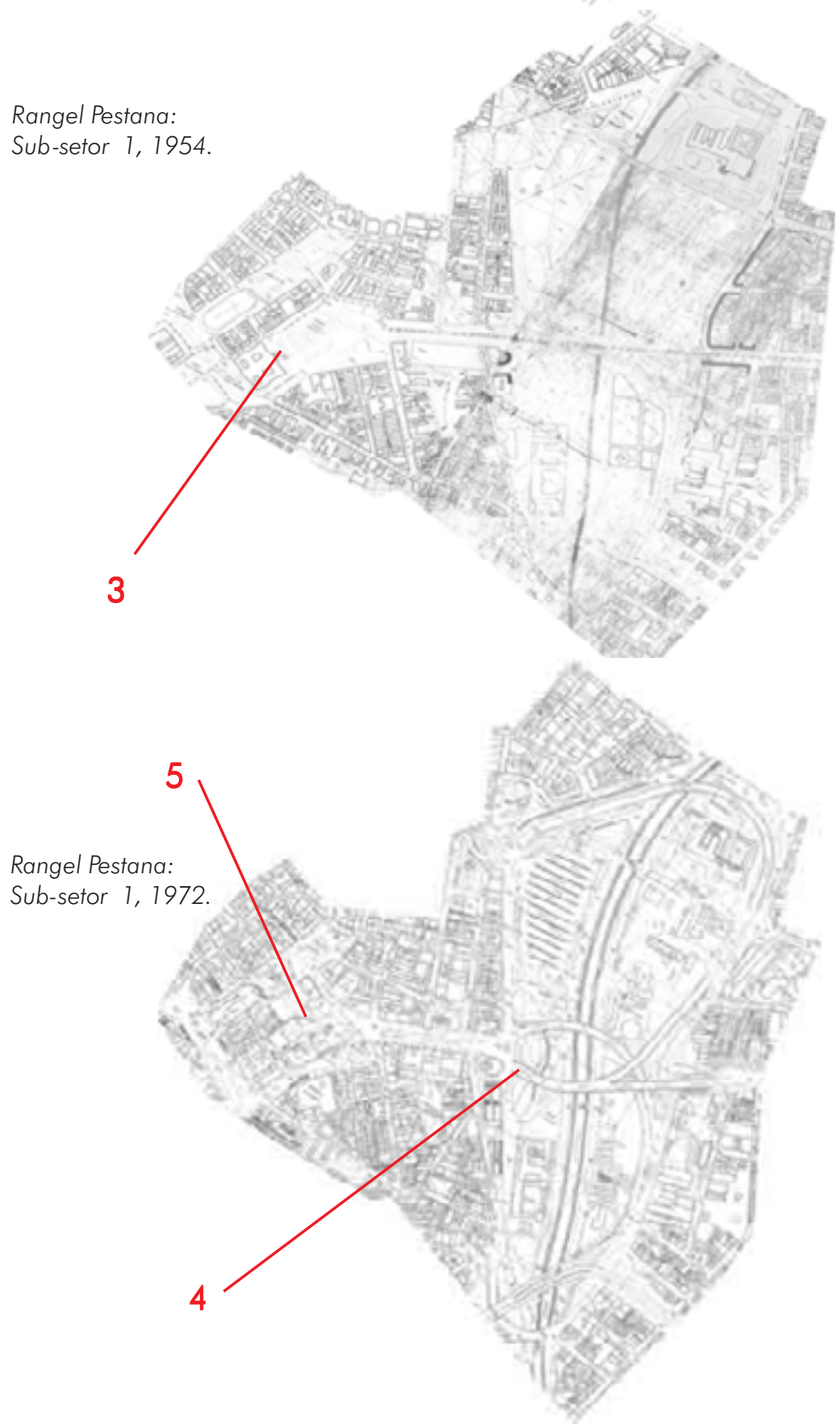


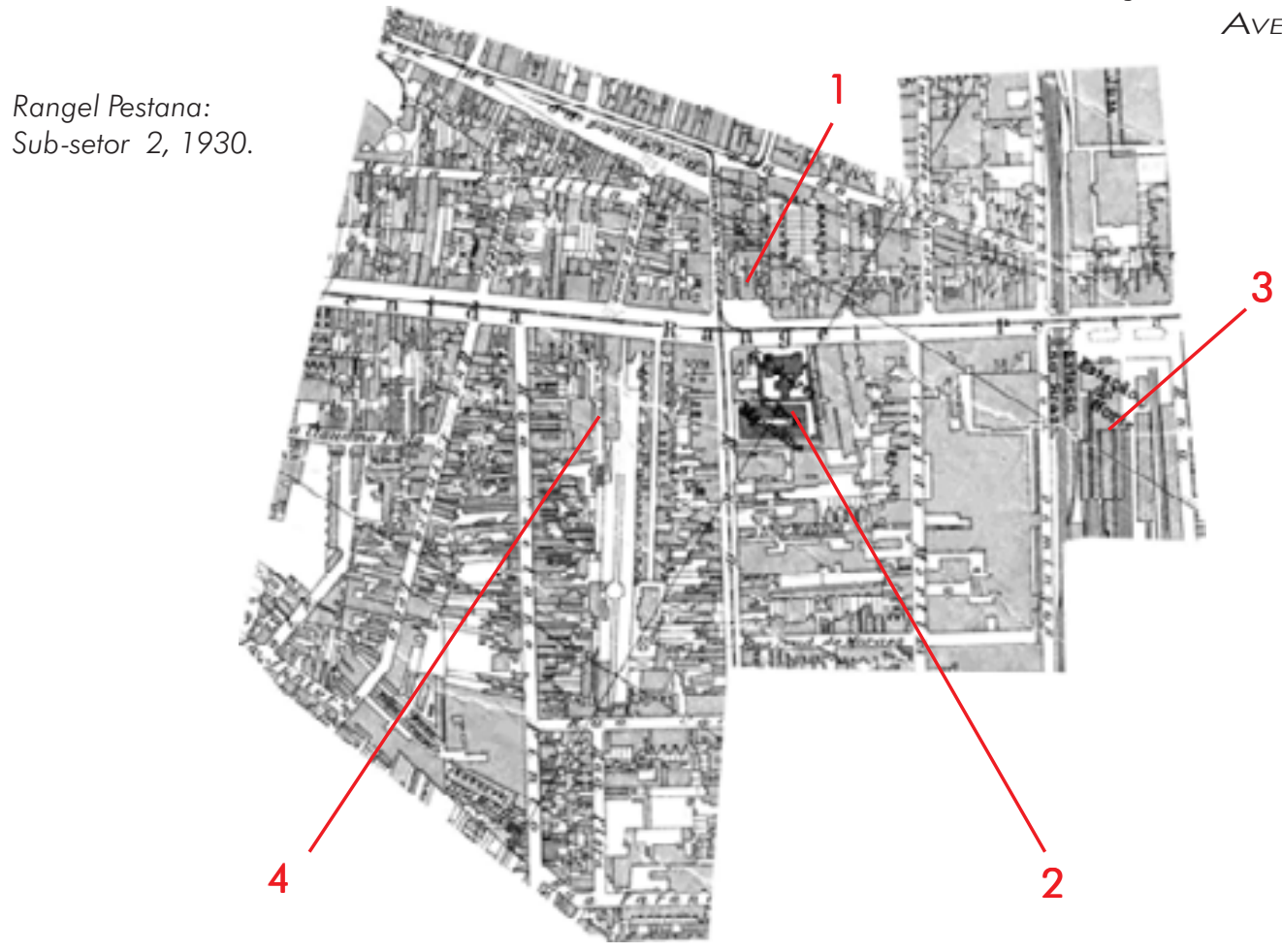

AVENIDA RaNGel PESTANA
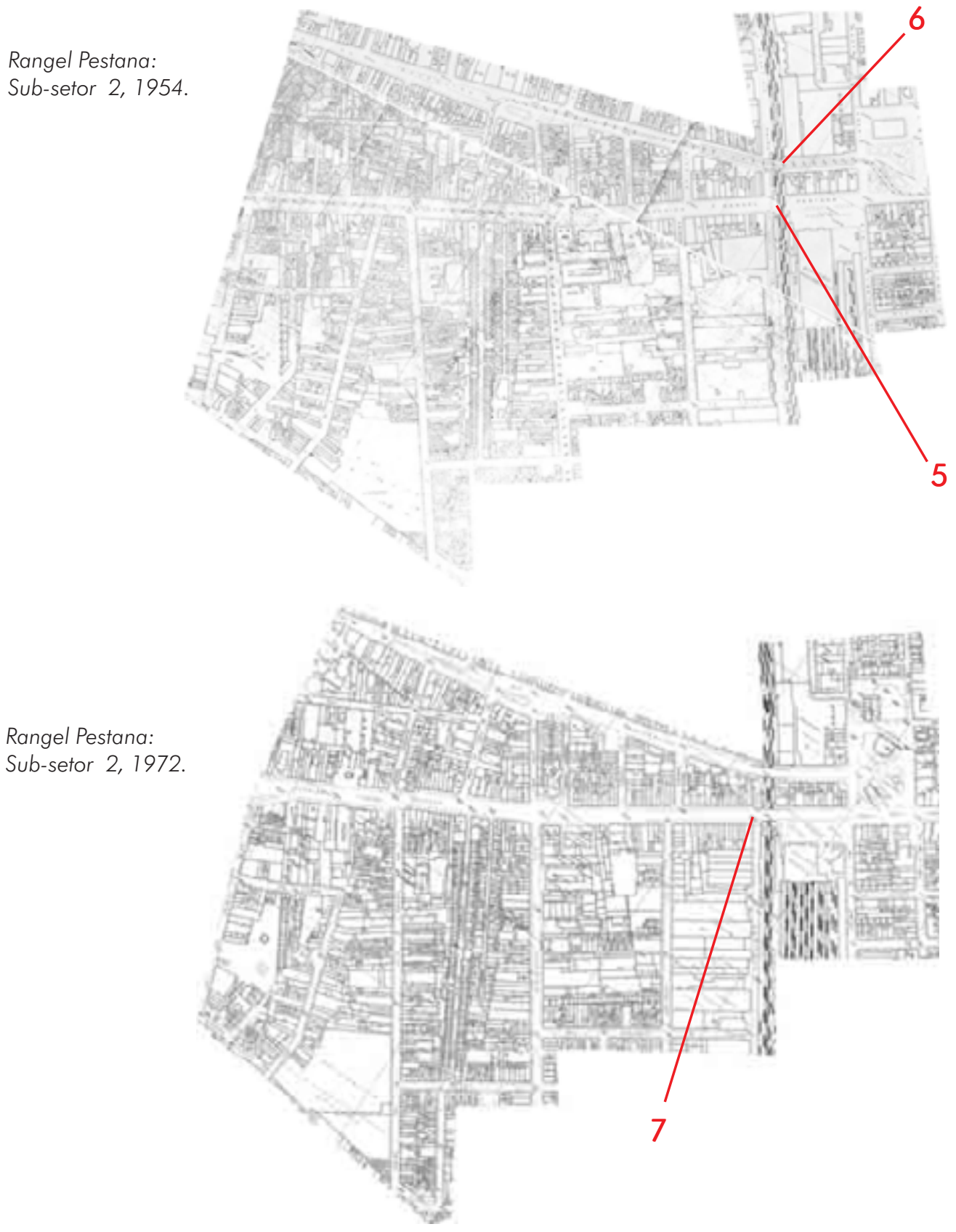
AS TRANSFORMAÇÕES DO PERÍODO 1960- 1980

Avenida RANGel Pestana
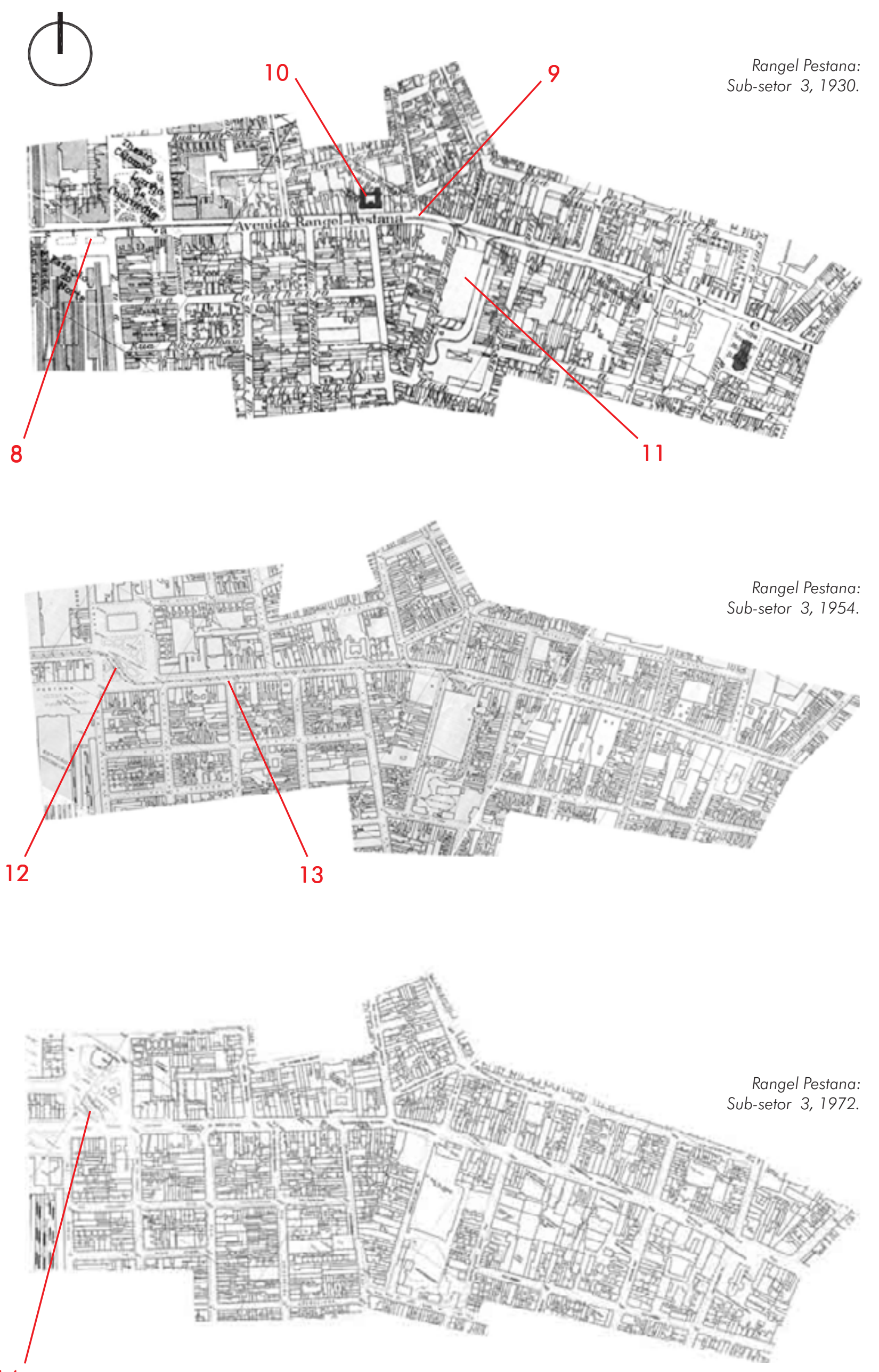

14 


\subsection{3 - Diametral Leste-Oeste: Radial Leste}

A componente diametral do Plano de Avenidas correspondente à ligação LesteOeste, teve como principais vias do percurso as avenidas São João e Rangel Pestana, ambas conectadas até 1948 pelo interior do Triângulo, e posteriormente pelo "Anel de Irradiação", a atual Rótula Central, passando necessariamente pelas Praças João Mendes e Clóvis Bevilacqua.

Vale lembrar que na década de 1950 a proposta para uma avenida de ligação leste-oeste havia recebido, nos planos de Moses para o sistema expresso e de Prestes Maia para o Metrô, calha segregada para o transporte público, feita por ônibus e trilhos, respectivamente. Ao invés disso, quando concluída, configurouse como via que dividiu as áreas dos bairros existentes em seu trajeto, não incorporou os espaços reservados ao transporte de massa e na extremidade oeste de seu percurso, implantou as pistas do Elevado Costa e Silva, destinado exclusivamente ao transporte individual.

Para o entendimento das transformações decorrentes da abertura dessa componente, a mesma foi dividida em três sub-setores, correspondentes ao conjunto de bairros Bexiga-Liberdade-Glicério e ao Brás, este contendo duas delimitações: até os trilhos ferroviários, abrangendo a atual divisão dos distritos pertencentes aos bairros centrais e no sub-setor seguinte, superando-a para analisar a continuidade da Radial. A divisão, portanto, considerou:

Sub-setor 1 - Percurso da atual Praça Roosevelt até o final do Parque D. Pedro II. Sub-setor 2 - Percurso do Parque D. Pedro Il até os trilhos ferroviários.

Sub-setor 3 - Percurso dos trilhos ferroviários até rua Bresser.

1. Pelos mapas de 1930 e 1954, o trecho da Radial que cortou os bairros do Bexiga, Liberdade e Glicério ainda não havia sido implantado, sendo possível notar a magnitude da escala dessa intervenção através do traçado atual projetado sobre o tecido urbano dos bairros atingidos e comparando com o viário já finalizado no mapa de 1972.

Partindo da Praça Roosevelt, visível em sua configuração original pelo mapa de 1954 (ref. 3), o traçado seccionou as quadras compreendidas entre as ruas João Passaláqua, Conselheiro Ramalho e Major Diogo (ref. 1), tomando a direção da rua Jaceguai cujo leito foi incorporado à via expressa, superando as avenidas Brigadeiro Luís Antônio e Liberdade e entre essas duas, o Vale do Itororó (futura 23 de Maio), sob viaduto (ref. 2). Essa orientação exigiu numerosos cortes e retirada de terra, para se obter as cotas que permitiram à via estar liberada de cruzamentos com as ruas e avenidas existentes. Os diversos taludes entre a Praça Roosevelt e o bairro da Liberdade testemunham essa a cirurgia urbana, como por exemplo, o aquele entre a Praça Almeida Júnior, na Liberdade, e a via expressa implantada. 


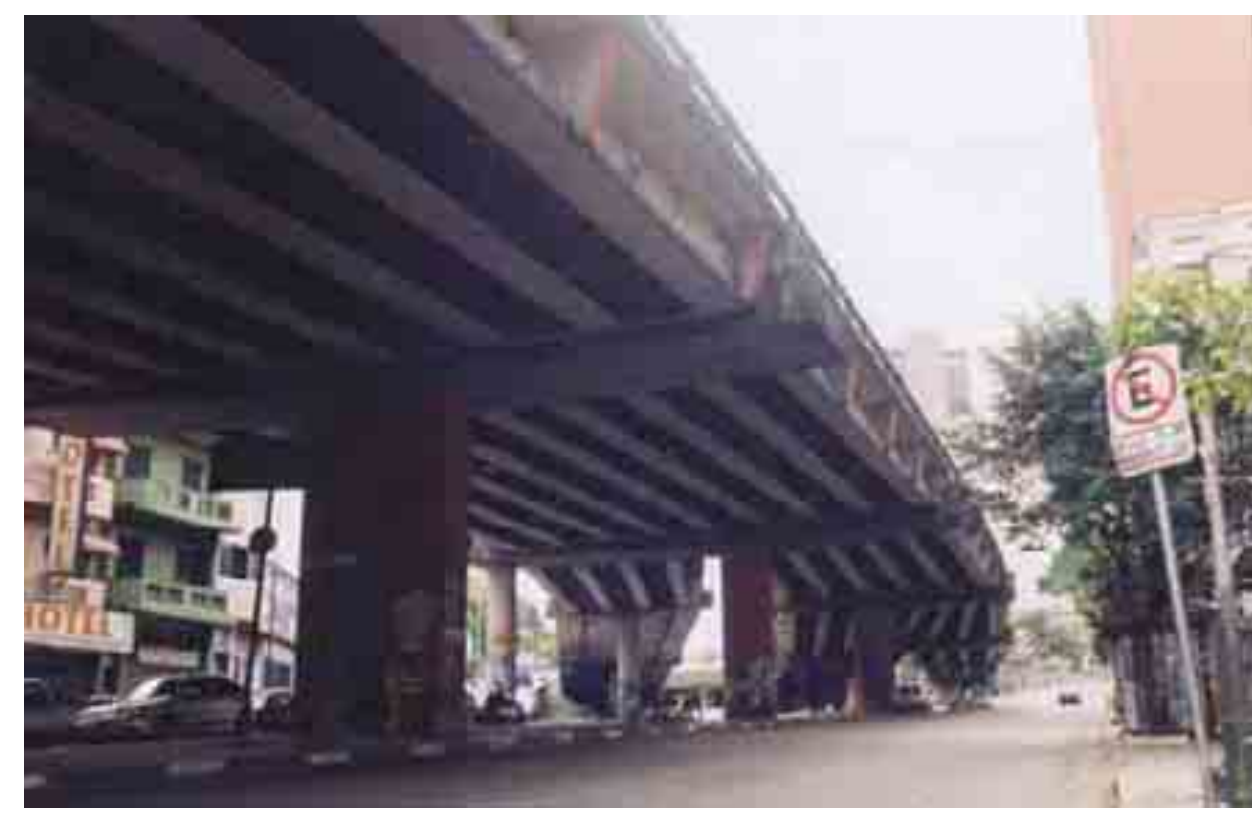

Fig.88: Elevado Costa e Silva, nas proximidades da Praça Roosevelt.

O Glicério foi superado através de viaduto que teve continuidade sobre o Parque D. Pedro II (ref. 4), daí se bifurcando em direção ao norte e ao leste. Em conseqüência, a área sudeste do Parque foi seccionada pela passagem do elevado e recebeu em seu entorno alças de acesso da avenida dos Estados e rampas de chegada para a avenida Rangel Pestana, a Luz e a Moóca.

2. $O$ percurso da Radial Leste que cortou o Brás no sub-setor que se inicia no Parque D. Pedro II pode ser analisado através do traçado projetado sobre o mapa de 1930, que foi implantado entre as ruas Visconde de Parnaíba e da Moóca, incorporando o leito das ruas Cel. Seabra e Placidina, além da demolição do casario existente (ref. 5). No mapa de 1954 verifica-se a implantação da Radial Leste já iniciada, com percurso se estendendo até a rua do Hipódromo, quando ainda era interrompida por uma quadra remanescente e a partir daí seguindo até encontrar outro obstáculo, representado pelos trilhos da SantosJundiaí. Pelo mapa de 1972, o traçado da Radial já se encontrava concluído nesse trecho, superando a ferrovia por viaduto.

3. $O$ sub-setor seguinte se encontra fora da delimitação dos distritos pertencentes aos bairros centrais enfocados neste trabalho, mas constitui importante área de transição com a Moóca. Pelo mapa de 1930 é possível observar o sistema viário interrompido em ambos os lados pela ferrovia, o mesmo ocorrendo no de 1954. Pela projeção do traçado atual nessas duas cartas, percebe-se que a orientação da via expressa seguiu a da rua Conselheiro Justino, incorporando-a e demolindo parte das quadras lindeiras. No seu prolongamento, cruza as ruas do Hipódromo e Bresser, com esta última superando a Radial por viaduto, como é possível observar na carta de 1972. 
AS TRANSFORMAÇÕES DO PERÍODO 7 960- 1980

RADIAL LESTE

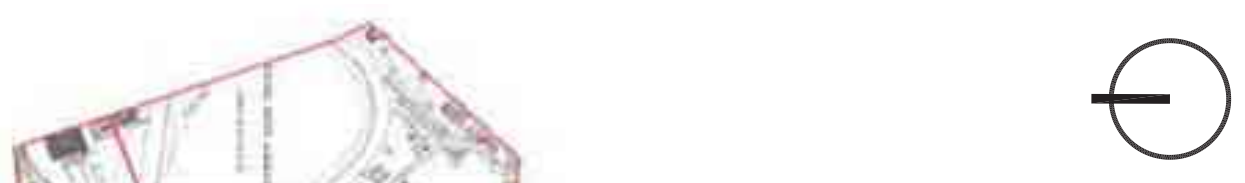

Sub-setor 3

Sub-setor 2

Futuro traçado da Radial Leste (traçado em vermelho), mapa índice 1930 
AS TRANSFORMAÇÕES DO PERÍODO $1960-1980$

RADIAL LESTE

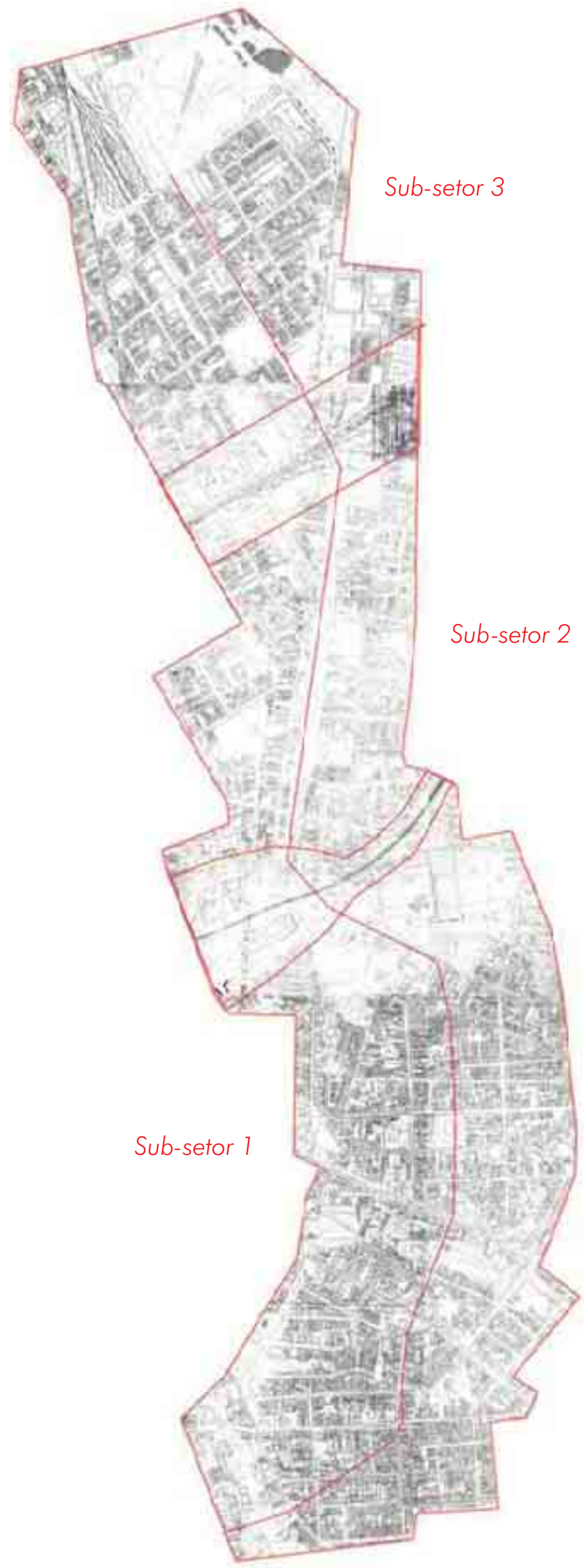

Sub-setor 3

Sub-setor 2 

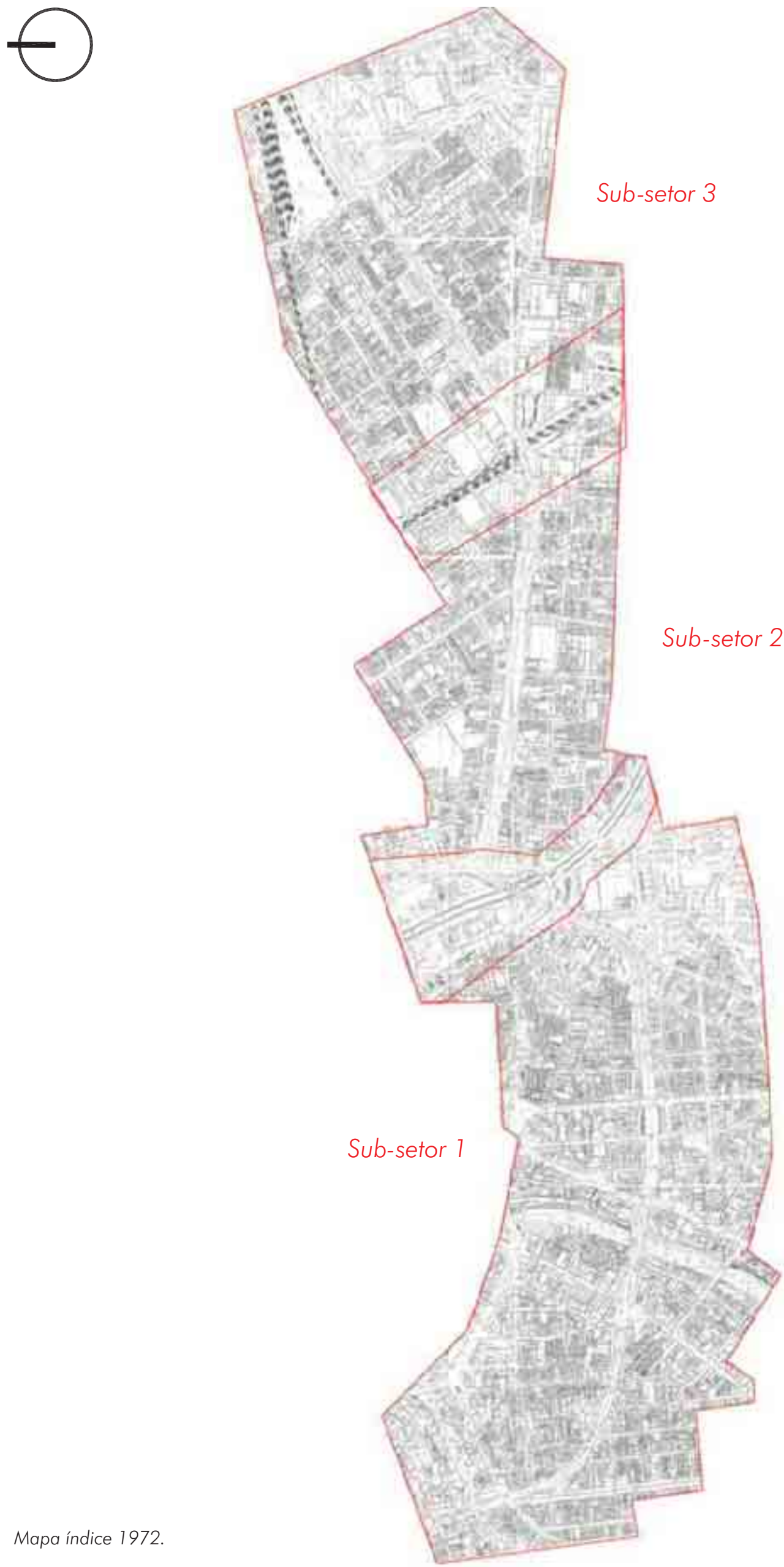
AS TRANSFORMAÇÕES DO PERÍODO 7 960- 1980

RADIAL LESTE
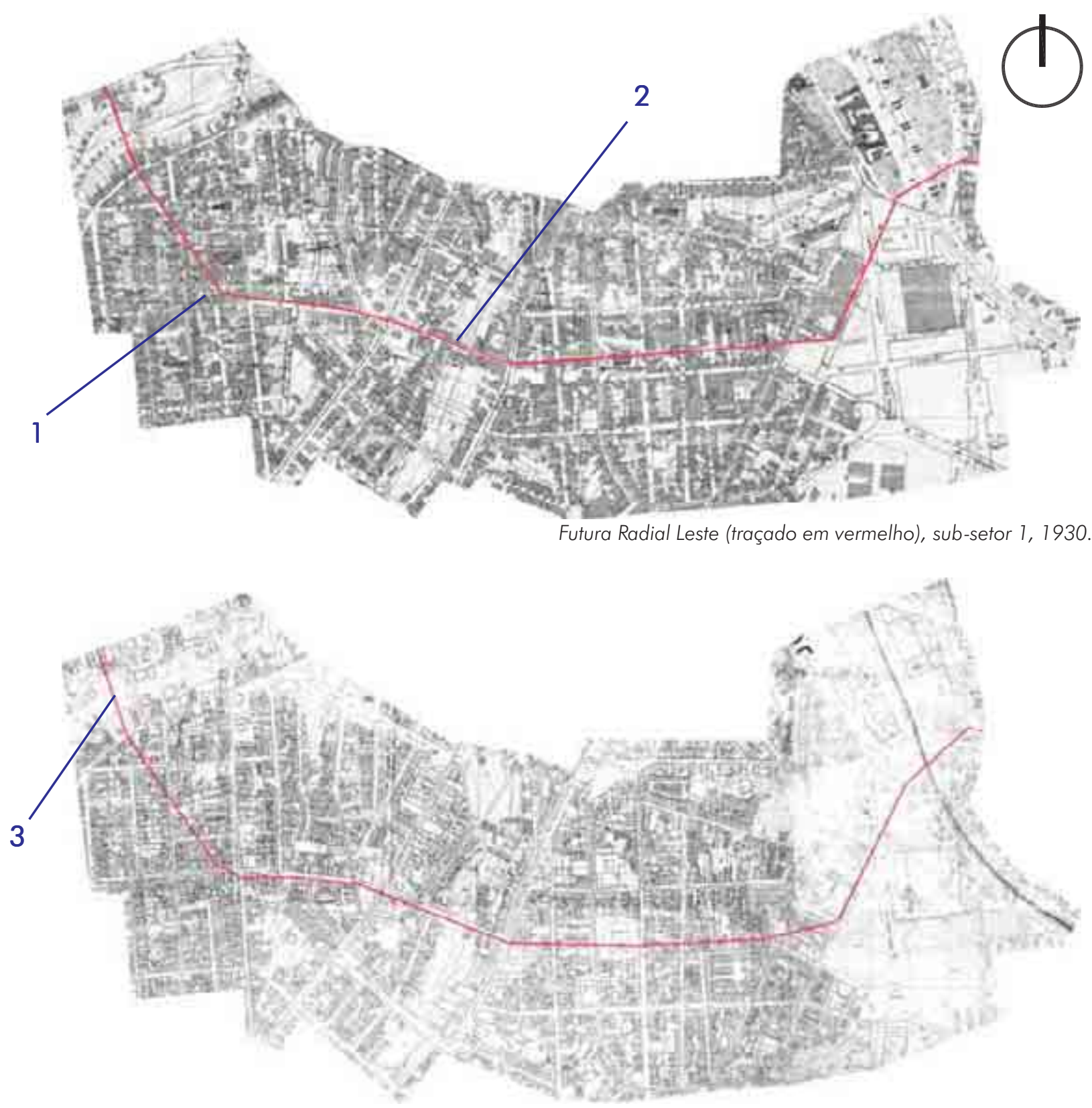

Futura Radial Leste (traçado em vermelho), sub-setor 1, 1954.

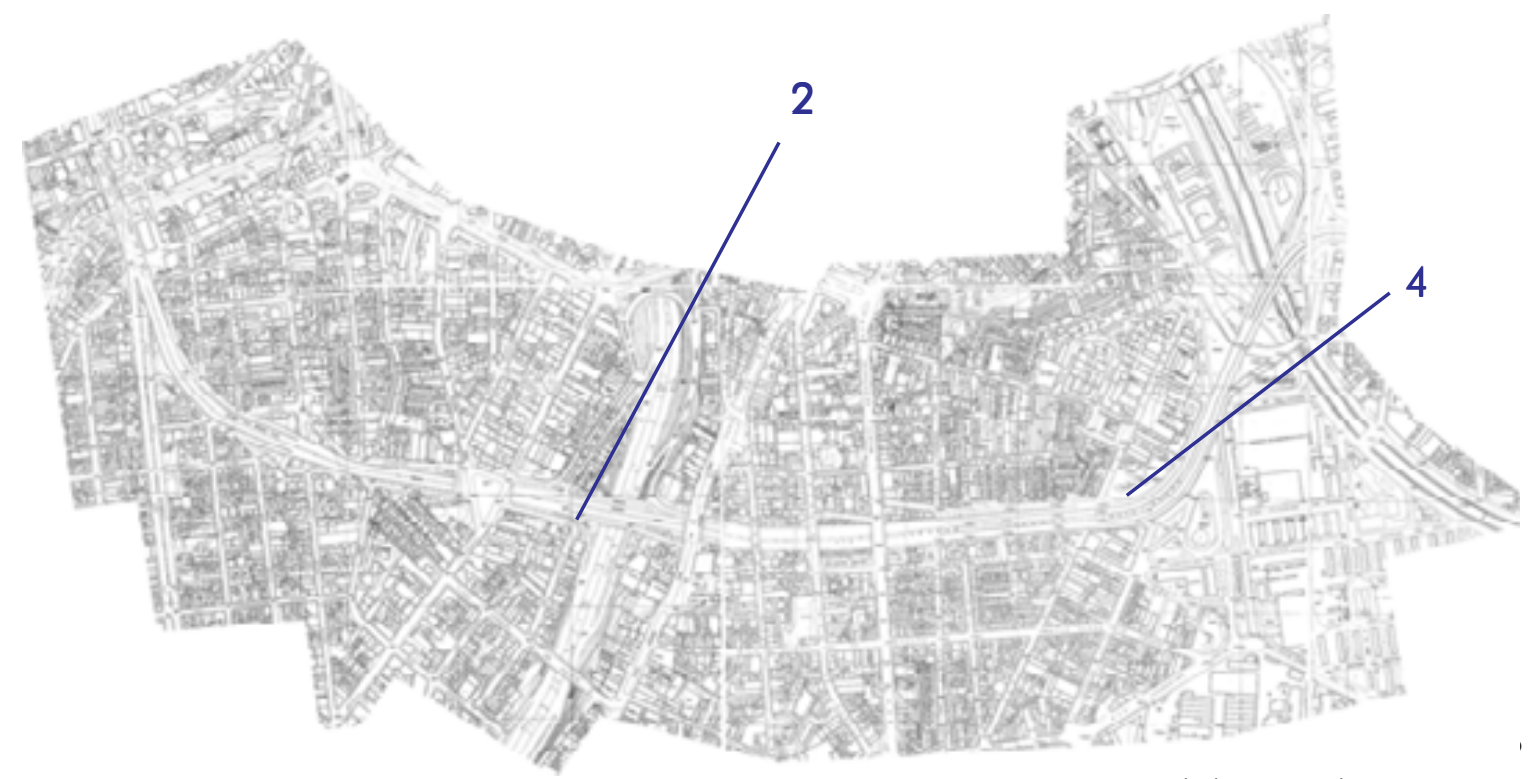

Radial Leste, sub-setor 1, 1972. 


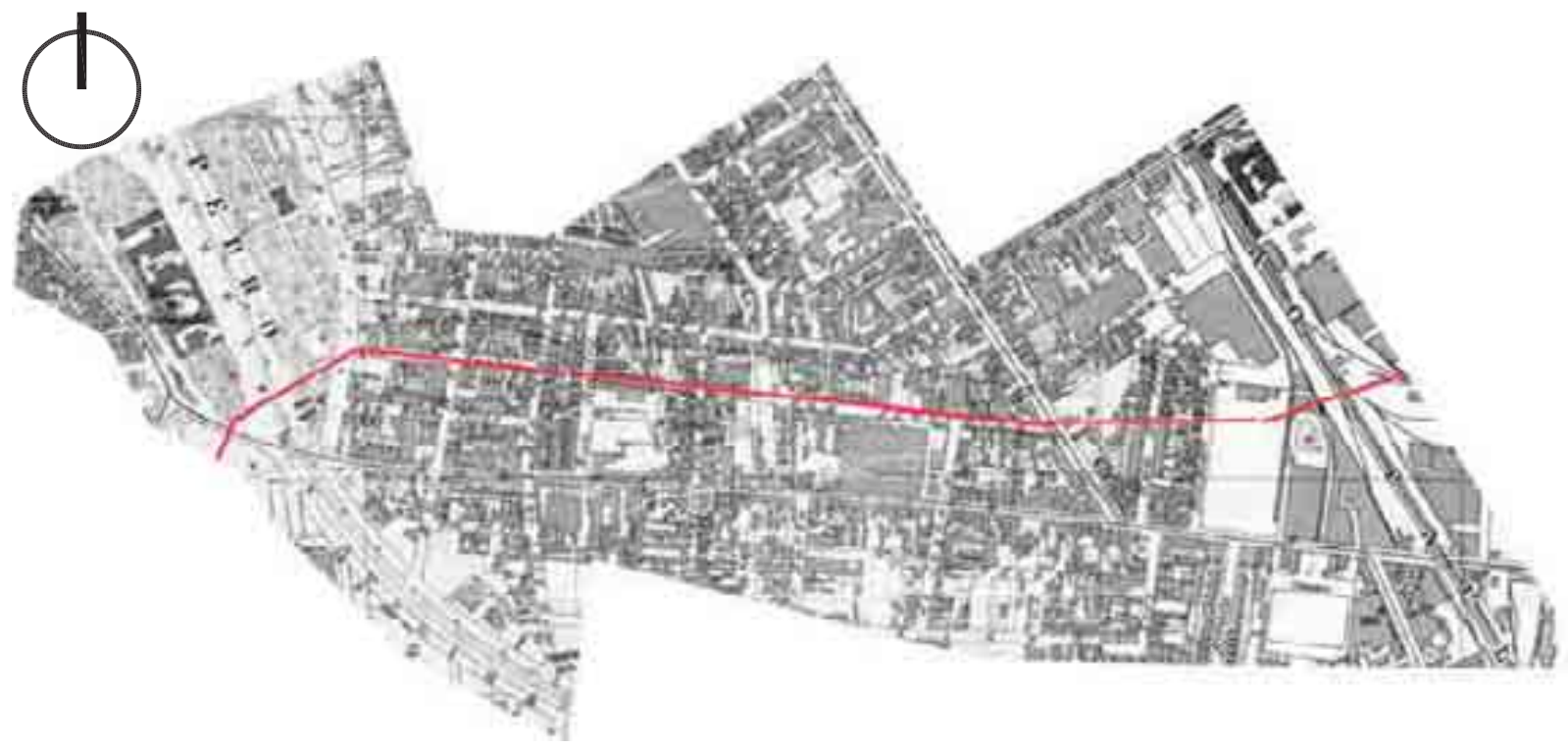

Futura Radial Leste (traçado em vermelho), sub-setor 2, 1930.

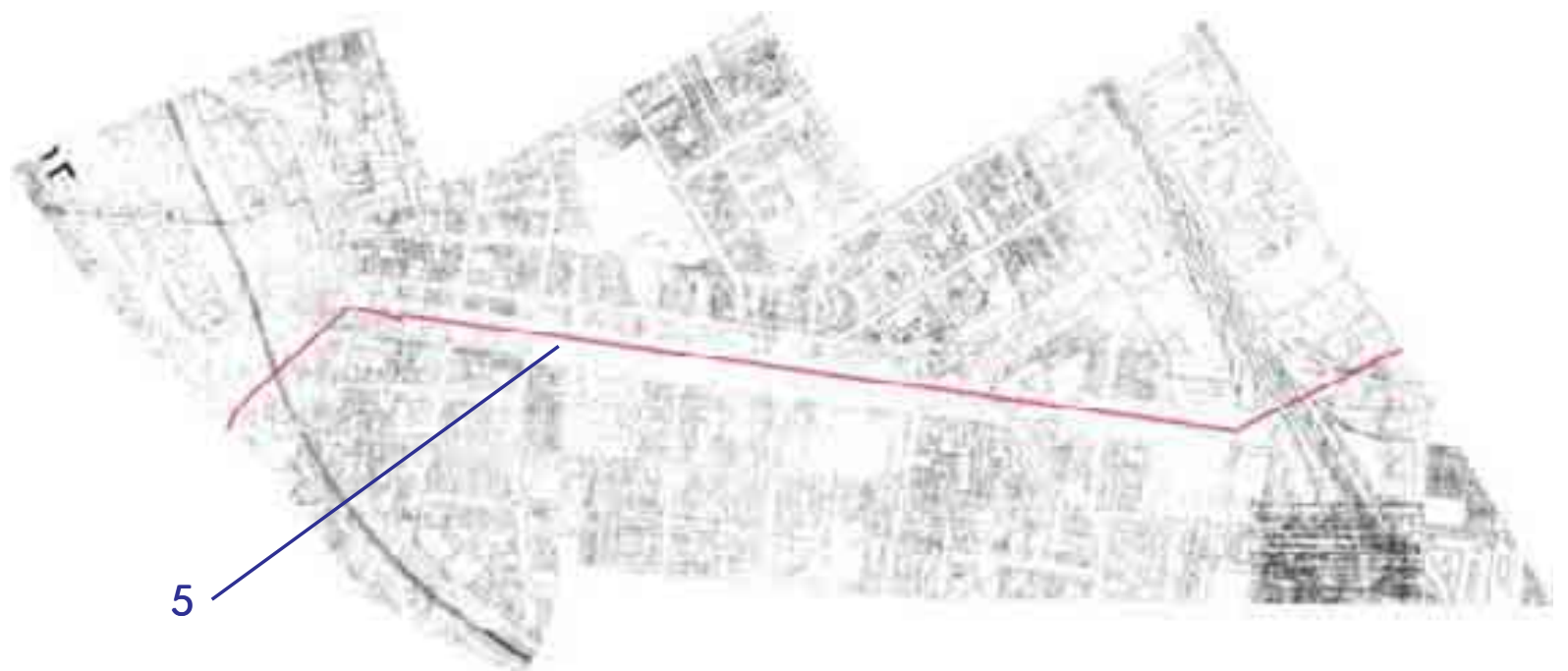

Futura Radial Leste (traçado em vermelho), sub-setor 2, 1954.

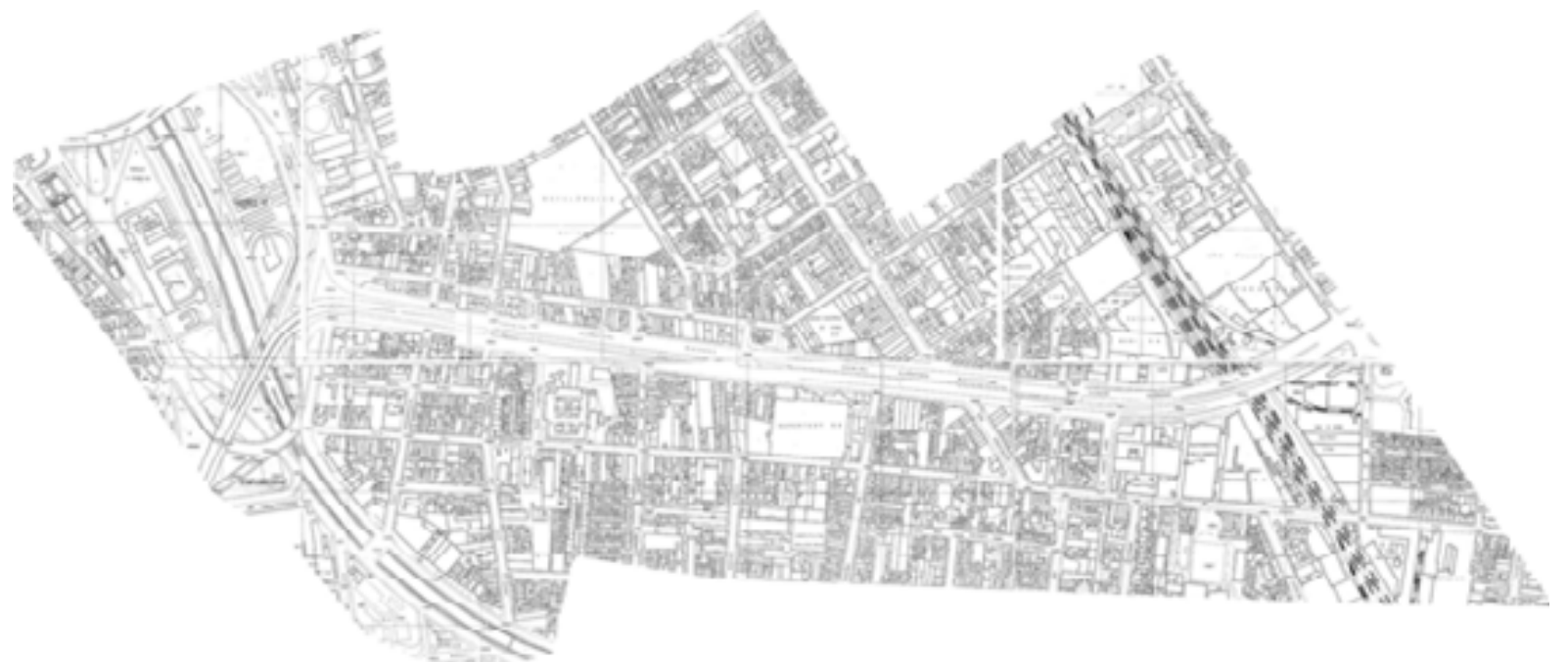

Radial Leste, sub-setor 2, 1972. 
AS TRANSFORMAÇÕES DO PERÍODO 1960 - 1980

RADIAL LESTE

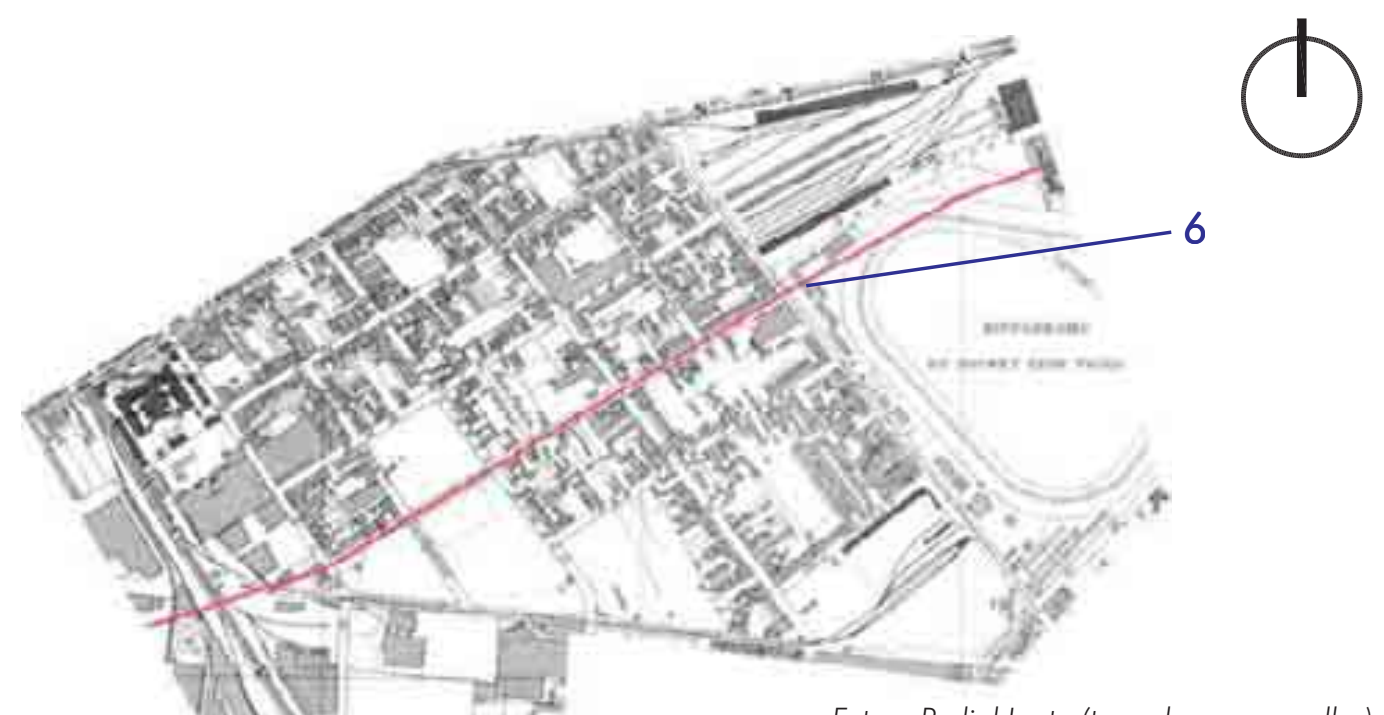

Futura Radial Leste (traçado em vermelho), sub-setor 3, 1930.
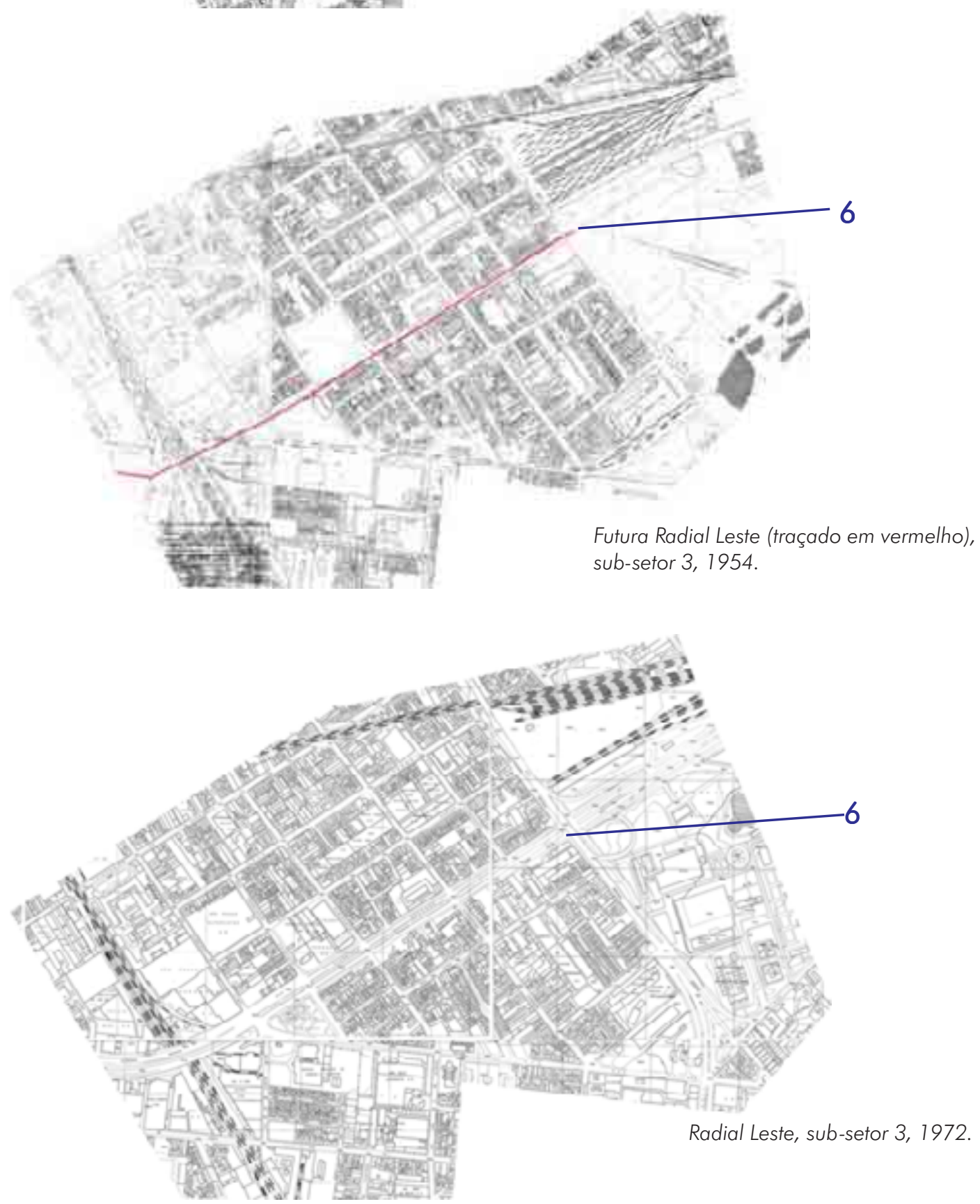


\subsection{4 - Diametral Leste-Oeste: Avenida São João}

Para a compreensão dos aspectos da estruturação dessa componente, além dos mapas cadastrais, foi também utilizado um trabalho da socióloga Lucila Hermann, que pesquisou a avenida São João nos seus estudos sobre Ecologia Urbana na metade da década de 1930. Nesse período, esse trabalho apontou as seguintes características físicas e sociais da São João:

- Ocorreram remodelações em dois períodos na Avenida. O primeiro, iniciado em 1911, incluiu a retificação e desapropriações do trecho inicial, provocando a saída das famílias de alta renda para a Água Branca, em função da expansão comercial e deterioração que o trecho apresentou. $O$ segundo realizado na administração de Pires do Rio, entre 1926-1928, abrangeu o trecho entre a rua Vitória e a Praça Marechal Deodoro, que apresentava tendência à verticalização para fins de moradia e uma área de deterioração que, segundo Hermann, antecedia a área de alta renda da Água Branca (Hermann apud RAM, XCIX, $1944,16 ; 26)$. Como será visto adiante, essa segunda etapa da ampliação se estendeu até a década de 1930.

- O Código Arthur Saboya estabeleceu para o lado par da avenida (direito no sentido centro-bairro), que sofreu a reformulação de 1911, o gabarito mínimo de quatro andares, fazendo com que na década de 1930 os edifícios desse lado fossem novos e com melhores condições que os do lado esquerdo, mencionados por Hermann como sendo constituída de "prédios velhos e baixos". No lado par, $81 \%$ dos prédios possuíam quatro andares ou mais, enquanto que do lado ímpar, $68 \%$ das edificações eram de apenas um andar (idem, 15;25).

Para analisar essa avenida, sua extensão foi dividida em três sub-setores:

Sub-setor 1 - correspondente ao seu início na Praça Antonio Prado até a avenida lpiranga

Sub-setor 2 - da avenida Ipiranga até a alameda Glete

Sub-setor 3 - da alameda Glete até a avenida Pacaembu

1. No mapa de 1930, todo o trecho compreendido pelo primeiro sub-setor já havia recebido ampliação, assim como o segundo até a rua Helvetia. Segundo o estudo sobre a São João, do seu início até a rua General Osório, a avenida apresentava $96 \%$ de prédios comerciais, situados principalmente do seu lado ímpar, isto é, lado esquerdo no sentido centro-bairro. $\bigcirc$ trecho inicial ligava-se ao centro e cruzava o Vale do Anhangabaú, que ainda possuía o paisagismo original do projeto de Bouvard (ref. 1). Hermann mencionou uma série de razões para a transformação da morfologia desse trecho, principalmente até o Largo do Paissandu, pois levando em conta a valorização daquela zona e a legislação que proibia prédios com menos de 8 andares, a verticalização ocorreria necessariamente. 
Comparando a carta de 1930 com a de 1954, verificam-se alterações no parcelamento, com maior divisão dos lotes no lado esquerdo da avenida, sentido centro-bairro e importantes alterações viárias implantadas pelo Plano de Avenidas, implicando na reestruturação do Vale do Anhangabaú que também incorporou, em 1954, a passagem subterrânea no cruzamento com a São João (ref. 2). Foi também igualmente transformada a avenida lpiranga (ref. 3), a primeira componente do Plano de Prestes Maia a ser implantada, sendo concluída em 1941 (Amadio, 1998, 58). No mapa de 1972, a ocupação ao longo da avenida manteve-se sem alterações significativas, uma vez que a verticalização ocorrida nas décadas de 1950 e 1960, já havia se consolidado, entrando em declínio, a partir desse período, a construção de edifícios.

2. Pelo mapa de 1930, o sub-setor que se inicia na avenida Ipiranga, mostra essa via e a Duque de Caxias sem os alargamentos que o Plano de Avenidas implantou. A Ipiranga ainda era ainda denominada como rua (ref. 3) e a futura Duque de Caxias incorporou o traçado da rua Maria Tereza (ref. 4), quando de sua ampliação. O Largo do Arouche também mostrava a configuração anterior ao Plano de Prestes Maia, que o interligou posteriormente à Praça da República pela ampliação da rua Vieira de Carvalho (ref. 5). Na altura da rua Helvetia, o mapa de 1930 registrou uma obstrução ainda existente ao alargamento da via (ref. 6), o que comprova o fato da ampliação da São João ter demolido o lado par da avenida, como mencionou Hermann, e por esse motivo, ali implantadas as novas tipologias na década de 1930.

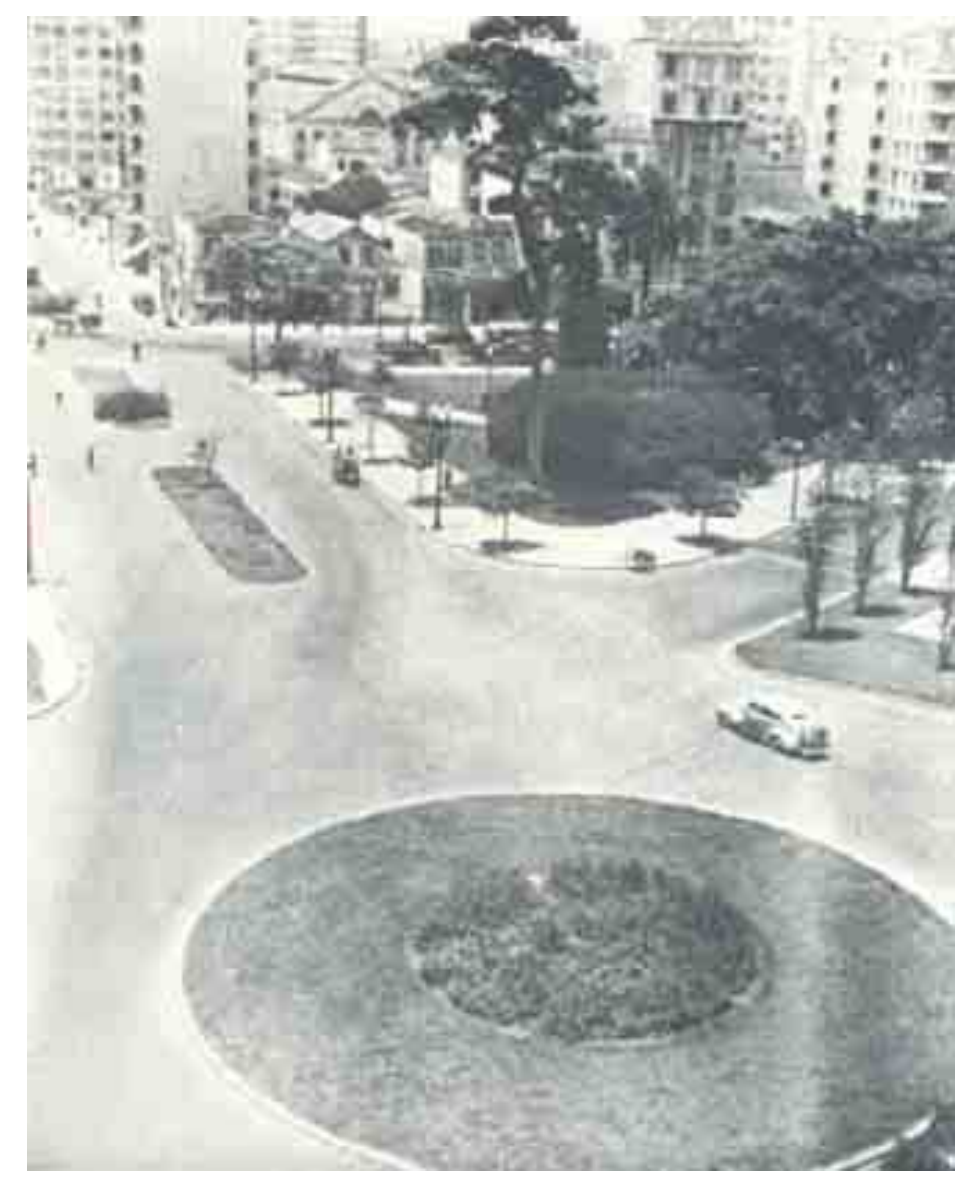

Fig. 89: Largo do Arouche e Rua Vieira de Carvalho, década de 1940. 
O mapa de 1954 registrou as avenidas Ipiranga e Duque de Caxias (ref. 4) já alargadas, o mesmo ocorrendo com a nova configuração do Largo do Arouche e da avenida Vieira de Carvalho, transformada em um boulevard (ref. 5). Nesse sub-setor a São João abrigou uma das mais simbólicas funções resultante da modernização da cidade, que foi a Cinelândia. Esta começou a formar-se fora do Triângulo, no Centro Novo, nos anos que antecederam a II Guerra Mundial, chegando ao seu auge na década de 1950, consagrando a São João como eixo principal da área que chegou a concentrar 25 salas de cinema (idem, 49). Percebe-se pelo mapa de 1954 a transformações ocorridas no parcelamento das faces de quadra da avenida, atestando já ter ocorrido a substituição das construções antigas também no lado ímpar, que não fora atingido pelos alargamentos da via nas décadas de 1910 e 1920.

O mapa de 1972 mostra a manutenção das características do parcelamento, com transformações indicativas da continuidade da verticalização na década de 1960, como por exemplo, a quadra em que situou o edifício do cine Majestic, na esquina da Duque de Caxias (ref. 7), a do edifício Andraus, entre as ruas Aurora e Pedro Américo (ref. 8) e aquela onde foi erguido o então edifício-sede do City Bank, na esquina com a avenida lpiranga (ref. 9). A transformação mais profunda ocorreu nas quadras entre as ruas Sebastião Pereira e Frederico Steidel, que foram cortadas pela via elevada construída sobre a São João no final da década de 1960, correspondente à ligação Leste-Oeste (ref. 10). A alça de acesso ao viaduto, na rua Helvetia, se situou exatamente no ponto em que, uma quadra interrompia o trecho alargado da avenida, pelo mapa de 1930.

A partir do trecho em que o viaduto se desviou da São João, rompendo as quadras mencionadas, seguiu sobre a avenida Amaral Gurgel até a altura da rua da Consolação, quando se transformou em via subterrânea à Praça Roosevelt, também construída nesse período, interligando-se ao complexo viário da Radial Leste, como foi visto na análise sobre essa componente.

3. No sub-setor que se inicia na rua Helvetia, seguindo até a avenida Pacaembu, o mapa de 1930 mostra a antiga configuração viária da São João, que terminava no encontro da rua das Palmeiras com a Praça Marechal Deodoro (ref. 11). A rua das Palmeiras interligava a São João com a avenida Água Branca, área de concentração da alta renda, como já mencionado. O trecho agora enfocado, juntamente com a rua das Palmeiras, foi analisado em 1935 por Hermann como apresentando a maior densidade da avenida, em relação às demais áreas. A relação utilizada pela autora foi a de habitantes por metro linear, impossível de ser convertida para metragem quadrada por não se conhecer os critérios que foram utilizados. De qualquer forma, a área enfocada apresentava a densidade de 1,6 indivíduos por metro linear, enquanto que aquela vinculada ao centro apresentava 0,66 e a de transição 0,73. Hermann creditava esse índice ao fato de existirem construções de 4 e 8 andares, na Praça Marechal Deodoro e pelo aproveitamento máximo do parcelamento, com média de 3 metros de frente 

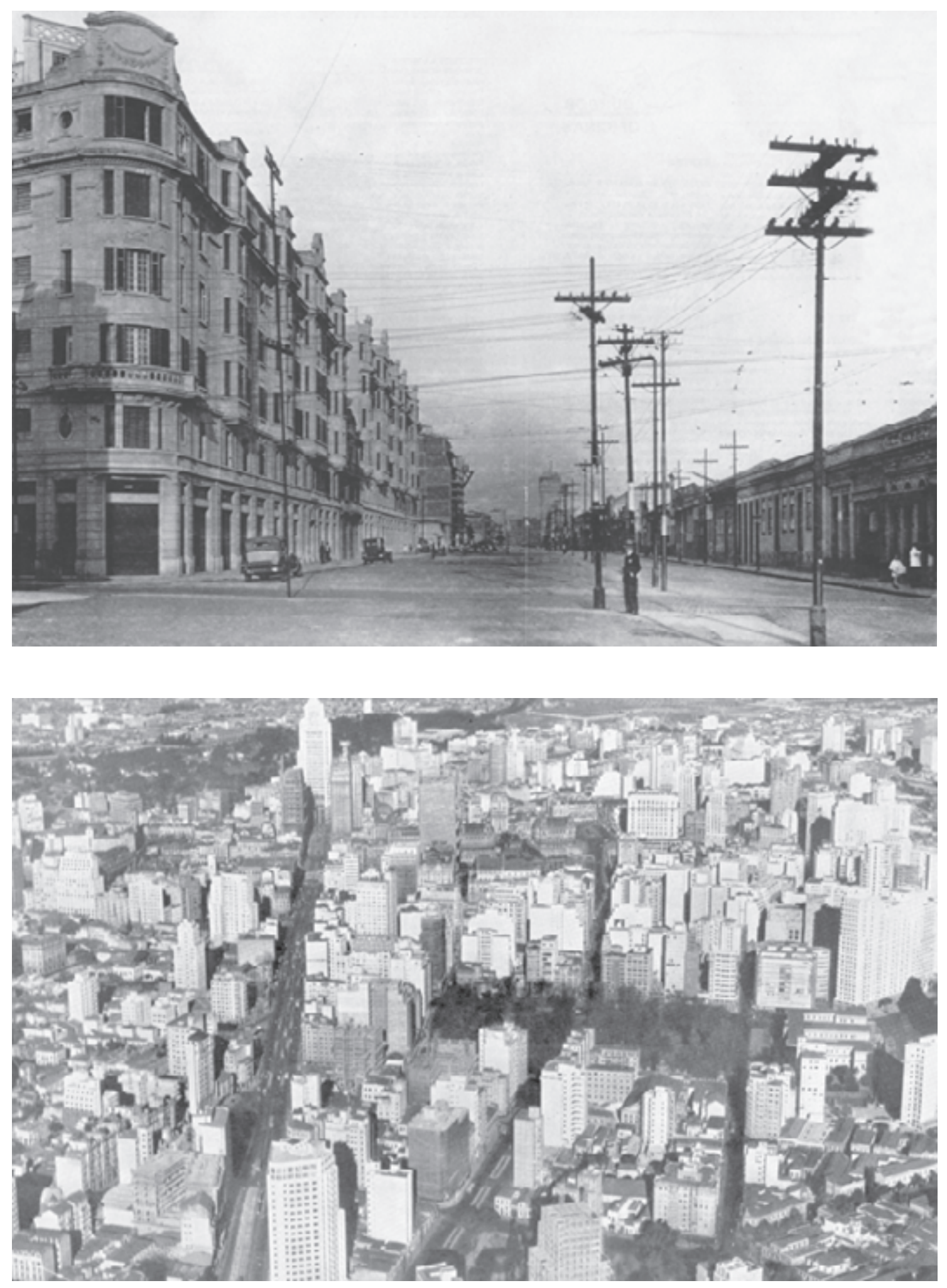

Fig.90 e 91: Avenida São João: Ao alto, lado ímpar da avenida com as constrções antigas, de gabarito baixo, poupadas no alargamentos da via entre 1910 e 1920. Acima, vista aérea, sentido centro, década de 1950. 
(Hermann apud RAM, XCIX, 1944, 33). Em relação ao antigo sistema viário, pode-se notar também que nesse período a avenida Pacaembu conectava-se à rua das Palmeiras (ref. 12).

Pelo mapa de 1954, a continuação da avenida São João já havia se completado, executado sobre o leito da rua das Palmeiras, que passou a ter início na Praça Marechal Deodoro (ref. 13). Foi igualmente implantada a continuação da avenida Pacaembu, através de um corte no terreno e da construção de um viaduto para esse novo trecho da avenida São João (ref. 14). Essas obras constaram também do Plano de Avenidas, que implantou melhoramentos em várias vias da cidade. Percebe-se que, para a alinhar o novo trecho com a Praça Marechal Deodoro, o alargamento da rua das Palmeiras ocorreu sobre as quadras do lado par (à direita no sentido centro-bairro), como aconteceu nos outros setores da avenida São João nas décadas anteriores. Com isso, mantiveram-se as características nas quadras do lado ímpar não atingidas pelas demolições, como é possível notar comparando os mapas de 1930 e 1954, mas houve grande transformação nas novas faces de quadra, indicando parte da verticalização desse trecho da avenida já ter ocorrido ao longo das décadas de 1940 e 1950.

O mapa de 1972 mostra a via elevada percorrendo a avenida e seccionando a praça Marechal Deodoro para a implantação de uma rampa de acesso (ref. 15). Essa interferência, com início na Largo Padre Péricles (ref. 16), provocou a instantânea decadência de toda a área, em troca da ampliação do fluxo para automóveis. É necessário considerar que poucas alterações foram registradas na ocupação, uma vez que a verticalização das faces de quadras lindeiras à avenida já havia ocorrido nas décadas anteriores à construção do elevado. 
AS TRANSFORMAÇÕES DO PERÍODO 1960 - 1980

AVENIDA SÃO JOÃO

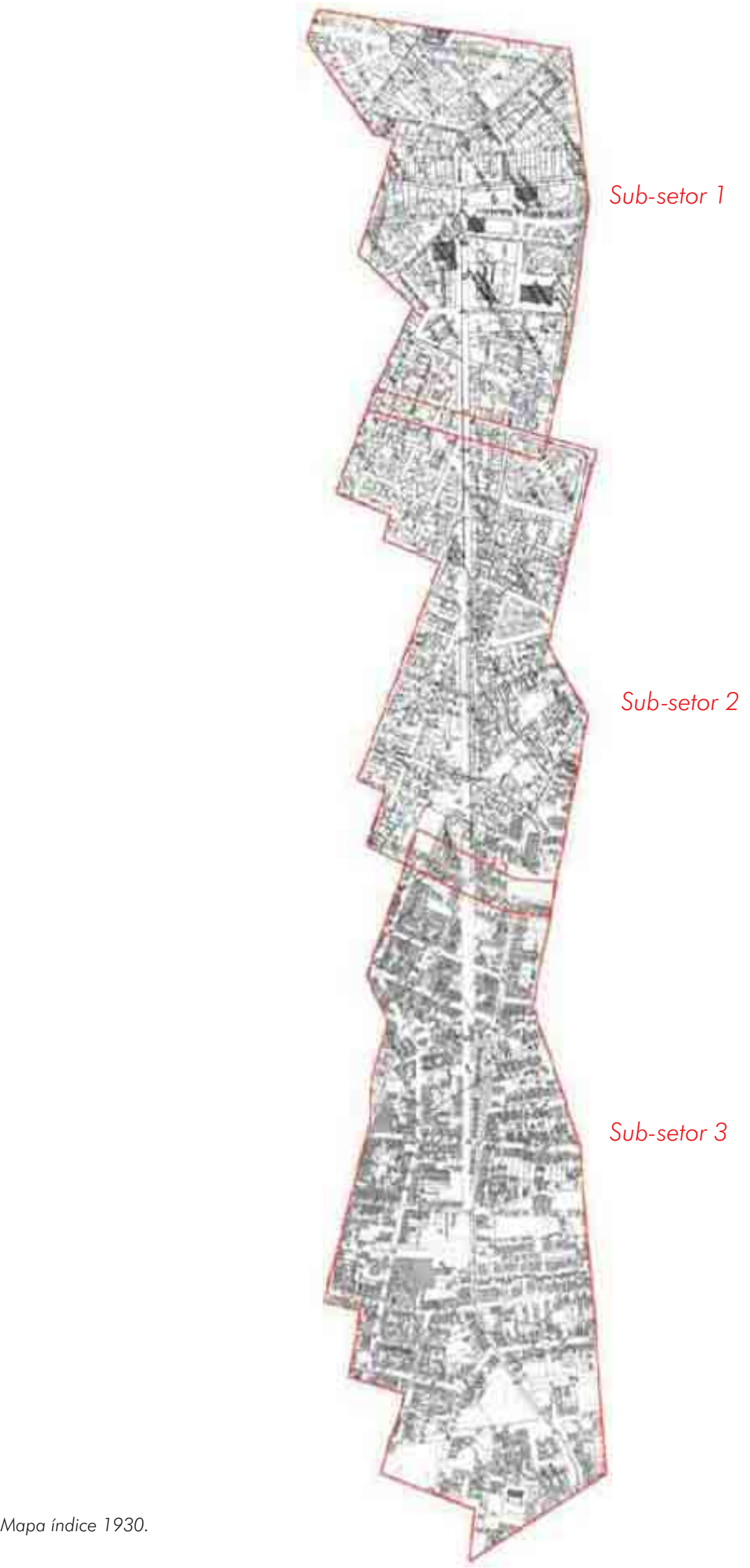



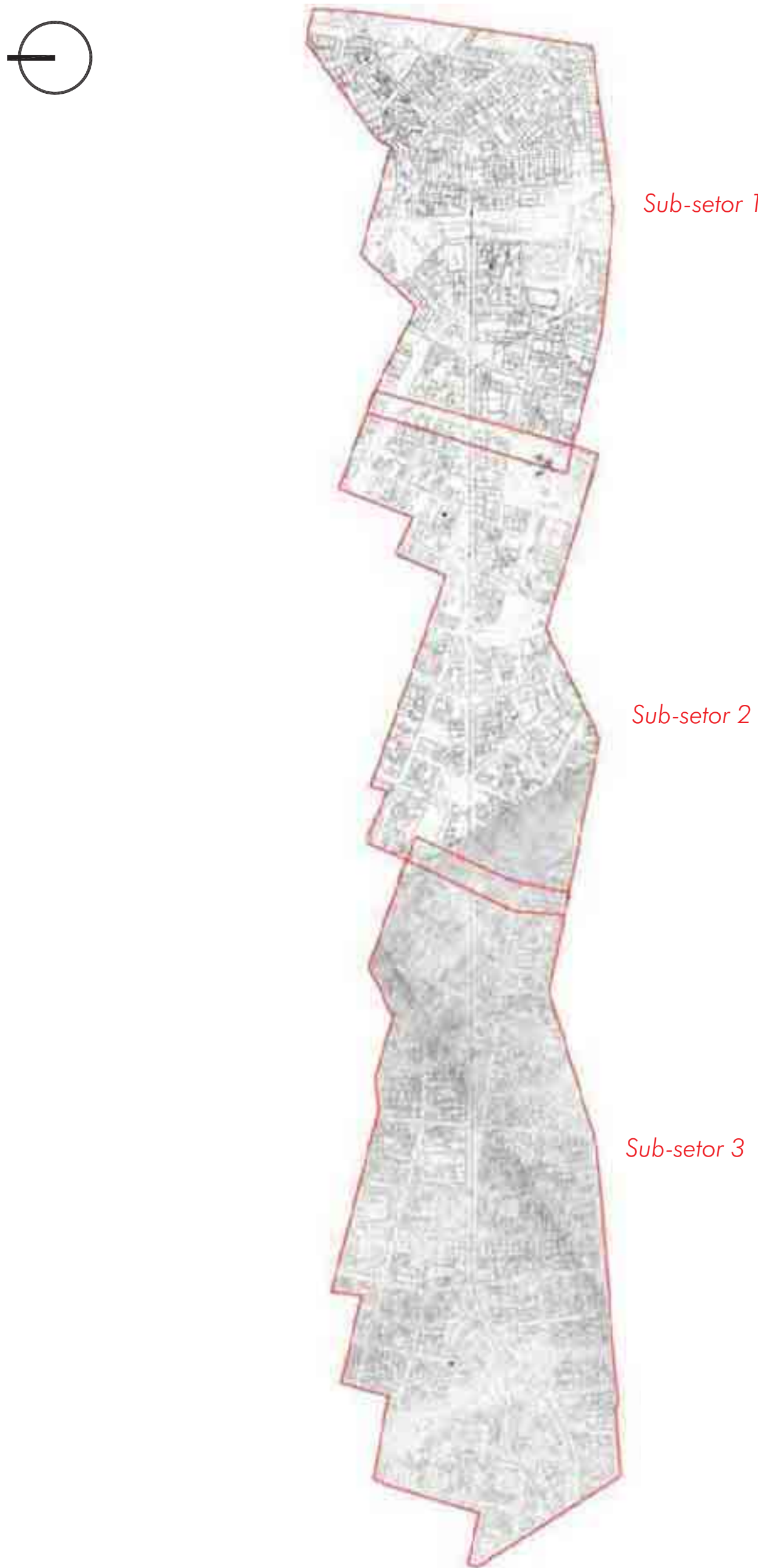
AS TRANSFORMAÇÓES DO PERÍODO 1 960- 1980

AVENIDA SÃO JOÃO

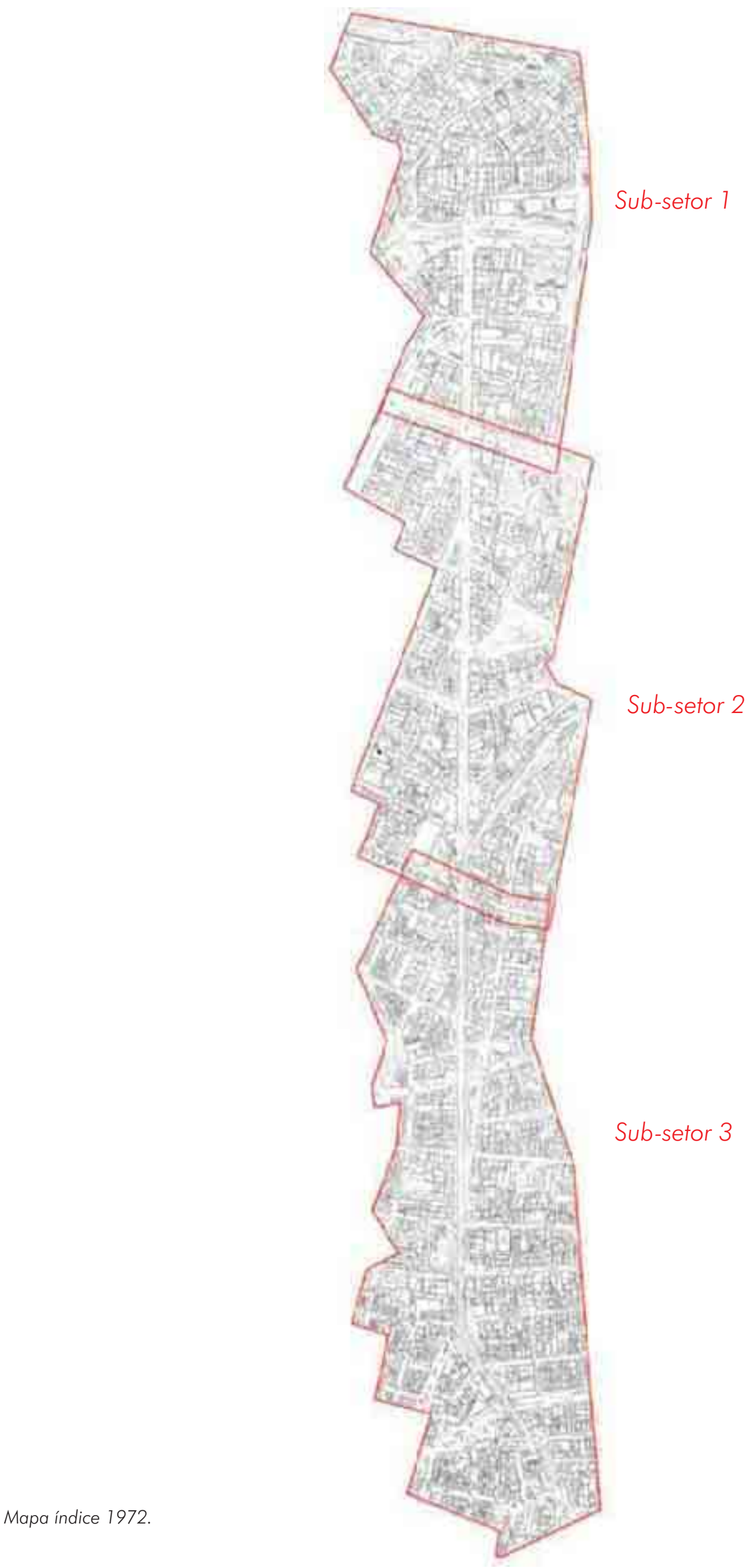




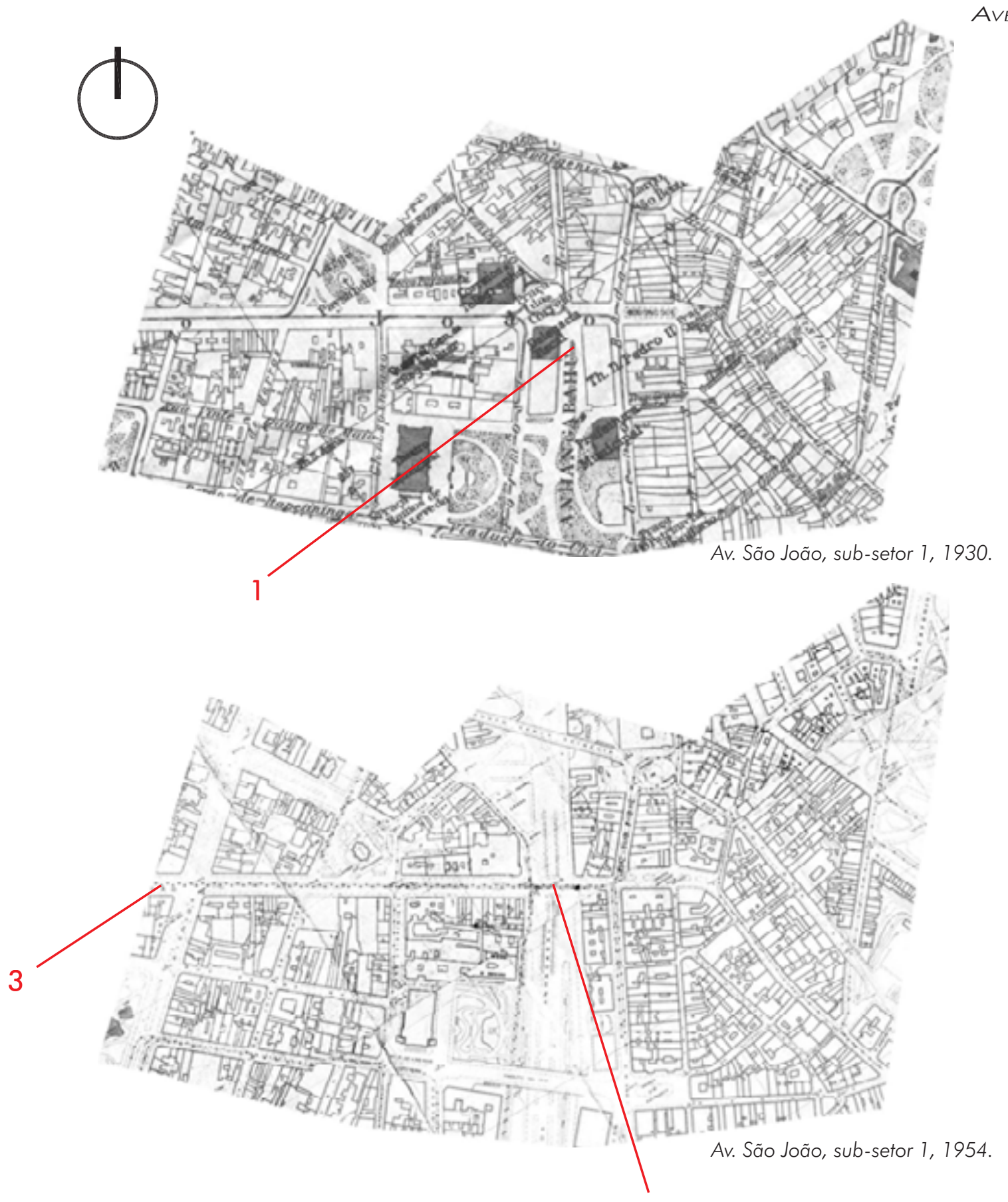

AVENIDA SÃO JOÃO 
AS TRANSFORMAÇÕES DO PERÍODO $1960-1980$

AVENIDA SÃO JOÃO

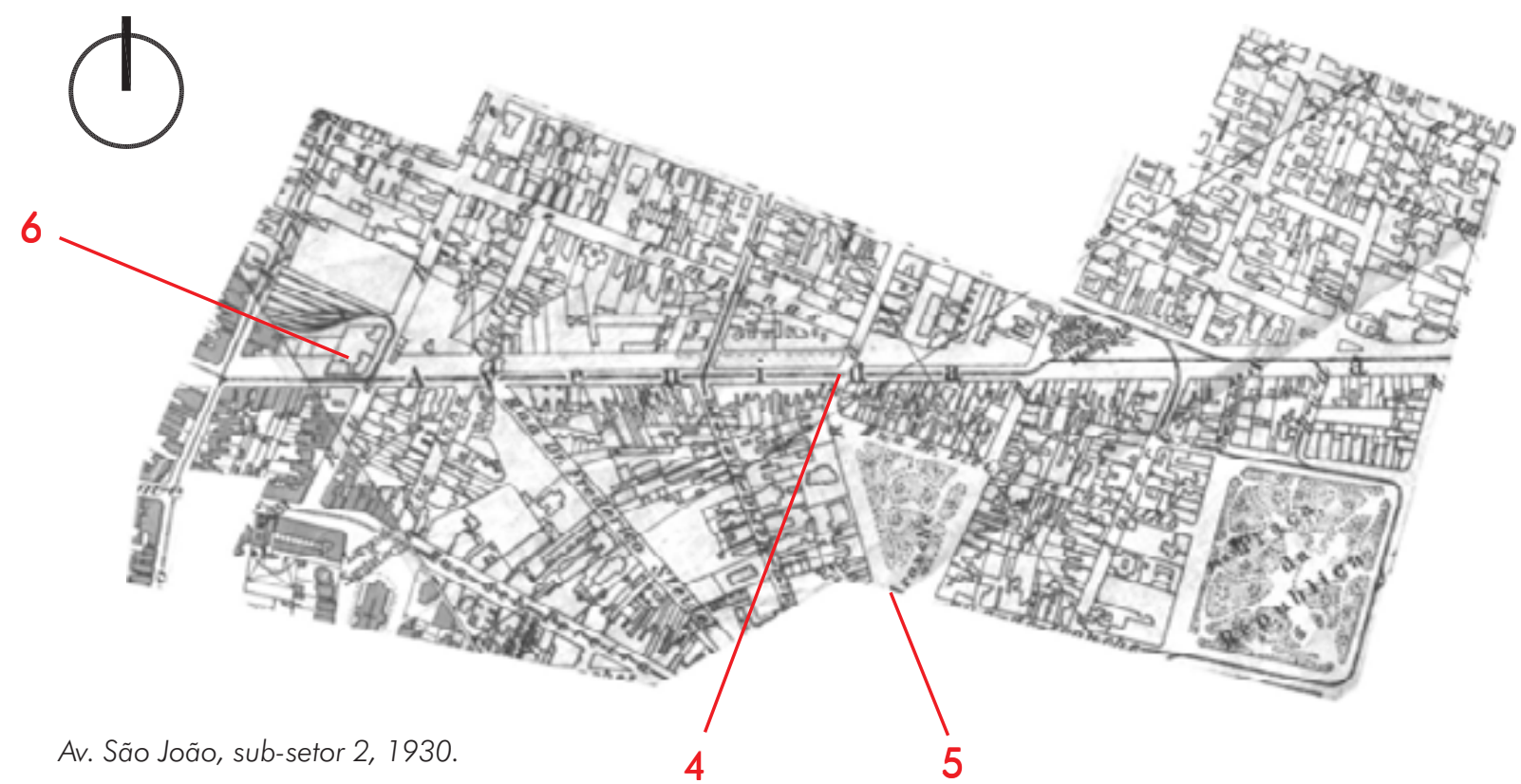

Av. São João, sub-setor 2, 1930.

4

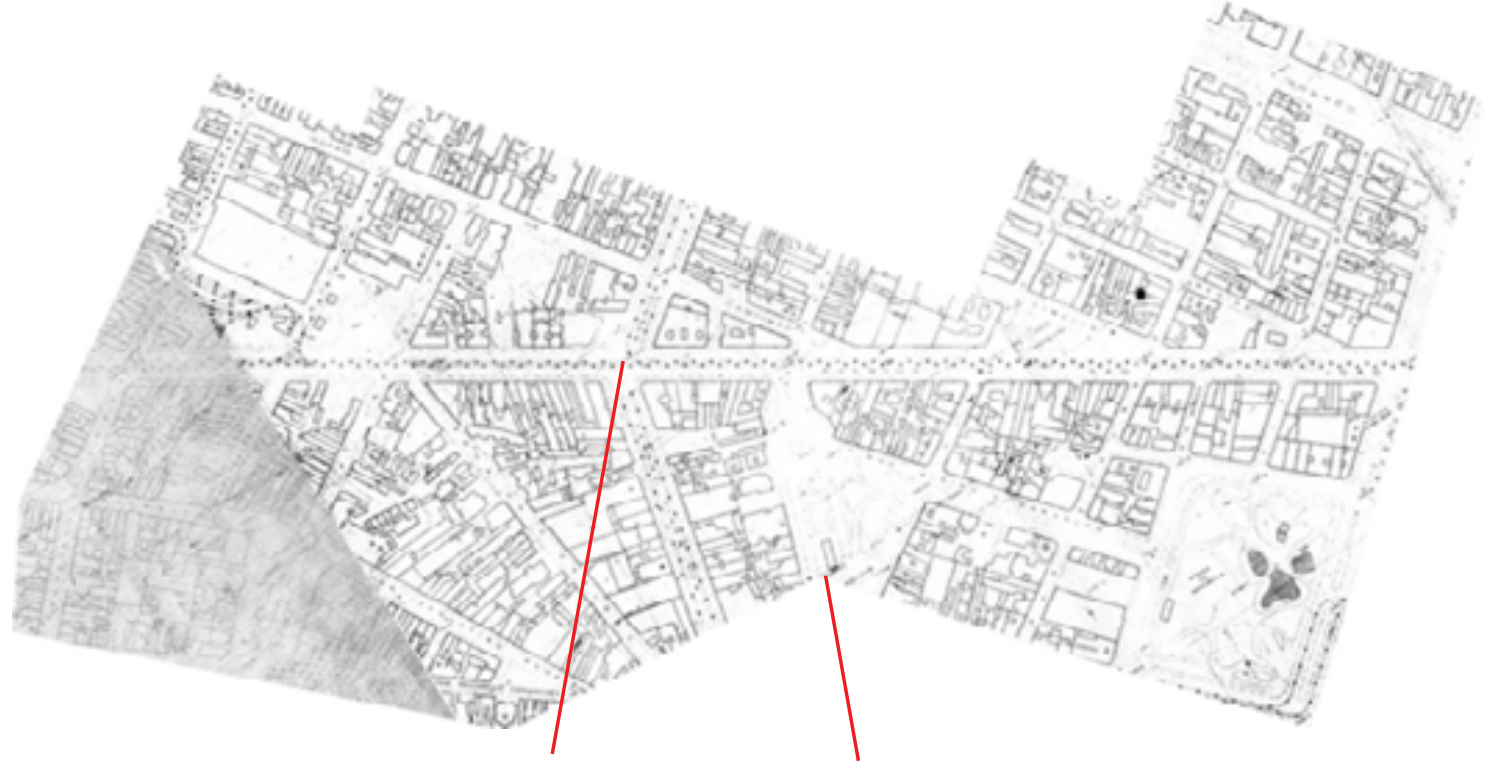

Av. São João, sub-setor 2, 1954.

4

5

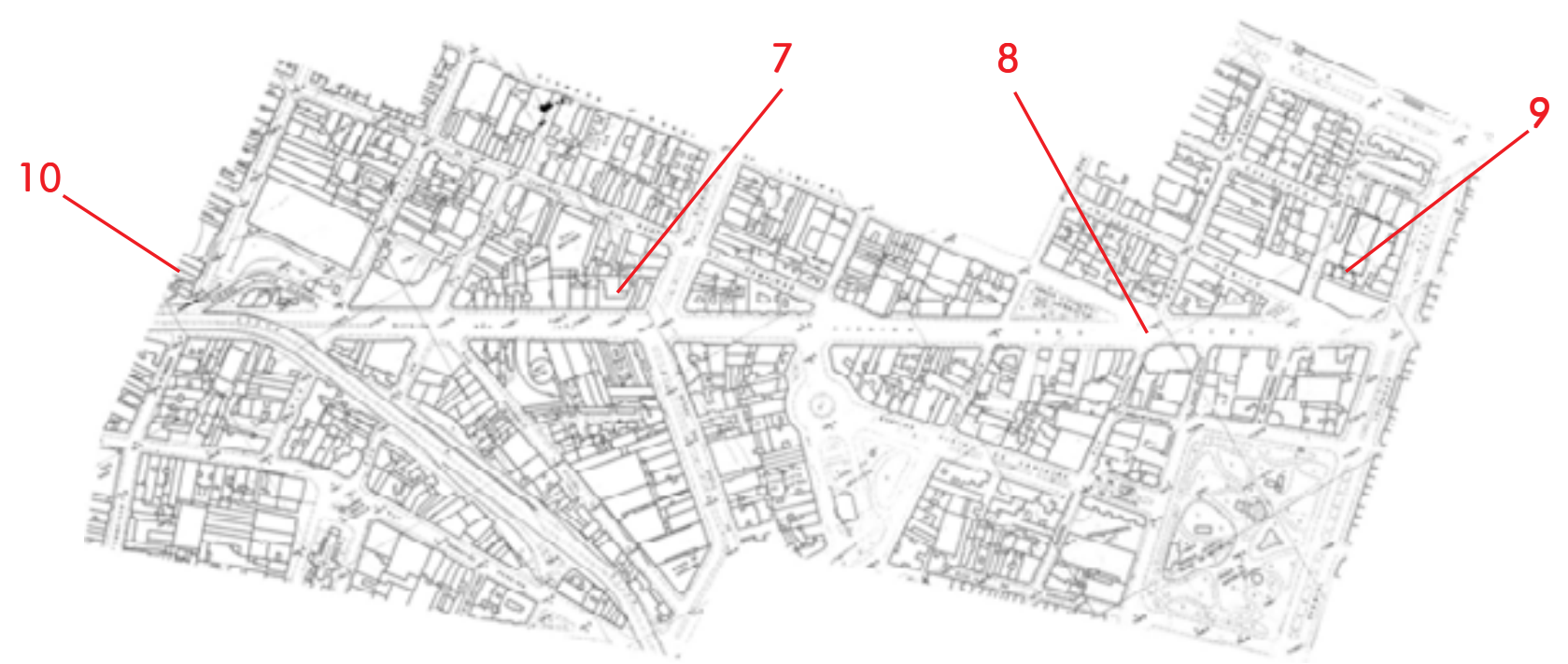

Av. São João, sub-setor 2, 1972. 

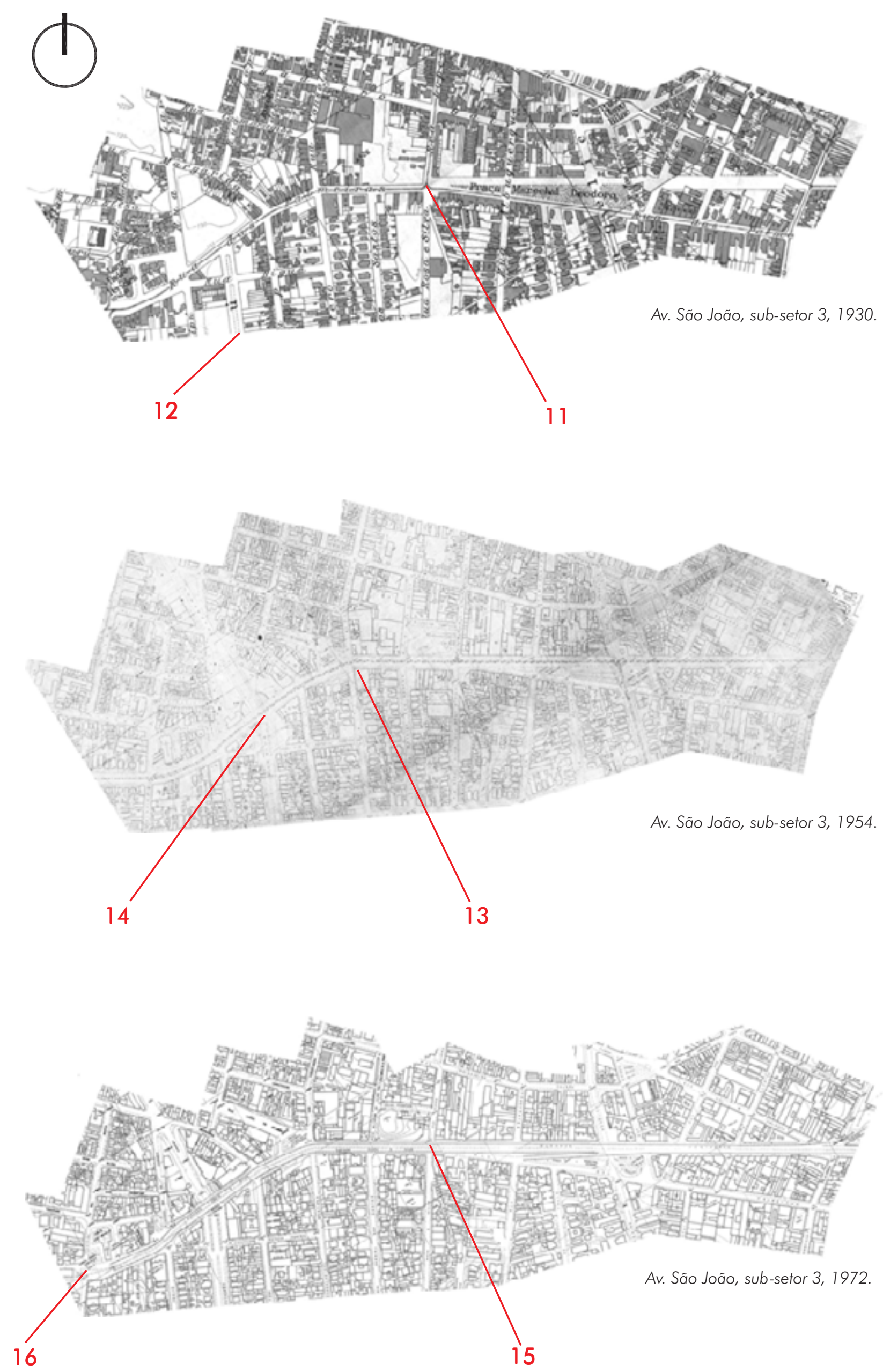


\subsection{5 - Componente sudeste: Avenida dos Estados}

Foi considerada nesta análise o limite do distrito Brás, para a definição da extensão ao sul da avenida dos Estados, que se prolonga até a marginal do rio Tietê. Por cruzar toda a cidade, no sentido sudeste-norte, acompanhando a canalização do rio Tamanduateí, essa avenida encontra em vários trechos, outras avenidas que fizeram parte do sistema viário proposto no Plano Melhoramentos de São Paulo. Foi dividida em três sub-setores:

1. Correspondente ao trecho que se inicia na Baixada do Glicério até os trilhos ferroviários na transição dos bairros Luz e Brás

2. Da ferrovia até a altura da Praça Armênia

3. Da Praça Armênia até a marginal Tietê.

1. Pelo mapa de 1930, nesse sub-setor a avenida tinha o Parque D. Pedro II como uma área de transição, já que pelo traçado da época, contornava-o pela rua da Figueira, do lado do Brás, e pela ruas Pedroso Alvarenga e 25 de Março, do lado do centro. Sua denominação anterior, avenida Tamanduateí, correspondia à maior parte de sua extensão, pois a avenida do Estado compreendia um pequeno trecho entre a antiga rua Anhangabaú, atual Carlos de Souza Nazaré e o início do Parque D. Pedro II. Ao longo das vias formadoras dessa ligação sudeste-norte, encontravam-se importantes equipamentos, como o Mercado Municipal e o Pátio do Parí, além evidentemente do próprio Parque. Nesse sentido, conectava essa região com bairros da Moóca,lpiranga e as cidades do ABC.

Comparando-se o mapa de 1954 com o de 1930, percebe-se que a avenida ainda contornava o Parque D. Pedro II, com uma transformação na sua parte norte, em que seccionou uma quadra junto da rua Américo Brasiliense para interligar a rua Santa Rosa com a avenida Senador Queirós. Nesse período, o rio Tamanduateí já havia recebido a sua retificação no interior do Parque e sobre ele foram construídas duas pontes, interligando as ruas Paula Souza e Carlos de Souza Nazaré com a área do Pátio do Parí e da zona cerealista.

O mapa de 1972 mostra duas alterações profundas produzidas na década de 1960, que se constituíram na passagem das pistas da avenida dos Estados pelo interior do Parque D. Pedro II e na implantação do complexo de viadutos que, assim como o novo traçado viário da avenida, seccionaram completamente o Parque. Por se tratar de uma área com ocupação antiga, relativamente poucas transformações ocorreram com o parcelamento ao longo do período analisado, podendo-se perceber que as principais ocorrências estiveram ligadas mais ao lado do centro, do que o do Brás.

2. Esse sub-setor inclui ao longo do percurso da avenida, a Vila Economizadora e a estação Tamanduateí do "Tramway" da Cantareira como principais referências. A morfologia dessa área também se manteve sem alterações significativas, 
comparados os mapas de 1930, 1954 e 1972, dando continuidade às características populares dos bairros da Ponte Pequena e do Canindé, situados no seu entorno. Merece ser lembrado que, nesse trecho da avenida dos Estados foi realizada no início da década de 1940 a pesquisa de Donald Pierson sobre os cortiços do Canindé, o que revela a ocorrência desse tipo de habitação nas quadras ao longo de sua extensão (Pierson apud RAM, LXXXI, 1942, 201).

3. Esse sub-setor apresentava no mapa de 1930, a avenida cruzando o antigo traçado da avenida Tiradentes e uma ocupação extremamente rarefeita, visto que sua maior parte se encontrava na Várzea do Tietê, ainda não retificado. Percebem-se duas áreas utilizadas por equipamentos públicos: a do Depósito Municipal e da Limpeza Pública. Tinha ainda como travessa a rua Itaporanga, posteriormente incorporada ao novo traçado da avenida Santos Dumont, como mostra o mapa de 1954.

É entretanto, pelo mapa de 1972, que as maiores transformações podem ser observadas, pois devido a conclusão da retificação do rio Tietê, a área ao longo da avenida foi totalmente ocupada por equipamentos públicos: no lado direito a Secretaria Estadual dos Transportes e a SABESP, e do lado esquerdo, as dependências da Administração Regional da Sé e o incinerador da usina de transbordo de lixo. Sempre margeando o canal do rio Tamanduateí, na foz deste com o rio Tietê, a avenida também se interrompeu, conectando-se à marginal, sem transposição das pistas e do rio. 
AS TRANSFORMAÇÕES DO PERÍODO 1960 - 1980

AVENIDA DOS ESTADOS

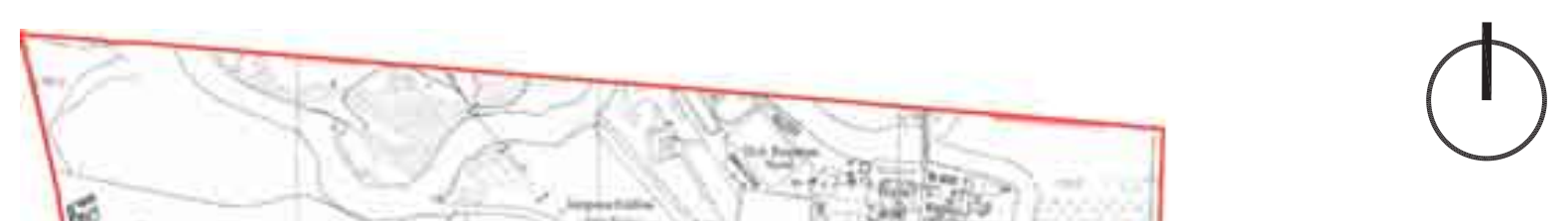

Sub-setor 2

Sub-setor 1

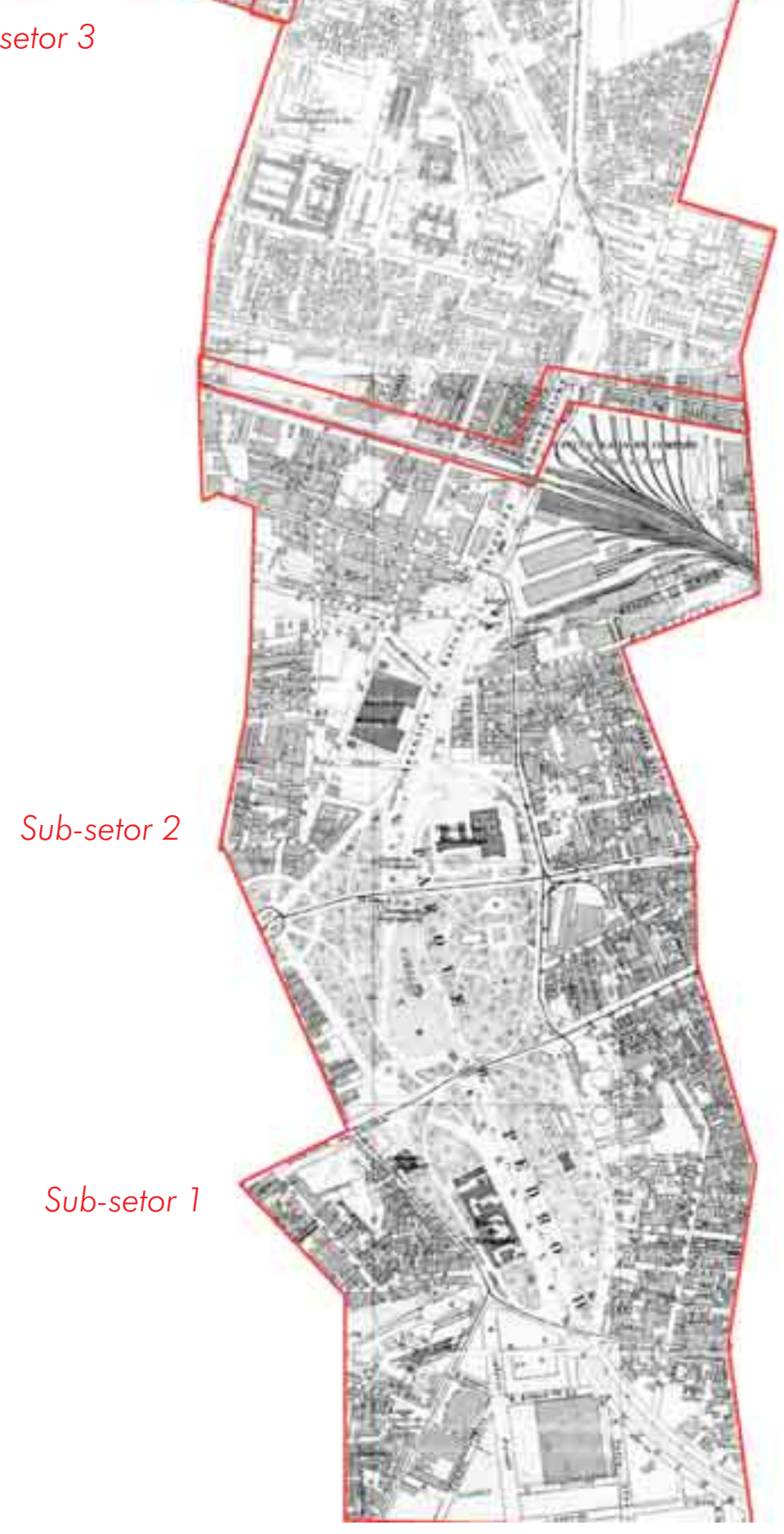


AS TRANSFORMAÇÕES DO PERÍODO $1960-1980$

AVENIDA DOS ESTADOS

()
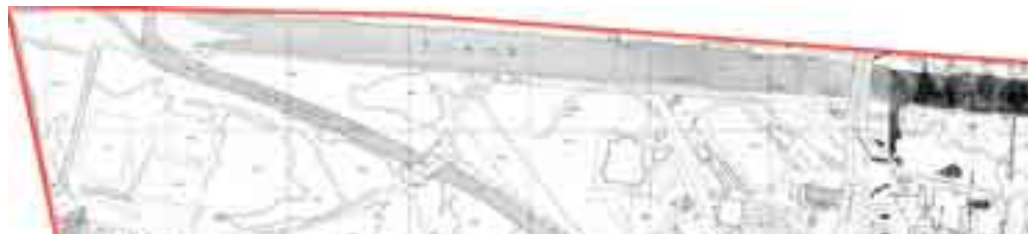

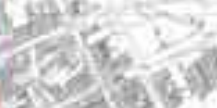

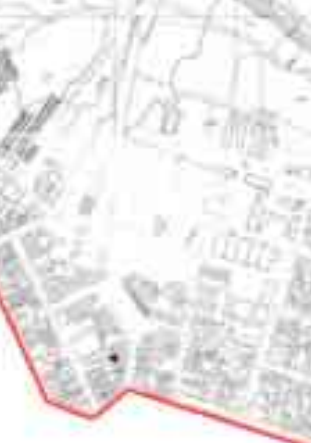

Sub-setor 3

Sub-setor 2

Sub-setor 1

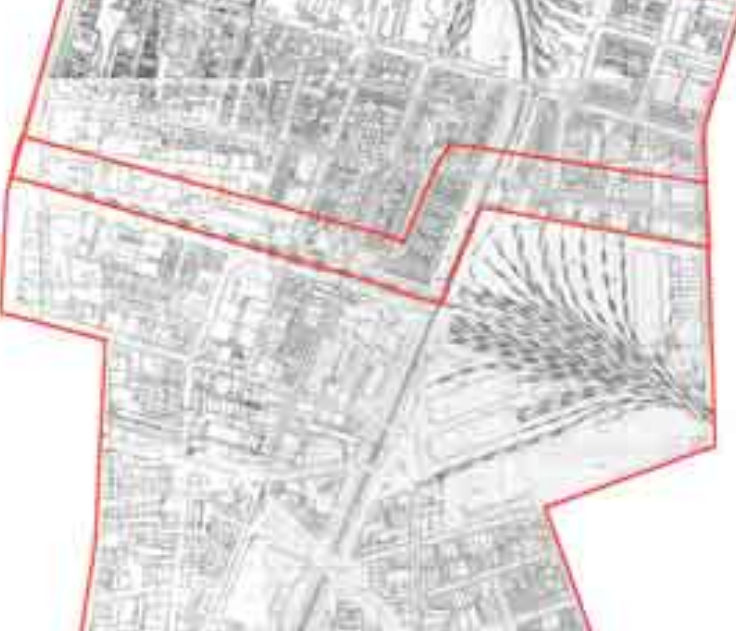


AS TRANSFORMAÇÕES DO PERÍODO $1960-1980$

AVENIDA DOS ESTADOS

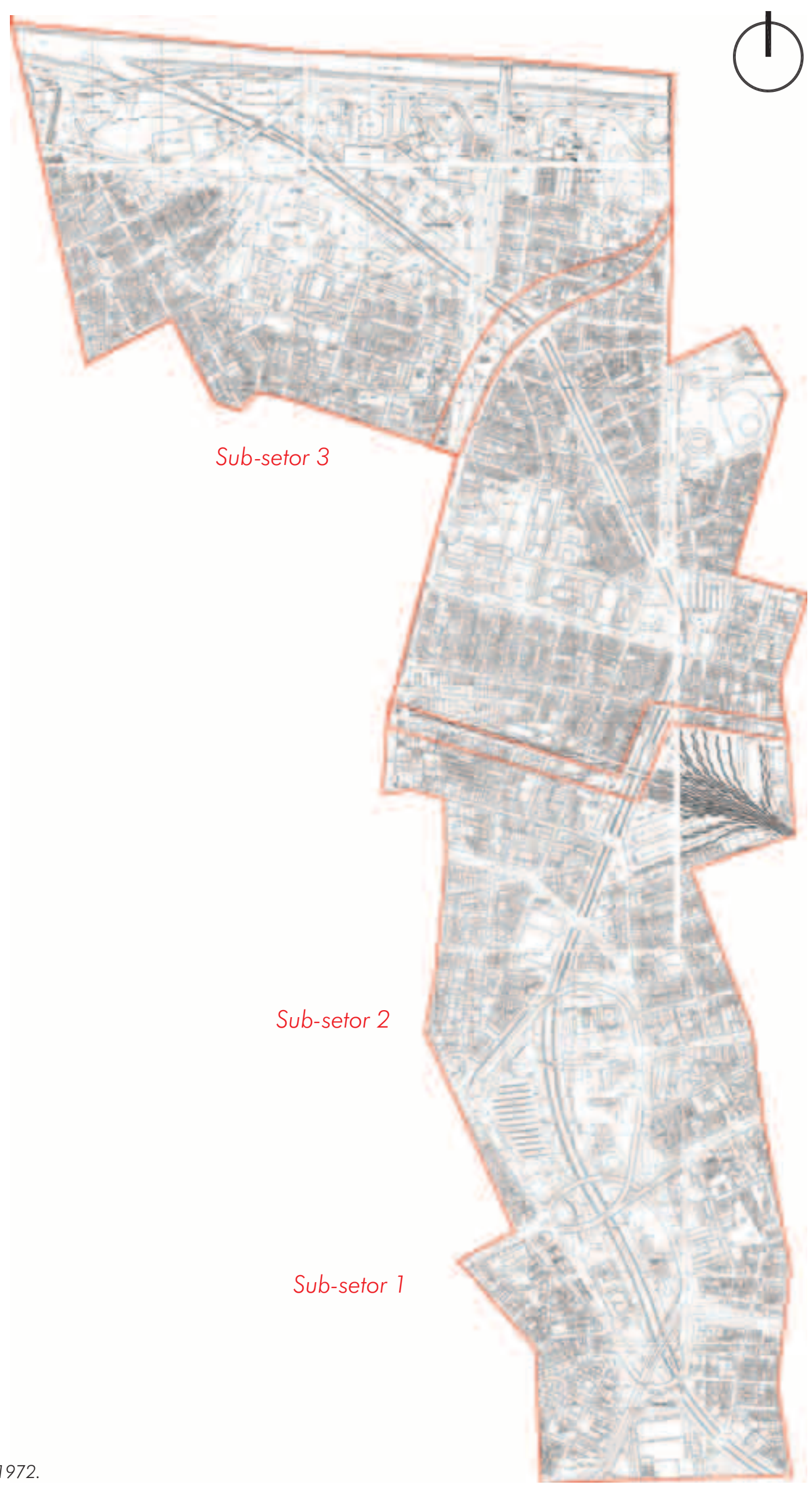



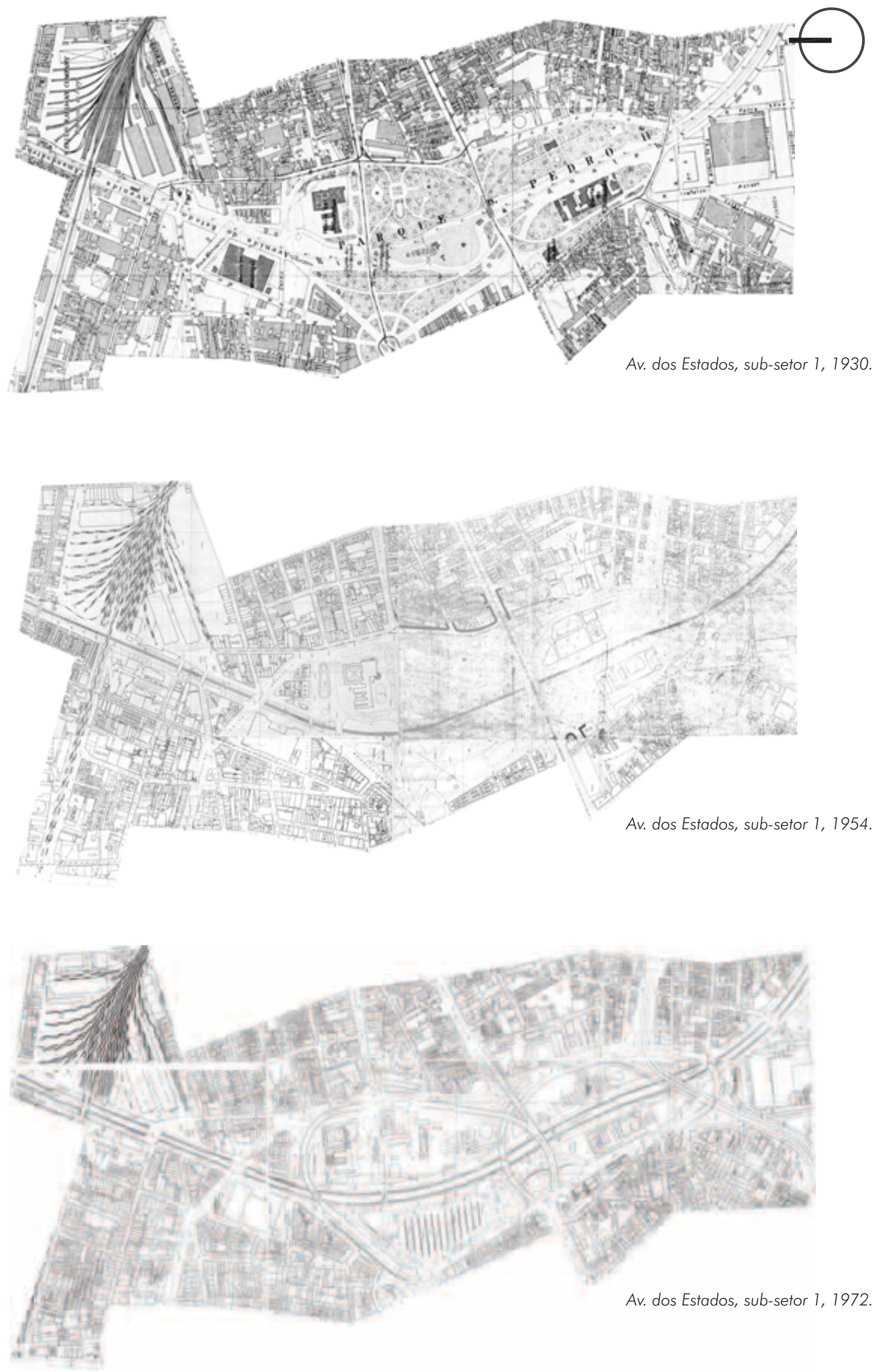
AS TRANSFORMAÇÕES DO PERÍODO 1960 - 1980

AVENIDA DOS ESTADOS

Av. dos Estados, sub-setor 2, 1930.
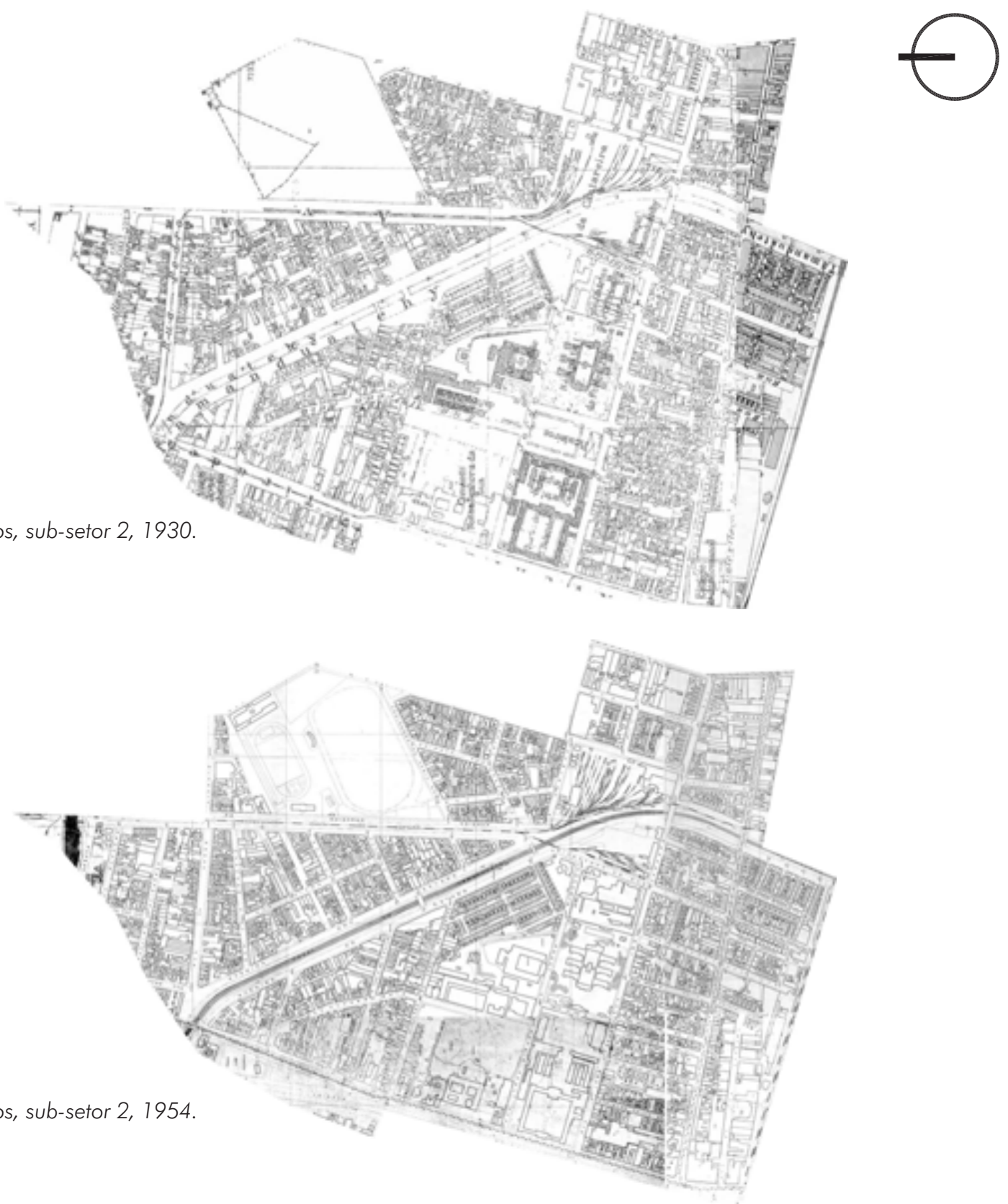

Av. dos Estados, sub-setor 2, 1954.

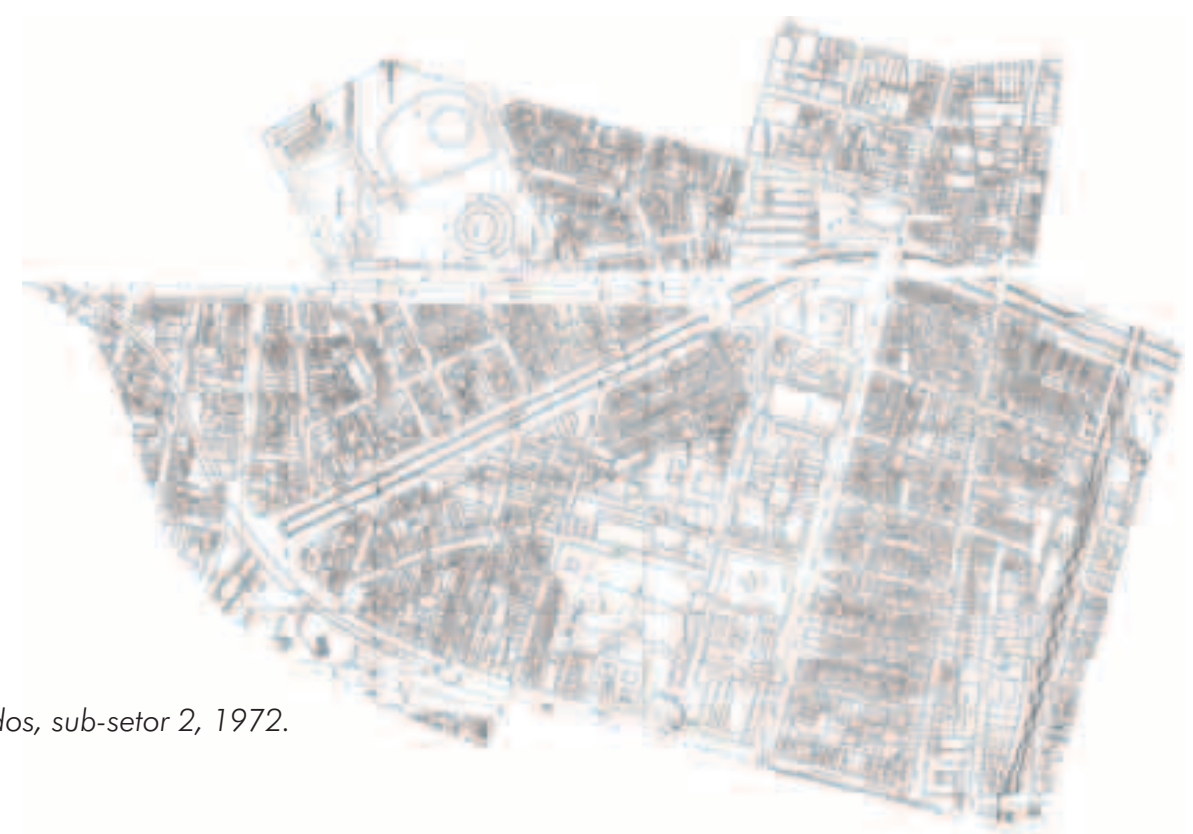

Av. dos Estados, sub-setor 2, 1972. 
()

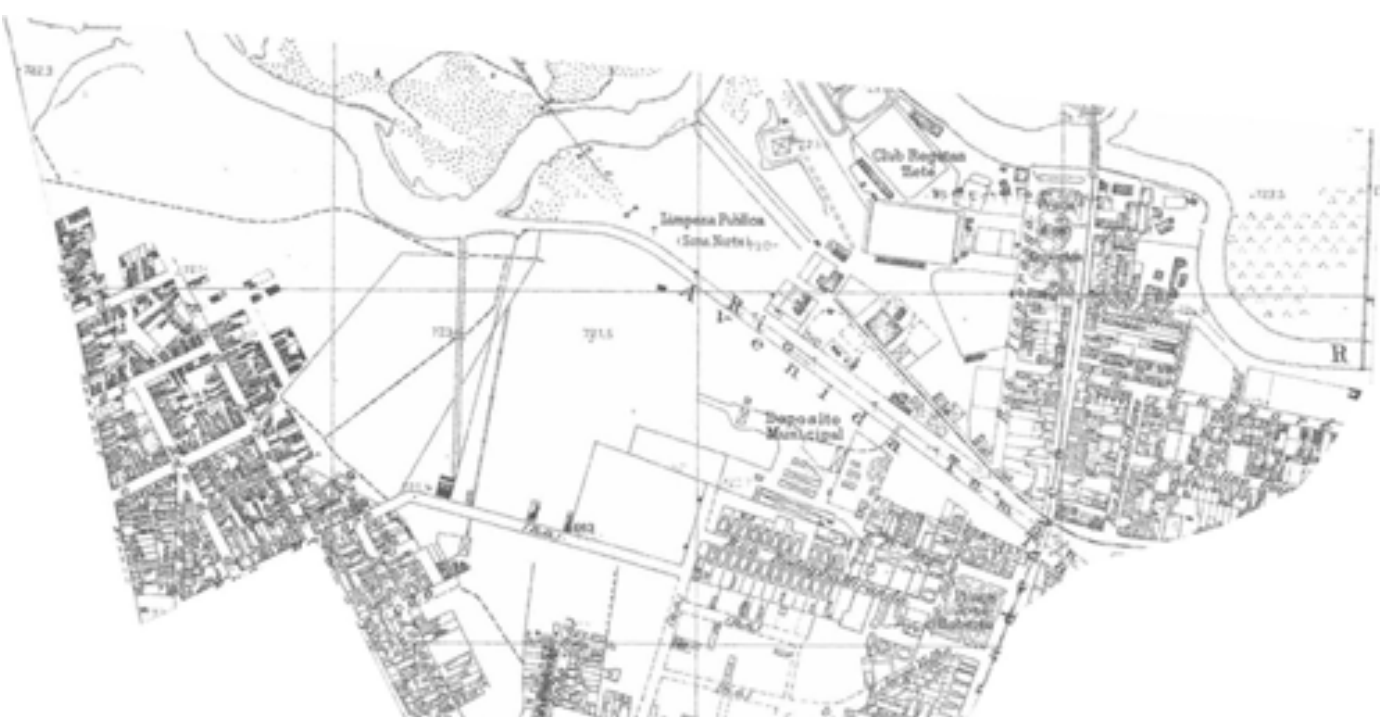

Av. dos Estados, (1) sub-setor 3, 1930.
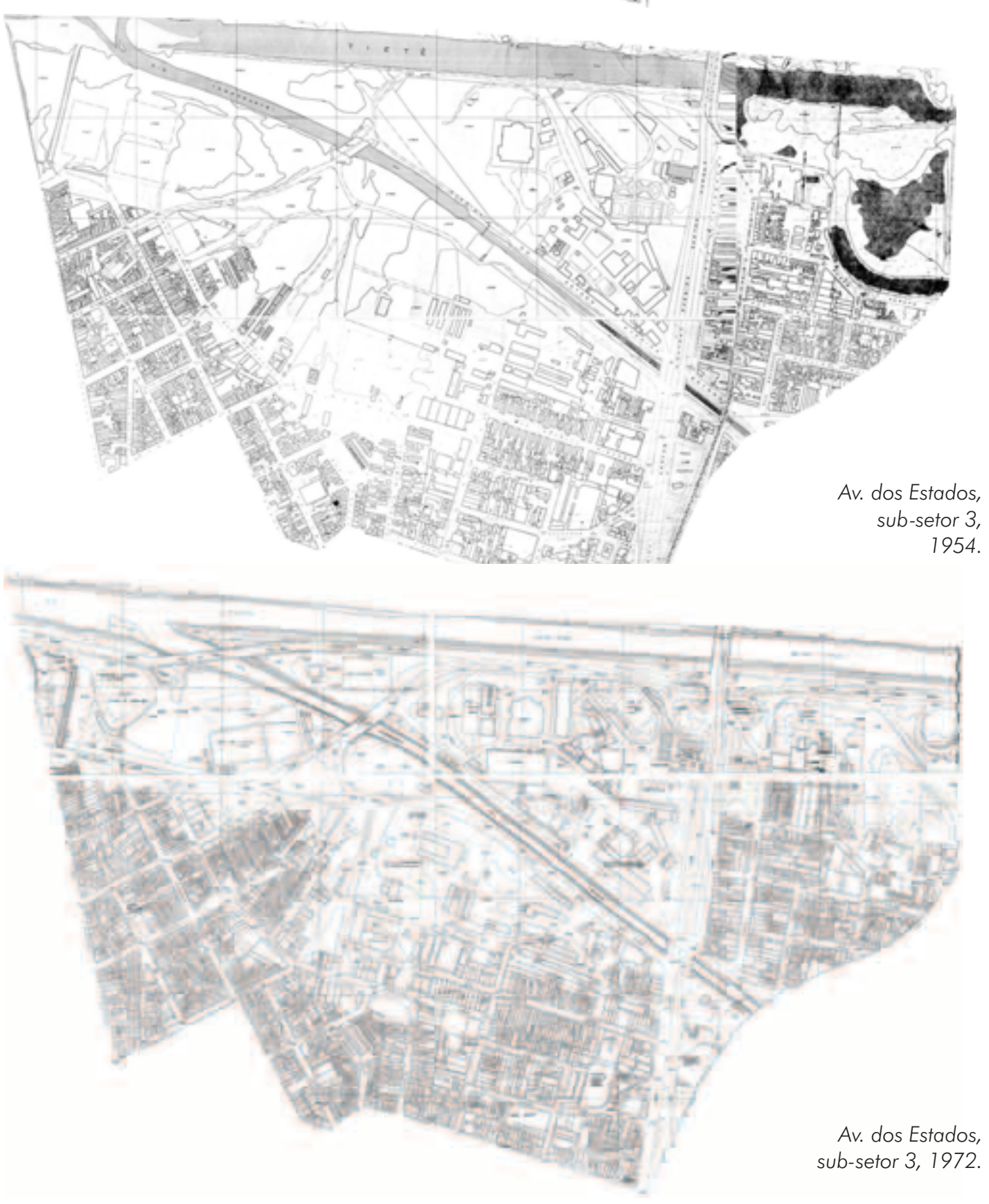


\subsection{6 - Componente sudoeste: a Rua da Consolação}

O trecho analisado dessa radial tem o seu inicio no cruzamento com a avenida São Luís e termina na avenida Paulista, não sendo incluída, portanto, a sua continuidade dentro do Jardim América, pelo fato de apresentar outras características históricas e morfológicas, inclusive não tendo sido ampliada na década de 1960, como foi o caso do trecho enfocado dentro do distrito Consolação. Esta via correspondia ao conceito de "radial de primeira classe", de Prestes Maia e o seu alargamento foi por ele iniciado em 1965, no seu segundo mandato como Prefeito (Porto, 1996, 60).

A rua da Consolação foi dividida em três sub-setores por caracterizarem áreas com influências diferenciadas:

Sub-setor 1 - do cruzamento da avenida São Luís até a rua Maria Antônia

Sub-setor 2 - da rua Maria Antônia até a rua Maceió

Sub-setor 3 - da rua Maceió até a avenida Paulista

Para a compreensão de alguns dos aspectos da transição ocorrida entre as décadas de 1950 e 1970, além dos mapas cadastrais, foi utilizado um estudo do geógrafo José Domingos Tírico publicado em 1958 no Boletim Paulista de Geografia-BPG, que permite identificar as características dessa via antes de ser transformada pela ampliação do seu leito.

- A rua possuía 641 edificações (incluindo o trecho da avenida Paulista até a rua Estados Unidos), com 10 terrenos vagos, apenas 10\% das edificações com mais de 2 andares e destas, 38 edificações de 5 a 20 andares. $50 \%$ das edificações da rua se constituíam em casas antigas (Tírico apud BPG, 1958, 37).

- Rampas e patamares: 1-Rampa da Biblioteca (ref. 1), 2-Patamar dos Judeus (ref. 2), 3-Rampa da rua Maria Antônia (ref. 3) 4-Patamar do Grupo Escolar (ref. 4) 5-Rampa do Cemitério (ref. 5), 6-Patamar do Cinema (ref. 6), (idem, 30).

1 - Esse sub-setor apresenta grande influência do centro, sendo possível perceber no mapa de 1930 essa área ainda com o arruamento anterior a abertura das avenidas Ipiranga e São Luís e da construção da Biblioteca Mario de Andrade e Praça D. José Gaspar, estas situadas na chácara da família Souza Queiroz, cujas instalações foram demolidas posteriormente (ref. 7). Tírico menciona a mescla de residências junto ao centro comercial, existente em fins do século XIX, fazendo crer que no trecho até a rua Araújo ainda se verificavam as antigas construções, que gradualmente se tornaram habitações coletivas. A Igreja da Consolação se encontrava ladeada pelo casario da chácara de Martinho da Silva Prado, demolida na década de 1940 (Porto, 1996, 59) e a Praça Roosevelt ainda não existia (ref. 8). A Igreja de Nossa Senhora da Consolação teve projeto de Maximiliano Hehl, o mesmo da Catedral de São Paulo. Com o lançamento de sua pedra fundamental em 1910, a primeira fase concluída em 1934 e a segunda apenas em 1959 (ibidem, 58). 
Fig 92: Biblioteca Mario de andrade e Praça D. José Gaspar, década de 1950.

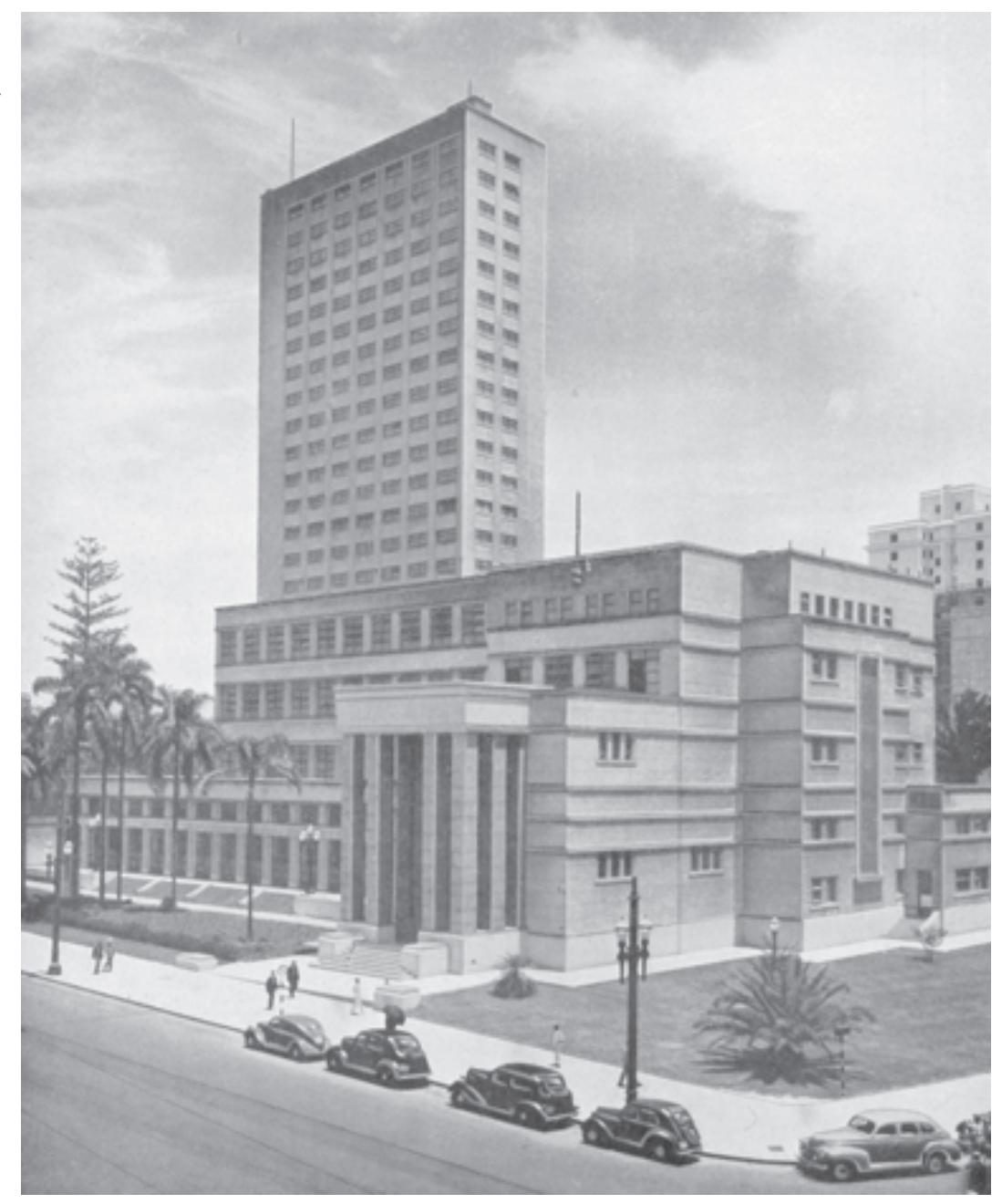

Ontigo traçado indicava a rua Martins Fontes ainda em projeto e a rua Major Quedinho acessando a Consolação pela avenida Nove de Julho.

Mesmo com as transformações viárias visíveis no mapa de 1954, percebe-se a manutenção das características do parcelamento, indicando ser essa a área mencionada por Tírico, correspondente à "Rampa da Biblioteca" e o "Patamar dos Judeus", ocupada principalmente por casas antigas. Essa primeira rampa da rua da Consolação (ref. 1) possuía antigos casarões transformados em casas comerciais e o mencionado patamar (ref. 2), situado entre as ruas Amaral Gurgel e Maria Antônia, possuía uma concentração de lojas de móveis, comércio exercido por membros da colônia judaica, onde se encontravam 7 lojas do lado da Amaral Gurgel e mais 3 do outro lado da Consolação (Tírico, 1958, 43). Certamente utilizando as antigas construções, o autor menciona também a existência de concentração de cortiços, que nesse sub-setor se localizavam principalmente entre as avenidas São Luís e rua Araújo e entre a Rego Freitas e Maria Antônia (idem, 39). 


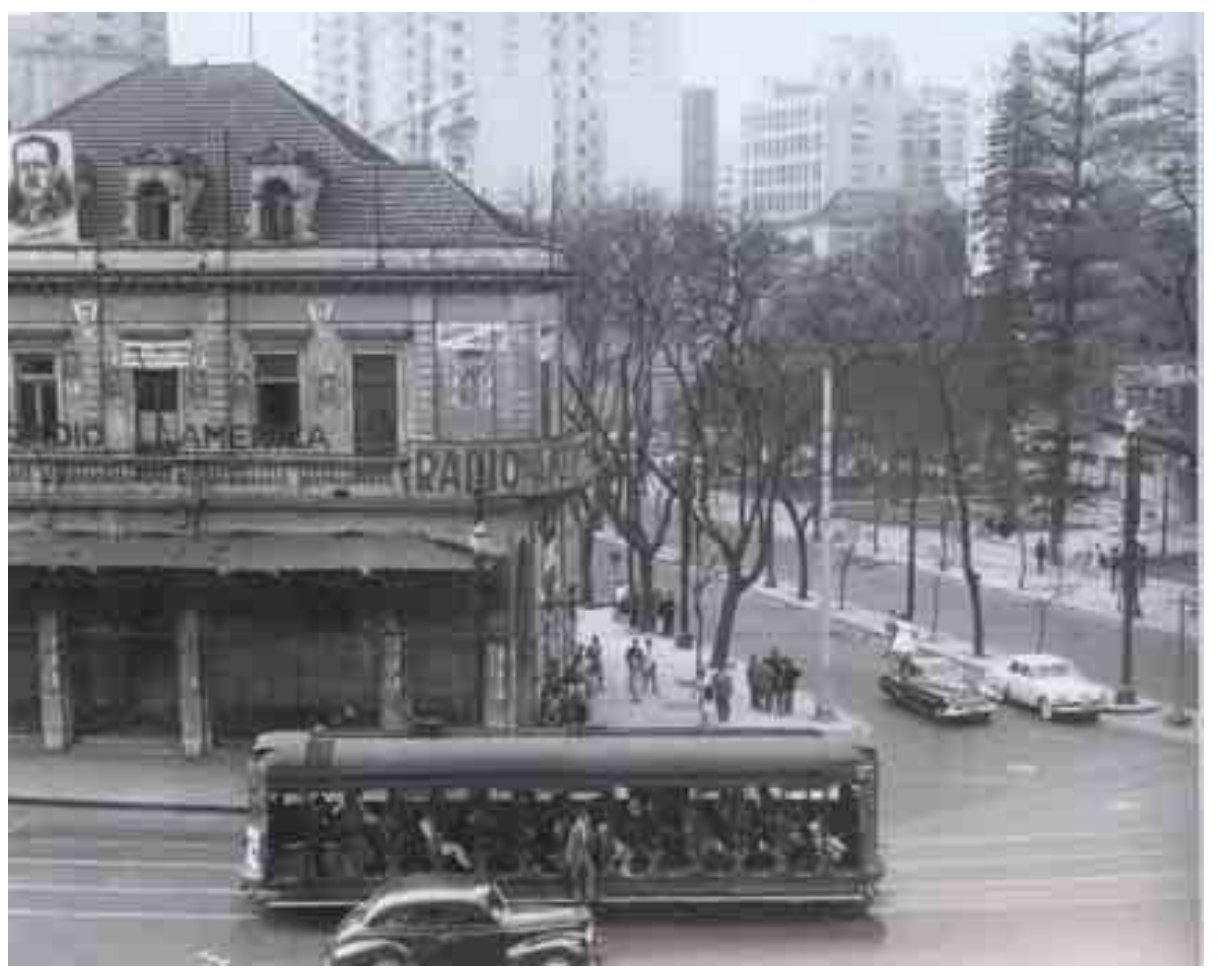

Fig 93: Cruzamento da Rua São Luiz com Rua da Consolação, 1954.

Outra categoria de habitação coletiva existente na rua da Consolação era a de pensões, disseminadas em toda sua extensão, mas com concentração próxima ao Cemitério. Somava-se uma terceira categoria que era a dos prédios existentes nos três primeiros quarteirões, mesclados aos casarões e que segundo o autor, formava-se em zona de prostituição. De qualquer forma, foi indicada a posse dos antigos casarões por empresas imobiliárias, que aguardavam o momento de derrubá-las para a construção de prédios de apartamentos (ibidem, 41).

Na carta de 1954 percebe-se ainda a presença de dois espaços públicos já configurados: a Praça Dom José Gaspar, com a Biblioteca Mario de Andrade, inaugurada em 1942 (ref. 7) e a Praça Roosevelt (ref. 8), da mesma época. No entorno dela, já havia ocorrido a transformação das antigas construções, que deram lugar à verticalização (op.cit, 36) e seu espaço era ocupado por feiras livres e posteriormente para estacionamento de automóveis (Amadio, 1998, 66).

As transformações viárias mostram a incorporação de um trecho da rua Epitácio Pessoa para a formação da avenida lpiranga. Próximo à Praça Dom José Gaspar, - Viaduto Major Quedinho substituiu a rua do mesmo nome anteriormente existente e a rua Martins Fontes já fora aberta também, ambas situadas junto à área de verticalização do centro. Nota-se na quadra triangular configurada pela rua da Consolação e as avenidas Ipiranga e São Luís, as antigas construções da 
Rampa da Biblioteca ainda ladeando a área do Edifício Copan (ref. 9), que se encontrava em construção em 1954, na época do vôo do levantamento Vasp.

O mapa de 1972 mostra transformações radicais na configuração do parcelamento e do sistema viário: percebe-se que a Rua da Consolação foi alargada exatamente sobre as antigas edificações existentes na "Rampa da Biblioteca (ref. 10)", o mesmo ocorrendo no trecho entre as ruas Rego Freitas e Amaral Gurgel, o antigo "Patamar dos Judeus (ref. 11)". Segundo o estudo mencionado, justamente esse trecho foi analisado como apresentando maior deterioração da rua (Tirico apud BPG, 1958, 51). A presença dos lotes de grandes dimensões indica a verticalização ter ocorrido já quase completamente na década de 1960, com a única exceção de um estacionamento ao lado do Edifício Copan.

O sistema Leste-Oeste se encontrava implantado, destruindo parte da quadra entre as ruas Rego Freitas e Amaral Gurgel. Nessa esquina, a quadra oposta foi cortada também para acomodar a alça de acesso do Elevado Costa e Silva para a rua da Consolação. $\bigcirc$ edifício-praça, construído em vala aberta, incorporou pistas subterrâneas de ligação com o setor Leste da cidade e substituiu a antiga Praça Roosevelt, envolvendo a Igreja da Consolação com inúmeros volumes e escadarias. Ainda não concluída, foi inaugurada no aniversário da cidade do ano de 1970 pelo general-presidente Médici e o prefeito-indicado Maluf (Amadio, $1998,66)$.

2 -Esse sub-setor que se estende da rua Maria Antônia até a rua Sergipe, possui duas referências que se associaram ao conjunto da cidade ainda no século XIX:

- O Cemitério da Consolação, inaugurado em 1858, então denominado Cemitério Municipal. (op. cit), 1958, 30; Porto, 1996, 56).

- O Reservatório da Consolação, inaugurado em 1881, pertencente ainda à Cia. Cantareira (Porto, 1996, 58).

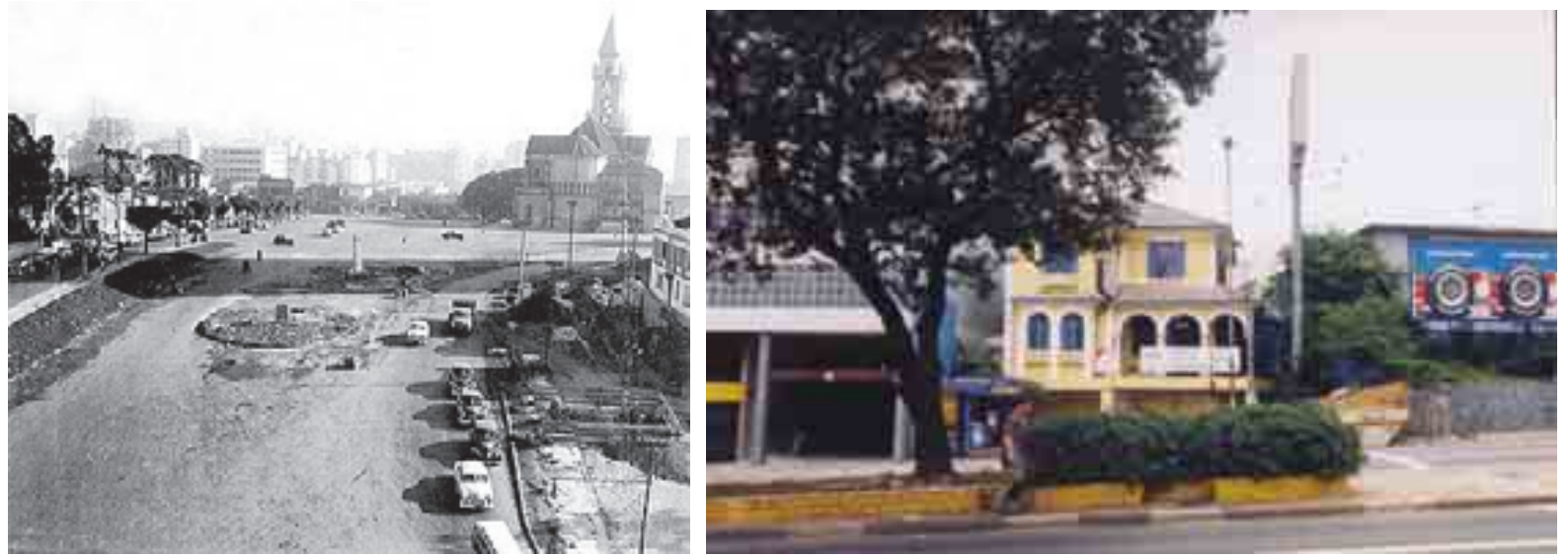

Fig 94 e 95: À esquerda, Pça. Roosevelt, 1957; à direita, tipologia remanescente na R. da Consolação, vizinha ao reservatório da Consolação (à direita da edificação), 2003. 
Compreende, pela denominação utilizada no estudo de Tírico à "Rampa da rua Maria Antônia (ref. 3)", o "Patamar do Grupo Escolar (ref. 4)" e a "Rampa do Cemitério (ref. 5)".

Confrontando-se as cartas de 1930 e 1954, assim como ocorreu no sub-setor anterior, naquele agora abordado percebe-se a manutenção das características básicas do parcelamento e da ocupação, confirmando a existência de um grande número de edificações antigas nessa rua. Aludindo ao período de 1958, Tírico mencionou a grande predominância de pensões nas quadras entre as ruas Maria Antônia e Sergipe. Nesse trecho também foi registrada, nas quadras fronteiriças ao Cemitério, a existência de uma série de atividades ligadas ao mesmo, como floriculturas e marmorarias (Tírico apud BPG, 1958, 41 -43). A carta de 1954 registra também a existência do Grupo Escolar São Paulo (ref. 12), na esquina da rua Antônia de Queiroz, inaugurado em 1933, situado em uma área então vazia pelo mapa de 1930 (Porto, 1996, 60).

Entretanto, a transformação mais profunda é registrada na carta de 1972, uma vez que os trabalhos de alargamento da rua já tinham sido concluídos. Comparando com a carta de 1954, percebe-se que o novo traçado foi ampliado em sua largura sobre as quadras do sentido bairro-centro, verificando-se a perda de recuos ou mesmo a demolição dos edifícios que estavam posicionados nessas quadras, como por exemplo, o recuo do Colégio Marina Cintra, antigo Grupo Escolar São Paulo. Esse trecho, o da "Rampa do Cemitério", era justamente composto por casas térreas geminadas, das primeiras décadas do século XX e de propriedade de empresas construtoras, que segundo Tírico, esperavam ainda no final da década de 1950 o plano municipal de alargamento para "iniciar a derrubada valorizadora" (Tírico, 1958, 52). Em conseqüência, a substituição das edificações e a mudança no padrão do parcelamento denunciando a verticalização, podem ser percebidas através da análise dos dois mapas cadastrais.

3 - Esse sub-setor é compreendido pela rua Sergipe até a avenida Paulista. Corresponde ao "Patamar do Cinema" vindo a se constituir em um espaço que apesentava predominância habitacional e pequeno comércio local, segundo o estudo. Confrontando os mapas de 1930 e 1954, pode-se perceber a manutenção das características básicas do parcelamento, sendo que em 1958 foi registrada a existencia de três cinemas nas proximidades da avenida Paulista. Nessa esquina, através do mapa de 1954, podem ser identificados os edifícios Anchieta, do escritório MM. Roberto, de 1948 e defronte a este, o edifício projetado por Giancarlo Palante.

O mapa de 1972 mostra a implantação do complexo viário de ligação da rua da Consolação e avenidas Rebouças e Paulista (ref. 13). Essa última já havia sido alargada também e recebido pista subterrânea para a ligação com a avenida Rebouças. O projeto da "Nova Paulista", entretanto, não foi implantado na íntegra. Uma matéria jornalística indica a reestruturação feita no projeto original, 
sob a alegação de correção dos erros verificados nas interligações, como por exemplo, a não existência das mesmas entre as avenidas Paulista e Rebouças e entre a Angélica, Rebouças e Dr. Arnaldo (FSP, 04/7/1970). Optou-se, nessa nova versão, pela alternativa com maior possibilidade de acessos aos eixos do sudoeste e oeste, eliminando-se a pista subterrânea que percorreria toda a avenida Paulista, de acordo com o projeto apresentado na gestão Figueiredo Ferraz.

Pode-se notar que o lado mais atingido pelo alargamento da rua da Consolação foi o do sentido bairro-centro, uma vez que nele foi incorporada uma faixa maior de ampliação do que o lado oposto. Com isso, todos os edifícios perderam os recuos ou mesmo foram demolidos. Prova desse fato foi a entrada para a galeria subterrânea de travessia de pedestres do lado dos cinemas, construída em 1970, ter sido embutida na fachada lateral do edifício projetado por Palante, encravada na esquina com a avenida Paulista. Devido essas transformações não terem afetado as quadras do sentido centro-bairro, o parcelamento e a ocupação entre a rua Maceió e a avenida Paulista mantiveram as características, o mesmo não ocorrendo com a quadra logo após o cruzamento desta, sentido Pinheiros, que se tornou uma ilha em meio ao sistema viário implantado. Nessa esquina, apesar do Edifício Anchieta ter perdido os recuos frontal e lateral, a entrada da galeria subterrãnea pôde ser implantada no passeio público, mesmo sendo uma interferência para o mesmo e para esse edifício (ref. 14).

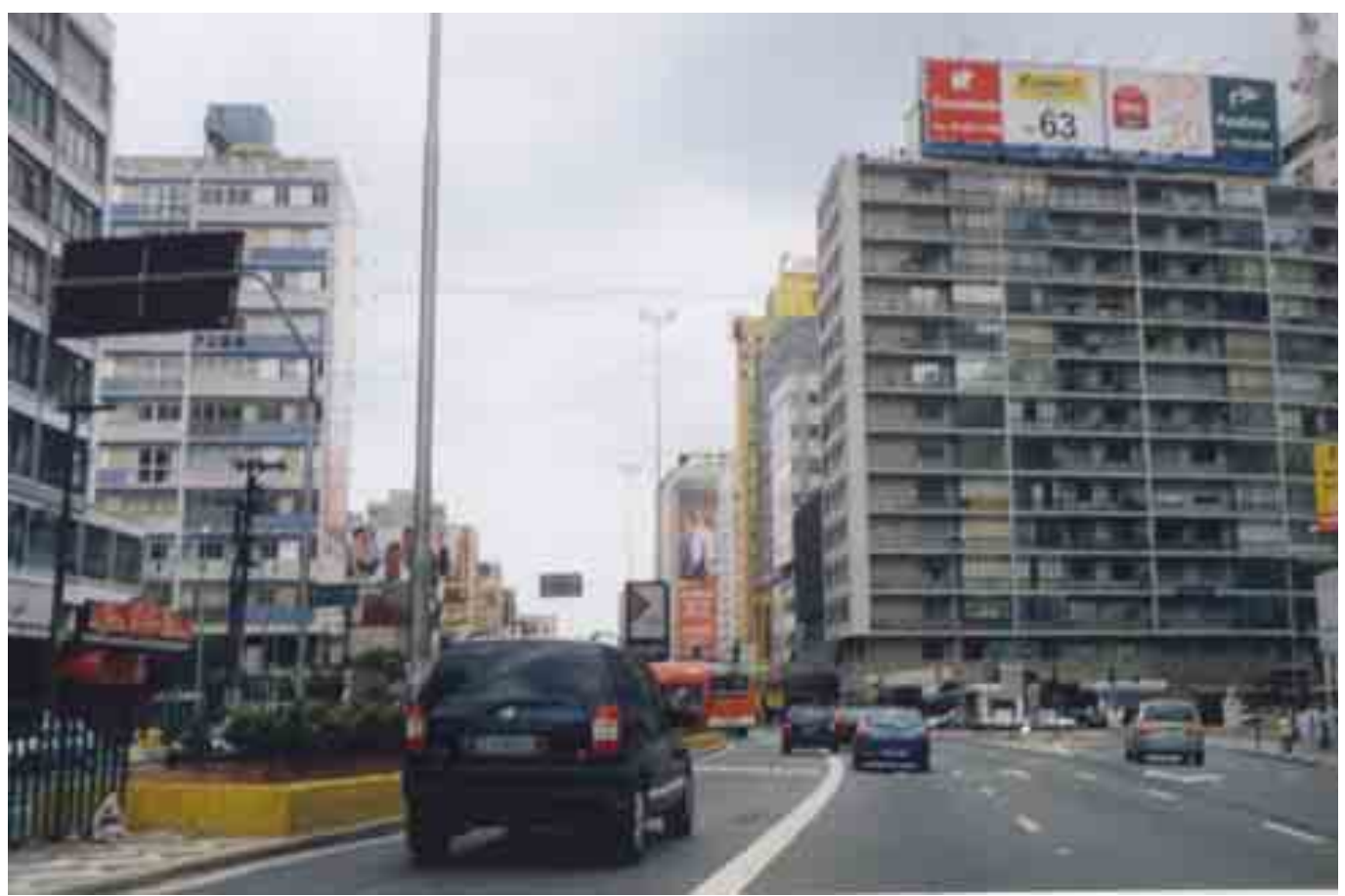

Fig 96: Rua da Consolação, no cruzamento com a Av. Paulista, 2003. À esquerda, edifício Anchieta, projeto do escritório MM Roberto; à direita, edifício projetado por Giancarlo Palante. 
AS TRANSFORMAÇÕES DO PERIOODO 1960 - 1980

RuA dA CONSOLAÇÃo
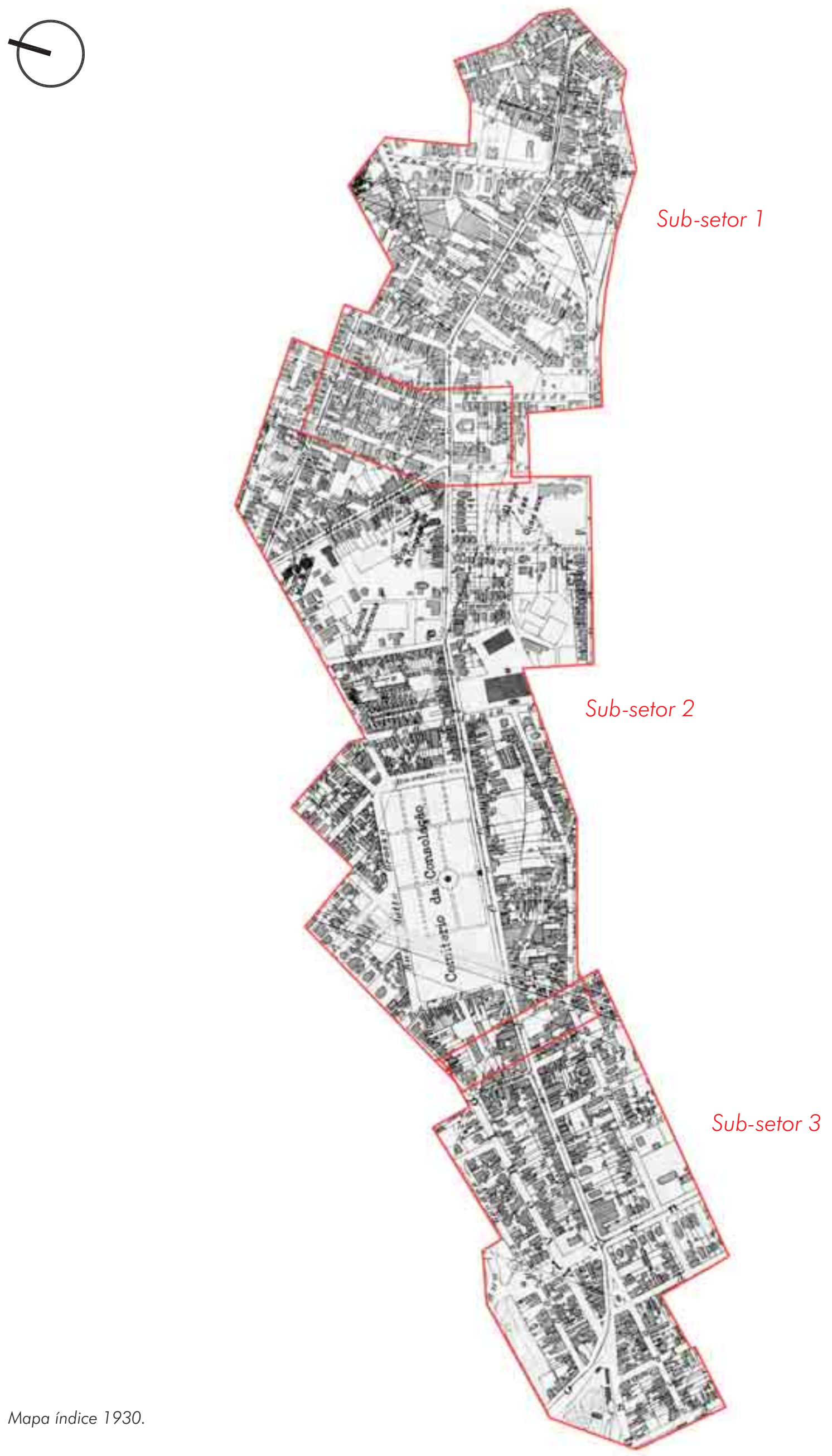


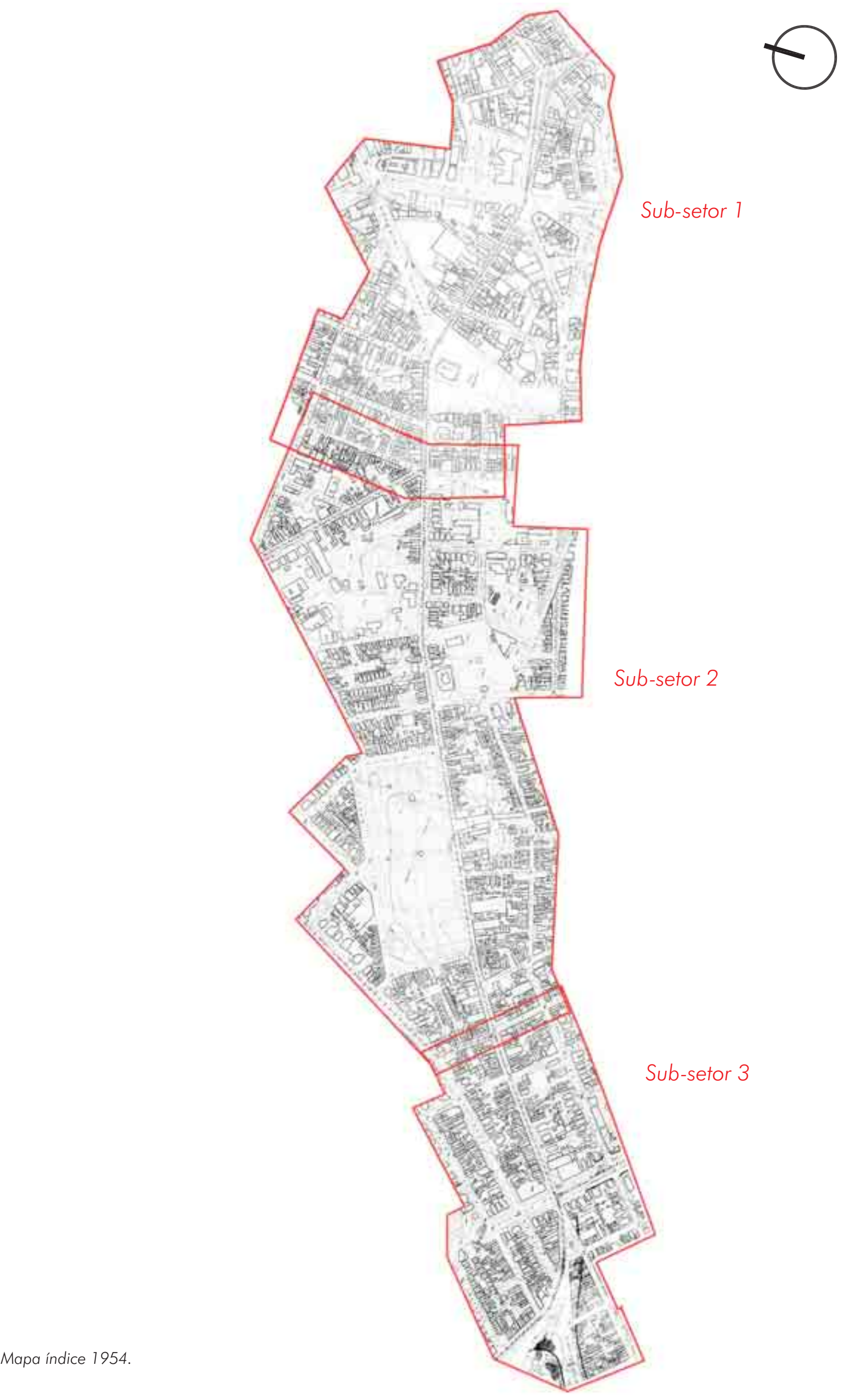


AS TRANSFORMAÇÕES DO PERÍODO 1960 - 1980

Rua da Consolação
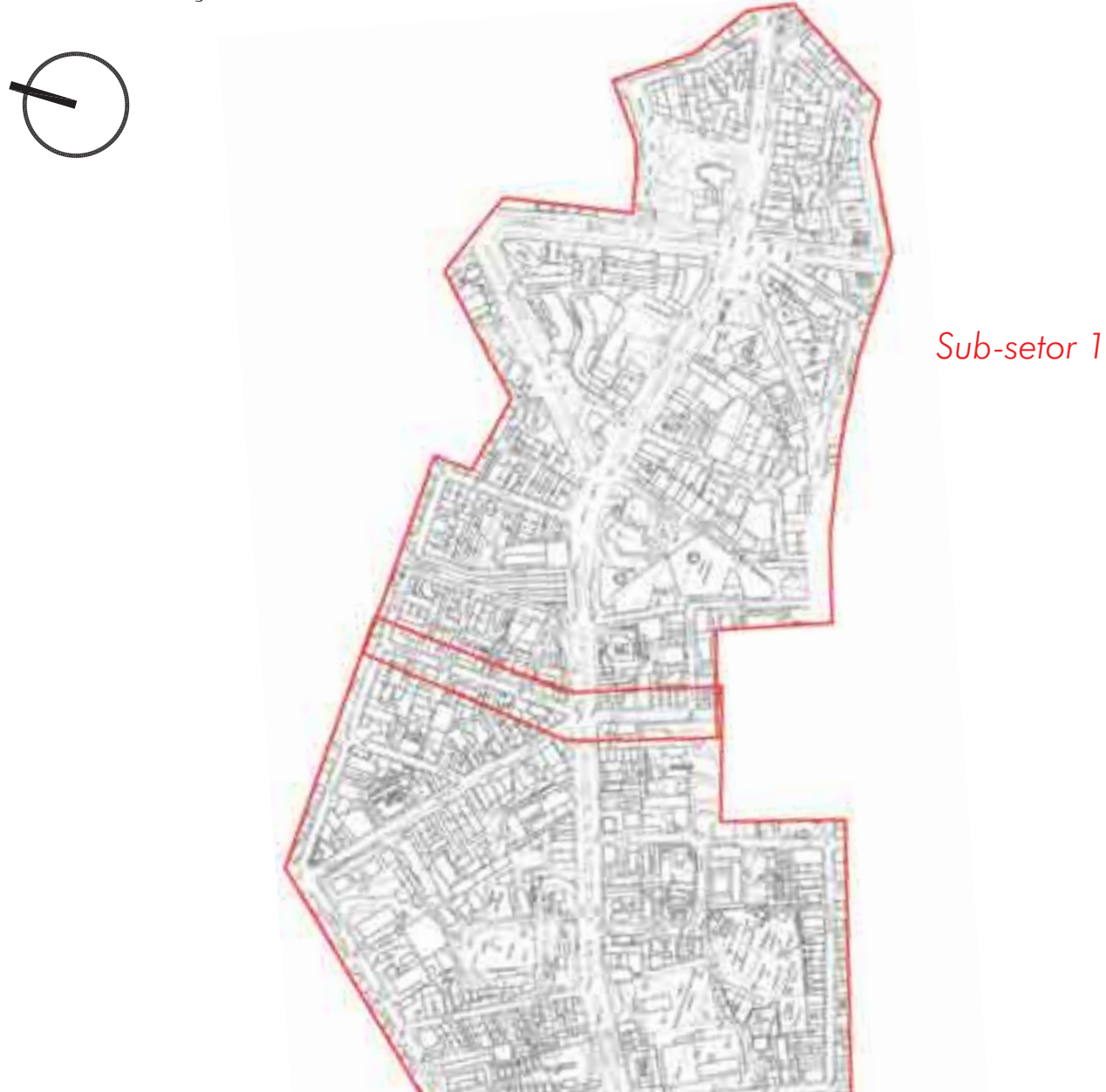

Sub-setor 2 

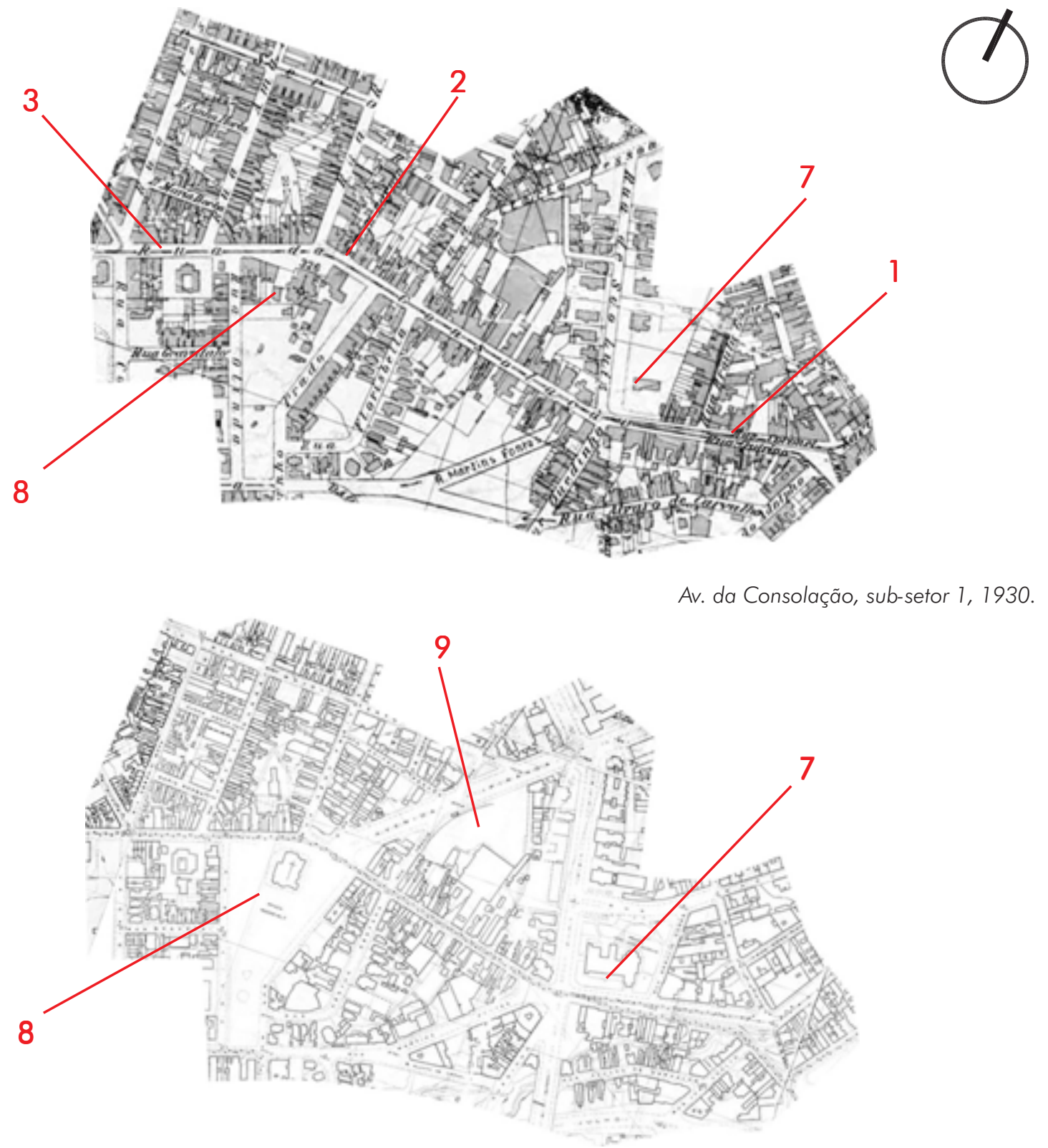

Av. da Consolação, sub-setor 1, 1954.

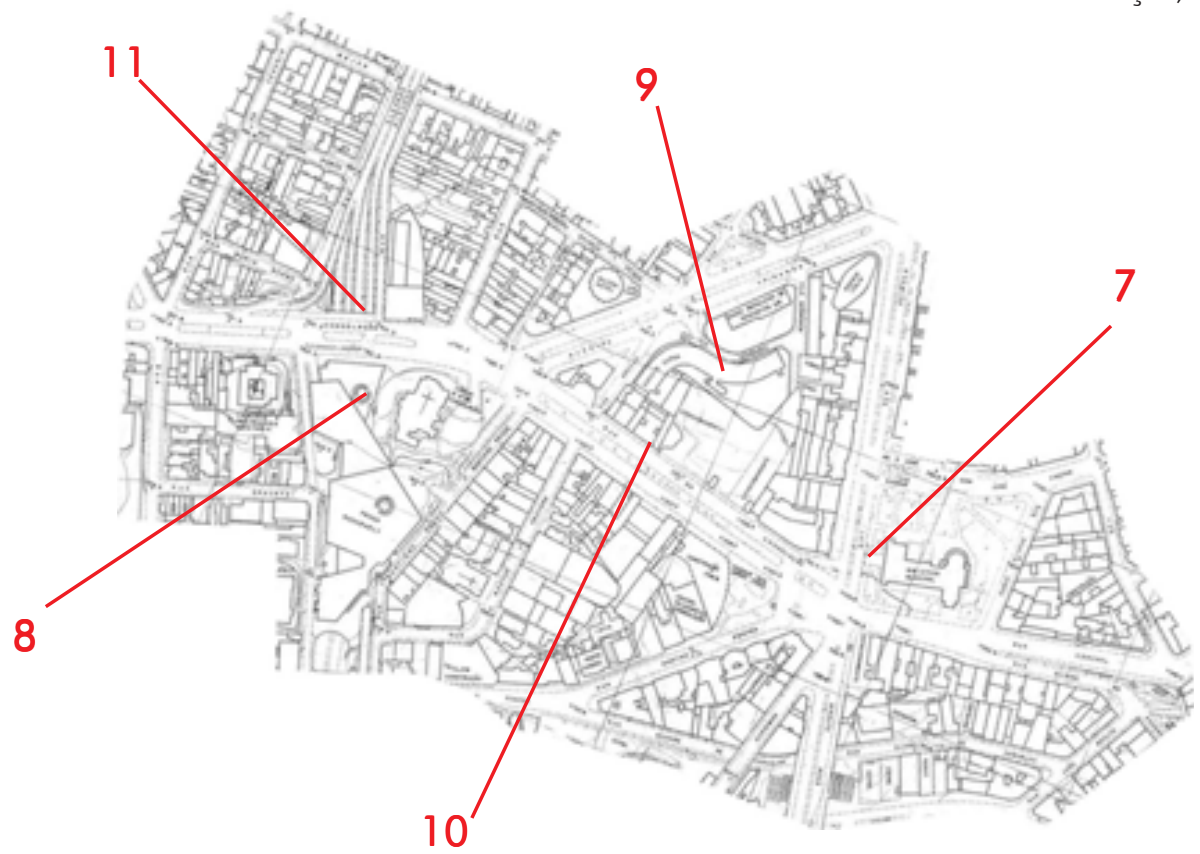

Av. da Consolação, sub-setor 1, 1972. 
AS TRANSFORMAÇÓES DO PERÍODO 1960 - 1980

RuA DA CONSOLAÇÃO

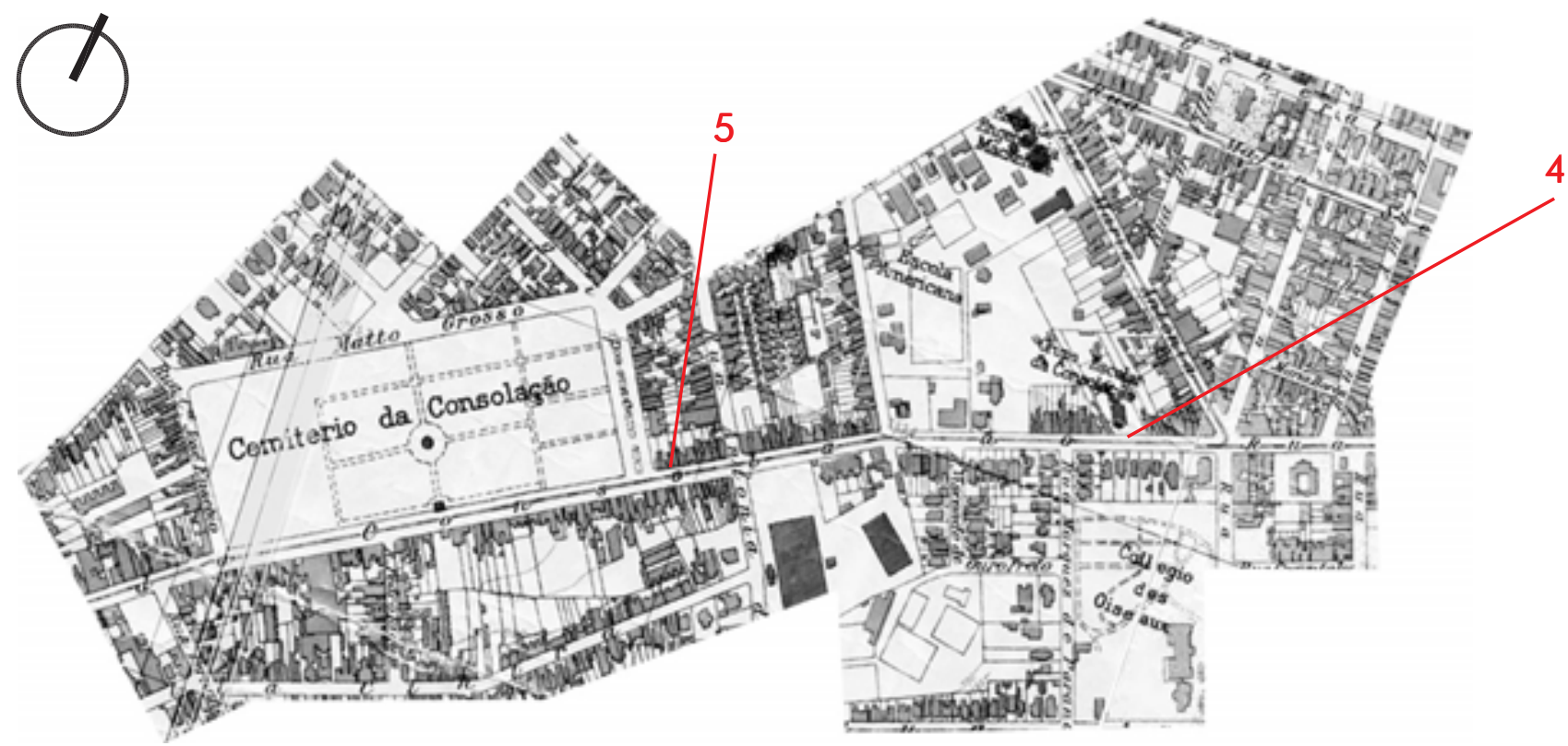

Av. da Consolação, sub-setor 2, 1930.

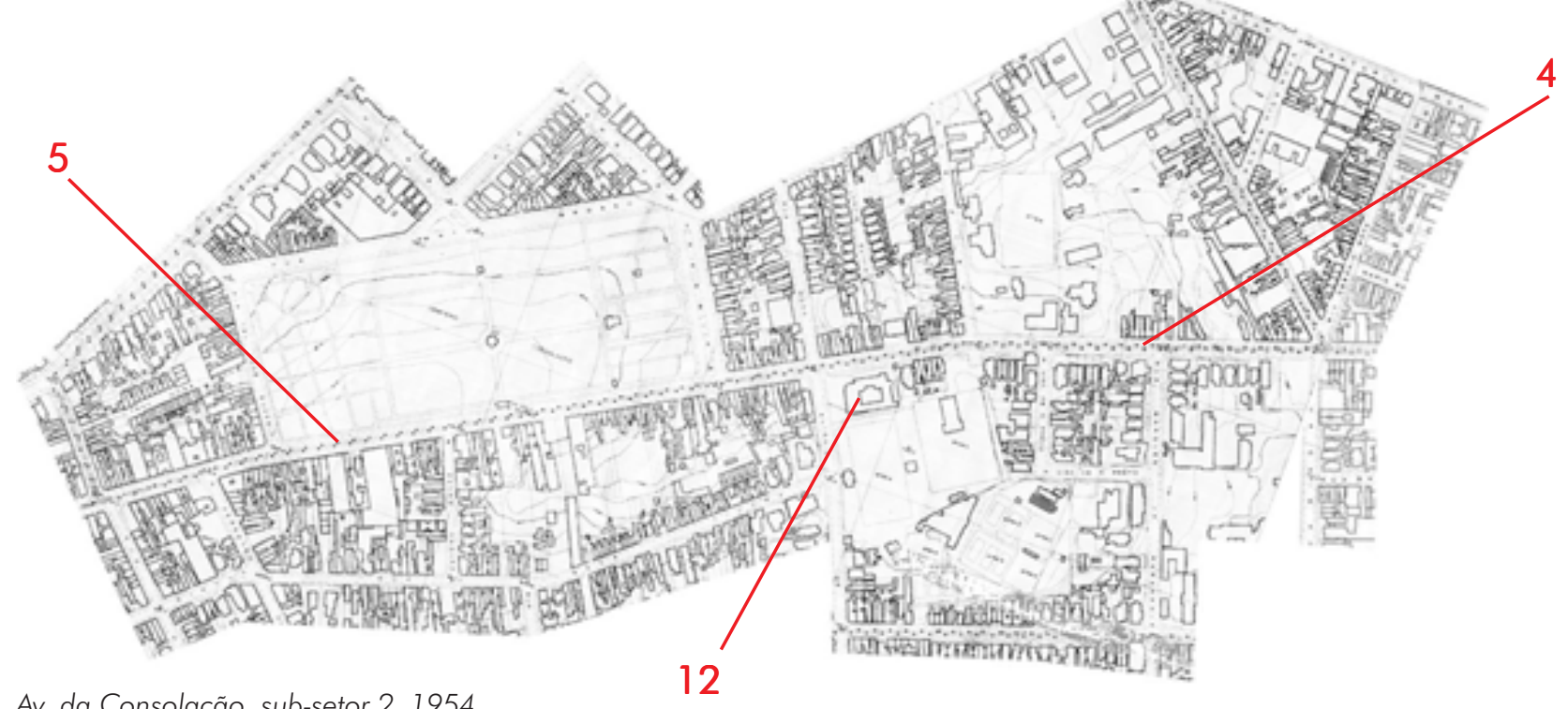

Av. da Consolação, sub-setor 2, 1954.

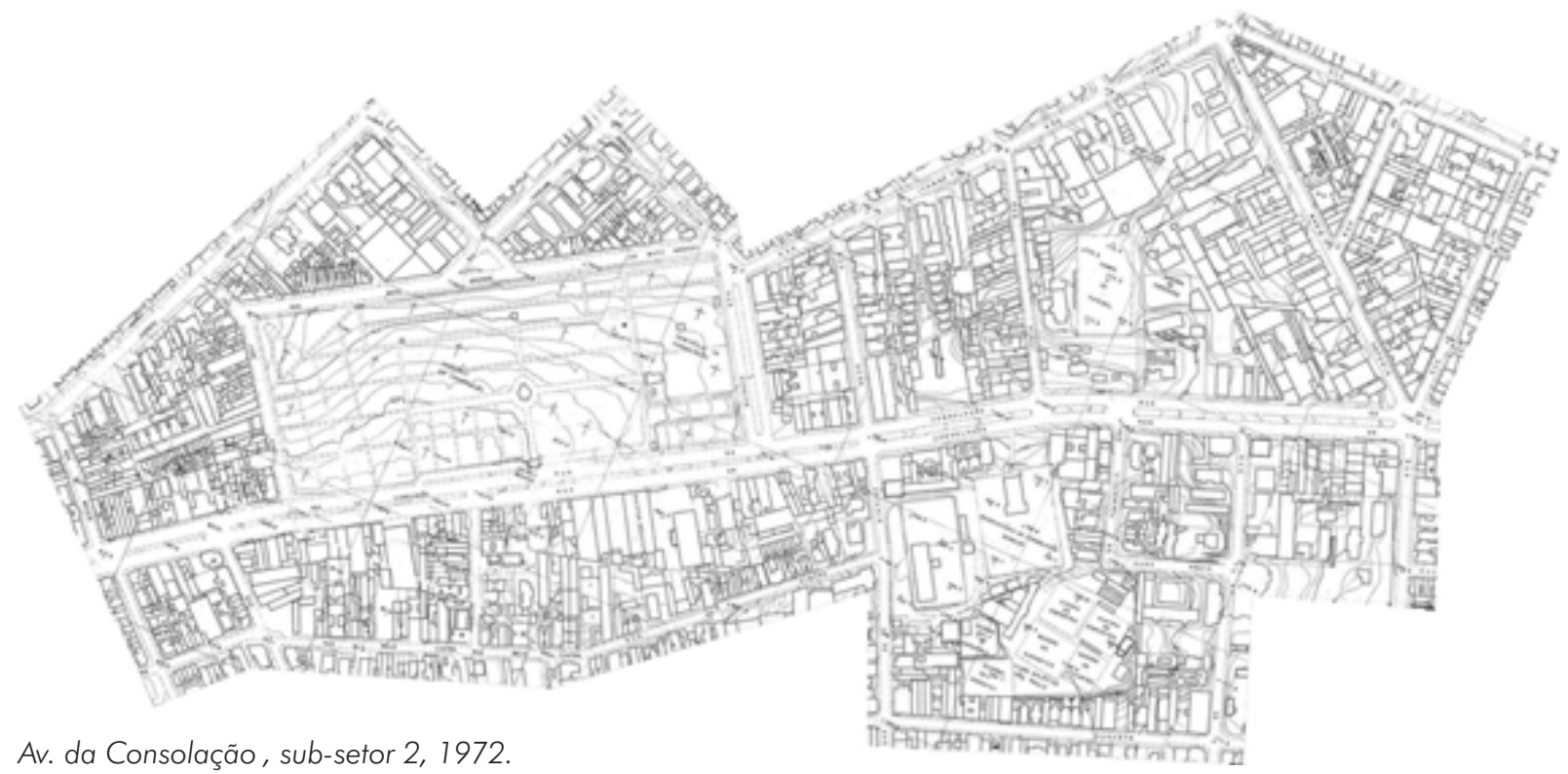



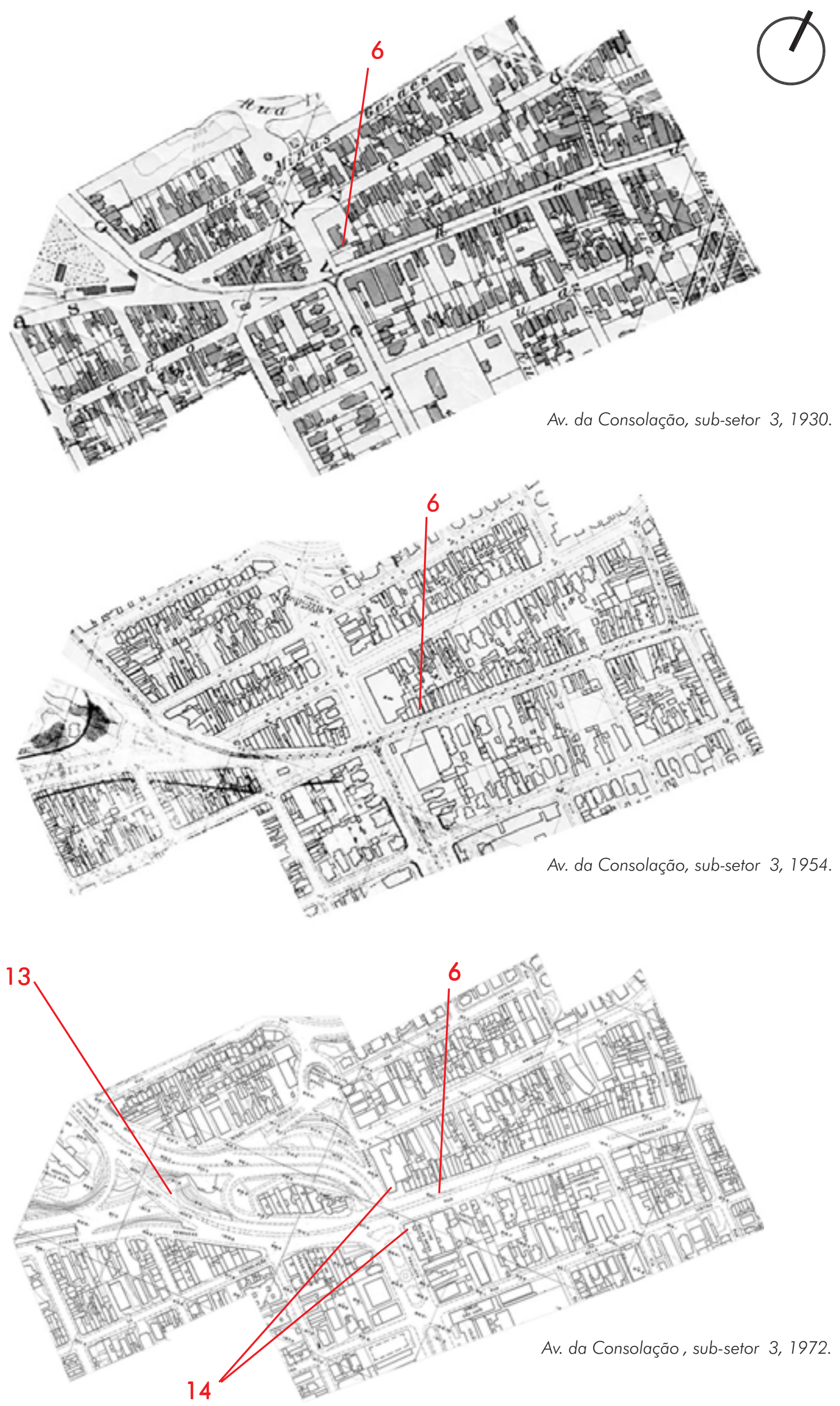


\subsection{Habitação: espaços diferenciados para os ricos e pobres}

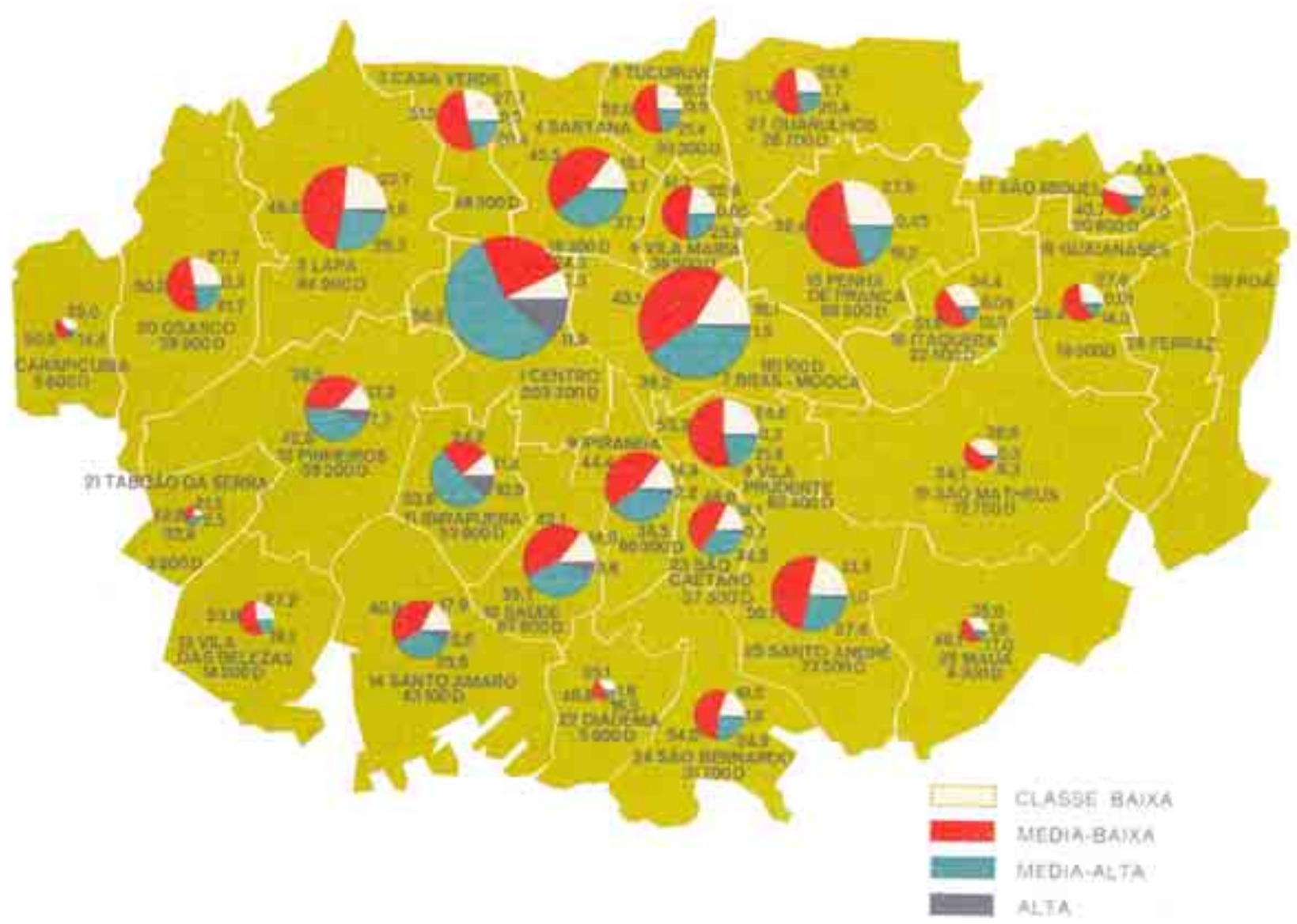

Fig. 97: Distribuição percentual de domicílios segundo as classes de renda, PUB, 1968.

Duas características principais marcaram o período 1960-1980 no que se referiu à habitação social e também às transformações nas condições de moradia da classe média brasileira, em particular a de São Paulo:

- $\bigcirc$ aprofundamento do sistema de auto-empreendimento ou autoconstrução para a produção da habitação popular associado ao recrudescimento do retalhamento do solo urbano nas áreas periféricas da cidade.

- A criação do Sistema Financeiro de Habitação, que através do Banco Nacional de Habitação - BNH se vinculou ao desenvolvimento imobiliário da classe média, para o financiamento da casa própria.

Como foi visto, após a construção das vilas operárias no início do Século XX, à habitação social apenas foram direcionados os programas dos Institutos de Aposentadorias e Pensões, implantados a partir do Estado Novo. No período 
pós-1964, a atuação do Banco Nacional de Habitação provocou um divisor de águas ao direcionar inicialmente seus recursos à construção de grandes conjuntos na periferia da cidade, e posteriormente, ao subvencionar a compra da casa própria para a classe média, financiando dessa forma, a verticalização dos bairros do centro expandido da cidade, a partir da década de 1970.

Esses aspectos podem ser traduzidos da seguinte forma: o Sistema Financeiro de Habitação utilizava os fundos de tempo de serviço da população (FGTS), que eram geridos pelo $\mathrm{BNH}$ e os aplicava na política habitacional do regime pós1964. Se as taxas de inadimplência tivessem crescimento permanente, a única forma de não provocar uma crise no FGTS (e com isso desestruturar toda a cadeia ligada ao desenvolvimento imobiliário e construção civil) seria a de subsidiar crescentemente a habitação social, transferindo renda para as classes populares. Esse caráter social-distributivo, antípoda do modelo de acumulação imposto pelo regime autoritário, certamente ocasionaria conseqüências à estruturação urbana, podendo encaminhar mais recursos aos crescentes problemas das favelas, cortiços e das periferias.

Entretanto, o BNH se constituiu como um banco e para que a insolvência dos mutuários fosse minimizada, passou a direcionar os financiamentos àquelas faixas de renda com condições de suportá-los, isto é, da renda média baixa e alta. Com isso, não apenas se agravaram os problemas das classes populares em relação à moradia e condições de vida, como parte dos recursos da poupança de todos os trabalhadores registrados do país foram drenados para financiar a classe média, o setor imobiliário e de construção civil, resultando essa cadeia na "verticalização do milagre", como Someck a classificou (1997, 25).

No que se referiu à construção dos conjuntos do $\mathrm{BNH}$, a atuação voltada às classes de baixa renda dos órgãos federais, estaduais e municipais significou uma negação dos problemas existentes nas áreas consolidadas, desencadeando entre outras conseqüências:

1. A desarticulação entre políticas urbanas e a produção da cidade, que provocou o agravamento dos problemas relacionados aos custos de implantação de infraestrutura e equipamentos sociais, a extensão da área urbanizada e aumento das distâncias a serem vencidas cotidianamente pelos moradores.

2. A ausência de cuidados para com a qualidade de vida dos moradores e para com o destino das áreas que receberam os conjuntos, aprofundando o processo de especulação imobiliária resultante da criação de novas áreas vazias entre a área urbanizada da cidade e os novos conjuntos (Andrade, Bonduki, orgs, 1993, 19).

Bonduki $(1998,282)$ indicou que graças à disseminação da auto-construção impulsionadora do crescimento periférico, em 1970, 54\% dos domicílios já eram 
próprios e 38\% de locação. Em 1950 esses números eram quase inversos, sendo $37 \%$ de domicílios próprios e 58\% de locação". O ítem "outras formas de ocupação" cresceu numericamente de 23.290 domicílios (5\% do total) em 1950, para 101.877 (8\% do total) em 1970, indicando possivelmente o crescimento das favelas.

Ainda segundo Bonduki, a dinâmica do crescimento periférico justificou o pequeno número de favelas que a cidade apresentava até a década de 1970. A contínua transferência para o próprio trabalhador do encargo de construção de sua habitação, associada à grande quantidade de terras para parcelamento nas áreas periféricas, foram as matrizes dessa solução que fez frente à reduzida participação de investimentos públicos e privados na produção da habitação social e nas suas condições urbanas (idem, 313).

Em contraponto ao espraiamento urbano e suas implicações habitacionais e ambientais, na área consolidada da cidade, particularmente nos bairros centrais, a participação do poder público limitou-se, quando muito, a políticas assistencialistas voltadas à população de baixa renda moradora de habitação coletiva, visto os cortiços terem permanecido como única alternativa para essa população nos espaços melhor equipados e estruturados da cidade.

Três formas de relação dos cortiços com o entorno urbano mostraram-se presentes nos bairros junto à área central da cidade:

- Cortiços surgidos no período de consolidação dos bairros que se caracterizaram por abrigar residências, majoritariamente populares, indústria e em menor escala, comércio. Situados em bairros como Brás, Pari e Moóca, os mesmos revelam semelhanças construtivas, sendo em sua maioria casas térreas construídas em lotes estreitos.

- Cortiços existentes em área de urbanização antiga, anterior a 1930, onde ocorreu processo de deterioração urbana relacionado ao incremento de atividades terciárias, principalmente o de comércio atacadista, tornando desinteressante a permanência de habitação das diversas camadas da população nesses bairros.

- Cortiços existentes em áreas de urbanização antiga que sofreram transformações. Por essas mudanças não implicarem em alterações significativas dos imóveis, estes passaram a se tornar interessantes para as camadas de renda média e baixa, como por exemplo na Mooca e Barra Funda, mas também encontrados na Consolação, Liberdade, Aclimação, Pinheiros e Perdizes. Em alguns casos, como o da Barra Funda, mesmo o padrão da maioria das residências unifamiliares se constituiu como médio-baixo e baixo, nessas áreas. (Sempla, 1985, 66/180).

Os motivos presentes no processo diferenciado de transformação dos bairros centrais, já foram abordados anteriormente e sua produção se deveu à acessibilidade provocada pelo Plano de Avenidas no setor sudoeste, que ao 
Fig. 98 e 99: Mapa temático, crescimento populacional
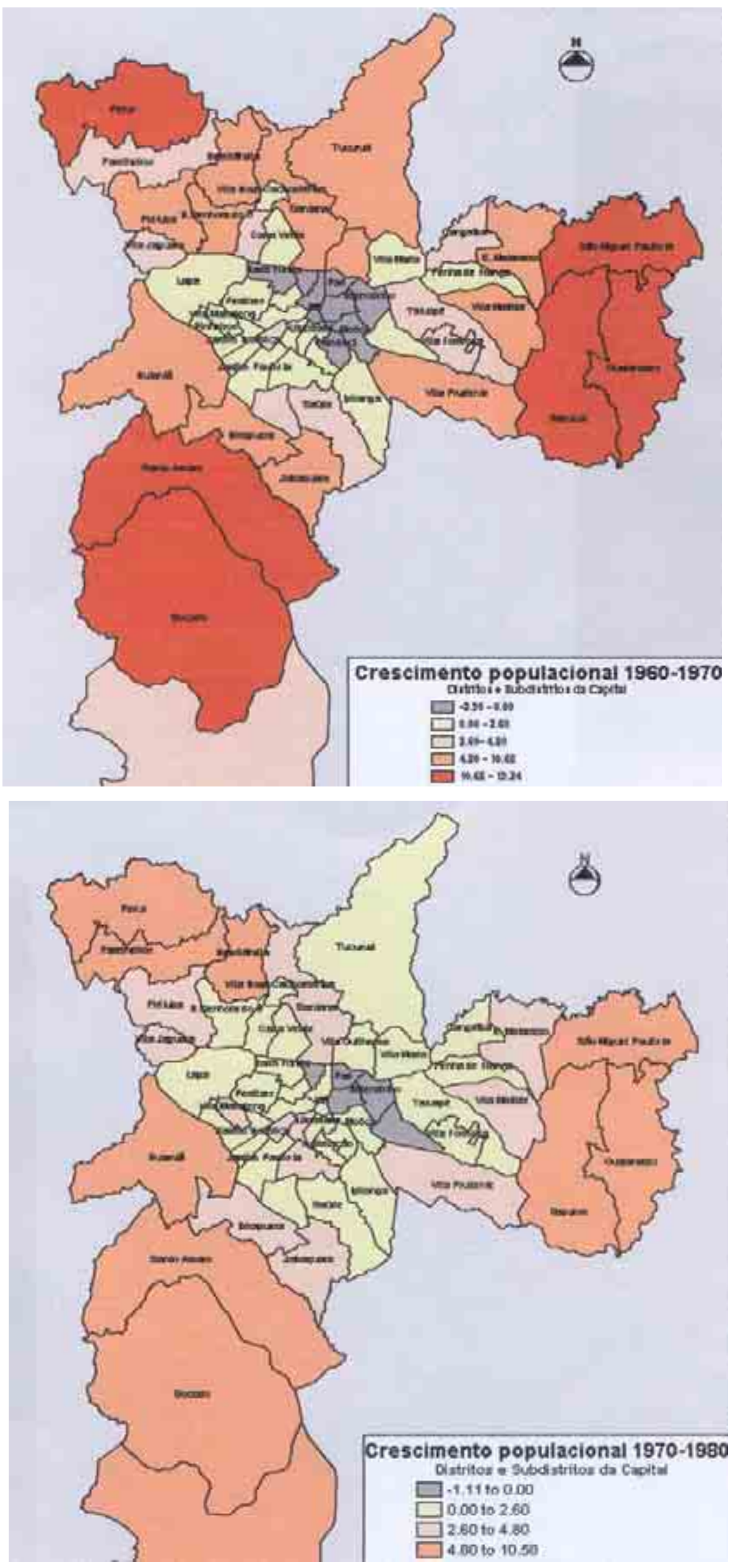
mesmo tempo se constituiu no quadrante preferencial de moradia das faixas de renda mais altas, atraindo o setor terciário avançado e toda uma rede de serviços voltados à essa população, tais como educação, saúde, lazer, cultura e consumo, como foi o caso dos shoppings centers. Tal setorização não apenas permaneceu ao longo da década de 1980, como também foi reforçada nas seguintes pelo surgimento de outros espaços caracterizados pelo seu direcionamento ao mercado habitacional de elite e de funções corporativas.

Outra explicação presente quando são feitas comparações entre os bairros próximos ao Centro, é a de que o intenso parcelamento do solo daqueles com origem popular ou de renda média baixa se constitui em sinônimo de dificuldade para a agregação de lotes necessária à verticalização. Essa relação entre o aproveitamento vertical do solo e a estrutura fundiária, embora procedente, como analisou Souza (1994, 237), deve ser complementada com desdobramentos provocados por outros fatores, como:

1. A Lei de Zoneamento de 1972, no tocante à fixação dos coeficientes de aproveitamento diferenciados e também pela consolidação dos usos e vocações dos setores urbanos. Nesse sentido, a análise de Souza comprova a inviabilidade de ocorrer a verticalização nas zonas Z2 em lotes com menos de $700 \mathrm{~m}^{2}$, devido as determinações da legislação e de taxa de ocupação, havendo portanto maior procura de lotes com maior metragem quadrada na cidade. Assim, a mesma autora mencionou a maior valorização das zonas Z3, em face do maior coeficiente permitido e da procura para verticalização das áreas equipadas e valorizadas (idem, 238).

Com a consagração das vocações urbanas pela Lei de Zoneamento, os espaços com incidência de atividades atacadistas, indústrias e outras ocupações comerciais de âmbito metropolitano viram reduzido o valor do solo urbano e rebaixada sua atratividade para finalidade habitacional, uma vez que para o mercado imobiliário os lucros de um empreendimento poderiam ser consideravelmente menores nas áreas "não-nobres" da cidade, mesmo estando próximas à centralidade, devido aos riscos ligados à demanda incerta e ciclo mais longo de retorno.

2. Os investimentos públicos diferenciados na produção da infra-estrutura urbana, particularmente no sistema viário, o principal indutor das novas ocupações da verticalização como foi visto no capítulo anterior. Tal aspecto é patente se comparadas as reformulações urbanísticas de eixos como as avenidas Consolação, Paulista, Faria Lima, todas a partir da década de 1960 e para o caso das duas últimas, incorporando projetos destinados a não apenas ampliar o fluxo de veículos, mas também implantando novas qualidades paisagísticas e simbólicas àquelas vias.

De maneira diversa, além da quase inexistência de recursos públicos voltados à reformulação da infra-estrutura viária para os bairros situados ao norte, nordeste 
e leste da área central, quando foram executadas, direcionaram-se exclusivamente à função de circulação e transporte, como no caso da avenida Tiradentes, após a implantação da linha Norte-Sul do Metrô e da implantação do elevado Costa e Silva, na região central e junto aos bairros Santa Cecília e Barra Funda, estes situados a oeste do centro.

3. O direcionamento do mercado imobiliário que incorporou os investimentos públicos em infra-estrutura, pressionou constantemente mudanças da Lei de Zoneamento nas bordas das áreas mais valorizadas e "expandiu" o status das mesmas para localizações próximas. Nesse caso, mesmo em bairros com o parcelamento constituído de pequenos e médios lotes, a transformação tipológica ocorreu através da substituição da ocupação horizontal pela paisagem vertical. No período abordado, trechos inteiros de bairros como Itaim, Vila Olímpia, Santana, Moema, Pinheiros, Santa Cecília e Mooca, entre outros, apresentavam um grande número de edifícios sendo construídos para a classe média. 


\section{Notas:}

${ }^{1}$ Sobre o assunto ver "O II PND e a Política Urbana Brasileira: Uma Contradição Evidente" da professora Maria Adélia A.de Souza em Deák, Schiffer (orgs)

2 "Na década de 1970, após o II Plano Nacional de Desenvolvimento - PND, iniciou-se um processo de reversão da concentração industrial, associado à desaceleração do crescimento, notadamente dos setores de bens de consumo duráveis e não duráveis. Dessa forma, os anos 70 caracterizaram-se pela redução do peso relativo da indústria metropolitana nos contextos estadual e nacional" (Emplasa, 1994, 37).

Em 1975 impôs-se restrições às indústrias poluidoras na Região Metropolitana de São Paulo, através do decreto lei $n^{\circ} 1413$. Em 1978, a lei estadual $n^{\circ} 1817$ instituiu o zoneamento industrial que considerou as diretrizes de descentralização do I Plano Metropolitano de Desenvolvimento Integrado - PMDI (Lagreca, 1999, 198)

${ }^{3}$ Sobre o assunto: “A fonte de recursos desses investimentos governamentais foram empréstimos concedidos pelo Banco Mundial, inicialmente através do programa norte-americano "Aliança para o Progresso". Para agenciar a alocação desses recursos, constituíram-se grandes empresas estatais (responsáveis pelos diversos serviços de infra-estrutura), que passaram a alimentar uma verdadeira rede de escritórios especializados na produção de megaprojetos e relatórios intermináveis, destinados a justificar os empréstimos e intermediar interesses particulares" (Sempla, 1990, 77)

${ }^{4}$ Constituição das empresas participantes e dos órgãos financiadores:

As empresas participantes foram: ASPLAN S.A - Assessoria em Planejamento; Leo A. Daly Company Planners-Architects-Enginieers; Montor Montreal Organização Industrial S.A; Wilbur Smith \& Associates.

Órgãos financiadores: Ministério do Planejamento e Coordenação Geral; Financiadora de Estudos e Projetos S.A - FINEP; United States Agency for International Development - USAID (PUB, 1968)

${ }^{5}$ As administrações regionais foram considerados como unidades urbanas pelo PUB, que incluiu também os distritos . Em 1965 foram criadas 7 ARs, em 1968 existiam 11 e o Plano propunha uma ampliação para 16 administrações regionais, proposta também existente no SAGMACS (Sócrates, 1993, 254).

${ }^{6}$ Nesse sentido, a proposta de Plano Diretor de 1985 analisou que a Marginal do rio Pinheiros e a avenida Nações Unidas, ao sediar um novo centro terciário avançado, provocaram a expansão residencial de Santo Amaro e Campo Limpo, ao invés da zona leste, como propunham as diretrizes do Plano (Sócrates, 1993, 34)

${ }^{7}$ Lei $\mathrm{n}^{\circ} 7.805$, de $1^{\circ}$ de novembro de 1972 , promulgada pelo prefeito nomeado José Carlos de Figueiredo Ferraz.

${ }^{8}$ Dados constantes do Cadastro Territorial, Predial, Conservação e Limpeza - TPCL, da Secretaria Municipal de Finanças.

${ }^{9}$ Em números absolutos, no ano de 1950 São Paulo contava com 264.174 domicílios ocupados por locatários e 167.953 ocupados por proprietários. No ano de 1970 a cidade contava com 486.472 domicílios ocupados por locatários contra 683.830 ocupados por proprietários (Bonduki, 1998, 282) 


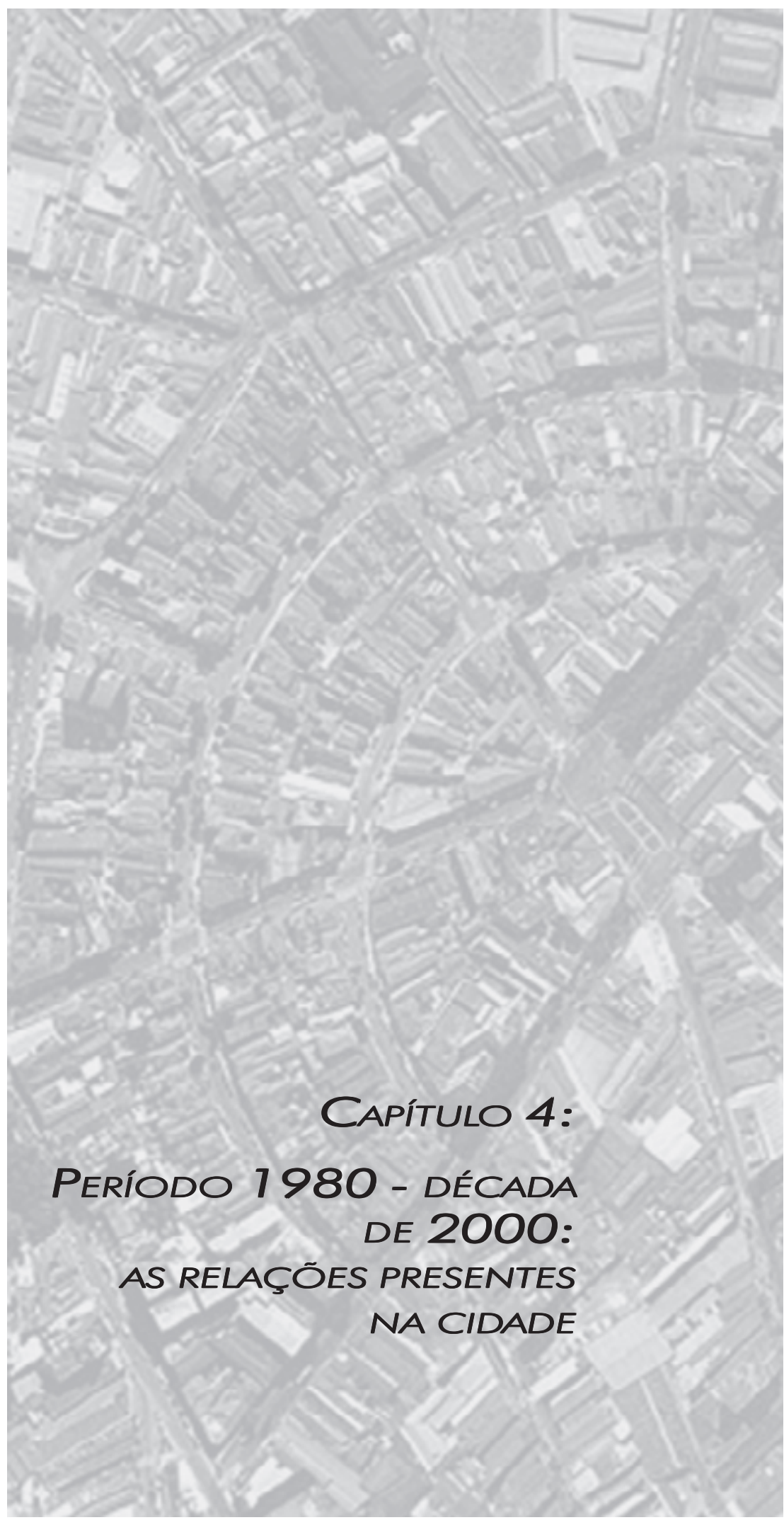




\section{Período 1980 - década 2000: as relações presentes na cidade.}

A tarefa de sintetizar transformações urbanas no período agora abordado, não é de fácil execução, considerando se tratar de um processo ainda em curso e com aspectos múltiplos e interconectados. A diferença está entre o distanciamento existente em relações das outras etapas, que permitiu divisar com maior clareza os agentes participantes, os cenários produzidos e as conexões entre a cidade e externalidades político e econômicas. Para o período agora enfocado, as transformações urbanas produziram situações que, embora concretas e traduzidas espacialmente, ainda apresentam e apresentarão desdobramentos, seja por motivos da dinâmica social e imobiliária, seja por escolhas ou decisões urbanísticas ou institucionais.

Por essas razões, a análise agora desenvolvida enfoca as linhas gerais da abertura da economia brasileira ao mercado mundial e se volta às principais decorrências dessa dinâmica na cidade: a desconcentração industrial, o crescimento do setor terciário e o recrudescimento da exclusão social. Esses temas, presentes em numerosas análises das ciências sociais, da economia e do urbanismo, traduziramse concretamente em novas espacialidades, integradas ou não à cidade consolidada.

Com relação a esse quadro, Spósito analisou a dinâmica da trama urbana constituída de "várias centralidades em definição e diferentes periferias em constituição" e destacou três processos que redefiniram o uso do solo no interior das cidades, que podem ser relacionadas à analise aqui desenvolvida para São Paulo:

- a lógica de comportamento espacial das empresas industriais.

- definição de novas configurações do habitat humano, que incluíram desde os grandes conjuntos construídos para a baixa renda na periferia da cidade à loteamentos fechados, apresentados como paraísos habitacionais em que se é facultado viver fora ou dentro da cidade.

- a estratégia de localização dos equipamentos de consumo de bens e de serviços, que potencializam fluxos para setores da cidade e novos preços das localizações assim produzidas. Incluem-se nesse caso os shopping centers, centros de exposição e convenções, centros empresariais, etc. (Spósito apud Damiani, (org), 2001, 90).

Na década de 1980 transformações estruturais começaram a ser introduzidas na orientação macro-econômica brasileira, com o esgotamento do modelo de substituição de importações que caracterizou a industrialização desde fins da década de 1940, produzindo reflexos na cidade de São Paulo, tanto espaciais quanto em relação aos empregos. Chamada de "década perdida", devido às crises de acumulação, aos fugazes períodos de crescimento e alta inflação, ocorreu 
nesse período o início de um ajuste que se aprofundou nas décadas de 1990 e 2000, que foi caracterizado por três condicionantes:

1. A exigência de qualificação dos recursos humanos

2. A difusão e incorporação pela industrialização de novas tecnologias

3. Novas formas de divisão do trabalho e cooperação, introduzindo a flexibilização de prestação de serviços, automação, reengenharia e a entrada de tecnologia nos processos de gerenciamento (Sempla, 1990, 20; Rolnick, 2001, 62)

O processo de transformações ocorrido na cidade no período 1980-década de 2000 será sintetizado através das dinâmicas caracterizadas a seguir. 


\subsection{Habitação e o mercado imobiliário}

O quadro observado no período posterior à década de 1980 mostra a diferença acentuada entre as apropriações pelas classes sociais relacionadas à habitação. Enquanto a valorização do solo da área consolidada produzida pela infra-estrutura e rede de serviços instaladas induziu à ampliação do aproveitamento vertical, a explosão do crescimento periférico e dos cortiços nos bairros centrais denunciaram as condições de empobrecimento de amplas camadas da população, mostrando reflexos em quase todos os distritos da cidade.

Em contraponto ao crescimento da verticalização da classe média, a extinção do BNH em 1986 implicou na redução de investimentos públicos para habitação social. Durante o período 1973-1986, em decorrência da política econômica brasileira e da incapacidade do Sistema Financeiro de Habitação atender a demanda por moradias, São Paulo apresentou um crescimento das favelas de mais de 1000\%, com quase um milhão de favelados distribuídos em 1600 núcleos pela cidade (Sempla, 1985, 14).

Outro aspecto crítico associado à incapacidade de atendimento das demandas habitacionais foi o fenômeno observado, desde a década de 1960, relacionado ao declínio do número de moradores dos bairros centrais, onde a transferência da população de baixa renda para localidades periféricas permaneceu um dado presente na expansão centrífuga da cidade, em que a possibilidade de autoconstrução e aluguéis mais baixos foram os atrativos. Rolnick $(2001,67)$ atribui a fenômeno a continuidade da exclusão territorial presente na cidade. Observouse, na realidade, um duplo movimento em relação a esse processo:

- o mapa de cota residencial por distritos mostra que os índices mais altos de metros quadrados de área construída residencial por habitante, encontrados nos distritos do centro expandido, se associam à diminuição demográfica desses mesmos setores:

Faixa 90,0 $\mathrm{m}^{2}$ ou mais: distritos Morumbi e Jardim Paulista

Faixa 65 a $89 \mathrm{~m}^{2}$ : Santo Amaro, Campo Belo, Itaim Bibi, Moema, Pinheiros, Alto de Pinheiros

Faixa 43 a 64,9 m²: Vila Andrade, Butantã, Vila Leopoldina, Lapa, Perdizes, Santa Cecília, República, Bela Vista, Liberdade, Vila Mariana, Saúde, Mooca, Tatuapé.

Faixa 25 a 42,9 m²: Sé, Barra Funda, Bom Retiro, Brás, Pari, Belém, Ipiranga, Cursino, Vila Prudente, Água Rasa, Carrão, Vila Formosa, Vila Matilde, Penha, Casa Verde, Santana, Vila Guilherme, Mandaqui e Tucuruvi.

Faixa até $24,9 \mathrm{~m}^{2}$ : os demais distritos do município

- além disso, o processo de esvaziamento dos bairros centrais foi diferenciado em relação às regiões aonde a habitação já vinha perdendo espaços para o 


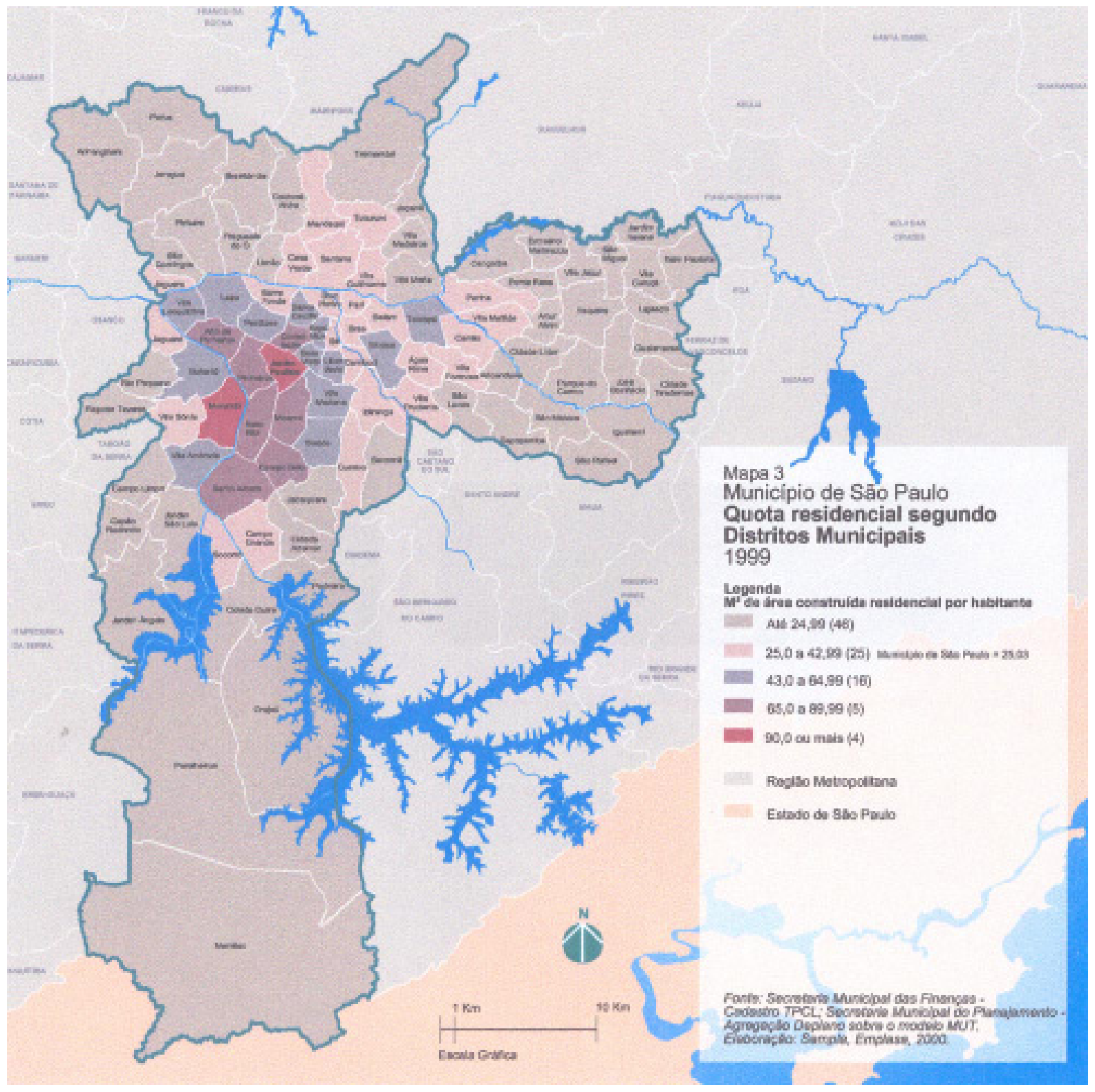

Fig. 100: Emplasa / Sempla, 2000

comércio e serviços e que não houve interesse do mercado imobiliário na produção de novas unidades, dadas as condições urbanas presentes ou às dificuldades de financiamento para as camadas de baixa renda. Um estudo da Secretaria Municipal de Planejamento mostrou que o fenômeno se constituiu em um processo combinado: ocupação horizontal nas bordas da cidade e aumento das taxas de ocupação em cortiços e habitações precárias, como mostram os dados a seguir:

- Na década de 1960-1970,84\% do crescimento populacional ocorreu na periferia.

. Na década de 1970 -1980, 86\% desse crescimento foi registrado nos distritos mais distantes do Centro. 
. Entre 1980 e 1987, o mesmo índice decresceu para 69\%, com o aumento de $11 \%$ da população nos anéis central e interior, em relação à $1 \%$ na década de 1960 e 7\% na década de 1970 (Sempla, 1990, 36).

Embora indicasse diminuição relativa do crescimento das áreas periféricas de São Paulo durante a década de 1980, o quadro da distribuição da população no município resultante do Censo de 2000 mostrou o recrudescimento dessa expansão, aliada ao esvaziamento dos distritos centrais:

- De 1991 a 2000 a região central perdeu 19,7\% dos moradores, enquanto a cidade cresceu $7,8 \%$

- 53 dos 96 distritos da cidade perderam população desde 1991

- Enquanto os distritos centrais perderam moradores, no extremo Oeste, o distrito Anhanguera ganhou 210\% desde 1991 (FIBGE/FSP 10/5/2001,C1).

Esse processo pode ser entendido levando em conta três aspectos principais, segundo o observado por três urbanistas (Carlos Guilherme Mota, Luís Carlos Costa e Raquel Rolnick):

- A incapacidade da maioria da população arcar com os custos dos empreendimentos imobiliários do mercado formal.

- Mudança de uso dos imóveis nas áreas próximas ao centro.

- Deterioração do espaço urbano nessas áreas (FSP, 10/5/2001, C1).

Nos espaços em que ocorreu um grande número de empreendimentos imobiliários para a camada de poder aquisitivo mais alto como Tatuapé e Morumbi, a população moradora original foi obrigada a se transferir.

Outros aspectos presentes na ocupação habitacional da cidade, que contribuíram para o agravamento das condições de moradia foram o aumento do número de domicílios desocupados, revelado também pelo Censo de 2000 e o crescimento da informalidade urbana. Outra matéria jornalística compilada a seguir, mostra a extensão desses problemas:

"12\% dos domicílios estão desocupados"

"A cidade de São Paulo tem um domicílio particular vago para cada dez existente em seu território...

De acordo com o Censo 2000, são 3,551 milhões de domicílios particulares no município, dos quais exatos 420.327 estão vagos. $\bigcirc$ montante equivale a quase $12 \%$ do total e seria suficiente para dar a cada morador de rua da cidade $(9.000$ hoje), 47 imóveis para morar...

Segundo Luiz Carlos Costa, da Faculdade de Arquitetura e Urbanismo da Universidade de São Paulo, esse é o resultado do divórcio entre a valorização imobiliária e o poder aquisitivo... 
A solução, segundo urbanistas, passaria por incentivos diversos vindos do poder público, inclusive fiscal, para a ocupação desses imóveis por famílias de renda mais baixa...

Segundo a urbanista Raquel Rolnik, está claro que o mercado não foi capaz de resolver a contradição entre oferta e demanda...

O distrito com mais domicílios vagos é Sapopemba (9.073 domicílios). Percentualmente quem lidera é a Sé com $26,84 \%$ dos domicílios vagos. O centro conta com $6 \%$ do total de domicílios, mas conta com $9 \%$ do total de vagos...

Segundo o Censo 2000 comparado com o de 1991, mostra que a população da cidade cresceu apenas 7,87\% enquanto o número de domicílios particulares saltou para 39,82\%. Isso ocorre devido as famílias nucleares e extensas se desmembraram em indivíduos que optam por viverem sozinhos e, então, multiplicam-se as habitações mais rapidamente do que a população". (JT, 26/3/01).

Distanciada do divórcio entre a valorização imobiliária e o poder aquisitivo das massas de baixa renda, a verticalização para a classe média caracterizou a atuação do mercado imobiliário em quase todos os setores do centro expandido da cidade: no Leste, nos bairros do Tatuapé e Penha, ao norte, em Santana, ao oeste, Perdizes, Pompéia e Lapa, ao sul, na região de Vila Mariana, Moema e Santo Amaro e ao sudoeste, no ltaim, Pinheiros, Cerqueira César e Vila Madalena. Excetuando o quadrante sudoeste, parte do crescimento vertical das outras regiões pôde ser atribuído também à acessibilidade criada pelas linhas do Metrô implantadas nessas áreas nas décadas de 1970 e 1980, que se somaram ao sistema viário implantado anteriormente.

Segundo dados da Emplasa/Sempla (2000/2001), os maiores índices de verticalização residencial no período 1991 -1999 ainda se encontravam na região da cidade considerada central, abarcando os distritos Sé, República, Santa Cecília, Bela Vista, Consolação e Jardim Paulista, todos apresentando índices próximos ou superiores a $90 \%$.

Com índices entre 50 e 75\%, situaram-se os distritos de Vila Mariana, Moema, Itaim-Bibi, Pinheiros, Barra Funda, Bom Retiro, Brás, Cambucí e Liberdade, além de Campo Belo, Saúde, Cursino, Vila Andrade e Vila Sônia.

Os distritos que apresentaram ao longo da década de 90 percentuais significativos de crescimento vertical foram: Vila Andrade (crescimento de 22\%), Vila Sônia, Morumbi, Vila Leopoldina, Casa Verde, Mandaqui, Tatuapé (crescimento de 18\%) (disponível em:Cd-rom Emplasa/Sempla, 2000).

No período posterior a década de 2000, dando continuidade às tendências da década de 1990, mas com diminuição da verticalização da área central, segundo dados divulgados sobre os lançamentos de edifícios, as áreas preferenciais incluíram um território da cidade de aproximadamente $1.500 \mathrm{~km}^{2}$, abrangendo a Vila Andrade, Moema, Santo Amaro, Campo Limpo, Lapa, Butantã, Barra 


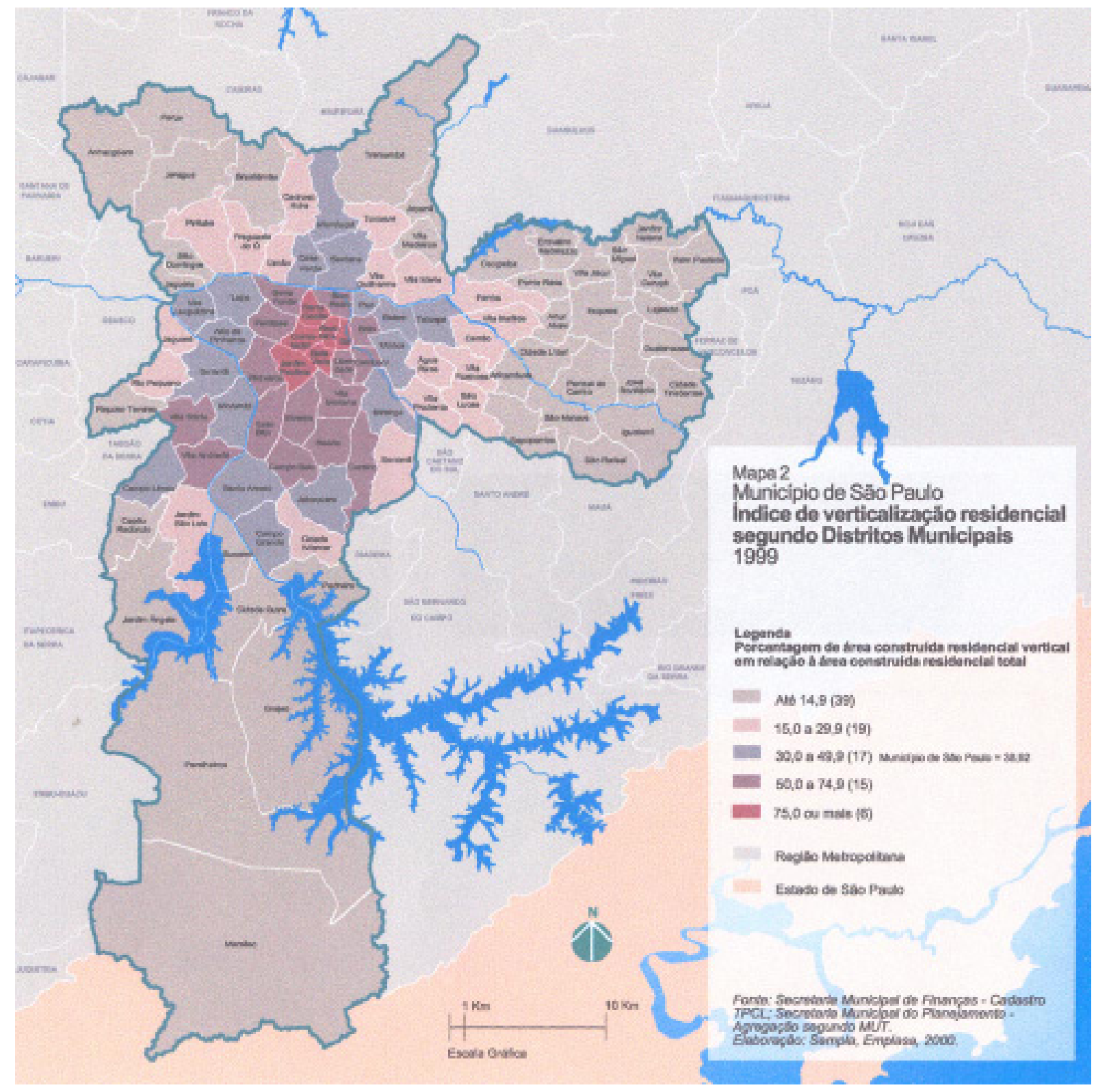

Fig. 101: Emplasa / Sempla, 2000

Funda, Tatuapé e Parque do Carmo. Visando a proximidade com bairros já verticalizados de padrão médio e alto, as localizações junto à Lapa e Vila Romana foram classificadas no ano de 2002 como as preferenciais para verticalização, iá que seriam beneficiadas com a saída das indústrias existentes na região (FSP/ Embraesp, 20/01/2002, pag 2).

A lógica imobiliária se implantou nas diferentes regiões da cidade levando em conta elementos específicos de atratividade e valorização a cada uma delas: 


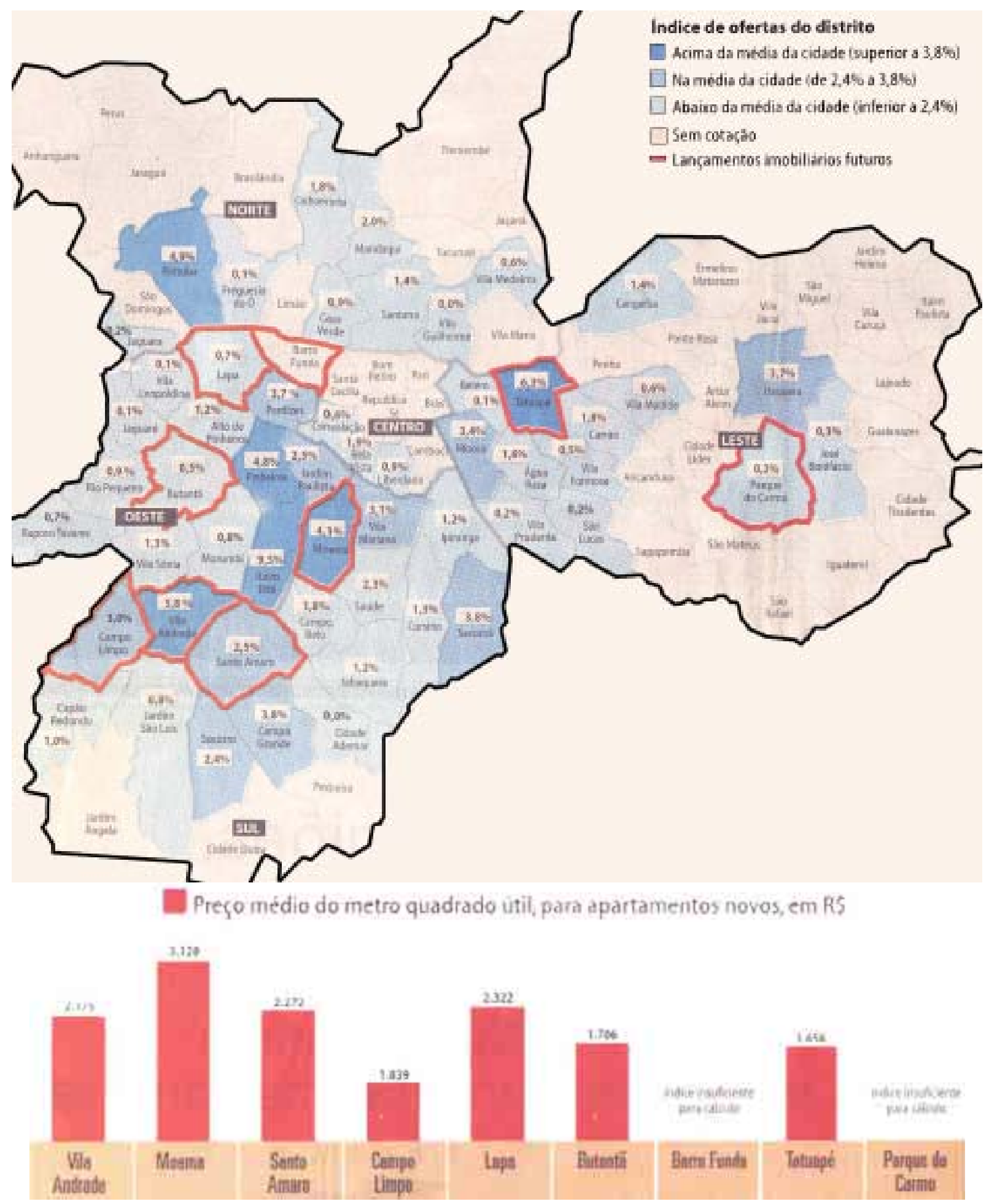

Fig. 102: Folha de São Paulo, caderno de Imóveis 2, de 20/02/02 
Na zona oeste: segundo a construtora Klabin Segal "a cidade irá crescer para onde resta lugar. A Vila Romana tem potencial para funcionar como uma continuação de Pompéia, Perdizes e Lapa". Com relação a Barra Funda, ainda segundo a empresa, as transformações ocorridas na Água Branca seriam os elementos de atração àquele bairro, semelhantemente o ocorrido com a Vila Olímpia, para o caso da reestruturação urbana (idem, 2).

Na zona sul: as obras viárias previstas na Operação Urbana Águas Espraiadas, como a ligação entre as avenidas Chucri Zaidan e João Dias, tornaram-se as indutoras da verticalização da Chácara Santo Antonio, transformando-se em uma continuação da Berrini e do Brooklin, segundo a empresa imobiliária Abyara (ibidem, 2).

Segundo a pesquisa realizada no ano de 2002 sobre o mercado imobiliário, a cidade apresentou 9.723 ofertas de apartamentos novos. Nesse universo, a menor participação foi representada pela zona central, que devido a saturação do espaço para construções verticais, participou com apenas 3,4\%. A zona sul, por sua vez, com maior extensão territorial $\left(724 \mathrm{~km}^{2}\right)$, concentrou a maior parte dos lançamentos, $37,9 \%$, sendo que o bairro do Itaim Bibi participou majoritariamente com 9,5\% (op.cit, 2).

De acordo com os consultores das empresas imobiliárias, os elementos de infraestrutura e as Operações Urbanas se constituiriam nos principais fatores de incentivo à verticalização. Assim ocorreu também para os distritos a leste, como o de Itaquera, com 36 lançamentos e o do Tatuapé com 26, no período compreendido entre dezembro de 1999 e novembro de 2001, onde o Metrô se tornou elemento indutor à ocupação. Com o lançamento da Linha 4, o mercado imobiliário já projetava a intensificação vertical na Vila Sônia. Para o mesmo período, foram verificados 74 lançamentos no Morumbi, 35 no Butantã, 34 no Campo Limpo e 26 em Moema (op. cit 2).

Confirmou-se, portanto, a tendência de concentração de lançamentos habitacionais nos quadrantes em que o processo de valorização imobiliária já se fazia presente desde as décadas de 1970 e 1980, estendendo-se para novos distritos e bairros nas décadas seguintes. No Brás, Bom Retiro e Pari, entretanto, pode-se considerar que a verticalização apresentou-se como exceção, restringindo-se a exemplares isolados, como os indicadores populacionais e de lançamentos já demonstraram. No primeiro bairro deve-se mencionar a construção, em meados da década de 1980, do grande conjunto de torres da $\mathrm{COHAB}$ ao longo da área demolida pelo projeto Cura na década de 1970. De toda a forma, esses distritos serão analisados mais profundamente na Parte II deste trabalho, uma vez que juntamente com transformações que podem ser notadas atualmente, os novos instrumentos de planejamento urbano poderão 
alterar a dinâmica de ocupação nesses espaços, promovendo o adensamento habitacional para distintas faixas de renda da população.

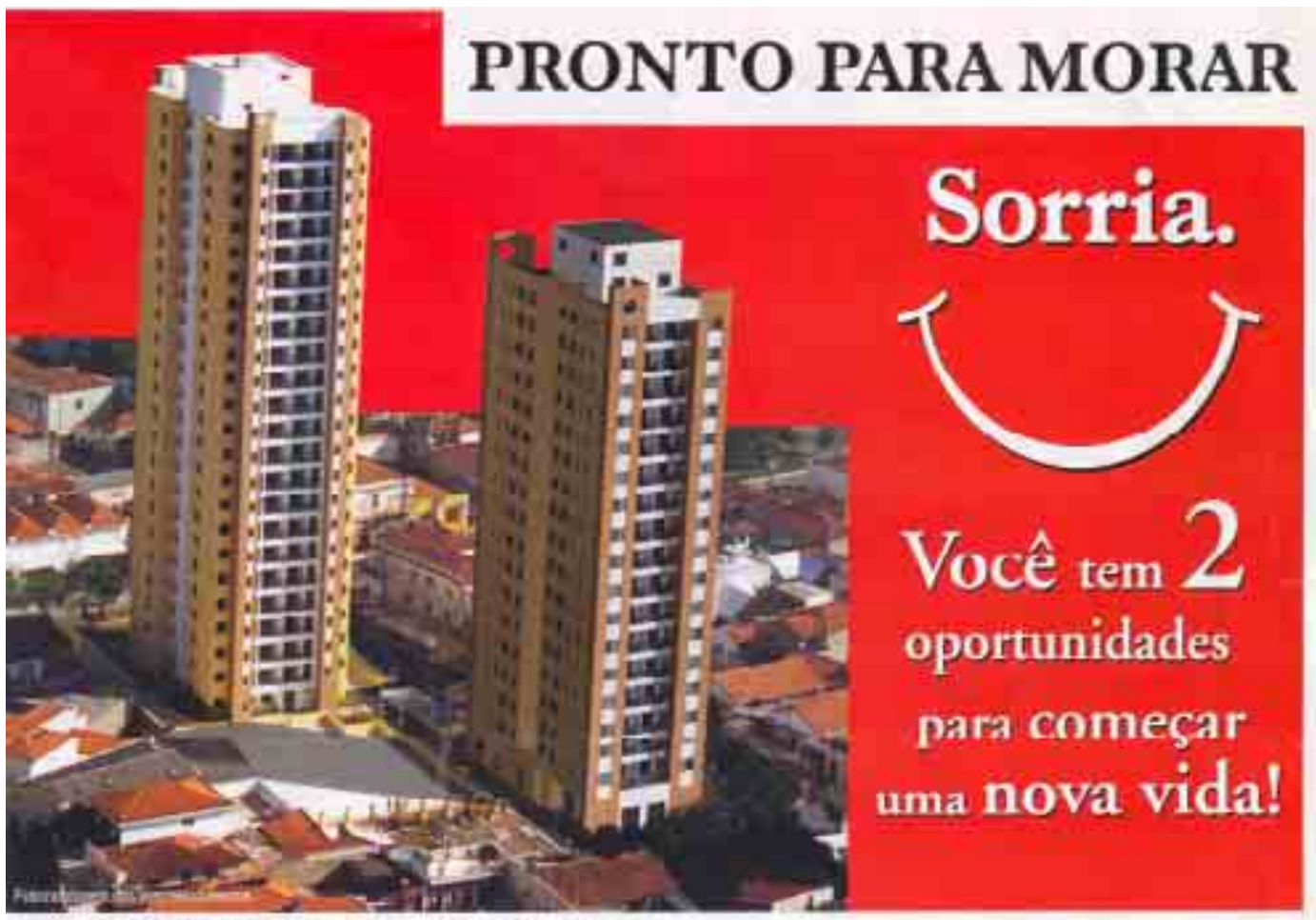

\section{CENTRO / PARI}

\section{Rua Padre Vieira, 62}

A $600 \mathrm{~m}$ da Estaçăo Armênia de metrố

e do Shopping D
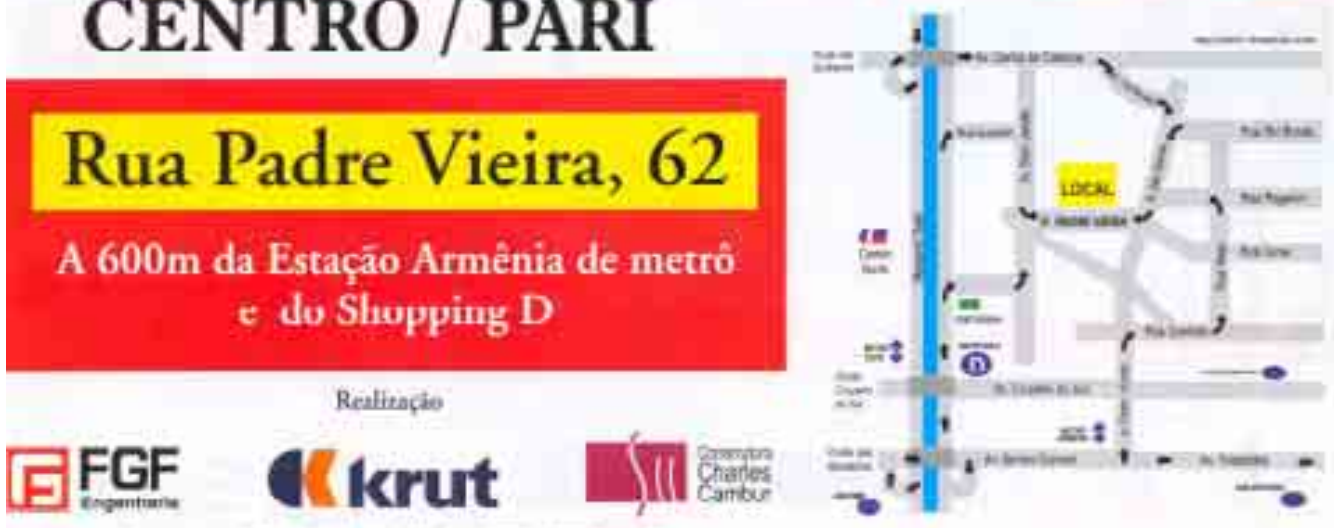

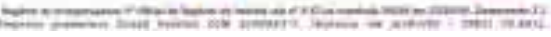

Fig. 103: Duas torres construídas no Canindé, junto ao Morro do Pari, 2000/2003. 


\subsection{A cidade e as novas ocupações industriais e de serviços}

fim da proteção ao parque industrial brasileiro, que foi mantida durante o longo período do regime militar, resultou na reconversão industrial que a cidade experimentou, com grandes diferenças entre o processo de descentralização desse setor ocorrido na década de 1970. Nesta nova etapa, as inovações representaram para a indústria um aumento de valor da produção acompanhado de diminuição de empregos (Sempla, 1990, 20).

Essa dinâmica se apresentou como qualitativamente diferente dos momentos anteriores, onde a estrutura industrial presente na cidade e os setores de construção civil, do comércio e serviços garantiram acesso aos empregos, quer especializados ou não. Da segunda metade da década de 1980 em diante, seguiu-se uma transferência de colocações de trabalho nos setores da economia, resultante da reestruturação ocorrida, como indicam os dados a seguir:

- Entre 1988 e 1998 houve uma diminuição da atividade industrial no Município de São Paulo, que caiu de 29,1\% para 17,8\%, respectivamente (Dieese apud Ferreira, 2003, 64).

- No mesmo período, o desemprego subiu de 8,2\% para 17\% (idem)

- O aumento do setor de serviços cresceu de 51,3\% para 62,4\% entre 1988 e 1998 (PMSP apud Ferreira, 2003, 64)

- Os empregos do setor de serviços subiram de 41\% em 1989 para 54,8\% em 1999 (Veras apud Ferreira, 2003, 64).

-Em 1999 17,8\% da mão-de-obra empregada vinculava-se à indústria de transformação, $2,4 \%$ à construção civil e $79 \%$ ao setor de comércio e serviços (Sempla 2000/2001, vol 3, 14)

Fruto desse quadro de mudanças estruturais, as transformações no interior da cidade puderam ser observadas fundamentalmente através dos seguintes elementos:

- Esvaziamento das áreas industriais tradicionais, principalmente daquelas espacialmente ligadas às ferrovias. Essa transformação teve início na década de 1980 aprofundando-se na seguinte, onde as empresas que ocuparam as faixas da industrialização pioneira ao longo dos eixos ferroviários ou em bairros próximos, como Brás, Mooca, Ipiranga e Lapa, transferiram-se ou cessaram de funcionar devido ao conjunto de fatores da lógica produtiva. Pesaram nessas mudanças as relações com transporte, localização em áreas sempre congestionadas e as características construtivas: porte incompatível com os ajustes impostos pela "reengenharia", obsolescência e inadequação das instalações frente às novas exigências produtivas e da legislação municipal e estadual para o setor, etc. 
- Relocação industrial para o interior do estado ou nas cidades próximas da Região Metropolitana. Embora o aprofundamento do processo de reestruturação da economia tenha efetivamente reduzido o número de empresas industriais, segundo estudo da Secretaria Municipal de Planejamento, a relocação significou uma maior flexibilidade de localização ao invés de perda de poder do centro de decisões, que no caso da cidade de São Paulo (Sempla, 1990, 22).

Nesse sentido, diferentemente da hierarquia estabelecida por uma grande concentração industrial em relação aos demais municípios ou regiões, como ocorreu, o centro de decisões passou a exercer a sua liderança devido aos atributos de competitividade implantados, resultando daí a exigência de qualificação dos recursos humanos, serviços industriais especializados e setores financeiros e gerenciais integrados. Nesse sentido, o estudo da Sempla afirmava que: "a evolução tecnológica, baseada crescentemente em meios sofisticados de comunicação, com plantas industriais flexíveis e integradas horizontalmente, ao mesmo tempo que torna a produção menos enraizada, reserva o papel de liderança exatamente no local onde estas inovações são geradas e difundidas" (idem, 22).

O tempo confirmou essa assertiva e São Paulo continuou a exercer o papel de centro de decisões, assim como ocorreu em grandes centros internacionais em que a cadeia produtiva baseada no Fordismo e no Taylorismo cedeu ante os novos padrões tecnológicos, de cooperação e divisão do trabalho (ibidem, 22). Aludindo a esse processo, Rolnick inferiu que a cidade chamada de locomotiva do progresso brasileiro na segunda metade do século XX, transformou-se após essa reestruturação "em um dos nós da conexão da economia nacional com o resto do mundo" (Rolnick, 2001, 63).

processo de reconversão industrial que se implantou, além de provocar o esvaziamento e mesmo o sucateamento de grande parte das instalações industriais, e por conseguinte dos bairros em que estas se implantaram, implicou em um desdobramento dos espaços do terciário avançado para além dos limites anteriores, dirigido pelas necessidades ditadas pela crescente internacionalização econômica. As linhas gerais desse processo, aqui descritas sinteticamente, servem de referência às decorrências espaciais ocorridas na cidade a partir de então, que verificou:

- O aprofundamento da "crise" da área central (aspas nossas), expressa pela transferência de empresas e estabelecimentos comerciais para as novas localizações, com maior prestígio urbano, apesar da área ter sido alvo de constantes investimentos públicos, como foram as obras do Metrô e pedestrianização do Centro. Esse processo, em curso desde a década de 1960, aprofundou-se nas seguintes e as intervenções que ocorreram se restringiram em sua quase totalidade às exigências de circulação e transportes (Amadio, 1998, 131). Com relação à transferência de atividades para outras áreas da cidade, Villaça analisou que: "a suposta deterioração do centro (inclusive suas 
dimensões política e ideológica) é antes de mais nada, uma questão de transformação de localizações. O que supostamente 'deteriorou' não foram os edifícios, mas os seus 'pontos'. O que deteriorou não foi o Martinelli enquanto edifício, mas o seu ponto" (Villaça apud Amadio, idem, 131, aspas do autor).

Esse quadro remete à continuidade do processo de substituição de localizações imposto pelo setor de serviços e o mercado imobiliário ao conjunto da cidade, pois mesmo a aprovação da Operação Urbana Centro em 1997, não acarretou qualquer alteração de rota do poder público ou da iniciativa privada na área central até o ano de 2001, quando a requalificação da área central foi retomada, incluindo nessa estratégia os bairros que o circundam, como será abordado adiante.

- O setor de serviços avançados, por sua vez, desdobrou-se dos espaços por ele estruturados e consagrados desde a década de 1960: a região da avenida Paulista e a avenida Faria Lima. Esse movimento, dirigido pelas atividades de ponta das corporações transnacionais, incluindo indústrias de alta tecnologia, o setor financeiro e empresas de consultoria, auditoria, seguros e agências, direcionou-se a espaços da cidade com ampla flexibilidade para a implantação de grandes conjuntos empresariais e de atividades a eles conectados.

Essas áreas foram enfocadas nas teses de doutorado de Van Wilderode (2000) e Whitaker Ferreira (2003) e serão abordadas também na análise sobre as Operações Urbanas desenvolvida adiante. As teses mencionadas aprofundam a investigação sobre os espaços corporativos conectados à economia globalizada, situados na região da marginal do rio Pinheiros, assim como outro trabalho da

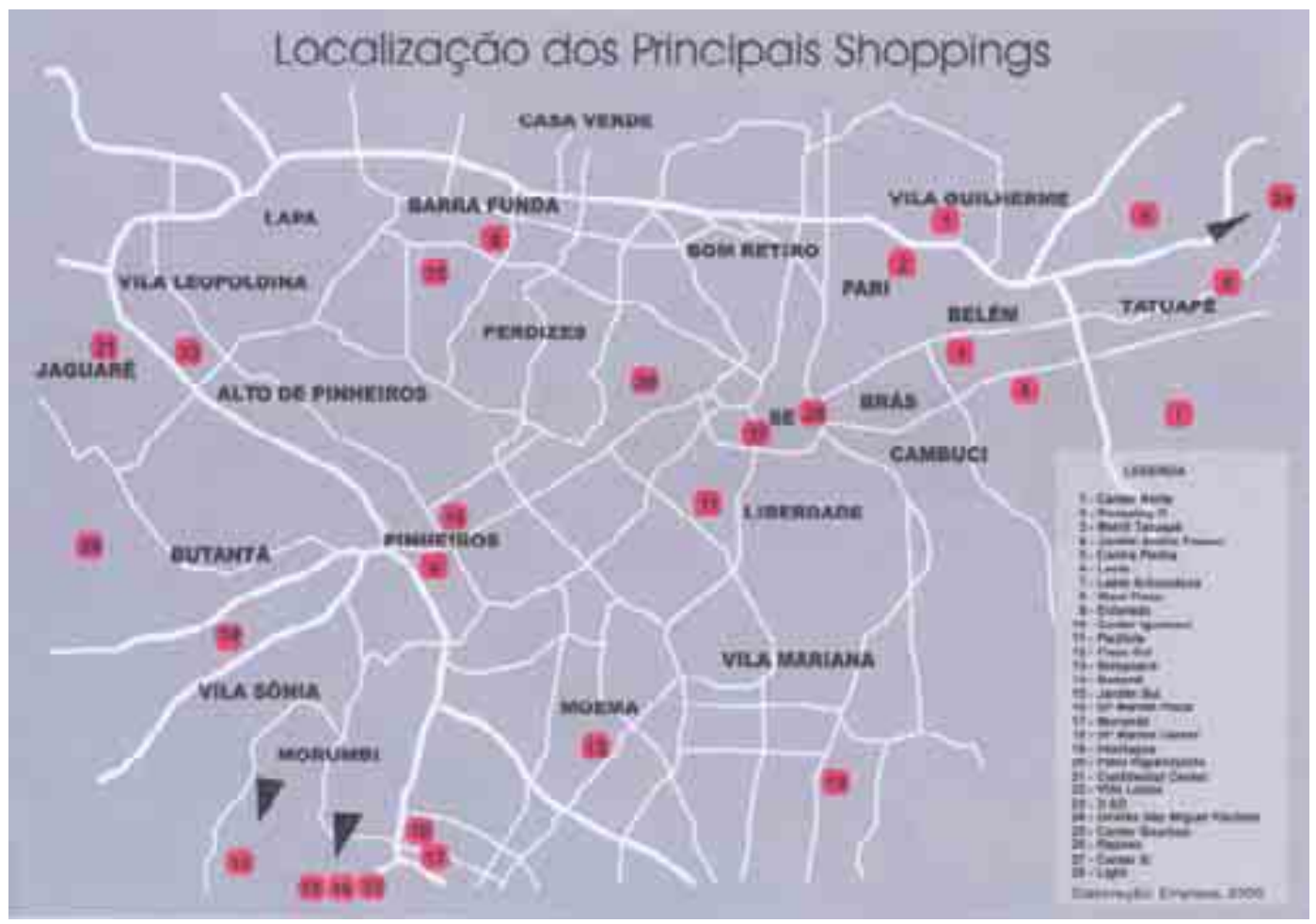

Fig. 104: Emplasa / Sempla, 2000 
Secretaria Municipal de Planejamento (2000/2001) também mostra a concentração de edifícios "inteligentes" como fruto da relação da globalização e desenvolvimento urbano que a cidade apresentou nesse período.

A incorporação de áreas para a construção de edifícios de escritórios nas avenidas Faria Lima, Luis Carlos Berrini e Nações Unidas, constituiu um vetor de nova expansão do mercado imobiliário para o sudoeste, implicando também na implantação de infra-estrutura por parte do poder público nessas áreas. Com relação à região da Berrini e Nações Unidas, como mostra Wilderode, cerca de quase dois milhões de metros quadrados para escritórios com características do marketing imobiliário de "edifícios inteligentes", foram incorporados entre 1980 e 1999. No início da década de 1980, a avenida Paulista ainda concentrava mais da metade desses edifícios, sendo que uma década depois, dois terços dos mesmos situavam-se na maior concentração desses espaços da cidade, a avenida das Nações Unidas (Wilderode, 2000, 208).

Segundo o autor, dois fatores sustentaram as transformações ocorridas quanto à propriedade imobiliária: a gradual perda de importância da ocupação pelo proprietário corporativo, processo que passou a existir após a década de 1980 e o desenvolvimento de outras formas de participação entre propriedade e uso, - que direcionou parte da demanda para edifícios de alto padrão e para a direção dos espaços de aluguel. (idem, 221, 223).

Na raiz da emergência dos novos espaços do setor terciário avançado, várias estratégias mercadológicas se entrelaçaram, como pode ser observado a seguir pelas informações compiladas de matéria jornalística intitulada "Marketing 'inventou' núcleo comercial da marginal Pinheiros":

"Segundo uma tese da FAU-USP, a ocupação da região da marginal Pinheiros por grandes empreendimentos comerciais é fruto de uma estratégia de marketing da indústria imobiliária (sic). Afirma também que no período de 1975 a 1998, o crescimento da importância da marginal coincide com o início da decadência do centro e com a migração de companhias e de instituições públicas.

A marginal passa a ser comercializada pelos promotores imobiliários como 'centro metropolitano do futuro' - e não outros centros como as avenidas Paulista e Brigadeiro Faria Lima.

O levantamento, feito pelo professor Eduardo Alberto Nobre, revelou que, em 1975, 54\% tinham como endereço o centro, 14\% a avenida Paulista, e 11\%, a marginal Pinheiros. Em 1998, 41\% delas já estavam na marginal, 21\%, na Paulista, e apenas $18 \%$, na área central.

Nobre também analisou o discurso de incorporadoras e concluiu que a 'insegurança' foi destacada para criar 'uma imagem negativa do centro' e 'atrair o cliente corporativo para outras regiões'...

Em 1971, a marginal não tinha obras de drenagem e abrigava moradias de média renda e pequenos focos industriais. $O$ arquiteto Carlos Bratke, autor dos 


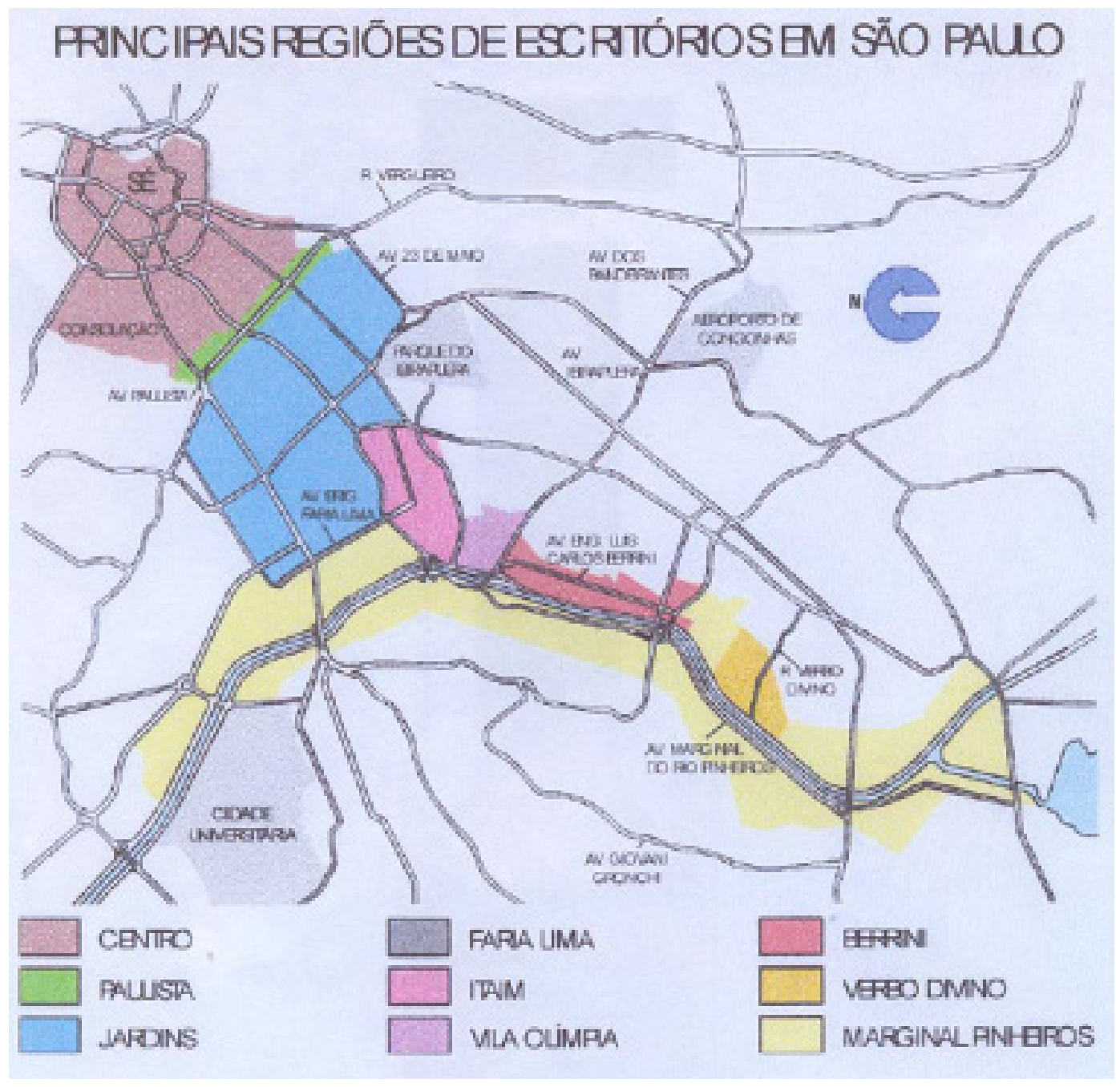

Fig. 105: Emplasa / Sempla, 2000

primeiros prédios da região, conta que chegou a estudar a Barra Funda, mas escolheu a marginal pelo baixo custo dos terrenos, por ser próxima ao Morumbi, pela topografia plana e pelos projetos viários que seriam construídos.

Ele diz que o início foi como um 'balão de ensaio': 'Compramos um terreno e deu certo, compramos mais um e deu certo'. Mas reconhece a importância dos 'formadores de opinião' nas fases seguintes da ocupação. 'É muito importante que se lance a coisa. Alguém influente tem que chegar e dizer: o chique é a marginal. É assim que acontece" (FSP, 30/1 1/2003, Imóveis 1, pag 1, aspas do editor ).

Outro registro fornece dados sobre a expansão do mercado imobiliário no setor de escritórios de alto padrão, baseados nas análises de empresas de consultoria especializadas nesse segmento: 
- Segundo a consultoria "Cushman \& Wakefield Semco", o primeiro trimestre do ano de 2003 apresentou uma retomada de resultados positivos na absorção desses imóveis, visto ter se verificado um recuo da alta vacância e aumento da demanda. Segundo a empresa, nesse período foram absorvidos $181 \mathrm{mil} \mathrm{m}^{2}$ úteis, sendo $69 \mathrm{mil} \mathrm{m}^{2}$ na região da avenida engenheiro Luís Carlos Berrini e da Vila Olímpia. $\bigcirc$ ano de 2000 foi indicado como o período de maior expansão desse setor pelos seguintes motivos: "havia pouco novo estoque e alta demanda gerada pelas companhias 'ponto com', o que acarretou na construção de novos empreendimentos". Segundo o diretor de negócios imobiliários dessa empresa (Paul Weeks), a concepção de novos edifícios foi feita de maneira pontual, sem análise de longo prazo. $O$ resultado foi um aumento de estoque representado no ano de 2002, por mais de 200 mil m$^{2}$ nesse segmento. (Gazeta Mercantil, 15/7/03, A17).

- A empresa de consultoria, a "Jones Lang LaSalle", indicou que a cidade dispunha de um total de 450 mil m² úteis vazios em escritórios de classe $A$ e AA. Para 2003 previam-se 170 mil m² e em projeto mais $760 \mathrm{mil} \mathrm{m}^{2}$, sendo que $40 \%$ desse total entrariam no mercado até 2006 e o restante até 2008. Segundo o diretor de operações dessa empresa (Helmut Fladt), o mercado de escritórios começou a se renovar a partir de 1993, quando "antes disso, a cidade não tinha prédios inteligentes, eram edifícios com lajes pequenas e a maioria dos empreendimentos comerciais estava concentrada na região da avenida Paulista"(idem, A17).

Ligado à expansão das atividades do terciário, segundo a empresa "Cushman Wakefield Semco" o setor de escritórios apresentou um estoque no ano de 2002 de 7,75 milhões $\mathrm{m}^{2}$, sendo $53,3 \%$ da categoria C. Entretanto, a mesma consultoria aponta que o segmento de escritório da categoria $A$ e $A A$ teve crescimento a partir dos primeiros anos da década de 1990, quando segundo a empresa "os empreendimentos começaram a agregar valor por conta da demanda do mercado" (ibidem, A17).

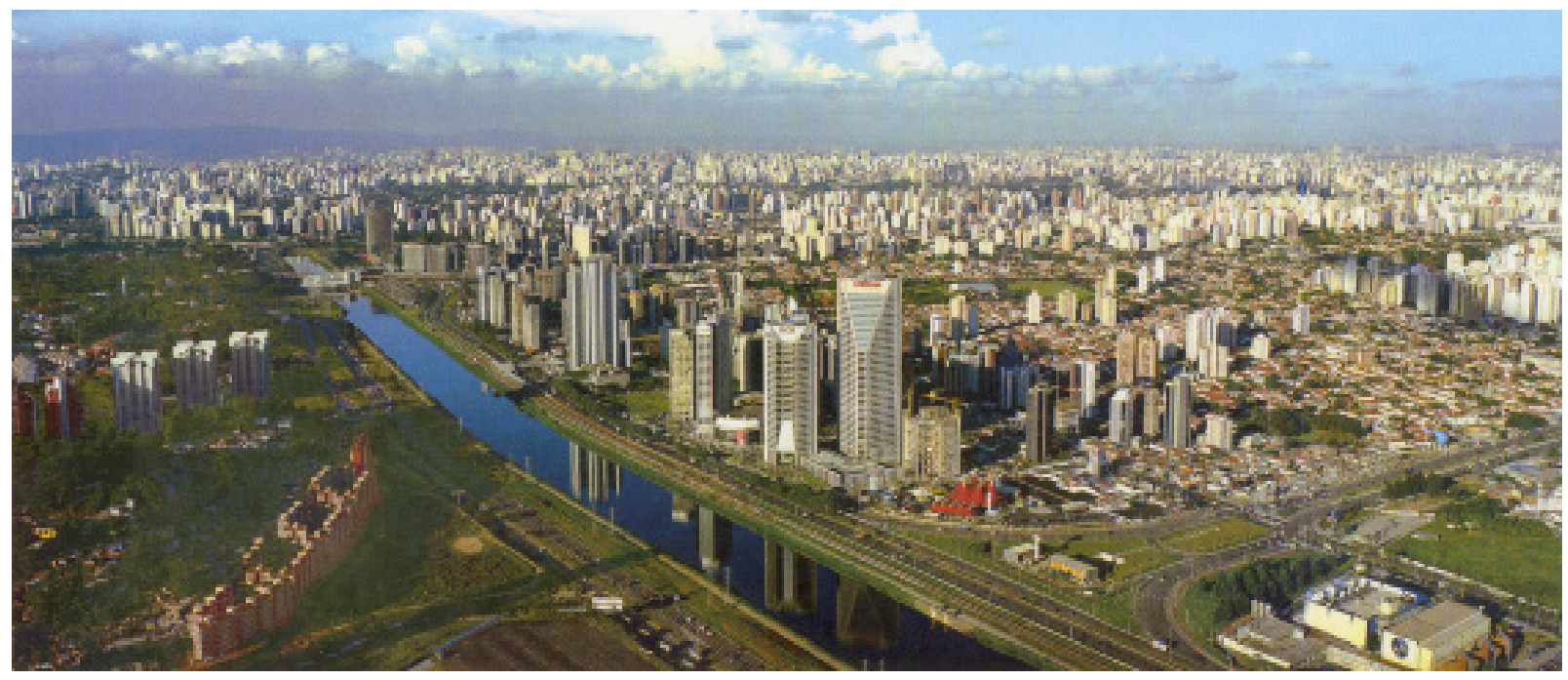

Fig. 106: Novo cartão postal: Marginal Pinheiros, altura da Av. Águas Espraiadas, 2000. 


\subsection{Operações Urbanas: remodelações dirigidas e espacialidade corporativa}

Um aspecto relevante ao uso e ocupação do solo das áreas consolidadas da cidade, surgido no período posterior à década de 1980, diz respeito às Operações Interligadas e Urbanas, que se constituíram em instrumentos baseadas no conceito de solo criado e fundamentaram-se na obtenção de recursos para obras urbanas através de parcerias com o setor privado. As primeiras, as Operações Interligadas, foram aprovadas em 1986, vigorando até 1998, quando foram julgadas inconstitucionais. Esse instrumento introduziu um mecanismo de contrapartida para a municipalidade da valorização decorrente do aumento do potencial construtivo permitido, conforme a situação requerida pelo empreendimento. Essa exceção à legislação do zoneamento, através do aumento do coeficiente de aproveitamento de um empreendimento, seria convertida em pagamento de um número estipulado de habitações de interesse social destinado à população favelada (Sempla, 2000/2001, n4, pg.5).

Os projetos dos empreendimentos eram submetidos à Secretaria Municipal de Planejamento e as licenças de aprovação ocorreram mediante as condições definidas pela Comissão Normativa de Legislação Urbanística - CNLU, da mencionada Secretaria. Inúmeras críticas foram feitas ao processo como um todo, sendo a principal, aquela que se referia à contrapartida destinada à Habitação Social, que em muitos casos não possibilitava nenhuma transformação da situação das favelas, dado o número reduzido de unidades que se obtinha através desse instrumento.

Já as Operações Urbanas, formuladas em 1985, foram incluídas na Lei Orgânica do Município de São Paulo apenas em 1989, e consistiram no estabelecimento de uma estratégia público/privada para a renovação de partes do território da cidade, onde a potencialidade de desenvolvimento poderia ser ampliada através de investimentos da municipalidade, concentrando para o local os interesses dos agentes privados (idem,6).

A participação pública foi vinculada à oferta de infra-estrutura suplementar e às ações voltadas à reversão dos aspectos de desqualificação ambiental, seja em função da obsolescência dos elementos construídos ou seja em função das limitações impostas pela legislação do zoneamento. $O$ instrumento de geração de recursos das Operações Urbanas, necessários para o custeio das melhorias públicas, se constituiu em uma concessão onerosa às exceções da normatização urbanística: esse mecanismo teria como ponto de partida a fixação de novos parâmetros para os coeficientes de aproveitamento de cada lote, em uma determinada área de interesse. $O$ novo potencial permitido passaria a ser utilizado pelos proprietários de imóveis ou agentes imobiliários mediante o pagamento de contrapartida financeira, cujo montante seria reempregado na própria áreafoco da Operação Urbana. Esse instrumento previa um estudo específico para 
definição dos objetivos e diretrizes urbanísticas, devendo também ser regulamentado sob a forma de lei (ibidem, 6).

A operação urbana Anhangabaú foi a pioneira, datando de 1991 e se aplicou a um perímetro de quadras envoltórias do Vale, então em fase conclusiva das obras de reurbanização. Após três anos de vigência e não apresentando os resultados esperados de atração dos interesses imobiliários, seu prazo se extinguiu. Foi seguida pelas Operações Urbanas Faria Lima e Água Branca, de 1995 e Centro, de 1997 (op.cit, 5). Desde a primeira, a gestão das Operações Urbanas passou a ser atribuição da Empresa Municipal de Urbanização - Emurb.

Essas Operações Urbanas tiveram resultados bastante diferenciados, em relação aos objetivos propostos: a Operação Urbana Centro não logrou a pretendida requalificação da Área Central, mesmo incorporando incentivos para a construção de edifícios com coeficientes de aproveitamento, que em alguns casos, chegava a doze vezes a área do terreno. Apenas a partir do ano de 2001, esse instrumento foi submetido a estudos de revisão de suas diretrizes, passando a fazer parte de outras estratégias de reabilitação urbana. Observando a sua aplicação no transcorrer de quatro anos desde sua aprovação, é possível inferir que "...as limitações à reversão do processo de deterioração e desqualificação do Centro, apontado pelo próprio mercado imobiliário, encontra o exemplo oposto na situação de outras áreas da cidade, como é o caso do novo pólo de edifícios comerciais na marginal Pinheiros, área em que se concentrou grande parte dos recursos do poder público municipal nos últimos anos..." (Amadio, 1998, 132).

Essa estratégia de concentração dos investimentos privados no sul-sudoeste da cidade, favorecidos por uma política urbana a eles dirigida, provocou também limitações ao alcance da Operação Urbana Água Branca, como será visto a seguir. Apenas na região de abrangência da Operação Faria Lima, a reformulação físico-ambiental provocada pela espacialidade corporativa foi implantada em profundidade e devido a essa escala, a análise do seu resultado e desdobramento urbanístico se mostra importante para a elucidação das formas diferenciadas de ocupação entre esse e os demais setores da cidade.

\subsubsection{Operação Urbana Água Branca}

A Operação Urbana Água Branca abrange uma área de 504 hectares na região Oeste, onde grandes investimentos públicos vinculados ao transporte, lazer e cultura foram implantados em fins da década de 1980 (Terminal Intermodal Barra Funda e Memorial da América Latina), somando-se a outros já existentes, como o Parque da Água Branca e SESC Pompéia e que atraiam também investimentos privados, como a construção do Shopping West Plaza e mais recentemente dois grandes edifícios de universidades particulares. A área, entretanto, apresenta uma série de problemas ligados à interrupção de sua malha 
viária pelos eixos ferroviários, obsolescência de grande parte das construções, drenagem deficiente e grandes vazios urbanos. Dada a sua localização, a Operação Urbana estabeleceu como objetivos:

- Promoção de novos padrões de uso e ocupação, compatíveis com as potencialidades da região

- Definição de diretrizes para a ocupação racional dos grandes vazios urbanos

- Melhoria do sistema de drenagem

- Ampliação do sistema viário

- Estabelecimento de padrões ambientais adequados para a criação de novos espaços públicos, implantação de áreas verdes e controle da permeabilidade do solo (Operação Urbana Água Branca, PMSP/Emurb, 1995, 3)

A sua divisão em dez sub-áreas visou identificar, em cada uma delas, as principais características urbanas e a adoção de estratégias de intervenção para as mesmas. Essa divisão teve como parâmetros:

- A proximidade do Terminal Barra Funda e seu raio de influência - Interferência do sistema viário existente e proposto

- Características similares em relação ao uso e ocupação do solo

. Compatibilidade em relação ao zoneamento

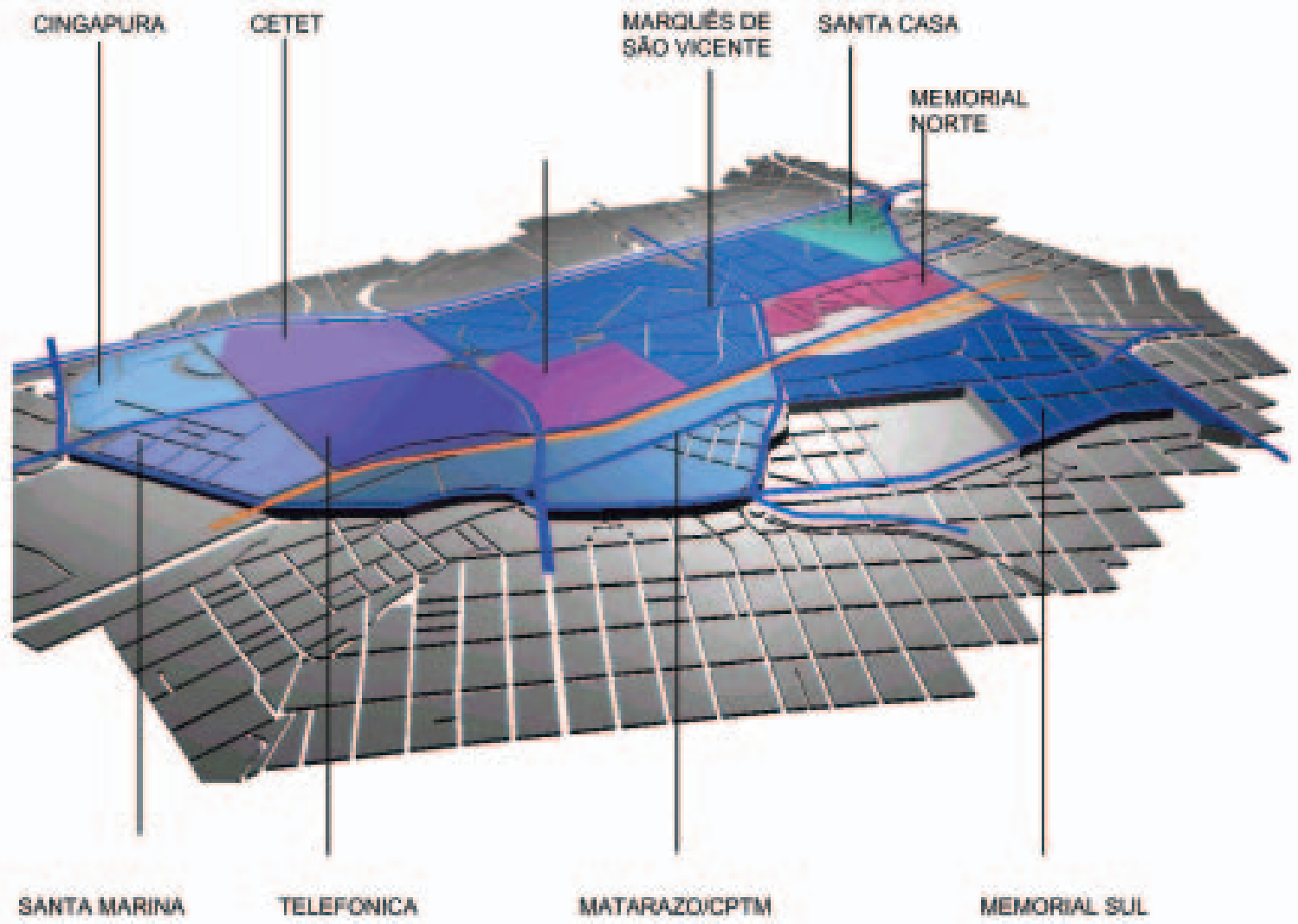

Fig. 107: Mapa das principais áreas de atuação da Operação Urbana Água Branca 


\section{. Existência de glebas vazias públicas e particulares}

A leitura da lei que promulgou a Operação Urbana Água Branca mostra um leque de objetivos partindo da melhoria das condições físico-ambientais da área como um todo, ao adensamento e reestruturação espaciais devido aos novos padrões de uso e ocupação do solo, à oferta de empregos no setor terciário, ao controle do uso industrial e à provisão de habitação de interesse social. Foram também previstas aberturas de vias e construção de pontes, como forma de reestruturar a acessibilidade da área, contribuindo também para a ocupação dos espaços isolados.

As decorrências urbanas de maior visibilidade dessa Operação foram a reestruturação de usos de trechos da avenida Francisco Matarazzo, a construção de edifício de escritórios da Telefonica, junto ao Viaduto Antártica, a demolição de parte dos galpões da rua Tagipurú, que faziam fundos ao Memorial da América Latina e a demolição da quase totalidade das antigas instalações das Indústrias Matarazzo, que deram lugar a quatro torres de escritórios. Foram também abertas duas avenidas paralelas à ferrovia, mas que não estabeleceram uma ligação maior com o sistema viário devido às interrupções ocasionadas pelos viadutos existentes.

Uma matéria jornalística expôs o porte do mencionado empreendimento construído na antiga área industrial:

"A área que era ocupada pela antiga sede das Indústrias Matarazzo, de 75.000m², na Barra Funda, deverá se transformar em um complexo comercial, com isso, deverá se impulsionar o mercado imobiliário. Para o consultor imobiliário do projeto (Lincoln Jorge Marques), a região que inclui trechos da Barra Funda e Campos Elísios, que antigamente eram destinadas às indústrias passarão para comércios e serviços.

Esta região não se torna atraente apenas pela disponibilidade de áreas, mas também pela infra-estrutura do bairro, o metrô, a proximidade do centro e de bairros nobres Higienópolis, Pacaembu, Perdizes e Pompéia, além do fácil acesso às estradas.

Na Barra Funda, nas décadas de 10 e 20, predominavam as grandes casas da classe média paulistana, pertencentes aos industriais e empresários do café, mas na década de 30, a região foi se deteriorando progressivamente.

Um outro fator que é apontado como um problema para a região foi a construção do elevado Costa e Silva, entre os anos de 1969 e 71. Além de enfrentar o problema das inundações freqüentes.

Em contrapartida, o trecho é favorecido por uma ampla área de lazer e serviços, tais como, o Memorial da América Latina, o Parque da Água Branca, o Playcenter, a Sociedade Esportiva Palmeiras e o Shopping West Plaza.

O terreno de $75.000 \mathrm{~m}^{2}$ da sede das indústrias Matarazzo foi dividido em 13 lotes para criar um grande pólo comercial. 
O primeiro projeto é um complexo com quatro torres de conjuntos comerciais (com área média a partir de $672 \mathrm{~m}^{2}$ ), orçado em $R \$ 150$ milhões, que será subsidiado por fundos de pensão ${ }^{5}$.

De acordo com o diretor da Ricci Engenharia.... existe uma expectativa que essa região se desenvolva, sendo uma alternativa para quem não quer ficar na região da marginal Pinheiros" (FSP, 08/3/1998).

Após dois anos, sob o título "Centro Comercial mudará a Água Branca", a construção de um setor de torres para o terciário na região Oeste foi registrada da seguinte forma:

"O empreendimento da Ricci Engenharia está mudando radicalmente a região da Água Branca, com a tentativa de não transformar o trânsito da avenida Francisco Matarazzo em um caos e sem ferir a lei de zoneamento, que proíbe edificações com altura superior a uma vez a área construída. Para que isso ocorra, a empresa primeiramente teve que fazer um estudo de impacto ambiental.

O resultado foi a inclusão do projeto na Operação Urbana Água Branca, criada em 1995 para a revitalização da região. A solução adotada pela empresa foi financiar a construção de uma avenida, paralela a linha do trem, que começa no viaduto Antarctica e termina na avenida Santa Marina, na Pompéia.

A construtora está investindo $R \$ 20$ milhões na construção dessa avenida e na drenagem dos terrenos para evitar enchentes" (FSP, 23/7/2000).

Em 2001 houve um concurso de projetos para a nova sede do Museu de Arte Contemporânea, vencido pelo arquiteto suíço Bernard Tschummi, cujo local de implantação escolhido foi a área vizinha às torres de serviços em construção, no espaço da antiga Indústria Matarazzo. Embora se constituísse em outro equipamento cultural, numa região que já contava com o Memorial da América Latina e o Sesc Pompéia, os objetivos envolvidos na escolha do local foram os de proporcionar diversificação funcional ao plano de reconfiguração urbanística daquela região, mas passados três anos do resultado do concurso, esse projeto para o novo Museu ainda não havia se concretizado.

Mesmo contando com as ações descritas, diferentemente do pretendido a Operação Urbana Água Branca não provocou uma transformação nos moldes ocorridos na região da marginal Pinheiros e sua vizinhança. $\bigcirc$ fato é que os seus resultados se mostraram restritos a verticalização de algumas áreas, como aquela em que foram implantadas as mencionadas torres e na avenida Marquês de São Vicente, nas imediações da avenida Pacaembu. Esse processo prendeuse à construção do Fórum Trabalhista e de empreendimentos privados de edifícios de escritórios anexos.

Em alusão à relativa falta de atratividade dessa Operação Urbana ao setor de edifícios de escritórios de alto padrão, foi considerado em uma análise sobre o mercado imobiliário que os grandes interesses desse setor estavam, 
já em 1998, concentrados na região das avenidas Luís Carlos Berrini, Nações Unidas e Nova Faria Lima, não havendo a mesma disponibilidade de capitais privados para a Água Branca, por ser considerada investimento de retorno mais longo. Considerava ainda que, apenas pela presença de uma grande empresa internacional de telefonia na rua Tagipurú, foi possível o empreendimento na área da antiga indústria Matarazzo ser lançado, sem apresentar a mesma demanda que a região da Berrini apresentava ${ }^{6}$.

Além dessas observações, é certo também que os altos investimentos públicos no sistema viário daquele novo distrito do terciário avançado, estabeleceram uma diferenciação com a área da Água Branca sob o ponto de vista da internalização desses investimentos por parte da iniciativa privada.

Dentro do objetivo de revisão das Operações Urbanas, no início do ano de 2004 foi anunciado pela Prefeitura de São Paulo o concurso de projetos denominado "Bairro Novo", incidente em uma área de grandes dimensões (1 milhão de $\mathrm{m}^{2}$ ) no perímetro da Operação Urbana Água Branca. Essa competição propôs em seu edital os objetivos já contidos na própria Operação Urbana em relação aos espaços e equipamentos públicos, aos novos usos e ocupações, à requalificação da paisagem e ainda à indicação de estratégias

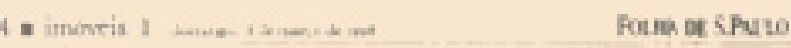

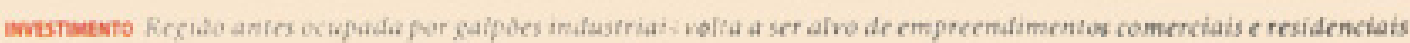 Ricci tem megaprojeto para a Barra Funda}

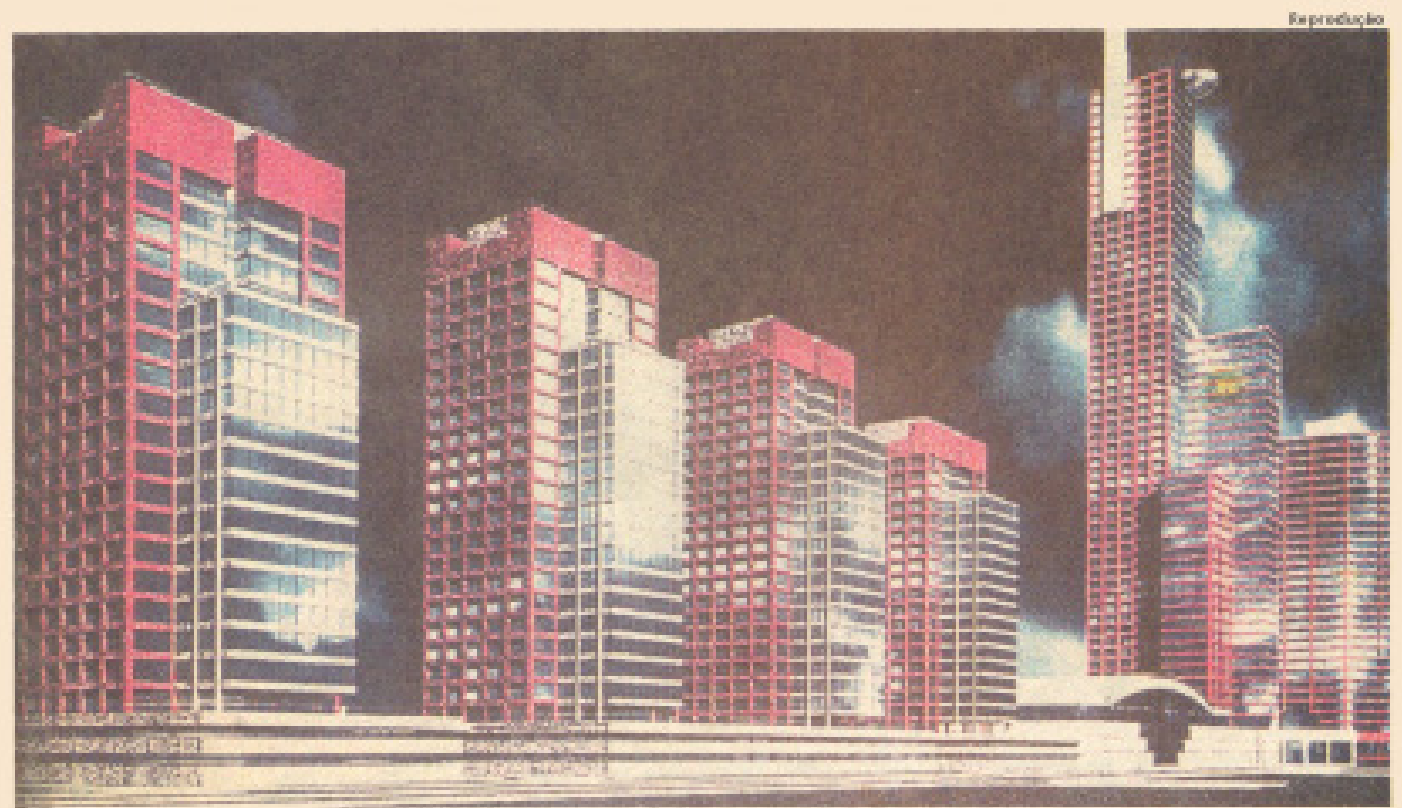

llustração do conjunto comercial que a Ricci vai lançar em 90 dias no terreno onde ficava a Matarazzo

Fig. 108: Matéria jornalística: verticalização e uso de escritórios na Barra Funda 
de implantação das propostas, contemplando as ações públicas e privadas necessárias à viabilização. Esses elementos foram sintetizados na apresentação do concurso que se voltou à propostas para um desenho urbano de "um novo bairro paradigmático de uma São Paulo metrópole global, justa, moderna e bela" (Bairro Novo, Concurso Nacional para um Projeto Urbano, termo de referência, PMSP, 2004, p.2).

Condizente com as observações feitas aos resultados da Operação Urbana Água Branca desde a sua promulgação em 1995, o enunciado desse Concurso incluiu a seguinte análise:

"A Operação Urbana, embora definisse as condições legais para que fossem firmadas parcerias entre a iniciativa privada e o Poder Público Municipal, carecia da proposta de um plano que servisse, a um só tempo, como fio condutor do processo de reurbanização da área e como instrumento de interlocução efetivo entre a Prefeitura, os empreendedores, os proprietários, moradores e usuários da região" (idem, 3).

Essa área, remanescente do período da industrialização pioneira da cidade foi escolhida pelo Concurso por se tratar de uma das últimas áreas subutilizadas que restaram na região entre os rios Tietê e Pinheiros e que segundo o urbanista Jorge Wilheim, Secretário Municipal de Planejamento de São Paulo, não se obteve resultados com a Operação Urbana lançada em 1995 (FSP, 25/4/2004, C1).

Dois depoimentos foram selecionados, como registro dos objetivos urbanísticos que envolveram esse Concurso:

"O interesse do mercado imobiliário pela região vai crescer com ou sem projeto. A grande vantagem de ter um planejamento urbanístico é que você não deixa o mercado imobiliário tão solto. Você pensa parâmetros de ocupação para oferecer aos empreendedores, que sozinhos pensam apenas nas suas construções, com resultados que não são bons do ponto de vista urbanístico".

Eduardo Della Mana, diretor do Secovi (Sindicato de Construtoras e Imobiliárias) (idem, C1).

"Eu não quero fazer uma nova Faria Lima. Que o prolongamento da avenida foi um sucesso de lançamento de imóveis, é indiscutível. Agora, que seja um lugar bom de morar, é discutível. O Bairro Novo vai ser bom para morar, e nós temos a convicção de que dá para ganhar dinheiro e fazer uma coisa boa para morar" Jorge Wilheim, Secretário Municipal de Planejamento de São Paulo (ibidem, C1).

Esses depoimentos vão de encontro ao ambiente urbano que foi produzido pela outra Operação Urbana analisada a seguir, mais precisamente à ênfase que foi dada ao mercado imobiliário de alto padrão voltado ao setor de serviços. No tocante ao mencionado Concurso na Água Branca, a sua divulgação no Instituto 


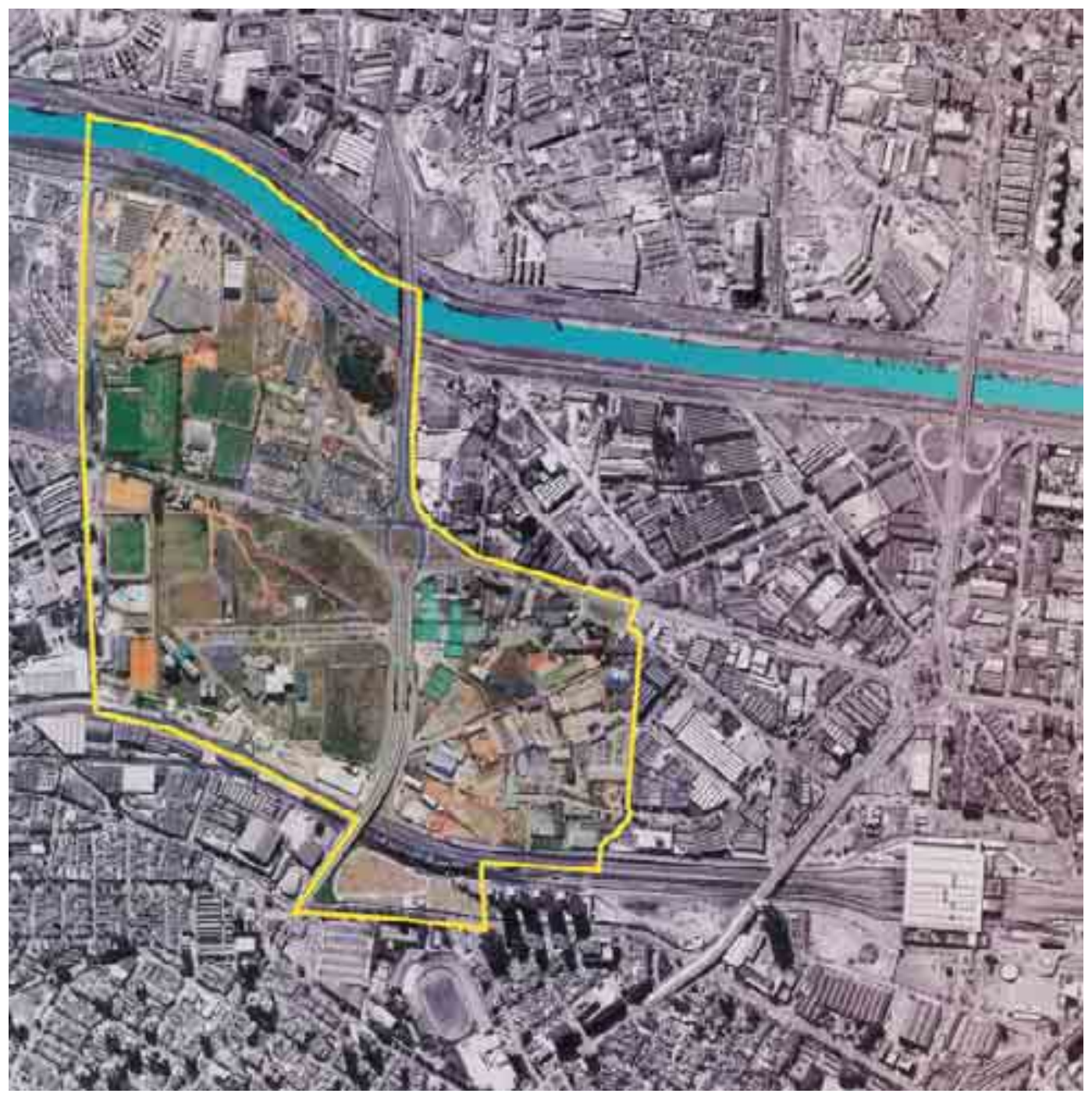

Fig. 109: Foto aérea destacando a área de intervenção, objeto do concurso "Bairro Novo".

de Arquitetos e Urbanistas de São Paulo incluiu também a menção de se constituir na primeira experiência de planejamento de um bairro da cidade realizada pela PMSP, já que os bairros planejados existentes foram aqueles implantados pela iniciativa privada, isto é, os que a Cia. City criou nas primeiras décadas do século XX, como este trabalho abordou anteriormente.

Assim, estabelecendo um paralelo com a Operação Urbana Faria Lima e o Concurso para a Reconversão Urbana do Largo da Batata, proposto em 2002 pela Prefeitura de São Paulo e que será visto a seguir, pode-se observar uma mesma estratégia para o desenvolvimento de novas centralidades, na qual a iniciativa privada integra um papel preponderante e o poder público "libera" através da Operação Urbana as ocupações para obtenção de fontes de recursos para a implementação de infra-estrutura e usos públicos.

Entretanto, por se tratar de uma região onde a mescla de usos e da população moradora definiu o seu caráter urbano, os desdobramentos das propostas que serão apresentadas e mesmo implantadas, deverão contemplar essas características, uma vez que a expansão de padrões urbanísticos adequados 
para habitação, incluindo a de baixa renda, e espaços para uso público, poderão irradiar para os bairros vizinhos um processo qualitativamente superior ao que os mecanismos de mercado impuseram à reestruturação.

\subsubsection{Operação Urbana Faria Lima}

A Operação Urbana Faria Lima abrange uma área de 450 hectares situada na região sudoeste da cidade, sabidamente uma das mais valorizadas e de maior dinâmica imobiliária de alto padrão para usos residenciais e de serviços. Proposta pela iniciativa privada na segunda metade da década de 1980, durante a gestão municipal de Jânio Quadros, posteriormente foi parcialmente incorporada no projeto de Plano Diretor de 1991 e encampada pela administração Maluf em 1993, com aprovação final no ano de 1995 (Sempla, 2000/2001, n 4, 7).

A justificativa técnica de melhoria do sistema viário da região sudoeste embasou essa aprovação, sendo proposta e executada através do prolongamento da avenida Faria Lima em direção à avenida Bandeirantes e Pedroso de Morais, nos bairros de Vila Olímpia e Pinheiros respectivamente. Essa ligação proporcionaria, segundo a justificativa, uma via paralela à marginal Pinheiros, contribuindo para desafogá-la.

Levando em conta que a existência da Operação Urbana vinculou-se à participação da iniciativa privada, programaticamente foi considerado essencial o equilíbrio entre os interesses dos setores público e privado. Assim sendo, foram propostos os seguintes objetivos:

1. $O$ adensamento populacional e melhor aproveitamento da infra-estrutura existente, bem como de sua ampliação, viabilizada pelos recursos provenientes da Operação Urbana

2. A renovação urbana da área de incidência da Operação

3. Obtenção de recursos para investimentos públicos oriundos das contrapartidas estabelecidas para a área de incidência direta e indiretamente beneficiadas (idem, 18).

A exposição de motivos dessa Operação Urbana, estabeleceu as seguintes análises sobre o seu alcance:

"A Zona Sul, como toda a Cidade de São Paulo, não tem uma política adequada de ocupação de sua área ou um planejamento específico formulado a partir da correta utilização de seu sistema viário...A Operação Urbana objetivada nesta mensagem foi proposta de forma a garantir que a introdução e a integração de diversos melhoramentos viários da marginal do Pinheiros e nos bairros de Pinheiros, Itaim, Vila Olímpia e Vila Funchal, seja complementada pela adoção de uma política de adensamento e ocupação do solo na região, compatível com a maximização do uso das redes de infra-estrutura, de transportes e de 


\section{LEGENDA}

[-.] PERIMETRODA LE 11.73 .-166

SETOP 1 - PNHEROS

SETOR 2 - FAFA UMM

SETOR 3 - HEUD PE EGRINO

SETCF 4 - OUMFIADRS

AREA EXCUUDA DA OPEAACIOO UREMNA

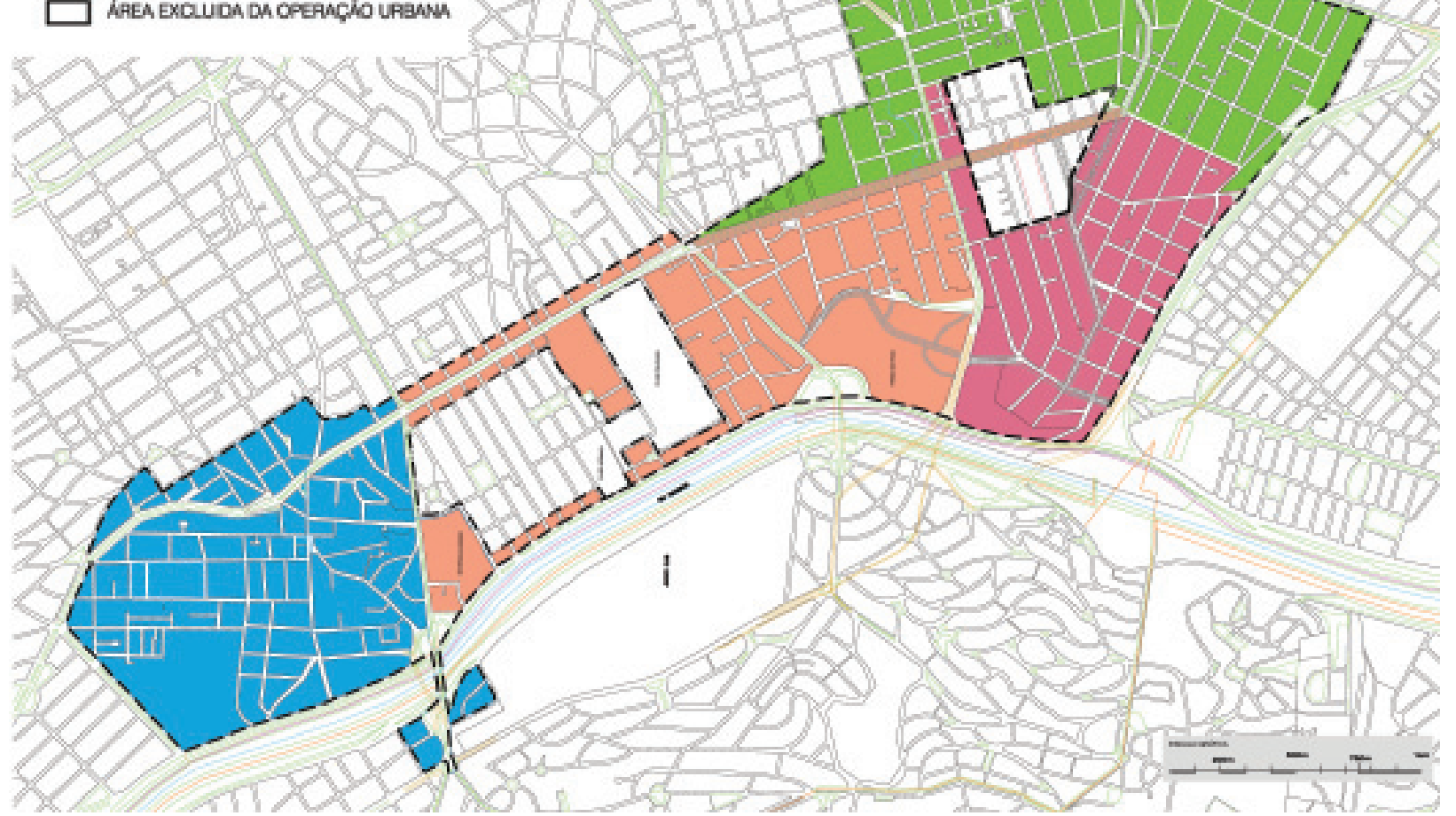

Fig. 110: Operação urbana Faria Lima.

serviços, que serão implementadas juntamente com o novo sistema viário" (Sempla, idem, 18).

Essa Operação Urbana teve a sua área dividida em cinco sub-perímetros Pinheiros, Itaim, Vila Olímpia, Vila Funchal e Uberaba - definidos pela situação lindeira à avenida Faria Lima e os seus trechos prolongados. Contou com um cálculo para a definição do potencial adicional de construção da ordem de $1.250 .000 \mathrm{~m}^{2}$ para as áreas diretamente beneficiadas, constantes no interior dos sub-perímetros e de $1.000 .000 \mathrm{~m}^{2}$ para as áreas indiretamente beneficiadas, estas consideradas como as não pertencentes aos sub-perímetros relacionados, mas incluídas no interior da Operação Urbana (Lei Municipal 1 1.732/95, s/pág).

Um documento da Secretaria Municipal de Planejamento descreveu as seguintes ações que deveriam ser desencadeadas com os recursos obtidos pela venda do potencial adicional de construção:

"O programa de investimentos inclui, além de obras viárias, um novo terminal de ônibus e habitações de interesse social, destinadas à venda financiada para a população favelada existente no perímetro e no seu entorno. Inclui também a construção de habitações multifaminilares, para a venda financiada à população residente na área desapropriada e que queira continuar na região e a aquisição 
de imóveis para a implantação de praças e equipamentos institucionais, necessários para comportar o aumento populacional decorrente da Operação Urbana. $\bigcirc$ custo previsto para essas obras foi estimado, à época, em 150 milhões de dólares, incluídos 120 milhões para desapropriações" (Sempla, 2000/2001, n 4, 7)

Confirmando os interesses do mercado imobiliário nessa área como um todo, apenas cinco anos após o início dessa Operação Urbana e utilizando apenas $25 \%$ do estoque de terrenos, os seus resultados foram registrados da seguinte forma, em relação à duas diretrizes urbanísticas:

- Utilização da concessão gratuita de área computável de $20 \%$ do lote quando os projetos de edifícios reservam no pavimento térreo espaços destinados à circulação e atividades de uso abertos ao público. Foram incorporados até o ano 2000, dez mil metros quadrados para essas finalidades.

- Os resultados tidos como positivos em relação ao incentivo à agregação de lotes, uma vez que nos bairros cortados pela extensão da avenida Faria Lima, Pinheiros e Vila Olímpia, o parcelamento considerado antigo só permitiria a construção vertical mediante o remembramento dos lotes. Nesse caso, foi verificado que no universo das 85 propostas aprovadas até então (ano 2000), $50 \%$ fizeram uso desse recurso, proporcionando assim "uma melhor configuração das quadras na região" (idem, 21).

Com relação ao uso do solo, os projetos aprovados permitiram a seguinte leitura:

- Predominância de edifícios de escritórios nas áreas lindeiras à avenida Faria Lima.

- Em Pinheiros, nas proximidades da avenida Pedroso de Morais, a ocupação mostrou-se mais variada, tendo sido aprovados edifícios de escritório, com um deles contendo centro de convenções (Centro cultural Tomie Otake, n.a), flats e hotéis, uso comercial em edifícios de pequeno porte e ampliação de colégio particular.

- Predominância de uso residencial nas proximidades das avenidas Cidade Jardim e Juscelino Kubistschek, havendo também junto a essa última a aprovação de edifícios de escritório com áreas comerciais.

- Na região denominada Uberaba, refletindo a ocupação da Vila Nova Conceição, a vocação para uso comercial de alto padrão manteve-se.

- Nas Vilas Olímpia e Funchal, as propostas aprovadas incluíram edifícios residenciais, de escritórios e reformas de edifícios existentes (ibidem, 21).

Deve-se incluir além das intervenções viárias diretas da Operação Urbana, os investimentos de grande monta empregados na construção de túneis interligando as avenidas 23 de Maio e Parque Ibirapuera, Juscelino Kubistschek e Cidade Jardim, que ampliaram ainda mais a acessibilidade de automóveis para essas 
áreas. O sistema de túneis iniciado na gestão Jânio Quadros, interrompido durante a de Luiza Erundina e retomado pela de Paulo Maluf, estendendo-se à de seu sucessor Celso Pitta, criou as condições necessárias para alavancar a dinâmica imobiliária e o retorno financeiro desejado para os investimentos privados canalizados para a área ${ }^{7}$. Essa interdependência entre infra-estrutura viária e mercado foi confirmada na entrevista de um diretor de consultoria imobiliária, a Empresa Brasileira de Estudos de Patrimônio - Embraesp, para o qual a valorização da área "deve-se ao conjunto de incentivos da operação urbana e a obras como os túneis Jânio Quadros e Ayrton Senna"(Luís Paulo Pompéia, FSP, 08/4/2002, 1)

Além disso, os programas de relocação da população favelada, como a que ocupava a Juscelino Kubstschek, foram incorporados ao Projeto Cingapura, que não implantou nenhum conjunto na área, mas sim em outros espaços da cidade. Acrescente-se também a ausência de um dos objetivos propostos na Lei da Operação Urbana em relação aos usos urbanos: a ampliação da avenida Faria Lima, tanto na direção do Itaim quanto na de Pinheiros, não incorporou nenhum espaço público, restando o paisagismo do canteiro central da avenida como aumento de área verde e permeável. Apenas em 2002 a Emurb anunciou a construção de uma praça na Vila Funchal, resultante da extensão da avenida Faria Lima em direção à Luís Carlos Berrini.

A drenagem de recursos públicos para essa Operação Urbana, se comparada à Operação Urbana Centro, aprovada dois anos depois, revela uma estratégia que foi a de privilegiar estritamente as localizações com maior interesse do mercado imobiliário, produzindo uma nova centralidade do terciário avançado, um espaço sempre mais segregado no quadrante sudoeste.

A comprovação dessa situação é revelada pelo balanço realizado no ano 2000, quando se afirmou ter sido a Operação Urbana revestida de sucesso devido aos benefícios urbanísticos obtidos até então. Nesse ano, segundo os dados divulgados, arrecadou-se aproximadamente 168 milhões de reais, montante que superou os custos das obras viárias realizadas, empregando-se parte dessa quantia para o ressarcimento das desapropriações (Sempla, 2000/2001, 22). Fica comprovada, portanto, a participação dos recursos orçamentários para o rápido desfecho das indenizações, mesmo porque estas não poderiam ter sido viabilizadas com a venda do potencial construtivo, uma vez que todo o processo de remembramento dos lotes e aprovação dos projetos foi posterior às transformações do parcelamento pré-existente e, por conseguinte, os recursos eram então inexistentes.

O predomínio dos interesses imobiliários na Operação Urbana Faria Lima ocorreu mesmo sob a nova gestão municipal que assumiu a Prefeitura a partir de 2001. Sob o sugestivo título de "Construtoras vendem obra não-prioritária", um jornal de São Paulo relatava no ano de 2001 o papel das incorporadoras e construtoras na "venda" do prolongamento da avenida Faria Lima até a Engenheiro Luís 


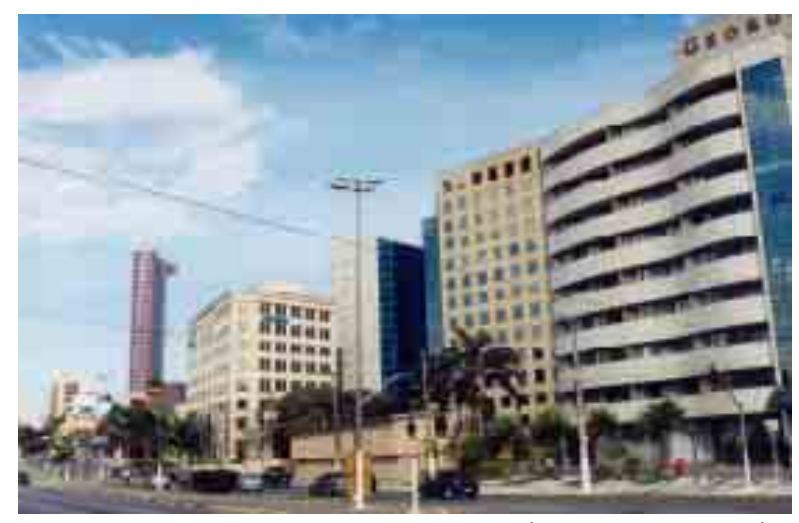

Fig. 111 e 112: Acima: Op. Urb. Faria Lima, trecho Pinheiros, 2004. Ao lado, Marginal Pinheiros, 2003.
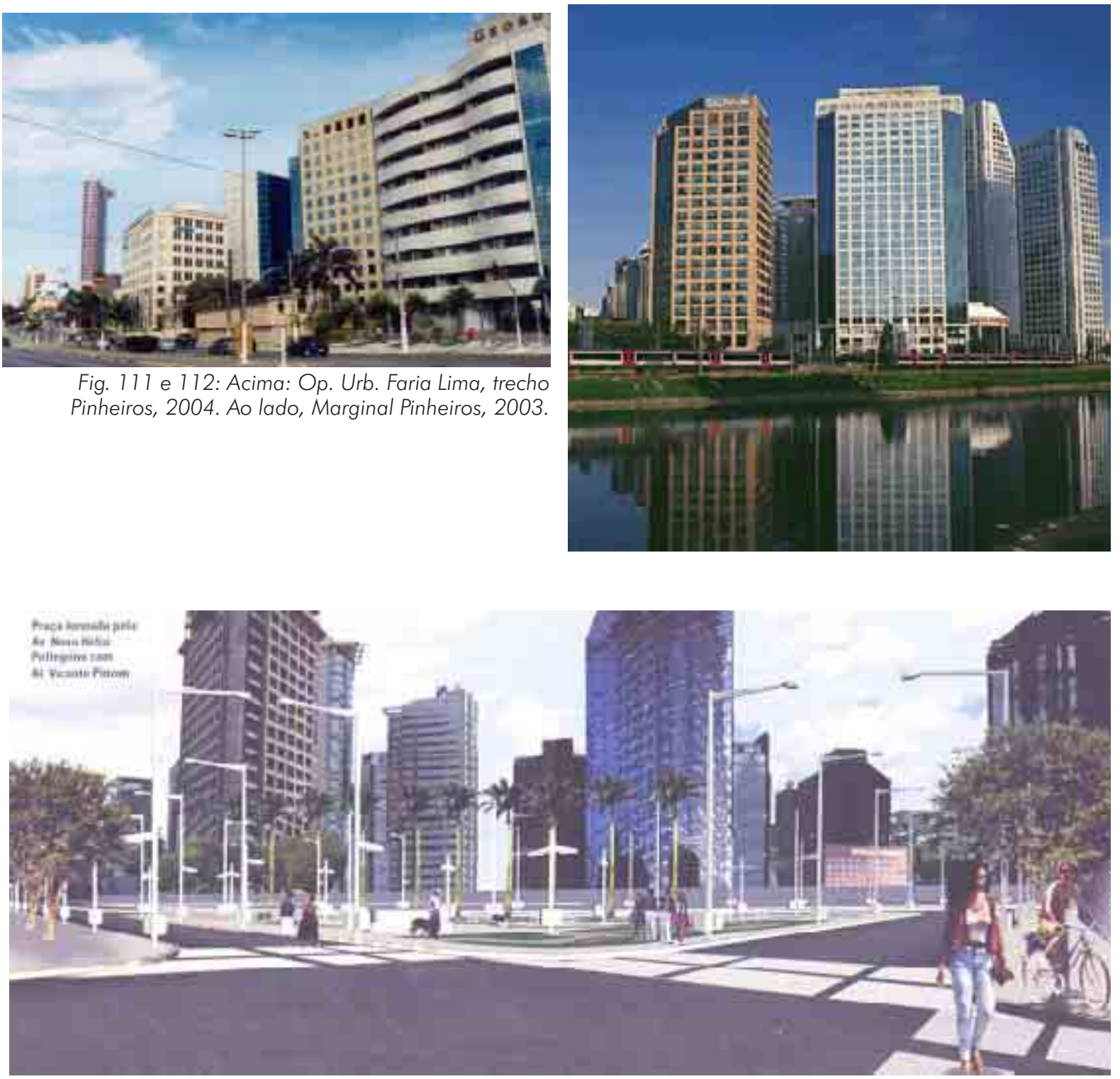

Fig. 1 13: Proposta da nova Praça Vicente Pinzon, o primeiro espaço público resultante da Operação Urbana Faria Lima.

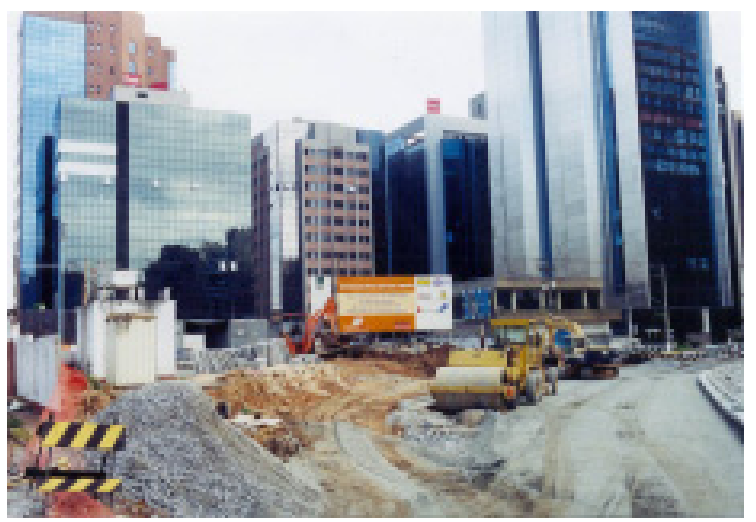

Fig. 114: Praça Vicente Pinzon em obras, 2004.

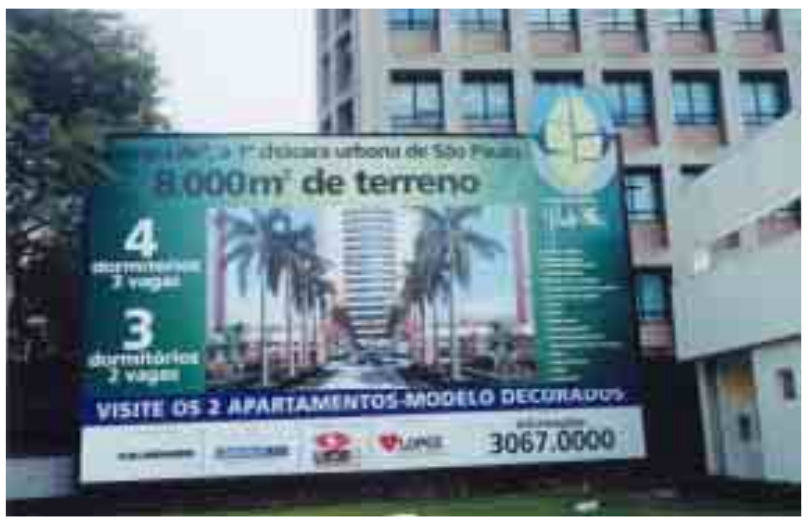

Fig. 115: Novos lançamentos de alto padrão, 2004. 
Carlos Berrini. Nesse ano, apesar dos desmentidos da Administração Regional de Pinheiros, imputando a essa obra um caráter não prioritário e especulativo, anúncios de empreendimentos já publicavam o mencionado trecho nas suas peças publicitárias. Esse foi o caso do "Continental Square Faria Lima", da construtora "InPar", cujo diretor anunciava que "a expectativa no mercado é que as obras sejam feitas em no máximo dois anos". Além desse, outros 12 lançamentos de edifícios comerciais concentravam-se nas proximidades do referido prolongamento, como mostra o mapa dessas incorporações (FSP, 08/4/2001).

No ano de 2002, para promover o mencionado empreendimento, a empresa "InPar" publicou um anúncio de página inteira divulgando a retomada do projeto de prolongamento pela Prefeitura, como mostrou o seu título: "Agora é pra (sic) valer: o prolongamento da Av. Faria Lima está decidido. Não perca tempo de decidir por essa opção de investimento: Fundo de Investimento Imobiliário Continental Square Faria Lima" (FSP, 23/3/2002, A1 1). Um fac-símile de matéria jornalística anexada a esse anúncio informava que dos 30 milhões de reais orçados para essa obra, a iniciativa privada iria arcar com 16 milhões (idem, A1 1).

Já em abril de 2002, a consultoria imobiliária "Colliers International do Brasil" fez publicar o informe publicitário sob o título: "O prolongamento da Av. Nova Faria Lima deve elevar o valor dos imóveis da região da Vila Olímpia em até 30\%" (FSP, 04/4/2002, A2). Essa peça publicitária destacou:

- O aumento da demanda para a ocupação e para novas incorporações da região devido ao prolongamento viabilizado pela parceria entre o Movimento Colméia, uma ONG constituída pela associação de moradores, usuários e empresários da Vila Olímpia, em parceria com órgãos da Prefeitura, que envolveu a EMURB, CET e Administração Regional de Pinheiros.

- O megaempreendimento da construtora InPar, então descrita como uma das maiores investidoras do projeto de prolongamento. A transcrição do anúncio mostra que a certeza que a empresa depositava na mencionada ampliação viária não estava equivocada: ..(o) "Continental Square Faria Lima irá marcar o centro da região, já que está sendo implantado no principal trecho da nova avenida. Razão mais do que suficiente para agradar aos investidores ou proprietários de unidades no empreendimento..." (idem, A2)

Divulgado por fim, no ano de 2002, o programa de extensão do sistema viário anunciado pela EMURB previa:

- Prolongamento da avenida Hélio Pelegrino, interligando a avenida Faria Lima à rua Funchal, além do alargamento da mesma entre as avenidas Bandeirantes e Juscelino Kubischek, afim de conectar a Faria Lima com a avenida Luís Carlos Berrini. Essa interligação previu a criação de uma praça formada pela nova avenida Hélio Pelegrino e a alameda Vicente Pinzon. 


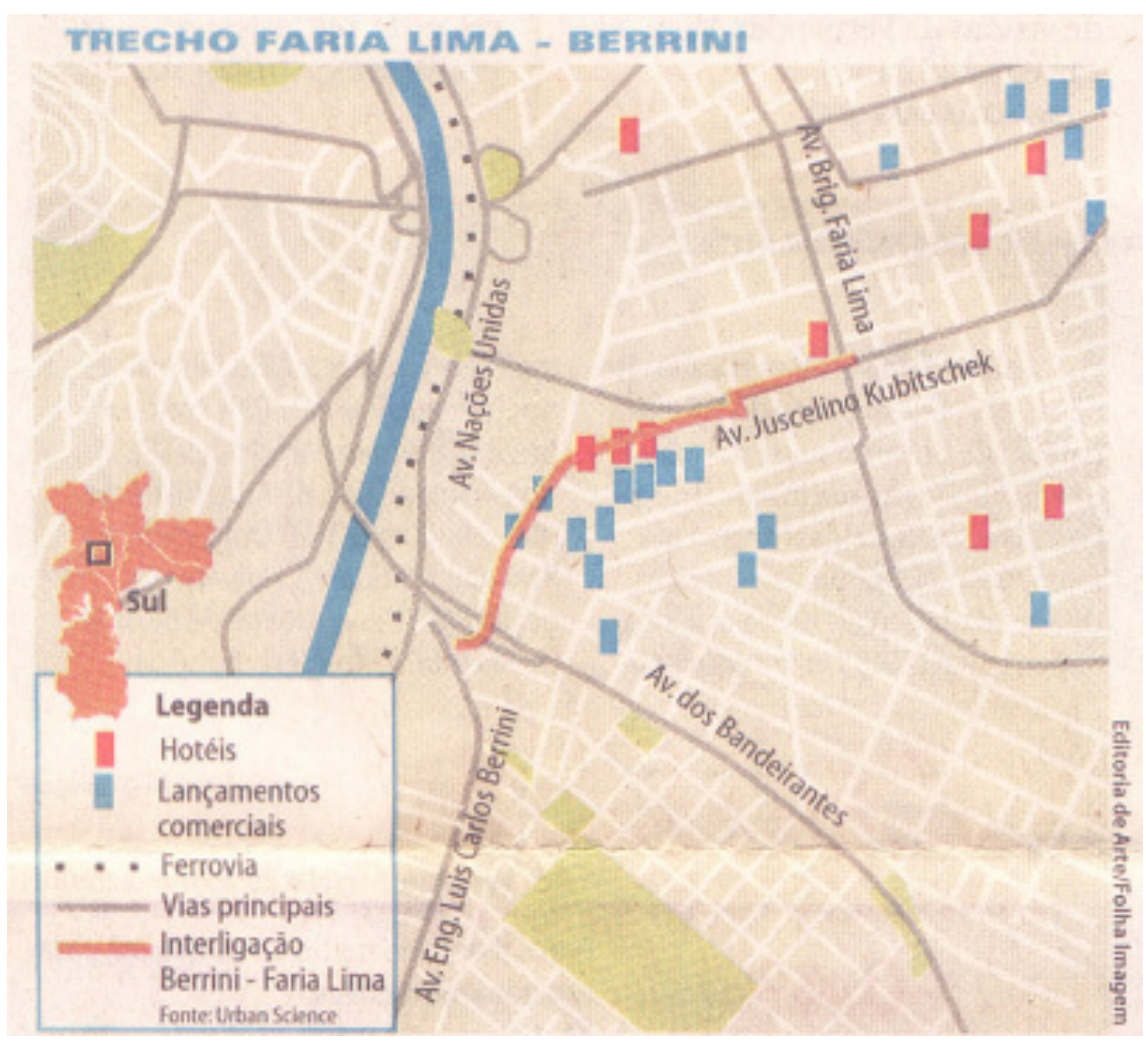

Construtoras vendem obra não-prioritária
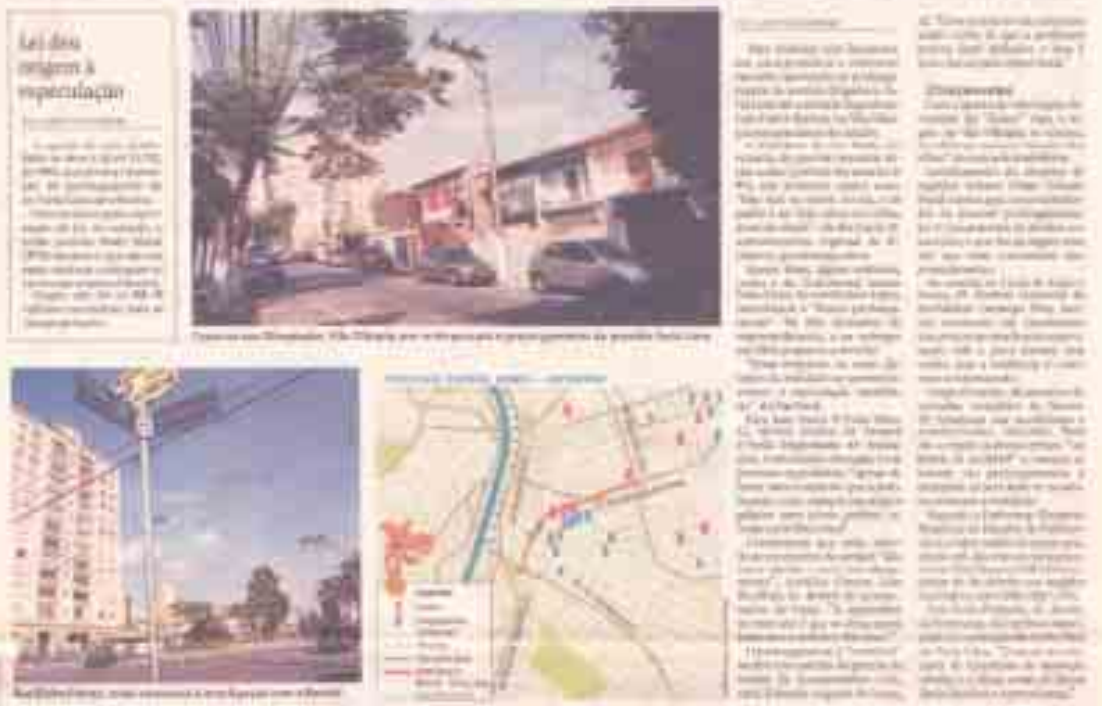

Fig. 116: Lançamento de edifícios comerciais, 2001 Fig. 117 : Matéria abordando as obras anunciadas pelas construtoras, 2001 

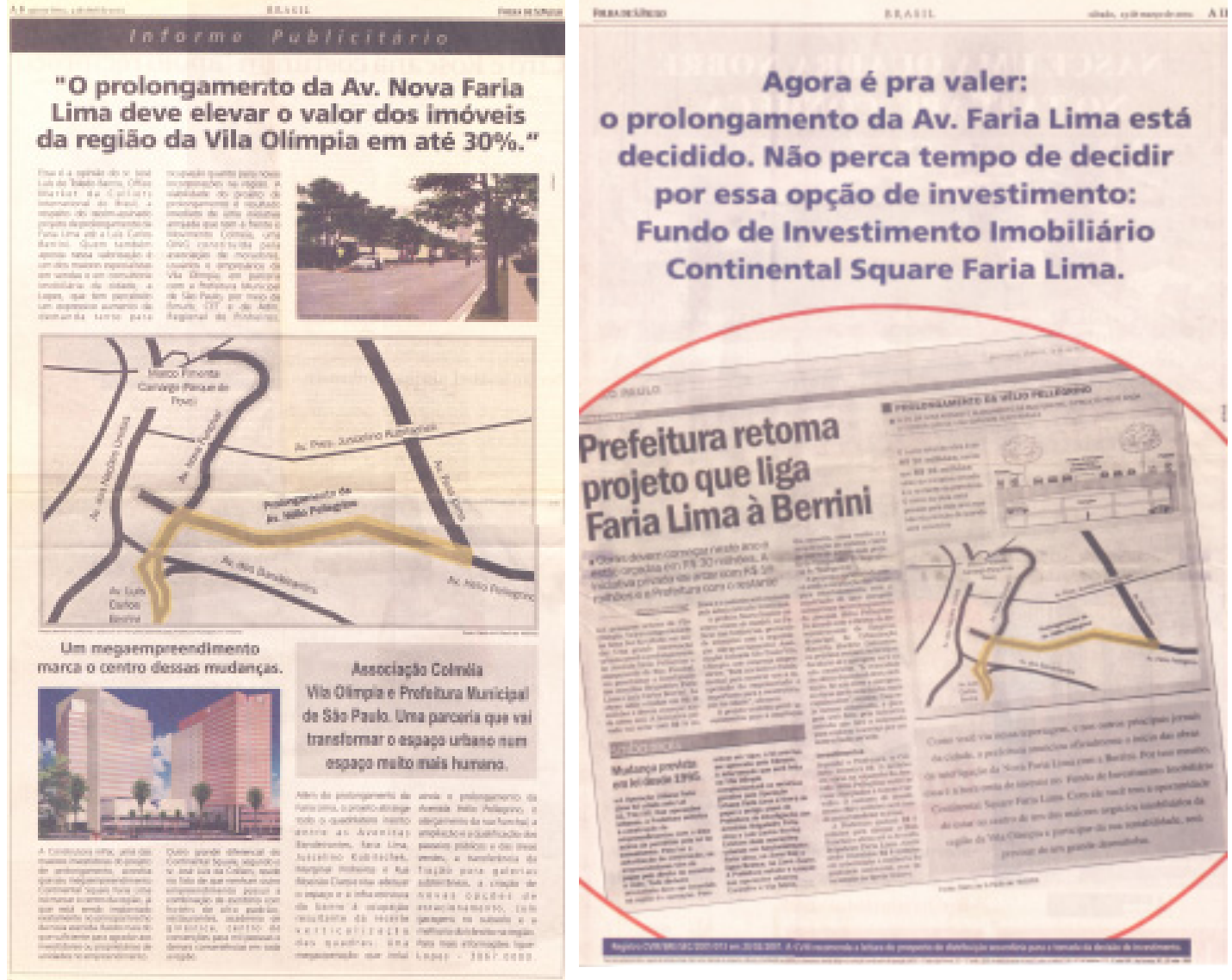

Fig. 118 e 119: Divulgação do empreendimento Continental Square, 2002.

\section{Um megaempreendimento marca o centro dessas mudanças.}
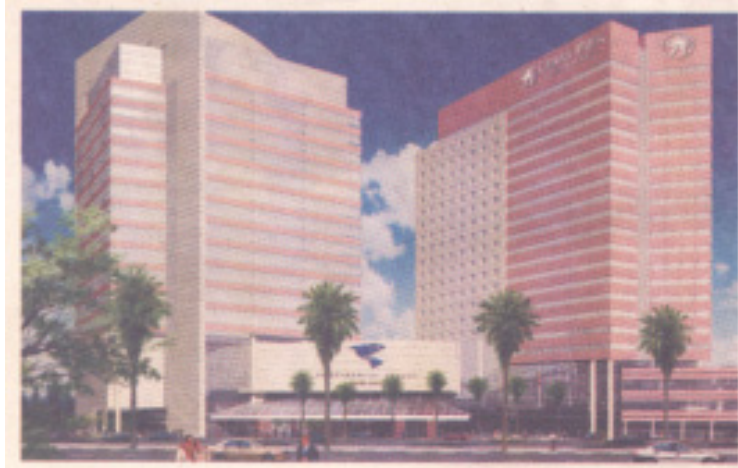

A Construtora InPar, uma das maiores investidoras do projeto de prolongamento, acredita que seu megaempreendimento Continental Square Faria Lima irá marcar o centro da regià, já que está sendo implantado exatamente no principal trecho da nova avenida. Razáo mais do que suficiente para agradar aos investidores ou proprietários de unidades no empreendimento

Fig. 120: Continetal Square Faria Lima, lançamento do empreendimento, 2002.

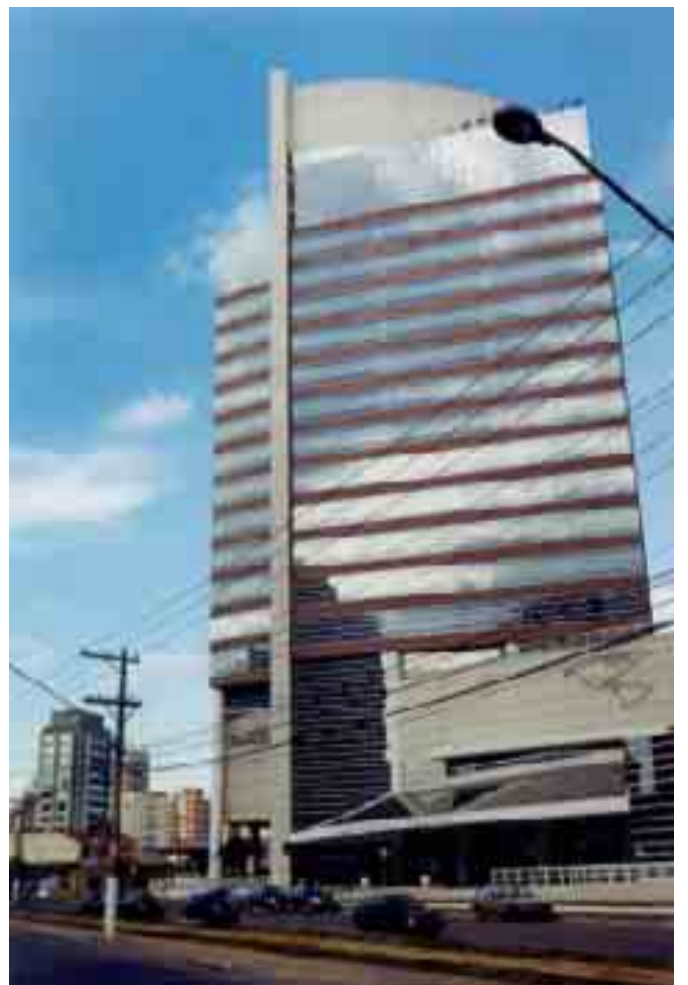

Fig. 121: Empreendimento concretizado, 2004. 


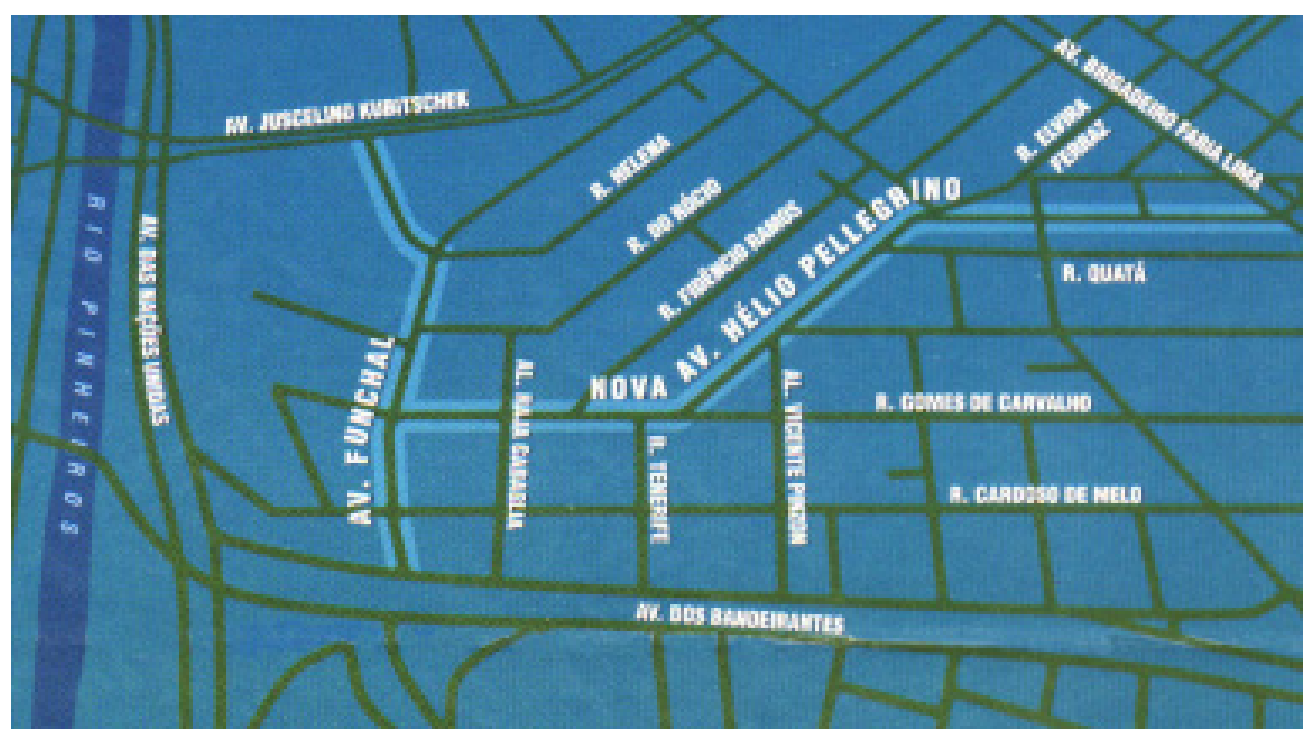

Fig. 122: Mapa da EMURB.

- No quadrilátero formado pela avenida dos Bandeirantes e ruas Funchal, Gomes de Carvalho e alameda Vicente Pinzon, implantação de projeto piloto para adequação da largura das vias, alargamento de passeios, abertura de galerias técnicas para o enterramento de fiação aérea, novos equipamentos, tais como postes, orelhões, pontos de táxi e ônibus e novo paisagismo. Dessas ações anunciadas, a ONG Colméia também arcaria com uma parte destinada à iniciativa privada. (Operação Urbana Faria Lima, folder Emurb, 2002, s/pag).

Também vinculado à Operação Urbana Faria Lima, no ano de 2002 a Prefeitura de São Paulo lançou o "Concurso Público Nacional de Reconversão Urbana do Largo da Batata", espaço público que perdeu suas características morfológicas históricas, tornando-se uma área remanescente das intervenções implantadas ao longo do tempo na avenida Faria Lima. Segundo o edital dessa competição de projetos, sinteticamente seus objetivos se ligaram à:

- "Valorização em quantidade e qualidade dos espaços públicos destinados à circulação, acessibilidade, estar, lazer, cultura, especialmente em função dos fluxos de pedestres, incluindo tratamento paisagístico e possíveis desapropriações, se necessário".

- "Alteração e reformulação do sistema viário com estudo de alternativas para o tráfego na área"

- "A articulação física e formal dos elementos de infra-estrutura, parcelamento do solo, traçado da malha de circulação, espaços abertos e edificações e hipóteses de nova configuração volumétrico-arquitetônica e funcional das quadras lindeiras ao Largo" (Edital - Concurso Público Nacional de Reconversão Urbana do Largo da Batata, PMSP/EMURB, 2002, pg 1) 
Além desses objetivos, considerados centrais para a definição do alcance do Concurso, foi a ele associada também a nova estação Faria Lima do Metrô, projeto do governo estadual e o conseqüente remanejamento das linhas de ônibus municipais e intermunicipais interconectados, por sua vez, com os trens urbanos da CPTM. Dessa forma foram relacionadas as propostas provenientes desse Concurso à escala estrutural metropolitana e para a viabilização do mesmo, foi determinado o valor limite de 60 milhões de reais, quantia obtida através da venda do potencial construtivo da própria Operação Urbana (idem, 1).

Segundo os autores do projeto vencedor ${ }^{9}$, as intervenções previstas incluíam a desapropriação da área de uma cooperativa desativada para a abertura de uma grande esplanada, a construção de um edifício de 22 andares para uso privado cuja contrapartida prevista seria a de um prédio de uso público com finalidades culturais. Além de calçadões e bulevares nas ruas vizinhas ao Largo, o projeto previu o remanejamento do terminal de ônibus existente, a retirada de linhas intermunicipais na região e a construção de garagens subterrâneas (Urbs, $n^{\circ} 27$, ago 2002, 40).

Não cabe aos objetivos deste trabalho analisar as propostas urbanísticas e arquitetônicas contidas nesse projeto, mas deve-se registrar que passados mais de dois anos da divulgação dos resultados do Concurso, inúmeras alterações ocorreram na previsão de sua implantação, bem como outros fatores urbanísticos se interpuseram na área-foco e de abrangência do mesmo. Inicialmente, o cronograma de obras da Linha 4 do Metrô sofreu consecutivos atrasos, sendo apenas iniciado na primeira metade do ano de 2004, conforme anunciado pelo Governo do Estado de São Paulo. Em se tratando de um elemento estruturador, esses adiamentos implicaram também no postergamento das ações municipais relacionadas diretamente à proposta de reconversão urbana, entre elas, a transferência dos terminais de ônibus que ocupam o Largo, a desapropriação dos imóveis e áreas apontados no projeto, etc.

Em segundo lugar, outros elementos foram incorporados à área, não previstos ou relacionados no recente Concurso, tais como as alterações no sistema viário provocados pelo rebaixamento das avenidas Euzébio Matoso e Cidade Jardim. Anunciados em fins do ano de 2003, embora tivessem seus custos orçados em 149 milhões de reais financiados pela própria Operação Urbana, representaram um reforço suplementar ao uso de automóveis em uma região que num passado recente, de outras gestões municipais, já havia recebido obras semelhantes.

Retomando o foco no uso e ocupação do solo, a questão mais crítica se relaciona à subordinação dessa Operação Urbana, desde sua origem, à estratégias do mercado imobiliário. Estas impuseram a profunda reconfiguração dos bairros das Vila Olímpia e Funchal através da extensão da avenida Faria Lima e do sistema viário interligado a ela, para a expansão dos serviços avançados e ainda uma polarização 


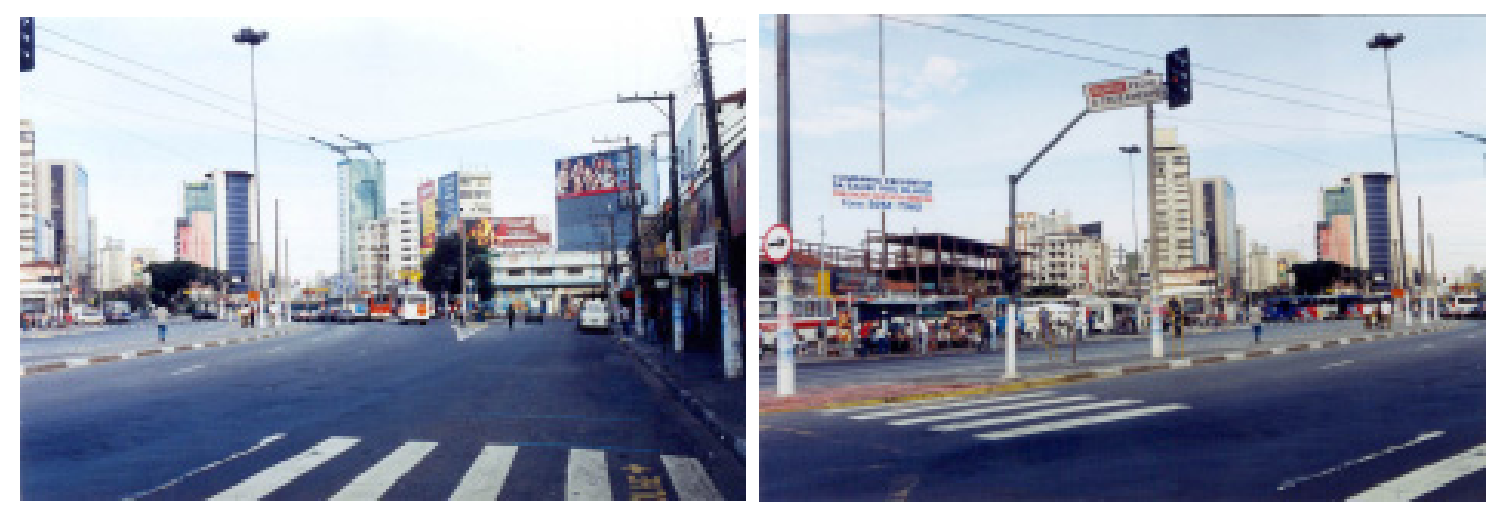

Fig. 123 e 124: Aspecto atual do Largo da Batata,

2003.
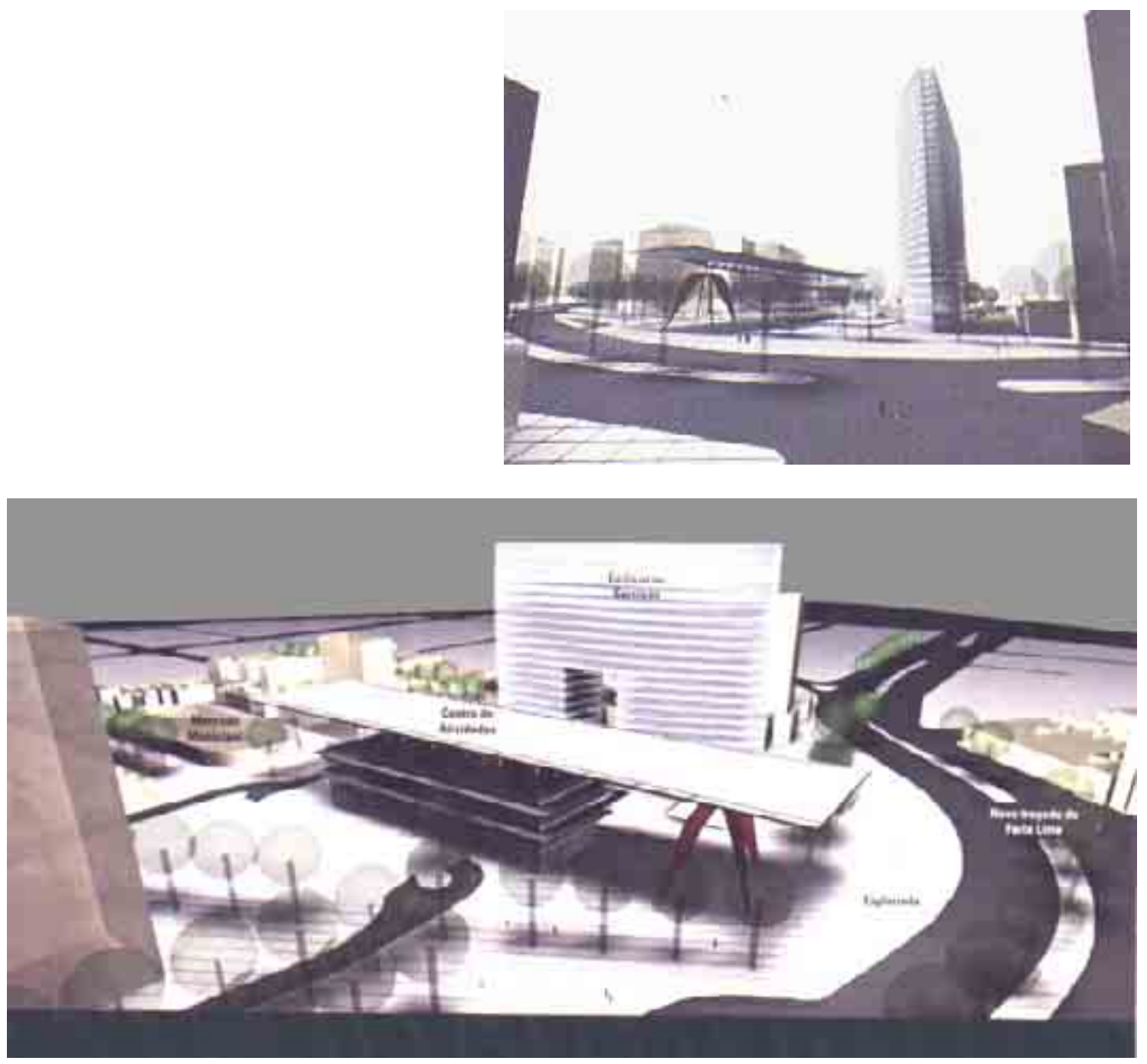

Fig. 125 e 126: Maquetes eletrônicas da proposta vencedora, concurso do Largo da Batata (Arq. Tito Livio Frascino e equipe). 
de investimentos públicos e privados em um setor urbano que deu continuidade à segregação histórica de usos e ocupação na área consolidada da cidade.

Conforme afirmou Alessandri Carlos, a Operação Urbana Faria Lima se constituiu em uma estratégia entre os promotores imobiliários, o setor financeiro e o poder público a eles associado. Esses agentes estiveram presentes na estratégia de constituição do novo eixo empresarial da avenida Faria Lima e a respeito da dinâmica ocorrida na Vila Olímpia, a autora analisou que: "havia uma certa estabilidade no mercado imobiliário, o que significa que a propriedade mudava pouco de mãos, pois a dinâmica do mercado estava na dependência dos pequenos proprietários. A consolidação da mancha urbana, por meio da generalização da mercantilização do solo urbano, associada à necessidade de reestruturação da malha viária da região, impõe como única solução a interferência do Estado para redefinir os limites da propriedade do solo urbano - não o anulando, mas fazendo a propriedade trocar de mãos, e possibilitando, com incentivos, o remembramento dos pequenos terrenos, permitindo com isso as mudanças de usos e funções, necessárias à continuidade da reprodução do capital" (Carlos, 2001, 23/25).

A situação urbana dos bairros na área do Itaim, Vila Olímpia e Funchal difere daquela de Pinheiros, onde nem mesmo o "Concurso de Reconversão Urbana do Largo da Batata" logrou a reestruturação pretendida, pelo menos a curto prazo. Nos bairros do sul-sudoeste, a transformação morfológica provocada pela Operação Urbana foi tão radical, que a identidade dos mesmos, antes espaços de moradia horizontal com parcelamento acentuado e serviços locais, alterou-se totalmente, havendo indícios da continuidade desse processo, como já assinalado.

Assim é que, a ligação do Itaim, Vila Olímpia e Vila Funchal com as avenidas Luís Carlos Berrini, Águas Espraiadas (renomeada Dr. Roberto Marinho) e Nações Unidas, definiu uma área altamente diferenciada do restante da cidade e mesmo de outros locais centrais. Inúmeros trabalhos e pesquisas voltam-se a estudar esse território em que os interesses corporativos aliados ao mercado imobiliário e ao poder público, criaram uma localização sem precedentes, tanto pela escala dessa ocupação, quanto pelo caráter de individualidade com que cada elemento se relaciona com o lugar.

Conforme divulgado pela Prefeitura de São Paulo, dos 2,25 milhões de metros quadrados de potencial adicional de construção definidos pela Operação Faria Lima, restam 58\%, um total equivalente a 1,31 milhões. A extensão dos interesses imobiliários poderá se ampliar com os novos mecanismos anunciados em 2004 para a compra do potencial construído e as já mencionadas alterações viárias na área de Pinheiros.

Com relação aos índices de aproveitamento, estes passarão a serem vendidos em leilão, de acordo com a Lei 13.769, de 26/01/04. Para a construção de até 


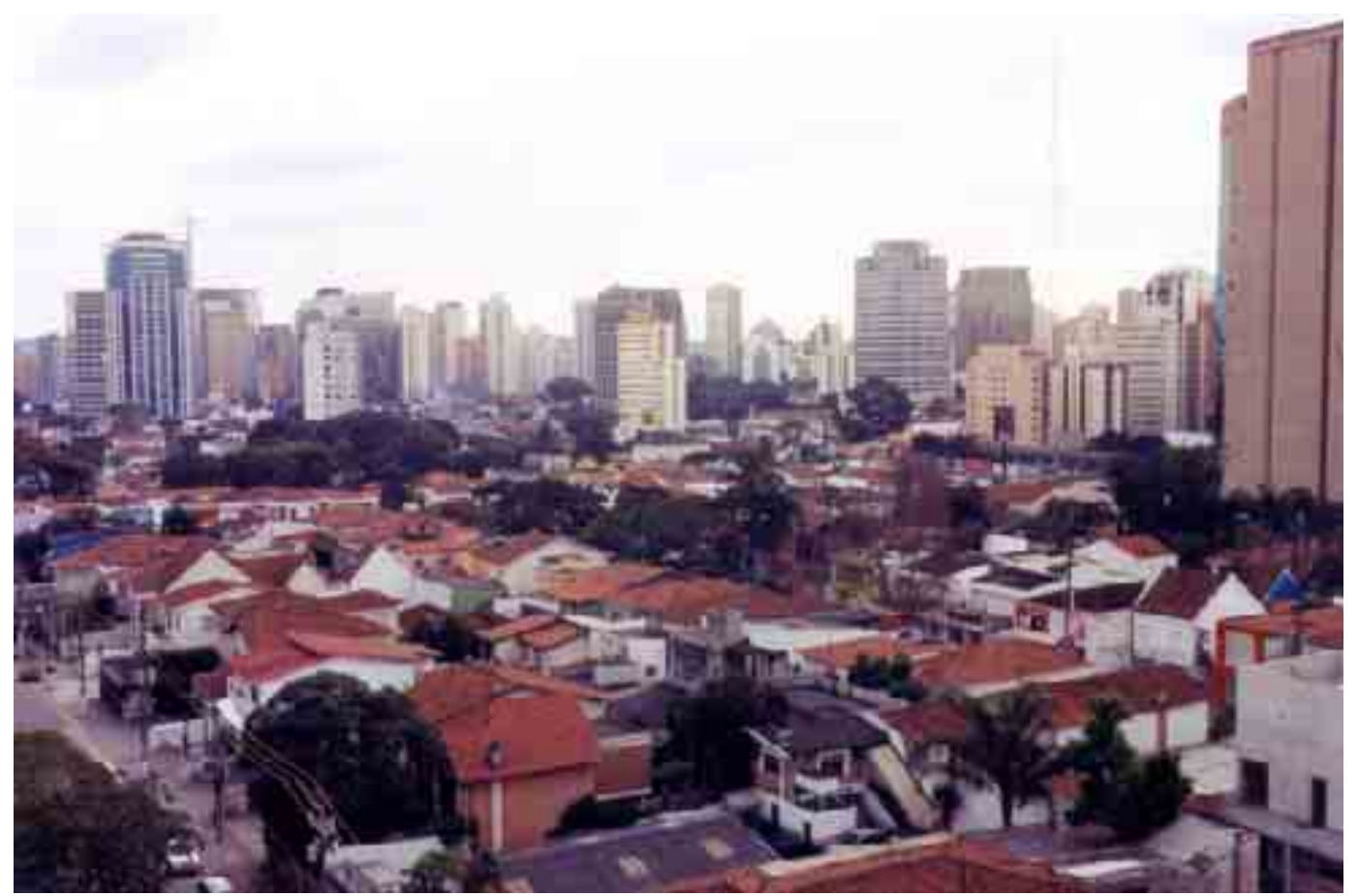

Fig. 127: Vila Olímpia e Vila Funchal: Contraste das diferentes tipologias e gabarito, 2004.

quatro vezes a área do terreno, o comprador terá que obter no mercado os "Certificados de Potencial Adicional de Construção - Cepacs". Segundo as informações do poder público municipal, foram arrecadados ao longo de nove anos o equivalente a 300 milhões de reais, que se vincularam ao pagamento da outorga onerosa de cada projeto aprovado. Com a nova forma de obtenção do potencial construído, este poderá ser comprado antecipadamente, à medida em que a decisão de construir for tomada (FSP, 22/01/01, Imóveis, 1).

Ao mesmo tempo em que se abre a opção à compra antecipada de "Cepacs", favorecendo a escolha de lotes mais baratos, a nova regra poderá simplesmente provocar especulação com os novos papéis. Outro risco é o da verticalização continuar ocorrendo com maior intensidade onde atualmente já existe uma grande concentração, o que pode ser evitado, segundo técnicos do poder público, com um custo maior de compra dos mencionados certificados nessas regiões.

Outro aspecto a ser considerado é o das conseqüências do aumento de acessibilidade que as reformulações viárias provocarão. Cabe indagar se os mesmos efeitos urbanos verificados na região da Vila Olímpia, não poderão ocorrer com a ligação do setor Pinheiros da mencionada Operação Urbana Faria Lima, com àquela proposta em 2003 para a Vila Leopoldina, que se interliga, por sua vez, com a Operação Urbana Água Branca, analisada anteriormente.

Por fim, justificando o sub-título "Remodelações dirigidas e espacialidade corporativa", pode-se avaliar a Operação Urbana Faria Lima como tendo 


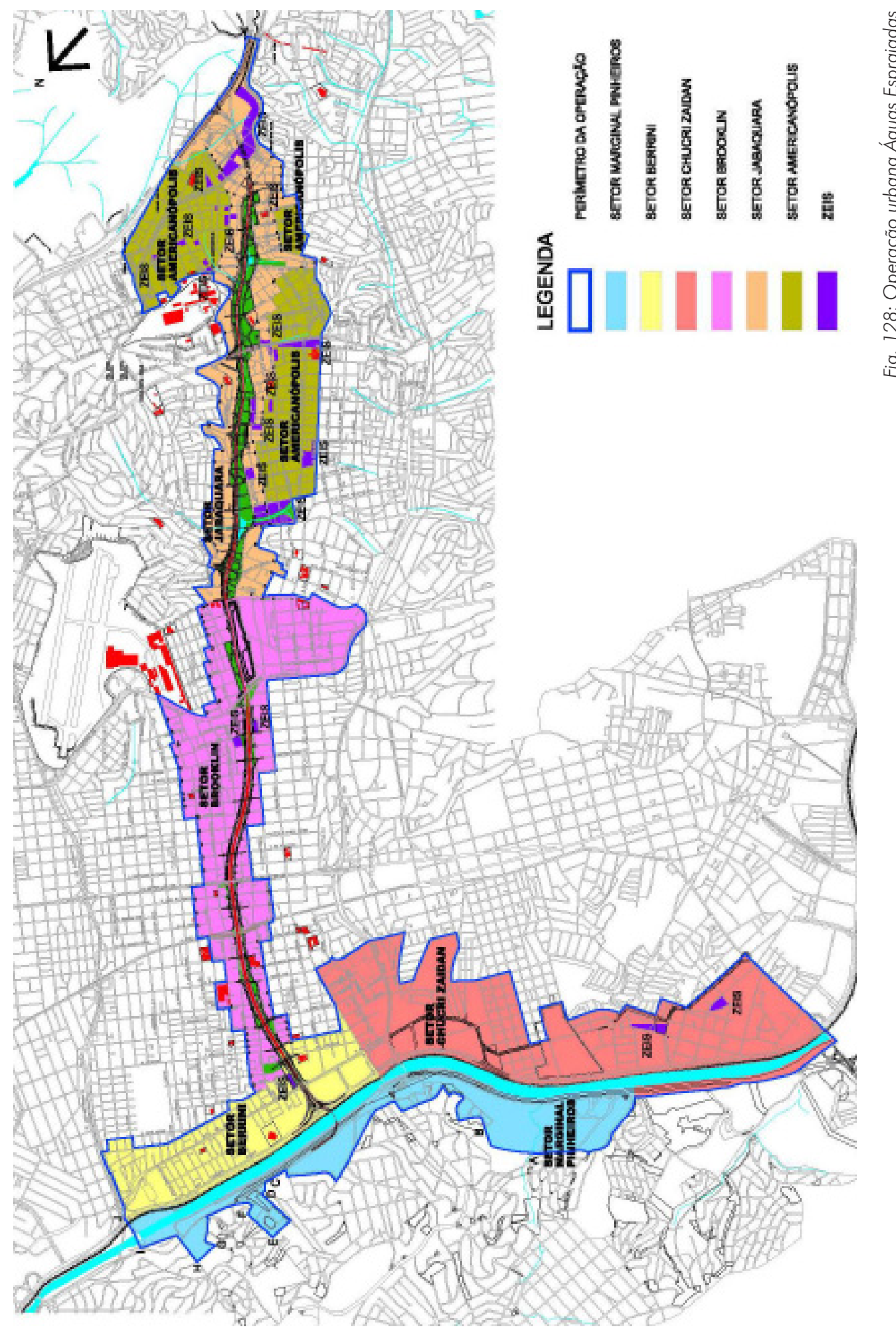


realizado uma incorporação sem precedentes para os espaços do setor do terciário avançado, com resultados profundamente distanciados dos objetivos de adensamento populacional e melhor aproveitamento da infra-estrutura existente, uma vez que, além das observações que já foram formuladas, pode-se considerar também que :

. Promoveu-se a formação de uma extensa área mono-funcional, dado o uso predominante dos edifícios construídos. Com essa desertificação do espaço urbano, mesmo as funções de moradia para a classe média foram relegadas, quanto mais a habitação social, que não foi contemplada pela cirurgia urbana promovida pelos agentes do mercado imobiliário.

. Os espaços em si se mostram eminentemente anti-urbanos: a escala do pedestre inexiste em quase toda a extensão da Operação Urbana, o automóvel predomina sobre o transporte público e os usos lazer e consumo que se constituem na animação urbana, conforme já assinalava Jacobs, foram confinados e em decorrência, ampliam a segregação funcional e social.

. A escala de "gentrificação" foi correspondente à do desmantelamento dos espaços pré-existentes nos bairros afetados pela Operação Urbana, onde se impôs a reestruturação espacial radical de seus elementos morfológicos e sociais, conforme também assinalou Alessandri Carlos (2001). Subjacente a essa dinâmica, as estratégias de marketing conduziram os investimentos privados a se concentrar em novas localizações na cidade, potencializadas por investimentos públicos, flexibilizadas pela legislação pertinente às Operações Urbanas e na direção dos setores de moradia das faixas de renda mais altas. Assim, outros espaços foram relegados a segundo ou terceiro plano, pois os interesses imobiliários não reconheceram na área central tradicional de São Paulo, os requisitos necessários para o "Central Business District" da cidade mundial.

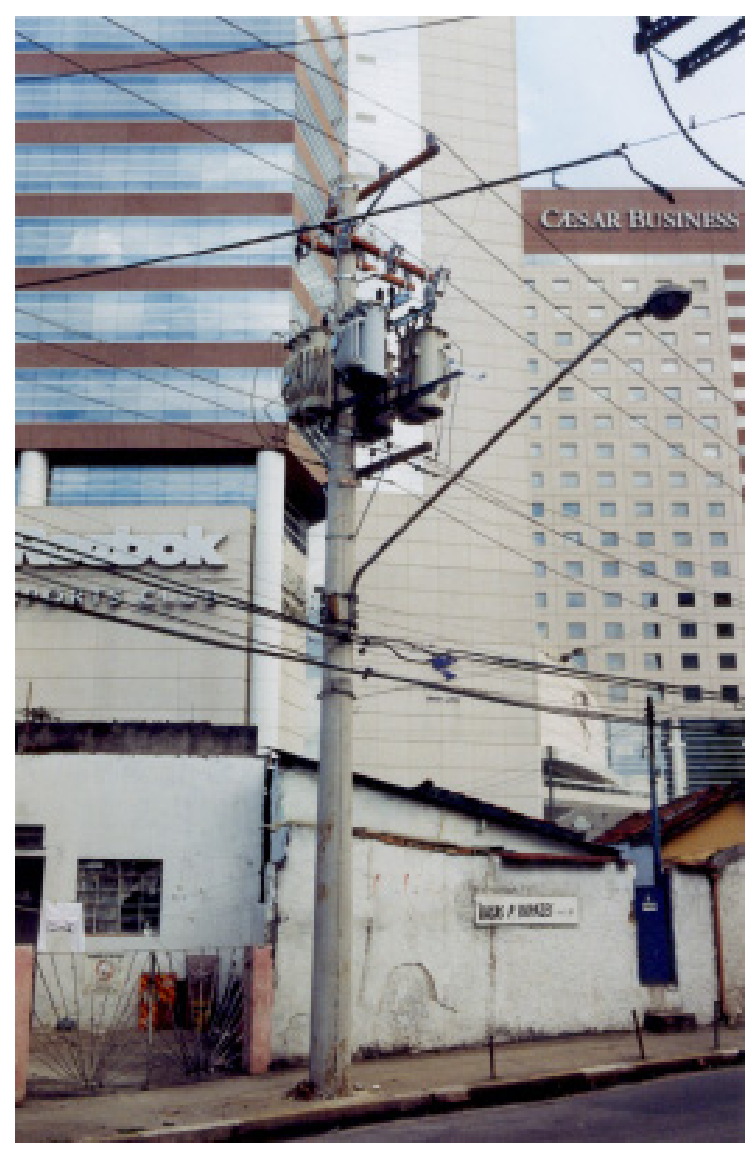

Fig. 129: Pensão-Cortiço em primeiro plano, Ceasar Park ao fundo. Rua da Olímpiadas, 2004. 


\section{Notas:}

${ }^{1}$ Sobre o assunto, Gottdiener (1993), Sassen (1994), Harvey (1995)

${ }^{2} \mathrm{Na}$ gestão municipal de 1989-1992, a requalificação da área central foi entendida como de importância estratégica para a cidade, tanto sob o ponto de vista funcional quanto simbólico. Para tanto foram desenvolvidos projetos pontuais conjuntamente com a conclusão do novo Vale do Anhangabaú e também proposta e aprovada a Operação Urbana Anhangabaú. Os dois outros governos municipais que sucederam o de Luiza Erundina, voltaram-se aos interesses imobiliários no quadrante sudoeste, que ditaram as pesadas e onerosas intervenções urbanas concentradas nesse setor.

${ }^{3}$ As Operações Interligadas foram aprovadas pela Lei $\mathrm{n}^{\circ} 10.209 / 86$.

${ }^{4}$ Operação Urbana Anhangabaú: Lei 11.090/91, administração Luiza Erundina; Operação Urbana Faria Lima: Lei n 11.732/95; Operação Urbana Água Branca: Lei n 11.774/95, ambas na administração Paulo Maluf; Operação Urbana Centro: Lei n $12.349 / 97$, administração Celso Pitta (idem, 5).

${ }^{5}$ Sobre os fundos de pensão, origem dos investimentos para a construção dos novos centros do terciário avançado em São Paulo, ver Wilderode, FAUUSP, 2000.

${ }^{6}$ Intervenção do economista Paulo Sandroni no debate sobre o projeto do Maharishi Tower, Sindicato dos Arquitetos de São Paulo, 1999.

${ }^{7}$ Segundo dados divulgados, os gastos em obras na gestão 1993-1996 representaram um terço de todas as obras licitadas no Brasil. Os custos declarados do túnel Ayrton Senna, com um quilometro e meio de extensão, foram de 552 milhões de reais (Amadio, jornal Página Central $\mathrm{n}^{\circ} 1$, out/1997, 35)

${ }^{8}$ Operações Urbanas Carandiru-Vila Maria, Vila Leopoldina e Vila Sõnia.

${ }^{9}$ Equipe vendecora - $1^{\text {o }}$ Prêmio - São Paulo SP (projeto $n^{\circ} 40$ )

Arquitetos Tito Livio Frascino, Fernando Pires, Alexandre Stefani, Letícia Lodi, Andréa Soares e RosaMariaLeal.

Engenheiro:JaimeVaisman

Consultores: Engenharia de Transporte: Protran Engenharia S/C Ltda / Instalações: Projetar Engenharia de Projetos S/C Ltda / Estruturas: Leão \& Associados Engenharia de Projetos S/C Ltda / Sistemas Construtivos: Universal Engenharia e Construções Ltda / Paisagismo: Arq. Sérgio Rubens Castanho Fiúza. 


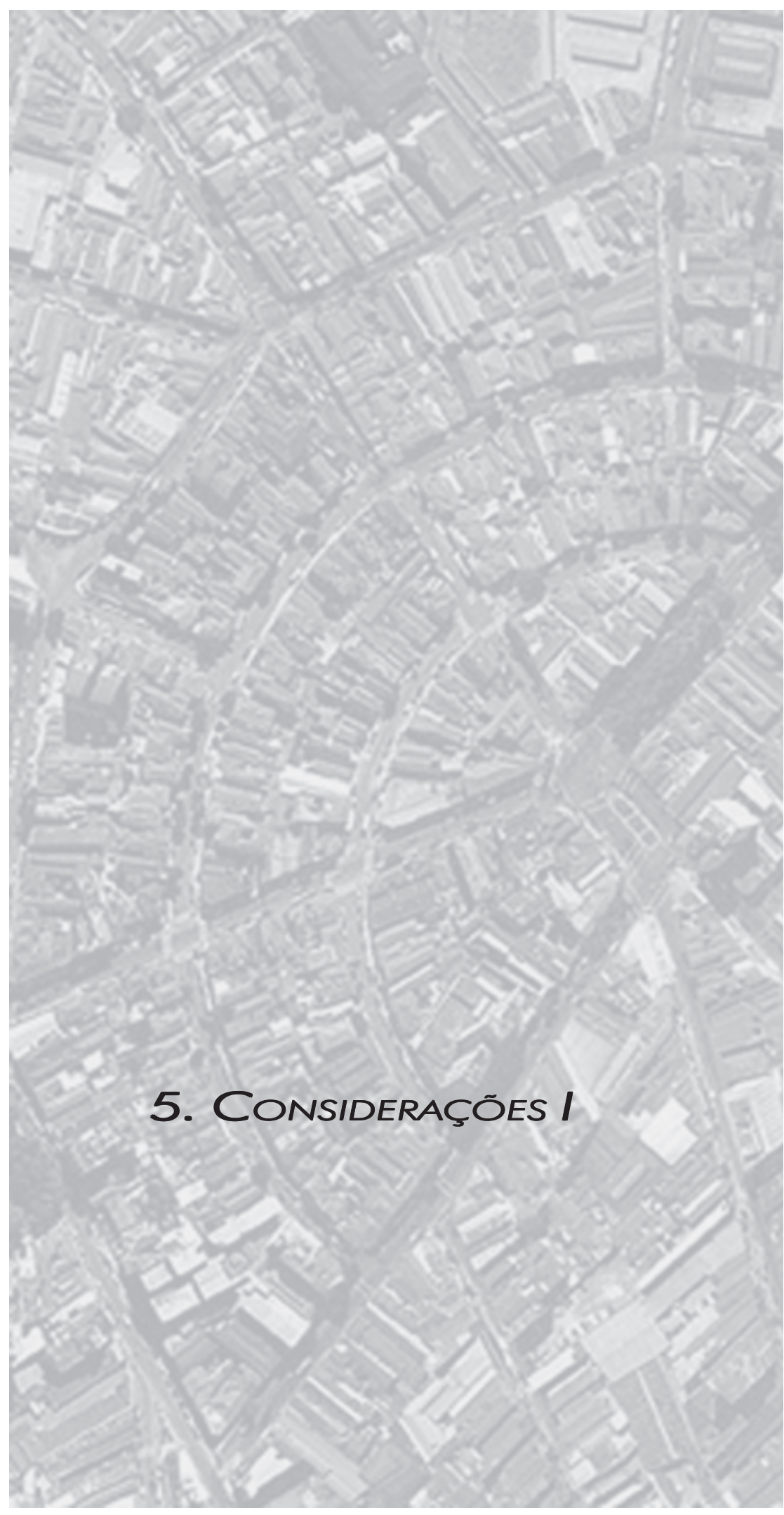




\section{Considerações I}

Visando facilitar o entendimento das análises desenvolvidas na Parte I deste trabalho, que abrangeu a Escala da Cidade mencionada na metodologia, foram relacionadas algumas considerações ainda parciais, mas que procuram alinhavar o desenvolvimento até aqui realizado.

Em fins do século XIX e início do século XX, a ocupação dos espaços próximos ao núcleo central ocorreu vinculando os elementos naturais e de infra-estrutura, somados à dinâmica social de uma cidade em transformação do seu caráter econômico. A rede de transporte, dirigida inicialmente para o atendimento da economia cafeeira, transformou-se em importante elemento organizador do espaço urbano, principalmente das atividades industriais e residenciais, delineando a setorização das atividades e tipologias que a cidade seguiu nas décadas seguintes.

Em relação à expansão urbana, não se logrou o controle desse processo, apesar de se constituir em matéria do Código de 1929 e sua consolidação de 1934. Os estudos sobre esse período mostram que, ao abdicar na prática dessa responsabilidade, o poder público criou as condições para que o setor privado assumisse o controle quase que absoluto da terra urbana. Incapaz de atuar em relação a abertura de loteamentos por parte do setor imobiliário, que criou uma crescente clandestinidade urbana nas franjas da cidade, sucederam-se anistias com o objetivo de "regularizar" o que foi produzido sem as mínimas obediências em relação às normas da legislação urbana (Scherer, Grostein, SMC, 184, 48, aspas nossas).

Importante agente da ocupação dos bairros nesse período foram as linhas de bonde, que dobraram os percursos dos eixos ferroviários, ao invés de servir as áreas não atendidas pelos mesmos, como foi o caso, ao Leste, da linha da avenida Rangel Pestana-Celso Garcia, correndo paralela à ferrovia Central do Brasil e a Oeste, a linha de bonde da avenida São João-Francisco Matarazzo, correndo paralela à Santos - Jundiaí e Sorocabana. Nesses trechos, o bonde foi o responsável pela distribuição de passageiros, propiciando a ocupação dos espaços entre as estações com um caráter misto, onde pequenas fábricas, oficinas e comércio conviveram com habitações de renda média e média baixa (Metrô, 1979, 19).

A imensa maioria dos imóveis, no período que perdurou até a década de 1940, eram destinados à locação, mesmo para domicílio da classe média e a moradia dos trabalhadores esteve condicionada à habitação coletiva - os cortiços - e vilas operárias. Ambas tipologias caracterizaram os bairros próximos ao centro em que as áreas industriais em crescimento e a rede organizada de transporte 
público, baseada nos bondes, definiram a localização da mão-de-obra junto aos postos de trabalho.

Considerando as propostas e projetos urbanísticos para a remodelação viária e estética da cidade, as transformações que o Plano de Avenidas desencadeou a partir de 1938, consagraram as componentes principais da estrutura urbana de São Paulo. Sempre associado à negação do transporte coletivo sobre trilhos e de ter favorecido a utilização dos ônibus e carros, a principal decorrência desse sistema viário foi, entretanto, a relação estabelecida com a verticalização de alguns bairros centrais em função do aumento da acessibilidade intra-urbana, particularmente ao vetor sudoeste que recebeu a maiorias das novas radiais.

No período que se seguiu à década de 1940, concomitantemente à crise da habitação provocada pela Lei do Inquilinato, assistiu-se à transferência ao trabalhador de todo o ônus da produção de sua moradia, que implicou no retalhamento das áreas periféricas da cidade. Essa etapa correspondeu às mudanças de ordem estrutural da economia do país e em particular da cidade, provocando o afluxo de migrantes e a conseqüente dispersão da moradia popular, facilitada pela expansão do sistema viário e das rodovias, como demonstraram os trabalhos de Petrone (apud Azevedo 1958) e Langenbuch (1971).

O conceito "periferia" foi associado à distância geográfica com a área equipada da cidade e também imputado aos espaços desprovidos de infra-estrutura para a oferta de condições razoáveis de habitabilidade. Depreende-se que, no período de expansão desses loteamentos consolidou-se, por outros caminhos, a concepção existente na República Velha de afastamento da habitação popular do núcleo consolidado da cidade. Porém, a combinação de transporte ferroviário e de ônibus, que viabilizou a expansão para as áreas distantes do centro, se mostrou sempre insuficiente, obsoleta e qualitativamente aquém dos padrões de conforto que o serviço deveria oferecer, o que foi confirmado taxativamente no relatório síntese do PUB, de 1968.

A característica principal dessas áreas foi a da abertura de loteamentos, que ocorreu sem cumprimento às normas urbanísticas estabelecidas pelo poder público, como "descontrole consentido" (Grostein, 1987). Nos distritos centrais, a construção irregular para finalidades de habitação das classes de renda mais baixa - os cortiços - desafiou as medidas oficiais de controle e erradicação da habitação coletiva, preconizadas desde o início do século passado pelo enfoque urbano-sanitarista. $O$ crescimento do número de cortiços nos bairros próximos ao centro ocorreu como resultado da inexistência de políticas oficiais para a habitação social, situação que perdurou nas décadas seguintes, como mostraram os índices de crescimento da população moradora em condições sub-normais na cidade. 
Apenas com os Institutos de Aposentadorias e Pensões - IAPs, foram formuladas alternativas à moradia popular, através de um pequeno número de conjuntos implantados nos bairros centrais, que incorporaram inúmeros elementos do partido modernista de habitação coletiva. $\bigcirc$ profundo abismo entre o pequeno número de unidades produzidas e a dinâmica do mercado imobiliário formal e clandestino, participante da produção da cidade, fizeram com que os conjuntos implantados fossem mais uma exceção do que uma alternativa condizente com o tamanho do problema então existente.

Fomentada pelo crescimento industrial da cidade, a complexidade dos problemas urbanos obrigou o poder municipal, na década de 1950, buscar instrumentos para intervenção, vindos de estudos e planos globalizantes e isso se constituiu na característica que distinguiu os trabalhos desse período, daqueles realizados nas décadas anteriores, aonde a ênfase ao sistema viário predominou, principalmente devido à atuação de Prestes Maia como urbanista e como Prefeito entre 19301945 (e posteriormente na década de 1960). Entretanto, apesar dos diagnósticos e propostas do relatório Moses e do trabalho do SAGMACS, a situação na área consolidada era da existência de $40 \%$ de espaços estocados pela especulação imobiliária, enquanto a dispersão centrífuga do crescimento urbano originava o crescimento desordenado da periferia, fato que se intensificou nas décadas seguintes.

Retomando as categorias de análise morfológica desenvolvidas por Solà-Morales - "urbanização, parcelamento e edificação" - depreende-se o papel preponderante para a modelagem do espaço urbano desempenhado pelo setor público (Prefeitura e Governo do Estado), uma vez que, como poder político e burocrático, a ele coube a condução de normas e diretrizes que beneficiaram os diversos atores da cena urbana, através:

1. Das concessões às companhias de serviços públicos, que atuaram de forma monopolista nas quatro primeiras décadas do século XX, estabelecendo vínculos com o setor imobiliário, como foi o caso da "Light and Power Co", onde a infraestrutura instalada se constituiu num importante fator de valorização do solo, provocando com isso, além da distribuição desigual dos serviços, uma crescente diferenciação funcional e espacial entre os bairros anexos ao centro.

2. Da incapacidade de efetiva regulamentação e gestão urbanística em relação aos diversos agentes do setor imobiliário, proprietários de terras, incorporadores e construtores, que tiveram seu campo de ação livre, tanto para a definição dos espaços da elite, como para a produção da cidade irregular.

3. Da implantação de um pré-zoneamento, que evoluiu do centro histórico para os bairros de elite: as restrições para usos impostas inicialmente no velho Triângulo, tiveram seqüência nos bairros aristocráticos a oeste e sudoeste, com a incorporação das normas ditadas pelos loteadores à legislação urbanística, quer 
para o tamanho dos lotes e os índices de ocupação, quer para os padrões construtivos. Contribuiu para a consagração dessa setorização a acessibilidade criada pelas avenidas do Plano de Prestes Maia, que alterou a relação de aproveitamento do solo, principalmente das áreas em que a escassez relativa da base fundiária se prendeu a melhores padrões urbanísticos ofertados, como nos Campos Elísios, Higienópolis e avenida Paulista, inicialmente e depois no Jardim América, Jardim Europa, Pacaembu e Sumaré.

Como resultado direto desse processo, coube à verticalização dar continuidade às diferenças originadas por esse pré-zoneamento. Em contaponto, nos bairros não caracterizados como nobres, ou mesmo tidos como fabris, foi admitida uma ampla liberdade para o parcelamento e a produção do espaço. Os padrões urbanísticos resultantes dessa utilização foram fatores preponderantes para que essas áreas também continuassem a se constituir em uma reserva de solo mais barato (comparativamente aos bairros onde a moradia das classes média e alta predominava), atraindo além de indústrias, o uso comercial e ocupação horizontalizada, com forte presença de habitações coletivas e cortiços. Bairros como Belém, Moóca, Bom Retiro, Brás, Canindé e Parí tiveram sua morfologia urbana estruturada segundo essas condicionantes.

Essa compartimentação resultou em um processo diferenciado para os espaços de vida e moradia da população: uma renovação constante nos bairros conectados ao Centro Novo - Consolação, Santa Cecília e parte do Bexiga através da verticalização e a consolidação de condições urbanas que passaram a não propiciar a permanência dos moradores dos bairros do Brás, Bom Retiro e Parí, ocorrendo uma transferência para outros setores da cidade. Isso se deu, entre outros fatores, pela disputa nesses bairros entre a função comercial e a residencial, que provocou além do gradual esvaziamento populacional, verificável já nas décadas de 1960 e 1970, o desinteresse do setor imobiliário em novas construções, realimentando o círculo de desvalorização dessas localizações.

Para isso contribuiu também a Lei de Zoneamento de 1972, consagrando os usos e ocupações existentes, admitindo para a zona mista de baixa densidade (Z2), a nucleação das indústrias, galpões e armazéns dos bairros do Bom Retiro, Pari e Brás. A conseqüência foi a desvalorização dos terrenos com coeficiente de aproveitamento igual a 2, uma vez que para a construção de edifícios altos, foi necessário situá-los em zonas com coeficientes maiores. Nessa "brecha" penetraram (mais ainda) os usos representados por armazéns de estocagem e revenda, lojas de confecções e produtos domésticos, pequenas indústrias, etc.

Por outro lado, alimentando o círculo de atratividade, nas áreas onde o setor de serviços criou novos postos de trabalho da classe média - o setor "white colar" moderno - e complementou as condições de lazer e cultura dos seus moradores, houve o incremento da população através do processo de verticalização 
habitacional, que exigiu também, da parte do poder público, investimentos na acessibilidade e no ambiente construído desses espaços. Apesar das recomendações do PUB e PDDI em direcionar um setor administrativo no norte da área central, na região de baixa densidade da Ponte Pequena, naquele período o terciário avançado "escolheu" a região da avenida Paulista como a nova centralidade, aliás, como os próprios Planos tinham percebido.

Em conjunto ao processo de expansão da área urbanizada através do parcelamento dos espaços periféricos, a partir da década de 1970 e mais fortemente na seguinte, a cidade verificou a diversificação industrial e o crescimento do setor terciário, estruturado pela nova etapa da economia brasileira, em que estiveram presentes a ampliação do mercado de consumo para a classe média, patrocinada no período do "milagre brasileiro".

A década de 1980 mostrou um processo qualitativamente diferente das etapas anteriores, devido às alterações na cadeia "produção-circulação-distribuiçãoconsumo", operadas pela maior presença do trabalho intelectual nesse circuito, o que resultou em um crescimento dos serviços especializados (Santos, 1997, 3). A distinção entre as áreas da cidade foi fortalecida pela caracterização de áreas que corresponderam:

- Aos setores vinculados ao comércio e serviços do varejo e atacadistas, que requereram adaptação física de instalações dos bairros tradicionais, processo verificado no Brás, no Pari e no Bom Retiro.

- Aos setores vinculados ao terciário avançado, onde a tecnologia se caracterizou como componente principal. Assim como ocorreu na região das avenidas Paulista e Faria Lima, nas décadas de 1950, 1960 e 1970, a ocupação a partir de 1980 da Marginal Pinheiros significou a formação de um novo setor de escritórios de alto padrão, numa área anteriormente caracterizada por vazios urbanos e depósitos industriais. No vetor sudoeste, o mercado imobiliário condicionou a atuação do poder público à reestruturação da infra-estrutura e do parcelamento do solo.

Essa subordinação dos investimentos públicos aos interesses privados pode ser observada com nitidez em dois momentos: na década de 1970, com a implantação da Nova Paulista, que adequou essa avenida e a radial de acesso, a Consolação, à crescente verticalização que ocorria em sua extensão. Mais recentemente, na Operação Urbana Faria Lima, onde o elevado aporte de recursos públicos sustentou a dinâmica imobiliária que reconfigurou radicalmente região, impulsionada pela implantação de sistema viário para automóveis e remembramento do parcelamento, ambas condições necessárias para a verticalização do período da globalização. 
PARTE 2 


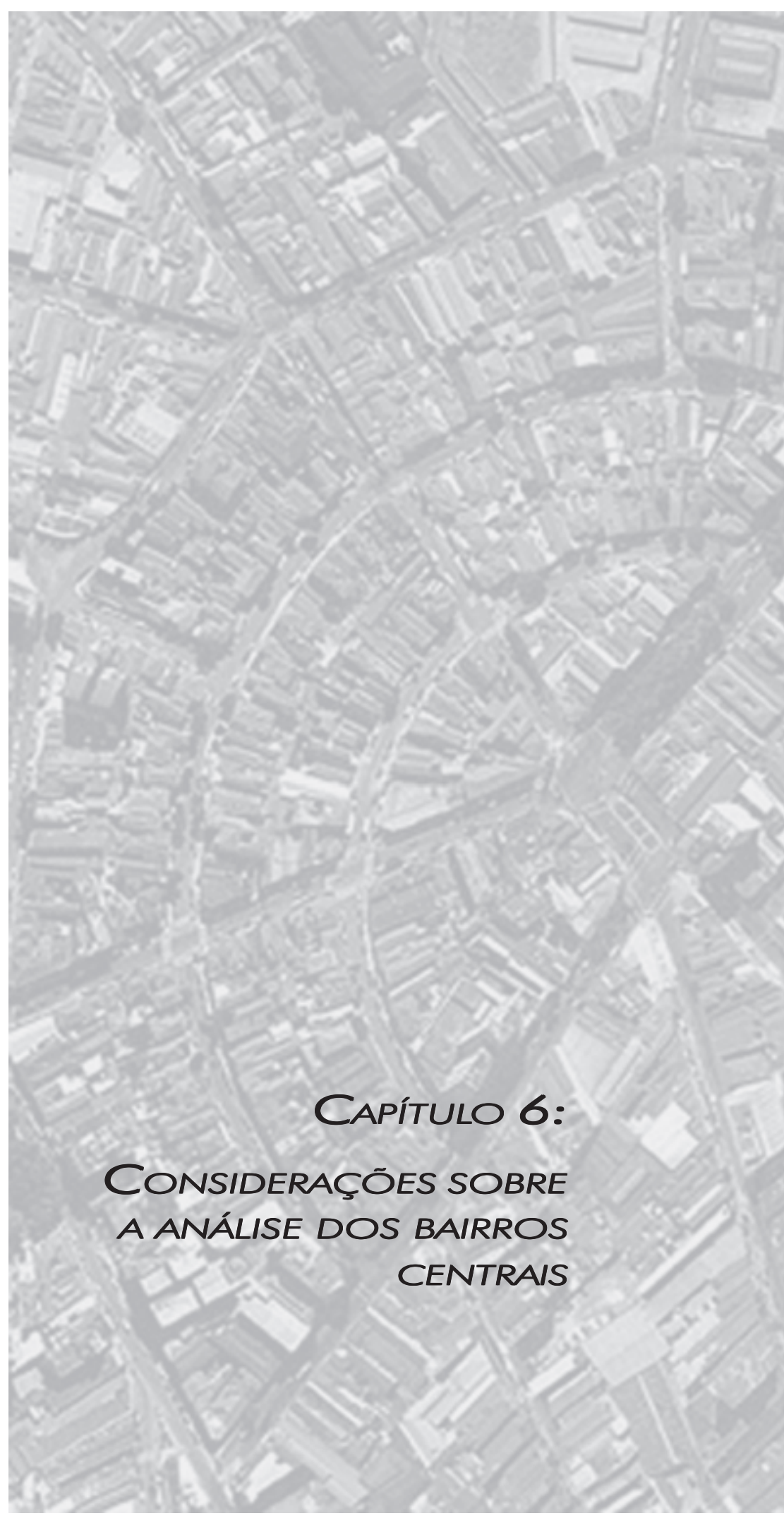




\section{6 - Considerações sobre a análise dos bairros centrais}

A extensão territorial e social definida pelos bairros, possui uma compreensão direta para o conjunto da sua população moradora ou usuária, pois neles estão presentes os elementos mais facilmente reconhecíveis da identidade local, que podem ser expressos pelos aspectos já mencionados "urbanização (infra-estrutura), parcelamento e edificação", além daqueles de ordem social e funcional, associados por exemplo, ao perfil de renda dos habitantes, relações de vizinhança, vocação da área, etc. Incluem-se também as referências presentes na área, sejam elas construídas, monumentos ou edificações significativas e também a paisagem.

Em se tratando de bairros tradicionais de São Paulo, como são o Bom Retiro, Brás e Pari, cuja estruturaçãa reporta o trajeto histórico da própria cidade, ocorrida na transição da economia agrícola e comercial para a industrial, os elementos que os caracterizam tem um significado fortemente vinculado às origens sociais da ocupação pioneira e embora tenham sofrido transformações acentuadas ao longo do tempo, é possível observar a permanência dessas características, mescladas com os novos usos existentes e novas apropriações por parte da população moradora e dos usuários. Como indicou Villaça, o estudo da história (no caso, a estruturação urbana de um ou mais espaços), se faz do presente para o passado, e não de forma inversa (apud Deák, Schiffer, orgs, 1999, 181).

Nesse sentido, analisar o desenho urbano desses bairros representa um esforço para de aprofundar um olhar voltado às características ou qualidades com que esses espaços foram constituídos. É justo entender, portanto, que essas qualidades são expressas pela morfologia urbana das partes do território investigado.

Outro conceito que merece atenção é o de identidade, associada a um determinado espaço urbano. Como alerta Ramos, embora apresentando aspectos diferenciados, pois nenhum bairro é totalmente homogêneo, a identidade vinculase ao bairro como um todo, dentro de um todo maior que é a cidade a qual pertence. Seguindo essa formulação, o significado da mesma é o de se constituir em identidade sócio-espacial (Ramos, 2001 , 9), pois sua caracterização ocorreu relacionada a uma localização urbana e a processos sociais, como já foi assinado.

Essas proposições ligam-se à análise sobre os bairros centrais desenvolvida na presente etapa do trabalho. Na Parte l, a escala de abrangência foi a da estruturação do anel de bairros envoltórios do núcleo central de São Paulo, chegando a consolidação de seus usos e ocupações, o que implicou em investigar os processos gerais envolvidos na formação e transformação dessa morfologia, que ocorreu de forma diferenciada entre os quadrantes da cidade. Como foi indicado na metodologia, a partir dessa escala, desenvolveu-se uma investigação sobre os aspectos da estruturação interna dessas áreas enfocando suas características morfológicas específicas e as relações espaciais e funcionais 
existentes entre os bairros. Nesse sentido, a análise ampliará a escala de representação, passando dos mapas de abrangência municipal para a cadastral desse território pesquisado.

Na sua origem os bairros das cidades brasileiras ligaram-se à tradição trazida de Portugal, onde os mesmos corresponderam à organização das paróquias da Igreja Católica: cada uma delas tinha sua igreja e seu santo de devoção, com a comunidade organizada em torno dela e de outros elementos como os mercados e feiras (F. Santos, 1988, 1 16). Em relação a esse quadro, Sposati relacionou a divisão intra-urbana da cidade à herança republicana desses territórios paroquiais, uma vez que cabia à Santa Sé receber declarações de casamento, nascimento e morte, além dos seus vigários procederem também ao registro de terras dentro de suas freguesias, como dispunha a Lei de Terras de 1850, regulamentada em 1854 (Sposati, 2001, 44).

Devido ao processo histórico de estruturação, nas áreas mais antigas das cidades a permanência dos elementos urbanos torna mais fácil identificar os bairros tanto sua forma quanto as atividades ali existentes - ao contrário do que ocorre nas periferias, onde as áreas dos bairros se tornam maiores e seus limites e setores mais imprecisos (F. Santos, 1988, 1 16). Nesse caso, a morfologia urbana desvenda não apenas dados históricos e geográficos, mas também da hierarquia social existente na cidade.

Com relação à área de abrangência, F. Santos propôs que para os habitantes de um bairro, sua existência está mais ligada ao seu centro que ao reconhecimento dos limites que o caracterizam, isso porque na centralidade local ocorre a superposição de significados (as trocas, os serviços, os espaços de culto ou institucionais, etc.), que se mostra mais importante do que precisar onde começam e terminam zonas homogêneas ou de se definir tecnicamente os perímetros de abrangência $(1988,116)$.

A respeito dos limites entre os bairros se constituir em um entendimento difícil de ser precisado, comparado às divisões de origem oficial, o geógrafo Renato S. Mendes considerou também que "em virtude da sua individualização resultar da 'vox populi', além de não se confundir com a subdivisão político-administrativa, o bairro dificilmente pode ser delimitado com absoluto rigor, a exemplo do que costuma ocorrer com as regiões geográficas. Seus limites são imprecisos, quase diríamos impalpáveis, sendo comuns os casos em que seus próprios moradores divergem de opinião a respeito de uma ou mais ruas, quanto à sua inclusão neste ou naquele bairro. É que antes existem zonas de transição do que propriamente, linhas demarcatórias rígidas entre a maioria dos bairros da Paulicéia". Nesse sentido, segundo o autor, em alguns casos torna-se impossível delimitar onde acabaria um bairro e começaria outro, porque o "coração do bairro" seria mais 
fácil identificar, mas sua extensão não seria possível ser delimitada com precisão (Mendes apud Azevedo, (org), 1958, 186)

Assim, os bairros constituem setores de agregação e organização do espaço urbano e sua caracterização é condicionada aos aspectos históricos de sua formação, às especificidades físicas e sociais, tais como sistema viário, constituição de quadras e lotes, tipologias edificatórias, população moradora, etc. Entretanto, apesar de sua importância na organização do tecido urbano e do conjunto de vida da sua população, os bairros não constituem unidades referenciadas políticoadministrativamente como são os sub-distritos e distritos. Estes reúnem um número variado de bairros em seu interior e ainda que sua delimitação tenha sido alterada ao longo do tempo', dados e informações fundamentais para o urbanismo foram em continuam sendo vinculadas a eles e não aos bairros.

Frente a esse quadro de setorização da espacialidade da cidade, recorreu-se a uma inter-relação necessária para o aprofundamento da análise sobre o Brás, Bom Retiro e Pari, que vinculou os elementos informacionais disponíveis - estes vindos da divisão político-administrativa dos distritos - e os de cunho morfológico relacionados aos bairros, ainda que no caso de São Paulo suas delimitações por muitas vezes não sejam precisas.

Mendes também identificou esse problema no seu estudo analítico sobre os bairros da cidade, de 1958, considerando que os bairros possuem origens populares, decorrentes dos primeiros habitantes que lá se fixaram, não dependendo da iniciativa dos poderes públicos e sendo posterior a criação oficial de distritos ou subdistritos. Esse autor afirmou que "todavia, na maioria dos casos, o que a lei reconhece como subdistrito não corresponde ao que a população considera como bairro, embora o nome possa ser exatamente o mesmo. É que o bairro possui determinadas características muito próprias que, com o passar do tempo, se reforçam e acabam por individualiza-lo de maneira inconfundível, tanto para os que nele habitam, como no conceito geral da população citadina" (Mendes apud Azevedo, (org), 1958, 185).

Persiste, contudo, a necessidade de uma compreensão urbana mais aprofundada dessa abrangência espacial, a fim de auxiliar e precisar o que dela se desejou obter. Para tanto, inicialmente se recorreu à proposição que entende o espaço como algo que transcende a dimensão físico-material ao compreendê-lo como espaço social (Ramos, 2001 ,9).

Ao se transportar esse conceito para o campo da arquitetura e do urbanismo, é possível estabelecer uma primeira aproximação com a idéia de "lugar onde se manifestam os fatos urbanos, isto é, a área em que é possível detectá-los" proposta por Aldo Rossi $(1995,62)$. Para a delimitação dos fenômenos que ocorrem nessa superfície, Rossi defendeu a proposição de "área-estudo" como método de trabalho e como definição de um elemento qualitativo da cidade. Serviu-se 
dessa definição para precisar os fatos que ocorrem em determinado local, como por exemplo a relação entre o parcelamento e um tipo de habitação, que exige uma investigação sobre os lotes vizinhos para a observação se o objeto de estudo se revela uma ocorrência única ou resultado de condições mais gerais da cidade. Isto significa perceber não apenas o fenômeno isolado, mas o tecido urbano onde o mesmo se realizou.

Assim sendo, a área-estudo reúne também um espaço definido por características históricas, coincidentes com um fato urbano preciso. Nesse caso, se delimita um conjunto com características próprias e qualidades dos fatos urbanos cujo reconhecimento constitui a aproximação com o conhecimento da própria estrutura dos mesmos. Colabora para o conhecimento dessa estrutura a identificação da relação entre tipologia edificatória e morfologia urbana, uma vez que, segundo Rossi, em sua grande parte, a estrutura pode ser esclarecida através dessa relação (idem, 63).

Foi indicado como essencial para a análise do entorno urbano analisado, a definição dos limites da área estudada, quer entendido como "área-estudo" associada ao conceito sociológico de bairro, quer ao conceito de "recinto", entendido como uma seção da cidade. Ao fazer essa observação, Rossi pretendeu ressaltar as diferenças que existem entre os fatos urbanos na cidade que podem ser obscurecidas por análises distorcidas, presentes no campo da arquitetura e urbanismo, nas quais o crescimento urbano se configura como um processo contínuo (ibidem, 63).

Avançando na elaboração desse autor, as partes da cidade definidas pelas "áreasestudo" constituem-se em unidades do conjunto urbano, que se destacam por apresentar diferentes momentos de crescimento ou que, como determinados bairros, adquiriram caráter próprio. $\bigcirc$ estudo dos mesmos se destaca como o "momento particular do estudo da cidade", onde dois de seus traços estariam configurados: a massa e a densidade, manifestadas pela continuidade da ocupação espacial no plano horizontal e vertical (op. cit, 67).

Ao associar o conceito de área-estudo ao conceito de bairro, Rossi considerou ser este último um setor da forma urbana estreitamente ligado à evolução e natureza da cidade, ocorrendo nessas partes uma experiência (urbana) concreta. Assim, dentro da morfologia social, o bairro se constitui em uma unidade morfológica e estrutural caracterizada por "uma certa paisagem urbana, por um certo conteúdo social e por uma função; portanto, uma mudança num desses elementos é suficiente para fixar o limite do bairro" (op.cit, 70). Rossi prosseguiu reafirmando as diferenciações que são partes integrantes da cidade: "mas sustentamos aqui que esses bairros não são tão subordinados, mas suas partes relativamente autônomas; suas relações não são explicáveis como uma simples função de dependência, mas devem ser referidas a toda estrutura urbana" (op.cit, 
70). Nesse sentido, cabe retomar a formulação de Ramos, no que se refere à relação do bairro a um todo maior que é a cidade, a qual ele pertence.

Se sob o ponto de vista morfológico o bairro se configura como "momento particular do estudo da cidade", como propôs Rossi anteriormente, duas formulações sociológicas se contrapõe no que se refere ao caráter organizador da vida de sua população. A primeira estabelece uma análise na qual o bairro se constitui como unidade de base da vida urbana, favorecendo ao seu morador se referenciar física e coletivamente através dessa unidade sócio-espacial. Essa proposição estabelece ainda o bairro como lugar onde se desenvolve a vida pública e se organiza a representação popular (George apud Ramos, 2001, 11)

A segunda concepção estabelece uma crítica a essa proposição, sendo encontrada na formulação de Lefebvre, para quem o entendimento de bairro é o de uma unidade sociológica relativa, possível de ser pensada apenas tendo a cidade como totalidade. Nesse sentido, a base da vida urbana não seria o bairro, mas sim o centro, isto porque a noção de centralidade seria o fator que tornaria possível a cidade e seus bairros. Nesse caso, se quis afirmar que o bairro além de não se constituir em uma unidade autônoma, submete-se sempre a processos que moldam seu caráter físico e social (Lefebvre apud Ramos, 2001, 11). Nesse sentido, as formulações de Lefebvre podem também ser estendidas aos processos gerais intervenientes na formação local, já que os bairros sintetizaram espacialmente um fluxo originado na centralidade, seja ela um lugar "centro" (a rede viária radio-concêntrica), centro das decisões políticas, ou ambas.

Para a pesquisa deste trabalho, delimitar a área-estudo implicou em seu corte espacial e foi necessário relacionar as breves análises sociológicas para aprofundar seu entendimento. Considerar os bairros como base da vida urbana e assim, além de material, local de identidade e referência social, levanta a indagação de quais relações urbanas existiram para que isso tivesse campo para ocorrer.

Uma das respostas para essa questão foi indicada quando as análises sobre a estruturação dos bairros pesquisados (assim como outros tantos da cidade) enfocaram as limitações à mobilidade existente em São Paulo até a década de 1940, que implicou na grande proximidade entre os locais de moradia e trabalho. A espacialidade resultante, isto é a morfologia urbana, teve suas características estruturadas em função dessa alternativa ou condicionante de vida da população. Nesse caso, é válido relacionar esse aspecto com a profunda identificação entre os habitantes e os seus locais de moradia na cidade, como foi o caso dos bairros do Bexiga, Barra Funda, Bom Retiro, Brás, Pari, Belém, Mooca, Ipiranga, Lapa, etc., que de maneira característica participaram do cenário urbano de São Paulo.

Dessa forma, compreender a investigação sobre a morfologia urbana como "o estudo analítico da produção e da modificação da forma urbana no tempo" 
(Samuels apud Del Rio, 1991, 71), implica em reconhecer articulação apontada por Lefebvre para uma caracterização do fenômeno urbano, isto é, a compreensão de duas estruturas que atuam em simultaneidade: a morfológica, reunindo os sítios, as situações, os imóveis, ruas, praças, monumentos, bairros e vizinhança e a sociológica, reunindo por seu turno, a complexa distribuição da população, suas categorias sócio-profissionais, dirigentes e dirigidos, etc. (Lefebvre, 2004, 109, grifo do autor).

Levando em conta essa fundamentação, serão desenvolvidos os seguintes conteúdos nos capítulos subsequentes:

1. Análise dos distritos Bom Retiro, Brás e Parí através de sua formação histórica e através de documentação cartográfica, a fim de inventariar as transformações ocorridas nesses espaços a partir da década de 1930. Os distritos foram divididos em sub-setores, que corresponderam no caso do Bom Retiro e do Pari, a delimitação dos bairros no seu interior. Para tanto foi utilizado como critério a conceituação de Rossi sobre a unidade morfológica e social que caracteriza a noção de bairro, onde a mudança de algum dos elementos internos pode fixar o limite entre os mesmos e os demais em seu entorno (Rossi, 1995, 70).

2. Análise dos projetos de transformação radical desses bairros e projetos de requalificação direcionados aos bairros pesquisados.

3. Indicação de cenários possíveis para áreas específicas desses bairros, relacionando as propostas existentes e outras que poderão somar-se às mesmas. 


\section{Notas:}

1 A Lei Municipal $n^{\circ} 11.220$ de 1992 instituiu os atuais 96 distritos como divisão administrativa adotada também pelo I.B.G.E como unidade de coleta de informações. Um número variado de distritos são englobados pelas Sub-prefeituras, que são unidades de gestão. Antes disso, segundo Spozati, a Lei Municipal n 14.334 de 1944 havia criado a sub-divisão no interior do distrito, denominando-se então sub-distritos às 38 sub-áreas à qual a cidade inteira havia sido dividida. Foram criados também por essa Lei, os distritos de São Miguel Paulista, Guaianases, Itaquera, Parelheiros e Perus. Em 1948 foi a vez da criação do distrito de Jaraguá, em 1959 o de Ermelino Matarazzo, em 1980 o de Itamim Paulista e em 1985 os de São Mateus e Sapopemba. Em 1991 a cidade contava com 48 sub-distritos e 10 distritos (Sposati, 2001, 29) 


\section{1 - Distrito do Bom Retiro}

\subsection{1- Luz}

O atual distrito do Bom Retiro engloba os bairros da Luz, Ponte Pequena e do próprio Bom Retiro. $\bigcirc$ bairro da Luz se caracteriza por ser a ocupação mais antiga, devendo o seu nome à antiga Ermida da Luz, erguida em 1585 ainda no local posteriormente ocupado pelo Convento da Luz, quando essa área era denominada de Guaré e se constituía no limite da cidade junto à várzea do Tietê. As vias de comunicação principais foram o Caminho da Luz, correspondendo à atual rua Florêncio de Abreu, que cortava o então denominado Campo da Luz. Outra via que também ligava essa área ao centro era a rua Alegre, atual Brigadeiro Tobias (Cesar et alli, 1977, 65). Essa área corresponde àquela intermediária entre os atuais bairros da Luz, Ponte Pequena e Canindé.

A circulação primitiva esteve condicionada a rústicas pontes sobre o ribeiro Guaré, sobre o Tamanduateí e sobre o rio Tietê. Denominadas de Pontes Pequena e Grande, efetivamente apenas em 1866 foi inaugurada a ponte metálica projetada por um engenheiro da San Paulo Railway que estabeleceu uma ligação satisfatória com os Campos de Santana e os caminhos que levavam a Minas Gerais e Goiás. Essa ponte foi reformada em 1924 e substituída pela atual Ponte das Bandeiras em 1942, durante a primeira gestão de Prestes Maia como prefeito (Jorge, 1988, 39-49). Pelos mapas existentes, a Ponte Pequena, que superou o rio Tamanduateí e emprestou o seu nome ao bairro, localizou-se nas proximidades da atual Praça Armênia, cruzando o rio na altura da rua Pedro Vicente, sendo toda a área de várzea já aterrada nas primeiras décadas do século XIX, chamandose Aterrado de Sant'Anna (Cesar et alli, 1977, 78).

Na segunda metade do século XVIII foi construído o Convento da Luz, que atualmente abriga o Museu de Arte Sacra. Esse edifício recebeu uma ampliação no início do século XX, guardando sua atual configuração. Na última década do século XVIII, foi criado o Jardim Botânico, que efetivamente foi concluído em 1825, tornando-se o maior espaço aberto da cidade, passando a ser denominado Jardim Público (idem, 67). Mesmo perdendo parte de sua área para a construção do Liceu de Artes e Ofícios e da nova Estação da Luz, inaugurados em 1900 e 1901 respectivamente, desde o século XIX o Jardim da Luz se manteve como um dos locais prediletos para o lazer dos paulistanos por muitas décadas seguintes.

No século XIX o bairro da Luz recebeu ainda outros equipamentos importantes: a Cadeia Pública, ou Casa da Correção, inaugurada em 1852 e o Seminário Episcopal, de 1855. Do primeiro edifício só resta o portal de entrada junto à avenida Tiradentes, sendo a área ocupada pela Caixa Econômica Federal desde meados da década de 1970. Com a República, a Cadeia Pública recebeu o nome Presídio Tiradentes, sendo ali encarcerados os sindicalistas da década de 


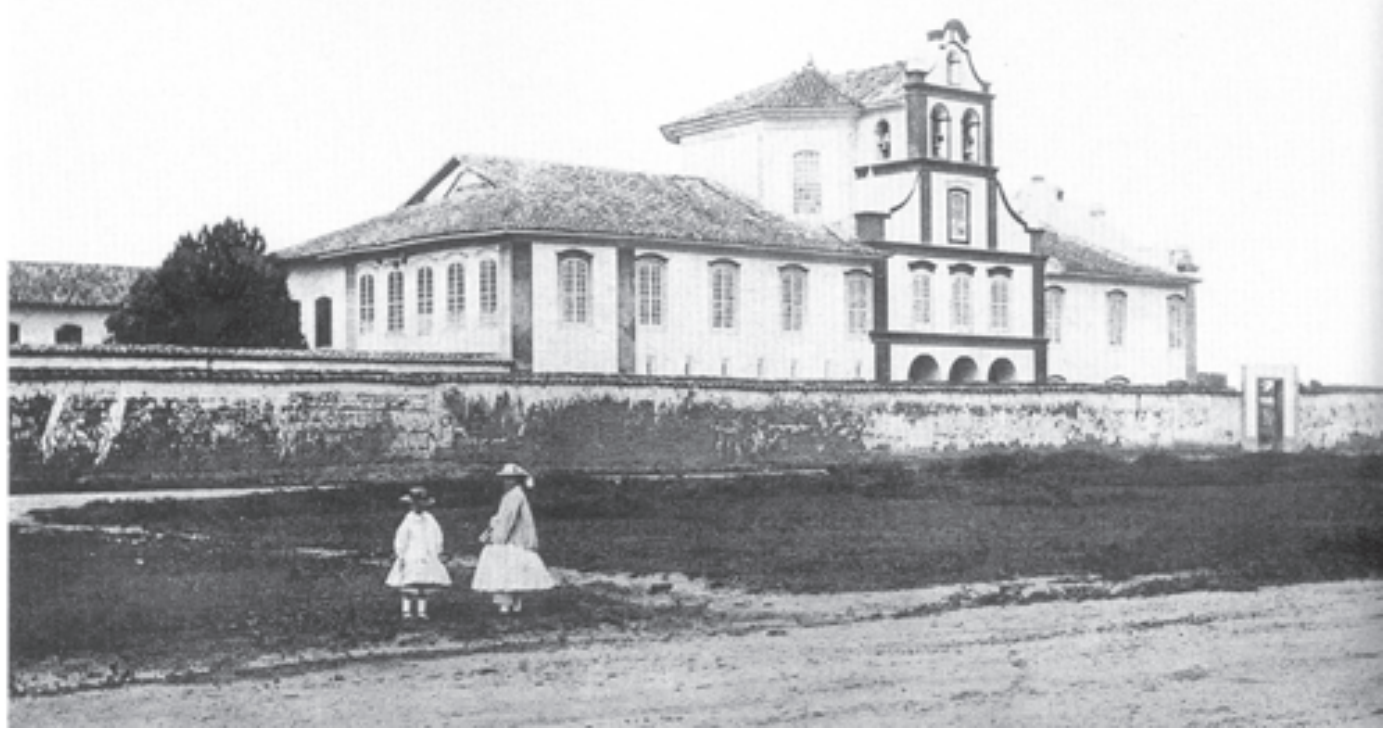

Fig. 130: Convento da Luz, 1875.

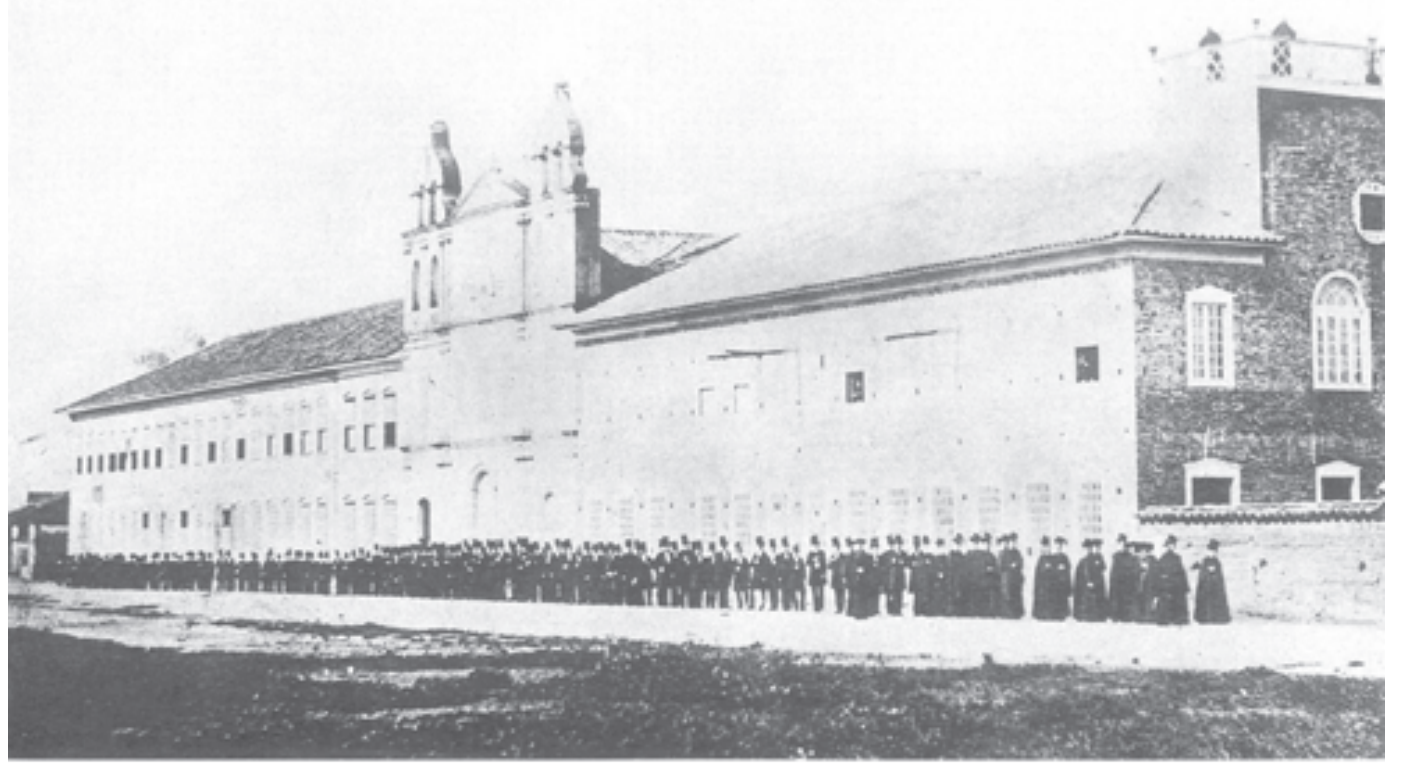

Fig. 131: Seminário Episcopal, 1860.

1910, o escritor Monteiro Lobato, preso durante o Estado Novo e os perseguidos políticos do regime pós-1964 (Jorge, 1988, 73-78).

Novos edifícios somaram-se aos anteriores: em 1895 foi concluído o Quartel da Força Pública e em 1900 o Liceu de Artes e Ofícios, ambos projetados por Ramos de Azevedo. Foi construída entre 1888 e 1992 a primeira usina elétrica 
da cidade, que fornecia energia para - quartel e o hospital da Força Pública, localizados juntamente a ela na rua João Teodoro. Na parte lateral do Jardim Público, junto à atual avenida Tiradentes, em 1894 foi construído o prédio do Instituto de Eletrotécnica, também com projeto de Ramos de Azevedo, que se tornaria o edifício principal da Escola Politécnica. Ao lado dela, junto à esquina da avenida Tiradentes, se encontrava a casa do Marquês de Três Rios, onde efetivamente foi iniciado o curso da Politécnica e que posteriormente foi demolida (Cesar et alli, 73).

Com relação à Estação da Luz, concluída em 1901, o estudo de Toledo indica ter sido esse um símbolo da Metrópole do Café, com o projeto e todo o seu material importado da Inglaterra. A construção dessa Estação de $7.500 \mathrm{~m}^{2}$ criou um novo centro focal na cidade, beneficiada ainda pela sua situação junto ao Jardim Público (Toledo, 1983,82). Seu projeto foi creditado a Charles Henry Driver, membro do Real Instituto Britânico de Arquitetos e essa obra se constituiu em um dos exemplos mais importantes da utilização do ferro na arquitetura paulistana na transição dos séculos XIX e XX (Kühl apud JT, 08/3/1997, 2).

Da mesma época, a Vila dos Ingleses constituiu um exemplar de conjunto de residências de classe média, implantada numa área em que a proximidade com a estrada de ferro conferia status. Foi projetada pelo engenheiro Eduardo de Aguiar D'Andrada, chileno de nascimento, e consta que foi local de residência dos engenheiros ingleses da San Paulo Railway (SEMPLA/Emplasa, 1984, 263)

A estruturação viária se deveu, como já abordado, às duas vias de comunicação principais do centro com o Campo da Luz, que foram o Caminho da Luz, correspondendo à atual rua Florêncio de Abreu e a rua Alegre, atual Brigadeiro Tobias. Segundo Jorge, essas ruas formavam uma bissetriz interrompida pelos trilhos da San Paulo Railway que seccionava a área no sentido leste-oeste, interrupção solucionada com o rebaixamento dos trilhos em seis metros, por ocasião da construção da Estação da Luz. No sentido norte-sul, o Caminho da Luz, posteriormente rua da Luz, se articulava com o "caminho da Freguesia de 


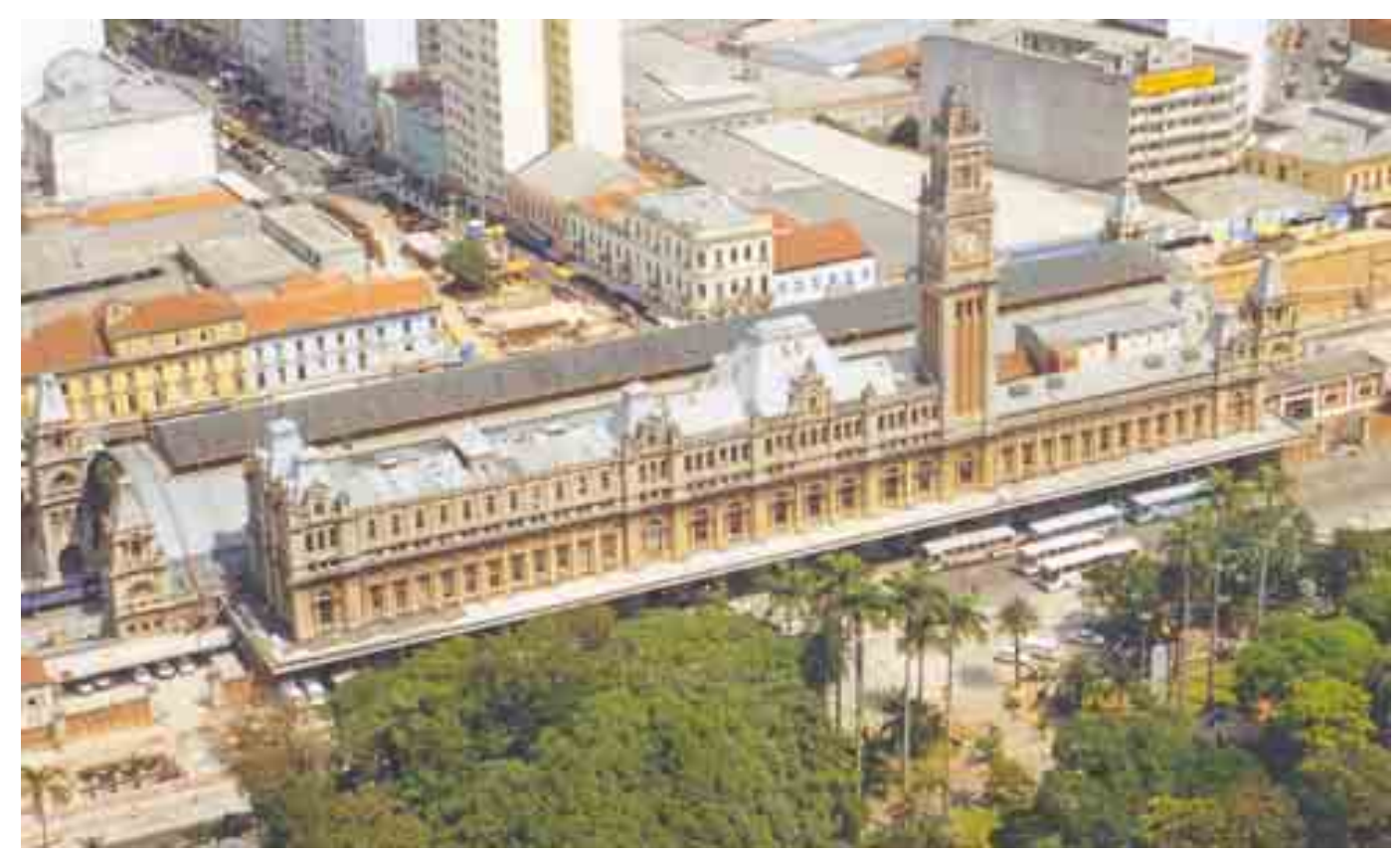

Fig. 133: Estação da Luz, 2001.

São João de Atibaia", dando origem ao traçado da atual avenida Tiradentes, denominação recebida em agosto de 1916, no período republicano. Em 1870 foi proposta também uma ligação direta das porteiras da ferrovia até as margens do Tietê, via formada muitas décadas depois pela atual avenida Santos Dumont (Jorge, 1988, 93).

Outra via importante para a estruturação local e ligação com o Brás, foi a rua aberta em 1872 na gestão de João Teodoro, que recebeu o seu nome. Essa rua interligou as duas estações ferroviárias da San Paulo Railway, e posteriormente também a da Estrada de Ferro do Norte, recebendo ainda na última década do século XIX, a estação principal do Tramway da Cantareira. A ligação entre a Luz e o Bom Retiro foi estabelecida através do prolongamento da rua João Teodoro e da abertura da rua Três Rios, a primeira, atual Ribeiro de Lima, conectando-se com a alameda Glette e a segunda com a Nothmann, ambas acessando o então recém parcelado Campos Elísios (Jorge, 1988, 85; Toledo, 1983, 70).

Um elemento de destaque presente na área de transição entre a Luz, Ponte Pequena e Pari foi a implantação do Tramway da Cantareira, que esteve relacionado com a expansão da infra-estrutura da cidade em fins do século XIX e com a própria expansão urbana dos bairros ao norte da cidade. A ferrovia serviu inicialmente para o transporte de materiais das obras de abastecimento de água da Cia. Cantareira, transformada na Repartição de Águas e Esgotos RAE, após ter sido encampada. em 1892 pelo Governo do Estado. Sua finalidade foi a de substituir as juntas de boi necessárias para conduzir as tubulações e demais insumos ao alto da Serra, sendo implantados 13 quilômetros dessa 
pequena ferrovia, que iniciou sua operação em 1893, ainda com a estação inicial situada em Santana. (disponível em: ferrovias urbanas <http:// www.wernervana.hpg.com.br> em 2004)

Em 1894 foi concluída a primeira estação no Pari, na rua João Teodoro esquina com a rua Cantareira, já que toda a tubulação necessária ao abastecimento de água passou a ser embarcada desse ponto e os trilhos margeavam o Tamanduateí, seguindo ao norte pela avenida Cruzeiro do Sul. Em 1918 o antigo galpão cedeu lugar à nova estação, denominada Tamanduateí. A ferrovia também incorporou a função de recreio, servindo para transporte de passageiros para o alto da Serra da Cantareira.

Um ramal alcançando o Campo da Luz foi construído em 1897, percorrendo a rua Jorge Miranda e com estação no cruzamento dessa via com a atual avenida Tiradentes. Destinou-se ao transporte de tijolos produzidos pelas olarias da Vila Galvão e se situou estrategicamente junto à Estação da Luz e da região central, no local onde atualmente há uma das saídas da Estação Tiradentes do Metrô, junto ao Quartel da Polícia Militar (ibidem).

Em 1904 os seus trilhos foram estendidos também à Várzea do Carmo, alcançando a Estação Mercado, situada na atual Praça Fernando Costa através da rua da Cantareira, assim denominada em função do percurso do trem. Esse prolongamento teve a dupla finalidade de transporte do material para as obras de retificação do rio Tamanduateí, uma vez que as pedras utilizadas provinham da região da Cantareira e também para atender os passageiros situados junto ao centro da cidade. A partir de 1918 essa extensão foi desativada, substituída pelo serviço de bondes, mais eficiente e que interligava também essa área com Santana, voltando a ser a estação principal aquela situada na rua João Teodoro. Em 1927 pretendeu-se a eletrificação da linha ferroviária, o que não foi levado a cabo, mas em 1942, com a ferrovia da Cantareira sendo incorporada à Sorocabana, iniciaram-se estudos para o aumento da bitola. (Jorge, 1988, 90; disponível em <http:// www.wernervana.hpg.com.br> em 2004).

Em 1910 foi a vez do início de operações do ramal que ligou o bairro de Guapira, posteriormente denominado Jaçanã, à linha inicial. Chegando no limite do município de São Paulo com Guarulhos, o prolongamento desse ramal atingiu aquela cidade já em 1912. Essa ligação, seguindo na direção da Parada Inglesa, conectou bairros até então servidos por um sistema viário precário (Jorge, 1988, 90; disponível em <http:// www.wernervana.hpg.com.br> em 2004). Mesmo apresentando limitações técnicas quanto ao número de composições e sua estreita bitola (60 centímetros), esses trilhos favoreceram o crescimento dos subúrbiosestação, processo analisado por Langenbuch (1971), além de contribuir para a ocupação da área da Vila Guilherme e Vila Maria, segundo o mesmo autor. 


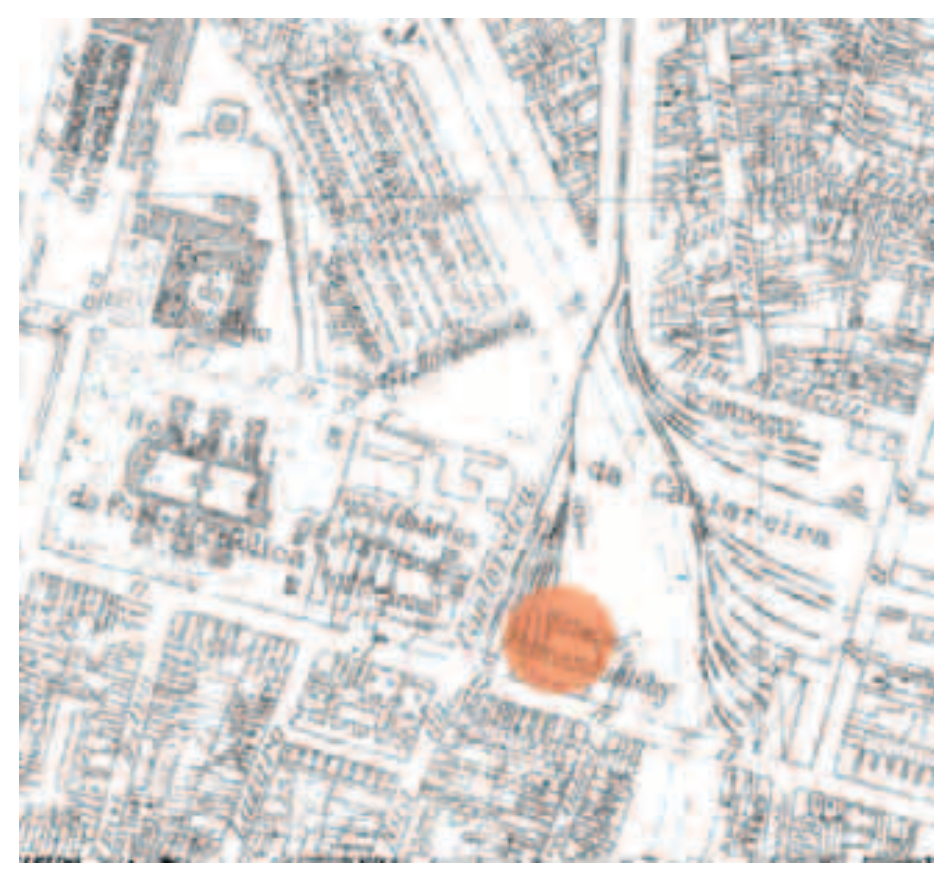

Fig. 134: Mapa Sara-Brasil,

mostrando a localização da

Estação Tamanduateí, "Tramway

da Cantareira", 1930.

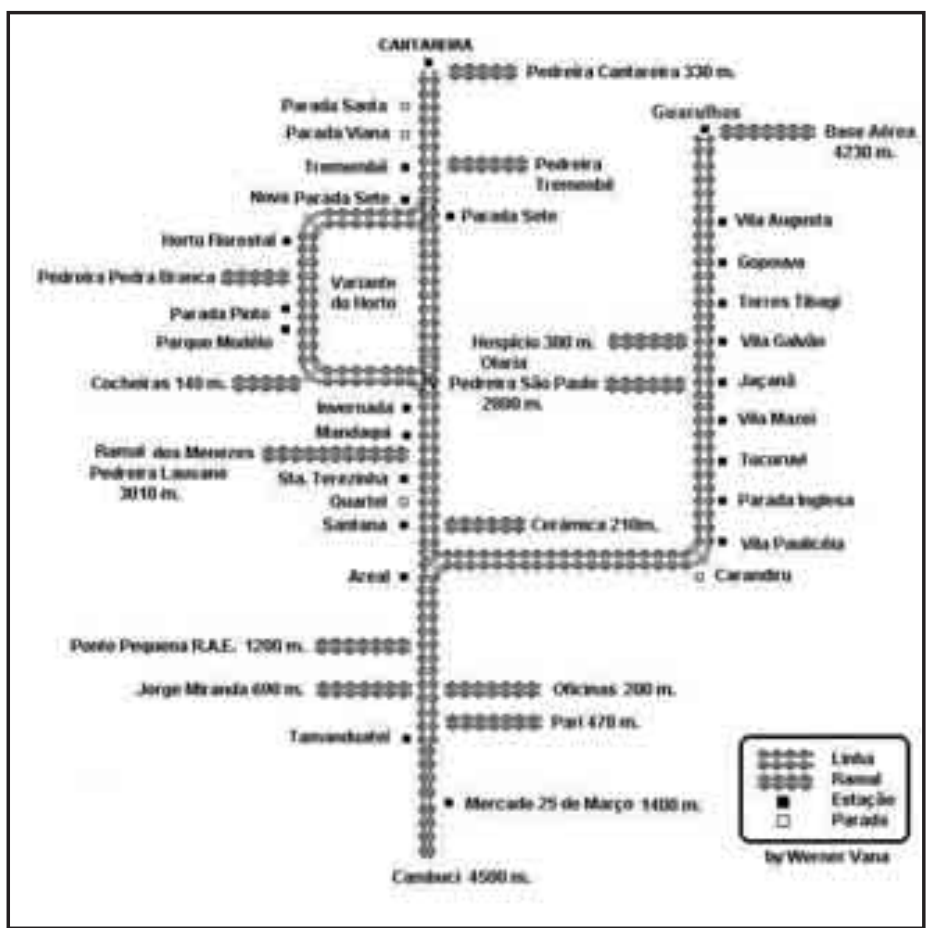

Fig. 135: Mapa esquemático

com o percurso do "Tramway da Cantareira"

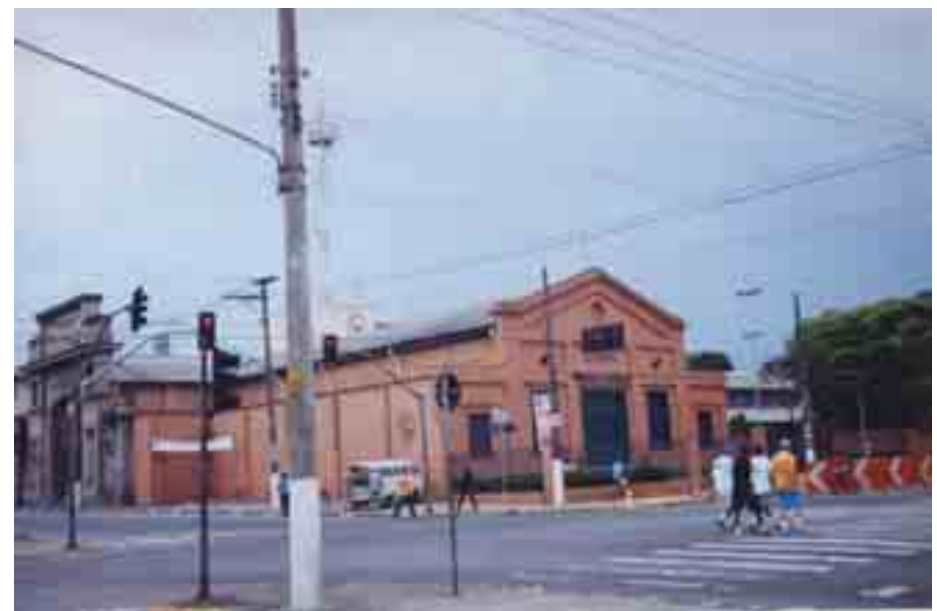

Fig. 136: Antigo local da

estação Tamanduateí, hoje Liceu de Artes e Ofícios de São Paulo. 
Anteriormente ao Plano de Avenidas a Tiradentes ligava-se à rua Florêncio de Abreu compondo a espinha dorsal da cidade, conectadas com as ruas da Liberdade e Domingos de Moraes, já que a ligação norte-sul se efetuava pelo interior do Triângulo (Maia, 1930, 117). Entre 1938 e 1945 foi construída a "Anhangabaú Inferior", posteriormente apenas Anhangabaú, recebendo na década de 1960 a denominação definitiva de Prestes Maia, como já visto na Parte I.

Aproximadamente até o período que seguiu a II Guerra Mundial, o bairro da Luz apresentou referências únicas para a cidade, representadas pelas estações ferroviárias de caráter monumental da Ferrovia Santos-Jundiaí, antiga San Paulo Railway, e da Sorocabana (Ramos de Azevedo, 1914 e Stokler das Neves, 1926). Devido às limitações da rede rodoviária de então, todo o transporte para o interior de São Paulo e outros estados do país, com exceção do Rio de Janeiro, tinha seu ponto inicial ou final nessa área. Esse fator foi determinante para o apogeu de uma rede hoteleira nas cercanias das estações, mas com o declínio do transporte ferroviário a partir da década de 1950, também foi gradualmente abandonada.

Outros marcos relevantes seguiram o mesmo destino devido ao processo de abandono crescente do bairro em relação a outras áreas da cidade: o Jardim da Luz perdeu o status de cartão postal da cidade que manteve durante décadas, substituído por outros espaços com seletividade social exigida pelas elites, como - Jardim Trianon, a Praça da República e o Parque da Aclimação. Na década de 1960, foram transferidas as Escola Politécnica e a Faculdade de Odontologia e Farmácia. Parte do patrimônio histórico foi seriamente ameaçado enquanto que as condições de moradia da população local também se precarizaram, podendo ser verificada essa situação pelo aumento do número dos cortiços nessa área. 


\subsection{2- Ponte Pequena}

Adjacentes à Luz, e tendo com esse bairro espaços que poderiam ser considerados comuns dada a impossibilidade de se estabelecer limites divisórios precisos, o Bom Retiro e a Ponte Pequena tiveram sua formação baseada no parcelamento das chácaras e sítios a partir do século XIX, limitando-se a oeste com o bairro dos Campos Elísios e a leste com o Canindé, respectivamente.

Os mapas de 1881 e 1897 mostram aspectos formadores do bairro da Ponte Pequena no Aterrado da Luz: no primeiro, além do rio Tamanduateí a área em continuidade ao Caminho da Luz ainda não havia sido arruada, havendo apenas pontes de travessia sobre esse rio e sobre o Tietê. No mapa de 1897, a área já apresentava o viário delineado, mostrando as ruas atualmente existentes - Pedro Vicente, Guaporé, Porto Seguro, Eduardo Chaves - e a rua Itaporanga, paralela à avenida Tiradentes, que ao contrário desta, não atravessava $\mathrm{O}$ rio Tietê. $\mathrm{A}$ Ponte Grande, de concepção ferroviária, alinhava-se a avenida Tiradentes, deslocada à montante da atual Ponte das Bandeiras. Esta deu continuidade ao traçado monumental da avenida Santos Dumont, que por sua vez, incorporou o leito da rua ltaporanga.

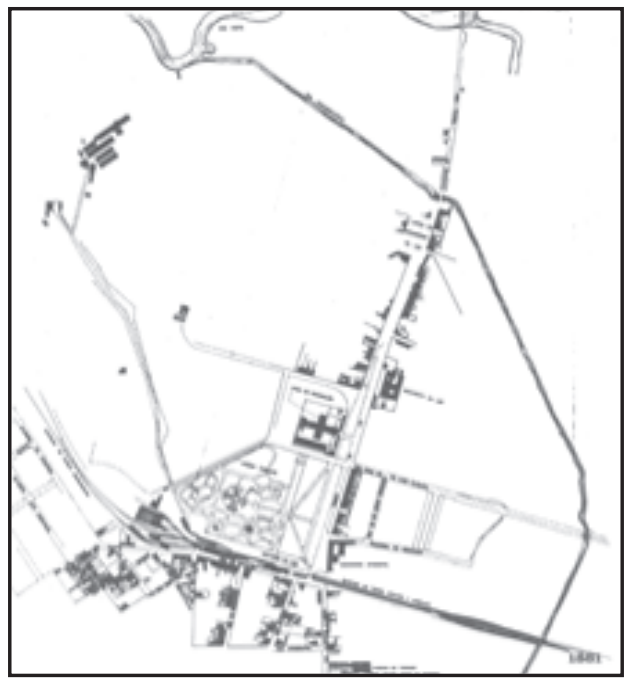

Fig. 137: Ponte Pequena, 1881.

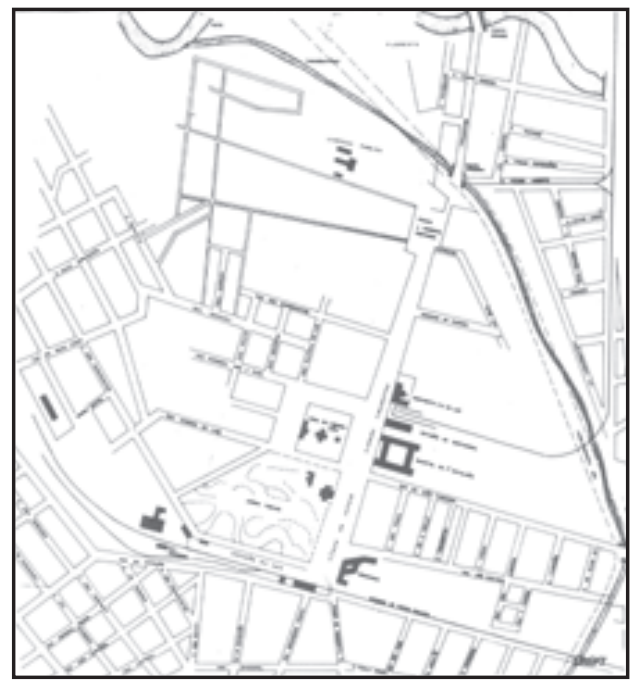

Fig. 138: Ponte Pequena, 1897.

Desde o início de sua ocupação, o bairro se caracterizou pela modéstia das moradias e pela mescla da habitação com algumas indústrias e com o comércio. As vilas e as travessas, ruas consideradas não oficiais pelo Código de Obras de 1929, comprovam ter sido a Ponte Pequena um dos bairros constituintes da extensa faixa de urbanização com características populares, que se estendeu ao longo das terras pouco valorizadas da várzea do Tietê: Catumbi, Canindé, Bom Retiro e Barra Funda. A situação desses bairros e particularmente a Ponte Pequena, pode ser traduzida pelas enchentes periódicas que ocorreram naquela área em 
1906, 1919 e 1929 (Eletropaulo, 1993, 28; Sevcenko, 1992, 29). Segundo registros da enchente de 1919, foram atingidas as "pessoas mais pobres e humildes da cidade" em alusão aos numerosos moradores que ocupavam a área atingida, concentração que ocorria segundo Sevcenko, justamente pelos preços mais baratos dos terrenos e dos aluguéis (Sevcenko, 1992, 29).

Das construções notáveis, a Ponte Pequena só possuiu o registro da Estação de Tratamento de Esgotos, posteriormente demolida. O perímetro do bairro, antes delimitado pela várzea do Tietê ao norte e ao leste e o Aterrado da Luz a oeste, foi definido posteriormente pelas avenidas Santos Dumont ao oeste e a Cruzeiro do Sul a Leste, que possuía desde 1894 os trilhos do Tramway da Cantareira, criando assim um limite com o bairro do Canindé. A rua Pedro Vicente, por sua vez, que estabeleceu a ligação entre os dois bairros, cruzava a avenida Cruzeiro do Sul através de passagem de nível sobre os trilhos da Cantareira.

Embora atingida periodicamente pelas cheias do Tietê, a Ponte Pequena dividia com o Bom Retiro a presença dos clubes de regatas e das competições de remo e natação da cidade, visto a Ponte Grande primeiramente e depois a Ponte das Bandeiras terem sido a linha de chegada dessas provas. Sua toponímia guarda também os locais anteriormente utilizados para o transporte fluvial, como ocorre com a denominação das ruas Porto Seguro e Porto Calvo, caminhos que acessavam os meandros do rio.

Um fato relevante associado à linha do Tramway e à infra-estrutura implantada nessa região, foi o do aproveitamento de estruturas metálicas para a construção da ponte sobre o rio Tietê. Os elementos estruturais utilizados para a construção dessa travessia vieram de um viaduto projetado pelo engenheiro Alberto Kuhlmann em 1888, a ser construído na área central da cidade, ligando o Largo São Bento com o Largo do Paissandu. Posteriormente à importação dos componentes, a Câmara dos Vereadores impediu a construção dessa via elevada, sendo as peças depositadas próximas à várzea do rio e aproveitadas para a construção de três pontes, sendo uma delas a da ferrovia. Essa ponte foi desmontada em 1964 para a construção da atual ponte Cruzeiro do Sul, sendo que a ferrovia foi totalmente desativada em 1965 (Jorge, 1988, 90; diisponível em <http:/ /www.wernervana.hpg.com.br> em 2004).

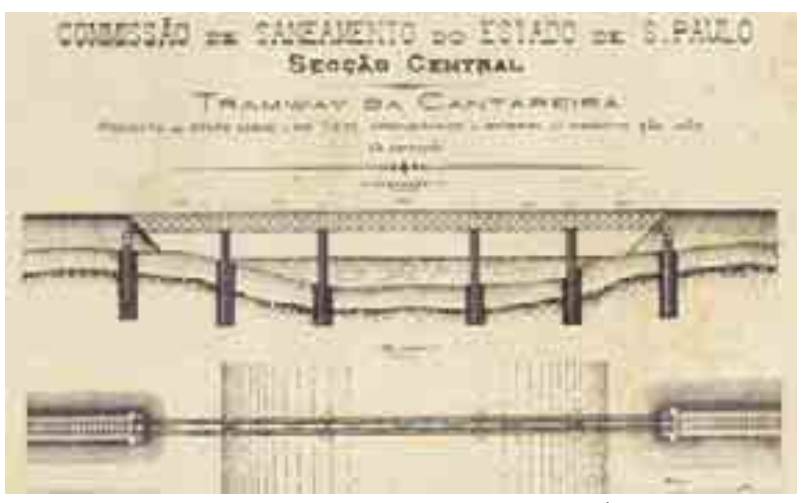

Fig. 139: Projeto para a ponte sobre o Rio Tietê, reaproveitando estruturas metálicas da ligação PaissanduSão Bento não executada. 


\subsection{3 - Bom Retiro}

Com relação ao Bom Retiro, antigos registros indicam ter sido inaugurada por volta de 1859 a primeira grande olaria da cidade nesse bairro (Jorge, 1988, 78). Denominada como Olaria Manfred, utilizou a argila da várzea dos rios Tamanduateí e Tietê e seu proprietário, Manfred Meyer, após adquirir uma grande extensão de terras, procedeu ao seu arruamento, que originou o parcelamento de parte do bairro. Pelos registros históricos, desde o seu nascimento o Bom Retiro apresentou o caráter de uso misto, uma vez que nele abrigaram-se os imigrantes italianos e também foram instaladas fábricas, como a de tecidos na rua Anhaia e uma cervejaria na rua dos Italianos (Dertônio, 1971, 12).

Apesar da presença dos imigrantes e das indústrias nessa área, o loteamento da chácara Mauá, empreendida em 1879 pelos alemães Glete e Nothman, que originou o bairro vizinho dos Campos Elísios, proporcionou a presença da aristocracia cafeeira no entorno do Bom Retiro, onde entre 1880 e 1890, também foram loteadas as chácaras "Bom Retiro", que emprestou o nome ao bairro, a "Dulley", o "Sítio do Carvalho", entre outras. Essa dinâmica certamente influenciou a existência de equipamentos de prestígio no bairro, além da Escola Politécnica, como os que se seguem:

- na área ocupada pela chácara Dulley, onde foi aberta a rua Três Rios, foi construída a Escola de Farmácia em 1904, que funcionava desde 1899 na Santa Efigênia e em 1912 anexou a Escola de Odontologia e Obstetrícia (idem, 13-38).

- nessa mesma rua, foi iniciada em 1907 a construção do Colégio Santa Inês, projeto do engenheiro-arquiteto Domingos Delpiano, que havia projetado também Liceu Coração de Jesus em fins do século XIX (SEMPLA/Emplasa, 1985, 389). Foi fundado para ser uma casa de educação exclusivamente para meninas e moças e para atividades beneficentes e assistenciais. Atendeu durante muito tempo em regime de internato, sendo que em 1928 passou a sediar também o curso normal (Disponível em: <http://www.portal.prefeitura.sp.gov.br/ dph.smc.pmsp>em março 2004).

- embora situado nas imediações do Bom Retiro, mas praticamente no seu limite com Campos Elísios, foi construído na passagem dos séculos XIX e XX outro colégio de ordem religiosa, o Liceu Coração de Jesus, igualmente de Delpiano, inaugurado em 1900 como um liceu de comércio, artes e ofícios anexo ao Santuário do Sagrado Coração de Jesus. A construção desde último foi iniciada em 1881 e concluída em 1901 (SEMPLA/Emplasa, 1984, 175-389).

Outro equipamento instalado no bairro, no começo do século XX, juntamente com a estação de tratamento da Ponte Pequena, mostra as preocupações sanitárias existentes na cidade: o Desinfetório na rua Tenente Pena, que atuava 
na desinfecção de casas quando surgia o registro de doenças epidêmicas (Dertônio, 1971, 34).

Nas décadas seguintes, a ferrovia San Paulo Railway, futura Santos-Jundiaí, ao percorrer os limites entre o Bom Retiro e os bairros vizinhos, definiu os espaços lindeiros à linha que foram ocupados pelas indústrias. Esse fato, aliado à imigração européia, transformou o Bom Retiro em um bairro com características operárias, sendo registrado em sua toponímia os locais ocupados pelas colônias, como por exemplo a rua dos Italianos, ou a rua dos Imigrantes, futura José Paulino.

Um estudo sobre a formação do Bom Retiro considerou ter surgido esse bairro com estrutura e funções específicas, atribuindo esse fato às poucas ligações com outros bairros, situação só melhorada por volta de 1900 quando se construiu a passagem de nível sob as ferrovias, resultando a ligação da alameda Nothman com a rua Silva Pinto, além de melhoramentos nas ligações com a Santa Efigênia, com o Brás e o Parí (Mendes apud Azevedo (org) 1958, 197).

Pela Lei municipal $n^{\circ} 3.427$ de 1929, parte do bairro ainda se encontrava em área suburbana, sendo o limite entre a zona urbana definido pelas atuais ruas Jorge Velho, Salvador Leme, Afonso Pena, Bandeirantes, Joaquim Murtinho, Guarani, Tocantins, Matarazzo, Jaraguá e avenida Rudge (Dertônio, 13-17).

Ao longo das primeiras décadas do século XX, o Bom Retiro se transformou num mosaico de etnias, que se juntaram aos primeiros moradores, como mostrou Véras em seu estudo sobre a imigração estrangeira: sírios-libaneses e armênios a partir de 1920, estes últimos refugiados do massacre turco e os judeus, que na década de 1930 já somavam 20.000 pessoas, sendo o Bom Retiro a primeira preferência dessa população, que superou os imigrantes italianos no bairro (Véras, 2003, 92-94).

A função comercial no Bom Retiro se iniciou a partir da rua José Paulino, que no início do século passado estabelecia a ligação do bairro com o centro e com a rua São Caetano e os bairros do Brás e do Pari. Para os usuários da ferrovia que utilizavam a Estação da Luz, a penetração às ruas do bairro se dava por essa via. Essa função de ligação fez com que a rua José Paulino apresentasse um caráter comercial diversificado, com membros da colônia portuguesa explorando as lojas de produtos alimentícios, os da colônia árabe as de roupas e a partir de 1940, a colônia judaica também voltada a esse setor (Dertônio, 1971, 78-79). Na rua Sólon, devido à proximidade da ferrovia e da facilidade em se estender ramais, inúmeras indústrias se instalaram nas primeiras décadas do século XX, entre elas, a montagem dos carros da Ford, como já visto anteriormente. No caso da Barra Funda, a área contígua ao Bom Retiro, recebeu um parcelamento que favoreceu a presença de grandes lotes para as indústrias, havendo mesmo uma continuidade viária entre os dois bairros, como no caso das ruas Barra do Tibagí e do Bosque. 

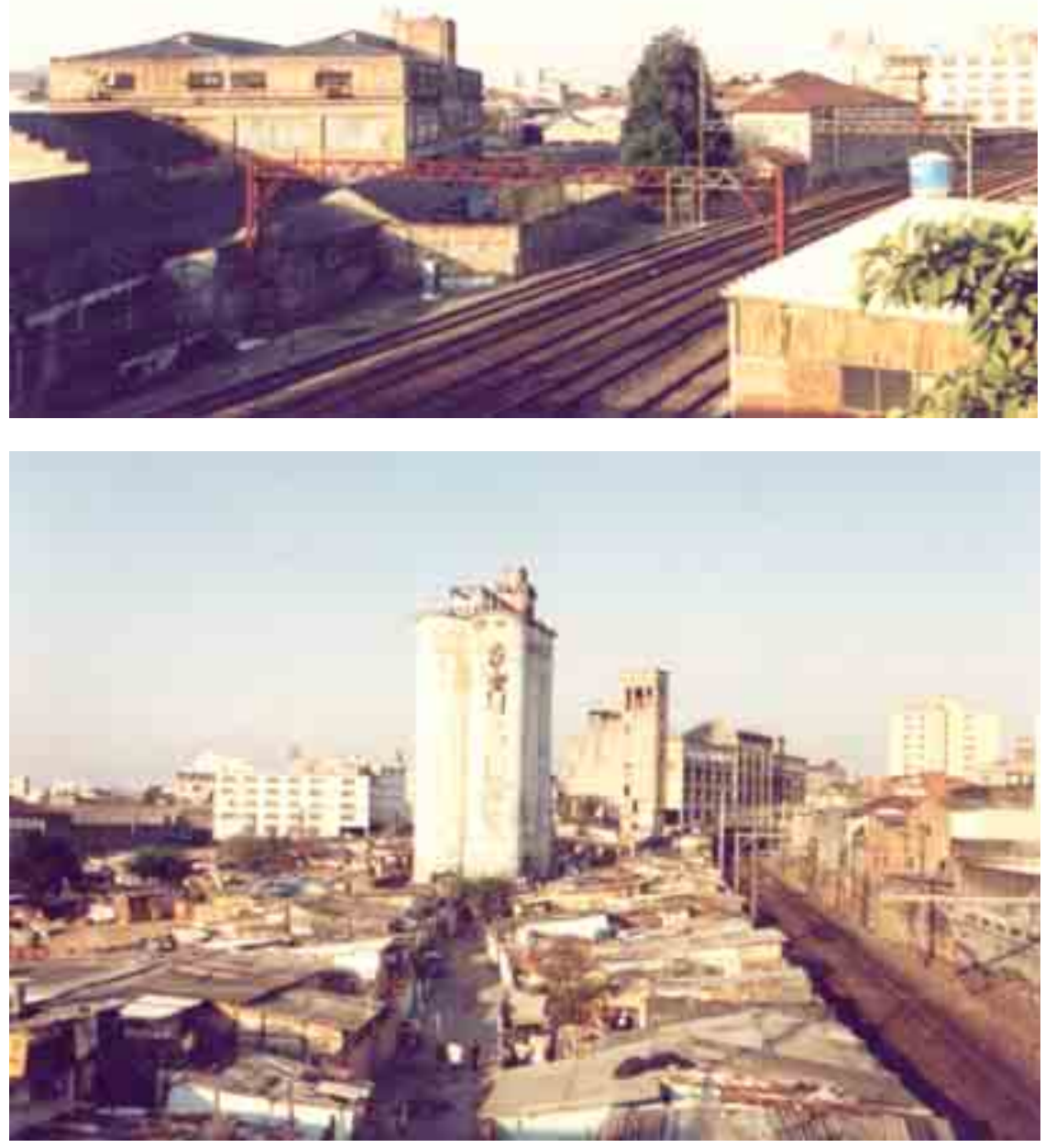

Fig. 141: Orla

ferroviária, antigo Moinho Santista.

Ao longo do século XX, o Bom Retiro gradualmente cedeu os locais de moradia para o comércio, embora mantendo certas concentrações caracterizadas por tipologias diferenciadas, mas com predomínio popular, como ocorreu nos espaços próximos da Barra Funda. Apenas em áreas próximas ao Jardim da Luz e rua Três Rios uma setorização de renda mais alta passou a predominar, expressa por edifícios de gabarito médio ocupados principalmente por membros da colônia judaica.

O Bom Retiro já apresentava os traços presentes na atualidade desde a década de 1950, quando Mendes assim descreveu sua morfologia: "O bairro do Bom 
Retiro nada apresenta de especial em sua paisagem urbana. Predomina o casario velho e modesto, em geral datando de fins do século XIX e início do atual. Mas há dois aspectos dignos de referência: em primeiro lugar a penetração dos 'arranha-céus' residenciais, sobretudo na rua Prates e vizinhanças; em segundo lugar a recente conquista da várzea pelo bairro, através dos prolongamentos de muitas de suas ruas e a ligação com a várzea da Barra Funda, no trecho servido pela avenida Rudge. Daí vem resultando uma certa separação entre duas porções do bairro - a que localiza nas colinas (com suas fábricas, oficinas, casas de comércio, população israelita) e a que se expande pela várzea do Tietê (com população de nível de vida bem mais modesto) (Mendes apud Azevedo, (org), 1958, 204).

Mendes também verificou a existência do fenômeno da diminuição da população, pois o subdistrito do Bom Retiro tinha em 1934, 28.449 habitantes, em 1940, 27.617 e em 1950, 23.043 habitantes. Contudo, o mesmo apresentava altos índices de densidade demográfica, pois enquanto a Santa Ifigênia possuía746 hab/Km², o Bom Retiro tinha 9.600 hab/Km² (idem, 199)

A partir da década de 1960 o bairro começou a receber membros da colônia coreana, que se instalaram no ramo de confecções, substituindo gradualmente ao longo das décadas seguintes, a participação dos árabes e judeus no setor. Outro fenômeno foi o do fechamento ou transferência das indústrias que anteriormente ocupavam o bairro, proporcionando o crescimento das atividades comerciais direcionadas ao ramo de confecções e também a atratividade para grupos de imigrantes latino-americanos se fixarem no Bom Retiro ou em bairros vizinhos, em busca de oportunidades de trabalho.

Fig. 142: Chácara Carvalho, residência de Antônio Prado, Barra Funda.

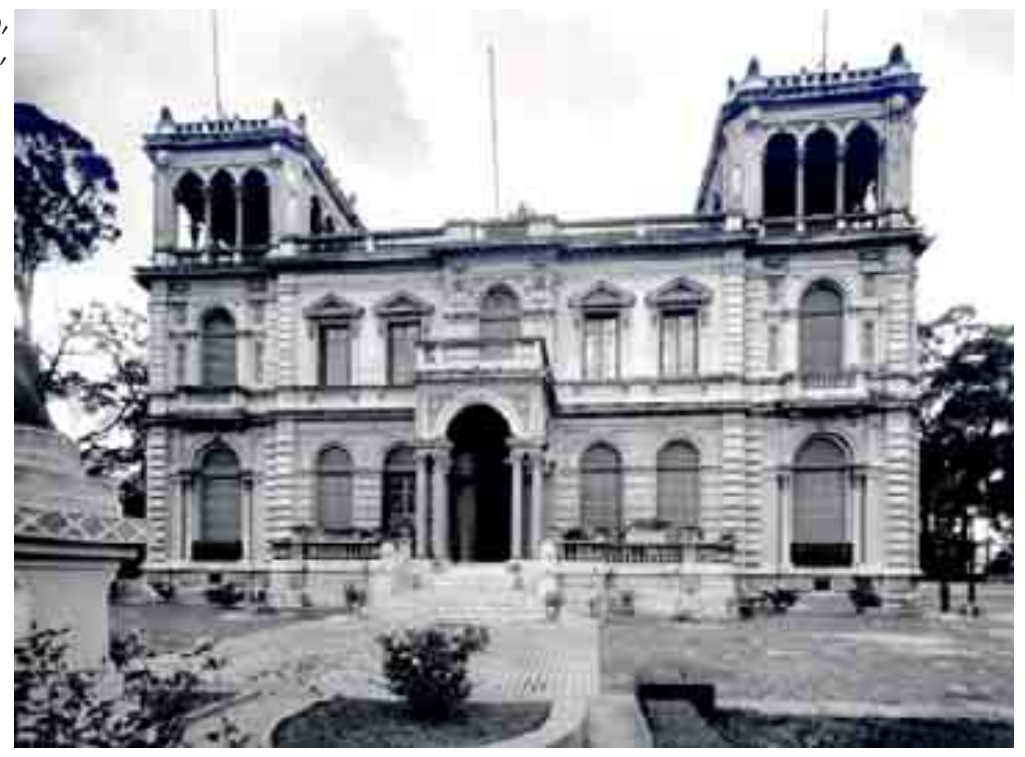




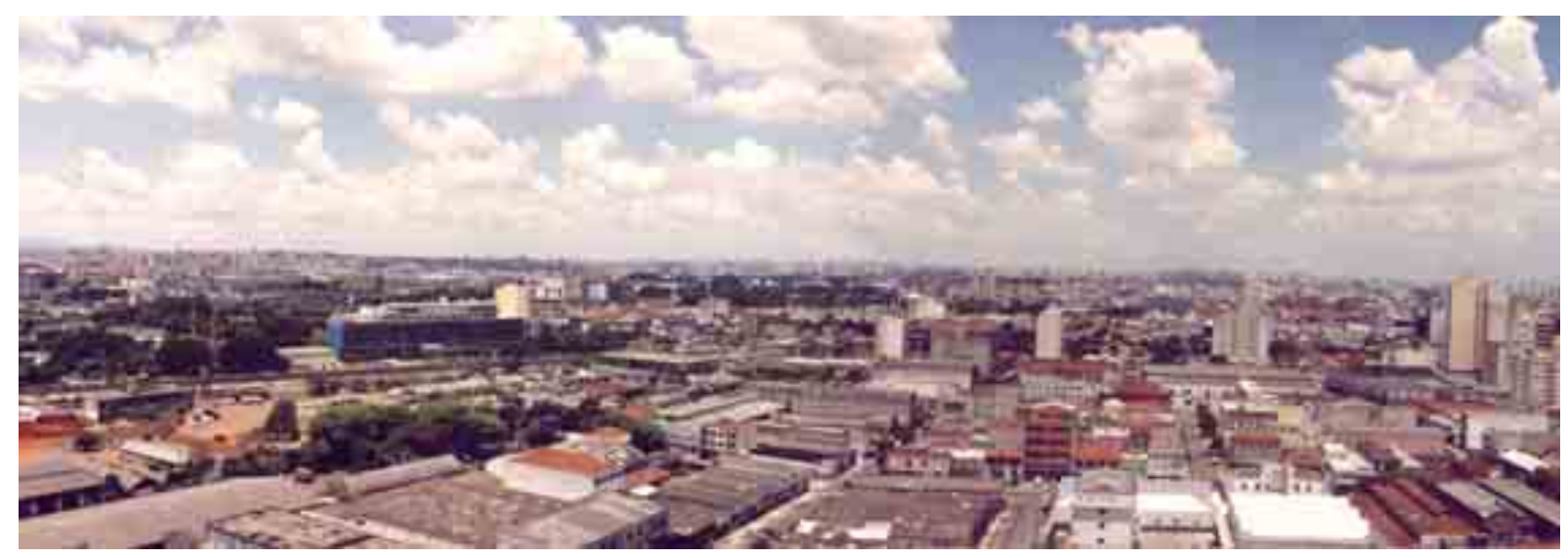

Fig. 143: Vista aérea, Bom Retiro, sentido Av.

Estados, 2001.

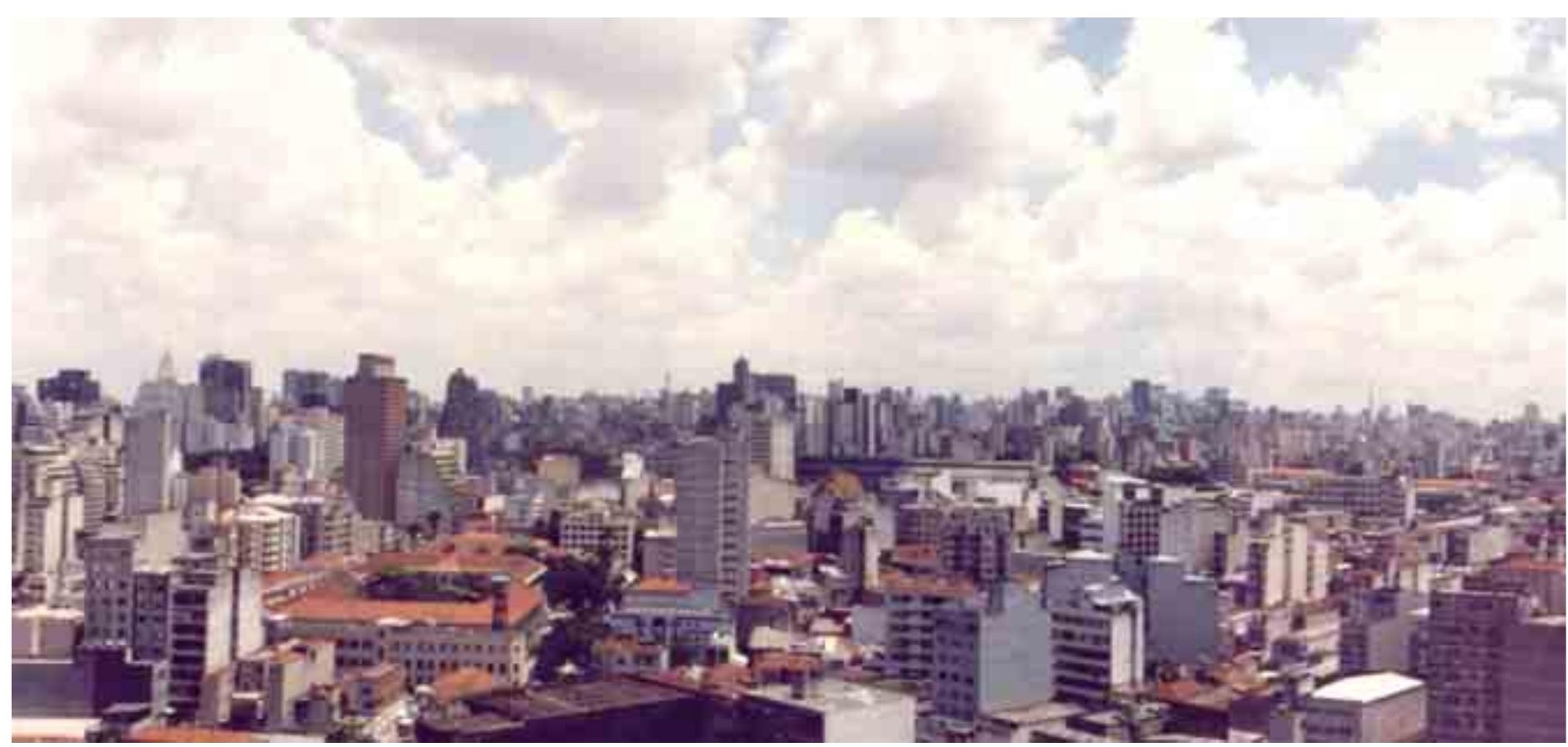

Fig. 144: Vista aérea, Bom Retiro, sentido Barra

Funda, 2001. 


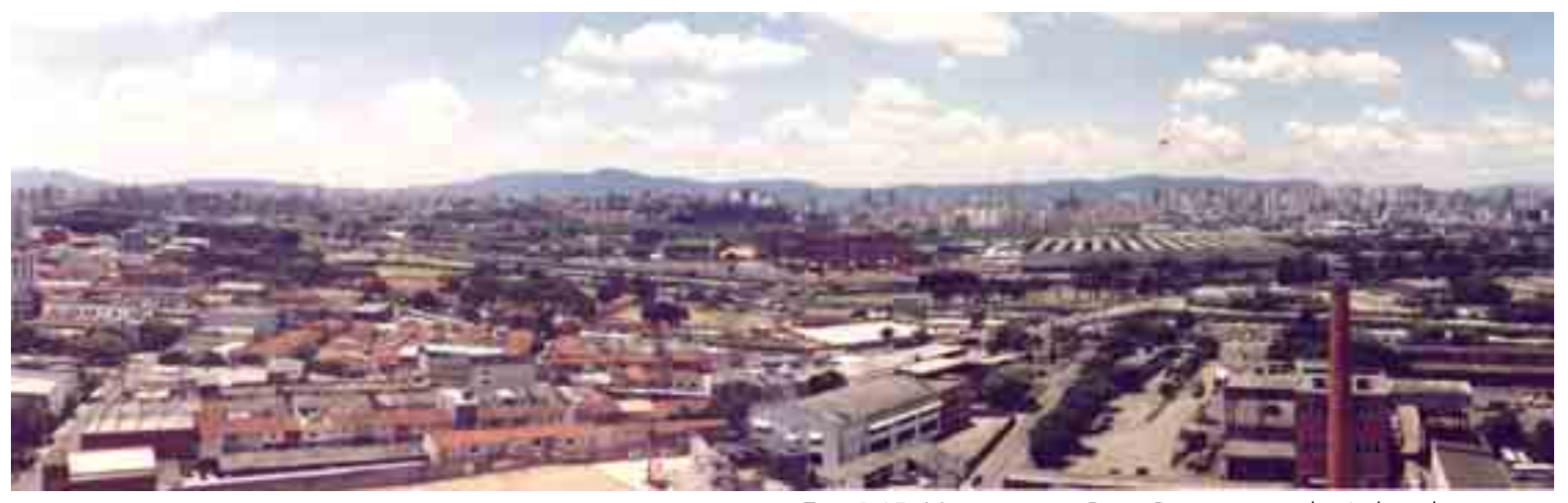

Fig. 145: Vista aérea, Bom Retiro, sentido Anhembi,

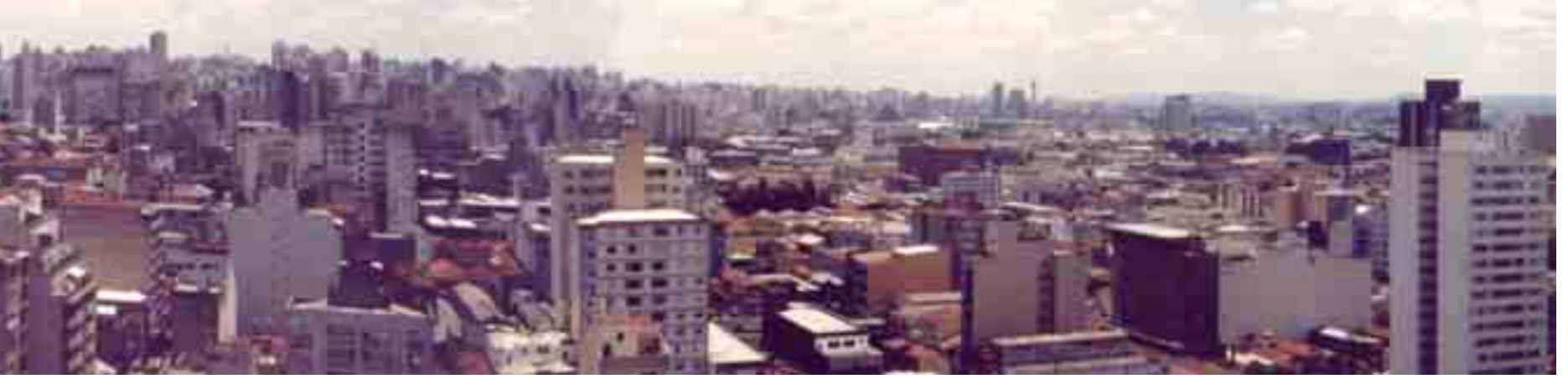




\subsection{4 - Análise dos sub-setores}

O distrito do Bom Retiro já apresentava pelo levantamento cartográfico de 1930 quatro vias estruturais, as avenidas Rudge, Tiradentes, Tamanduateí (futura dos Estados) e a Cruzeiro do Sul. A avenida Tiradentes, a principal ligação norte-sul da cidade, conectava a rua Voluntários da Pátria, em Santana, através da Ponte Grande. A Avenida Cruzeiro do Sul, que dividia a Ponte Pequena e o bairro do Canindé, ainda não havia recebido essa denominação na carta de 1930 e se constituía em uma via, com os trilhos do trem da Cantareira correndo em nível elevado por aterro em seu eixo.

Com exceção das ruas que chegavam na Várzea do rio Tietê, praticamente todo o sistema viário se encontrava implantado, bem como a maioria da área já se encontrava parcelada e ocupada. A principal alteração viária ocorreu exatamente com na ligação norte-sul, como já enfocado na análise da evolução das radiais do Plano de Avenidas.

O distrito pode ser divido em três sub-setores, que correspondem aproximadamente à extensão dos bairros em seu interior, definidos por características morfológicas e funcionais:

$1^{\circ}$ - Esse sub-setor caracteriza-se por se constituir em uma referência histórica e paisagística da cidade, formado pela área envoltória do Jardim da Luz, incorporando a Estação e a quadra entre o jardim e a atual Praça Cel Fernando Prestes, onde se localizaram também a Cadeia Pública e o Colégio Prudente de Morais. Apresentava-se integrado ao norte e oeste com a área do Bom Retiro e ao sul com a área central, onde, como foi visto anteriormente, ainda não havia sido aberta a avenida Anhangabaú Inferior. Ao leste compreende a face de quadra da avenida Tiradentes onde se situavam o Colégio Arquidiocesano, o Quartel da Força Pública e o Convento de N. Sa da Luz, atual Museu de Arte Sacra, estendendo-se até a avenida Tamanduateí, incorporava as ruas 25 de Janeiro, São Caetano, João Teodoro, Jorge Miranda e tendo como limite a rua Rodrigo de Barros.

O mapa de 1954, confrontado com o de 1930, não mostra alterações no entorno do Jardim além do novo edifício do Colégio Prudente de Morais, projeto de 1950 do arquiteto Hélio Duarte e acréscimos no Presídio Tiradentes. Ao sul, a avenida Anhangabaú já havia sido aberta, formando a componente principal do Plano de Avenidas juntamente com a avenida Tiradentes. No mapa de 1972, a alteração mais evidente foi a da obra da construção da linha Norte-Sul do Metrô defronte a Pinacoteca do Estado, antigo Liceu de Artes e Ofícios. Como decorrência da implantação da linha subterrânea do Metrô, nessa época a avenida Tiradentes perdeu o conjunto escultórico em homenagem a Ramos de Azevedo, situado defronte da Pinacoteca do Estado, antigo Liceu de Artes e Ofícios, que estabelecia uma relação com esse edifício e o Jardim da Luz, além de criar uma identidade a uma das principais portas da cidade. 


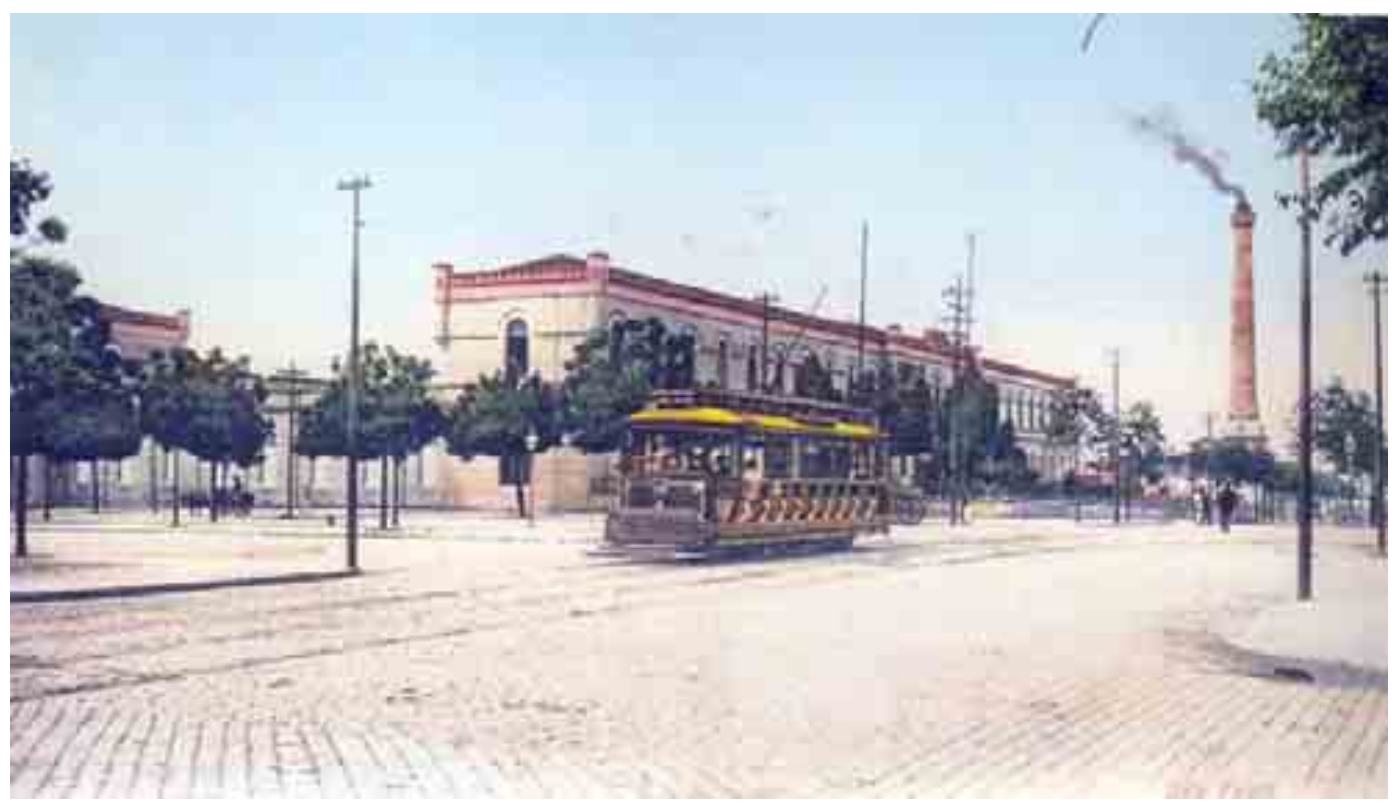

Fig. 146: Av. Tiradentes, 1907.

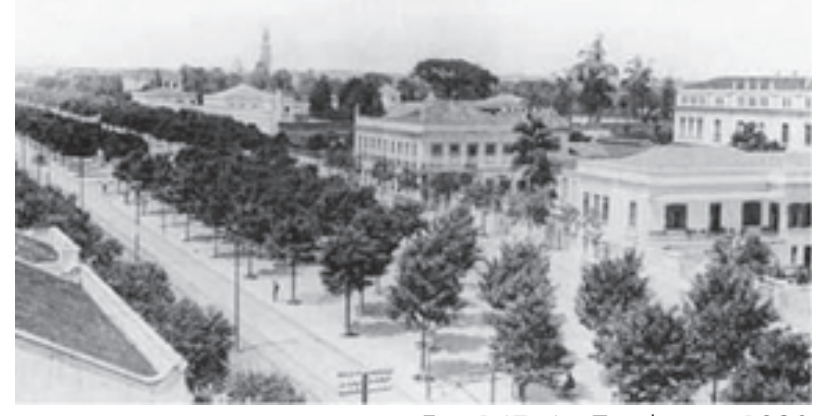

Fig. 147: Av. Tiradentes, 1920.

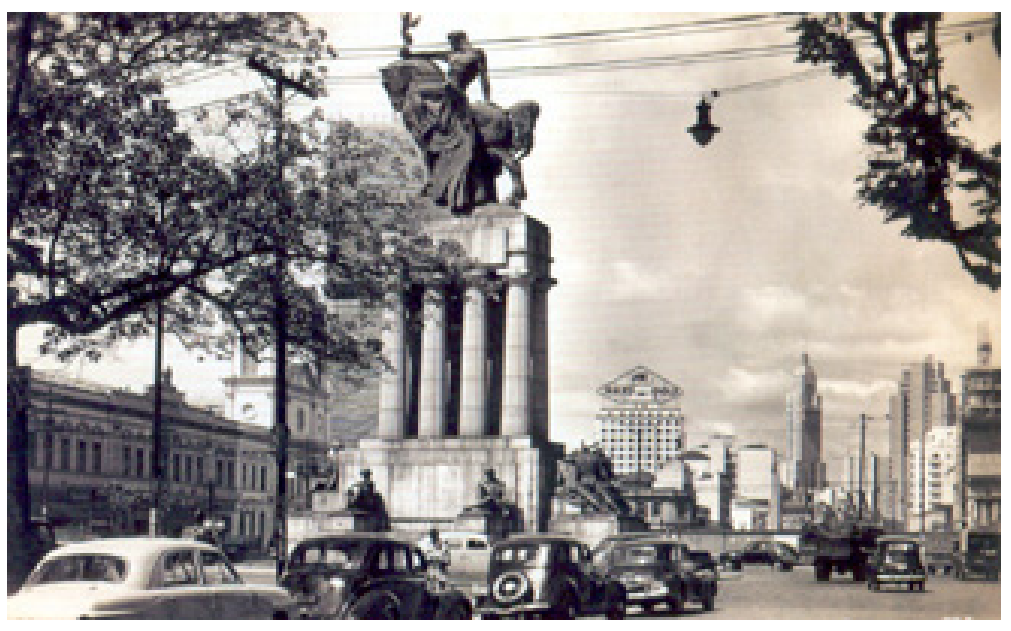

Fig. 147: Conjunto escultórico em homenagem à Ramos de Azevedo na Av. Tiradentes, déc. 1950. 
Entre as ruas Jorge Miranda e João Teodoro encontravam-se implantados os edifícios do Quartel da Cavalaria, a Usina Elétrica, o Hospital da Força Pública, - Liceu de Artes e Ofícios e a Estação Tamanduateí, do Tramway da Cantareira. As ruas Jorge Miranda e da Cantareira já haviam perdido os ramais da ferrovia. O limite constituído pelas avenidas Tamanduateí (atual dos Estados) e Cruzeiro do Sul caracterizava-se como uma transição entre os bairros da Luz, Brás e Canindé. A Vila Economizadora, construída em 1907, bem como todo o casario já se encontrava implantado nesse sub-setor, na confluência da Ruja S. Caetano com a Av. Tamanduateí.

Pelo levantamento cadastral de 1954 a ocupação permaneceu inalterada, tanto em relação às quadras entre as ruas João Teodoro e 25 de Janeiro, quanto às instituições militares e religiosas. Já pelo levantamento de 1972 verifica-se a retirada dos trilhos e a demolição das instalações do Trem da Cantareira, ocorrida em 1964. A demolição de parte das instalações da antiga Usina de Energia só foi ocorrer na década de 1980 para o alargamento da rua João Teodoro.

Nas ruas João Teodoro e São Caetano, a ocupação se mostrou diferenciada em relação às especializações que foram se desenvolveram em cada uma delas. $\mathrm{Na}$

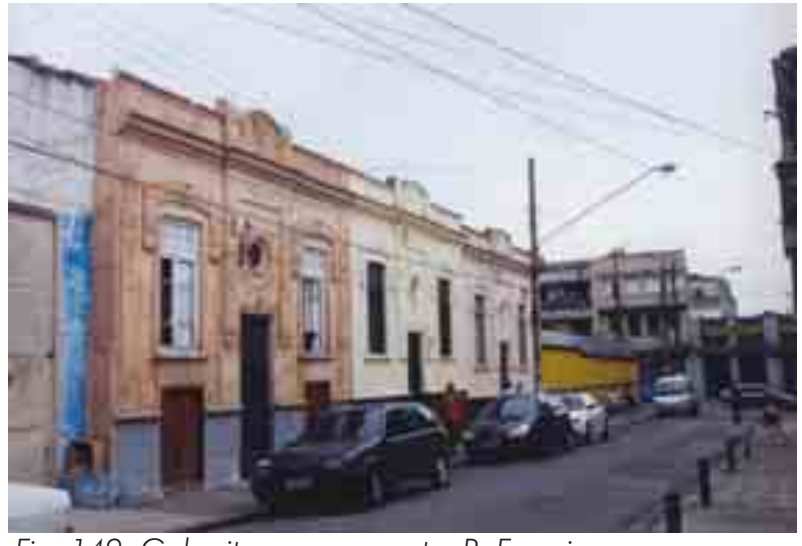

Fig. 149: Gabarito remanescente. R. Francisco Sá Brabosa, travessa da R. Cantareira, 2004.

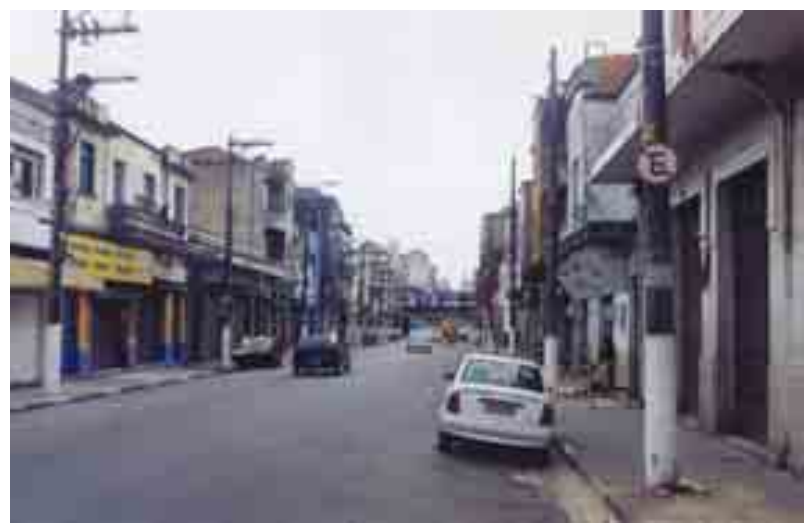

Fig. 150: Rua Cantareira, sentido centro, 2004. primeira, verificou-se o uso para moradia com diferentes tipologias em sua extensão com maior presença de estabelecimentos comerciais na direção da avenida Tiradentes. Verifica-se a permanência de antigas residências unifamiliares, juntamente com pequenos edifícios, com o pavimento térreo, por vezes, também possuindo estabelecimento comercial. O perfil dessa rua é mais diversificado do que o da São Caetano, pois reuniu desde lojas para venda de fardamentos militares, cestas de vime, oficinas, depósitos variados, hotéis e até indústrias de pequeno porte. Na rua São Caetano a ocupação diversificada incluiu um setor comercial especializado em confecções 
para noivas, edifícios de serviços e lojas de máquinas de costura, vocações que foram reforçadas desde a década de 1950. Além da presença da Vila Economizadora nessa própria via, a moradia popular coexistiu também com as atividades comerciais em toda sua extensão, fato verificado pela presença de inúmeros edifícios residenciais de gabaritos baixo e médio, que foram construídos desde as primeiras décadas do século XX, concentrados principalmente no trecho entre as ruas Monsenhor Andrade e da Cantareira.

Nas transversais às ruas João Teodoro e São Caetano, a tipologia construtiva predominante foi a de moradia horizontalizada, em sua maioria de pequenas residências térreas ou mescladas com espaço para comércio, implantadas nas divisas dos lotes, constituindo conjuntos agrupados. Embora sempre essa área tenha apresentado uso misto, a não renovação dos imóveis causada pelo crescimento da atividade comercial e da circulação, provocou alterações tanto na antiga tipologia quanto no perfil dos moradores, com significativo aumento da população encortiçada desde a década de 1970. Devido a esse processo, para essa área foi proposto no ano de 2002 um plano para atuação conjunta de habitação social e requalificação ambiental, o Programa de Reabilitação Integrada do Habitat - PRIH Luz, da Prefeitura de São Paulo, que será abordado adiante.

$2^{\circ}-$ Esse sub-setor compreende a área mais relacionada com a identidade do Bom Retiro, que abarca o seu perímetro comercial e os espaços que foram ocupados por atividades industriais, na transição com o bairro da Barra Funda. Como não poderia ser diferente, devido a integração dos espaços, alguns locais e marcos são identificados também com a Luz, como por exemplo, a Escola Politécnica. Além dela, no interior desse sub-setor, pela carta de 1930 as principais referências já se encontravam
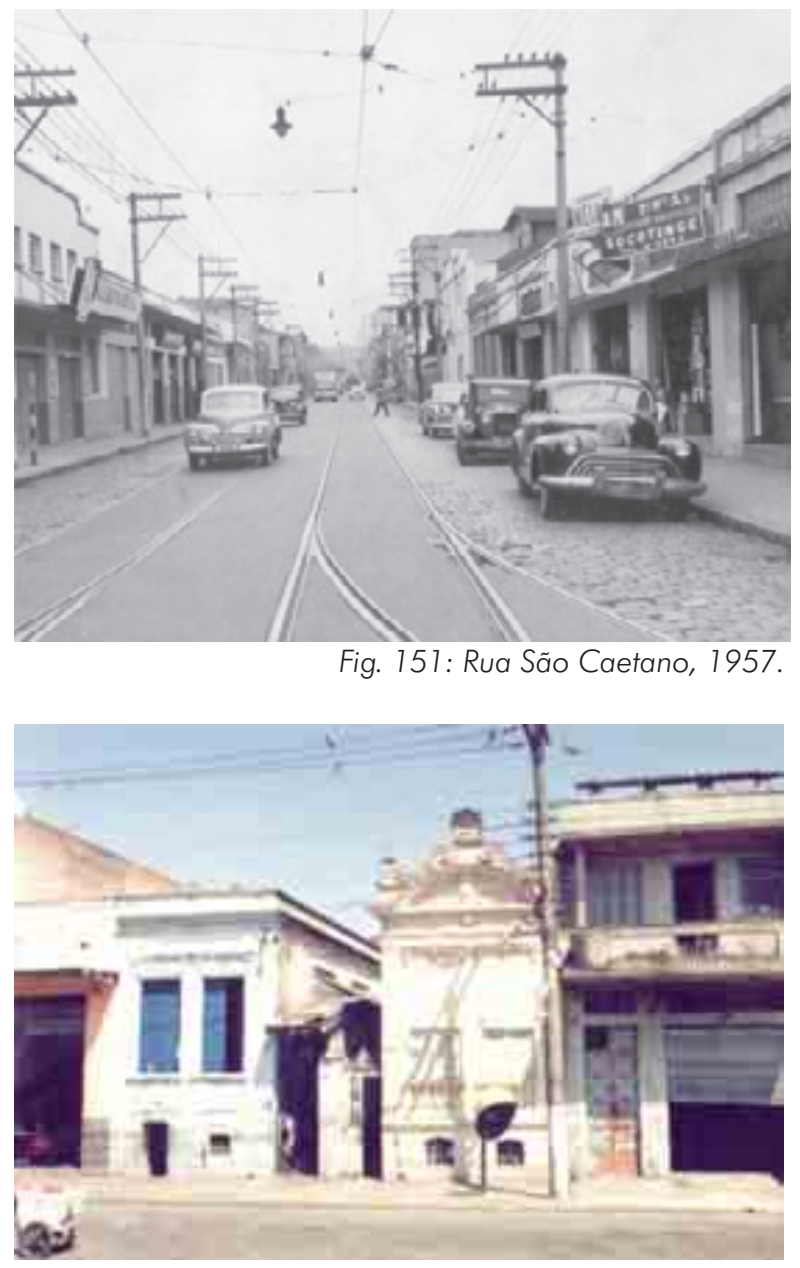

Fig. 152: Tipologias remanescentes. Rua João Teodoro, 2004. 


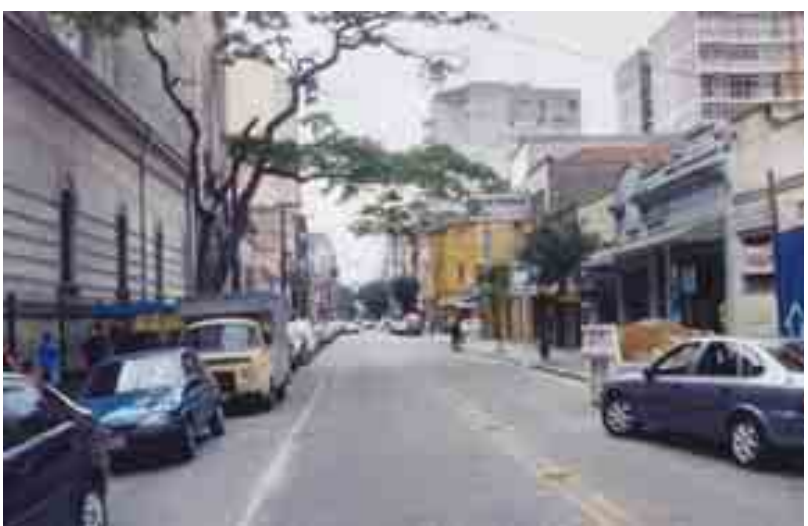

Fig. 153: Rua Três Rios. implantadas na rua Três Rios, representadas pelo Colégio Santa Inês e pela Escola de Farmácia e Odontologia.

Apesar do sistema viário se encontrar quase totalmente implantado, a avenida Tiradentes apresentava seu antigo traçado, além da ruas Bandeirantes, Prates, Jorge Velho, Salvador Leme e João Kopke constarem ainda como vias projetadas e consideradas pela legislação municipal de 1929 como pertencentes ao perímetro suburbano.

Ao sul, os eixos ferroviários se constituíram em uma barreira vencida em apenas três locais: pela avenida Tiradentes, devido ao rebaixamento da linha férrea, pela ponte desta sobre a alameda Nothmann e pela passagem em nível na alameda Rio Branco. Apesar da barreira representada pelos trilhos, até essa via, posteriormente denominada avenida Rio Branco, o parcelamento apresentava características semelhantes às do Bom Retiro, mudando além desta para lotes muito maiores no então aristocrático bairro dos Campos Elísios.

Pelo levantamento de 1954, a principal alteração nesse sub-setor foi a de ter sido concluída a ocupação da área compreendida entre as ruas Bandeirantes e Rodolfo Miranda, indicando a continuidade da vocação mista do bairro, com residências e galpões. Além disso, percebe-se o início de transformação do perímetro compreendido pelas ruas Prates, Afonso Pena, Bandeirantes e Três Rios, onde alguns lotes foram remembrados para permitir o aproveitamento vertical, como foi observado pelo estudo de Mendes, já em 1958.

No levantamento de 1972 verifica-se a ocupação dos poucos lotes que ainda figuravam vazios na carta cadastral anterior, comprovando a intensificação do parcelamento, como no caso da rua Anhaia, mais próxima à ferrovia e do final da rua Prates, interrompida pelos muros da Administração Regional da Sé. $\bigcirc$ perímetro compreendido pelas ruas Prates, Afonso Pena, Bandeirantes e Três Rios apresentou considerável remembramento dos lotes, indicando o aumento da verticalização que seguiu um padrão de gabaritos médios, configurando uma área de uso misto com serviços mais voltados à população moradora do que nos quarteirões comerciais. Essa ocupação definiu também uma ocupação mais homogênea da classe média, com a presença de famílias da colônia judaica.

Ao norte esse sub-setor delimita-se pela Várzea do rio Tietê e pelas avenidas Rudge e Tiradentes a oeste e leste respectivamente. A rua Júlio Conceição 
estabelece a transição da área comercial com aquela que foi ocupada pelas indústrias. Pela carta de 1930, a malha viária já interconectava toda a área do bairro, se constituindo em prolongamento daquela que estruturava também a Barra Funda. A principal barreira à ocupação urbana era a Várzea do Tietê, mas já existiam os clubes de regatas na margem desse rio, que se constituía em importante área de recreio. Outras presenças eram a da Limpeza Pública e do Depósito Municipal, nas áreas que receberiam posteriormente a usina de transbordo de lixo e a Administração Regional da Sé.

O parcelamento permite identificar grandes lotes a partir da rua Tenente Pena em direção à Várzea do Tietê, configurando a área industrial do Bom Retiro, também ligada à Barra Funda pelo sistema viário e pelas linhas das ferrovias. Ruas como Barra do Tibagí, no Bom Retiro e do Bosque, na Barra Funda, apresentam continuidade de traçado, da divisão fundiária e da ocupação, entremeando lotes de grandes e pequenas dimensões.

A carta de 1954 mostra que o aumento da ocupação da Várzea do rio Tietê, nos vinte e sete anos que separaram esse levantamento cadastral do anterior, não se mostrou tão intenso quanto o verificado no período seguinte, até 1972. Considerando que as fotos aéreas foram realizadas em 1954, verifica-se a continuidade do padrão anteriormente existente, sendo significativo o parcelamento ao longo da avenida Rudge, que contrasta com o das outras vias estruturais do bairro, devido ao fato da ocupação dessas já haver ocorrido antes da década de 1950.

Outra diferenciação ocorre na transição do Bom Retiro com a Barra Funda, já que nesse último bairro é possível se verificar um significativo aumento da ocupação, principalmente na sua área mais baixa. Devido a eliminação de alguns meandros existentes na margem esquerda do rio Tietê, pelo levantamento de 1954 já começara a ser configurada a área de equipamentos públicos ao longo do canal do Tamanduateí. A implantação da avenida Santos Dumont e da Ponte das Bandeiras, como anteriormente visto, definiram o principal eixo de ligação norte-sul da cidade.
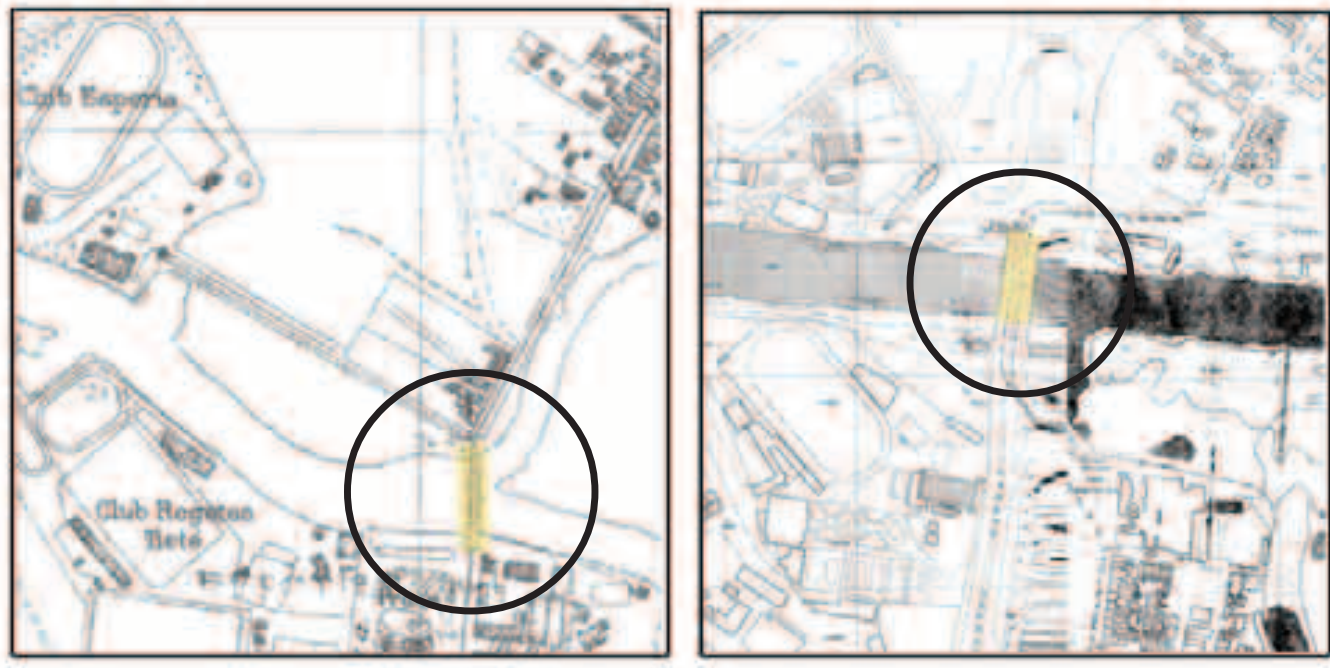

Fig. 154: Detalhes dos mapas de 1930, à esquerda (Ponte Grande) e 1954, à direita (Ponte das Bandeiras) sobre o rio Tietê. 
Pelo mapa de 1972 a ocupação ao longo do rio Tietê se caracterizou como a principal alteração em relação ao período anterior, uma vez que as características morfológicas gerais foram mantidas sem mudanças significativas. As transformações foram provocadas pela implantação de dois importantes elementos infra-estruturais: a conclusão da retificação do Tietê e do traçado da avenida marginal ao rio, ambos concluídos em fins da década de 1960. Esses dois elementos contribuíram para a existência de inúmeras áreas lindeiras remanescentes, desde a Lapa até o Belenzinho, e no caso do Bom Retiro, ampliaram a ocupação da Várzea e definiram os espaços públicos ocupados pelo Parque onde foi implantado o Estádio Municipal de Beisebol, entre as duas pistas da marginal. Seguindo a margem esquerda do canal do Tamanduateí, implantou-se também a área do Departamento de Limpeza Pública, com usina de transbordo de lixo e incinerador e as dependências da Administração Regional da Sé, ambas ocupando aproximadamente seis hectares.

Na margem direita do canal, foi construído o edifício da Secretaria Estadual de Transportes e toda a área restante foi ocupada pelas instalações da SABESP, configurando uma área de continuidade ao clube de regatas que ficou segregado do rio Tietê devido às pistas expressas da marginal.

Na atualidade, dois setores apresentam maior presença da habitação no bairro:

- O setor constituído por edifícios de gabarito médio no quadrilátero das ruas Afonso Pena, Bandeirantes, Três Rios e Correia de Melo, que inclue ruas Guarani e Amazonas.

- O setor constituído pelo perímetro das ruas Sólon, avenida Sérgio Tomás, avenida Rudge e rua dos Italianos, que incluem as ruas Barra do Tibagí, Jaraguá e Javaés. Nesse caso, verifica-se a presença de edifícios com poucos andares e a presença maior de habitação horizontal, ainda com conjuntos de características populares do início do século passado, como é o caso do renque de casas na rua Barra do Tibagí e dos conjuntos na rua Sólon.

$3^{\circ}$ - Esse sub-setor compreende o bairro da Ponte Pequena e uma área de transição entre este e o bairro da Luz, em que a rua Rodrigo de Barros fecha o perímetro entre as avenidas Tiradentes e Cruzeiro do Sul, sendo que o rio Tietê era vencido na época pela Ponte Grande.

Com o sistema viário totalmente implantado já na década de 1930, a área entre as ruas Rodrigo de Barros e Pedro Vicente permite observar o intenso parcelamento, com poucos lotes vazios. As construções, alinhadas ao longo do comprimento dos lotes, revelam as características morfológicas existentes até a atualidade, com a presença de inúmeras vilas entre as avenidas Tiradentes e Cruzeiro do Sul. Acima da rua Pedro Vicente, o conjunto de vias interligava as avenidas mencionadas com a Praça dos Esportes, atual Bento de Camargo, 


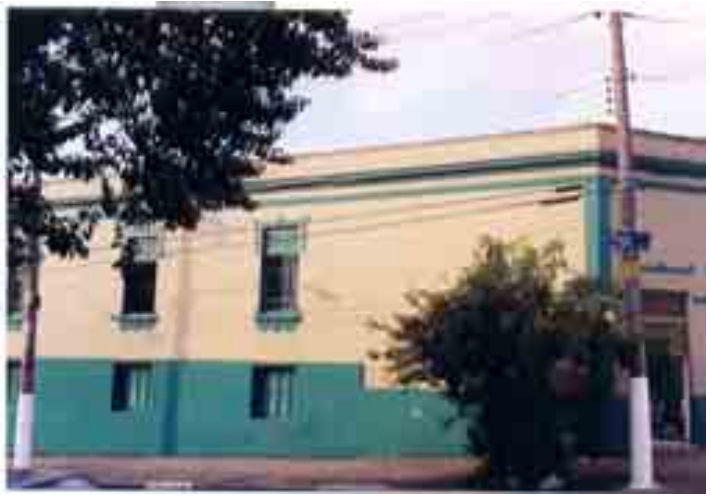

Fig. 155: Tipologia remanescente, Rua Sólon.

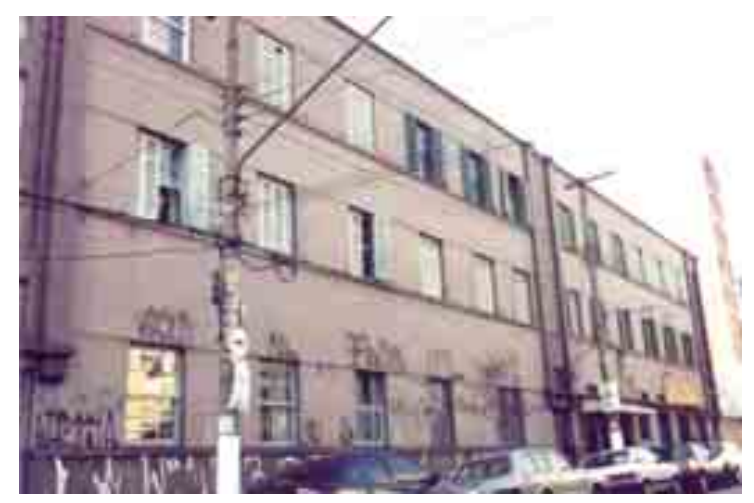

Fig. 157: Rua Sólon, tipologia remanescente.

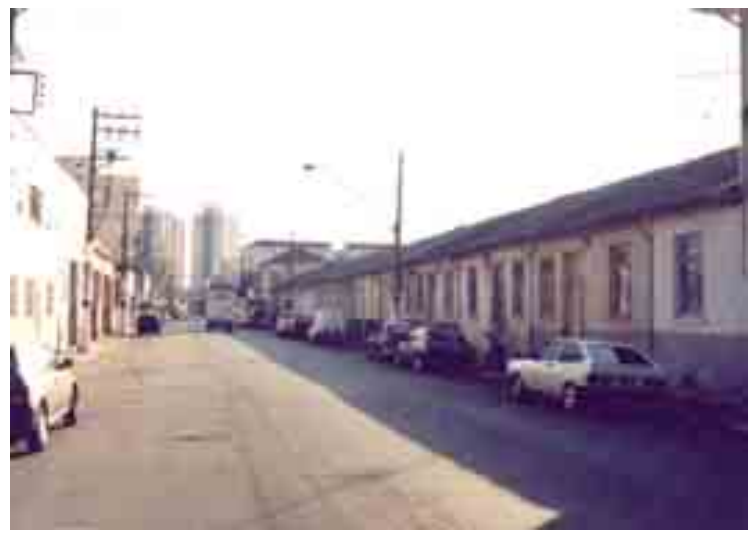

Fig. 159: Tipologia remanescente na Rua Barra do Tibagi. Ao fundo, verticalização na Barra Funda.

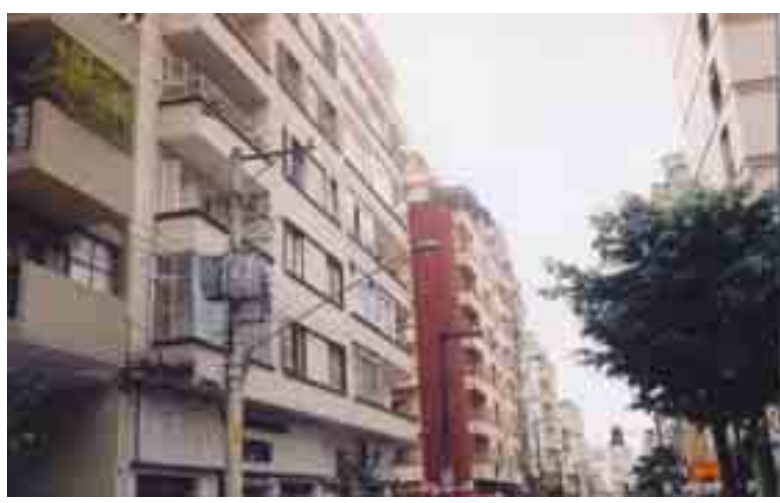

Fig. 156: Rua Amazonas: Quadras com edifícios de gabarito médio.

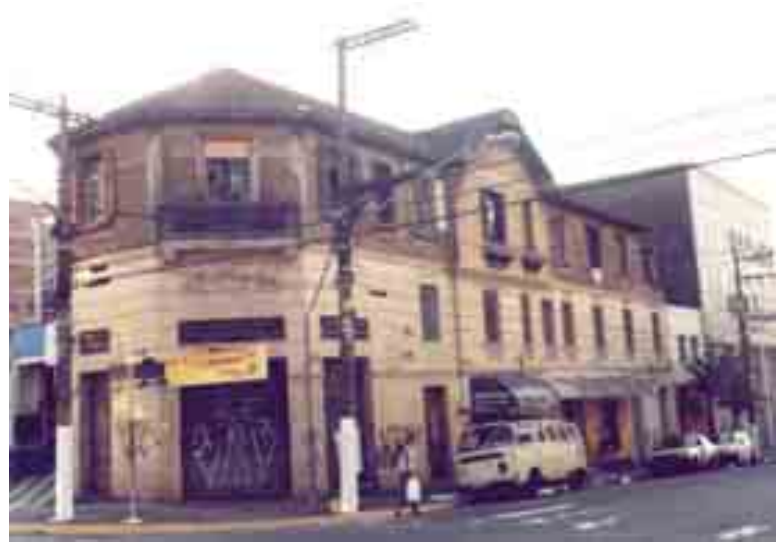

Fig. 158: Rua Sólon, tipologia remanescente.

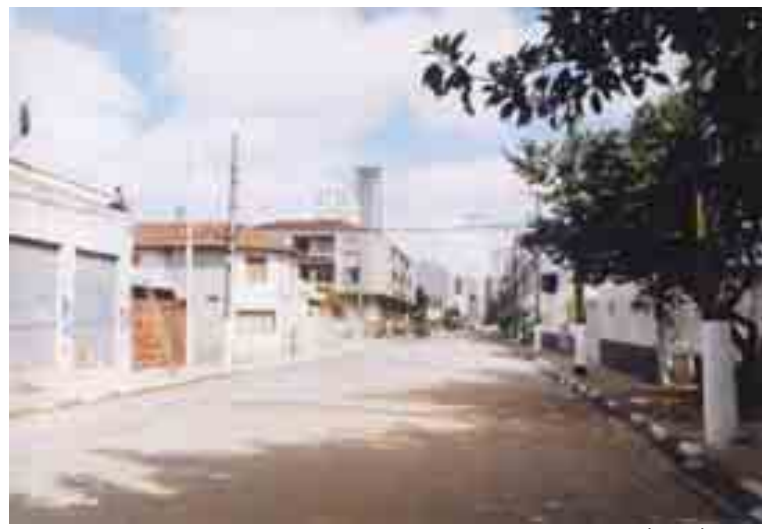

Fig. 160: Rua Barra do Tibagi. 
delimitada pelas ruas Itaporanga, Porto Seguro e avenida Tiradentes, com a Ponte Grande posicionada no eixo desta última. Como foi observado anteriormente, a rua Pedro Vicente se constituía na interligação entre os bairros da Ponte Pequena e do Canindé, possibilitando aos seus moradores acesso à zona norte através da Ponte Grande e Voluntários da Pátria.

Pelo mapa de 1954 a ocupação apresenta-se basicamente inalterada, sendo perceptível apenas o adensamento resultante da construção em lotes que pelo levantamento cadastral anterior se mostravam vazios. Exemplo do ocorrido é encontrado na quadra compreendida pelas ruas Porto Seguro, Porto Calvo, Dom Rodó e Guaporé, que se mostrava desocupada na carta de 1930, tendo sido ocupada por galpões de uma tecelagem posteriormente. Em relação ao traçado viário, a maior alteração foi a da abertura da avenida Santos Dumont e demolição da Ponte Grande, passando a Praça dos Esportes a ser ladeada por duas avenidas.

O mapa de 1972 indica que a conclusão da canalização do rio e da implantação da avenida marginal possibilitaram o surgimento de outras áreas públicas junto a esta última, ocupada também por um clube. Outra alteração presente em 1972 foi a conclusão da Igreja da Boa Morte, situada na rua Guaporé, apenas indicada no levantamento anterior, mas que se constituiu em uma referência do bairro.

A intervenção mais significativa foi, entretanto, provocada pela presença do Metrô, já indicada no mapa de 1972, tendo reconfigurado a praça existente na avenida e implantado estação aérea, projeto do arquiteto Marcelo Fragelli. A linha do Metrô, por superar a Ponte Pequena em elevado, não ocasionou demolições nesse bairro, preservando a configuração estruturada ao longo do século XX, incorporando apenas uma rua paralela à Pedro Vicente para adequação de terminal de ônibus. Para a travessia do rio Tietê, utilizada pela linha do Metrô, foi construída a ponte Cruzeiro do Sul que em 1964 desativou a antiga ponte ferroviária do Trem da Cantareira.

Verifica-se ainda na atualidade a presença das antigas tipologias nas faces de quadra não atingidas pela reformulação viária da avenida Tiradentes. Defronte à Praça Armênia, inúmeras quadras são constituídas de pequenas vias de acesso à avenida dos Estados, com casario remanescente da história da cidade, um conjunto urbano com forte presença de cortiços.

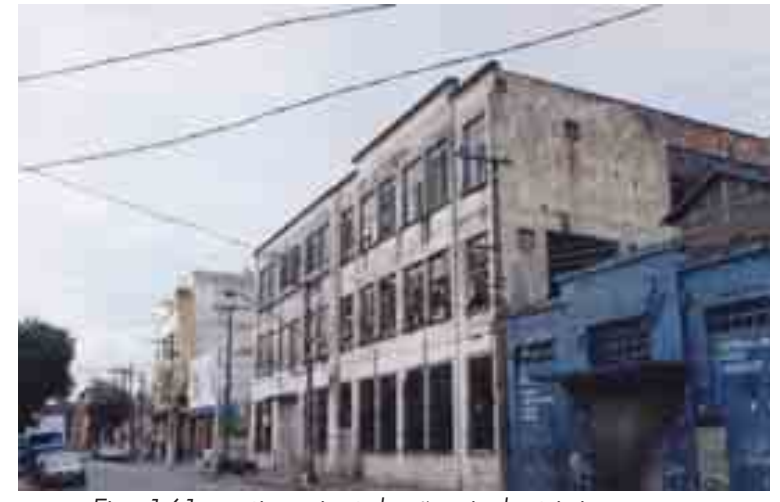

Fig. 161: antigas instalações industriais, R. Deocleciana.

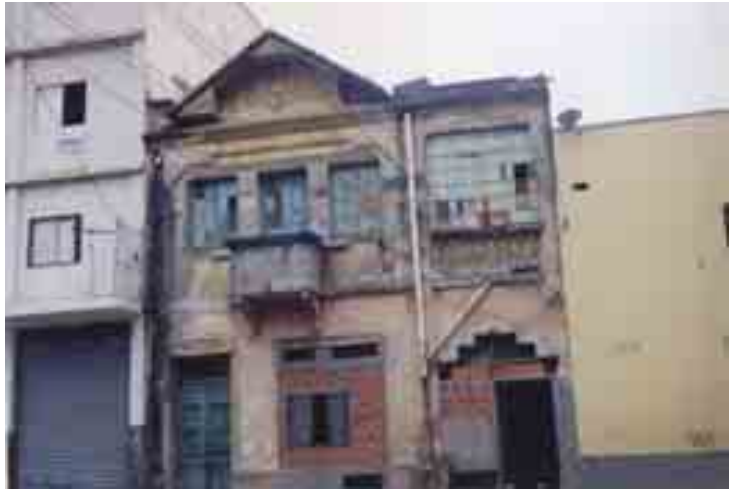

Fig. 162: Casario remanescente, $R$. Deocleciana, utilizado como cortiço, 2004. 


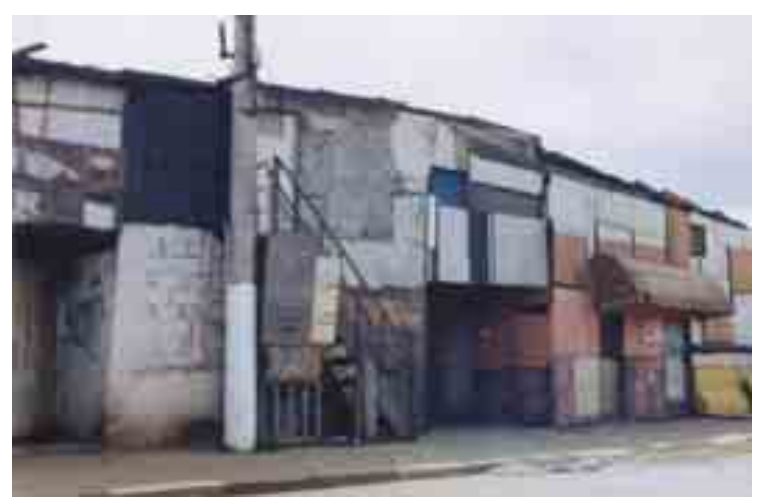

Fig. 163: Antiga entrada, Favela do Gato, 2003.

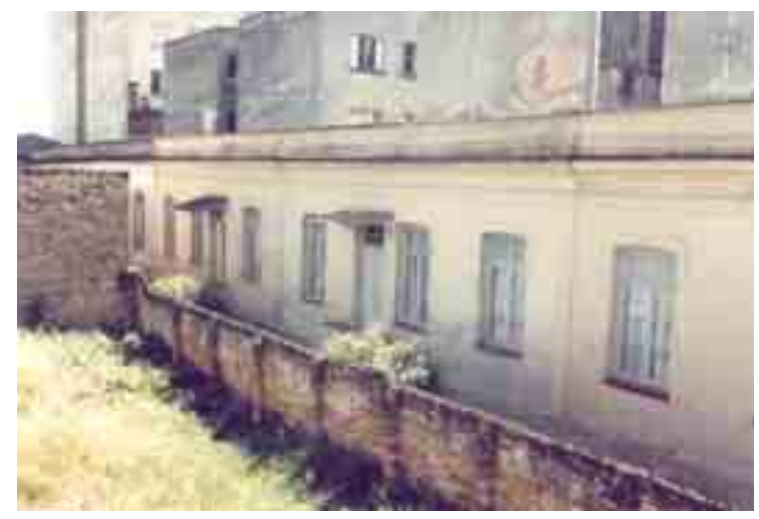

Fig. 165: Vila Operária, Av. Tiradentes.

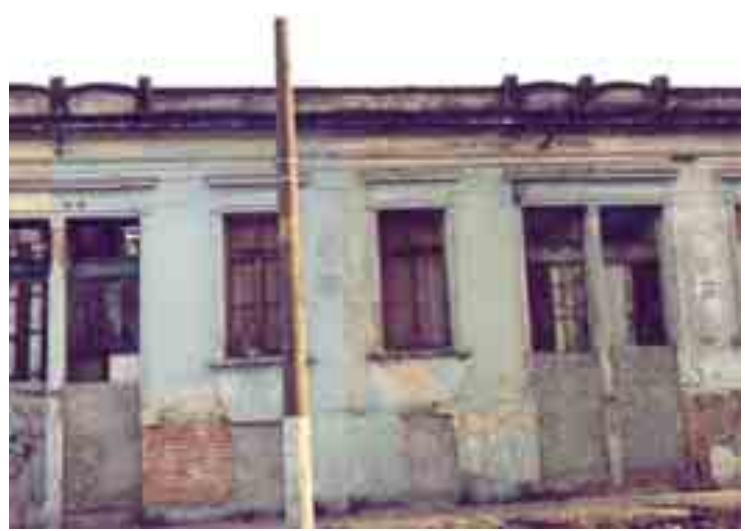

Fig. 167: Casario remanescente, R. Porto Seguro.

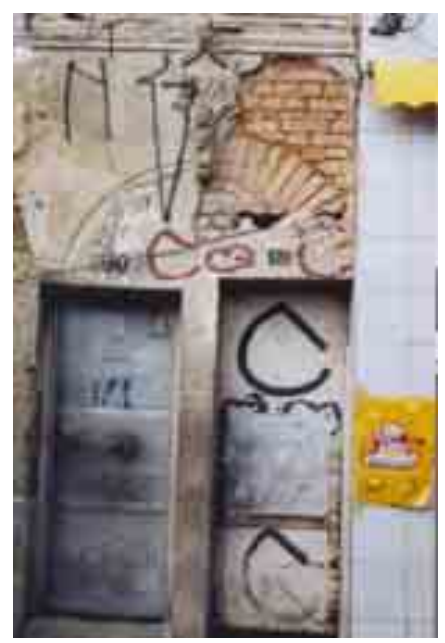

Fig. 169: Detalhe de edificação remanescente, R. Eduardo Chaves.

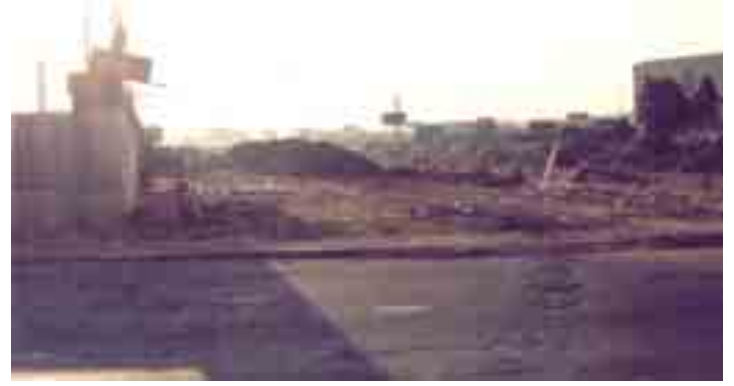

Fig. 164: Margem do Rio Tamanduateí com a Favela do Gatoiá retirada. Ao fundo, Hotel

Anhembí, 2004.

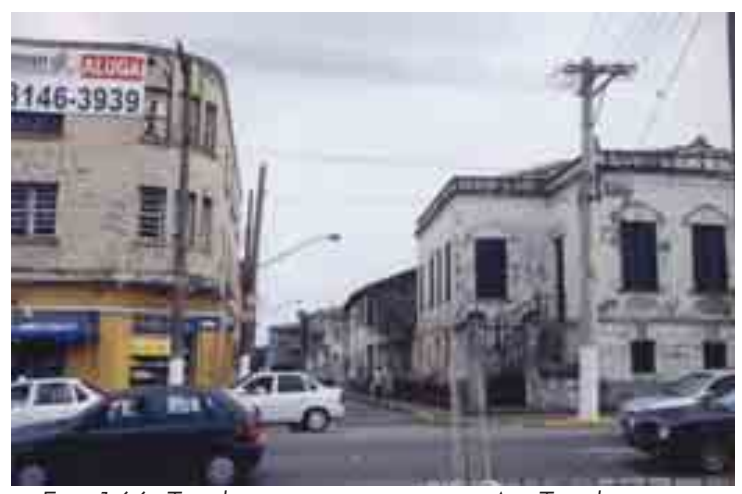

Fig. 166: Tipologia remanescente, Av. Tiradentes.

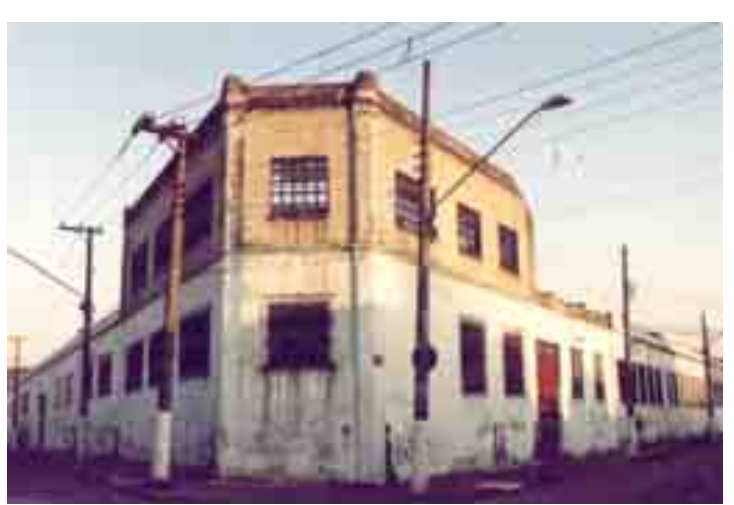

Fig. 168: Antiga instalação industrial, R. Porto Seguro x R. Porto Calvo.

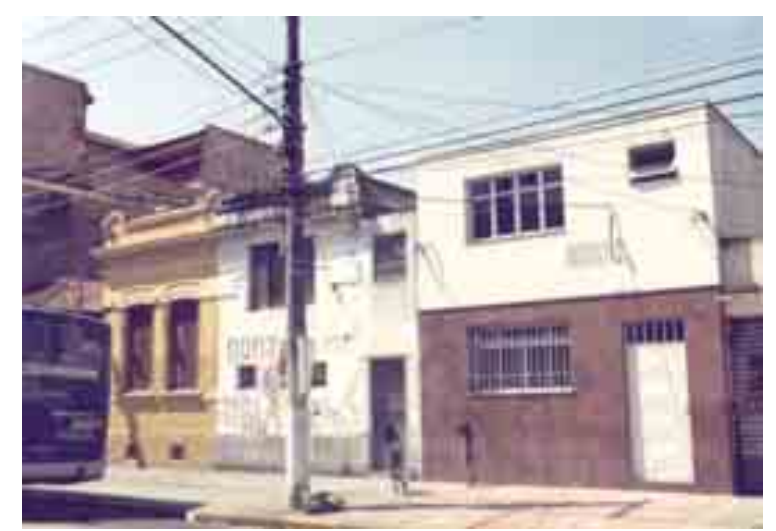

Fig. 170: Tipologias remanescentes, R. Eduardo Chaves. 


\subsection{Distrito do Brás}

Ocupando a parte oriental da cidade, antigos registros mostram o Brás como um local estruturado pela estrada que ligava as duas colinas históricas dos tempos coloniais: São Paulo de Piratininga e Nossa Senhora da Penha de França. A Estrada Geral, ou Caminho da Penha, atual avenida Rangel Pestana, possuía algumas chácaras na sua margem e dois braços procuravam os bairros da Moóca e do Pari: o primeiro seguia em direção ao atual Alto da Moóca e o segundo pelas atuais ruas do Gasômetro e Monsenhor Andrade (Torres, 1985, 58).

Assim como os caminhos que atravessavam o Campo da Luz tiveram finalidade religiosa e o fizeram também para ligar a cidade com Minas Gerais, as atuais avenidas Rangel Pestana e Celso Garcia se constituíram em rotas religiosas e vias de importância social e econômica, ligando a Imperial Cidade de São Paulo à Côrte, através do Vale do Paraíba (idem, 58). Depois do Convento do Carmo, ampla área vazia o separava da capela do Senhor Bom Jesus dos Matozinhos, construída pelo português José Brás e que apresentava alguma concentração de população no seu entorno. Nesse local, foi construída posteriormente a atual igreja Matriz do Brás, concluída em 1903. (ibidem, 65-75). Durante décadas o bairro foi ocupado apenas por chácaras, como a de Inácio José de Araújo, que desde 1860 plantava uvas para fazer vinho. Nesse local passou a existir posteriormente o Largo do Brás, renomeado em 1865 em homenagem à Praça da Concórdia em Paris.

A chegada das ferrovias alterou profundamente a situação da acanhada Freguesia do Brás e foi seguida de obras importantes para aquela região, como o aterrado da Várzea do Carmo. Como foi analisado por Morse e Langenbuch na Parte I deste trabalho, a preferência das ferrovias pelos terrenos planos não permitiu a coincidência de traçado com os velhos caminhos coloniais, provocando a decadência de núcleos que serviam de apoio às tropas de burros, como foi o caso da Freguesia do Ó e da Penha, diferentemente do Brás, que mesmo sendo antigo pouso de tropas, recebeu em 1865 a San Paulo Railway e em 1875 a Estrada de Ferro do Norte (DPH, 1980, 38)

Iniciando os serviços de infra-estrutura urbana que foram implantados na cidade por grupos estrangeiros, em 1872 o Brás recebeu a primeira usina de gás, construída e explorada por ingleses. Localizou-se nas proximidades da atual Casa das Retortas, na rua da Figueira, que cortou a chácara de propriedade da Marquesa de Santos. Essa usina se destinava ao fornecimento de energia para a iluminação pública e só com a drenagem da Várzea do Carmo, empreendida no governo de João Teodoro (1872-1875), foi viabilizada a sua operação. $O$ primeiro edifício foi demolido por volta de 1912, funcionando quase duas décadas com a Casa das Retortas, construída em 1889 para as mesmas finalidades (DPH, 1980, 20). 
No ano de 1877 a Estação do Norte foi concluída, com o Brás já sendo ligado ao Bom Retiro através das ruas abertas na Luz, sendo que esses dois bairros também receberam a estação da Estrada de Ferro Sorocabana em 1875. As funções comercial e industrial mudaram o aspecto desses bairros, havendo nos registros da Câmara Municipal menções sobre o fluxo de mercadorias e pessoas entre as Estações do Norte e Sorocabana, que exigiam melhoramentos das vias. No Brás, iniciou-se a transformação do entorno do Largo da Concórdia, como também das ruas Piratininga e Carneiro Leão. (DPH, 1980, 38-39; Torres, 1985, 108).

Em fins do século XIX o incremento populacional do Brás decorreu da imigração estrangeira, particularmente dos italianos, premidos pela crise no campo de seu país de origem: em apenas quatro anos, de 1886 a 1890, o bairro viu sua população saltar de 5.998 para 16.807 habitantes. A escolha do Brás como local de moradia pode ser explicada tanto pela presença de indústrias, que foram um fator de atração à mão de obra destinada inicialmente à lavoura cafeeira, como também da Hospedaria dos Imigrantes, que passou a funcionar a partir de 1888 na rua Visconde de Parnaíba. Estudos mostram também uma preferência pelo Brás dos imigrantes napolitanos, enquanto que no Bom Retiro se concentraram os venetos e no Bexiga os calabreses (DPH, 1980, 43), devendose a essa distribuição os seus antecedentes histórico-sociológicos da região de origem na Itália (Véras, 2003, 85).

Em 1881 o bairro mostrava traçadas as ruas do Gasômetro, do Brás (atual Rangel Pestana), além da Piratininga. Monbeig mencionou a "epidemia de urbanização" que ocorreu na cidade entre 1890 e 1900, quando sua população saltou de 65 mil para 240 mil habitantes, ocorrendo nesse período a abertura de ruas populares no Bom Retiro e Barra Funda, além do início da urbanização do Canindé e Pari (Monbeig apud Torres, 1985, 111).

Até os primeiros anos de 1900, no Largo da Concórdia funcionou o Mercado do Brás. Na sua fachada a inscrição "Intendente de Obras Dr. Gomes Cardim, Câmara Municipal de 1897" indicava a época de sua construção. Após sua desativação em 1906 o edifício foi arrendado e passou a abrigar o Teatro Colombo, também chamado Teatro do Brás, planejado por Artur Fried e inaugurado em 1908. Em 1966, quando já não funcionava há cinco anos, esse Teatro que recebeu importantes companhias dramáticas e

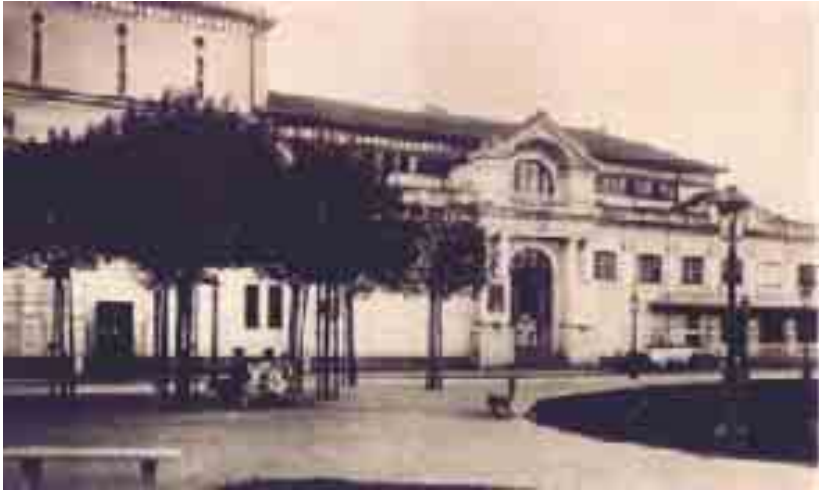

Fig. 171: Teatro Colombo. 
musicais européias, sofreu um incêndio e foi destruído (disponível em: <htpp:// www.igc.sp.gov.br>2004). Atestando sua importância para o bairro, outro elemento de referência situado no Largo da Concórdia foi o do Cine-Teatro Frontão do Brás, edifício de 1927 que abrigou sede de clube social e dos cines Babilônia e Brás, transformando-se posteriormente em loja de eletrodomésticos e totalmente descaracterizado na década de 1990 (SEMPLA/Emplasa, 1984, 349).

Conhecido como um bairro com forte presença do proletariado, na passagem do século XIX o Brás reunia um conjunto de estabelecimentos de ensino para diferentes faixas da sua população, alguns deles voltados ao aprendizado dos filhos dos operários, como foi o caso da Escola Profissional Feminina Prof. Carlos de Campos, de 1911 e da Escola Normal, futuro Colégio Anchieta e Romão Puiggari do final do século XIX.

Na Várzea do Carmo, posteriormente aos melhoramentos que deram origem ao Aterrado do Gasômetro e do Aterrado do Brás, realizados durante o governo de João Teodoro, em 1888 foi proposta e autorizada a construção de um parque, através de concessão da Câmara Municipal, sendo o mesmo viabilizado quase vinte e cinco anos depois. O Parque da Várzea do Carmo, a partir de 1921 denominado Dom Pedro II, apenas foi viabilizado com a venda de parte da sua área para financiamento das obras, operação ocorrida em 1914. No ano 1917, em meio ao grave surto de gripe espanhola que assolou a cidade, as obras foram iniciadas, com a Várzea do Carmo dividida em vinte e cinco áreas e implantado em quatro anos o projeto realizado em 1911 por Antoine Bouvard.

Com toda a sua área ajardinada e equipada com rede subterrânea de drenagem, - Parque recebeu em 1920, o Palácio das Indústrias, importante elemento do plano de recuperação da Várzea do Carmo. Nesse ano, embora incompleto, esse edifício destinado a exposições agrícolas, comerciais e industriais, recebeu a Exposição Internacional de São Paulo, o primeiro evento desse tipo a ocorrer na cidade. O Palácio, cujo projeto é atribuído a Domiziano Rossi, da equipe de Ramos de Azevedo, foi concluído apenas em 1924, ano de sua inauguração oficial (SEMPLA/Emplasa, 1984, 417).

Em 1925, outro equipamento de prestígio foi destinado ao entorno do Parque, o Mercado Municipal, que mesmo não se situando no Brás, foi indutor da ocupação comercial de parte da área do bairro. Com as obras iniciadas em 1928 e concluídas em 1933, o edifício de quase 13 mil metros quadrados projetado por Ramos de Azevedo tornou-se uma referência arquitetônica da cidade e a sua central de abastecimento por mais de três décadas, transferindo para lá os comerciantes que ocupavam até então o Mercado Velho, na rua 25 de Março (URBS, set/out 1998, 56). Com esse equipamento monumental, consolidou-se no Brás a área de comercialização de produtos primários, a Zona Cerealista, 
Fig. 172: Colégio

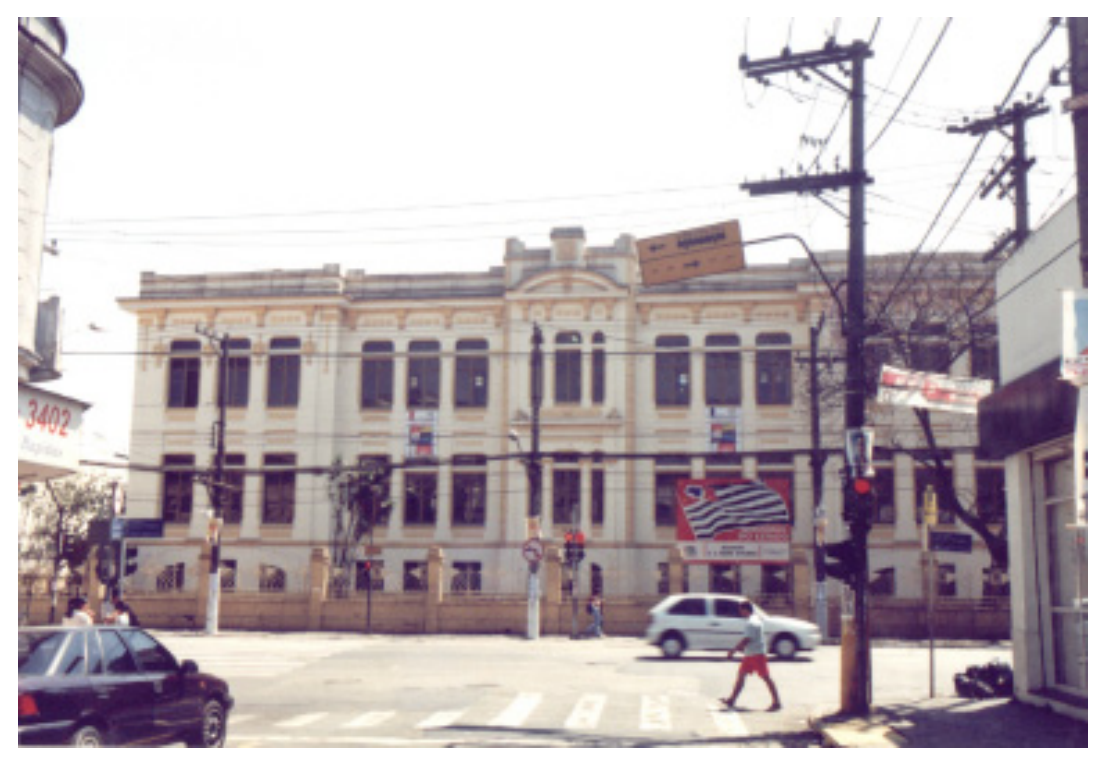

Fig. 173: Colégio Carlos de Campos.

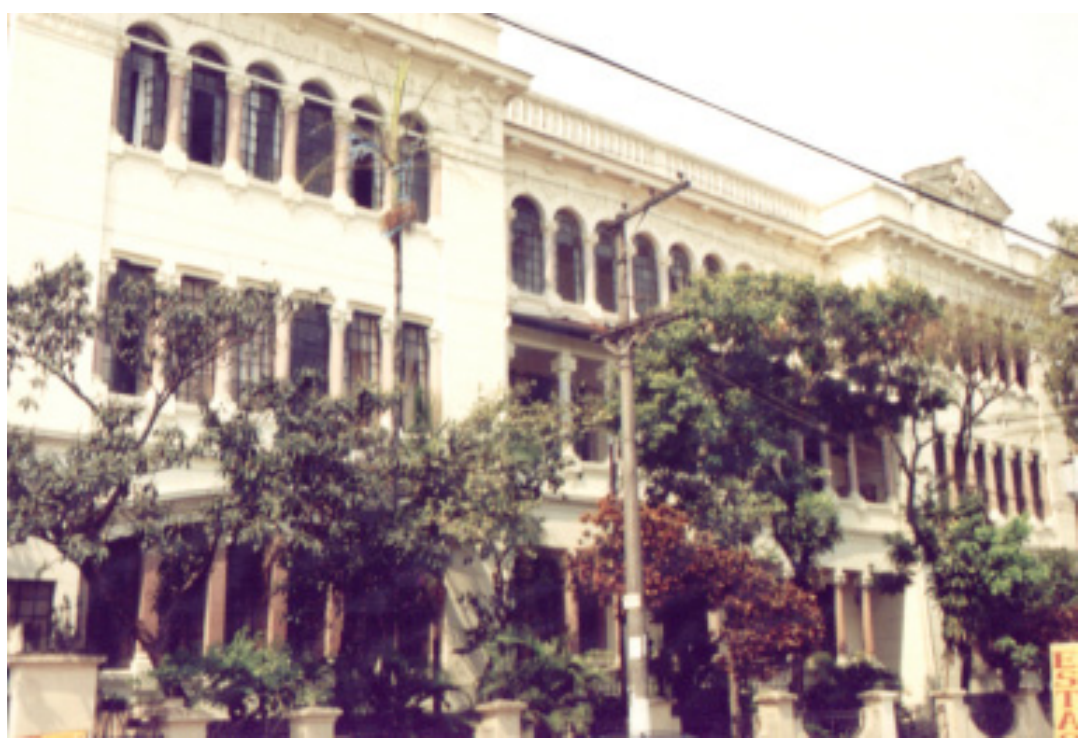

Fig. 174: Colégio Romão Puiggari.

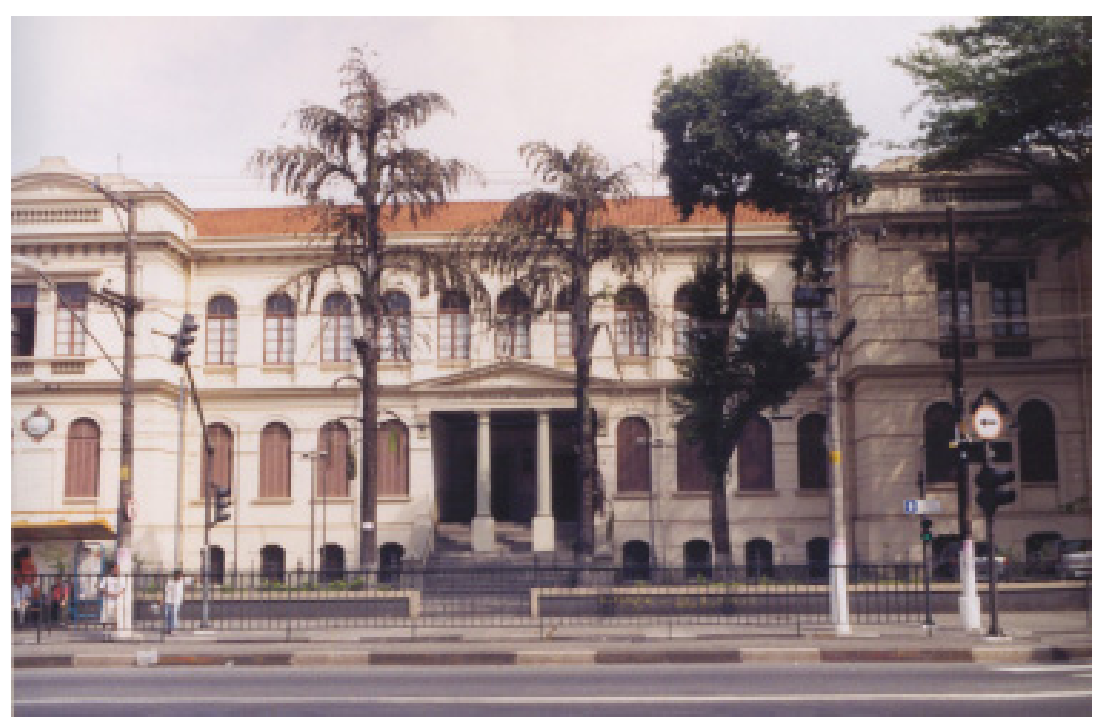


beneficiada também pelas ferrovias que transportavam as safras do interior e dos subúrbios próximos da cidade.

A retificação do rio Tamanduateí e o aterro da Várzea, a partir de 1914, implicaram num duplo benefício para a área do Brás e para a cidade. Para a primeira, pelo Parque ter se constituído na área de lazer principal dos bairros fabris a leste do núcleo central e para a cidade por ter obtido uma ligação dos bairros do sudeste com o norte, além daquela do centro com os bairros do leste. Mas, já em 1938 o Parque recebeu a construção do viaduto da avenida Rangel Pestana, o prolongamento da rua Tabatinguera e da avenida Mercúrio (URBS, jun/jul 1998, 52) e o Plano de Avenidas consagrou a avenida dos Estados como radial, que cortou o Parque longitudinalmente, estabelecendo a ligação com os municípios industriais do $A B C$.

Sob o ponto de vista econômico, no Brás estruturaram-se pelo menos cinco fortes atividades, além da industrial, constituídas pela zona de comércio diversificado, zona cerealista, zona madeireira, confecções e máquinas operatrizes. Um estudo sobre a função comercial do Brás assim descreveu a espacialidade da área que se estendia do Largo do Brás até a rua Bresser, que reunia lojas, agências bancárias, cinemas, bares e confeitarias: "A paisagem urbana, nessa principal área do comércio varejista, não se distingue pela beleza dos edifícios. Na verdade, a maioria das casas comerciais aloja-se em velhos pardieiros, construídos em fins do século passado e em princípios do atual; as reformas feitas nas fachadas de alguns deles não conseguiram esconder ou disfarçar seu aspecto anti-estético. Os 'arranha-céus' de cimento armado são, ainda, em número relativamente pequeno, o que contribui para que o Brás e arredores ofereçam uma fisionomia antiquada, em contraste marcante com a vizinha Área Central da cidade" (Mendes apud Azevedo, (org), 1958, 241)

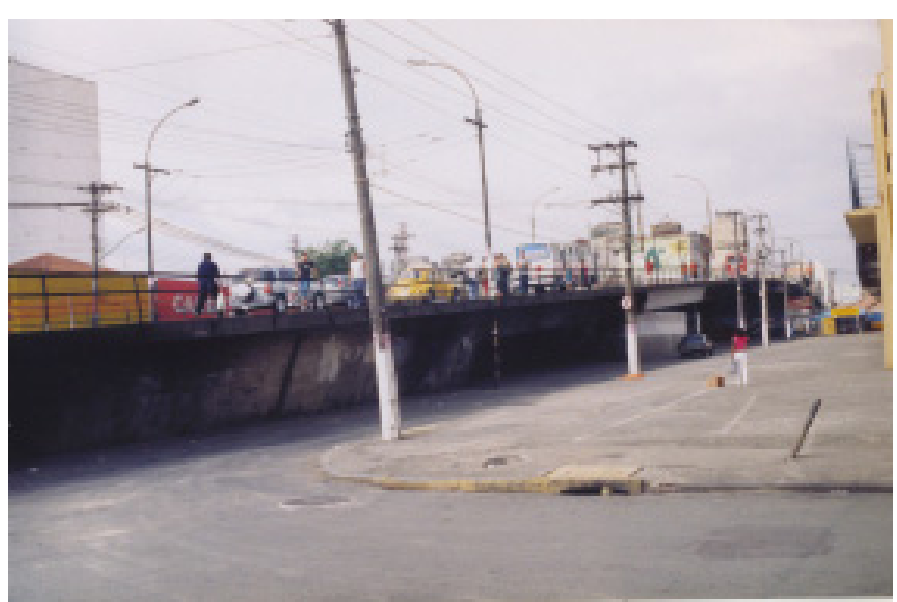

Fig. 175: Viaduto Rangel Pestana, inaugurado em 1968.
A zona cerealista, formada pela vizinhança com o Mercado Municipal, foi a única área de abastecimento de grãos e hortifrutigranjeiros até a década de 1960, quando uma grande enchente determinou 0 início dos estudos de um centro de abastecimento na Vila Leopoldina, estando a Zona Cerealista já comprometida com os congestionamentos e 
inadequação dos depósitos em uma área de grande circulação. Em 1969 o Ceasa foi inaugurado na zona oeste da cidade, mas a Zona Cerealista não se transferiu por inteiro. Embora sem a mesma importância que possuía anteriormente, continuou a ser alvo de seguidos planos para sua mudança total e apenas em meados da década de 1990, após longo período de deterioração ambiental, parte de sua área passou por um processo de requalificação dos depósitos e edifícios residenciais que foi planejado e executado pelos próprios comerciantes locais.

A zona madeireira começou a receber os primeiros estabelecimentos no início da década de 1940, quando uma loja foi aberta na rua do Gasômetro. Igualmente à Cerealista, recebeu estudos para sua transferência devido ao impacto provocado na área pelo transporte de cargas, que passou a utilizar intensamente os caminhões a partir da década de 1950. Com a descentralização das lojas, o Brás dividiu com os bairros de Pinheiros, Lapa e Butantã esse tipo de comércio, mas uma outra especialização, a do comércio de couros, também se localizou nas ruas próximas à avenida Rangel Pestana, ambas caracterizando a maior concentração desses estabelecimentos na cidade.

A zona de confecções e de máquinas operatrizes, por sua vez, se estruturaram em conseqüência direta das indústrias têxteis e metalúrgicas existentes no Brás, através do processo de vizinhança e aglutinação. As confecções seguiram ao longo da rua Oriente, ocupando gradativamente suas transversais, tais como Silva Telles, Müller, Barão de Ladário, etc. Uma hipótese para essa ocupação é a de ter ocorrido um processo semelhante ao da rua José Paulino, em que a área passou a ser alvo do trabalho de membros da colônia sírio-libanesa, que

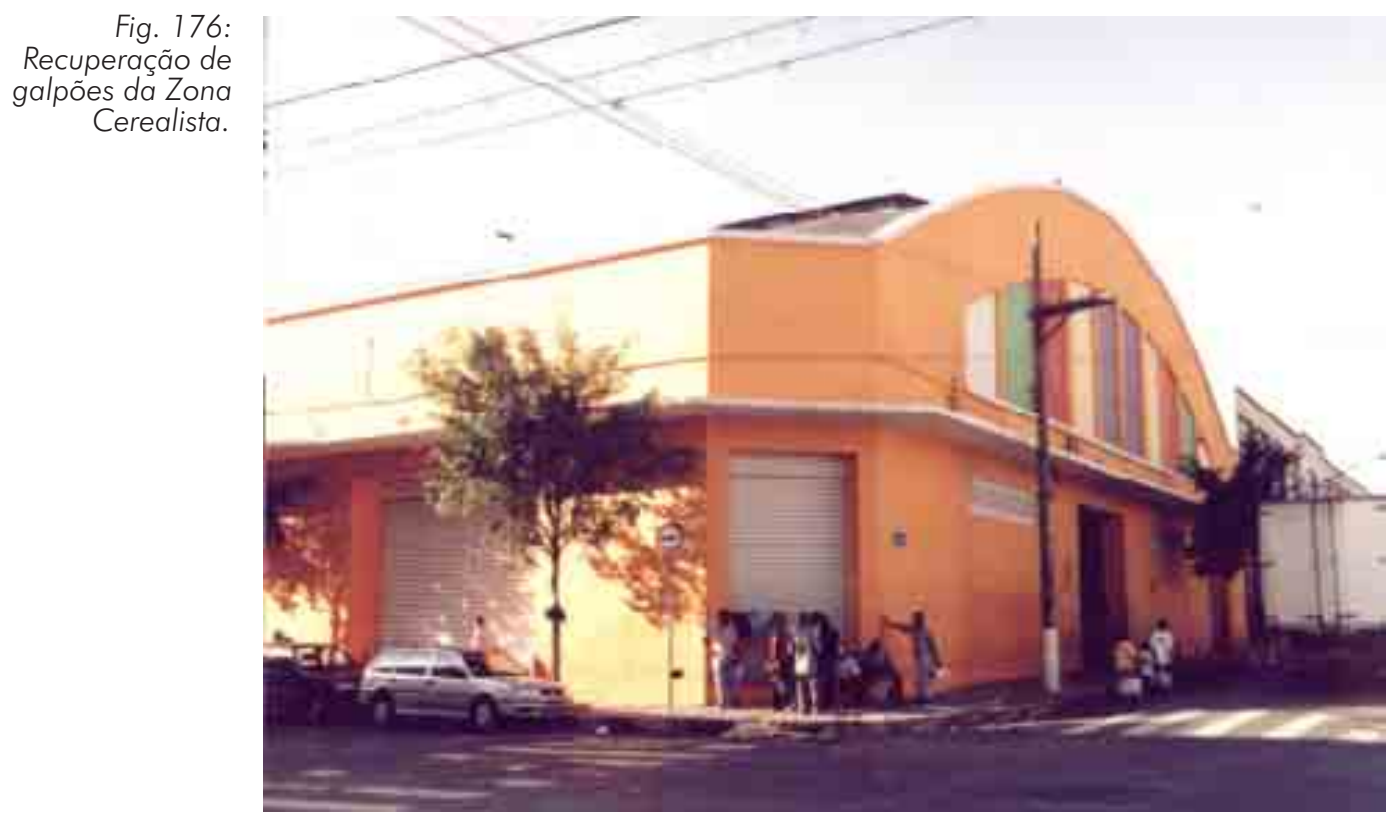


como explicou Véras, havia se fixado nas proximidades da zona do mercado, a partir da década de 1920 (2003, 92-94). Uma comprovação desse fato pode se encontrar na toponímia original da rua, que era a de "rua do Oriente". A zona de máquinas operatrizes ocupou principalmente a rua Piratininga, junto à concentração de metalúrgicas do Brás e das zonas fabris da Moóca e Ipiranga, bairros estes acessados por essa via e que também possuíam grande número de indústrias desse ramo.

Juntamente com as transformações ocorridas no Brás, o Parque D. Pedro II, que foi considerado o "vestíbulo da cidade", por Prestes Maia, também perdeu suas características originais, tornando-se cada vez mais um local de passagem. $\bigcirc$ Palácio das Indústrias abrigou entre 1947 e 1968 a Assembléia Legislativa do Estado e posteriormente, órgão da Secretaria de Segurança Pública. A partir de 1968 foi implantado também o complexo de viadutos que seccionou o Parque, constituindo-se em uma intervenção que comprometeu profundamente seu espaço e qualidade de área pública.

Um desses viadutos, conectou a zona oeste ao traçado recém-completado da Radial Leste, que na década de 1950 recebeu nas propostas de Moses para o sistema expresso e de Prestes Maia para o Metrô, calha segregada para o transporte público, feita por ônibus e trilhos, respectivamente. Ao invés disso, quando concluída, configurou-se como via expressa que dividiu as áreas dos bairros existentes em seu trajeto, não incorporou os espaços segregados reservados ao transporte de massa e na extremidade oeste de seu percurso, implantou as pistas do Elevado Costa e Silva, destinado exclusivamente ao transporte individual e causador de intenso impacto na avenida São João e suas imediações.

Outra transformação de grande escala ocorrida na morfologia dessa área foi desencadeada como decorrência da passagem da linha Leste-Oeste do Metrô. A partir de 1975, essa intervenção implicou na desapropriação e demolição de 944 casas de 28 ruas do Brás (DPH, 1980, 60), que deram lugar a um grande espaço vazio quando em 1977 as obras finalmente foram iniciadas. Muitas

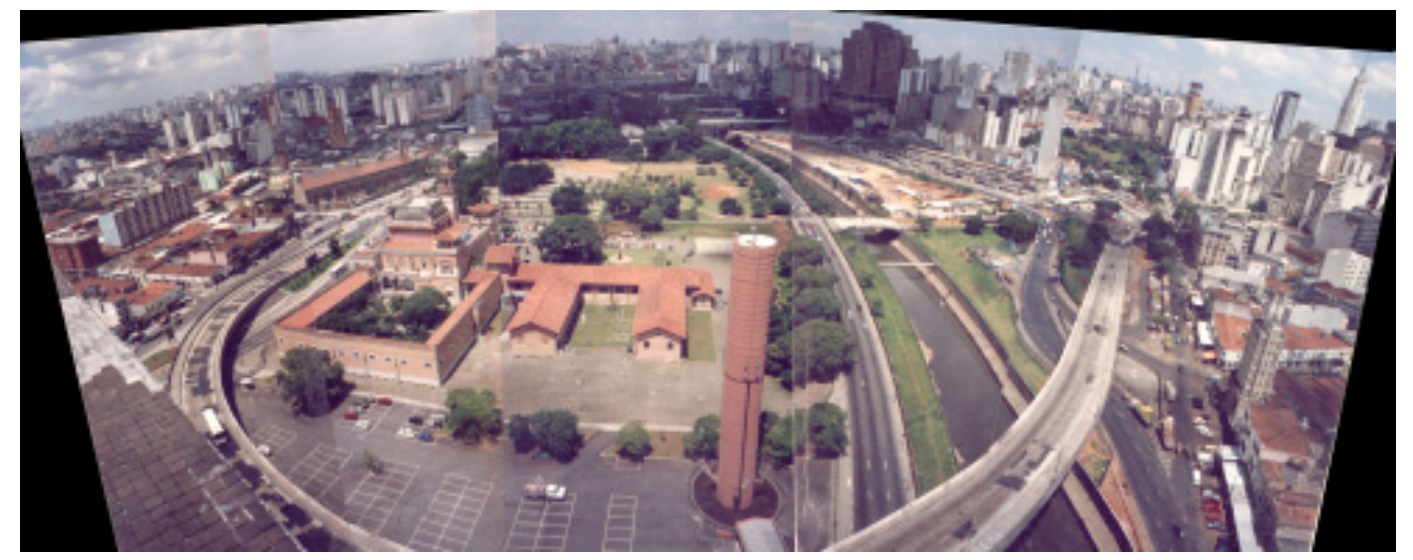

Fig. 177: Sistema viário cortando o Pq. D. Pedro II. 
dessas casas e vilas não se encontravam no trajeto da linha, mas em seu entorno. Essa intervenção integrou o Projeto CURA Brás-Bresser (Comunidades Urbanas de Recuperação Acelerada) e eram previstas as seguintes atuações no bairro:

1 - Programa para implantação de habitações, comércio e serviços na quadra entre a rua Piratininga, Campos Sales e Caetano Pinto. Foram propostos edifícios habitacionais de 14 andares com seis apartamentos em cada andar-tipo.

2- Construção de escola de educação infantil e creche junto à Estação Bresser. Construção de creche na rua da Alfândega e Centro Cultural na rua Domingos Paiva.

3- Reurbanização do Largo da Concórdia.

4- Recuperação da Praça Agente Cícero e das áreas entre os Viadutos Rangel Pestana e do Gasômetro.

5- Recuperação da área sob o viaduto Alberto Marino para a ampliação da Praça Agente Cícero

6- Construção de uma passagem subterrânea sob o leito da ferrovia, ligando a Praça Agente Cícero à avenida Rangel Pestana (idem, 60).

O então denominado "Novo Bairro", seria o resultado dos programas de recuperação urbana desenvolvidos pelo Projeto CURA na região. $O$ órgão municipal encarregado dessas intervenções, a EMURB, previa que a na área onde as mesmas seriam implantadas, ocorreria uma transformação tal que se igualaria ao cenário de outras áreas da cidade densamente povoadas, com vários prédios e sobrados de dois e três andares, absorvendo uma parte do crescimento da população. Uma publicação técnica da Prefeitura e do Metrô afirmava que "o antigo centro de concentração dos imigrantes italianos, o bairro do século XIX, será esquecido pelos paulistanos, tornando-se mera recordação da história de São Paulo" (PMSP/Metrô, 1979, 115, grifo nosso).

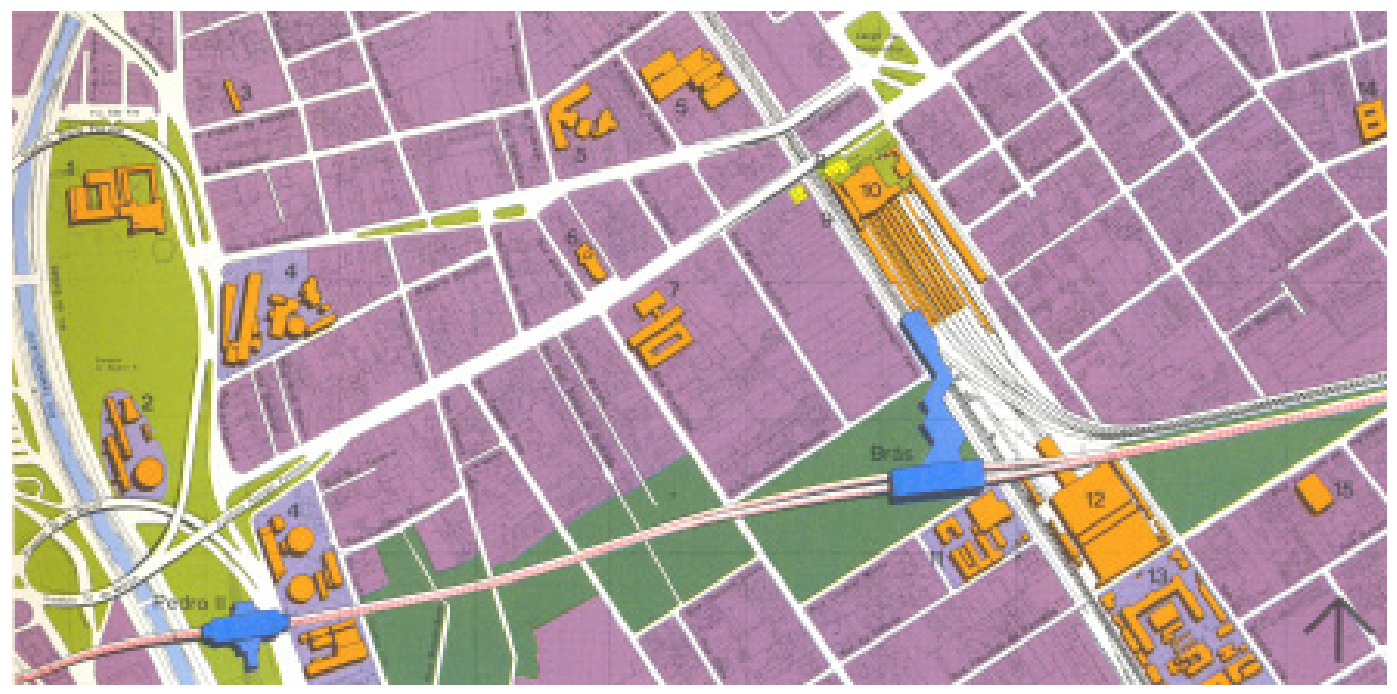

Fig. 178: Interveção do Projeto CURA na região das hoje estações de metrô Pedro II e Brás. 


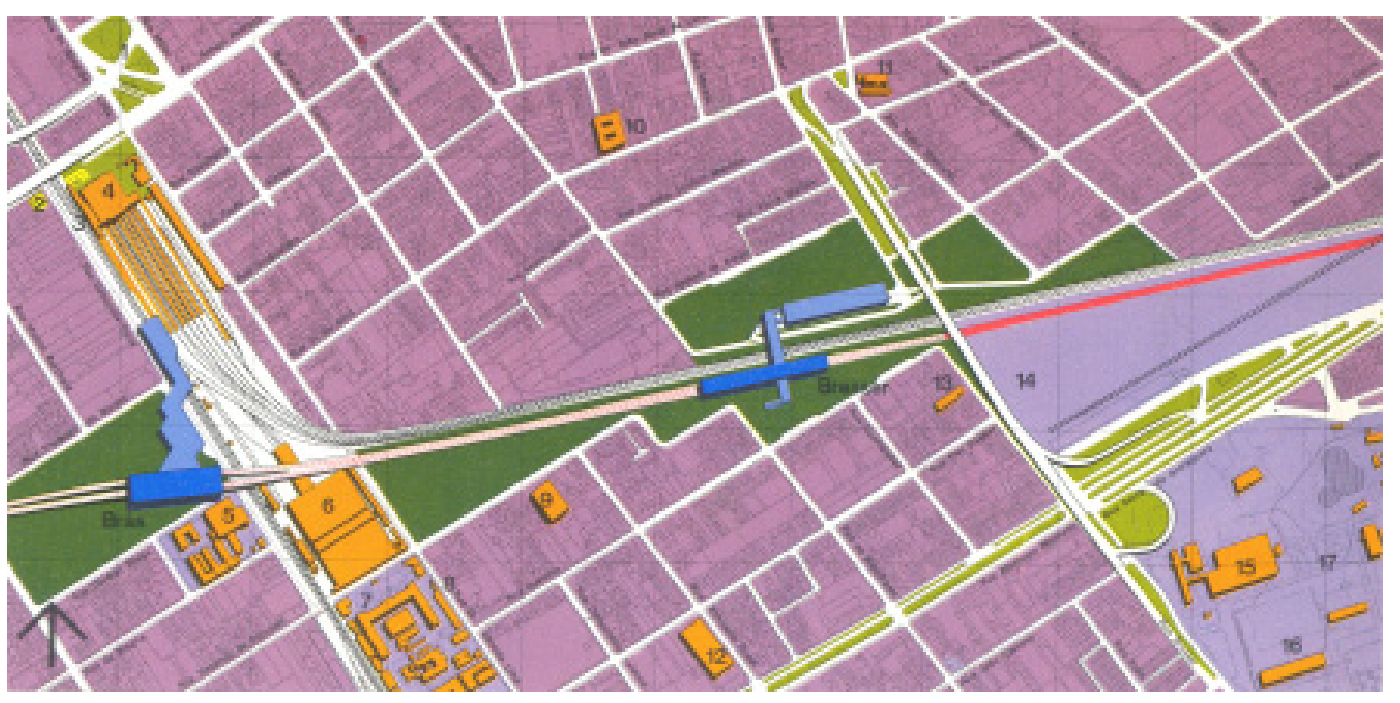

Fig. 179: Interveção do Projeto CURA na região das hoje estações de metrô Brás e Bresser. 


\subsubsection{Análise dos sub-setores}

O sistema viário do setor urbano que engloba o distrito do Brás apresentava pelo levantamento cartográfico de 1930 uma avenida estrutural de grande importância, a Rangel Pestana, e outras vias articuladoras de sua área com os bairros vizinhos, as ruas Oriente, do Gasômetro, da Figueira e Moóca. O Brás foi dividido em quatro sub-setores correspondentes às referências existentes em cada um, áreas de transição entre um sub-setor outro, e também entre o bairro e aqueles a ele interligados:

$1^{\circ}$ - Esse sub-setor foi definido por se caracterizar como uma área de influência mútua entre Parí e Brás, dada toda a malha viária implantada integrar essa área, que se comunicava também com a Luz através das ruas São Caetano e João Teodoro. A primeira se constituiu no acesso principal tanto à penetração dos bairros do Canindé e Parí, através da avenida Valtier, como também do Brás, através da Monsenhor Andrade. Essa via atravessava os trilhos da San Paulo Railway em nível, atingindo assim um setor do Brás com grande número de indústrias e acessando também a rua Oriente.

A rua João Teodoro (atual limite de distrito entre o Brás e o Parí) e as poucas quadras que a distanciavam da rua Oriente apresentavam um parcelamento uniforme, caracterizado por uma série de ruas ortogonais, muitas vez interrompidas por quadras de maiores dimensões, como é o caso das ruas Elisa Whitacker, Henrique Dias e Júlio Ribeiro. Verifica-se que a continuidade desta última rua foi assinalada como não oficial no Levantamento Sara Brasil.

A continuidade da malha viária entre o Brás e o Parí revela uma diferenciação importante com a do entorno do Bom Retiro, pois ali a disposição das linhas ferroviárias interrompia ligações com os Campos Elísios e Santa Efigênia. Apesar dos trilhos também seccionarem o Brás, a continuidade das vias permitiu uma integração acentuada entre os bairros envoltórios, criando barreiras ao longo dos eixos ferroviários pelo fato de ali ter se instalado um grande número de indústrias, margeando mais a San Paulo Railway do que a Ferrovia do Norte. Mesmo assim é possível observar na carta cadastral de 1930 a continuidade do tecido urbano de uma vasta região, compreendendo o Brás, Parí, Canindé, Belenzinho e Moóca.

Além da proximidade com as estações ferroviárias, outro aspecto importante para a estruturação dessa área foi o do transporte de bondes. $O$ mapa da Light de 1925 já mostrava a linha que vinha da Luz e percorria a ruas São Caetano, Monsenhor Andrade e Oriente até o seu final. Essa rua desempenhou um papel de via de penetração e distribuição percorrendo longitudinalmente parte do Brás, o mesmo ocorrendo com a rua João Teodoro em relação ao Parí. Ambas em paralelo direcionavam-se à área do Catumbí e Belenzinho, através de ligações 
com outras vias, interconectando áreas com grande atividade industrial e de moradia popular.

Um dos limites desse sub-setor foi formado pelo Pátio do Parí, que reunia os armazéns e ramais ferroviários da San Paulo Railway e que funcionou como alfândega seca da cidade. Esse espaço já possuía a configuração atual, cercado por armazéns e edificações ao longo da rua São Caetano e Monsenhor Andrade. Nessa via, entre a rua Oriente e a linha férrea e próxima ao Parí, situou-se a Escola Profissional Feminina Professor Carlos de Campos, criada em 1911. Essa escola instalou-se, inicialmente, num antigo sobrado na rua Monsenhor de Andrade, onde anteriormente funcionou o Colégio Azevedo Soares. Em meados da década de 1920, esse primeiro edifício foi considerado inadequado, o que levou o Governo do Estado a construir um novo prédio para a escola, de acordo com os preceitos de higiene, harmonia e beleza. Em 1930, foi entregue a primeira etapa da construção, sendo que a outra prevista não foi executada (disponível em <http:// www.etecarlosdecampos.com.br> em 2004).

Uma alteração ocorrida na rua Monsenhor de Andrade diz respeito à passagem em nível sobre a ferrovia da área do Parí para a área do Brás, que favorecia o acesso ao Largo da Concórdia ou à Estação Roosevelt, que era intensamente utilizada até a década de 1970 e que posteriormente foi fechada. Como alternativa para a travessia ao outro lado da mesma rua, restou a passarela metálica implantada também pela San Paulo Railway no final da rua Rodrigues dos Santos, que conecta a rua do Bucolismo, no outro lado da ferrovia.

Esse sub-setor apresenta a rua Oriente e avenida Rangel Pestana como as duas vias principais, com a diferença que na primeira, as ruas transversais de ligação Brás-Parí não foram interrompidas ao cruza-la, enquanto que na Rangel Pestana, a malha viária não manteve a continuidade, apresentando ligações seccionadas entre os dois lados daquela avenida. Além das estações ferroviárias, teve como referências espaços e equipamentos que caracterizaram o bairro - o Teatro Colombo e o Largo da Concórdia - fronteiriços às Estações do Norte e do Brás, além de outro estabelecimento de ensino importante nesse bairro, a Escola Normal, posteriormente Colégio José de Anchieta, com as mesmas funções daquela situada na Praça da República, posteriormente denominada Caetano de Campos .

Pela carta de 1930 é possível verificar a concentração dos grandes lotes e instalações industriais nas áreas lindeiras à San Paulo Railway, que caracterizavam a principal zona fabril da cidade. $O$ parcelamento intenso da área, como de resto em todo o bairro, apresentava raros vazios e apenas nas proximidades da rua Bresser os lotes apresentavam dimensões maiores, mas também com caráter industrial. No cruzamento das ruas Bresser e Sampson foi construído um conjunto que exemplifica a permanência das características construtivas do início do século 
XX, a Vila Simeone, que manteve nas cartas de 1954, 1972 e na foto aérea de 2000 a mesma configuração verificada no levantamento Sara-Brasil. Através dessa carta cadastral é possível verificar nessa Vila a solução da abertura de travessas, usual nas áreas e conjuntos de habitação popular da época, que por descumprirem as normas urbanísticas que definiam as larguras das mesmas, passavam a ser consideradas não oficiais.

A transformação urbana mais destruidora de um espaço que se constituiu em importante referência do bairro, ocorreu no Largo da Concórdia e seu entorno imediato. Confrontada com o levantamento de 1930, na carta de 1954 se verifica a existência do viaduto da rua do Gasômetro sobre os trilhos da San Paulo Railway, que em sua extremidade junto ao Largo, seccionou uma grande quadra lindeira à ferrovia. $\bigcirc$ Largo contava ainda com o Teatro Colombo, mas parte de sua área junto a avenida Rangel Pestana foi cortada para receber trilhos dos bondes que utilizavam o viaduto e estabeleciam a ligação do centro com o Belém, Tatuapé, Mooca e Penha.

O mapa de 1972 mostra a existência do outro viaduto sobre a linha ferroviária, construído em 1968 para solucionar o problema da passagem em nível da avenida Rangel Pestana. Adotando uma das alternativas preconizadas por Prestes Maia, que propunha também uma passagem subterrânea para o local, o Viaduto contou com balanços laterais para a espera de linha do Metrô, o que nunca ocorreu (Torres, 1985, 199). Apesar de resolver o problema de circulação viária da maneira mais econômica do que uma passagem subterrânea, ao substituir as "Porteiras do Brás", esse viaduto ocasionou impactos no entorno do Largo, como o enclausuramento do pedaço de quadra que já havia sido seccionada pelo viaduto do Gasômetro, um obstáculo à Estação Roosevelt e um sempre crescente fluxo de veículos na avenida Rangel Pestana, além de espaços precários nos baixos dos viadutos. Na década de 1960, o Largo da Concórdia se transformou em um terminal de transporte e em 1966 perdeu sua última característica relevante com o incêndio do Teatro Colombo (idem, 175).

Atualmente a função comercial, ligada às confecções, predomina no sub-setor, com maior presença de habitação entre as ruas João Teodoro e Oriente. Entre esta e a avenida Rangel Pestana, com exceção de alguns espaços remanescentes na rua Rodrigues dos Santos, o comércio ocupa todas as quadras. Ocorre também uma renovação de tipologias, com prejuízo à arquitetura e às funções anteriormente existentes, como é o caso da substituição dos galpões anexos ao Pátio do Parí, na rua Monsenhor Andrade e da demolição da maior parte das instalações do antigo colégio Liceu Acadêmico São Paulo, na rua Oriente. Em ambos os casos, os remanejamentos estão ligados à construção de centros de compras do ramo de confecções. 

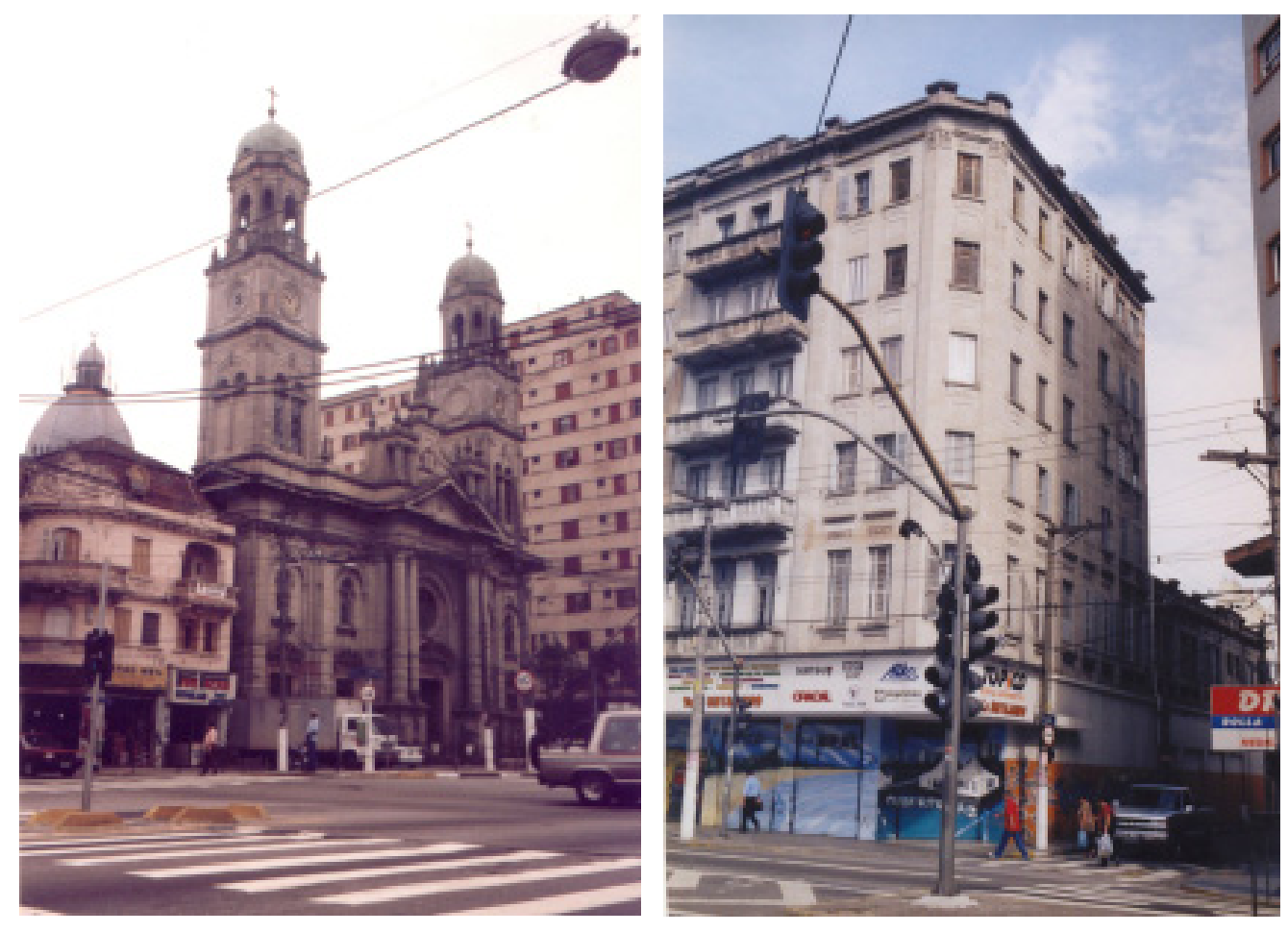

Fig. 180 e 181: Rangel

Pestana - à esquerda,

greja Matriz do Brás; à

direita, tipologia de

verticalização da década de 1940.

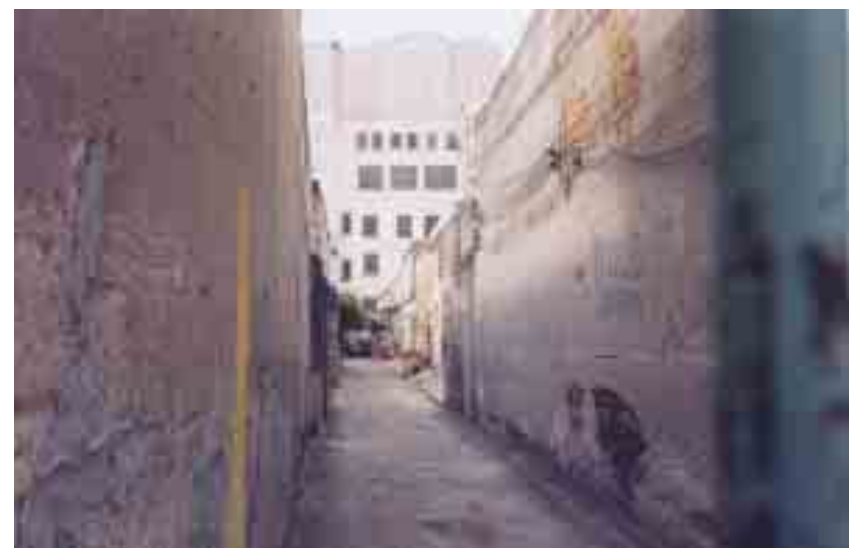

Fig. 182, 183 e 184: Ao lado, vila operária na Av. Rangel Pestana. Abaixo: A esquerda, Shopping de confecções; à direita, transformação do antigo liceu Acadêmico São Paulo, 2004.
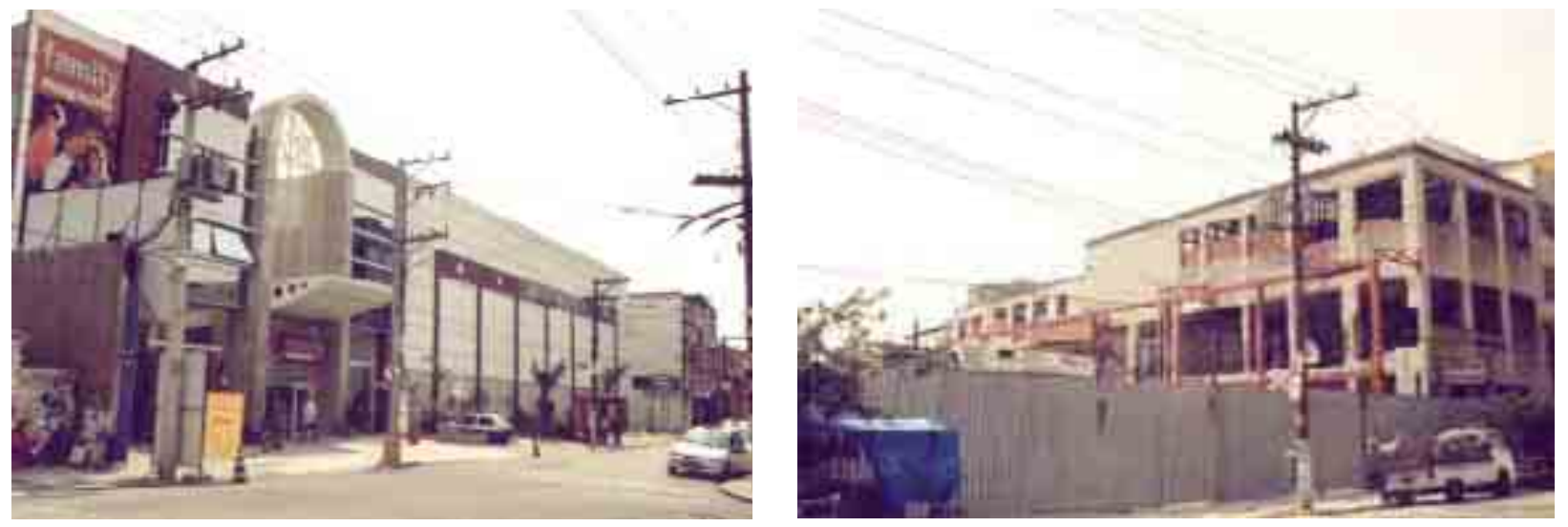
$2^{\circ}$ - A análise deste sub-setor no mapa cadastral de 1930 permite observar que, devido a presença das estações do Norte e da San Paulo Railway, os lotes de maiores proporções para as instalações industriais não se localizaram junto aos trilhos da San Paulo Railway, estando distribuídos pelo conjunto de quadras. Duas vias transversais à Rangel Pestana, ruas do Hipódromo e Bresser, cruzavam a ferrovia Essa última prolongava-se também até o Parí, cruzando a rua João Teodoro, e se constituía num dos raros eixos transversais à avenida Rangel Pestana a promover a ligação nordeste - sudeste, ou seja, a ligação entre o Parí e a Mooca.

As Estações Ferroviárias se constituíram nas principais referências desse setor, juntamente com a Hospedaria dos Imigrantes, situada na rua Visconde de Parnaíba, denominada no levantamento Sara-Brasil "Departamento Estadual do Brasil". Esse edifício foi projetado por Mateus Haussler, a partir meados da década de 1880, que projetou posteriormente o Palácio dos Campos Elísios em 1899 (SEMPLA/Emplasa, 1985, 428). Está situado atualmente na área do distrito da Moóca, mas a identificação histórica sempre a relacionou com o bairro do Brás. Na década de 1940, substituindo os trens que chegavam do Porto de Santos com imigrantes europeus para a Hospedaria, os chamados "paus de arara", caminhões vindos do Nordeste trazendo migrantes miseráveis, faziam ponto perto dos muros da Estação Roosevelt (disponível em <http://www. patrimoniosp.com.br> em 2004).

Outra referência que a carta cadastral de 1930 permitia observar era a garagem de bondes situada na avenida Rangel Pestana, esquina com rua José de Alencar, que ocupava também uma grande área da quadra. Essa garagem recebia os bondes que percorriam o trajeto do centro ao Brás, através da rua Oriente e os que ligavam o centro à Penha. Dentro da malha viária desse sub-setor, encontrava-se também a Estação de Bombeiros do Norte, situada na rua do Hipódromo.

Observa-se que em 1930 a passagem pela Ferrovia do Norte era feita em nível pelas ruas do Hipódromo e Bresser, em 1954 apenas pela Bresser e na década de 1970 já se fazia por viaduto através dessa via, permanecendo a passagem do Hipódromo interrompida. Nesse sentido, é o sub-setor em que a barreira dos trilhos ferroviários criou mais interferências até a década de 1970, sendo acrescido na década seguinte, também o Metrô.

Em fins da década de 1970 a construção do Metrô trouxe outra intervenção de vulto, desta feita no limite do sub-setor com a Moóca. Foi representada pela implantação da Estação Bresser e a desapropriação das quadras do entorno dentro do programa de renovação urbana do Projeto CURA Brás-Bresser. Junto a essa Estação, duas quadras foram desapropriadas e todas as habitações demolidas para dar lugar às torres residenciais que foram construídas apenas em meados da década de 1980, como ocorreu também na extensão da linha em direção da Estação da Sé, em outra área do Brás. 


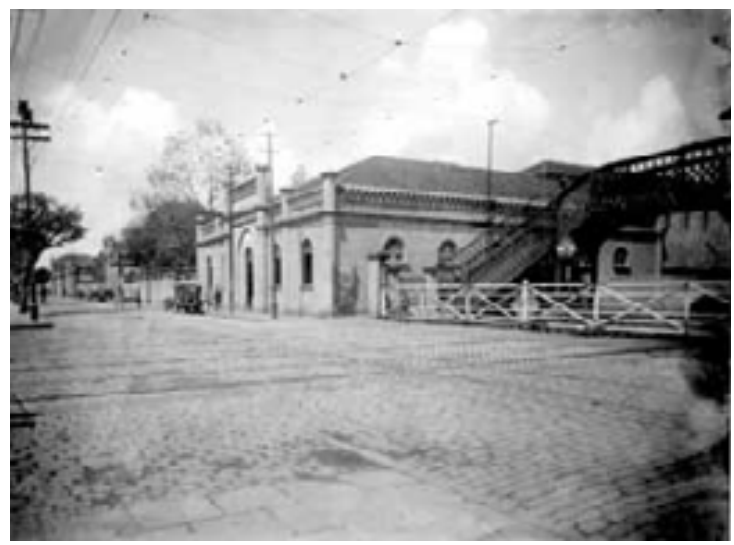

Fig. 185: Hospedaria dos Imigrantes, 1910.

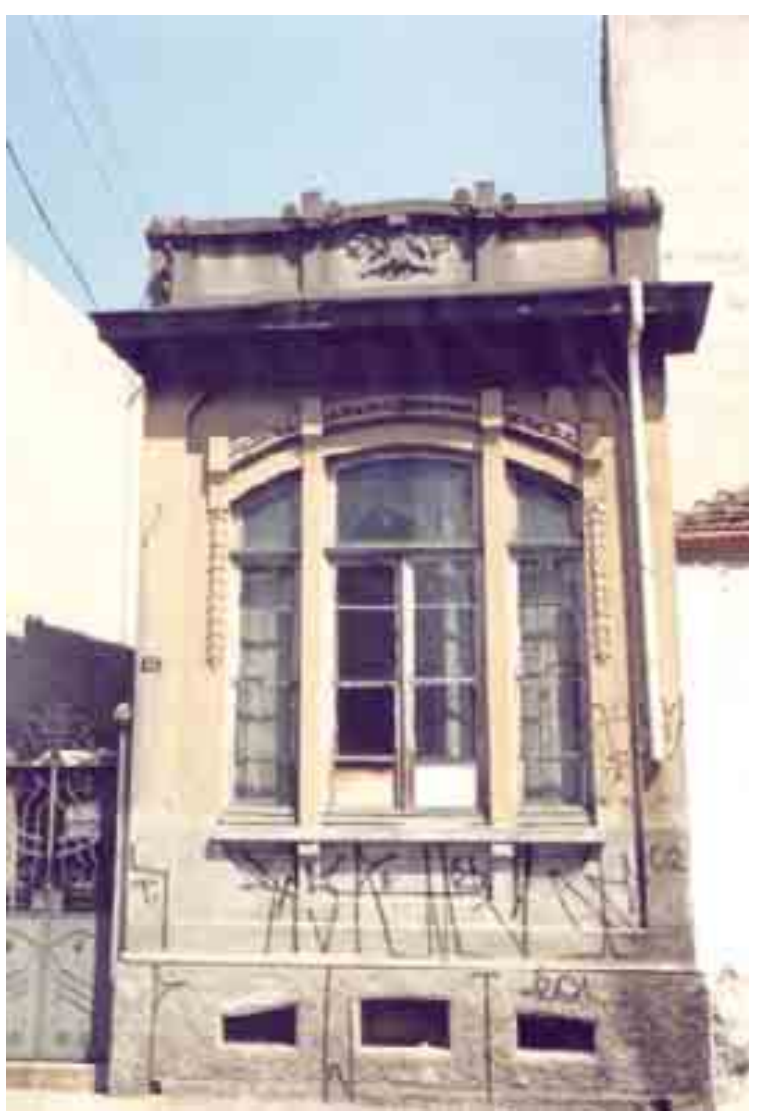

Fig. 186: Tipologia remanescente, Rua do Hipódromo.
Atualmente esse sub-setor se apresenta com um processo de encortiçamento elevado em suas construções, particularmente no perímetro compreendido entre as ruas Dr. Almeida Lima, junto à estação Roosevelt, do Hipódromo, avenida Rangel Pestana e Vinte e Um de Abril, que inclui as ruas Cavalheiro, Paulo Afonso e Uruguaiana. Nesse espaço, a quase totalidade dos edifícios e residências, abrigam habitações coletivas em precário estado e além dos inúmeros depósitos, e transportadoras, a região serve ainda como rodoviária de ônibus particulares que se dirigem ao nordeste do país. Outro aspecto evidente é a total ausência de áreas livres e espaços públicos, pois os poucos existentes, abrigam as atividades do comércio informal.
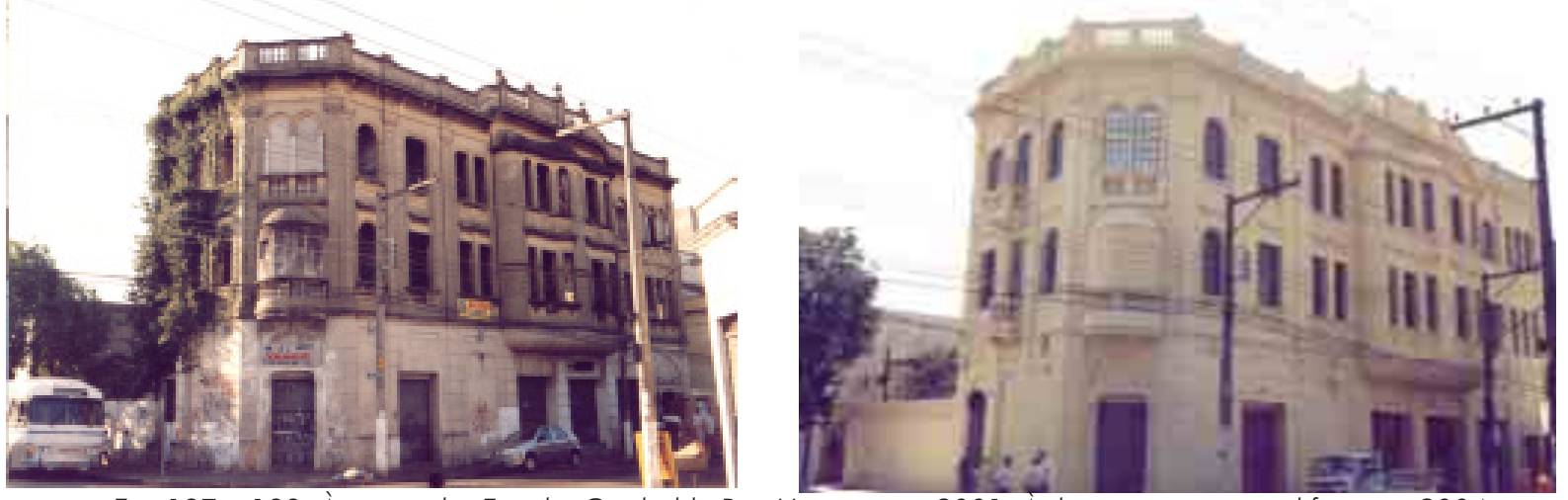

Fig. 187 e 188: À esquerda, Família Garibaldi, Rua Uruguaiana 2001. Á direita, o mesmo edifício em 2004. 
$3^{\circ}$ - Esse sub-setor e o seguinte apresentam como uma das características urbanas principais, a de estabelecer contato com o núcleo central, realizado através de toda extensão do Parque D Pedro II. Nele, as inúmeras referências que a carta de 1930 permite identificar, iá eram existentes desde o final do século XIX: Pátio do Parí, Largo do Parí, Casa das Retortas, Vila Queiroga, rua Monsenhor de Andrade, rua do Gasômetro, etc. A rua da Alfândega interligava a rua do Gasômetro ao Pátio do Parí, que tinha a rua Américo Brasiliense (atual Prof Eurípedes Simões de Paula) como uma das delimitações. A mesma situação se apresentava no mapa de 1954, sendo que o de 1972 mostra a rua Mendes Caldeira já aberta, definindo novos acessos tanto pela rua Santa Rosa, como pela da Alfândega, além de nova delimitação ao Pátio.

Duas outras importantes referências situavam-se na rua Monsenhor Andrade: o Moinho Matarazzo e a Tecelagem Mariângela, do mesmo grupo empresarial. A primeira indústria tinha também um dos seus limites de lote lindeiro à ferrovia e o outro com a rua Flórida, atual rua do Bucolismo. Entre esta última e sua paralela, a rua Sampaio Moreira, foi implantada uma vila de casas populares também com acesso através de rua não oficial pelo mapa de 1930, atualmente denominada rua Vadico.

Tanto a rua do Gasômetro quanto a avenida Rangel Pestana possuíram linhas de bonde que acessavam ao centro. Na primeira, em direção aos bairros, a linha bifurcava-se na direção da rua Piratininga e na direção da Monsenhor Andrade. Na Rangel Pestana, a linha seguia na direção da Penha, passando em nível pelo cruzamento com os trilhos da San Paulo Railway e ladeando a Ferrovia do Norte após sua estação. Outra característica da rua do Gasômetro e da avenida Rangel Pestana era a de não possuírem os viadutos sobre os eixos ferroviários, como já visto.

Ainda pelo mapa de 1930, o Parque dom Pedro II apresentava o paisagismo original de Bouvard e a rua do Gasômetro o cortava transversalmente defronte ao Palácio das Indústrias, superando em sua outra extremidade, os trilhos da estrada de ferro em nível. Em 1954 o Parque já era cortado por bondes através da Rangel Pestana, cuja passagem sobre os trilhos da ferrovia Santos-Jundiaí ainda se fazia em nível. Pelo mapa de 1972, tanto a rua do Gasômetro quanto a avenida Rangel Pestana superavam os trilhos ferroviários por viadutos.

Assim como essas travessias sobre a ferrovia provocaram desdobramentos na região do Largo da Concórdia, contribuindo para sua descaracterização, o complexo de viadutos implantado a partir de 1968 causou o aprofundamento da deterioração do Parque Dom Pedro II e do seu entorno. Com o Parque retalhado por vias expressas aéreas, seu caráter de área de lazer foi abandonado e apenas na década de 1990 sua requalificação foi ensaiada com a transferência da sede da Prefeitura para o Palácio das Indústrias. 
Outro espaço livre presente no sub-setor analisado é do Pátio do Pari, área de galpões ferroviários implantada a partir de 1891 pela San Paulo Railway para o depósito de mercadorias de exportação e importação e que com o declínio dos transportes ferroviários, entrou em desuso, com seus 16 hectares constituindo uma interrupção do tecido urbano entre a área central e os bairros da Luz, Pari, Canindé e Brás.

Nesse sub-setor encontram-se também delimitadas duas áreas de comércio especializado de São Paulo, que emprestaram forte identidade ao local e ao próprio bairro do Brás: a Zona Cerealista e a Madeireira, articuladas entre o Parque D. Pedro II, o Largo da Concórdia e a avenida Rangel Pestana. A morfologia desse perímetro intercala galpões utilizados por depósitos, com edifícios de moradias e ainda vilas remanescentes das primeiras décadas do século XX, como é o caso da Vila Queiroga.

Atualmente esse sub-setor aglutina uma série de espaços de interesse, que receberam iniciativas públicas e privadas para sua reabilitação: como já mencionado, em fins da década de 1990, os galpões da zona cerealista foram reformados pelos seus proprietários, que promoveram melhoramentos também em diversos edifícios residenciais dessa área. Por outro lado, a Prefeitura definiu projetos para o Parque D. Pedro II e rua do Gasômetro, incluindo nessas ações, a reconversão do Palácio das Indústrias como um Centro de Convenções e a Casa das Retortas em museu e centro cultural. No primeiro semestre de 2004 houve também a desapropriação do edifício São Vito, para futura requalificação como habitação social.
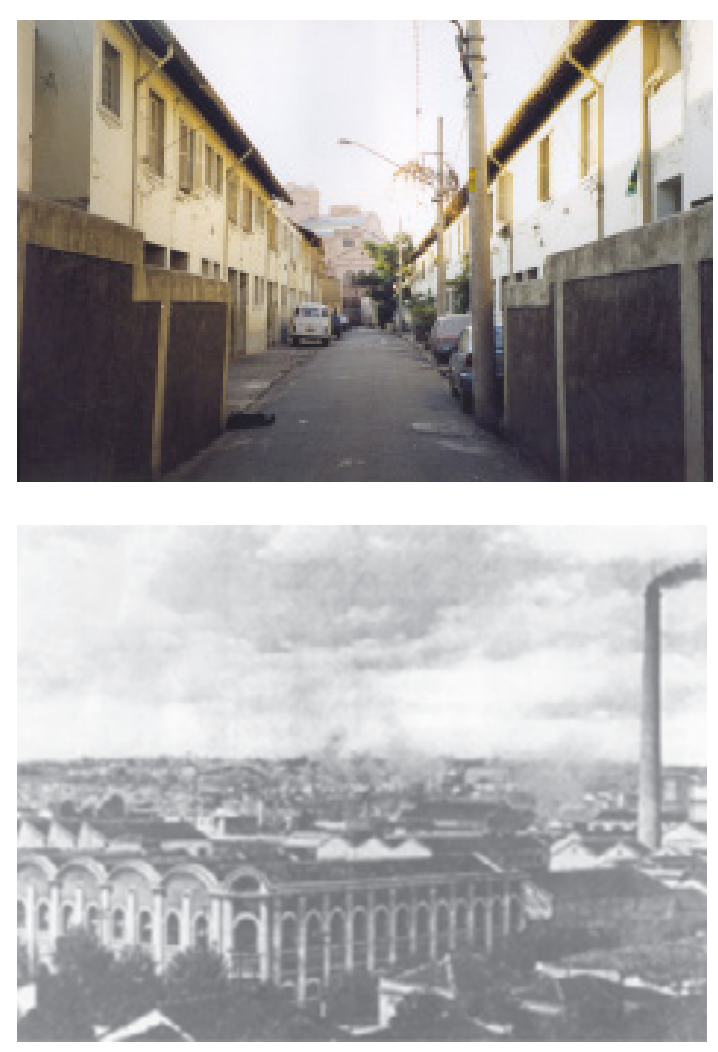

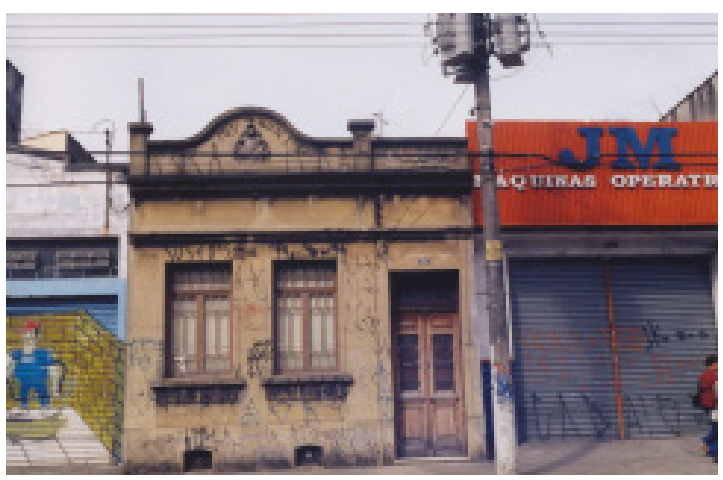

Fig. 189, 190 e 191: Acima, à esquerda: Vila Vadico; à direita, Tipologia remanescente na Rua Piratininga. Ao lado, tecelagem Mariângela, início do séc. XX. 


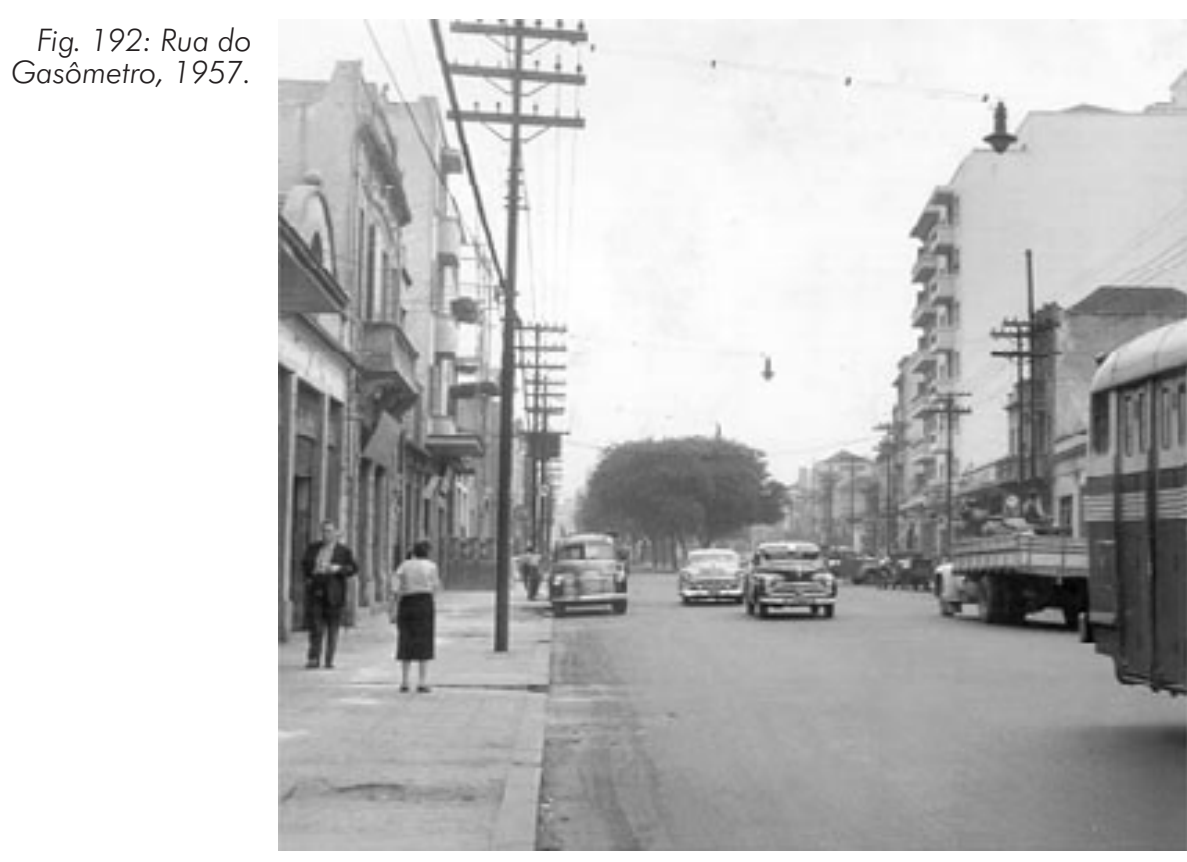

Fig. 193: Rua do Gasômetro,2003.

Fig. 194: Rua do Gasômetro: Tipologia remanescente, comércio de madeiras, 2003
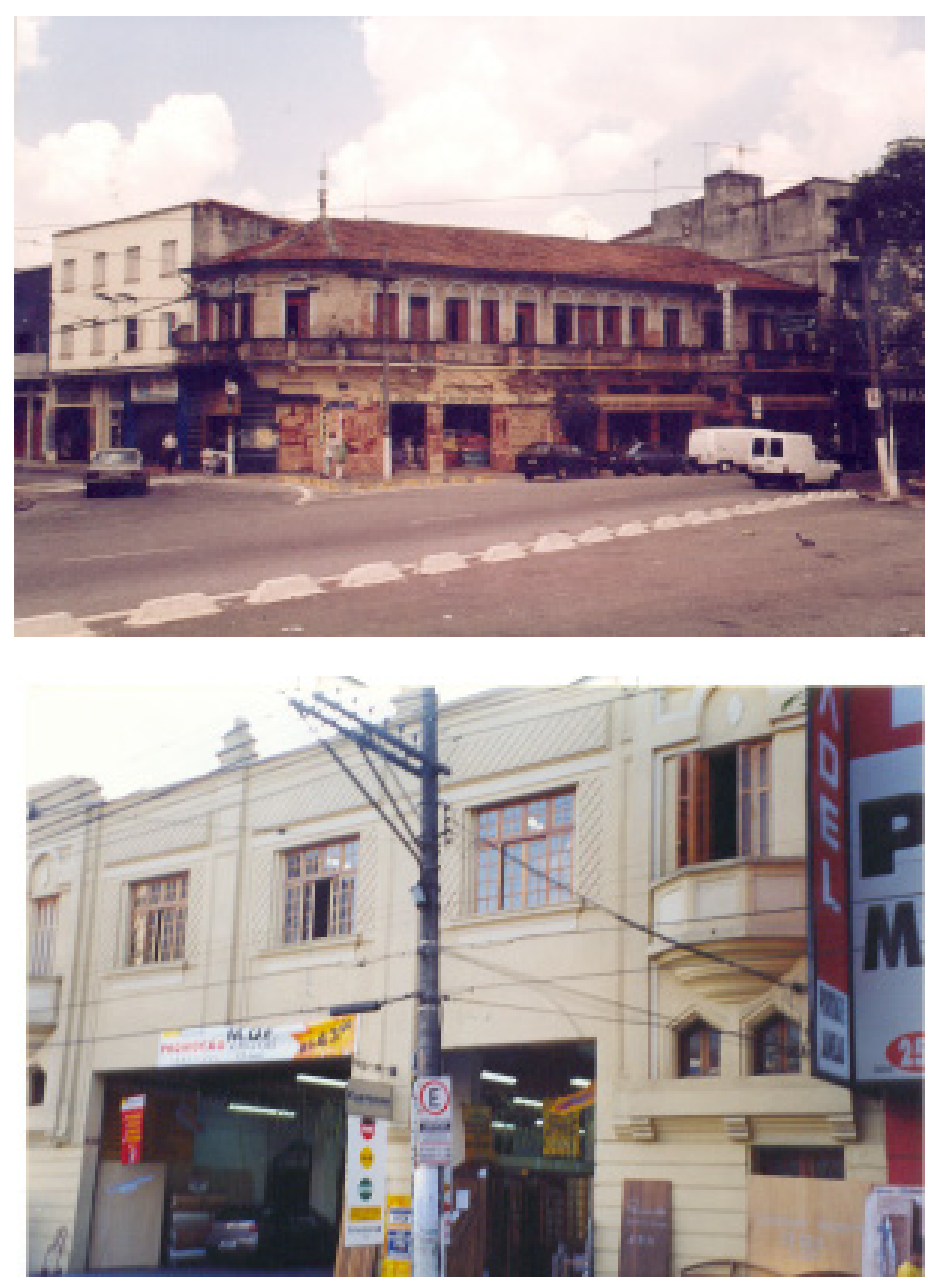
$4^{\circ}$ - Pelo mapa de 1930 esse sub-setor apresentava implantadas as suas referências principais, representadas pelos grandes tanques cilíndricos do Gasômetro, fronteiriços à rua da Figueira e ao Parque Dom Pedro II, além do Grupo Escolar do Brás, atual E.E Romão Puiggari, edifício de 1898 projetado por Ramos de Azevedo, fronteiriço à Matriz do Brás e junto da Escola Técnica Masculina, na rua Piratininga.

Como nos espaços do Bom Retiro, Parí e do próprio Brás, o parcelamento do solo obedeceu ao padrão de lotes com testada de pequena metragem e bastante profundos em relação à quadra, proporcionando a ocupação intensiva pelos cortiços e vilas, exemplificado pelo perímetro compreendido pelas ruas Carneiro Leão, Visconde de Parnaíba e Piratininga, que abrangia também as ruas Caetano Pinto, Campos Sales e Paraná, espaço integrado por um grande número de cortiços. $\bigcirc$ exame dessa carta mostra também uma série de ruas consideradas não oficiais, como é o caso da Travessa Malvina, na rua Piratininga, próxima a Escola Técnica Masculina e da Vila Rosa, na rua Carneiro Leão próxima a Azevedo Júnior.

A presença de lotes ocupados por edifícios de grandes dimensões na carta cadastral de 1930, revela também a continuidade da principal zona fabril da cidade, que acompanhava a ferrovia e se mesclava ao tecido urbano, revelando a intensidade da ocupação então existente. A rua da Moóca estabelecia o limite entre a ocupação com as características anteriores e aquela com maior aproveitamento para finalidade de moradia. Nesse caso, como de resto em toda a área pesquisada, verificava-se também a presença de diversas ruas consideradas não oficiais, como era o caso do entorno da rua Xingu, próximo à rua Coronel Cintra, onde assim foram nomeadas a Vila Alvarenga e a rua Andrade Reis.
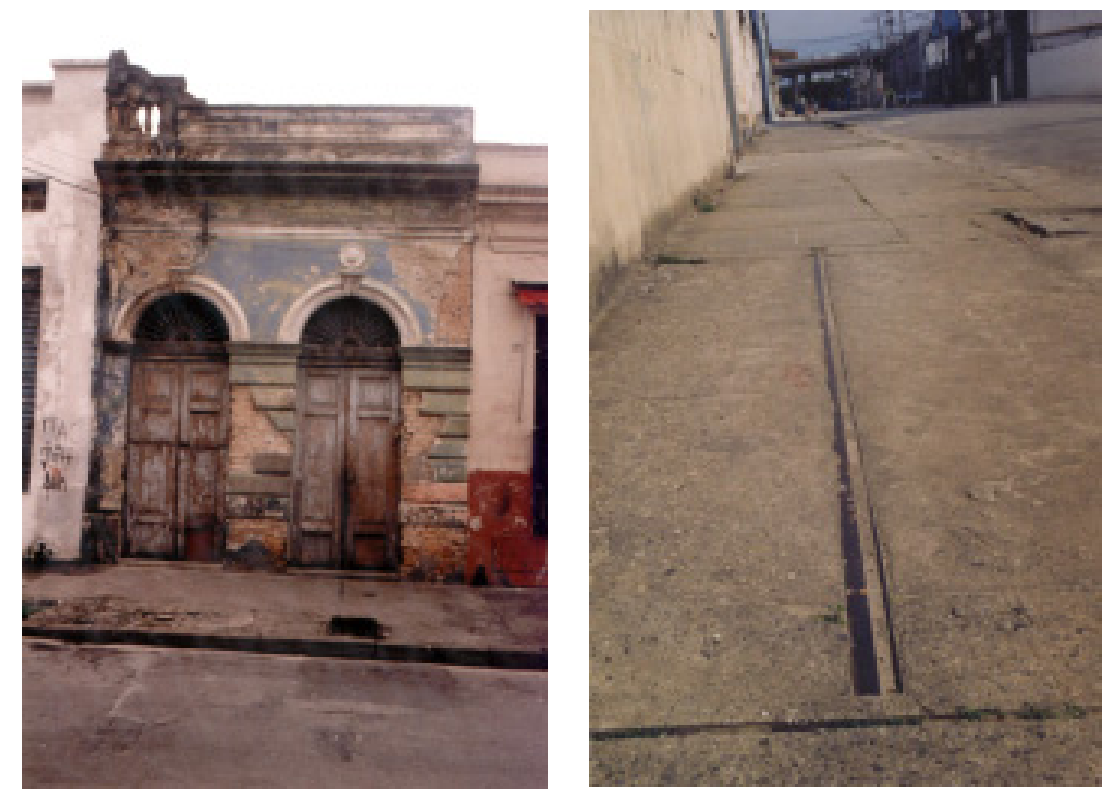

Fig. 195 e 196: À esquerda, tipologia remanescente, Rua Caetano Pinto. A direita, sinal do tempo: Trilho de bonde na Rua Martin Bouchard. 


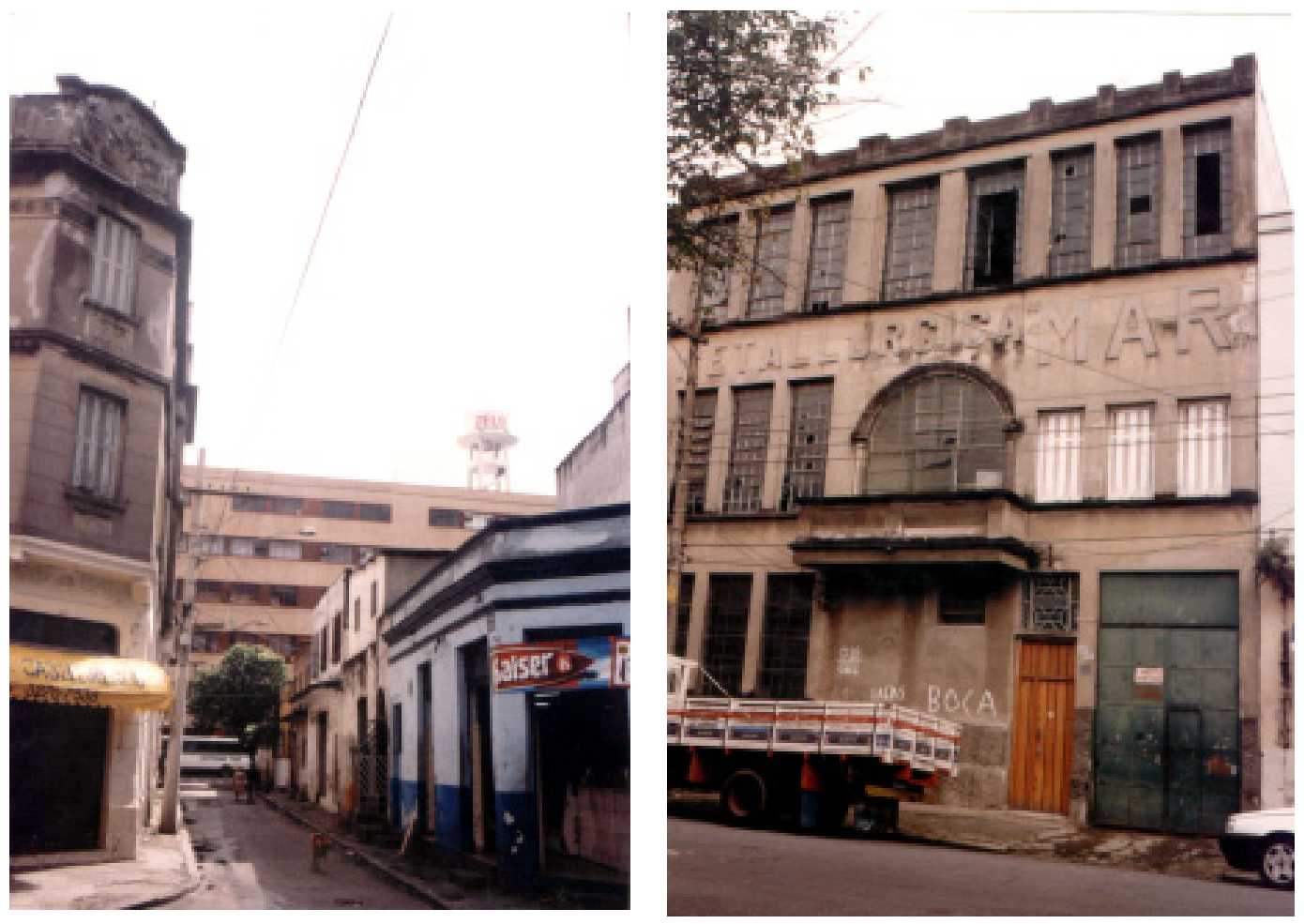

Fig. 197 e 198: À esquerda, Travessa Sobral x R. Carneiro Leão. À direita, antigas instalações industriais na R. Carneiro Leão.

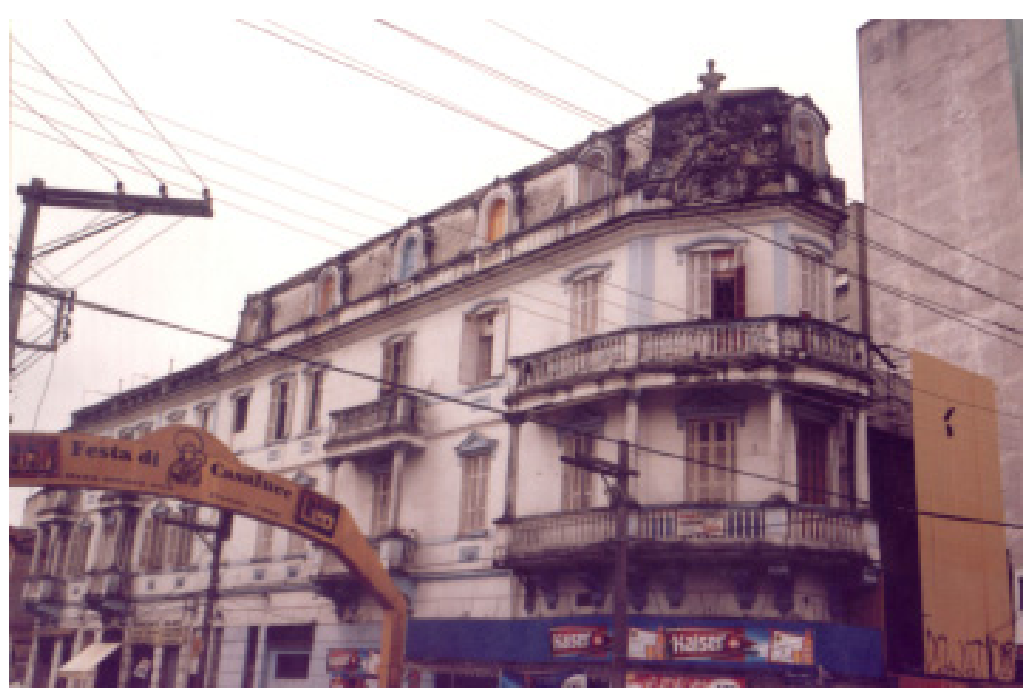

Fig. 199: R. Carneiro Leão $\times$ Av. Rangel Pestana. 


\subsection{Parí}

Situado a nordeste do núcleo central, as origens do Pari remontam ao século XVI, pois já em 1593 o Caminho do Pari era conhecido. A sua denominação deriva da atividade da pesca baseada em um processo primitivo de captura que utilizava uma cerca de taquara, denominada Parí, que atravessava o rio de margem a margem. O Pari começou a ser urbanizado em fins do século XIX, em conexão com a Luz e o Brás, sendo a ferrovia o elemento estruturador de indústrias e de vilas operárias. Em seus limites com o Brás, foi instalado também um equipamento que desempenhou importante papel na definição da vocação da sua área envoltória: a alfândega seca no Pátio do Pari, um conjunto de depósitos da San Paulo Railway ligados ao comércio de importação e exportação.

Conectado ao Parí, as origens do Canindé também remontam o século XVI, quando era conhecido por Guaré. Em 1856 o bairro era constituído pela Chácara Couto de Magalhães, loteada em fins do século XIX, ganhando o nome de uma das principais cidades do estado do Piauí. (Gazeta do Brás, nov. 1976; NP, 7/ $11 / 1976,12)$. Destacando-se na planície ocupada pelos bairros do Pari e Canindé, o Morro do Pari, também chamado de Alto do Pari, foi o local que apresentou uma urbanização caracterizada por vielas e becos, relacionada aos imigrantes que ocuparam gradativamente o local. No início do século XX, toda a área dos bairros do Pari e do Canindé ainda abrigava as atividades das olarias, de propriedade dos italianos e da criação de gado, dos portugueses (idem, 12). As olarias deixaram ainda na toponímia da rua que liga o Pari (bairro mais alto) ao Canindé (bairro mais baixo), o testemunho dessa atividade.

Em 1911 foi iniciada a construção daquela que se tornou a mais importante referência do bairro, a lgreja de Santo Antônio do Pari, fruto de uma ação entre os doadores das colônias italianas e portuguesas para sua construção. Essa Igreja formou juntamente com o Lgo. Padre Bento um espaço que emprestou forte identidade ao bairro, recebendo também um conjunto escultórico.

Por estar próximo ao centro da cidade de São Paulo e de outros bairros populosos, a ocupação do Parí se realizou de forma crescente, sendo elevado à categoria de $25^{\circ}$ Subdistrito da Capital pela lei no 8.637 de 1934. Sua extensão, de 5,46 $\mathrm{Km}^{2}$, abrangia o Canindé, a Vila Guilherme e vilas adjacentes, sendo que em 1964 a Vila Guilherme se desmembrou desse subdistrito, que passou a abranger somente o bairro do Canindé, com sua área caindo para 2,75 $\mathrm{Km}^{2}$. Em conseqüência dessa diminuição, a sua densidade demográfica, que era de 64,1 hab/ha em 1960, aumentou para 1 11,6 hab/ha (ibidem, 12).

As transformações urbanas ocorridas no Parí e no Canindé alteraram uma paisagem que, segundo o capomastri Oliviero Fuzari, na década de 1920 era ainda formada por pastos, chácaras e várzeas. Segundo esse mestre-de-obras italiano, nascido em Lucca, na Toscana, a sua atividade foi intensa já na metade da década de 1930, tendo construído aproximadamente 100 casas na área do 
Fig. 200: Casario remanescente na R. Juruá Canindé, 2003.

Fig. 201, 202 e 203: Ao lado, Pça. Padre Bento em 1957. Ábaixo, à esquerda, placa comemorativa da inauguração do conjunto escultórico; à direita, $P$ ça.

Padre Bento em 2003.
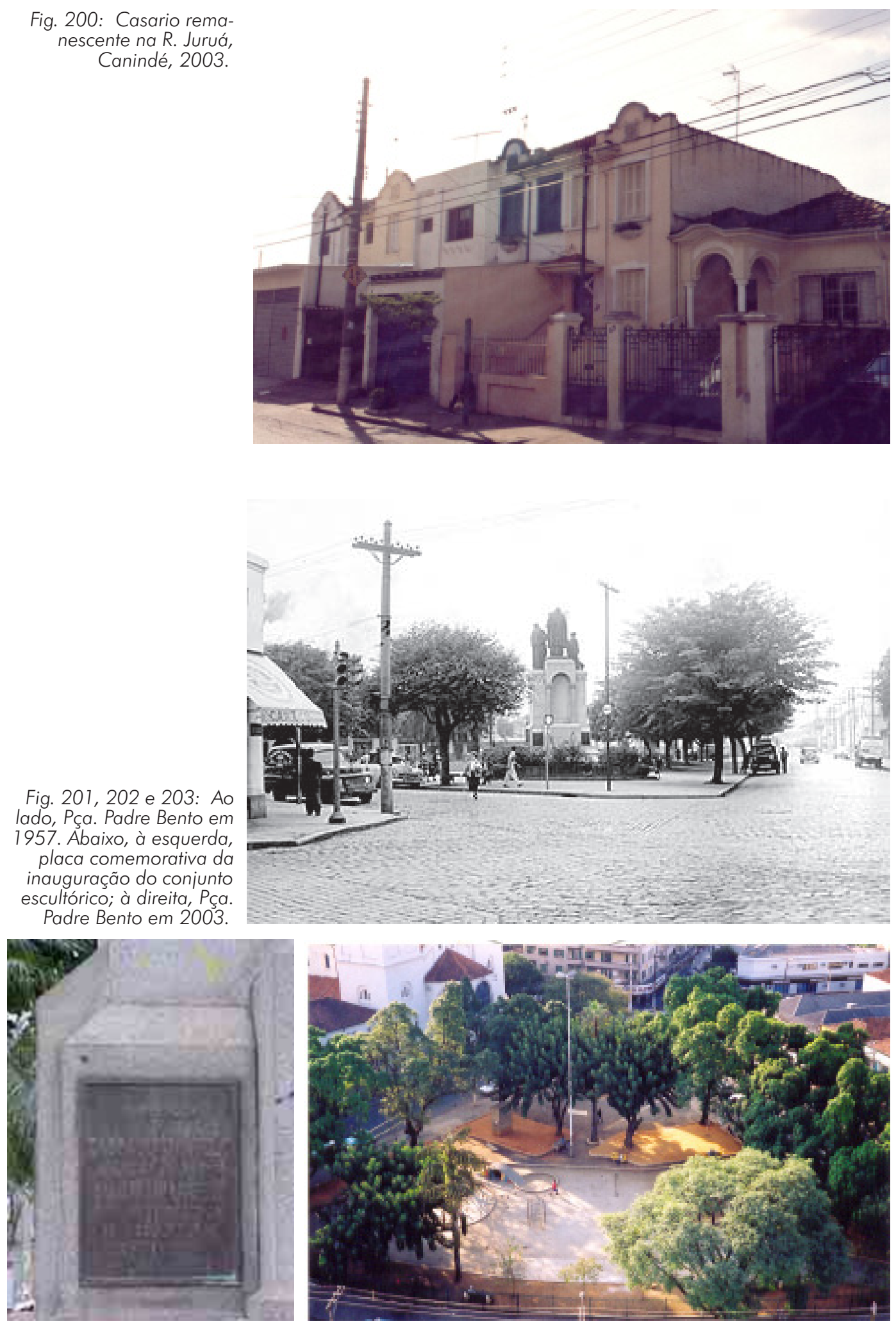
Pari e Canindé, dentre elas 16 sobrados na rua Juruá e todos os da rua Mario Ibara de Almeida, entre outras obras (op. cit, 12).

Nas primeiras décadas do século XX, parte do Parí já se encontrava conectado ao Brás e ao Belenzinho, onde as vilas operárias como a Queiroga e Vila Maria Zélia já haviam sido construídas, assim como ocorria com a Luz, no caso da Vila Economizadora. Na área compreendida pelo Canindé, as quadras ao longo da atual avenida Cruzeiro do Sul revelam a similaridade da tipologia com as da Ponte Pequena, situadas entre essa via e a avenida dos Estados, antiga Tamanduateí. Por contar, além do obstáculo representado pela Várzea do Tietê, com áreas que permaneceram vazias por longo período, como o do Campo da Força Pública ou da proximidade das lagoas formadas pela extração de argila, - bairro mostrou setores rarefeitos demográficamente e em alguns casos, ambientes semi-rurais que perduraram por muitas décadas.

Sob o ponto de vista da ocupação, ao longo das décadas de 1950 e 1960 o Parí e o Canindé mantiveram as características básicas dos períodos anteriores: a mescla da habitação com indústrias de pequeno e médio porte, baixa oferta de serviços públicos, área comercial com predominância do ramo de confecções na transição com o Brás e diversificado número de indústrias em seu tecido urbano. Grande parte do casario do início do século XX, construído já como cortiço ou adaptado para tal, mesclava-se nas ruas com renques de casas térreas ou de pequenos sobrados. $O$ sobrado que incluía um salão comercial no térreo e uma residência no andar superior foi também uma tipologia disseminada desde as primeiras décadas do século $X X$, com grande permanência ainda nos dias atuais.

Apesar da predominância dessas tipologias, um diferencial foi o de alguns conjuntos de quadras se caracterizaram por apresentar um padrão de moradia muitas vezes superior às demais, tanto no Parí, em maior grau, quanto no Canindé. Esse fato comprova a forma menos segregada de moradia que existiu nesses bairros, e em geral na cidade. As quadras mencionadas apresentavam lotes de maiores proporções, um casario com recuos frontais e laterais, maiores volumes e jardins, todos esses exemplos do "morar à francesa" (Lemos, 1999, 23) característicos dos bairros de alta renda da cidade, reproduzidos em escala reduzida outras nas áreas da cidade.

Diferentemente do Bom Retiro e do Brás, onde tal ocorrência se verificou em quantidade muito menor, aquelas formadas no Pari e no Canindé contrastavam com os inúmeros cortiços e até uma favela já existente na década de 1960. Algumas hipóteses podem ser formuladas:

- Sob o ponto de vista da ocupação ocorreu uma substituição das primeiras construções desses bairros, ou simplesmente o preenchimento dos lotes ainda vazios, ambos denunciados por edificações mais recentes. 
- A ocupação horizontal predominante no Parí e Canindé atendia a um setor da classe média que em outros bairros encontrou na verticalização uma alternativa de novas formas de moradia, como pode ter sido o caso do Bom Retiro.

- No Brás e no Bom Retiro, tanto a idade das construções, quanto a homogeneidade do parcelamento, constituído predominantemente de pequenos lotes, impedia a existência dos setores de moradia horizontal de padrão médio encontrados no Pari. Um indicador dessa diferença é o maior número de pequenos edifícios no Brás e no Bom Retiro, que no Canindé e Parí. Como se sabe, as construções com até quatro pavimentos foram uma solução econômica para a moradia popular e de classe média em bairros centrais a partir da década de 1940, barateando o custo da habitação.

Nas décadas de 1960 e 1970 as inúmeras indústrias alimentícias e revendas que se aglutinaram no distrito, emprestaram ao mesmo uma de suas características mais recentes: a de "bairro doce", que no entanto já nas décadas seguintes entrou em declínio. Esse fator se deu em função da legislação municipal e estadual, limitadoras das atividades e da ampliação dos estabelecimentos, bem como ao crescente interesse comercial em relação à utilidades domésticas de baixo custo, que se tornou uma especialização do local.
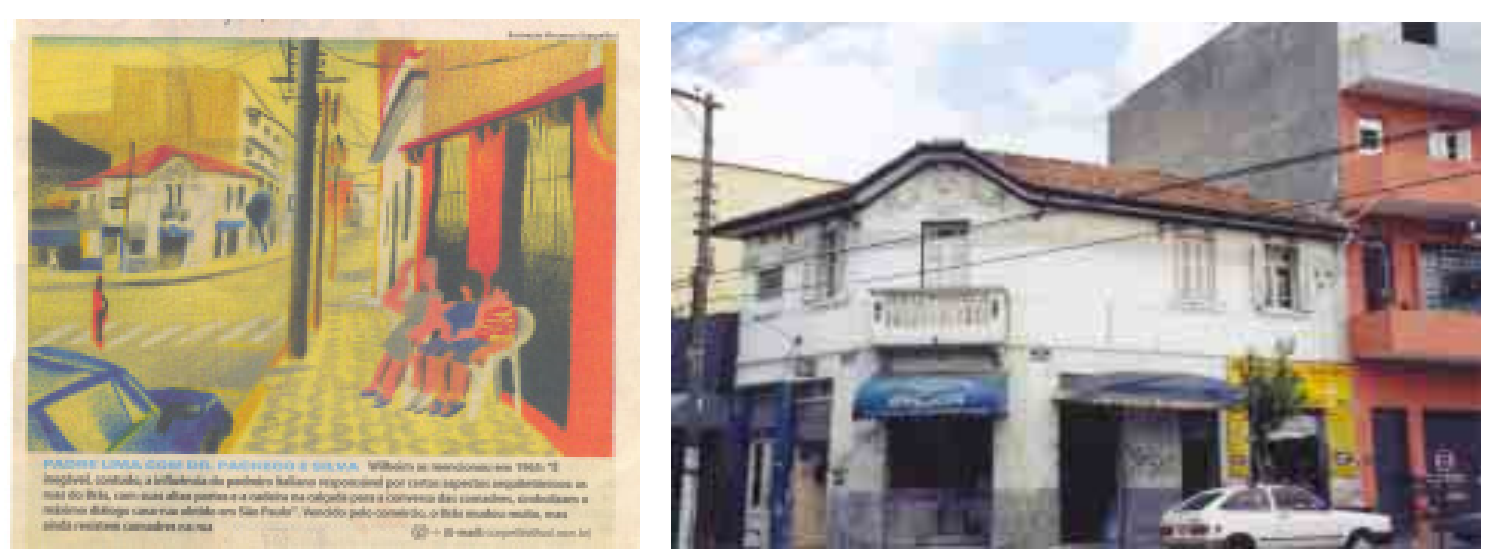

Fig. 204, 205 e 206: Acima, à esquerda, ilustração jornalística mostrando casario da R. Padre Lima, o mesmo aparecendo em foto de 2003 à direita. Ao lado, edificação remanescente,

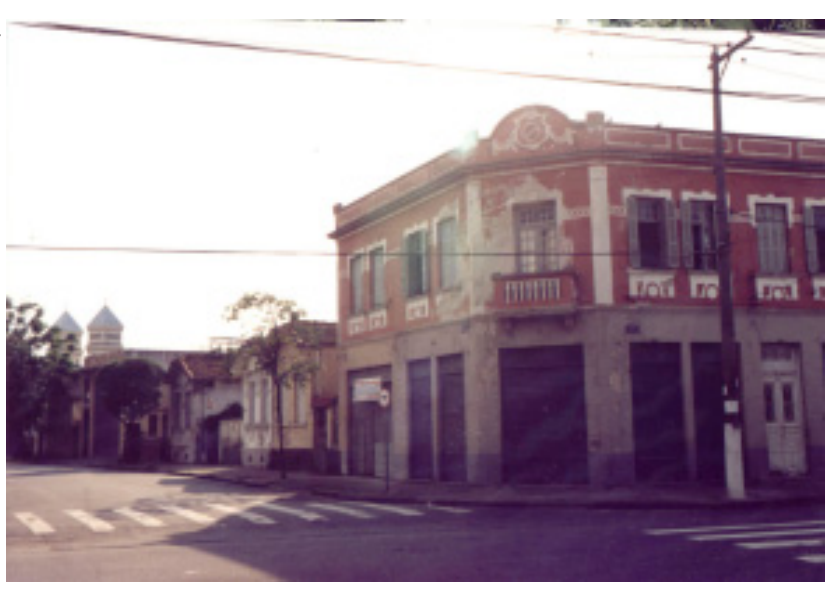




\subsubsection{Análise dos sub-setores}

Diferentemente dos setores urbanos Bom Retiro e Brás, todo o setor do Parí não contou com vias que fizeram parte do sistema estrutural da cidade para a ocupação de seu território, o que o configurou e ainda configura como uma ilha entre os bairros ao norte e ao leste do núcleo central.

Os mapas históricos mostram a abertura de ruas em continuidade ao tecido já existente de bairros contíguos, como comprova a situação no detalhe do mapa de 1915 em relação ao de 1930. A inexistência de uma carta cadastral anterior ao levantamento Sara Brasil impede o exame da ocupação dos lotes, mas podese verificar que o sistema viário já havia sido em grande parte implantado, com exceção de algumas vias interrompidas em 1915.

Pelo mapa de 1930 o setor do Parí foi subdividido em três sub-setores, que obedeceram basicamente o critério da proximidade das áreas internas dos mesmos com os bairros limítrofes:

$1^{\circ}$ - O primeiro sub-setor corresponde à área que o bairro do bairro do Canindé abrange, mostrando a grande extensão ainda não ocupada da Várzea do Tietê, próxima ao morro do Pari (ref. 1). A área lindeira à ferrovia da Cantareira, atual avenida Cruzeiro do Sul (ref. 3), apresentava-se a partir da rua João Teodoro com o arruamento contínuo ao da Ponte Pequena e Luz, estando o espaço do Campo de Manobras da Força Pública, identificado no mapa de 1915, ainda não ocupado em 1930, assim como parte do seu entorno imediato, esparsamente urbanizado (ref. 4).

Toda a região próxima da estação Tamanduateí (ref. 5) encontrava-se ocupada, principalmente as transversais à rua do Canindé, como a Vidal de Negreiros, Afonso Arinos e Pasteur, que se caracterizavam como área de habitação popular. Apenas nas proximidades da rua João Teodoro se verificava a presença de lotes de grandes dimensões ocupada por galpões (ref. 6), corroborando as análises que indicaram ter restado à habitação popular ocupar as terras mais baixas dos bairros fabris. Como assinalado anteriormente, a rua Pedro Vicente estabelecia a ligação ao norte entre o Canindé e a Ponte Pequena, cruzando a linha de trem em nível. Acima dessa rua e da rua Araguaia, já na Várzea, apenas edificações isoladas e uma série de ruas assinaladas como não oficiais podem ser percebidas pelo mapa cadastral, indicativas da estrutura semi-rural ainda existente nessa região, mencionada na entrevista de um antigo morador do bairro.

A avenida Valtier (ref. 7) configurou um dos limites desse sub-setor com o seguinte, o do bairro do Parí, possuindo pelo mapa de 1915 o início de arruamento nas extremidades junto às ruas João Teodoro e das Olarias, não havendo continuidade a partir desse ponto. Já em 1930 a mesma via mostra-se traçada, o mesmo ocorrendo com sua continuação até a rua Araguaia, a rua Padre Vieira. $O$ 


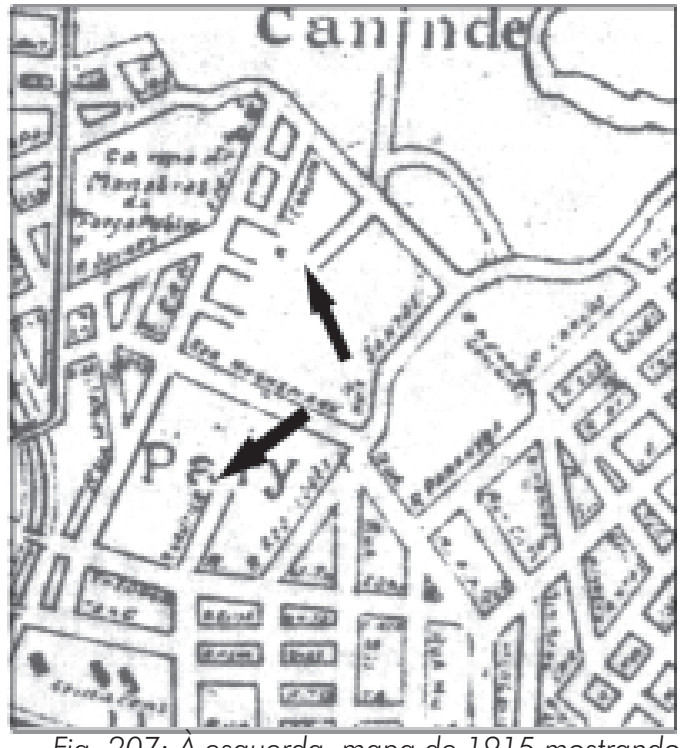

Fig. 207: A esquerda, mapa de 1915 mostrando o seccionamento da Av. Valtier; à direita, a mesma

mapa da Light de 1925 não indicava o funcionamento de linha para o Canindé, pois o bonde mais próximo fazia o trajeto das ruas São Caetano, Monsenhor Andrade e rua Oriente. Como o mapa cadastral indica ter sido implantada a linha de bonde para o Canindé (linha 49) e nas áreas mais alagadiças ela requereu previamente aterros, pode ser considerada a hipótese dessa área indicada como não ocupada em 1915 ter recebido essas melhorias para posterior parcelamento.

No mapa de 1954 as alterações mais perceptíveis ocorreram na área próxima ao Campo da Força Púbica, nas imediações das ruas Canindé e Araguaia. Diferentemente das quadras anteriormente estruturadas, formou-se um setor residencial com características diversificadas: na rua Araguaia e Itaquí, setores mais populares, na rua Olarias e Pascoal Malatesta, setores de classe média, com esta última rua se constituindo na única do bairro com padrão de casas isoladas, com recuos e padrão construtivo diferenciado.

Fig. 208: "Morar à francesa", edificação na R. Pascoal Malatesta, Canindé.

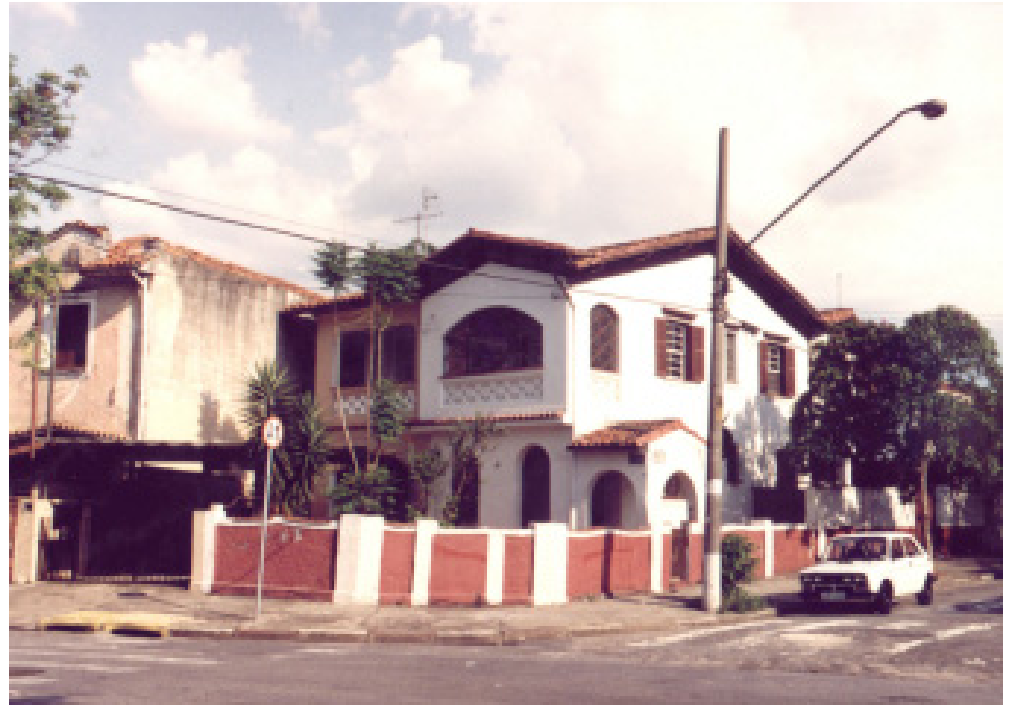


Em comparação à carta de 1930, na de 1954 o Campo da Força Pública apresentava ocupação, o mesmo ocorrendo com o entorno do campo dos clubes Estrela do Pari e Serra Morena, nas proximidades da rua da Piscina. Outra alteração ocorrida se refere à existência da garagem de bondes na rua Padre Vieira, esquina com a rua Araguaia, uma vez que na anterior a mesma não se encontrava assinalada (ref. 8). A existência de lagoas formadas pela extração de areia ou argila, interrompia a rua Pascoal Raneri (ref. 9), cuja continuação era denominada Estada do Porto e ocupava uma grande extensão onde, no início da década de 1960 se implantou a Associação Portuguesa de Desportos (ref. 10), limitada pela rua Azurita e posteriormente a Escola Técnica Federal, situada na rua Pedro Vicente (ref. 11).

Ainda pelo mapa de 1954, a Várzea do rio Tietê apresentava certa ocupação ao longo das ruas Pascoal Ranieri e Araguaia, apesar de não haver sido definido o arruamento em alguns trechos. Na carta de 1972, além dos equipamentos mencionados anteriormente, percebe-se o adensamento da ocupação, bem como o traçado viário definitivo, com exceção da avenida Bom Jardim, que era interrompida por galpões de transportadoras na altura da rua lturama (ref. 12), trecho que posteriormente foi vencido, ligando-a com a rua Araguaia.

Predominam no parcelamento os lotes de pequenas dimensões, com inúmeras vilas e ruas com casas em renque, geminadas de ambos os lados. Em meio a essa tipologia, pelo mapa de 1972 encontravam-se distribuídos galpões de empresas transportadoras e de indústrias alimentícias, que se fixaram no Canindé e no Parí durante as décadas de 1960 a 1980. A área próxima à rua da Piscina caracterizou-se por reunir espaços públicos e privados ligados ao esporte e educação, contrastando com o restante do bairro, densamente ocupado.

Atualmente, nesse sub-setor dois processos ocorrem simultaneamente: a disputa do comércio por pontos de venda e a construção de duas torres habitacionais no Canindé. No primeiro caso, novas construções ou reconversão de edifícios
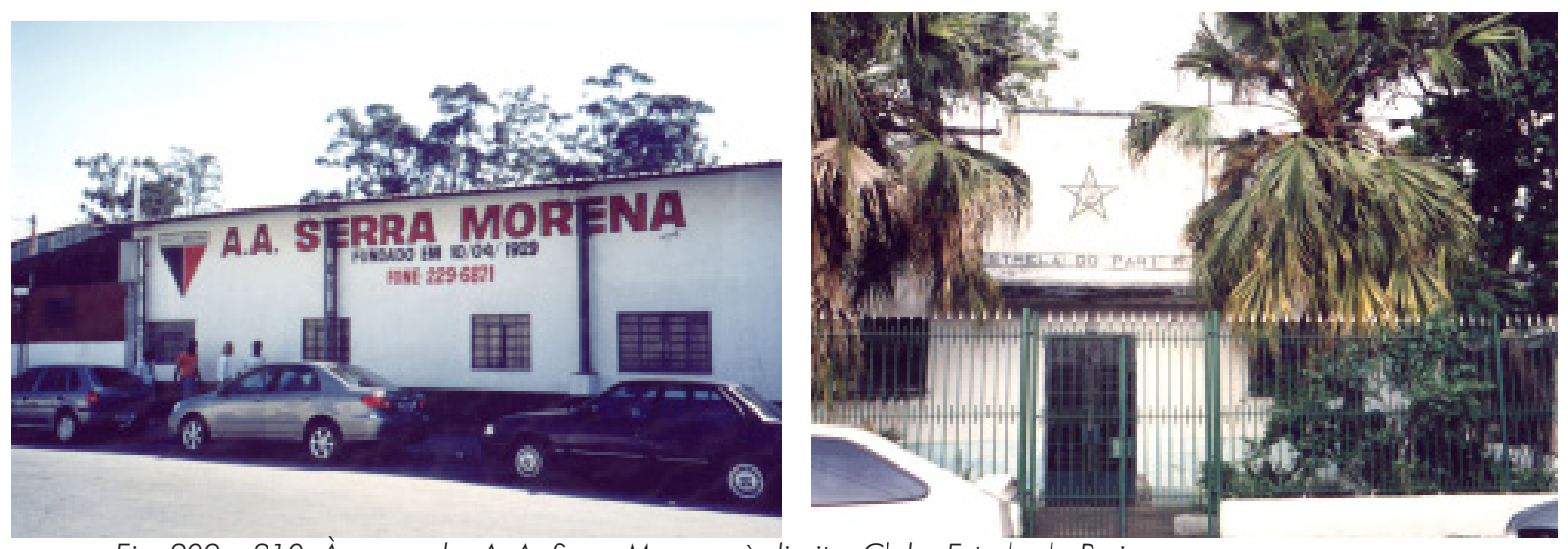

Fig. 209 e 210: À esquerda, A. A. Serra Morena; à direita, Clube Estrela do Pari. 
Fig. 211: Verticalização no Canindé, ao fundo.

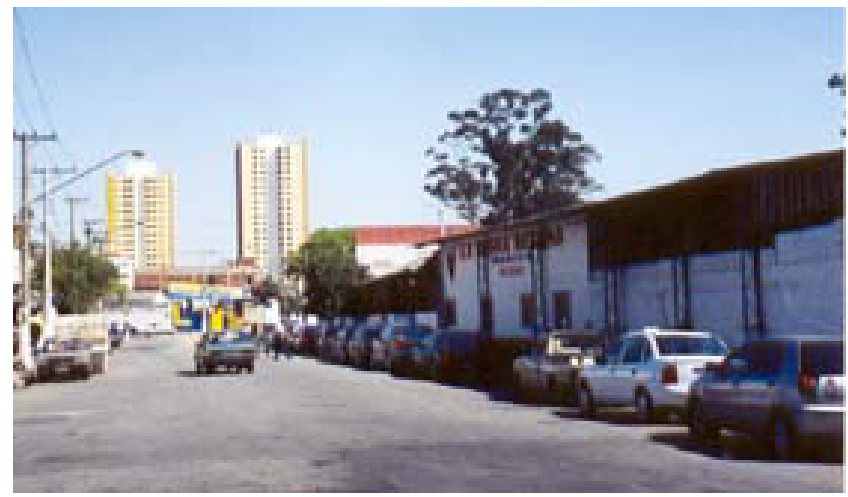

Fig. 212 e 213: Ao lado, Conjunto Olarias no início de sua construção; abaixo, em fase de conclusão.
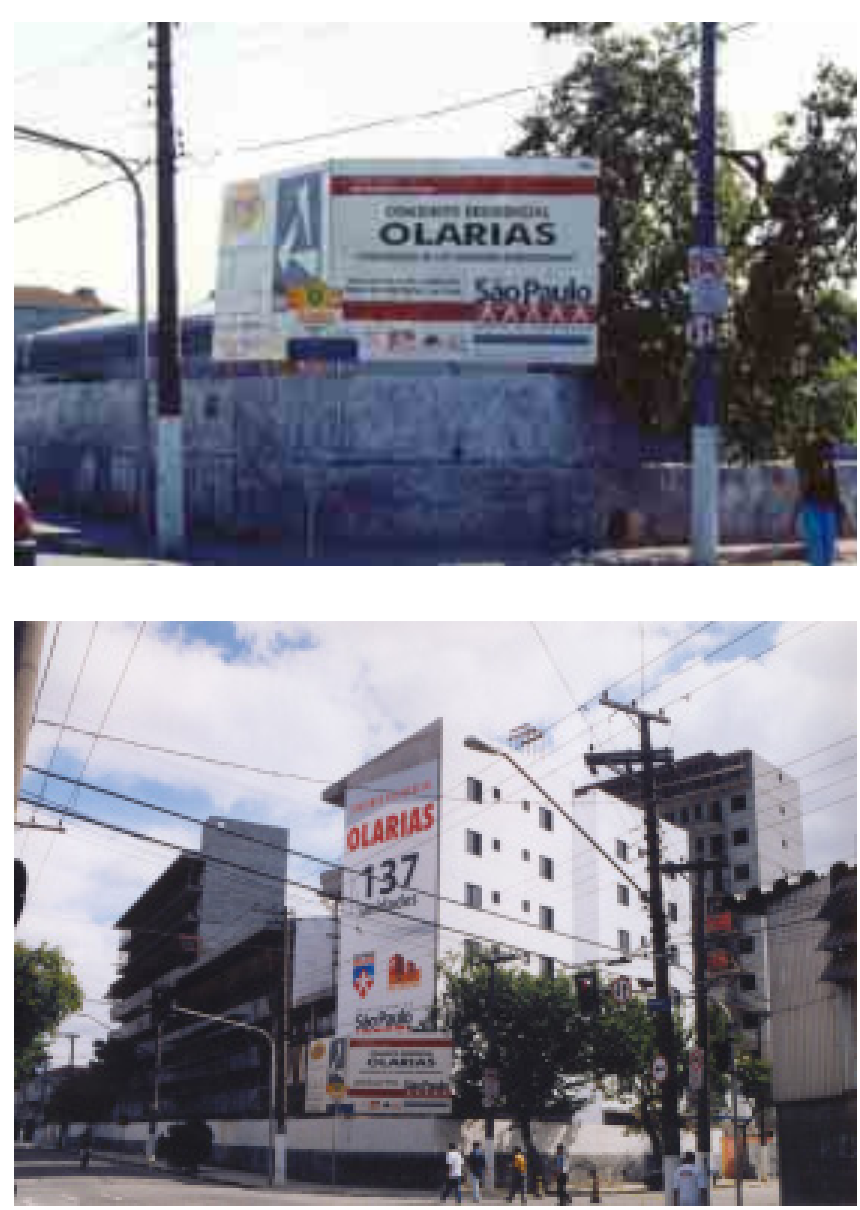

existentes se expandem ao longo da avenida Valtier e suas travessas, com atividade voltada principalmente a utilidades domésticas. Nesse processo, foi inclusive demolido antigo casarão naquela avenida, que serviu nos últimas quatro décadas como órgão público destinado ao combate de endemias e epidemias. Mais recentemente foi construído um conjunto para habitação de interesse social, na Rua das Olarias, que também poderá contribuir para a reversão do processo de esvaziamento populacional que a área apresentou. 

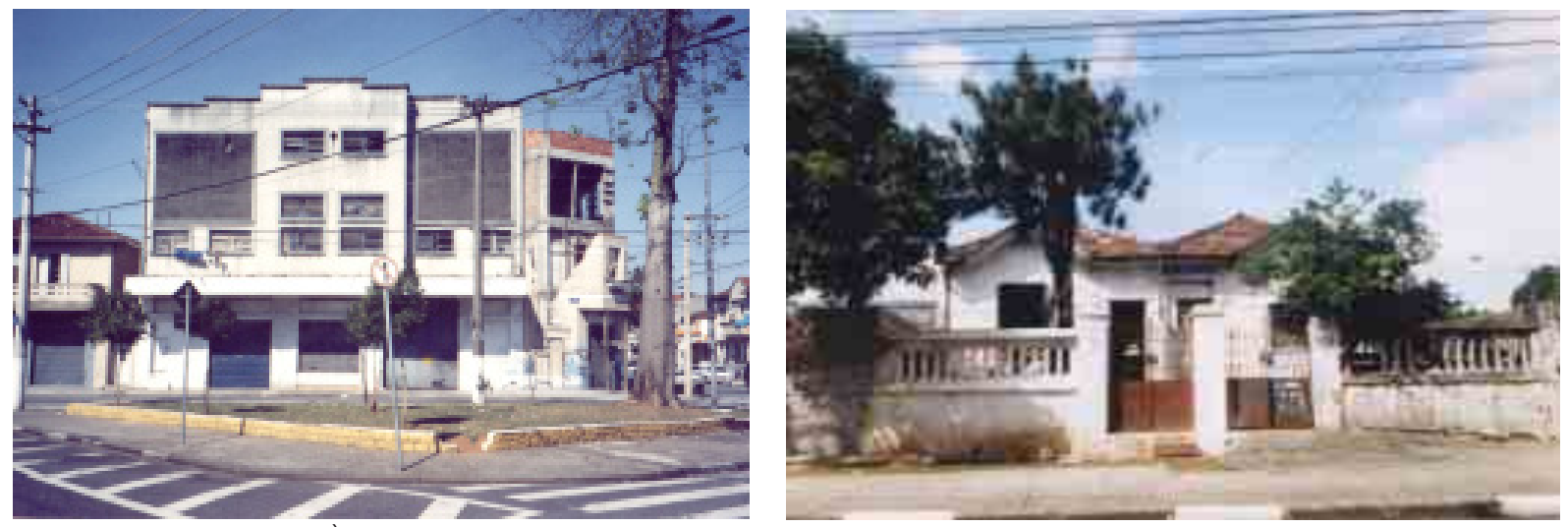

Fig. 214 e 215: À esquerda, antigas instalações do Cine Haiti; à direita, habitação econômica no Canindé.

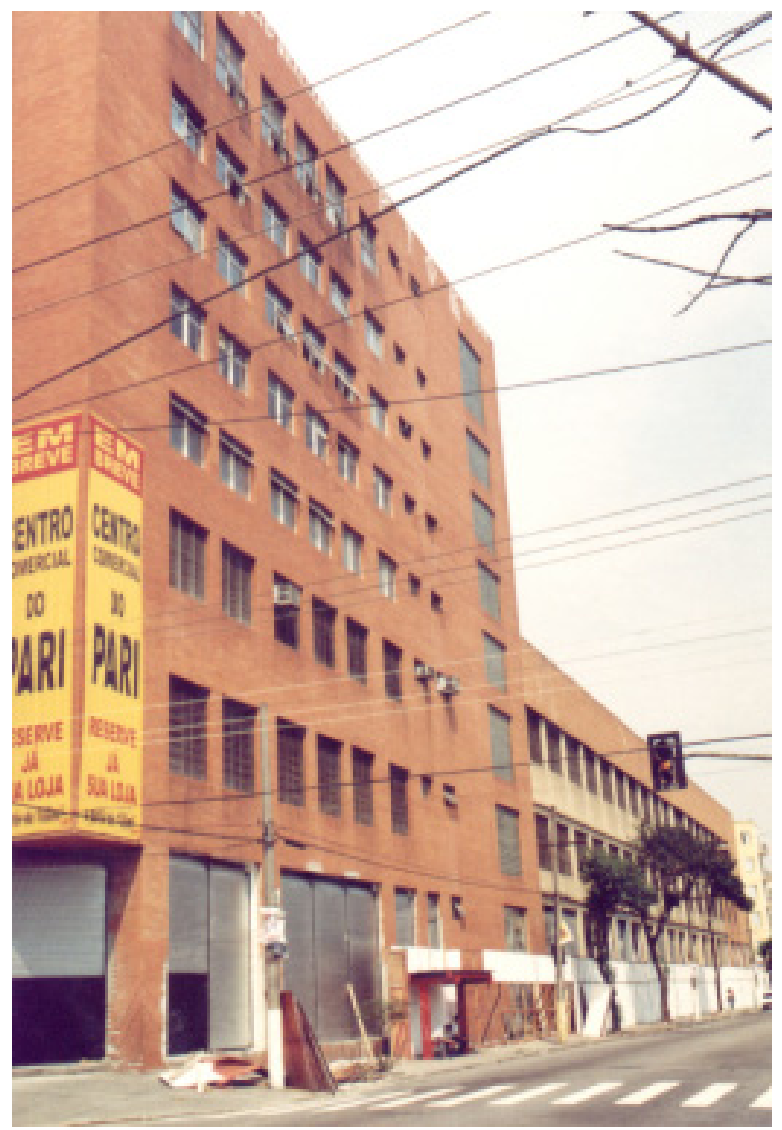

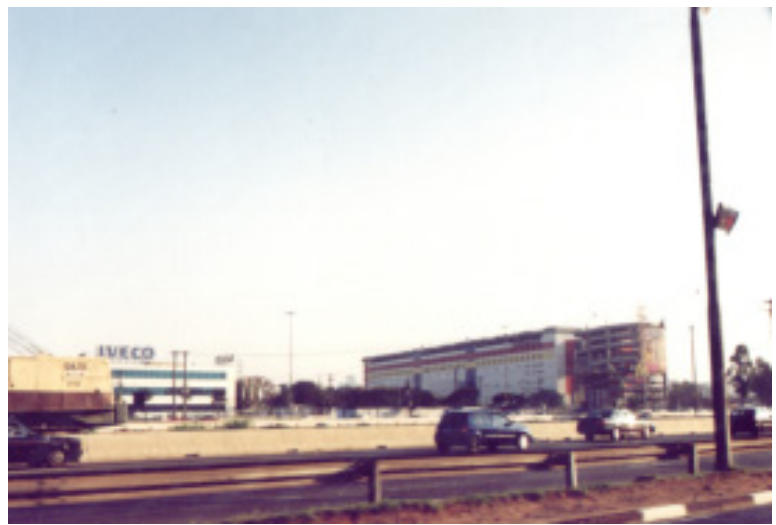

Fig. 216 e 217: A direita, grandes equipamentos ao longo da Marginal Tietê

A esquerda, antigas instalações da indústria Tostines na Av. Valtier, 2004. 
$2^{\circ}$ - Esse sub-setor caracteriza a área do bairro do Parí propriamente dito, intercomunicando-se com a do Canindé e com a do sub-setor seguinte, caracterizada por ser área de transição com o Brás. O mapa de 1930 indica já haver ocorrido a ocupação das quadras ao longo da avenida Valtier, assim como em parte de suas transversais (ref. 7). Assim como o sub-setor anterior, nas proximidades da rua João Teodoro, o parcelamento indicava a presença de lotes ocupados por galpões industriais em meio aos lotes habitacionais e na rua Thiers, entre a Hanemann e Conselheiro Dantas, a presença da indústria inglesa de ensacamentos de juta (ref. 10), que ocupava metade dessa quadra e permaneceu por muitas décadas no bairro, visível na fotografia aérea da década de 1940.

Os mapas de 1915 e de 1930 mostram a adoção de uma solução incomum não só nesse sub-setor, como também em todos os outros bairros analisados, que foi a do traçado viário não obedecer as regras de arruamento ortogonal. No mapa de 1915, a rua Rodrigues dos Santos estendia-se até a Várzea do Tietê, havendo uma área não ocupada entre ela e as ruas Paraíba e Carlos de

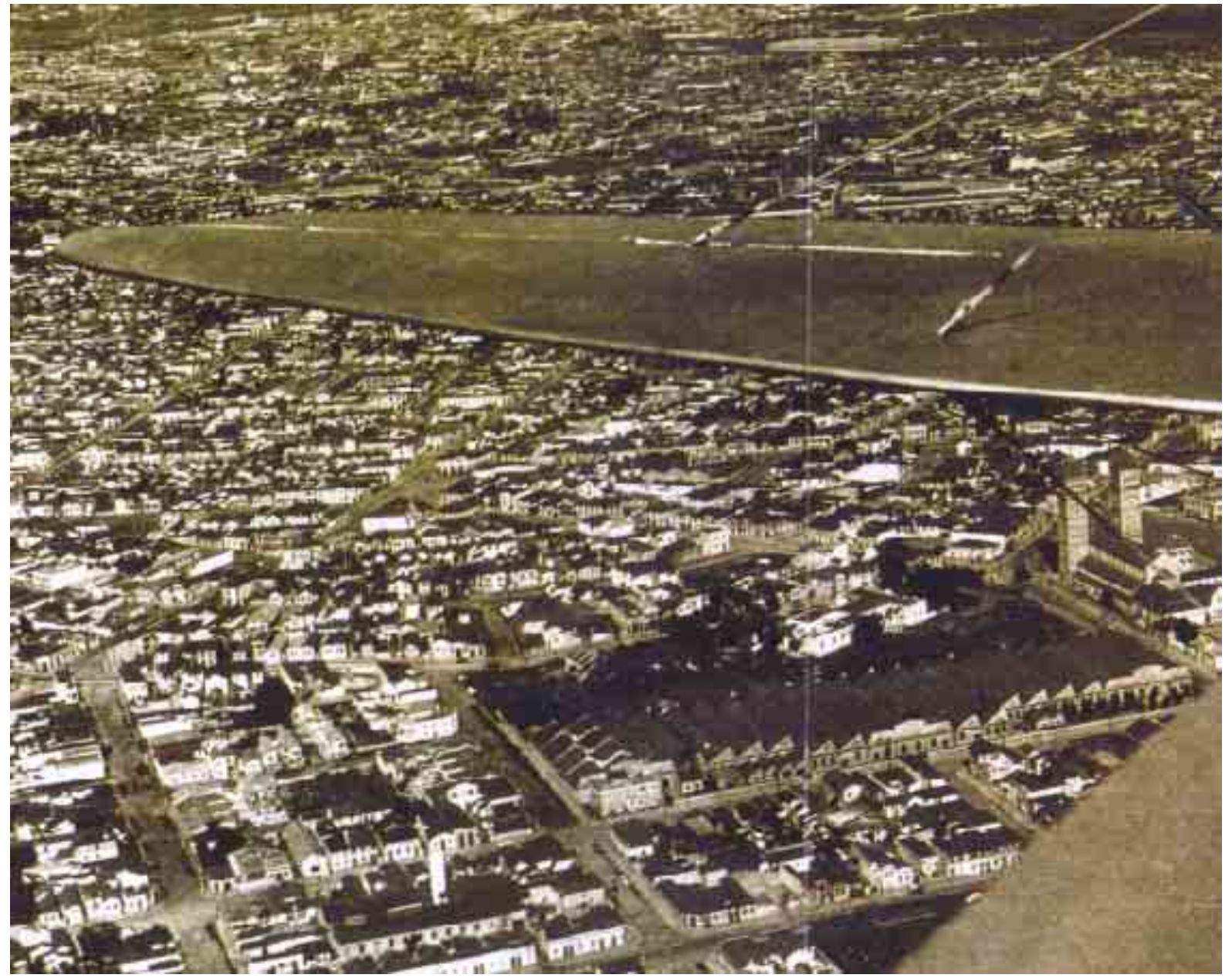

Fig. 218: Vista aérea, Pari, década de 1940. 

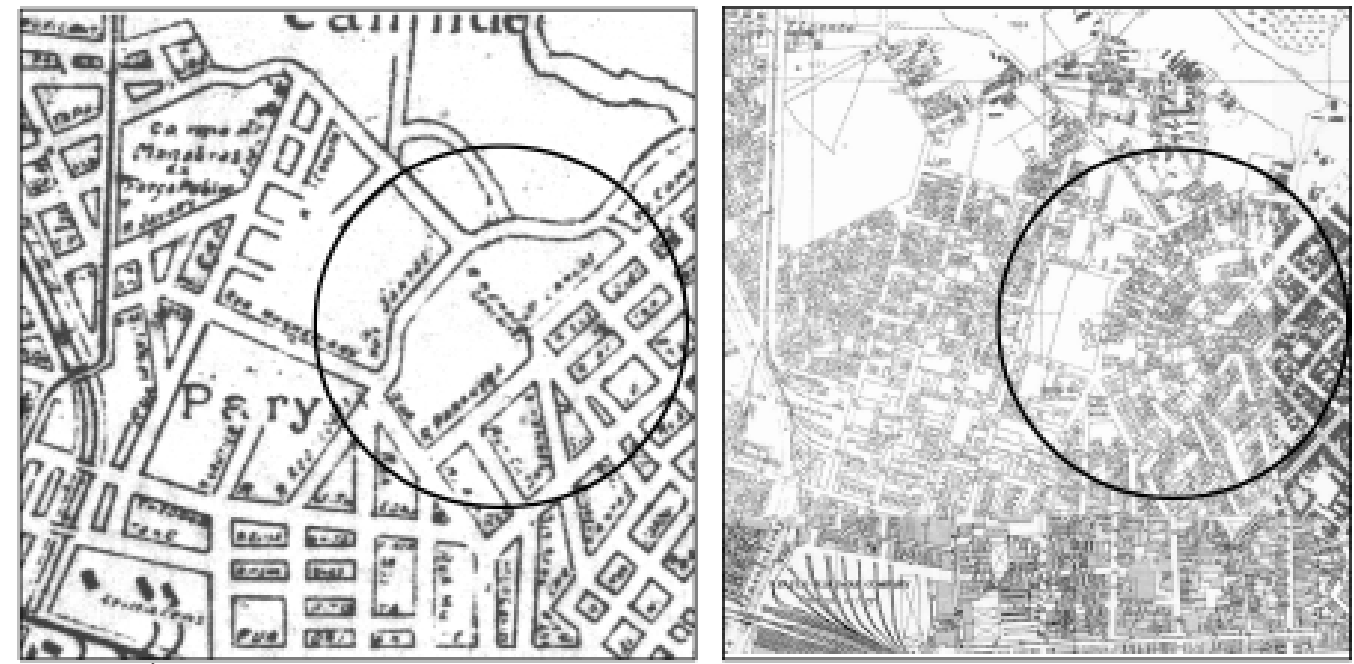

Fig. 219: À esquerda, ruas em arco do Pari, em mapa de 1915; à direita, o mesmo local em mapa de 1930.

Campos, sendo que no cruzamento das ruas Hanemann e Conselheiro Dantas já estava configurado o desenho triangular do Largo Padre Bento (ref. 11). No mapa de 1930 já haviam sido traçadas a rua Rio Bonito (ref. 12), como assim passou a ser denominada a rua Rodrigues dos Santos a partir da rua Hanemann, e as ruas em arco paralelas Coronel Morais (ref. 13) e Padre Lima (ref. 14), seccionadas em ângulo pelas ruas Dr. Ornelas e Pacheco e Silva, ambas interconectadas à Carlos de Campos através do Largo Eduardo Rudge.

Essa solução, incomum pelo fato da legislação exigir ruas retas desde 1923 (Lei Municipal 261 1), não havia sido implantada ainda no mapa da Light de 1925, indicando que o arruamento e posterior parcelamento dessa área foi feita de forma conjunta pelo mesmo agente e que se procurou seguir um traçado mais orgânico que o usualmente feito então na cidade, pois os arcos além de

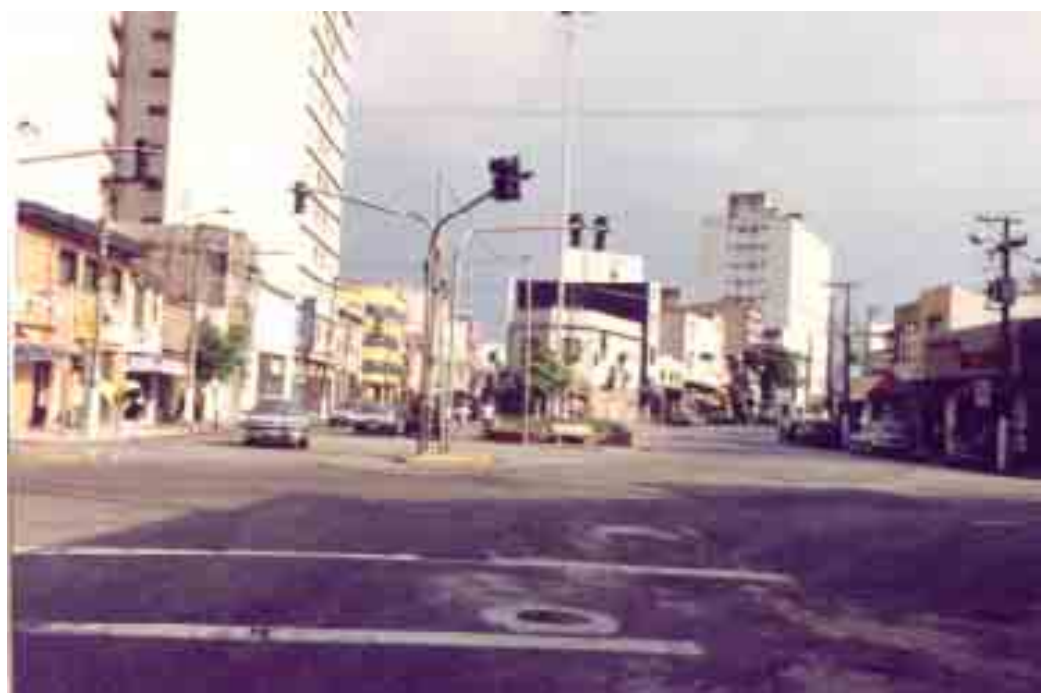

Fig. 220: Lgo. Eduardo Rudge, Pari. 
contornarem o Morro do Parí a partir da rua Rio Bonito, permitiram uma extensão maior para ser loteada e quadras mais homogêneas do que aquelas executadas simplesmente pela extensão do arruamento existente.

A área dentro do sub-setor analisado, definida pelas ruas em arco, teve características predominantemente residenciais, uma vez que, apesar de áreas livres, não se registravam os galpões industriais comuns em outros sub-setores, como os do Bom Retiro e Brás. Na carta de 1954 percebe-se o aumento da ocupação de toda essa área, não havendo mais lotes desocupados e na de 1972, apenas remembramentos de lotes com novas construções. Como foi abordado anteriormente, essas quadras se caracterizaram por apresentar um padrão de moradia muitas vezes superior às outras do bairro, principalmente no Parí, com extensão desse padrão até a avenida Bom Jardim, devido à ocupação no entorno do Morro do Parí.

No mapa de 1930, a rua Carlos de Campos (ref. 15), antiga denominação da atual avenida, já havia sido alargada em relação a 1915 apenas até a rua Cachoeira, acessando as áreas alagadiças da Várzea e transpondo o rio Tietê, estabelecendo a ligação do Parí com a Estrada da Coroa, na Vila Guilherme, ainda esparsamente ocupada em suas áreas mais baixas. Consta que a essa primeira ponte, de madeira e latões, foi construída a mando do loteador da Vila Guilherme, Guilherme Praum, em 1929. Assim como não haviam sido conquistados os terrenos da Várzea na área do Canindé, o mesmo ocorria no Pari, havendo apenas algumas indicações de arruamento projetado.

Essa situação se alterou nas décadas seguintes, pois em 1954 a ocupação do Morro do Parí e do seu entorno imediato se apresentava bem mais consolidada que na carta de 1930, embora ainda apresentasse vazios. $O$ limite da área urbanizada até o rio Tietê era a avenida Bom Jardim (ref. 12) e, com a
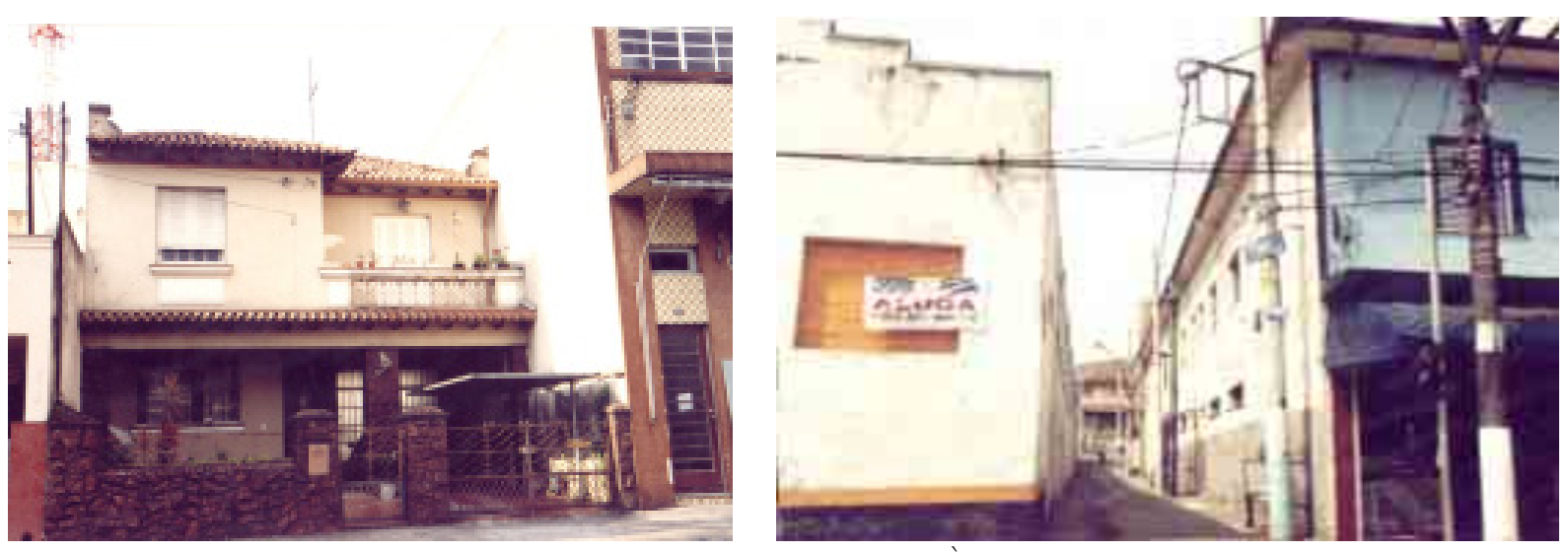

Fig. 221 e 222: À esquerda, tipologia mais recente na R.

Padre Lima.

À direita, Travessa Ester M. Bergsten, Morro do Pari. 
pavimentação desta na década de 1960, não apenas ocorreu o adensamento da área analisada, como houve a expansão da ocupação horizontal até a Marginal do Rio Tietê (ref. 16). Contrastou com o padrão construtivo implantado anteriormente nas proximidades do Morro do Parí, que apresentava lotes e habitações maiores, pois a área mais recentemente urbanizada, seguiu a ocupação do Canindé, com intenso aproveitamento do solo, pequenas ruas ou vielas entre as quadras e entremeada com grandes lotes, no caso, de indústrias alimentícias, de embalagens e transportadoras.

Atualmente, nesse sub-setor, o mercado imobiliário se encontra estagnado para fins habitacionais, não se registrando nenhum lançamento de novas unidades, apesar de suas características. Propostas e projetos definidos pelo Plano Regional Estratégico, poderão reverter esse processo, possibilitando ações que potencializem essas áreas para fins de residência e também para a melhoria da paisagem urbana.

$3^{\circ}$ - Esse sub-setor do Pari caracterizou-se por estabelecer uma transição com o Brás e o Catumbi. A integração do tecido urbano do Pari com o Brás ocorria com a continuidade da malha viária e homogeneidade da ocupação caracterizada pelo intenso parcelamento das quadras. Mais próximo à Várzea, a rua Silva Telles tinha ainda, pela carta de 1930, uma parte de sua extensão projetada (ref. 17), entre as ruas Carlos de Campos e Santa Rita, sendo esta última o limite com - Catumbi e Belenzinho (ref. 18). Esparsas edificações indicavam a continuidade da ocupação do Catumbi sobre as áreas do Parí (ref. 19), nas proximidades do rio Tietê, permitindo observar que a urbanização não havia conquistado a Várzea desse rio, certamente devido à procura de terras mais altas e menos sujeitas às inundações.

Assim como ocorreu com a avenida Bom Jardim, a sua extensão, a avenida Pedroso da Silveira (ref. 20) somente se mostrou traçada na carta de 1954, com grande parte das quadras do perímetro definido entre esta e a avenida Carlos de Campos, rua Santa Rita e rua Joaquim Carlos já ocupadas. Na rua Santa Rita localizavam-se a lgreja do mesmo nome e a grande garagem dos bondes que serviam o Brás (ref. 21), ambas referências dessa área.

Como foi analisado anteriormente, a continuidade do tecido urbano entre os bairros do Parí, Brás, Belenzinho e Catumbi revelava uma extensa área de usos mistos, habitação popular e de classe média, que obedecia os padrões consolidados pela finalidade de aluguel para essa faixa de renda. Na área de transição entre o Brás e o Catumbi, verificou-se a construção de inúmeras vilas e renques de casas geminadas dominando as ruas. Esse padrão pode ser observado também pela carta de 1972, ocorrendo apenas a ocupação das poucas áreas vazias ou lotes subdivididos (ref. 22). 
A travessia do rio Tietê se fazia pela ponte de concreto que ligava diretamente as avenidas Carlos de Campos e Guilherme, na Vila Guilherme. Dotada de apenas uma pista e inúmeras vezes coberta pelas cheias do rio, em fins da década de 1960 essa ponte foi substituída pela atual, já com quatro pistas e construída em arco abatido com apoios (ref. 23). Outras alterações que a carta de 1972 permite observar em relação à de 1954 é a Praça llo Ottoni, antes uma grande rotatória na extremidade daquela ponte e os edifícios da Biblioteca Municipal Adelpha Fiqueiredo (ref. 24) e do Colégio Estadual Frei Paulo Luigi, ambos edifícios modernistas da década de 1960. Essa área contava ainda com um campo de futebol e equipamentos, que posteriormente passaram a fazer parte de um Centro Desportivo Municipal - CDM.

Atualmente esse sub-setor não apresenta nenhum indício de transformação do seu meio construído que possibilite, através de novas unidades habitacionais, um aumento do número de moradores. Em parte da sua área, ocorre também uma disputa com o comércio interligado ao Brás, além de antigas atividades, como comércio tradicional e oficinas. Entretanto, foi proposto um projeto para moradores da terceira idade, no entorno da Biblioteca Adelpha Figueiredo, que também incorpora outros equipamentos sociais. Juntamente com esse edifício, poderão se somar outras ações, como por exemplo, a integração do CDM hoje existente ao bairro (ref. 25), uma vez que as duas áreas são de propriedade municipal e se encontram defronte uma da outra, na avenida Carlos de Campos.

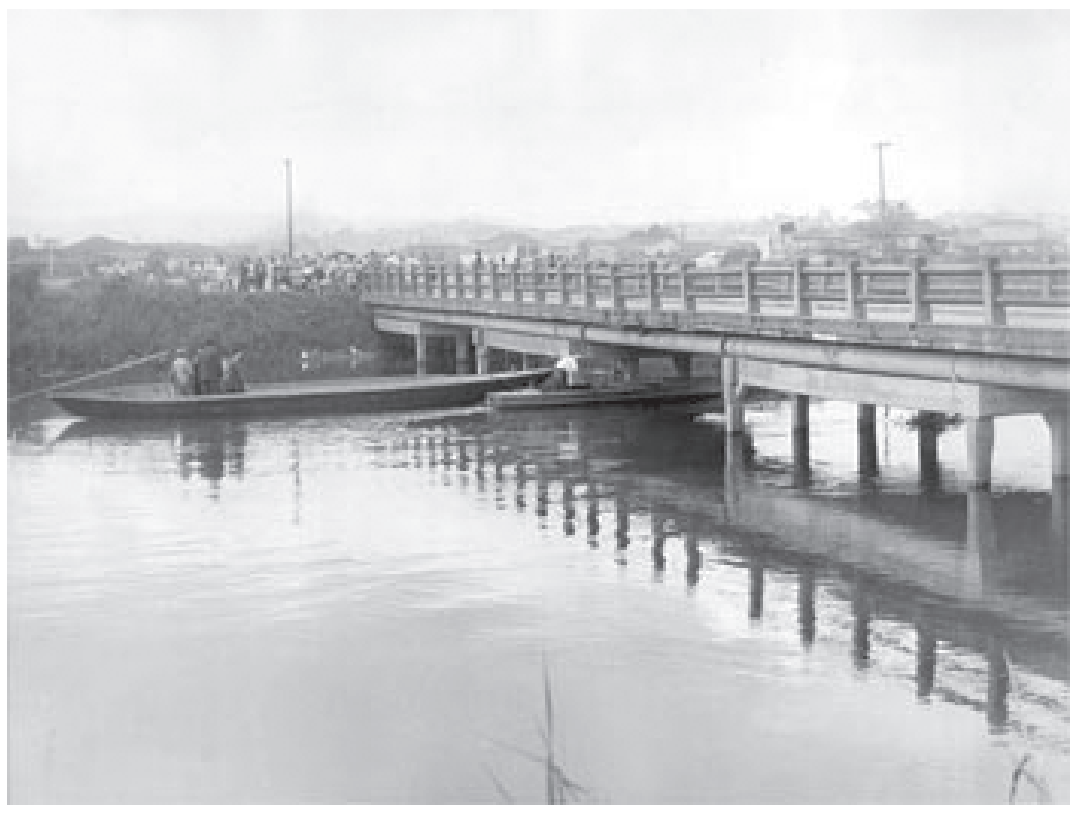

Fig. 223: Ponte sobre o Rio Tietê, ligando Av. Carlos de Campos e Av. Guilherme, 1958. 


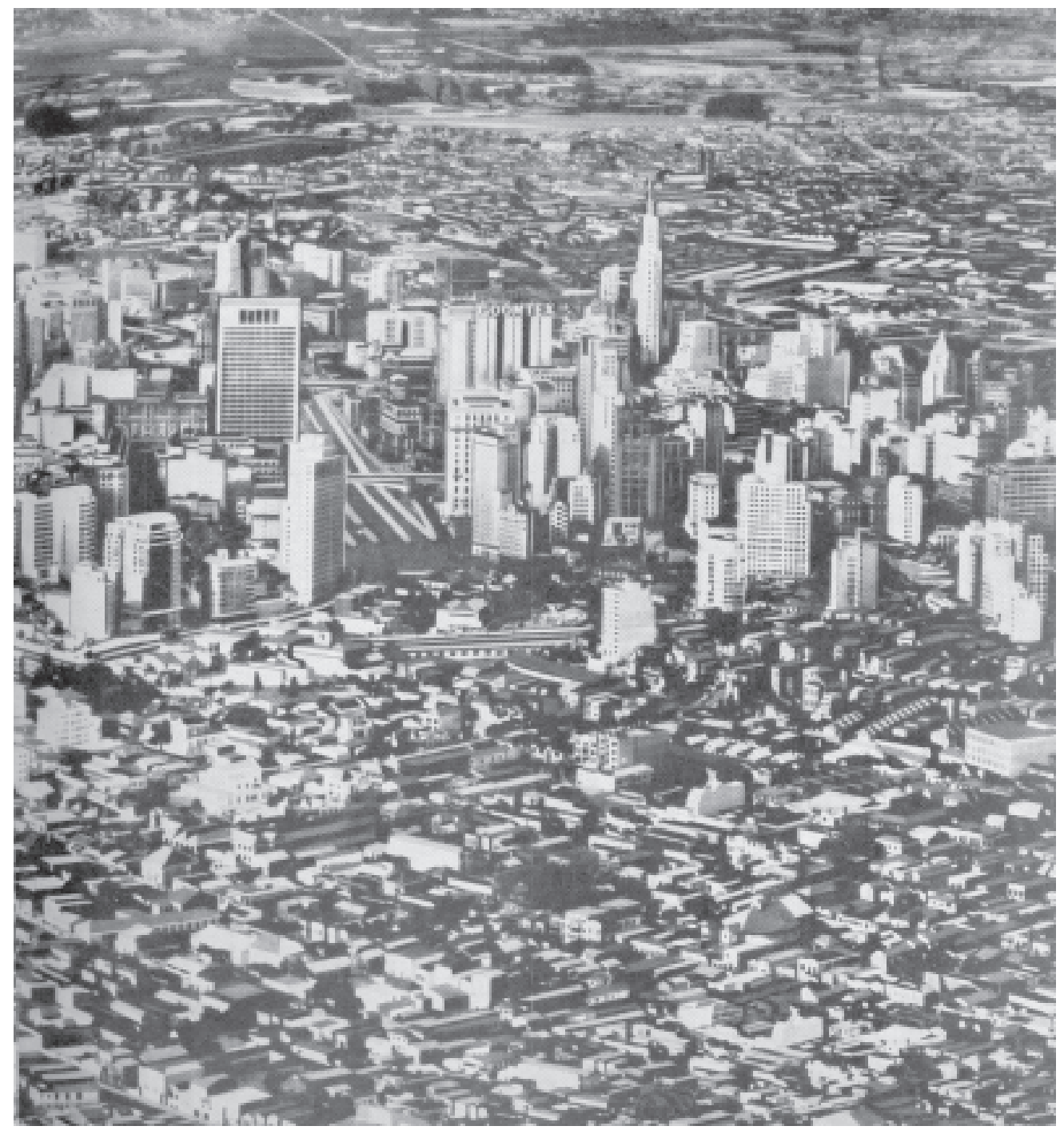

Fig. 224: Vista aérea, década de 1940.

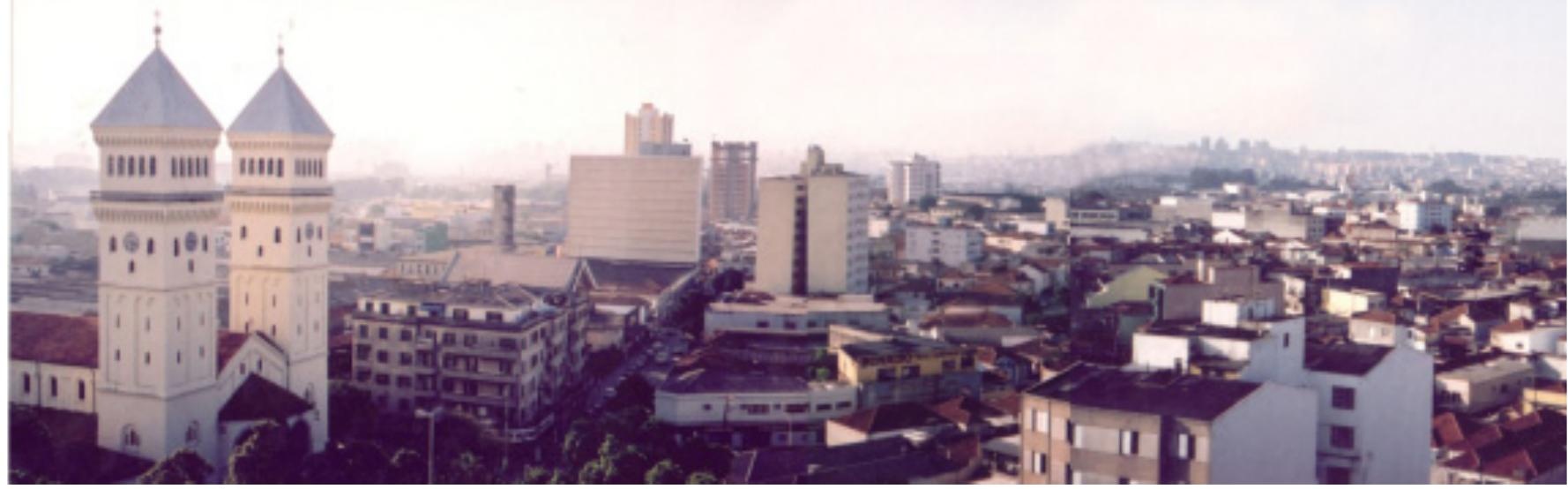

Fig. 225: Vista do Pari, 2002. 


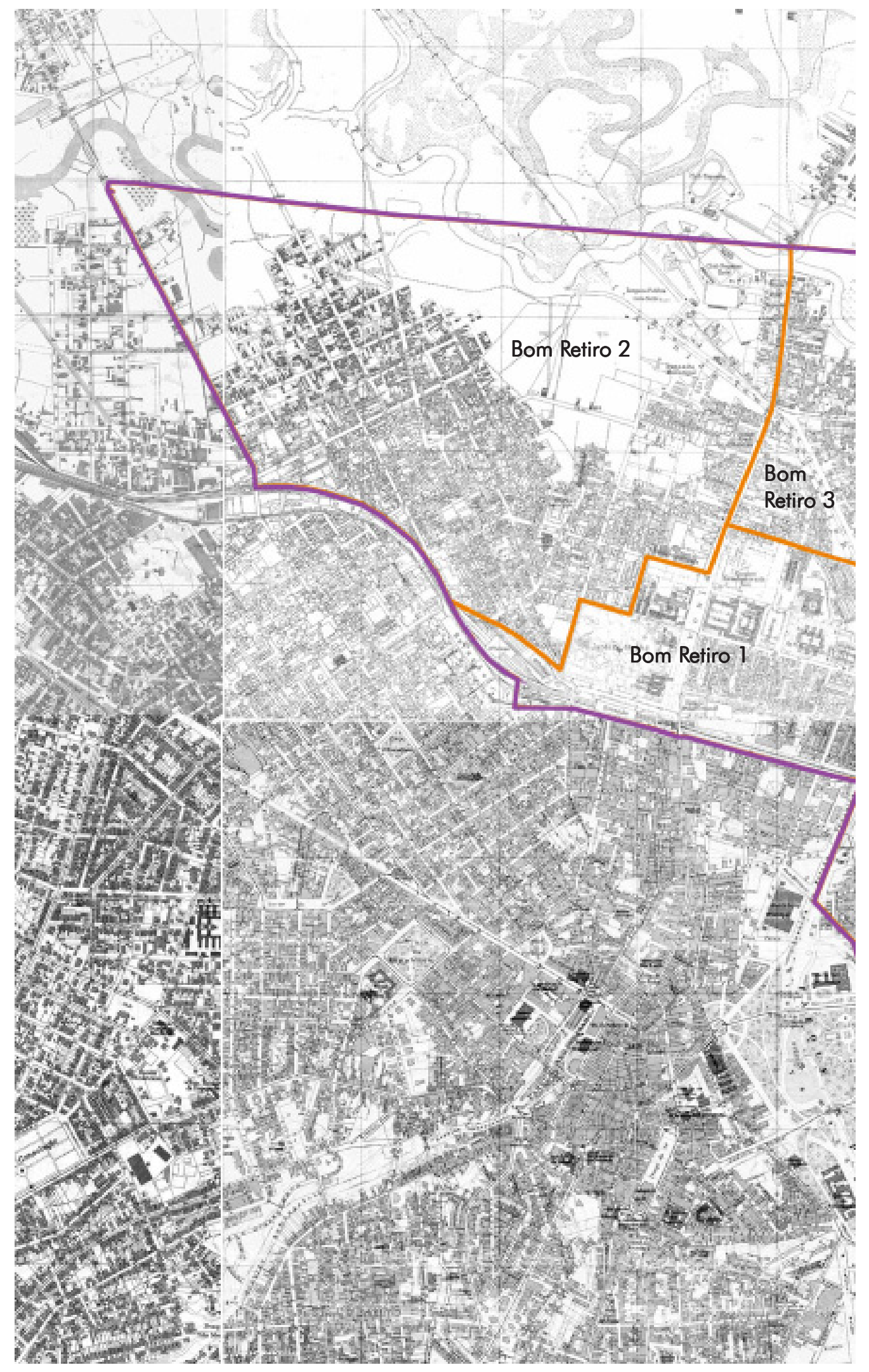




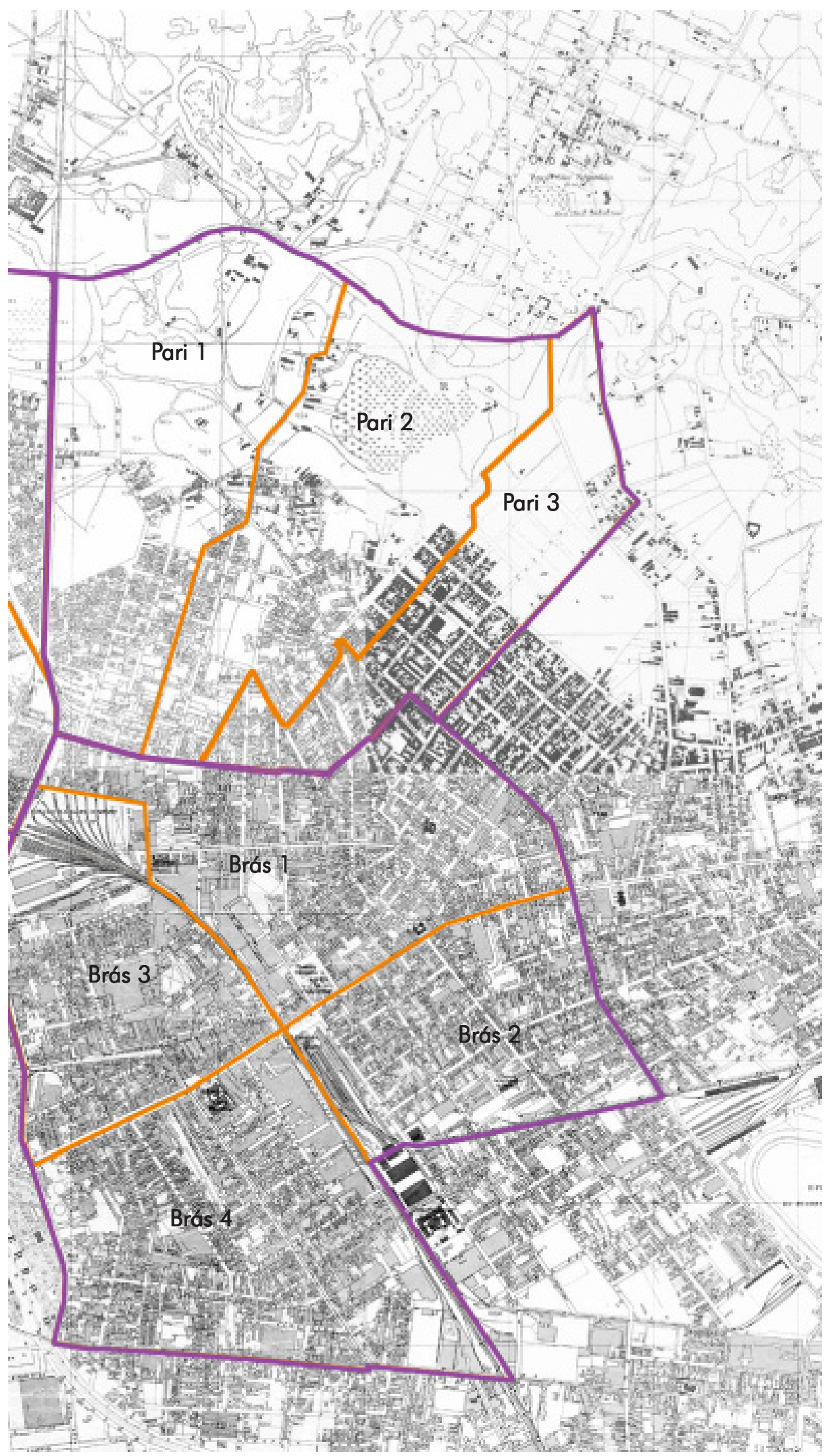

Mapa índice 1 - Sub-setores dos distritos Bom Retiro, Brás e Pari, 1930. 


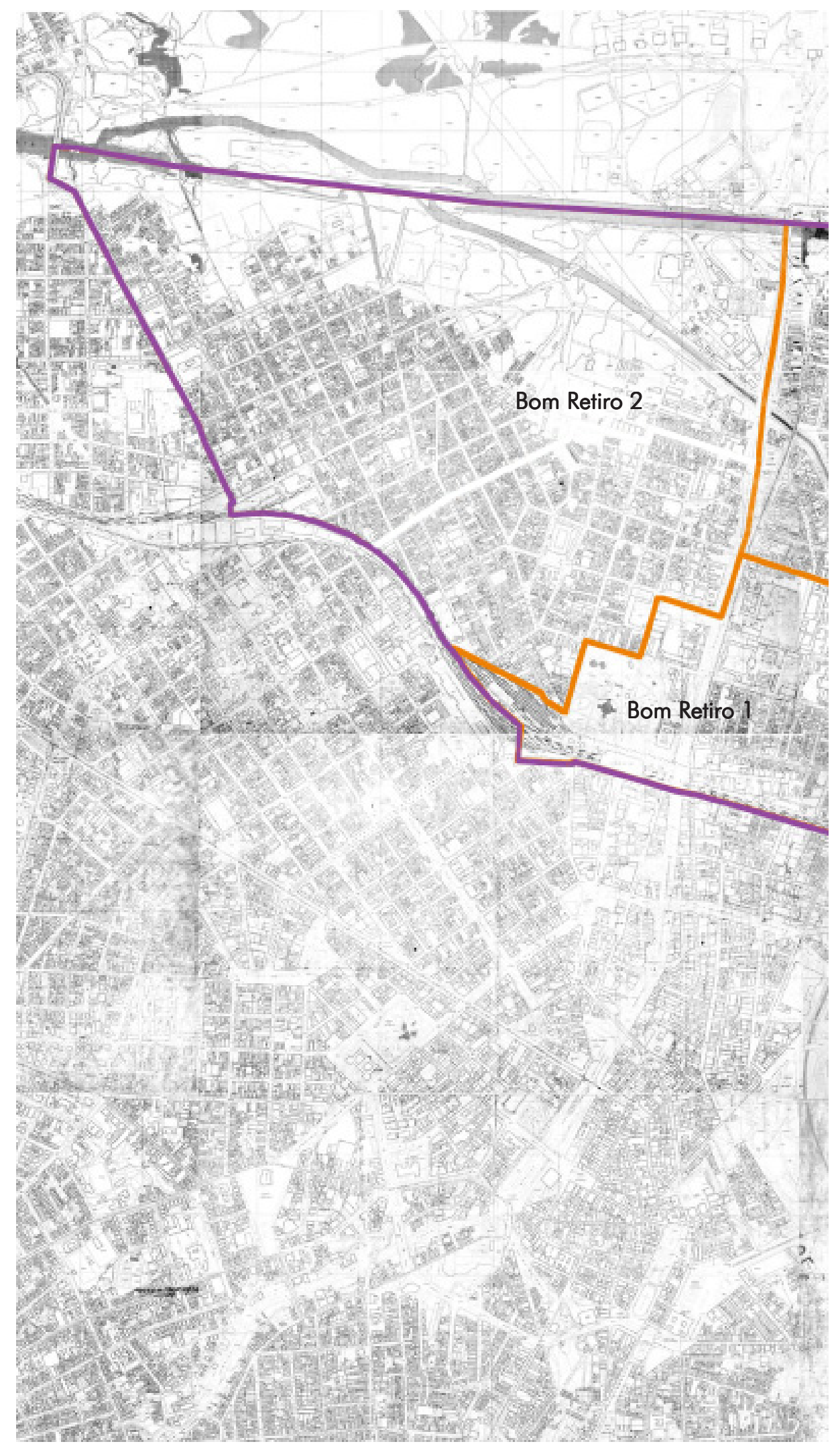




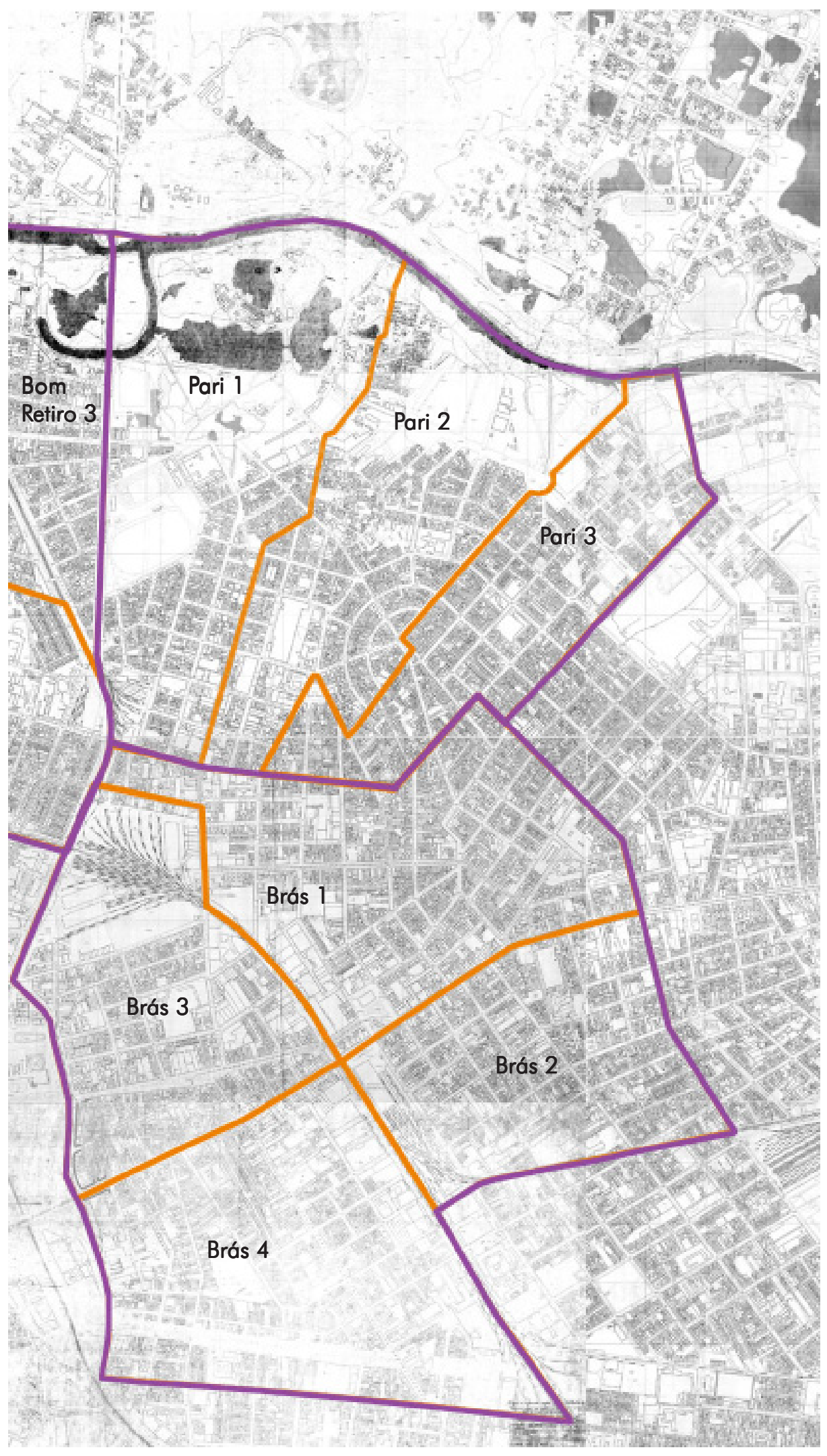

Mapa índice 2 - Sub-setores dos distritos Bom Retiro, Brás e Pari, 1954. 


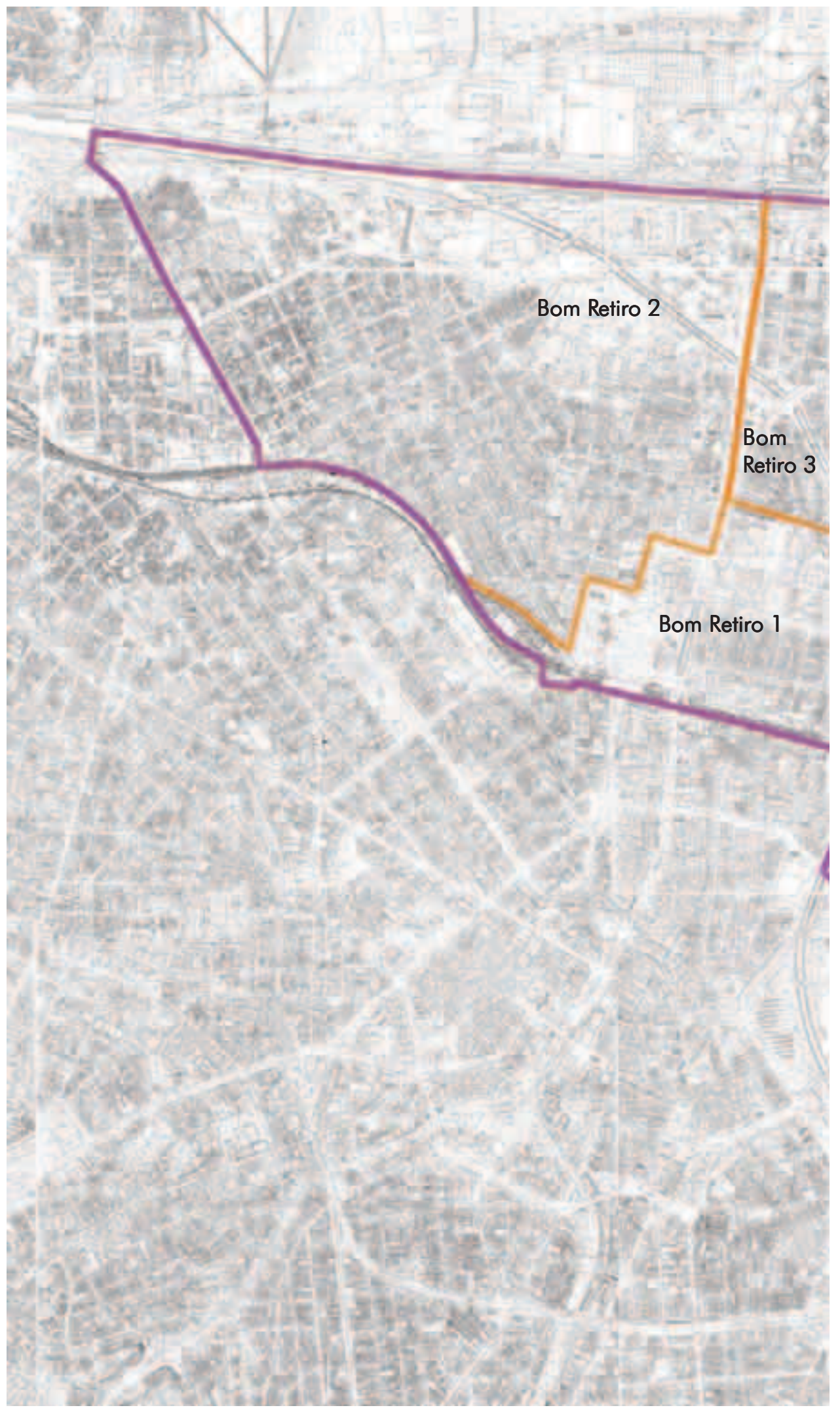




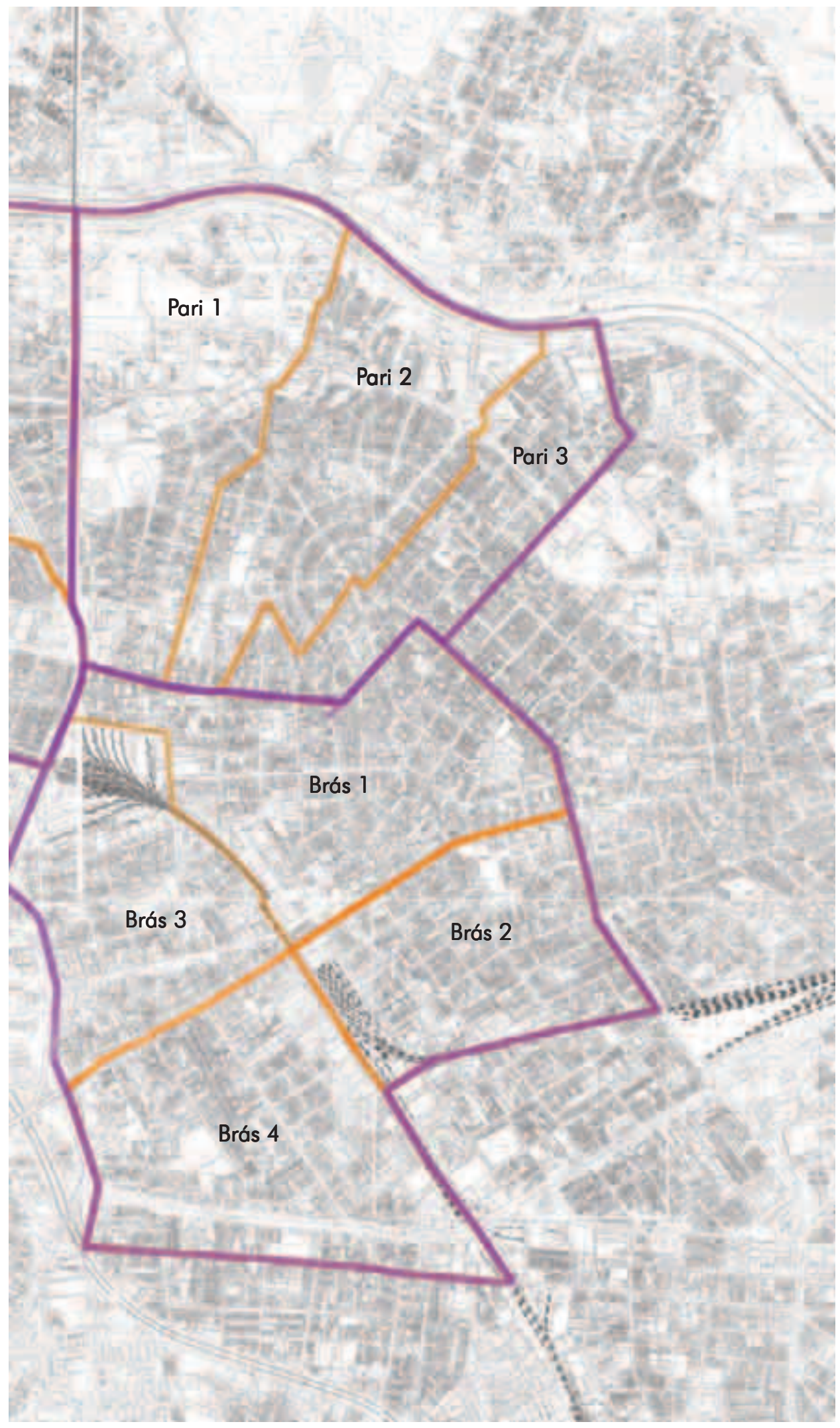

Mapa índice 3 - Sub-setores dos distritos Bom Retiro, Brás e Pari, 1972. 


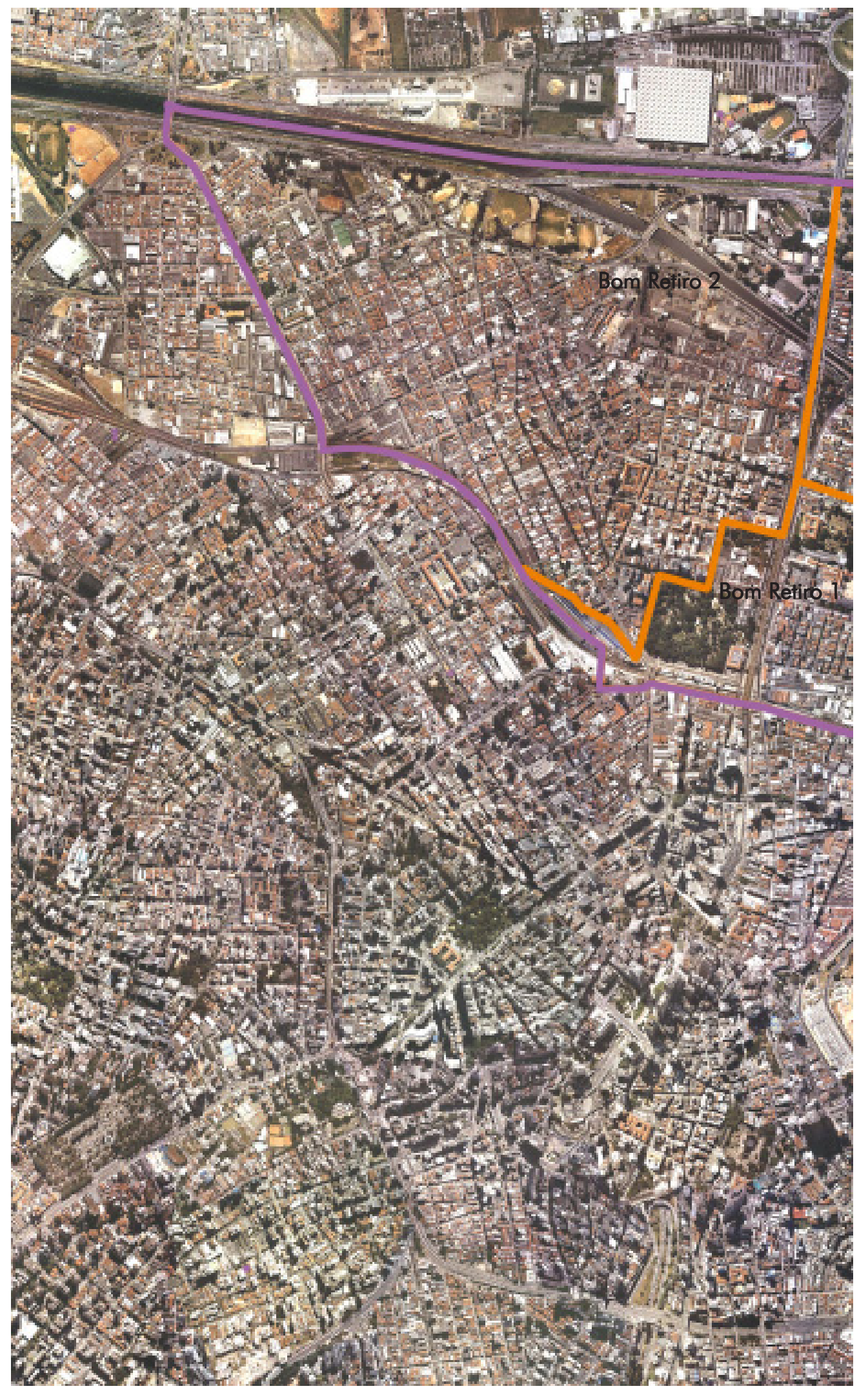




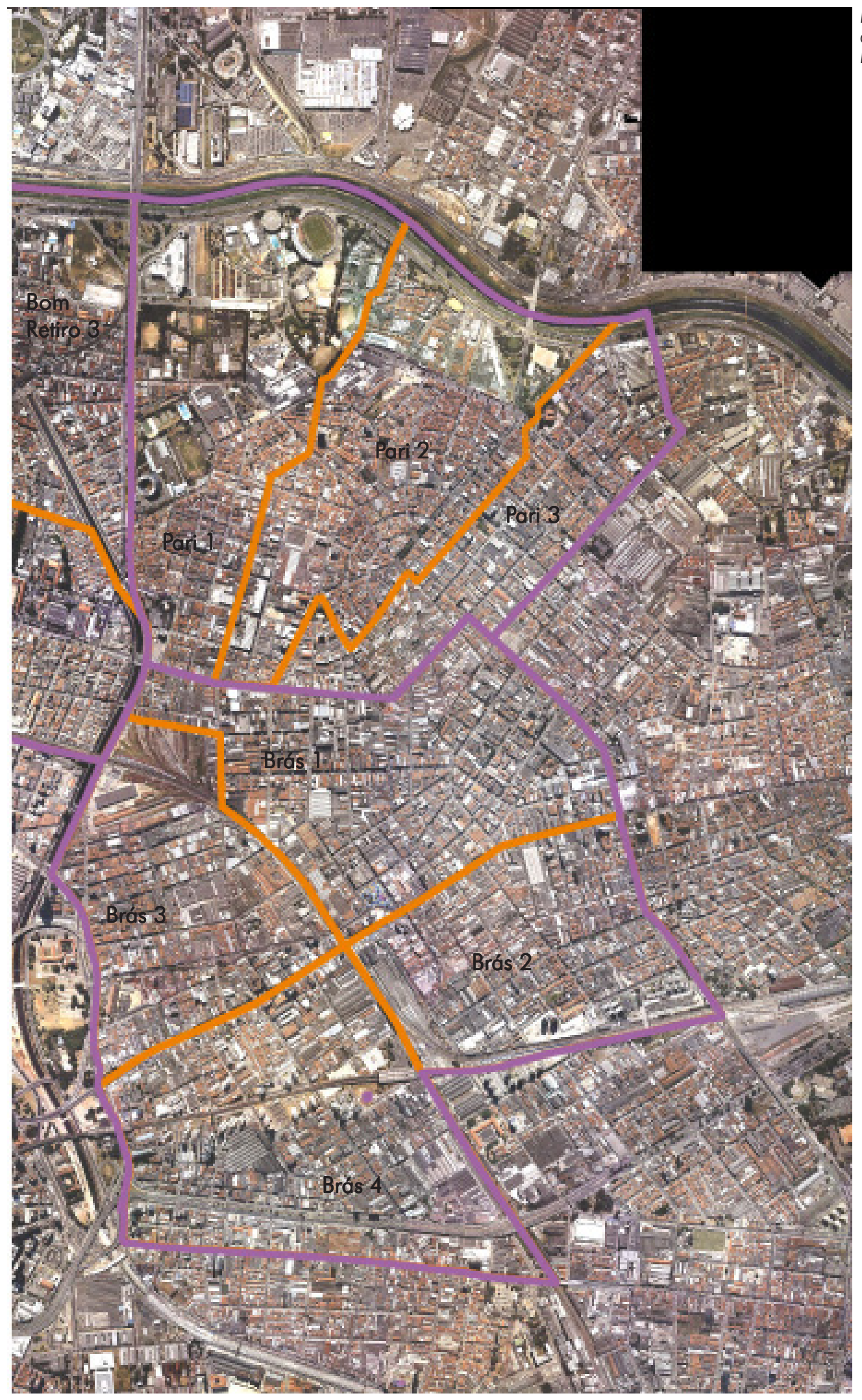

Foto índice 1 - Sub-setores dos distritos Bom Retiro, Brás e Pari, Base, 2000. 


\section{Bom Retiro: Sub-setor 1 (Luz)}

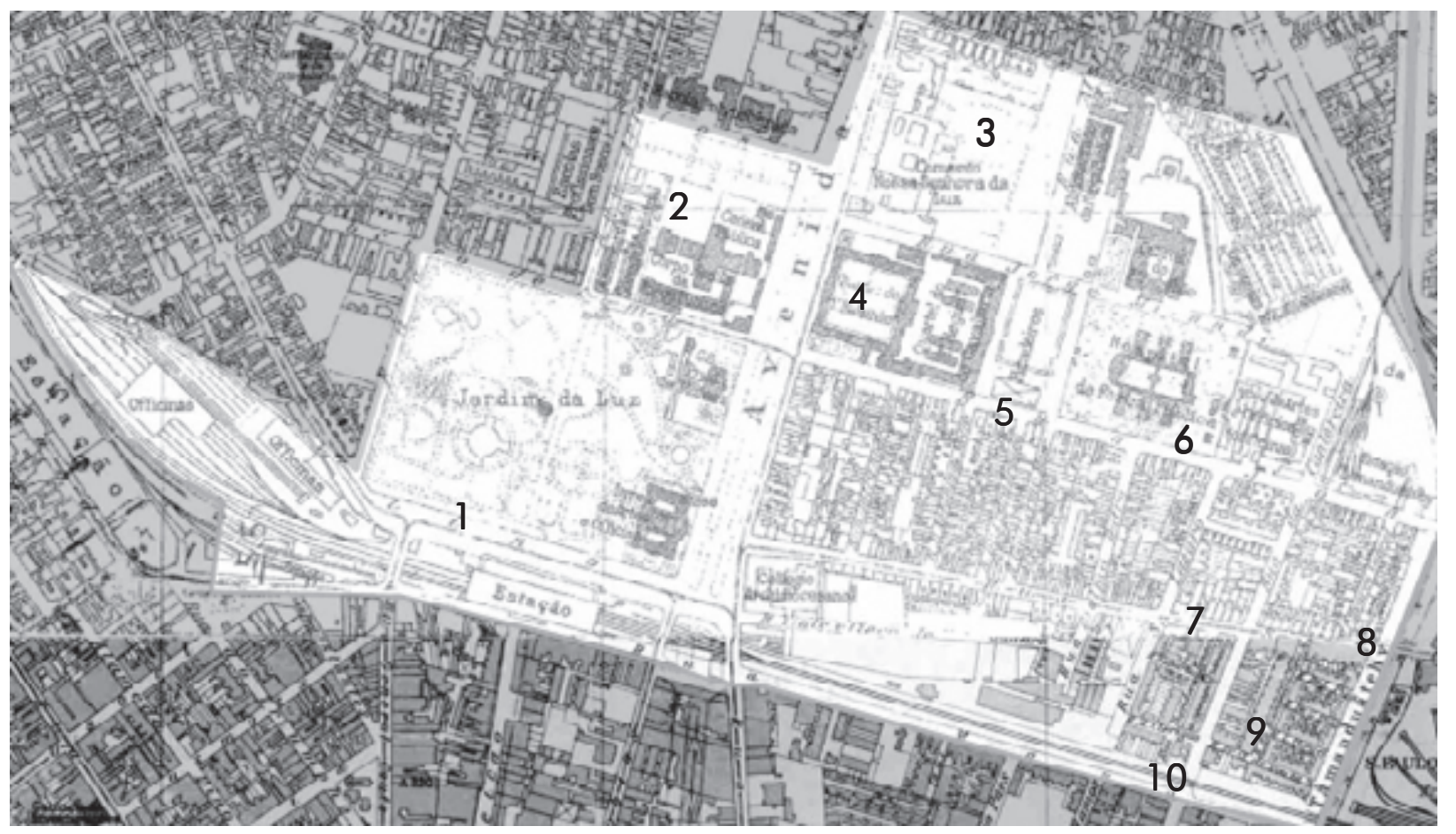

1930: 1. Estação da Luz; 2. Presídio Tiradentes; 3. Convento N. Senhora da Luz;

4. Quartel da Força Pública; 5. Rua João Teodoro; 6. Estação Tamanduateí (Cantareira);

7. Rua São Caetano; 8. Av. Tiradentes (Estados); 9. Vila Economizadora; 10. Rua Cantareira.

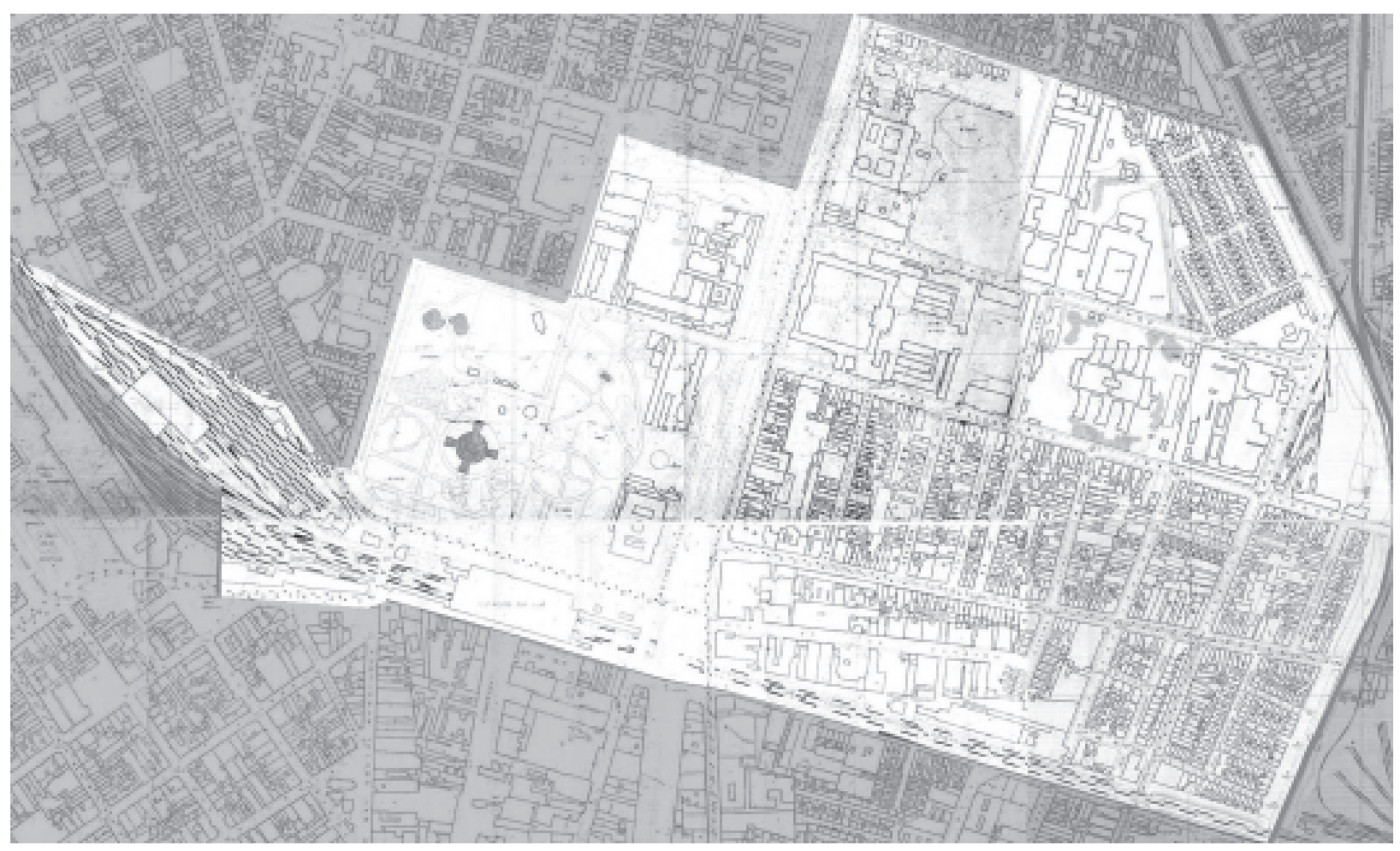




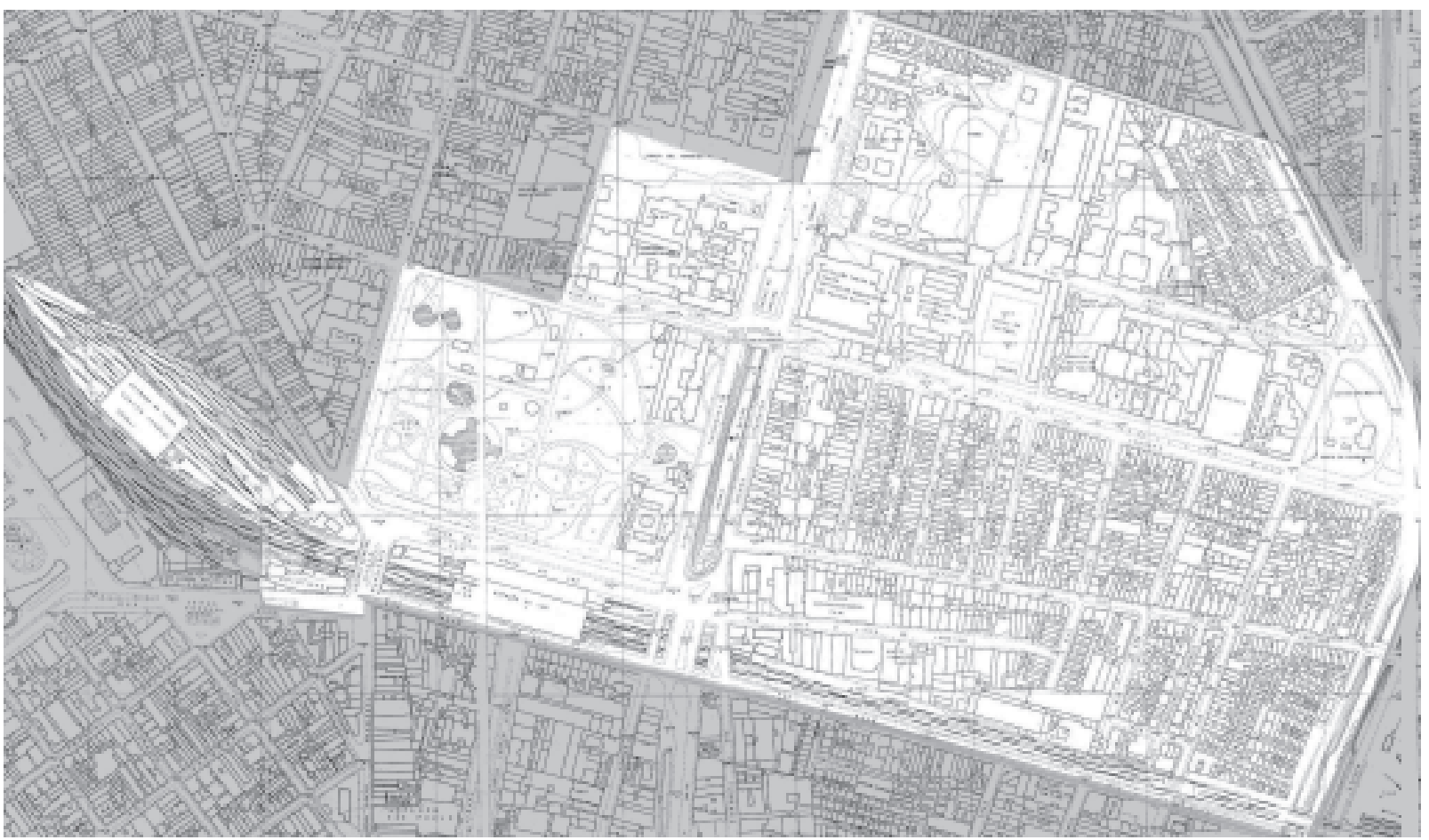

1972

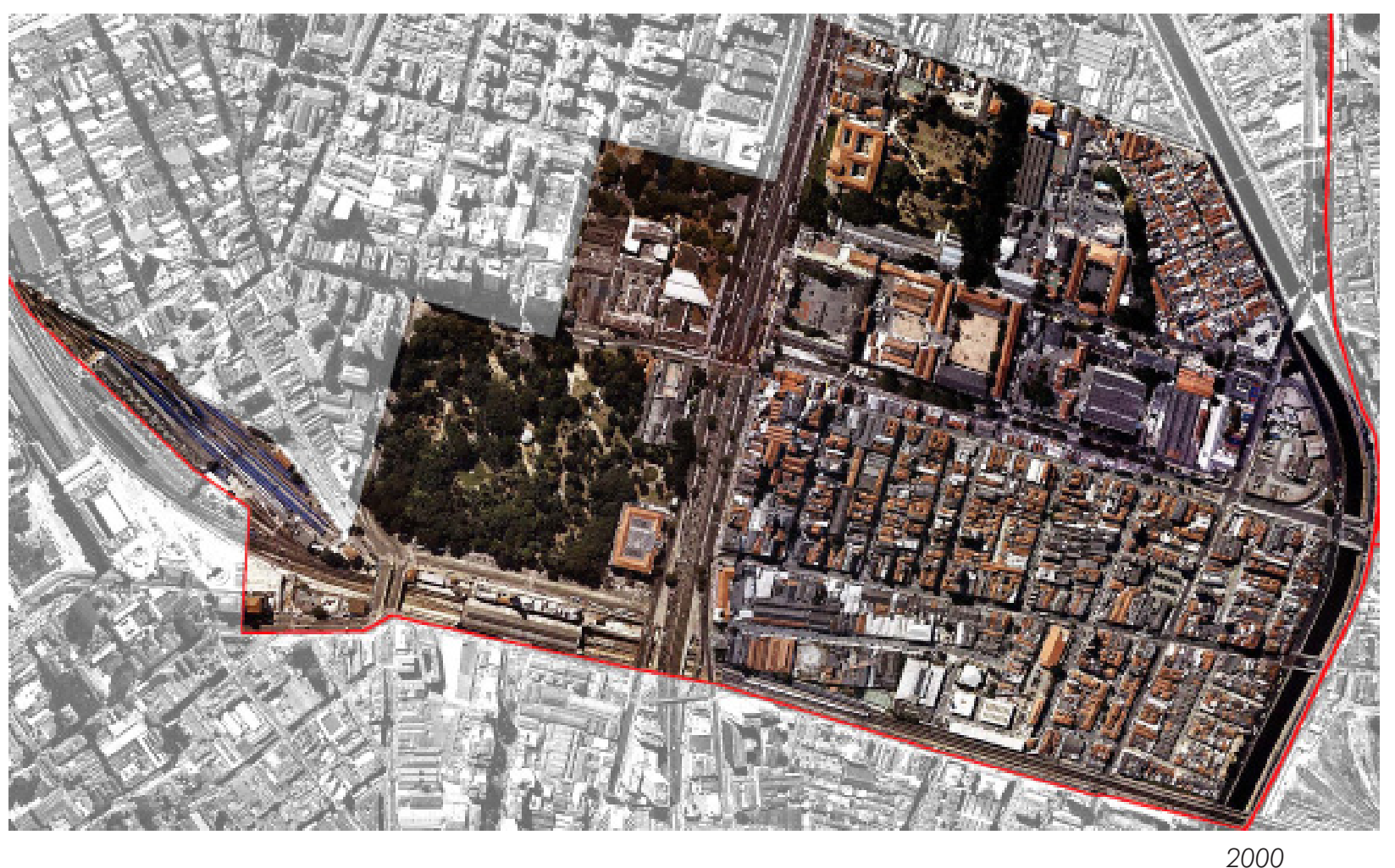


Bom Retiro: Sub-setor 2 (Bom Retiro)

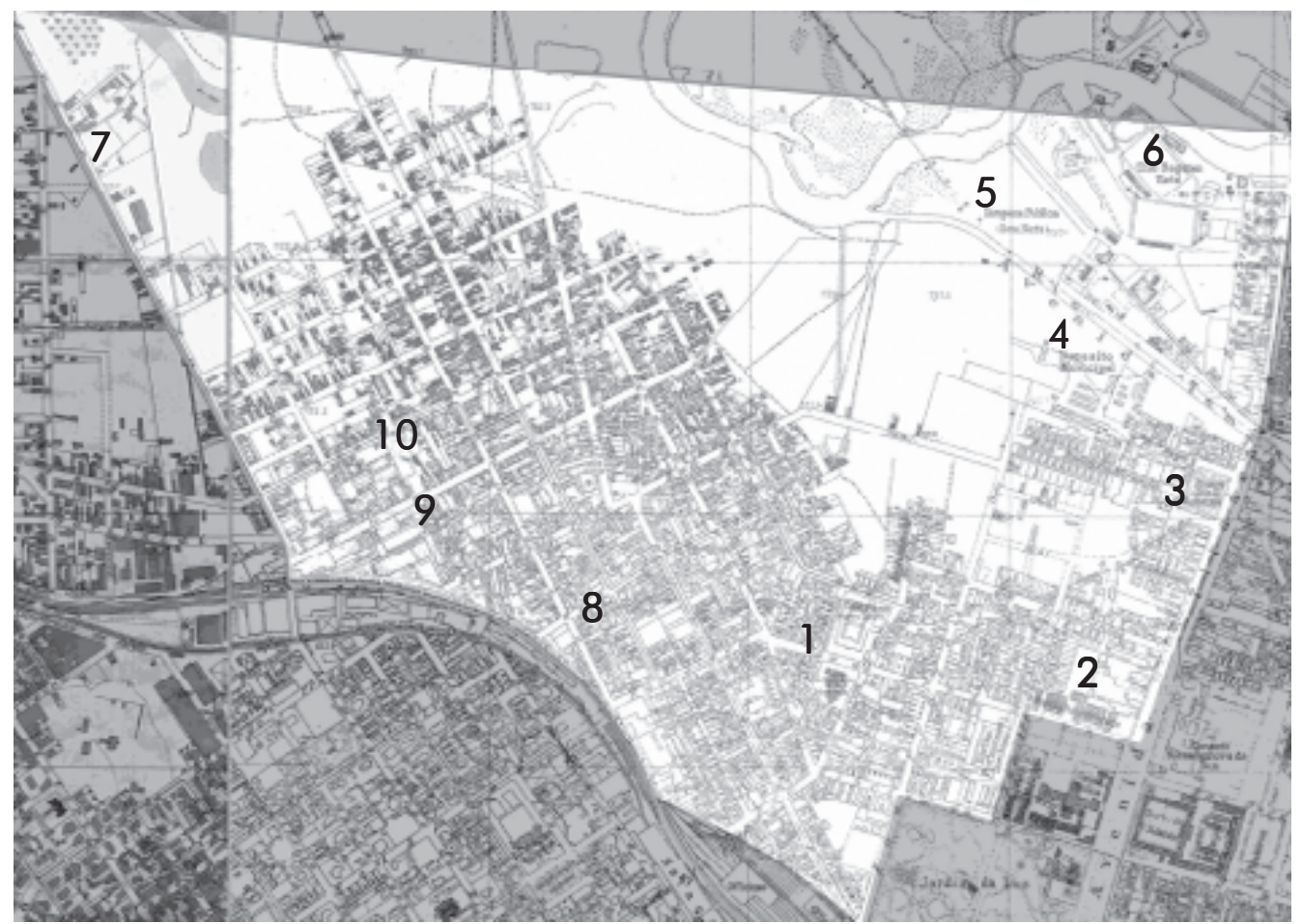

1930: 1. Colégio Sta. Inês e Faculdade de Farmácia e Odontologia; 2. Escola Politécnica; 3. Pça José Roberto; 4. Depósito Municipal; 5. Limpeza Pública; 6. Clube Tietê; 7. Av. Rudge; 8. R. Júlio Conceição; 9. R. Sólon; 10. R. Barra do Tibagi.

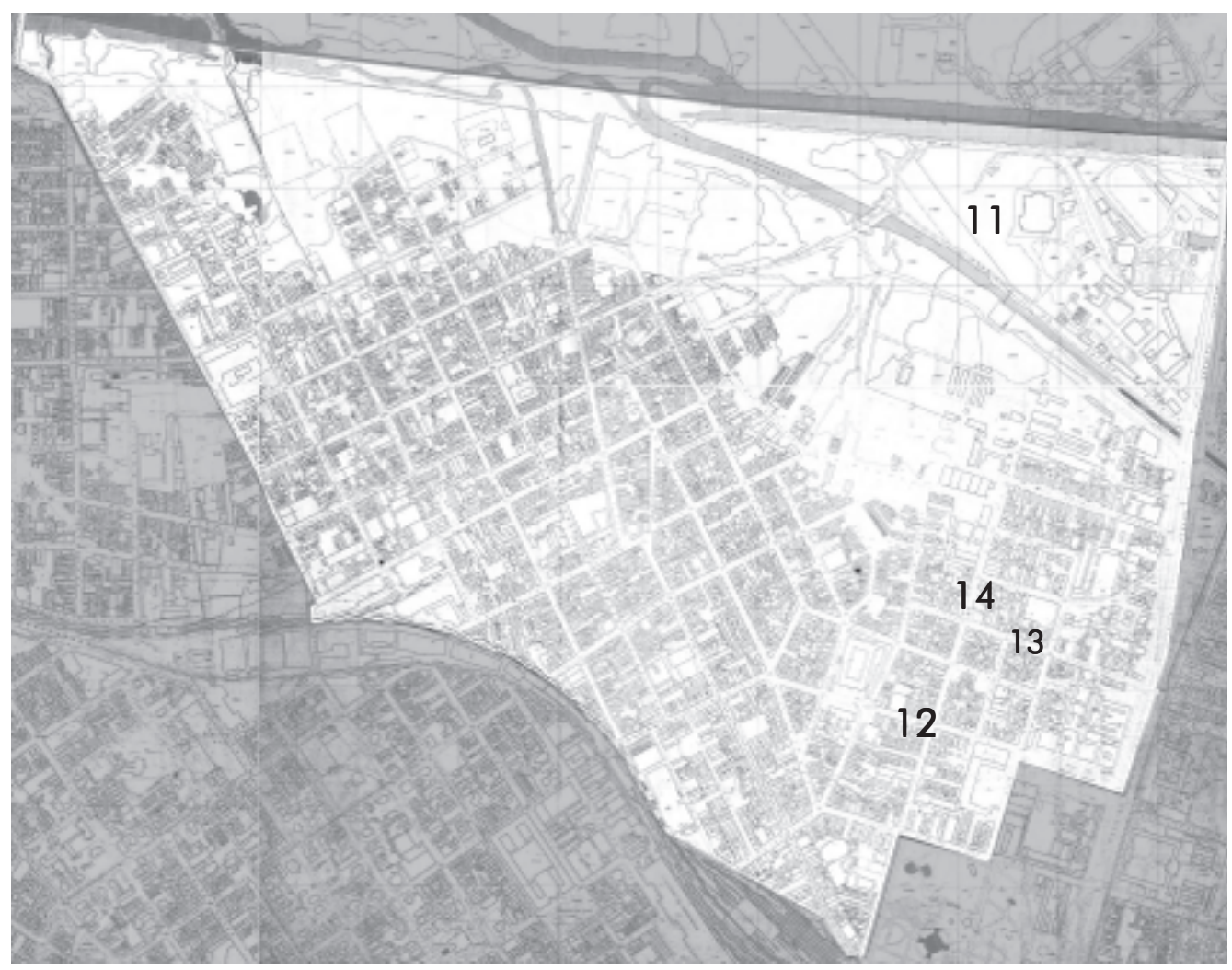

1954: 11. Área de equipamentos públicos; 12. R. Três Rios; 13. R. Bandeirantes; 14. R. Prates. 


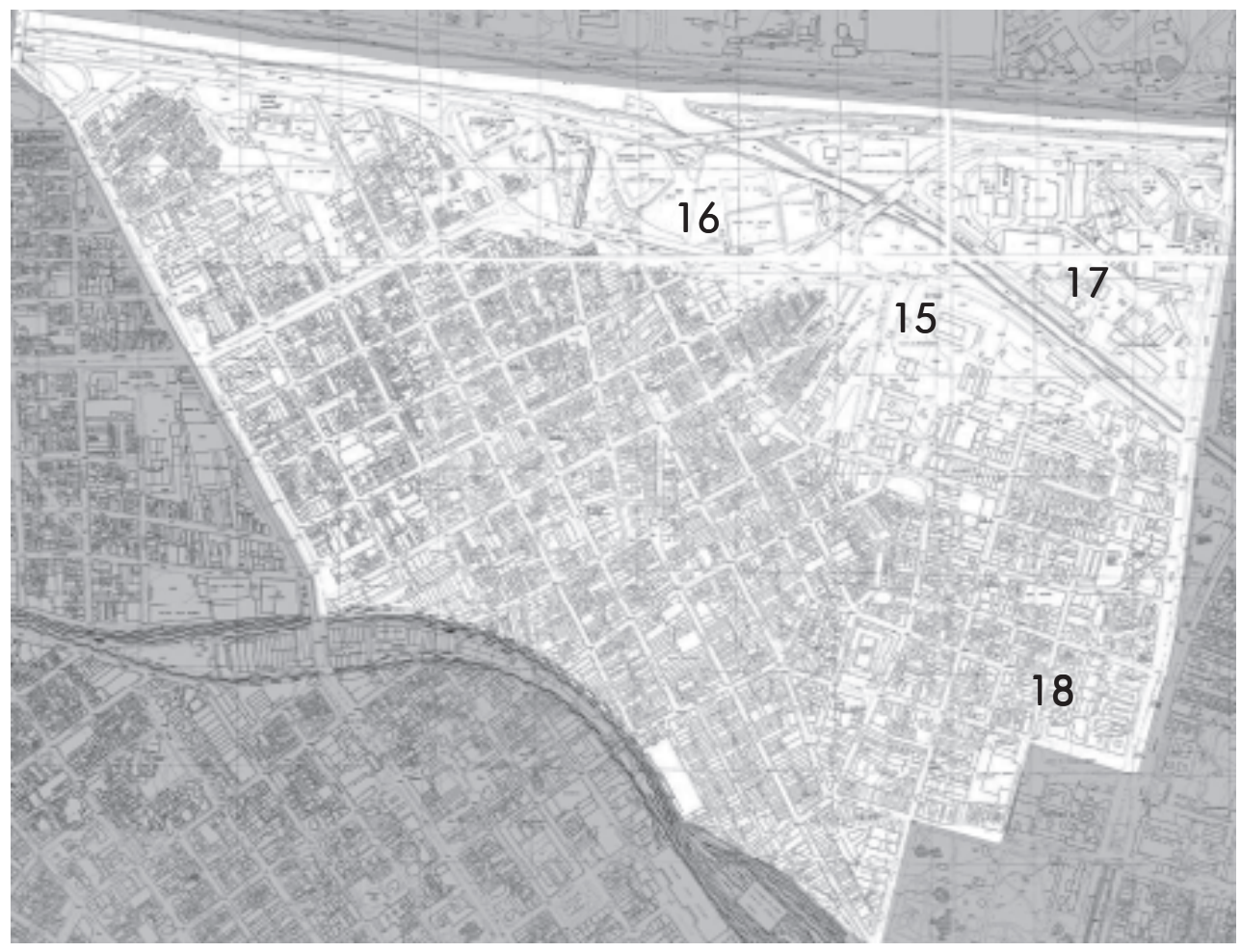

1972: 15. Usina de transbordo e Administração Regional da Sé; 16. Estádio de baseball e parque público; 17. Área SABESP e Secretaria de Transportes; 18. Area verticalizada.

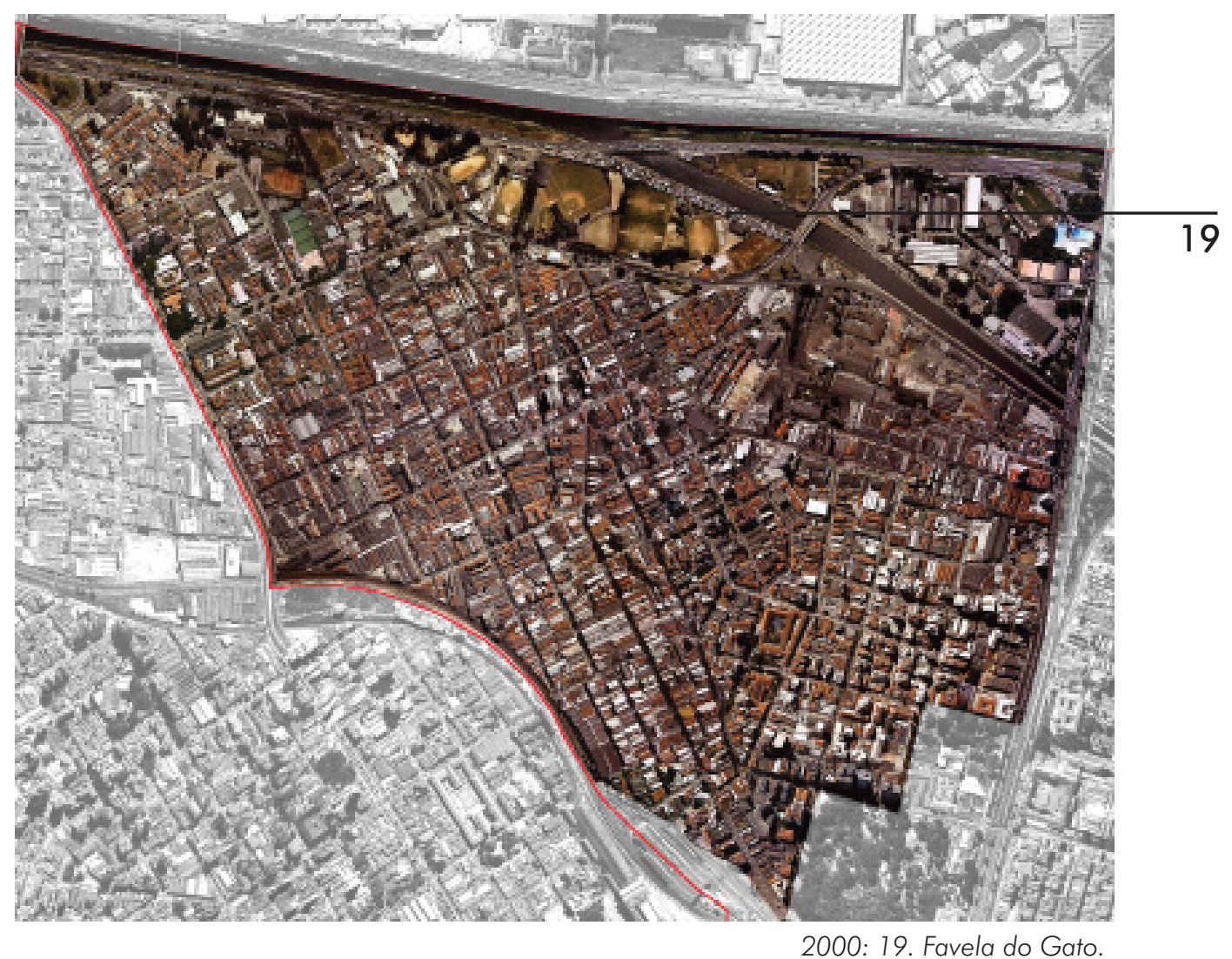




\section{Bom Retiro: Sub-setor 3 (Ponte Pequena)}

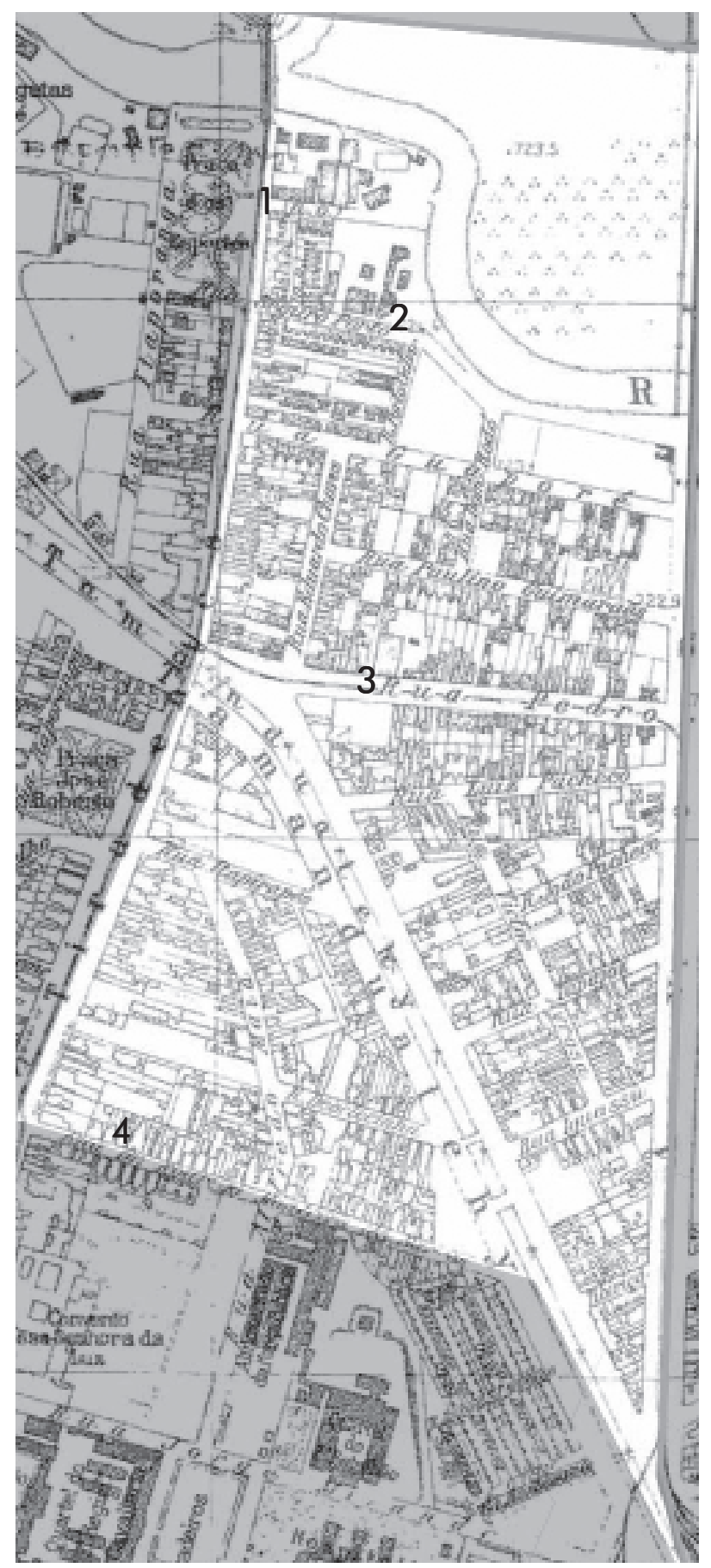

1930: 1. Av. Tiradentes, Pça. dos Esportes e Ponte Grande; 2. R. Porto Seguro; 3. R. Pedro Vicente; 4. R. Rodrigo de Barros.

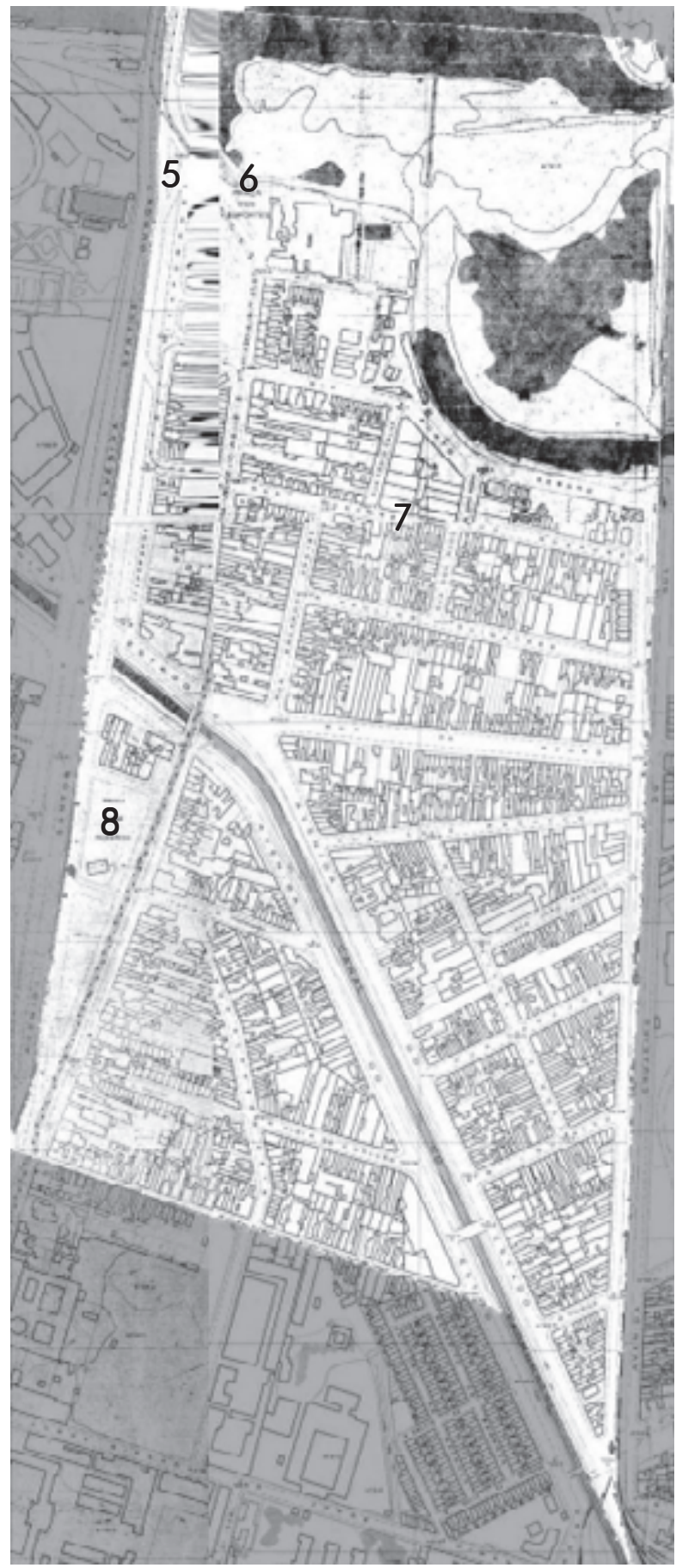

1954: 5. Av. Santos Dumont e Ponte das Bandeiras; 6. Pça dos Esportes;

7. Tecelagem (R. Guaporé, Dom Rodo, Porto Calvo e Porto Seguro); 8. Pça. José Roberto. 


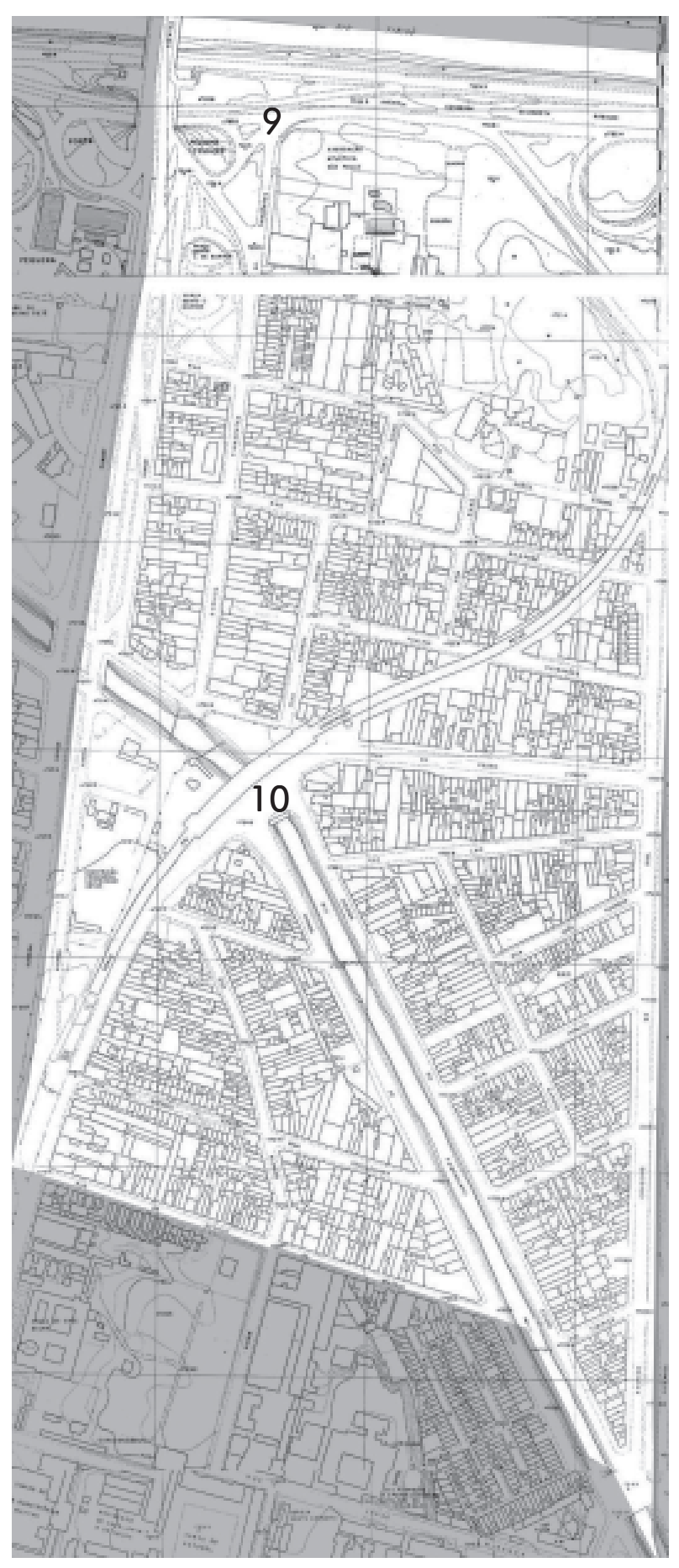

1972: 9. Pça Bento de Campos (antiga dos

Esportes); 10. Estação Metrô Ponte Pequena (atual

Armênia) e Pça. Armênia (antiga (José Roberto).

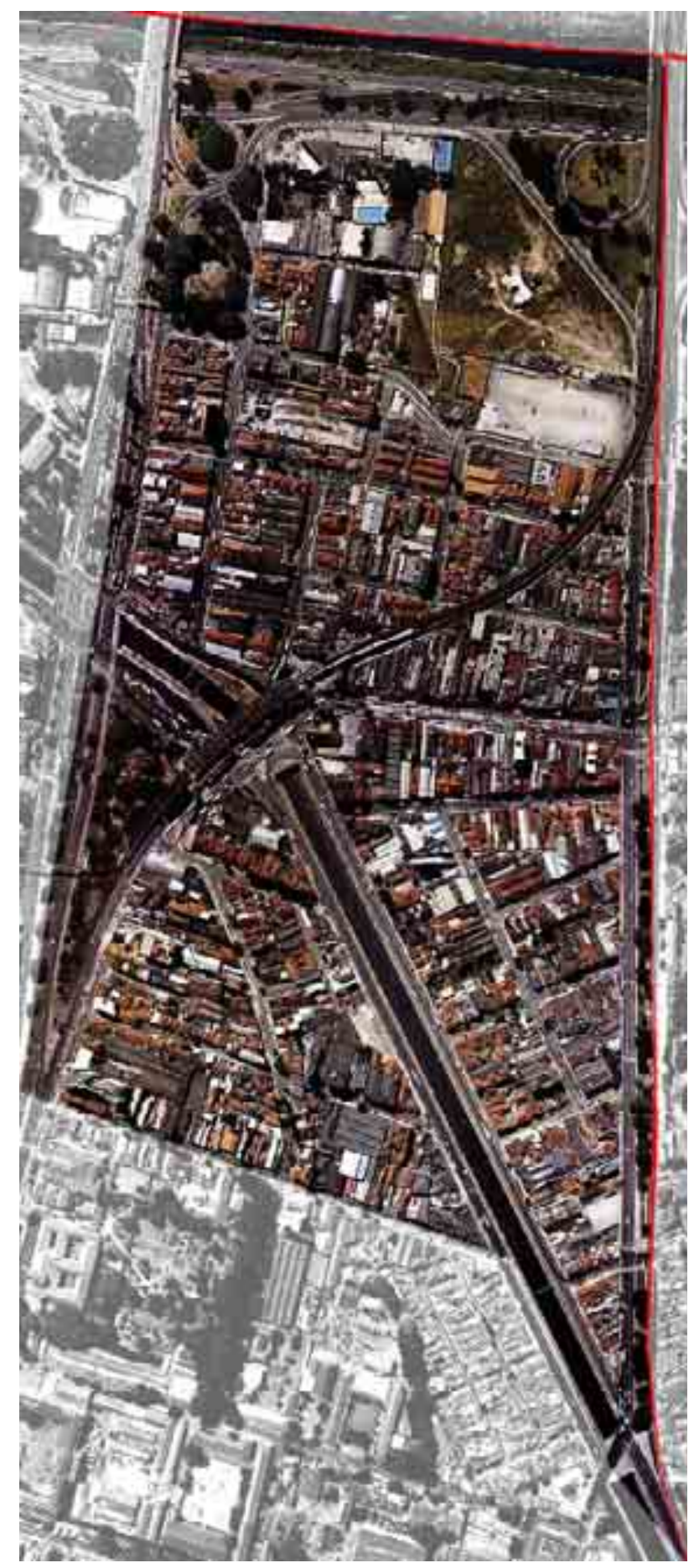

2000 
Brás: Sub-setor 1

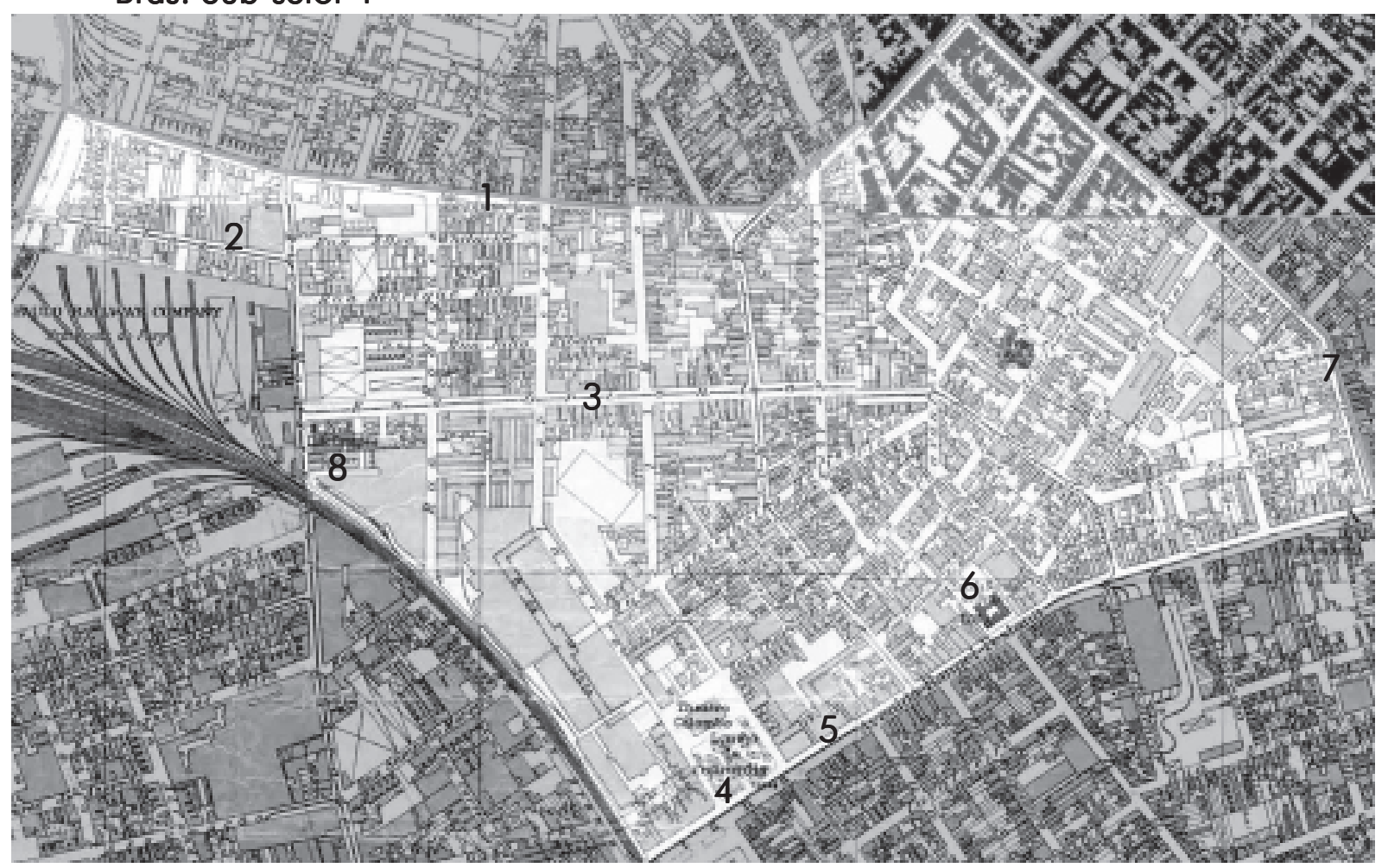

1930: 1. R. João Teodoro; 2. R. São Caetano; 3. R. Oriente; 4. Lgo. da Concórdia; 5. Av. Rangel Pestana; 6. Escola Normal (atual E. E. José de Anchieta); 7. R. Bresser; 8. Colégio Carlos de Campos.

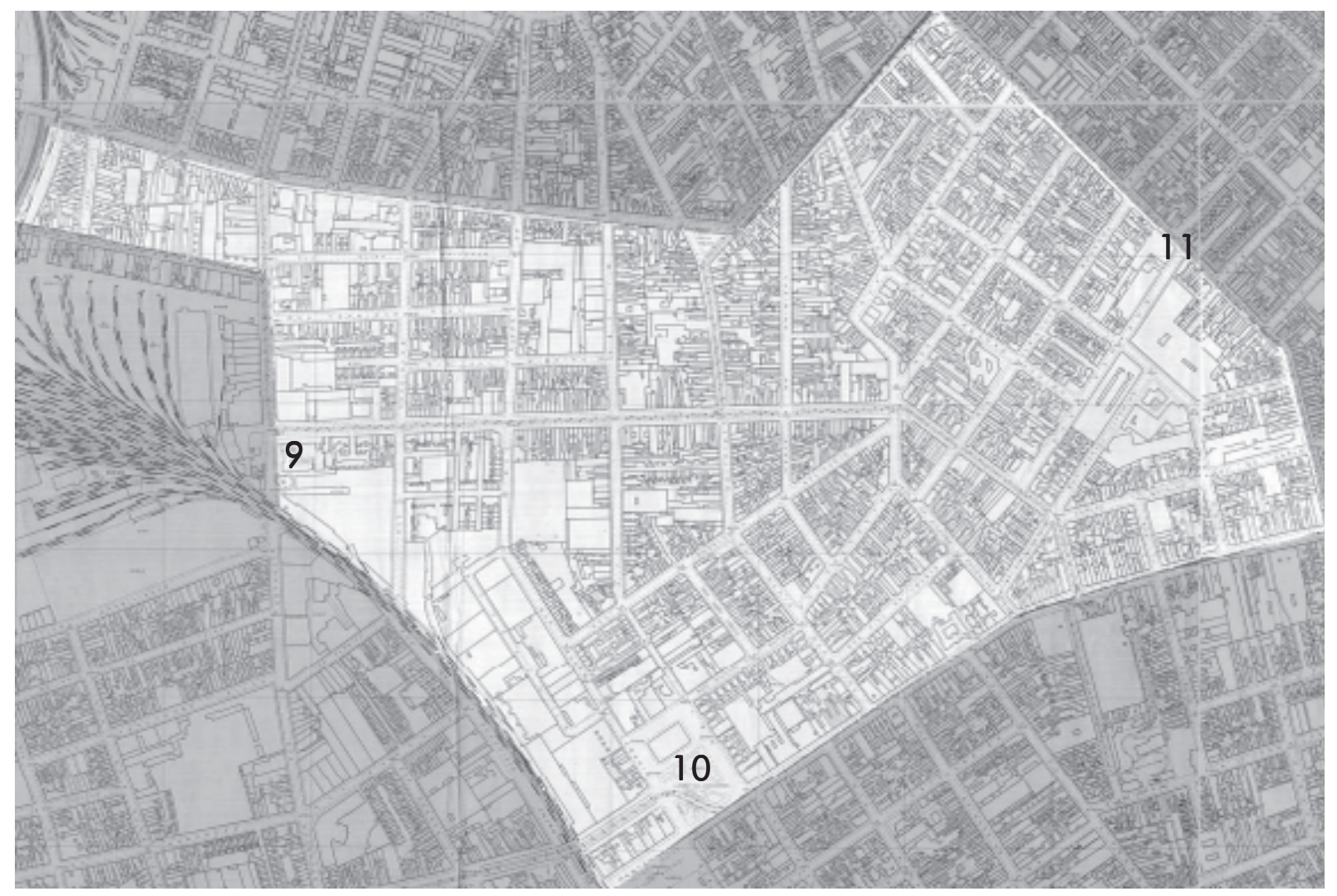

1954: 9. Colégio Carlos de Campos; 10. Lgo. da Concórdia; 11. R. Bresser e Vila Simeone. 


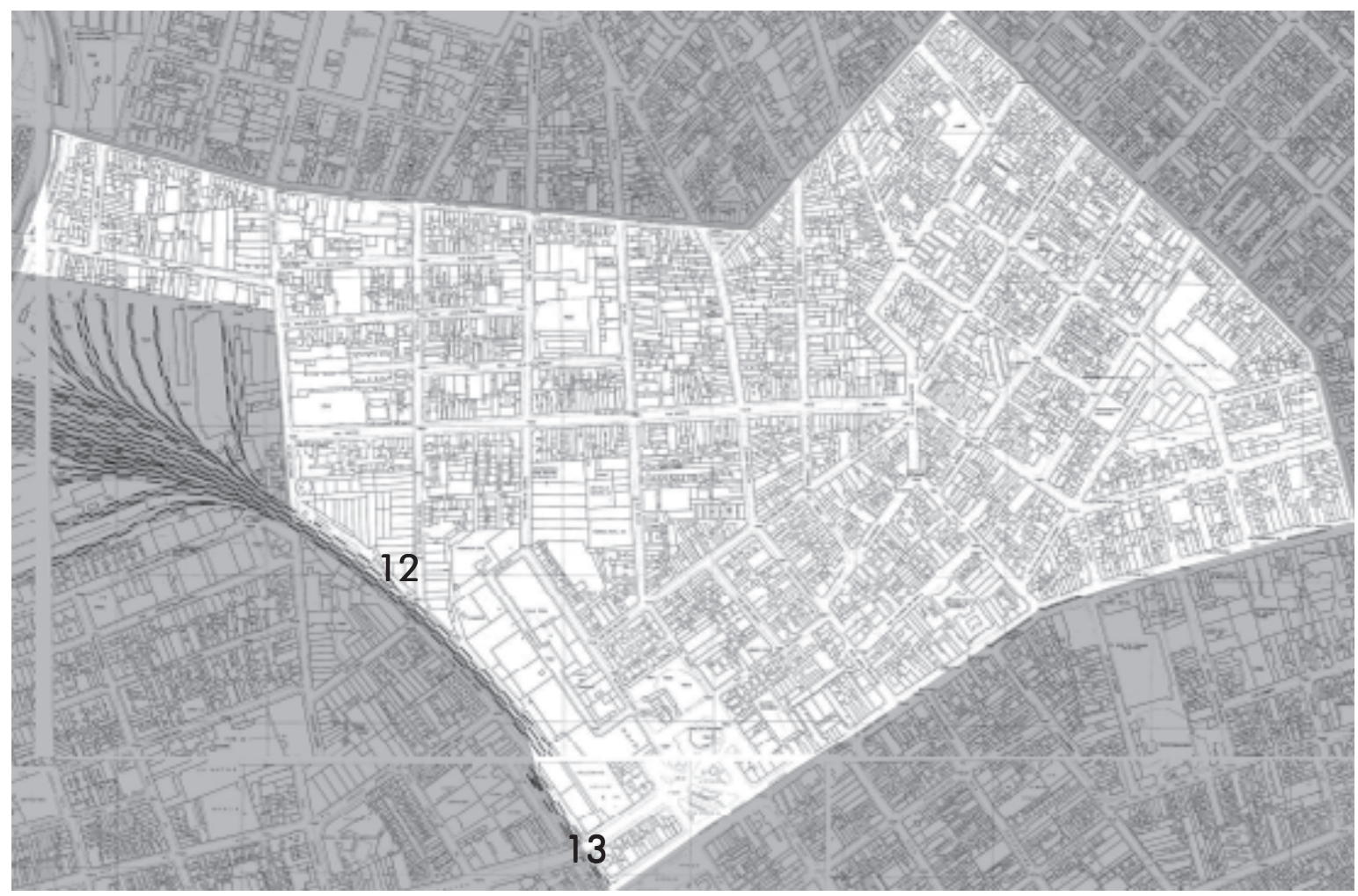

1972: 12. Ponte de ligação entre R. Rodrigues dos Santos e R. do Bucolismo; 13. Viaduto sobre a ferrovia Santos-Jundiaí (antiga "San Paulo Railway").

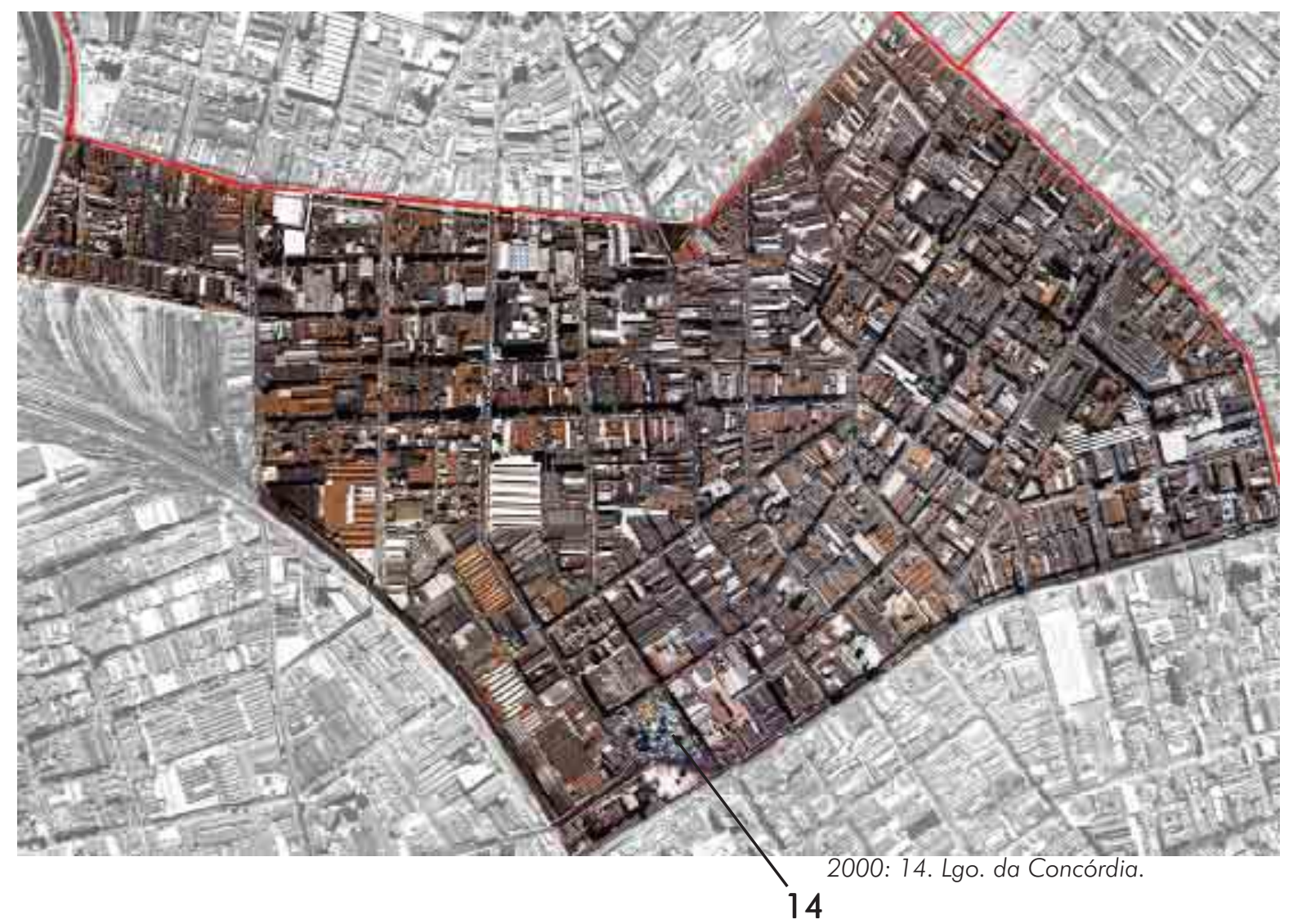




\section{Brás: Sub-setor 2}

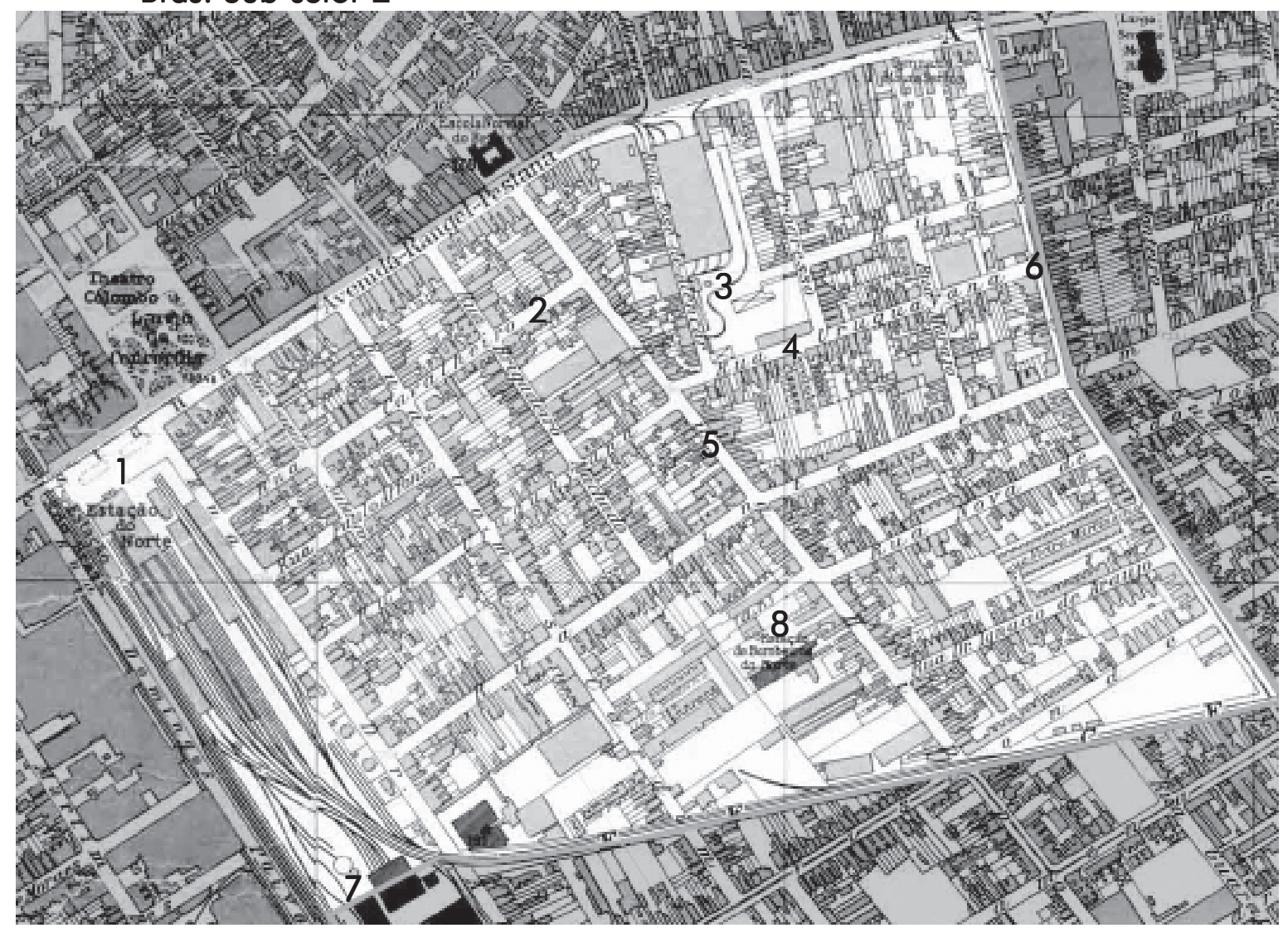

1930: 1. Estação do Norte; 2. R. Conselheiro; 3. Estação de bondes; 4. R. Uruguaiana; 5. R. do Hipódromo; 6. R. Bresser; 7. Hospedaria dos Imigrantes; 8. Estação de Bombeiros.

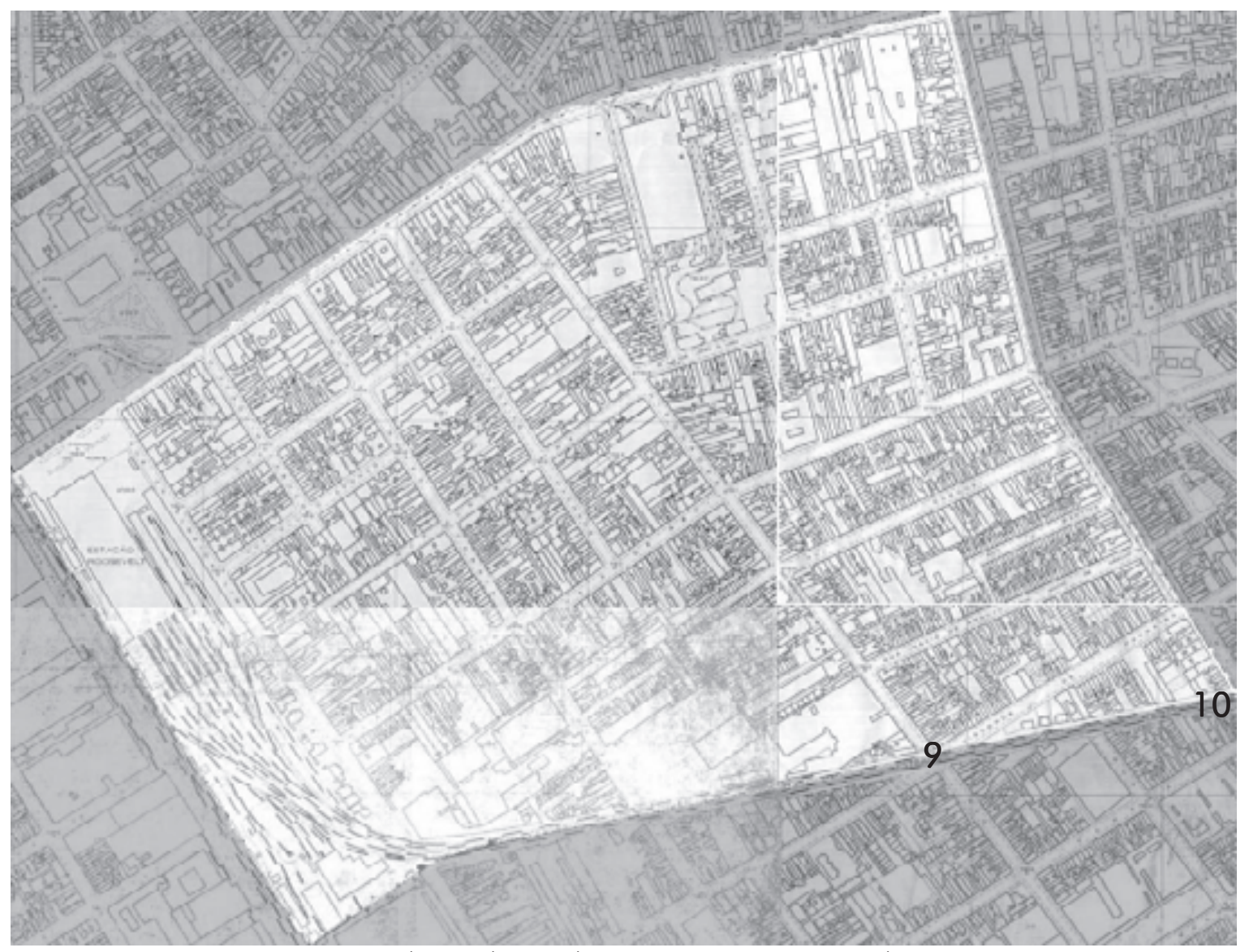

1954: 9. Passagem em nível na R. do Hipódromo; 10. Passagem em nível na R. Bresser. 


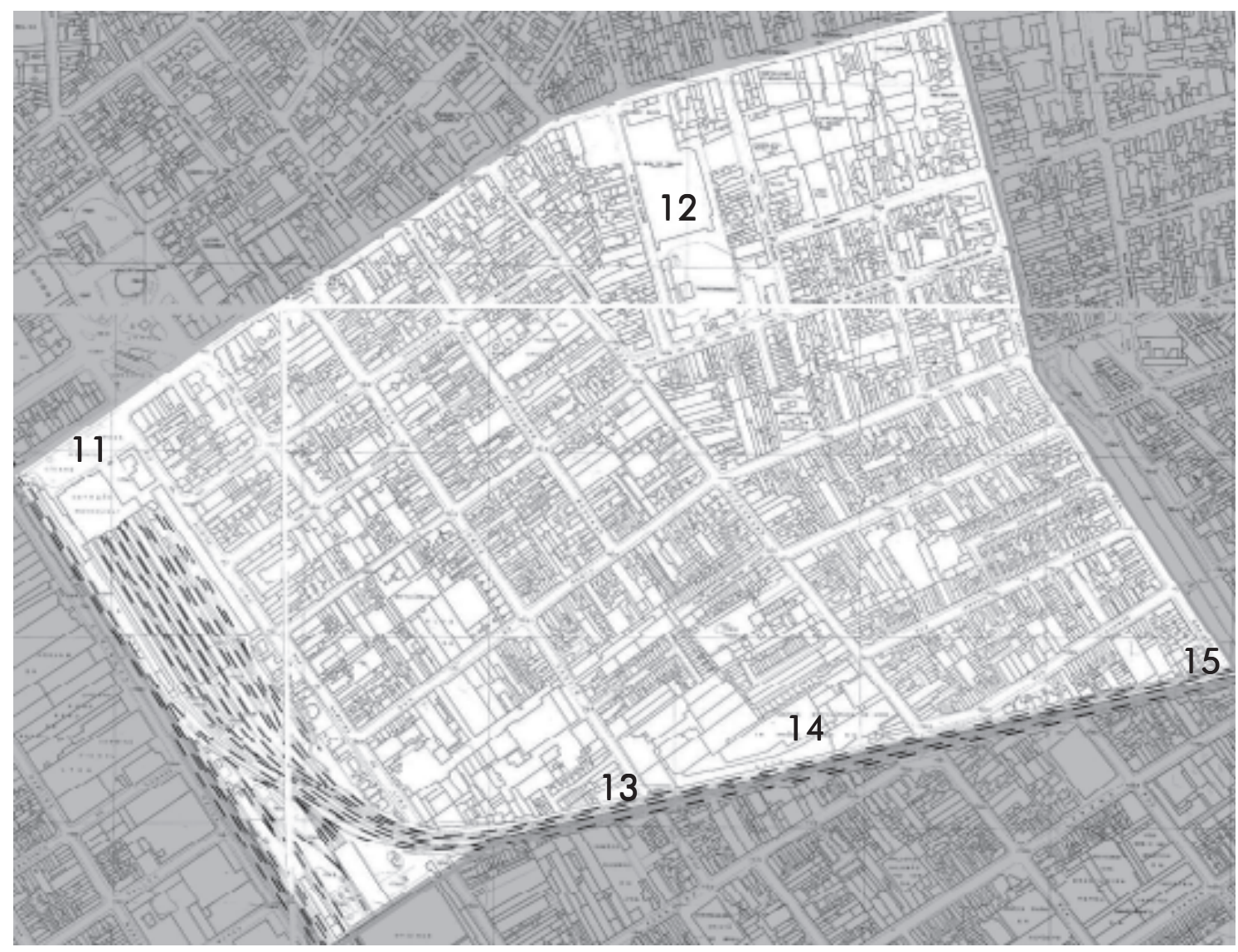

1972: 11. Estação Roosevelt; 12. Antiga garagem dos bondes; 13. R.F.F.S.A. (atiga Central do Brasil); 14. Area do Projeto CURA Brás-Bresser.

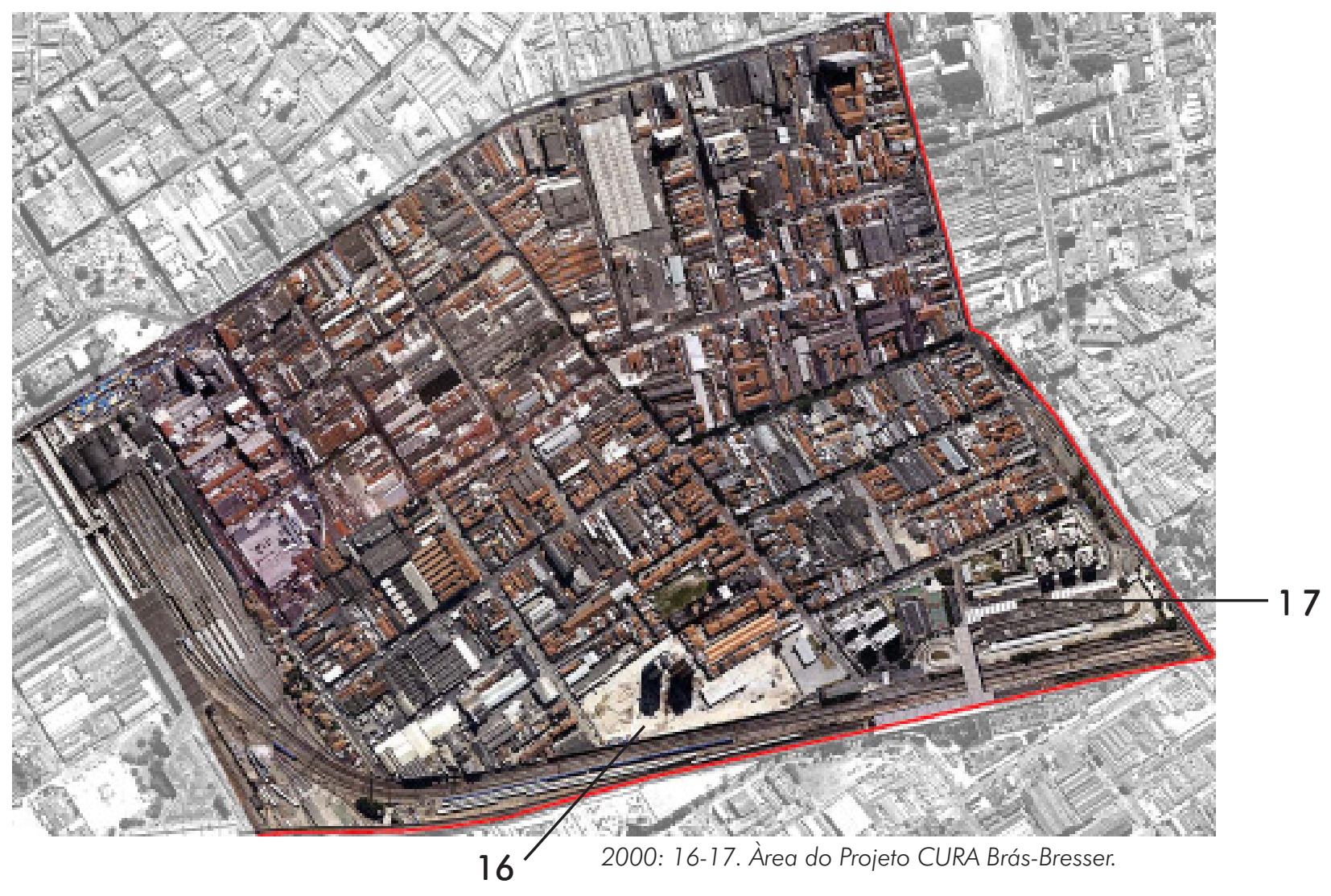


Brás: Sub-setor 3

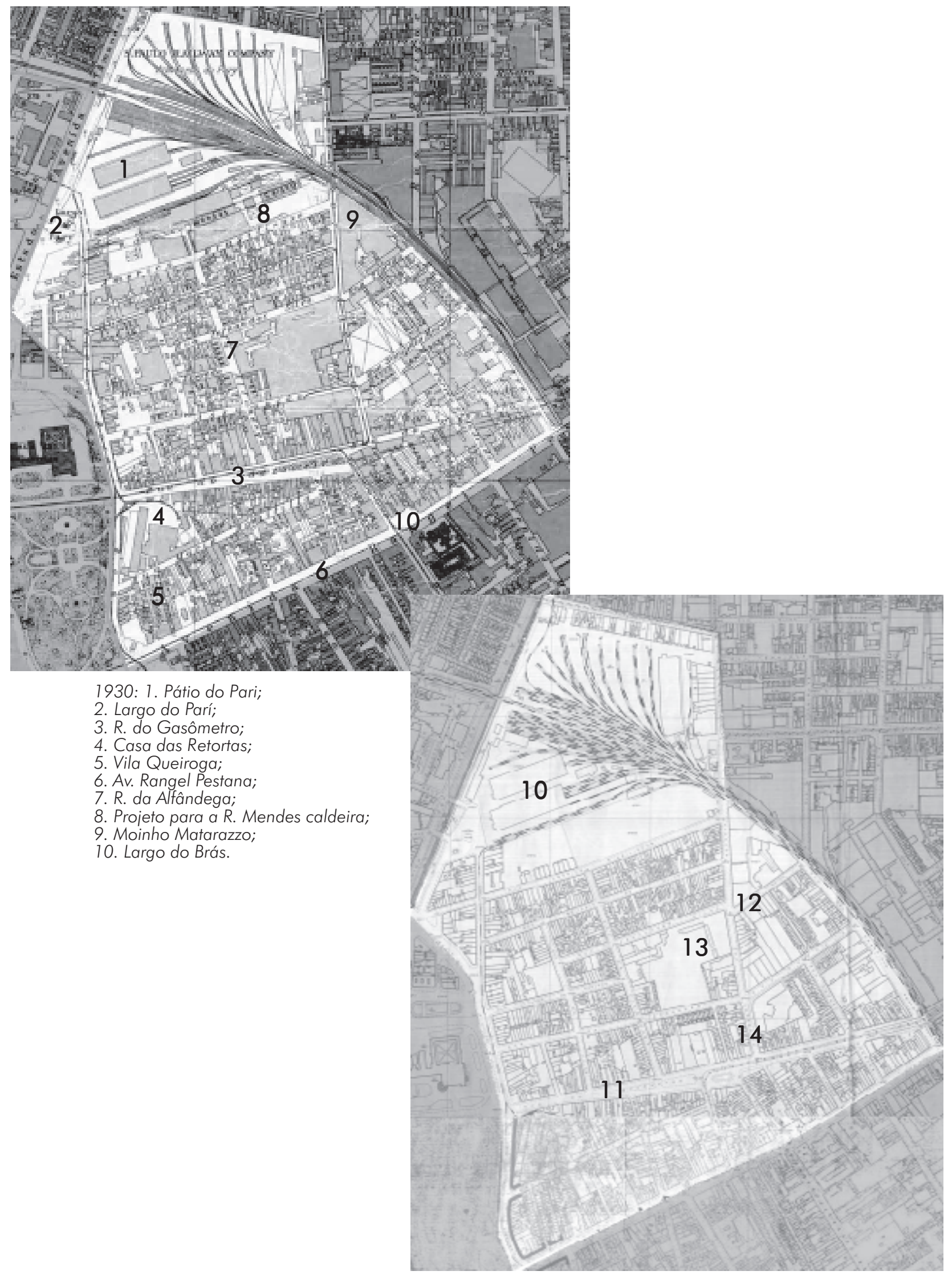

1954: 10. Pátio do Pari; 11. R. do Gasômetro; 12. R. do Bucolismo; 13. Tecelagem Mariângela (Matarazzo); 14. R. Mons. Andrade. 


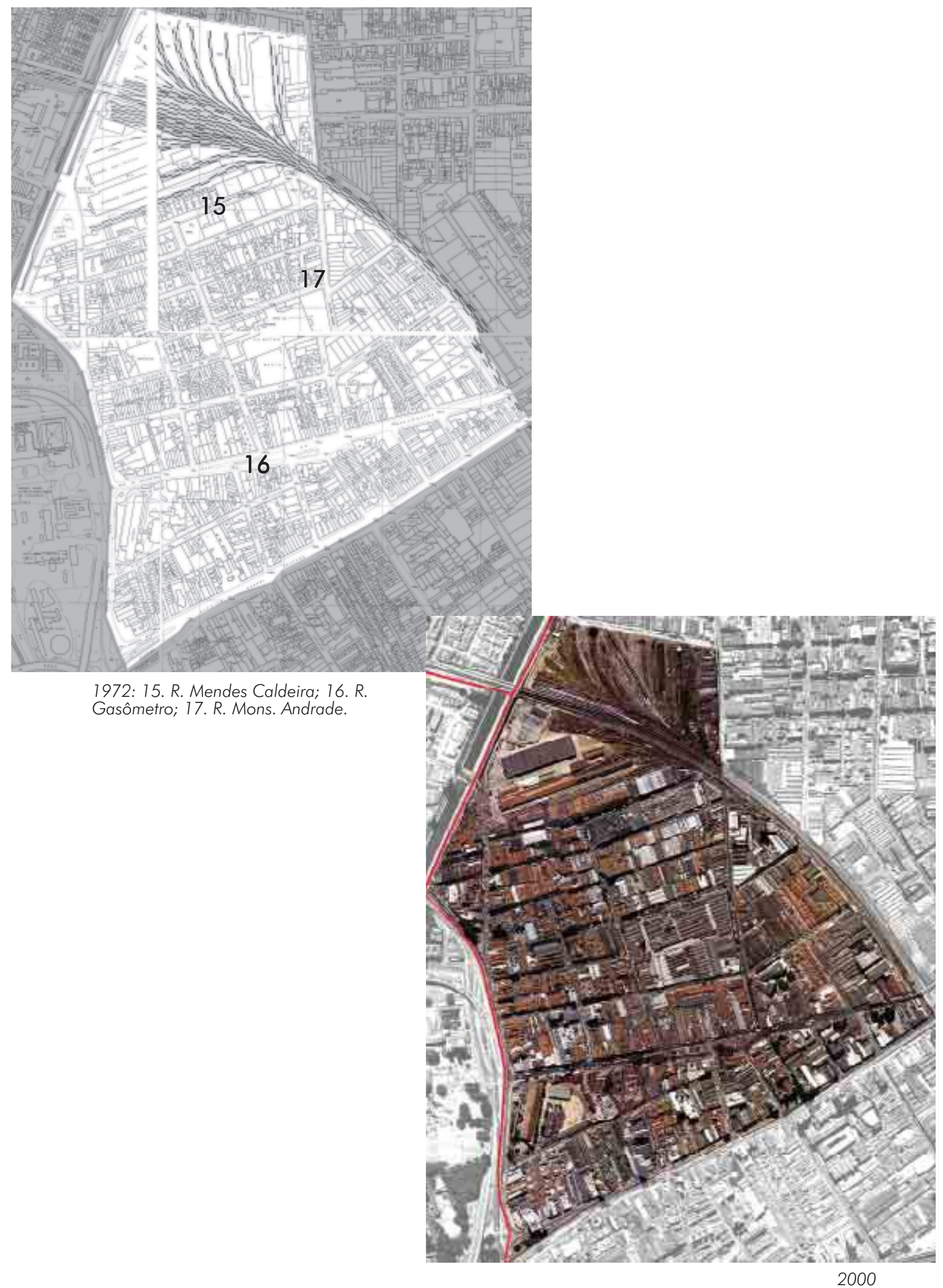




\section{Brás: Sub-setor 4}

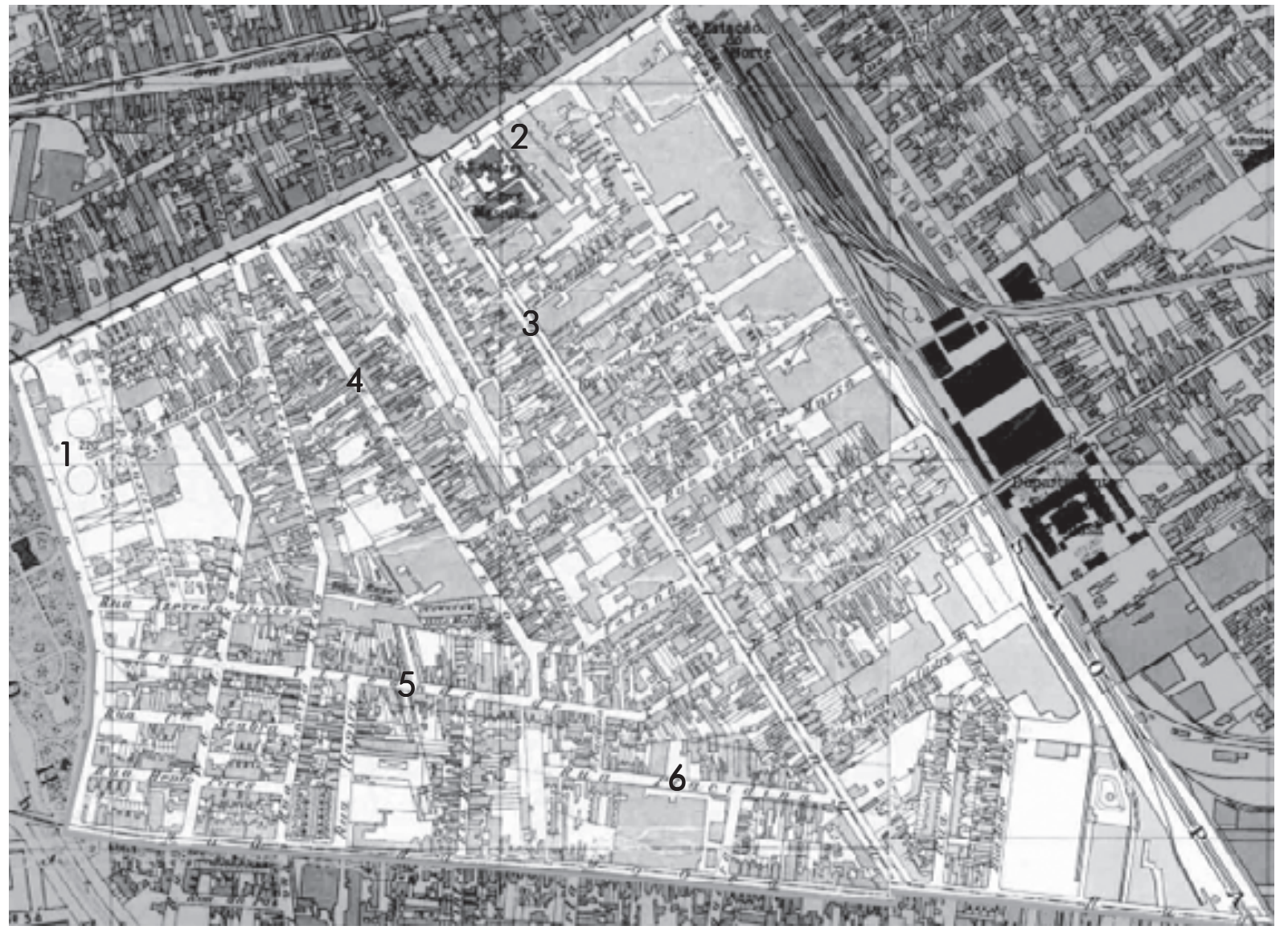

1930: 1. Tanques do Gasômetro; 2. Grupo Escolar Romão Puiggari; 3. R. Piratininga; R. Caetano Pinto; 5. R. Visconde de Parnaíba; 6. R. Placidina.

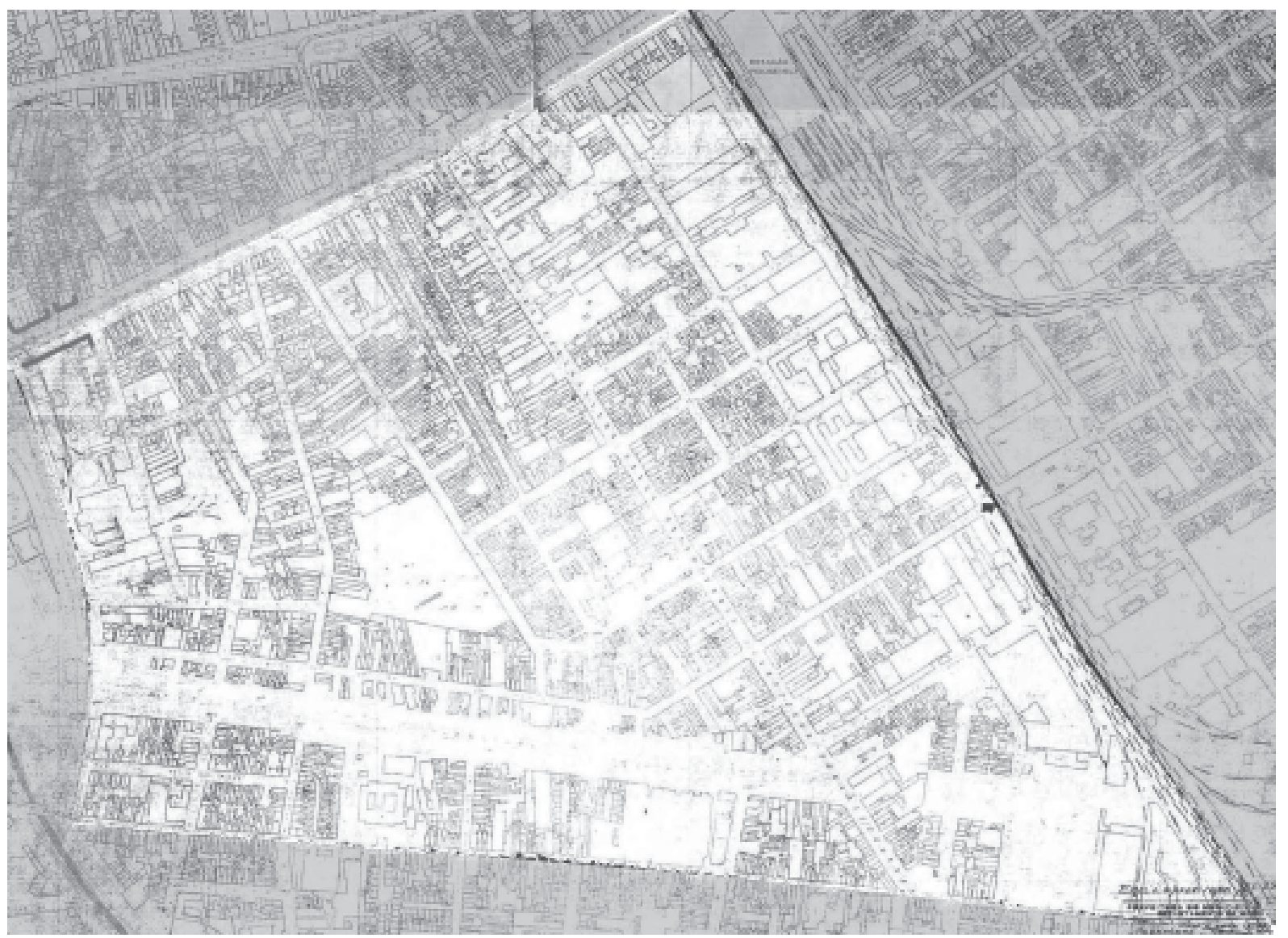




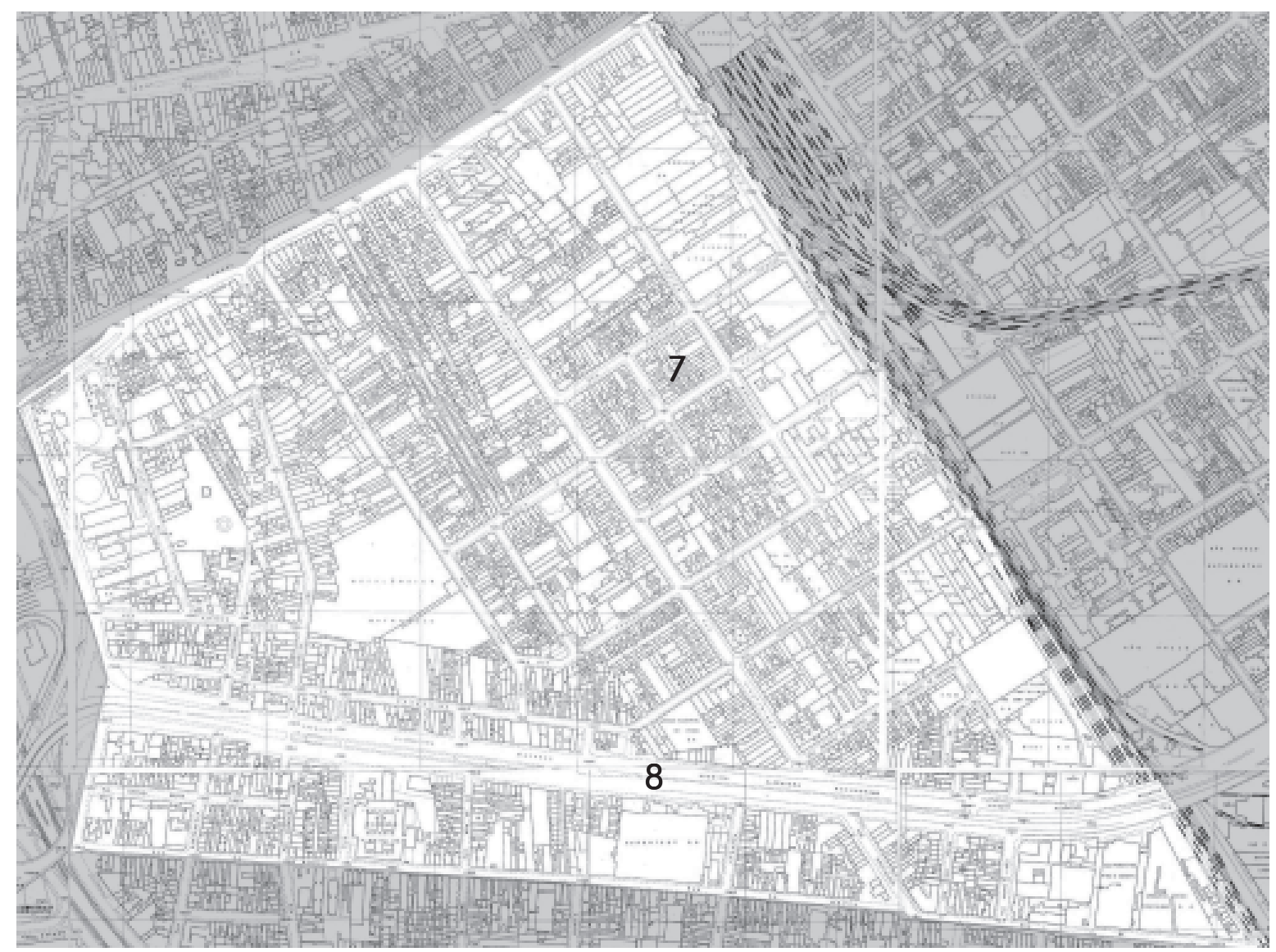

1972: 7. Quadras demolidas do Projeto CURA, 8. Radial Leste.

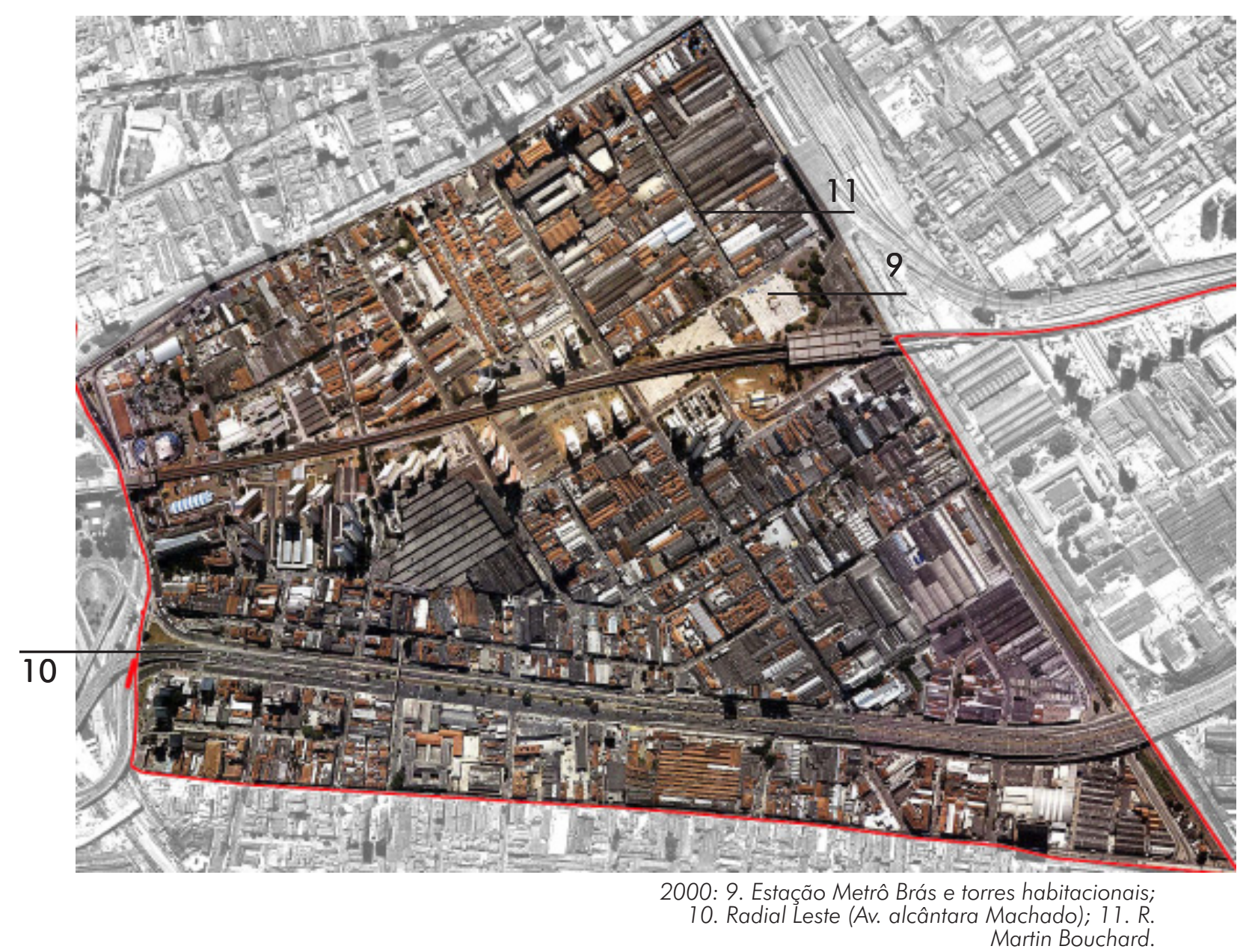




\section{Pari: Sub-setor 1}

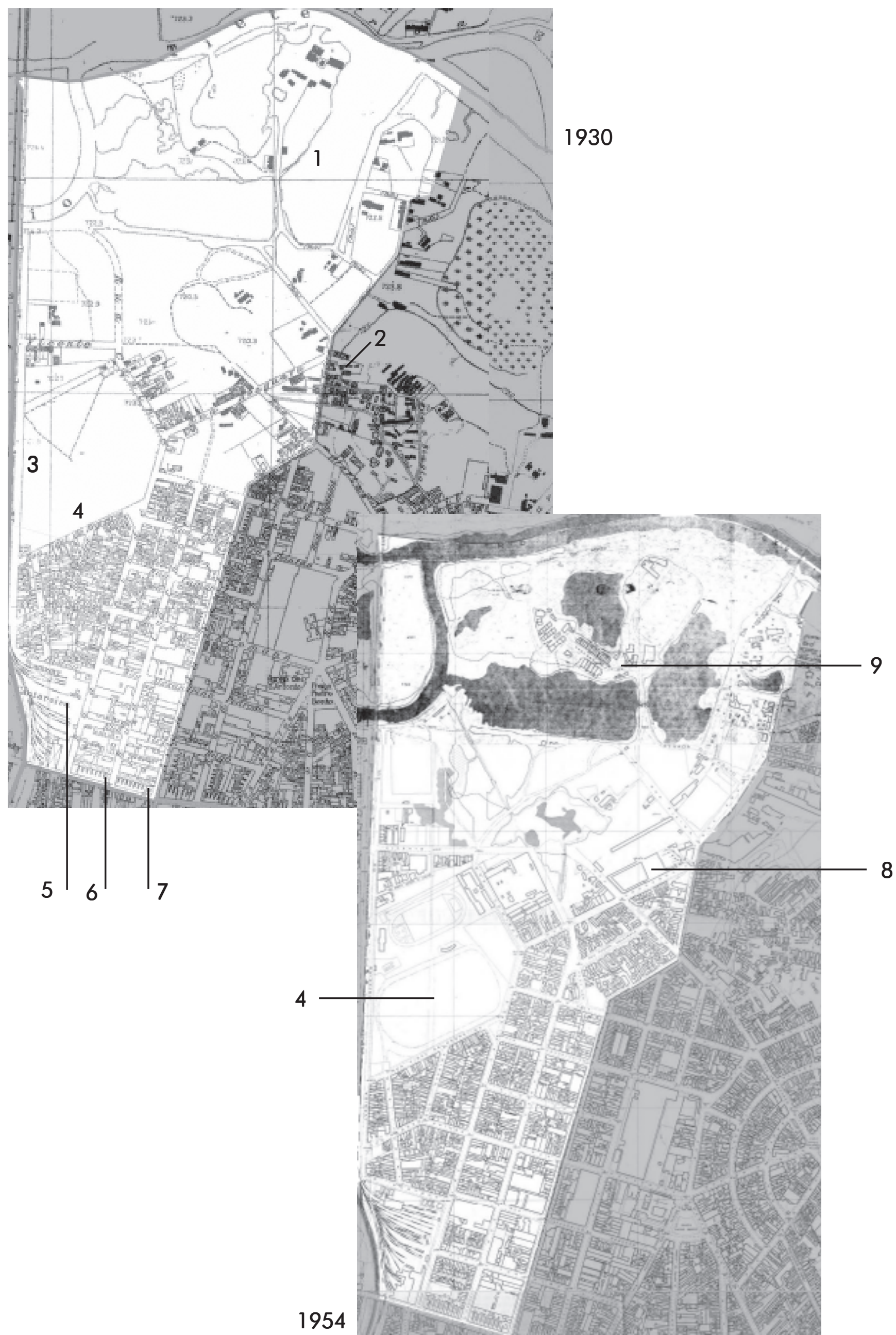




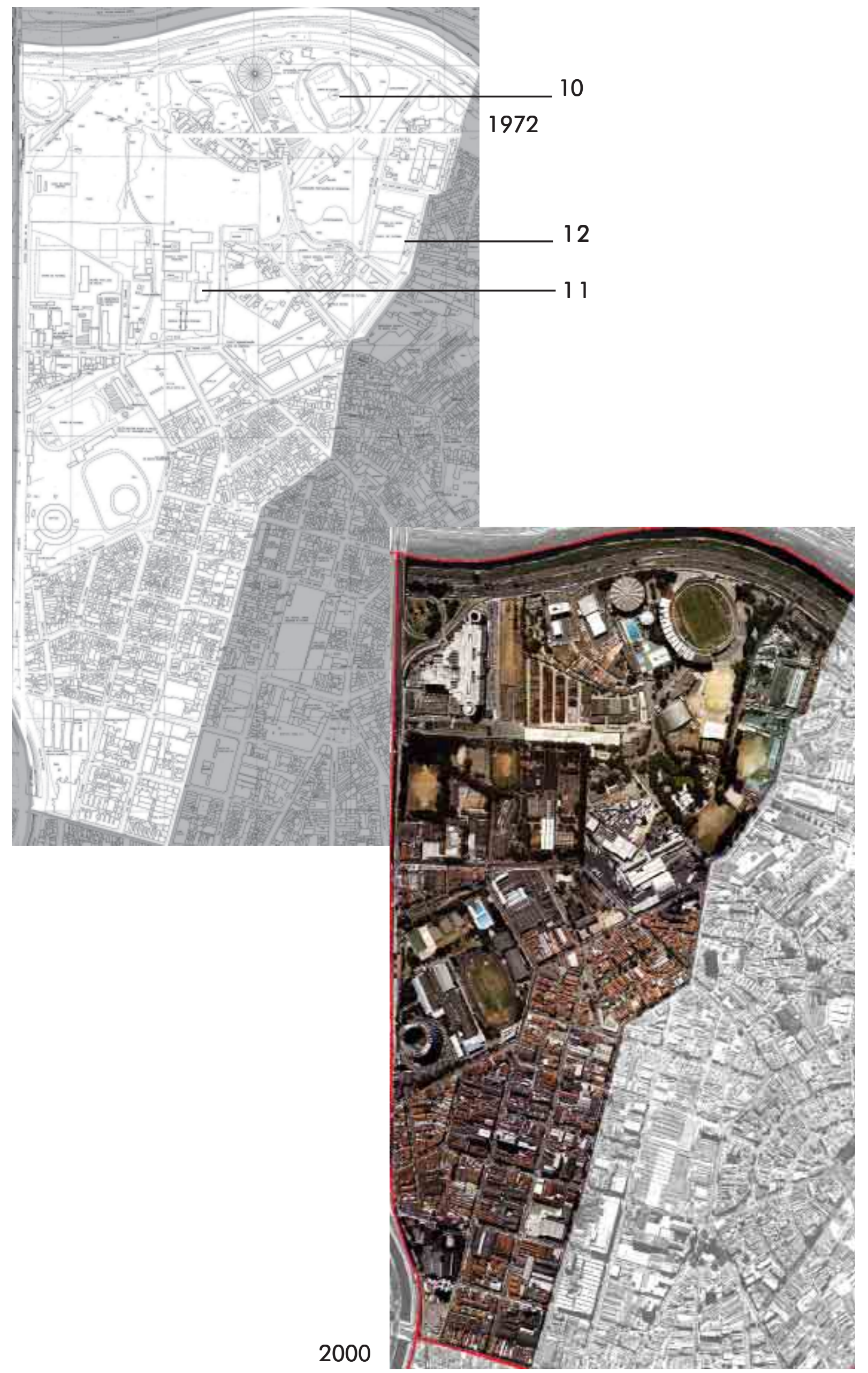


Pari: Sub-setor 2

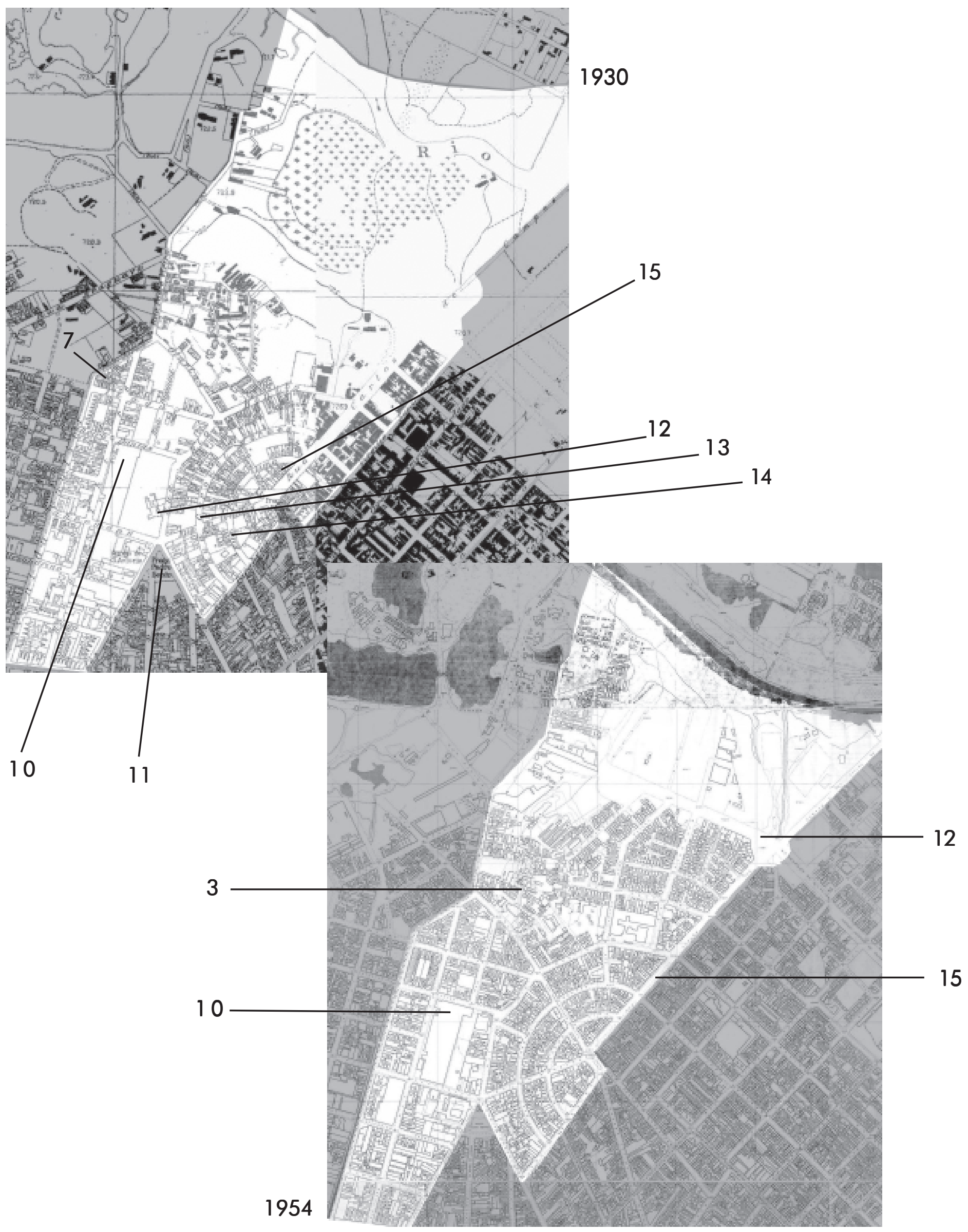




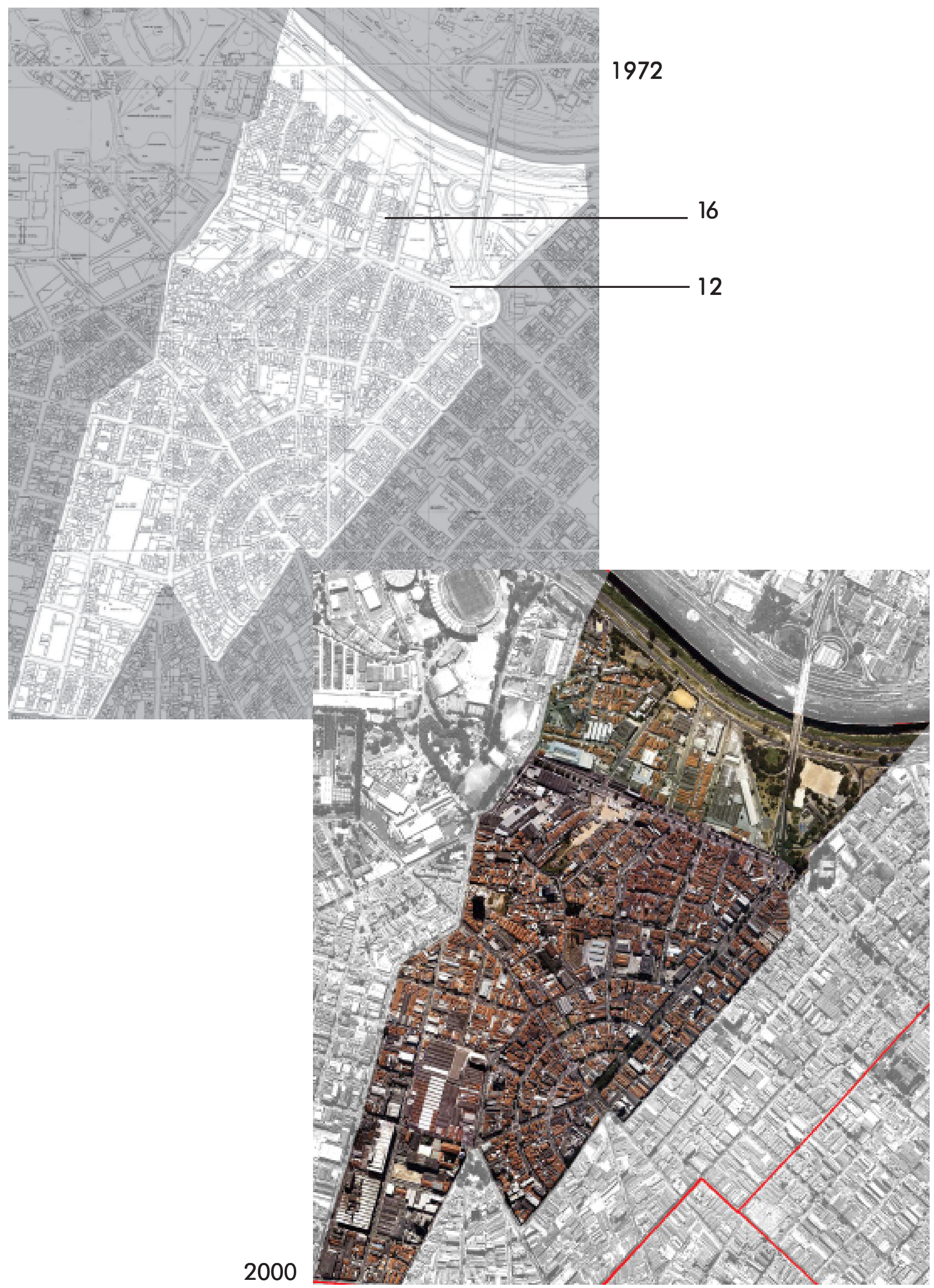


Pari: Sub-setor 3
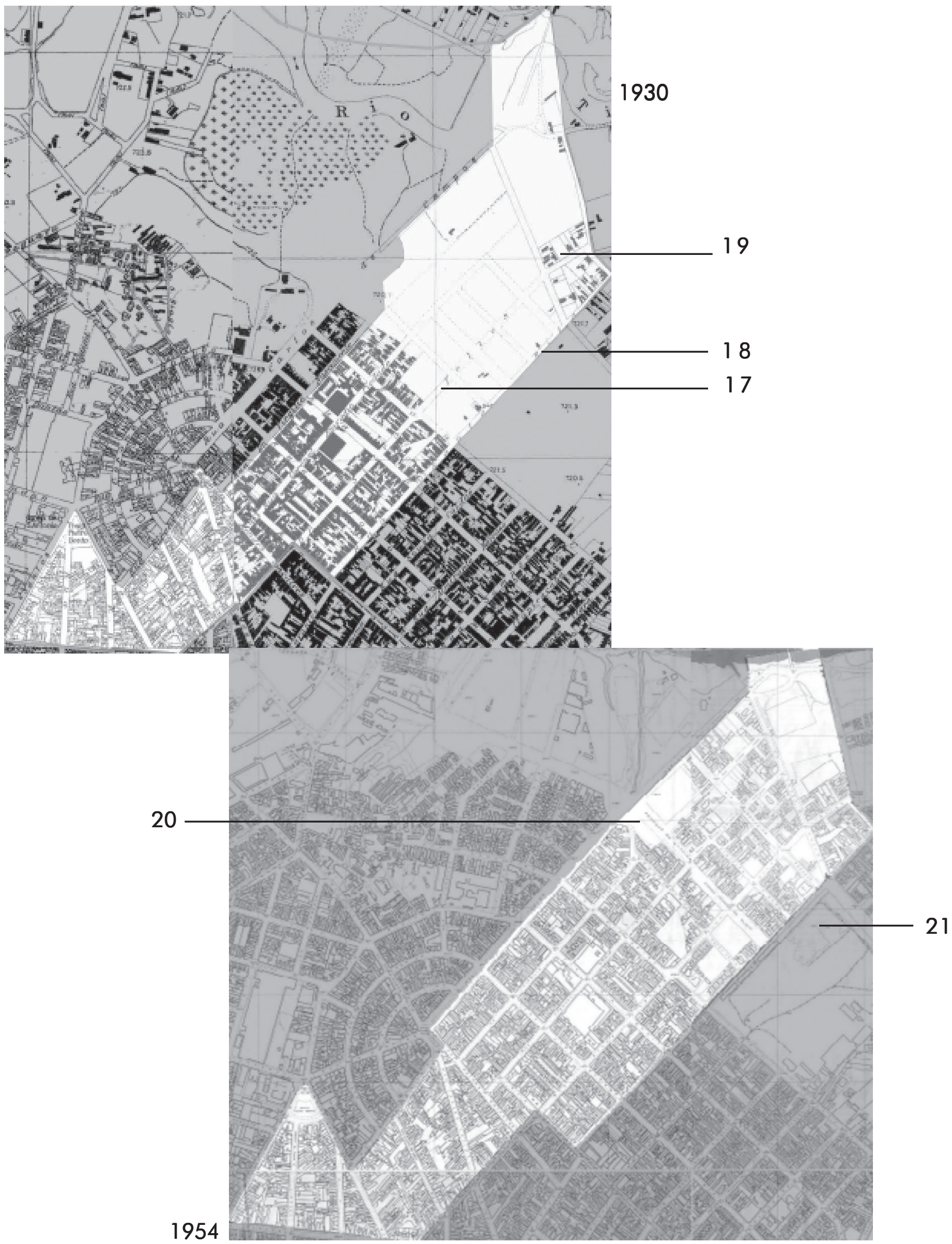


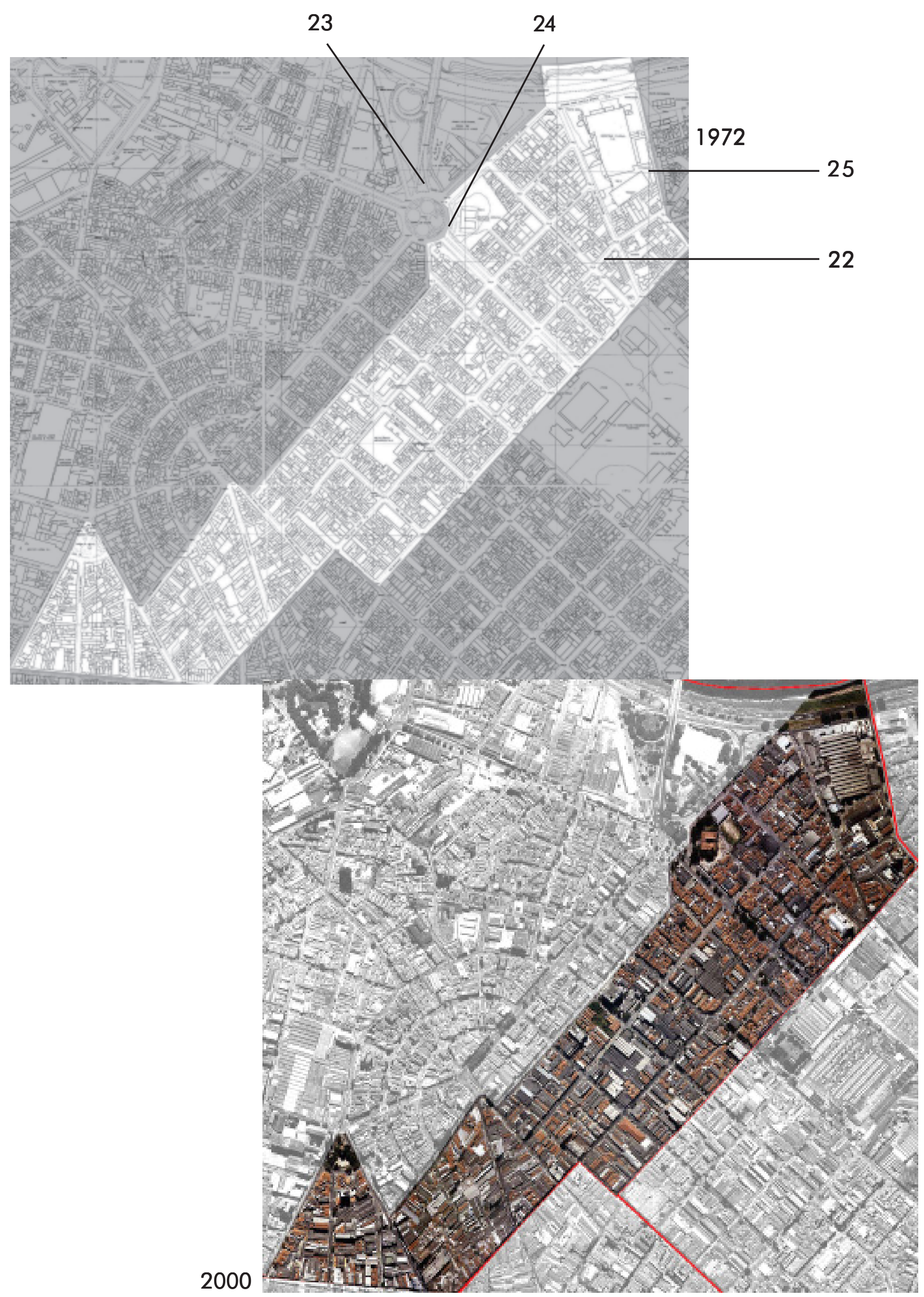




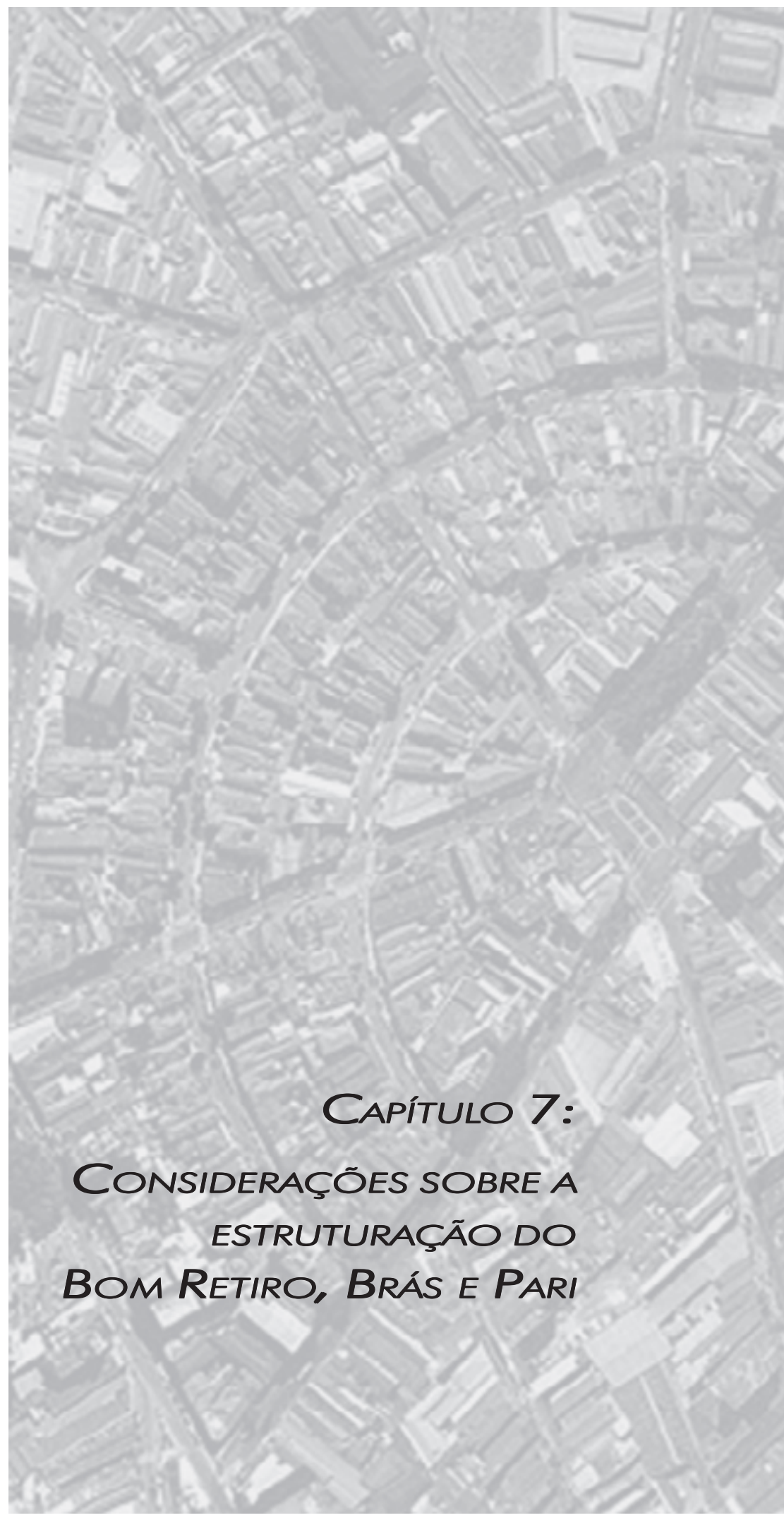




\section{Considerações sobre a estruturação do Bom Retiro, Brás e Parí.}

Os bairros situados nos distritos do Bom Retiro, Brás e Parí, foram enfocados através dos mapas cadastrais da cidade e outras fontes existentes, com a finalidade de se obter um entendimento topológico desses espaços, complementando os aspectos já abordados na Parte I deste trabalho, que estruturaram a configuração e as funções desses bairros centrais analisados. Procurou-se também um registro que expressasse a interação das estruturas morfológicas e sociológicas, conforme propôs Lefebvre $(2004,109)$, pois dessa maneira pôde ser contemplado o objetivo-problema desse desenvolvimento, que se revestiv em identificar como a espacialidade dos bairros centrais foi definida e quais transformações ocorreram, concomitantemente aos processos gerais da cidade.

Os bairros analisados se constituíram historicamente em um território com a ocorrência de atividades industriais, serviços voltados às camadas sociais mais populares e alta incidência de habitação horizontalizada, com fraca presença de verticalização. A essas características somou-se também a existência de uma infra-estrutura voltada ao transporte da população trabalhadora e de cargas, tais como ferrovias, estações e grandes terminais de linhas de ônibus, além de zonas de comércio atacadista, vias de tráfego pesado inter-regional, aliados a uma base fundiária fragmentada em pequenas propriedades e com presença significativa de habitação de baixa renda, representada pelo grande número de cortiços. Com esse caráter urbano, mesmo se localizando junto à centralidade, essas áreas localizadas em terras baixas das várzeas dos rios Tietê e Tamanduateí, tiveram reforçada a tendência de desvalorização ambiental e imobiliária.

Percebeu-se através dos capítulos que analisaram as transformações ocorridas ao longo das principais radiais do Plano de Avenidas, das Operações Urbanas e da estruturação dos bairros, o quanto que foram diferenciados os processos de remodelação da infra-estrutura, do reparcelamento e da verticalização na cidade. A leitura comparativa dos mapas mostrou, mais que a permanência das características urbanas dos bairros analisados, a sua quase estagnação, se confrontado com o ocorrido em outros bairros da cidade.

Mas cabe perguntar qual estagnação ocorreu, se os bairros em tela apresentam, sem dúvida, uma dinâmica comercial importante? A resposta para essa questão não se relaciona a apenas um aspecto, pois ocorreu no Bom Retiro, Brás e Parí, um processo interligado de depreciação do uso habitacional e perda das qualidades paisagísticas e ambientais. Inúmeras áreas nesses bairros se encontram extremamente rebaixadas, quer pelo padrão de suas construções, quer pelo uso pela população encortiçada, quer pela interferência com atividades prejudiciais à moradia, como tráfego intenso, funções comerciais que extravasam para as ruas a circulação dos veículos e das mercadorias, etc. 
Nesse caso se enquadram boa parte do Canindé, a região da João Teodoro e São Caetano, na transição entre a Luz e o Parí, o entorno da estação Roosevelt e parte da zona cerealista, no Brás e as quadras entre a avenida Tiradentes e avenida dos Estados, na Ponte Pequena. Não se configuram com problemas idênticos, já que existe uma variação em razão da localização, dos imóveis presentes no lugar e do número de habitantes e usuários existentes. Mas, sem dúvida constituem um quadro de extrema complexidade social e urbano.

Já foi citado também, no capítulo referente ao Zoneamento, o caráter conservador que revestiu esse instrumento, quando de sua aprovação, em 1972. A manutenção das vocações, usos e ocupações se constituiu, sem dúvida em uma das razões para as áreas aqui analisadas terem permanecido com os mesmo padrões, ou até mesmo pior. Mas em outras áreas da cidade, nas proximidades de setores de alta renda, as zonas de baixa densidade se transformaram, certamente porque:

- Não contavam com atividades que provocavam os impactos urbanos como os das zonas de comércio atacadista ou da proximidade de grandes terminais de transportes ou eixos viários de tráfego pesado;

. Houve remodelação da infra-estrutura urbana, preparando o bairro, ou parte dele para a verticalização;

- Se constituíram em zonas de transição, uma reserva de área pronta a ser incorporada pela expansão da verticalização, como comprovam os casos de Moema e das Vilas Madalena e Olímpia, entre outros.

Relacionado a essa análise, nos capítulos da parte seguinte do trabalho serão analisados dois conjuntos de projetos para o Bom Retiro, Brás e Parí. O primeiro grupo é composto por duas propostas, das décadas de 1980 e 1990, não realizadas, mas bastante esclarecedoras quanto às finalidades de transformação do existente, que direcionaram uma cirurgia urbana de grandes proporções para a remodelação da infra-estrutura e da morfologia. $\bigcirc$ segundo grupo inclui uma série de planos, projetos e programas do poder público, com vistas à reversão do processo de esvaziamento populacional, através da utilização das áreas mais equipadas e do estancamento da degradação do ambiente e da paisagem urbana. 
Parte 3 



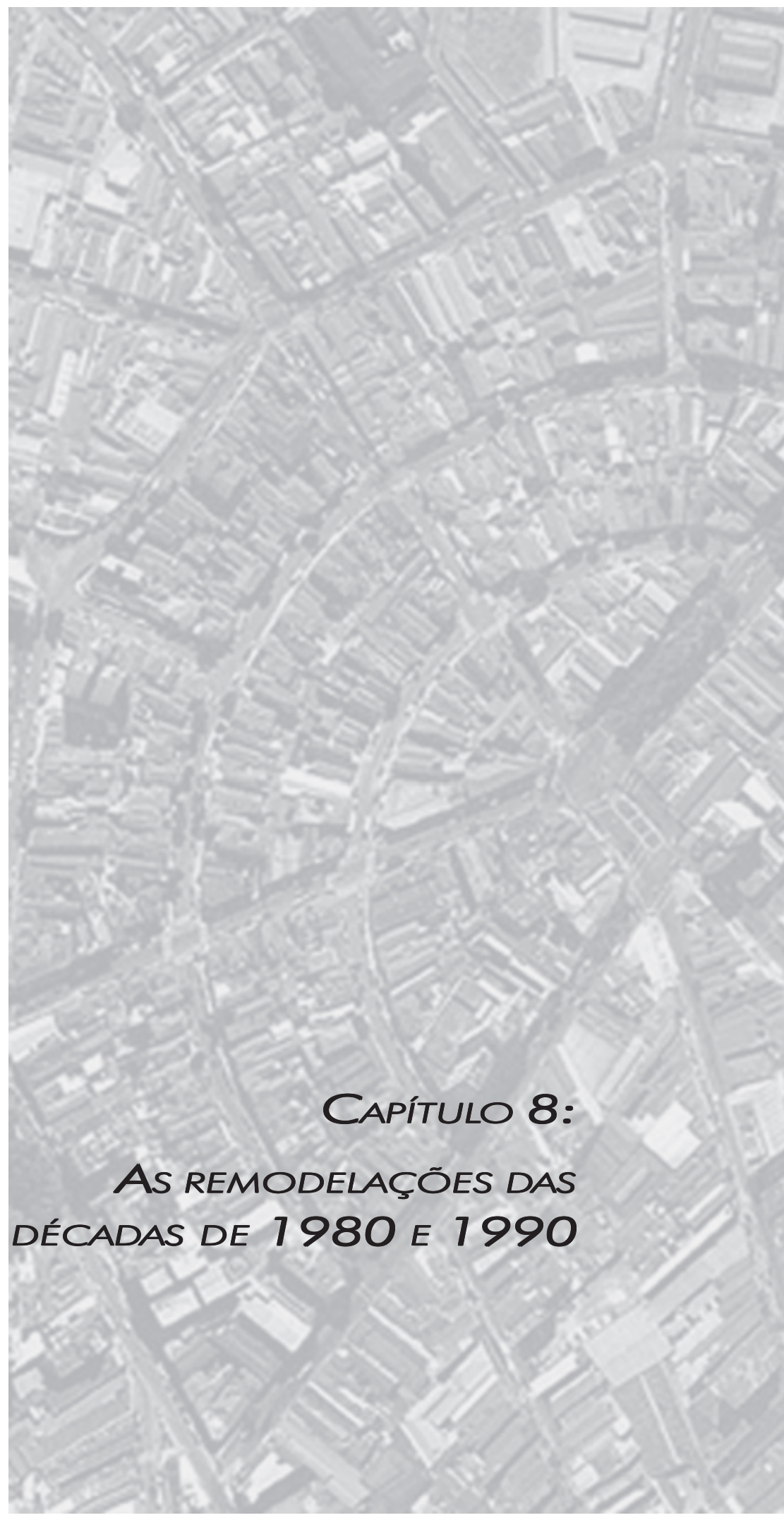




\section{8- As remodelações das décadas 1980 e 1990}

Os dois projetos seguintes foram incluídos neste trabalho visando duplamente, analisar o partido urbanístico dos mesmos, que adotou a demolição de parte dos bairros considerados deteriorados como necessária aos seus objetivos e 0 contraponto deles com as propostas de requalificação dos espaços e funções existentes. 


\section{1. - Parque do Tietê}

Esse projeto nasceu de um convite do então Prefeito Jânio Quadros ao arquiteto Oscar Niemeyer ${ }^{1}$ para, segundo as palavras do ex-prefeito, "reconciliar o rio com a cidade". Conforme esclarecia o próprio memorial do projeto, tratou-se de um "parque metropolitano central, inserido na trama urbana da Cidade, na margem esquerda do rio Tietê, alongando-se pelos bairros da Lapa, Barra Funda, Bom Retiro, Parí, Belenzinho, Tatuapé e Penha, numa extensão de dezoito quilômetros e largura variável de trezentos a mil metros" (Niemeyer et alli, 1986, s/pag).

O Parque agregaria aproximadamente 10 milhões de metros quadrados de espaços verdes, bosques e jardins, além da implantação de equipamentos e serviços de interesse social nos setores de educação, saúde e cultura, prevendose cerca de um milhão de usuários diários. Em sua exposição de motivos, o memorial descritivo do projeto também relacionava sua existência como elemento de grande importância para a macrodrenagem da cidade, uma vez que seria implantado no trecho mais crítico do canal, representando uma alternativa menos onerosa para o aumento da vazão e rebaixamento da linha d'água, além do acréscimo da área permeável no limite urbanizado da várzea, contribuindo para a diminuição do escoamento superficial, estravazamento das águas e redução da erosão. Nesse sentido, nas áreas baixas sujeitas a inundações, seriam

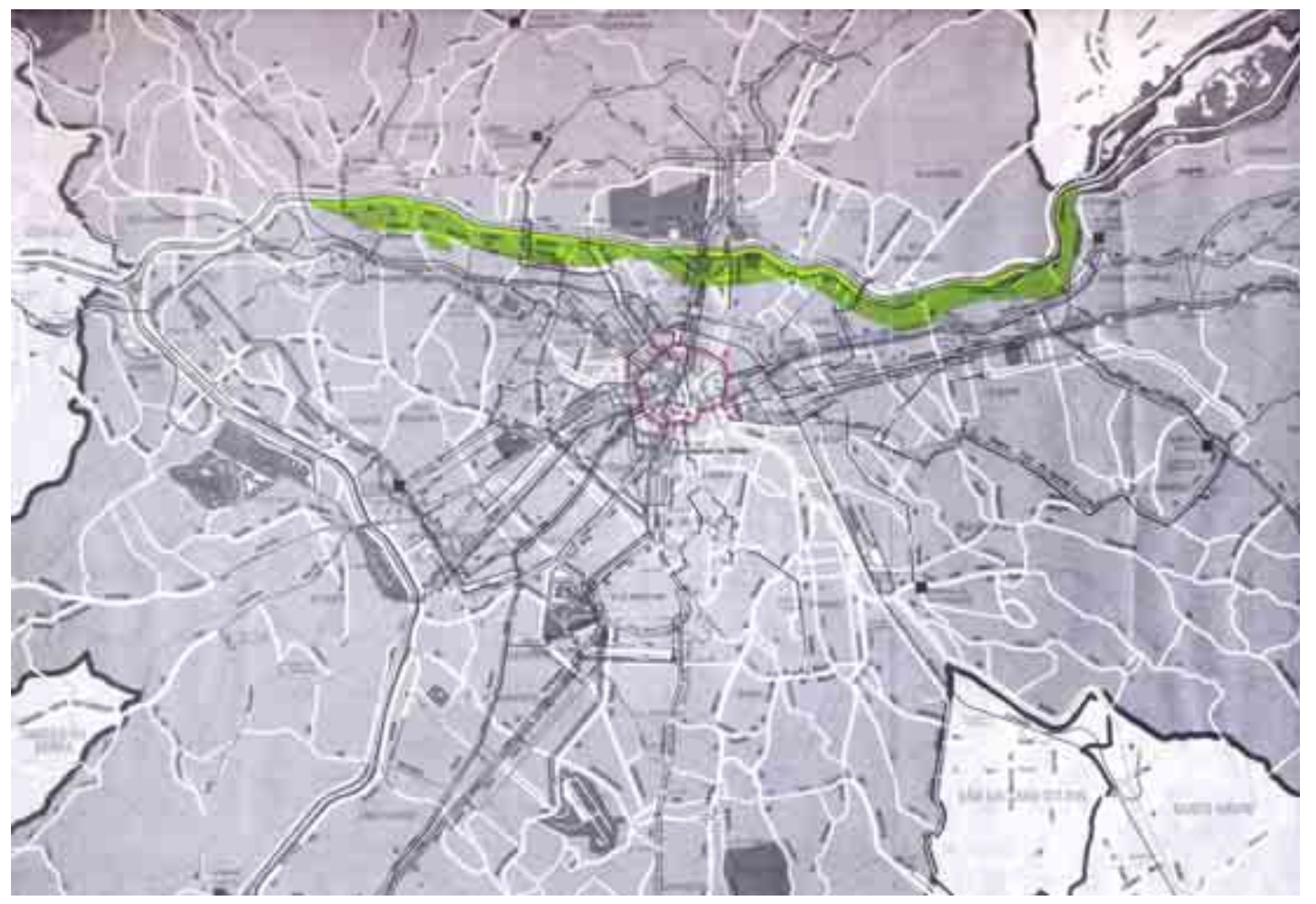

Fig. 226: Implantação do Projeto Tietê no município de São Paulo. 
implantados apenas equipamentos como parques, campos esportivos e demais elementos passíveis de resistir aos efeitos temporários das cheias. Relativo a esses problemas, o memorial considerou também a viabilização de postos de navegação de serviços, tais como, materiais e equipamentos de desassoriamento, materiais de construção e deposição dos resíduos sólidos. Numa segunda etapa estava prevista também a navegação turística e esportes náuticos (idem, 1986, s/pag.).

O sistema viário, importante elemento de configuração da proposta, seria estruturado em dois níveis: a circulação externa afastada do rio, composta por via expressa elevada e via de superfície, ambas no limite do Parque e com separação de fluxos de diferentes modalidades. A circulação interna seria composta por vias-parque, acessos de serviço e estacionamentos. (ibidem, 1986, s/pag).

As edificações previstas no Parque englobavam os seguintes conjuntos:

1. Centro cívico - Situado no cruzamento dos eixos cardeais, no centro do Parque, entre as avenidas Santos Dumont e Cruzeiro do Sul. Constaria dos edifícios-sede do governo municipal, suas secretarias e empresas, a fim de criar um ponto de identificação do governo para a população. Reuniria um edifício do governo do município e quatro de secretarias e empresas municipais, além de auditório, praça cívica para um milhão de pessoas e garagens para 9.000 veículos. A área construída chegaria a $440.000 \mathrm{~m}^{2}$.

2. Centro cultural - situado na região entre o Belenzinho e o Tatuapé, englobando:

- Centro de divulgação para exposições, biblioteca, cinema e museu;

- Centro de criação, com escolas de música, dança e artes gráficas e visuais

- Centro de eventos, reunindo teatro para 1000 pessoas, auditório para 2000 pessoas e auditório aberto para 50.000 pessoas

- Centro de convivência, reunindo áreas de animação cultural e exposições ao ar livre, restaurantes e comércio especializado.

. A área construída desse complexo seria de $120.000 \mathrm{~m}^{2}$

3. Escritórios - $\bigcirc$ projeto do Parque do Tietê reunia dois setores que juntamente com o Centro Cívico formariam uma sucessão de conjuntos na área central do Parque, que seria mais densamente edificada. Os setores empresariais seriam o Cruzeiro do Sul, na Ponte Pequena e o das Bandeiras, próximo à foz do rio Tamanduateí. Propunha-se a sua construção pelo setor privado e constaria dos seguintes elementos: 
. Setor Empresarial das Bandeiras: 5 torres de 40 andares, área construída $850.000 \mathrm{~m}^{2}$, atendendo 57.000 usuários

. Setor Empresarial Cruzeiro do Sul: 3 torres de 40 andares, área construída $400.000 \mathrm{~m}^{2}$, atendendo 27.000 usuários.

4. Habitações - $\bigcirc$ projeto previu dois setores residenciais, situados a leste e oeste, com apartamentos de 60,90 e $120 \mathrm{~m}^{2}$, construídos através da participação da iniciativa privada. Num primeiro momento, os conjuntos seriam erguidos em áreas disponíveis, perfazendo um total de 10.000 moradores. Os restantes dos 150.000 moradores previstos seriam alocados na área do Parque, respeitando-se o direito de preferência dos moradores que seriam deslocados. As torres seriam construídas segundo o plano de massas prefixado no projeto e o memorial considerava que a COHAB não havia ainda atingido o patamar de 80.000 unidades entre apartamentos e casas, embora atuasse desde 1965. Os setores seriam:

. Setor Residencial Aricanduva

65 blocos de habitações - 13.200 unidades

Área construída: $1.200 .000 \mathrm{~m}^{2}$

População: 66.000 habitantes

. Setor Residencial da Água Branca

86 blocos de habitações - 16.800 unidades

Área construída: $1.800 .000 \mathrm{~m}^{2}$

População: 84.000 habitantes

- Apoios: educação e saúde, esporte e lazer, abastecimento e comércio

5. Núcleos de lazer

O Parque do Tietê previa o atendimento para até um milhão de pessoas ao longo de sua extensão, onde seriam dispostos campos e quadras esportivas, balneários, pistas e tanques de modelismo, parques infantis, abrigos, restaurantes, enfermarias, vestiários, sanitários, etc. Numa segunda etapa, junto à margem do rio, seriam instalados núcleos esportivos de náutica (op. cit, 1986, s/pag).

Uma vez descritas as proposições gerais do Parque do Tietê, o seu lançamento foi cercado de sérias críticas que consideraram tanto o processo de escolha e vinculação da equipe, determinado pelo executivo municipal, quanto pelo seu caráter urbano. Nesse sentido, as observações de entidades profissionais e arquitetos convergiram para o fato de haver se desconhecido os projetos já existentes para as áreas de incidência da proposta do Parque. Como foi abordado na Parte I deste trabalho, pelo menos dois planos urbanísticos propuseram a implantação de um setor administrativo municipal nas imediações da Ponte Pequena, o Relatório do Departamento de Urbanismo (1961) e o Plano Urbanístico 
Fig. 227: Maquete, Projeto Tietê

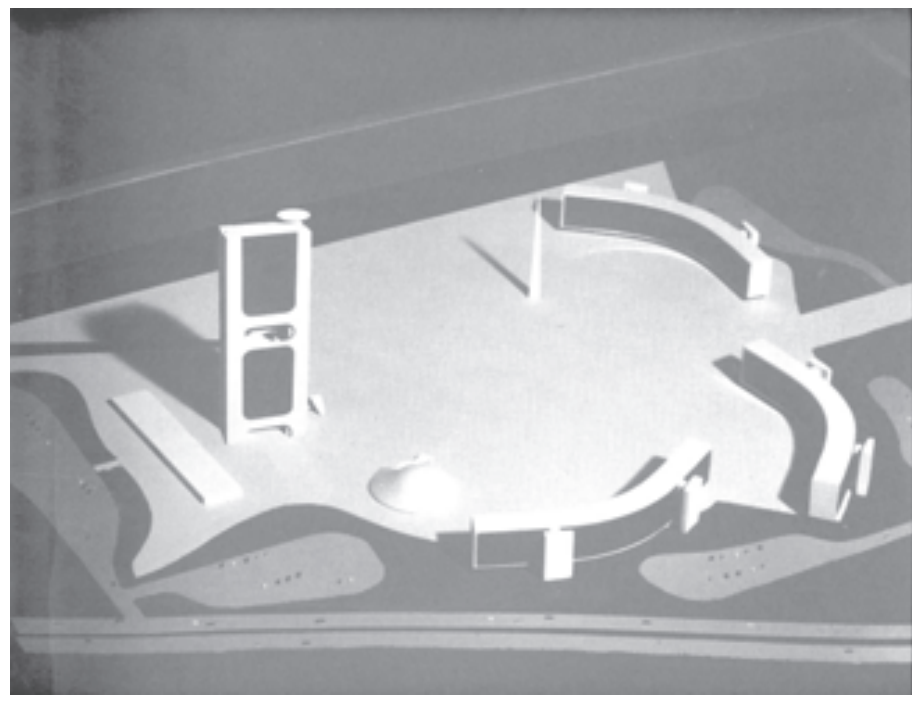

Fig. 228: Ilustração, Projeto Tietê.

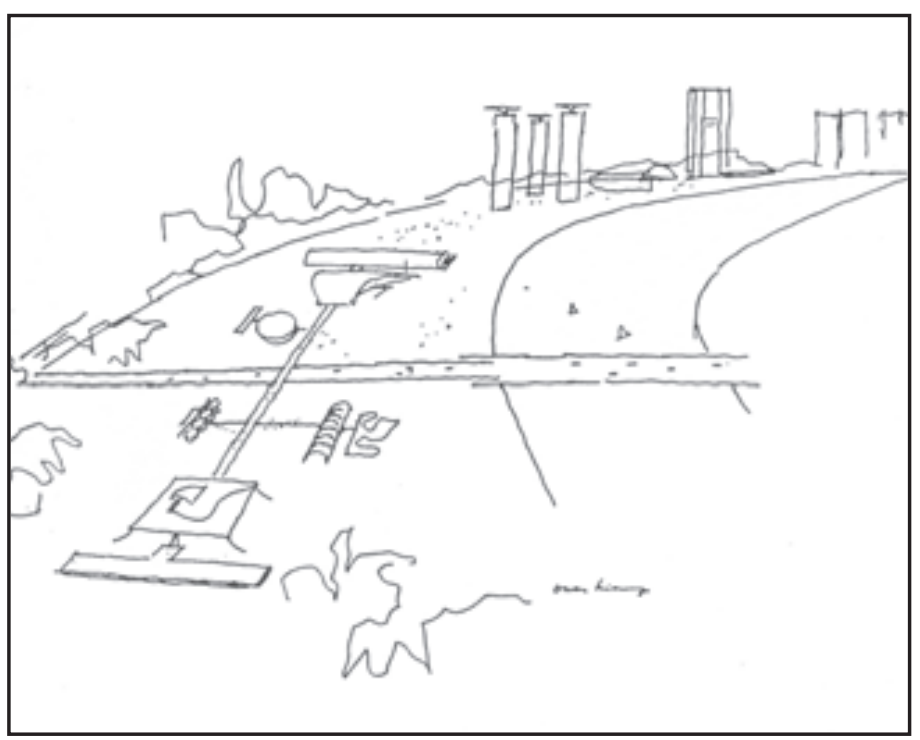

Básico (1968), que fundamentou o Plano Diretor de Desenvolvimento Integrado de 1972.

Além do setor administrativo da Ponte Pequena mencionado nos planos urbanísticos, foram também relacionados, o Plano de Saturnino de Brito, de 1928, e as oportunidades existentes na margem direita do Tietê, que na década de 1960 reuniam o Campo de Marte e amplas áreas desocupadas, que posteriormente receberam equipamentos como o Shopping Norte, sistema viário e indústrias. Esses elementos fizeram parte de um projeto desenvolvido à época do Departamento de Urbanismo da Prefeitura sem continuidade nas gestões posteriores a 1966. Em meados da década de 1970, outra proposta de edifício administrativo na Ponte Pequena foi formulada, desta feita pelo escritório RinoLevi, que indicava a existência de áreas públicas disponíveis e sua posição 
estratégica junto ao eixo viário norte-sul e ao Metrô (Wilheim apud Projeto, $\mathrm{n}^{\circ}$ 86, abril 1986, 87).

Apesar dos argumentos em defesa dessa mega-operação da parte de seu principal autor, Oscar Niemeyer, que considerou essa cirurgia urbana uma solução radical e necessária para corrigir o erro que representou o "emparedamento" do rio Tietê pelas duas marginais (Niemeyer apud Projeto, idem, 88), os debates conduzidos pelos órgãos de representação dos arquitetos e urbanistas ${ }^{2}$ apontaram questões mais amplas, que trataram da conveniência da operação de renovação urbana proposta, devido ao fato de haver outras áreas com maior carência de serviços públicos e habitacionais. Outros aspectos críticos mencionados se relacionaram à viabilidade econômica da operação, uma vez computados os recursos para desalojamento e transferência de pessoas e empresas, além da destruição do patrimônio comercial e imobiliário. Nesse sentido, sem um estudo de viabilidade econômica e urbanística que ponderasse os riscos da implantação ou de superdimensionamento, o projeto como um todo poderia se mostrar inadequado a curto prazo, tanto pelas áreas de ocupação inviável, quanto pela apropriação pelos interesses especulativos das áreas mais vantajosas (Projeto, $n^{\circ} 86$, abril 1986, 87).

A participação dos setores populacionais atingidos e dos profissionais vinculados aos problemas urbanos da cidade ampliaram a repercussão do assunto no campo popular e no técnico especializado, resultando em um sério questionamento

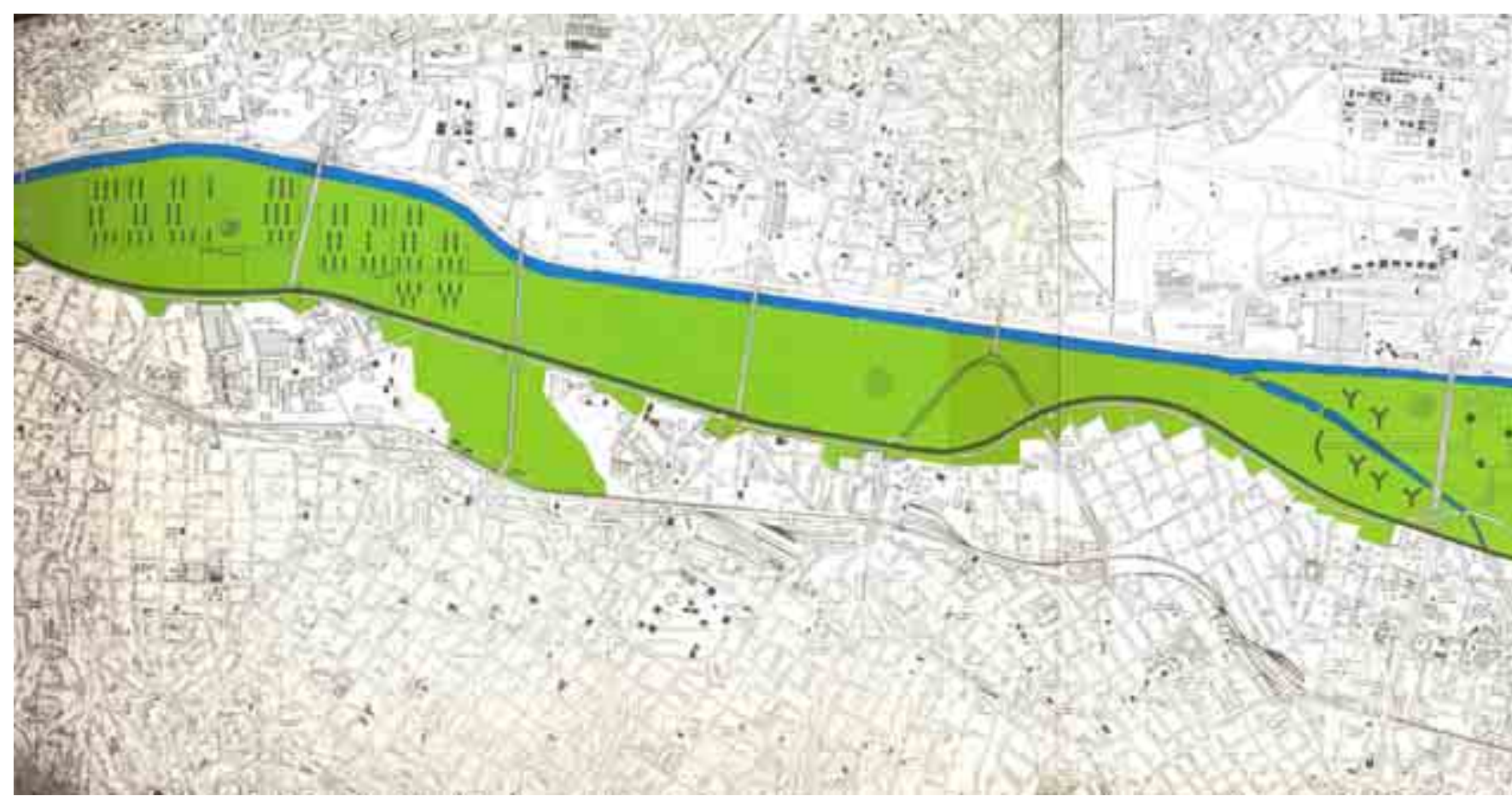

Fig. 229: Implantação da proposta ao longo da Marginal Tietê. 
alternativas consistentes para o conjunto da área e sua viabilização, já que a mais recente proposta (1984) havia sido retirada da Câmara pelo executivo e vigorava o PDDI de 1972, incapaz de responder a esse tipo de proposição. Nesse sentido, Jorge Wilheim, Secretário de Planejamento em cuja gestão foi formulada a mencionada proposta de Plano, também mencionou os estudos que haviam sido realizados para a Várzea da Barra Funda, então prestes a receber o novo terminal do Metrô, e que não foram considerados no Parque do Tietê (ibidem, 87).

- Uma segunda consideração se relaciona à área urbana então abarcada pela renovação urbana incluída no mencionado projeto. Nos bairros do Bom Retiro, Ponte Pequena, Canindé e Parí, os limites do Parque se ampliavam para abrigar - Centro Cívico, incorporando o parque existente na foz do Tamanduateí, onde se situava o Estádio Municipal de Beisebol, no primeiro bairro, passando pela Praça Armênia, na Ponte Pequena, Ginásio da Polícia Militar e rua Itaquí, no Canindé, rua Rio Bonito no Parí, até o seu limite na rua Santa Rita, quando a largura do Parque Tietê diminuia. Nessa altura, a alça da ponte da Vila Guilherme seria deslocada da avenida Carlos de Campos para a rua Silva Telles, uma rua local. Já no bairro do Belenzinho, conectado ao Parí, o Parque chegava até o limite da Vila Maria Zélia. Além disso, como o seu memorial esclarecia, o limite do Parque era percorrido pela nova via expressa estrutural, que substituiria a marginal do Tietê em dois níveis, resolvendo em superfície o fluxo local e em elevado a circulação de passagem.

Todos esses elementos reforçaram a reação de diversos segmentos, desde os moradores do Parí, um dos setores mais atingidos, às categorias profissionais que não entendiam ser esse projeto viável sob o ponto de vista urbanístico e econômico e legítimo sob o ponto de vista social, dado os desdobramentos que o mesmo provocaria na cidade através de uma atuação, que mesmo de grande escala, era pontual e desconectada das demandas urbanas mais gerais da cidade, que incluíam a recuperação do patrimônio construído e priorização para os problemas sociais mais prementes.

Passadas as etapas de apresentação, o projeto do Parque Tietê foi abandonado pelo próprio Prefeito que o havia solicitado e julgado não prioritário pela gestão municipal seguinte. $\bigcirc$ arquiteto Oscar Niemeyer, que mais tarde elaborou o Memorial da América Latina (1989) e o Sambódromo (1992), declarou em matéria jornalística sobre os projetos não realizados em São Paulo, entre eles o Parque do Tietê: "...em São Paulo, três vezes isso ocorreu. Só falta de sensibilidade ou de otimismo pode explicá-lo. E um deles foi a urbanização do rio Tietê. Recordome do empenho com que elaboramos o projeto. A equipe que organizei com colegas dessa cidade. A razão indiscutível que o recomendava: dar a praia que The falta...e o projeto claro, irrecusável que apresentamos. Desviar uma das estradas que acompanham aquele rio, criando a praia artificial tão desejada. Aí 
seriam previstos os equipamentos que o local imaginado exigiria...um grande parque aquático como o que agora projetei para Moscou. Faltou entusiasmo. $\bigcirc$ entusiasmo com que Ciccillo Matarazzo iniciou o Ibirapuera e Octavio Frias iniciou - Copan, com a longa e ondulada fachada de vidro que o caracteriza" (FSP, 12/ $11 / 2001,3)$.

Não se trata de analisar tardiamente a estética dos edifícios propostos ou a importância de uma intervenção para resgatar o rio Tietê para a cidade, mas sim o caráter urbanístico proposto por esse projeto. A citação de Oscar Niemeyer foi incluída para ilustrar esse caráter, o da "arquitetura grande", a prevalência do desenho sobre a cidade real, que conforme afirma Adilson Macedo, "a arquitetura grande como conceito e metodologia é diferente da maneira de ver os espaços segundo uma ordenação orgânica..." (Macedo apud SEDUR 1986, 33). Nesse sentido, é importante a menção também feita por Niemeyer na apresentação do projeto do Parque, deste se constituir em "uma obra que representaria para São Paulo mais do que representou para o Rio de Janeiro a abertura da Avenida Rio Branco - julgada por Le Corbusier, da maior importância, entusiasmado com a coragem e o discernimento de Pereira Passos, que a construiu" (Niemeyer et alli, 1986, s/pág.) 


\subsection{Maharishi Tower}

Na metade do ano de 1999, foi divulgada a surpreendente notícia da construção do edifício mais alto do mundo, que seria implantado numa área situada entre - Brás, Luz e Parí. Apresentado pelos empreendedores e pela Prefeitura simultaneamente, o prédio seria produto do grupo Brasilinvest junto com o Maharishi Global Development Fund (MGDF), fundo internacional de investimentos imobiliários, de Nova lorque, que financiaria em US\$1,65 bilhões essa obra. (FSP, 8/6/1999, 3-6). Segundo os investidores, o prédio teria 108 andares e 494 metros de altura, superando a Petronas Tower, na Malásia, que registrava 452 metros. Na tentativa de "abrasileirar" o nome do edifício, esse passou a ser denominado de "São Paulo Tower", e segundo o representante desse empreendimento, o objetivo do projeto era "fazer com que a cidade concretize finalmente a sua vocação de cidade global e centro mais importante de negócios da América Latina" (Garneiro in OESP 03/6/1999, D1 1).

Ao contrário do Parque do Tietê, em que a equipe liderada por Niemeyer produziu na ocasião um estudo preliminar de implantação, não foi apresentado nenhum elemento mais concreto do mega-edifício, apenas divulgada uma simulação de sua implantação e volumetria por maquete eletrônica. Todo o debate sobre o mesmo transcorreu sem um único documento técnico, seja dos seus empreendedores, seja da Prefeitura que abraçou a proposta, pois apenas foram utilizadas as informações divulgadas por jornais e revistas. $\bigcirc$ projeto foi desenvolvido nos Estados Unidos pelo arquiteto Minori Yamasaki ${ }^{3}$, o mesmo autor do Word Trade Center de Nova lorque. Sua concepção baseava-se na arquitetura védica, incorporando elementos da cultura hindu e a edificação piramidal era composta da junção de quatro torres que seriam separadas por um vazio interno e divididas em seis blocos de 15 andares cada um. Previa-se uma circulação diária de 80 mil pessoas e 25 mil automóveis (Veja, novembro 1999).

O componente de marketing urbanístico representado pelo gigantismo do edifico fez com que sua altura fosse aumentada para superar os 508 metros do International Financial Center em Taiwan, que seria concluído em 2002, vencendoo por 2 metros para se constituir no prédio mais alto do mundo quando fosse finalizado em 2005. Sua implantação exigiria uma base de 7,5 hectares e seria feita num parque de um milhão de metros quadrados (Super, março 2000, 57). Descontados os quase 100 metros de diferença entre as cotas do Parque Dom Pedro II e da avenida Paulista, o mega-edifício seria visto nesse local com 410 metros de altura, equivalentes a duas vezes e meio o Edifício ltália (165 metros).

Esse projeto recebeu de pronto o apoio da gestão municipal de então, sendo firmado protocolo de intenções com os empreendedores objetivando uma linha de incentivos para a desapropriação de terrenos, a liberação de avenidas, 
URRANISMO

\section{Ímã de energias cósmicas}

Principios esotéricos da cultura védica indiana orientam a construção.

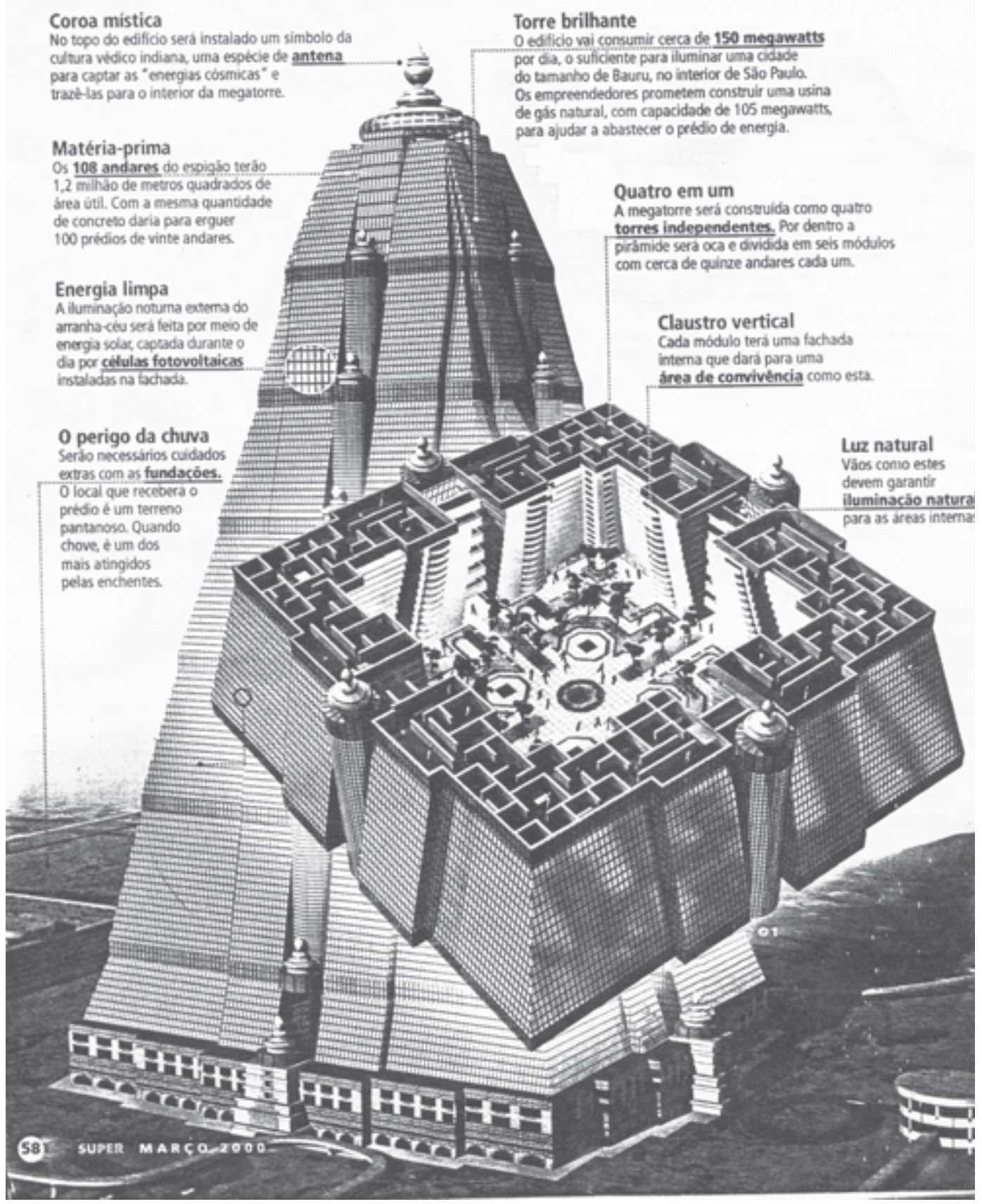

Fig. 230: Progrma - Maharish Tower 
mudanças no parcelamento e no zoneamento (FSP, 8/6/1999,3-6). Conforme o presidente do órgão gestor da área central, o Procentro, afirmou na ocasião "existe na região central, na área em que está prevista a construção do prédio, áreas industriais, pátio ferroviário e galpões abandonados, que, se o proprietário não os renova, a Prefeitura tem o direito de fazer isso, previsto na Lei da Operação Urbana Centro. Isso pode ser feito para um projeto como esse". Mencionou ainda que por se tratar de um projeto com capacidade de reconfigurar a cidade, mudando suas ruas, novas estações de ônibus e Metrô, necessitaria de apoio do governo local, em qualquer parte do mundo onde fosse construído (Fiusa in FSP, 8/6/1999, 3-6).

Após inúmeras contradições sobre o fato da arquitetura do prédio permanecer ou não como Minori Yamasaki havia definido, o que se confirmou, sua implantação foi definida como abrangendo a área compreendida pelas ruas São Caetano, ao norte, avenida Rangel Pestana, ao Sul, Rua Antonio Paes, a oeste e rua Barão de Ladário, ao leste (FSP, 17/10/1999, 3-11. Uma equipe de arquitetos brasileiros ficou a cargo das adaptações necessárias no prédio e da sua implantação ${ }^{4}$ e apesar das dúvidas sobre sua viabilidade, sua realização foi defendida levando em conta os argumentos da reurbanização da área BrásParí, da geração de empregos que o mesmo poderia proporcionar e da arrecadação em impostos à cidade, pois o representante da Brasilinvest previa cerca de 2.200 empregos diretos e 3.200 indiretos (OESP, 03/6/1999, D1 1) e a geração de 15 milhões de reais de IPTU por ano (Garnero in FSP, 17/10/1999, 3-11).

Vista como uma região que apresentava decadência e deterioração, a área da implantação correspondia exatamente à da Zona Cerealista. Seu entorno contaria com um monotrilho, sendo prevista ainda uma linha de Metrô na rua São Caetano e uma ligação dessa área com o Aeroporto Internacional de Cumbica também por trilhos. A construção de um anel viário de acesso ao prédio, com um custo estimado em R\$378 milhões também estaria a cargo dos empreendedores. Apesar do gigantismo da renovação urbana e da sua arquitetura totalmente estranha aos parâmetros culturais e paisagísticos da cidade, o Maharishi Tower contou com apoios importantes, que incluíram os do arquiteto Oscar Niemeyer e da Associação Viva o Centro, entidade envolvida com a recuperação do Centro (FSP, 17/10/1999, 3-11).

Entretanto as críticas ao empreendimento voltavam-se aos riscos envolvidos numa operação de tal magnitude, a mutilação de uma importante área da cidade, o isolamento da torre em meio ao parque previsto, a sua incompatibilidade arquitetônica, etc. Como no projeto do Parque do Tietê, uma parcela da população mostrou-se refratária à proposição, a dos antigos moradores dos bairros atingidos, receosos da transferência para outras localizações mais distantes e em apartamentos pequenos. 


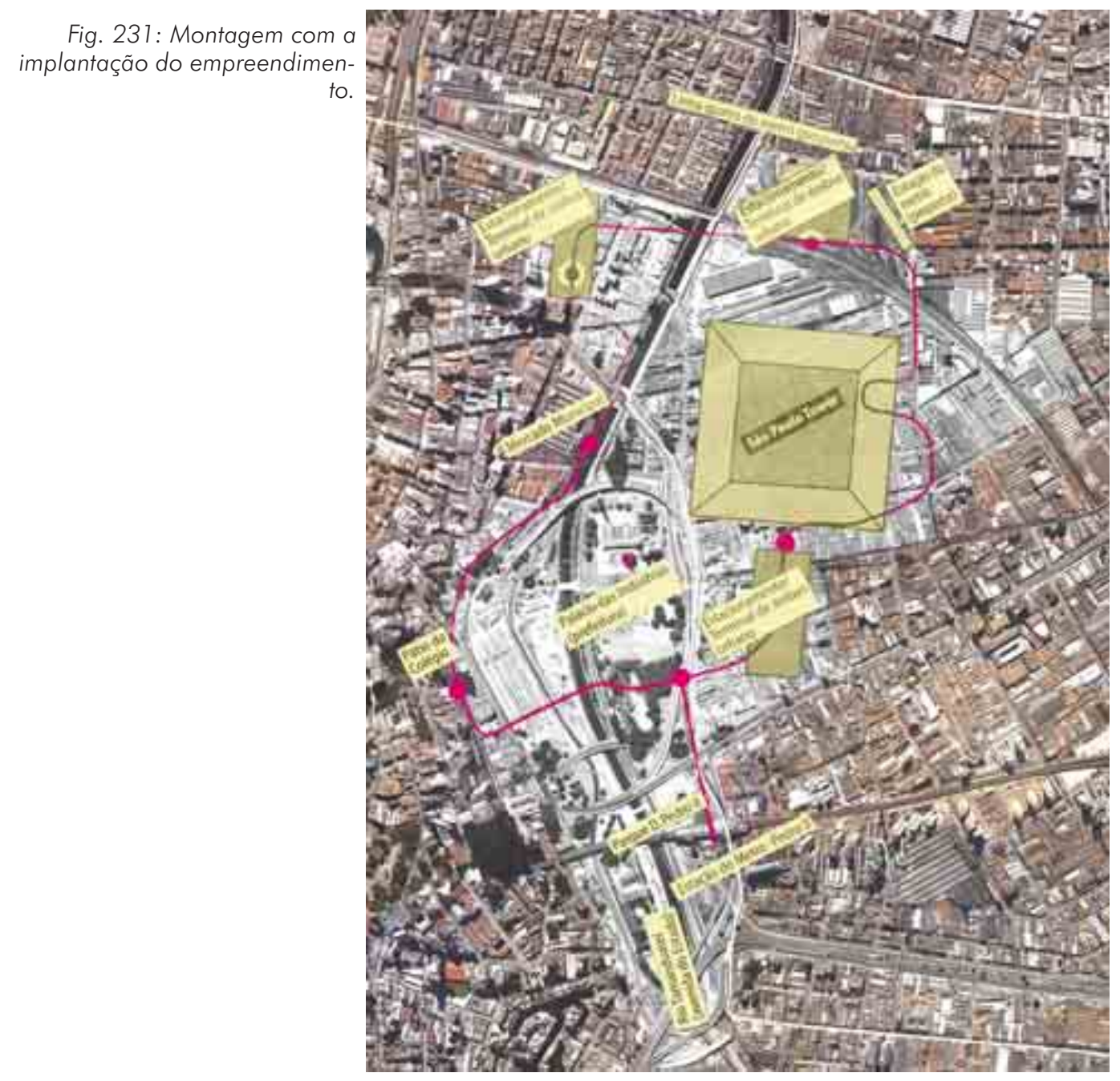

A localização do edifício e a utilização dos instrumentos previstos na Operação Urbana Centro para um único empreendimento também se constituíram em uma polêmica: o presidente do Procentro mencionou ter sido o local de implantação uma das condições da gestão municipal para a construção da torre com seu apoio e incentivo. Nas suas palavras "o interesse era que ficasse em uma área que estivesse em processo de degradação e não em uma área já congestionada de prédios" (Fiusa in FSP, 8/6/1999, 3-6). Ocorre que uma realização de tal envergadura, baseada na reconfiguração radical do território, só poderia ser viabilizada com incentivos urbanísticos, mas o valor do solo urbano se constituía em um claro impeditivo para a construção do mega-edifício na área das Operações Urbanas então em curso, na avenida Faria Lima e na Água Branca.

Configurou-se um cenário em que a especulação imobiliária se mostrou um elemento presente na realização dos objetivos do grupo associado americano- 
brasileiro responsável pelo empreendimento: o seu lançamento em São Paulo ocorreu após a recusa de Miami e de uma cidade da Holanda em aceitarem o projeto (Super, 2000, 61) e a sua localização na região Brás-Parí implicava em incorporar um valor do solo bastante depreciado em relação a outras áreas mais valorizadas da cidade e que contava ainda com áreas públicas, como o Pátio do Parí. Além disso, a região era estratégica do ponto de vista da localização: servida por transporte ferroviário e do Metrô, que previa na época a extensão da Linha 4 para o Brás, passando pela rua São Caetano, proximidade da Marginal do Tietê e com acesso ao Aeroporto Internacional.

Em maio de 2000, no mesmo dia em que o Prefeito foi afastado por medida judicial, o grupo brasileiro anunciou sua intenção de retirar o projeto para aprovação, visando apresentá-lo na gestão municipal seguinte, por discordar da demora no envio do projeto para a Câmara Municipal e da exigência de um depósito de 1,65 bilhões de dólares como garantia de realização do mesmo (JT, 29/5/2000). Na realidade, nada fazia crer que a megatorre teria as facilidades urbanísticas e políticas apontadas quando de seu anúncio, devido ao tempo necessário para executar todas as desapropriações, a incorporação de áreas públicas como as vias de circulação ou o Pátio do Parí, de propriedade federal, as transformações necessárias na infra-estrutura existente, etc. Na prática, o projeto foi abandonado, já que a gestão municipal que assumiu a cidade a partir de 2001 adotou outros caminhos para o tratamento das áreas urbanas de São Paulo com os problemas que a região do Brás-Parí apresentava, para a qual havia sido proposto simplesmente o seu parcial desaparecimento com a construção daquele que seria o maior edifício do mundo.

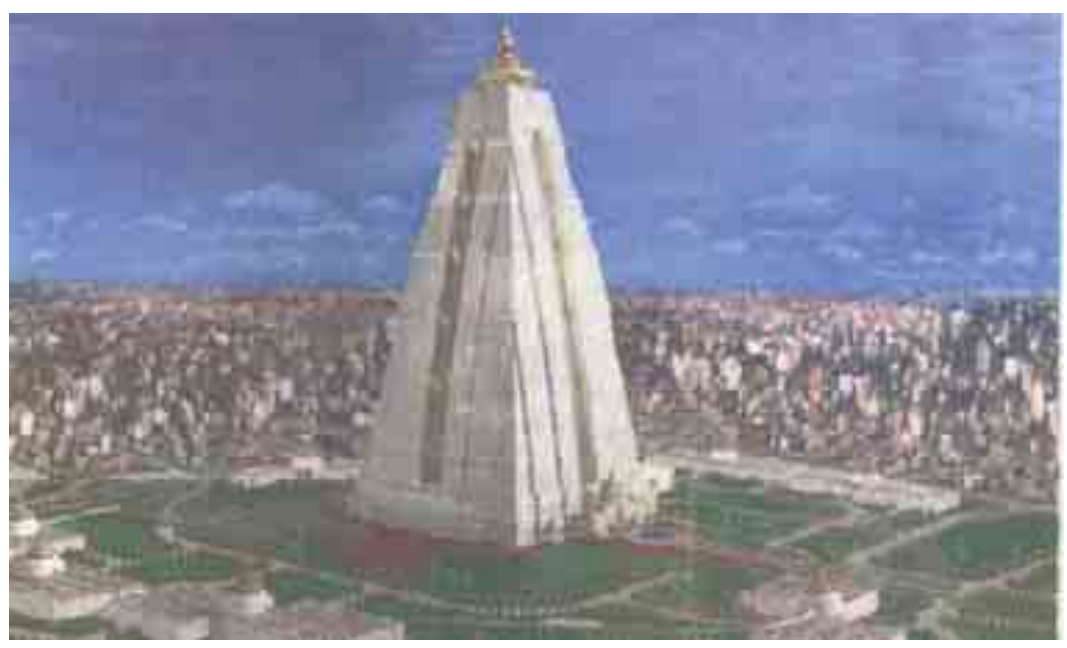




\section{3 - Breves comentários sobre os projetos Parque do Tietê e Maharishi Tower}

Com o objetivo de examinar a concepções das propostas urbanas direcionadas aos bairros pesquisados, foram relacionadas aquelas que maior divulgação tiveram nas décadas de 1980 e 1990, por caracterizarem uma prática de renovação urbana radical, implicando na destruição de grandes extensões do tecido urbano do território enfocado. Ambas propostas provocaram polêmicas pelo gigantismo da escala de intervenção, característica típica das "cirurgias urbanas" apregoadas no período posterior à II Guerra Mundial e que visaram a substituição dos espaços das cidades considerados anômalos por outros funcionalmente e formalmente adequados à novas funções.

Foram incluídos nesse rol de intervenções dois projetos: o Parque Tietê, de 1986 e o "Maharishi Tower", de 1999. Inicialmente pode-se dizer que, apesar da escala (urbana), foram concebidos como o próprio termo designa: projetos. As diferentes linguagens da arquitetura proposta por cada um, convergem para $\circ$ ponto comum da renovação total de espaços dos bairros aqui pesquisados, como se os mesmos não tivessem nenhuma importância na história da cidade e para a vida de seus próprios habitantes.

A semelhança desse aspecto não pode ser confundida, porém, com a mesma inserção junto ao mercado imobiliário: enquanto que o Parque do Tietê foi justificado por um discurso poético e técnico, o "Maharishi Tower" o fez direta e pragmaticamente, sem intermediação entre a megatorre do capitalismo globalizado e sua implantação local, que exigia a eliminação do existente em seu entorno. $O$ primeiro, não reconheceu os mecanismos e interesses (ocultos ou não) presentes em um corte de centenas de quadras ao longo do Tietê, nem como viabilizar financeiramente a operação, nem como evitar a apropriação pelo mercado imobiliário dos investimentos públicos. O segundo viabilizar-se-ia através da compra pura e simples do território, conforme os empreendedores anunciaram e da utilização dos instrumentos da Operação Urbana Centro, conforme os integrantes da gestão municipal daquela época confirmaram.

Em parte pelo seu gigantismo, em parte pelo caráter autoritário de sua proposição, ambos os projetos foram inviabilizados. Para os objetivos deste trabalho, foram analisados primeiro como um registro das propostas dirigidas ao Bom Retiro, Brás e Pari e como um contraponto à ações que possibilitam a permanência da identidade morfológica, associada também à recuperação das funções de moradia e trabalho da população. Entretanto, não se mostra distante o paralelo entre essas duas propostas e os resultados que as operações urbanas podem desencadear na cidade se não forem definidos os parâmetros de limitação para as forças atuantes na configuração do espaço urbano, figurando entre as principais, o mercado imobiliário. 


\section{Notas:}

${ }^{1} \mathrm{O}$ projeto foi desenvolvido em 1986 na EMURB por uma equipe de arquitetos convidados por Oscar Niemeyer: Hélio Pasta, Hélio Penteado, Júlio Katinsky, Ruy Otake e Walter Makhol..

${ }^{2}$ O Instituto de Arquitetos do Brasil-SP e o Sindicato de Arquitetos de São Paulo divulgaram publicamente sua posição crítica ao projeto do Parque do Tietê e à forma como foi proposto. Além de matérias jornalísticas, as notas dos dois órgãos foram registradas na referência bibliográfica mencionada no texto.

${ }^{3}$ Além do projeto das torres gêmeas de Nova Iorque, destruídas no atentado terrorista de 11 de setembro de 2001, o arquiteto Minori Yamasaki projetou na década de 1950 o conjunto de PruittIgoe, que foi implodido em 15 de julho de 1972, fixando segundo Charles Jenks, a morte do Movimento Moderno de Arquitetura (Arantes, 1995, 49).

${ }^{4}$ Alcindo Dell' Agnese, Benedito Abud, Cândido Malta Campos Filho, Edo Rocha. (FSP, 17/10/ 1999, 3-11) 


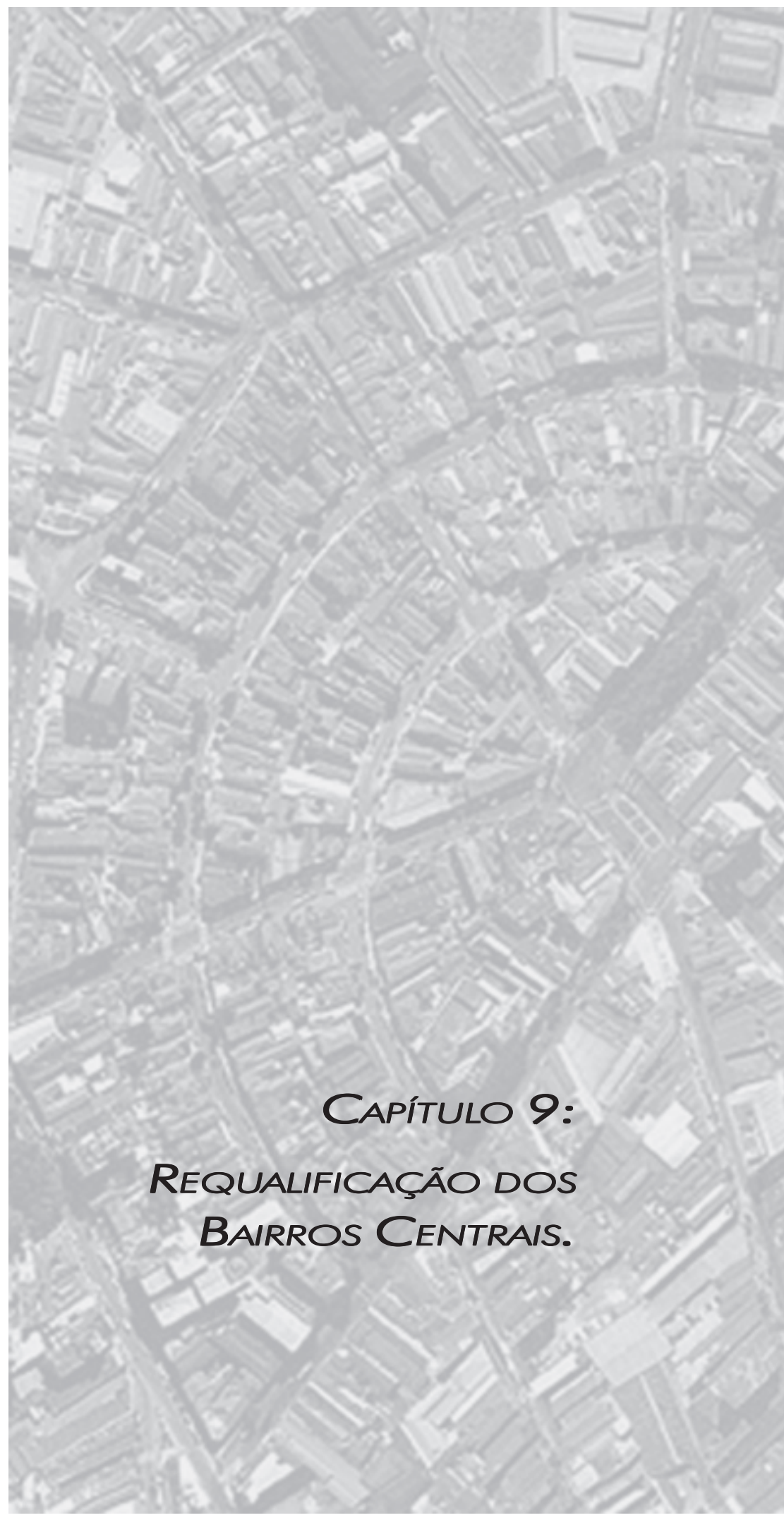




\section{9 - Requalificação dos Bairros Centrais}

Os planos, programas e projetos relacionados a seguir foram propostos dentro do âmbito do poder público municipal a partir de 2001 e consideraram como diretriz principal a valorização dos bairros centrais em suas dimensões morfológicas e funcionais, contemplando também a necessidade de adensamento populacional nessas áreas providas de infra-estrutura, transportes, equipamentos de saúde, educação e lazer. Nesse sentido, foram também relacionadas as ações do órgão estadual responsável pela produção de habitação nas faixas social e econômica, que incidiram nos bairros aqui pesquisados.

Foram caracterizados três eixos para sintetizar as atuações urbanísticas:

- Projetos de redesenho de espaços públicos

- Programas habitacionais

- Planos urbanos: Plano Diretor Estratégico e Planos Regionais 


\section{1 - Programa Reconstruir o Centro}

Diferentemente dos projetos que propuseram a renovação urbana dos bairros centrais, em maio de 2001 o "Plano Reconstruir o Centro" foi desenvolvido pelo poder público municipal para, através de políticas urbanas integradas, reverter as tendências que o centro e os bairros que o circundam apresentaram nas últimas décadas. As estratégias definidas por esse Programa foram:

- O resgate do caráter público do espaço público

- A ampliação do uso residencial e garantia à diversidade de funções

- Consolidação da identidade do centro metropolitano

- Promoção de ações urbanísticas com inclusão social

- Criação de mecanismos de gestão democrática, voltados para o interesse coletivo

(AR-SÉ/Procentro/PMSP, 2001,20)

Esse Plano analisou os seguintes aspectos: Território, Patrimônio, Acessibilidade, Diversidade funcional e social, Moradia e Trabalho.

Fizeram parte do Plano, propostas reunidas nas categorias: eixos de requalificação da paisagem urbana, projetos paisagísticos específicos e programas de habitação:

\section{Eixos de requalificação da paisagem urbana}

Para os bairros centrais enfocados neste trabalho, foram definidas as seguintes atuações

- Av. Carlos de Campos / Rua Oriente/ Rua Barão de Ladário: distritos Pari e Brás - eixo de ligação entre os distritos Pari e Brás. Implantação de projeto paisagístico nas vias, valorização das praças e espaços públicos e apoio ao centro comercial do Brás.

- Rua Três Rios e Praça Coronel Fernando Prestes: distrito Bom Retiro: projeto de requalificação paisagística da Praça, estendendo esses padrões para o eixo da rua Três Rios, onde, além dos estabelecimentos comerciais, estão instalados o Teatro TAIB, a Oficina Cultural Oswald de Andrade e o Colégio Santa Inês.

2. Projetos paisagísticos específicos

- Orla ferroviária e Pátio do Pari:

- Parque Dom Pedro II:

- Projeto para a rua 25 de Março

- Projeto para o Mercado Municipal, seu entorno e consolidação de pólo gastronômico 
- Zona cerealista: transferência das atividades atacadistas e utilização de áreas ocupadas por galpões, para fins habitacionais, incluindo a possibilidade de novos espaços públicos.

\section{Morar no Centro}

Contribuir para o repovoamento da área central, viabilizar moradia para a população de baixa renda no centro e nos bairros vizinhos, reabilitar edifícios desocupados para uso habitacional e melhorar a qualidade de vida dos moradores do centro (AR-SÉ/Procentro/PMSP, 2001, 29).

O programa previa as seguintes atuações

- Produção de novas unidades habitacionais, através da construção de edifícios ou reforma e reciclagem de prédios vazios.

- Perímetros de reabilitação integrada do habitat - PRIH: intervenção integrada em conjunto de quadras com concentração de moradias precárias, havendo novas construções para habitação social, melhoria das condições dos cortiços, reabilitação do patrimônio, criação ou melhoria de espaços para atividades econômicas e das áreas verdes e equipamentos.

- Implantação do sistema de locação social, com valores compatíveis com os salários dos locatários

- Viabilização de soluções habitacionais específicas para moradores de rua, casa de abrigo de mulheres e idosos.

- Projeto habitacional para os moradores da Favela do Gato, situada na Marginal Tietê, integrada com o parque e centro esportivo do Estádio Municipal de baseball.

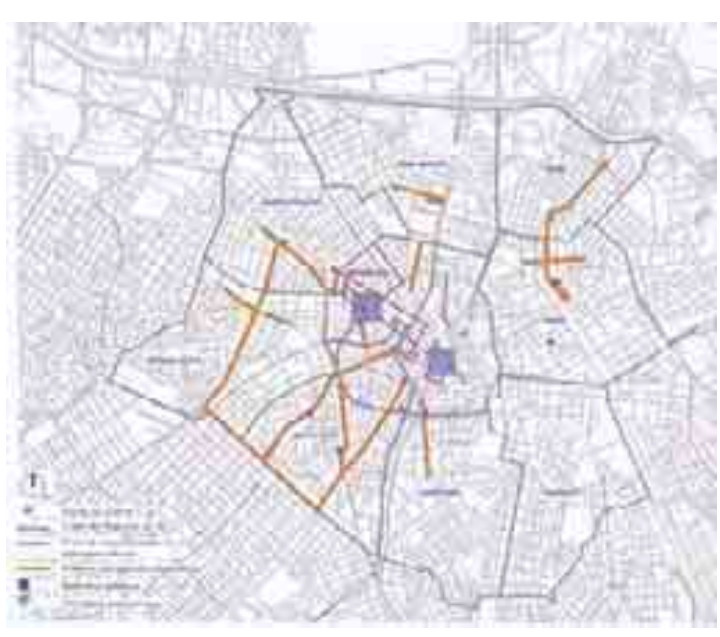

Fig. 233: Mapa esquemático, Programa Reconstruir o Centro, 2001.
Em 2002, o Plano Reconstruir o Centro se tornou referência para os projetos enviados ao Banco Interamericano de Desenvolvimento - BID, visando a obtenção de financiamento para sua execução. O montante desse financiamento, que superava a quantia de US $\$ 100$ milhões, contava ainda com a contrapartida municipal. Entretanto, por exigência dessa instituição, os programas e projetos, restringiramse ao centro, excluindo as demais propostas voltadas aos bairros centrais, que ficaram sob o encargo da Sub-prefeitura Sé. 


\subsection{Projetos nos Bairros Brás, Parí e Bom Retiro}

No ano de 2002, foram propostas ações para locais nos bairros do Brás, Pari e Bom Retiro. No primeiro foram desenvolvidos projetos paisagísticos para a Praça Torquato Neto e um projeto preliminar para a praça Benemérito José Brás, debatido junto à população moradora e usuária do local. No distrito do Pari, foi implantado novo projeto para Largo Padre Bento, que deveria se conectar ao da avenida Carlos de Campos e ao Centro de Apoio Integral ao Idoso, na extremidade dessa via. No Bom Retiro foi desenvolvido o Projeto de Habitação Social para a Favela do Gato, integrado ao de requalificação do parque público existente nessa área.

\section{Praça Torquato Neto}

Área anexa à Praça Benemérito José Brás, de menores dimensões (aproximadamente $5.000 \mathrm{~m}^{2}$ ) e com a mesma interferência da linha aérea do metrô Leste-Oeste. Esse espaço também recebeu um projeto de requalificação no início da década de 1990, logo após a que ocorreu na praça maior. No início de 2002, foi implantado novo projeto paisagístico' ${ }^{1}$, contemplando as solicitações de moradores e entidades com sede nas imediações. No entorno dessa praça encontram-se várias torres residenciais da $\mathrm{COHAB}$, sendo a mesma utilizada pelos moradores dos edifícios, principalmente os jovens. Conta com rampa de skate e quadra de futebol e a maior parte de sua área não se encontra impermeabilizada, como no caso da praça José Brás.

O projeto buscou adequar os equipamentos e principalmente valorizar paisagísticamente um espaço um tanto confinado nas sobras de quadras entre as tradicionais ruas do Brás, Caetano Pinto e Carneiro Leão.

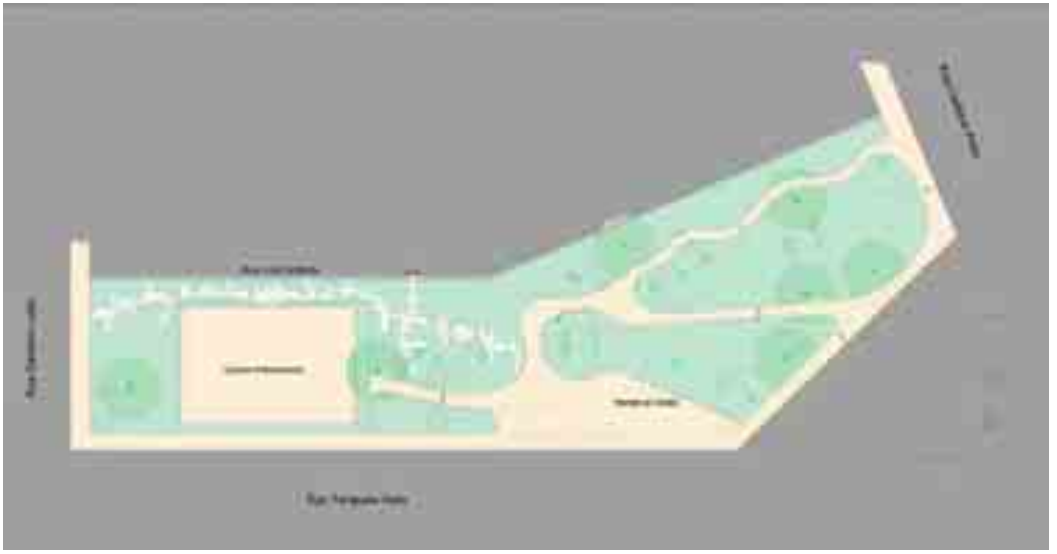

Fig. 234: Projeto para Praça Torquato Neto. 


\section{Largo Padre Bento}

Assim como as propostas e projetos no Brás, esta intervenção foi executada pela Subprefeitura Sé antes do distrito Pari ser integrante da Subprefeitura Moóca. Esse projeto ${ }^{2}$ faria parte de uma intervenção que buscava articular espaços públicos existentes ao longo da ligação Pari-Brás, através da implantação de melhores padrões paisagísticos para a Praça llo Ottoni, avenida Carlos de Campos, Largo Eduardo Rudge, Largo Padre Bento e Largo da Concórdia, proposto pelo Plano Reconstruir o Centro, intervenção essa que ocorreu apenas no local aqui mencionado.

Definido urbanisticamente pelas vias que interligam os bairros Pari e Brás, o Largo Padre Bento se constitui em uma centralidade local da maior importância, tanto pelo seu caráter histórico, quanto paisagístico e funcional. $\bigcirc$ seu formato triangular é dominado, em um dos lados, pela escala monumental da igreja Santo Antônio do Pari, construída em 1922, e seus outros lados ocupados por pequeno comércio e super-mercado. Em sua proximidade existem residências e edifícios habitacionais de gabarito médio, sendo para eles um espaço de lazer e descanso bastante raro, devido a intensa ocupação do bairro.

O Largo é apropriado por moradores da região de diversas faixas etárias. Diariamente são utilizadas mesas para jogos pela terceira idade e espaços de recreação para crianças e adolescentes. Eventualmente o espaço serve de local para quermesses e uma feira de produtos alimentícios bolivianos, que ocorria aos domingos à noite e ali permaneceu por algum tempo, foi transferida para outra localidade do bairro, já que na região é grande a presença da colônia boliviana, mas no Largo essa atividade se mostrou inapropriada.

A intervenção consistiv em recuperar as qualidades paisagísticas do local, através da demolição das barreiras causadas por canteiros altos e inadequados,

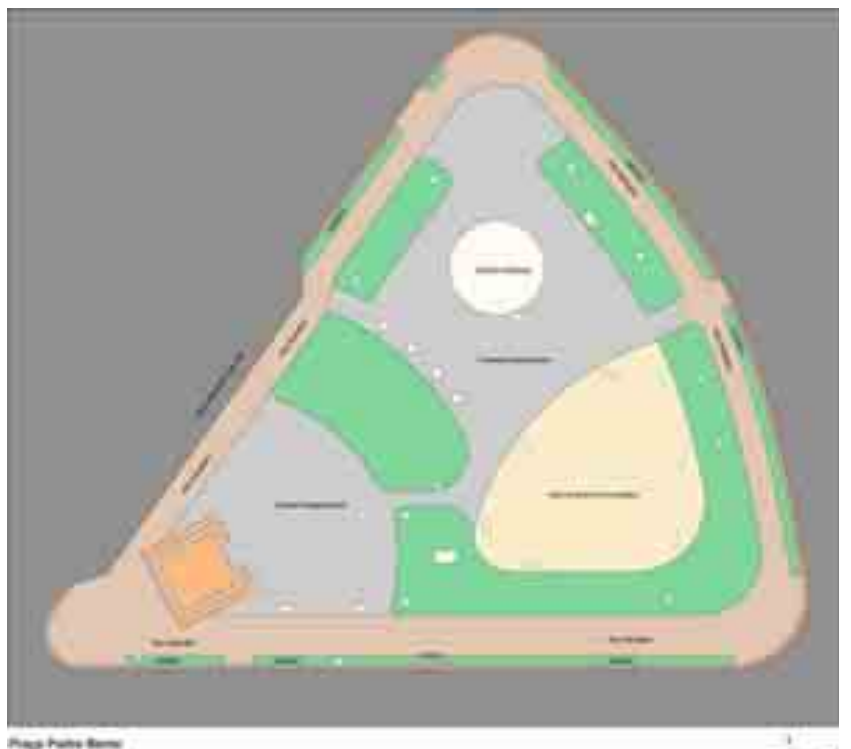

Fig. 235: Projeto para Praça Padre Bento. substituição do mobiliário, melhoria da iluminação pública, construção de baia para táxi, tratamento fito-sanitário, substituição do piso e aumento da área permeável. Buscouse também a valorização do conjunto escultórico implantado em um dos vértices do espaço, que se constitui em uma importante referência urbana do bairro. 


\subsection{Propostas do Programa Habitação no Centro - PMSP}

As propostas que se seguem, situadas nos bairros do Pari, Brás e Bom Retiro, fizeram parte do programa que a Prefeitura de São Paulo desenvolveu para a área central da cidade, considerando aí também os bairros que o circundam. Os estudos tiveram início em 2001 e os projetos foram debatidos por setores da administração pública e da sociedade civil, sendo considerados também os meios de viabilização para os mesmos, uma vez que se mostrava impossível atender a demanda existente com os recursos orçamentários de uma gestão municipal.

Esse Programa partiu da premissa que a cidade de São Paulo sofreu historicamente um processo de expulsão da população de baixa renda para as áreas periféricas e de esvaziamento dos espaços mais centrais, próximos a oferta de empregos e dotados de equipamentos sociais e infra-estrutura. Entretanto, para as faixas de renda média, média/baixa e baixa, o Centro apresenta uma alternativa concreta para a produção de unidades habitacionais pelos seguintes motivos:

. Alguns bairros centrais em que o Programa incide não estão no foco de interesses do mercado imobiliário para a produção de apartamentos de luxo ou de edifícios de escritórios.

. Apresentam disponibilidade de áreas livres e possibilidade de reforma de edifícios residenciais e comerciais para habitação social

. É a região da cidade melhor servida pelo transporte.

Apesar desses aspectos vantajosos para a localização de habitação social na área central e bairros circunvizinhos, esse estudo demonstrou que desde 1995 as cooperativas autofinanciadas, que atuam no mercado residencial da Grande São Paulo, não construíram nessa área pelo alto valor dos terrenos existentes.

Um reflexo dessa situação, que alia o esvaziamento do uso habitacional nos bairros e área central e alto preço do solo urbano, é a grande incidência de cortiços. Ainda em 1993, segundo dados da FIPE, o anel de bairros que circunda o centro abrigava 20\% da população encortiçada de São Paulo. O Programa desenvolvido pela Prefeitura analisou que essa população pagava valores muito altos de aluguel para morar em péssimas condições, sendo que uma parte dela poderia arcar com programas de locação social e outra parte em programas de aquisição de unidades.

Utilizando recursos dos agentes habitacionais públicos e privados (Caixa Econômica Federal, CDHU, Fundo Municipal de Habitação e cooperativas) a atuação do Programa de Habitação de Interesse Social foi focado nas seguintes modalidades:

- Intervenções em terrenos ou edifícios isolados: buscando oferecer solução habitacional através da produção de novas unidades ou reforma e reciclagem 
de edifícios existentes, visando também a recuperação física e funcional de quadras abandonadas ou sub-utilizadas.

- Perímetros de reabilitação integrada do habitat (PRIH): objetivando intervenção em áreas dos bairros centrais que apresentam quadras deterioradas com a incidência de cortiços. A produção habitacional nesses casos se dará conjuntamente com a criação e requalificação de equipamentos, ampliação de áreas verdes, melhoria das condições de cortiços e reabilitação do patrimônio.

De maneira complementar a essas modalidades, foi estudado ainda um programa público de locação social, compatível com as necessidades familiares e com a capacidade de pagamento da população usuária. Esse sistema, para famílias com renda até 6 salários mínimos, fez parte do convênio entre a Prefeitura e a Caixa Econômica Federal através do Programa de Arrendamento Residencial PAR, que previu a reforma ou construção de imóveis residenciais ou comerciais para fins de moradia e seu arrendamento com opção de compra após 15 anos.

A ampliação dessa modalidade, que se constitui na solução básica das políticas habitacionais européias há décadas, além de interferir nos preços de aluguéis praticados pelos proprietários de cortiços, contemplou os seguintes aspectos:

- O percentual de domicílios alugados na área e bairros centrais é bastante superior ao de outros bairros

- Grande concentração de cortiços que atende população com menor renda ou sem condições de comprová-la

. Existência de reivindicação por parte dos movimentos sociais por moradia, para que seja viabilizado (SEHAB, 2001,4). 


\subsubsection{Programa de Reabilitação Integrada do Habitat - PRIH}

Esse programa foi desenvolvido pela Secretaria da Habitação da Prefeitura de São Paulo e objetivou uma atuação voltada à habitação social em áreas dos bairros centrais juntamente com a revitalização urbana do entorno, já que os locais onde a incidência de cortiços foi verificada, apresentavam também parte de sua estrutura física deteriorada, como é o caso de partes do Glicério, Brás, Parí, Canindé, Moóca, Bexiga, etc.

Os seus objetivos foram assim definidos:

- Valorização das potencialidades do bairro e da comunidade como protagonistas das transformações urbanas

- Promoção e mobilização de grupos visando a sua organização e o exercício da cidadania

- Inclusão social da população de baixa renda e melhoria das condições habitacionais.

Os programas foram desenvolvidos tendo como base levantamentos físicoambientais detalhados por um "escritório-antena", que pesquisou o número de cortiços, moradias precárias, imóveis ociosos ou de interesse de preservação, oportunidades imobiliárias, assim como as características paisagísticas e ambientais dos espaços livres (PMSP/SEHAB, março de 2004).

A pesquisa dos perímetros 1, 2 e 3, referentes ao setor que reúne os bairros Luz, Brás e Parí, foi desenvolvida por uma assessoria contratada pela Secretaria Municipal de Habitação e COHAB ${ }^{3}$. Esse trabalho foi iniciado em 2001 e concluído em 2002.

\section{Perímetro 1}

O Perímetro 1 foi delimitado pela Av. Tiradentes, Rua João Teodoro, Rua da Cantareira, Rua Mauá (linha do trem) até a Av. Tiradentes novamente. Corresponde à área de transição Luz-Parí e encontra-se dentro da Operação Urbana Diagonal Sul.

\section{Levantamento da área}

Número de quadras: 22

Área aproximada: 22,23 ha

Uso predominante: comercial/ residencial

Resumo de Usos: residencial/cortiços - 81 unidades

Serviços públicos: 5 Imóveis

Oportunidades na área: $29.157 \mathrm{~m}^{2}$

Unidades Novas - 979 unidades

Unidades Reabilitadas (reforma de cortiços) - 324 unidades 
Total de Unidades - 1296 unidades

Imóveis tombados -Vila Residencial (V.Economizadora - 6 quadras) e Igreja Percentual da área verde existente: $0 \%$

Problemática da área: Esse perímetro se caracterizou pela presença de galpões de fábricas, terrenos e estacionamentos na Rua 25 de Janeiro, além do cortiço da "Vilinha" da rua 25 de Janeiro. Nele se incluíam cerca de 56 cortiços nas Ruas João Teodoro, Dutra Rodrigues, Dialma Dutra, Dom Antonio de Melo, Guilherme Maw, Rua da Cantareira, Francisco Sá Barbosa, Pedro Álvares Cabral. A área apresentava ainda diversos terrenos de propriedade da Cúria Metropolitana de São Paulo, passíveis de serem utilizados em futuros projetos.

A grande concentração de cortiços, a presença de imóveis indicando oportunidades imobiliárias e a existência de entidades prestadoras de serviços públicos e comunitários indicavam ter o Perímetro 1 grande potencial para requalificação integrada.

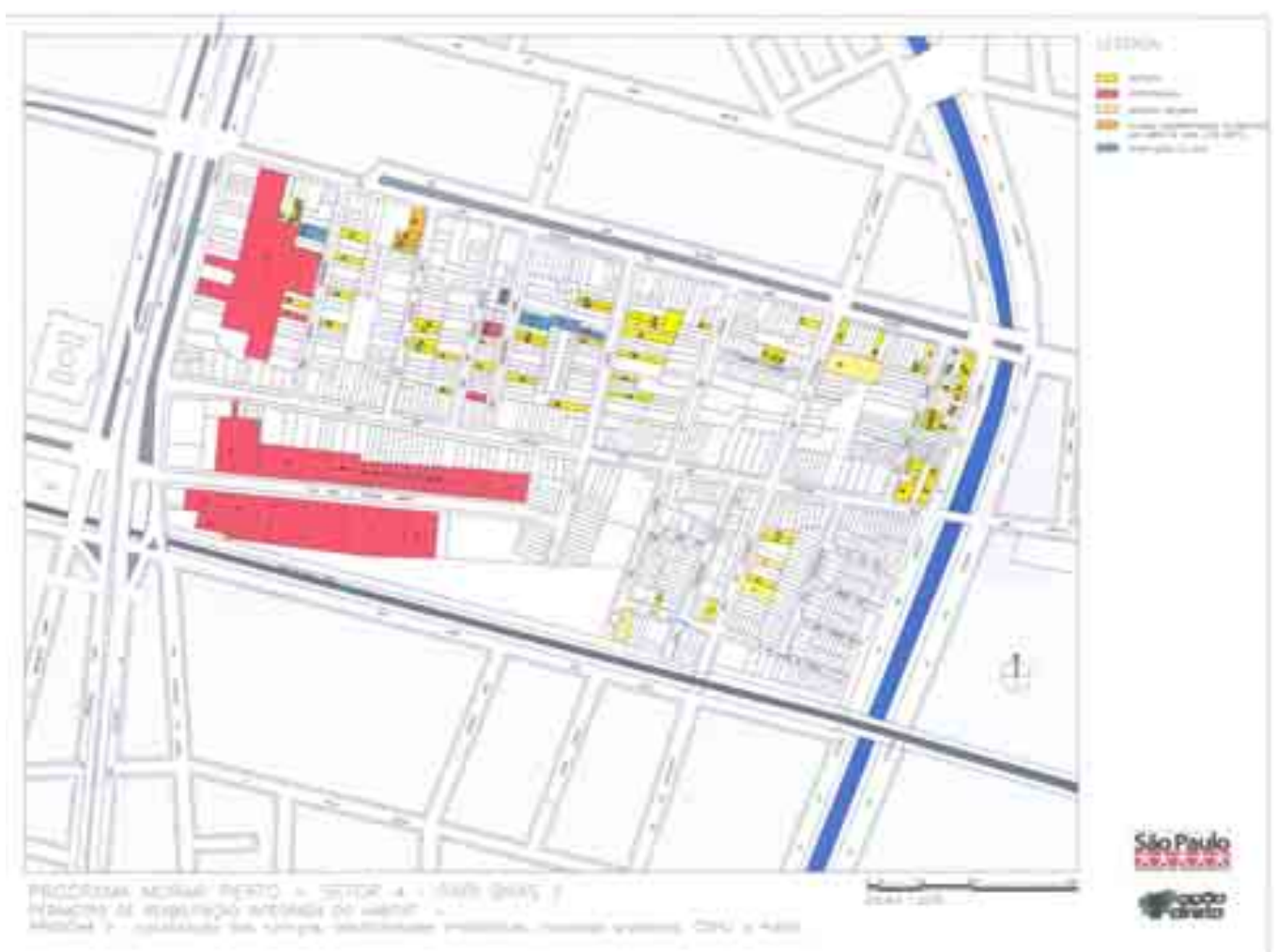

Fig. 236: PRIH, perímetro 1.

\section{Perímetro 2}

O Perímetro 2 situou-se no bairro do Canindé e se incluía dentro da Operação Urbana Diagonal Sul. Foi delimitado pela Av. do Estado, Av. Cruzeiro do Sul, 
Rua Vidal de Negreiros, Rua Conselheiro Dantas, Rua Carnot, Rua Alexandrino Pedroso, Rua Thiers, Rua João Teodoro, Rua Monsenhor Andrade, Rua São Caetano até avenida do Estado.

Levantamento da área

Número de quadras: 20

Área aproximada: 28,90 ha

Cortiços - 73 unidades

Uso misto: residencial-comercial

Percentual de áreas vazias: 0,49\% (área $1.443 \mathrm{~m}^{2}$ )

Serviços públicos: 2 imóveis

Oportunidades na área: $44.805 \mathrm{~m}^{2}$

Número aproximado de habitação para serem produzidas:

Unidades Novas - 1494 unidades

Unidades Reabilitadas - 300 unidades

Total de Unidades - 1794 unidades

Imóveis tombados - Patrimônio: não há

Percentual da área verde existente: 0\%

Problemática da área: o Perímetro 2 caracterizou-se pela presença de grande número de cortiços com tipologias variadas: edificações de 2 pavimentos com presença de comércio no pavimento térreo e cortiço no pavimento superior, cortiços tipo casa isolada com entrada independente e cortiços de quintal com

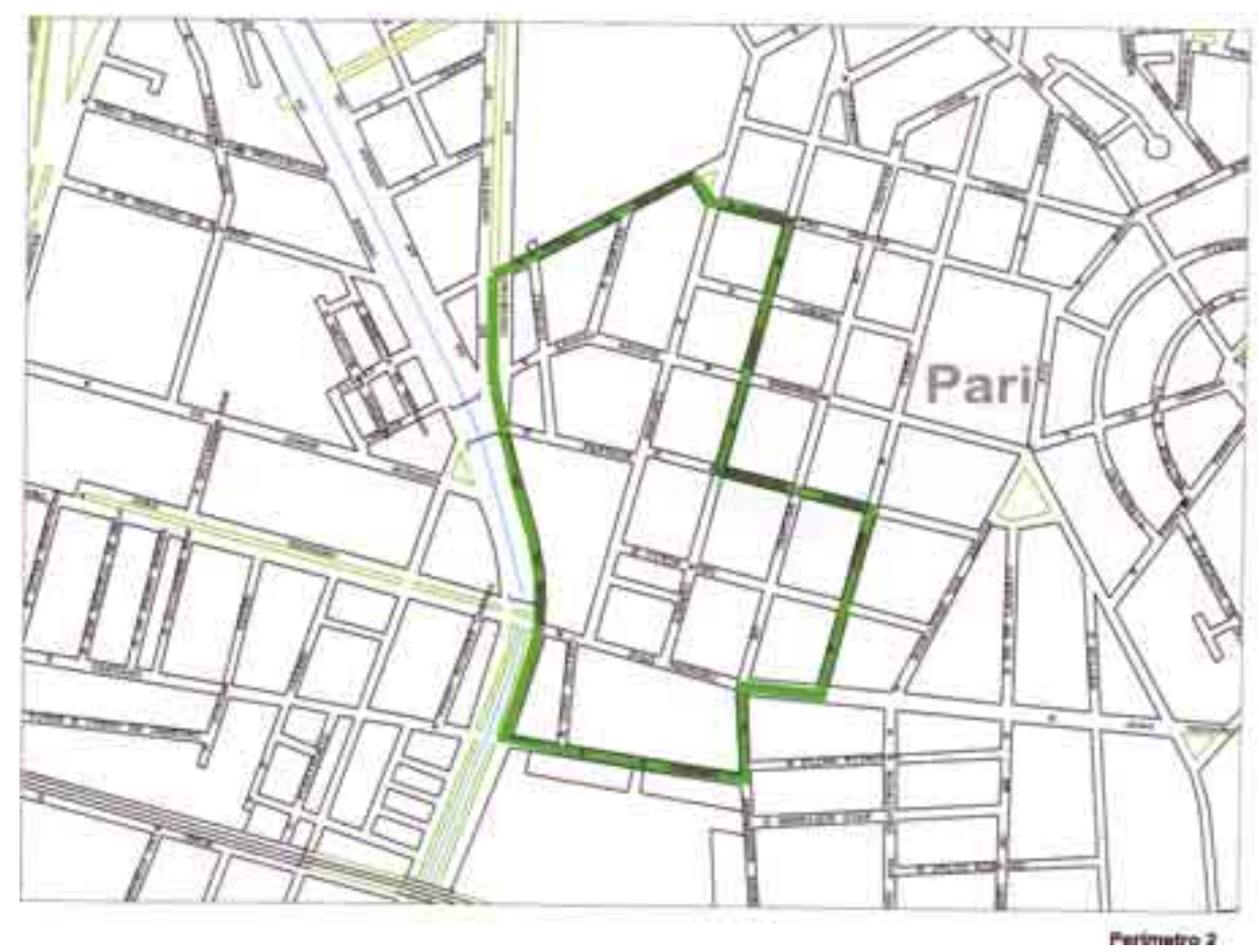

Fig. 237: PRIH, perímetro 2. 
maior aproveitamento do fundo dos lotes e miolos de quadras. Nesse perímetro foi construído no final da década de 1990, um conjunto habitacional pela CDHU e o "Programa de Atuação em Cortiços - PAC" previa ainda outras intervenções nas suas proximidades, como será visto adiante.

Estudos e análises mais aprofundados indicaram potencialidade para a reabilitação urbana e habitacional por meio de reformas e transformações físicas mínimas nos imóveis, com o envolvimento dos proprietários, moradores e até comerciantes da região para a melhoria da habitabilidade nas moradias - com provável diminuição do adensamento e provisão de unidades habitacionais na região - reformas e restauros de fachadas e requalificação dos espaços públicos urbanos, em operações fomentadas pela Prefeitura com a participação de outros setores nesse processo.

\section{Perímetro 3}

O Perímetro 3 foi delimitado pelo Viaduto Gasômetro, Rua Correia de Andrade, Rua Sampaio Moreira, Rua Monsenhor Andrade, Rua do Bucolismo, Rua Rodrigues dos Santos, Rua Silvio Penteado, Rua Barão de Ladário até o Viaduto do Gasômetro novamente. Abrange parte do bairro do Brás e localiza-se dentro da Operação Urbana Centro.

Levantamento da área

Número de quadras: 5

Área aproximada: 15,33 ha

Uso predominante/ Resumo de Usos:

Imóveis ociosos - Galpões

Percentual de áreas vazias: 0,53\% (área $=822 \mathrm{~m}^{2}$ )

Serviços públicos: nenhuma unidade

Oportunidades na área: $34.936 \mathrm{~m}^{2}$

Número aproximado de habitação para serem produzidas

Unidades Novas - 1165.

Unidades Reabilitadas: 0

Total de Unidades - 1165

Imóveis tombados - 57

Percentual da área verde existente: 0\%

Problemática da área

O Perímetro 3 caracterizou-se pela presença de grande quantidade de áreas de imóveis vagos ou ociosos como galpões de fábricas vizinhos ao Pátio Ferroviário do Pari e o antigo Moinho Matarazzo. Nesse quadrilátero estão situados edifícios e galpões com valor arquitetônico, grandes áreas ociosas, degradadas, sem 
integração com outras partes da cidade, apresentando também subutilização e inadequação das soluções de circulação para pedestres e automóveis. Além da produção habitacional, esse Perímetro também se mostrou adequado à produção de equipamentos de cultura, esporte, lazer. As áreas circunvizinhas também poderão ser requalificadas para esses ou outros usos, como por exemplo, áreas verdes.

A definição desse Perímetro intencionou provocar a integração das quadras de ambos os lados, separadas pela linha férrea, e também por isso, decadentes, degradadas e abandonadas. Visou também contribuir para soluções integradas de reabilitação, articuladas com os outros dois perímetros da mancha Pari/Brás 2 - utilizando, por exemplo, as operações casadas de desadensamento-remoção e provisão habitacional.

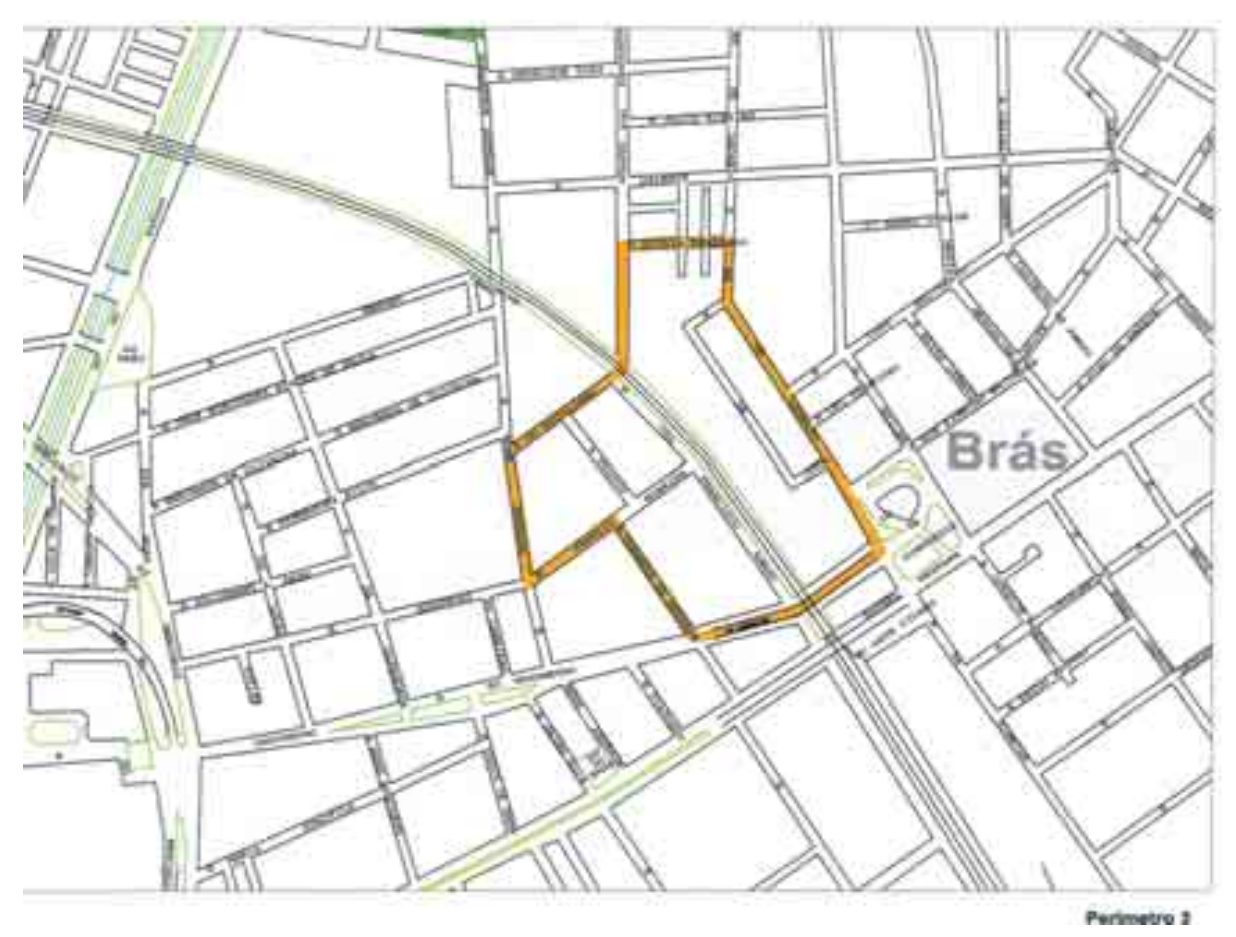

Fig. 238: PRIH, perímetro 3. 


\subsection{2 - Conjunto habitacional para o Bom Retiro - Parque do Gato}

Esse projeto foi desenvolvido pela $\mathrm{SEHAB} / \mathrm{COHAB}$ para abrigar os moradores da "Favela do Gato", que se formou a partir de 1993 às margens do rio Tamanduateí, junto à sua foz com o rio Tietê. Tratava-se de uma área que apresentava riscos de desabamentos, inundações e incêndios, que de fato ocorreu no início do ano de 2001.

A população foi remanejada para abrigos provisórios nas proximidades do local sendo cadastrada para as futuras unidades no conjunto habitacional a ser construído. Embora se tratando de uma favela, pelo fato da mesma se encontrar em bairro central, a área em que estava instalada foi considerada uma ZEIS-3 (Zona Especial de Interesse Social), o que segundo o Plano Diretor aprovado em 2002, vinculava projeto urbanístico também para o seu entorno.

A área onde o projeto foi desenvolvido localiza-se entre a avenida Marginal Tietê pista expressa e local, tratando-se de área pública com 17,5 hectares onde foi construído o Estádio Municipal de Baseball Mie Nishii e ao longo do tempo cedida para várias entidades que instalaram galpões para escolas de samba, além de dois Centros Desportivos Municipal - CDM.

Além dessas características, a área localiza-se defronte ao complexo do Anhembi, do outro lado do rio Tietê. Tal situação colabora ainda mais para a vocação de parque público desse espaço, com utilização intensiva dos equipamentos não só para a população que irá ocupar o conjunto habitacional, mas para toda a região vizinha que não possui áreas públicas com qualidade. $\bigcirc$ projeto para o conjunto previu também áreas para oficinas, centros de formação de mão-deobra para confecções, tenda para shows e torre mirante de 40 metros de altura.

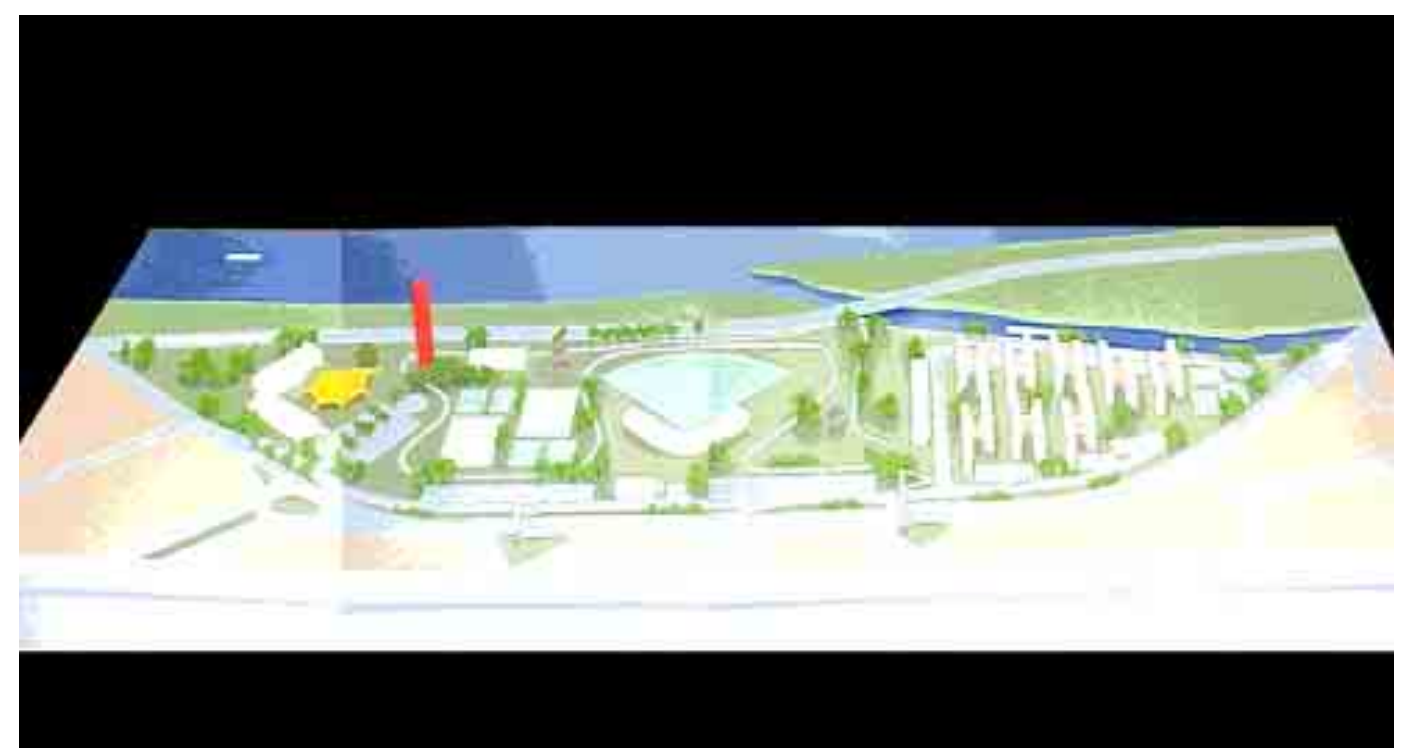

Fig. 239: Maquete do projeto Favela do Gato, 2002. 
O conjunto contou com 10 blocos de prédios de 4 andares, somando 486 unidades (aproximadamente 112 a mais que as famílias cadastradas da Favela do Gato). Essas unidades foram compostas por tipologias com áreas úteis de 27,36 e $48 \mathrm{~m}^{2}$, respectivamente para kitchnete, apartamento com 1 e 2 dormitórios. Para a população moradora, o conjunto contou também com quadras esportivas e creche. No edifício, localizado na transição entre o conjunto habitacional e o Parque foi proposto também serviços tais como padaria, farmácia e banca de jornal e revistas (SEHAB/COHAB, 2002).

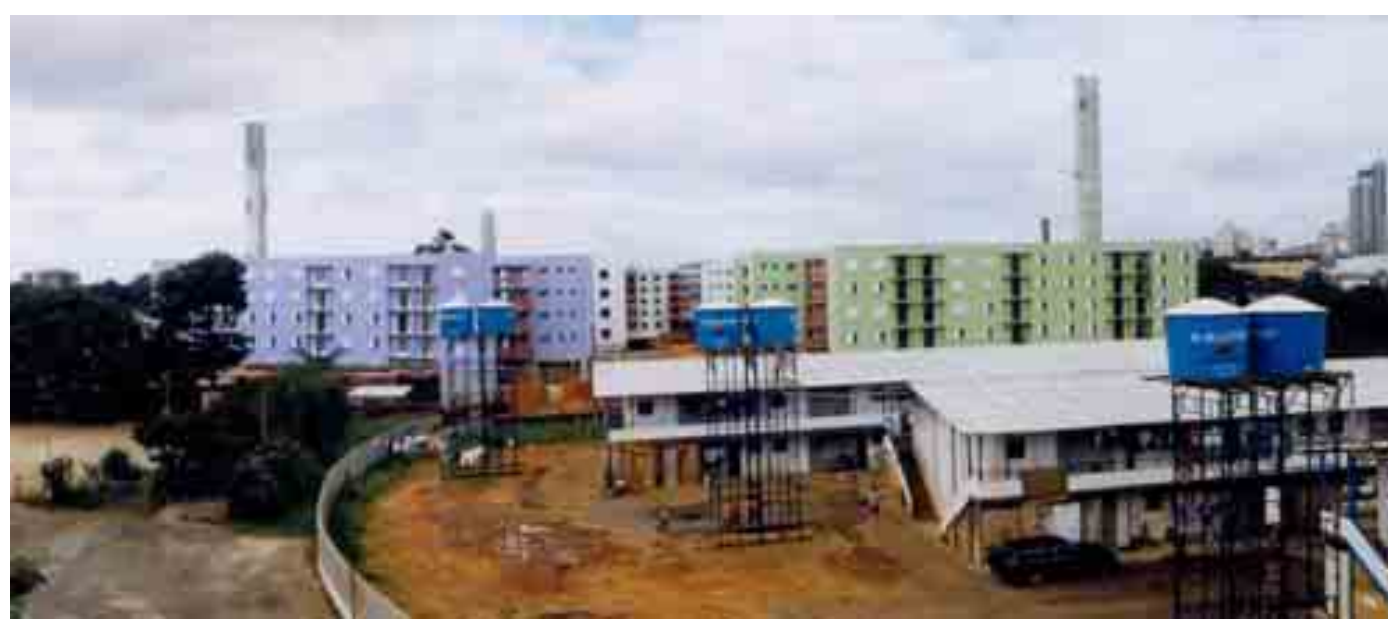

Fig. 240: Parque do Gato, 2004. 


\subsection{Propostas do Programa Habitacional CDHU}

A atuação desse órgão esteve relacionada ao Programa de Atuação em CortiçosPAC, que implantou um conjunto no Canindé e a construção de torres habitacionais populares no bairro do Brás. Intencionou reorientar a aplicação de recursos para habitação popular, dirigindo parte dos mesmos para construção de moradias em áreas centrais de cidades médias e grandes. No caso específico de São Paulo, o foco foi dirigido para o Centro e os bairros vizinhos com maior incidência de cortiços da cidade.

Os objetivos do programa voltaram-se para três atuações principais:

1. Além da produção de moradias, a possibilidade de induzir a renovação urbana e a revalorização de áreas degradadas da idade.

2. Otimização da infra-estrutura, serviços e equipamentos públicos, em face da sub-utilização dos mesmos.

3. Construção de tipologias habitacionais passíveis de permitir o adensamento das áreas, através da utilização de potencial construtivo para reduzir os custos da produção das unidades (CDHU, 1996, 2).

O estudo analisou que as formas de produção de habitação popular adotadas pelo poder público historicamente se basearam no barateamento das unidades habitacionais, através da relação preço-localização dos terrenos, o que de maneira geral conduziu a ocupações na periferia da cidade, onerando o poder público pela necessidade de provimento de infra-estrutura nas áreas desprovidas da mesma. $\bigcirc$ estudo preliminar propôs ainda o objetivo de responder a curto e médio prazo a demanda que era estimada em 115.000 unidades, representando um universo de 600.000 pessoas moradoras em cortiços na cidade de São Paulo (idem, 2).

Em 1998 esse Programa sofreu alterações em sua estruturação, com a entrada do Banco Interamericano de Desenvolvimento (BID) na construção de moradias no município de São Paulo. Como resultado das alterações introduzidas no programa, estabeleceu-se a meta de 5000 moradias para serem construídas de 2002 a 2005, sendo 4.400 delas no município de São Paulo (CDHU, 2002).

As torres que foram construídas na rua Canindé fizeram parte de um grupo de projetos não implantados, também propostos ao distrito do Pari. Contudo, os Perímetros de Reabilitação Integrada do Habitat, vistos anteriormente, incluíram essas propostas, como foi o caso do diagnóstico elaborado para o Perímetro 1, na Luz. O mapa do PAC Piloto também mostra essa interface, já que foram assinalados atuações nas ruas Dutra Rodrigues e Guilherme Maw. 


\section{Conjunto rua Canindé}

Dados do projeto:

Início: 1999

Conclusão: maio de 2002

Número de unidades: 160

Área: $42 \mathrm{~m}^{2}$

Projeto: arq. Ruy Otake

Fig. 241 e 242: Ao lado, torre CDHU, 2003. Abaixo, vista da inserção urbana das edificações
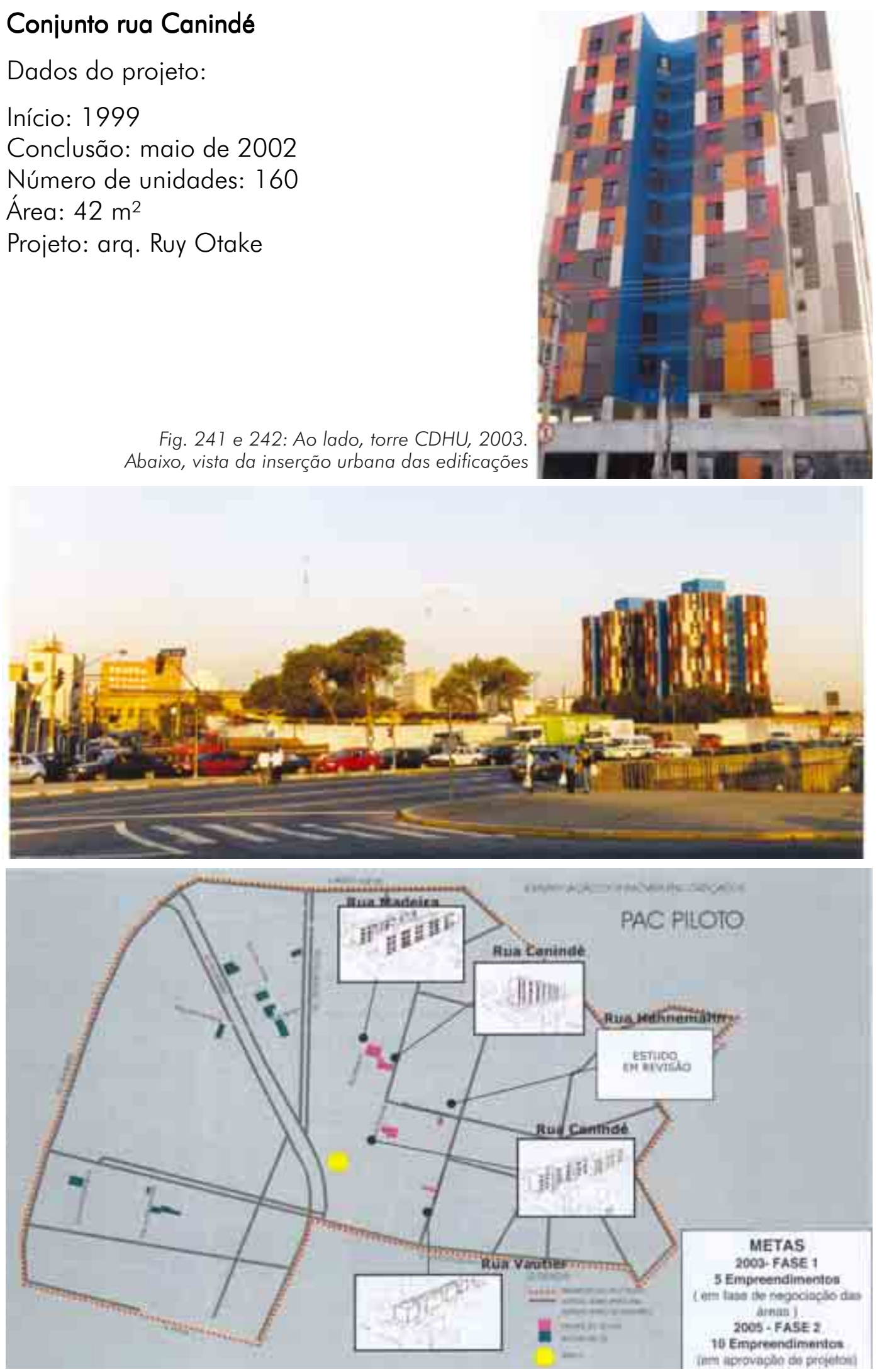

Fig. 243: Mapa esquemático com áreas de intervenção, PAC Piloto. 

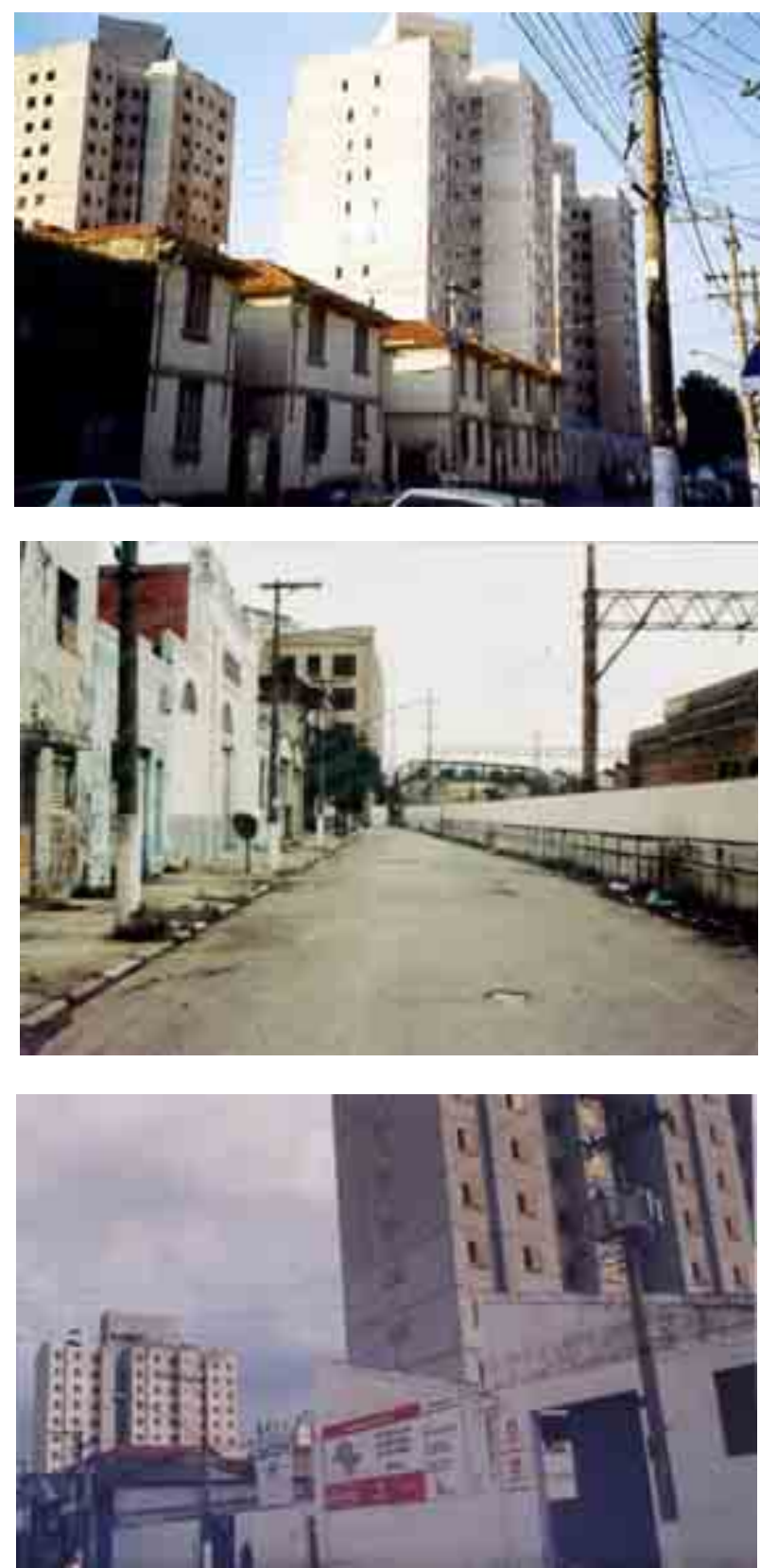

Fig. 244, 245 e 246: De cima para baixo: Conjunto na R. Cel. Francisco Amaro, Brás, 2003. Ponte metálica de ligação Brás-Pari, junto ao conjunto acima mencionado e galpões que foram demolidos, 2003.

Conjunto na R. Martin Bouchard, Brás, 2004.

\section{PAC Piloto}

\section{Programa Pro Lar}

Através desse programa foram construídas torres habitacionais no Brás para a faixa econômica. Em 2003 foram erguidos quatro edifícios na rua Sampaio Moreira, junto da linha férrea, em um espaço anteriormente ocupado por galpões em precárias condições. Esse conjunto se encontra localizado dentro do Perímetro 3 do PRIH-Brás, sendo construídas 200 unidades com área de 42 e $48 \mathrm{~m}^{2}$.

Seguindo as mesmas características tipológicas, no ano de 2004 foram construídas na rua Martin Buchard, 252 unidades em área que já contava com as torres da COHAB, construídas no fim da década de 1980, junto da estação Brás do Metrô. O adensamento populacional nessa área era previsto pelas Zonas de Especial Interesse Social ZEIS-3, definidas no Plano Diretor Estratégico e abordadas a seguir. 


\section{5 - Plano Diretor Estratégico}

Com relação aos planos e programas urbanísticos para a área dos bairros centrais, 30 anos após a promulgação da Lei de Zoneamento de 1972, foi aprovado no ano de 2002 o Plano Diretor Estratégico do Município de São Paulo ${ }^{4}$ e após o mesmo, foi iniciada a elaboração dos Planos Regionais Estratégicos das Subprefeituras, apresentados no segundo semestre de 2003 para debate na Câmara Municipal e aprovado em 2004 ( Lei 13.885/2004).

Para compreensão das propostas dos Planos Regionais Estratégicos incidentes nos bairros centrais, sintetizamos os principais aspectos contidos no Plano Diretor Estratégico:

\section{. ELEMENTOS ESTRUTURADORES}

Rede viária estrutural

Rede estrutural de transportes

Rede de eixos e pólos de centralidade

Rede hídrica estrutural

\section{. ELEMENTOS INTEGRADORES}

Habitação

Equipamentos sociais

Áreas verdes

Espaços públicos

\section{. MACROZONEAMENTO}

1. Macrozona de Proteção Ambiental: mananciais, áreas com cobertura vegetal e áreas a serem recuperadas. As zonas de uso incidentes nesta área são:

ZER - 1: zona exclusivamente residencial de baixa densidade ZERp: zona exclusivamente residencial de proteção ambiental ZMp: zona mista de proteção ambiental ZCPp: zona centralidade de proteção ambiental ZPDS: zona de proteção e desenvolvimento sustentável ZLT: zona de lazer e turismo ZPE: zona especial de preservação

2. Macrozona de Estruturação e Qualificação Urbana: área urbana consolidada Na macrozona de Estruturação e Qualificação Urbana a instalação do uso residencial e o desenvolvimento das atividades urbanas estão subordinados às exigências dos elementos estruturadores definidos no Plano Diretor Estratégico e nos Planos Regionais Estratégicos das Subprefeituras. Estão compreendidas nessa porção do território, as seguintes zonas de uso: 


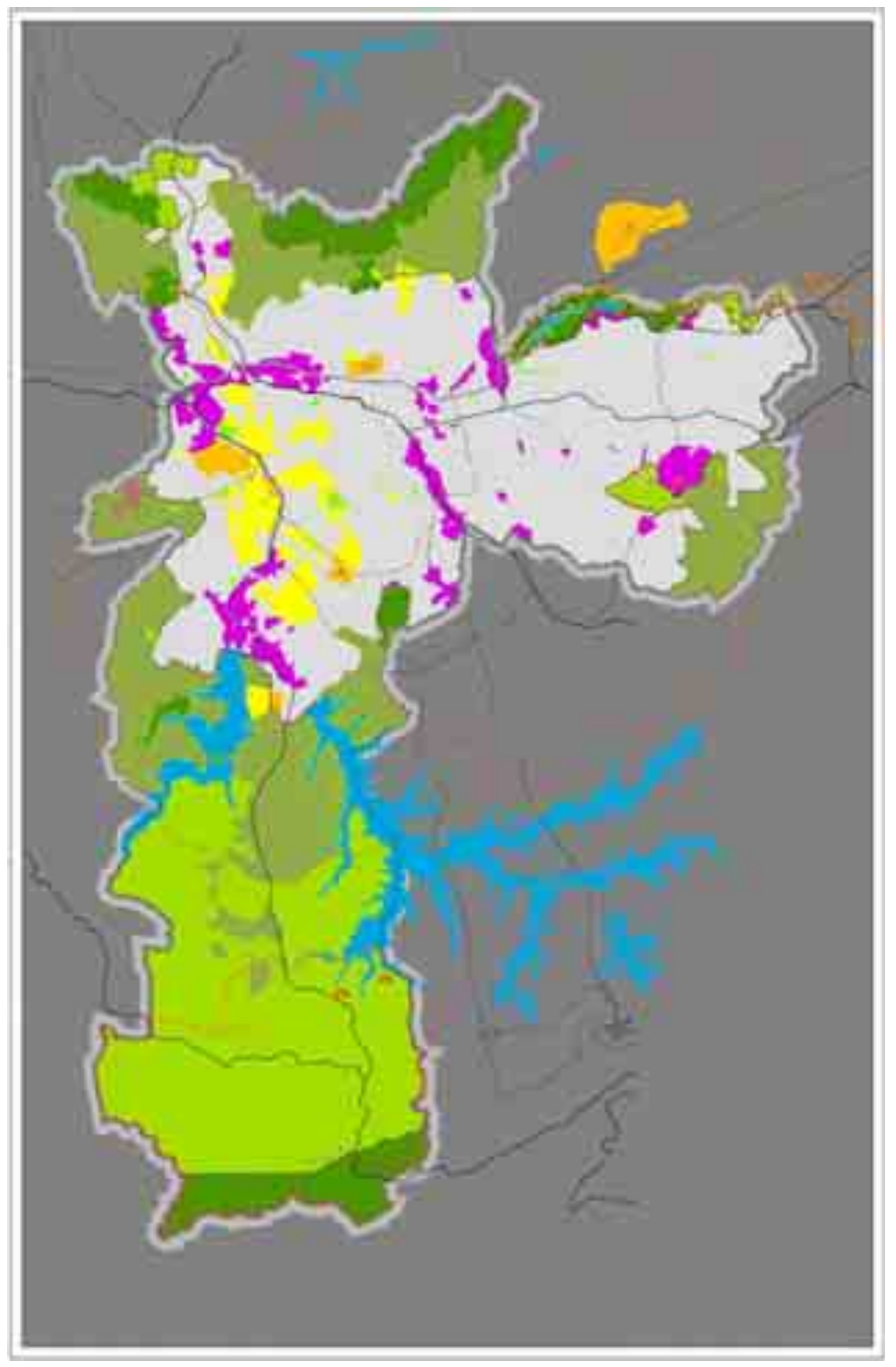

Fig. 247: Macrozoneamento, PDE, 2002.

Zonas de Centralidade: Polar, Linear e Linear em Zer - ZCP , ZCL e ZCLz destinadas a uma maior diversidade e intensidade dos usos não residenciais, admitindo usos potencialmente incômodos. Com exceção da ZCLz, com regras mais restritivas, o que distingue as lineares das polares é que integram as $Z C L$, os lotes lindeiros a trechos de vias internos à zona mista, numa faixa de até 40 metros medidos a partir do alinhamento da via. Ambas com predominância de usos não residenciais, classificam-se de acordo com os coeficientes de aproveitamento em:

a. ZCLa-coeficiente de aproveitamento básico igual a 1,0 e máximo variando de 1,0 até o limite de 2,5;

b. ZCLb - coeficiente de aproveitamento básico igual a 2,0 e máximo variando de 2,0 até o limite de 4,0; 
c. ZCPa - coeficiente de aproveitamento básico igual a 1,0 e máximo variando de 1,0 até o limite de 2,5;

d. ZCPb - coeficiente de aproveitamento básico igual a 2,0 e máximo variando de 2,0 até o limite de 4,0;

Zona estritamente residencial - ZER. Correspondem às Z1 no antigo zoneamento

Zona predominantemente industrial - ZPI: destinadas à implantação de usos diversificados, preferencialmente para usos industriais incômodos e outras atividades não residenciais incômodas. São estabelecidos os coeficientes de aproveitamento: mínimo igual a 0,1; básico igual a 1,0 e máximo igual a 1,5.

Zona mista - ZM: corresponde ao restante do território da Macrozona de Estruturação e Qualificação excluídos os perímetros de ZER, ZPI e Zonas Especiais. Caracteriza-se pela conjugação de usos residenciais e não residenciais, inclusive no mesmo lote ou edificação, respeitados os critérios de incomodidade e qualidade ambiental do uso residencial. Classificam-se em:

ZM-1: densidade demográfica e construtiva baixa, coeficiente de aproveitamento básico e máximo iguais a 1,0;

ZM-2: densidade demográfica e construtiva média, coeficiente de aproveitamento básico igual a 1,0 e máximo variando de 1,0 até o limite de 2,0;

ZM-3a: densidade demográfica e construtiva alta, coeficiente de aproveitamento básico igual a 1,0 e máximo variando de 1,0 até o limite de 2,5;

ZM-3b: densidade demográfica e construtiva alta, coeficiente de aproveitamento básico igual a 2,0 e máximo variando de 2,0 até o limite de 2,5;

. ZONAS ESPECIAIS - situam-se em qualquer zona do território do Município, têm características específicas e normas próprias de uso e ocupação do solo e edilícia.

1. Zona de proteção ambiental: ZEPAM

2. Zona de produção agrícola/mineral: ZEPAG

3. Zona de proteção ao patrimônio cultural - ZEPEC: transferem potencial construtivo

4. Zona Especial de Interesse Social 1 - ZEIS 1: área abrangida por favelas e loteamentos precários;

5. Zona Especial de Interesse Social 2 - ZEIS 2: áreas com predominância de glebas, terrenos não edificados ou subutilizados adequados à urbanização;

6. Zona Especial de Interesse Social 3 - ZEIS 3: áreas encortiçadas no espaço urbano consolidado 
7. Zona Especial de Interesse Social 4 - ZEIS 4: glebas ou terrenos não edificados e adequados à urbanização em áreas de proteção ambiental para atender população removida de áreas de risco e de preservação permanente.

As Zonas de Especial Interesse Social - ZEIS 3 se constituem em uma categoria de zona especial quanto às regras de parcelamento, uso e ocupação do solo "objetivando a criação de condições favoráveis para uma atuação concentrada de agentes públicos e privados visando a melhoria das condições de habitabilidade dos cortiços e a reforma de edifícios abandonados, com a destinação de novas unidades para a provisão habitacional" (PDE, PMSP, 2002).

Essas zonas estarão isentas do pagamento da outorga onerosa pelo direito de construir acima do coeficiente máximo permitido, podendo ainda ser isenta dessa cobrança a área construída destinada a outros usos desde que haja HIS em igual proporção no mesmo empreendimento. Em síntese, nessas áreas será possível atingir o limite máximo igual a 4,0 (quatro) sem o pagamento de contrapartida, obedecidas as condições acima descritas.

\section{. NOVOS INSTRUMENTOS URBANÍSTICOS}

Área de Intervenção Urbana - AIU

AIU parques lineares

AIU eixos viários

AIU eixos de transporte coletivo

AIU eixos e pólos de centralidade

Parcelamento, edificação e utilização compulsórios (segundo Estatuto das Cidades) Incidência do direito de preempção (segundo Estatuto das cidades)

Áreas de operação urbana

\section{. NOVOS INSTRUMENTOS DE GESTÃO URBANA}

- Transferência do direito de construir

- Operações urbanas consorciadas

. Fundo de Urbanização - reunir e canalizar os recursos de outorga onerosa

Zoneamento ambiental

. Estudo de impacto ambiental e de vizinhança

. Avaliação ambiental estratégica

Com relação aos coeficientes de aproveitamento permitidos, o Plano Diretor Estratégico definiu o índice máximo de 2,5 para toda a cidade, com exceção das zonas estritamente residenciais ou outras que pudessem receber algum tipo de restrição, como por exemplo, as áreas que contam com imóveis tombados, as ZEPECs. O coeficiente adicionado equivaleu a 4 , também para as Operações Urbanas e eixos e pólos de reestruturação, havendo a contrapartida da outorga onerosa (concessão paga) para a passagem de $C . A=2,5$ para C. $A=4$. 


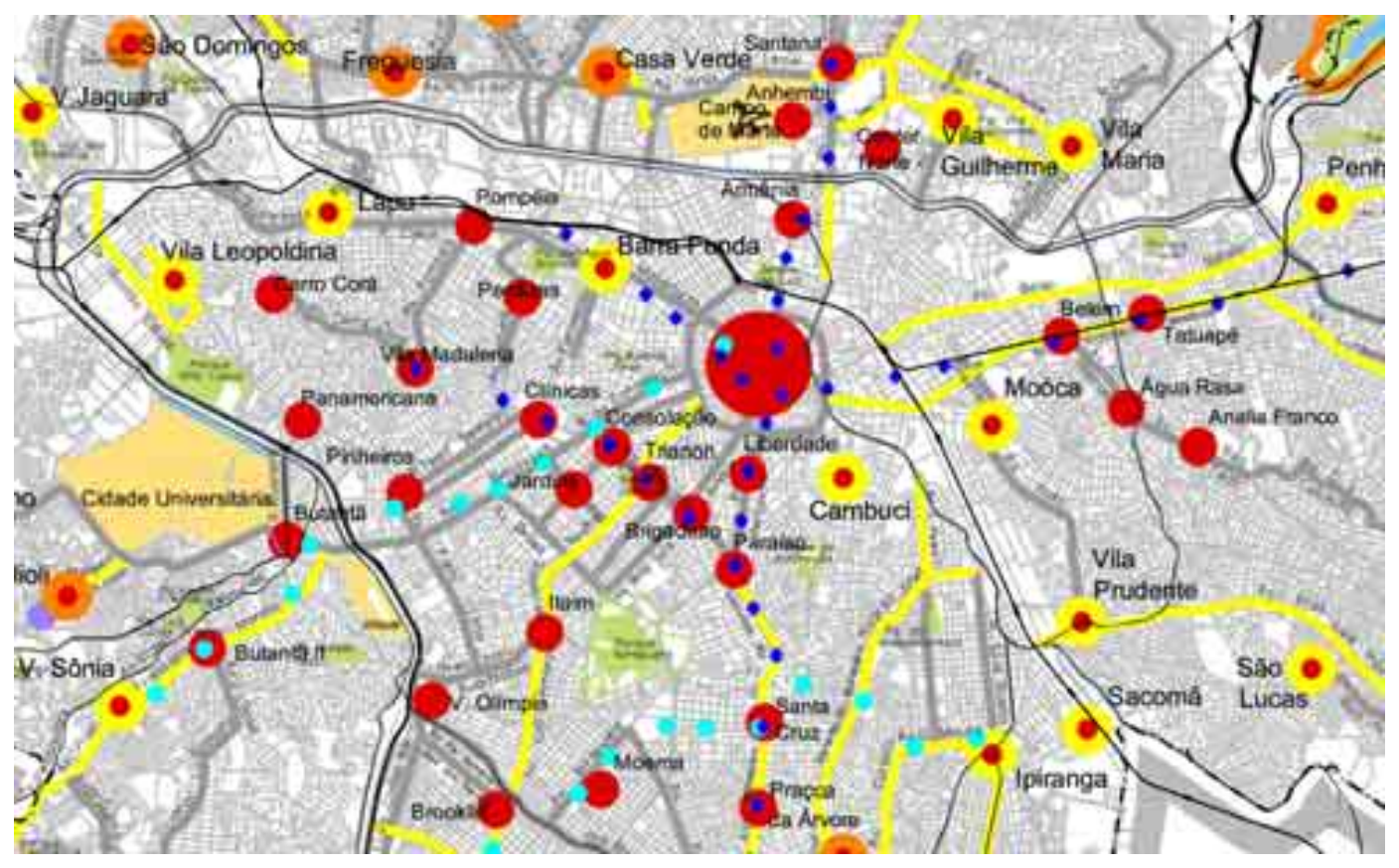

Fig. 248: Pólos regionais, PDE, 2002. 


\subsection{Operações Urbanas Propostas}

O principal diferencial entre as Operações Urbanas -O.U. propostas após 2001 e as O. U. Faria Lima, Água Branca e Centro, aprovadas anteriormente, referese ao fato de que estas últimas não obedeceram nenhum projeto urbanístico quando de sua implantação. Entre as nove Operações Urbanas aprovadas no Plano Diretor Estratégico ${ }^{5}$, quatro incidiram nos distritos Bom Retiro, Brás e Pari as O.U. Centro, Diagonal Sul, Diagonal Norte e Celso Garcia. De acordo com a Secretaria Municipal de Planejamento Urbano, as Operações Urbanas foram definidas pela Lei Federal do "Estatuto da Cidade" 6 como intervenções dentro de perímetros e condições determinadas por lei própria e constantes no Plano Diretor Estratégico, sendo que esse instrumento determinou a exigência de um projeto próprio que abordasse problemas relativos a quatro esferas urbanísticas: infra-estrutura, meio ambiente, transporte e habitação social (Sempla, 2004, s/ pág).

Nesse sentido, cada Operação Urbana necessariamente incluiu um Plano de Ordenação Urbanística-PRIOU, que em linhas gerais compreende:

- Estudo de viabilidade de diretrizes, que através da caracterização e definição das propostas arquitetônicas, urbanísticas e paisagísticas constituirão um programa de investimentos públicos direto para a operação urbana em tela, contendo análises de viabilidade de sua implantação, custos e prazos. Objetivase a seleção dos projetos de obras públicas e alternativas para a viabilização da O.U. quanto às negociações envolvendo concessões urbanísticas, desapropriações, etc.

- Estudo de potencial de construção: proposição de cenários de configuração do sistema edificado, que observando as pré-existências físicas, sociais e ambientais existentes, formulará as possibilidades de ampliação do potencial construtivo dentro do proposto pelo Estatuto da Cidade e pelo Plano Diretor Estratégico.

- Plano Geral de Implementação: compatibilização, articulação e integração dos elementos de caracterização e propositivos da Operação Urbana. O seu objetivo é o de estabelecer linhas prováveis de encadeamento das ações, estipular as fases de implementação, custos e benefícios esperados através de uma abordagem de conjunto que inter-relaciona as escalas, temas e fatores de transformação, associando programas de investimentos públicos e indução ao investimento privado (PMSP, 2003, 7).

A "Operação Urbana Diagonal Sul" foi criada com o objetivo de revitalizar o uso de um território com cerca de 20 milhões de $\mathrm{m}^{2}$ disposto ao longo da ferrovia que corta os bairros do Ipiranga, Vila Prudente, Moóca, Brás e Pari. Para tanto, sua atuação se relaciona ao provimento e atualização da infra-estrutura de drenagem, viária e de transportes, na requalificação urbanística do espaço 
construído e do patrimônio histórico, incluindo o aumento dos espaços livres e aumento da densidade populacional através de alternativas para a habitação de várias faixas de renda.

Tendo em vista o adensamento, revitalização do uso do solo e habitação, as diretrizes dessa Operação Urbana definiram quatro intervenções em torno de estações projetadas como transposições e centralidades: Tamanduateí, Ipiranga, Moóca e Largo da Concórdia. Prevê-se ainda outra centralidade projetada no Pátio do Parí. Segundo essas diretrizes, os recursos da Operação Urbana serão destinados também para a reurbanização de favelas e para as melhorias necessárias às áreas das Zonas de Especial Interesse Social ZEIS-3.

Em parte dos setores sudeste e leste dos distritos centrais, sobrepõe-se à Diagonal Sul a "Operação Urbana Centro", em curso desde 1997. A pouca eficácia desse instrumento, utilizado apenas para venda de potencial construtivo e o coeficiente de aproveitamento então aprovado para essa área, que em alguns casos chegava a 12, levaram a uma série de estudos sobre sua revisão devido a sua coincidência com a $\bigcirc$. U. Diagonal Sul nos setores próximos da orla ferroviária e com os índices aprovados no Plano Diretor Estratégico, que estabeleceram em 4 o coeficiente máximo na cidade.

Com relação à Operação Urbana Diagonal Norte, que compreende o vetor noroeste estruturado pela ferrovia a partir do anel de bairros centrais, sua

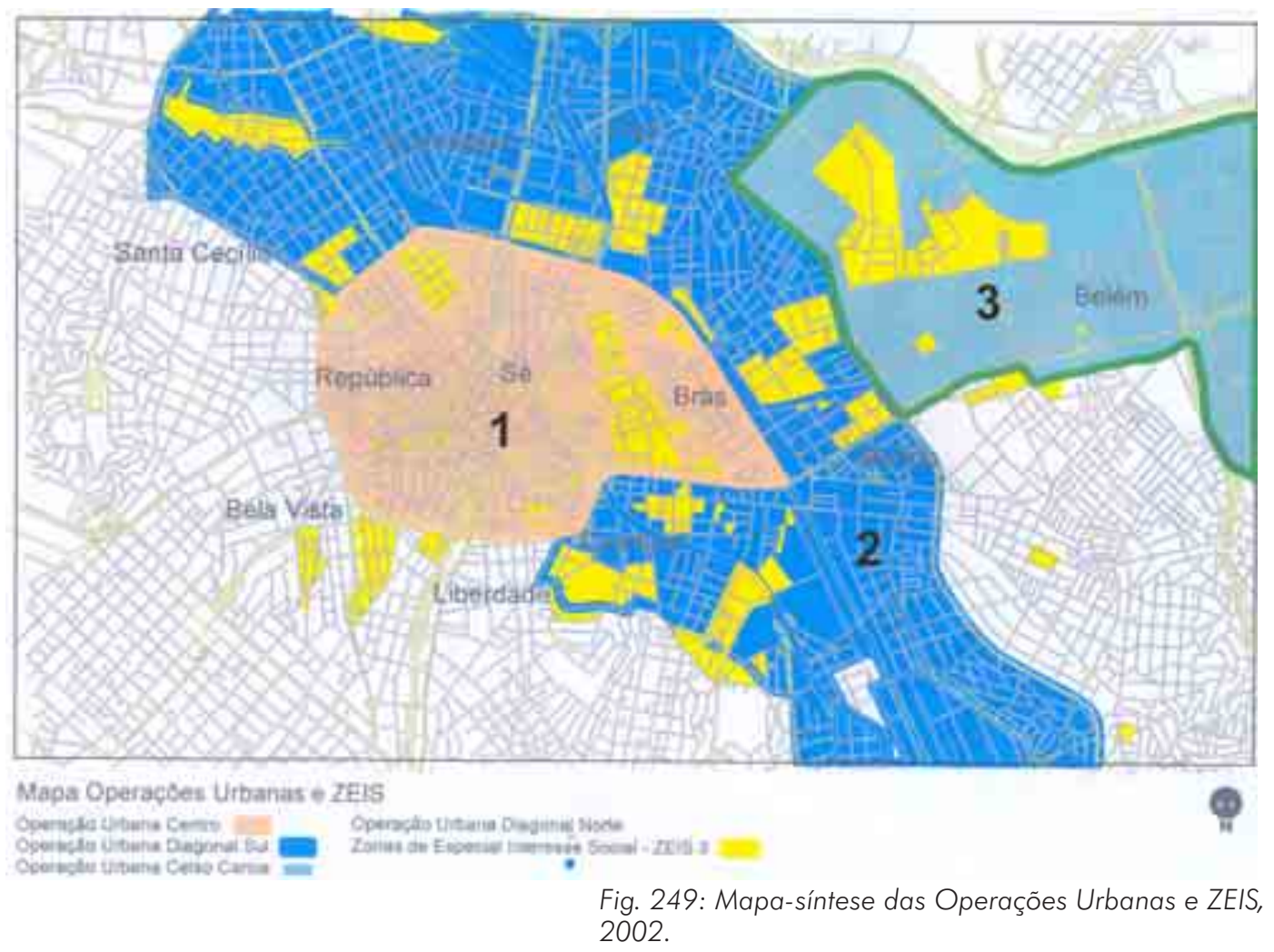


implantação condicionou-se à revisão da Operação Urbana Água Branca, que conforme foi examinado na Parte I deste trabalho, recebeu propostas vindas do Concurso Nacional para Projeto Urbano "Bairro Novo". Entretanto, entre esta área e os bairros abrangidos pela O.U. Diagonal Sul ocorre um diferencial importante que é a do valor do solo dos bairros da Barra Funda, Água Branca e Lapa, que impõe outras medidas aos interesses já existentes do mercado imobiliário, diferentemente do que acontece no vetor sudeste.

Além das Operações Urbanas mencionadas, foi proposta também para os bairros do Belém, Belenzinho, Brás e Pari a Operação Urbana Celso Garcia, objetivando requalificar física e funcionalmente os espaços desses bairros, como por exemplo a própria avenida Celso Garcia, esvaziada tanto sob o ponto de vista populacional como de suas atividades econômicas. 


\subsection{Planos Regionais Estratégicos dos Distritos Bom Retiro, Brás e Pari}

Os Planos Regionais Estratégicos (PRE) propostos para os distritos aqui enfocados se constituíram em uma oportunidade relevante para a análise de seus aspectos urbanos, problemas e potencialidades locais, não contemplados na escala do Plano Diretor Estratégico, porém norteados pelos seus instrumentos aprovados sob a forma de lei.

Efetivamente, pela primeira vez a cidade contou com essa escala de planejamento urbano, cuja proposição já fora formulada desde o relatório da SAGMACS e da proposta do PUB, nas décadas de 1950 e 1960, respectivamente. Os trabalhos, iniciados no ano de 2002, foram conduzidos em duas etapas, compreendidas pelo quadro situacional e pelo quadro propositivo, com a participação de setores da população que reuniu moradores, entidades, empresas e militantes de movimentos sociais, de meio ambiente, etc.

Os distritos Bom Retiro, Brás e Pari tiveram uma dinâmica diferenciada em relação a esse processo, uma vez que fizeram parte de subprefeituras diferentes, o que impediu análises mais integradas sob o ponto de vista da relação entre os bairros centrais, extensão de projetos voltados à paisagem urbana, etc. Entretanto, as diretrizes definidas pelo Plano Diretor Estratégico e pelas Operações Urbanas por ele criadas, estabeleceram um pano de fundo comum, estruturado pelo emprego dos coeficientes de aproveitamento mínimos e máximos, pelos critérios voltados aos pólos e eixos de centralidade, que se converteram nas Áreas de Intervenção Urbanística -AIU e pelas políticas urbanísticas de transportes, meio ambiente e habitação.

De acordo com a Secretaria Municipal de Planejamento, "o Plano Diretor Estratégico do Município de São Paulo definiu como ação estratégica da Política de Urbanização e de Uso do Solo (Artigo 78 da Lei Municipal 13.430/01) o desenvolvimento de Planos Regionais para as subprefeituras (Inciso IX).

Segundo o $\S 3^{\circ}$ do Artigo 273, "Os planos regionais deverão ser elaborados com a participação dos munícipes dos diversos bairros que compõem cada região, nos diagnósticos, concepção, aprovação, monitoramento, fiscalização e revisão em todas as ações, com base em plena informação, disponibilizada pelo Executivo, a elas concernentes, em tempo para subsidiar o processo de discussão, elaboração e decisão".

Segundo o Artigo 274, "os Planos Regionais, observando os elementos estruturadores e integradores do Plano Diretor Estratégico, complementarão as suas proposições de modo a atender às peculiaridades do sítio de cada região e às necessidades e opções da população que nela reside ou trabalha."

No Artigo 277 lê-se que "Nos Planos Regionais deverão constar, no mínimo: 
1 - delimitação das novas áreas em que se aplicam os instrumentos da Lei Federal $n^{\circ} 10$ 257, de 10 de julho de 2001 - Estatuto da Cidade;

II - hierarquização do sistema viário local e plano de circulação e transporte;

III - proposta de destinação de áreas e equipamentos públicos e áreas verdes;

IV - áreas reservadas para bolsões, conforme lei 11322 de 22 de dezembro de 1992;

$\checkmark$ - projetos de intervenção urbana;

$\mathrm{VI}$ - proposta de tombamento ou outras medidas legais de prestação e preservação de bens móveis e imóveis da região;

VII - aplicação no território da subprefeitura, das diretrizes de uso e ocupação do solo previstas no Plano Diretor Estratégico;

VIII - proposta de composição, com Subprefeituras vizinhas, de instâncias intermediárias de planejamento e gestão, sempre que o tema ou serviço exija tratamento além dos limites territoriais da Subprefeitura;

IX - proposta de ação articulada de planejamento e gestão com as Subprefeituras e municípios limítrofes, com base em diretrizes governamentais para a Política Municipal de Relações Metropolitanas;

$X$ - proposta de ações indutoras do desenvolvimento local, a partir das vocações regionais;

$X I$ - indicação de prioridades, metas e orçamento regional para a Subprefeitura; XII - proposta de prioridades orçamentárias relativas aos serviços, obras e atividades a serem realizadas da Subprefeitura" (PRE Subprefeitura Sé, Quadro situacional, PMSP/SEMPLA/Polis, 2002, 9).

processo de análise urbana dos territórios da Subprefeitura Sé, que entre outros abrange o distrito Bom Retiro, priorizou os subsídios para a elaboração de uma estratégia de regulação do uso e ocupação do solo visando dar sustentação aos programas, propostas e ações definidos para a região. Os objetivos específicos que se inseriram nesse escopo foram:

."Definição de diretrizes para mudanças de zoneamento no centro

. Detalhamento de critérios de sub-utilização e não utilização de imóveis e levantamento de áreas passíveis de utilização desse instrumento

-Revisão das áreas delimitadas como Zonas Especiais de Interesse Social

. Definição de diretrizes para a revisão da Operação Urbana Centro e diretrizes para elaboração de Operação Urbana Diagonal Sul

. Definição de áreas de preservação histórica e ambiental para aplicação da transferência do direito de construir

.Definição sobre a destinação das áreas públicas da Subprefeitura" (idem, 10).

Em relação à Subprefeitura Mooca, que abrange os distritos do Pari e Brás, o Plano Regional definiu os seguintes objetivos específicos: 
".Detalhamento de critérios de sub-utilização e não utilização de imóveis e levantamento de áreas passíveis de utilização dos instrumentos do Estatuto da Cidade

.Revisão das ZEIS estabelecidas

.Definição de áreas verdes e de preservação histórica e ambiental para aplicação do instrumento de transferência do direito de construir

.Propor uma articulação e implementação de instrumentos urbanísticos que estimulem a presenvação de conjuntos arquitetônicos históricos como vilas, fábricas e casario

.Levantamento dos conjuntos de interesse histórico local

- Levantamento e definição à destinação das áreas públicas da Mooca

. Revisão da malha viária e sistema de transporte visando integrar vias estruturais propostas e sugerir novas vias locais em áreas carentes das mesmas

.Estabelecer priorização em relação às demandas habitacionais mais urgentes, como favelas, cortiços e habitações precárias

.Propor diretrizes e rever perímetros das Operações Urbanas Celso Garcia e Diagonal Sul" (PRE Subprefeitura Mooca PMSP/SEMPLA/Polis, Quadro situacional, 2002, s/pág.).

\section{Uso e ocupação do solo}

De acordo com as diretrizes do Plano Diretor Estratégico, os instrumentos urbanísticos incidentes nos distritos compreendidos por este trabalho caracterizam toda a sua área com coeficiente de aproveitamento passível de atingir o índice igual a 4, exceção feita aos espaços com a presença de imóveis tombados. Tal situação é resultante da sobreposição a esse território das Operações Urbanas Centro, Diagonal Sul, Diagonal Norte e Celso Garcia, além dos eixos de transportes estruturais, que implicam na delimitação de uma faixa de 300 metros (por face de quadra) ao longo dos corredores servidos por ferrovia, Metrô e corredores de ônibus e num raio de 600 metros no entorno das estações desses modos de transporte.

Com isso, o PRE deve definir as diretrizes para áreas adensáveis e não-adensáveis, através da utilização de parâmetros sobre a capacidade da infra-estrutura existente, tal como carregamento do sistema viário e das redes de serviços públicos. Além disso, o estoque de potencial construtivo ${ }^{7}$ para outorga onerosa, obtido pela diferença entre os coeficientes básico (utilização do c.a. $=2,5$ ) e máximo (utilização do c.a. $=4$ ) mostra que não poderá ser utilizado em sua totalidade, devido a diversos fatores, tais como a presença de imóveis tombados e das construções existentes não serem substituídas em sua totalidade por novas edificações com coeficiente de aproveitamento máximo.

O Plano Regional da Subprefeitura Sé detectou que as áreas com maior estoque de potencial construtivo se encontram presentes nos locais de usos 
predominantemente não residenciais, com baixa densidade de moradores. Para essas áreas foram definidas diretrizes que observam o estímulo aos usos residenciais, aproveitando-se o estoque do potencial construtivo, principalmente naquelas quadras com mais de $80 \%$ da área construída com usos não residenciais. Para tanto, os controles de adensamento e de incomodidade deverão se constituir em parâmetros definidores do desempenho da ocupação (PRE Subprefeitura Sé, 2004, 21).

\section{Habitação social}

Para os bairros compreendidos pelos distritos Bom Retiro, Pari e Brás, os Planos Regionais consideraram as propostas para Habitação Social formuladas pelos órgãos públicos diretamente relacionados ao problema, delimitando assim as áreas de ZEIS 3 constantes nessa região. Para se ter uma idéia aproximada da demanda, tendo como base a ZEIS 3 que compreende o "Perímetro de Reabilitação Integrada do Habitat-PRIH" no bairro da Luz, foi estabelecido um índice para calcular o estoque estimado de todas as ZEIS 3 aprovadas na Subprefeitura Sé. Esse cálculo do estoque de potencial construtivo foi feito a partir da diferença entre o aproveitamento bruto real e o aproveitamento potencial. Chegou-se ao valor de $882568,44 \mathrm{~m}^{2}$. Considerando que $50 \%$ desse estoque destina-se à Habitação de Interesse Social - HIS e estimando unidades com 50 $\mathrm{m}^{2}$ de área, tem-se uma produção estimada de 8.825,68 unidades. (PRE Subprefeitura Sé, 2004, 65). Para os distritos do Pari e Brás, tal cálculo não foi desenvolvido, limitando-se o Plano Regional a delimitar as áreas de incidência do direito de preempção e das ZEIS.

\section{Diretrizes para a definição das áreas de intervenção urbana}

Para o distrito Bom Retiro, que compreende os bairros da Luz, Bom Retiro e Ponte Pequena, foi proposto um conjunto significativo de intervenções urbanísticas:

\section{. Integração ferroviária das estações Brás, Luz e Barra Funda}

. Linha ferroviária entre o Brás e o aeroporto Internacional de Cumbica em Guarulhos

- Modernização da linha ferroviária entre o Brás e o município de São Caetano do Sul na região do Grande ABC paulista

- Conjunto de ações previstas no Programa de Reabilitação do Centro envolvendo intervenções nas áreas dos calçadões, no Parque dom Pedro II, dentre outras

- Conjunto de ações do Programa Morar no Centro envolvendo as definições para os Perímetros de Reabilitação Integrada do Habitat - PRIH

. Conjunto de ações previstas no projeto Monumenta Luz

Algumas dessas propostas se relacionam ao governo estadual e outras ao governo municipal e se constituem em intervenções estruturais e pontuais que irão provocar 
diferentes impactos sobre a realidade da Subprefeitura Sé. Foram propostas também intervenções complementares nas vias estruturais e eixos que atravessam e articulam esses perímetros. São elas:

- Rio Tamanduateí - reabilitação urbanística e paisagística ao longo do rio articulando o parque proposto na ZIR do Cambucí, o equipamento metropolitano a ser implantado no Parque Dom Pedro ll e a Reabilitação da Foz do rio Tamaduateí

. Avenida Tiradentes - reformulação viária buscando a integração do conjunto arquitetônico no perímetro Monumenta Luz melhorando a oferta de espaços públicos no local (PRE Subprefeitura Sé, 2004, 89).

Já para os distritos do Brás e do Parí, os seguintes Pólos e Eixos de Centralidade foram selecionados para serem alvo de projetos urbanísticos visando sua reestruturação, para os mesmos serão relacionados projetos de desenho urbano da via e do entorno, melhoria na acessibilidade do pedestre, espaços para carga e descarga de veículos, programas paisagísticos, etc.: Largo da Concórdia, Largo Padre Bento e avenida Rangel Pestana. Além dessas indicações, foram selecionados os seguintes eixos e ruas comerciais a requalificar:

\section{. Rua do Gasômetro}

. Ruas de comércio especializado no Brás e Pari: rua Oriente, rua Maria Marcolina, rua Silva Teles, rua Thiers, avenida Valtier, rua Cavalheiro, rua Almirante Barroso, rua Firmino Whitacker, rua Monsenhor Andrade e avenida Carlos de Campos (PRE Subprefeitura Mooca, 2004, 2).

Com relação às Zonas Especiais de Proteção Ambiental e ao Patrimônio Cultural (ZEPAMs e ZEPECs), no distrito Bom Retiro foram delimitadas as áreas de incidência do Projeto Monumenta e para o Brás e o Pari foram propostas:

Brás: Estação do Pari, Antigo Lanifício Paulista (rua João Boemer), Gasômetro da rua da Figueira, ponte metálica da estrada de ferro (altura da rua do Bucolismo), residências no entorno da Vila Queiroga.

Pari: traçado urbano e casario remanescente do Morro do Pari, edifício industrial da rua Thiers x rua Hanemamm, Igreja Santo Antônio do Pari, edifício do Liceu Acadêmico São Paulo, ETE Carlos de Campos.

Os mapas que fizeram parte do Plano Regional das Subprefeituras Sé e Mooca, apresentados a seguir em uma montagem conjunta, demonstram as situações descritas em relação ao uso e ocupação do solo propostas:

Mapa Macrozona de Estruturação e Qualificação Urbana

- as cores em tom laranja variam da mais clara à mais escura, representando:

- Zonas de Centralidade Linear e Polar A

- Zonas de Centralidade Linear e Polar B 
Considerando que toda a área consolidada foi caracterizada como de uso misto, essa gradação mostra as zonas menos e mais permissivas em relação aos coeficientes de aproveitamento. De acordo com o exposto anteriormente, são áreas envoltórias aos eixos de transporte estrutural que poderão chegar até o coeficiente máximo permitido, de acordo com critérios e parâmetros estabelecidos para cada caso.

Nas tonalidades cinza as áreas correspondem:

- Cinza claro: zona mista de baixa densidade

- Cinza médio: zona mista de média densidade

- Cinza escuro: Zona mista de alta densidade - A

- Cinza mais escuro: zona mista de alta densidade - B

Essa gradação implica na densidade real existente para cada zona, estando praticamente todo o Pari na zona de média densidade, com a presença de alta densidade tipo A no Canindé, nas imediações da av. Cruzeiro do Sul (alta densidade tipo B só se aplica ao distrito Santa Cecília, com forte presença de verticalização).

Como é possível observar, comparando-se o mapa mencionado com o que inclui as Operações Urbanas e as Áreas de Intervenção Urbanas - AlU, todo o território se encontra sob a incidência de ambos instrumentos, variando no caso, as diretrizes direcionadas a cada um deles, mas que possibilitam a utilização dos coeficientes de aproveitamento máximo, de acordo com os critérios para o adensamento dessas áreas.

Finalmente, deve-se considerar que parte dos projetos propostos para as Áreas de Intervenção Urbanística já tiveram início, sendo alguns indicados anteriormente, como foi o caso daqueles implantados no Bom Retiro, no Parí e no Brás. De toda maneira, o conjunto de instrumentos urbanísticos aqui expostas de maneira sintética, mostra a possibilidade de ser desencadeado um processo capaz de articular as transformações mais imediatas e aquelas que demandam um prazo mais longo para sua efetivação, visando a requalificação física, funcional e ambiental do território abordado e melhores condições de moradia para os atuais e para os novos habitantes desses bairros. 


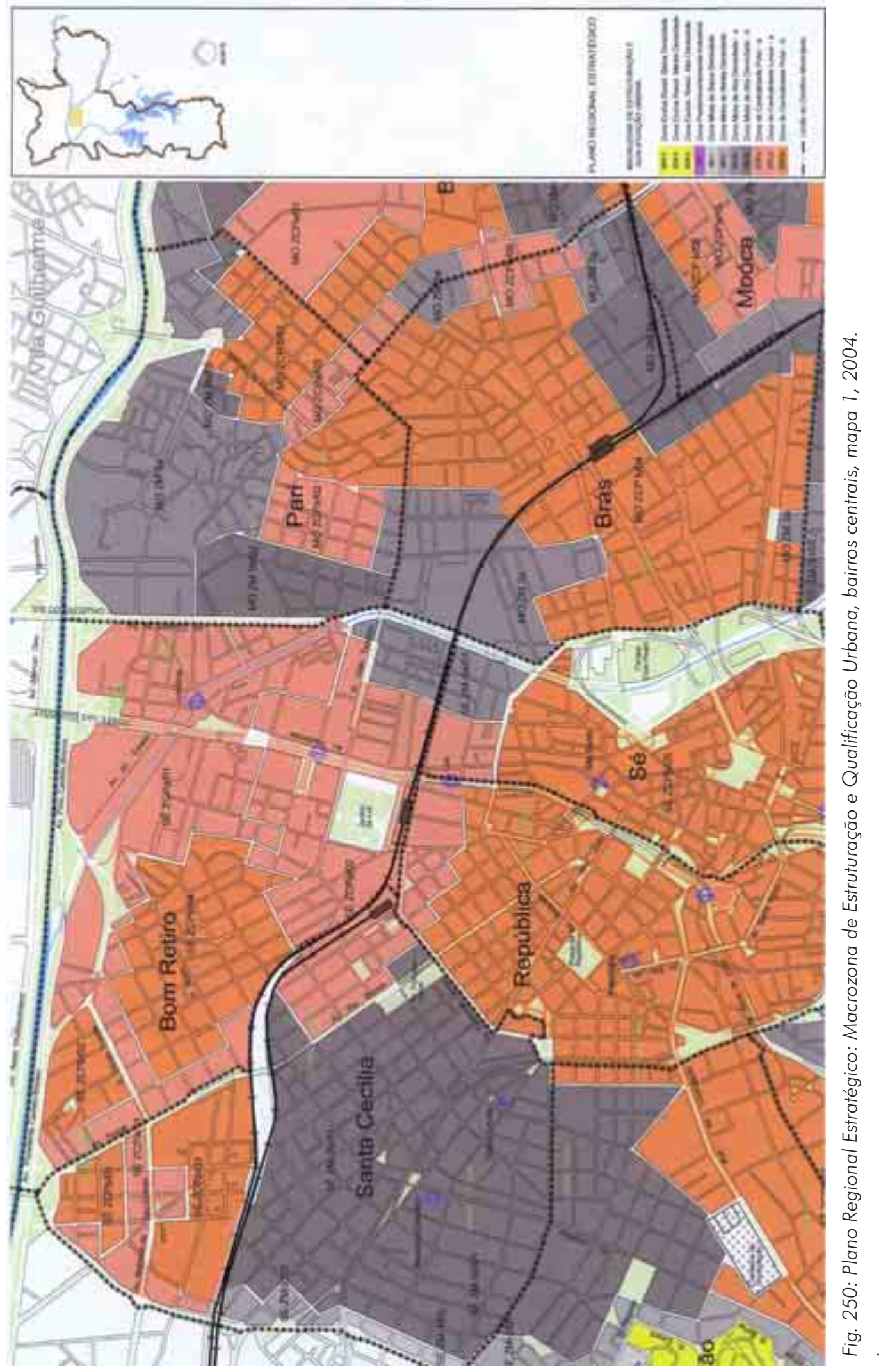




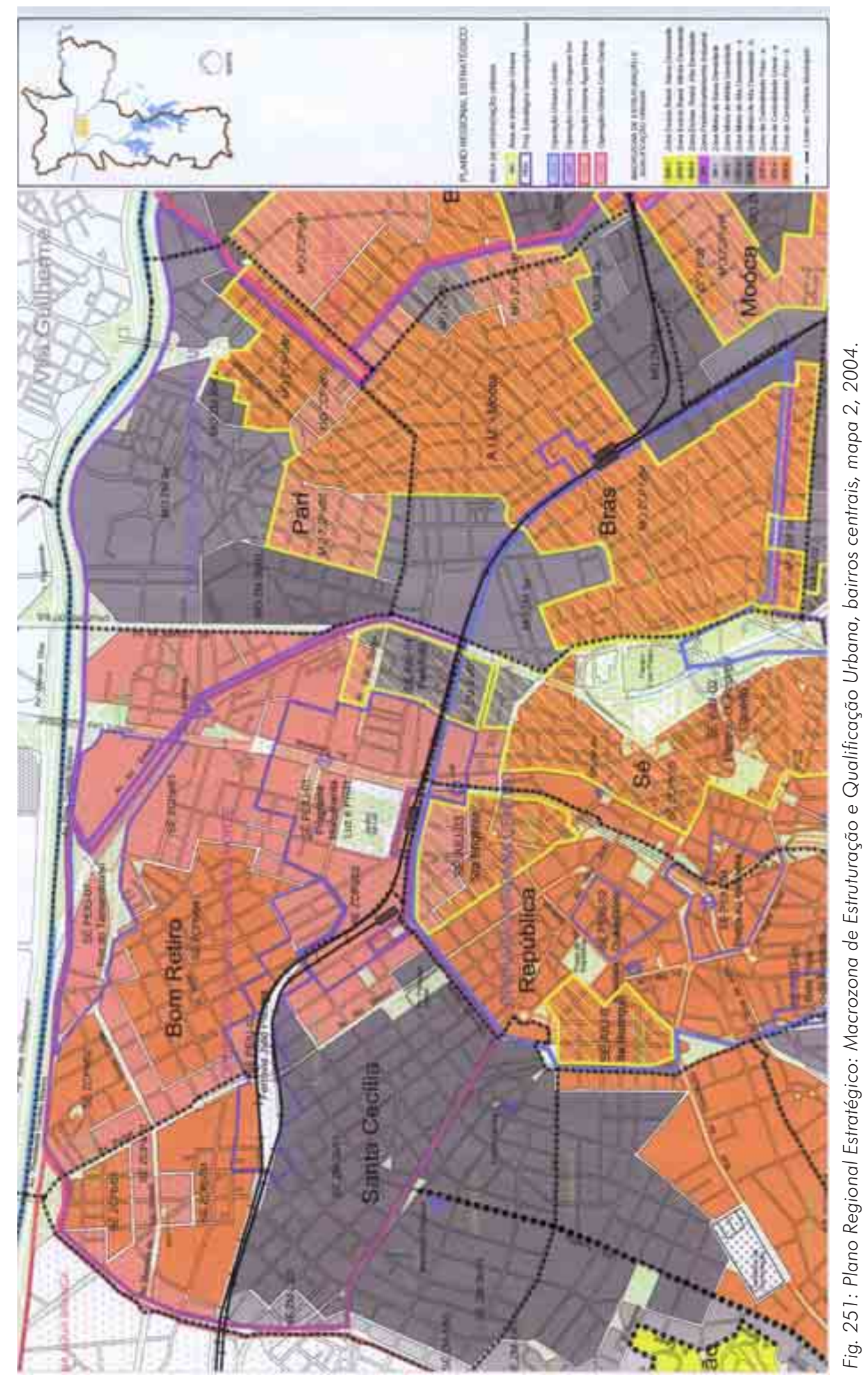




\section{Notas:}

${ }^{1}$ Subprefeitura Sé/Procentro: arq. Alonso Lopes e equipe.

${ }^{2}$ Sub-prefeitura Sé/Procentro: arq. Decio Amadio e equipe.

${ }^{3}$ Ação Direta- Assessoria para Habitação.

${ }^{4}$ PDE: Lei Municipal n 13.430, de 13 de setembro de 2002.

${ }^{5}$ Vila Maria, Vila Leopoldina-Jagaré, Vila Sônia, Diagonal Norte, Diagonal Sul, Celso Garcia, Rio Verde-Jacu, Santo Amaro, Tiquatira e Capela do Socorro.

${ }^{6}$ Estatuto da Cidade: Lei Federal n 10.257 de 10 de julho de 2001.

${ }^{7} \mathrm{O}$ estoque do potencial construtivo levou em conta os coeficientes de aproveitamento bruto das quadras fiscais. 


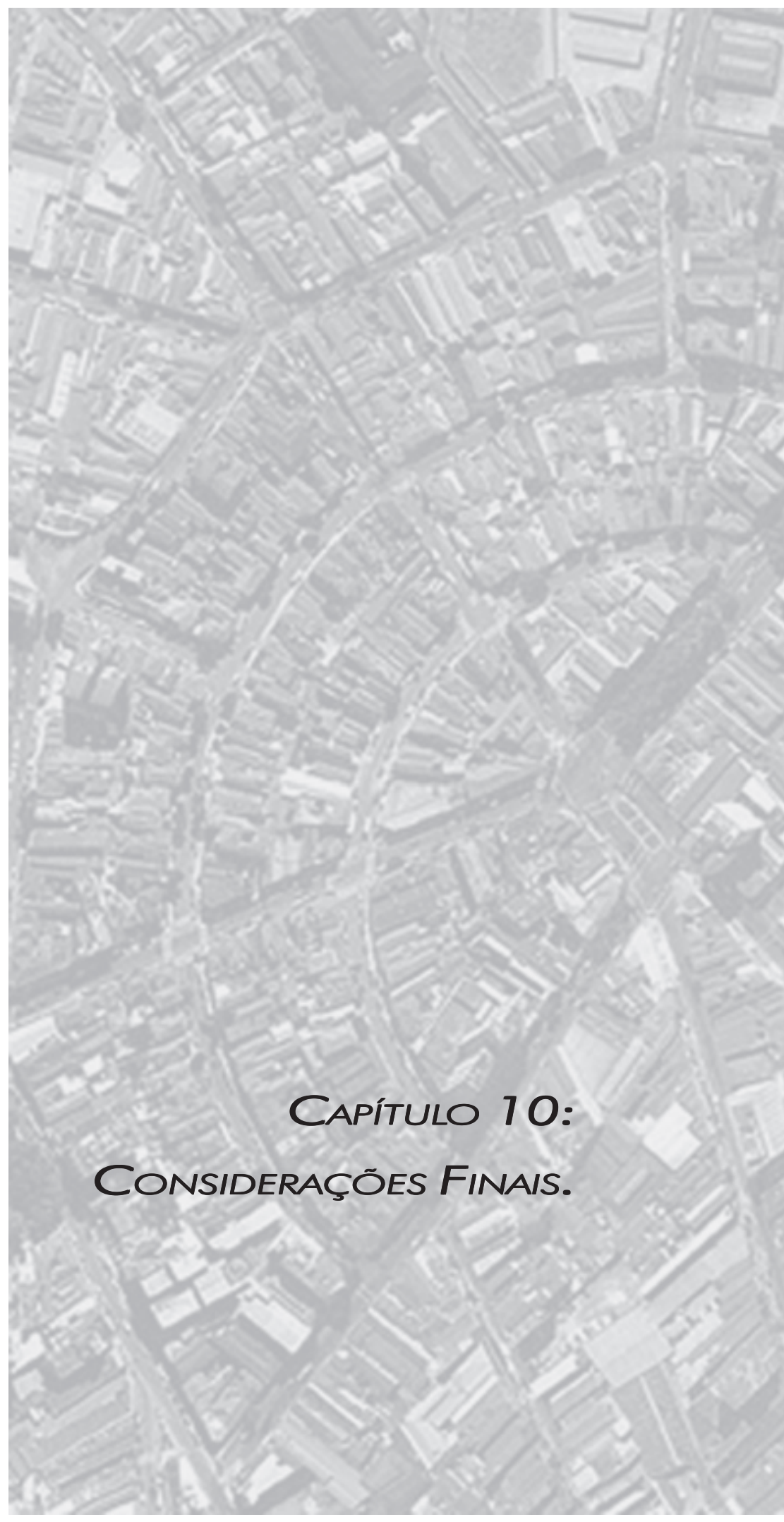




\section{Considerações finais}

I - No primeiro período abordado por este trabalho, que abrangeu das décadas finais do século XIX às três primeiras do século XX, a estruturação dos bairros no entorno do Centro já havia ocorrido de forma quase que completa, uma vez que as principais tendências espaciais já tinham sido definidas. Como indicaram os mapas de 1930, apenas a Várzea do Tietê não fora ocupada, pois o rio ainda não se encontrava canalizado. Na década de 1950, o levantamento aerofotogramétrico Vasp, mostra que parte dessa área já recebera urbanização, mostrando-se consolidada na década seguinte.

Como foi observado nas considerações da Parte I deste trabalho, a área compreendida pelos bairros do Bom Retiro, Brás e Parí se diferenciou morfológica e funcionalmente dos demais bairros centrais, pelos processos que aqui se procurou aprofundar, implicando em um quadro que provocou a ociosidade para fins habitacionais e deterioração ambiental e paisagística de consideráveis parcelas dos referidos bairros.

Não caberia repetir as considerações anteriores para caracterizar essa dinâmica, mas sim apontar as diferentes atuações urbanísticas verificadas entre os bairros ao sudoeste e aqueles aqui focalizados, processo este que se implantou já nas primeiras décadas do século XX, mas se aprofundou a partir de 1950, com a setorização cada vez mais pronunciada que a verticalização habitacional e dos serviços desencadeou nos espaços vizinhos do Centro Novo em direção à avenida Paulista.

Sinteticamente, tal processo se deveu:

1. Primeiramente as concessões às companhias de serviços públicos, que atuaram de forma monopolista nas quatro primeiras décadas do século XX, onde a infraestrutura instalada se constituiu num importante fator de valorização do solo, provocando com isso uma crescente diferenciação funcional e espacial entre os bairros anexos ao centro.

2. Incapacidade de efetiva regulamentação e gestão urbanística em relação aos diversos agentes do setor imobiliário, que tiveram seu campo de ação livre para a definição dos espaços da elite e para a produção da cidade irregular.

3. Implantação de um pré-zoneamento que incidiu no Centro e nos bairros aristocráticos a oeste e sudoeste, com a incorporação das normas ditadas pelos loteadores para o tamanho dos lotes, os índices de ocupação e os padrões construtivos. Como foi visto, contribuiu para a consagração dessa setorização a acessibilidade criada pelas avenidas do Plano de Prestes Maia, que alterou os valores do solo urbano nos diferentes bairros centrais. Nesse sentido, as ampliações das avenidas Nove de Julho e Consolação foram fator necessário, mas não suficiente para 0 crescimento vertical nos moldes que ocorreu nos 
bairros de renda mais alta, já que as condições de segregação já haviam sido postas anteriormente. Prova disso é o fato de terem ocorrido outras ampliações, como no caso da avenida Tiradentes, e o mesmo processo não ter ocorrido.

4. Os padrões urbanísticos resultantes da utilização e ocupação do solo nos bairros analisados neste trabalho foram fatores preponderantes para que essas áreas continuassem a se constituir em uma reserva de solo mais barato, atraindo além de indústrias, o uso comercial e ocupação horizontalizada, com a presença de habitações coletivas e cortiços.

5. Segundo essas condicionantes, a compartimentação resultou em um processo diferenciado para os espaços de moradia e vida da população: uma renovação constante nos bairros conectados ao Centro Novo e a consolidação de condições urbanas que passaram a não propiciar a permanência dos moradores dos bairros do Brás, Bom Retiro e Parí. Isso ocorreu, entre outros fatores, pela disputa nesses bairros entre a função comercial e a residencial, que provocou além do gradual esvaziamento populacional, verificável já nas décadas de 1960 e 1970, o desinteresse do setor imobiliário em novas construções, realimentando o círculo de desvalorização dessas localizações.

Observadas as características topológicas do território analisado, depreende-se que em seu interior a diferenciação de áreas, de padrões construtivos e de conservação, constituem uma marca da morfologia urbana ali existente. Em primeiro lugar, as terras baixas e os setores próximos às aglomerações fabris ou instalações ferroviárias receberam as ocupações populares, ainda existindo uma considerável parcela das construções remanescentes do início do século passado, geralmente bastante deterioradas. Em segundo lugar, as diversas atividades comerciais contribuem para o rebaixamento da paisagem urbana às funções utilitárias, não só pelo excesso visual de anúncios e outros elementos, mas também pela descaracterização das tipologias, que passam por um processo de transformação para serem adaptadas às atividades do comércio. Mesmo referências que haviam sido indicadas para proteção no recente processo dos Planos Regionais Estratégicos, foram demolidas parcial ou totalmente.

Levando-se em conta essas observações, quando o tema deste trabalho foi definido, relacionando-o ao desenho urbano dos bairros centrais, o desafio de seu desenvolvimento foi aprofundar os fatores que estruturaram essas configurações, particularmente do Bom Retiro, Brás e Pari, procedendo ao cotejamento com as hipóteses formuladas. Como a estruturação da cidade privilegiou a localização de determinados atores em detrimento de outros, tornase importante associar a afirmação de Villaça, que analisou ser a localização dos bairros de classe média, seu comércio e serviços, determinada pela interação dos fatores de acessibilidade, proximidade com local de trabalho, etc, que minimizam os deslocamentos. À medida que essas áreas se definem, crescem 
progressivamente as exigências por padrões ambientais e de vizinhança requeridos por essa classe $(1978,22)$. Segundo o mesmo autor, a localização dos melhoramentos em uma região, e não em outra, se torna vital para o estudo do arranjo territorial decorrente $(1998,138)$.

Para compreender o processo de estruturação da configuração dos espaços pesquisados, foi também fundamental associar a formulação do prof. Milton Santos sobre a relação região e lugar, uma vez que os bairros pesquisados consistiram no recorte urbano de um todo: "a região e o lugar não tem existência própria. A região e o lugar, aliás, definem-se como funcionalização do mundo e é por eles que o mundo é percebido empiricamente...a cada momento histórico os recursos como o capital, a população, a força de trabalho, o excedente, são distribuídos de diferentes maneiras e localmente combinados, o que acarreta uma diferenciação no interior do espaço total e confere a cada região ou lugar a sua especificidade e definição particular (1995,131, grifo nosso). Nesse sentido, essas formulações também podem ser relacionadas ao objetivo-problema desta tese, que foi o de identificar nas categorias propostas por Solà-Morales "urbanização, parcelamento e edificação" e suas combinações, a matriz da configuração espacial do território analisado.

Conforme mostraram as análises desenvolvidas neste trabalho, essas categorias devem ser entendidas dentro da formulação de Lefebvre para a caracterização do fenômeno urbano, que é composta de duas estruturas que atuam em simultaneidade: a morfológica e a sociológica (Lefebvre, 2004, 109). Por isso, estabelecendo um paralelo com Lefebvre e citando mais uma vez o prof. Milton Santos para elucidar as condicionantes da diferenciação morfológica: "lugar é o objeto ou conjunto de objetos. A localização é um feixe de forças sociais se exercendo em um lugar" (Santos, 1997, 2).

II - Entre o início da elaboração do trabalho, no ano 2000 e sua conclusão, foi possível acompanhar o desenvolvimento dos diversos planos e projetos propostos para o território enfocado. Nesse sentido, pode-se afirmar que tal dinâmica alicerçou as duas justificativas expostas no início da tese, relativas à:

- A inadequação urbanística de serem mantidas áreas sub-aproveitadas nos bairros centrais, tanto pelos custos impostos à cidade, como também pelas conseqüências físicas, ambientais e paisagísticas que um vasto setor urbano, em condições de visível precariedade, à ela impõe.

- A existência nesses espaços, de uma base territorial com disponibilidade de áreas livres e baixa densidade populacional, que pode suportar um aumento do número de moradores, aliado a ações revitalizadoras do ambiente urbano, quer no sentido das suas funções, quer na sua paisagem. 
A imobilidade que atualmente se verifica para o mercado imobiliário de classe média, poderá ser alterado com o emprego dos instrumentos do Plano Diretor Estratégico, das Operações Urbanas propostas para a área e dos Planos Regionais, que estabelecem os critérios para o adensamento das mesmas. Nos parece que a principal estratégia para esses bairros seria a de combinar duas frentes de atuação urbanística, a saber:

1. $\bigcirc$ aumento de densidade através do incentivo à moradia de faixas de renda diversificadas, o que poderá ser garantido pela existência das ZEIS 3 que possibilitam a construção de habitação social nas áreas delimitadas pelos perímetros dos PRIHs e nos demais espaços definidos como tal. Esse instrumento possibilita o acesso à moradia popular nas áreas centrais, que de outra forma seria inviabilizada pelo aumento do preço do solo urbano, decorrente da atuação do mercado imobiliário formal.

Por outro lado, atualmente assiste-se uma produção residual de novas unidades para classe média nesses bairros, em relação a outros quadrantes dos bairros centrais e do centro expandido. Essa atuação, que ocorre de forma esporádica em algumas áreas, como a do Canindé, poderá ser dinamizada através dos instrumentos que prevêem maiores coeficientes para as áreas dotadas de requisitos urbanísticos para tal: infra-estrutura e transporte de massa. Entretanto, embora seja desejável esse aumento da densidade habitacional através de novas construções, é necessário que o mesmo ocorra dentro de parâmetros que conduzam a uma interação com a morfologia existente, e não sua destruição, e para isso, os instrumentos também previstos nos Planos Diretor e Regionais Estratégicos deverão ser aplicados quando necessário, tais como as ZEPECs, que contemplam as áreas de proteção histórica e cultural.

2. A implantação de novos padrões físico-ambientais, através de propostas de desenho urbano que articulem desde grandes espaços vazios ou sub-utilizados, como as áreas lindeiras às ferrovias, pátios ferroviários e áreas municipais ociosas às atuações relacionadas à melhoria da qualidade local sob o ponto de vista de sua configuração e ambiente. Exemplos dessa potencialidade se encontram em espaços dos três distritos enfocados:

Bom Retiro: onde os próprios públicos da Subprefeitura Sé e da Limpurb (usina de transbordo de lixo) poderiam ser reconvertidos para funções que abrigassem moradia e ao mesmo tempo, reintegrassem a margem esquerda do Tamanduateí ao bairro, que atualmente já conta com o Parque do Gato na foz daquele rio. Como essa área historicamente se mostrou desabitada e atualmente parte das instalações estão ociosas e apresentam também inconveniência ambiental, um plano seria necessário para assegurar novos padrões de desenho urbano para o local. 
Pari: novos projetos para a revalorização do bairro poderão se integrar a outros recentemente construídos, como o do conjunto habitacional da rua Olarias, não apenas para habitação, mas como complemento à habitabilidade local, promovendo a melhoria dos seus padrões urbanísticos. Nesse caso se incluem as áreas entre as ruas da Piscina e Araguaia, que já dispõe de equipamentos públicos de educação e de esportes, e que integrados aos terrenos municipais atualmente desocupados, e portanto merecedores de novas destinações, poderão configurar um setor importante para a vida da sua população moradora.

Brás: o adensamento populacional que irá ocorrer nas proximidades da Praça Benemérito José Brás (Estação Brás do Metrô), fruto da construção de conjuntos habitacionais, faz com que esse espaço, que ainda se configura como um grande vazio, mereça tratamento paisagístico condigno, integrando-o à rua Piratininga, à Rangel Pestana e rua do Gasômetro, de maneira a lograr não apenas a valorização local, mas contribuindo também para a do Brás, o bairro que é a mais importante testemunha das transformações urbanas da cidade de São Paulo em mais de um século de história. 


\section{BIBLIOGRAFIA}

Andrade, Carlos R. Monteiro de; Bonduki, Nabil; Rosseto, Rossella (org) - "Arquitetura \& Habitação Social em São Paulo - 1989 - 1992"

USP, Escola de Engenharia de São Carlos, São Paulo, 1993

Arantes, Otilia Beatriz Fiori - "O Lugar da Arquitetura depois dos Modernos" Edusp, São Paulo, 1995

Aymonino, Carlo - "El Significado de las Ciudades"

H. Blume Ediciones, Madri, Espanha, 1980

Azevedo, Aroldo de (org) - "A Cidade de São Paulo - Estudos de Geografia Urbana" Vol. II: A Evolução Urbana - Companhia Editora Nacional, São Paulo, 1958

Azevedo, Aroldo de (org) - "A Cidade de São Paulo - Estudos de Geografia Urbana" Vol. III: Aspectos da Metrópole Paulista - Companhia Editora Nacional, São Paulo, 1958

Bacon, Edmund N. - "Design of Cities"

Penguin Book, NY, USA, 1974

Barnett, Jonathan - "Urban Design as Public Policy"

Architectural Record Books, NY, USA, 1974

Bentley, Alcock, Murrain, McGlynn, Smith - "Responsive Environments"

Architectural Press, Londres, Inglaterra, 1985.

Blay, Eva Alterman - "Eu Não Tenho Onde Morar - Vilas Operárias na Cidade de São Paulo"

Editora Nobel, São Paulo, 1985

Bertolli Filho, Cláudio, - "A Gripe Espanhola em São Paulo- 1918: Epidemia e Sociedade" Editora Paz e Terra, São Paulo, 2003.

Bonduki, Nabil - "Origens da Habitação Social no Brasil" Estação Liberdade, FAPESP, São Paulo, 1998

Campos F”, Cândido Malta - "Cidades Brasileiras: seu controle ou o caos - o que os cidadãos devem fazer para a humanização das cidades no Brasil"

Ed. Nobel, São Paulo, 1989

Carlos, Ana Fani Alessandri - "Espaço-tempo na metrópole: a fragmentação da vida cotidiana"

São Paulo, Contexto, 2001 
Choay, Françoise - "O Urbanismo"

Editora Perspectiva, São Paulo, 1979

Cullen, Gordon - "Paisagem Urbana"

Edições 70, Lisboa, Portugal, 1983

Déak, Csaba, Schiffer, Sueli Ramos (orgs) - "O Processo de Urbanização no Brasil" Edusp, São Paulo, 1999

Dean, Warren - "A Industrialização de São Paulo"

Difel, São Paulo, 1990

Del Rio, Vicente - "Introdução ao Desenho Urbano no Processo de Planejamento" Editora Pini, São Paulo, 1990

Donne, Marcella delle - "Teorias sobre a Cidade"

Edições 70, Lisboa, Portugal, 1990

Engels, Frederich- "A Situação da Classe Trabalhadora na Inglaterra" Martins Fontes, São Paulo, 1975.

Furtado, Celso - "Formação Econômica do Brasil"

Cia. Editora Nacional, São Paulo, 1971

Gerodetti, João Emílio, Cornejo, Carlos - "Lembranças de São Paulo - a capital paulista nos cartões postais e álbuns de lembranças"

Studio Flash, São Paulo, 1999

Harvey, David - "Condição Pós-Moderna"

Editora Loyola, São Paulo, 1995.

Howard, Ebenezer - "Cidades-Jardins de Amanhã"

Hucitec, São Paulo, 2002

Kostof, Spiro - "The City Shaped"

Thames \& Hudson, Londres, Inglaterra, 2001

Langenbuch, Juergen Richard (org) - "A Estruturação da Grande São Paulo - estudo de geografia urbana"

Fundação IBGE, Rio de Janeiro, 1971

Lefebvre, Henri - "A Revolução Urbana"

Ed. UGMG, Belo Horizonte, 2004

Lefebvre, Henri - "O Direito à Cidade"

Ed. Moraes, São Paulo, 1991 
Lévi-Strauss, Claude - "Saudades de São Paulo"

Cia. Das Letras, São Paulo, 1996

Leme, Maria Cristina da Silva (org) - "Urbanismo no Brasil 1895 - 1965"

FUPAM/ Studio Nobel, São Paulo, 1999

Lemos, Carlos A.C. - "A República Ensina a Morar (Melhor)"

Editora Hucitec, São Paulo, 1999

Lemos, Carlos A.C.- "Ramos de Azevedo e seu Escritório"

Pini, São Paulo, 1993

Lynch, Kevin - "A Imagem da Cidade"

Martins Fontes, São Paulo, 1999

Lynch, Kevin - "City Sense and City Design"

MIT Press, USA, 1991

Lopes, Rodrigo - "O Mundo Construído"

Forense Universitária, Rio de Janeiro, 2001

Macedo, Sílvio Soares - "Higienópolis e Arredores: Processo de Mutação da Paisagem Urbana"

Pini - Ed. da Universidade de São Paulo, São Paulo, 1987

Mancuso, Franco - "Las Experiencias del Zoning"

Editorial Gustavo Gili, Barcelona, 1980

Maia, Francisco Prestes - "Introdução ao Estudo de um Plano de Avenidas para a Cidade de São Paulo"

Cia. Melhoramentos de São Paulo, São Paulo, 1930.

Martins, José de Souza - "Conde Matarazzo: O Empresário e a Empresa" Hucitec, São Paulo, 1973

Massarani, Emmanuel; Dellelis, Rosana (org) - "A Era do Trem"

Editora LF\&N, São Paulo,1999

Morse, Richard M. - "Formação Histórica de São Paulo"

Difusão Européia do Livro, São Paulo, 1970

Netto, Gabriel Ayres - "Código de Obras Arthur Saboya"

Edições LEP, São Paulo, 1947

Nucci, João Carlos - "Qualidade Ambiental \& Adensamento Urbano"

Humanitas, São Paulo, 2001 
Panerai, Catex, Depaule - "Formas urbanas: de la manzana al bloque"

Editorial Gustavo Gili, Barcelona, 1980

Petrone, Pasquale - "Pinheiros: Estudo Geográfico de um Bairro Paulistano"

Editora da Universidade de São Paulo, São Paulo, 1963

Portela, Fernando - "São Paulo 1860-1960: A Paisagem Humana"

Editora Terceiro Nome/Albatroz, São Paulo, 2004

Porto, Antônio Rodrigues - "História da Cidade de São Paulo através de suas Ruas" Carthago Editorial, São Paulo, 1996

Porto, Antônio Rodrigues - "História Urbanística da Cidade de São Paulo 1554 - 1988" Carthago \& Forte Editoras Associadas, São Paulo, 1992

Reale, Ebe - "Brás, Pinheiros, Jardins: Três Bairros, Três Mundos"

Pioneira - Ed. da Universidade de São Paulo - São Paulo, 1982

Rolnik, Raquel - "A Cidade e a Lei"

Fapesp/Studio Nobel, São Paulo, 1997

Rossi, Aldo - "A Arquitetura da Cidade"

Martins Fontes, São Paulo, 1995

Sampaio, Maria. Ruth Amaral de (org) - "São Paulo 1934-1938: Os anos da Administração Fábio Prado"

USP/FAU, São Paulo, 1999

Sampaio, Maria Ruth Amaral de (org) - A Promoção Privada de Habitação Econômica e a Arquitetura Moderna 1930-1964

Rima, São Carlos, 2002

Sampaio, Maria Ruth Amaral de (org) - "Habitação e Cidade"

FAUUSP, São Paulo, 1998.

Solà-Morales i Rubió, Manuel - "Las formas de crescimiento urbano"

Edicions Universitat Politécnica de Catalunya, Barcelona, 1997

Santos, Carlos Nelson Ferreira dos - "A Cidade como um Jogo de Cartas" Universidade Federal Fluminense, Projeto Editores, São Paulo, 1988

Santos, Milton - "Espaço \& Método"

São Paulo, Nobel, 1997

Santos, Milton - "A Natureza do Espaço - Técnica e Tempo, Razão e Emoção".

Hucitec, São Paulo, 1995 
Saskia, Sassen - "As Cidades na Economia Mundial"

Studio Nobel, São Paulo, 1998

Sevcenko, Nicolau - "Orfeu Extático da Metrópole"

Companhia das Letras. São Paulo, 1993.

Silva, Sérgio - "Expansão Cafeeeira e Origens da Indústria no Brasil"

Editora Alfa-Omega, São Paulo, 1995

Singer, Paul - "Desenvolvimento Econômico e Evolução Urbana"

Cia Editorial Nacional, São Paulo, 1968

Somekh, Nadia; Campos, Candido Malta (orgs) - "A Cidade que não Pode Parar: Planos Urbanísticos de São Paulo no Século XX"

Editora Mackpesquisa, São Paulo, 2002

Somekh, Nadia - "A Cidade Vertical e o Urbanismo Modernizador"

Studio Nobel/Edusp, São Paulo, 1997

Souza, Maria Adélia Aparecida de - "A Identidade da Metrópole"

Editora Hucitec - Edusp, São Paulo, 1994

Souza, Maria Adélia A. de; Santos, Milton (orgs)- "A Construção do Espaço"

Editora Nobel, São Paulo, 1986

Sposati, Aldaíza - "Cidade em Pedaços"

Ed. Brasiliense, São Paulo, 2001

Toledo, Benedito Lima de - "Prestes Maia e as Origens do Urbanismo Moderno em São Paulo".

Empresa das Artes, São Paulo, 1996

Toledo, Benedito Lima de - "São Paulo, Três Cidades em Um Século"

Cia. Editora Duas Cidades, São Paulo, 1983

Vargas, Heliana Comin - "Espaço Terciário: o lugar, a arquitetura e a imagem do comércio"

Editora Senac, São Paulo, 2001

Varas, Alberto - "Buenos Aires - Metrópolis"

Facultad de Arquitectura, Diseño y Urbanismo, Buenos Aires, Argentina, 1997

Vaz, Lillian Fessler - "Habitação Coletiva No Rio de Janeiro, Séculos XIX e XX".

Ed. 7Letras, Rio de Janeiro, 2002 
Véras, Maura Pardini Bicudo - "DiverCidade: Territórios Estrangeiros como Topografia da alteridade em São Paulo"

EDUC, São Paulo, 2003

Villaça, Flávio - "O Espaço Intra-Urbano no Brasil"

Studio Nobel, São Paulo, 1998

Villaça, Flávio - "Uso do Solo Urbano"

Fundação Prefeito Faria Lima, São Paulo, 1978

Yázigi, Eduardo - "O Mundo das Calçadas"

Humanitas/Imprensa Oficial, São Paulo, 2000

Whittick, Arnold (org)- "Enciclopédia de la Planificacion Urbana"

Instituto de Estudios de Administración Local, Madri, Espanha, 1975

Xavier, Alberto; Lemos, Carlos; Corona, Eduardo - "Arquitetura Moderna Paulistana" Editora Pini, São Paulo, 1983

\section{TESES e DISSERTAÇÕES}

Amadio, Decio - "Alguma Coisa Acontece: uma investigação sobre o centro de São Paulo"

Dissertação de Mestrado, FAUUSP, 1998

Bartalini, Vladimir - "Praças do Metrô: Enredo, Produção, Cenários, Atores"

Disssertação de Mestrado, FAUUSP, 1988

Bógus, Lucia Maria Machado - "(Re)Urbanização: Por Quê e Para Quem?"

Tese de Doutorado - FAUUSP, 1988

Ferreira, João Sette Whitaker - "São Paulo: o mito da cidade-global"

Tese de doutorado, FAUUSP, 2003

Filardo Jr., Angelo S.- "Territórios da Eletricidade - A Light em São Paulo e o Projeto da Serra de Cubatão 1925-1950"

Dissertação de Mestrado, FAUUSP, 1998

Grostein, Marta Dora - "A Cidade Clandestina: Os Ritos e os Mitos" Tese de doutorado, FAUUSP, 1987

Lefévre, José Eduardo de Assis - "O Transporte Coletivo como Agente da Estruturação do Centro da Cidade de São Paulo"

Dissertação de mestrado, FAUUSP, 1986 
Mello Filho, José Rollemberg - "Arquitetura no Contexto Urbano Antigo"

Dissertação de Mestrado - FAUUSP, 2001

Meyer, Regina - "Metrópole e Urbanismo -São Paulo anos 50"

Tese de doutoramento, FAUUSP, 1991

Sales, Marta Maria Lagreca de - "Projeto Urbano: Opção Metodológica e Algumas

Práticas"

Dissertação de Mestrado, FAUUSP, 1999

Ramos, Aloísio W. - "Fragmentação do Espaço Da-Na Cidade de São Paulo: Espacialidades Diversas no Bairro da Água Branca"

Dissertação de Mestrado FFLCH USP - Departamento de Geografia, 2001

Santos, Emmanuel Antonio dos - "O Plano e a Paisagem"

Tese de doutorado, FAUUSP, 2001

Simões Jr., José Geraldo - "O Setor de Obras Públicas e as Origens do Urbanismo na Cidade de São Paulo"

Dissertação de Mestrado, FGV, 1990

Sócrates, Jodete Rios - "PDDI SP - 1971: Uma Oportunidade Perdida"

Tese de doutorado, FAUUSP, 1993

Someck, Nadia - "A (des) Verticalização de São Paulo"

Dissertação de mestrado, FAUUSP, 1987

Teixeira, Antonio Carlos - "Cortiço: O Pequeno Espaço do Povo"

Dissertação de Mestrado, FAUUSP, 1986

Wakisaka, Tânia - "Zoneamento de Uso, Ocupação do Solo e Produção do Espaço Urbano em São Paulo"

Dissertação de mestrado, FAUUSP, 1991

Wilderode, Daniel Julien Van - "Cidade à venda: interpretações do processo imobiliário" Tese de doutorado, FAUUSP, 2000

Wolff, Sívia Ferreira Santos- "Jardim América: o primeiro bairro-jardim de São Paulo e sua arquitetura"

Tese de doutorado, FAUUSP, 1998

Zioni, Silvana - "Transporte Público em São Paulo"

Dissertação de Mestrado, FAUUSP, 1999 


\section{DOCUMENTOS}

São Paulo (Cidade) - "Programa Morar no Centro"

PMSP/SEHAB, 2004

São Paulo (Cidade) - "As novas Operações Urbanas"

PMSP/SEMPLA, 2004

São Paulo (Cidade) - "Bairro Novo - Concurso Nacional para um Projeto Urbano"

Termo de Referência, PMSP/EMURB, 2004

São Paulo (Cidade) - PRIOU Operação Urbana Butantã-Vila Sônia

PMSP/SEMPLA, 2003

São Paulo (Cidade) - PRIOU Operação Urbana Carandiru-Vila Maria PMSP/SEMPLA, 2003

São Paulo (Cidade) - PRIOU Operação Urbana Jaguaré-Vila Leopoldina PMSP/SEMPLA, 2003

São Paulo (Cidade) - Plano Regional Estratégico da Subprefeitura Moóca PMSP/Instituto Polis, 2003

São Paulo (Cidade) - Plano Regional Estratégico da Subprefeitura Sé PMSP/Instituto Polis, 2003

São Paulo (Cidade) - Plano Diretor Estratégico

PMSP/Sempla, 2002

São Paulo (Cidade) - Requalificação Urbana da Foz do Tamanduateí $\mathrm{PMSP} / \mathrm{SEHAB} / \mathrm{COHAB}, 2002$

São Paulo (Cidade) -"Concurso Público Nacional de Reconversão Urbana do Largo da Batata"

Edital do concurso - PMSP/EMURB, 2002

São Paulo (Cidade) - "Programa Reconstruir o Centro"

PMSP/Administração Regional da Sé, 2001

São Paulo (Cidade) - "Programa Habitação no Centro"

PMSP/SEHAB, 2001

São Paulo (Cidade) - "Evolução do Uso do Solo nos Anos 90"

PMSP/Sempla, Volume 1, 2000/2001 
São Paulo (Cidade) - "Globalização e Desenvolvimento Urbano"

PMSP/Sempla, Volume 2, 2000/2001

São Paulo (Cidade) - "Perfil Socioeconômico do Município de São Paulo"

PMSP/Sempla, Volume 3, 2000/2001

São Paulo (Cidade) - "Operação Urbana Faria Lima"

PMSP/Sempla, Volume 4, 2000/2001

São Paulo (Cidade) - "São Paulo em Números"

PMSP/Sempla, Volume 9, 2000/2001

São Paulo (Cidade) - "Operação Urbana Centro"

EMURB, doc. Interno, 2001

São Paulo (Cidade) - "Cadernos Regionais"

SEMPLA, 1996

São Paulo (Cidade) - Cidade, ano III, PMSP, DPH, 1996

São Paulo (Cidade)- "Operação Urbana Água Branca"

Documento técnico, PMSP/EMURB, 1995

São Paulo (Cidade)- "Cortiços: Programa de Habitações Populares da Região Central de São Paulo"

PMSP/SEHAB/HABI, São Paulo, 1992.

São Paulo (Cidade) - "Evolução Urbana da Cidade de São Paulo 1872 - 1945"

Série Bibliografia, ELETROPAULO / SMC, São Paulo, 1990

São Paulo (Cidade) - "Parque do Tietê - Plano de Reurbanização da Margem do Rio Tietê"

Oscar Niemeyer (org), Estúdio RO, 1986

São Paulo (Cidade) - "Cadastro de Referências Urbanas Zona Leste"

Série Documentos, SEMPLA/PMSP, 1985

São Paulo (Cidade) - "Cortiços em São Paulo: frente e verso"

Série Documentos, SEMPLA/PMSP, 1985

São Paulo (Cidade) - "A Cidade de São Paulo: Planos e Realizações"

COGEP/PMSP, 1980

São Paulo (Cidade) - "Leste-Oeste: em busca de uma solução integrada"

PMSP/Metrô, 1979 
São Paulo (Cidade) - "Zoneamento da Cidade de São Paulo"

Polimapas editora, 1978

Cerqueira Cesar, Roberto de (org) - "Área da Luz, Renovação Urbana em São Paulo" COGEP/Editora Perspectiva, São Paulo, 1975.

São Paulo (Cidade) - Plano Urbanístico Básico de São Paulo, PUB

PMSP, 1968.

São Paulo (Cidade) - "Sociedade para a Análise Gráfica e Mecanográfica Aplicada aos Complexos Sociais - SAGMACS"

PMSP, 1958

São Paulo (Cidade) - "Edição comemorativa da visita do Presidente Roosevelt ao Brasil" Editoram Melhoramentos, São Paulo, 1953

São Paulo (Estado) - "PAC - Programa de Atuação em Cortiços"

Companhia de Desenvolvimento Habitacional do Estado de São Paulo - CDHU, 2002

São Paulo (Região Metropolitana) - "Plano Metropolitano da Grande São Paulo 1993/ 2010 - Proposta"

Emplasa, São Paulo, 1994

São Paulo (Estado) - "Guia do Estado de São Paulo: A Região da Capital Paulista" IBGE / Conselho Nacional de Geografia no Estado de São Paulo, vol I, São Paulo, 1962.

\section{PUBLICAÇÕES}

São Paulo (Região Metropolitana) - "Memória Urbana: A Grande São Paulo até 1940" Emplasa, São Paulo, 2001

São Paulo (Estado) - "Ligação: Saneamento, Meio Ambiente e Desenvolvimento Sustentável"

SABESP, São Paulo, set/out 2000

"Cerda, Pionero Del Urbanismo Moderno"

Ministerio de Fomento, Madri, Espanha, 1998

"São Paulo Centro: Uma Nova Abordagem" Associação Viva o Centro, São Paulo, 1996

São Paulo (Cidade) - "Paulicéias Perdidas" SMC/PMSP, 1991 
São Paulo (Cidade) - "São Paulo: crise e mudança"

Sempla, Ed. Brasiliense, 1990

São Paulo (Cidade) - "Salas de Cinema em São Paulo"

Simões, Inimá Ferreira - SMC/PMSP, 1990

São Paulo (Cidade)- "Luz, Notícias e Reflexões"

Jorge, Clóvis de Athayde - Série História dos Bairros de São Paulo - SMC/PMSP, 1988

São Paulo (Cidade) - "Consolação, uma reportagem histórica"

Jorge, Clóvis de Athayde - Série História dos Bairros de São Paulo - SMC/PMSP, 1985

São Paulo (Cidade) - "Brás"

Mendes Torres, Maria Celestina Teixeira - Série História dos Bairros de São Paulo -

SMC/PMSP, 1985

São Paulo (Cidade) - "1 de Maio: Imagens e História do Trabalho"

Departamento do Patrimônio Histórico/SMC/PMSP, São Paulo, 1985

São Paulo (Cidade) - Revista do Arquivo Municipal, SMC, 1984

São Paulo (Cidade) - "Casa das Retortas: Brás, Espaço e Uso"

DPH/PMSP, Cadernos 2, São Paulo, 1980

São Paulo (Cidade) - "O Bairro do Bom Retiro"

Dertônio, Hilário - Série História dos Bairros -SMC/PMSP São Paulo, 1971

São Paulo (Cidade) - "Rua da Consolação: Uma das Artérias da Capital Paulista"

Tírico, José Domingos - Boletim Paulista de Geografia, julho de 1958

São Paulo (Cidade) - Revista do Arquivo Municipal - RAM

PMSP - Departamento Municipal de Cultura, São Paulo

Hermann, Lucila - vol. 99, 1944 - "Estudo do Desenvolvimento de São Paulo através da Análise de Uma Radial: A estrada do café"

Simonsen, Roberto - vol. 82, 1942 - "Conferência Inaugural da Jornada de Habitação Econômica"

Siciliano, Heribaldo - vol. 82, 1942 "Habitação Econômica em Sentido Vertical"

Pierson, Donald - vol. 81, 1942 - "Habitações em São Paulo: Estudo Comparativo"

São Paulo (Estado) - "A Cidade da Light 1899-1930"

Departamento do Patrimônio Histórico,/ELETROPAULO, 1990

"Anais do II Seminário de Desenho Urbano - SEDUR"

Diversos - CNPq / FINEP / Ed. Pini, São Paulo, 1986 
(História) Companhia City de Desenvolvimento

Cia. City, São Paulo, 1980

Espaço \& Debates, $n^{\circ} 37,1994$

Espaço \& Debates, $n^{\circ} 34,1994$

Espaço \& Debates, $n^{\circ} 17,1986$

\section{REVISTAS}

Projeto, $n^{\circ} 291$, mai 2004

URBS, $n^{\circ} 33$, jan/fev 2004

URBS, $n^{\circ} 32$, out/nov 2003

Metrômix, $n^{\circ} 20$, fevereiro de 2003

URBS, $n^{\circ} 20$, fev/mar 2001

"Ligação: Saneamento, Meio Ambiente e Desenvolvimento Sustentável"

SABESP, São Paulo, set/out 2000

URBS, $n^{\circ} 9$, set/out 1998

URBS, $n^{\circ} 8$, jun/jul 1998

Polis, 1991, $\mathrm{n}^{\circ} 03$

Projeto, $n^{\circ} 86$, abril 1986

\section{BASES CARTOGRÁFICAS}

FAUUSP - Mapas históricos, SARA-Brasil (dec. 1930), VASP (dec. 1950), GEGRAN (dec. 1970)

SEHAB (Resolo)/ PMSP - Fotos do levantamento aerofotogramétrico disponibilizado para o "Plano Reconstruir o Centro", 2001

SEMPLA/ PMSP - Levantamento GEGRAN (dec. 1970)

SEMPLA/ PMSP - Mapas Plano Diretor Estratégico e Planos Regionais Estratégicos

\section{ROM}

"Por Dentro do Município de São Paulo"

Emplasa/SEMPLA - 2000 


\section{SITES}

http://www.wernervana.hpg.com.br

http://www.portal.prefeitura.sp.gov.br

http://www.portal.prefeitura.sp.gov.br/dph.smc.pmsp

http:// www.etecarlosdecampos.com.br

http://www.patrimoniosp.com.br

hHp://www.ford.com.br

http://gmb.com.br

\section{HEMEROTECA}

"Idosos terão conjunto habitacional no Pari - Diário de São Paulo, 07/6/2004

"O desafio da informalidade urbana" - Jornal da Tarde, 05/6/2004

"Chegada do Metrô transforma bairros em São Paulo" - Folha de São Paulo, 15/3/

2004"

"Faria Lima vai a leilão" Folha de São Paulo, 23/02/2004

"São Paulo paga alto preço por invasão das várzeas" - Folha de São Paulo, 08/02/

2004

"Coração da cidade perdeu força desde 1991" - Folha de São Paulo, 25/01/2004

"Como será o mercado daqui há 50 anos?" - O Estado de São Paulo, 25/01/2004

"Marketing inventou núcleo comercial da marginal Pinheiros" - Folha de São Paulo, $30 / 11 / 2003$

"Marta vai comprar e reformar o São Vito" - Folha de São Paulo, 13/8/2003

"Recuperada, praça do Brás é devolvida aos moradores" - Jornal da Tarde, 06/5/

2002

"Construtoras apontam na direção oeste" - Folha de São Paulo, 20/01/2002

"! $2 \%$ dos domicílios estão desocupados" - Folha de São Paulo, 10/5/2001

"Bom Retiro vira bulevar da moda" - Jornal da Tarde, 2001

"População explode em área irregular" Folha de São Paulo, 24/9/2000

"Sem prefeitura, mutirão recupera Brás"- Folha de São Paulo, 29/7/2000

"Centro comercial mudará Água Branca" - Folha de São Paulo, 23/7/2000

"Megatorre empaca e fica para depois" - Jornal da Tarde, 29/5/2000

"Cidade empilhada" - Superinteressante, março de 2000

"Queda de renda esvazia a avenida Celso Garcia- Folha de São Paulo, 28/2/2000

"O maior de todos" - Veja, novembro de 1999

"Projeto do megaprédio chega à Câmara" - Folha de São Paulo, 17/10/1999

"Moradores e comerciantes se dividem sobre a torre" - O Estado de São Paulo, 20/ 10/1999

"SP dá facilidade a prédio mais alto do mundo" - Folha de São Paulo, 08/6/1999

"Arquitetos esperam com ansiedade o projeto final do "Godzilla' do centro de SP" -

O Estado de São Paulo, 03/6/ 1999

JT, 08/3/1997, 2)

"Ricci tem projeto para a Barra Funda" - Folha de São Paulo, 08/3/1998

"Em busca do arquiteto da Estação da Luz" - Jornal da Tarde, 08/3/1997 
"São Paulo está comemorando hoje o aniversário de um ilustre paulista quatrocentão: $\bigcirc$ Bairro do Pari" - Notícias Populares, 07/1 1/1976

"Parí está aniversariando: 403 anos de tradição"- Gazeta do Brás, novembro de 1976

"Uma Nova Ligação: Consolação-Rebouças-Dr. Arnaldo" - Folha de São Paulo, 04/ $7 / 1970$

\section{IMAGENS}

fig 01 -PMSP/SMC; fig 02 e 03-Massarani/Dellelis, 1999; fig 04 e 05-Gerodetti/Cornejo, 1999; fig 06-Ed. Melhoramentos, 1953; fig 07-Lemos, 1993; fig 08-Ford do Brasil; fig 09- autor; fig 10-Gerodetti/Cornejo, 1999; fig 11 e 12-Segawa, 2000; fig 13, 14, 15, 16- PMSP/SMT; fig 17-PMSP/SMC/DPH; fig 18-Sabesp, 2000; fig 19 e 20-autor; fig $21<$ www.wernervana.hpg.com.br>; fig 22-Ed. Melhoramentos, 1953; fig-22- PMSP/ SMC/DPH; fig 24, 25, 26-autor; fig 27 e 28-Segawa, 2000; fig 29-autor; fig 30Toledo, 1996; fig 31 - PMSP/Procentro, 2000; fig 32-autor; fig 33 e 34-Bonduki, 1998; fig 35 a 42-autor; fig 43-Toledo, 1996; fig 44 e 45-autor; fig 46,47, 48-Howard, 2002; fig 49-Toledo, 1996; fig 50 a 53-Cia City, 1980; fig 54-PMSP/SMC/DPH; fig 55-Ed. Melhoramentos, 1953; fig 56-Bonduki, 1998; fig 57 e 58-autor; fig 59-Bonduki; fig 60-PMSP; fig 61 -Bonduki; fig 62 e 63-autor; fig 64-PMSP/SMC/DPH; fig 65-Toledo, 1996; fig 66-Somekh/Campos, 2002; fig 67-Metrô; fig 68-Cogep, 1980; fig 69Someck/Campos, 2002; fig 70-Azevedo, 1958; fig 71 e 72-Condomínio Cj. Nacional; fig 73-Quatro rodas especial n 4 ; fig 74 e 75-PUB, 1968; fig 76-Gegran 1972; fig 77-Gerodetti/Cornejo, 1999; fig 78-Portela, 2004; fig 79-Arq. Folha de São Paulo; fig 80-Ed. Melhoramentos, 1953; fig 81,82,83-Gerodetti/Cornejo, 1999; fig 84-Ed. Melhoramentos, 1953; fig 85-Metromix, 2003; fig 86-PMSP/SMC/DPH; fig 87-Arq. Folha de São Paulo; fig 88-autor; fig 89 e 90-PMSP/SMC/DPH; fig 91e 92-Ed. Melhoramentos, 1953; fig 93-Portela, 2004; fig 94-Arq. Folha de São Paulo; fig 95 e 96-autor; fig 97-PUB, 1968; fig 98 e 99-Vespoli, 2004; fig 100 e 101-SEMPLA/Emplasa, 2000; fig 102 FSP 20/2/02; fig 103-folder FGF/KRUT; fig 104 e 105-SEMPLA/Emplasa, 2000; fig 106-Studio Stajano, 2000; fig 107-PMSP/SEMPLA/EMURB, 2004; fig 108FSP 08/3/98; fig 109-folder PMSP/SEMPLA/EMURB, 2004; fig 110-PMSP/EMURB, 1995; fig 111 e 112 -autor; fig 113 -folder EMURB, 2002; fig 114 E 155-autor; fig 116 e 117-FSP, 2001; fig 118, 119, 120-FSP, 2002; fig 121 -autor; fig 122-folder EMURB, 2002; fig 123 e 124-autor; fig 125 e 126-PMSP/SEMPLA/EMURB, 2002; fig 127 autor; fig 128-EMURB, 2004; fig 129-autor; fig 130 e 131-Portela, 2004; fig 132autor; 133-Postcard, 2001; 134-SARA-Brasil, 1930; fig $135<$ www.wernervana.hpg.com.br>; fig 136-autor; fig 137 e 138-Cerqueira Cesar (org), 1975; fig 138<www.wernervana.hpg.com.br>; fig 140 e 141 -autor; fig 142 <www.boniconsilii.com.br>; fig 143, 144, 145-autor; fig 146-Gerodetti/Cornejo, 1999; fig 147-PMSP/SMC/DPH; fig 148-Arq. Folha de São Paulo; fig 149 e 150autor; fig 151-Arq. Folha de São Paulo; fig 152 e 153-autor; fig 154-mapas SARABrasil e VASP; fig 155 a 170-autor; fig 171-PMSP/SMC/DPH; fig 172 a 176-autor; fig 177-eq. Melissa, 1999; fig 178 e 179-PMSP/METRÔ, 1979; fig 180 a 184-autor; fig 185-PMSP/SMC/DPH; fig 186 a 190-autor; fig 191-PMSP/SMC/DPH; fig 191-Arq. 
Folha de São Paulo; fig 193 a 200-autor; fig 201-Arq. Folha de São Paulo; fig 202 e 203-autor; fig 204-FSP, 2001; fig 205 e 206-autor; fig 207-mapas 1915 e SARABrasil; fig 208 a 217-autor; fig 218-PMSP/SMC/DPH; fig 219-mapas 1915 e SARABrasil; fig 220, 221 e 222-autor; fig 223 Arq. Folha de São Paulo; fig 224-Ed. Melhoramentos, 1953; fig 225-autor; 226 a 229-Niemeyer, 1986; fig 230Superinteressante, 2000; fig 231 -montagem a partir de FSP 17/10/99,; fig 232-JT, 29/5/2000; fig 233-PMSP/Adm.Regional da Sé/Procentro; fig 234 e 235- PMSP/ Subprefeitura Sé; fig 236- PMSP/SEHAB; fig 237 e 238- Vespoli; fig 239 e 240- PMSP/ SEHAB; fig 241 e 242-autor; fig 243-PAC-CDHU; fig 244 a 246-autor; fig 247 e 248PMSP/SEMPLA; fig 249-autor; fig 250 e 251 -PMSP/SEMPLA.

\section{MAPAS}

mp 01 - Toledo, 1996; mp 02, 03, 04, 05-FAUUSP; mp 06, 07, 08-Rolnick, 1997; mp 09 Ligação/Sabesp, 2000; mp 10, 11, 12, 13-Rolnick; mp 14 e 15-FAUUSP; mp 16SARA-Brasil

\section{CRÉDITOS}

Tratamento gráfico dos mapas e editoração: arq. Alfredo Francelino Faliana Mapas temáticos - soc. Tereza Cristina Vespoli

São Paulo, novembro de 2004

e-mail:de.amadio@vol.com.b

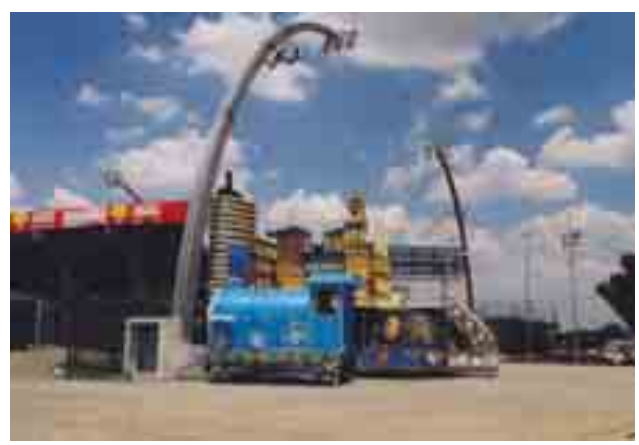

